Artemis Rodrigues Fontana Ferraz

\title{
ARQUITETURA MODERNA DAS ESCOLAS "S" PAULISTAS, 1952-1968: PROJETAR PARA A FORMAÇÃO DO TRABALHADOR
}

Tese apresentada à Faculdade de Arquitetura e Urbanismo da Universidade de São Paulo para obtenção do título de Doutor em Arquitetura e Urbanismo

Área de Concentração: História e Fundamentos da Arquitetura e Urbanismo

Orientadora: Maria Lucia Caira Gitahy 
AUTORIZO A REPRODUÇÃO E DIVULGAÇÃO TOTAL OU PARCIAL DESTE TRABALHO, POR QUALQUER MEIO CONVENCIONAL OU ELETRÔNICO, PARA FINS DE ESTUDO E PESQUISA, DESDE QUE CITADA A FONTE.

e-mail: artemis@artemisedionizio.com.br

Ferraz, Artemis Rodrigues Fontana

F381a Arquitetura moderna das escolas "S" paulistas, 1952-1968: projetar para a formação do trabalhador / Artemis Rodrigues Fontana Ferraz. --São Paulo, 2008.

520 p. : il.

Tese (Doutorado - Área de Concentração: História e Fundamentos da Arquitetura e do Urbanismo) - FAUUSP.

Orientadora: Maria Lúcia Caira Gitahy

1.Escolas - Arquitetura - São Paulo (Estado) - 1952-1968

2.Arquitetura moderna 3.Trabalhadores - Formação 4.SENAI 5.SENAC 6.SESC I.Título

CDU 727.1(816.1)

Projeto Gráfico e preparação de imagens

Artemis R. F. Ferraz e Aline R. Fontana

Capa

Artemis R. F. Ferraz e Aline R. Fontana 
À Dionízio Eduardo Ferraz 
A todos que me acompanharam até aqui.

다단

Ao Deus que me guarda, orienta e abre os melhores caminhos.

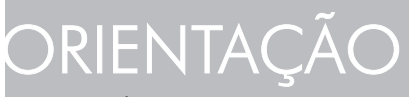

À orientadora Prof. Dra. Maria Lucia Gitahy, pela amizade, confiança, estímulo, experiência, rigor e preciosa sabedoria insubstituível em cada passo desta pesquisa. Ao Prof. Dr. Kenneth Frampton da Graduate

School of Architecture, Planning and Preservation, Columbia University, Nova York, pelo apoio durante o período de pesquisa desenvolvida nesta Universidade.

\section{SUPORTE}

Às professoras integrantes da Banca de Qualificação,

Dra. Mônica Junqueira de Camargo e

Dra. Maria Alice Rosa Ribeiro, pelas importantes contribuições apresentadas à tese. Aos funcionários responsáveis pelos arquivos da Faculdade de Arquitetura e Urbanismo de Santos (FAUS), do SENAI e da Memória do SENAC, pela disponibilização de material aqui documentado, parte fundamental para

a leitura arquitetônica. À equipe de trabalho das bibliotecas da FAUUSP e da Columbia University.

\section{AMOR}

Aos meus pais, José Antonio e Gerlena, por todo o amor. Aos meus irmãos, Aline e Alexandre, pela torcida constante, em especial à minha irmã pela ajuda na edição gráfica da tese. Ao marido e amigo arquiteto Dionízio pela compreensão "sem fronteiras", o meu muito obrigada.

\section{AMIZADE}

Aos colegas do Grupo de Pesquisa do HSTTFSAU, meus agradecimentos pelas ricas contribuições produtivas. Em especial ao amigo Fernando Atique pela "dica" e incentivo desde o processo seletivo do doutorado em 2003. Ao grande amigo Jeff Buggini, meu querido Pio, pela ajuda e suporte com a pesquisa em Nova York.
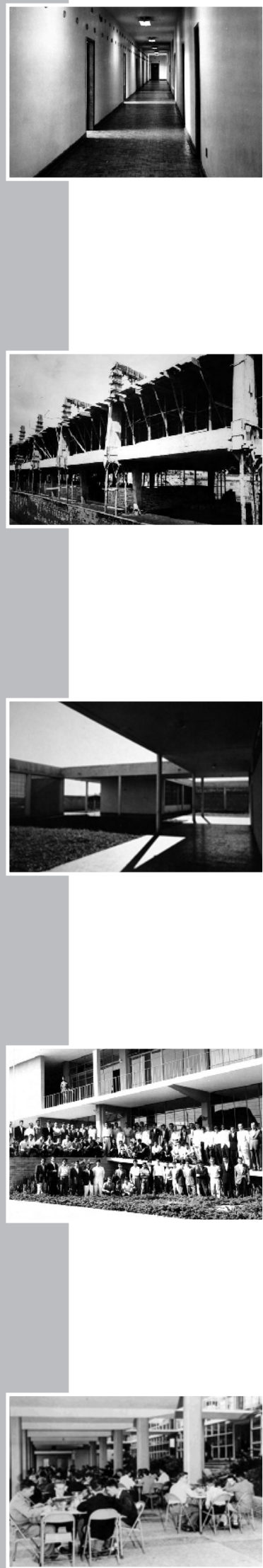




\section{CAPÍTULO 1}

As origens e referências dos "S": SENAI, SESC e SENAC

1.1 Estado Novo e pós-Segunda Guerra: a criação dos "S"

1.2 Mudanças na orientação político-educacional brasileira 1.2.1 A experiência da Primeira República:

da industrialização às reformas educacionais na década de 1920

1.2.2 Industrialização e organização racional do trabalho:

propondo "reforma social"

1.2.3 A valorização do ensino profissionalizante durante o Estado Novo

1.2.4 A redemocratização: a luta pela "educação para todos"

1.2.5 $\mathrm{O}$ regime militar e $\mathrm{o}$ incentivo à formação de cunho profissionalizante

1.3 A experiência norte-americana:

trabalho, educação e arquitetura

1.3.1 American Progressivism: "Learn by Doing"

1.3.2 A demanda pela educação vocacional: Adult Education in America

1.3.3 Educação em transição:

a perceptível mudança em meados do século XX

1.3.4 Inovações arquitetônicas e soluções técnicas do edifício-escola dos anos 1950: American Trade Schools e seus atributos físicos, psicológicos e sociais

\section{CAPÍTULO 2}

Mudança arquitetônica a partir da década de 1950: a experiência das escolas dos "S" no Estado de São Paulo

2.1 As escolas dos anos 1940

2.1.1 SENAI

2.1.2 SESC-SENAC

2.2 Arquitetura Moderna para a Escola Integral nas décadas de 1950 e 1960

2.2.1 SENAI 1952-1968: modernas escolas para o ensino da indústria 2.2.2 SESC-SENAC 1955-1968: modernas escolas para o ensino do comércio

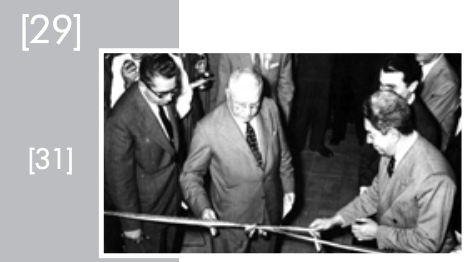

[50]

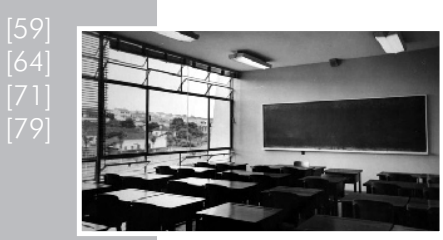

[81]
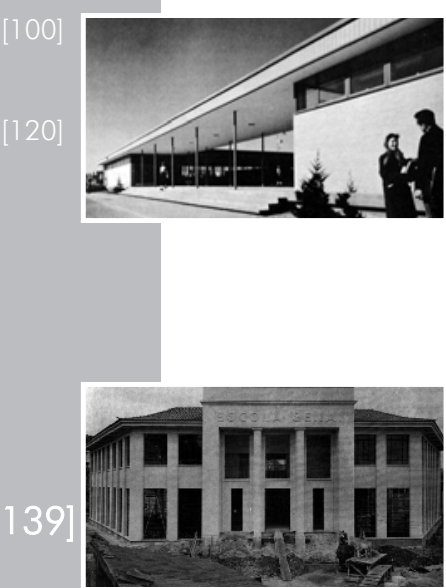

$[141]$

$[141]$

$[149$

[157]

[162]

[325]

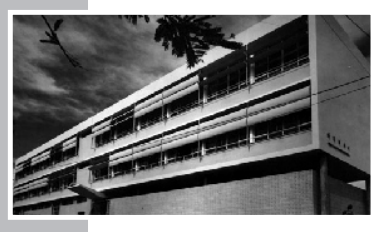



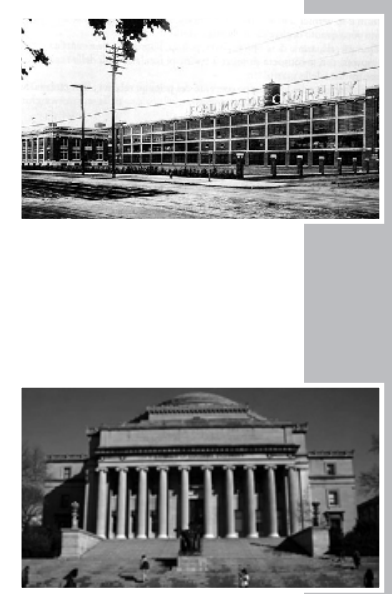

3.2 Educação: elo da modernização do ensino brasileiro 3.2.1 Os educadores John Dewey (1859-1952) e Anísio Teixeira (1900-1971): um levantamento inicial 3.2.2 Aspectos educacionais aplicados ao edifício-escola: os princípios das modernas escolas " $\mathrm{S}$ " 3.2.3 Do Manifesto à construção de uma Escola Nova e Progressiva

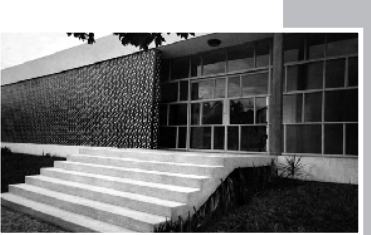

\subsection{Arquitetura Moderna: um gesto para a educação 3.3.1 Arquitetos e engenheiros dos " $\mathrm{S}$ " paulistas: idealizadores e realizadores dos conceitos implícitos em um modo de fazer o edifício-escola}
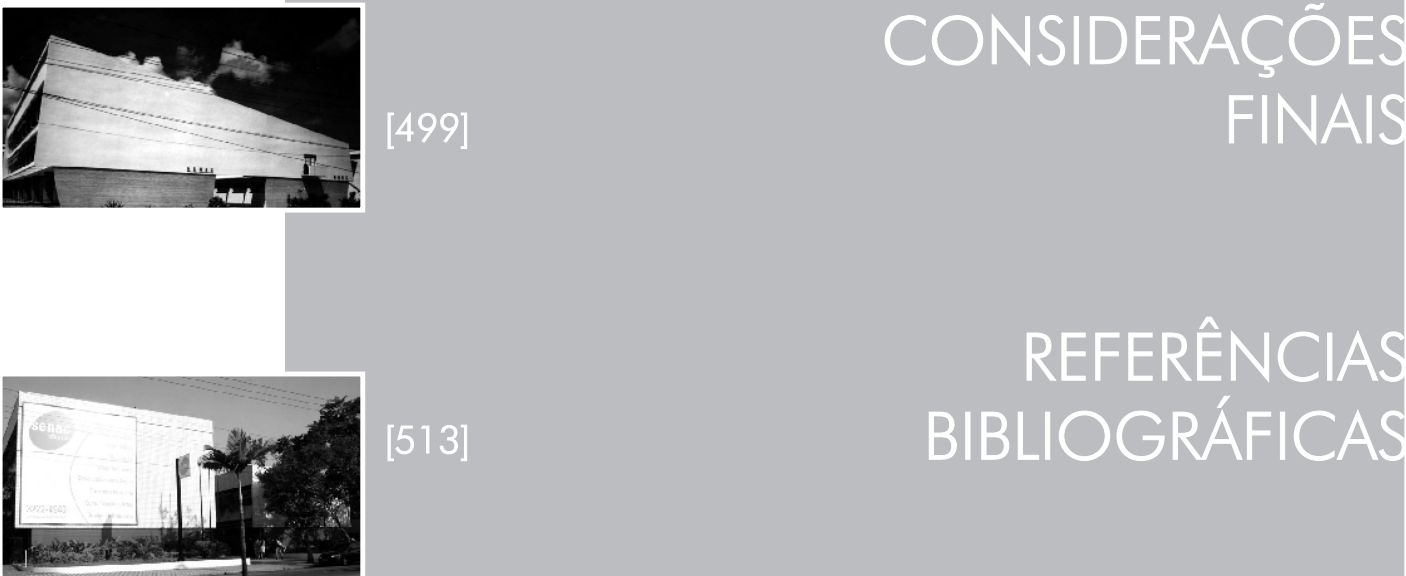


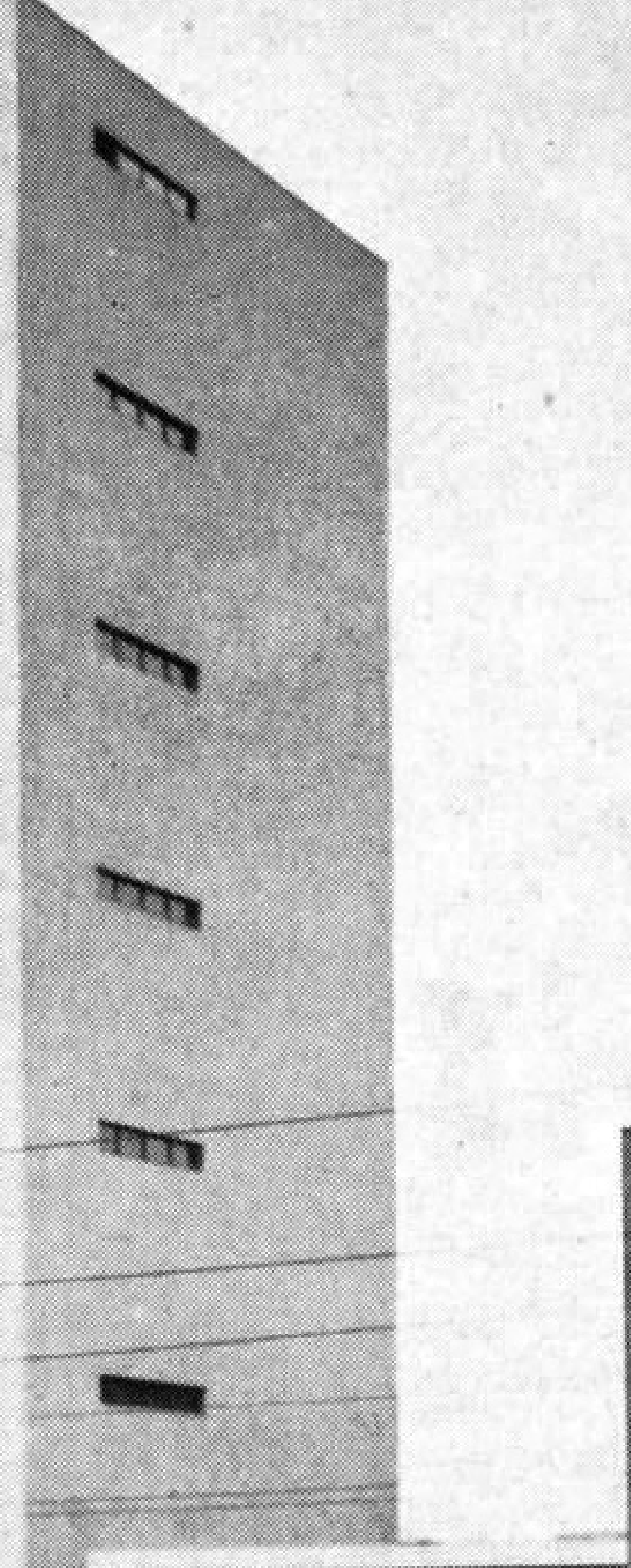


Ao olhar mais atento para a historiografia da arquitetura moderna paulista é possível notar a necessidade de estudos sobre um conjunto de obras que marca presença no processo de afirmação da mesma, a arquitetura escolar moderna realizada nas décadas de 1950 e 1960 como parte de um sistema de edifícios voltados à formação do trabalhador. Trata-se da rede de escolas técnicas dos três "S": SENAI (Serviço Nacional da Aprendizagem Industrial), SESC (Serviço Social do Comércio) e SENAC (Serviço Nacional de Aprendizagem Comercial), especialmente desconhecida no que diz respeito à localização no interior do estado de São Paulo, apenas em raras exceções reconhecida. Esta tese buscou pesquisar e documentar de forma sistemática e lançar um olhar analítico sobre as escolas modernas dos três "S", uma importante produção arquitetônica que se destacou, no estado de São Paulo, como parte de um sistema de formação do trabalhador. É interessante perceber como certos aspectos do edifício-escola moderno tiveram o objetivo de serem estimuladores de uma forma de vida democrática por meio de características físicas, todas elas presentes em cada uma das escolas "S". Analisá-las, levando em conta a história e os fundamentos sociais da sua produção, lendo suas características arquitetônicas, interpretando a proposta de cada idealizador e, investigando sua atualização quanto às experiências similares nos EUA, é o objetivo desta pesquisa.

Consciente da atuação de âmbito nacional dos três serviços "S", esta tese limita suas atenções ao estado de São Paulo, a região mais industrializada do Brasil, berço da burguesia responsável pela concepção e criação destas três grandes instituições e, além disto, significativamente palco da atuação dos industriais e engenheiros paulistas que defenderam e implantaram a organização racional e administração científica do trabalho, participando do debate internacional a respeito desde o início do século XX. É acreditando na construção de uma historiografia capaz de produzir estudos cada vez mais focalizados e profundos, que esta tese se insere. Já se pode observar trabalhos acadêmicos, referenciados ao longo da tese, na produção recente da história da arquitetura moderna brasileira que 
abrem caminhos para esta investigação da arquitetura e dos profissionais idealizadores dos "S. Aliás, desde os primeiros registros da arquitetura moderna no Brasil, algumas destas obras foram notadas. Dois livros famosos o fizeram: o livro organizado pelo MOMA (Museu de Arte Moderna de Nova York), Brazil Builds: Architecture New and Old, 1652 -1942, de Philip L. Goodwin, acompanhou a exposição Brazil Builds que também circulou no Brasil em 1943 e, o livro publicado em 1956, Modern Architecture in Brasil, de Henrique E. Mindlin. Este último, publica a Escola de aprendizado industrial Anchieta, em São Paulo (MINDLIN,1999:164-165), iá contemplando a importância daquela produção arquitetônica paulista do SENAl juntamente com sua produção carioca, a Escola de aprendizado industrial em Niterói, Rio de Janeiro (MINDLIN, 1999:162-163). Segundo SEGAWA (1999:14) estes dois livros "são trabalhos apologéticos da arquitetura moderna, [...], formadores de mitografias da moderna arquitetura brasileira".

Quanto às fontes documentais, as publicações periódicas da época apresentam um grande número de obras "focalizadas", incluindo as escolas dos três sistemas "S". Portanto, os periódicos especializados da época constituem uma das principais fontes de informação bibliográfica sobre os exemplares modernos dos " $\mathrm{S}$ " explorados, sendo eles: Acrópole, Arquitetura e Engenharia, Arquitetura e Decoração Habitat, Bem Estar, além do periódico $A B$, publicado em 1972, e de outros artigos publicados pela revista Arquitetura e Urbanismo.

Tendo os "S" como tema central, é oportuno destacar os trabalhos publicados pelos próprios Serviços, ainda lacunares no que diz respeito à arquitetura moderna, mas essenciais como registros institucionais e/ou comemorativos que ajudam a divulgar as formas de trabalho do SENAI, SENAC e SESC. Diferentemente das publicações dos "S", e de importância metodológica para esta pesquisa, há o livro publicado por Barbara Weinstein, (Re)Formação da classe trabalhadora no Brasil (1920-1964), um trabalho de análise da história social brasileira voltado principalmente ao SENAI. Para compreender as relações entre os requisitos da qualificação profissional, a filosofia pedagógica dos métodos de ensino 
(principalmente industrial e comercial) e os estudos que recuperam o processo histórico internacional e brasileiro, vários autores foram consultados. Sobre o período histórico e o paradigma técnicoeconômico taylorista-fordista, buscou-se apoio em autores muito conhecidos como Eric Hobsbawn, David Noble, Harry Braverman, Maria Victória Benevides, Bóris Fausto, entre outros. Já, sobre a Escola Nova e a filosofia pedagógica, a pesquisa voltou-se a autores como John Dewey, Fernando de Azevedo, Anísio Teixeira e Hélio Duarte. Foram investigadas também as dissertações e teses relacionadas ao longo do trabalho.

A consulta aos arquivos de projetos arquitetônicos e respectivo material iconográfico foi fundamental para a tese, sobretudo para a investigação dos projetos originais dos " $\mathrm{S}$ " modernos. Assim, por meio dos arquivos do SENAI, SESC e SENAC, juntamente com o arquivo da Faculdade de Arquitetura e Urbanismo de Santos (FAUS), os projetos arquitetônicos foram investigados - levantados, fotografados, analisados e parcialmente redesenhados (quando necessário).

Contando já com um corpo de evidências coletadas no Brasil sobre o objeto de estudo e com a hipótese de possíveis relações em propostas norte-americanas tanto no campo da gestão do trabalho, quanto nos campos da pedagogia e, especialmente, no da arquitetura, aponta-se a pertinência da visita ao acervo bibliográfico e documental da Columbia University, Nova York, dado o vínculo de Anísio Teixeira com John Dewey. Sendo assim, o plano de atividades no exterior, sob a orientação do Prof. Kenneth Frampton, traz novos desafios à tese. Coleta-se em Nova York documentação e bibliografia sobre o paradigma técnico-econômico taylorista-fordista, sobre os métodos pedagógicos de renovação do ensino (industrial e comercial) e sobre a Arquitetura Moderna das escolas americanas.

Assim, ao pesquisar o período significativo da arquitetura moderna paulista do início da década de 1950 até aproximadamente - final da década de 1960, despontam inúmeras questões merecedoras de investigação quanto às escolas " $\mathrm{S}$ " modernas. Quais eram as demandas educacionais da sociedade brasileira? Quais eram as propostas para a educação do trabalhador? Qual o perfil do jovem que se inscrevia para os cursos do SENAI, SESC e SENAC? 
Como era a escola naquele momento? Qual grupo de educadores, arquitetos, engenheiros e administradores vinham atuando na concepção de uma escola moderna paulista? Como e em que momento a arquitetura atendeu às principais premissas pedagógicas implantadas por estes Serviços? Quais os agentes sociais envolvidos? Que indústria e que comércio eram aqueles? Quais eram, então, os princípios aplicados à arquitetura? Houve referências internacionais no processo de concepção destas escolas modernas "S"? Ao complementar a pesquisa nos Estados Unidos, na Columbia University, novas questões apareceram na averiguação de uma atualização dos profissionais brasileiros quanto à experiência americana de construção de escolas similares. Quais premissas norteamericanas podem ser comparadas àquelas características dos " $\mathrm{S}$ "? Qual o vínculo dos agentes envolvidos nos "S" modernos com o "americanismo"? Com a modernização pedagógica? Qual a relação da pedagogia com a arquitetura norte-americana das escolas técnicas e vocacionais?

Inegavelmente esta tese foi construída para investigar os exemplares dos "S" e acabamos optando pelo desafio de responder a estas questões. Dividida em três capítulos, procura abranger os diversos aspectos pertinentes à compreensão dos "S", o momento histórico, os agentes sociais envolvidos, as referências norteamericanas e a própria arquitetura produzida. Neste percurso, interessa à pesquisa explorar a maneira como estes Serviços expressaram na arquitetura moderna de suas escolas, as estratégias envolvidas em sua pedagogia. $\bigcirc$ fato é que entre diferentes campos de indagação, a investigação dos vários períodos dentro do século XX revela interligações e repercussões no ensino e na arquitetura da escola industrial e comercial brasileira.

Desta forma, o capítulo 1, intitulado As origens e referências dos "S": SENAI, SESC e SENAC, trata primeiramente da criação dos "S" dentro da década de 1940, do Estado Novo ao período pósSegunda Guerra Mundial, como uma resposta aos problemas da economia nacional que se voltava para uma aceleração da industrialização brasileira. Apresenta as estratégias dos personagens históricos envolvidos na construção de cada "S", fossem eles políticos, 
empresários industriais, comerciais ou outros profissionais, todos comprometidos em promover uma verdadeira reforma social através da qualificação do trabalhador brasileiro para atender aos requisitos da economia do período.

Num segundo momento, o capítulo 1 enfatiza as mudanças na orientação político-educacional brasileira, construindo uma abordagem histórica, e acompanhando suas influências aos " $\mathrm{S}$ ", $\mathrm{da}$ década de 1920 até o final da década de 1960. Entre diferentes campos de indagações, os "S" são investigados enquanto agências voltadas para a formação do trabalhador da indústria e do comércio brasileiro que tiveram seu desenvolvimento vinculado aos desafios do século XX. Assim, há o esforço em articular as complexas relações entre os diferentes períodos do século $X X$, objetivando compreender como as premissas pedagógicas das escolas "S", expressas pela arquitetura moderna, foram concretizadas a partir da década de 1950. A partir da década de 1920, as reformas educacionais buscam modernizar o ensino preparando um novo modo de vida associado a um mundo em que a presença de um mercado de massas e de uma produção em massa encontra sua metáfora emblemática na linha de montagem do modelo americano automobilístico " $\mathrm{T}$ ", produzido pela Ford. Em seqüência, a década de 1930 é sublinhada pelo impulso centralizador da Segunda República - a Revolução de 1930, o corporativismo, a racionalização do trabalho, o avanço da produção industrial, o investimento na mão-de-obra especializada. Em outra direção, o Manisfesto dos Pioneiros da Educação Nova (1932) aponta a educação como direito de todos (1934), e a criação de universidades. Já o terceiro período, marca a tentativa de conter a democracia e enfatiza a valorização do ensino profissionalizante durante o Estado Novo (1937-1945). Também, coloca os questionamentos relacionados à educação, existentes à época, como a discussão dos slogans "educação para todos" e "dualismo social" e, enfatiza a Constituição de 1937 e sua política educacional voltada à preparação do trabalhador para as oportunidades do mercado, apoiando o ensino pré-vocacional e profissional. Este terceiro perído culmina no início da década de 1940 com a criação do SENAl, apoiada por Getúlio Vargas. Já o quarto período, a 
"redemocratização" pós Segunda Guerra Mundial, resgata a volta da "educação para todos" dentro dos preceitos proclamados na década de 1930 pelos Pioneiros da Educação Nova. Também, trata da renascente democracia da República Nova e a responsabilidade do Estado, quanto à educação, e enfatiza os momentos de criação do SESC e do SENAC dentro das discussões sobre as diretrizes para a educação nacional. Este é o período fértil da educação, que deu suporte ao crescimento e consolidação dos " $\mathrm{S}$ ", dentro da idéia de escola-classe e escola-parque. Assim, como referência para a arquitetura das escolas "S", O Convênio Escolar, um acordo estabelecido entre o Estado e o município de São Paulo, é destacado por sua atuação no campo da arquitetura escolar e por ser, em si mesmo, uma escola que preparou os arquitetos e outros profissionais envolvidos na concepção das escolas " $\mathrm{S}$ ". $O$ fato é que, o momento das décadas de 1950 e 1960, aqui chamado "era de ouro" da construção de escolas dos "S" - numa referência ao trabalho do historiador Eric Hobsbawm'-, inspirou a construção das escolas "democratizadas" pela arquitetura moderna. Por fim, o quinto período limita a pesquisa no final da década de 1960, num momento em que um golpe dentro do golpe militar abortou as iniciativas de se renovar a educação brasileira, ampliando os horizontes da formação do trabalhador e, do contrário, buscou estreitar a formação educacional geral, atribuindo a esta um cunho profissionalizante.

A terceira e última parte do capítulo 1 apóia-se em pesquisa realizada na Columbia University e revela a importância das referências internacionais, em especial a norte-americana, no momento histórico pós - Segunda Guerra Mundial. Estas referências informaram as opções quanto à gestão do trabalho, à pedagogia e à arquitetura relevantes aos "S". Ressalta o contexto histórico do movimento social que galvanizou as camadas médias norteamericanas, denominado "The Progressive Movement". Compreende a mudança pedagógica voltada à educação vocacional norteamericana, amplamente disseminada pelo aumento da oferta e da

\footnotetext{
' Hobsbawm publicou estudos importantes como: A Era da Revoluções (1789-1848), A Era do Capital (1848-1875) e A Era dos Impérios (1875-1914). Também, especificamente sobre o século XX, Hobsbawn é responsável pela A Era do Extremos, publicado em 1994, na Inglaterra.
} 
demanda por escolas técnicas e pelo ensino adulto, que rebate nas novas soluções projetuais da arquitetura do edifício-escola. Neste sentido, procura-se apontar este momento de mudança na arquitetura escolar norte-americana, da escola tradicional para a moderna, como influência na atitude, hábito, comportamento e criatividade do indivíduo. Quanto à renovação pedagógica, é surpreendente constatar como a experiência norte-americana de modernização desta arquitetura voltada para a formação do trabalhador deu-se no mesmo período de construção das escolas modernas dos "S" no Brasil. Os requisitos americanos mostram como a pedagogia guiou a arquitetura do edifício-escola, com pressupostos semelhantes à "era de ouro" da arquitetura dos "S". Isto é, nota-se uma "americanização" tanto no plano das idéias, quanto nas práticas, neste caso específico aqui estudado.

Já o capítulo 2, intitulado Mudança arquitetônica a partir da década de 1950: a experiência das escolas dos "S" no Estado de São Paulo, apresenta os grandes produtos desta trama, as escolas "S". Primeiramente, apresenta as escolas dos anos 1940, de linguagem tradicional, e mostra as distintas fases de sua evolução. Reconhecida como uma década de transição, a década de 1940 obviamente marca a implantação inicial de cada "S", dos primeiros estabelecimentos com caráter de emergência, em prédios alugados, até $\mathrm{o}$ início da construção das primeiras escolas, projetadas no final desta década, com características monumentais. As escolas até então construídas passaram a não satisfazer às exigências pedagógicas do ensino industrial e comercial, e a idéia de construir novas escolas foi reconhecida. Sendo assim, como seria esta escola diferenciada, voltada para o aluno? Este capítulo trata de responder a esta questão.

Em seqüência, a segunda parte do capítulo 2 enfatiza o objeto de estudo desta tese, as modernas escolas "S" no Estado de São Paulo. Com o propósito de ampliar a perspectiva de análise da arquitetura moderna brasileira, são pesquisados, documentados, apresentados e analisados de forma individualizada os projetos arquitetônicos de 23 escolas do SENAI e 10 do SESC e do SENAC, em ordem cronológica, concebidos de 1952 a 1968. Ao compreender estes dois momentos históricos, o primeiro da década de 
1940 e o segundo de 1952 até 1968, é notável como os projetos deste segundo momento fizeram parte da nova pedagogia em sintonia com a arquitetura moderna. Assim, pelo estudo destas 33 projetos é possível comparar os novos princípios pedagógicos aplicados à arquitetura escolar dos "S". Complementar à "leitura" documental e bibliográfica, a "leitura" projetual das obras investigadas confirma a mudança pedagógica dos "S", na década de 1950, e revela os dados físicos e conceituais de cada escola, juntamente com seus idealizadores. As escolas adotaram um novo programa construtivo: salas de aula, oficinas, administração, recreio, auditório, sala de reunião, biblioteca, teatro ao ar livre, sede da associação de exalunos, campo de esportes e piscina. E, atendendo a esta nova concepção, a opção pela arquitetura moderna visando despertar o aluno para os seus atributos, e para sua própria formação de trabalhador. Apresentadas pelo SENAl, as sete características pedagógicas - crescimento, flexibilidade, atratividade, interligação, sociabilidade, rendimento e economia - foram utilizadas na arquitetura de suas escolas, assim como foram rebatidos nos demais " $\mathrm{S}$ " voltados ao ensino comercial. Afora o papel da arquitetura e de seus idealizadores, a relação das escolas também revela a localização da rede dos três "S". Para o SENAl, são projetados cerca de $60 \%$ dos edifícios na cidade de São Paulo e na grande região metropolitana: Escola Anchieta Vila Mariana, São Paulo (1952); Internato, Campinas (1952); Têxtil Central do Brás, São Paulo (1952); Escola João Martins Coube, Bauru (1953); Escola de Piracicaba (1954); Pavilhão Social do Brás, São Paulo (1956); Escola e Internato de Santos (1956); Escola de Tatuapé (1957); Escola de São Caetano do Sul (1957); Escola de Jundiaí (1957); Escola de Sorocaba (1958); Escola Fundação Romi, Santa Bárbara d'Oeste (1958); Oficina de calçados Mooca, São Paulo (1959); Escola de Mogi das Cruzes (1959); Escola da Mooca, São Paulo (1960); Escola de Ribeirão Preto (1960); Escola de São Bernardo (1961); Escola de São Carlos (1961); Escola Conde José Vicente de Azevedo, Alto do Ipiranga, São Paulo (1964); Escola de Osasco (1964); Escola de Guarulhos (1967); Escola do Bom Retiro, São Paulo (1968); Escola de Limeira (1968). Já, ao observar a relação das escolas SESC e SENAC nota-se que 70\% dos edifícios 
foram projetados no interior e no litoral paulista: Escola Sesc-Senac de Ribeirão Preto (1955); Escola Sesc-Senac de Marília (1955); Escola Sesc-Senac de Bauru (1956); Escola Senac de Araraquara (1956, não construída); Escola Sesc-Senac de Santos ( 1956); Edifício Sede em São Paulo (1957); Escola Senac de São José do Rio Preto (1958); Edifício Avenida Tiradentes em São Paulo (1963); Escola Senac de Botucatu (1964); Escola Senac de Santo André (1964). Desta maneira, tanto para o ensino da indústria, como para o ensino do comércio, em todo o estado de São Paulo é notável o papel do aperfeiçoamento técnico dos trabalhadores no período em tela.

Após explorar a maneira como os "S" expressaram na arquitetura de suas escolas as estratégias dos agentes sociais envolvidos em sua construção, o capítulo 3 segue no sentido de reconhecer o papel destes agentes na construção dos Princípios técnicos, educativos e arquitetônicos animadores da "Escola Nova" dos "S". Divido em três partes, este capítulo é fundamental para compreender como esta arquitetura moderna brasileira dialogou com - paradigma técnico-econômico predominante no plano internacional, as propostas pedagógicas e $O$ ensejo de seus idealizadores no modo de fazer o edifício-escola. Primeiramente, é investigada a hipótese de que o conteúdo do ensino industrial e comercial ministrado pelos " $\mathrm{S}$ " esteja ligado aos requisitos da formação profissional focalizados nos quadros do paradigma técnicoeconômico taylorista-fordista, incluindo os avanços da psicologia aplicada. Qual seria o trabalhador urbano-industrial desejável no estado de São Paulo? Quais seriam os "requisitos" do mercado de trabalho da época? Pensando nestas questões é importante notar que este paradigma técnico-econômico nasce nos Estados Unidos, no final do século XIX, no momento da reestruturação produtiva conhecida como Segunda Revolução Industrial. Mas, ao período estudado, especialmente após a Segunda Guerra Mundial, difunde-se pelo mundo todo, em primeiro lugar, pela própria Europa. A posição dos EUA após o conflito é um facilitador. Em São Paulo, o debate de idéias é introduzido desde os anos da Primeira Guerra, graças a líderes empresariais como Roberto Simonsen e Roberto Mange, atualizados no plano das idéias, buscaram sempre colocar o Brasil em 
contato com a modernidade. No entanto, é só nos anos aqui estudados, desde a década de 1940, é que se chega ao terreno das práticas. Assim, é importante entender o trabalho do SENAI, SESC e SENAC na formação do trabalhador brasileiro dentro de premissas pautadas pelo paradigma técnico-econômico predominante no plano internacional e de origem norte-americana. Os "S" pensavam a formação do trabalhador com ênfase na prática, buscando ensinar por meio da experimentação associada à teoria, dentro do princípio técnico de "saber como fazer". Outra vertente relacionada ao fordismo é a própria contribuição de Ford à arquitetura industrial norte-americana, referenciada pela historiografia da arquitetura moderna, ao reconhecer o valor dos projetos do "arquiteto de Ford", Albert Kahn.

Na segunda parte deste capítulo são evidenciados os métodos pedagógicos de modernização no ensino industrial e comercial, promovidas pelos educadores Anísio Teixeira (1900-1971) - e seus companheiros do movimento pela Escola Nova -, baseados nas idéias de John Dewey (1859-1952). O vínculo entre as Américas é enfatizado. As características pedagógicas implantadas pelos "S" foram baseadas na pedagogia norte-americana? Quais seriam as repercussões destes métodos no ensino industrial e comercial brasileiro? $\mathrm{E}$, ainda mais claramente, como os aspectos educacionais poderiam estar relacionados às sete características pedagógicaarquitetônicas das modernas escolas "S"? De fato, tais indagações são tratadas de forma cautelosa no decorrer deste capítulo, constatando o elo da modernização no ensino brasileiro.

A terceira parte do capítulo 3 destaca os autores da moderna arquitetura paulista das escolas "S", com ênfase nos arquitetos e engenheiros de espírito pioneiro, que atuaram fortemente na construção da arquitetura moderna escolar na década de 1950. Vale aqui sobressair o papel desta geração tanto na construção dos "S" como na arquitetura moderna brasileira enquanto resposta própria, nacional aos problemas de seu tempo. Primeiramente, pela ordem cronológica das escolas projetadas, é estabelecida a primeira geração dos autores "S" pelos projetos concebidos para o SENAI - Hélio de Queiroz Duarte, Ernest Robert de Carvalho Mange e Roberto José 
Goulart Tibau - e, para os SESC e SENAC - Oswaldo Corrêa Gonçalves, Eduardo Corona, Rubens Carneiro Viana e Ricardo Siervers. Esta geração, além de ser a pioneira a projetar os "S" modernos, é também assim denominada por ser representada pelos arquitetos e engenheiros que já vinham atuando anos antes no Convênio Escolar. Além desta primeira geração, apoiada por Roberto Mange e pela atuação do engenheiro Luiz Alfredo Falcão Baver, a partir de 1957 outros nomes foram surgindo e formando a segunda geração dos "S". No SENAl destacam-se Lúcio Grinover, Ayako Nishikawa, Melanias M. Nagamini, Luiz Carlos Costa e Ariaki Kato e, no SESC e no SENAC, Osmar Tosi, Adolfo Rubio Morales, Jorge Wilheim e Miguel Juliano e Silva. Como referência brasileira, as modernas escolas " $\mathrm{S}$ " paulistas revelam-se uma marca da consistente relação entre estas duas gerações que, ao atender os diferentes requisitos da indústria e do comércio, caracterizam diferentemente os traços de cada edifício-escola.

Atingindo o objetivo principal de ampliar a perspectiva de análise da arquitetura moderna brasileira, dentro do processo de investigar, documentar e compreender o alcance da arquitetura moderna produzida pelas escolas "S" paulistas, é que culmina 0 projetar para a formação do trabalhador. Por fim, as considerações finais desta tese tratam do diálogo entre Brasil e Estados Unidos na arquitetura das escolas vocacionais - por meio de dados já apresentados nos capítulo 1, 2 e 3 - e, do estado atual de conservação arquitetônica de alguns exemplares das escolas modernas "S", por meio de levantamento fotográfico. Com as mudanças sociais e econômicas do final do século $X X$, qual será $O$ destino das modernas escolas dos "S", marcos da arquitetura brasileira?

Como toda pesquisa, além de algumas respostas, esta tese oferece muitas novas indagações. 

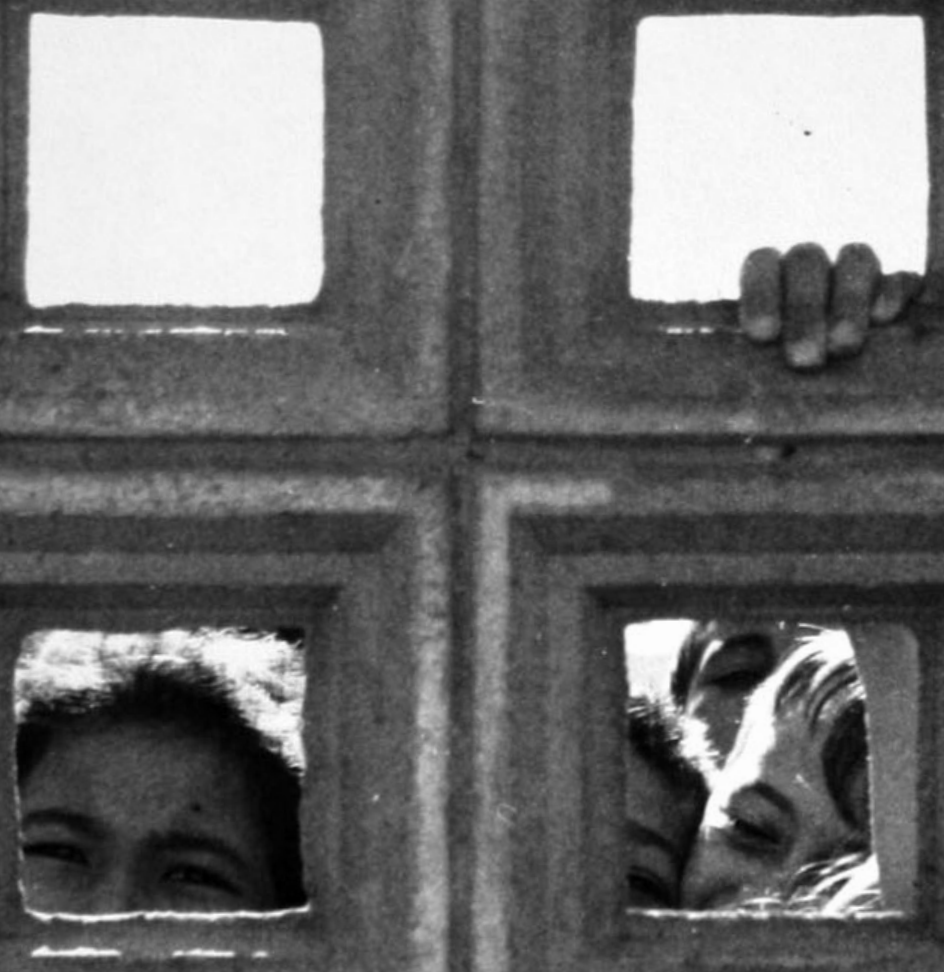

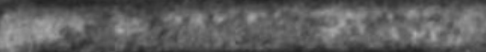

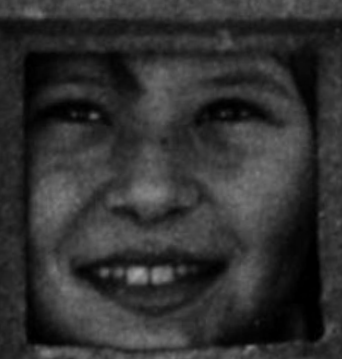

As origens e referências dos "S" SENAI, SESC e SENAC 


\section{As origens e referências dos "S": SENAI, SESC e SENAC}

Com o intuito de ampliar a perspectiva de análise da arquitetura moderna brasileira, é preciso ressaltar, na área escolar, a importante produção que se destacou no estado de São Paulo como parte de um sistema de formação do trabalhador, os três "S": SENAI (Serviço Nacional da Aprendizagem Industrial), SESC (Serviço Social do Comércio) e SENAC (Serviço Nacional de Aprendizagem Comercial). Para tal, é necessário, neste estudo, analisar os agentes sociais envolvidos com a fundação e o funcionamento de cada "S", durante o período em foco. Embora a compreensão dos "S" seja fundamental, este estudo não pretende dar conta de todos os aspectos da história institucional desses órgãos. Pelo contrário, interessa à pesquisa explorar a maneira como estes Serviços expressaram na arquitetura de suas escolas, as estratégias dos agentes sociais envolvidos em sua construção, fossem eles empresários industriais, comerciais ou outros profissionais, todos eles comprometidos em promover uma verdadeira reforma social através da introdução do trabalhador brasileiro na vida urbana moderna.

A criação dos "S", do Estado Novo ao período pós-Segunda Guerra Mundial, é entendida como uma resposta aos problemas da economia nacional, num momento histórico em que o Brasil vivia um período de desenvolvimento da industrialização. Ao mesmo tempo, este capítulo procura construir uma abordagem histórica das mudanças na orientação metodológica e da política educacional brasileira, acompanhando suas influências e sua evolução da década de 1920 até o final da década de 1960.

A pesquisa atenta também para a importância das referências internacionais que informavam as opções pedagógicas, industriais e arquitetônicas adotadas pelos Serviços estudados aqui. Neste sentido, no contexto do movimento social norte-americano denominado como "progressivismo", foi importante compreender o aumento da demanda por escolas técnicas e pelo ensino adulto. É no âmbito deste 
movimento que se dá a mudança pedagógica naquele país, as novas soluções projetuais utilizadas e, a compreensão do edifício-escola como influência na atitude, hábito, comportamento e criatividade do indivíduo. Esta experiência norte-americana tem sido menos estudada do que a fundamental referência encontrada nos pressupostos da Arquitetura Moderna, em especial a influência dos $\mathrm{CIAM}^{\prime}{ }^{\prime}$ e da Bauhaus², que permitem compreender de que maneira o propósito de uma nova vida social implicou em abranger vários aspectos ao criar uma nova arquitetura.

interessante é perceber como certos aspectos do edifício moderno acabaram por ter como objetivo serem estimuladores de uma forma de vida democrática. Muitas destas características físicas estão presentes nas modernas escolas "S". Analisá-las, levando em conta sua história e os fundamentos sociais da sua produção é o objetivo desta pesquisa.

\footnotetext{
1 Além da experiência norte-americana de uma arquitetura pós-guerra, a nova arquitetura dos " $\mathrm{S}$ " estava informada a respeito de outras vertentes internacionais importantes no ideário do Movimento Moderno. Embora muito conhecida é preciso lembrar a importância dos CIAM's (Congressos Internacionais de Arquitetura Moderna) e, dentre eles, ressaltar o objetivo do I CIAM de estabelecer um programa geral de ação que visava tirar a arquitetura do impasse acadêmico e colocá-la em seu verdadeiro meio econômico e social (KOPP, 1990: 147) através de uma habitação para o mínimo nível de vida. Assim, a arquitetura moderna dos "S", ainda que de cunho técnico, social e econômico, não habitacional, também refletiu a sua maneira este pensamento: mostrar o papel que a arquitetura deveria desempenhar na solução dos problemas do modo de vida do homem no novo contexto da sociedade industrial, romper com a tradição de uma arquitetura pautada por aspectos estéticos e evidenciar as relações entre arquitetura, economia e sociedade. Os "S", cada qual como uma unidade, buscavam atender ao ensino renovado e à arquitetura moderna. Assim, ao voltar ao contexto histórico internacional, esta síntese de aprimoramento e a noção de unidade vêm de encontro a propostas já anunciadas no início do século $X X$.

${ }^{2}$ Além dos CIAM's, vale lembrar parte do que Gropius pretendia para a Bauhaus2: uma escola alemã de arte e tecnologia idealizada como uma nova unidade, o objeto industrial produzido visando a grande massa, um ensino pautado entre o paralelismo da prática e da teoria, o contato com a realidade de trabalho, a experiência de cada estudante de trabalhar nas oficinas, o produto standard e, a presença de professores adequados para o êxito da formação a obter (GROPIUS, 1997: 29-44). Estes princípios remetem aos conceitos pedagógicos preconizados principalmente pelo SENAI, na década de 1950, tais como interligação, sociabilidade, rendimento e economia. Ainda dentro desta relação com a Bauhaus, paralelamente à integração do ensino à arquitetura, no Sistema "S" é nítida a evolução da noção de funcionalidade como uma boa resolução dos problemas de organização de locais de trabalho, de reunião e de convívio em comum. Também, à medida em que a arquitetura dos "S" propunha tornar o edifício-escola uma das bases do progresso brasileiro, quer seja na indústria, no comércio ou nos serviços sociais, é evidente a busca por soluções nos aspectos técnicos (ventilação e iluminação), sociais (trabalho em grupo) e espaciais (circulação e integração entre as partes) também assumidas na Bauhaus.
} 


\subsection{Estado Novo e pós-Segunda Guerra: a criação dos "S"}

A criação dos "S", entre o Estado Novo e a República Nova, tem um caráter corporativista dentro de uma década marcada pela crescente presença do Estado nas relações industriais, cada vez maior desde o começo do século XX. A responsabilidade pela capacitação profissional e por serviços sociais voltados aos trabalhadores da indústria e do comércio, foi delegada às organizações dos " $\mathrm{S}^{\prime \prime}$. Por decreto do governo, adotou-se um modelo de financiamento tripartite em que Estado, empresários e trabalhadores de cada setor contribuíam para a manutenção destes Serviços. Na prática, os industriais brasileiros assumiram o controle do SENAI (e do SESI) e os empresários do comércio o controle do SESC e SENAC, desempenhando papel fundamental no desenvolvimento das relações industriais e da disciplina de trabalho no Brasil. Assim, os "S" buscaram articular a colaboração entre as classes e diminuir a luta entre elas, bem aos moldes do que era preconizado à época de sua criação.

Tendo os "S" como tema central, é oportuno rever a produção historiográfica a eles dedicada, lacunar no que diz respeito à arquitetura moderna, mas essencial ao trabalho do historiador, abrangendo as contingências que ajudam a explicar as formas assumidas pelo trabalho do SENAI, SENAC e SESC. Primeiramente, cabe destacar os trabalhos publicados pelos próprios Serviços, aqui classificados metodologicamente, como trabalhos institucionais e ou comemorativos.

Especificamente sobre o SENAI, cabe destacar os trabalhos publicados dentro desta classificação. Dividido em dois volumes, o livro De homens e máquinas (1991) é um inventário colocado ao público como instrumento de pesquisa para o conhecimento da

3 Estes órgãos foram financiados e administrados por associações industriais e comerciais, do que pelo próprio Estado que os criara. 
história do SENAI e do ensino industrial. Apoiando-se na documentação deixada por Roberto Mange, apresenta parte do arquivo pessoal do eminente professor, doado ao Arquivo Edgard Levenroth da Universidade de Campinas (UNICAMP), garantindo o acesso a pesquisadores e reafirmando o sentido histórico deste acervo. Outra referência na historiografia do SENAl é O Giz e a graxa - meio século de educação para o trabalho (1992), uma publicação comemorativa do primeiro século do SENAI de São Paulo. Constitui um estudo sobre alguns aspectos de industrialização brasileira, antes e depois do SENAI, evidenciando a importância do mesmo não somente como uma instituição prestadora de serviços à sociedade, através do preparo do trabalhador industrial, mas como um representante da concretização de um projeto educacional brasileiro. Também, como publicação recente, Histórias e Percursos; o Departamento Nacional do SENAl 1942-2002 (2002), comemora os 60 anos deste órgão no Brasil, focalizando os personagens que fizeram o SENAI, assim como o processo de consolidação de seu papel histórico no quadro do ensino profissional brasileiro. Já dentro das publicações do SESC, destaca-se o SESC São Paulo 50 anos - uma idéia original (1997), um livro comemorativo dos primeiros 50 anos deste serviço, que apresenta a síntese de sua história, seus objetivos e algumas de suas escolas. Outro livro institucional, publicado pelo SENAC, Rede de Unidades SENAC-SP: Novos paradigmas arquitetônicos em educação (1994), apesar do título, não aborda as unidades escolares modernas em estudo, mas sim enfatizada os "novos paradigmas arquitetônicos" da década de 1980.

De uma maneira geral, estes livros publicados pelos próprios "S", como um todo, divulgam o objetivo de cada Serviço e enfatizam principalmente os aspectos positivos de suas atuações, sem ressaltar uma visão crítica do Serviço dentro da história social brasileira. Também, entre os poucos livros que lidam com a arquitetura, nota-se a lacuna na análise das escolas dos "S" no período delineado por esta pesquisa.

\footnotetext{
${ }^{4}$ Estes, responderam à prática de ações educacionais e à oferta de diversificados serviços educacionais, tais como o exercício de atividades práticas até $\circ$ desenvolvimento de softwares.
} 
Diferentemente das publicações de caráter institucional ou comemorativo, de importância metodológica para esta pesquisa é o livro publicado por Barbara Weinstein, (Re)Formação da classe trabalhadora no Brasil (1920-1964) como um trabalho de análise da história social brasileira que muito contribui na compreensão da história e premissas dos "S", principalmente do SENAI. A autora historia a "invenção" e atuação deste órgão em São Paulo, entre 1920 e 1964, e ressalta que seu surgimento significou a vitória de seus idealizadores na tarefa de convencer o Estado e os próprios industriais da necessidade de sua existência. Mais que isso, analisa sua contribuição para a implantação de uma organização racional do trabalho, treinando uma mão-de-obra especializada, como exemplo de uma idéia materializada em um projeto de reforma da sociedade brasileira.

Consciente do papel dos três "S" como organizações nacionais, esta pesquisa concentra suas atenções no estado de São Paulo, por uma série de razões. A primeira, é que o estado de São Paulo é, sem dúvida, a região mais industrializada do Brasil e conseqüentemente sempre foi área de conflitos entre capital e trabalho. A segunda, é que a burguesia paulista foi a responsável pela concepção e criação destas três grandes instituições. Além disto, embora o entusiasmo pela racionalização esteja associado à Europa do pós-Segunda Guerra ${ }^{5}$, significativamente foram os industriais e engenheiros paulistas que defenderam e implantaram a organização racional e administração científica, participando do debate internacional a respeito desde o início do século XX. Sendo assim, a liderança empresarial paulista teve importante papel político e ideológico na história do Brasil do século XX, estendido além das fronteiras de seu Estado:

\footnotetext{
5 Dentro do processo de difusão do taylorismo vale destacar que "a difusão das técnicas tayloristas ocorre no país natal de Taylor no primeiro quartel deste século $(X X)$. Neste momento, tanto dirigentes industriais quando operários qualificados procuram reorganizar as relações de trabalho dentro da fábrica: se os primeiros desejavam quebrar a crescente autonomia dos segundos, obtida em função do ascenso do movimento sindical americano, estes almejavam ampliar sua esfera de interferência na definição das condições de trabalho", segundo RAGO \& MOREIRA (2003:39). A difusão do taylorismo na Europa só expande-se mais completamente no segundo pós-Guerra.
} 
"Contudo, os conceitos de organização racional e administração científica não poderiam ser considerados como idéias estrangeiras, exceto no sentido mais convencional de terem surgido fora das fronteiras físicas do Brasil. Seria mais apropriado dizer que essas idéias iriam se tornar tão intimamente ligadas à modernidade que poderiam facilmente atravessar as fronteiras de quaisquer sociedades em processo de industrialização. Ao mesmo tempo, a organização racional, no sentido lato, era passível de modificações em contextos nacionais específicos".

(WEINSTEIN, 2000:26)

Sobre as origens dos "S" e o papel que estes desempenharam no Brasil, não se pode ignorar as circunstâncias históricas em que é difundido um discurso sobre a "organização racional", a "administração científica" e a "paz social", desde a década de 1920, entre os educadores, engenheiros e industriais paulistas. $\bigcirc$ interesse pela racionalização, crescente na década de 1920, longe de ser um modismo, intensificou-se nas décadas de 1930 e 1940 assumindo formas progressivamente institucionalizadas para sua disseminação (ver item 1.2 deste capítulo). Como parte da implementação e concretização do tecido social urbano, industrial e comercial, preconizado por este discurso, surgem os "S" na década de 1940. Apesar desta crescente valorização da racionalização durante os anos formativos, cada um dos " $\mathrm{S}$ " encontrou resistência ideológica e política, deparou-se com oposição às suas atividades e com críticas de empresários que se opunham e subestimavam o trabalho proposto. Neste sentido, no que diz respeito ao SENAI, Bárbara Weinsten (2000) enfatiza:

\footnotetext{
"As memórias das pessoas ligadas ao SENAI naqueles primeiros anos sempre mencionam a indiferença ou hostilidade em relação à organização. Segundo um dirigente do SENAI ligado a área da psicotécnica, os industriais viam o SENAI como 'mais uma instituição governamental que estava lá só para tirar o dinheiro deles' Muitos desses depoimentos afirmam que, inicialmente, as indústrias enviavam seus aprendizes
} 
menos promissores, os 'piores alunos' ao SENAI, pois eles consideravam o programa como perda de tempo. [...]. Ao que parece, o SENAI, inovador em sua estrutura em seu caráter ao mesmo tempo público e privado, deparava-se com grande ceticismo entre os industriais".

(WEINSTEIN, 2000:191-192)

Assumindo atitudes flexíveis, o SENAI, SENAC e SESC foram se adaptando às mudanças políticas, econômicas e culturais brasileiras. Assim, é importante relatar separadamente o percurso de cada um destes três órgãos para melhor compreender suas características institucionais, ainda hoje duradouras. Os Decretos-leis que criaram os três "S" e a legislação posterior regulamentando esses novos serviços traçaram apenas o esboço inicial de suas estruturas. Ou seja, a missão de cada "S", descrita com precisão e, ao mesmo tempo, às claras, permitiu aos empresários da indústria e do comércio a abertura para alimentá-los com programas adequados ao seu tempo. A fundação e o percurso histórico dos "S", na prática, não foram idênticos mas, sem dúvida, essas três organizações motivaram diferentes tipos de objeções da parte dos empresários industriais e comerciais aos quais prestaram serviços.

A organização dos "S", intimamente vinculada à formação do trabalhador incorpora, durante e após a Segunda Guerra, as questões colocadas pela reestruturação produtiva mundial, conhecida como a Segunda Revolução Industrial. A criação propriamente dita do SENAI (Decreto-lei 4.048/1942), em 22 de janeiro de 1942, surge assim dentro do governo de Getúlio Vargas (1882-1954) 6 num contexto político que já havia efetuado a implantação das escolas de aprendizes (Constituição de 1937) e a obrigatoriedade dos cursos de aperfeiçoamento profissional (Decreto-lei 1.238/1939). Sem dúvida, a Confederação Nacional da Indústria (CNI), implantada desde 1938, propiciara o surgimento do primeiro "S", SENAl. Ao término da Segunda Guerra e com a expansão das indústrias nacionais, a importância da formação e do treinamento profissional tornou-se

\footnotetext{
6 Getúlio Vargas, ditador do Brasil durante o Estado Novo (1937-1945), apoiou a criação do SENAI em 1942. Segundo FAUSTO (1994:335), entre 1930 e 1945 o governo Vargas passou por várias fases, mas desde logo a política trabalhista aparece como um dos aspectos mais coerentes de seu governo.
} 
cada vez mais evidente, culminando na criação da Confederação Nacional do Comércio (CNC), em 1945. Em 1946, no governo provisório de José Linhares (1886-1957) ${ }^{7}$, é criado o SENAC (Decretos-lei 8.621/1946) $^{8}$, em 10 de janeiro de 1946, no mesmo dia em que a primeira diretoria do CNC toma posse 9 . Posteriormente, - governo Dutra $(1883-1974)^{10}$ criou O SESC (Decreto-Lei 9.853/1946), em 13 de setembro de 1946, atribuindo à CNC a incumbência de criar a entidade desde logo denominada Serviço Social do Comércio, com a finalidade de promover o bem-estar social.

Líderes empresariais, entre eles Roberto Simonsen, tornaram então a iniciativa de consolidar as Confederações da Indústria e do Comércio, como órgãos de cúpula do setor sindical empresarial, instituindo, paralelamente o SENAI - SESI, em 1945, e o SESC SENAC, em 1946. Assim, é criado o modelar sistema de aprendizagem profissional e serviço social dos industriários e dos comerciários brasileiros. Especificamente quanto ao SENAI, vale ressaltar que o Ministro da Educação Gustavo Capanema"1, no âmbito da "Reforma Capanema", em 1942, regulamentou as Leis Orgânicas do Ensino, compostas por Decretos-lei ${ }^{12}$ que estruturaram o ensino industrial e comercial, sendo responsável pela criação do

7 José Linhares, advogado, foi presidente da República durante três meses e cinco dias, de 29 de outubro de 1945 a 31 de janeiro de 1946. Exerceu a presidência por convocação das Forças Armadas, como presidente do Supremo Tribunal Federal, após a derrubada de Vargas (FAUSTO, 1994).

${ }^{8} \mathrm{O}$ presidente José Linhares baixou os Decretos-leis 8.621 e 8.622 em 10 de janeiro de 1946, sendo o primeiro para atribuir à CNC o encargo de organizar e administrar escolas de aprendizagem comercial, criando o Serviço Nacional de Aprendizagem Comercial, e o segundo, para regulamentar a aprendizagem dos comerciários (Decretos-leis 8.621 e 8.622).

${ }^{9}$ A primeira diretoria da Confederação do Comércio tomou posse em 10 de janeiro de 1946, em sessão solene realizada no Teatro Municipal do Rio de Janeiro (SENAI, 1991).

${ }^{10} \mathrm{O}$ general General Eurico Gaspar Dutra toma posse como Presidente da República do Brasil em 31 de janeiro de 1946. Seu governo foi marcado pela promulgação da nova Carta Constitucional, em 18 de setembro de 1946, que regeu a vida do país, com caráter liberal e democrático, por mais duas décadas (FAUSTO, 1994). Dutra também foi o responsável pela criação de outro "S", o Serviço Social da Indústria (SESI), em 25 de junho de 1946, conforme Decreto-lei 9.403/1946.

${ }^{11}$ Gustavo Capanema esteve à frente do Ministério da Educação durante o governo Getúlio Vargas, de 1934 a 1945 (FAUSTO, 1994:337). O papel de Capanema foi importantíssimo no ensino brasileiro e pode ser explorado em Tempos de Capanema (SCHWARTZMAN, BOMENY \& COSTA, 1984).

12 Foram estes os Decretos-lei: Decreto-lei 4.073, de 30 de janeiro de 1942, que organizou o ensino industrial; Decreto-lei 4.048, de 22 de janeiro de 1942, que instituiu o SENAl; Decreto-lei 4.244, de 9 de abril de 1942, que organizou o ensino secundário em dois ciclos: o ginasial, com quatro anos, e o colegial, com três anos; Decreto-lei 6.141, de 28 de dezembro de 1943, que reformou o ensino comercial. 
próprio SENAI. Assim, o Decreto-lei 4.048/1942 cria o SENAI "com o intuito de propiciar a organização e a administração, em todo País, de escolas de aprendizagem para industriários" e, ao mesmo tempo, fornece aos industriais um escudo técnico para enfrentar uma nova era de mobilização sindical e democratização. Dentro do processo de criação e expansão do SENAI, o empresariado industrial brasileiro reconheceu a necessidade de instituir não apenas a aprendizagem de menores como também o treinamento, aperfeiçoamento e a especialização dos empregados adultos (BOLONHA, 1969:3).

Para entender a criação do SENAl, antes mesmo da Lei Orgânica do Ensino Industrial ${ }^{13}$, é preciso evidenciar a atuação de dois personagens históricos: Roberto Cochrane Simonsen (18891948) ${ }^{14}$, engenheiro civil formado na Escola Politécnica de São Paulo em 1909 (GITAHY \& PEREIRA, 2002:139) e, Roberto Mange (1885$1955)^{15}$, engenheiro formado pela Escola Politécnica de Zurique em 1910 (SENAI, 1991:9).

13 Esta lei foi assinada oito dias após a criação do SENAI, conforme Decreto-lei 4.073, de 30 de janeiro de 1942, que organizou o ensino industrial.

${ }^{14}$ A trajetória de Roberto Simonsen é estritamente relacionada ao estudo proposto. Engenheiro civil adepto do taylorismo, Simonsen começou a discutir a racionalização do trabalho já durante o funcionamento de sua empresa, a Companhia Construtora de Santos (fundada em 1912). Nos anos seguintes, investiu em outros setores, como a indústria de materiais de construção. Em 1916, fundou e passou a presidir o Centro dos Construtores e Industriais de Santos, que objetivava inovar nas relações entre patrões e empregados no Brasil. Em 1928, atendendo aos industriais paulistas, foi criado o Centro das Indústrias do Estado de São Paulo (CIESP), de cuja primeira diretoria Roberto Simonsen fez parte como vice-presidente. Foi responsável pela criação do IDORT, em 1932. Em 1935 assumiu a presidência da Confederação Industrial do Brasil (ClB), posteriormente rebatizada como Confederação Nacional da Indústria (CNI). Em 1937, assumiu a presidência da Federação das Indústrias do Estado de São Paulo (FIESP). Em 1942, no ano da criação do SENAI, Simonsen foi nomeado para o conselho consultivo da Coordenação de Mobilização Econômica, órgão federal que desempenhou importante papel na condução da economia brasileira no contexto da Segunda Guerra Mundial (SENAI, 1992). Assim, sua liderança foi evidente na modernização industrial brasileira do período. Ao falecer, Simonsen era, além de senador, presidente da Companhia Construtora de São Paulo, presidente da Cerâmica São Caetano, presidente da Companhia Paulista de Mineração, presidente da Federação das Indústrias do Estado de São Paulo, vicepresidente da Confederação Nacional de Indústrias e vice-presidente do Conselho Superior da Escola Livre de Sociologia e Política.

15 Roberto Mange foi um dos fundadores do IDORT junto com os engenheiros Armando de Salles Oliveira e Aldo Mário de Azevedo (também diretor do CIESP entre 1930 e 1931), e os empresários Henrique Dumont Villares e Luís Tavares Alves Pereira, que desempenharam papéis importantes na organização da indústria no país. "O Instituto de Organização Racional do Trabalho surgiu a partir do trabalho de uma comissão constituída em 1929 pela Associação Comercial de São Paulo, que gerou o Instituto Paulista de Eficiência, transformado em junho de 1931 em IDORT. O Instituto integraria um sistema de instituições cujo objetivo era organizar a elite industrial brasileira e viabilizar projetos formulados pela categoria. Haveria de integrar este sistema o CIESP (transformada em 1931 em FIESP), o IDORT, o SENAI, o SESI e a Escola Livre de Sociologia e Política de São Paulo. O aumento da produtividade, via racionalização do trabalho e a promoção da cooperação entre operário e patrão, 
"Simonsen, à frente da Federação das Indústrias do Estado de São Paulo, percebia com clareza a importância da mão-de-obra qualificada para a continuidade do crescimento industrial, principalmente de São Paulo. Roberto Mange, professor da Politécnica de São Paulo, era o pioneiro, no Brasil, no emprego de métodos racionais na formação de trabalhadores e aplicava seus conhecimentos em diversas entidades paulistas, além de dar assessoria ao próprio Ministério da Educação e Saúde. Do encontro dos dois, ocorrido ainda nos anos 30, resultou não só uma sólida amizade, mas também a concepção de muitos projetos".

(SENAI, 1992: 56)

Com o SENAI, Roberto Simonsen e Roberto Mange consolidaram uma série de realizações que vinham desenvolvendo desde a década de 1920, cada um atuando em seu campo, entretanto com o objetivo comum de colocar o Brasil em contato com a modernidade da Segunda Revolução Industrial.

\begin{abstract}
“Durante o período que vai de meados da década de 1920 a meados da década de 1930, o entusiasmo das lideranças dos industriais brasileiros e de seus aliados intelectuais pela racionalização e pela administração científica se manteve. Embora as idéias expressas em primeiro lugar por Roberto Simonsen e Roberto Mange na década anterior tenham sofrido algumas modificações, o interesse pelo taylorismo básico e pelos princípios fordistas aumentou e assumiu novas formas institucionais".
\end{abstract}

(WEINSTEIN, 2000: 71)

A aparente precocidade do movimento de racionalização no contexto brasileiro está vinculada às carreiras destes dois homens,

solidária com este aumento, era o objetivo central do IDORT" (CORREIA, 2002:1). A trajetória de Mange, suas idéias revelam sua fundamental atuação no SENAI. Mange assumiu o Departamento Regional de São Paulo do SENAl em 28 de agosto de 1942, até 1955, ano de sua morte. Salienta-se que primeiramente, a partir de 1942, Mange adotou a idéia das escolas funcionarem em edifícios emprestados, as chamadas instalações provisórias. Posteriormente, no início da década de 1950, após estudos feitos como diretor do Departamento, Mange ressaltou a necessidade de adaptar o SENAI às "características intrínsecas" do aluno, inclusive à arquitetura de suas escolas, uma feição particular e inconfundível. Assim, a idéia de construir novas escolas foi por ele reconhecida (SENAI, 1992). 
engenheiros que representaram de formas inter-relacionadas as aspirações daqueles que defendiam a racionalização como uma solução para os problemas econômicos e sociais brasileiros. Os engenheiros "Robertos", um que se tornou industrial e o outro que se tornou educador, assumiram de diferentes formas a disseminação e implementação dos princípios da organização racional do trabalho, principalmente em São Paulo. Neste sentido, os "S" são exemplares destas formas progressivamente institucionalizadas.

Apesar da racionalização estar diretamente ligada à economia industrial e aos agentes sociais a ela associados, cabe destacar que estes não estavam sozinhos, mas sim em contato com um crescente grupo $^{16}$ (educadores, médicos, engenheiros e outros profissionais) que também trabalhou pela racionalização, porém como uma base ideológica. Para eles, o método científico era um meio de reorganizar não somente a indústria e o comércio, mas também a sociedade brasileira. Dentro deste pressuposto e, no que tange ao escopo desta tese, Roberto Mange é figura proeminente deste grupo de profissionais e intelectuais, nitidamente presente na criação e na história do SENAI.

O trabalho do SENAI, pioneiro no Brasil, teve suas origens ligadas ao IDORT - Instituto de Organização Racional do Trabalho (1931) e ao CFESP - Centro Ferroviário de Ensino e Seleção Profissional (1934), e, nas suas origens, esteve fortemente ligado à ferrovia ${ }^{17}$ (SENAI, 1992:59). A história destes órgãos não é objeto aqui, entretanto é marcante no caso do SENAI a presença e a influência dos que atuaram neste cenário dos anos 1930 no Brasil.

\footnotetext{
"Embora fundamentais, operários qualificados não são a única necessidade da sociedade industrial em seu conjunto. Aos novos métodos de aprendizagem e produção devem ser associados ritmos de vida e comportamentos, destinados a reforçar essa 'pedagogia do industrialismo', e isso vai acontecer nas escolas, nas fábricas, nos escritórios, nas ruas e até nas casas. Para
}

\footnotetext{
${ }^{16}$ Este grupo, já originado no IDORT, era formado por proeminentes educadores como Lourenço Filho e Fernando de Azevedo, médicos como Geraldo de Paula Souza e Moacyr Alvaro e, engenheiros como Gaspar Ricardo Júnior e Roberto Mange (WEINSTEIN, 2000:46).

17 Até 1952 o ensino ferroviário oferecido pelo SENAI achava-se centralizado no Departamento Regional de São Paulo, onde funcionava o Serviço de Escolas Ferroviárias e de Isenção (SENAI, 2002:41).
} 
dar conta desse conjunto de exigências, no inverno de 1931, foi inaugurado o Instituto de Organização Racional do Trabalho - IDORT. Desta vez, coube à Associação Comercial de São Paulo patrocinar os estudos destinados à implantação desse veículo fundamental de estudo, promoção e aplicação dos princípios da organização racional do trabalho. [...]. Lourenço Filho, educador; Armando de Salles Oliveira, engenheiro e diretor do jornal 'O Estado de São Paulo'; Aldo Mário de Azevedo e Henrique Dumont Villares, industriais; Geraldo de Paula Souza e Antônio Carlos Pacheco e Silva, médicos; Roberto Mange, engenheiro, diretor da Escola Profissional de Mecânica do Liceu de Artes e Ofícios, coordenador do Instituto de Higiene de São Paulo... Essas as personagens principais da história dos primeiros anos do IDORT, com Roberto Mange, mais uma vez, ocupando papel de destaque".

(SENAI, 1991: 98-99)

A experiência de Roberto Mange funde-se com sua íntima relação com o SENAI. A questão da qualificação técnica da mão-deobra já vinha sendo por ele encaminhada e experimentada ${ }^{18}$, porém ainda com abrangência limitada. Por força da aproximação entre governo e empresários, esta questão, que tomou corpo na década de 1930, tornou-se incontestável na década de 1940. Mais uma vez, na concretização dos planos para a ampliação e aperfeiçoamento do ensino profissional para a indústria, a atuação de Roberto Mange, fundamental para o SENAl, estendeu-se da criação em 1942, até sua morte, em 1955, sempre como diretor do Departamento Regional de São Paulo (6 ${ }^{a}$ Região).

Desde a Primeira Guerra Mundial, os trabalhadores brasileiros viveram a transição de uma economia agrária para a crescente urbanização e industrialização, aceleradas pelas dificuldades de importação causadas pela mesma. Esta transição apontou a utilidade de um programa de treinamento para a adaptação dos trabalhadores aos novos métodos construtivos e de técnicas industriais. O SENAI foi um "promissor programa de treinamento padronizado" (MINDLIN,

\footnotetext{
18 Entre essas, além das ações de Mange no IDORT (1931) e no CFESP (1934), destaca-se sua atuação no Liceu de Artes e Ofícios, na década de 1920, como diretor do Curso Profissional de Mecânica (ver capítulo 3).
} 
1999:31) que colaborou por reduzir os problemas técnicos das construções, juntamente com o crescimento das indústrias locais. Além disso, sua atuação não se restringiu somente a um padrão científico para a formação profissional, mas também foi referencial para experiências em outras áreas ${ }^{19}$.

O alcance territorial do SENAl é evidente, desde 1942, quando foi organizado nacionalmente em dez regiões administrativas, de acordo com suas respectivas atividades industriais. Essa estruturação era composta por: $1^{a}$ Região - Maranhão, Piauí e Ceará; $2^{a}$ Região - Rio Grande do Norte, Paraíba, Pernambuco e Alagoas, $3^{a}$ Região - Sergipe e Bahia, $4^{a}$ Região - Rio de Janeiro e Espírito Santo; $5^{a}$ Região - Minas Gerais; $6^{a}$ Região - São Paulo; $7^{a}$ Região - Paraná e Santa Catarina; $8^{a}$ Região - Rio Grande do Sul; $9^{a}$ Região - Pará, Amazonas e os territórios do Amapá, Rio Branco e Acre; $10^{a}$ Região Mato Grosso, Goiás e território de Guaporé (atual Rondônia).

No que diz respeito à infra-estrutura e à arquitetura das primeiras escolas SENAI, na década de sua formação, os edifícios seguiram padrões tradicionais, com linguagens do ecletismo ao racionalismo, e refletiram as fases distintas de evolução da indústria: de instalações provisórias em prédios emprestados a projetos de prédios definitivos e próprios. Nesta fase, algumas destas escolas foram projetadas pela empresa Severo Villares ${ }^{20}$, projeto do escritório Técnico Ramos de Azevedo21. Já no final da década de 1940, o

${ }^{19}$ Como por exemplo, no que diz respeito à racionalização na moradia, o IDORT desempenhou no país um papel central na aplicação do taylorismo na organização da moradia, difundindo idéias e práticas referentes à construção, ao projeto e arranjo interno da casa e à reorganização das tarefas domésticas, de modo a aumentar a eficiência no âmbito dos diferentes aspectos associados à habitação. Ainda nas décadas de trinta e quarenta, alguns arquitetos e engenheiros como Affonso Reidy, Carmen Portinho e Henrique Mindlin, contribuíram através de escritos e de realizações para difundir concepções de racionalização da habitação postuladas nos primeiros Congressos Internacionais de Arquitetura Moderna (CIAM). Também, iniciativas no campo da moradia foram realizadas pelos Institutos de Aposentadorias e Pensões, especialmente pelo Instituto dos Industriários (CORREIA, 2004).

20 Caracterizadas pela segunda fase da década de 1940, estas escolas foram construídas em terrenos próprios do SENAl, com o projeto de prédios definitivos, com o estudo das necessidades industriais e com o início de muitas construções. Por isso, nessas escolas, foi dada ênfase especial ao que se refere às oficinas para aprendizes, indispensáveis ao desenvolvimento do sistema SENAI. Numa fase preliminar de ação, estas novas escolas tinham uma arquitetura tradicional, com aspecto aproximado do neoclássico, padrão utilizado em edifícios ainda hoje existentes, conforme apresentado no capítulo 2.

${ }^{21}$ Vale lembrar que a carreira de Francisco de Paula Ramos de Azevedo (1851-1928) esteve diretamente relacionada com Roberto Mange, primeiramente, na década de 1910, na Escola Politécnica de São Paulo e, na década de 1920, no Liceu de Artes e Ofícios (GITAHY, 1986). 
momento de avaliação do desempenho do SENAI desencadeou uma mudança arquitetônica. Mange, após estudos feitos como diretor do SENAl, evidenciou no início da década de 1950 a necessidade de se adaptar toda a organização do ensino "às características intrínsecas" do aluno SENAI, "inclusive à arquitetura de seus estabelecimentos de ensino, uma feição eminentemente particular e inconfundível" (BAUER, 1953:6). Assim, a partir da década de 1950, a idéia de construir novas escolas foi reconhecida.

Seguindo a mesma trajetória de criação do SENAI, o SENAC, em 1946, já no fim do Estado Novo e durante o Governo Provisório, foi regulamentado pelo Ministério da Educação e Saúde Pública, que neste momento estava a cargo de Raul Leitão da Cunha. A Lei Orgânica do Ensino Primário, composta por Decretos-lei ${ }^{22}$ que regulamentaram o ensino primário, normal e agrícola, também foi responsável pelo Decreto-lei 8.621/1946 que cria o SENAC. Com o intuito de propiciar a organização e administração, em todo o País ${ }^{23}$, de escolas de aprendizagem comercial para empregados do setor comercial, o SENAC estava concretizando as mudanças exigidas pela sociedade após a Revolução de 1930.

Decreto-lei 8.621/1946, antes de dispor sobre a criação do SENAC, no artigo $2^{\circ}$, atribui à CNC "o encargo de organizar e administrar, no território nacional, escolas de aprendizagem comercial" e, estas escolas, deveriam manter "cursos de continuação ou práticos e de especialização para os empregados adultos do comércio, não sujeitos à aprendizagem". Precisamente, no artigo $3^{\circ}$, os objetivos educacionais e sociais do SENAC são delineados:

\footnotetext{
22 Foram estes os Decretos-lei: Decreto-lei 8.529, de 02 de janeiro de 1946, para organizar o ensino primário a nível nacional; Decreto-lei 8.530, de 02 de janeiro de 1946, para organizar o ensino normal; Decretos-lei n 8.621 e 8.622, de 10 de janeiro de 1946, que criaram o SENAC; Decreto-lei n. 9.613 de 20 de agosto de 1946, para organizar o ensino agrícola.

${ }^{23}$ Segundo informações obtidas na Memória Institucional do SENAC em São Paulo, sob os cuidados de Lígia Palhares Silva, o SENAC foi sediado na Capital Federal e descentralizado por meio de Conselhos Regionais e Departamentos Regionais, sendo que o Conselho Regional do Estado de São Paulo, eleito em 13 de julho de 1946, foi o primeiro do Brasil a iniciar suas atividades e a planejar seu órgão executivo, o Departamento Regional de São Paulo. O SENAC de São Paulo foi então instalado do prédio da Associação Comercial de São Paulo, no dia lo de setembro de 1946, iniciando sua contribuição no desenvolvimento da ação educacional em comércio e serviços. Ainda, em dezembro de 1946, a Administração Regional passou a ocupar prédio próprio, na rua Florêncio de Abreu, 305, em São Paulo. No ano de 1950, o SENAC foi transferido deste prédio para prédio alugado na Rua Vieira de Carvalho, 172 e o prédio até então ocupado foi adquirido pelo SESC-SP.
} 


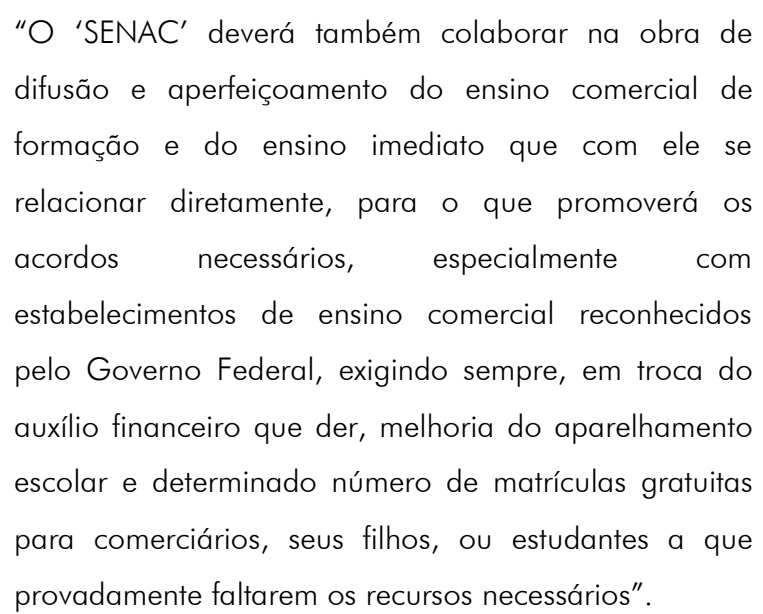

(Decreto-lei 8.621/1946, artigo 3)

Sucessivamente foi criado o SESC através do decreto-lei 9.853, no dia 13 de setembro de 1946, publicado três dias depois no Diário Oficial da União. Em seu artigo $1^{\circ}$, este decreto-lei também atribui à Confederação do Comércio o encargo de criar o Serviço Social do Comércio, da mesma forma como foi estabelecido o SENAC, com os objetivos de "planejar e executar, direta ou indiretamente, medidas que contribuam para o bem-estar social e a melhoria do padrão de vida dos comerciários e de suas famílias, e bem assim para o aperfeiçoamento moral e cívico da coletividade". Já $\circ$ artigo $3^{\circ}$ instituiu uma contribuição compulsória (um pequeno porcentual sobre o montante da folha de pagamento dos empregados), em favor do SESC, "para custeio dos seus encargos" e define como contribuintes "os estabelecimentos comerciais enquadrados nas entidades sindicais subordinadas à Confederação Nacional do Comércio" e os "demais empregadores" que possuam empregados segurados no IAPC (o antigo Instituto de Aposentadoria e Pensões dos Comerciários). Desta forma, o decreto-lei de 1946, além de criar o "bem estar social", conferiu estrutura ao sistema sindical, pois a obrigação de contribuir para o SESC estabeleceu a vinculação da empresa ("os estabelecimentos comerciais") à CNC.

Apenas cinco dias após a criação do SESC vale lembrar que foi promulgada a nova Carta Constitucional, em 18 de setembro de 1946, a qual orientou a vida do país por mais duas décadas, com caráter liberal e democrático. Esta nova Constituição, na área da educação, determinava a obrigatoriedade do ensino primário e diretrizes para as bases da educação nacional. Além disso, a nova 
Constituição fez voltar o preceito de que a educação é direito de todos, inspirada nos princípios proclamados pelo "Manifesto dos Pioneiros da Educação Nova", nos primeiros anos da década de 30. Assim, a criação do SESC, assim como o SESI, adotou modelo semelhante, cabendo a essas entidades privadas estudar, planejar e executar medidas para o bem-estar social e a melhoria do padrão de vida dos trabalhadores do comércio e da indústria, respectivamente. Completava-se, desse modo, o modelo corporativista que acabou por envolver a classe empresarial na organização e manutenção de entidades destinadas à execução de atividades tanto nas áreas de serviços sociais como de formação profissional.

Juntas, as unidades SESC e SENAC, instalaram na década de 1940 as primeiras escolas em municípios como Ribeirão Preto, Santos, Campinas, Bauru, Taubaté, São José do Rio Preto, Franca, Araçatuba, Lins, Botucatu e Araraquara, além da própria Capital. Estes edifícios escolares, de linguagem tradicional, assim como as primeiras escolas do SENAI, foram instaladas em prédios alugados, muitas vezes inadequados para $\bigcirc$ planejamento funcional e pedagógico das atividades propostas de comércio, serviço, cultura e lazer. Assim, se neste primeiro momento as instalações das escolas SESC e SENAC não atenderam aos aspectos da aprendizagem, já no início da década de 1950 a concepção de seus espaços educacionais foi modificada.

Ainda, a coexistência se destaca na criação tanto do SESC como do SENAC. Além de terem sido criados pela CNC, com os decretos-lei baixados pelo Governo Federal, ambos foram resposta aos problemas da economia nacional, discutidos um ano antes, em 1945, na chamada Conferência das Classes Produtoras do Brasil. Vale lembrar que esta Conferência ocorreu entre os dias $1^{\circ}$ e 6 de maio de 1945, na cidade de Teresópolis, no Rio de Janeiro, num momento em que a Segunda Guerra Mundial estava chegando ao fim e $\circ$ Brasil vivia um período de industrialização e de comércio em desenvolvimento, no qual a produção nacional colaborou na substituição das importações e no processo de urbanização. Os empresários brasileiros que se reuniram nesta Conferência, representantes da agricultura, indústria e comércio, divulgaram um 
documento denominado Carta Econômica de Teresópolis, o qual recomendava ao Governo Federal medidas para atender às crescentes necessidades de trabalho na área mercantil. Estes líderes empresariais propuseram $\mathrm{o}$ aperfeiçoamento do ensino médio e superior do comércio, economia e administração, além do estímulo à criação de escolas pré-profissionais. Ainda, segundo SESC (1997:26), estes líderes empresariais fizeram "uma série de recomendações para a melhoria das condições gerais da vida da população brasileira", com o objetivo de encontrar um caminho para a justiça social, harmonizando capital e trabalho. Nessa reunião surgiu a carta da Paz Social, implantando a filosofia e o conceito de serviços sociais custeados também pelas classes patronais.

Não há dúvida de que os decretos-lei que deram origem aos SENAI, SENAC e SESC, instituíram para sua receita a contribuição compulsória das indústrias e das empresas comerciais, com a convicção de que sem receita financeira estas entidades evidentemente não poderiam funcionar. Cada um destes decretos estabelecia os encargos de seus respectivos serviços, como pode ser observado nos artigos $4^{\circ}$ e $5^{\circ}$ do decreto-lei 8.621/1946 do SENAC:

"Art. 4 Para o custeio dos encargos do "SENAC", os estabelecimentos comerciais cujas atividades, de acordo com o quadro a que se refere o artigo 577 da Consolidação das Leis do Trabalho, estiverem enquadradas nas Federações e Sindicatos coordenados pela Confederação Nacional do Comércio, ficam obrigados ao pagamento mensal de uma contribuição equivalente a um por cento sobre o montante da remuneração paga à totalidade dos seus empregados.

$\S 1^{\circ} \bigcirc$ montante da remuneração de que trata este artigo será o mesmo que servir de base à incidência da contribuição de previdência social, devida à respectiva instituição de aposentadoria e pensões.

$\S 2^{\circ} \mathrm{A}$ arrecadação das contribuições será feita, pelas instituições de aposentadoria e pensões e o seu produto será posto à disposição do "SENAC", para aplicação proporcional nas diferentes unidades do país, de acordo com a correspondente arrecadação, deduzida a cota necessária às despesas de caráter geral. Quando as instituições de aposentadoria e pensões não possuírem serviço próprio de cobrança, entrará o 
"SENAC" em entendimento com tais órgãos a fim de ser feita a arrecadação por intermédio do Banco do Brasil, ministrados os elementos necessários à inscrição desses contribuintes.

$\S 3^{\circ}$ Por empregado entende-se todo e qualquer servidor de um estabelecimento, seja qual for a função ou categoria.

$\S 4^{\circ} \bigcirc$ recolhimento da contribuição para o "SENAC" será feito concomitantemente com a da que for devida às instituições de aposentadoria e pensões de que os empregados são segurados.

Art. $5^{\circ}$ Serão também contribuintes do "SENAC" as empresas de atividades mistas e que explorem, acessória ou concorrentemente, qualquer ramo econômico peculiar aos estabelecimentos comerciais, e a sua contribuição será calculada, apenas sobre o montante da remuneração paga aos empregados que servirem no setor relativo a esse ramo".

(Decreto-lei 8.621/1946, artigos $4^{\circ}$ e $5^{\circ}$ )

No caso do SENAl, segundo WEINSTEIN (2000:120), - critério para distribuição dos recursos financeiros beneficiou as áreas mais industrializadas, porém isso não foi de forma gratuita para os industriais, responsáveis pela sobrevivência financeira deste órgão. Criadas por um decreto federal, as contribuições eram compulsórias assim como a contratação do número de aprendizes na indústria, em função do tempo em que cada uma destas indústrias havia garantido seus estudos.

"De acordo com o decreto-lei, toda empresa industrial deveria dar uma contribuição mensal de dois cruzeiros por operário, que depois passou a ser de um por cento da folha de pagamento, para proteger o SENAI dos efeitos da inflação. As empresas com mais de 500 operários eram obrigados a pagar uma sobretaxa de $20 \%$ dos seus pagamentos mensais, mas essa contribuição adicional era destinada à pesquisa e a estágios no exterior, que seriam de maior proveito para as empresas maiores. [...]. Nesse sentido, o SENAI fora organizado para combinar os melhores elementos dos dois campos: a capacidade de coerção do Estado e tendência do setor privado a valorizar a autonomia".

(WEINSTEIN, 2000:120) 
A legislação sobre contribuições compulsórias, presente na criação de cada "S", aumentou o poder e o alcance dos mesmos, em todo o Brasil. Esta base material, na origem dos três "S", reforça o caráter corporativista e tripartite do sistema dos "S" (Estado, empresa e sindicato). Durante o Estado Novo, Vargas apelava para um modelo corporativo de Estado, um sistema político no qual o poder legislativo foi atribuído às corporações. Estas corporações uniam verticalmente setores industriais, comerciais e outros, em um modelo inspirado no autoritarismo tão em voga na época. Este modelo visava estimular a colaboração entre as classes.

Estado, como poder central, buscava consolidar uma estrutura corporativista apresentada como solução para a eficiência e modernização, tão requeridas naquele momento no Brasil. Embora estivesse fechado à participação política da sociedade civil, a elite empresarial, pricipalmente industrial, conseguiu tornar-se o centro das decisões através de diversos conselhos e comissões técnicas, que atuavam junto aos ministérios, conforme previsto pela Constituição de 1934 e mantido na Constituição de 1937. No caso do SENAl, vale lembrar que Roberto Mange participou de várias dessas comissões, tanto ligado ao Ministério do Trabalho como ao Ministério da Educação.

\footnotetext{
"O advento do estado Novo consolidou a participação da classe empresarial nas instâncias governamentais. Multiplicavam-se os órgãos técnicos, principalmente aqueles ligados ao Ministério do Trabalho, Indústria e Comércio e ao Ministério da Educação e Saúde".
}

(SENAI, 1991:74)

O SENAI, por exemplo, deve ser visto como fruto de uma destas comissões técnicas, composta por empresários industriais, junto ao Estado. Em 1941, um ano antes da criação do SENAI, Getúlio Vargas nomeou uma comissão de industriais com o objetivo de que estes estudassem a criação de sistema destinado à formação profissional. Esta comissão foi composta por Euvaldo Lodi, Valentim Bouças e Roberto Simonsen. Estes, para desenvolver o trabalho técnico, convocaram Roberto Mange, entre outros, para colaborar na elaboração de um projeto de lei para a questão da aprendizagem 
industrial. Como resultado, esta comissão propôs a Gustavo Capanema, a criação do Serviço Nacional de Seleção, Aperfeiçoamento e Formação de Industriários (SENAFI), a ser sustentado a partir de uma taxa mensal, paga pelo empregador sobre cada operário, cobrada pelo Instituto de Aposentadoria e Pensão dos Industriários (IAPI). Desta forma, os empresários apresentaram ao governo uma solução para a organização do sistema de ensino industrial no país, benéfica para si mesmos, principalmente no que diz respeito à verba obtida com a arrecadação feita pelo IAPI.

\footnotetext{
"Quase todas as conclusões desse relatório lograram ser incorporadas à proposta de decreto-lei apresentada pela comissão em dezembro de 1941. Capanema, mais uma vez, levantou inúmeras objeções às propostas da comissão. [...]. Capanema chegou a expressar sua aversão ao nome da organização, com sua ênfase mais no 'aperfeiçoamento' que na educação, e recomendou que o programa fosse chamado Serviço Nacional para a Educação Profissional dos Industriários. De nada adiantaram as críticas de Capanema, exceto pela denominação do programa, mas ainda aqui sal vitória foi apenas parcial: no texto final do decreto-lei, a nova organização recebeu o nome de Serviço Nacional de Formação de Industriários. Era evidente que Vargas não partilhava das restrições de seu ministro da Educação ao novo programa, uma vez que ele o assinou com rapidez incomum. Em 22 de janeiro de 1942, Vargas e os ministros da Educação e do Trabalho promulgaram o decreto-lei n ${ }^{\circ} 4048$, criando o SENAI".
}

(WEINSTEIN, 2000: 117-118)

Os decretos-lei dos "S" foram um chamado à ação que, além de influenciar nas decisões econômicas, revelou como os empresário industriais e comerciários deram forma ao pensamento de grupos, à idéia corporativista de organizar a classe trabalhadora ao Estado. Dessa forma, a criação dos "S" ocorreu, ainda que sob o abrigo de um Estado autoritário. A determinação constitucional de encarar o ensino vovacional e pré-vocacional como dever do Estado (a ser cumprido por empresas e sindicatos) teria favorecido a criação dos "S", visando à formação do trabalhador para a indústria e o 
comércio, paralelamente às Leis Orgânicas da Educação Nacional (citadas anteriormente): do ensino industrial e secundário (1942), do ensino comercial (1943) e, do ensino primário, normal e agrícola (1946).

Representado um esforço de concretização da política educacional brasileira, os "S" surgem neste contexto, baseando-se no treinamento técnico para preenchimento de postos de trabalho definidos, com ênfase no fazer, e mantendo o caráter assistencialista da educação técnica. Esta estrutura dos "S", entretando, nas décadas seguintes, sofre uma positiva mudança. É exatamente no momento da expansão e renovação educacional, concretizado nas modernas escolas concebidas nas décadas de 1950 e1960, que esta pesquisa se insere, apontando um paralelo entre o que ocorre em termos de consolidação tanto da pedagogia dos " $\mathrm{S}$ " quanto da arquitetura moderna paulista.

É interessante perceber que, no Brasil, a pesquisa em história da arquitetura pouco explorou, até o momento, as complexas relações entre a linguagem das escolas dos três "S", na década de 1940, com o campo da gestão do trabalho e da política educacional, no período em que foram criados. Tampouco, as modernas escolas "S" tem sido vinculadas ao campo da pedagogia, na época, manifestando-se por uma nova educação brasileira. A proposta era educar, e não apenas treinar, um trabalhador qualificado. De sua ação formativa e pedagógica à arquitetura moderna implantada nos anos 1950, os "S" ampliaram e criaram suas referências. Crê-se, então, que esta investigação compete a fim de melhor compreender e iluminar 0 objeto desta pesquisa. 


\subsection{Mudanças na orientação político-educacional brasileira}

Para compreender a arquitetura moderna produzida pelos sistemas SENAI, SESC e SENAC nas décadas de 1950 e 1960, procura-se construir uma abordagem histórica e metodológica capaz de dar conta do problema aqui analisado.

Como se trata de redes escolares voltadas à qualificação do trabalhador industrial e comercial, estabelecidos no período histórico amplamente conhecido como o da Segunda Revolução Industrial, foi preciso indagar a respeito de aspectos da gestão empresarial daqueles anos - em suma perguntamo-nos a respeito da difusão do paradigma técnico-econômico taylorista fordista no Brasil - na esteira de algumas obras de história econômica e sociologia do trabalho que lidam com os requisitos da qualificação do trabalhador naquele período (RIBEIRO, 1986 e GITAHY, 2000).

Da mesma maneira, o período assiste no Brasil a um movimento de renovação dos métodos pedagógicos, o famoso movimento em prol da Escola Nova. Uma das figuras inspiradoras do mesmo, o baiano Anísio Teixeira, fez seus estudos na Columbia University sob a orientação de John Dewey. Interessa a esta pesquisa compreender a modernização da filosofia pedagógica tal como ela incide nos métodos do ensino industrial e comercial.

E, por fim, um terceiro campo de indagações que compõe e é central à construção da abordagem histórica proposta, é o da presença da própria Arquitetura Moderna, que adquire, no período em estudo, reconhecimento no Brasil e no exterior, com forte conteúdo simbólico. As redes de edifícios escolares aqui focalizadas apresentam-se como uma rica oportunidade para o entendimento dos desafios e dos impasses colocados por sua produção.

A seguir, procura-se acompanhar as mudanças na orientação político-educacional brasileira, pertinentes à compreensão do objeto desta pesquisa. 


\subsubsection{A experiência da Primeira República: \\ da industrialização às reformas educacionais \\ na década de 1920}

O Brasil entrou no século XX com um setor industrial crescendo no bojo de uma economia agrária - exportadora, que predominou até a crise de 1929. É exatamente a partir daí que a indústria brasileira expandiu-se, a um ritmo inédito, superior ao do crescimento da agricultura.

\footnotetext{
"Com um impulso desta ordem, a indústria brasileira expandiu-se a um ritmo até então - entre 1929 e 1939, sua taxa de crescimento foi de $125 \%$ em oposição a uma agricultura que cresceu apenas $20 \%$ no mesmo período. Estes números, na realidade, revelam a ocorrência de um processo de transferência de recursos de um setor agrícola em declínio para um setor industrial em ascensão, com o redirecionamento do excedente acumulado com o capital cafeeiro. Pode-se dizer que, à sua maneira e dentro de seu contexto histórico específico, o Brasil estava vivendo a sua revolução industrial".
}

(SENAI, 1992:21)

Entretanto, para compreender este processo de ascensão da produção industrial cabe aqui resgatar algumas idéias e experiências do Brasil, nas primeiras décadas do século XX. Enquanto os governos da República Velha trabalharam para a formação de um mercado de trabalho abundante, alguns empresários e educadores procuraram atualizar o debate sobre o desenvolvimento industrial.

\footnotetext{
"Felizmente para esse grupo de jovens industriais ambiciosos, ele não estavam sozinhos em sua luta. [...]. Muitos dos principais membros desse grupo não tinham ligação direta com a economia industrial, mas todos eles tinham relações - seja de parentesco, de apadrinhamento ou de amizade - com importantes figuras do mundo industrial. No Brasil, como em toda
} 


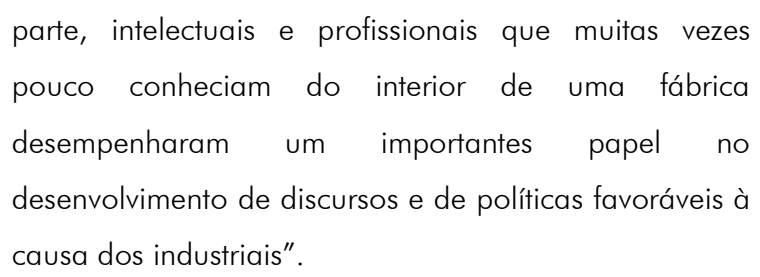

(WEISNTEIN, 2000:45)

fato é que, as articulações do grupo industrialista cuidaram de buscar o apoio do Estado, desde o início do século XX, para garantir o investimento necessário à educação visando à formação profissional qualificada. Roberto Mange representou um marco, neste sentido. Primeiramente, em 1913, como professor da Escola Politécnica de São Paulo, Mange aceita o convite de Antonio Francisco de Paula Souza, diretor da escola, para assumir a cátedra de Engenharia Mecânica aplicada às Máquinas. Dez anos depois, em 1923, Mange torna-se superintendente do Curso de Mecânica Prática no Liceu de Artes e Ofícios ${ }^{24}$ de São Paulo, formando trabalhadores para as principais ferrovias do Estado de São Paulo, como a Companhia Paulista, Sorocabana, Mogiana e a São Paulo Railway. O sucesso deste curso proliferou em 1930, quando a Estrada de Ferro Sorocabana ${ }^{25}$ resolveu assumir a formação de seus profissionais, convidando Roberto Mange para ser o responsável pela implantação do Serviço de Ensino e Seleção Profissional da Estrada de Ferro Sorocabana, dando continuidade ao trabalho iniciado na década de 1920. Assim, Mange dá continuidade a seus estudos voltados à seleção profissional, levados a efeito na Escola Politécnica desde 1913, no Liceu de Artes e Ofícios desde 1923, e no Serviço de Ensino e Seleção Profissional da Estrada de Ferro Sorocabana, em 1930.

\footnotetext{
"Não se deve esquecer que Ramos de Azevedo, que orientou o Liceu de Artes e Ofícios durante trinta anos começara sua carreira na construção de ferrovias no interior do Estado. Este relacionamento iria se estreitar após a criação do Curso Profissional de Mecânica, em
}

\footnotetext{
${ }^{24}$ Cabe destacar, em São Paulo, a experiência do ensino profissional desenvolvida no Liceu de Artes e Ofícios, escola iniciada no final do século XIX. A experiência do Liceu abriu caminhos à criação do SENAl e, de certa forma, obteve a continuidade e expansão de sua proposta através deste (GITAHY, 1986).

$25 \mathrm{Em} \mathrm{1930,} \mathrm{o} \mathrm{diretor} \mathrm{da} \mathrm{Estrada} \mathrm{de} \mathrm{Ferro} \mathrm{Sorocabana} \mathrm{era} \mathrm{o} \mathrm{engenheiro} \mathrm{Gaspar}$ Ricardo Júnior (SENAI, 1991:62).
} 
1923, como uma ampliação do Curso de Mecânica Prática, já existente. As ferrovias Paulista, Mogiana, Sorocabana e São Paulo Railway enviam aprendizes de suas oficinas e os mantém em São Paulo por quatro anos, aperfeiçoando-se no Liceu. $O$ diretor do curso era Roberto Mange".

(GITAHY, M., 1986: 25)

Outro engenheiro de grande influência neste contexto foi Roberto Simonsen. Começando sua carreira na primeira década do século XX, em 1909 trabalhou na Southern Brazil Raiway, em 1910 foi chefe da Companhia de Melhoramentos de Santos e, em 1912, fundou a Companhia Construtora de Santos. Este engenheiro, enquanto empresário industrial, pautou experiências pioneiras no campo da organização do trabalho. Agindo diretamente como técnico administrador, diferentemente mas complementar ao técnico educador Mange, Simonsen trabalhou de forma sistemática e consciente visando aplicar métodos racionais de organização à empresa e desenvolver novas relações de trabalho.

\footnotetext{
"As preocupações mais amplas expressas por Simonsen em dois pronunciamentos públicos em dezembro de 1918, e mesmo no preâmbulo do relatório da companhia daquele ano, indicam que ele já tinha uma visão do taylorismo e da racionalização que ia muito além dos problemas e relações trabalhistas no âmbito estrito de sua firma. [...]. Talvez o mais revelador seja o fato de que ele se refira principalmente a engenheiros e administradores (obviamente incluindo-se aí) mais que a empresários ou patrões. Ao que parece, ele preferia destacar o traço de sua identidade que implicava conhecimento técnico, de preferência à sua autoridade como empresário".
}

(WEISNTEIN, 2000:36)

Ainda no contexto da década de 1910, um elemento atuante na educação profissional em São Paulo, ainda que formal e alheio aos defensores de métodos científicos de treinamento para o trabalho, eram as escolas fundadas por ordens religiosas que davam treinamento para o trabalho manual. Dentro deste conceito, o Decreto 
7.566/1909, de 23 de setembro, propôs a criação de "escolas de aprendizes artífices", distribuídas pelos Estados brasileiros. Nesse documento foram instituídos dezenove sistemas escolares de educação profissional com o objetivo de oferecer aos "desfavorecidos da fortuna" o preparo técnico e instrumental com o intuito de afastar o ócio e a criminalidade e trazer afeição ao trabalho (FONSECA, 1961).

\begin{abstract}
"A destinação do ensino profissional a uma classe social menos favorecida evidencia o caráter assistencialista imputado a esse tipo de educação desde a sua origem e a sua conseqüente marginalização no cenário educacional, principalmente no que se refere às oportunidades de acesso à educação superior".
\end{abstract}

(SIMÃO, 2004:23)

A maioria dos trabalhadores de São Paulo nas primeiras décadas do século XX aprendia ofício de maneira tradicional. $O$ aprendiz, pela observação, iniciava-se nos aspectos do mesmo e, quando mais velho, atingia o nível de competência de um oficial. Neste sentido, durante a Primeira República, foi produzida uma legislação ${ }^{26}$ sobre o ensino, entretanto os problemas do campo educativo persistiam, tais como: analfabetismo, insuficiente número de escolas primárias, deficiente preparação pedagógica e científica dos professores. Além de tudo, o tradicionalismo desta aprendizagem não condizia com os "métodos científicos" de treinamento para o trabalho, defendidos por Mange, Simonsen e outros, como por vários educadores. Da mesma forma, nem todos os políticos partilhavam desta visão da educação e, em $1911^{27}$, um documento foi

\footnotetext{
${ }^{26}$ Além do decreto $7.566 / 1909$, outros decretos foram propostos no início do século XX como: Decreto 1.606, de 29 de janeiro de 1906, criou o Ministério dos Negócios da Agricultura e Comércio, incluindo entre suas atribuições os assuntos relativos ao ensino profissional; Decreto 7.649, de 11 de novembro de 1909, estabeleceu que as aulas dos cursos primários noturnos seriam dadas por professores normalistas, e, as de desenho, por professores especialistas; Decreto 7.763, de 23 de dezembro de 1909, dispôs sobre estabelecimentos de ensino profissional nos Estados (www.planalto.gov.br/ccivil_03/decreto-lei/principal_ano.htm).

$27 \bigcirc$ Decreto 9.070, de 25 de outubro de 1911, regulamentou as escolas de aprendizes artífices, ampliando alguns pontos do Decreto 7.566/1909. Em 1918 o Decreto 13.064, de 12 de junho, aprovou um novo regulamento para as escolas de aprendizes artífices, trazendo inovações, como por exemplo, o curso primário obrigatório para todos os alunos (www.planalto.gov.br/ccivil_03/decretolei/principal_ano.htm).
} 
fundamental ao estabelecimento de uma rede nacional e gratuita de escolas profissionais:

"Art. 1 Em cada um dos Estados da República, o Governo Federal manterá, por intermédio do Ministério da Agricultura, Indústria e Comércio, uma escola de aprendizes artífices, destinada a ministrar gratuitamente o ensino profissional primário.

Parágrafo único. Será também criada no Distrito Federal uma escola de aprendizes artífices, logo que o Congresso habilite o Governo com os meios necessários à sua instalação e manutenção.

Art. $2^{\circ}$ Nas escolas de aprendizes artífices procurar-se-á formar operários e contra-mestres, ministrando-se o ensino prático e os conhecimentos técnicos necessários aos menores que pretenderem aprender um ofício, havendo para isso as oficinas de trabalho manual ou mecânico que forem mais convenientes ao Estado em que funcionar a escola, consultadas, quanto possível, as especialidades das indústrias locais.

Parágrafo único. Estas oficinas serão instaladas à medida que a capacidade do prédio escolar, o numero de alunos e demais circunstâncias o permitirem, a juízo do Governo.

Art. $3^{\circ}$ Além das oficinas, haverá em cada escola de aprendizes artífices dois cursos obrigatórios: primário, para os alunos que não souberem ler, escrever e contar e de desenho, para todos os alunos.

Art. $4^{\circ} \mathrm{O}$ regime das escolas será o de externato e o aprendizado das oficinas durará quatro anos.

Art. $5^{\circ} \mathrm{O}$ ano escolar abrangerá o espaço de 10 meses e os trabalhos das aulas e oficinas não poderão exceder de quatro horas por dia para os alunos dos $1^{\circ}$ e $2^{\circ}$ anos e de seis para os de $3^{\circ}$ e $4^{\circ}$.

Parágrafo único. $\bigcirc$ diretor, de acordo com os professores e mestres de oficinas e tendo em vista as condições climáticas do lugar em que funcionar a escola, marcará o ano letivo e organizará o horário das aulas e oficinas, submetendo o seu ato à aprovação do ministro". 
Em 1921 é constituído o Serviço de Remodelação do Ensino Profissional Técnico (extinto em 1930), com a tarefa de elaborar material didático específico para a formação profissional. Em 1928, os industriais que já se reuniam na Associação Comercial de São Paulo, fundaram o CIESP ${ }^{28}$ - Centro das Indústrias do Estado de São Paulo, destacando a Roberto Simonsen a vice-presidência.

Neste momento, de grande importância foram as reformas educacionais, de abrangência estadual, como a de Lourenço Filho (1897-1970), no Ceará, em 1923, a de Anísio Teixeira (1900-1971), na Bahia, 1925, a de Francisco Campos e Mario Casassanta, em Minas Gerais, em 1927; a de Fernando de Azevedo (1894-1974), no Rio de Janeiro, em 1928 e a de Carneiro Leão, em Pernambuco, em 1928 (TOBIAS, 1972:371-372). As transformações sociais neste período reforçaram o papel social da educação como meio de desenvolvimento da sociedade, no qual o progresso foi vinculado à educação e aos conhecimentos técnicos e científicos. Na esfera da educação, propunham reformar o que os modernizadores chamavam de "casas de saber"29, sob a influência do pensamento de John Dewey (1859-1952), todavia sem negar a importância dos aspectos artísticos e humanísticos da mesma. Tal preocupação com a educação foi elemento-chave para promover o crescimento da sociedade industrial e urbana, no período. Assim, dentro deste contexto de reformas educacionais, foi esboçado o movimento denominado Escola Nova, solidificado na década de 1930 com a pela divulgação do Manifesto da Escola Nova, em 1932. No grupo de intelectuais que acreditavam no ensino público como um meio de combater as desigualdades

\footnotetext{
${ }^{28} \mathrm{O}$ CIESP teve como presidente Francisco Matarazzo, maior industrial do Estado e do País; vice-presidente Roberto Simonsen; e, nos demais cargos, representantes das principais empresas da época: Horácio Lafer, Jorge Street, José Ermírio de Moraes, Antônio Devisate, Plácido Meirelles, Carlos Von Bulow e Alfredo Wesflog. A solenidade de posse aconteceu no dia $1^{\circ}$ de junho de 1928 e foi presidida por Júlio Prestes, então Governador do Estado.

29 "Nem sempre, entretanto, foram as escolas, assim, laboratórios e oficinas. No passado, eram muito mais casas de saber literário. Preparavam homens de cultura, que iam devotar aos trabalhos de especulação e de imaginação, preocupados em formular os sentimentos, as aspirações e os pensamentos de uma época ou de uma civilização. As escolas formavam o quadro intelectual da nação, o quadro dos cultores e divulgadores do saber humano: professores, escritores, poetas e filósofos. Desapareceu, por acaso, esta função da escola?". (TEIXEIRA, 1935:26, negrito da autora).
} 
sociais, destaca-se, no escopo deste trabalho, a presença de Anísio Teixeira.

Teixeira, em seu relatório de viagem apresentado ao governo do estado da Bahia, em 1928, deixa clara sua posição como "diretor geral de instrução, comissionado em estudos na América do Norte". Este relatório, mais tarde publicado sob o título, Aspectos Americanos de Educação (1928), divulga as idéias de Dewey, traduzidas na pedagogia da Escola Nova.

\footnotetext{
"Apresentar, pois, na Bahia, em um breve resumo, tão fiel quanto me foi possível, as idéias com que Dewey fixa o atual sentido de educação, pareceu-me meio talvez favorável, para despertar um interesse concreto pela revisão de nossas próprias concepções".
}

(TEIXEIRA, 1928:7)

As idéias reformistas que influenciaram o debate educacional no Brasil foram, sem dúvida, contemporâneas de publicações advindas de outros campos de conhecimento que circulavam, naquele momento. No campo da gestão do trabalho, era muito influente o livro Princípios da Administração Científica, de Frederick Winslow Taylor (1856-1915), de 1911; seguido da publicação do livro Administração Geral da Indústria, de Henri Fayol (1841-1925), em 1916 com grande repercussão na Europa (especialmente após a Segunda Guerra Mundial), e da publicação do livro My life and my work, de Henry Ford (1863-1947), em 1922. Assim, podemos notar que a difusão do paradigma taylorista-fordista inicia-se, já na primeira metade do século XX, no Brasil.

No caso do ensino voltado à qualificação do trabalhador, é interessante observar como as idéias educacionais norte-americanas também estiveram entrelaçadas aos métodos de trabalho propostos. De acordo com WIK (1972), Henry Ford adotou os princípios de Dewey no treinamento técnico do trabalhador: 
"Since Ford's industrial career had been a pragmatic adventure, he naturally thought education should be pragmatic, functional, and utilitarian. He ascribed to the John Dewey principles of learning by experience, vocational training, and educating the whole person. $\mathrm{He}$ believed an educated person could do a lot of things, including living a life which was useful and happy".

(WIK, 1972:196-197)

É interessante observar que a Ford Motor Company, fundada em 1903, a primeira companhia a aplicar a montagem em série de automóveis nos EUA, cedo expandiu seus negócios no Brasil, aonde começou a atuar, já em 1919, de início, com importação de automóveis. Como observa o historiador:

\footnotetext{
"Muito do grande boom mundial foi assim um alcançar ou, no caso dos EUA, um continuar de velhas tendências. $\bigcirc$ modelo de produção em massa de Henry Ford espalhou-se para indústrias do outro lado dos oceanos, enquanto nos EUA o princípio fordista ampliava-se para novos tipos de produção [... $]^{\prime \prime}$.
}

(HOBSBAWM, 1995: 259)

Com os desdobramentos da Primeira Guerra Mundial, da crise de 1929, da Revolução de 1930 entre outros fatores, a industrialização passa a ser uma meta central, assumida pelo Estado e pela sociedade brasileira.

Neste sentido, o ensino profissional foi ganhando novos rumos, à medida que as exigências por uma maior qualificação do trabalhador intensificaram-se, com a necessidade de atender os requisitos colocados pelo desenvolvimento de uma sociedade urbana e industrial. 


\subsubsection{Industrialização e organização racional do trabalho: propondo "reforma social"}

A dinâmica de diversificação da vida social pode ser observada a partir da Revolução de 1930, marcada pela crise da cafeicultura e pelo surto da industrialização. Neste sentido, o Brasil foi um dos países que se industrializou adotando padrões técnicoeconômicos da Segunda Revolução Industrial, claramente expressos nas políticas da Segunda República (1930-1936). O debate cultural que acompanhou este processo de modernização incluiu os argumentos dos engenheiros em prol da organização racional do trabalho. É justamente neste período, a partir da década de 1930, no Brasil, que o próprio Estado intensifica a construção das bases para impulsionar a dinâmica do par urbanização/industrialização.

No campo da arquitetura, as aspirações por um "país moderno", correntes na década de 1930 expressavam-se em diferentes linguagens, que se apresentavam como formas de interpretar os novos ritmos da modernidade, como as tendências racionalista e déco ${ }^{30}$. No campo do planejamento urbano, é notória a figura de Anhaia Mello ${ }^{31}$ que, influenciado pelo debate urbanístico norte-americano, em 1933, aponta como se deveria organizar um Plano Urbano de acordo com os princípios científicos: "é coordenar os elementos físicos, estatísticos e dinâmicos, e cuidar da legislação necessária a essa coordenação" (MELLO, 1933: 214).

No campo do debate sobre a industrialização, destaca-se o trabalho, do IDORT. Como ambiente de experiências e pesquisas relativas à organização do trabalho, o IDORT foi um importante centro intelectual dos industriais brasileiros no que se refere à racionalização, e a difusão do taylorismo. A gestão empresarial preocupou-se com os requisitos de qualificação do trabalhador e, ao treiná-los, buscou realizar o que considerava uma verdadeira "reforma social".

${ }^{30}$ Segundo ALANIS (1996: 30) o déco "surge simultaneamente com o nacionalismo: todos os arquitetos que não acreditavam no neocolonial, no ecletismo, nem na grandiloqüência das beaux arts encontram na morfologia do déco um impulso em direção à modernidade".

${ }^{31}$ Anhaia Mello foi prefeito da cidade de São Paulo de 06/12/1930 à 25/07/1931. 
"Nesta ação, o Instituto se empenhou em ampla promoção do taylorismo. Produzir mais e melhor em um tempo mais curto era o objetivo básico da racionalização do trabalho postulada. Eficiência, cooperação e racionalidade foram conceitos básicos promovidos pelo IDORT. A idéia de cooperação adotada fundamentavase na promoção de boas relações no ambiente de trabalho, entre patrões e empregados e entre chefes e funcionários de empresas de utilidade pública. Eventualmente, o tema se estendia à esfera doméstica, falando-se na necessidade de cooperação entre os membros da família. A eficiência e a racionalidade são pensadas em termos do combate ao desperdício e aos acidentes (no trabalho, no trânsito, etc) e da otimização do uso do tempo. A luta contra o desperdício promovida pelo órgão ganhou contornos amplos, voltando-se contra - desperdício de tempo, de recursos, de energia, de mão-de-obra, de equipamentos e até de palavras. conceito "tempo é dinheiro" permeia toda a discussão promovida sobre o tema da eficiência".

(CORREIA, 2004: 81)

Segundo WEINSTEIN (2000) em seu livro (Re)Formação da classe trabalhadora no Brasil (1920-1964), o termo "organização racional" abrangeu uma variedade de modificações possíveis em contextos nacionais específicos.

\footnotetext{
"Os brasileiros que defendiam filosofias como o taylorismo e o fordismo costumavam adaptar aspectos do discurso racionalizante para abrigar suas próprias concepções sobre os trabalhadores brasileiros e sobre a sociedade brasileira".
}

WEINSTEIN (2000: 26)

Organizar racionalmente o trabalho foi então uma estratégia para a reorganização do trabalho de acordo com princípios "científicos", recusando métodos empíricos pautados na prática e na tradição. Desta maneira, o taylorismo e o fordismo, somados à psicologia aplicada, formavam a base intelectual da discussão internacional a respeito da organização do trabalho, que se fortaleceu e estendeu já no final da Primeira Guerra Mundial. No Brasil, os 
industriais e engenheiros de São Paulo estavam sintonizados com este debate a respeito da racionalização, as voltas com os desafios de uma sociedade em processo de industrialização. Assim, eficiência, cooperação e racionalidade foram promovidas para gerar produtividade em tempo reduzido, e evitar acidentes de trabalho. A otimização do uso do tempo era recomendada para evitar o seu desperdício, assim como o da energia, do trabalho, de equipamentos, entre outros.

\footnotetext{
"Não há dúvidas de que, privilegiando a produtividade e a rentabilidade, os tayloristas e fordistas estavam exprimindo uma preferência com óbvias conotações políticas, mas sempre tendo o cuidado de disfarçá-la com a linguagem da ciência e de sua contribuição para o bem-estar social".
}

(WEINSTEIN, 2000: 75)

Nos anos 1930, trabalho e educação informaram concomitantemente as preocupações de Roberto Mange no IDORT. Outra reorganização política fundamental para a educação para o trabalho no Brasil foi a criação do Ministério do Trabalho, Indústria e Comércio e do Ministério da Educação e Saúde Pública na mesma década. O Ministério do Trabalho, Indústria e Comércio estabeleceu condições específicas para a sindicalização, tanto operária quanto patronal. Um claro exemplo neste sentido é a criação da $\mathrm{CNI}$, em 1938, já na legislação do Estado Novo, congregando as federações e sindicatos patronais em nível nacional.

Dentro deste contexto, é igualmente importante a atuação dos educadores, publicando o Manifesto dos Pioneiros da Educação Nova, em 1932. O manifesto, como um documento emblemático redigido inicialmente por Fernando de Azevedo ${ }^{32}$, foi obra coletiva de educadores brasileiros (certamente informados quanto a renovação da educação norte-americana), com o anseio de romper com $\circ$

32 Manifesto dos Pioneiros da Educação Nova compõe-se de três partes. A primeira, de autoria de Fernando de Azevedo, aborda o problema educacional brasileiro, mencionando suas deficiências e propondo uma reconstrução dentro do socialismo-radical. A segunda parte, de autoria de 26 educadores, dos quais Fernando de Azevedo e Anísio Teixeira faziam parte, expunha não somente a pedagogia da Escola Nova "mas também a Filosofia da Educação social-radical". A terceira parte, apêndice, completa o Manifesto (TOBIAS, 1972:384). 
passado colonial brasileiro, em um esforço de modernizar o País. Vale lembrar que, juntamente com os educadores, Mange acompanhou de perto o debate que levou ao manifesto, tendo participado das discussões sobre o ensino profissional, baseado nos princípios de organização racional do trabalho, que já havia ocorrido nos cursos do Liceu de Artes e Ofícios de São Paulo.

\footnotetext{
“Na História da Educação Brasileira jamais um escrito teve repercussão semelhante ao Manifesto dos Pioneiros; seus líderes queriam deveras uma revolução, que realmente provocaram. Declarando-se contra a Educação Clássica, considerada arcaizada e superada, propunham a Educação Nova. Tinham consciência do valor da educação para o país, uma vez que os 26 signatários iniciavam o Manifesto dizendo: 'na hierarquia dos problemas nacionais, nenhum sobreleva em importância e gravidade ao da educação'.
}

(TOBIAS, 1972:384-385)

Assim sendo, cabe destacar a visão do educador Anísio Teixeira do problema do ensino brasileiro e especificamente o ensino profissional. Para ele:

\footnotetext{
"A inversão de fatores já insinuada - tomar os efeitos pelas causas e vice-versa -acresce, assim, a compreensão fragmentária ou parcial do problema e sua redução a um ou outro aspecto aparentemente predominante. Tudo, para que as soluções rápidas e 'salvadoras' possam ser arquitetadas e ensaiadas com o alarido promissor e impaciente dos milagres. Mas, ai de vós, que os milagres não se realizam...".
}

(TEIXEIRA, 1935: 22)

Dentro da compreensão de que a educação era um "fenômeno da civilização" e não uma receita, a escola era vista como parte desta "reforma social". Segundo TEIXEIRA (1935), em seu livro Educação para a Democracia, toda educação escolar era profissional, partindo da própria premissa de que o ensino profissional significava preparação de operários, isto é de pessoas para atuarem em diferentes tipos de ocupação. 
"Na escola primária, pois, é uma escola profissional.

Como a escola secundária. E a escola superior. Todas são também técnicas. Porque, de um modo ou de outro, são técnicas que se ensinam nessas escolas. Mais gerais, algumas. Mais especiais, outras. Mas sempre, técnicas, isto é, processos racionais, tão científicos quanto possível, de se fazerem as coisas e de se explicaram os fenômenos".

(TEIXEIRA, 1935: 25)

Neste sentido, "educar para a democracia", a educação como uma "reforma social" é reforçada em 1934, com o lema "educação é direito de todos", promulgado na nova Constituição Brasileira de 1934. Ainda na década de 1930, houve a criaçao de duas universidades brasileiras, seguindo as normas do Estatuto das Universidades Brasileiras de 1931. Assim, foram criadas a Universidade de São Paulo, em 1934, por iniciativa do governador Armando Salles de Oliveira e, a Universidade do Distrito Federal ${ }^{33}$, em 1935, pelo então Secretário da Educação do Distrito Federal, Anísio Teixeira.

Durante os anos 1930, criou-se também uma legislação favorável à indústria, com medidas protecionistas, financiamentos e a regulamentação do mercado de trabalho. Dentro deste período, do Governo provisório (1930-1934) ao Governo Constitucional (19341937) de Getúlio Vargas, medidas de política trabalhista e educacional contribuíram decisivamente para a produção industrial nacional, notadamente em São Paulo e Rio de Janeiro ${ }^{34}$.

$$
\begin{aligned}
& \text { "A partir de 1937, o Estado começou a assumir a } \\
& \text { posição de investidor no campo da indústria pesada e } \\
& \text { nas atividades de infra-estrutura, setores pouco } \\
& \text { atraentes para a iniciativa privada". }
\end{aligned}
$$

(SENAI, 1991: 70)

À medida que se aprofundou a crise da economia cafeeira, $\mathrm{O}$ impulso à industrialização foi dado por meio da atuação do Estado, fundamental na implantação da indústria brasileira e, consequentemente, no investimento na educação para o trabalhador.

${ }^{33}$ Quando a Universidade do Distrito Federal foi criada, no atual município do Rio de Janeiro, nela foi estabelecida a Faculdade de Educação, a qual abrigava o Instituto de Educação organizado por Anísio Teixeira (CUNHA, 19).

${ }^{34} \mathrm{O}$ antigo Centro Industrial do Brasil (CIB), criado em 1904, se transformou em Centro Industrial do Rio de Janeiro, em 1939 (SENAI, 1991, 71). 


\subsubsection{A valorização do ensino profissionalizante durante o Estado Novo}

Durante 0 Estado Novo, o crescimento industrial estava intimamente ligado à política econômica, como um instrumento de crescimento e modernização do país. Assim, a Constituição de 1937 adotou a política educacional de preparação para o trabalho, enfatizando o ensino pré-vocacional e profissional. Desta maneira, os militares, elementos de sustentação do Estado Novo, incorporaram a industrialização como um projeto nacionalista. Vale lembrar que a ditadura Vargas, ou Estado Novo, começou com o golpe de 10 de novembro de 1937 e se estendeu até 29 de outubro de 1945, quando Getúlio foi deposto pelos próprios militares que haviam dado a ele sustentação, a princípio. Apoiado pelas classes médias e por amplos setores da burguesia agrária e industrial, o Estado Novo atuou dentro da perspectiva corporativista, de nacionalismo econômico e forte impulso à industrialização.

"Os anos do regime de Vargas, especialmente a ditadura do Estado Novo, permitiram que a burguesia industrial aperfeiçoasse sua 'disciplina de classe'. Além disso, os industriais elaboraram um projeto de industrialização e paz social patrocinado pelo Estado e usaram seu acesso ao poder do Estado para impor esse projeto aos membros de sua própria classe que se mostravam relutantes. Na verdade, os primeiro anos da década de 1940, um período de grandes lucros, de bons amigos no governo e de sindicatos sob controle - um período em que destacados 'líderes operários' organizavam banquetes para gentes como Roberto Simonsen e Morvan Dias de Figueiredo - deve ter ficado na memória dos industriais como uma 'idade do ouro' da colaboração entre as classes". 
Com a Segunda Guerra Mundial, há uma aproximação maior entre Brasil e Estados Unidos, durante o Estado Novo. Em 1942, Vargas apoiou a instalação da Missão Cooke, no Rio de Janeiro, formada por técnicos norte-americanos e brasileiros, procurando reexaminar a estrutura da economia brasileira e a contribuição do Brasil à guerra. Segundo BAER (1966), esta missão resultou numa pesquisa analítica que indicou o Sul do Brasil como a região mais propícia para liderar a indústria do país. Também, como obstáculos ao desenvolvimento industrial brasileiro, foram apontados: o inadequado sistema de transportes e de distribuição de combustíveis, a falta de recursos para investimentos industriais, a produção insuficiente de energia elétrica e o baixo nível das instituições para treinamento técnico.

\footnotetext{
"A tentativa seguinte de analisar a economia brasileira, recomendar mudanças em sua estrutura e indicar os meios para alcança-las foi feita pela Missão Cooke, constituída de técnicos norte-americanos e patrocinada conjuntamente pelos governos brasileiro e dos Estados Unidos. A missão visitou o país em 1942 e 1943. Sua origem fôra $\mathrm{o}$ ingresso de ambos os países na guerra e seu objetivo era avaliar a contribuição que o Brasil poderia dar ao esfôrço de guerra. Isto implicava, naturalmente, num reexame profundo da estrutura da economia, com vistas a influenciar a direção de seu crescimento.

Seu trabalho representou a primeira pesquisa analítica, e sistemática feita a respeito da economia brasileira com o objetivo de formular um programa de ação. Empreendeu-se pela primeira vez uma análise econômica do ponto de vista regional, dividindo-se o país em três regiões distintas (Nordeste, Centro-Oeste e Sul) cujas características econômicas diferenciavam-se suficientemente para justificar métodos de análise e programas de desenvolvimento substancialmente diversos. Importante conclusão da Missão Cooke foi a de que o esforço principal deveria ser concentrado no desenvolvimento do sul do país, uma vez que esta parte do Brasil reunia as melhores condições para um rápido crescimento econômico. Assim, não só as análises de base, como também as recomendações feitas, apoiavam-se na concepção de que o crescimento geral do país deveria ter, como ponto de partida, a ênfase no desenvolvimento do sul. Acreditava-se que, a partir desse núcleo de desenvolvimento, o crescimento se difundiria inevitavelmente pelas demais regiões.

A missão analisou os fatores que possibilitariam ao sul do país alcançar o maior grau de desenvolvimento, e especialmente industrializar-se (por exemplo, o fato de o sul se ter beneficiado em maior escala do auge da exportação do café no período mais recente, ter recebido maior quociente de imigrantes europeus qualificados em fins do século passado e inícios do século passado e inícios do século XX etc.). Declarou ela que mesmo em suas seções mais avançadas, a
} 
indústria ainda revestia caráter relativamente simples (isto é, limita-se á simples transformações de matériasprimas ou produtos alimentares), estava assentada em unidades pequenas e operava com margens excessivas de lucro.

A Missão Cooke analisou inúmeros fatores (hoje em dia tão familiares aos economistas especializados em problemas do desenvolvimento), que representava obstáculo ao crescimento rápido e, especialmente, à industrialização. Entre estes contavam-se: o inadequado sistema de transportes, $O$ atrasado sistema existente para a distribuição de combustíveis, a falta de recursos para investimentos industriais, bem como de mecanismos aptos a canaliza-los para esta finalidade, as restrições ao capital estrangeiro, limitações à imigração, baixo nível das instituições para treinamento técnico e sua completa inexistência em certas regiões, ausência de produção em grande escala, política de investimentos apoiada em expectativa de lucros extraordinários, instalações inadequadas para produzir energia elétrica, e assim por diante.

Depois de examinar essas condições sócio-econômicas e de dar o balanço dos recursos do país, a missão concluiu pela possibilidade de se criarem muitas industrias no sul. Acreditava ela que, como ponto de partida, devia ser instalada uma siderurgia em escala razoavelmente grande e que isto forneceria a base para a criação da indústria produtora de bens capital. Recomendou, ainda o desenvolvimento das indústrias de madeira e papel, de que o Brasil só produzia 25 por cento de suas necessidades de consumo, e o desenvolvimento da indústria têxtil, com vistas a exportar seus produtos.

A missão acreditava que a tarefa básica de industrializar - país deveria ser deixada à iniciativa privada, dedicando-se o governo brasileiro ao planejamento industrial geral, a facilitar o crédito industrial e a proporcionar mais ensino técnico".

(BAER, 1966: 32-34)

Seguindo a recomendação de prover educação técnica para o desenvolvimento da indústria, a valorização do ensino profissionalizante foi então decisivamente apoiada pelo Estado Novo. Assim como o planejamento centrado no Estado, o ensino vocacional e pré-vocacional foram estabelecidos visando à formação de profissionais qualificados para e indústria e o comércio, notadamente presentes nas Leis Orgânicas da Educação Nacional, do ensino industrial e secundário (1942) e do ensino comercial $(1943)^{35}$. Ao observar o texto da Lei Orgânica do Ensino Industrial, é possível encontrar as "bases de organização do ensino industrial" e os "conceitos fundamentais do ensino industrial", delineados em 1942: 
"Art. $3^{\circ} \mathrm{O}$ ensino industrial deverá atender:

1- aos interesses do trabalhador, realizando a sua preparação profissional e a sua formação humana;

2- aos interesses das empresas, nutrindo-as, segundo as suas necessidades crescentes e mutáveis, de suficiente e adequada mão-de-obra;

3- aos interesses da nação, promovendo continuamente

a mobilização de eficientes construtores de sua economia e cultura.

Art. $4^{\circ} \bigcirc$ ensino industrial, no que respeita à preparação profissional do trabalhador, tem as finalidades especiais seguintes:

1- formar profissionais aptos ao exercício de ofício e técnicas nas atividades industriais;

2- dar a trabalhadores jovens e adultos da indústria, não-diplomados ou habilitados, uma qualificação profissional que thes aumente a eficiência e a produtividade;

3- aperfeiçoar ou especializar os conhecimentos e capacidades de trabalhadores diplomados ou habilitados;

4- divulgar conhecimentos de atualidades técnicas".

(Decreto Lei 4.073/1942, Lei Orgânica do Ensino Industrial)

Neste sentido, funda-se o SENAI, em 1942, tanto apoiado pelo governo Vargas como pelos líderes industriais Roberto Simonsen e Roberto Mange.

"Dado o caráter rudimentar das estatísticas da indústria brasileira àquela época, muito do esforço do SENAI em seus primeiros tempos foi dedicado ao 'mapeamento' da economia industrial de São Paulo. A equipe do Departamento de Registro Industrial do SENAI visitou milhares de estabelecimentos industriais a cada mês para determinar a localização física das indústrias, a concentração geográfica de determinados setores (por exemplo, as empresas têxteis ou metalúrgicas), a percentagem de operários especializados e de aprendizes, e outros fatores relevantes para a tomada de decisões sobre a localização das escolas e o número de aprendizes que as firmas esperavam mandar ao SENAI. Trabalhando em estreita colaboração com a 
FIESP, em fins de 1943 o SENAI inspecionara 8122 indústrias na capital e começara a fazer o levantamento das firmas dos subúrbios industriais e do interior. Enquanto isso, o Departamento de Controle 'policiava' o sistema para garantir que os industriais recolhessem a soma devida, por intermédio do Instituto de Aposentadoria e Pensões dos Industriários (IAPI), aos cofres do SENAI".

(WEINSTEIN, 2000:138)

Assim, durante o período da Segunda Guerra Mundial, uma somatória de fatores favoreceu o processo de crescimento da indústria brasileira. Os pareceres da Missão Cooke, a organização dos industriais, o apoio do governo à industrialização e a legislação encarregaram-se de regulamentar o mercado de trabalho e, conseqüentemente, valorizar o ensino profissionalizante.

\begin{abstract}
"A causa imediata do esforço de industrialização que se seguiu à segunda Guerra Mundial foi semelhante à de outras situações que, anteriormente, haviam provocado surtos de desenvolvimento industrial - ou seja, dificuldades no setor externo da economia -, mas, sua característica principal foi bem diversa da apresentada por outros períodos. A diferença básica consistiu em ter a industrialização deixado de ser um expediente ocasional para transformar-se em uma decidida política no sentido de modificar drasticamente a estrutura da economia brasileira".
\end{abstract}

(BAER, 1966: 35)

Segundo BAER (1966), outro fator contribuiu no crescimento da industrialização brasileira: o financiamento externo para $\bigcirc$ crescimento das indústrias de base. Como marco na fabricação de aço brasileira, em 1941, o governo brasileiro obteve um empréstimo norte-americano para a construção da Companhia Siderúrgica Nacional e, em 1945, a Usina Siderúrgica de Volta Redonda já estava em funcionamento.

Sob a ótica de Bárbara Weinstein, a Segunda Guerra impulsionou a industrialização brasileira, a qual se desenvolveu significativamente e justamente na década de 1940: 
"Tentativas sistemáticas de promover a administração científica e a padronização da indústria brasileira datavam da década de 1930, mas esses objetivos ganharam especial relevância na década de 1940, em primeiro lugar devido às pressões da produção da época da guerra, depois como uma resposta à perversa 'onda inflacionária', e à ameaça da concorrência estrangeira no pós-guerra".

(WEINSTEIN, 2000:158)

Embora a década de 1940 tenha assistido a um esforço de sistematização na política educacional brasileira é preciso considerar - caráter dualista desta legislação. O "dualismo" é a divisão marcante da educação oferecida entre favorecidos e desfavorecidos. Assim, a concepção dualista que preconizava uma educação profissional, para o povo, e uma educação acadêmica, para a elite, ainda permeava as Leis Orgânicas da Educação Nacional. Sem a presunção de uma análise destas leis, mas com o objetivo de destacar - caráter da educação, cabe enfatizar esta distinção, notada pelo olhar dos educadores daquele momento.

\footnotetext{
"A ênfase em educação técnica, profissional, industrial, em oposição à educação acadêmica e intelectual, refletia ainda o velho dualismo, em que os poucos seriam longamente educados para si mesmos e para as suas funções especializadas e os muitos receberiam apenas o treino necessário ao trabalho a que se destinavam".
}

(TEIXEIRA, 1968: 48)

Anísio Teixeira, em seu livro Educação não é privilégio (1957), chama este dualismo de "arcaísmo" da escola brasileira. $\bigcirc$ educador defende a escola "unitária" como uma agência de educação sob três campos de trabalho.

\footnotetext{
"Esta sociedade, está claro, teria de preparar trabalhadores para as três fases do saber, isto é, a pesquisa, o ensino e a tecnologia, mas todos teriam tudo em comum, exceto o gosto diferenciado por essas fases diversas do conhecimento científico, de sua natureza, unitário".
} 
Neste sentido, é interessante observar que os cursos do SENAI foram considerados por Teixeira como um novo método de trabalho escolar adequado ao seu tempo.

\footnotetext{
"Sendo esta a escola adequada aos dias de hoje, até que ponto a escola brasileira dela se aproxima? Temos do novo método de trabalho escolar vários exemplos. [...]. Os institutos onde se faz, verdadeiramente, a pesquisa científica adotam os métodos novos. São assim os cursos do SENAl e alguns cursos profissionais ou técnicos industriais".
}

(TEIXEIRA, 1957: 21)

Procurando levar à prática suas idéias, além de Anísio Teixeira, Lourenço Filho e Fernando Azevedo continuaram como líderes dos educadores, ainda durante o Estado Novo. Chegaram a ocupar cargos na administração pública ligados à educação e trabalharam intelectualmente os temas da Educação mas não compartilhavam dos ideais educativos do governo Vargas, especialmente Teixeira, que possuía uma visão crítica daquela ideologia.

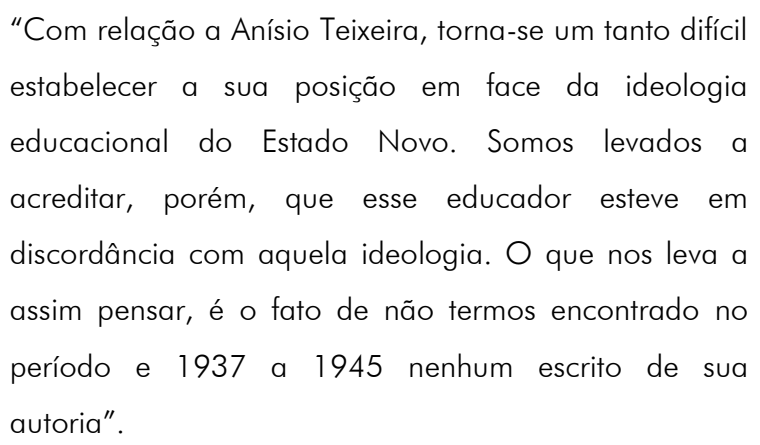

(SILVA, 1980:40)

Exercendo um importante papel, a educação foi um instrumento ideológico, além de profissionalizante na ditadura Vargas. Sem dúvida, o Estado Novo inaugurou um período de organização dos líderes da burguesia e cooperação com o governo Vargas. $\bigcirc$ fato é que nos primeiros anos da década de 1940 houve "colaboração" entre as classes, governo e sindicatos, liderados pela elite empresarial. Já, no final do Estado Novo, no período pós-guerra, estas lideranças passaram a investir financeiramente e ideologicamente na qualificação do trabalhador, no bojo de uma nova era de mobilização sindical e de redemocratização. 


\subsubsection{A redemocratização:}

\section{a luta pela "educação para todos"}

Com o declínio da hegemonia européia, abalada por duas Guerras Mundiais, afirma-se a expansão mundial dos EUA. Hobsbawm (1988), em seu livro A Era dos Impérios, 1875-1914, sintetiza as características mais amplas da economia mundial deste período da seguinte forma: a primeira, seria uma base geográfica da economia mais ampla do que antes; a segunda, seria uma economia notavelmente mais pluralista e não monocêntrica; a terceira, seria a revolução tecnológica; a quarta, a dupla transformação da empresa capitalista (em sua estrutura e em seu modus operandi); a quinta, seria uma transformação do mercado dos bens de consumo (quantitativa e qualitativa); a sexta, um crescimento acentuado do setor terciário da economia e, por fim, a sétima característica, seria o papel crescente do governo e do setor público. Dentre estas, cabe enfatizar duas características: a dupla transformação da empresa capitalista e a produção voltada ao mercado de massas. Ambas acarretaram transformações notáveis na concentração de capital, no aumento de escala das empresas, na expansão da industrialização e nas estratégias de gestão do trabalho baseadas no taylorismo-fordismo.

\footnotetext{
"Com o aumento da população, da urbanização e da renda real, o mercado de massa, até então mais ou menos restrito à alimentação e ao vestuário, ou seja, às necessidades básicas, começou a dominar as indústrias produtoras de bens de consumo. A longo prazo, isto foi mais importante que o notável crescimento do consumo das classes ricas e favorecidas, cujo perfil de demanda não mudou de maneira acentuada. Foi o Ford modelo $T$, e não o Rolls-Royce, que revolucionou a indústria automobilística".
} 
Assim, o desenvolvimento econômico do pós-Segunda Guerra deve ser entendido como o início da denominada "Era de Ouro", por Eric Hobsbawm (1995:264), em seu livro Era dos Extremos: o breve século XX, 1914-1991: "A Era de Ouro democratizou o mercado". Esta "era", o período do pós Segunda Guerra Mundial ao até o início dos anos 1970, foi fundamental nas transformações econômica, social e cultural da história mundial. Como agentes do rápido crescimento econômico, a tecnologia e conseqüentemente a indústria foram decisivas neste sentido:

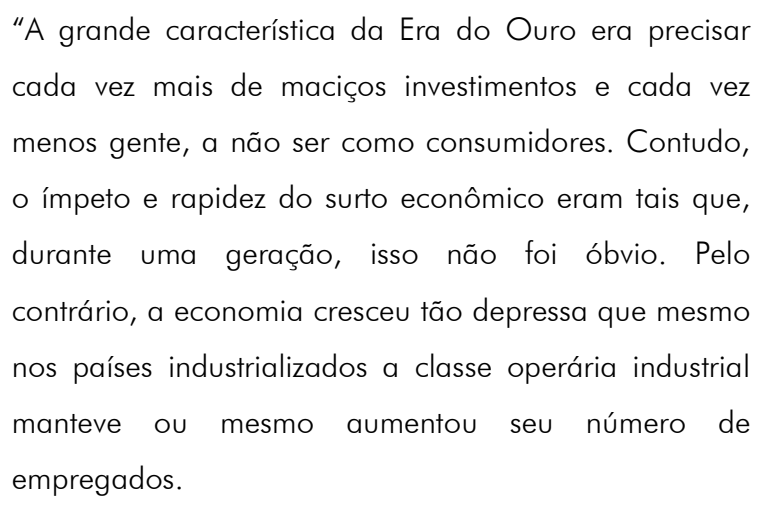

(HOBSBAWM, 1995: 262)

No Brasil não foi diferente. $\bigcirc$ rápido desenvolvimento econômico também pode ser observado nos países do Terceiro Mundo, ainda que em suas devidas limitações. Como por exemplo, o aumento do número de caminhões foi um fator que evidenciou positivamente $\mathrm{o}$ aumento da riqueza na sociedade ocidental. Por outro lado, os países mais desenvolvidos foram os que mais produziram a pesquisa e o desenvolvimento da inovação tecnológica. Assim, dentro de diferentes contextos e proporções, HOBSBAWM (1995) afirma a expansão econômica industrial tanto nas regiões capitalistas e socialistas, como no Terceiro Mundo: 
podia-se reconhecer o desenvolvimento econômico de muitos países do Terceiro Mundo pelo aumento do número de caminhões".

"Pesquisa e Desenvolvimento tornaram-se fundamentais para o crescimento econômico e, por esse motivo, reforçou-se a já enorme vantagem das 'economias de mercado desenvolvidas' sobre as demais. [...]. O 'país desenvolvido' típico tinha mais de mil cientistas e engenheiros para cada milhão de habitantes na década de 1970, mas o Brasil tinha cerca de 250, a Índia 130, ○ Paquistão uns sessenta, o Quênia e a Nigéria cerca de trinta".

(HOBSBAWM, 1995: 259 e 261, respectivamente)

É exatamente neste contexto de transformações do pósSegunda Guerra que o desenvolvimento econômico paulista atinge seu ápice. Reforçando a participação das instituições tripartites no ensino técnico brasileiro, o SESC e o SENAC foram criados, em 1946. Da mesma forma, a ação do SENAl junto à indústria passou a expandir-se em escala, sendo apoiado como um projeto nacionalista, de desenvolvimento da indústria nacional.

No plano cultural, o crescimento também se revela. São criados os dois ${ }^{36}$ primeiros cursos de arquitetura de São Paulo, o departamento paulista do $I A B$, além de instituições culturais e movimentos literários, que dinamizam a vida cultural da cidade.

\footnotetext{
“De fato, a cidade de São Paulo será marcada pelo intenso processo de industrialização que, deflagrado à época de Getúlio Vargas, se consolida no governo de JK. Através da cidade de São Paulo é possível observar o surgimento de uma sociedade de massas mais complexa e diversificada em termos sociais, econômicos, produtivos e comportamentais, ao mesmo tempo em que os problemas de planejamento e infraestrutura urbana revelam os limites dos paralelos estabelecidos com o cenário de expansão econômica mundial [...]".
}

(ALVES, 2003: 12)

36 Os dois cursos foram a Faculdade de Arquitetura Mackenzie em 1947 e a Faculdade de Arquitetura e Urbanismo da Universidade de São Paulo em 1948 (SEGAWA, 1999: 130). 
Assim, se as décadas de 1920 e 1930 assistiram a uma significativa mudança da liderança industrial com relação à racionalização do trabalho, à intervenção do Estado e ao corporativismo, é na década de 1950 que renasce a democracia da República Nova, a redemocratização. Getúlio Vargas, aos assumir o governo em 1950 num ambiente político diferente daquele do Estado Novo, enfrentou a transformação urbana e industrial do Brasil. Ainda que em meio a um governo tumultuado pelas acusações de corrupção, o debate cultural em torno da "educação para todos" emerge. A responsabilidade do Estado, quanto à educação, inspirou diretrizes educacionais que retornavam aos preceitos da década de 1930, dos Pioneiros da Educação Nova. O período fértil das discussões sobre a educação nacional, dos anos 1950, deram suporte ao crescimento dos três "S".

Nitidamente, a ação do educador Anísio Teixeira ${ }^{37}$ é importante influência pedagógica para as escolas dos "S" e, especialmente para os arquitetos que as projetaram. Em 1950, inaugura em Salvador, o primeiro núcleo de uma obra educacional de grande valor, o Centro Educacional Carneiro Ribeiro, modelo experimental denominado Escola classe - Escola parque. Teixeira, continuando sua trajetória iniciada no Rio de Janeiro, idealizou um projeto complexo, marcado pela passagem da "escola de poucos" para a "escola de todos". Assim se exprime Hélio Duarte a respeito da obra de Anísio:

\footnotetext{
"Anísio Teixeira foi honrado pela ONU e pela UNESCO, condecorado pelos governos francês e americano e, lamentavelmente, em nosso país o Autor de Educação não é privilégio não teve, por parte do mundo oficial da educação um reconhecimento à altura dos indiscutíveis méritos de seu espírito. Entretanto, é bom que se afirme, ao homem que desprezara a riqueza para se tornar somente EDUCADOR e assim poder propor, experimentar e
}

\footnotetext{
37 Sob a liderança de Anísio Teixeira, então diretor do Instituto Nacional de Estudos Pedagógicos (INEP), destaca-se a criação do Centro Brasileiro de Pesquisas Educacionais (CBPE). Segundo XAVIER (1999), o CBPE foi criado em 1956 e funcionou como núcleo de atuação de educadores e cientistas sociais interessados em consolidar um campo cultural no país.
} 
provar um modelo educacional compatível com a realidade brasileira, só haverá um tipo de homenagem capaz de consagrar tão nobre e tão alto feito: a adoção e a disseminação por todos esses brasis do sistema: escolas-classe escola-parque".

(DUARTE, 1973: 5)

Outra referência essencial para os arquitetos que projetaram os "S" modernos foi o Convênio Escolar, um acordo estabelecido entre o Estado e o município de São Paulo que propiciou as premissas do movimento de renovação da moderna arquitetura escolar paulista. Desde a criação da Comissão Executiva do Convênio Escolar, em 1948, o problema escolar e a arquitetura foram pela primeira vez tratados por uma comissão de serviço público, com o objetivo de viabilizar a construção de novas escolas. Assim, sob a coordenação de Hélio Duarte, os projetos do Convênio começaram a ser feitos a partir de 1949 pela primeira equipe de arquitetos e engenheiros: os arquitetos de formação carioca Eduardo Corona e Roberto Tibau, o engenheiro civil paulista Ernest Mange, e o engenheiro-arquiteto de formação paulista Oswaldo Corrêa Gonçalves. Neste sentido, a atuação do Convênio não ficou limitada apenas à sua função no campo da arquitetura escolar, passou a ser em si mesma uma escola, em face do preparo que proporcionou a todos os envolvidos.

Convênio, além de construir escolas, projetou outras instalações comunitárias como parques infantis, ginásios, bibliotecas e teatros populares, e adotou em seus projetos as concepções da pedagogia moderna inspiradas por Anísio Teixeira e outros pioneiros da Escola Nova. Assim, tendo em vista que o novo conceito de educação incluía uma ampliação das vivências sociais e culturais, o Convênio visava tornar a escola ativa e interessante através dos diversos processos pedagógicos. Dentro dos princípios que pautaram a moderna arquitetura escolar dos "S", é preciso destacar que os autores dos projetos concebidos na década de 1950, em sua maioria $^{38}$, foram os mesmos que já vinham atuando anos antes no

38 Utilizando e aprimorando a experiência obtida durante o Convênio Escolar nas primeiras escolas modernas dos "S", Hélio Duarte, Ernest Mange, Roberto Tibau, Oswaldo Gonçalves e Eduardo Corona atenderam à tarefa de projetar escolas que fossem um incentivo permanente no plano da educação. 
Convênio Escolar, projetando uma série de grupos escolares. $\mathrm{Na}$ mesma direção, o ensino técnico abriu-se para a busca de uma formação integral ao operário, buscando um novo conceito de aprendizado profissionalizante que incluía maior abrangência educativa e social. Surge, assim, a denominada "educação integral". $E$, os "S", passaram a ser em si mesmos "Escolas Novas" fundamentadas neste princípio educacional.

Dentro da filosofia da Escola Nova, certos conceitos pedagógicos são análogos às características arquitetônicas que nortearam as modernas escolas "S", a partir da década de 1950. Roberto Mange, atuando na direção do SENAI, modifica os métodos de ensino até então adotados e altera o tipo de escola construída. Apoiando-se em um novo conceito de educação, Mange buscava uma escola ativa e interessante, identificada com seu ambiente físico. À arquitetura moderna, deste ponto de vista, foi atribuído um papel na renovação do ambiente social, pela escola.

\footnotetext{
"Segundo ele [Mange] o operário qualificado, a figura que ele considerava tão crucial para a harmonia e a produtividade industrial, tinha que ser socializado para agir como um cidadão produtivo em todos os campos".
}

(WEINSTEIN, 2000:279)

Após o governo de Getúlio Vargas (1951-1954), segue-se um momento de turbulência política, mas a democracia consegue se manter e estabilizar durante o governo de industrialização do país outro importante presidente, o governo de Juscelino Kubitschek (1956-1961). Segundo BENEVIDES (1979: 47), o governo Kubitschek foi de "aparência" estável, não no sentido de ausência de crises, mas sim pela estabilidade proporcionada pelo desenvolvimento contínuo, pelo Plano de Metas ${ }^{39}$, pela euforia de Brasília e, principalmente, pela manutenção do regime democrático. O Plano de Metas, com o objetivo de "acelerar o processo de acumulação aumentando a produtividade dos investimentos existentes e aplicando novos

39 O objetivo do Plano de Metas, segundo BENEVIDES (1979: 210), era "acelerar o processo de acumulação aumentando a produtividade dos investimentos existentes e aplicando novos investimentos em atividades produtoras. Como fim último propunha elevar o nível de vida da população, através de novas oportunidades de emprego, visando um futuro melhor $[\ldots]^{\prime \prime}$. 
investimentos em atividades produtoras" (BENEVIDES, 1979: 210), propunha elevar o nível de vida da população por meio de novos empregos. Com o objetivo desenvolver a indústria de base, investir na construção de estradas e de hidrelétricas e fazer crescer a extração de petróleo, o Plano de Metas almejava arrancar o Brasil de seu subdesenvolvimento e transformá-lo num país industrializado. Assim, os industriais brasileiros continuaram investindo nos diversos setores e as multinacionais intensificaram seus investimentos no Brasil. $O$ significado do Plano de Metas no processo de modernização do país pode ser aquilatado pela mudança do padrão de industrialização, com prioridade para a indústria pesada, como a de construção naval, automobilística, siderúrgica, entre outras.

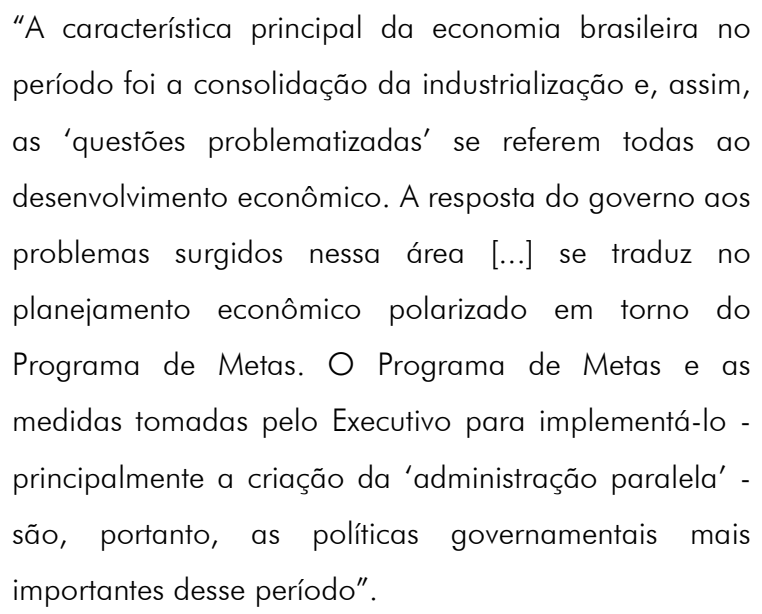

(BENEVIDES, 1979: 208-209)

Sem dúvida, os cinco anos de Juscelino na presidência brasileira consolidaram 0 desenvolvimento industrial e sua concentração cada vez mais intensa no estado de São Paulo. Com isso, a demanda de mão-de-obra qualificada aumentou e o ensino técnico passou a ser uma das condições para sustentar 0 arranque industrial.

"De acordo com levantamentos do Serviço de Cadastro e Controle do SENAI-SP, executados em 1956, a indústria paulista demandava um maior grau de qualificação da mão-de-obra nos setores de mecânica, metalurgia e eletricidade".

(SENAl, 1992: 34) 
A partir da década de 1940, as primeiras escolas dos "S" tem por pressuposto a difusão dos métodos de gestão do trabalho tayloristas e fordistas, ainda bastante restritos ao modelo "dual" de ensino do período da Segunda Guerra. Porém, com a consolidação e ampliação de seu trabalho nas décadas de 1950 e 1960, a "era do ouro" dos "S" inspirou a construção de escolas "redemocratizadas" pela arquitetura moderna. Buscava-se formar trabalhadores para uma sociedade que falava em democracia, reforma social, educação escolar, desenvolvimento tecnológico e racionalização do trabalho.

É exatamente neste momento histórico que se coloca esta pesquisa. Sem dúvida, a partir da década de 1950, os arquitetos desempenharam importante papel na vida cultural e social paulista e sua ação nos "S" se expandiu na década de 1960 até o período em que $\circ$ golpe militar atingiu a educação, com seu caráter antidemocrático. Como os arquitetos dos "S" vivenciaram este processo de mudanças políticas, econômicas e sociais tão sentidas no campo educacional? Como seus projetos modernos, sua produção arquitetônica respondeu a estes desafios? 


\subsubsection{O regime militar e o incentivo à formação de cunho profissionalizante}

Após o governo de Juscelino e a renúncia de seu sucessor Jânio Quadros, o Brasil passou a ser governado por João Goulart. Em 1964, no entanto, sofre o Golpe de Estado. Este período, marcado pela ditadura militar, é um momento de repressão e censura na sociedade brasileira. Ao mesmo tempo, o programa econômico de estabilização adotado entre 1964 e 1967 teve como efeito a desaceleração do crescimento industrial.

\footnotetext{
"Governments relied on large-scale international borrowing to overcome these problems and to build the economic infrastructure vital to industrial expansion. Then, as they were required to meet stiffer and stiffer conditions for the renegotiation and expansion of these loans, they adopted austerity measures that were designed to be borne primarily by the working class".
}

(BERGQUIST, 1986:3)

Em que pese o retrocesso da democracia, o apoio do governo à formação de cunho profissionalizante foi mantida, no período pós-64, preconizando-se uma estreita relação entre educação e trabalho. Neste sentido, como agente formador do trabalhador industrial, O SENAI ampliou seus cursos noturnos, aproveitando integralmente o uso do edifício escola, como fruto do convênio estabelecido com o Programa Intensivo de Preparação de Mão-deObra Industrial (PIPMOI) ${ }^{40}$, do Ministério da Educação, assim como do convênio com o Banco Nacional da Habitação e o Ministério do Trabalho. Sob estas condições, aumenta a importância dos cursos do SENAI.

\footnotetext{
"O novo regime militar, com sua orientação tecnocrática e modernizante, certamente anunciava uma melhora das condições do SENAI e o aumento de seu prestígio. Em termos imediatos e concretos, isso significava captação e transferência de recursos mais eficiente e a reativação, no SENAI de São Paulo, dos cursos noturnos para adultos".
}

(WEINSTEIN, 2000:354)

\footnotetext{
${ }^{40}$ A sigla PIPMOI mudou para PIPMO em 1972.
} 
Mesmo ao ensino básico e acadêmico é conferido um caráter de ensino profissionalizante. Neste sentido, foram realizadas a Reforma do Ensino Superior (Decreto-lei 5.540/68) e, posteriormente, a Reforma do Ensino de $1^{\circ}$ e $2^{\circ}$ Graus (Decreto-lei 5.692/71) que atribuiu ao ensino de $2^{\circ}$ grau uma formação técnica de nível médio, confundindo os objetivos dos dois sistemas antes existentes.

Porém, sem dúvida, o regime militar também trouxe mudanças no discurso dos "S" e em seus programas, que tiveram que se adaptar à nova ordem. O número de escolas construídas na "era do ouro" dos "S" entrou em declínio a partir do golpe militar. Afinal, a modernização dos programas "S" foi diminuída à medida que em vez da ênfase aos aspectos educativos, o treinamento técnico passou a ser incentivado nas próprias fábricas, como direcionava o PIPMOI.

"Séria conseqüência disso foi a queda do prestígio do SENAI frente ao regime militar, que passou a considerar as escolas do SENAl como luxo desnecessário e as contribuições mensais ao SENAl como ônus indevido para os empregadores".

(WEINSTEIN, 2000:356-157)

O regime militar acabou enfraquecendo a modernização pedagógica e arquitetônica dos "S" por meio da sua visão estreita de formação profissional e de socialização do trabalhador. Sufocando a democracia, os Atos Institucionais aprofundam a política repressiva do regime militar. A "era do ouro" dos "S" só sobrevive até o ano de 1968, quando o Ato Institucional $n^{\circ} 5$ é promulgado pelos militares. Assim, o ano de 1968 deve ser visto como a transição entre o "fim" e ○ "início" de um novo período dos "S". O fim da "era de ouro" dos "S" e o início de uma nova fase de extraordinária ampliação destes sistemas de aprendizagem, dentro de uma expansão que demandou novas iniciativas a partir da década de 1970.

"Como atestará qualquer um com o mínimo conhecimento de Brasil ou México, elas produziram burocracia, espetacular corrupção e muito desperdício mas também uma taxa de crescimento anual de $7 \%$ nos dois países durante décadas [...], os dois conseguiram a desejada transição das economias industriais modernas. $\mathrm{Na}$ verdade, o Brasil se tornou por algum tempo o oitavo maior país industrial do mundo não comunista". 


\subsection{A experiência norte-americana: trabalho, educação e arquitetura}

Esta parte da tese, apóia-se em pesquisa realizada nos EUA no acervo documental e bibliográfico da Columbia University e procura esclarecer - no período em que o assim chamado "americanismo" (GRAMSCl, 2001) coloca-se como um modelo em expansão, vitorioso, no término da Segunda Guerra - até que ponto o debate sobre a experiência norte-americana for referência para a arquitetura moderna das escolas dos sistemas "S" no período em tela. Assim, por meio de quatro sub-itens, são examinadas: o movimento social norte-americano conhecido como "progressivismo"; o apoio do governo às escolas técnicas norte-americanas para jovens e adultos; 0 sistema de educação em transição em meados do século $X X$; e por fim, a mudança da linguagem arquitetônica e as soluções e atributos projetuais utilizados no edifício-escola principalmente nas décadas de 1950 e 1960.

Sem dúvida, é importante compreender o momento em que ressalta uma mudança pedagógica profunda na história social, política e econômica dos Estados Unidos, principalmente voltada à educação vocacional, e como a mesma foi apropriada pelo programa e pela arquitetura do edifício-escola, no mesmo período em que observamos uma renovação pedagógica e arquitetônica nos "S". Cabe notar mudanças de ênfase, justificadas por uma filosofia educacional que abandonou a psicologia introspectiva, em favor da pragmática, e substituiu o indutivo por um processo de pensamento dedutivo. Se o objetivo da vida era eficiência, numa visão pragmática, qual seria na educação o motivo do sucesso? Quais eram os ideais sociais e econômicos das escolas vocacionais? Como isso sustentou, na prática, as formas institucionais adotadas? A citação abaixo sugere algumas das reflexões desdobradas, ao longo deste capítulo, sobre 0 "valor intrínseco" da educação nos Estados Unidos daqueles anos: 
"Life in a modern democracy is strenuous. The door of opportunity is theoretically open to all. Able-bodied persons are expected to be worthily employed. Even the rich cannot remain inactive without suffering the scorn of their fellows. People generally prefer to strive -some, to acquire fame; some, to attain social position; but most, to make money. For them education is thought to furnish the formula for success. No matter whether he follows the theory of mental discipline or that of the efficacy of specific vocational training, nearly everybody believes that education furnishes the means to the common goal success. Many seek training directly preparatory to a vocation; many seek learning, mistaking it for culture; many are satisfied with the empty shell - the diploma or the credit - for even this has a value in a workaday world which asks few questions. The pursuit of education, or at least the credentials thereof, has thus been linked with that of the strenuous life outside the school. Mature students, who may not fully comprehend the intrinsic worth of education, are nevertheless quite aware of its value in exchange. So people struggle for education and the schools thrive".

(NOBLE, 1954: 469-470, negrito da autora)

\title{
1.3.1 American Progressivism: "Learn by Doing"
}

\begin{abstract}
"A designação 'escola nova', necessária, talvez, em início de campanha, para marcar vivamente as fronteiras dos campos adversos, ganharia em ser abandonada. Por que não 'escola progressiva', como iá vem sendo chamada, nos Estados Unidos?"
\end{abstract}

(TEIXEIRA, 1967: 25)

Ao abordar o tema educação, a relação da prática com a teoria, do "aprender fazendo", e assim o título "Learn by Doing", deve ser compreendida dentro da experiência do "The Progressive Education Movement". Este movimento situa-se no campo do "progressivismo americano" desenvolvido entre o final da década de 1890 até a Primeira Guerra Mundial. A força deste movimento visava 
uma vasta reforma política, filosófica, moral, educacional e profissional voltada para a democracia, a eficiência e o progresso, tendo galvanizado importantes figuras dentro de um amplo arco político incluindo nomes como Thorstein Veblen (1857-1929), Upton Sinclair (1878-1968), Frederick Winslow Taylor (1856-1915), John Dewey (1859-1952), Frederick Law Olmsted Júnior (1870-1957) e Henry Ford (1863-1947), entre tantos outros, profissionais, empresários, donas de casa, enfim, obtendo um forte apoio das "classes médias"41.

Com o intuito de compreender a experiência da educação para o trabalho norte-americana e sua repercussão no Brasil apontam-se alguns aspectos desta educação "progressiva". Neste sentido, "The Progressive Education Movement" protestou contra a inércia dos métodos de ensino, a rotina da educação institucionalizada e, a supremacia do tradicionalismo nas escolas.

\begin{abstract}
"By 1920, the progressive Education Association had been organized and throughout the country. It was recoanized bv anv one of number of catch phrases such as activity movement, 'child-centered school, activity curriculum', 'creative youth', or centers of interest'. Espousing pragmatism with its realistic implications it promoted the project method".
\end{abstract}

(NOBLE, 1954: 491)

É exatamente dentro deste período, entre 1880 e 1930, que aconteceu o esforço dos EUA de renovar a educação através da experiência. A partir do século XIX, a indústria baseada na ciência resultou em crescimento sem precedentes da economia do país. Neste sentido, a história da tecnologia moderna na América é objeto de

${ }^{41} \bigcirc$ "Progressive Movement" procurou combater os problemas de uma sociedade em rápido processo de urbanização e industrialização. Na imprensa, os chamados "muckraking journalists" apontavam a corrupção nos governos municipais, o abuso do trabalho infantil, a criminalidade, as práticas de mercado desonestas. Um grande número de associações baseadas em trabalho voluntário buscou expandir a rede escolar, construir playgrounds, desbaratar as máquinas políticas corruptas. Conseguiram aprovar em lei salários mínimos para mulheres, compensações por acidentes de trabalho e regulamentação das condições de trabalho. Também obtiveram vitórias fiscalizando a qualidade do leite, da água, dos medicamentos. Aprovaram leis antitruste, especialmente no sistema bancário. É desta época o voto feminino, a eleição direta para senador e a proibição do comércio de bebidas alcoólicas (CHAMBERS, 2000). 
David F. Noble (1977) em seu livro American by Design: Science, Technology, and the Rise of Corporate Capitalism, um estudo que discute a criação da economia capitalista moderna americana.

\begin{abstract}
"In the early nineteenth century the colleges were firmly in the hands of the classicists and the clerics, and there was considerable academic disdain for the study of experimental science and even more for the teaching of the "useful arts". Technical education in the United States, therefore, developed in struggle with the classical colleges, both inside and outside of them. One form of this development was the gradual growth of technological studies within the classical colleges, resulting from the reorientation of natural philosophy toward the empirical, experimental, scientific search for truth and from the pressures of some scientists and powerful industrialists for practical instructions; the other was the rise of technical colleges and institutes outside of the traditional colleges in response to the demands of internal improvement projects like canal-building, railroads, manufactures, and, eventually, science-based industry".
\end{abstract}

(NOBLE, 1977: 20)

Sem dúvida, o avanço da ciência é uma das respeitáveis tendências deste momento. As conseqüências sociais revolucionárias vinculadas aos princípios científicos aplicados à indústria são observadas claramente por todos os setores sociais e encontram elaboração também no campo da educação. Segundo DEWEY (1916), a implicação desta mudança é que a ciência deve servir ao bem-estar social e aplicar-se à metodologia da educação. Em seu livro, Democracy and education: an introduction to the philosophy of education, ele revela sua posição de que não é mera coincidência a reunião entre o ideal de progresso e o avanço da ciência. Para este filósofo e pensador do progressivismo, a ciência familiarizou o homem com a idéia de desenvolvimento, tendo como efeito prático a "progressiva" melhoria da sociedade. 
"Science taking effect in human activity has broken down physical barriers which formerly separated men; it has immensely widened the area of intercourse. It has brought about interdependence of interests on an enormous scale. It has brought with it an established conviction of the possibility of control of nature in the interests of mankind and thus has led men to look to the future, instead of the past".

(DEWEY, 1916: 263)

A visão de outro envolvido com o "progressivismo", Henry Ford, reforça sua defesa de uma educação pragmática, funcional e útil. Ford valoriza no pensamento de Dewey os princípios de aprendizagem pela experiência, formação profissional e educação do ser humano em sua totalidade. E, como enfatiza a citação abaixo, a geração jovem foi o público alvo de sua filosofia de educação:

\footnotetext{
"Ford had faith in young people. He believed the older generation had failed to provide the kind of education designed to prepare graduates to cope with the modern world. As a result, they were frustrated, insecure, and rebellious".
}

(WIK, 1973: 196)

Reforçando a idéia da educação pela ciência juntamente com a aprendizagem pela experiência, um autor contemporâneo ao período em tela, Stuart Noble (1954), em A History of American Education, aborda como a experimentação por meio de laboratórios, notória a partir do início do século XX, revolucionou os métodos de produção, transporte e comunicação e, assim, modificou os hábitos e costumes da sociedade. Como exemplo desta natureza, cabe destacar a Companhia GE, General Electric Company, que em 1900, estabelecida em Schenectady, NY, um dos primeiros laboratórios de ciência básica em uma empresa industrial, seguido por muitos outros, como enfatiza o autor:

"Other large corporations provided research facilities in the years that followed. Now, these, as well as the laboratories of the great universities and federal agencies, are delving into the mysteries of pure science as diligently as they are seeking to find new applications of established principles". 
Ao observar o papel social do American Progressivism é interessante notar sua expansão direta na educação e na escola do início do século XX. Enquanto os primeiros resultados de longo alcance tecnológico e industrial puderam ser percebidos em torno de 1900, a insatisfação com a rede pública de ensino era generalizada. A crítica era caracterizada por acusações de que a escola passava longe da "vida real" da sociedade e acabava por não abordar os próprios problemas da comunidade em que estava inserida. Os pontos desfavoráveis eram referentes não só ao currículo e à instrução, mas também aos edifícios escolares.

A escola passou a ser instigada a atender o "culto da eficiência" e a "nova ciência da educação", dentro de uma aprendizagem escolar aplicável à vida do mundo moderno. Diversas inovações tornaram-se marcas do sistema escolar gerado nesta era progressista, tais como: escolas de férias, playgrounds, centros sociais, classes para deficientes (físicos e mentais) e extensivos programas de formação profissional. A escola, como uma instituição vital, procurou responder e integrar os interesses da sociedade. Poderia a escola servir à comunidade? Questões como esta foram respondidas por meio de inovações no sistema escolar.

Assim, neste momento do progressivismo, dois eventos devem ser observados, no campo da educação secundária americana. Primeiramente, nota-se o aumento da demanda da educação secundária nitidamente expresso pelos dados estatísticos apresentados por WILLIE \& MILLER (1988:33). Entre 1890 e 1910, a população da escola secundária aumentou de 203.000 para 900.000 em toda a nação. O segundo evento, de caráter pedagógico, foi o relatório final de 1918, The Cardinal Principles of Secondary Education, denominado pela sigla CRSE. Este relatório tratou as metas da educação na democracia, seus objetivos principais, bem como o papel do ensino secundário na consecução destes objetivos. Os objetivos da escolaridade - a maneira pela qual os sistemas educativos poderiam responder a seu papel na sociedade americana do século XX - foram considerados a parte mais importante do relatório. E, a aplicação destes objetivos deveria abranger desde a educação elementar até o ensino superior. 
"There were seven objectives: health, command of fundamental processes, worthy home membership, vocation, citizenship, worthy use of leisure time, and ethical character. The commission advocated that every subject taught in the schools should be organized to contribute to the accomplishment of these central objectives".

(WILLIE \& MILLER, 1988: 35)

Neste sentido, ao abordar o movimento social, denominado American Progressivism, percebemos justamente sua repercussão ao longo do século XX. Ao consultar bibliografia sobre a educação americana, é possível afirmar que nas décadas de 1950 e 1960, o significado do termo "educação progressiva" ainda estava presente. Ao mesmo tempo em que este termo vai desaparecendo dos livros sobre educação, seus pressupostos, significados e muitos dos princípios defendidos pelo movimento ainda são propagados por estes mesmos livros. É surpreendente a nítida percepção de como o espírito que estava no cerne do The Progressive Education Movement permaneceu na década de 1950, ainda que não exatamente da mesma maneira. Características que foram combatidas na década de 1950 (tanto quanto no passado "progressivo"), ainda faziam parte de muitas escolas, tais como a repressão, a rotina e o conservadorismo. O fato é que, o idealismo progressista, continuou a fazer parte das teorias e avanços na área da educação. Princípios como integração, orientação e unidade foram direcionados para a cura dos problemas diagnosticados no início do século XX.

Vale destacar o esforço de Anísio Teixeira, na década de 1960, por uma educação baseada na experiência, dentro da "educação progressiva". É interessante obvervar que, em 1934, o educador escreveu Educação Progressiva: uma introdução à filosofia da educação e, em 1967 republicou o mesmo livro com outro título Pequena Introdução à Filosofia da Educação: A Escola Progressiva ou A Transformação da Escola - passando a "educação progressiva" para o subtítulo. É nítido como, na década de 1960, esta designação havia perdido seu uso e sua originalidade como termo, porém a teoria da experiência adotada como base de sua filosofia, continuava a ser estudo e pesquisa nas formas de aplicação da educação. 
"Conservamos, entretanto, a referência à escola progressiva, como registro histórico do período inicial de implantação das novas concepções, que vêm transformando a escola e fazendo da educação, em nosso século, uma educação em mudança permanente, em permanente reconstrução, buscando incessantemente reajustar-se ao meio dinâmico da vida moderna, pelo desenvolvimento interno de suas próprias forças melhor analisadas, bem como pela tendência de acompanhar a vida, em todas as suas manifestações".

(TEIXEIRA, 1967: 13)

Resgatada a influência do American Progressivism, no campo da educação ao longo do século $X X$, cabe, a seguir, compreender como repercutiu na educação dos jovens e adultos americanos e, posteriormente, na concepção de suas escolas. As contribuições deste debate aos pressupostos dos três "S" brasileiros começam assim a ser identificadas.

\subsubsection{A demanda pela educação vocacional: Adult Education in America}

"Cuáles son las fuerzas sociales e ideológicas que, en las sociedades industriales, condicionan a la educación de los adultos y le dan su sentido? Según nosotros, estas fuerzas provienen a la vez del cambio político y de la organización social (con sus ideologías y sus concepciones del mundo); del campo del trabajo (de la producción, de la economía, pero también del ejército); del conocimiento científico, de la creación en el campo del espíritu, de la educación; del sistema escolar (definidos los individuos a la vez por su nivel de educación y por su nivel de calificación con vistas a la producción); en fin, de la vida personal (relaciones privadas y obligaciones sociales, diversiones, intereses personales). Estos diversos campos, naturalmente, se ínter penetran, y condicionan todos ellos a la educación de los adultos". 
Para melhor compreender os princípios de "educação permanente" aplicada à educação de jovens e adultos no ensino profissionalizante dos "S" no Brasil, é imprescindível compreender parte a experiência do ensino vocacional nos EUA. A educação americana dos adultos, nas escolas públicas, nasceu de uma série de experiências, tais como: cursos noturnos, formação profissional, cursos de instrução geral, cursos de alfabetização e programas de educação secundária. Os cursos públicos noturnos foram fundados na década de 1830, em New York, Lovisville, Boston e Baltimore, para fornecer aos jovens, principalmente àqueles que não haviam completado grau de escolaridade, cursos de aprendizagem vocacional capazes de gerar emprego. A partir de 1900, outras cidades americanas reconheceram a importância dos cursos noturnos e, segundo COPELAND ${ }^{42}(1976,80)$, na virada do século os EUA abrigava mais de 165 escolas noturnas regulares. Já, o estudo de $\operatorname{KORNBLUH}^{43}(1987,13)$ afirma que, em 1910, mais de 100 escolas públicas na cidade de New York ofereciam classes noturnas em diferentes cursos, tais como: língua estrangeira, ciências, assuntos comerciais, artes domésticas e habilidades vocacionais.

Segundo NOBLE (1970), na primeira metade do século XX havia muitos tipos de escolas vocacionais e estas ofereciam diversos cursos de acordo com a demanda industrial de cada comunidade.

\footnotetext{
"Vocational schools of many types, including technical high schools, full-day trade schools, part-time trade schools, and continuation schools, now sprang up. These offered a short cut to the trades either by abbreviating the period of apprenticeship or by eliminating it altogether. A long list of trades came to be taught in this way, including carpentry, bricklaying, painting, plumbing, patternmaking, gas fitting, steam engineering, printing, sheet-metal work, and electric repairing.

The industrial demands of each community determined the number and variety of the trades offered by any particular
}

42 Harland Copeland é autor do capítulo Educación permanente. Educación de adultos presente no livro La Escuela y la educación permanente. Este livro foi primeiramente publicado em Paris, em 1972 e posteriormente, em 1976, traduzido para o espanhol e publicado no México.

43 Joyce Kornbluch é autora do livro New Deal for Work's Education: The Worker's Service Program 1933-1942, publicado em 1987. 
school. [...]. In this respect, their instruction tended to converge on that of the manual training schools".

(NOBLE, 1954:405-406)

Na década de 1930, uma vertente de extrema importância na educação vocacional ao adulto foi o Programa de Serviço ao Trabalhador, estabelecido entre 1933 e 1942, dentro do New Deal ${ }^{44}$, este programa foi implementado nos Estados Unidos sob o governo do Presidente Franklin Delano Roosevelt, que trabalhou para reformar a economia norte-americana, após a crise de 1929. Nests contexto, foram criadas várias agências federais ${ }^{45}$, dentre elas a Work's Progress Administration, conhecida pela sigla WPA. Neste sentido, cabe destacar o livro New Deal for Work's Education: The Worker's Service Program 1933-1942, publicado em 1987, sob autoria de Joyce Kornbluch.

\begin{abstract}
"Started as a relief project by the Roosevelt Administration, the New Deal's Emergency Education Program (EEP) soon established itself as one of the most innovative and controversial education efforts in the nation's history. Each year, the EEP put as many as 200,000 teachers, administrators, and clerical employees to work organizing a remarkably wide range of classes in an equally varied range of settings".
\end{abstract}

(KORNBLUH, 1987:3) Project, reorganizado e renomeado em 1939 como Worker's Service Program, o primeiro programa de educação nacional ao trabalhador nos Estados Unidos, patrocinado pelo próprio governo. Como dado

\footnotetext{
${ }^{44}$ O New Deal teve grande influência na política econômica e social adotada no Brasil pelo Presidente Getúlio Vargas, o mesmo que apoiou, em 1942, a criação do primeiro "S", SENAI.

45 Estas agências federais foram designadas em várias siglas: CCC (Civilian Conservation Corps), TVA (Tennessee Valley Authority), AAA (Agricultural Adjustment Administration), PWA (Public Works Administration), FDIC (Federal Deposit Insurance Corporation), SEC (Securities and Exchange Commission), CWA (Civil Works Administration), SSB (Social Security Board), WPA (Works Progress Administration) e NLRB (National Labor Relations Board).
} 
estatístico, o livro revela a estimativa de que um milhão $0^{46}$ de trabalhadores foram alcançados por este projeto, dentro do período de nove anos, entre 1933 e 1942, até o final dos projetos do New Deal.

\begin{abstract}
"The New Deal work's education program disseminated information about work's rights [...]. Its written policy statements supported worker's rights to organize and bargain collectively in unions of their own choosing. Classes focused on social issues as well as on working conditions and workplace problems. In addition to courses in general adult education and social studies, union members could request classes in public speaking, parliamentary procedure, union administration, labor law, and collective bargaining. Conferences and forums on current events were scheduled in many areas of the country. Libraries were set up in union hall. State and local advisory committees were organizations to link the program with the labor movement and community organizations and to develop an infrastructure that, it was hoped, would continue the programming after the New Deals' demise".
\end{abstract}

(KORNBLUH, 1987:5)

New Deal, com os programas de serviço e educação ao trabalhador, teve um considerável impacto no futuro dos trabalhadores americanos, funcionando como um elo entre as tentativas das três primeiras décadas do século XX, e o dinâmico período de crescimento do movimento trabalhista e das instituições de educação aos jovens e adultos. WILLIE \& MILLER (1988), em Social goals and educational reform: American schools in the twentieth century, afirmam que a década de 1930 foi a primeira, de várias décadas seguintes, em que múltiplos grupos de investigação, comunidades de pesquisa e comissões de reforma trouxeram à luz simultâneos estudos da educação americana em geral, em particular a educação secundária.

\footnotetext{
${ }^{46}$ Mais de duzentas mil pessoas foram empregadas por ano pelo EEP, sendo a média mensal o relevante número de quarenta mil pessoas empregadas. (KORNBLUH, 1987:36).
} 
"It hoped to support a diversification in curricula that might respond to the varied needs of youth".

WILLIE \& MILLER (1988:36)

Neste sentido, se a década de 1930 abriu novos caminhos e importantes projetos, a década de 1950 merece atenção no cenário da educação adulta americana, já transformada. Segundo STUBBLEFIELD (1994), autor do livro Adult Education in the American Experience: from de Colonial Period to the Present ${ }^{47}$, é justamente na metade do século XX que os Estados Unidos incorporou a instrução à idade adulta, expressa por diferentes meios como as escolas públicas, universidades, museus, bibliotecas e até mesmo a televisão.

\footnotetext{
"A rising educational level and the emergence of the postindustrial society made continuing education the norm of adult life. [...]. Continuing education for work performance, and workplace sponsorship of education, became central features of the postwar period".
}

STUBBLEFIELD (1994:251)

A grande questão levantada nos anos 1950 era de que a atenção ao treinamento técnico e específico não correspondia ao número cada vez mais elevado de trabalhadores técnicos profissionais.

\footnotetext{
"From 1950 to 1958 alone, professional technical workers increased from 9 percent to 11 percent of all workers".
}

WILLIE \& MILLER (1988:46)

Neste sentido, nos EUA, assim como no Brasil, o período posterior à Segunda Guerra Mundial modificou profundamente $\mathrm{O}$ desenvolvimento da escola e da educação. No que diz respeito ao ensino vocacional, o que essencialmente o caracteriza é a

$47 \bigcirc$ autor esclarece que os interesses dos cientistas sociais e dos educadores ao ensino adulto foram combinados em 1946, ao criarem uma nova prática social denominada como laboratório de treinamento. O National Training Laboratory (NTL) foi organizado e administrado como um programa de Educação Nacional associado à Divisão da Associação da Educação Adulta (STUBBLEFIELD, 1994: 281). 
preocupação de democratizar o ensino, abrindo juntamente com a capacitação ao acesso ao ensino superior. A educação adulta passou a ser tratada do ponto de vista econômico e político, porém conjuntamente com as necessidades do aluno, desenvolvendo mais do que conhecimento cultural, atuando na sua personalidade como um todo.

A década de 1960 deu continuidade, por exemplo, por meio dos "Atos" de ensino pelos quais o governo apóia financeiramente 0 ensino vocacional. A educação com o intuito de garantir qualificações técnicas profissionais, também ajudou na conquista da própria cidadania norte-americana a grande parte dos adultos. Vale lembrar que o fluxo crescente de imigrantes aos EUA, desde o início do século $X X$, colaborou nesta procura por um tipo de aprendizado capaz de gerar condições necessárias ao emprego.

\begin{abstract}
"La finalidad de las primeras escuelas nocturnas era la formación profesional. Ésta tuvo un nuevo desarrollo gracias a los fondos aprobados de acuerdo con la Smith-Hughes Act de 1917 y la Vocational Educators Act de 1963. Ésta última estipula que las personas de cualquier edad que tuvieran necesidad de mejorar sus conocimientos o de adquirir nuevos podrían realizar estadías de formación profesional o de reciclaje de alta calidad".
\end{abstract}

(COPELAND, 1976:81)

O Adult Education Act de 1966, seguindo aos Atos de $1917^{48}$ e de $1963^{49}$, veio a confirmar o então Programa de Educação Básica aos Adultos. A formação profissional americana alcançou uma grande extensão com estes programas de educação adulta. Neste sentido, cabe observar a valorização americana ao ensino vocacional adulto,

48 Segundo NOBLE (1954:407), a Lei Smith-Hughes, aprovada em 1917, deu um decisivo ímpeto para o desenvolvimento da educação vocacional. A lei habilitava o governo federal a cooperar com os estados para pagar os salários dos professores da agricultura, comércio, indústria, e economia nas escolas secundárias; apoiar as instituições de ensino superior que se dedicam à formação de professores destas disciplinas.

49 Também, em 1963, o Economic Opportunity Act deu um novo impulso aos programas de alfabetização de adultos. Fundos públicos do orçamento federal foram destinados à educação de adultos desprovidos da língua inglesa, pois o não conhecimento da língua era uma grande desvantagem nas relações de trabalho entre empregado e empregador. 
evidente por meio de leis, porém mais que isso, evidente em relação à base orçamentária provida. Vale ressaltar que entre 1964 e 1970 a educação de base dos adultos recebeu um montante financeiro de aproximadamente 200 milhões de dólares provenientes do orçamento federal (COPELAND, 1976).

Nas décadas de 1950 e 1960, no caso do ensino vocacional e técnico adulto, o edifício escola passou a ser fundamental para atender à pedagogia da "educação permanente" ${ }^{50}$.

\footnotetext{
"Es necessaro no olvidar que la noción moderna de educación permanente ha encontado su origem en la necesidad de dar una base teórica más segura al desarrollo de la educación de los adultos y que sólo después fue aplicada esta noción en todos los niveles de la educación".
}

(KOTASEK, 1976:129)

Dentro desta visão, o autor ${ }^{51}$ compreende o conceito de "educação permanente" em três etapas sucessivas de reflexão. $\mathrm{Na}$ primeira, conforme citação acima, o conceito tem origem na educação aos adultos. A segunda etapa compreende a escola como uma preparação para a vida e a educação ao adulto como um complemento a esta preparação. Assim, entre educação de jovens e educação de adultos não existe uma barreira, e sim certa continuidade. Por fim, na terceira etapa, a mais significativa ao conceito, propões-se uma educação concebida para se estender durante toda a vida e, não apenas com o fim de uma escolaridade obrigatória (diploma). Estas etapas permitem chegar a uma concepção de "educação permanente" que proporcionava bases sólidas e novas à arquitetura de suas escolas.

Sendo assim, inúmeras questões merecedoras de investigação surgiram entre o conceito de "educação permanente" e o edifício-

50 A denominada "educação permanente" segue na mesma direção da denominada "educação integral". Conforme abordado, os "S" também passaram a ser "Escolas Novas" fundamentadas neste princípio educacional. Na mesma direção, o ensino técnico brasileiro nos anos 1950 e 1960 seguiu pela busca de uma formação completa ao operário, procurando atender tanto a ordem educativa como a social. ${ }^{51}$ Jiri Kotasek é autor do capítulo La idea de educación permanente en la reforma actual de los sistemas educativos y de la formación, parte do livro La Escuela y la educación permanente. 
escola: tem o programa de educação de adulto influenciado as atitudes dos jovens frente à educação permanente? Como os jovens são atraídos pelos programas de educação permanente de sua escola? Qual a imagem que os jovens têm das escolas de aprendizagem permanente e da educação de adultos? A escola, como um elemento de continuidade educativa, deveria então propiciar e interpenetrar os diversos campos sociais e ideológicos da educação, tais como: nível de qualificação escolar, organização social e política, universo do trabalho, conhecimento científico e prático, relações privadas e de interesse social.

Vale enfatizar que dentro do sentido de continuidade, a noção de "educação permanente" engloba não apenas o adulto, mas também o jovem. Jovens e adultos foram estimulados a participarem conjuntamente em todo o tipo de aprendizagem. Por exemplo, os jovens poderiam trabalhar durante o dia por tempo parcial e estudar nos cursos noturnos e, os adultos seriam modelos de "alunos permanentes" para os jovens. Dentro desta visão, a escola seria um centro de comunicação para a comunidade e poderia, desta maneira, elaborar programas que refletissem tantos os problemas dos jovens como dos adultos.

\footnotetext{
"Se han disociado durante demasiado tiempo los programas de educación para los jóvenes de los destinados a los adultos. Hacer participar directamente a los jóvenes en los programas de adultos y de educación permanente es un medio de suscitar entre ellos una actitud favorable al aprendizaje a lo largo de toda su vida".
}

(COPELAND, 1976:84)

Dentro da visão crítica de Harry Braverman (1974), em seu livro Trabalho e Capital Monopolista. A Degradação do trabalho no século XX. Segundo o autor, durante o século XX, o modo capitalista de produção se expandiu principalmente nas áreas industriais e do avanço tecnológico: 
"A necessidade de ajustar o trabalhador ao trabalho em sua forma capitalista, de superar a resistência natural intensificada pela tecnologia mutável e alternante, relações sociais antagônicas e a sucessão de gerações, não termina com a 'organização científica do trabalho', mas se torna um aspecto permanente da sociedade capitalista.

Em conseqüência, surgira, dentro dos departamentos do pessoal e de relações trabalhistas, nas organizações de apoio externo, escolas como as de relações industriais, departamentos universitários de Sociologia, e outras instituições acadêmicas e paraacadêmicas, um complexo de disciplinas acadêmicas e práticas, destinadas ao estudo do trabalhador. Logo depois de Taylor, surgiram a Psicologia industrial e a Fisiologia industrial para aperfeiçoar os métodos de seleção, adestramento e motivação dos trabalhadores, e foram logo ampliadas numa pretensa Sociologia industrial, para o estudo da oficina como um sistema social. $\bigcirc$ aspecto básico dessas diversas escolas e das correntes no seio delas é que, diferentemente do movimento da gerência científica, não se interessam em geral pela organização do trabalho, mas pelas condições sob as quais o trabalhador pode ser induzido a melhor cooperar no esquema de trabalho organizado pela engenharia industrial".

(BRAVERMAN, 1977: 124-125)

O autor continua o texto acima e levanta os problemas enfrentados na educação ao trabalhador adulto dentro do esquema de trabalho então organizado pela sociedade industrial:

"Os processos abrangentes da sociedade capitalista são tomados por essas escolas como dados inexoráveis, e aceitos como 'necessários e inevitáveis' em qualquer forma de 'sociedade industrial'. Os problemas em foco são os de gerência: insatisfação expressa pelas elevadas taxa de abandono de emprego, absenteísmo, relutância ao ritmo de trabalho imposto, indiferença, negligência, restrições à produção, e hostilidade ostensiva à administração". 
As associações americanas de trabalhadores adquiriram consciência da importância de sua ação educativa organizada para os adultos, somando suas ações a do Estado. Com a importância do trabalho na sociedade americana, muitos estabelecimentos instituíram programas de formação profissional, tanto ao jovem como ao adulto. A demanda de escolas técnicas e de programas vocacionais nos EUA foi registrada por meio de índices estatísticos e anúncios publicados em periódicos da época. A figura a seguir ilustra as linhas de ocupação seguidas após o término do colegial, na época, e enfatiza que a maioria dos alunos, um índice de 60\%, acaba por seguir "carreiras técnicas".
Figura 1: Diagrama ilustrativo

que mostra quais linhas de ocupação os estudantes americanos seguiam após o término do colegial. Observar a linguagem arquitetônica tradicional até então vigente no edifício-escola. Fonte: CAUDILL (1954:36)

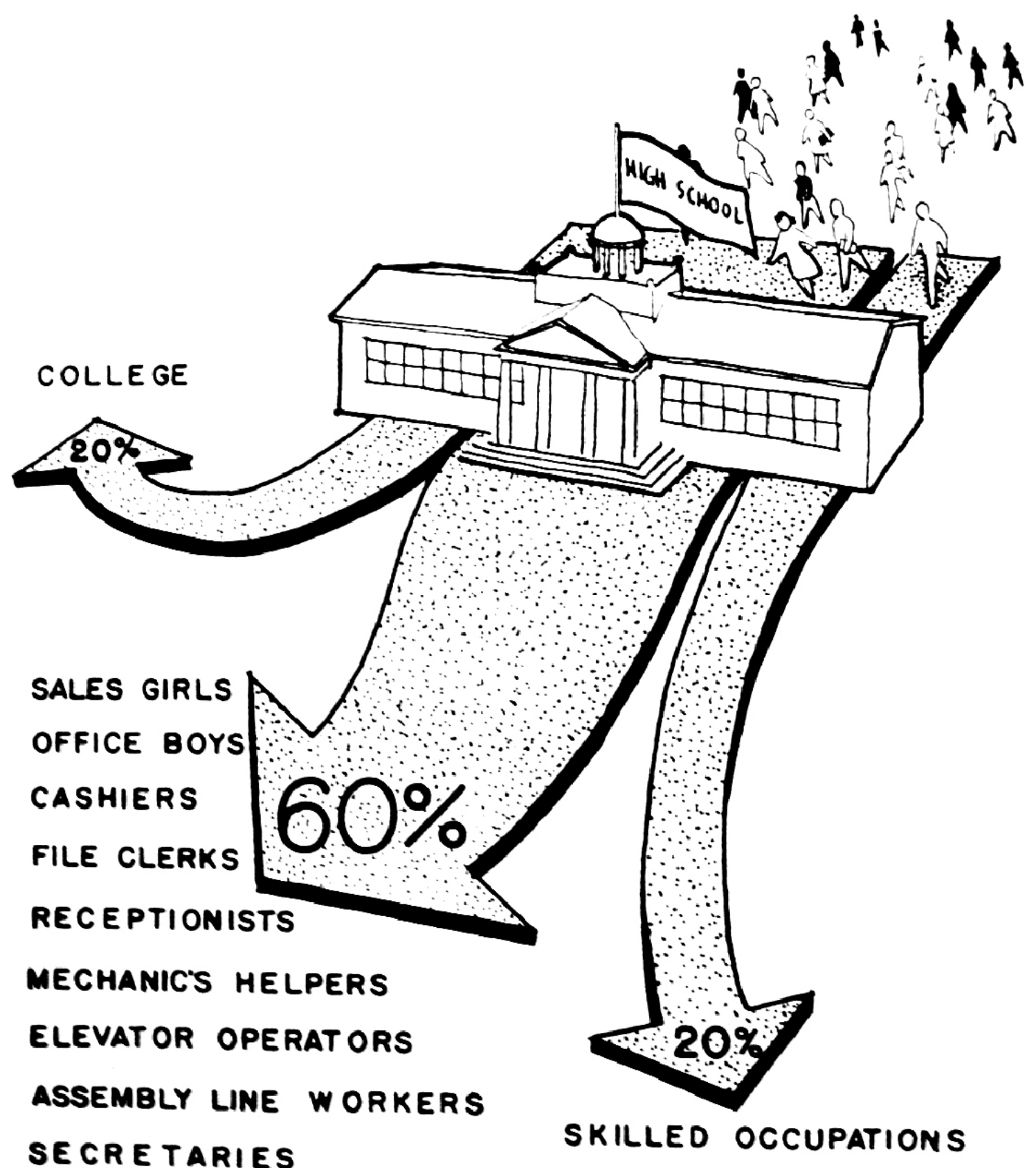



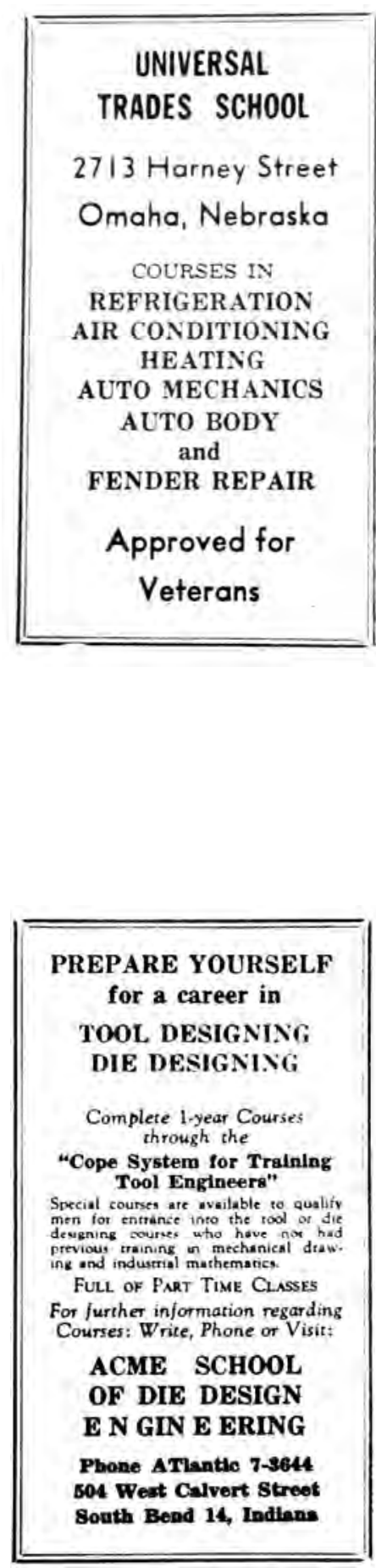

Figura 3: Anúncio de Escola Técnica em Indiana, publicado 1958.

Fonte: American Trade Shools Directory 1957-1958
De suma relevância à pesquisa, as décadas de 1950 e 1960 revelam a presença marcante de Trade and Vocational Schools nos EUA exatamente no mesmo período de florescimento das escolas modernas dos "S" brasileiros. Tanto o comércio como a indústria americana recorreram ao financiamento público e privado para preparar os adultos ao trabalho. A escola privada surge como uma instituição importante entre as que distribuem a formação profissional na comunidade.

Como prova desta demanda, publicações da época revelam dados estatísticos como, por exemplo, o anuário "American Trade Shools Directory", de 1957-1958, que publica: Trade and Vocacional Schools, classificadas por seus cursos e listadas por Estados e cidades; anúncios de cursos em evidência na época, tais como em Nebraska, enfaticamente "Approved by Veterans" e, em Indiana, "Full of Part time Classes", reforçando a idéia de cursos em carga horária parcial. A motivação, em ambos os anúncios, é clara. A escola profissionalizante teria então como tarefa essencial fazer da educação um instrumento agradável em si e produtivo para o futuro. Para ser eficaz, o edifícioescola passa a adotar novas características essenciais ao aprendizado e à educação: individualização da escola para adaptá-la aos alunos e à comunidade; individualização da administração, da instrução e de outros serviços para adaptá-los ao aluno.

As transformações ao longo do século $X X$, do edifício-escola americano voltado ao ensino vocacional e técnico, são abordadas a seguir, ressaltando a mudança pedagógica norte-americana rebatida na arquitetura, no mesmo período de construção das escolas modernas dos "S" no Brasil. As escolas construídas para a educação adulta, idealizadas sob as novas necessidades educacionais, sociais e econômicas do Pós - Segunda Guerra Mundial, são reconhecidas juntamente com análise das publicações pertinentes ao objeto de estudo. 


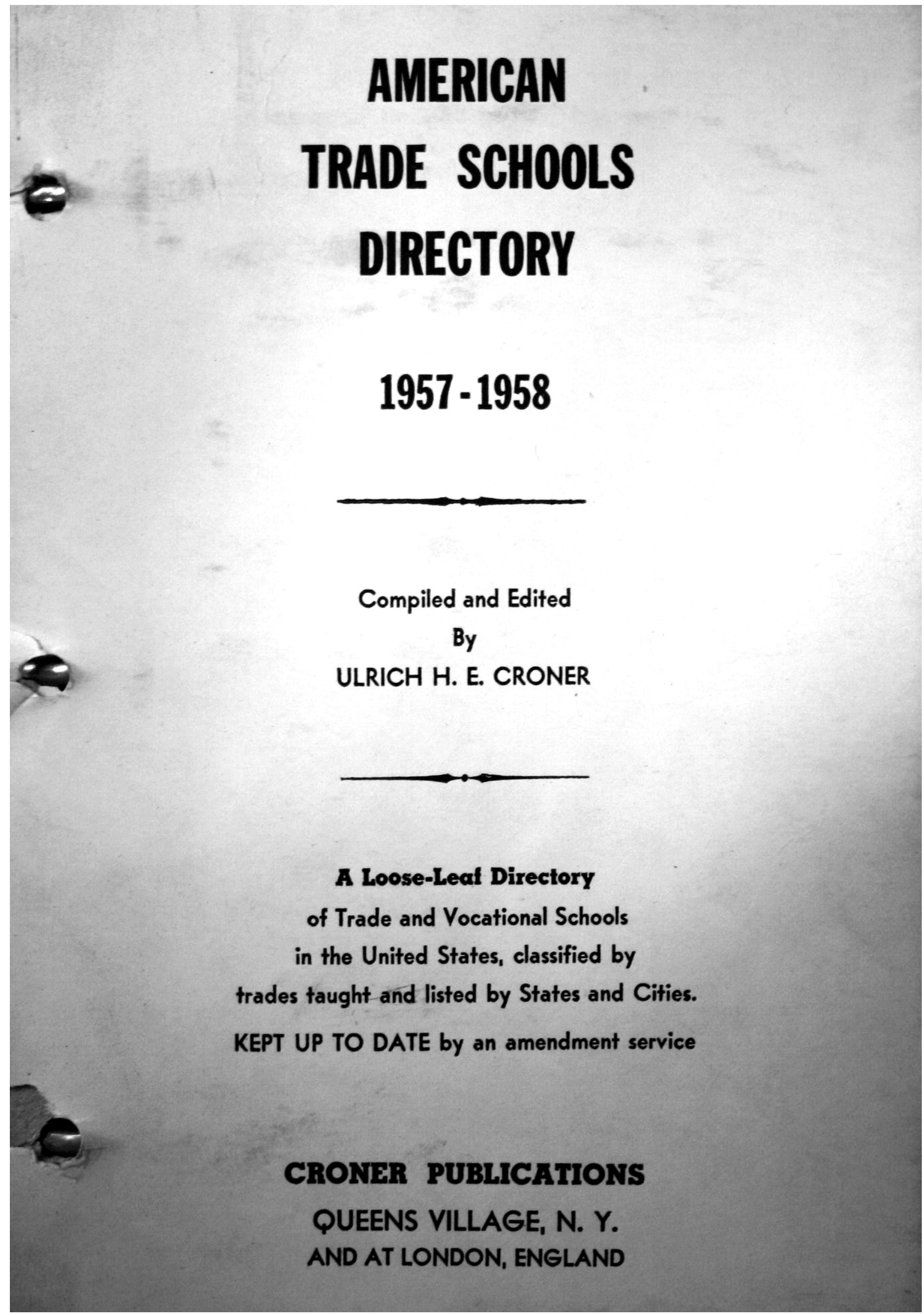

Figura 4: Capa do Diretório American Trade Shools Directory, 1957-1958. Fonte: American Trade Shools Directory 1957-1958 


\subsubsection{Educação em transição:}

\section{a perceptível mudança em meados do século XX}

As modernizações da educação americana no início do século XX carregou temas que se desenvolveram no âmbito da história da arquitetura escolar por todo século. Inicialmente, o edifício-escola, ainda que tratado mais como uma questão de higiene e de bem estar dos estudantes, mostrou o intento de tornar a experiência da educação mais aberta e adequada aos alunos. Assim, principalmente dentro do contexto das cidades americanas recém industrializadas, estas definições educacionais alargaram a forma de compreender as diferentes possibilidades oferecidas pela escola.

Sem a pretensão de retornar a história da arquitetura escolar americana, pelo contrário, esta parte da pesquisa objetiva mostrar como os arquitetos e/ ou engenheiros responderem em formas projetuais específicas e distintas às necessidades dos alunos tais como entendidos pela reforma americana do sistema educativo. Assim, dentro de um século que assiste a uma sociedade em rápida transição, cabe aqui o desafio de explorar e interpretar parte dos exemplares que foram significantes ao contribuir com a arquitetura escolar americana, citando alguns edifícios e arquitetos influentes. Neste sentido, procura-se captar o momento de mudança da escola tradicional para a moderna. Por um lado, há um impulso pela disciplina e controle através do jogo dos espaços e; por outro lado, como que um desejo emergente de incentivar a criatividade individual pela produção dos edifícios que não fossem isolados e confinados, mas sim abertos e interativos, características fundamentais da estratégia educacional que influenciou o edifício-escola em seu desenvolvimento ao longo do século XX.

Segundo DUDEK (2000), em Architecture of Schools the New Learning Environments ${ }^{52}$, para equilibrar esses radicais impulsivos do

\footnotetext{
52 Architecture of Schools the New Learning Environments (2000) é um livro guia que ilustrada e detalha tecnicamente a arquitetura escolar. O autor, Mark Dudek, enfatiza o desenho do edifício escolar como um campo particularmente especializado que abrange as teorias da mudança educativa, os requisitos espaciais e psicológicos para o crescimento das crianças, bem como as questões práticas, fundamentais para a construção deste tipo de edifício-escola.
} 
início do século XX, pode-se dizer que os mais privilegiados sistemas de educação privada tenderam a manter uma abordagem de edifícios para o ensino - buildings for education -, que foram deliberadamente definidos para torná-los institucionalizações por direito próprio. Isto pode ser observado particularmente na tradição inglesa da escola pública, na qual as hierarquias rebatem em uma arquitetura que pouco mudou nas últimas décadas do século XIX e início do século XX. Como exemplo, vale ressaltar os aspectos do desenho das "Board Schools" como o início de um sistema educacional em evolução na Inglaterra. Segundo STILLMAN (1949), em The Modern School, estes projetos serviram de referência posterior, muito além do que pretendiam. Ainda que providas de novas características espaciais, como salas de aulas interligadas por corredores de acesso, a divisão espacial destes projetos enfatizava fortemente 0 controle administrativo da escola. As salas de aula eram agrupadas ao redor de um hall central onde presidia a administração, com imediato controle visual de todas as salas

\footnotetext{
"The characteristic plans shown overleaf reveal the improved accommodation in the way of classrooms and washing facilities, in the provision of internal corridors for easier access, and in the addition of accommodation for teachers".
}

(STILLMAN, 1949:11)

Ao observar as plantas características da escola inglesa, do final do século XIX e início do século XX, é possível "ler projetualmente" a educação incidente. Partindo da tipologia adotada nas "Board Schools"53, o edifício-escola passou por diferentes

Explora as exigências funcionais dos espaços individuais, tais como salas de aula, salas música, salas de artes e áreas de lazer como o ginásio. Além disso, o autor discute outros fatores, como os efeitos de cor, luz, textura e imagens, sobre o comportamento, juntamente com os aspectos mais práticos da concepção de conforto e saúde. $O$ autor aborda como o contexto histórico da escola é contrabalanceado por uma concepção muito envolvida pelo impacto do projeto sobre o currículo educacional. Como livro-guia, apresenta estudos de caso, em todo o mundo, que abordam as questões importantes na criação da escola moderna.

53 As Board Schools foram criadas a partir do Ato de Educação Elementar de 1870. Segundo STILLMAN $(1949,11)$ até o advento das Board Schools, as escolas eram dependentes da lgreja, frequentemente ocupavam áreas próximas às mesmas, e acoplavam uma tendência estilística neogótica prevalecente e um caráter eclesiástico ao edifício escola. Porém, a medida pioneira do ato de 1870 forneceu instrução 
Figura 2: Planta típica das Board Schools, escolas inglesas do final do século XIX. Observar a planta "fechada" e definida em torno do hall central.

Fonte: The Modern School (1949:12) soluções espaciais que possibilitam a leitura de um espaço construído dentro de parâmetros educacionais e sociais da época. A figura abaixo caracteriza o projeto de uma Board School: uma planta fechada, em torno de um hall central, com pouca atenção aos critérios de ventilação e bem-estar dos alunos. Ainda assim, estas escolas abriram caminho a novas idéias educacionais ao introduzir: salas de aula separadas para cada grupo de idade, um salão central para atividades gerais da escola e salas específicas para atividades práticas.

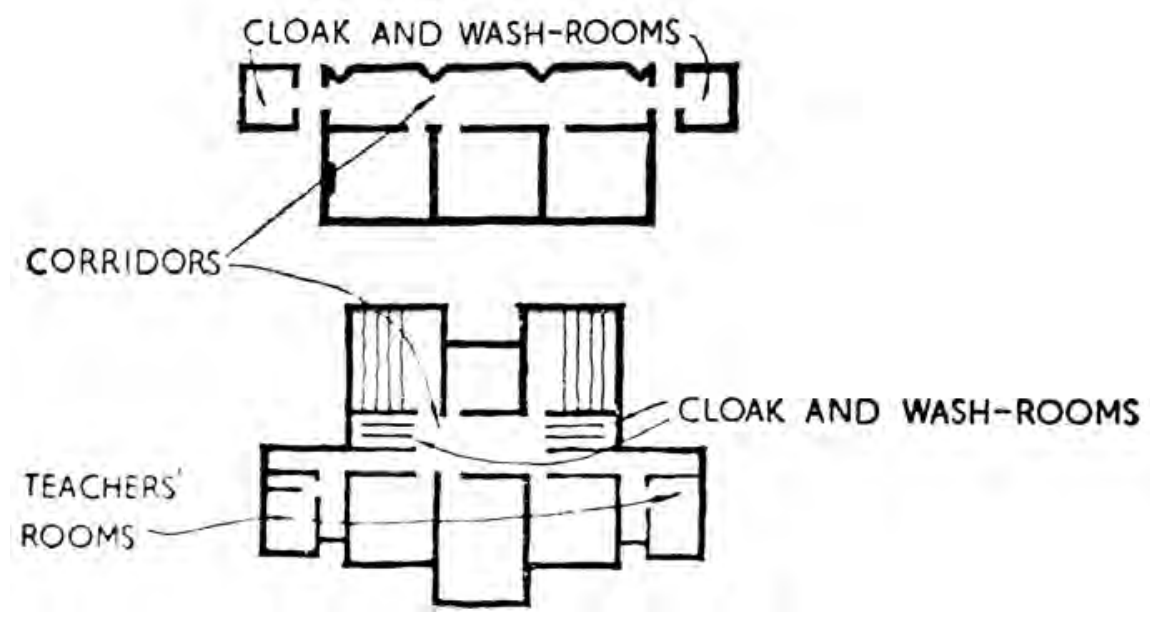

Já, a figura a seguir mostra a planta desenvolvida pela idéia de uma escola mais aberta, criada a partir das "Council Schools" Estas escolas trouxeram um novo padrão no edifício-escola, particularmente nos requisitos que se referem à luz natural, ventilação e higiene. Com ênfase à ventilação cruzada e à dimensão das janelas, corredores e varandas passaram a ser utilizados para separar o hall das salas de aula. Na relação entre educação e arquitetura, ao

para a população inteira de Inglaterra e de Wales, com o poder de construir e funcionar escolas nos lugares até então desprovidos da escola. Até o Ato Educacional de 1902 a chamada Board School foi a maior fornecedora educacional em Londres e suas infra-estatura e política desenvolvidas foram uma influência importante em Londres ao longo dos anos seguintes.

${ }^{54}$ As Council Schools foram criadas a partir do Ato de Educação de 1902, segundo STILLMAN (1949,13-14). Estas escolas adotaram um novo projeto centrado na saúde e no bem-estar dos alunos. 
comparar ambas as plantas é notório como as escolas inglesas do início do século XX vieram para dar expressão às mudanças que colocaram a Board School, bem como os tipos anteriores a esta, ainda mais fora de uso.

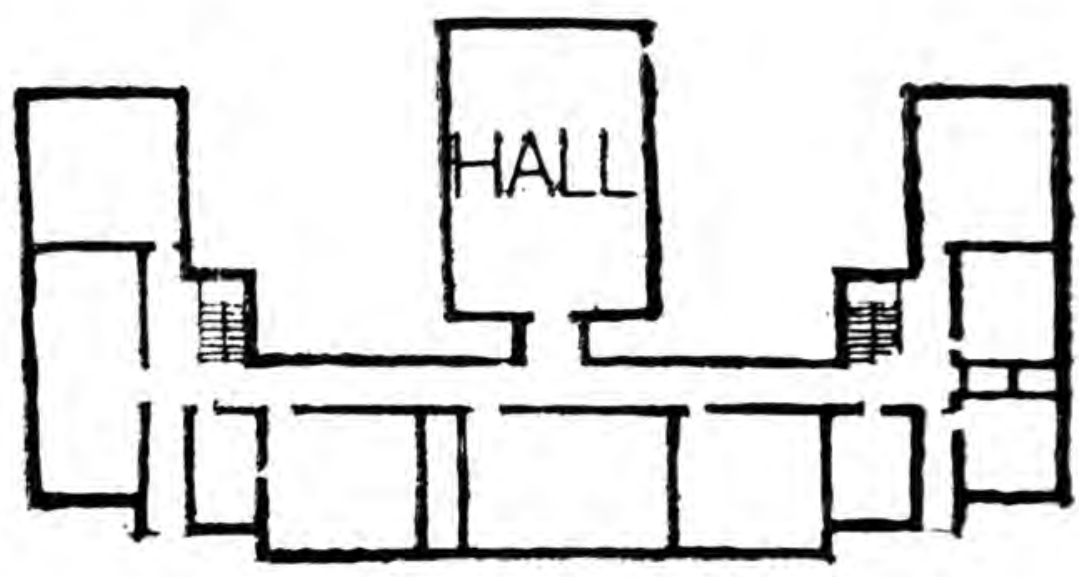

Esta referência à Inglaterra pode causar estranheza, mas o fato é que ao pesquisar o desenvolvimento da escola norte-americana no século XX, referências à escola inglesa são colocadas, dada sua importância na compreensão do tema. Por outro lado, o padrão escolar inglês nada mais segue do que a linguagem dos edifícios cívicos da época, tais como igrejas, cadeias, museus e até mesmo residências oficiais. A linguagem adotada, monumental e tradicional, assim como o formato e a simetria da planta o comprovam. De forma significativa, a teoria educacional estava apenas começando a "instigar" a prática arquitetural.

E na experiência norte-americana, como eram as escolas no início do século XX? Para a construção desta resposta, o papel do arquiteto no desenho das escolas das grandes cidades americanas conforme apontam as discussões da Board Education, em Chicago foi fundamental.

Segundo HAAR (2002:1.21), a Chicago Board of Education tinha no início do século uma escola para professores, juntamente com 15 escolas de ensino superior e 234 escolas de ensino elementar, totalmente freqüentadas por mais de 250 mil estudantes.
Figura 2: Planta típica das Council Schools, escolas inglesas do início do século XX.

Observar a planta "aberta", propiciando melhor ventilação, e o uso de corredores, separando o hall das salas de aula. Fonte: The Modern School (1949:12) 
Com a demanda, a escala e os aspectos programáticos do edifícioescola começaram a mudar. É dentro deste âmbito do "progressivismo americano", abordado anteriormente (1.3.1), que começam a ficar perceptíveis as relações entre arquitetura e educação, entre arquiteto e filósofo. $\bigcirc$ autor aponta Dwight Heald Perkins (1867-1941), como arquiteto da Chicago Board of Education que idealizou aproximadamente 40 novas escolas e ampliações dentro do período de cinco anos, de 1905 a 1910. E, John Dewey, como filósofo desta "educação progressiva", estabeleceu o Laboratory School de Chicago ${ }^{55}$. Como educar um cidadão dentro da cidade a fim de fazer avançar as condições da própria cidade? Arquitetura e educação, em resposta à cidade industrial.

Neste sentido, a figura a seguir exemplifica uma das escolas de Perkins, notáveis no início do século XX pela variedade de escala, inovação técnica e complexidade de programas. $\bigcirc$ arquiteto, ao usar a planta $T$, buscava maximizar iluminação e ventilação, orientar as salas de aula para a face leste ou oeste, facilitar o acesso aos banheiros localizados nas extremidades do edifício, englobar lazer na escola por meio do ginásio e do auditório.

Figura 3: Bernhard Moos School, 1907, $1711 \mathrm{~N}$.

California Avenue, Chicago. Observar a escola americana de Perkins em comparação com a típica escola inglesa da figura 2.

Fonte: HAAR (2002:1.23)

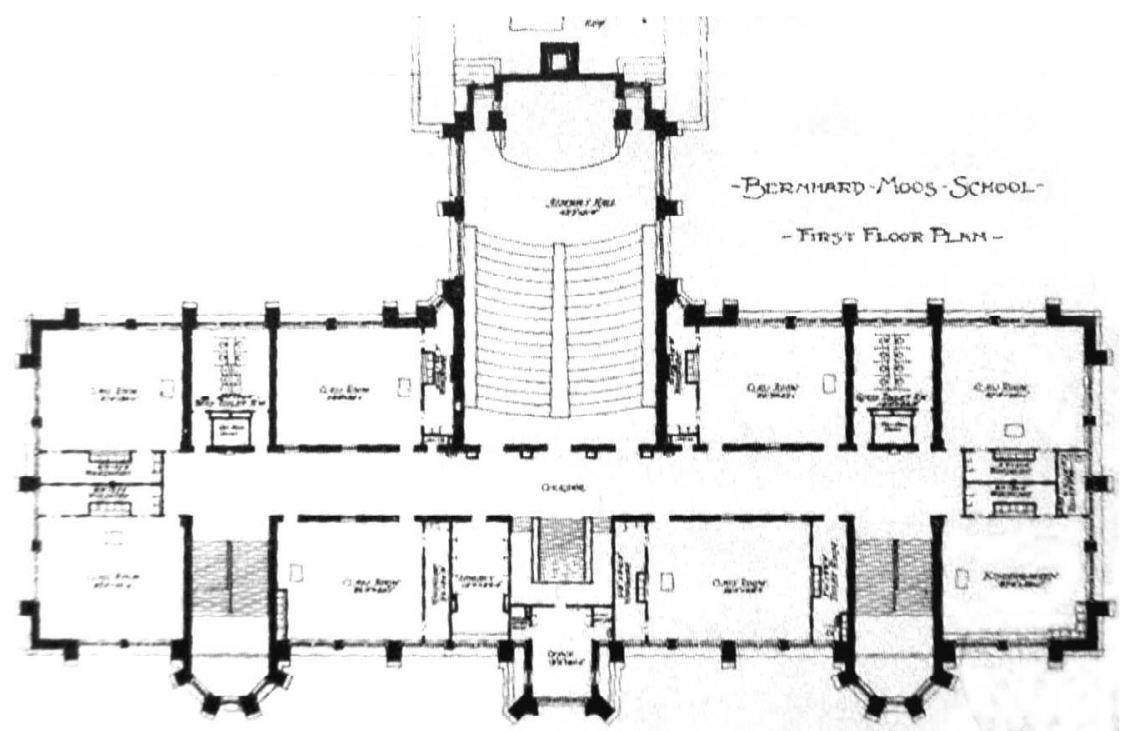

55 O denominado Lab School foi fundado em 1896 por John Dewey, em Hyde Park, Chicago. Esta escola-laboratório começou como uma instituição "progressiva" associada à Universidade de Chicago, na qual Dewey atuava desde 1894. Dewey desenvolveu sua pedagogia nesta experiência como fundador das University of Chicago Laboratory Schools e aplicou o material obtido por meio desta no seu primeiro grande trabalho sobre educação, A Escola e a Sociedade, The School and Society (1900). 
Ao observar a Bernhard Moos School (figura 3) de 1907, é perceptível a semelhança com a escola inglesa do início do século XX (figura 2), abordada anteriormente. Porém, nota-se também que muitas escolas deste tipo ainda foram construídas nas décadas de 1920-1940, até mesmo as escolas vocacionais.

Neste sentido, aproximando o edifício-escola norte-americano ao objeto de estudo desta pesquisa é preciso responder: como era a arquitetura das escolas destinadas ao ensino comercial e industrial na primeira metade do século XX? Cabe aqui destacar duas grandes publicações da época que ilustram e apresentam as necessidades das escolas vocacionais deste período: School Architecture: Principles and Practices, um livro publicado em 1921 pelo arquiteto John J. Donovan e, The American School and University, um anuário publicado a partir de 1930 sobre o desenho, construção, equipamentos, utilização e manutenção dos edifícios educacionais.

O livro School Architecture: Principles and Practices (1921) apresenta os edifícios e os equipamentos para as escolas vocacionais das duas primeiras décadas do século XX. Observa-se a preocupação com a adaptabilidade além dos problemas construtivos de iluminação, ventilação, aquecimento e higiene. Eles procuravam responder questões como: A que função educacional o edifício deve servir? Quais são as necessidades desta fase da educação para que os arquitetos possam fazer provisão em seus planos e especificações? $E$, para responder estas questões, seria necessário um conhecimento geral dos tipos de educação e a distinção entre suas funções. No caso da educação vocacional, o objetivo era formar um produtor inteligente, quer seja de mercadorias ou de serviços (1921: 157). As Trade and Industrial Schools foram tratados estabelecidas neste livro em sua especificidade com relação à educação em geral, tais como a preocupação de fazer uma escola de maior dimensão para propiciar espaço adequado ao ensino do trabalho. Desta forma, o ensino industrial e comercial é chamado de new education e esta nova educação requereu um novo tipo de edifício-escola para atender à demanda da indústria: 


\footnotetext{
"The rapid growth of industrial schools is a development of the educational system designed to meet the demand in the industries for more skilled workmen, foremen, and superintendents. The situation is rapidly becoming serious and must be met by a system of industrial training which will supply the ever-increasing demands of industry for intelligent man power. To meet this demand, trade and industrial schools are needed".
}

(DONOVAN, 1921:160)

Assim, no início do século $X X$, os principais fatores considerados ao fazer o "novo" edifício-escola para a educação industrial ou comercial foram: a localização da escola em área suficientemente grande para possibilitar sua expansão futura; a elaboração de plantas e equipamentos visando o aumento da eficiência; a área da fábrica com grande quantidade de luz natural; as divisões internas temporárias ou móveis; o interior do edifício-escola dividido basicamente em ambientes para oficina, salas de aula, ciências e artesanato, salas administrativas, banheiros, recreação, refeitório e depósito.

Cabe destacar nestas escolas os princípios de "flexibilidade", com divisórias móveis como paredes internas, e de "rendimento", incluindo o ensinar por meio da experiência. Ao conectar a prática com a instrução teórica, o edifício deveria ser construído para replicar estreitamente as condições da indústria ou do comércio. Ao seu tempo, estes mesmos princípios foram posteriormente aplicados pelos "S" brasileiros na década de 1950.

\footnotetext{
"As a means of securing greater 'flexibility', the room in which the related instruction is given should be near the shops. This arrangement will enable the instructors to connect the practical shopwork with the related instruction, and will make available much of the shop equipment for laboratory purposes".
}

(DONOVAN, 1921:165) 


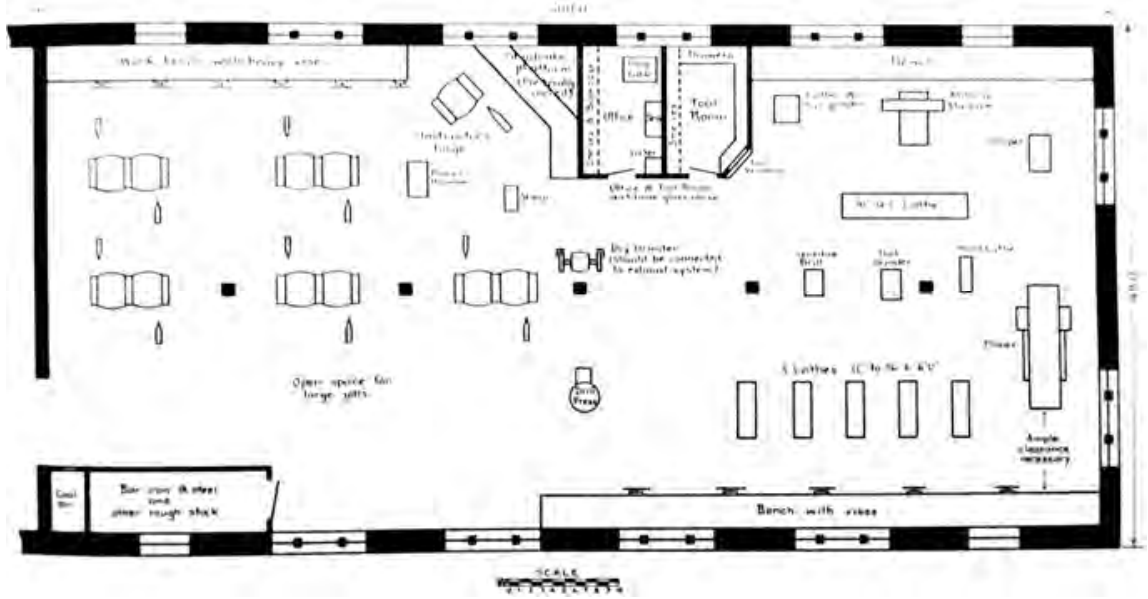

Figura 4: Planta típica de uma sala equipada para os cursos de

forja e oficina de máquinas, década de 1920. Observar a preocupação em projetar um espaço suficientemente

dimensionado à atividade proposta: "open space for large jobs".

Fonte: School Architecture: Principles and Practices (1921:165)

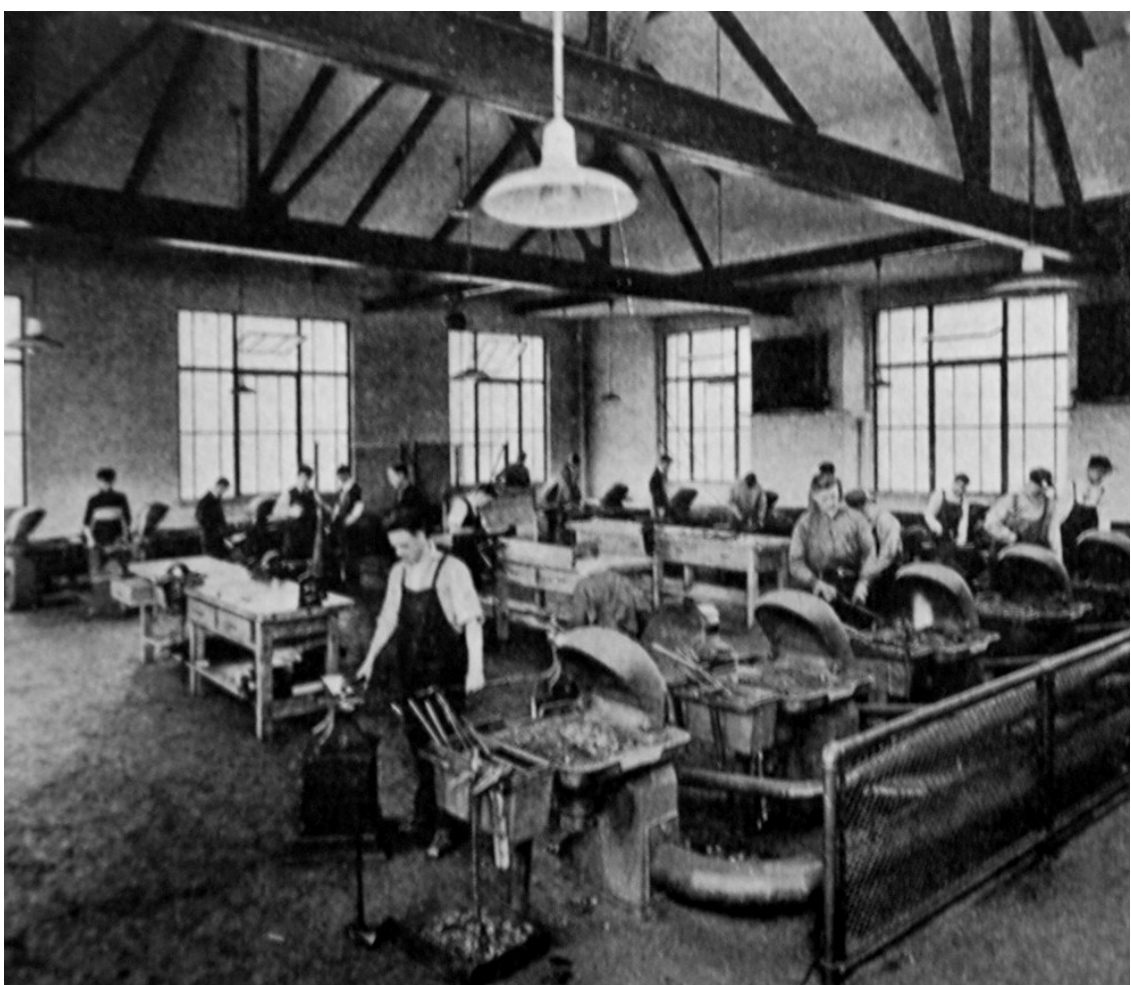

Figura 5: Oficina de forja e de madeira na Pullman Free School,

Pullman, Illinois. Observar a grande quantidade de luz natural neste ambiente de treinamento manual.

Fonte: School Architecture: Principles and Practices (1921:188)

Como exemplo do ensino vocacional no início do século XX, podemos observar o projeto de algumas escolas como: Boy's Technical High Schools (1906, Milwaukee, Winsconsin), David Ranken Junior, School of Mechanical Trades (1907, Saint Louis, Missouri), Worcester Boy's Trade School (1910, Worcester, Massachusetts), William Hood Dunwoody Industrial Institute (1914, Minneapolis, Minnesota). 


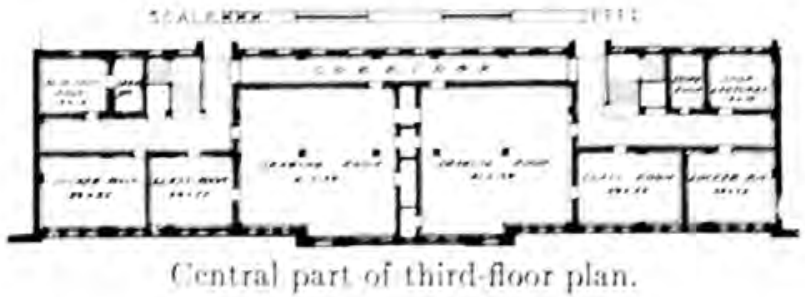

Figura 6: Boy's Technical High Schools, 1906, Milwaukee, Winsconsin. Comparar as semelhanças com a figuras 2 . Fonte: School Architecture: Principles and Practices (1921:181)

Figura 7: David Ranken Junior, School of Mechanical Trades, 1907, Saint Louis, Missouri. Esta escola foi adicionada ao edifício já existente (menor). Observar como o novo edifício segue a solução já apresentada nas figuras 2 e 3 .

Fonte: School Architecture:

Principles and Practices

(1921:174)

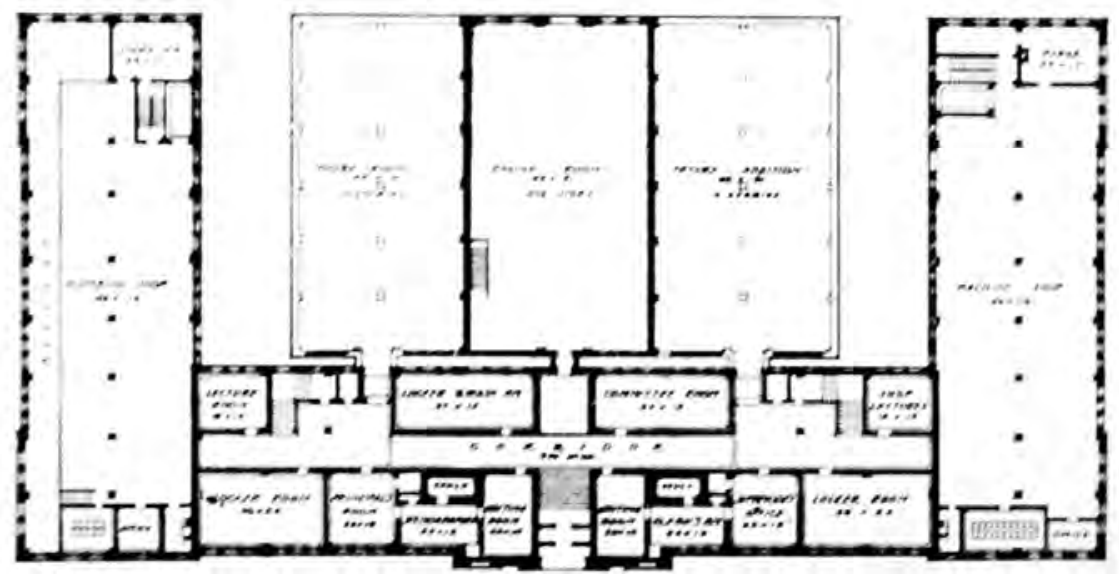

First-floor plan.
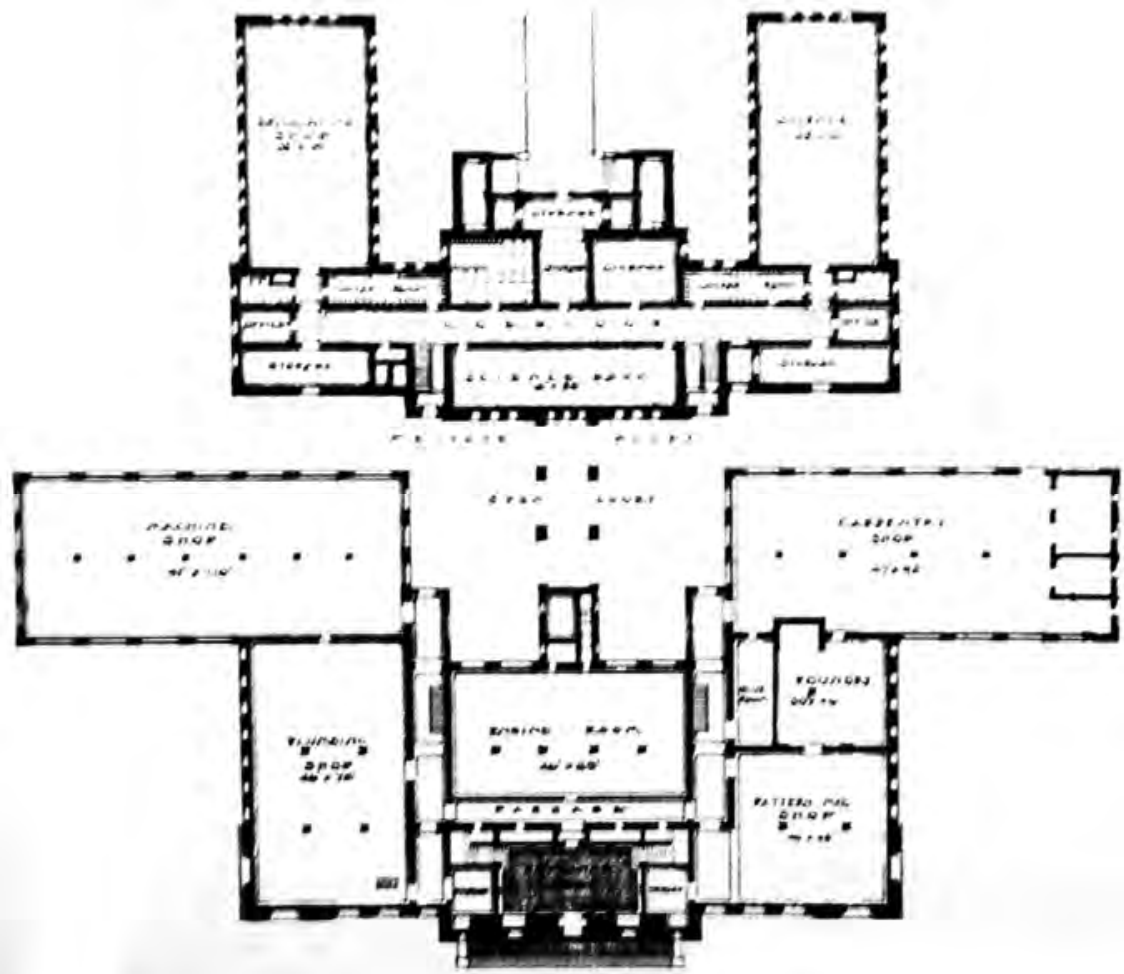

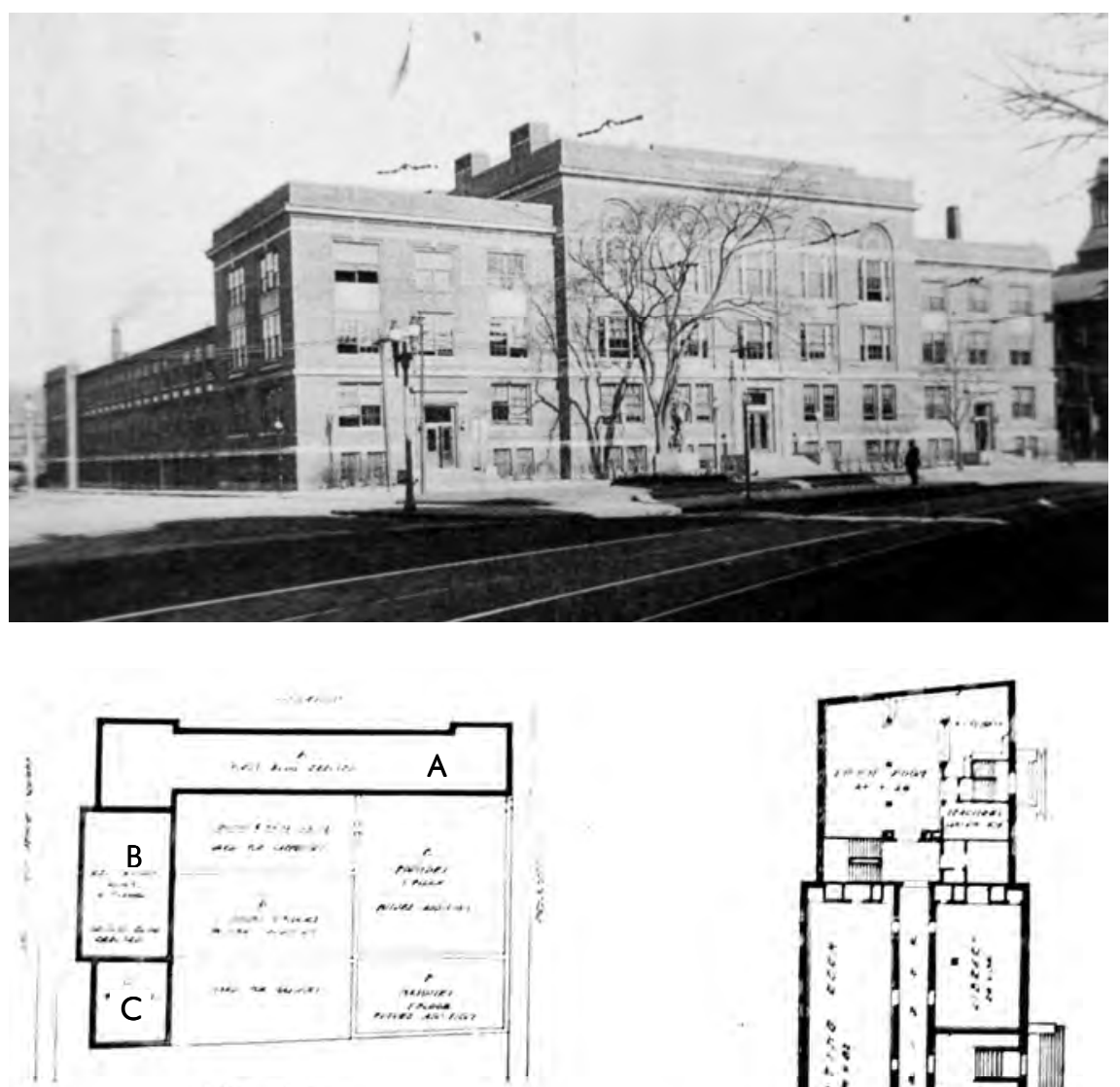

Plot plan.

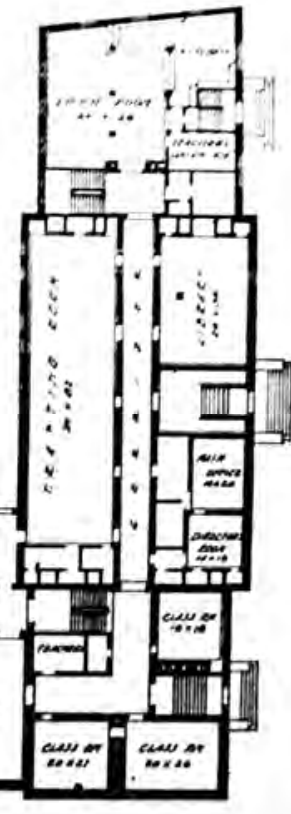

First-floor plan.

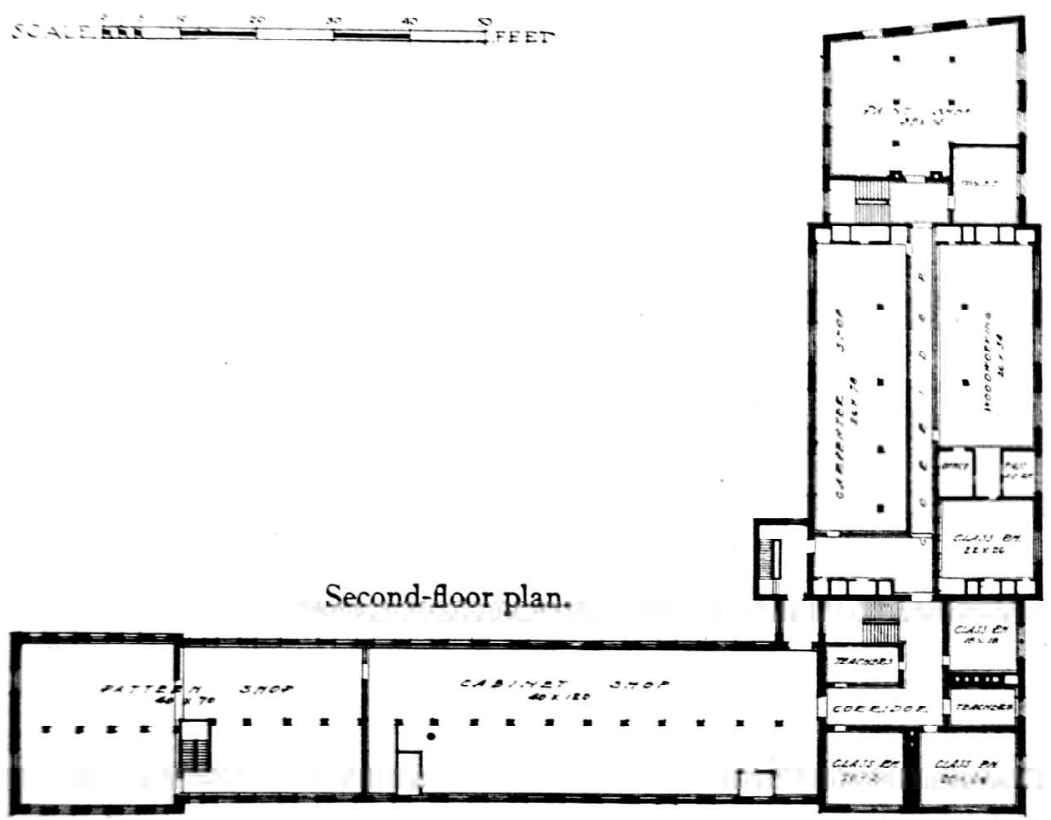

Figuras 8, 9 e 10: Worcester Boy's Trade School, 1910, Worcester, Massachusetts. Construída por etapas, a escola em forma de $L$ foi dividida em 3 partes interligadas e denominadas A, B e C. Observar a dimensão das oficinas projetadas para possibilitar as especificidades do treinamento manual da época.

Fonte: School Architecture: Principles and Practices 

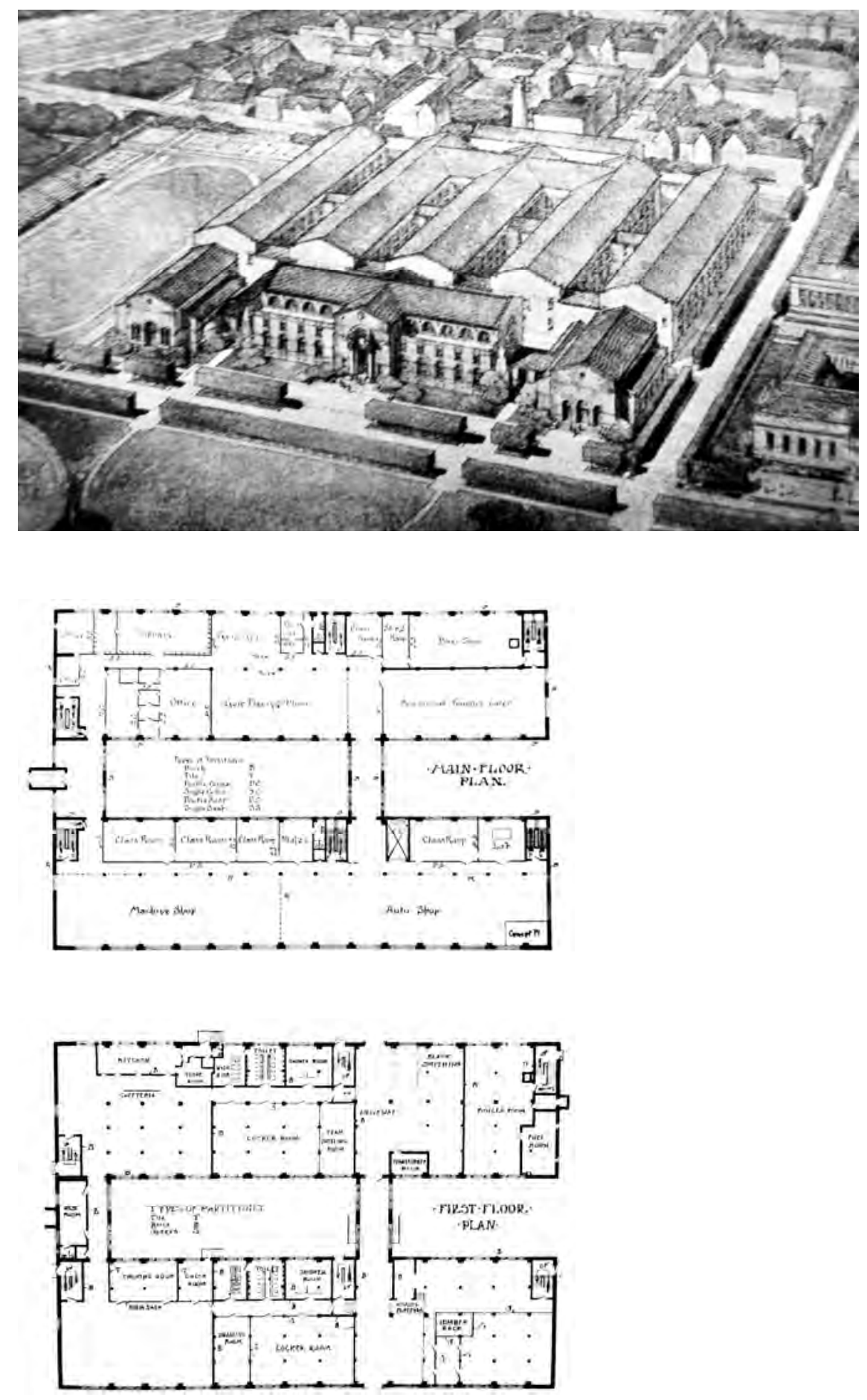

Figuras 11, 12, 13 e 14: William Hood Dunwoody Industrial Institute, 1914, Minneapolis, Minnesota. Solução de blocos paralelos conectados por passarelas e abertos aos jardins internos. Uso das divisões internas temporárias ou móveis. Fonte: School Architecture: Principles and Practices (1921:178-180)

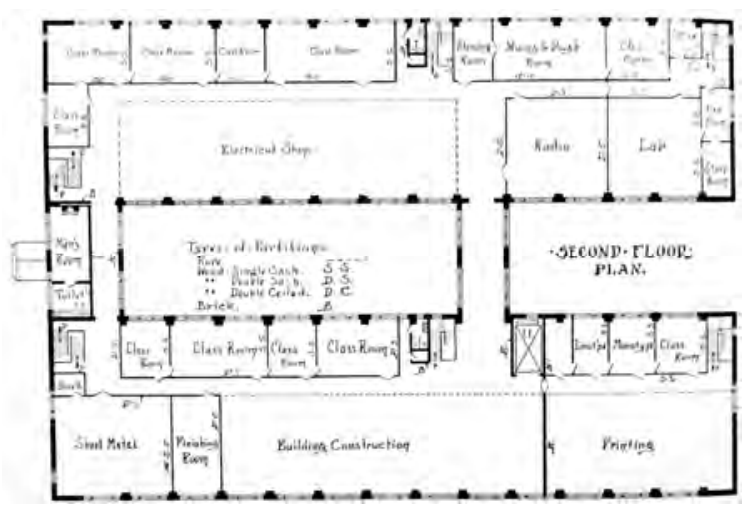


Para exemplificar a afirmação anterior, de que o padrão de muitas escolas do início do século XX ainda foi utilizado nas décadas de 1930-1940, apresenta-se o anuário The American School and University. Este anuário, especificamente no volume de 1931-1932, publica o edifício-escola direcionado à educação comercial e industrial.

Dentro da educação comercial, Earl Wingert Barnhart ${ }^{56}$ discorre sobre o tema dentro da década de 1930 e afirma que a linguagem convencional da escola comercial não era radicalmente diferenciada de qualquer outro edifício-escola de grande porte. Dentro do ensino vocacional, o autor apresenta algumas escolas comerciais: Samuel J. Peters Boy's High School of Commerce (New Orleans, LA), John Hay High School (Cleveland, Ohio) e High School of Commerce (Portland, Oregon). À sua maneira, o autor apresenta uma visão crítica destas escolas ao afirmar que a "aparência" destes edifícios não era essencialmente diferente, assim como o lay-out muitas vezes não apresentava uma solução especial mais eficiente ao desenvolvimento da prática comercial.

\footnotetext{
"Unfortunately, the particular provisions needed for the most effective conduct of many commercial classes have not been incorporated in the building plans of commercial high schools, for the same reasons that vocationally efficient commercial curricula have not been developed. Indeed, quite often academic high school principals have assumed that the teaching practices developed in the private commercial schools of a halfcentury or so ago were psychologically sound, and therefore they have often recommended for their own schools the large bookkeeping and type-writing rooms used in private business schools as a revenue-producing convenience".
}

BARNHART (1932:374-375)

\footnotetext{
56 Earl Wingert Barnhart, nascido em 1882, é autor da seção VII do anuário The American School and University 1931-1932 (1932:372-380). Como representante do Serviço de Educação Comercial e da Federal Board para a educação vocacional, Barnhart organizou em 1930 a publicação Vocational education for those engaged in the retail meat business: the program developed in cooperation with the National Association of Retail Meat Dealers, de autoria de Federal Board for Vocational Education, relacionada à educação comercial.
} 


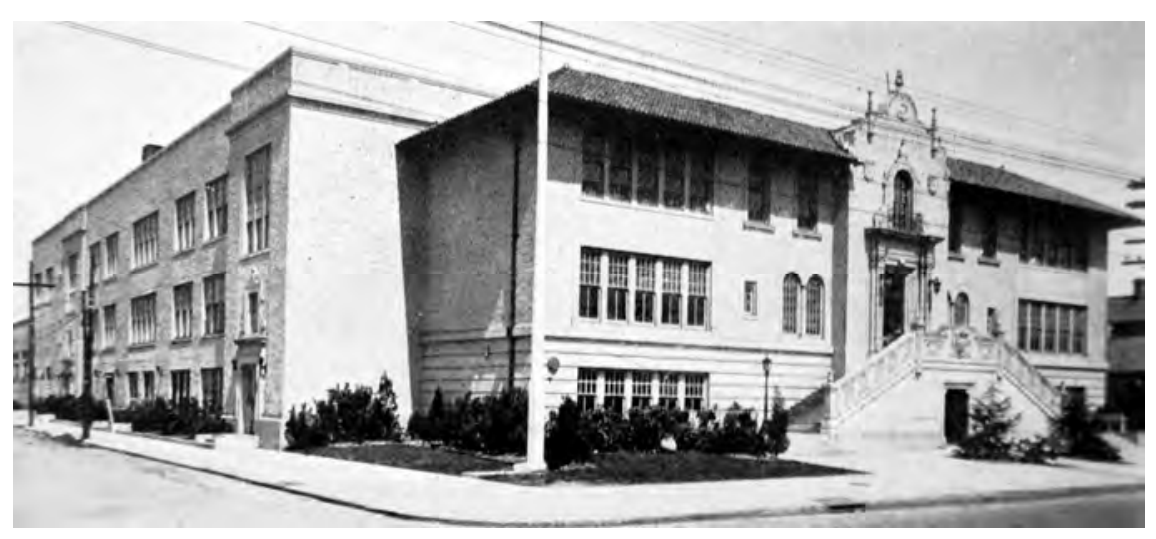

Figuras 15, 16 e 17:

Escolas de ensino comercial da década de 1920,

respectivamente: Samuel J. Peters Boy's High School of Commerce (New Orleans, LA), John Hay High School (Cleveland, Ohio) e High School of Commerce (Portland, Oregon).

Fonte: The American School and University 1931-1932

(1932:372-373)

Figura 18: Sala de aula equipada para dar instrução na operação de máquinas de calcular:

Observe o desenho das mesas para este tipo de uso.

Fonte: The American School and University 1931-1932 (1932:375)
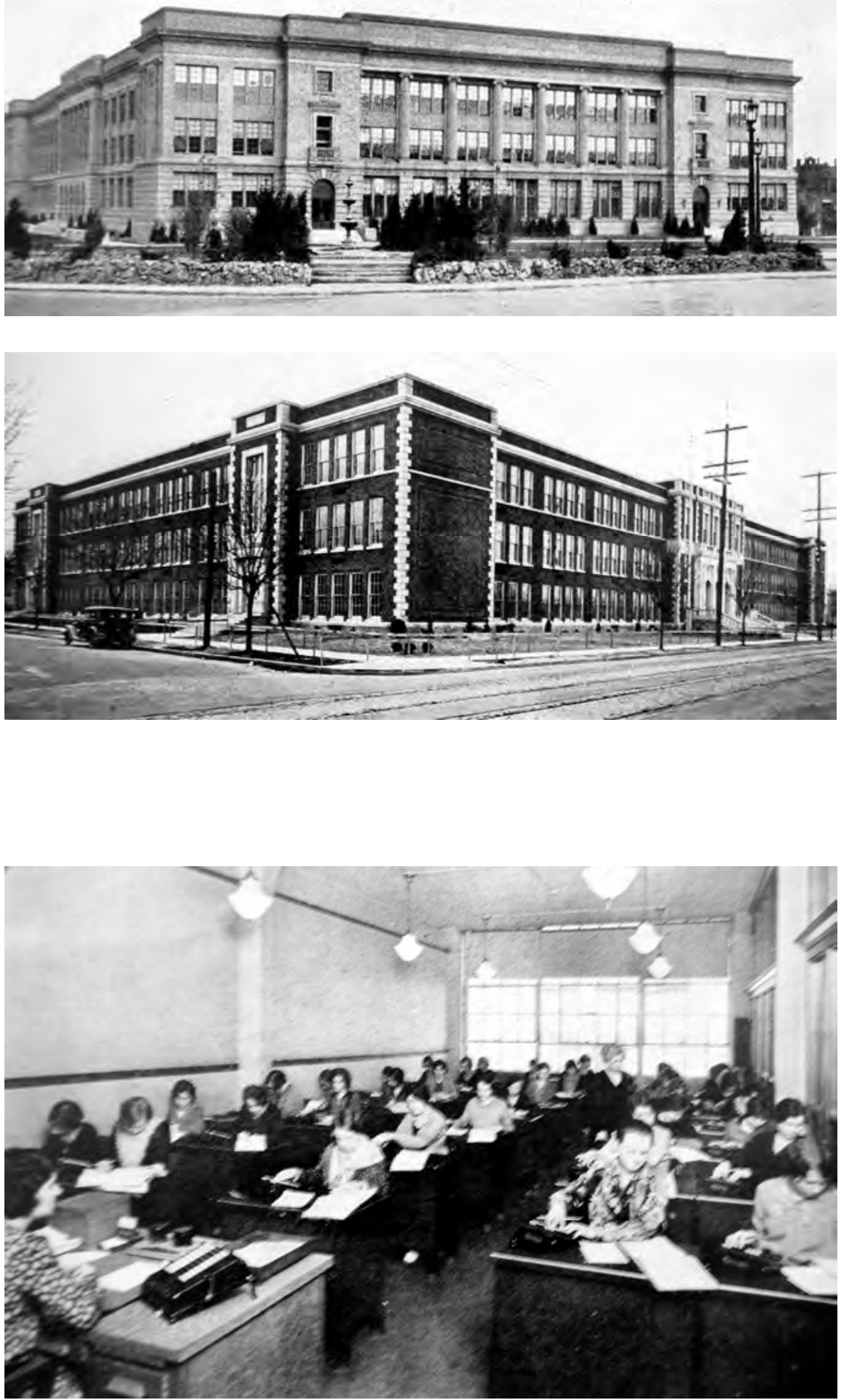
Dentro da educação industrial, o mesmo anuário apresenta os fatores que influenciaram no desenho das escolas vocacionais industriais da época. Algumas recomendações são feitas em relação à construção do edifício-escola - os pavimentos devem suportar o peso das máquinas - e às oficinas - que requerem luz de dois ou mais lados (e não unilateral). $O$ aspecto do "crescimento" também é nítido, ao pensar numa escola que poderia se expandir de acordo com a demanda da indústria:

\footnotetext{
"The building will be filled to capacity in a few years if the demand for vocational education continues at the present rates. However, provisions have been made so that the building can be added to in two places. The present wing may be extended. Another wing can be constricted form the other end of the building parallel to the present wing. The space for the secondary corridor for this wing has been made into a temporary storeroom for use until any addition to the building requires that space".
}

YOUNG 57 (1932:415)

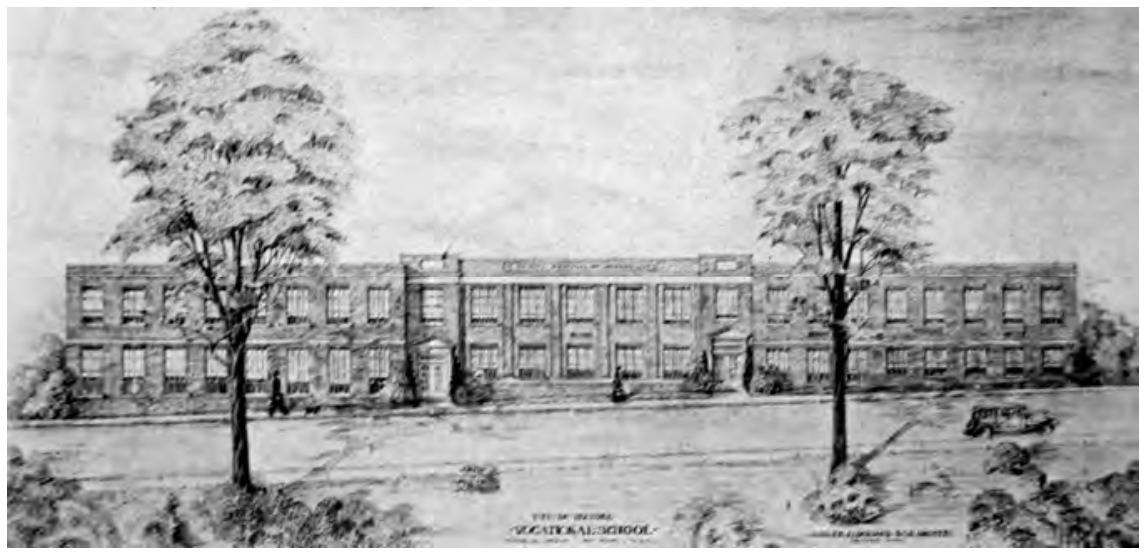

Ao percorrer e ler os exemplares aqui evidenciados é nítido como a escola vocacional nas três primeiras décadas do século XX procurava responder às questões pedagógicas de seu tempo. Soluções espaciais, técnicas e construtivas procuravam atender aos princípios mencionados na bibliografia de "flexibilidade", "rendimento", "crescimento", entre outros. Buscando ser um moderno edifício-escola, não dispensava, no entanto, a linguagem

57 Lloyd P. Young foi Diretor de Pesquisa e Orientação do Departamento da Escola de Holyoke, Massachusetts, de acordo com The American School and University 19311932 (1932:413).
Figura 19: Escola de ensino industrial proposta para a cidade de Holyoke, Massachusetts, pelos arquitetos G. P. B. Alderman Company. Fonte: The American School and University 1931-1932 (1932:413) 


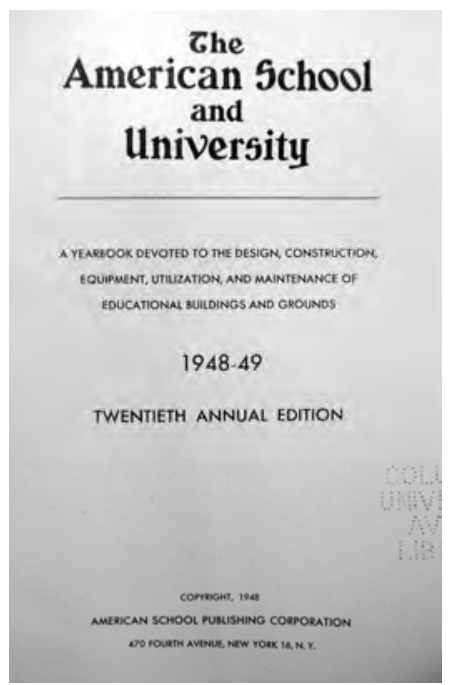

Figura 20: Capa do anuário The American School and University 1948-1949

Fonte: The American School and University

1948-1949
Figura 21: Propaganda publicada em 1949. Observar a imagem tradicional do edifício-escola.

Fonte: The American School and University

1948-1949 (1949: 349) arquitetônica tradicional, austera e imponente, bem como as soluções em planta, ainda estavam embasadas em velhos modelos, muitas vezes aplicados semelhantemente em edifícios com outras funções.

Foi no final da década de 1940 que esta feição tradicional passou a ser pensada de outra maneira, principalmente no período pós-Segunda Guerra. É justamente neste ponto que a experiência da arquitetura escolar norte-americana vem colaborar diretamente com as escolas brasileiras "S", reafirmando o mesmo período de transformação e afirmação de uma nova arquitetura no ensino vocacional, tanto nos Estados Unidos como no Brasil.

Como evidência deste momento de transição, o anuário The American School and University 1948-1949, por um lado publica propagandas da época que refletiam a imagem de um edifício-escola tradicional e, por outro, projetos e artigos que enfatizavam 0 "desenho dos edifícios educacionais para as necessidades de amanhã" planejados para terem continuidade nas edições futuras, conforme as figuras abaixo:

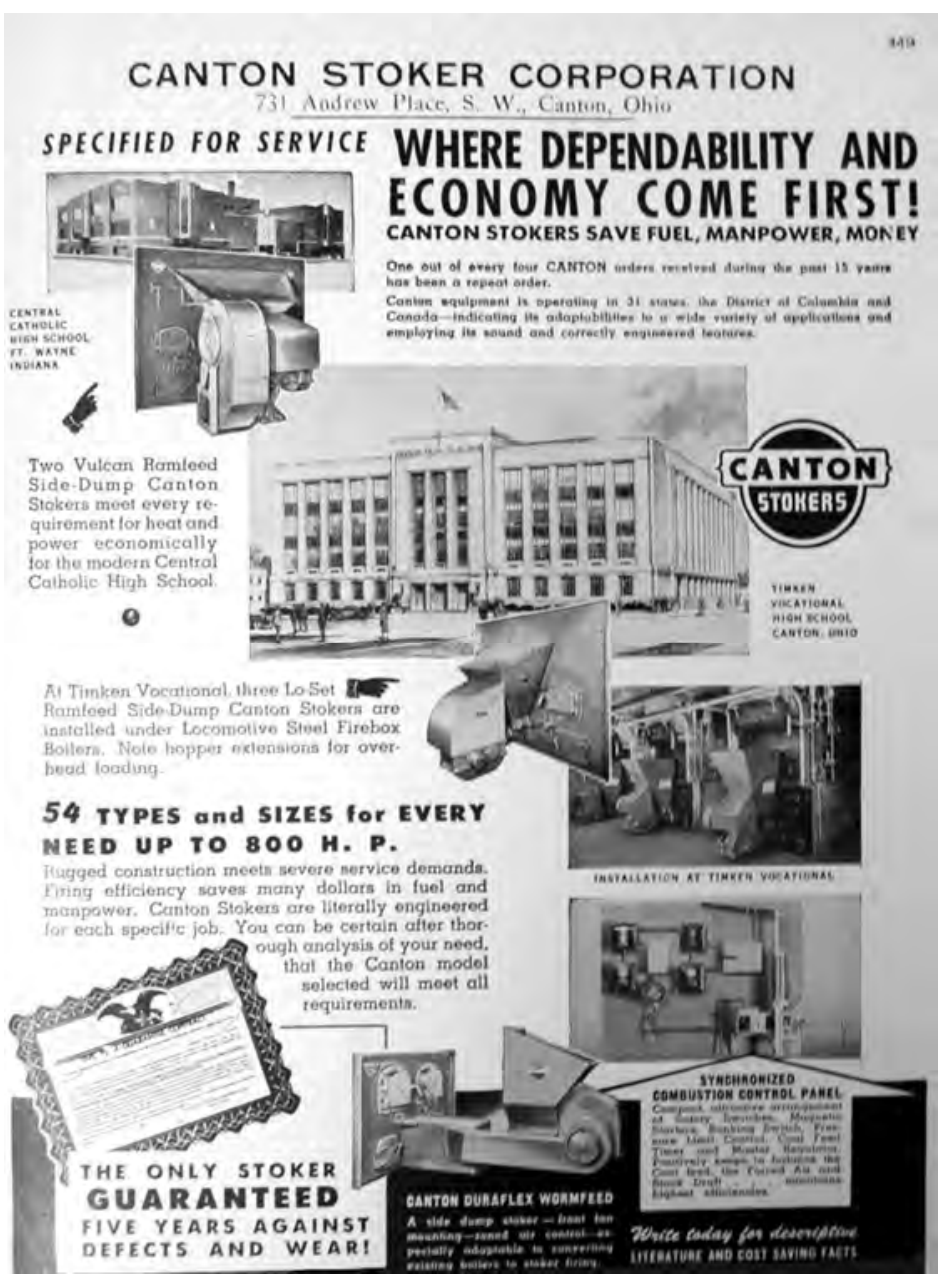




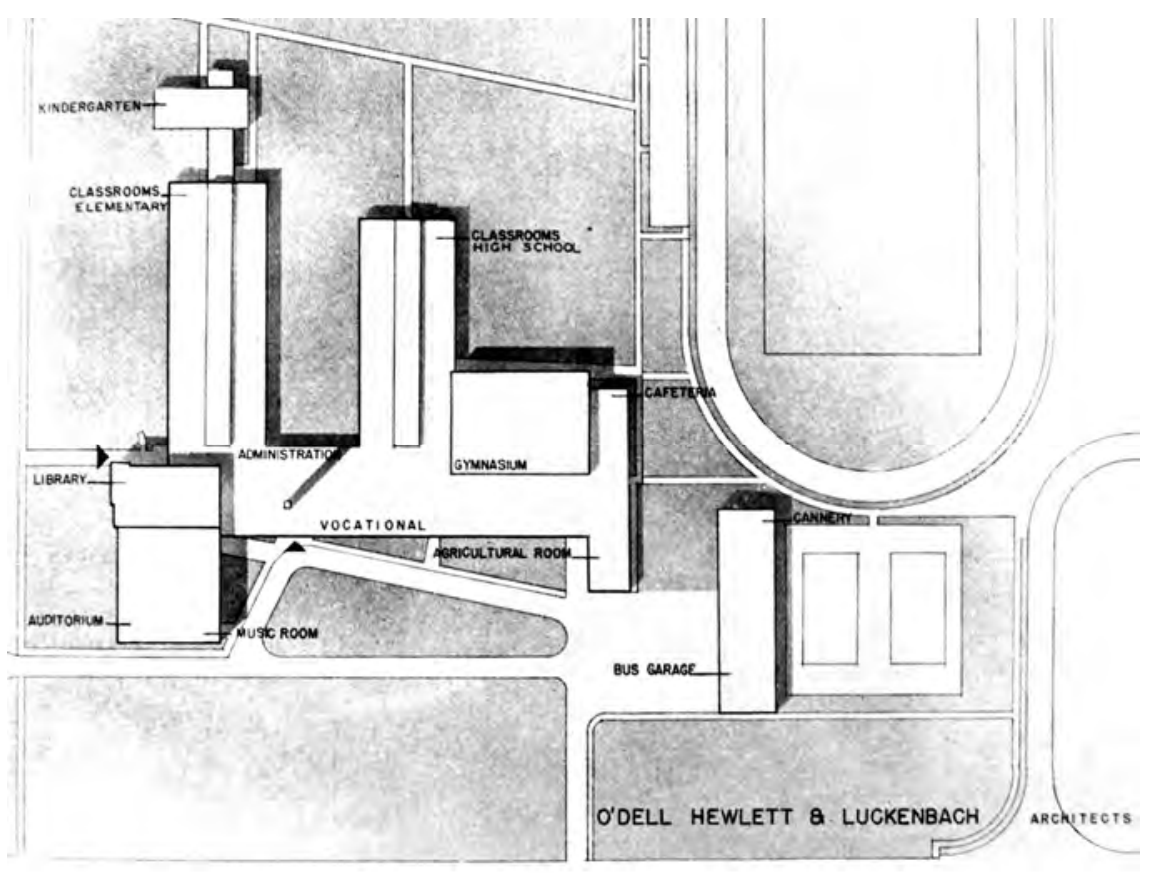

Figura 22: Litchfield Community School. Implantação geral de uma escola para ensino elementar, secundário e vocacional. O'dell Hewlett \& Luckenbach arquitetos. Fonte: The American School and University 1948-1949 (1949:267)

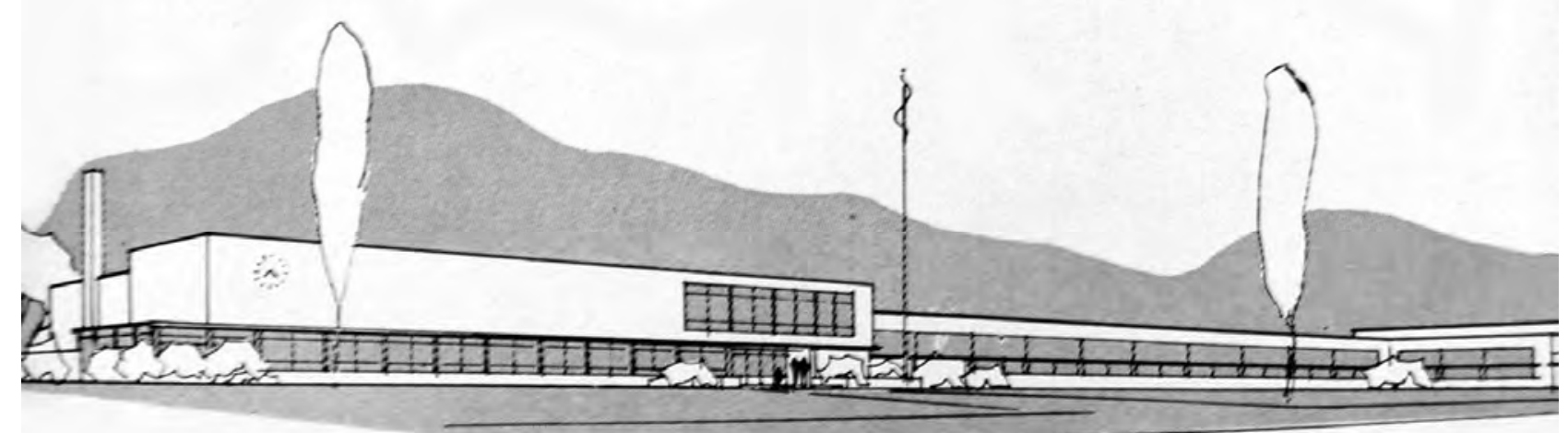

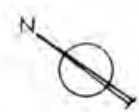

HIGH SCHOOL PLAYGROUND
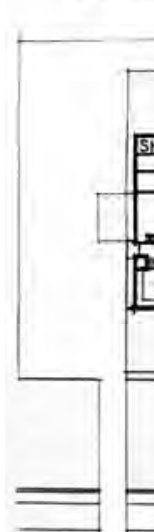

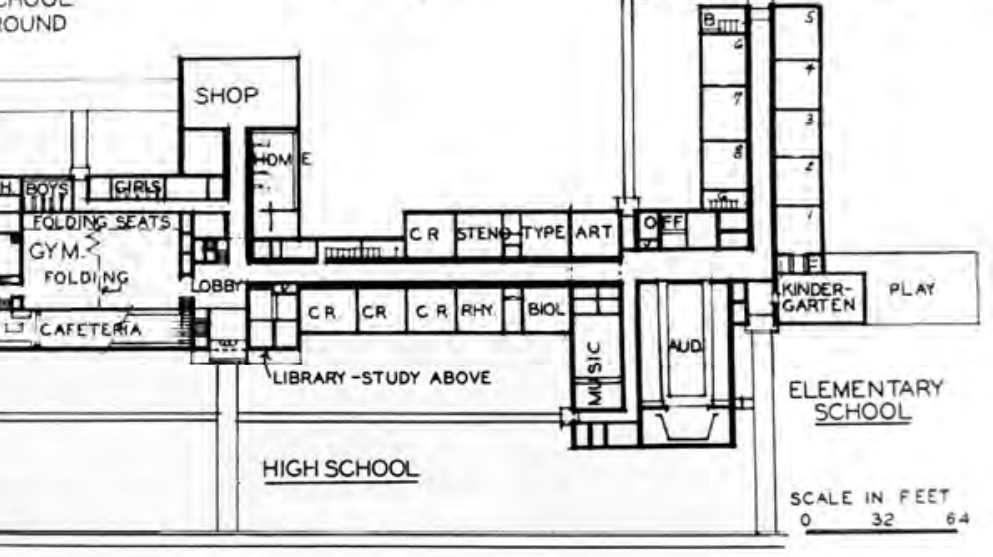

Figuras 23 e 24: New Baltimore Grade and High School. Projeto de uma escola para ensino elementar e secundário. Eberle M.

Smith arquitetos e engenheiros associados.

Fonte: The American School and University 1948-1949 (1949:268) 


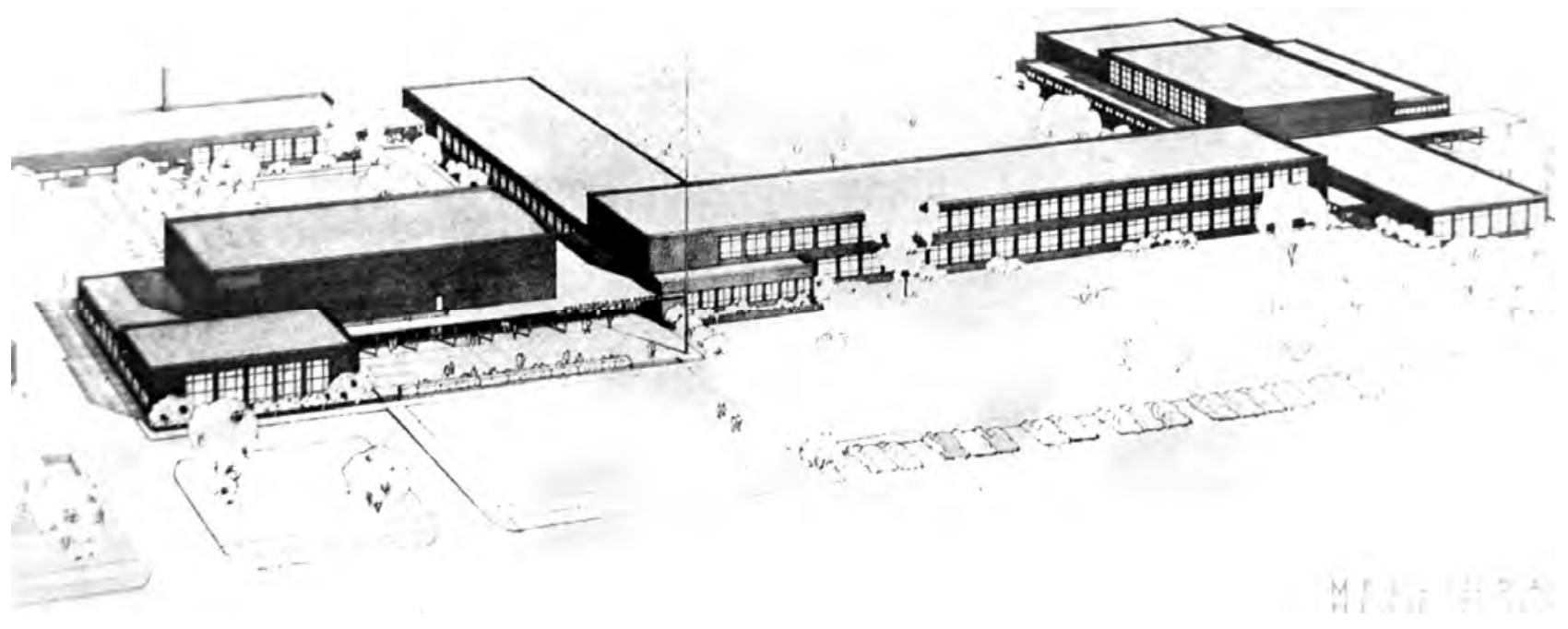

Figuras 25 e 26: Melvindale High School. Projeto de uma escola para ensino secundário e vocacional. Eberle M. Smith arquitetos e engenheiros associados.

Fonte: The American School and University 1948-1949 (1949:269)

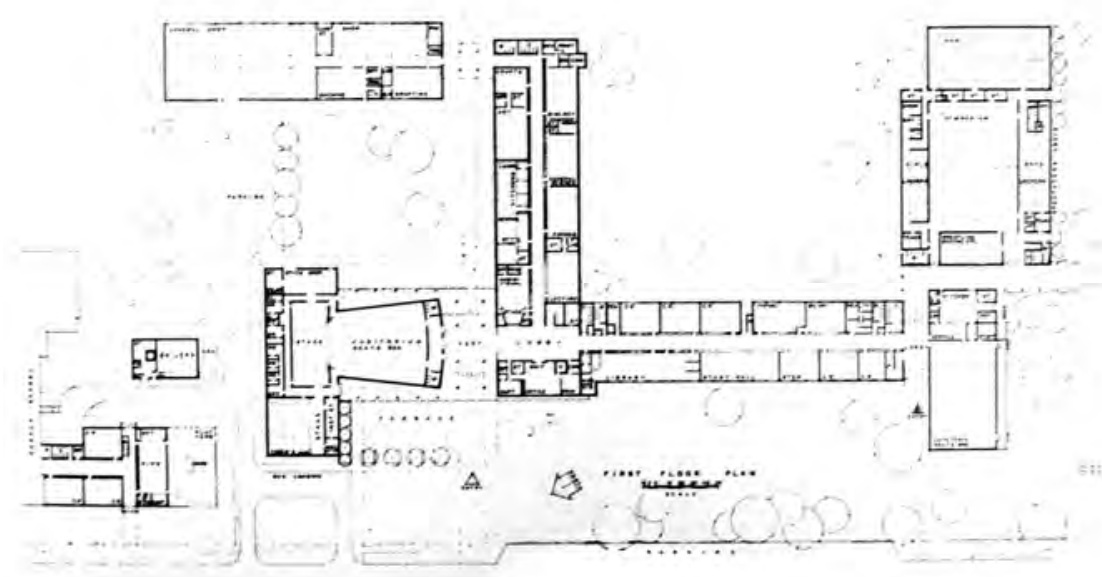



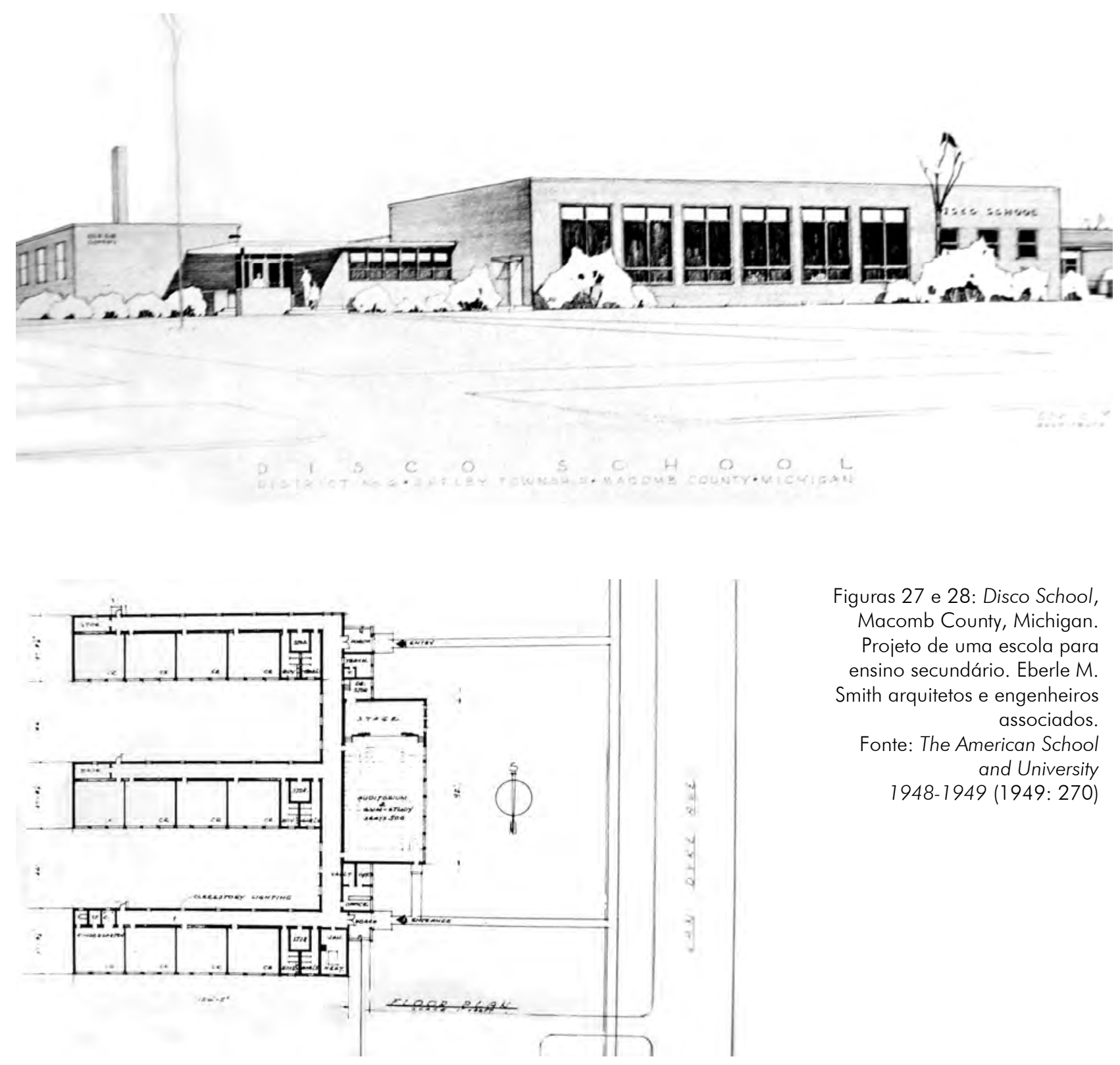

Figuras 27 e 28: Disco School, Macomb County, Michigan. Projeto de uma escola para ensino secundário. Eberle $M$.

Smith arquitetos e engenheiros associados.

Fonte: The American School and University 1948-1949 (1949: 270) 


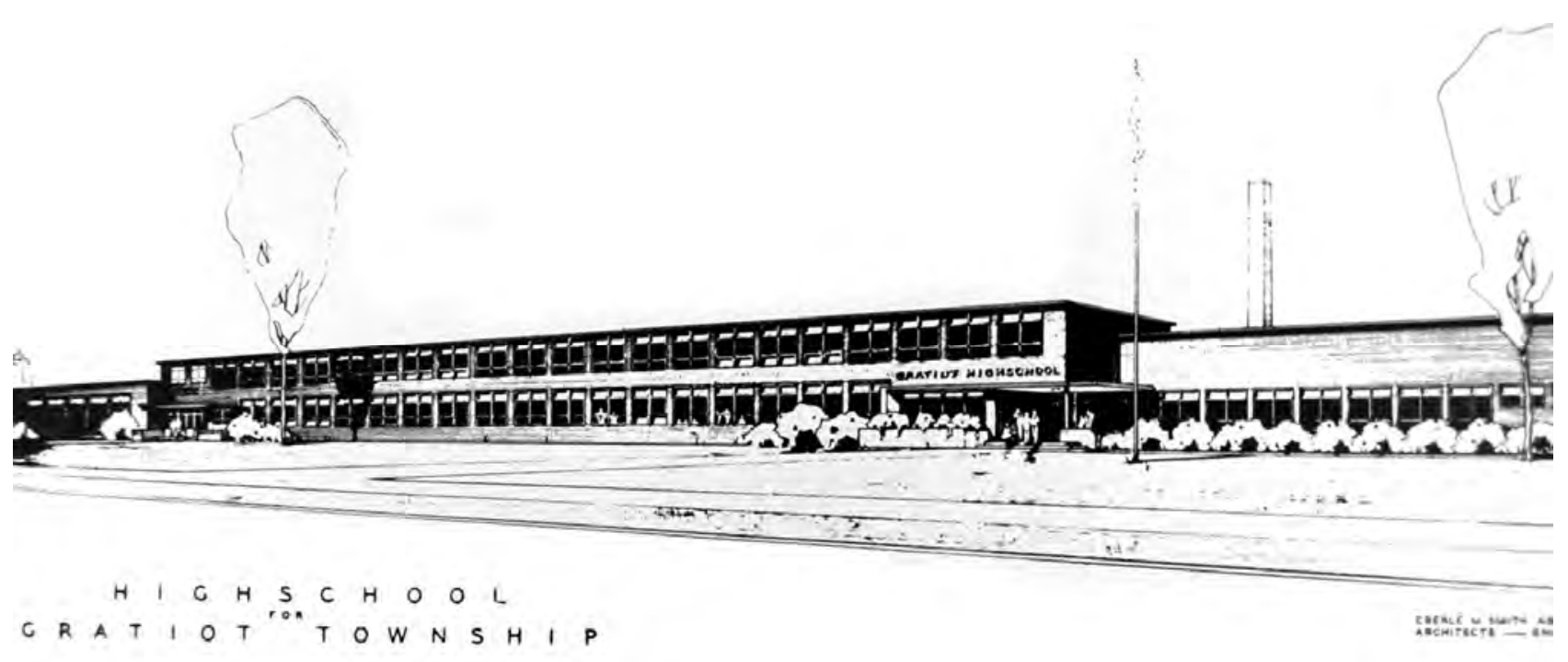

Figuras 29 à 31: High School for Gratiot Township. Eberle M. Smith arquitetos e engenheiros associados.

Fonte: The American School and University 1948-1949 (1949:271)
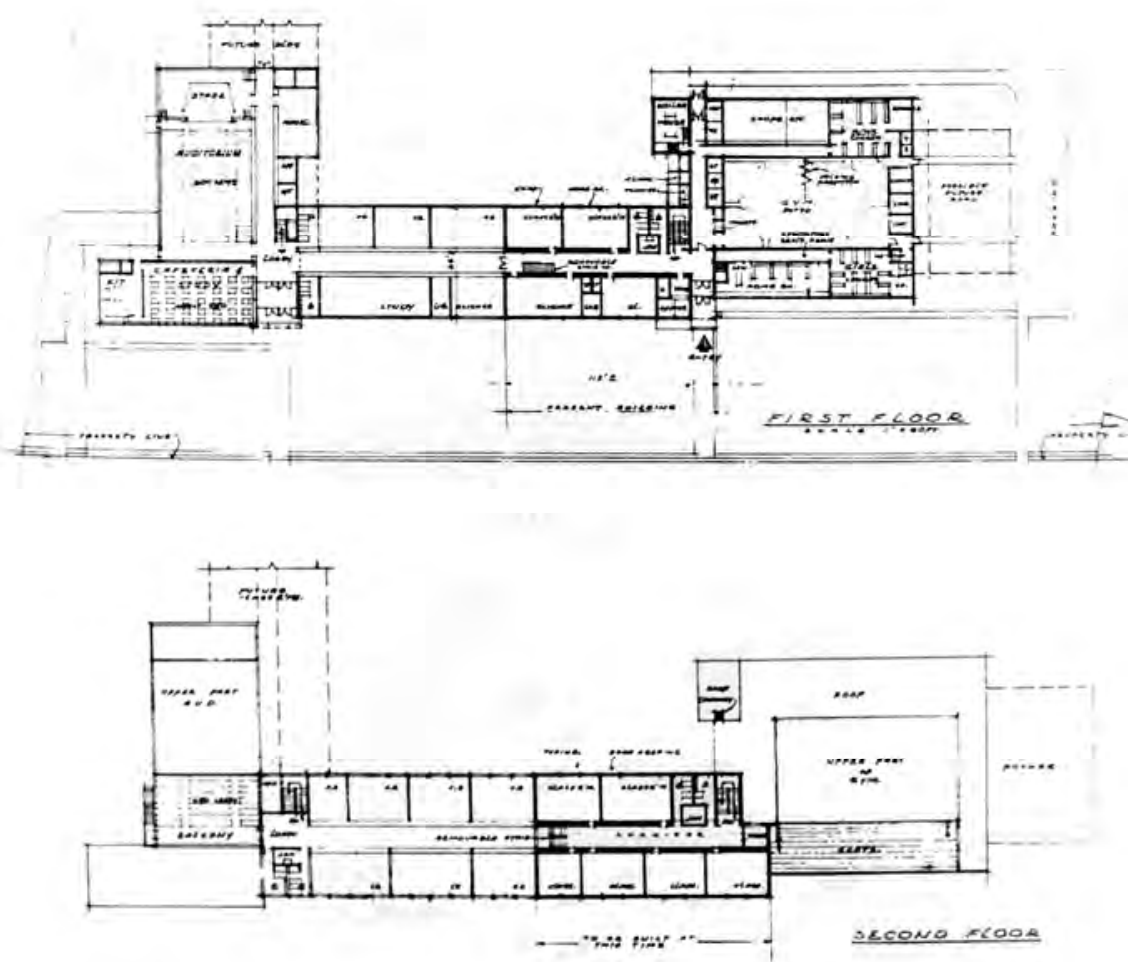

Ao observar a linguagem destas novas escolas, propostas no final da década de 1940, é notável como o vocabulário da arquitetura tradicional havia se tornado obsoleto. As soluções apresentadas trazem à tona projetos, técnicas e materiais utilizados para trazer maior eficiência funcional nas escolas, expressas tanto no interior do edifício como no exterior. $\bigcirc$ fato é que esta relação não atingiria seu resultado se aplicado a velhas estruturas e aos "estilos" históricos, tanto na educação quanto na arquitetura. 
"Thoughtful analysis will show, however, that today's building, to be a part of today's life, and to be satisfactory to the demands of today's youth, must be approached to form a contemporary point of view making full use of all of the richness of our production. It is difficult to picture General Motors doing a Georgian or Gothic factory today. Likewise, it is difficult to imagine a cyclotron being housed behind a Georgian façade".

$\mathrm{RICH}^{58}$ (1949:112)

Ao rever o edifício-escola americano na primeira metade do século XX é possível acompanhar como as mudanças pedagógicas, sociais, econômicas e políticas se concretizaram na arquitetura. Em contrapartida, as concepções da educação são "apoiadas" e mesmo "avançadas" pelo caráter do edifício em si mesmo. Este percurso leva ao momento de mudanças inéditas na arquitetura escolar dos Estados Unidos em meados do século $X X$, no mesmo período de transição arquitetônica das escolas "S" brasileiras.

\footnotetext{
"New methods of construction will emerge, new designs will be created, and new inventions will provide greater comfort, safety, and healthful conditions in school building. School buildings will be improved, in greatest degree, however, where educational objectives are refined and detailed and where the true functions of education are aided and advanced by the character of the building itself".
}

ENGELHARDT $^{59}$ (1949:62)

Ao constatar a referência norte-americana para as escolas dos "S" no Brasil, cabe agora mostrar como a pedagogia norte-americana se "apoiou" na arquitetura de suas escolas nas décadas de 1950 e 1960. Fatos e dados relevantes provam como os princípios que guiaram estas obras foram semelhantes em ambos os países, ainda que adaptados às devidas realidades sócio-econômicas e culturais.

\footnotetext{
58 Lorime Rich, arquiteto, é autor do artigo College Architecture in transition, publicado no The American School and University 1948-1949 (1949:109-112).

59 Nickolaus Louis Engelhardt (188-1960) escreveu o artigo The Evolution of the School Building, publicado no The American School and University 1948-1949 (1949:55-62). O autor foi professor de educação no Teachers College, Columbia University, de 1917 a 1942 e de 1942 a 1947.
} 
1.3.4 Inovações arquitetônicas e soluções técnicas do edifícioescola dos anos 1950:

American Trade Schools e seus atributos físicos, psicológicos e sociais

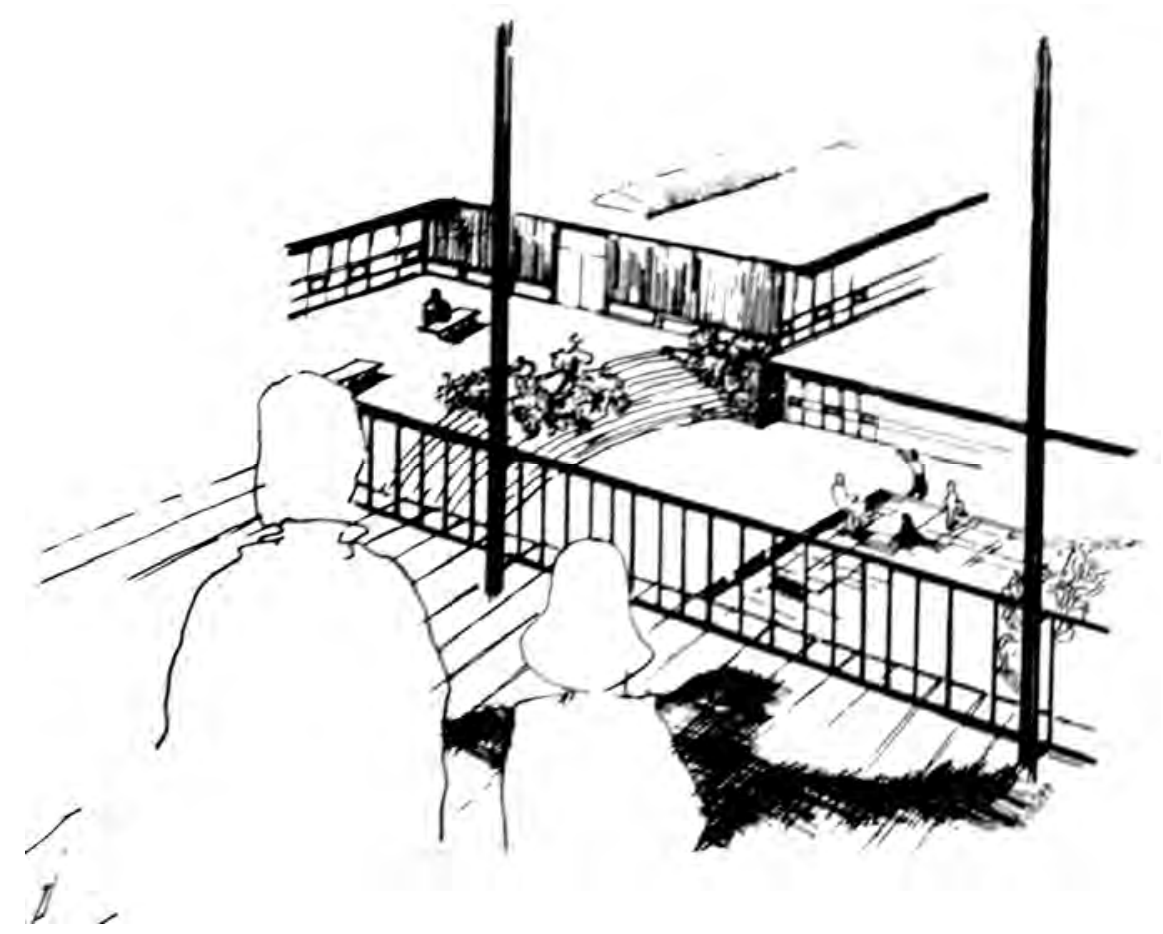

Educação e arquitetura: o espaço como o denominador comum entre ambas. Se a educação requer certos espaços para desempenhar sua função, a arquitetura envolve os caminhos e os efeitos ao planejar e incluir estes espaços - assim era o pensamento na década de 1950. Sabendo que os princípios da educação poderiam ser facilitados pelos projetos escolares, os planejadores do edifício-escola deveriam conhecer estes princípios para criar um novo tipo de espaço.

Quais eram estes princípios traduzidos para a arquitetura? Como reconhecer se uma escola tinha o velho conceito da disciplina ou o novo conceito da motivação? Questões como esta rebatiam em uma arquitetura mais formal (disciplina) ou informal (motivação). 
Como premissa, a década de 1950 apresenta uma escola desenhada para uma variedade de situações de aprendizado. A "flexibilidade" acompanhando as naturais mudanças das teorias da educação é nítida na nova arquitetura escolar norte-americana deste momento. Aplicada à arquitetura, flexibilidade significa fluidez, versatilidade, convertibilidade e expansibilidade do espaço, conforme afirma CAUDILL (1954). Neste sentido, as escolas vocacionais tinham que responder ao progresso educacional e aos esforços dos educadores por meio de espaços flexíveis planejados para duplos ou triplos usos e adaptáveis às mudanças técnicas e às expansões futuras.

\footnotetext{
"Generally when school planners speak of flexibility of space they are referring to all four qualities of space fluidity, versatility, convertibility, and expansibility - [...]. Flexibility is a good word, but to the skilled architect, who has a well-developed concept of space, the word has much too broad a meaning, and he feels that it should be broken down into the four categories mentioned.
}

CAUDILL $(1954,139)$

Dentro da visão de preparar os alunos para a vida e não para - academicismo, a escola vocacional reconheceu sua responsabilidade de responder as necessidades educacionais do aluno para fazê-lo competente para suprir as necessidades da sociedade. E, quais eram estas necessidades tanto da sociedade como da juventude? O livro publicado em 1944, Planning For American Youth, an educational program for youth of secondary-school age, da National Association of Secondary School Principals, listou estas dez necessidades imperativas da sociedade e da juventude como "linhas de base" ou um instrumento usado para o próprio planejamento do edifício. $\bigcirc$ momento de transição teve então sua resposta concretizada na arquitetura da década de 1950. Neste sentido, quais foram as necessidades imperativas da arquitetura escolar naquele momento? Quais foram seus atributos físicos, psicológicos e sociais? Neste sentido, CAUDILL (1954: 50-51) apresenta no livro Toward better school design vários princípios e métodos da educação traduzidos em termos de arquitetura. Por exemplo, para atender a uma educação que visasse considerar as necessidades da 
comunidade, a arquitetura planejaria uma escola com área de recreação, auditório e ginásio. $\bigcirc$ fato é que a arquitetura buscava atender ao aspecto social da educação, interligando as necessidades da sociedade e da juventude. Aprender fatos e habilidades não era suficiente, igualmente importante era saber a melhor maneira de aplicá-los.

É exatamente a partir da segunda metade do século XX que estas necessidades são claramente demandadas à arquitetura, apoiadas e direcionadas por diversas publicações sobre 0 planejamento do edifício-escola. De acordo com American School and University 1959-1960 (1960:217-218), muitos departamentos de educação estadual distribuíram dentro de cada estado um pertinente material para orientar as plantas das escolas. Estes boletins, manuais ou informativos alcançaram outras áreas do país e ao todo foram cerca de 180 publicações com diferentes tópicos para orientar o projeto escolar, entre eles: educação adulta, educação de negócios, planejamento educacional, necessidades da construção, auditórios, centro comunitário, custos, escolas vocacionais. Entre estes manuais cabe destacar o material publicado dentro do Estado de New York, Planning Guide for Vocational-Industrial and Vocational-Technical Building Facilities for Comprehensive High Schools, em 1950, um guia de planejamento específico para a escola vocacional industrial e técnica.

"The 38 state departments of education publish or distribute a total of 180 manuals, booklets and bulletins, on 45 different topics dealing with school plants". 


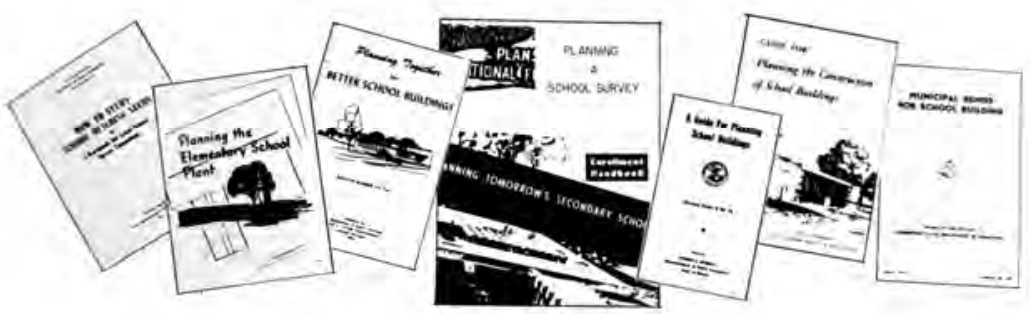

\section{STATE EDUCATION DEPARTMENT PUBLICATIONS ON THE SCHOOL PLANT}

A forte demanda do ensino vocacional pôde ser comprovada por meio de gráficos e tabelas. É surpreendente observar o custo e o número dos edifícios educacionais construídos durante a década de 1950, conforme American School and University 1959-1960 (1960:101-107). Em 1958 foram investidos nas escolas públicas 3.05 bilhões de dólares e nas universidades 718 milhões de dólares (figura 2). Quanto ao número de edifícios construídos, a escola pública se destaca ao quase triplicar de 3316 escolas em 1949 para 9190 em 1958, conforme figura 3.

\section{Total number of public school buildings built 1949-1958}

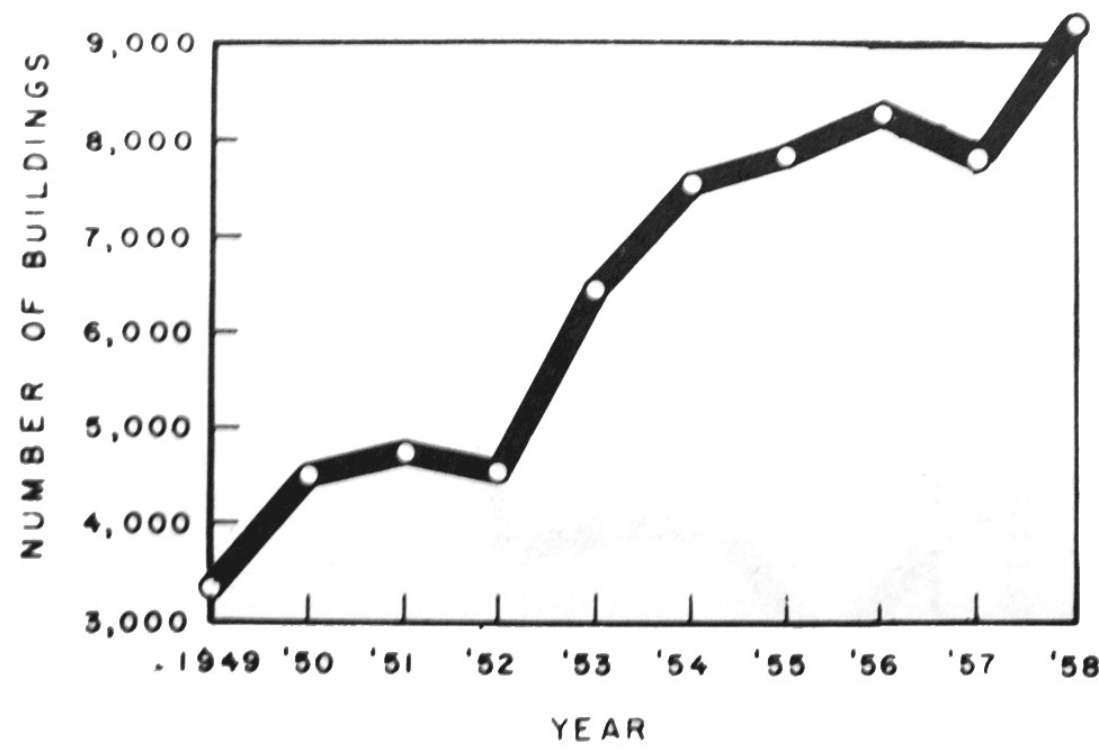

Figura 1: Boletins, manuais e informativos publicados na década de 1950 para guiar os

projetos dos edifícios-escolas.

Fonte: American School and University 1959-1960 (1960:217)

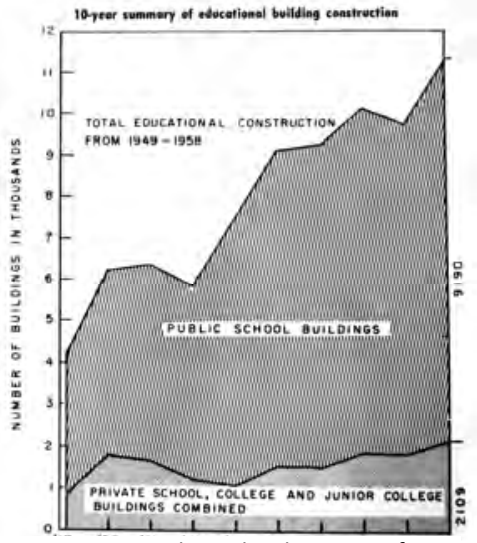

Figura 2: A década de 1950 foi o período de milhares de novas escolas planejadas e construídas nos EUA.

Fonte: American School and University 1959-1960 (1960:119)
Figura 3: Gráfico que evidencia o aumento das escolas públicas construídas de 1949 a 1958 . O número aproximadamente triplicou em 9 anos.

Fonte: American School and University 1959-1960 (1960:103) 
Dentro desta demanda, de todos os edifícios construídos em 1958, $81 \%$ eram escolas públicas, 11\% universidades, 6\% escolas particulares e $2 \%$ Junior Colleges. As figuras abaixo ilustram os gráficos sobre o número de universidades e Junior Colleges construídos durante a década de 1950. A construção do Junior Colleges, centros de treinamento vocacional, atingiu os mais altos picos durante os anos de 1956 (foram construídas 306 escolas com o custo de 60,60 milhões de dólares) e 1958 (247 escolas com o custo de 57 milhões de dólares) em todo os Estados Unidos.

Figura 4: A construção de escolas vocacionais, Junior Colleges, atingiu seu auge no ano de 1956. Fonte: American School and University 1959-1960 (1960:106)

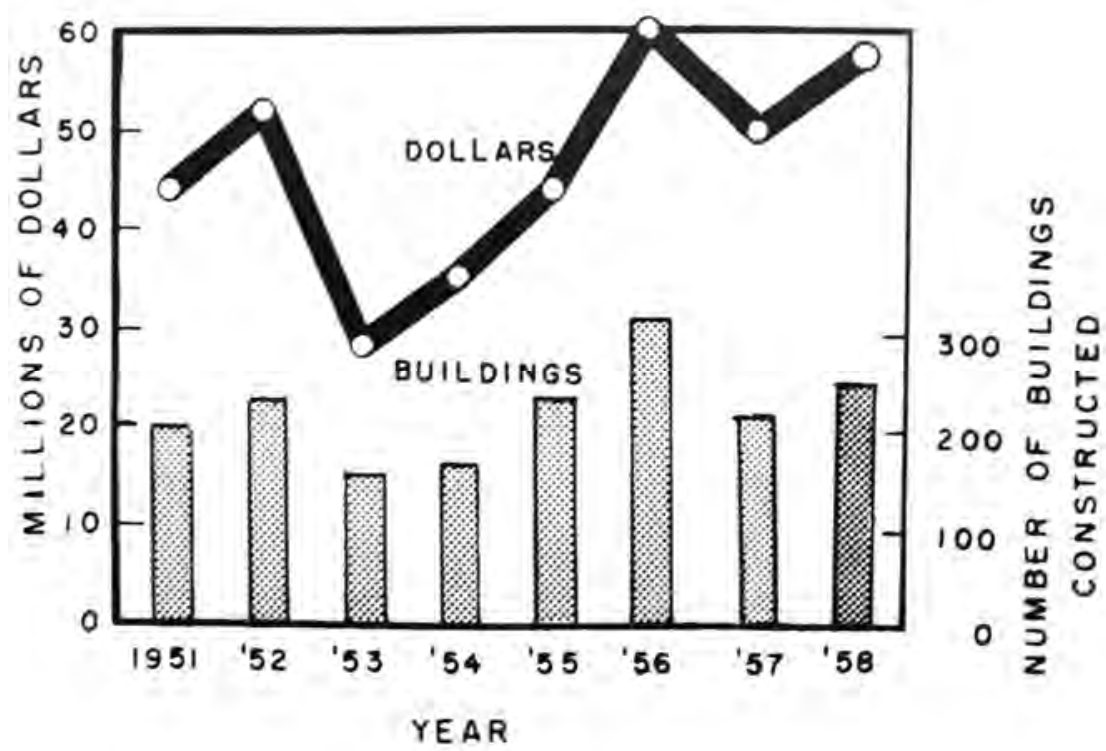

Figura 5: Em toda a década de 1950, os anos de 1951 e 1958 registram grande investimento financeiro na construção das novas universidades americanas.

Fonte: American School and University 1959-1960 (1960:106)

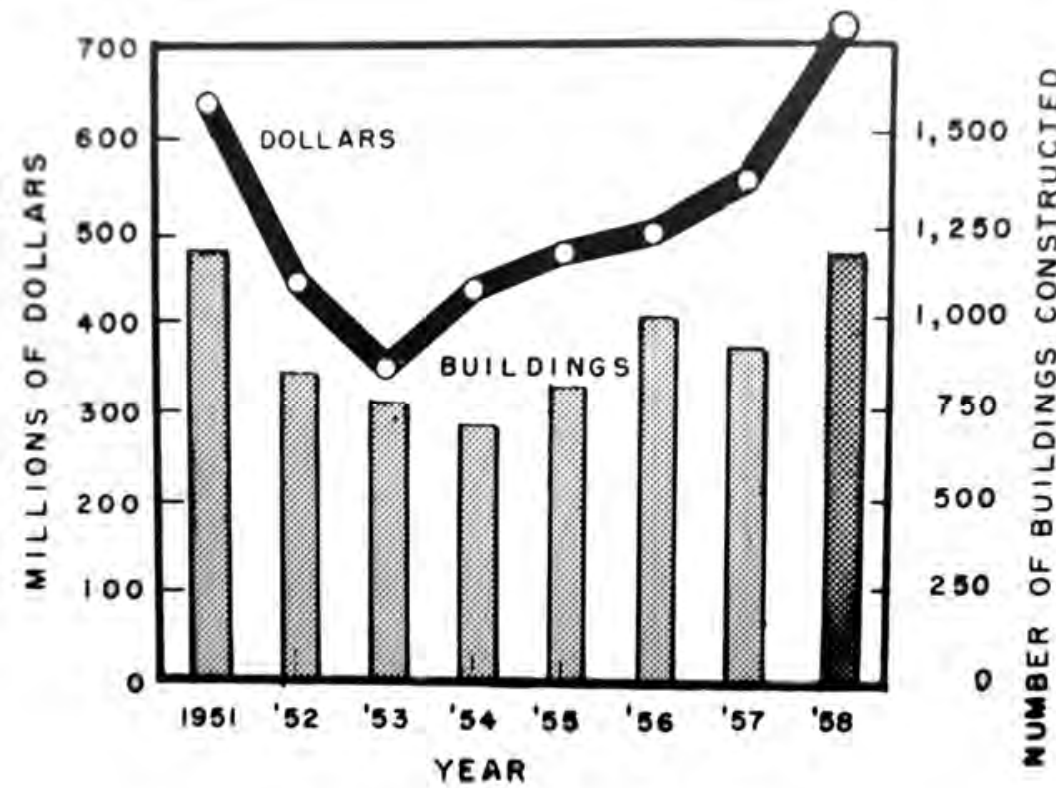


Diante desta demanda, a quantidade se tornou um fator aliado à qualidade que, obviamente, não poderia ser sacrificada ou esquecida. Educadores, arquitetos, engenheiros, consultores e cidadãos comuns também visavam à questão da qualidade, agindo em cooperação um com os outros: teorias educacionais foram revistas, mudadas e aperfeiçoadas; projetos do edifício-escola seguiram novas direções na criatividade, economia, aplicação de materiais e métodos construtivos; terrenos amplos foram explorados para um máximo aproveitamento da escola. Para ilustrar estas questões de qualidade, são apresentadas duas escolas construídas na década de 1950: Lamphere High School (Madison Heights, Michigan) e New Kensington High School (New Kensington, Pennsylvania).
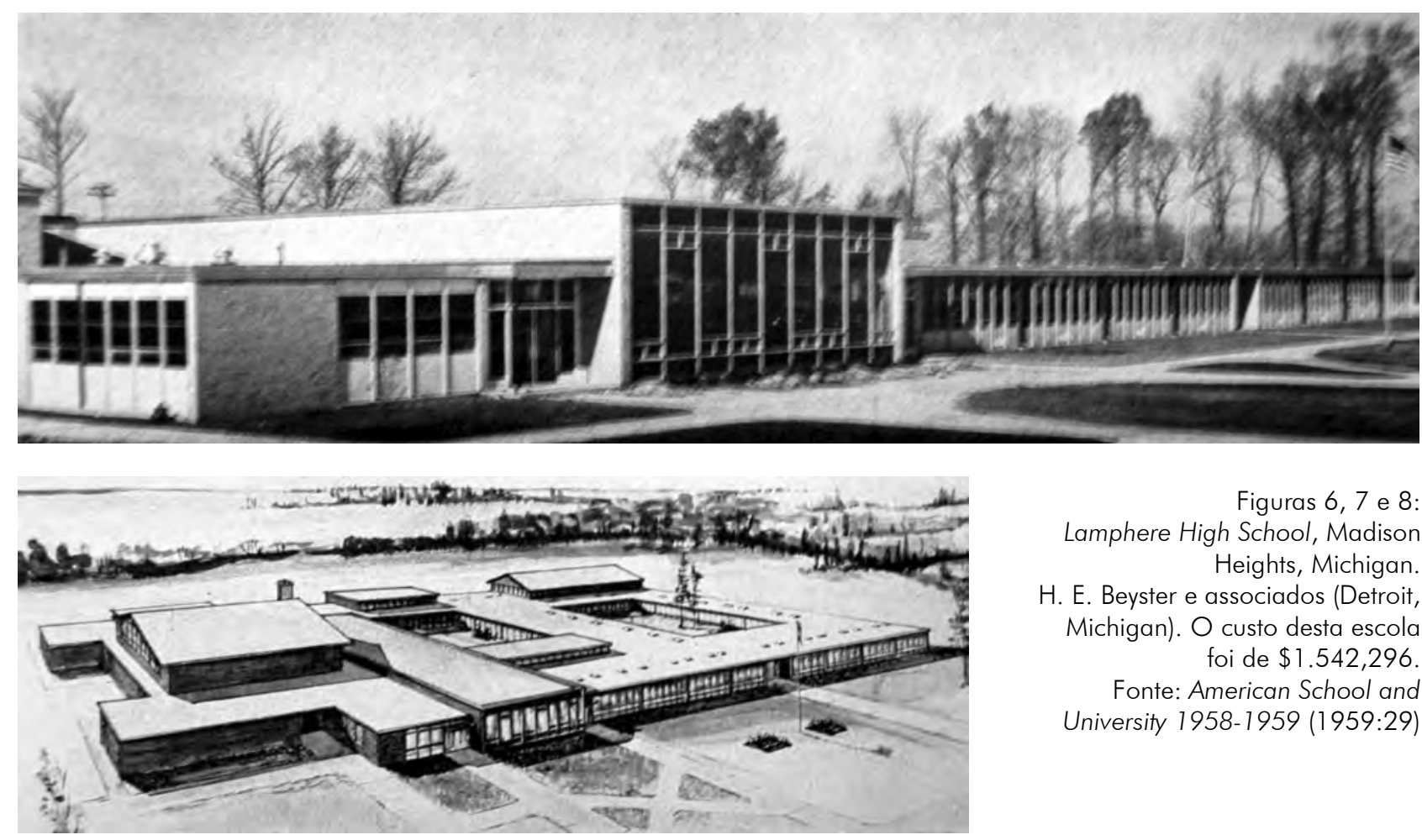

Figuras 6, 7 e 8: Lamphere High School, Madison Heights, Michigan. H. E. Beyster e associados (Detroit, Michigan). O custo desta escola foi de $\$ 1.542,296$. Fonte: American School and University 1958-1959 (1959:29)

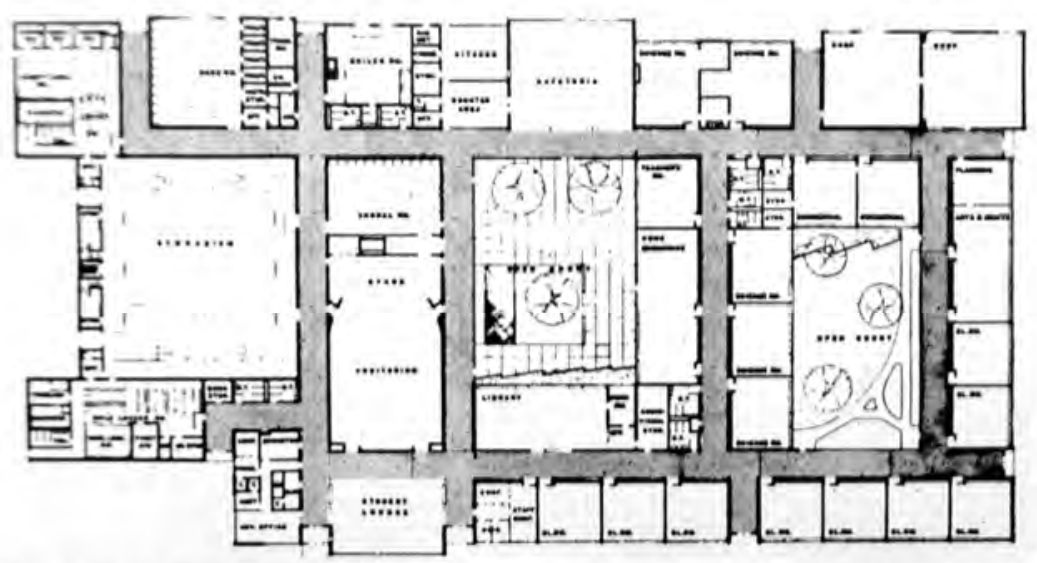

Floor plan 


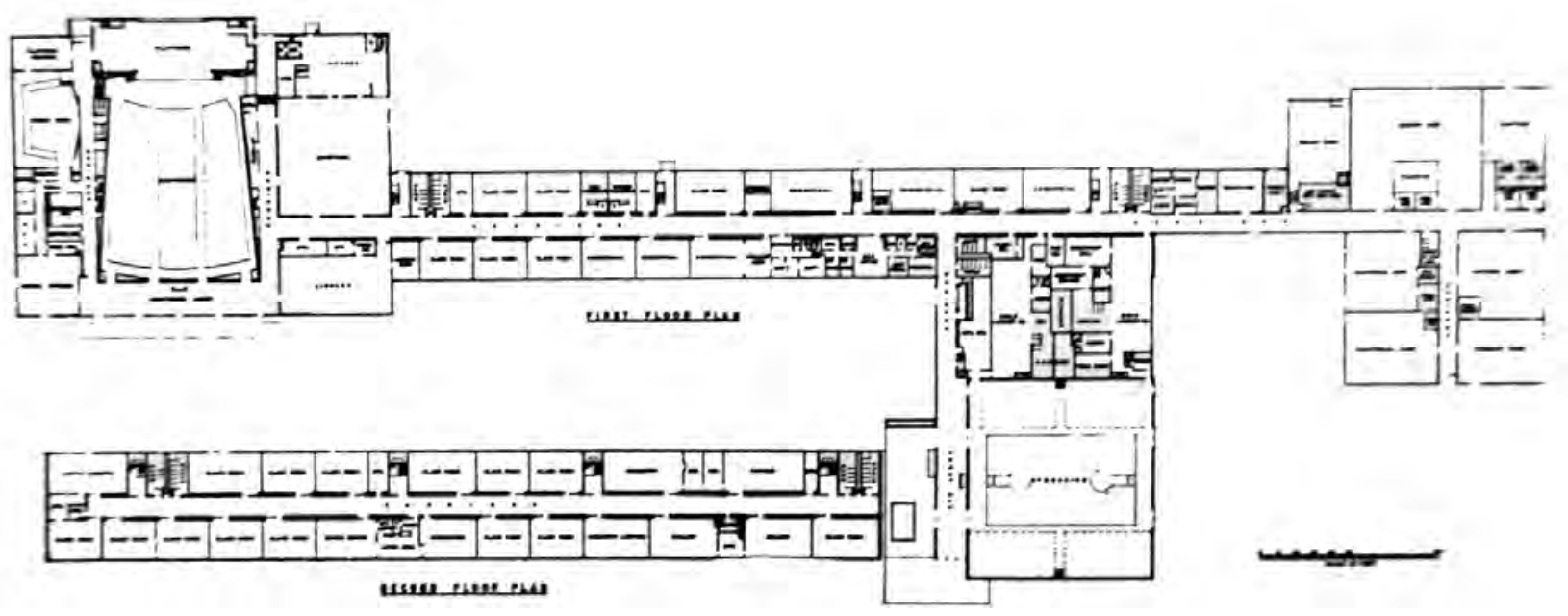

Figuras 9, 10 e 11 :

New Kensington High School, New Kensington, Pennsylvania. Hunter, Campbell \& Rea, arquitetos associados (Altoona, Pennsylvania). Observar o espaço do auditório e a dimensão da escola espalhada no terreno. $O$ custo desta escola foi de $\$ 2.507,180$. Fonte: American School and University 1958-1959 (1959:30)
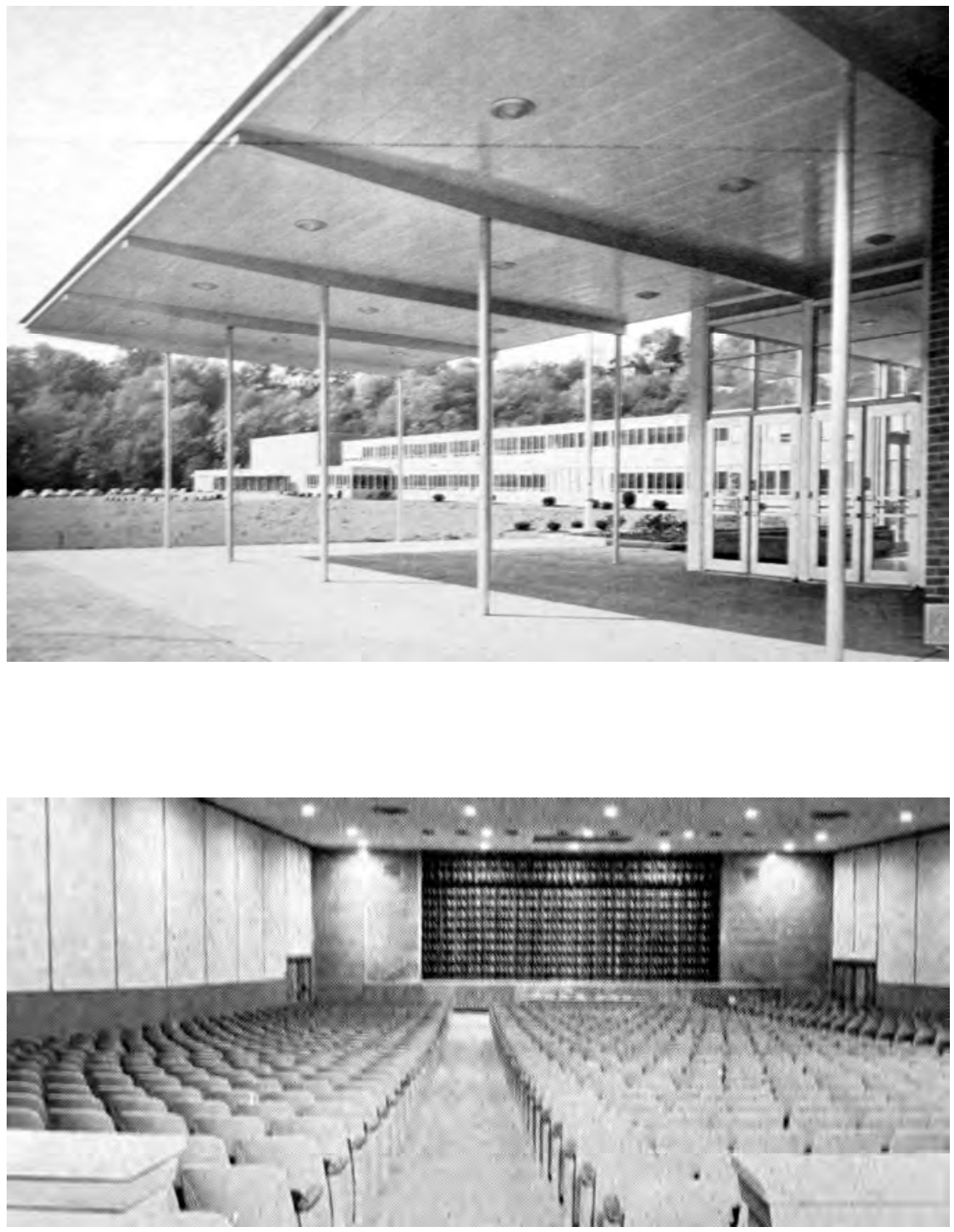
Nestes exemplos, a composição do espaço estava intrinsecamente ligada à qualidade do edifício-escola. Além da divisão interna, é interessante observar as composições geométricas geradas pelos principais elementos de uma escola. Cada bloco, também denominado unidade da escola, era composto por salas de aula, administração, área de alimentação, educação física, assembléia e oficina. Neste sentido, seguem alguns croquis com as variações apresentadas por CAUDILL (1954):

"It has been said that space is the medium of the architect. Of course it is a necessity that he must know something of the technology of materials and structure which must be used to enclose space, but just as important, and even more so, he must know how to compose space. It is the job of the architect to compose the main elements of space into an efficient and beautiful school plant".

CAUDILL (1954, 140)
Figuras 12 à 17: Seis variações geométricas das unidades que compunham a implantação geral das escolas secundárias. Cada bloco, também denominado unidade da escola, era composto por: salas de aula $(A)$, administração $(B)$, área de alimentação (C), educação física (D), assembléia (E) e oficina (F)

Fonte: CAUDILL (1954:155)
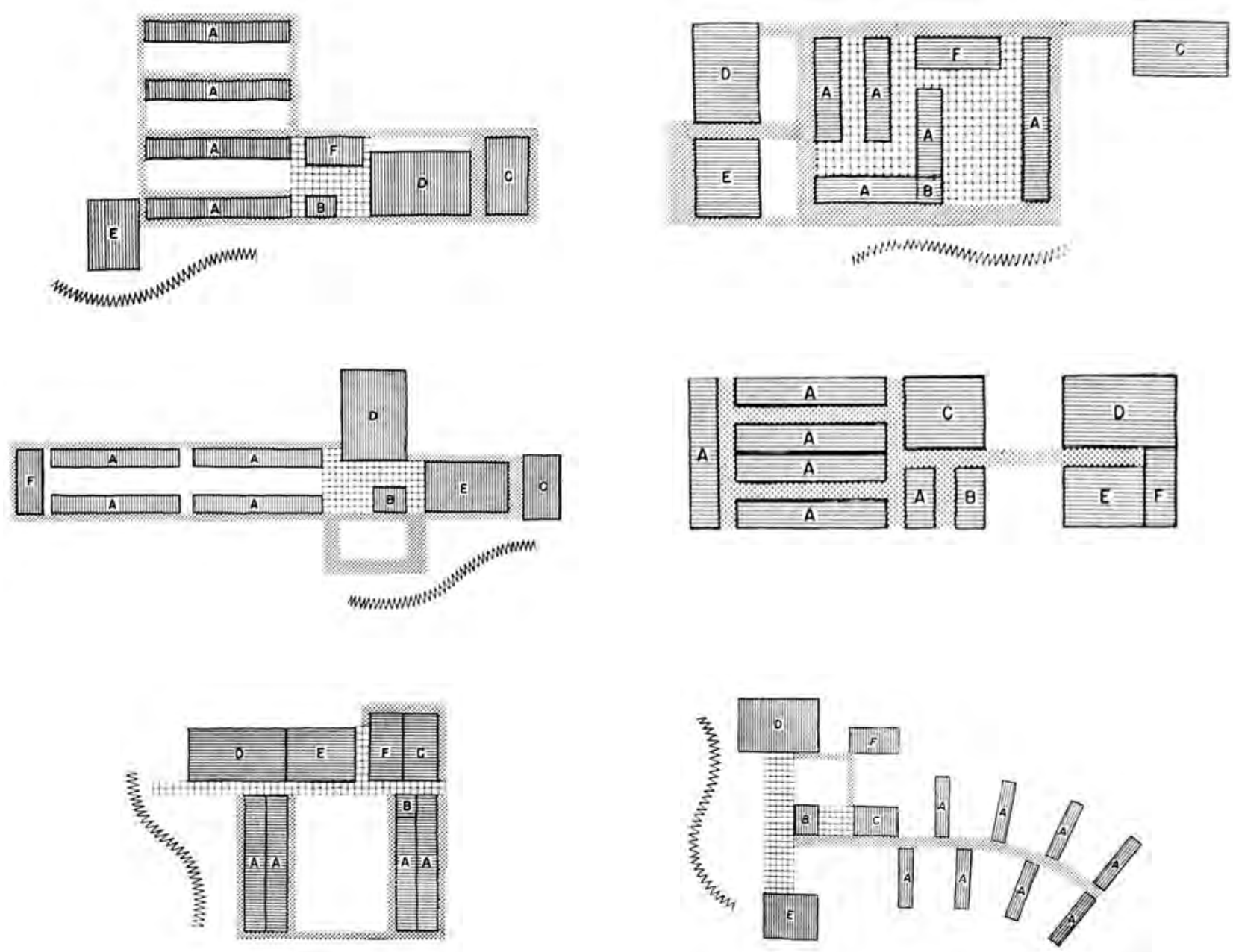
Qualidade e geometria também estavam relacionadas ao custo de construção da escola. Ao observar o croqui abaixo, é possível comparar as mudanças que ocorrem na forma da planta, elevação e sala de aula. Embora ambas as escolas tenham a mesma área construída, a planta da década de 1950 tem apenas 60\% da área de parede externa em relação à escola tradicional. Já em relação à elevação, a silhueta moderna tem somente um degrau na linha de cobertura, facilitando a técnica construtiva. Também, a sala de aula moderna apresenta iluminação natural tri-lateral (economia da luz artificial) e um volume espacial menor (66\%) do que a escola tradicional.

Figura 18: Compare as mudanças que ocorreram no formato da planta, elevação e sala de aula do edifício-escola. Qualidade e geometria também estavam relacionadas ao menor custo da escola moderna.

Fonte: CAUDILL (1954:95)

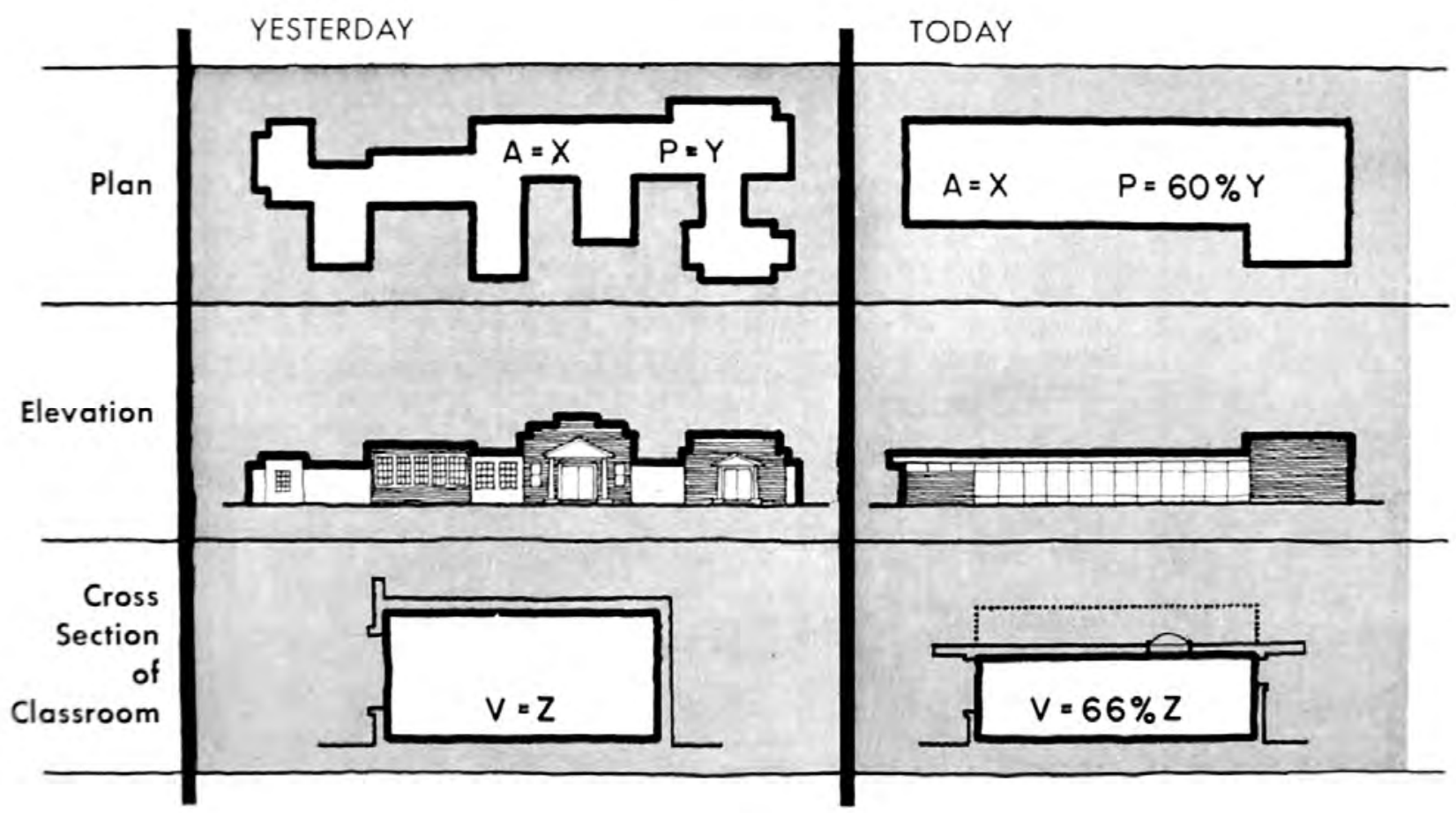


Buscando também a qualidade, a própria arquitetura do edifício-escola respondia às demandas imperativas dos jovens, tais como: desenvolver habilidades, saúde, cidadania e vida familiar; compreender o método científico; apreciar as artes; respeitar os outros e pensar racionalmente. Para mostrar estas demandas aplicadas à arquitetura, a Norman High School (Norman, Oklahoma) é aqui utilizada como referência (Architectural Record, 1956:60-66 e CAUDILL, 1954:38). Projetada como um centro comunitário para jovens, seis premissas foram estabelecidas para conceber a arquitetura desta escola: a população continua a crescer (crescimento), há mudanças nas técnicas de ensino e nos cursos (flexibilidade), o aluno passa o mesmo tempo nos corredores que em qualquer sala de aula (interligação), um programa educacional efetivo e equilibrado permite a cada aluno participar completamente das atividades de grupo em sala de aula (rendimento e economia), a escola é usada durante todo o ano para a educação, recreação e melhoramento da comunidade (sociabilidade), a planta da escola deve ser realmente um centro social para os jovens de segundo grau (atratividade).

Eis aqui o cerne da questão: as premissas desta escola norteamericana podem ser comparadas às principais características norteadoras, implantadas na década de 1950, nas novas escolas dos "S" brasileiros (capítulo 2). As características dos "S", aqui apresentadas sinteticamente, se identificam com as premissas da Norman High School. As firmas Caudill, Rowlett, Scott e Associados e, Perkins e Will Arquitetos e Engenheiros Associados, foram os autores responsáveis por este projeto.
Figura 19: Norman High School, Norman, Oklahoma. Projeto de Caudill, Rowlett, Scott e associados e, Perkins e Will arquitetos e engenheiros associados. Fonte: Architectural Record (1956:60-66)

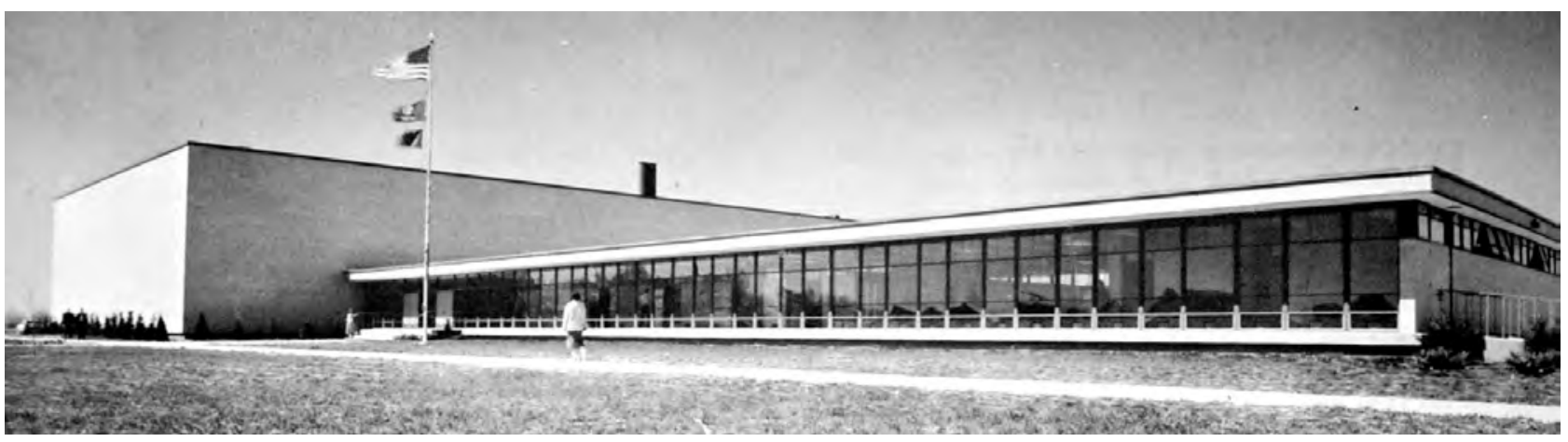




\section{EXPANSIBILITY}

Figura 20: Observe neste croqui a primeira premissa de crescimento expressa pela arquitetura. $\bigcirc$ estágio 1 é a implantação da escola Norman High School.

O estágio 2, as futuras salas de aula e laboratório.

O estágio 3 , outras futuras ampliações.

Fonte: Architectural Record (1956:61)

Figura 21: Este croqui mostra a segunda premissa de flexibilidade. Divisões internas móveis são propostas dentro de uma planta livre pontuada pelas colunas estruturais. Também a iluminação por domus permite que o interior seja dividido de várias maneiras, sem sacrificar a iluminação natural.

Fonte: Architectural Record (1956:61)

Figura 22: Observar como os corredores externos, passarelas iluminadas e abertas, substituem os tradicionais corredores fechados e proporcionam interligação física e visual entre os blocos da escola.

Fonte: Architectural Record (1956:60)

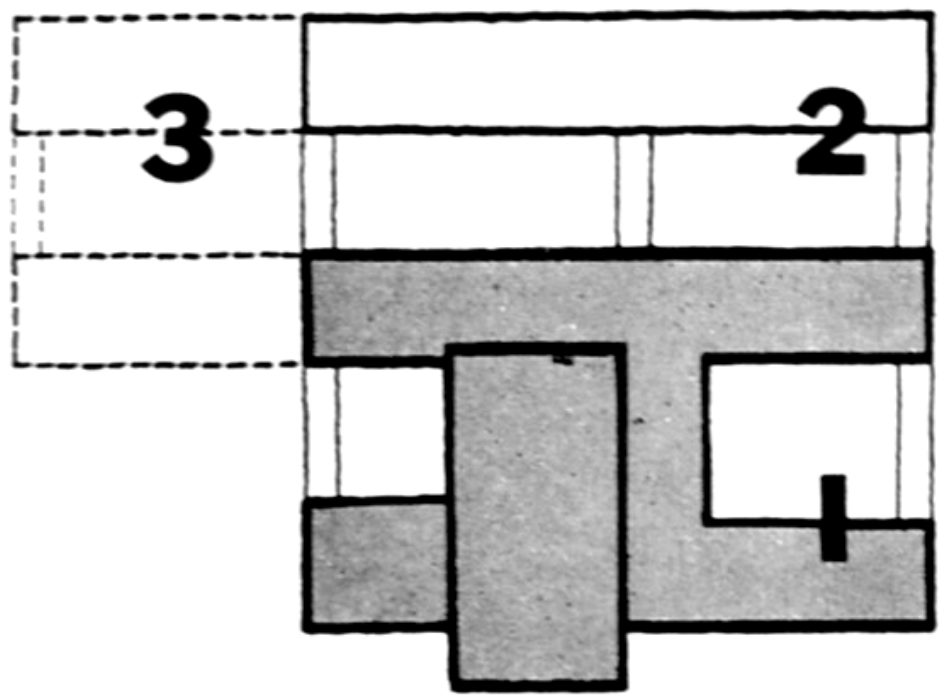

FLEXIBILITY

$$
\text { TOP LIGHTED }
$$
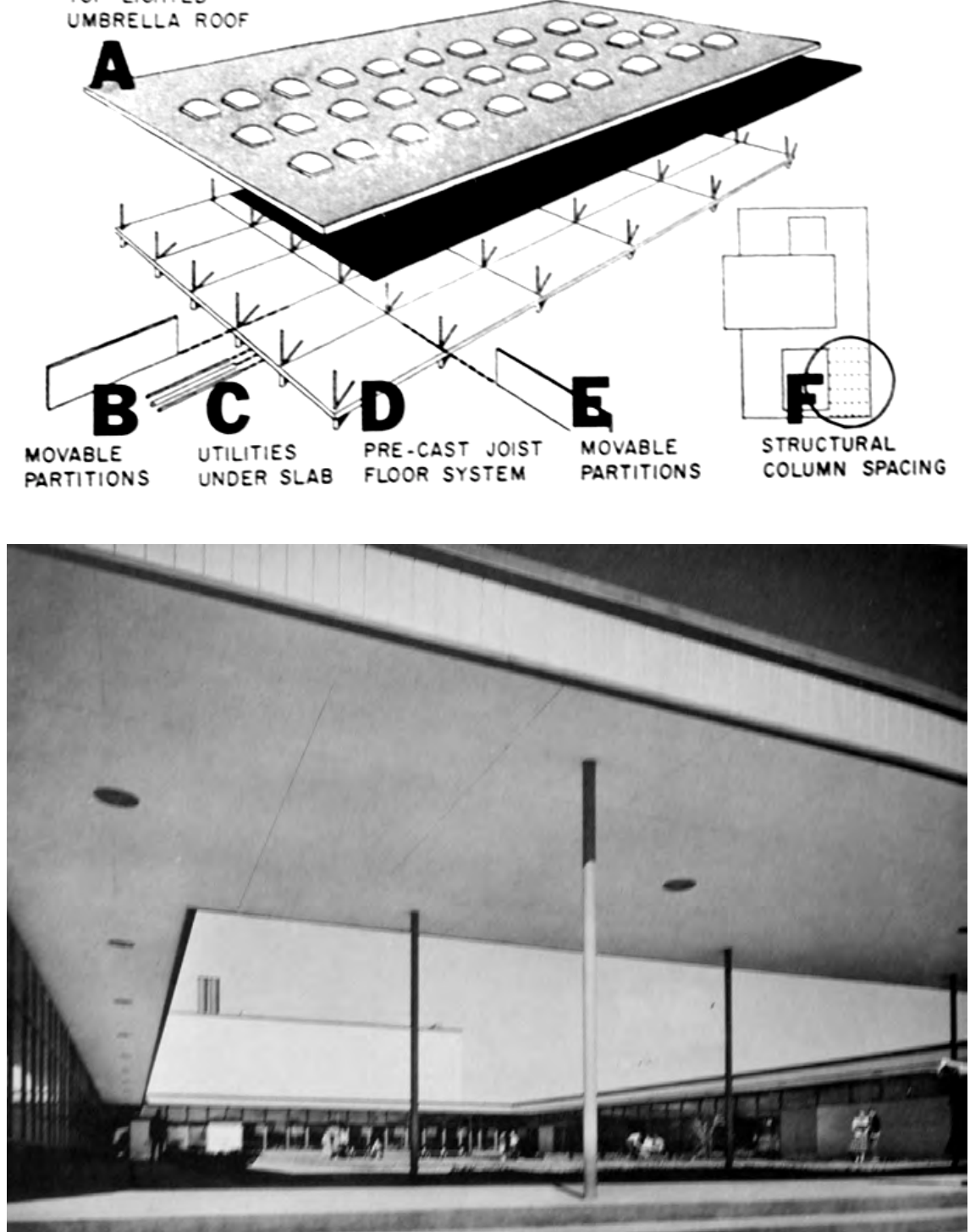


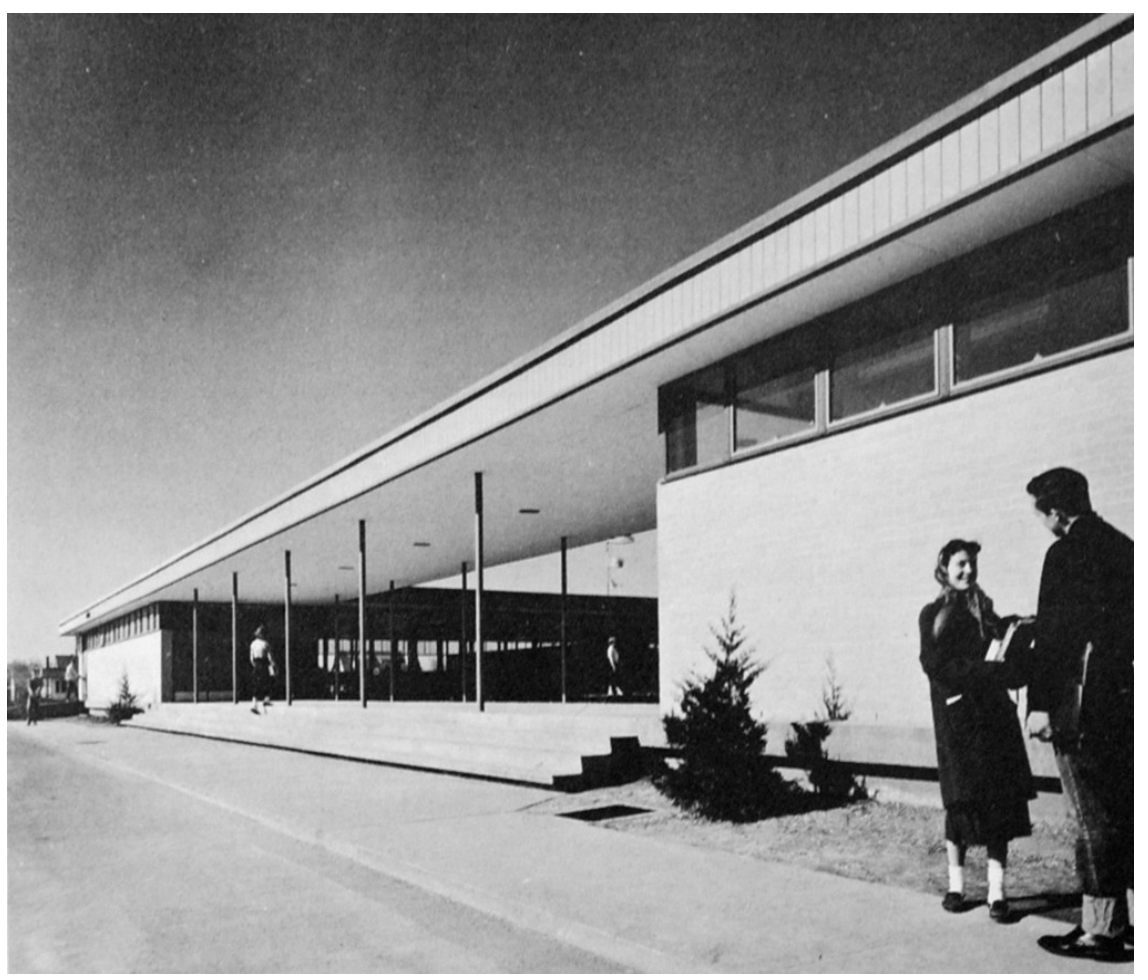

Figura 23: A linguagem do edifício-escola, de linhas retas e sem o tradicional caráter monumental, buscava ser atrativa como um centro social para os jovens de segundo grau. Fonte: Architectural Record (1956:60-61)

A Norman High School, assim como outras escolas deste período, é exemplo dos seis conceitos preconizados em seu projeto e responde à "economia" como um fator preponderante tanto no sentido de melhor aproveitamento dos recursos naturais - ventilação e iluminação - como no sentido de percorrer menores fluxos dentro da própria escola. How far should we go? (Architectural Record, 1956:244) Questões como esta deveriam ser atendidas, assim, a distância a ser percorrida pelo aluno entre um ambiente e outro deveria evitar longos fluxos e, se estes existissem, deveriam envolver os princípios sociais da educação.

Outra importante característica das escolas norte-americanas da década de 1950 também presente nas novas escolas dos "S" brasileiros são as "unidades da escola", isto é, a escola composta por blocos de edifícios interligados entre si. (conforme figuras 12 à 17 que apresentam algumas das composições geométricas geradas por estes elementos). Estas unidades foram pensadas como edifícios modulares, marcados por eixos estruturais eqüidistantes e divididos de acordo a especificidade de cada bloco. 


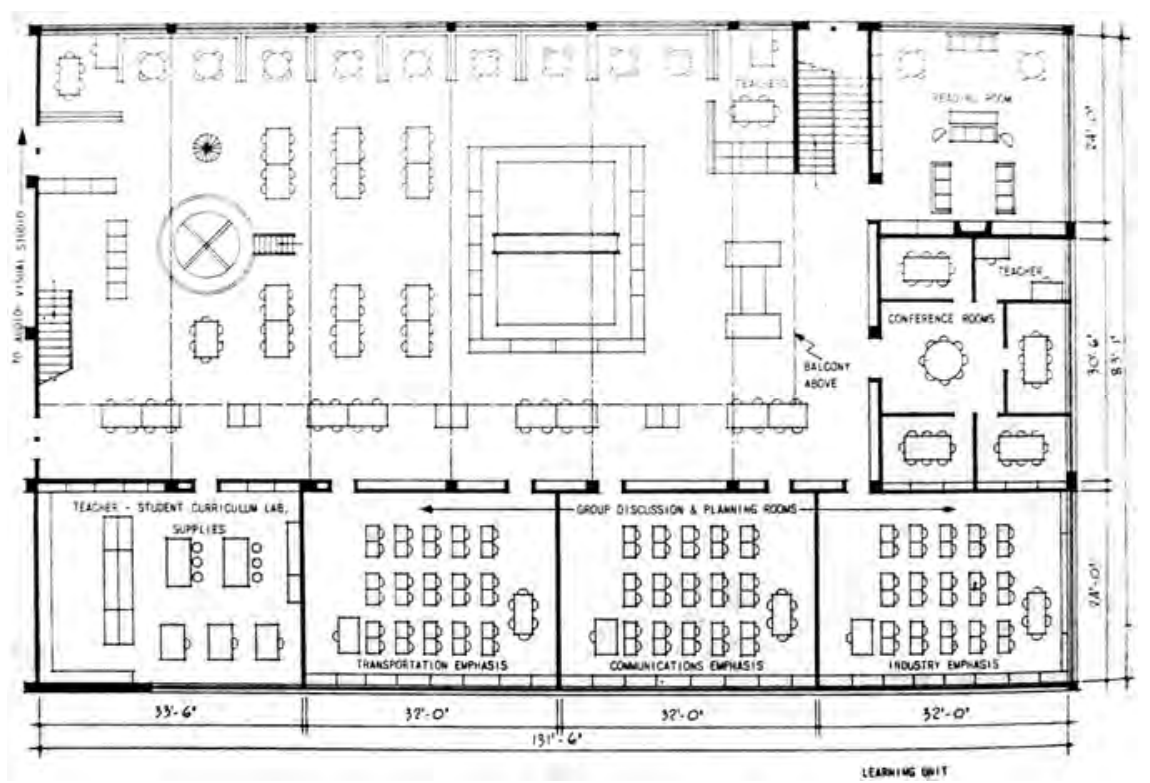

Figuras 23 e 24: Plantas do pavimento térreo e superior de uma unidade de

aprendizagem, Learning Unit. Observe a forma retangular do bloco modulado por eixos estruturais e eqüidistantes. Fonte: Architectural Record (1956:244-245)

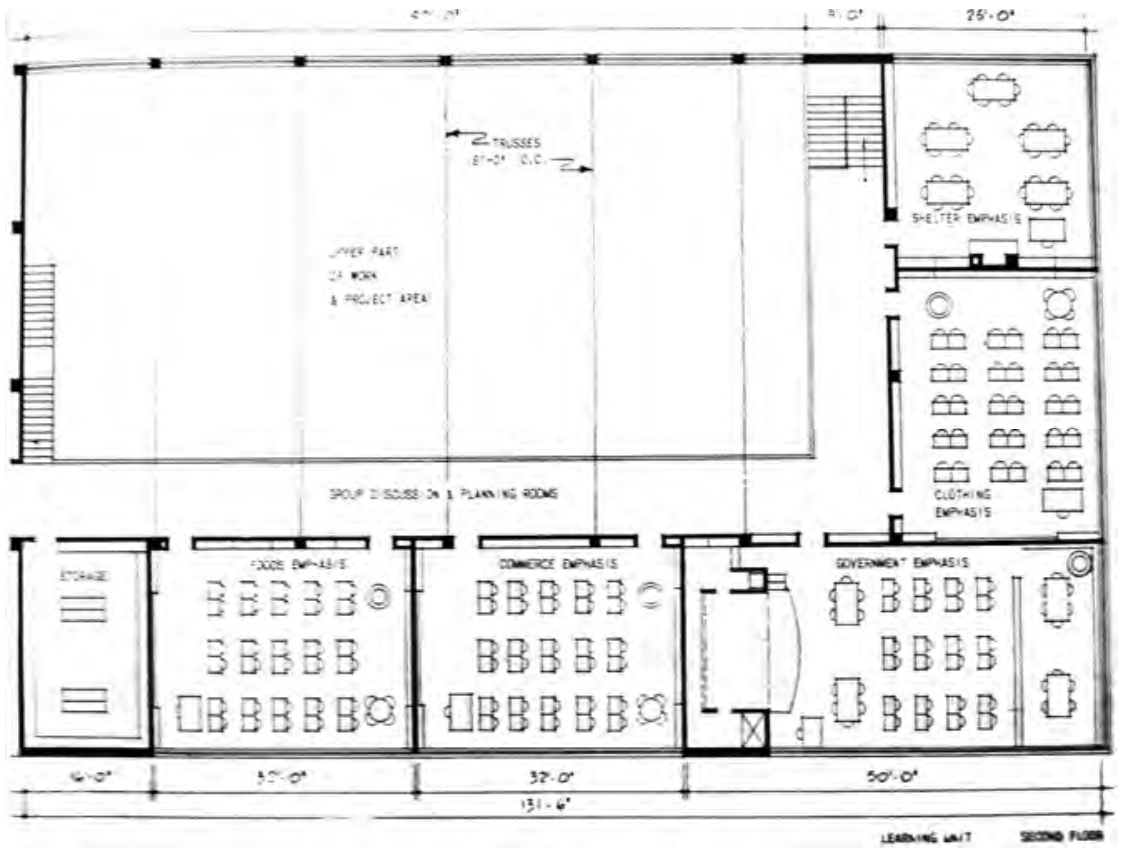


Ao tratar do aspecto inovador da década de 1950, não se pode omitir que, em 1953, um grupo ${ }^{60}$ de educadores, arquitetos e administradores escolares se encontraram na cidade de Charlotte, N.C., para discutir e revelar as conclusões que nortearam a arquitetura desta moderna escola norte-americana, conforme detalhadamente publicou o livro Architectural Record (1956:223-247).

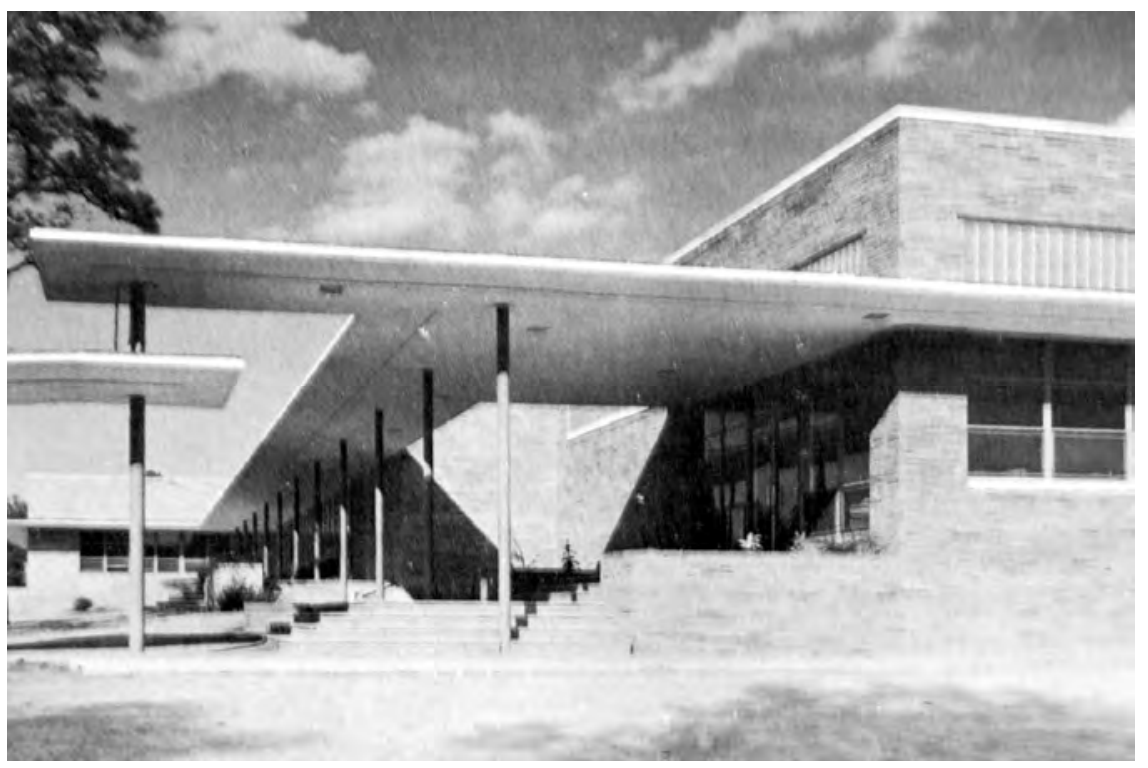

A West Charlotte Senior High School (Charlotte, N.C.), projeto dos arquitetos Graves \& Toy, traduz na arquitetura as conclusões da reunião de 1953. Esta escola merece atenção pelo seu programa de ensino adulto vocacional e técnico estabelecido dentro das premissas de uma moderna escola, com ênfase à flexibilidade e ao crescimento.

\footnotetext{
"There is strong adult program, and the school is already serving as a community cultural, recreational and social center".

"Though the school plant is developed as a campus it is a relatively compact disposition of departmentalized units, each - as we have seen - susceptible of expansion, to permit maximum flexibility and variety in growth".
}

Architectural Record (1956:260 e 265)

${ }^{60}$ Este grupo foi composto por William Curtis (administrador escolar), Nickolas Louis Engelhardt (educador), Alonzo J. Harriman (arquiteto), Stanton Leggett (educador), Frank G. Lopez (membro da Architectural Record), John W. McLeod (arquiteto), Joseph W. Molitor (fotógrafo) e um grupo ligado à Myers Park High School (Charlotte) John French (diretor), Elmer Garinger (superintendente) e James Stenhouse (arquiteto).
Figura 25: Myers Park High School, Charlotte, N.C. Observar a arquitetura desta escola, local onde o grupo de educadores, arquitetos e administradores escolares se reuniram em 1953.

Fonte: Architectural Record

(1956:225) 


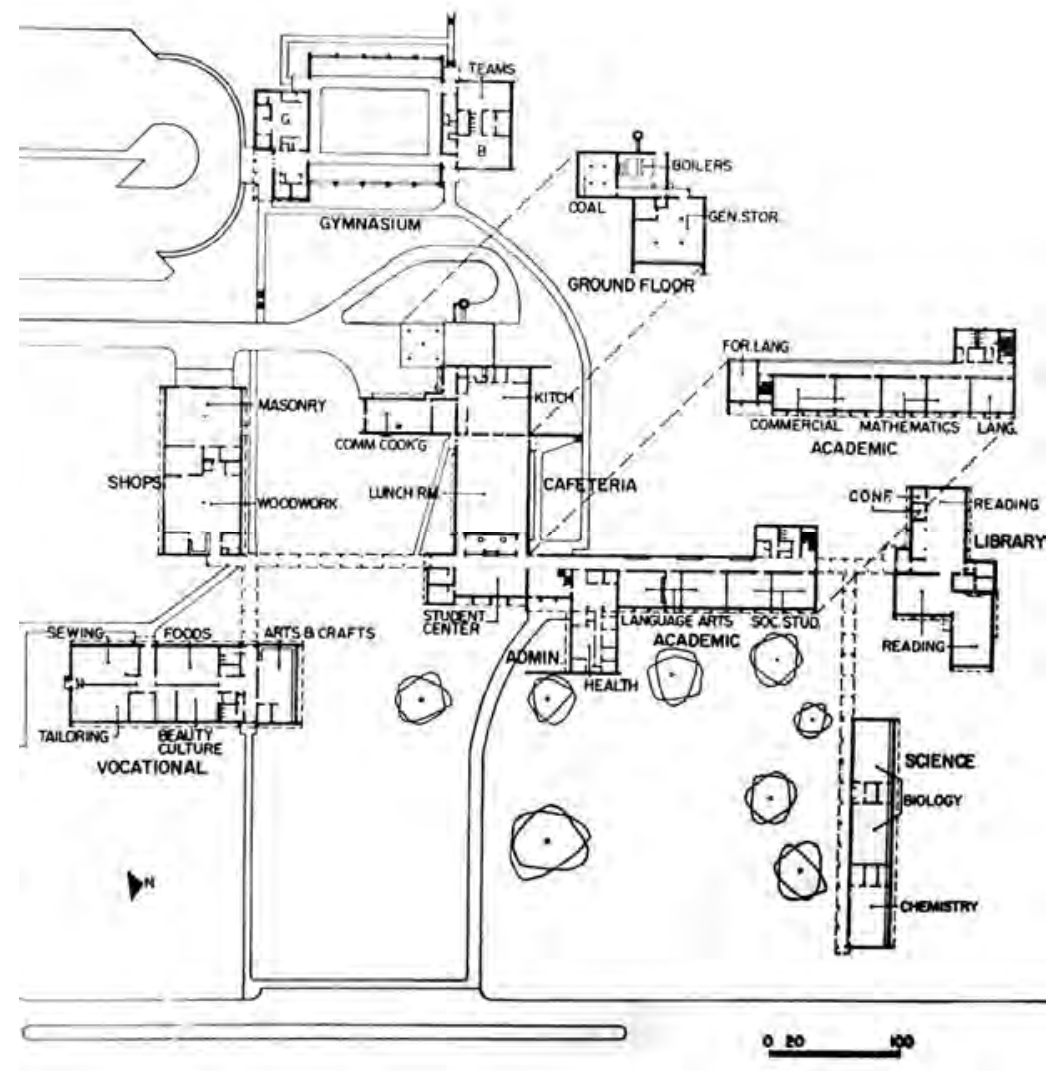

Figuras 26 à 29: West

Charlotte Senior High School, Charlotte, N.C. Arquitetos Graves \& Toy. Consultores educacionais Engelhardt \& Leggett.

Fonte: Architectural Record (1956: 260,261,263)

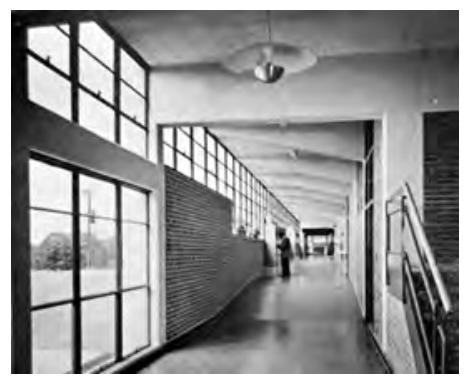

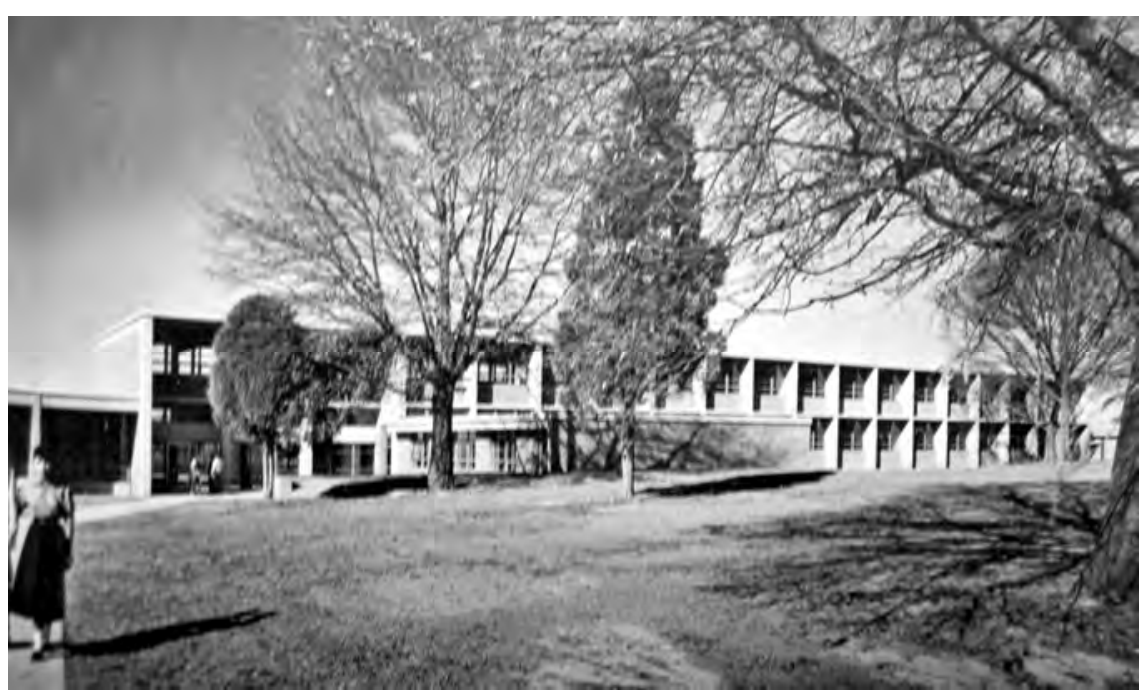

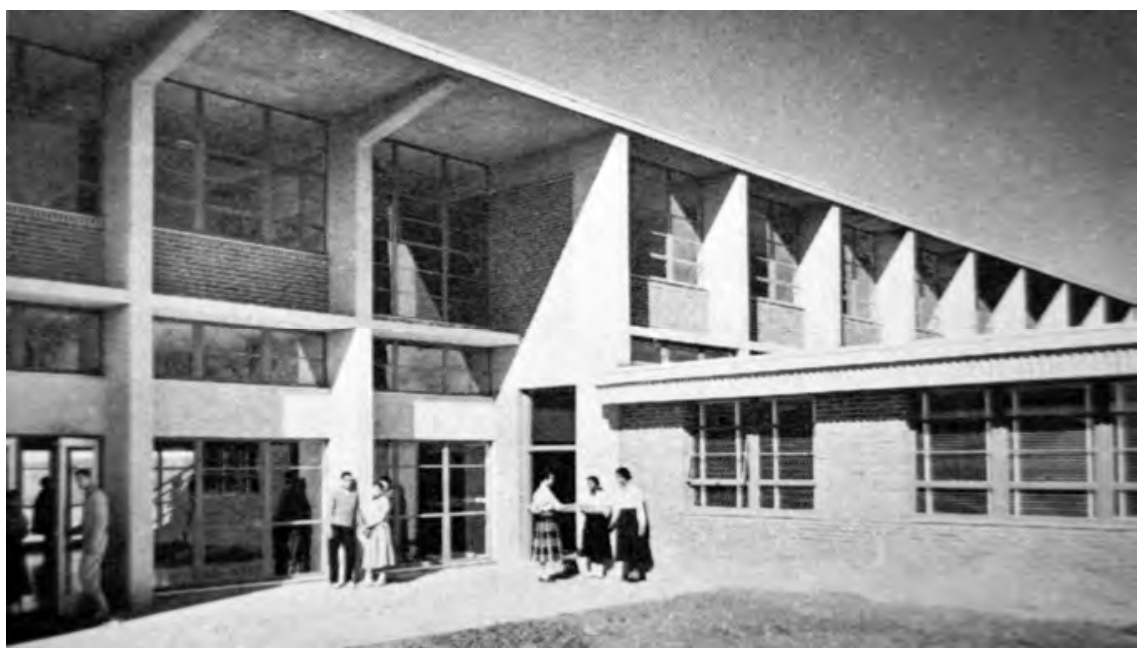


Ao revelar parte da iconografia de algumas escolas técnicas norte-americanas construídas na década de 1950 fica enfatizada a idéia do edifício-escola como influência na atitude, no hábito, no comportamento e na criatividade do indivíduo. Esta seletiva amostragem expõe as soluções técnicas e projetuais utilizadas na educação democrática e "americanista", referência clara na concepção das escolas modernas dos "S" brasileiros como um espaço social, recreacional, flexível e aberto. Conhecendo a experiência norte-americana, cabe agora o desafio de investigar, documentar e interpretar cuidadosamente as modernas escolas " $\mathrm{S}$ " brasileiras, no Estado de São Paulo, percorrendo o processo evolutivo das mesmas da década de 1940 até a consolidação desta nova arquitetura escolar na década seguinte. 


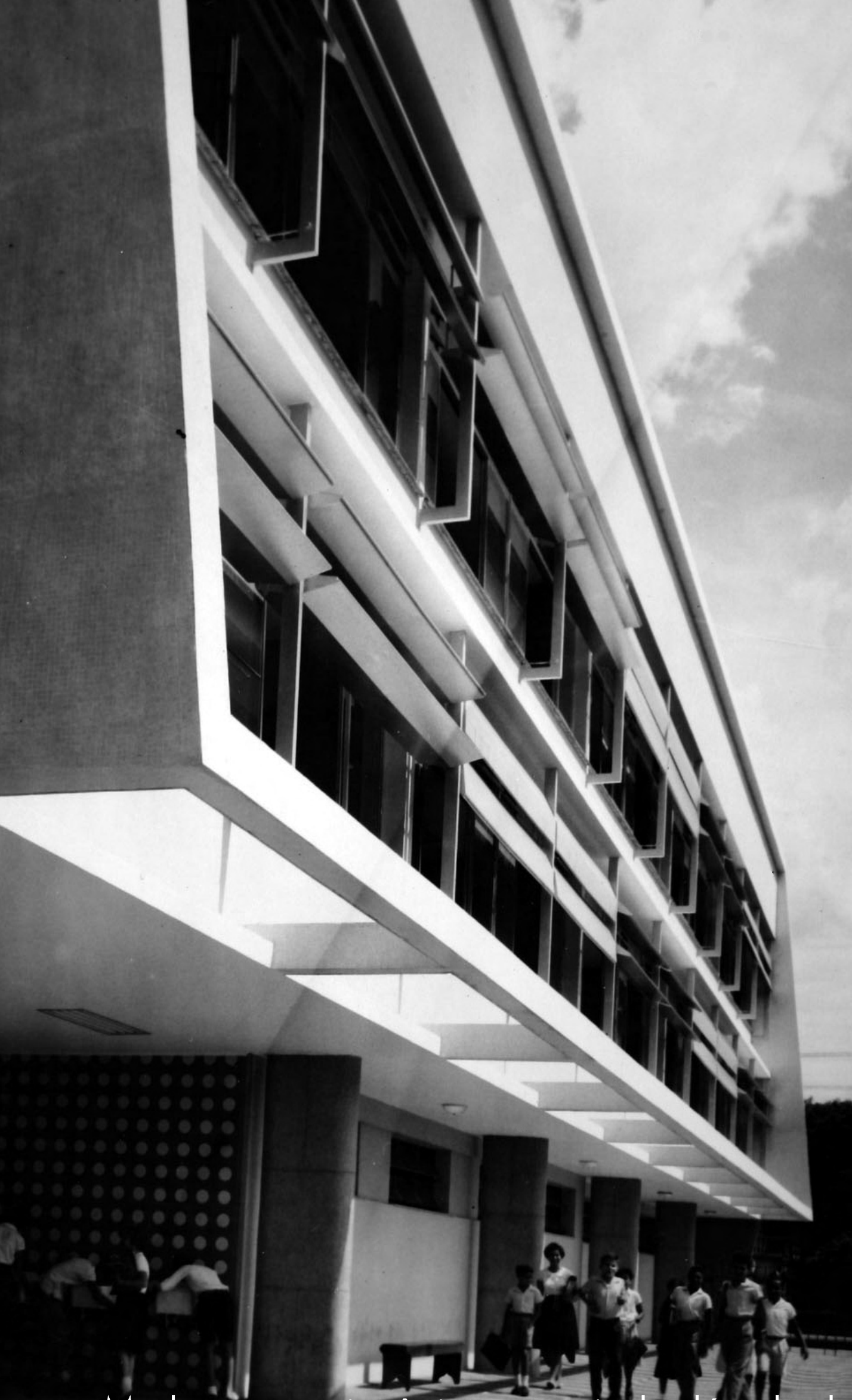

Mudança arquitetônica a partír da década de 1950: a experiência das escolas dos "S" ne 


\section{Mudança arquitetônica a partir da década de 1950: a experiência das escolas "S" no Estado de São Paulo}

No Brasil, a criação do SENAl na década de 1940 foi fortemente enraizada na organização racional do trabalho como base para a modernização do ensino voltado à qualificação do trabalhador industrial. Da mesma forma, o conceito de modernidade ligado ao desenvolvimento econômico do país afirmou os demais "S", SESC e SENAC. No que se refere à industrialização, comércio e assistência social, a arquitetura dos " $\mathrm{S}$ " cresceu continuamente, quer pela importância de sua arquitetura aplicada à pedagogia, quer pelo desenvolvimento de seus projetos. Para a criação das escolas dos três sistemas " $\mathrm{S}$ " foram importantes as referências brasileiras, como $\circ$ Liceu de Artes e Ofícios, no qual colaboraram Ramos de Azevedo e Roberto Mange, e o Convênio Escolar, que passou a ser, em si mesmo, uma escola em face ao preparo que proporcionou aos arquitetos e engenheiros dos "S". Além destas experiências, nota-se uma atualização dos envolvidos com a experiência norte-americana de uma arquitetura pós-Segunda Guerra.

Reforçando o objetivo de ampliar a perspectiva de análise da arquitetura moderna brasileira, este capítulo documenta e analisa a importante produção que se destacou no Estado de São Paulo para atender à formação do trabalhador, através dos três "S", com ênfase nas modernas escolas das décadas de 1950 e 1960.

Dividido em duas partes, este capítulo primeiramente percorre as escolas "S" dos anos 1940' e mostra as distintas fases do processo de evolução de cada "S". Trata-se de uma década de transição, que caminhou para uma mudança arquitetônica na década seguinte. Desta forma, a segunda parte deste capítulo é dedicada à década de

1 A década de 1940 que marcou a arquitetura em São Paulo, como a criação das escolas de arquitetura institucionalmente autônomas da engenharia, o surgimento oficial do Departamento Paulista do Instituto de Arquitetos do Brasil (IAB), assim como o I Congresso Brasileiro de Arquitetos. 
1950 com ênfase no objeto de estudo desta tese, as modernas escolas "S" no Estado de São Paulo. São documentadas e analisadas 23 escolas do SENAI e 10 escolas do SESC e SENAC por meio de uma minuciosa pesquisa do projeto arquitetônico de cada edifícioescola projetado de 1952 até 1968. Esta etapa esclarece quais foram os sete princípios pedagógicos aplicados à arquitetura dos "S", documenta os projetos investigados e revela os dados físicos conceituais e projetuais de cada escola dos três " $\mathrm{S}$ ". Ao compreender estes dois momentos históricos, o primeiro na década de 1940 e o segundo de 1952 até 1968, cabe revelar os projetos que fizeram parte da nova pedagogia, utilizada no segundo período, em sintonia com a arquitetura moderna

Os "S", como instituições educacionais que ofereceram escolas inovadoras e diferenciadas, a partir da década de 1950, buscaram soluções alcançadas pela arquitetura moderna que se estenderam à década de 1960. 


\subsection{As escolas dos anos 1940}

\subsubsection{SENAI}

Ao avaliar o desenvolvimento da arquitetura das escolas do SENAl, na década de 1940, percebem-se três fases distintas, acompanhando a evolução deste serviço industrial.

Roberto Mange, como diretor do Departamento Regional da $6^{a}$ região $^{2}$ do SENAl, adotou em 1942 a idéia das escolas funcionarem em edifícios emprestados, as chamadas instalações provisórias, como, por exemplo, foi utilizado o Instituto Dom Bosco (figura 1). Esta primeira fase ${ }^{3}$ veio com a implantação inicial do Departamento Regional e com o estabelecimento de escolas de emergência em prédios alugados, desprovidos de oficinas.

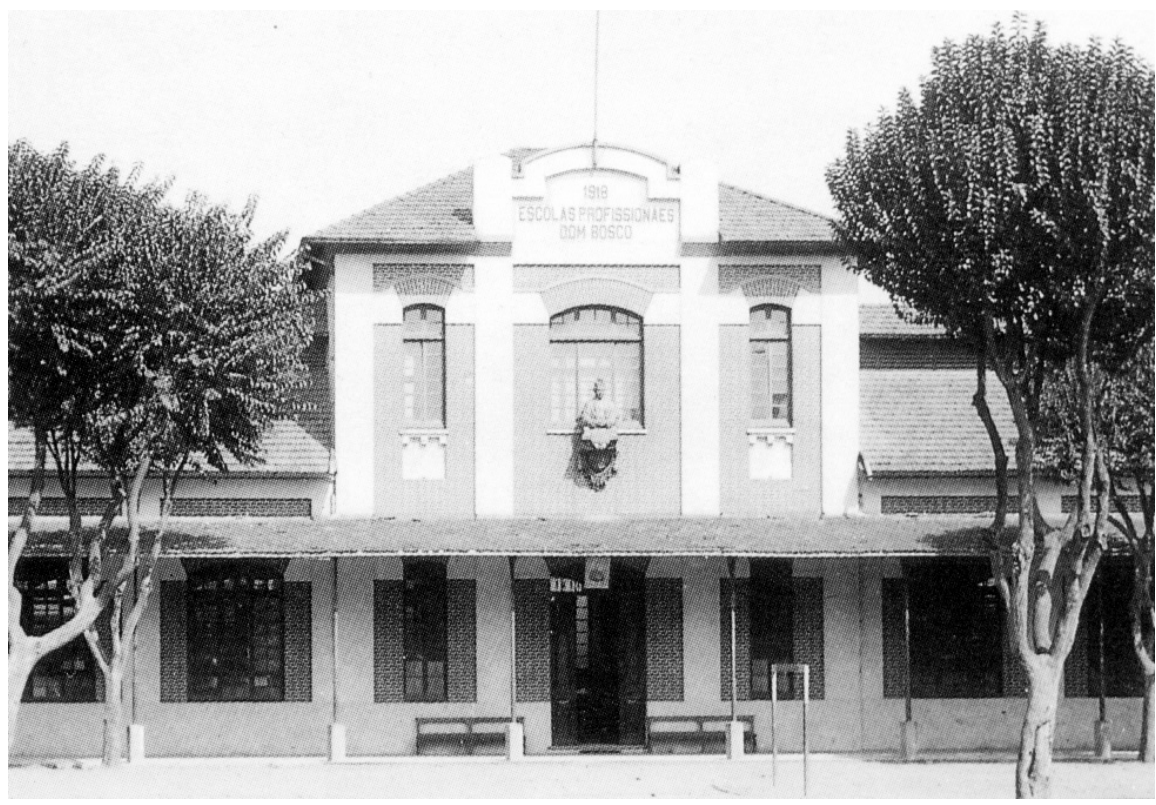

Figura 1: No início o SENAl funcionava em instalações provisórias, edifícios emprestados para acolher os aprendizes. Fonte: SENAI (1991:127)

No final de 1945, pressionado por ameaças de estatização, o SENAI acelerou a construção de suas primeiras escolas, projetadas com características monumentais.

${ }^{2}$ A partir de 1942 o SENAl foi organizado nacionalmente em dez regiões, sendo que a $6^{a}$ região compreendia o estado de São Paulo (SENAI, 1991:125).

${ }^{3}$ Esta primeira fase permitiu a arrancada inicial das atividades do SENAI, a tomada de contato com as empresas industriais e a definição legal de matrículas de menores (conceito de aprendiz). 
"Após três anos de funcionamento, o SENAl havia crescido, e muito. Além de manter cursos extraordinários para a formação rápida e aperfeiçoamento da mão-de-obra, mediante acordo com Escolas Profissionais, contava com várias unidades escolares, tanto no Interior quanto da Capital, além de escolas mantidas nas indústrias sob regime de isenção".

SENAI (1991:136)

Esta segunda fase ${ }^{4}$ da década de 1940 teve início com a compra de terrenos, com o projeto de prédios definitivos, com 0 estudo das necessidades industriais e com o início de muitas construções. Por isso, nas novas escolas, foi dada ênfase especial ao que se refere às oficinas para aprendizes, indispensáveis ao desenvolvimento do Sistema Senai. Ainda de modo modesto, numa fase preliminar de ação, as novas escolas tinham uma arquitetura tradicional, padrão utilizado em edifícios ainda hoje existentes como a Escola Roberto Simonsen do Brás (figura 2) e a Escola Horácio Augusto da Silveira da Barra Funda (figura 3), ambas em São Paulo, projetos da empresa Severo Villares (SENAI, 1992:158). Segundo o engenheiro Luiz Alfredo Falcão Baver ${ }^{5}$, primeiro chefe da Divisão de Obras da Instituição:

"[...] os primeiros projetos de escola do SENAI partiam do princípio - uma idéia do próprio Roberto Mange - de que o mais importante numa escola é a oficina, Por isso, o SENAI basicamente colocou as oficinas junto à rua e em grandes painéis de vidro, vitrinas através das quais o trabalho dos instrutores e dos alunos permaneceria ao alcance da vista de quem quer que passasse na rua. Essa escolas caracterizam-se por um aspecto imponente de construção, com um pórtico muito bonito $[\ldots]^{\prime \prime}$

SENAI (1991:8)

\footnotetext{
${ }^{4}$ Nesta segunda fase o SENAI contava com 72 escolas em funcionamento, mantidas pelo SENAI ou pelas fábricas em regime de isenção, com 606 cursos de 52 ofícios diferentes e com cerca de 18.000 alunos (SENAl, 2002:29).

${ }^{5}$ Luiz Alfredo Falcão Baver ingressou no SENAl até chegar ao cargo de engenheiro chefe do Serviço de Obras, atividade que exerceu por 13 anos (VASCONCELOS, 1992:154). Responsável pela construção de inúmeras escolas SENAI, Baver foi uma figura bastante significativa entre os engenheiros de todo o Brasil, principalmente por sua atuação na luta para o controle de qualidade das construções de concreto.
} 


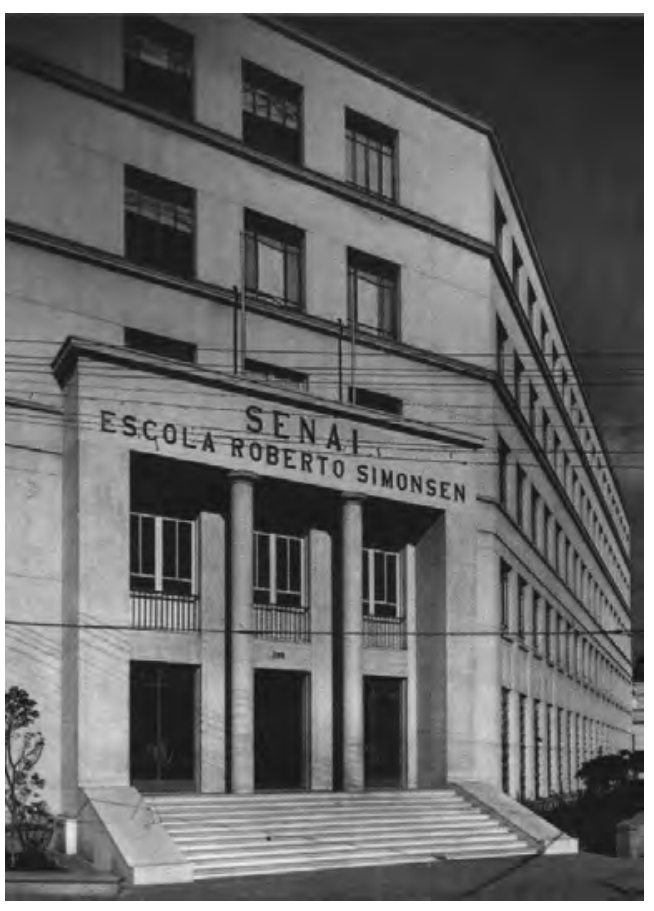

Figura 2: As escolas SENAI Roberto Simonsen em São Paulo. Fonte: SENAI (1991:9)

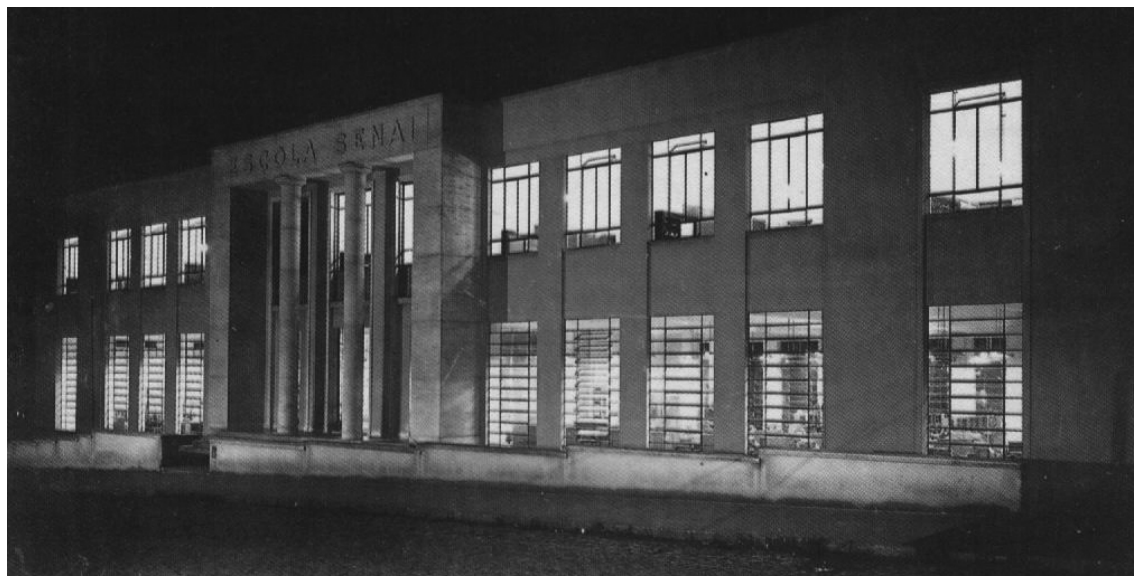

Figura 3: Escola SENAI Horácio Augusto da Silveira, Barra Funda

São Paulo, exemplo típico do padrão de arquitetura escolar adotado no início pelo SENAI.

Fonte: SENAI (1991: 9)

Figura 4: Selo do projeto da Escola SENAI Horácio Augusto da Silveira, Barra Funda, São Paulo, 1945. Observar o nome de Severo Villares.

Fonte: Foto Ferraz, arquivo SENAI

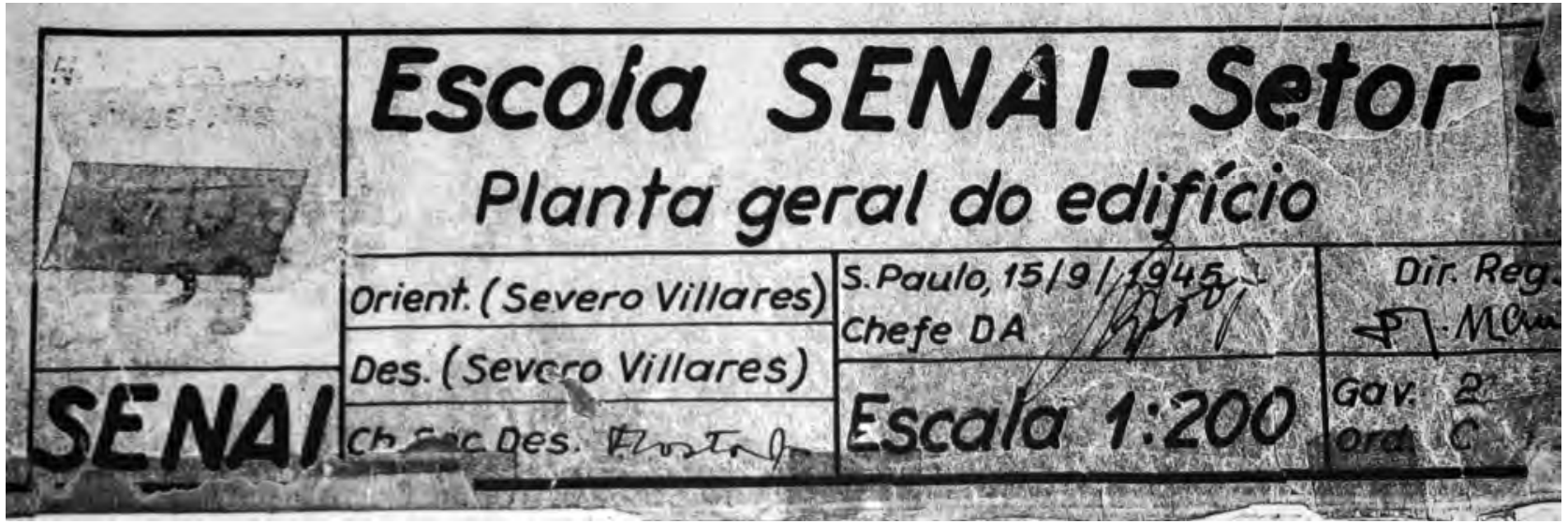



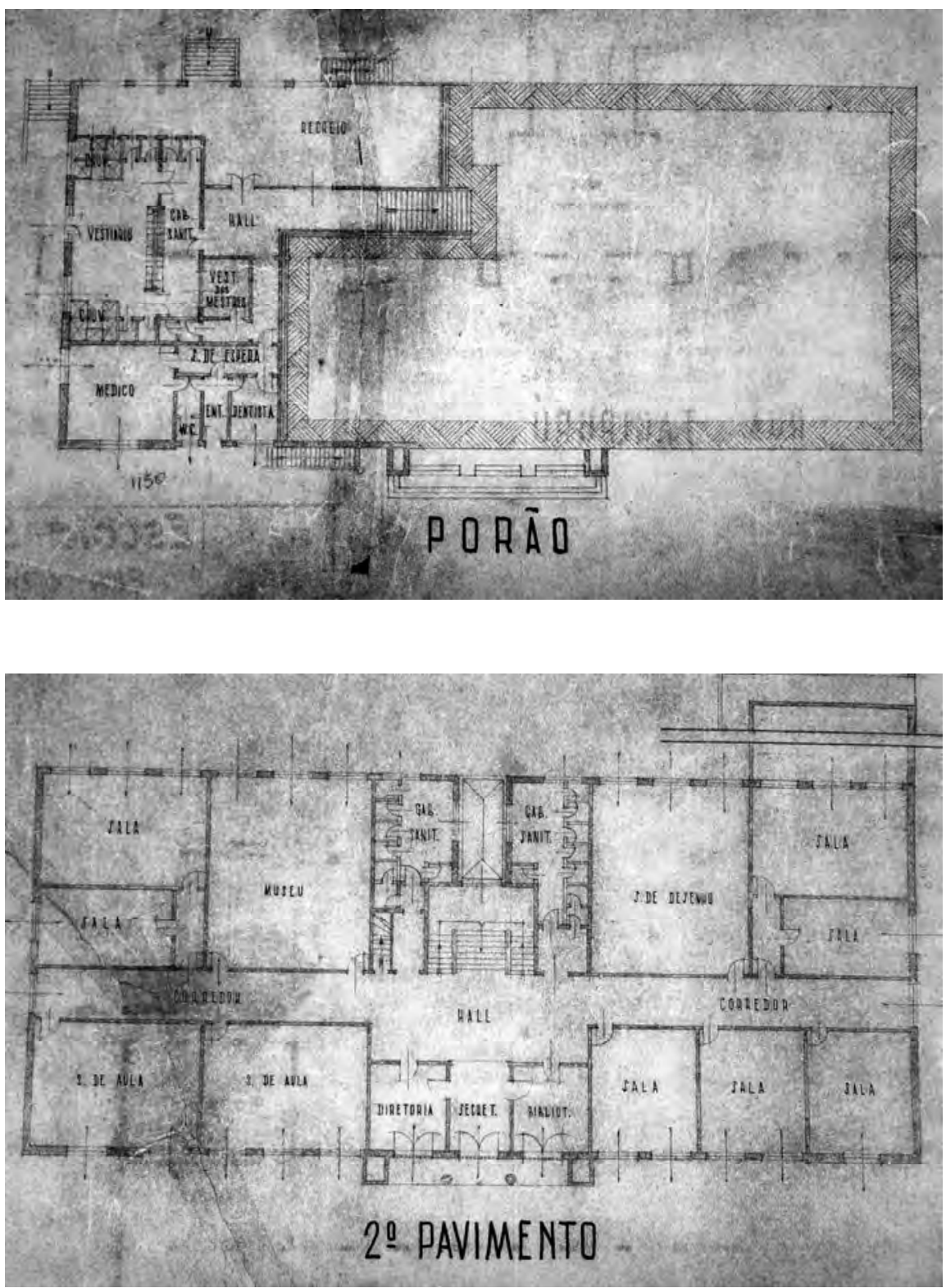

Figuras 5 à 7: Projeto da Escola SENAI Horácio Augusto da Silveira, Barra Funda, São Paulo, 1945. Planta dos três pavimentos.

Fonte: Foto Ferraz, arquivo SENAI

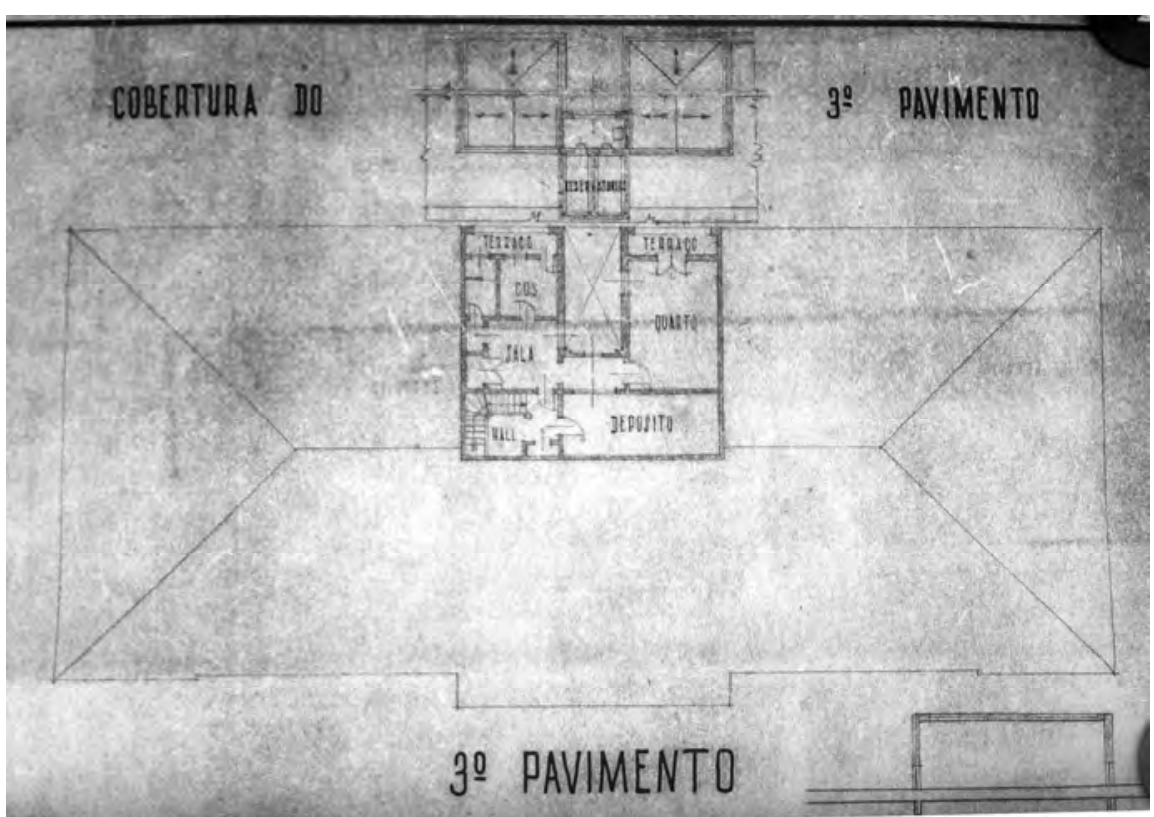


Vale lembrar que, durante o Estado Novo, a idéia da busca do conhecimento industrial assumiu status de ideologia, identificada como instrumento para conduzir a nação à independência política e econômica. Neste sentido, a região sul do país foi apontada como a mais propícia para liderar a arrancada industrial do país (SENAI, 1991:76).

Diante da necessidade de investir em educação e visando à formação de mão de obra qualificada, Roberto Mange acreditou, neste momento do SENAI, numa pedagogia do industrialismo ${ }^{6}$ para a qual a arquitetura produziu uma escola para ser mostrada para $\bigcirc$ industrial, uma arquitetura mais fabril do que essencialmente escolar. Também, nesta fase, a educação tinha como base o slogan de "Escola Nova", pautado no Manifesto dos Pioneiros da Escola Nova”. Roberto Mange acompanhou de perto o debate que levou ao Manifesto tendo participado das discussões sobre $\bigcirc$ ensino profissional. Ainda, no Brasil, a implantação de métodos baseados nos princípios de organização racional do trabalho já havia ocorrido antes nos cursos do Liceu de Artes e Ofícios de São Paulo, em destaque o Curso de Mecânica Prática criado em 1923, por Roberto Mange, a convite de Ramos de Azevedo ${ }^{8}$, então diretor do Liceu.

O contato de Roberto Mange com Ramos de Azevedo explica as escolas novas do SENAl, na década de 1940, terem sido projetadas pela empresa Severo Villares, ligada ao Escritório Técnico Ramos de Azevedo. Outro evidente exemplo desse padrão de projeto arquitetônico é a escola Cambuci, a "escola nova", um edifício de dois pavimentos que, conforme INFORMATIVO SENAl ${ }^{9}$ (1947) abrigava no térreo - hall de entrada, oficina na ala esquerda com $257 \mathrm{~m}^{2}$ de área e capacidade para 196 alunos, oficina na ala direita

\footnotetext{
${ }^{6} \mathrm{Na}$ pedagogia do industrialismo o elemento homem era fundamental, devendo ser estudado e conhecido em suas aptidões para assegurar sua adequação ao lugar de trabalho, manter e determinar a intensidade do trabalho e, simplificar as operações complexas. Esta pedagogia tinha, da associação destes procedimentos, o rendimento máximo com o menor esforço (SENAI, 1991:103).

7 Este manifesto foi publicado em 1932 e originado dos debates da $4^{\text {a }}$ Conferência Nacional de Educação, realizada no Rio de Janeiro, em dezembro de 1931. Vale lembrar que anos antes, em 1929, no artigo intitulado "Escola Nova", Lourenço Castanho Filho propôs um sistema de ensino, avaliação e orientação para as escolas brasileiras, baseado nos princípios do taylorismo (AZEVEDO, 1937: 175-192).

${ }^{8}$ Roberto Mange já havia tido contado com Ramos de Azevedo na Escola Politécnica de São Paulo (GITAHY, 1986).

9 O Informativo SENAI, a primeira publicação interna do SENAI, foi um pequeno jornal que divulgava as reuniões do pessoal técnico e da chefia do SENAI.
} 
Figura 8: Escola Cambuci em São Paulo. Edifício de dois pavimentos, exemplo da "escola nova" representada por uma arquitetura racionalista. Fonte: SENAI (1992:159) também com $257 \mathrm{~m}^{2}$ de área e capacidade para 72 alunos, gabinetes médico e dentário, refeitório, sala de recreação e biblioteca; no pavimento superior - salas de aulas teóricas e dependências administrativas.

Outro fator importante na "escola nova" era sua localização. As escolas deveriam ser alocadas em regiões onde o desenvolvimento industrial justificasse uma demanda de trabalhadores qualificados em ofícios determinados, portanto deveria ser: de fácil acesso, próxima de meios de condução, localizada na zona industrial, em terreno suficientemente grande para permitir área de recreação e futuras ampliações (SENAI, 1992:158).

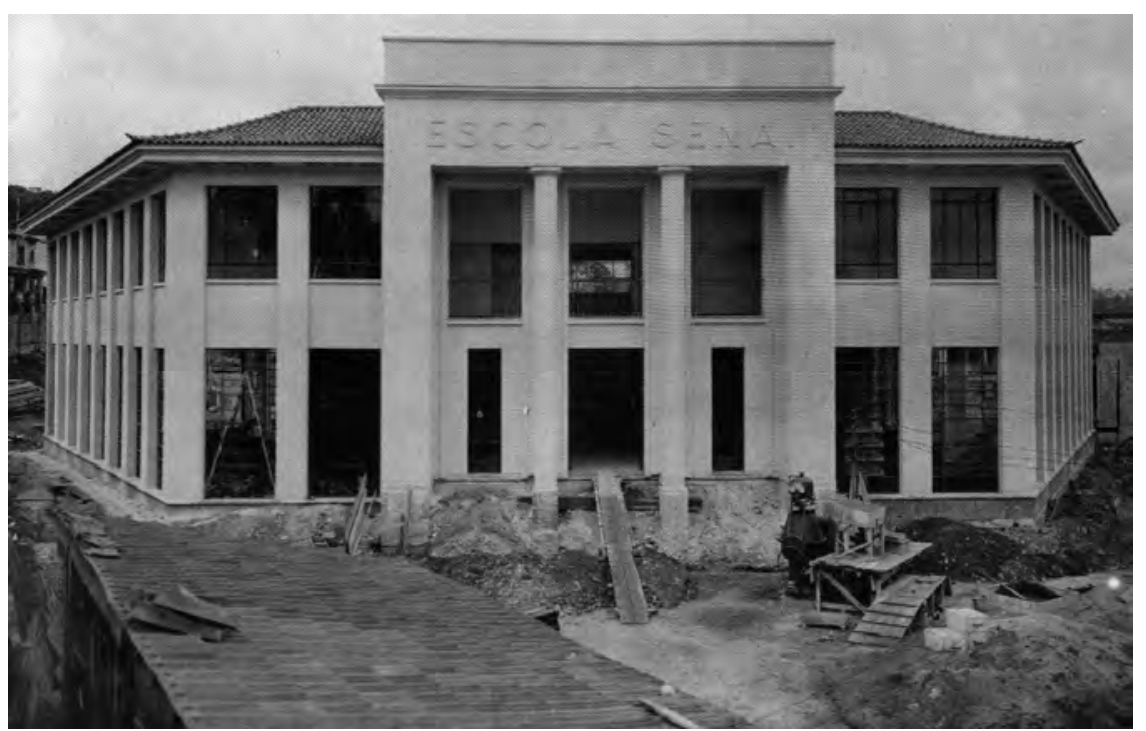

Após seis anos de criação, e antes de concluir todos os edifícios, o SENAl começou a dar uma maior atenção ao problema da qualidade e rendimento do ensino, ao ajustamento dos cursos às necessidades efetivas da indústria e da produção prevista. Portanto, o Relatório de 1948 caracteriza a terceira fase ${ }^{10}$ da década de 1940, o momento de avaliação do desempenho da instituição, as preocupações e orientações de um sistema em consolidação e ampliação. Pode-se destacar nesta fase os projetos para o Pavilhão Social de São Carlos, 1949 (figura 9 à 11), e o projeto para o internato de Campinas, 1950 (figura 12 à 14), ambos encontrados no arquivo do SENAI.

\footnotetext{
10 Na terceira fase da década de 1940, em 1948, o SENAI estava presente em 18 Estados do país, oferecendo 431 cursos de formação de artífices, 30 de aperfeiçoamento e 145 cursos de outras modalidades (SENAI, 2002:30).
} 
Figura 9: Projeto do Pavilhão Social de São Carlos, 1949.

Projeto do Serviço de Obras do SENAI. Exemplo da arquitetura racionalista do final da década de 1940.

Fonte: Foto Ferraz, arquivo SENAI
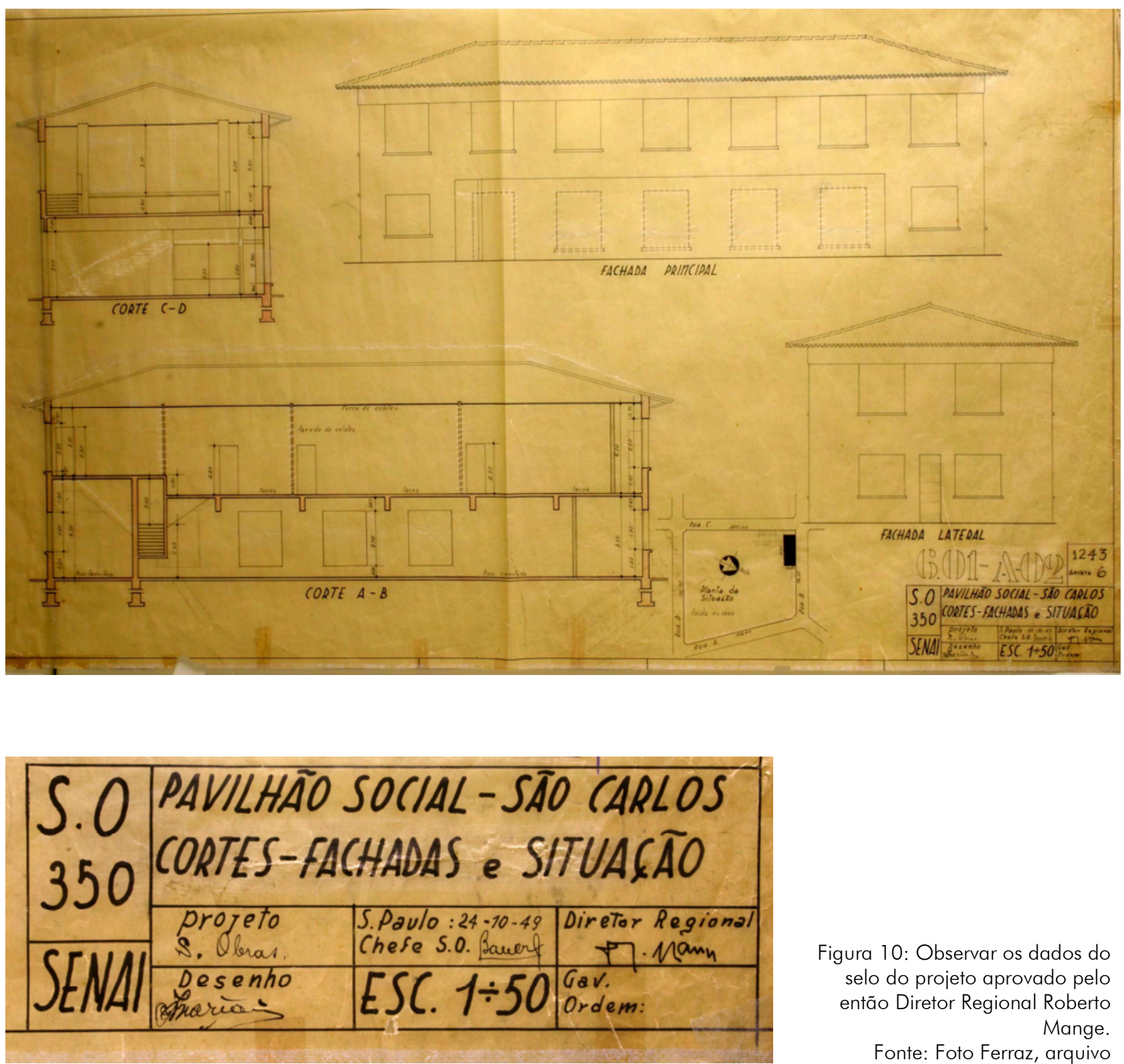

Figura 10: Observar os dados do selo do projeto aprovado pelo então Diretor Regional Roberto Mange.

Fonte: Foto Ferraz, arquivo SENAI

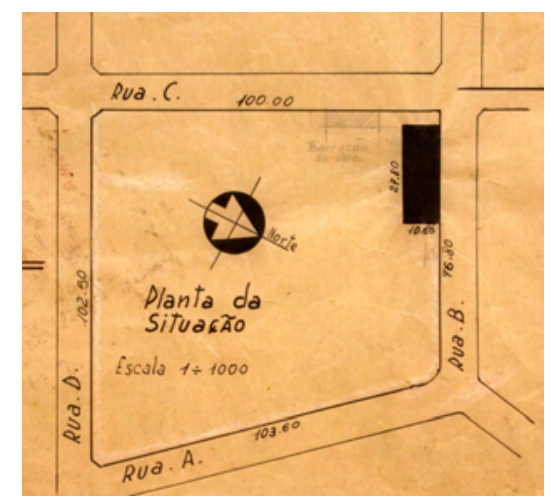

Figura 11: Localização do Pavilhão Social no lote, São Carlos, 1949.

Fonte: Foto Ferraz, arquivo SENAI 
Figura 12: Projeto da fachada principal do internato de

Campinas, 1950. Exemplo da arquitetura racionalista

concebida até 1950.

Fonte: Foto Ferraz, arquivo

SENAI

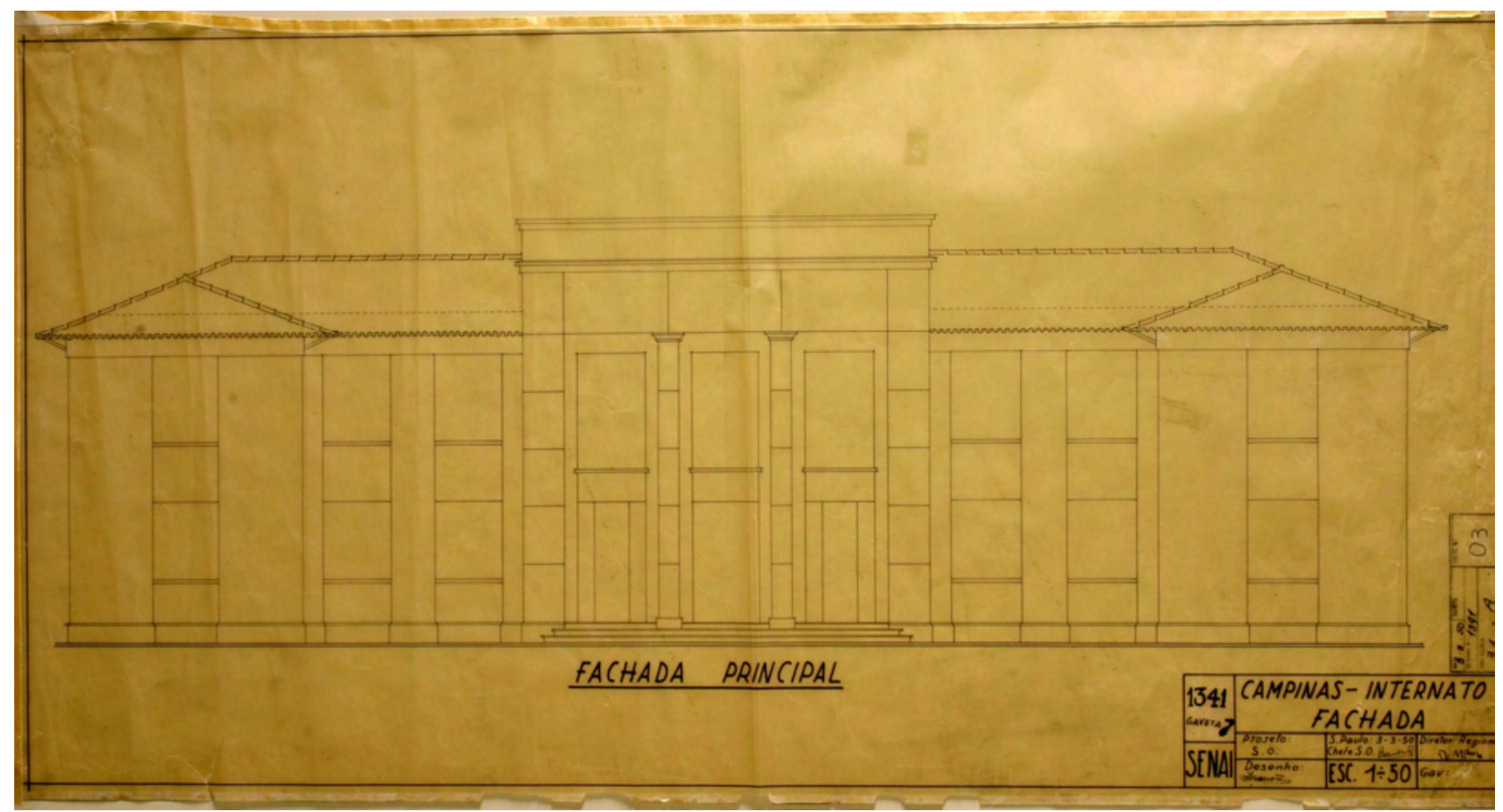

Figura 13: Observar os dados do selo do projeto com a assinatura de Baver e Mange.

Fonte: Foto Ferraz, arquivo SENAI

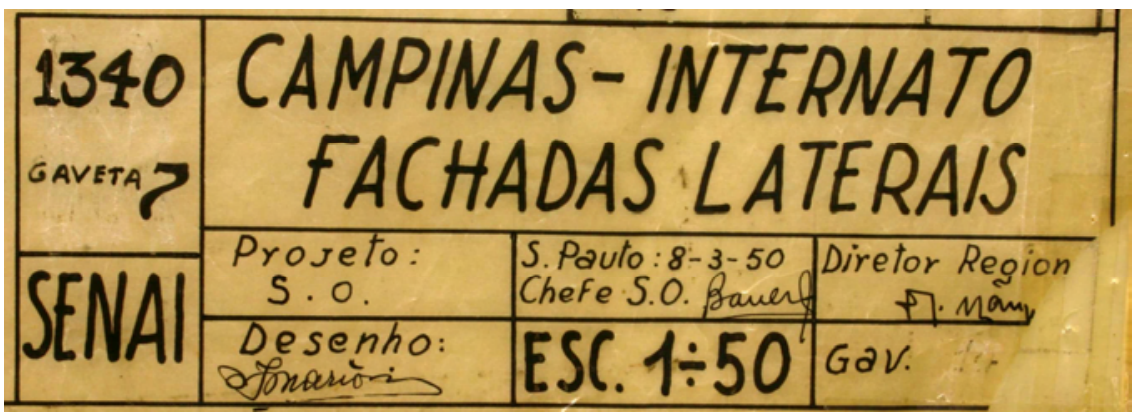

Figura 14: Fachada lateral esquerda do internato de Campinas, 1950.

Fonte: Foto Ferraz, arquivo SENAI

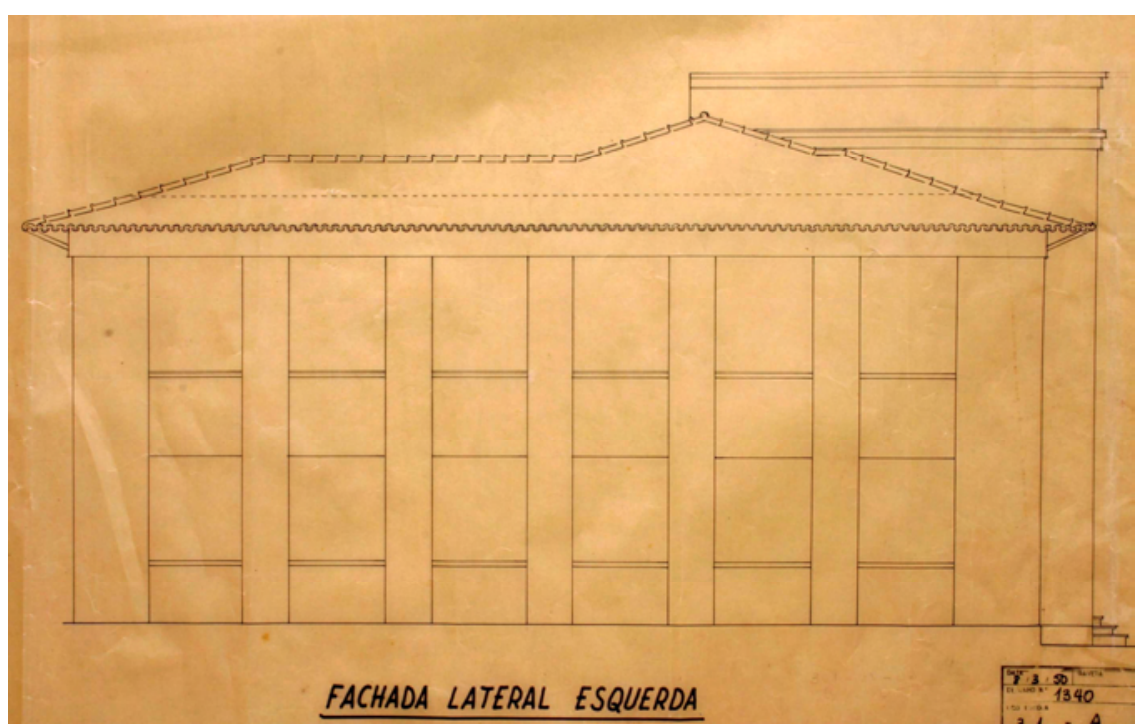


Com vistas à consecução dos objetivos do SENAl, o padrão de arquitetura foi modificado a partir de 1950, quando a Diretoria Regional determinou ao Serviço de Obras que introduzisse no SENAI os padrões da arquitetura moderna. Esta mudança, motivada por razões de ordem pedagógica levou em conta também as insatisfatórias condições ambientais (ventilação, iluminação, espaços desorganizados). Somou-se à evolução das teorias educativas, a colaboração de arquitetos, engenheiros, técnicos e professores, na concepção dos prédios escolares modernos. A nova organização visava uma arquitetura que, considerando a especificidade do ensino industrial, possibilitasse uma escola diferenciada para o aluno com a aplicação do conceito de "educação integral". "1

Os projetos com características monumentais foram abandonados e o SENAI passou a pensar numa escola para o aluno, projetada de acordo com um novo modelo de educação, a "educação integral", uma nova pedagogia que não se interessava mais em ser uma escola de aparência suntuosa para o industrial.

\subsubsection{SESC-SENAC}

A rede de unidades SESC e SENAC em São Paulo instalada na década de 1940 instalou suas primeiras escolas nos municípios de Ribeirão Preto, Santos, Campinas, Bauru, Taubaté, São José do Rio Preto, Franca, Araçatuba, Lins, Botucatu e Araraquara, além da própria Capital.

\footnotetext{
11 As reflexões em torno da "educação integral" dentro do contexto da aprendizagem industrial foram se tornando cada vez mais presentes desde 1946, quando Roberto Mange começou a questionar acerca da compatibilidade entre a formação técnica e a educação integral do indivíduo. Mange criticou o trabalho desenvolvido no SENAI: "Se bem que com o desenvolvimento da cultura geral, da educação moral e cívica e das lides abrangidas pelo Serviço Social se procure acatar e elevar o espírito do aprendiz, subsiste algo de antagônico com a rigidez da técnica do trabalho em que a individualidade, o culto pela matéria, o senso artístico e o amor ao belo não têm oportunidade de se expandir" (RELATÓRIO SENAI-SP, 1946:9).
} 
Ao observar o percurso evolutivo destes serviços, percebe-se que nesta primeira fase as escolas funcionavam em prédios alugados e desprovidos de qualquer planejamento funcional e pedagógico para o desenvolvimento das atividades propostas de comércio, serviço,

cultura e lazer.

Figura 15: No início o SENAC funcionava em instalações provisórias, edifícios alugados como a Escola SENAC "Castro Mendes" de Campinas, instalada em 1947

Fonte: Memória Institucional do SENAC-SP.
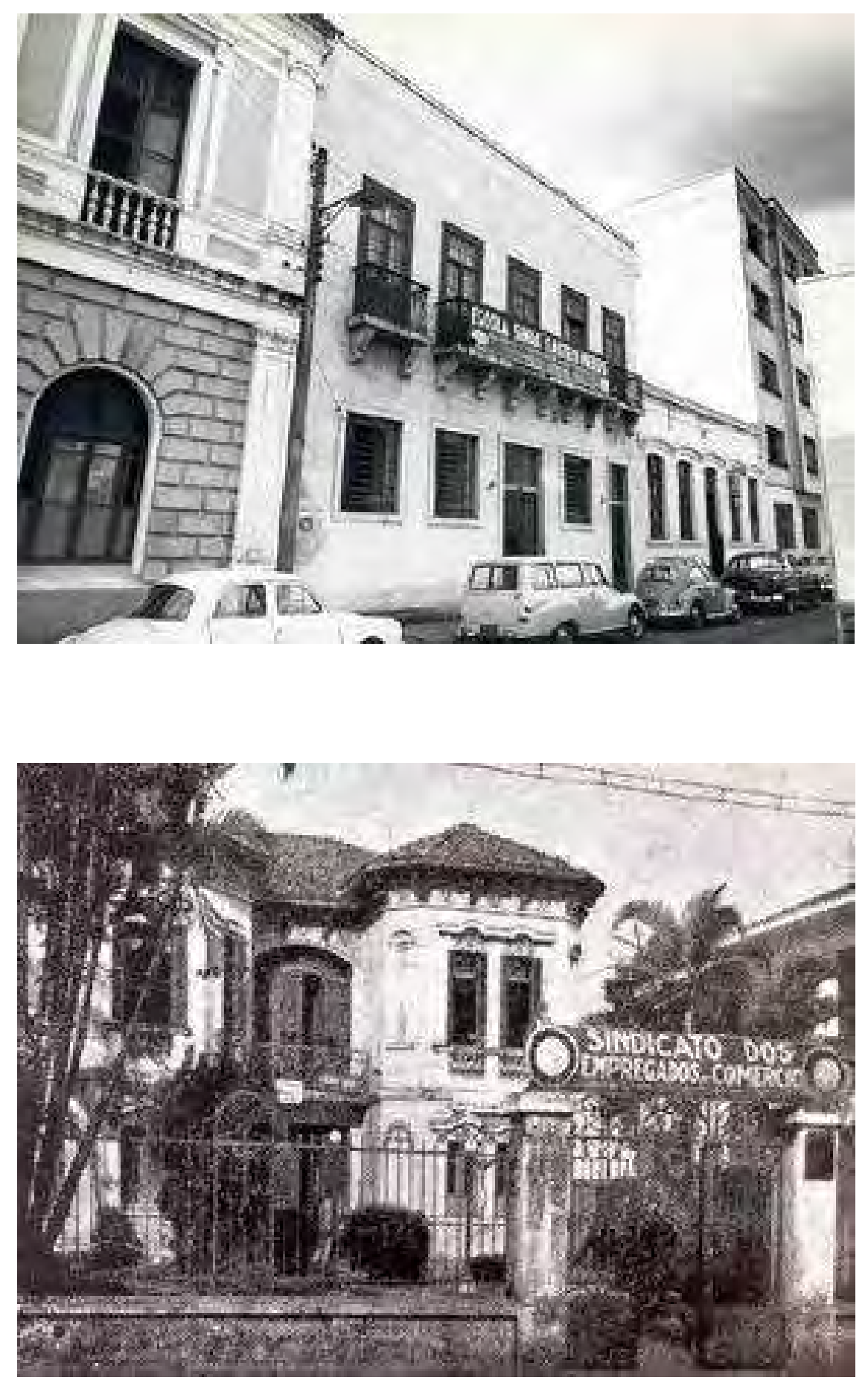

Figura 16: Escola SENAC "José Gomes da Silva" de Ribeirão Preto, instalada em 1947 no do prédio do Sindicato dos Empregados no Comércio. Fonte: Memória Institucional do SENAC-SP. 

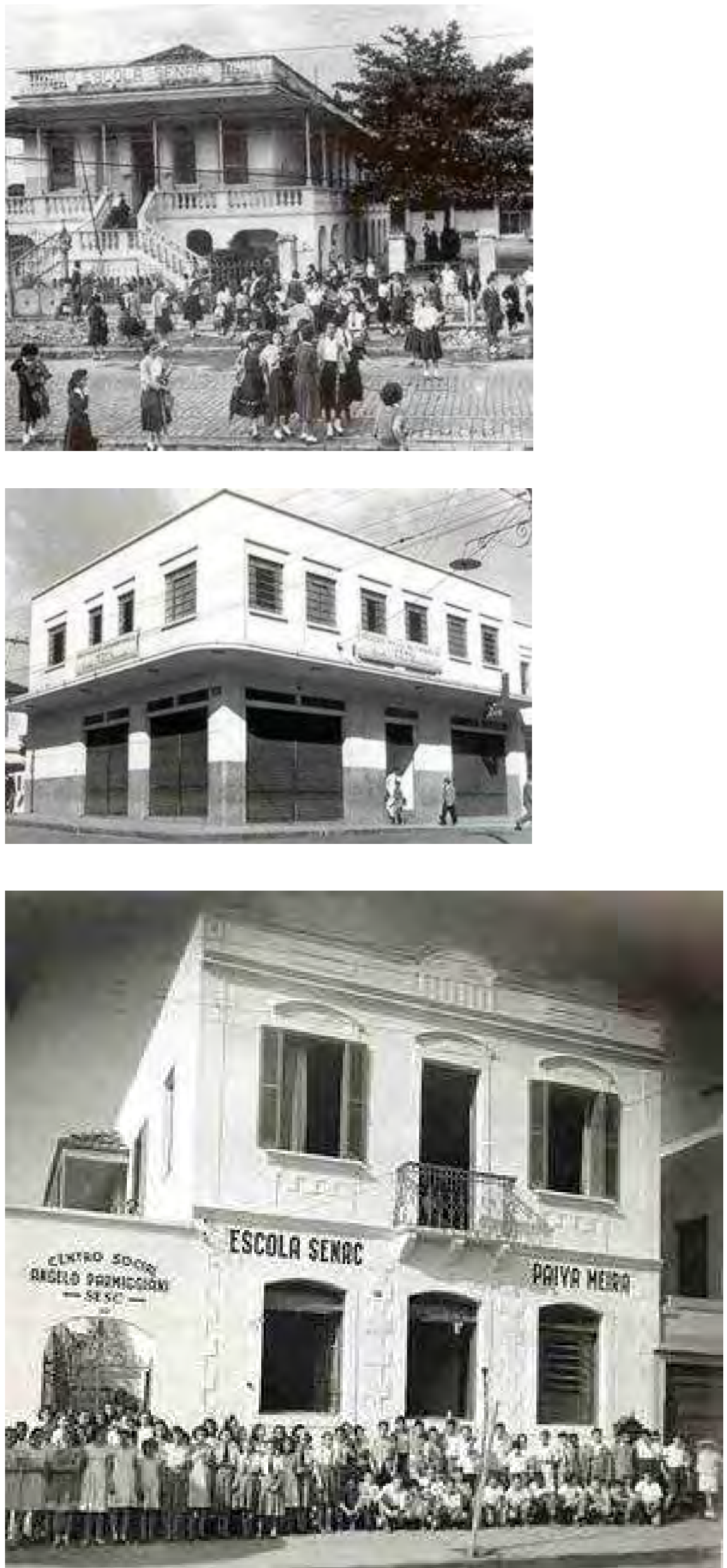

Figura 17: Escola SENAC

"Gabriel Dias da Silva", rua Conselheiro Nébias, 309, Santos, instalada em 1947.

Fonte: Memória Institucional do SENAC-SP

Figura 18: Escola SENAC "Nelson Fernandes", rua $1^{\circ}$ de Agosto 2-71, Bauru, instalada em 1948.

Fonte: Memória Institucional do SENAC-SP.
Figura 19: Escola SENAC "Paiva Meira", rua Tiradentes, 484-490, São José do Rio Preto, instalada em 1948. Fonte: Memória Institucional do SENAC-SP. 
Figura 20: Escola SENAC "Marcelino de Carvalho", rua Conselheiro Moreira de Barros, 177, Taubaté, instalada em 1948.

Fonte: Memória Institucional do SENAC-SP.

Figura 21: Escola SENAC "Antônio G. L. Mont'Serrat", Praça lzabel Arruda, 72,

Botucatu, instalada em 1949.

Fonte: Memória Institucional do SENAC-SP.

Figura 22: Escola SENAC

"Henrique Bastos Filho", rua 9 de Julho, 160, Araraquara,

instalada em 1949.

Fonte: Memória Institucional do SENAC-SP.
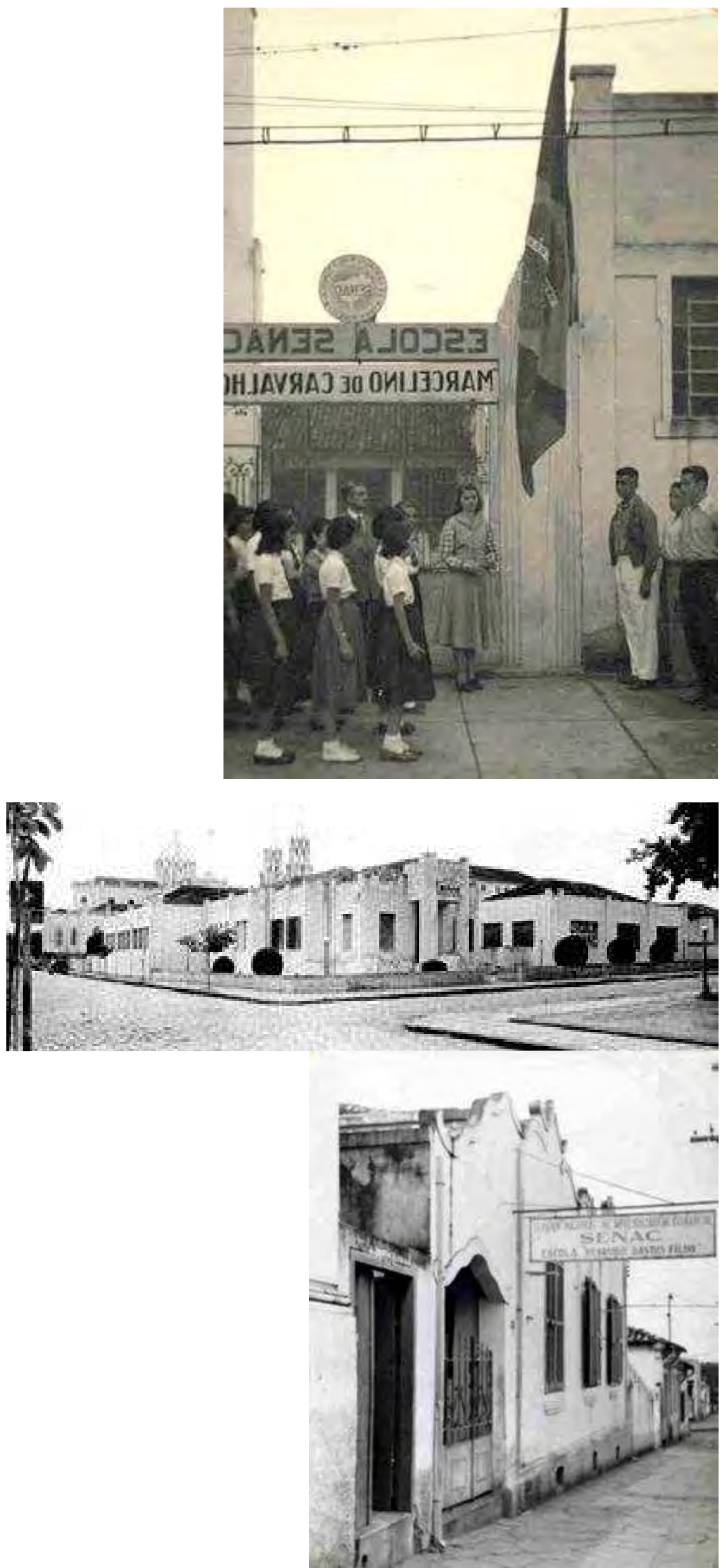
Se neste primeiro momento os primeiros edifícios da década de 40 não atenderam aos aspectos práticos e funcionais da aprendizagem, sendo inadequados para a educação, já no final desta mesma década e início dos anos 1950, as instalações marcaram uma segunda fase caracterizada por "espaços educacionais tradicionais, dotados de salas de aulas convencionais, laboratórios de ciências, pátio de recreio, quadras de esporte e ambientes administrativos e pedagógicos, que procuravam atender as necessidades de aprendizagem da época" (SENAC, 1994:6).

Exemplo deste padrão de projeto arquitetônico da segunda fase é a Escola SENAC da Capital, posteriormente chamada de Escola SENAC "Brasílio Machado Neto". Adquirido em 1948, o edifício ainda de modo modesto, numa fase preliminar de ação, representou as novas escolas com uma arquitetura tradicional próxima ao racionalismo. Seu programa construtivo abrigava os espaços educacionais necessários como salas de aula, sala de recreação e quadra de esporte (figuras 24 à 26).

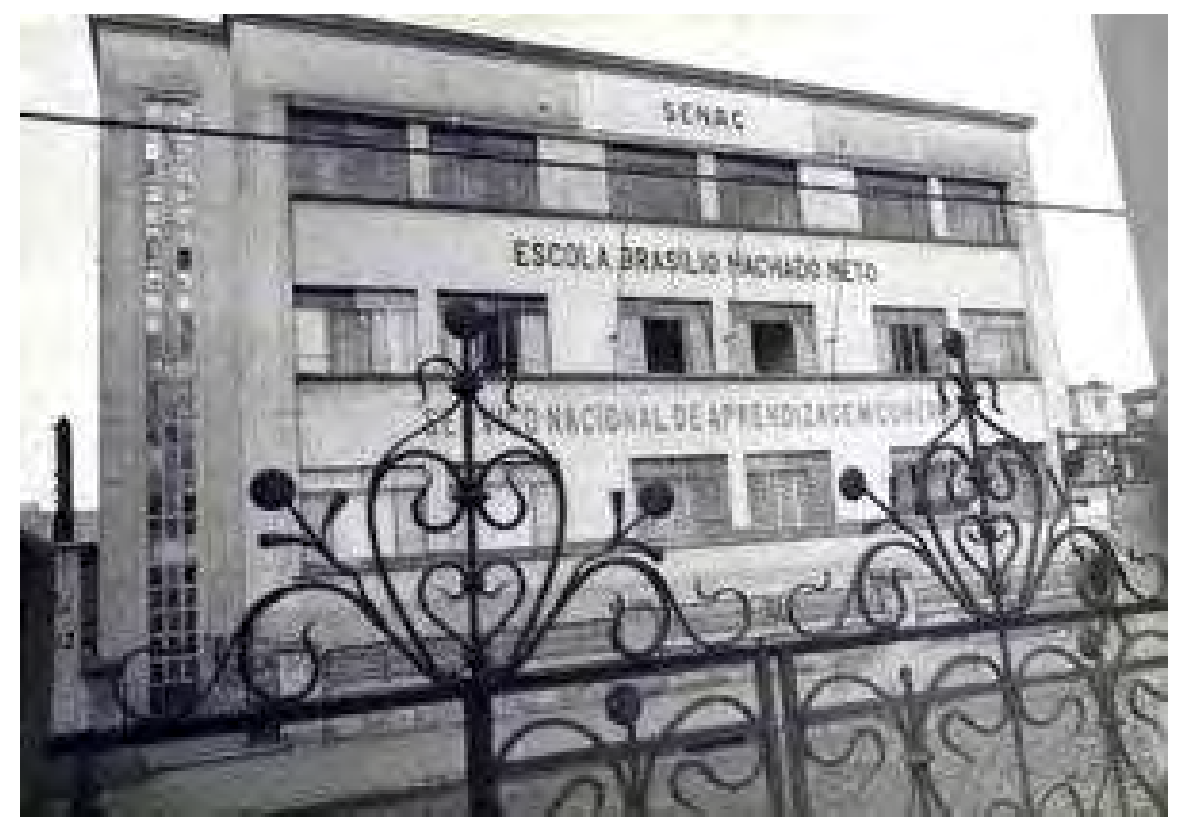

Figura 23: Antiga Escola SENAC

"Brasílio Machado Neto", rua Galvão Bueno, São Paulo, comprada em 1948 e posteriormente desativada. Seus espaços revelam a presença de novos ambientes educacionais. Fonte: Memória Institucional do SENAC-SP. 

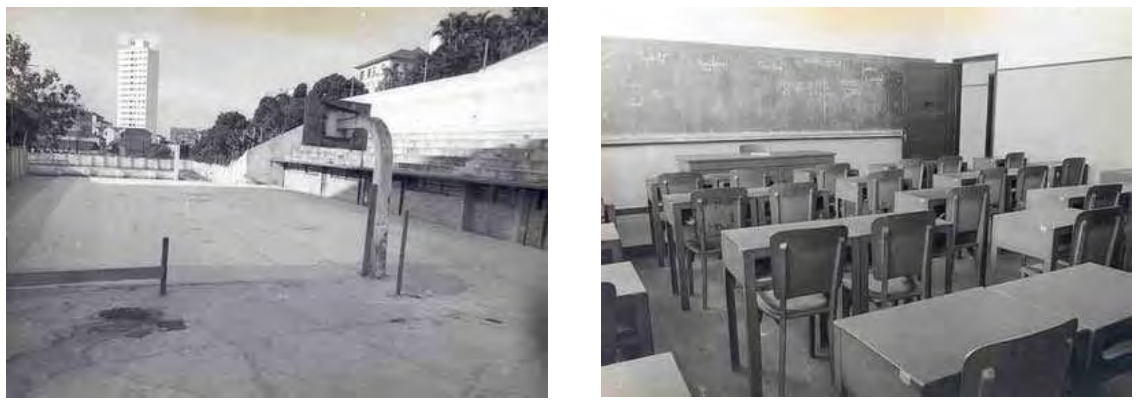

Figuras 24 à 26: Antiga Escola SENAC "Brasílio Machado Neto" e seus novos espaços educacionais: quadra, sala de aula e recreio coberto.

Fonte: Memória Institucional do SENAC-SP.

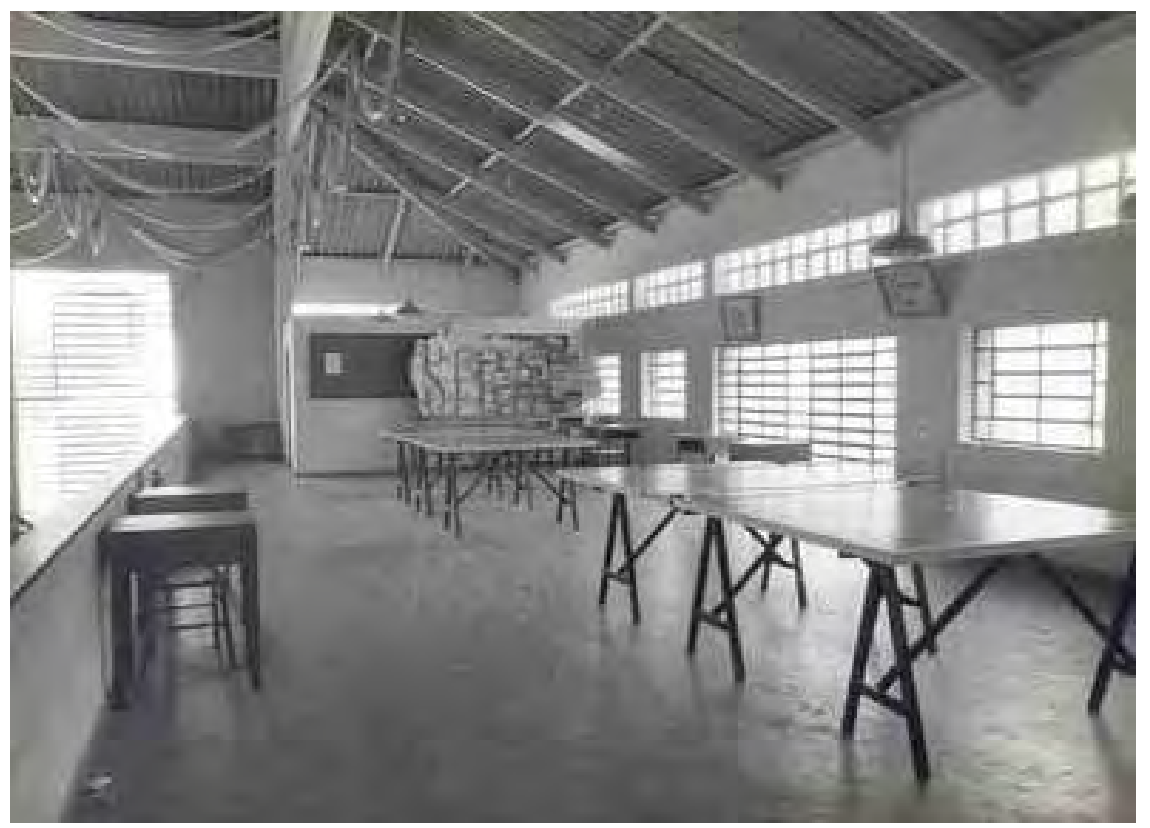


É preciso ressaltar que, nesta segunda fase, a compra de alguns prédios foi essencial para adequar as instalações pedagógicas. Como exemplo, destacam-se as aquisições: em 1950 do prédio da antiga Escola SENAC "Gabriel Dias da Silva", Santos" (ver figura 16), em 1951 do edifício na rua Doutor Vila Nova 228, São Paulo ${ }^{13}$ e, em 1953 de dois andares do Edifício B da rua 24 de Maio, 208, São Paulo ${ }^{14}$.

ventre estas aquisıçoes, o eaıtıcıo adquirıao na rua voutor Vila Nova foi demolido em 1954 devido a problemas estruturais e, segundo relatórios da Memória Institucional do SENAC-SP, em 1957 o Conselho Regional do SENAC de São Paulo aprovou a construção de um novo edifício que instalaria as sedes ${ }^{15}$ da Administração Regional do SENAC-SP e do SESC-SP. O novo prédio, então chamado Edifício Sede, foi elaborado em 1957 por Oswaldo Corrêa Gonçalves juntamente com o Escritório Técnico Ramos de Azevedo, Engenharia Arquitetura e Construções, Severo e Villares SA.

\begin{abstract}
"Foi aprovada a Escritura de Especificações e Estipulação de Condomínio, com atribuição de partes autônomas, cabendo ao SENAC-SP os $2^{\circ}, 3^{\circ}, 4^{\circ}$ e $9^{\circ}$ andares e ao SESC-SP o térreo, $1^{\circ}, 5^{\circ}, 6^{\circ}, 7^{\circ} 8^{\circ}$ e $10^{\circ}$ andares, sendo que parte dessas áreas seriam locadas para utilização da Federação do Comércio do Estado de São Paulo".
\end{abstract}

(SENAC, s.d)

\footnotetext{
12 Este prédio foi posteriormente demolido e no seu lugar foi projetada a nova Escola SESC-SENAC, em 1959, por Oswaldo Corrêa Gonçalves.

13 Este edifício foi construído em 1946, com 6 pavimentos, para funcionamento do Liceu Nacional Rio Branco.O piso inferior era destinado à garagem e servia de acesso à escada e hall de elevador, enquanto os demais pavimentos abrigavam as salas de aula e moradia de alguns membros docentes da Escola. O Edifício foi comprado pelo SENAC para receber a Administração Regional e a Escola SENAC "João Nunes Júnior". Inicialmente foi aprovada a reforma do prédio, porém devido aos problemas estruturais, o mesmo foi demolido em 1954 para em seu lugar ser construído o atual Edifício Sede do SENAC-SP.

${ }^{14}$ Foram adquiridos dois pavimentos do Edifício B da rua 24 de Maio em caráter de urgência para a Administração Regional do SENAC-SP ter um lugar para se abrigar. Quando o Departamento Regional do SENAC-SP transferiu-se para o Edifício Sede, estes dois andares foram reformados e se transformaram na Escola SENAC "Lauro Cardoso de Almeida", inaugurada em 1964. Em 1970, com a mudança desta escola, os andares foram novamente reformados para abrigar a Escola SENAC "Raphael Ferraz", inaugurada em 1970 e desativada em 1984. Atualmente este espaço, novamente remodelado, abriga o Centro de Tecnologia em Administração e Negócios do SENAC, inaugurado oficialmente em 1985.

15 Atualmente o Edifício Sede, também conhecido como Edifício Visconde de Cayru, abriga somente o SENAC-SP, pois na década de 70 a Federação do Comércio e o SESC-SP mudaram-se para edifício adquirido na avenida Paulista.
} 
Figura 27: Prédio comprado em 1951, rua Dr. Vila Nova, 228, São Paulo, com o objetivo de transferir a Administração Regional que estava em prédio alugado, localizado na rua Vieira de Carvalho, 172. 0 edifico da rua Vila Nova foi posteriormente demolido e no seu lugar foi projetado o atual Edifício Sede do SENAC. Antes da demolição, a Administração Regional foi transferida para 0 Edifício B da rua 24 de Maio, 208, SP.

Fonte: Memória Institucional do SENAC-SP.

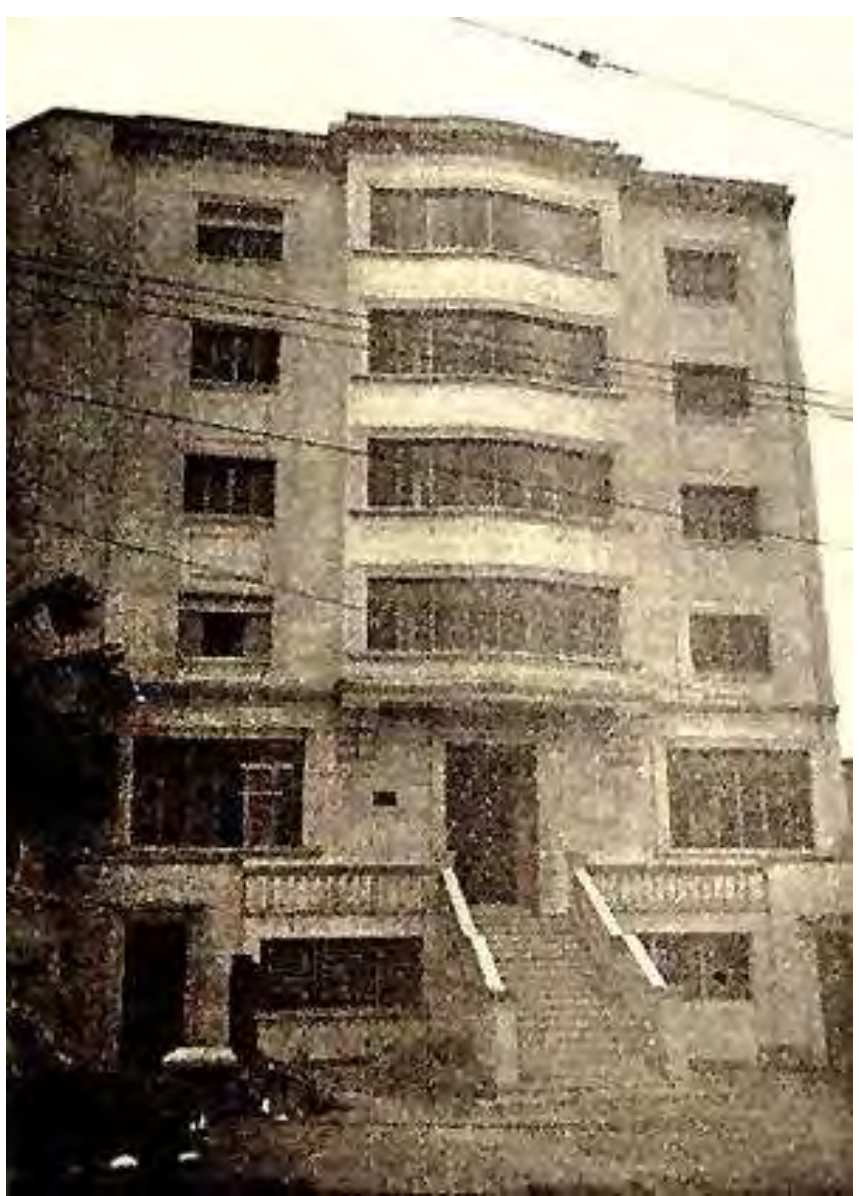


Apesar da preocupação de garantir melhores espaços educacionais e adquirir prédios definitivos, cabe destacar que na década de 1950 muitas atividades do SENAC-SP foram suspensas principalmente em 1953, como as Escolas SENAC que haviam sido instaladas em 1949 (em Araçatuba, Franca, Lins), em 1950 (em Piracicaba e Sorocaba) e em 1951 (em Catanduva). Ainda, de 1952 a 1955 não foi encontrada nenhuma nova instalação, além dos prédios adquiridos já mencionados anteriormente.

Com vistas à execução dos objetivos primordiais do SESC e do SENAC, o padrão da arquitetura foi modificado a partir de 1955, quando foram escolhidas as primeiras cidades ${ }^{16}$ nas quais seriam construídos os prédios próprios no interior do Estado de São Paulo, introduzindo os padrões da arquitetura moderna (ver estas escolas no sub-item 2.2.2). À mudança, para satisfazer condições educativas para o comércio, serviço, cultura e lazer, somou-se a evolução das teorias educativas e a colaboração de arquitetos e técnicos na concepção dos prédios escolares modernos.

\subsection{Arquitetura Moderna para a Escola Integral nas décadas de 1950 e 1960}

Ao avaliar a passagem do primeiro para o segundo período percebe-se a evolução destes serviços e a nítida mudança arquitetônica dos exemplares modernos concebidos a partir da década de 1950.

\footnotetext{
${ }^{16}$ As primeiras cidades escolhidas para a construção dos prédios a serem construídos especificamente para abrigar as escolas SESC-SENAC no interior do Estado foram: Ribeirão Preto, Bauru, Araraquara e Marília (segundo Relatório da Memória Institucional do SENAC).
} 
Juntamente com a referência americana, abordada anteriormente, é importante ressaltar que Baver, em 1950, foi à Europa a pedido de Roberto Mange para conhecer de perto os projetos de arquitetura escolar que estavam sendo desenvolvidos em vários países para atender à demanda educacional do pós-guerra, experiência esta que fundamentou uma mudança radical no conceito de arquitetura escolar do SENAI ${ }^{17}$.

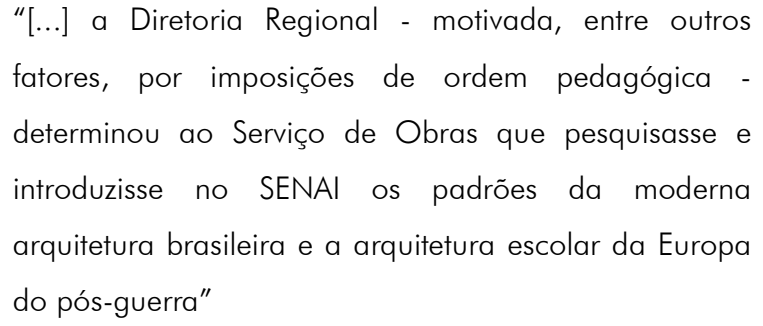

Além das experiências internacionais de uma arquitetura do pós-guerra, no contexto histórico brasileiro cabe lembrar o apoio do Estado Novo à criação do SENAl e da República Nova à criação do SENAC e SESC, e conseqüentemente a esta nova arquitetura realizada a partir dos anos 1950, em uma época em que o Estado tinha muita clareza de objetivos e apoiava a construção de alta qualidade. Neste sentido, a consolidação desta nova arquitetura escolar dos "S" contou, na década de 1950, com edifícios que se tornaram marcos da arquitetura moderna paulista, inovadores do padrão arquitetônico estabelecido pelos primeiros prédios de São Paulo ${ }^{18}$.

Confiante na arquitetura moderna, o educador Anísio Teixeira falou em "presságio de progresso", durante a apresentação de escolas públicas elaboradas pela Comissão do Convênio Escolar de São Paulo, confirmando o papel da arquitetura moderna e sua idéia de nacionalidade. Educação e arquitetura entrelaçadas pela indústria, comércio, serviços públicos, sociais e demais áreas do progresso brasileiro:

\footnotetext{
17 Baver confirmou a importância desta experiência internacional em depoimento ao Projeto Memória SENAI-SP, segundo o livro De homens e máquinas, volume I, p.12, publicado pelo SENAI em 1991.

${ }^{18}$ No Rio de Janeiro os irmãos Roberto foram os introdutores da arquitetura moderna no sistema SENAI. A Escola de Construção Civil do SENAI no Rio de Janeiro e a Escola Industrial do SENAI em Niterói, ambas projetadas pelos irmãos Roberto, foram publicadas na revista Arquitetura e Engenharia n 38 (1956:17) e n 14 (1950:38-41).
} 


\begin{abstract}
"Um pequeno grupo, entretanto, de arquitetos e engenheiros salva o espírito brasileiro, com essa arquitetura moderna que é, antes de tudo, um ato de confiança no país, no gênio de seu povo e no progresso do conhecimento humano.

Todos nós que sonhamos com um estado de entusiasmo para a grande aventura de construir a nacionalidade, temos, nesse movimento da arquitetura brasileira, uma pequena amostra do que poderíamos ser, se um contexto de esclarecimento e de fé se criasse, como se criou entre esses engenheiros, em nossa agricultura, nossa indústria, nosso comércio, nossa educação e nossos serviços públicos e sociais em geral".
\end{abstract}

(TEIXEIRA, in XAVIER, 1987: 207- 208)

Neste capítulo, quanto às fontes documentais, cabe destacar as publicações periódicas da época que apresentam um grande número das escolas modernas "S", uma arquitetura feita por profissionais que disseminaram a arquitetura moderna como parte de um sistema pedagógico também implantado no interior do estado. Assim, os periódicos da época especializados em arquitetura em acabaram constituindo-se em uma das principais fontes documentais em que vem se apoiando a historiografia da arquitetura moderna.

\footnotetext{
"A arquitetura como tema autônomo manisfestou-se nos anos de 1950-1960 com a circulação de quase uma dezena de periódicos especializados - publicações com pauta centrada na arquitetura (ou relacionada com as artes plásticas - uma parceria típica do momento) e não voltada apenas a alguns de seus aspectos, como as tradicionais revistas de decoração, engenharia e construção. Algumas delas tiveram boa duração: Acrópole (seu período foi entre 1950 e 1970), Arquitetura e Engenharia (1946-1965), Habitat (19501965 - dirigida inicialmente por Lina Bo Bardi), Brasil Arquitetura Contemporânea (1953-1957), AD Arquitetura e Decoração (1953-1958), Módulo (19551965 - revista do grupo de Oscar Niemeyer), Brasília (1957-1961 - publicação da estatal que construiu Brasília) e Arquitetura (1961-1969) - entre as mais importantes".
} 
Neste sentido, a maior fonte de informação bibliográfica sobre os exemplares modernos "S" são os periódicos da época, que divulgaram vários projetos arquitetônicos destas modernas escolas, sendo eles: Acrópole, Arquitetura e Engenharia, Arquitetura e Decoração Habitat, e Bem Estar. Vale lembrar ainda o periódico $A B$, publicado em 1972, sobre os projetos do SESC- SENAC. Complementares a estes periódicos, outros artigos publicados pela revista Arquitetura e Urbanismo, também se referenciam a importantes agentes e obras relacionadas a esta pesquisa. São eles: o artigo de Catharine Gati, Oswaldo Corrêa Gonçalves, construindo a profissão, publicado em 1995; o texto de Edite Galote R. Carranza e Ricardo Carranza, Documento Roberto José Goulart Tibau, publicado em 2002; o artigo de Hugo Segawa, Hélio Duarte, moderno, peregrino, educador, publicado em 1998.

Dentro dos periódicos consultados, especificamente sobre 0 SENAI, merece destaque a Acrópole. Assim, a número 197 do ano de 1955 apresenta um texto de Ernest Mange sobre o problema da arquitetura escolar juntamente com exemplares de modernos ginásios estaduais e projetos para o SENAI. Dez anos depois, a número 314 de 1965, lança uma edição especial sobre construções escolares e apresenta os trabalhos realizados individualmente e/ou em equipe pelos arquitetos Hélio Duarte, Lúcio Grinover, Marlene Picarelli e Roberto Tibau, ressaltando-se inúmeros projetos elaborados para atender ao SENAI. E, ainda outras edições divulgaram projetos específicos de cada cidade: número 217, número 241 do ano de 1958 e número 258 do ano de 1960, as quais publicaram respectivamente as escolas de Piracicaba, São Paulo (Têxtil do Brás) e Bauru. Outra revista de suma importância foi a Bem Estar 5/6 ano de 1960, dedicada na íntegra à aprendizagem industrial e à arquitetura de suas escolas, desde a evolução da indústria no Brasil, até os problemas educacionais e o SENAI no âmbito brasileiro. Ainda, a Habitat número 12 no ano de 1953 divulgou as primeiras escolas modernas: Escola Senai Anchieta da Vila Mariana e Técnica Têxtil Francisco Matarazzo do Brás, ambas em São Paulo, e a Escola João Martins Coube, em Bauru. 
Sobre o SESC e o SENAC, três edições da Acrópole merecem destaque: número 220 do ano de 1957, número 244 do ano de 1959 e número 253 do ano de 1959, que publicaram respectivamente as escolas de Ribeirão Preto, Marília, Bauru. Também a Habitat divulgou os projetos de Araraquara e Santos, respectivamente publicados no número 43 do ano de 1957 e no número 59 do ano de 1960. Ainda, a já citada revista $A B$ número 7 do ano de 1972 foi dedicada a cinco escolas projetadas na década de 1950, todas no interior do estado, nas cidades de Ribeirão Preto, Marília, Bauru e São José do Rio Preto. Assim, ao olhar mais atento, o objeto de estudo deste trabalho, a arquitetura moderna das décadas de 1950 e 1960 como parte dos Sistemas "S", desempenhou papel importante no processo de formação de nossa arquitetura, tanto na cidade de São Paulo como nas cidades do interior do estado, merecendo portanto este esforço de compreensão mais aprofundado. 


\subsubsection{SENAI 1952-1968:}

\section{modernas escolas para o ensino da indústria}

Mange, após estudos feitos como diretor do Departamento Regional da $6^{a}$ região do SENAl, salientou no início da década de 1950 a necessidade de se adaptar toda a organização do ensino "às características intrínsecas" do aluno SENAl, "inclusive à arquitetura de seus estabelecimentos de ensino, uma feição eminentemente particular e inconfundível" (BAUER, 1953, p.6). As escolas SENAl até então construídas não satisfaziam às exigências pedagógicas e sóciopedagógicas do típico aluno SENAI. Assim, a partir de 1951, a idéia de construir novas escolas foi reconhecida.

A partir de então, as principais características implantadas nas novas escolas do SENAl foram: crescimento, flexibilidade, atratividade, interligação, sociabilidade, rendimento e economia (GRINOVER, 1965:38). Crescimento da unidade escolar, sempre que possível, com o intuito de oferecer mais vagas; flexibilidade para atender à evolução da indústria nacional com à da pedagogia; atratividade para os alunos de uma escola construída para eles; interligação pelo menos visual entre a área de trabalho prático e a área de desenvolvimento teórico; sociabilidade entre alunos, famílias, docentes, trabalhadores e industriais, através de um ponto de contato e convívio em comum, como a formação de um clube operário; rendimento visando a possibilidade de realizar a educação integral e de tornar o ensino mais eficiente através do entrosamento entre teoria e prática, entre Escola e Indústria; economia no sentido de visibilidade integral, representada por iluminação natural, ventilação direta e um maior encurtamento das distâncias a percorrer de um ponto a outro.

Com o desafio de responder a esta nova filosofia, as escolas adotaram um novo programa construtivo: salas de aula, oficinas, administração, recreio, auditório, sala de reunião, biblioteca, teatro ao ar livre, sede da associação de ex-alunos, campo de esportes e piscina. E, atendendo a esta nova concepção, a aplicação da 
arquitetura moderna visando "o 'clima' do valor estético da arquitetura, com tudo o que a compõe, com o seu colorido e a sua claridade, suas formas simples e harmoniosas, despertando no aluno todos aqueles atributos que possibilitam a formação do homem" (BAUER, 1952:3). Os objetivos atingidos pela arquitetura tanto no tipo de instrução para o aprendizado como nos diversificados ambientes, podem ser, através de 23 exemplos (ver tabela 1), aqui reconhecidos através das escolas com as características próprias da nova arquitetura do SENAI. Edifícios em que "o como ensinar estava intimamente ligado ao como projetar".

Dentro dos princípios que pautaram esta moderna arquitetura do SENAl, é preciso destacar os idealizadores responsáveis pela autoria dos primeiros projetos concebidos na década de 1950: Hélio de Queiroz Duarte (1906-1989), Ernest Robert de Carvalho Mange (1922-2005) e Roberto José Goulart Tibau (1924-2003). Além destes, a partir de 1957 outros nomes surgiram, até o ano de 1968, tais como: Grinover, Ayako Nishikawa, Melanias M. Nagamini, Luiz Carlos Costa e Ariaki Kato.

Com o propósito de ampliar a perspectiva de análise da arquitetura moderna brasileira, são apresentados e analisados os projetos arquitetônicos de 23 escolas SENAI, em ordem cronológica, concebidos de 1952 a 1968. Com o objetivo de pesquisar os projetos de forma preliminar e individualizada, esta etapa obteve dados significantes à tese.

Primeiramente, a idéia de redesenhar parte do projeto original de algumas escolas, atendeu ao objetivo proposto de facilitar a leitura arquitetônica do projeto e representá-lo graficamente através de dados do projeto original, porém também revelou que muito dos projetos executivos originais foram desenhados com uma dimensão e cotados com outra, o que dificultou o trabalho de redesenho. Por outro lado, as pranchas originais, com grandes dimensões, difíceis de serem manuseadas e muitas vezes divididas pelos blocos (unidades da escola) de cada projeto (devido à dimensão das escolas), através do redesenho tornaram-se melhor compreendidos na apresentação do trabalho. Mas, devido à riqueza e expressividade dos desenhos encontrados, os projetos originais foram fotografados no próprio 
arquivo do SENAI e apresentados no trabalho como parte fundamental para sua leitura arquitetônica, auxiliados pelo redesenho quando necessário.

Quanto ao número de escolas encontradas dentro do período de estudo proposto, cabe destacar que: 14 foram projetadas na década de 50 e 9 na década de 60, isto é cerca de 60\% dos projetos foram concebidos da década de 50, enquanto $40 \%$ na década de 60 . A relação das escolas modernas do SENAI também revelou que, dentre os arquitetos e/ou engenheiros, Hélio de Queiroz Duarte foi quem projetou o maior número de escolas, sete escolas SENAI (seis na década de 50 e uma na década de 60), em parceria com Ernest Mange ou com Roberto Tibau. Na década de 60, o arquiteto que projetou mais escolas foi o funcionário do Departamento de Obras do SENAI, Melanias M. Nagamini (uma na década de 50 e cinco na década de 60). Ainda, a relação das escolas revelou a localização da rede SENAI, evidenciando que cerca de $60 \%$ dos edifícios foram projetados na cidade de São Paulo e na grande região metropolitana. Também, cabe destacar os diferentes tipos de oficina para cada cidade ou região de São Paulo, abrangendo várias atividades da indústria, tais como: têxtil, cerâmica, madeira (marcenaria e carpintaria), calçado, mecânica de automóvel, tornearia, construção civil, construção naval, eletricidade e metalurgia. Estes dados podem ser observados pela relação das escolas modernas do SENAI (19521968) apresentada por tabelas, gráficos e pela leitura projetual de cada escola investigada e mostrada a seguir.

Tendo em vista estes projetos arquitetônicos, é nítida a mudança do padrão de arquitetura a partir de 1950 em relação aos primeiros projetos do SENAI. 


\begin{tabular}{|c|c|c|c|c|c|}
\hline \multicolumn{6}{|c|}{ RELAÇÃO DAS ESCOLAS MODERNAS DO SENAI: 1952-1968 } \\
\hline ORDEM & $\begin{array}{c}\text { ANO } \\
\text { DE } \\
\text { PROJETO }\end{array}$ & ESCOLA E CIDADE & AUTORES & $\begin{array}{c}\text { ÁREA APROX. } \\
\text { DO TERRENO } \\
\mathrm{m}^{2}\end{array}$ & $\begin{array}{c}\text { ÁREA APROX. } \\
\text { CONSTRUÍDA } \\
\mathrm{m}^{2}\end{array}$ \\
\hline 1 & 1952 & $\begin{array}{l}\text { Escola Anchieta Vila Mariana, } \\
\text { São Paulo }\end{array}$ & $\begin{array}{l}\text { Hélio de Queiroz Duarte e } \\
\text { Ernest Robert de Carvalho Mange }\end{array}$ & $6.448,00$ & $2.400,00$ \\
\hline 2 & 1952 & $\begin{array}{l}\text { Internato, } \\
\text { Campinas }\end{array}$ & $\begin{array}{l}\text { Hélio de Queiroz Duarte e } \\
\text { Ernest Robert de Carvalho Mange }\end{array}$ & $*$ & * \\
\hline 3 & 1952 & $\begin{array}{l}\text { Têxtil Central do Brás, } \\
\text { São Paulo }\end{array}$ & $\begin{array}{l}\text { Hélio de Queiroz Duarte e } \\
\text { Ernest Robert de Carvalho Mange }\end{array}$ & $5.285,32$ & $12.000,00$ \\
\hline 4 & 1953 & $\begin{array}{l}\text { Escola João Martins Coube, } \\
\text { Bauru }\end{array}$ & Robert José Goulart Tibau & $10.407,50$ & $3.829,00$ \\
\hline 5 & 1954 & Escola de Piracicaba & $\begin{array}{l}\text { Hélio de Queiroz Duarte e } \\
\text { Ernest Robert de Carvalho Mange }\end{array}$ & $7.902,30$ & $2.460,00$ \\
\hline 6 & 1956 & $\begin{array}{l}\text { Pavilhão Social do Brás, } \\
\text { São Paulo }\end{array}$ & $\begin{array}{l}\text { Hélio de Queiroz Duarte e } \\
\text { Ernest Robert de Carvalho Mange }\end{array}$ & * & $1.500,00$ \\
\hline 7 & 1956 & Escola e Internato de Santos & Robert José Goulart Tibau & $9.371,25$ & $6.657,00$ \\
\hline 8 & 1957 & Escola de Tatuapé & Lúcio Grinover & $7.600,00$ & $3.400,00$ \\
\hline 9 & 1957 & Escola de São Caetano do Sul & $\begin{array}{l}\text { Hélio de Queiroz Duarte e } \\
\text { Ernest Robert de Carvalho Mange }\end{array}$ & $5.000,00$ & $4.041,00$ \\
\hline 10 & 1957 & Escola de Jundiaí & $\begin{array}{l}\text { Ayako Nishikawa e } \\
\text { Robert José Goulart Tibau }\end{array}$ & $*$ & $*$ \\
\hline 11 & 1958 & Escola de Sorocaba & Lúcio Grinover & $9.623,00$ & $3.645,00$ \\
\hline 12 & 1958 & $\begin{array}{l}\text { Escola de Santa Bárbara d'Oeste, } \\
\text { Fundação Romi }\end{array}$ & Lúcio Grinover & $*$ & $3.250,00$ \\
\hline 13 & 1959 & $\begin{array}{l}\text { Oficina de calçados Mooca } \\
\text { São Paulo }\end{array}$ & $\begin{array}{l}\text { Melanias M. Nagamini e } \\
\text { Luiz Carlos Costa }\end{array}$ & $5.150,00$ & 836,00 \\
\hline 14 & 1959 & Escola de Mogi das Cruzes & $\begin{array}{l}\text { Lúcio Grinover, Luiz Carlos Costa e } \\
\text { Ayako Nishikawa }\end{array}$ & $8.400,00$ & $*$ \\
\hline 15 & 1960 & $\begin{array}{l}\text { Escola da Mooca, } \\
\text { São Paulo }\end{array}$ & Melanias M. Nagamini & $20.315,00$ & $8.800,00$ \\
\hline 16 & 1960 & Escola de Ribeirão Preto & $\begin{array}{l}\text { Ernest Robert de Carvalho Mange e } \\
\text { Ariaki Kato }\end{array}$ & * & * \\
\hline 17 & 1961 & Escola de São Bernardo & Lúcio Grinover & * & $3.600,00$ \\
\hline 18 & 1961 & Escola de São Carlos & $\begin{array}{l}\text { Ernest Robert de Carvalho Mange e } \\
\text { Ariaki Kato }\end{array}$ & $8.965,00$ & $2.135,50$ \\
\hline 19 & 1964 & $\begin{array}{l}\text { Escola Conde José Vicente de } \\
\text { Azevedo, Alto do Ipiranga, São } \\
\text { Paulo }\end{array}$ & Melanias M. Nagamini & $21.424,00$ & $13.278,49$ \\
\hline 20 & 1964 & Escola de Osasco & Melanias M. Nagamini & $18.000,00$ & $7.248,27$ \\
\hline 21 & 1967 & Escola de Guarulhos & Melanias M. Nagamini & $14.788,00$ & $6.425,00$ \\
\hline 22 & 1968 & $\begin{array}{l}\text { Escola do Bom Retiro, } \\
\text { São Paulo }\end{array}$ & $\begin{array}{l}\text { Hélio de Queiroz Duarte e } \\
\text { Ernest Robert de Carvalho Mange }\end{array}$ & $*$ & $*$ \\
\hline 23 & 1968 & Escola de Limeira & Melanias M. Nagamini & $12.820,00$ & $5.089,78$ \\
\hline
\end{tabular}

Tabela 1: Relação das escolas modernas do SENAI:1952-1968. Os dados assinalados ( *) não foram encontrados nos documentos e projetos pesquisados.

Fonte: Autora 


\begin{tabular}{|c|c|c|c|c|}
\hline \multicolumn{5}{|c|}{ RELAÇÃO DAS ESCOLAS MODERNAS DO SENAI: 1952-1968 } \\
\hline ORDEM & $\begin{array}{c}\text { ANO } \\
\text { DE } \\
\text { PROJETO }\end{array}$ & ESCOLA E CIDADE & $\begin{array}{c}N^{\circ} \mathrm{DE} \\
\mathrm{DE} \\
\text { BLOCOS }\end{array}$ & $\begin{array}{c}\text { TIPO DE OFICINA } \\
\text { DA } \\
\text { ÉPOCA }\end{array}$ \\
\hline 1 & 1952 & $\begin{array}{l}\text { Escola Anchieta Vila Mariana, } \\
\text { São Paulo }\end{array}$ & 3 & $\begin{array}{l}\text { carpintaria, marcenaria, mecânica de } \\
\text { autos, torneiro mecânico e ajustador }\end{array}$ \\
\hline 2 & 1952 & $\begin{array}{l}\text { Internato, } \\
\text { Campinas } \\
\end{array}$ & 3 & (dormitório para aprendizes industriais) \\
\hline 3 & 1952 & $\begin{array}{l}\text { Têxtil Central do Brás, } \\
\text { São Paulo }\end{array}$ & 3 & têxtil \\
\hline 4 & 1953 & $\begin{array}{l}\text { Escola João Martins Coube, } \\
\text { Bauru }\end{array}$ & 2 & $\begin{array}{l}\text { metalurgia, madeira, motores e } \\
\text { construção civil }\end{array}$ \\
\hline 5 & 1954 & Escola de Piracicaba & 3 & $\begin{array}{l}\text { mecânica geral, elétrica } \\
\text { torneiro mecânico e ajustador }\end{array}$ \\
\hline 6 & 1956 & $\begin{array}{l}\text { Pavilhão Social do Brás, } \\
\text { São Paulo }\end{array}$ & 1 & (pavilhão social para os aprendizes industriais) \\
\hline 7 & 1956 & Escola e Internato de Santos & 3 & construção naval \\
\hline 8 & 1957 & Escola de Tatuapé & 3 & construção civil \\
\hline 9 & 1957 & Escola de São Caetano do Sul & 1 & cerâmica industrial \\
\hline 10 & 1957 & Escola de Jundiaí & 2 & $\begin{array}{l}\text { metalurgia, madeira, elétrica } \\
\text { têxtil e cerâmica }\end{array}$ \\
\hline 11 & 1958 & Escola de Sorocaba & 1 & $\begin{array}{l}\text { mecânica de autos, mecânica geral, } \\
\text { elétrica, têxtil e moveleira }\end{array}$ \\
\hline 12 & 1958 & $\begin{array}{l}\text { Escola de Santa Bárbara d'Oeste, } \\
\text { Fundação Romi }\end{array}$ & 4 & metalurgia, elétrica \\
\hline 13 & 1959 & $\begin{array}{l}\text { Oficina de calçados Mooca } \\
\text { São Paulo }\end{array}$ & 1 & produção de calçados \\
\hline 14 & 1959 & Escola de Mogi das Cruzes & 3 & mecânica geral, metalurgia, elétrica \\
\hline 15 & 1960 & $\begin{array}{l}\text { Escola da Mooca, } \\
\text { São Paulo }\end{array}$ & 3 & gráfica, celulose e papel \\
\hline 16 & 1960 & Escola de Ribeirão Preto & 3 & $\begin{array}{l}\text { carpintaria, funilaria, caldeiraria, mecânico } \\
\text { elétrico, torneiro mecânico e ajustador }\end{array}$ \\
\hline 17 & 1961 & Escola de São Bernardo & 3 & metalurgia e mecânica \\
\hline 18 & 1961 & Escola de São Carlos & 3 & $\begin{array}{l}\text { montagem, mecânica de autos, } \\
\text { torneiro mecânico e ajustador }\end{array}$ \\
\hline 19 & 1964 & $\begin{array}{l}\text { Escola Conde José Vicente de Azevedo, } \\
\text { Alto do Ipiranga, São Paulo }\end{array}$ & 5 & $\begin{array}{l}\text { mecânica de autos, metalurgia, } \\
\text { elétrica }\end{array}$ \\
\hline 20 & 1964 & Escola de Osasco & 4 & $\begin{array}{l}\text { metalurgia, elétrica, mecânica de autos, } \\
\text { construção civil }\end{array}$ \\
\hline 21 & 1967 & Escola de Guarulhos & 3 & $\begin{array}{l}\text { metalurgia, elétrica, mecânica de autos, } \\
\text { mecânica geral }\end{array}$ \\
\hline 22 & 1968 & $\begin{array}{l}\text { Escola do Bom Retiro, } \\
\text { São Paulo }\end{array}$ & 7 & têxtil e elétrica \\
\hline 23 & 1968 & Escola de Limeira & 3 & $\begin{array}{l}\text { mecânica de autos, mecânica de } \\
\text { usinagem e elétrica }\end{array}$ \\
\hline
\end{tabular}

Tabela 2: Relação das escolas modernas do SENAI: 1952-1968. Observar o número de blocos e o tipo de oficina em cada escola.

Fonte: Autora 


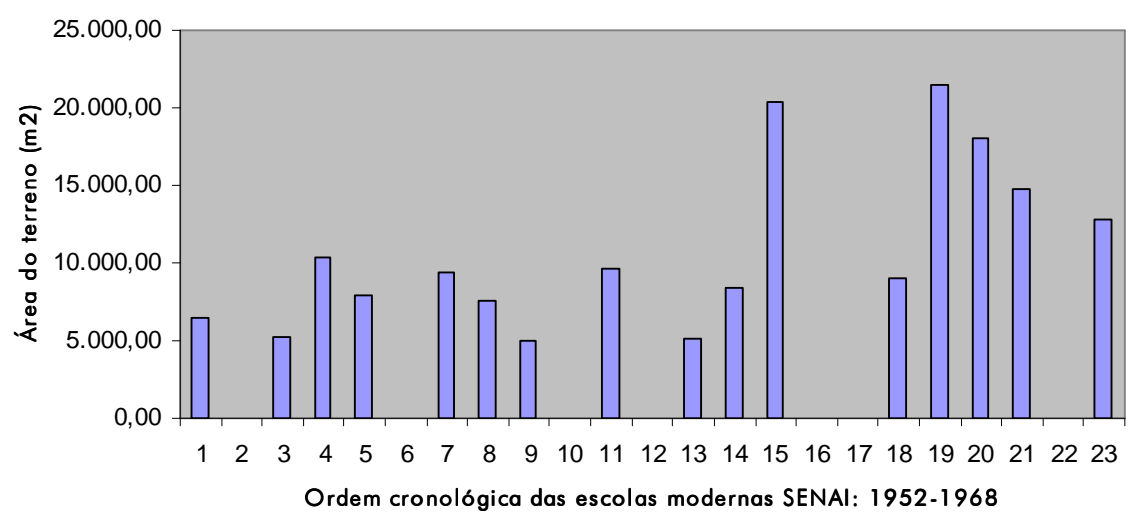

Gráfico 1: Observar as escolas SENAI (1952-1968) em relação à dimensão dos lotes. Fonte: Autora

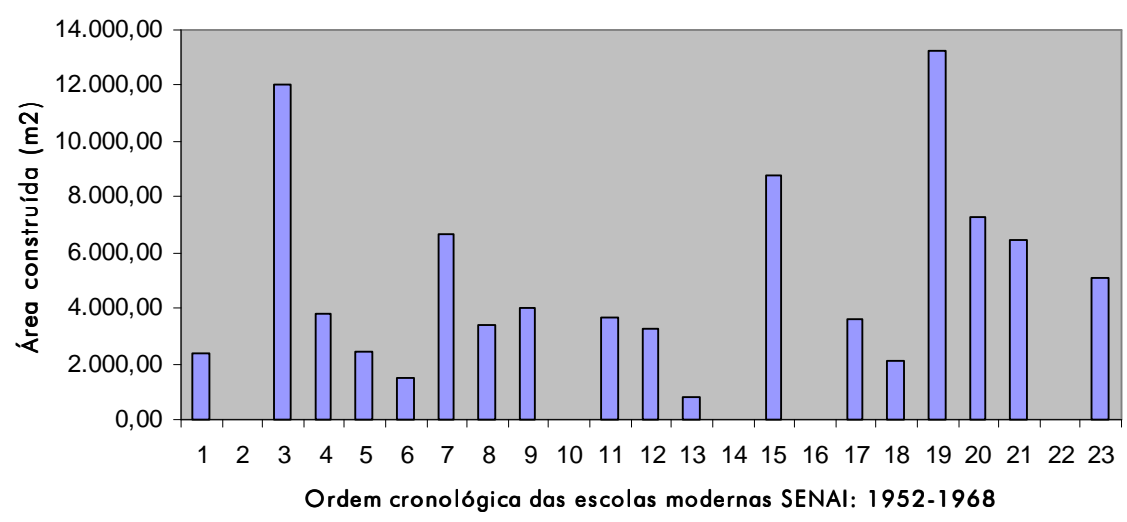

Gráfico 2: Observar as escolas SENAI (1952-1968) em relação à área construída. Fonte: Autora 


\section{PROJETO 1}

\section{Escola Senai Anchieta, Vila Mariana, São Paulo, 1952}

Projetada por Hélio de Queiroz Duarte e Ernest Robert de Carvalho Mange, a Escola SENAI Anchieta', na Vila Mariana, em São Paulo, foi a primeira escola a ser construída de acordo com a nova concepção (SENAI, 1992:160). Localizada à rua Tangará esquina com a rua Gandavo e implantada numa quadra de $6.448,00 \mathrm{~m}^{2}$, a escola foi composta inicialmente por três blocos caracterizados pela oficina, salas de aulas e pavilhão social, com aproximadamente 2.400,00m2 de área construída.

A escola teve seu programa construtivo composto de: oficinas, sete salas de aulas teóricas e uma de curso vocacional, administração e complementos, serviços de assistência social (médico-dentário), recreio coberto com refeitório e cozinha, auditório e biblioteca, campo de esportes e piscina.

A planta do projeto original não foi encontrada, porém foram encontradas diversas pranchas do projeto original, não executivo, que revelaram o ano de sua concepção, a implantação geral do projeto, cortes e elevações. A planta foi obtida através de publicações nos periódicos da época (figuras 3 a 5). Ainda, para facilitar a leitura arquitetônica do projeto e representá-lo graficamente através de significativos dados do projeto original, foram graficamente

Figura 1: Observar os dados do selo do projeto da Escola Senai Anchieta, Vila Mariana, São Paulo,concebido em fevereiro de 1952, com autoria de Hélio Duarte e Ernest Mange. Fonte: Foto Ferraz, arquivo SENAI

Figura 2: Planta de situação da Escola Senai Anchieta, Vila Mariana, São Paulo, 1952 Fonte: Foto Ferraz, arquivo SENAI redesenhados a implantação, o corte e a elevação (figuras 6 a 8).
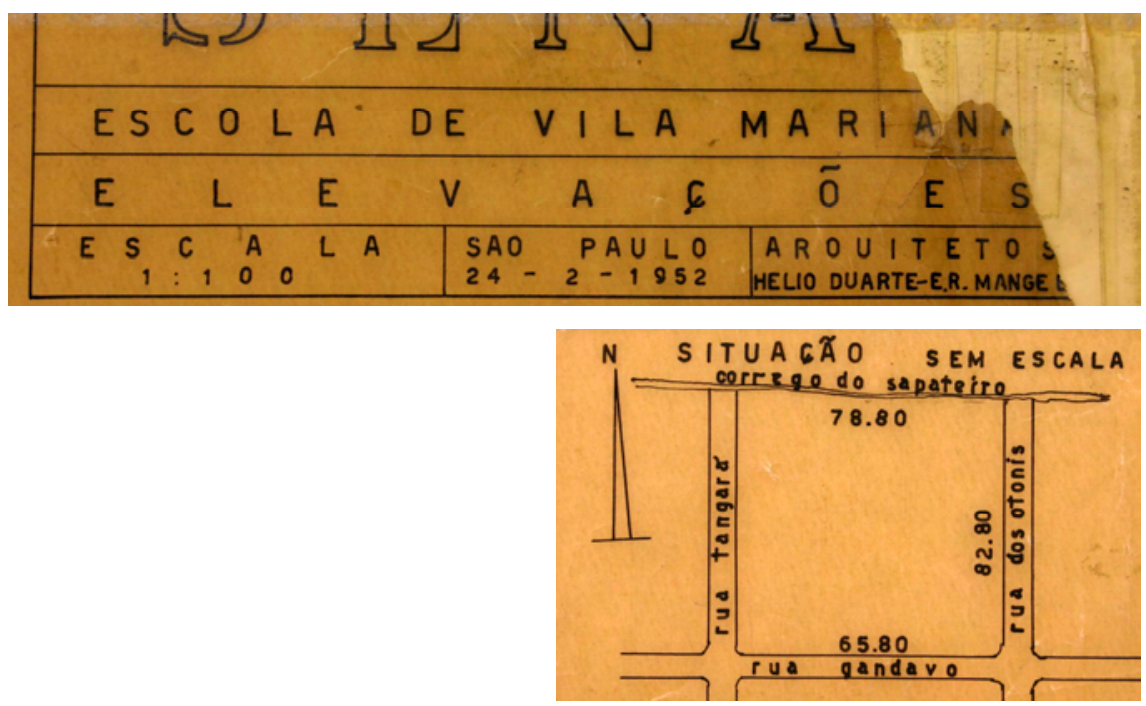

A Escola SENAI Anchieta foi publicada pelas revistas Acrópole n 197 (1955: 220 222), Bem Estar n 5/6 (1960:13) e Habitat nº 12 (1953:18). 


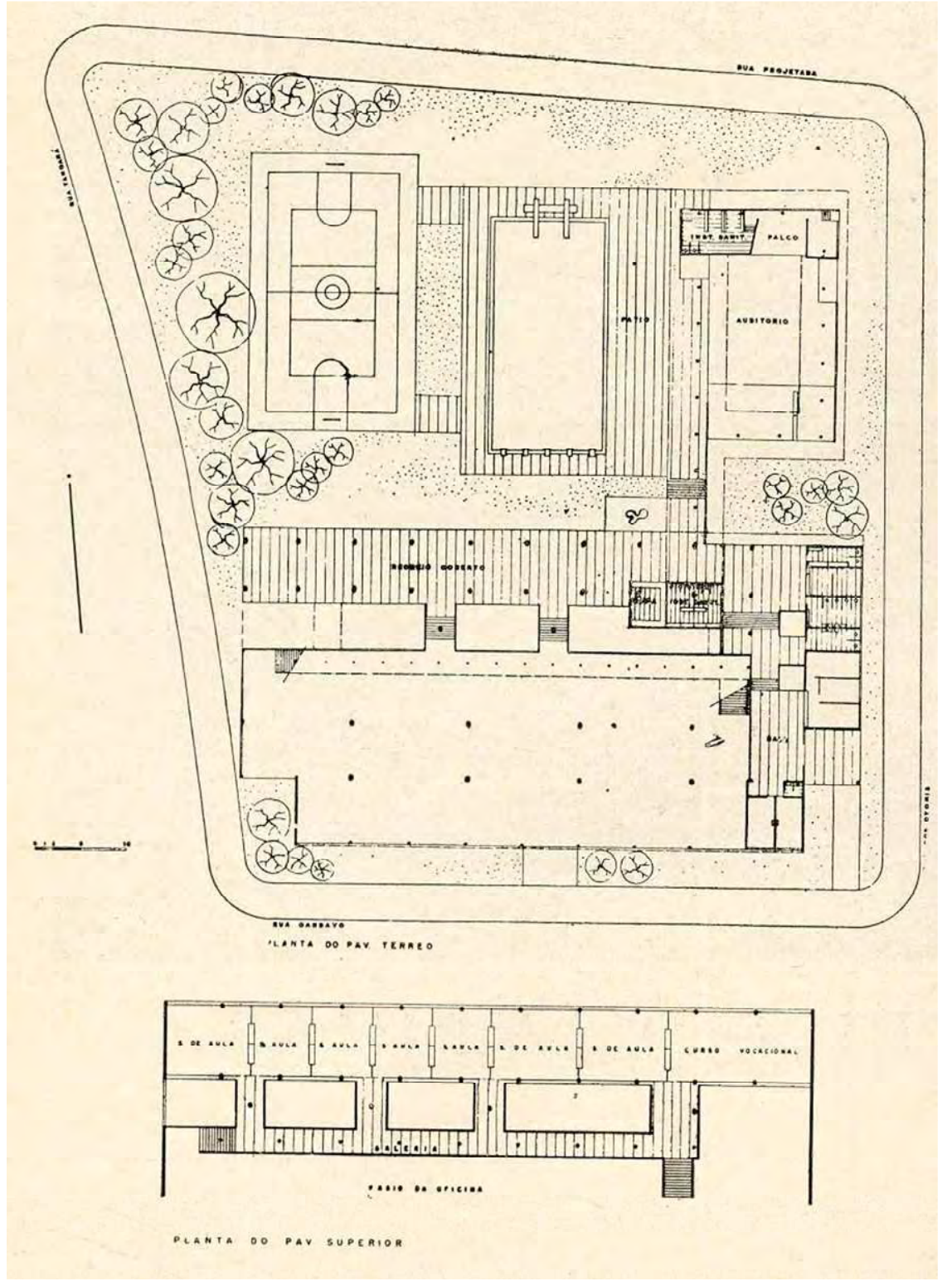

Figura 3: Plantas da Escola Senai Anchieta, Vila Mariana, São Paulo, 1952. O projeto original das plantas não foi encontrado no arquivo do SENAI. Fonte: Bem Estar n ${ }^{\circ}$ 5/6 (1960:13)

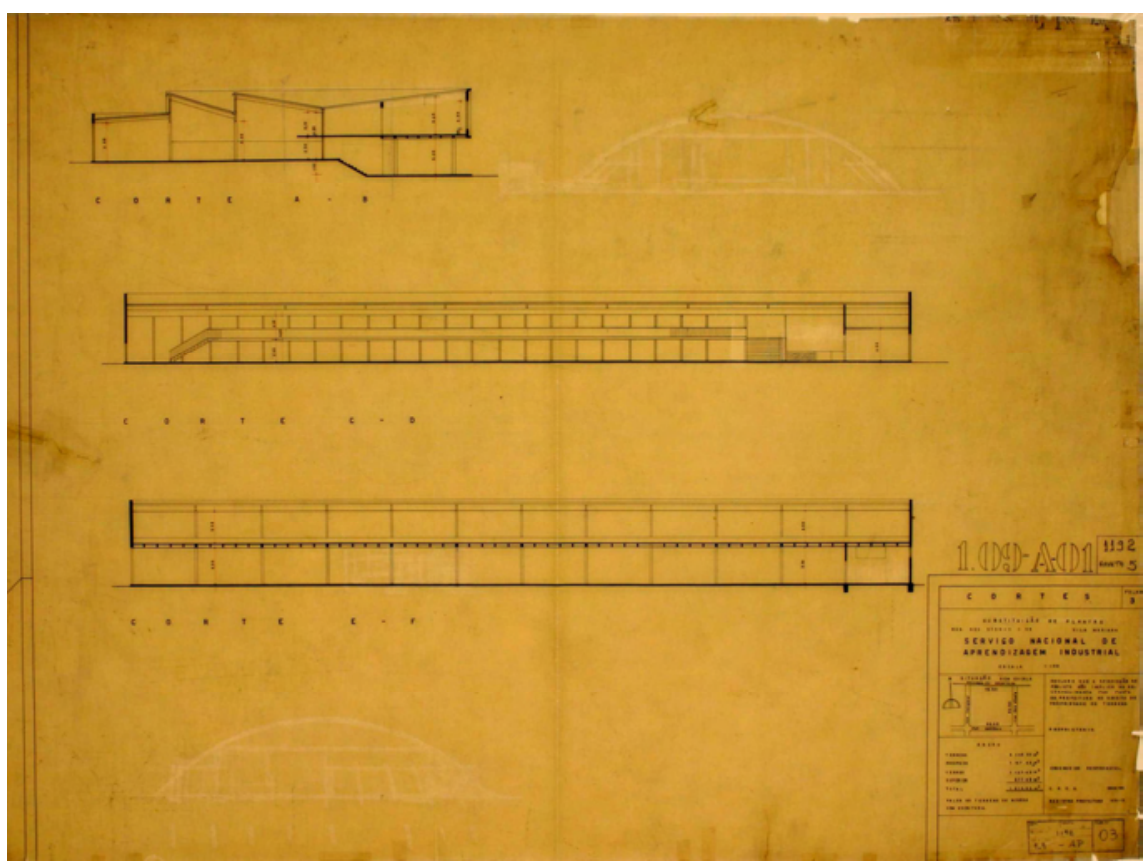

Figura 4: Prancha original dos Cortes da Escola Senai Anchieta, Vila Mariana, São Paulo, 1952. Cortes AB, CD e EF. Esta folha foi alterada, evidenciando que o Pavilhão Social foi "raspado" do papel vegetal. Originalmente o pavilhão foi projetado com cobertura em abóbada, no local da atual quadra de esportes. Fonte: Foto Ferraz, arquivo SENAI 
Figura 5: Prancha original das Elevações da Escola Senai

Anchieta, Vila Mariana, São Paulo, 1952. Elevações principal, lateral direita e esquerda.

Fonte: Foto Ferraz, arquivo SENAI

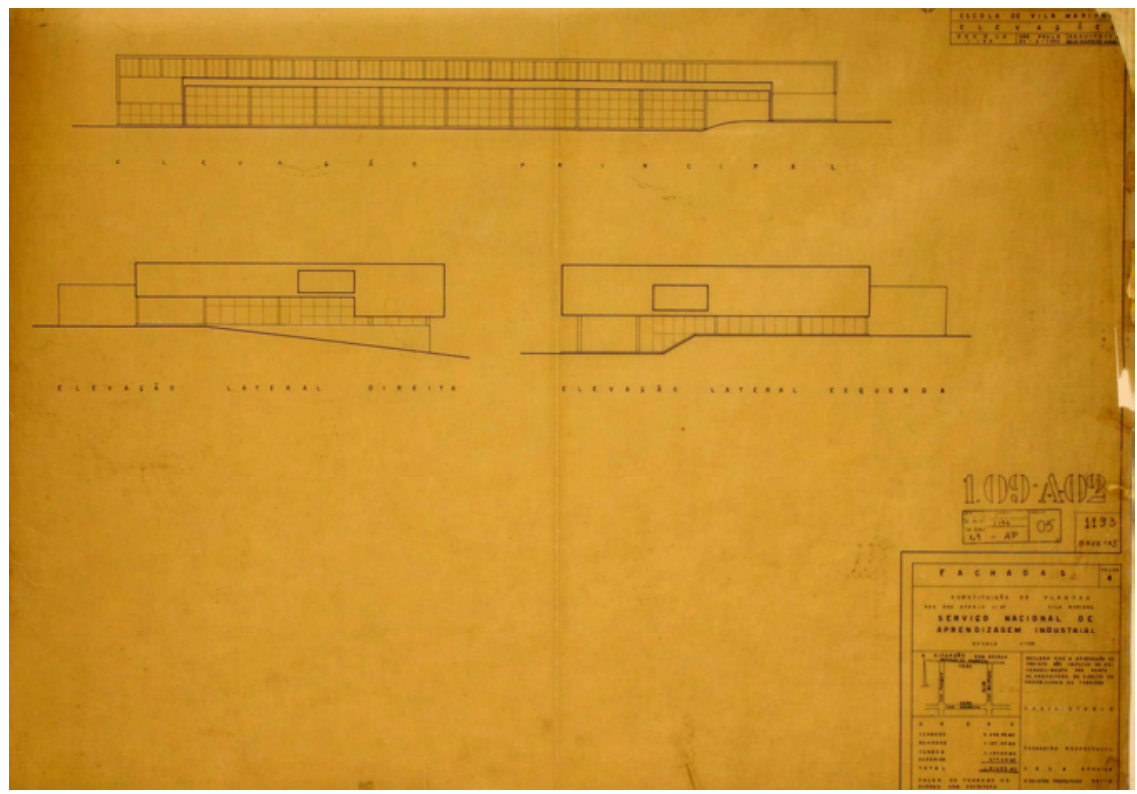

Figura 6: Redesenho da implantação geral.

Fonte: Ferraz, 2005

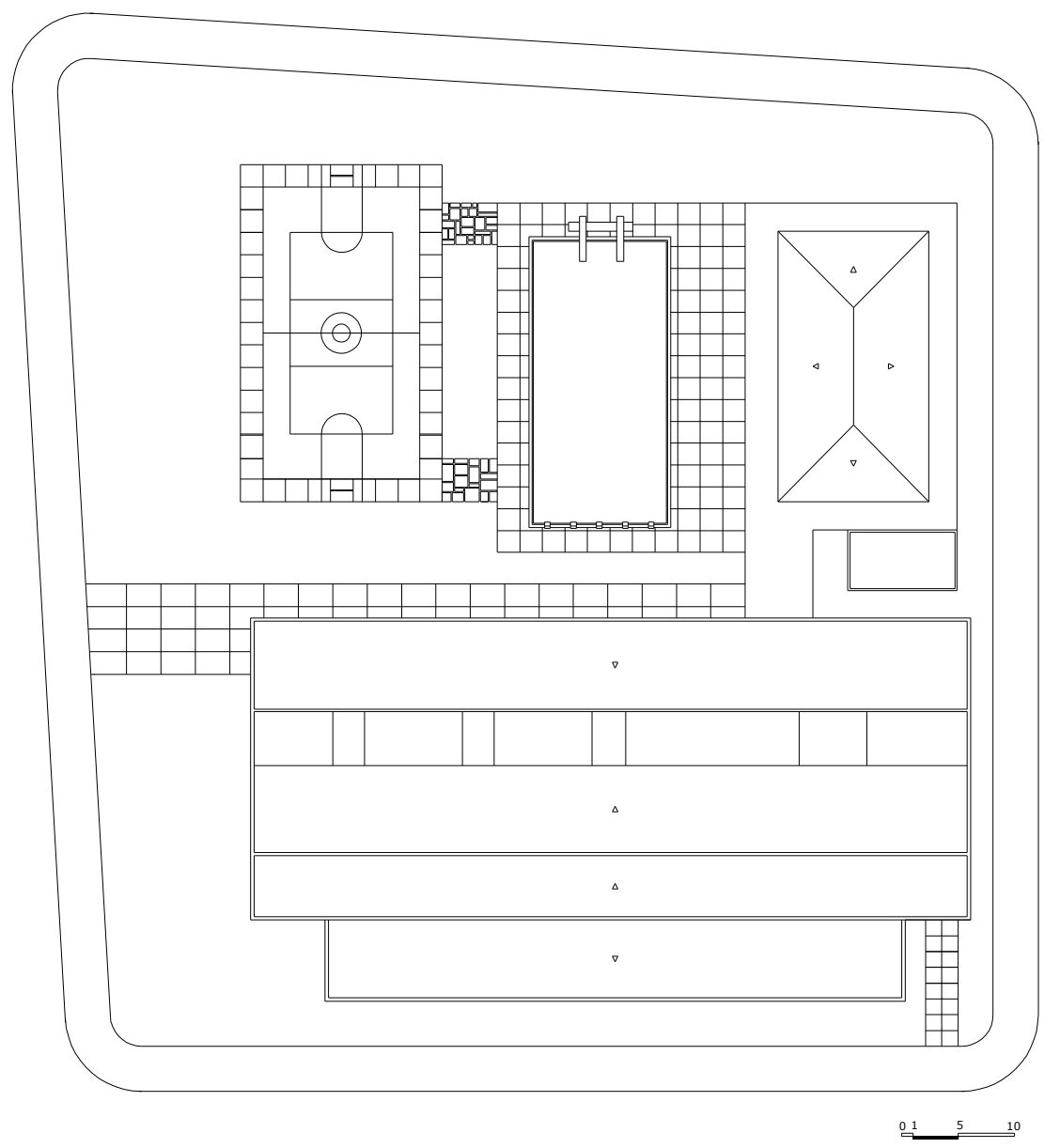




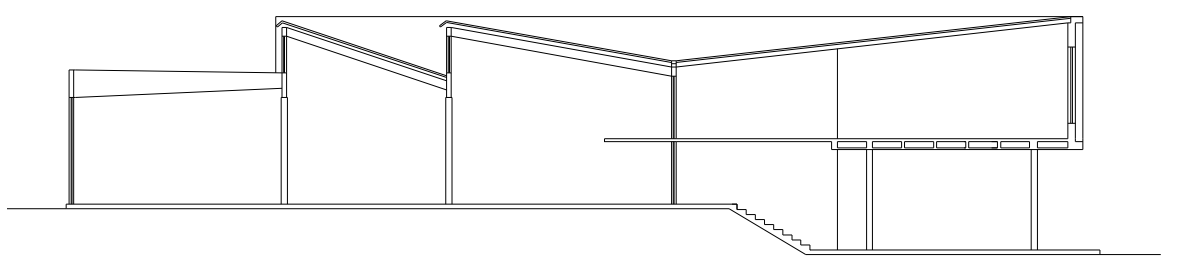

Figura 7: Redesenho do corte transversal dos blocos da oficina e salas de aula. Fonte: Ferraz, 2005

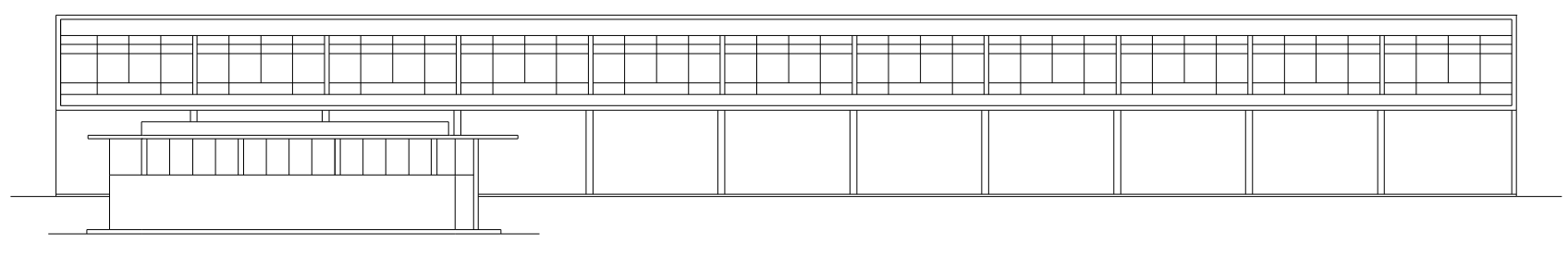

01 5 10

O Pavilhão Social, inicialmente projetado no local da quadra

Figura 8: Redesenho da elevação norte (rua dos Otonis). Fonte: Ferraz, 2005 de esportes, havia sido projetado com cobertura em abóbada conforme revela o projeto original e maquete publicada em periódico (Habitat n 12, 1953, p.18). O Pavilhão teve projeto e implantação alterados por seus próprios autores e o bloco definitivo do Pavilhão Social foi projetado ao longo da rua dos Otonis, com formato retangular conforme mostram as pranchas seguintes do projeto (figuras 6 à 11).

Figura 9: Planta de Situação da Escola Senai Anchieta com Pavilhão Social definitivo. Locação, cortes e elevações. Fonte: Foto Ferraz, arquivo SENAI

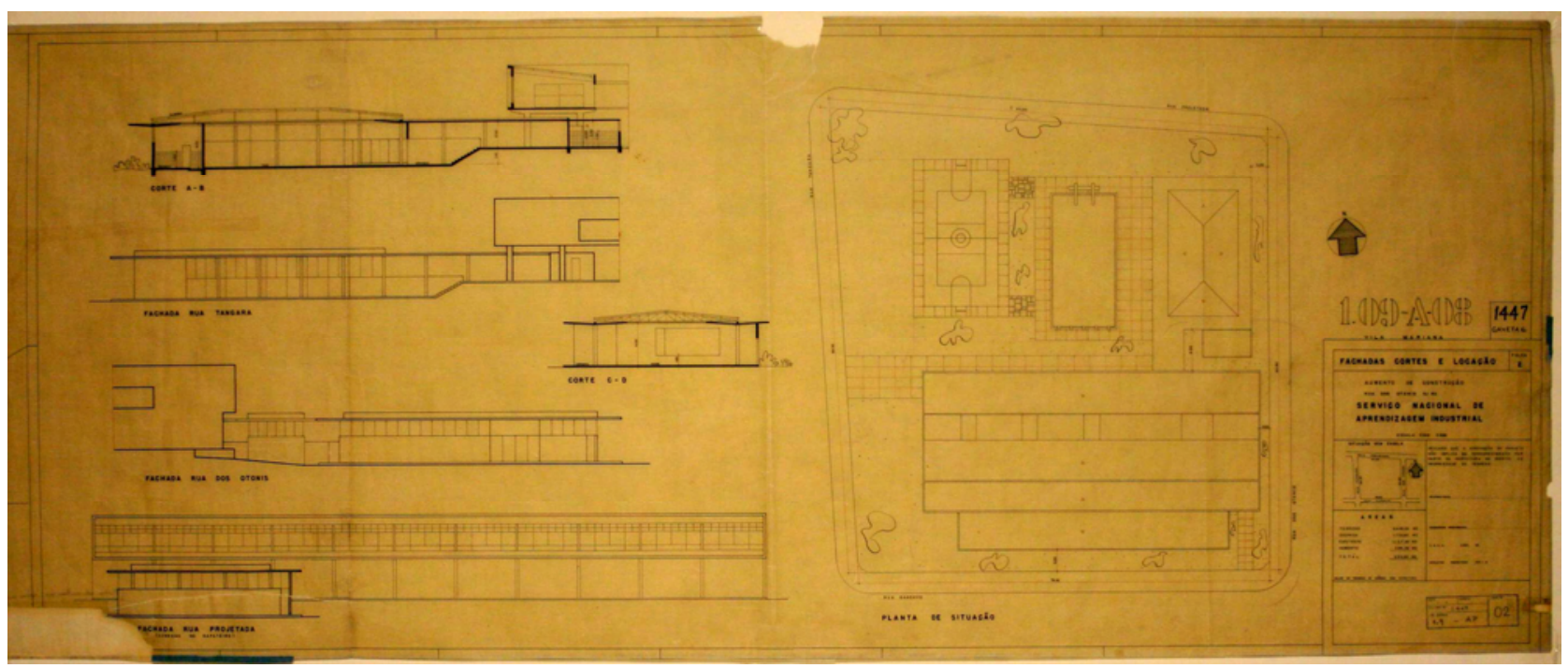




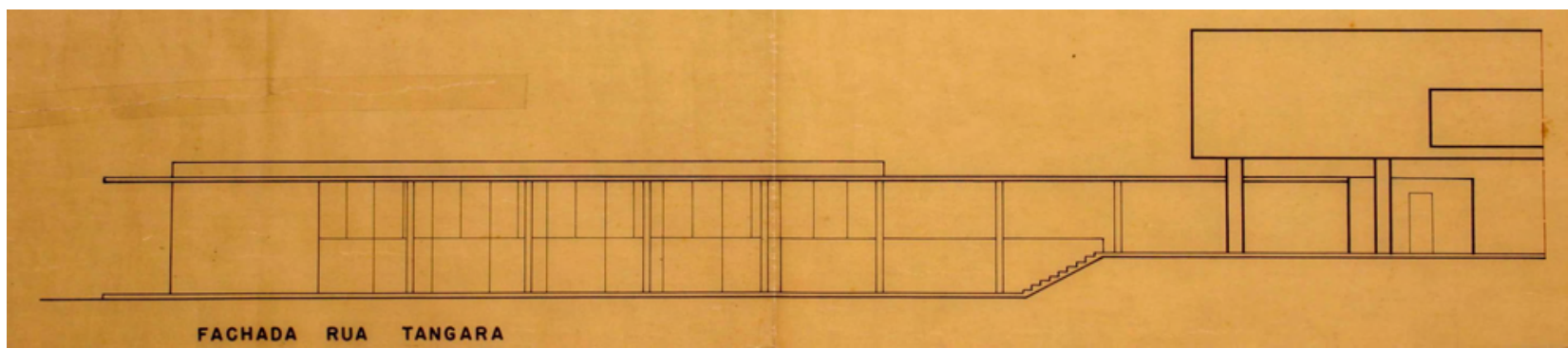

Figura 10: Elevação rua Tangará com Pavilhão Social definitivo.

Fonte: Foto Ferraz, arquivo SENAI

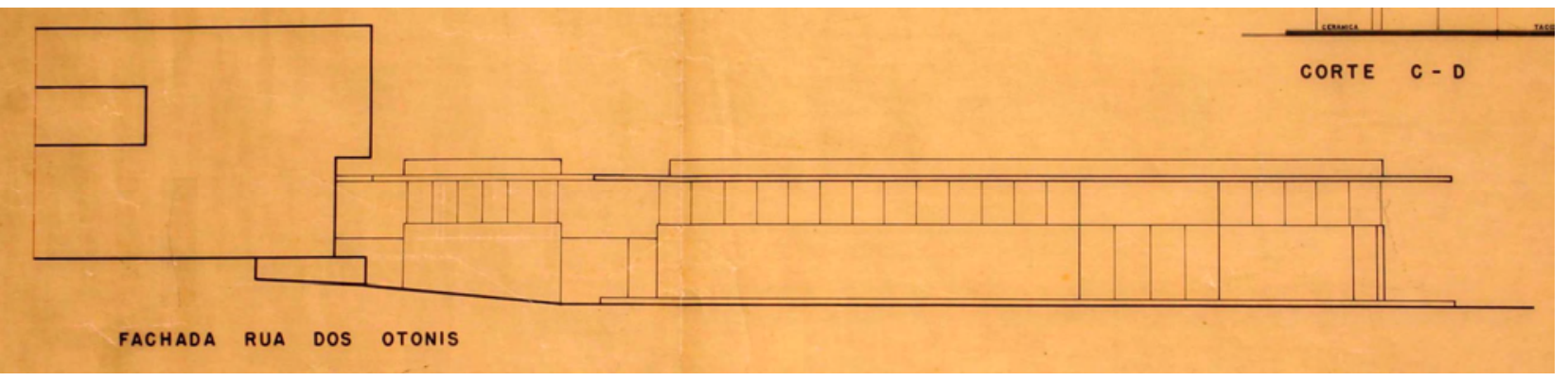

Figura 11: Elevação rua dos Otonis com Pavilhão Social definitivo.

Fonte: Foto Ferraz, arquivo SENAI

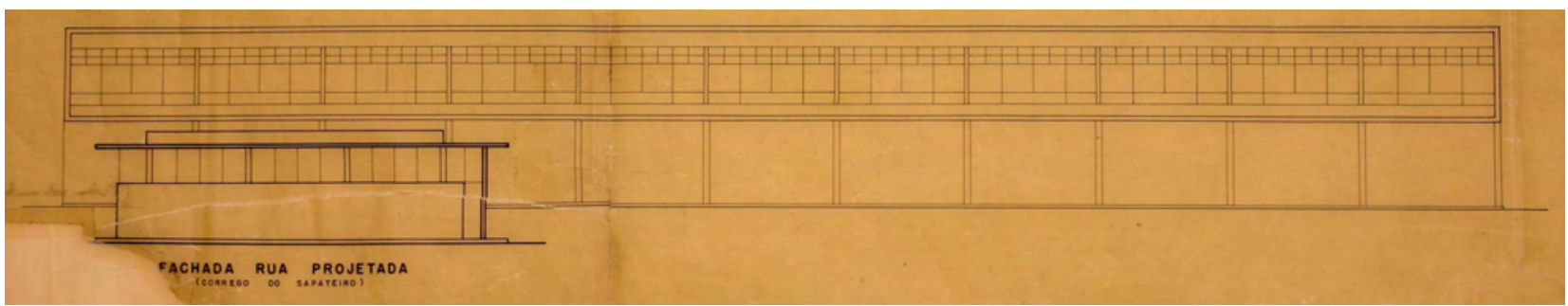

Figura 12: Elevação rua projetada, antigo Córrego do Sapateiro, com Pavilhão Social definitivo. Fonte: Foto Ferraz, arquivo SENAI

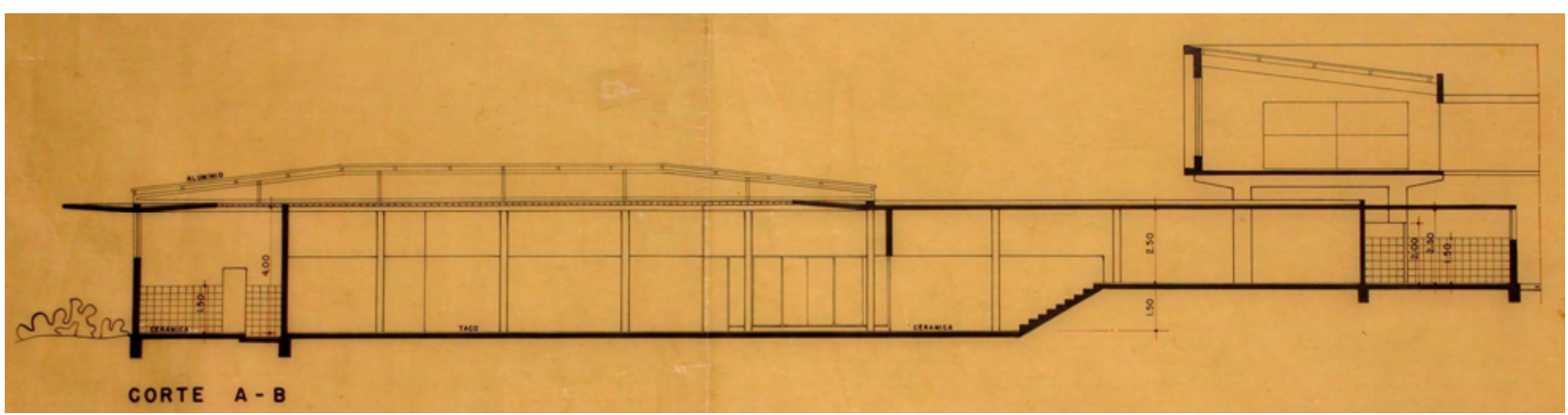

Figura 13: Corte dos blocos do pavilhão social definitivo e sala de aula.

Fonte: Foto Ferraz, arquivo SENAI

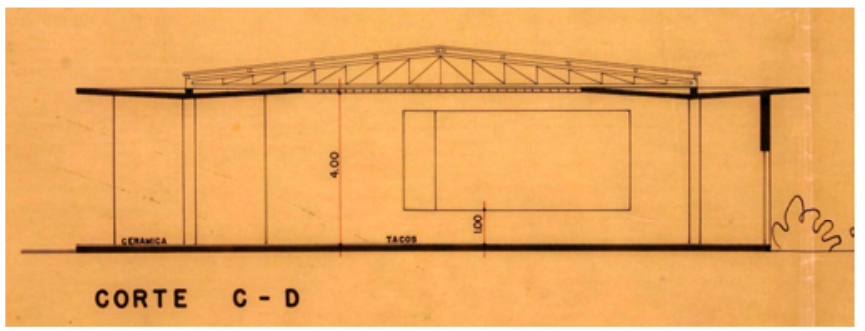

Figura 14: Corte do bloco do pavilhão social definitivo.

Fonte: Foto Ferraz, arquivo SENAI 
A oficina foi projetada num edifício horizontal implantado no nível mais alto do terreno, ao longo da rua Gandavo. Com grande área livre marcada apenas pela estrutura dos pilotis e pé-direito duplo, a oficina recebeu iluminação lateral e zenital voltada para a face sul, permitindo um melhor conforto térmico e adequada distribuição de luz. Na extremidade do mesmo bloco, também foi projetada a parte administrativa - diretoria, secretaria, recepção e sanitários. A interligação e o rendimento da prática com a teoria foram estabelecidos através de uma galeria que possibilitava tanto a visão das oficinas como $\mathrm{O}$ acesso às salas de aula (situadas no pavimento superior do recreio), respeitando as condições físicas básicas de isolamento e ao mesmo tempo fundindo os dois setores num só. Sob os corredores da galeria, foi projetada uma área ajardinada no desnível de piso entre um bloco e outro, proporcionando a integração das áreas verdes ao projeto.
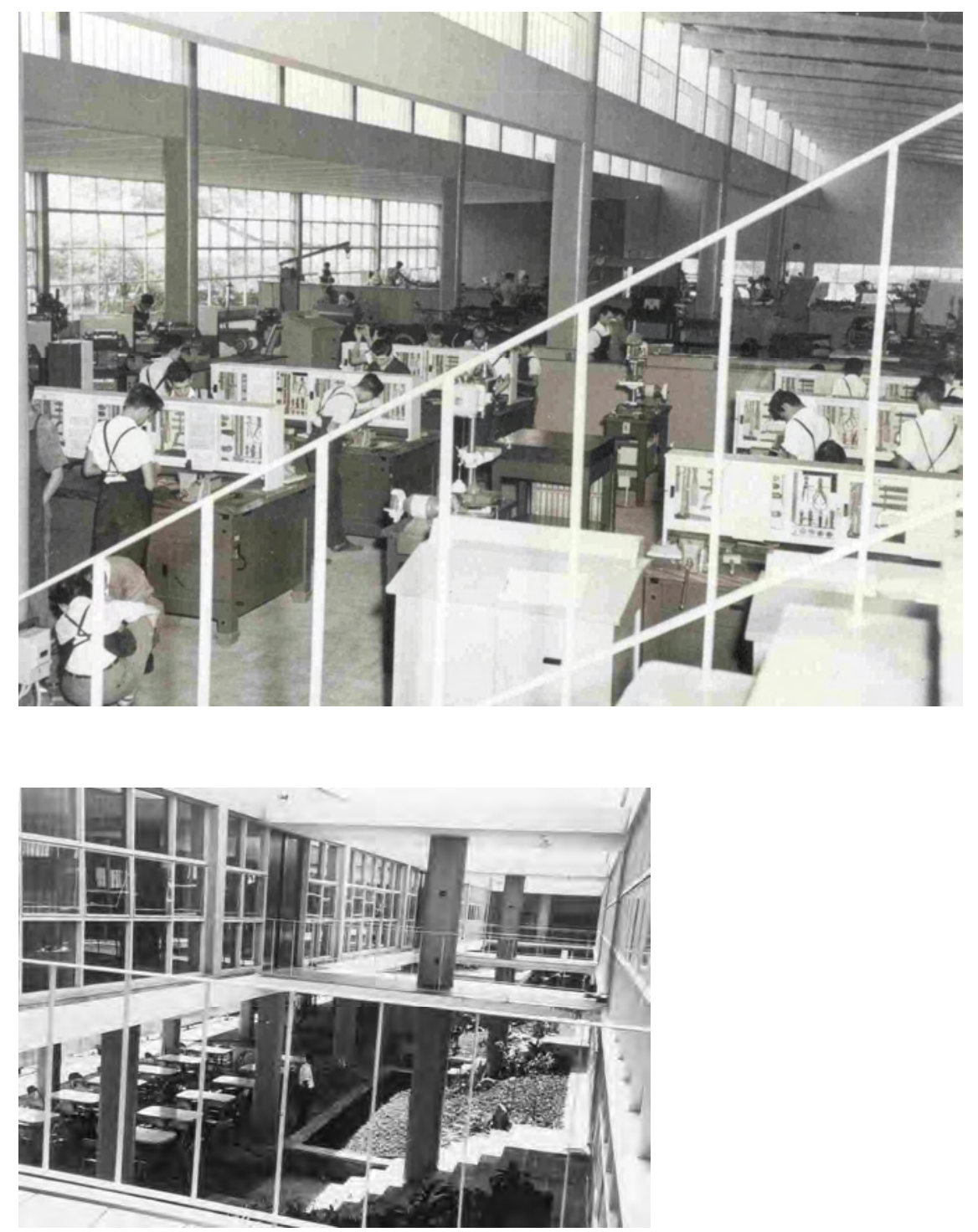

Figura 15: Foto interna da oficina. Escola SENAl Anchieta, Vila Mariana, 1954 Fonte: Arquivo Escola Anchieta
Figura 16: Galeria de ligação entre salas e oficinas sobre área ajardinada, Escola SENAI Anchieta, Vila Mariana, 1954 Fonte: Arquivo Escola Anchieta 


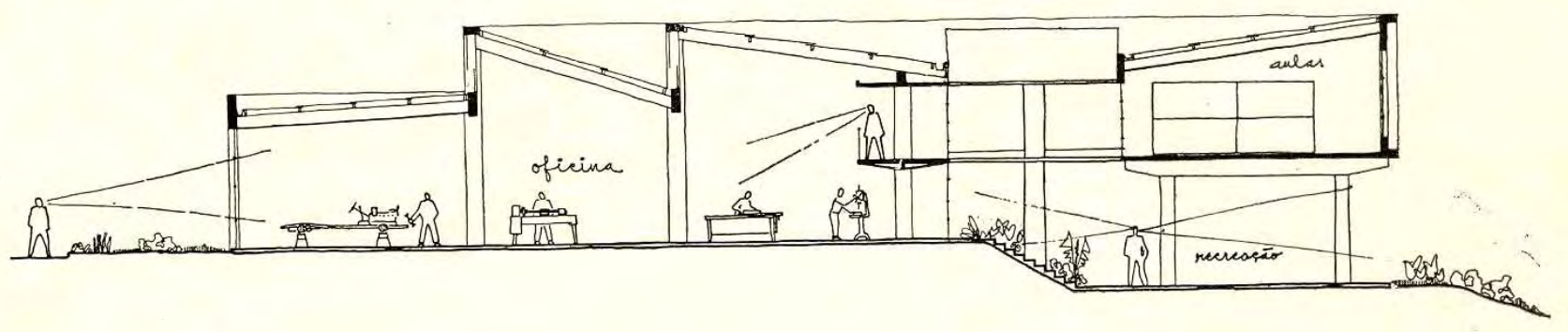

Figura 17: Corte esquemático do bloco da oficina e do bloco das salas de aula e recreio coberto. Observar a visibilidade da

No segundo bloco paralelo à oficina foram projetadas as oficina obtida pela circulação das salas de aula.

Fonte: Bem Estar n ${ }^{\circ}$ 5/6 (1960:13)

Figura 18: Visibilidade das salas aulas. Face norte observada da área esportiva. Escola SENAI Anchieta, Vila Mariana, 1954 Fonte: Arquivo Escola Anchieta

Figura 19: Recreio coberto. Observar a ligação com o bloco da oficina, lado direito da foto. Escola SENAI Anchieta, Vila Mariana, 1954

Fonte: Arquivo Escola Anchieta

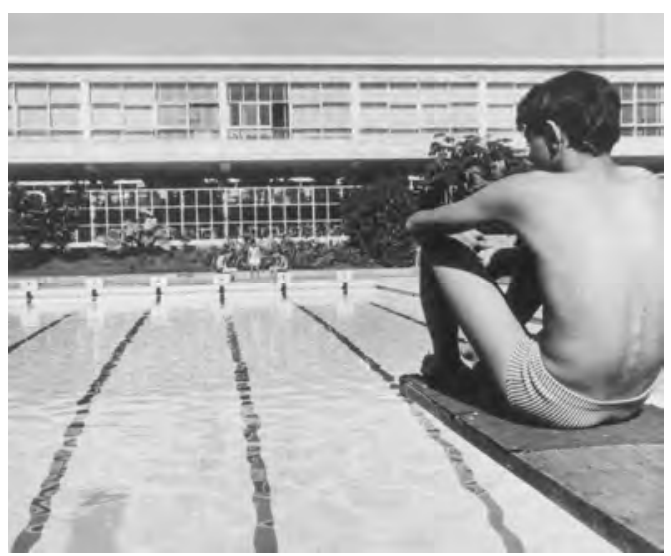
salas de aula e a sala vocacional no segundo pavimento. As oito salas receberam iluminação bilateral norte-sul através de grandes vãos envidraçados, permitindo ampla visibilidade das mesmas tanto através dos corredores de acesso da galeria como da área de atividade social e esportiva, atendendo à pedagogia da atratividade ao ser uma escola voltada para o aluno. Separadas por divisórias móveis que eram utilizadas como armários e quadro negro, as salas tinham flexibilidade de espaço de acordo com o crescimento da escola. $\bigcirc$ térreo deste mesmo bloco abrigava o pátio coberto do recreio marcado por pilotis, bem como a cozinha, sanitários e salas de assistência social.

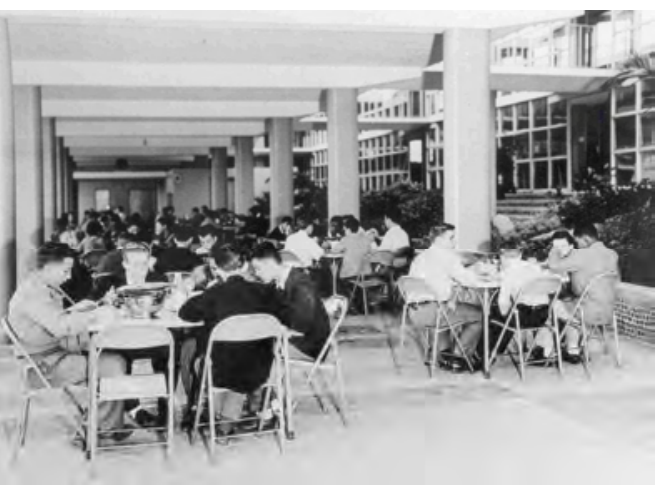


O terceiro bloco, o pavilhão social, foi projetado no mesmo nível das atividades esportivas e interligado à composição por uma plataforma coberta. Abrigava a biblioteca, grêmio estudantil, auditório, palco, vestiários e sanitários, e permitia a utilização múltipla de seus espaços através de painéis móveis.

A Escola Anchieta foi projetada para atender à formação de carpinteiros, marceneiros, mecânicos de automóvel, torneiros e ajustadores e, segundo Habitat $n^{\circ} 12$ (1953:18), foi projetada com capacidade para 260 alunos. Inaugurada parcialmente no IV Centenário da cidade de São Paulo, em 25 de janeiro de 1954, esta escola contava inicialmente com o paralelismo dos dois blocos principais (oficinas e salas de aulas), sendo que posteriormente 0 projeto foi executado em sua totalidade (piscina, quadra e pavilhão social). Em particular, a escola possuiu a Escultura de Anchieta $^{2}$ como o único exemplo no SENAI de integração da escultura simbólica no conjunto escolar.
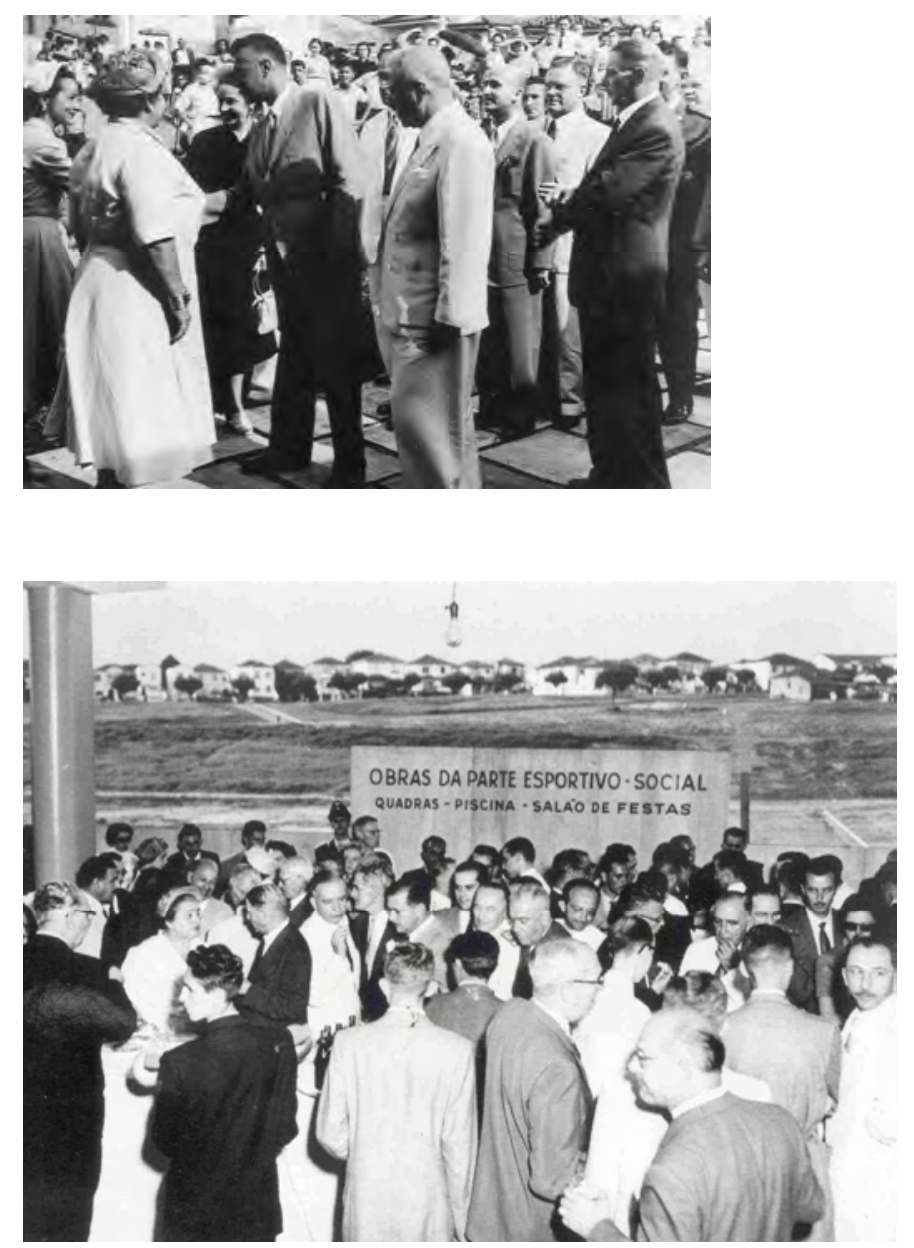

\footnotetext{
${ }^{2}$ A escultura Anchieta foi localizada na inauguração da escola de forma provisória no recreio coberto, posteriormente ocupou uma área próxima à piscina, local que se encontra ainda hoje.
}

Figura 20: Inauguração em 25 de janeiro de 1954. Observar Roberto Mange à direita da foto.

Escola SENAI Anchieta, Vila Mariana, 1954

Fonte: Arquivo Escola Anchieta

Figura 21: A escola foi inaugurada com os dois blocos paralelos da oficina e salas. A quadra, piscina e pavilhão social foram construídos posteriormente, conforme evidencia a placa. Escola SENAI Anchieta, Vila Mariana, 1954 Fonte: Arquivo Escola Anchieta 
As características particulares da pedagogia do SENAI condicionaram a solução arquitetônica adotada nesta escola. Assim, por exemplo, o paralelismo entre os dois blocos da oficina e salas, ligados entre si, acusa a intenção de interligação e rendimento, concretizando fisicamente a idéia de unir a teoria com a prática, respeitando algumas dificuldades como $O$ isolamento acústico, iluminação e ventilação. A escola também reflete arquitetonicamente outros pontos básicos da pedagogia do SENAI como: o crescimento e flexibilidade das salas de aula através das divisórias móveis, a atratividade da escola através da área esportiva (piscina e quadra) a sociabilidade através do espaço oferecido pelo pavilhão social como um ponto de convívio em comum, o rendimento através da organização espacial que permitia a intervisibilidade entre as partes, tornando a escola uma unidade e, a integração destas com as áreas verdes, esportivas e sociais, a economia de iluminação e ventilação através das aberturas projetadas de acordo com a função de cada ambiente, dentre outros.

Figura 22: Fachada principal da escola Senai Anchieta, Vila Mariana, 1954.

Fonte: Arquivo Escola Anchieta

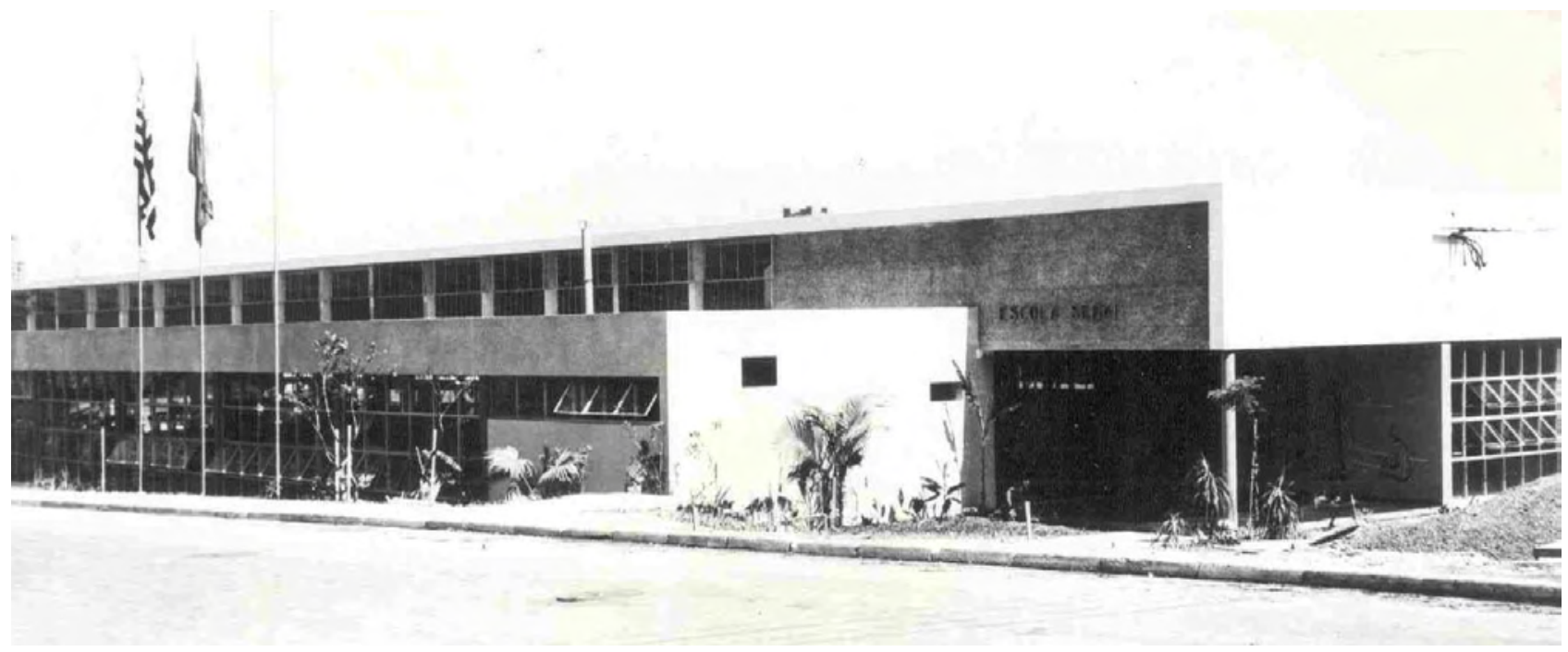




\section{Internato de Campinas, 1952}

Também projetado por Hélio de Queiroz Duarte e Ernest Robert de Carvalho Mange, o Internato de Campinas ${ }^{3}$ reflete as características da filosofia pedagógica do SENAI, porém diferentemente do programa construtivo de uma escola. Segundo Acrópole n 197 (1955:219), seu edifício foi projetado para abrigar aprendizes industriais, provenientes das cidades vizinhas, que cursavam a escola Senai de Campinas. O internato foi composto de três blocos, interligados entre si, caracterizados por dormitório, administração e refeitório (bloco 1), pátio coberto, sanitários e rouparia (bloco 2) e pavilhão social (bloco 3).

internato teve seu programa construtivo composto de: hall de entrada, portaria, diretoria, enfermagem, sala de assistência social, biblioteca, refeitório, cozinha, sanitários, lavanderia, dormitório, rouparia, auditório com palco, palco ao ar livre, arquibancada e piscina.

Nenhuma prancha do projeto original foi encontrada no arquivo do SENAI, apenas o processo de número 5.01 do primeiro Internato de Campinas, projetado em 1950, exemplar da arquitetura racionalista apresentada anteriormente neste trabalho (ver página 8). O conhecimento do Internato foi obtido por meio de duas publicações em periódicos da época, Acrópole nº 197 (1955:219) e Bem Estar nº 5/6 (1960:14).

\footnotetext{
${ }^{3}$ O Internato de Campinas foi publicado pelas revistas Acrópole nº 197 (1955: 219) e Bem Estar n 5/6 (1960:14).
} 
Figura 1: Planta do pavimento térreo do Internato de Campinas, 1952.

Fonte: Acrópole n¹97

(1955:219)

Figura 2: Planta do pavimento superior do Internato de Campinas, 1952.

Fonte: Acrópole n 197 (1955:219)
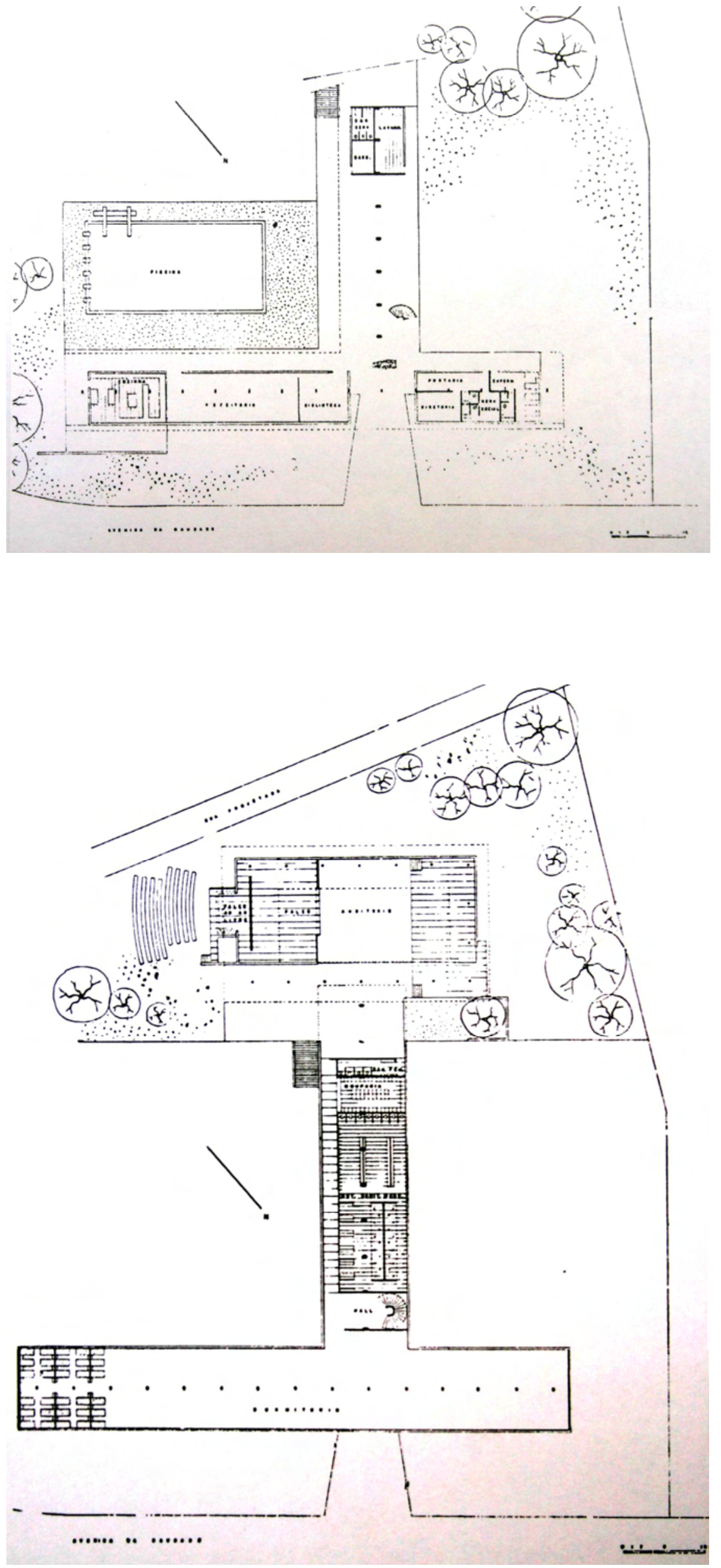
primeiro bloco foi implantado ao longo da Avenida da Saudade, com fachada voltada para a face nordeste. Projetado com dois pavimentos, o térreo era composto de hall de entrada, portaria, diretoria, enfermagem, sala de assistência social, biblioteca, refeitório, cozinha e sanitários, enquanto o pavimento superior abrigava $\circ$ dormitório, resolvido numa grande área livre marcada apenas pela modulação dos pilares centrais. A estrutura de concreto armado, com apoio central e forros inclinados, atendeu a necessidade da planta livre (flexibilidade) com o menor número de apoios possível, proporcionando tanto grandes áreas como plasticidade construtiva ao edifício. $\bigcirc$ dormitório utilizou a solução de um sistema de camas para dormitório coletivo, camas com mobilidade, suspensas durante o dia e abaixadas durante a noite, suavizando o espaço do dormitório coletivo. Além das camas, foi projetado um armário baixo para cada aluno. Com iluminação e ventilação bilaterais, o dormitório recebeu caixilhos de madeira com placas de fibro-cimento, paletas de ventilação e vidros de correr, segundo Acrópole nº 197 (1955:219), nas faces nordeste e sudoeste.

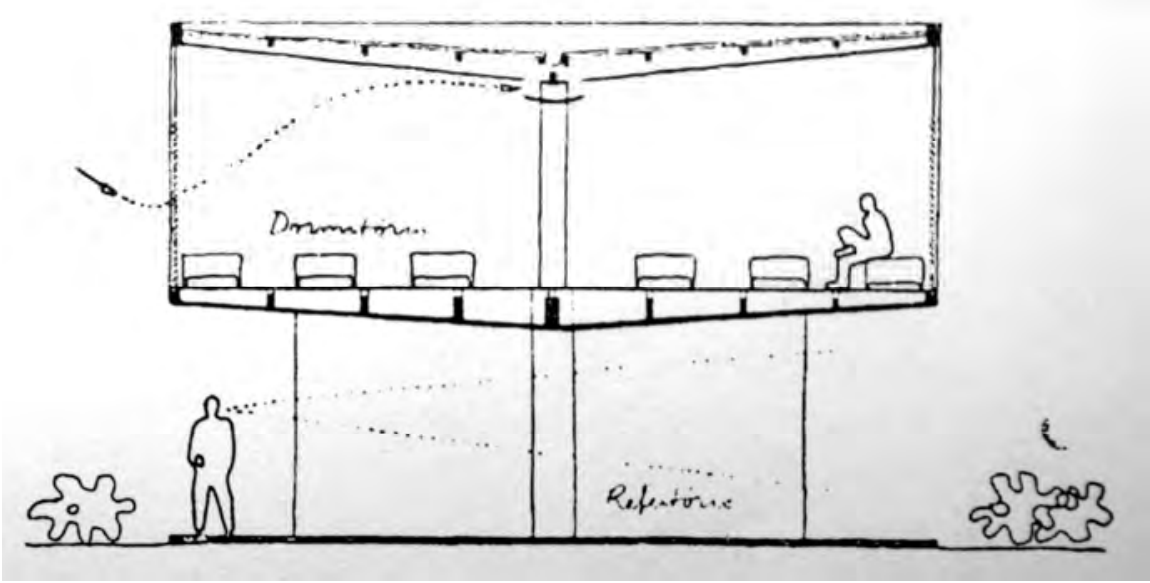

Figura 3: Planta do pavimento superior do Internato de Campinas, 1952. Fonte: Bem Estar n ${ }^{\circ}$ 5/6

(1960:14)

segundo bloco, perpendicular ao primeiro e ao terceiro, também foi projetado em dois pavimentos. No térreo, foi projetado o pátio coberto, um grande vão marcado apenas pela estrutura central, um espaço de circulação que possibilitava a sociabilidade ao interligar os blocos com a área livre utilizada para as atividades esportivas (piscina). Na extremidade sudoeste, o térreo ainda abrigava a lavanderia e complementos. No pavimento superior, com circulação lateral sudeste, foram projetados os sanitários e a rouparia, utilizados pelo dormitório do primeiro bloco. 
O terceiro bloco, o pavilhão social, era composto de auditório com palco e, na extremidade sudeste, palco ao ar livre voltado para a arquibancada externa. Projetado em um único pavimento e implantado no desnível mais alto do terreno, o Pavilhão social foi interligado ao segundo bloco e à área da piscina por uma escada.

O Internato tem como característica particular a sua estrutura de concreto armado com forro inclinado e modulação de pilares centrais que além de liberar as fachadas, reduz as fundações.

Figura 4: Fachada principal (nordeste) do Internato de Campinas, 1952. Vista do primeiro bloco, observar as aberturas utilizadas no pavimento superior do dormitório.

Fonte: Bem Estar n ${ }^{\circ}$ 5/6

(1960:14)

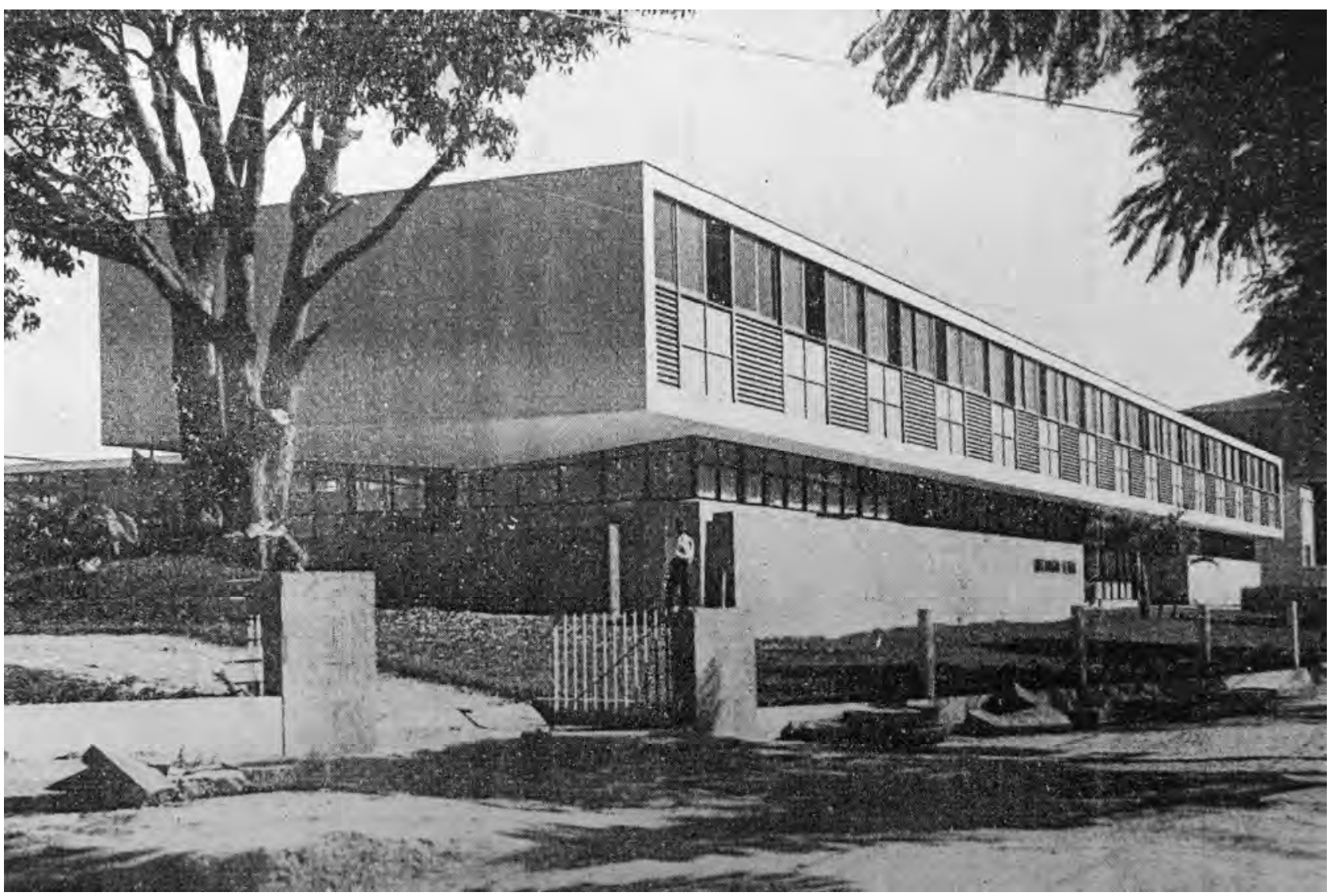




\section{PROJETO 3}

\section{Escola Técnica Têxtil Francisco Matarazzo, Brás, São Paulo, 1952}

Outro exemplo da nova arquitetura do SENAI foi a Escola Técnica Têxtil Francisco Matarazzo', no Brás, São Paulo, também projetada em 1952 por Hélio de Queiroz Duarte e Ernest Robert de Carvalho Mange. A escola reuniu os elementos do programa construtivo em três blocos, impondo o partido arquitetônico desenvolvido em altura devido ao extenso programa a ser construído em relação à área disponível do terreno. Tendo a verticalidade como característica diferenciada das demais escolas, os blocos evidenciam quatro volumes distintos em altura na fachada principal que, interligados, proporcionam harmonia ao projeto e somam aproximadamente $12.000,00 \mathrm{~m}^{2}$ de área construída.

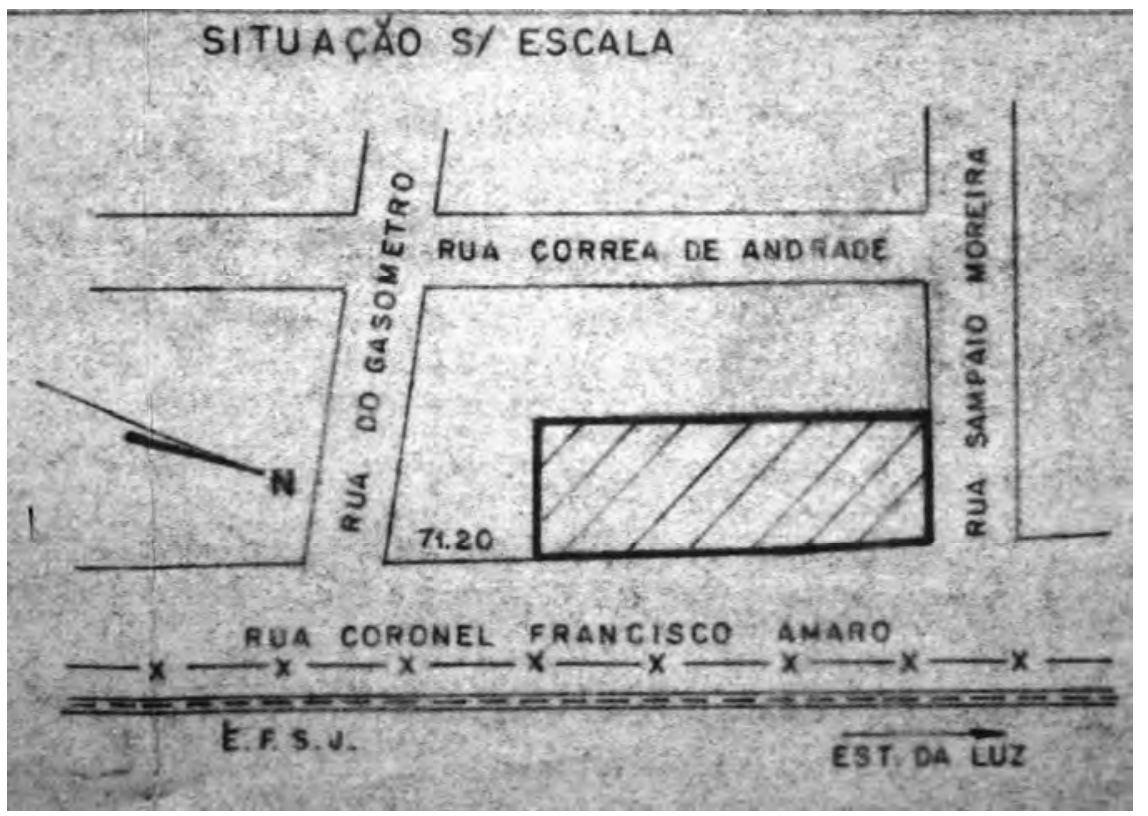

Figura 1: Planta de situação da Escola Senai Técnica Têxtil Francisco Matarazzo, Brás, São Paulo, 1952 Fonte: Foto Ferraz, arquivo SENAI

O programa construtivo foi dividido nos três blocos em quatro volumes. $O$ primeiro bloco (oficinas) contém dois volumes sendo que o volume ressaltado com seis pavimentos abriga as oficinas e $O$ volume recuado com oito pavimentos contém o auditório (no oitavo pavimento), oficina, refeitório e recepção (no primeiro pavimento). $\bigcirc$

\footnotetext{
A Escola Têxtil Central do SENAl foi publicada pelas revistas Acrópole n ${ }^{\circ} 197$ (1955:1 18), Acrópole n 241 (1958:10-13), Bem Estar n 5/6 (1960:12) e Habitat nº 12 (1953:19).
} 
segundo bloco (circulação), parte com a mesma altura do primeiro bloco, finaliza a composição do volume recuado do bloco principal reunindo as salas de aula anexas à oficina, depósito, elevadores, escada, sanitários e circulação, colocados nos nove pavimentos à meia altura do pé-direito das oficinas, sendo o último pavimento o da casa de máquinas e da caixa d'água. Como parte do segundo bloco surge o terceiro volume, de menor altura e com três pavimentos, responsável pela circulação que une o segundo com o terceiro bloco. terceiro bloco (salas de aula), com quatro pavimentos, marca $\bigcirc$ quarto volume e reúne administração, biblioteca, salas de aula, laboratórios, sanitários e recreio coberto. No térreo foram projetados espaços para área verde e de recreação, quadra de bola ao cesto e palco, que se integram com o recreio coberto do terceiro bloco devido ao emprego dos pilotis. Os três blocos, caracterizados, portanto, pelas oficinas, circulação e salas de aula, foram projetados estruturalmente independentes, com a preocupação de evitar ruídos e proporcionar vantagens econômicas, funcionais e estéticas.

$\bigcirc$ projeto original não foi encontrado, porém foram encontradas diversas pranchas do projeto executivo de reforma e ampliação, que revelaram as dimensões do terreno, blocos e ambientes, as plantas de todos os pavimentos de todos os blocos, os cortes e elevações. $O$ conhecimento de como era o projeto original foi obtido através de publicações nos periódicos da época que revelaram um croqui, as plantas dos diversos pavimentos, um corte esquemático e a elevação principal, os quais foram comparados com o projeto de reforma encontrado (figuras 2 a 8).

Figura 2: Croqui com os três blocos interligados, Escola Têxtil Central do SENAI, Brás, 1952.

Fonte: Acrópole n ${ }^{\circ} 241$

(1958, p. 12)

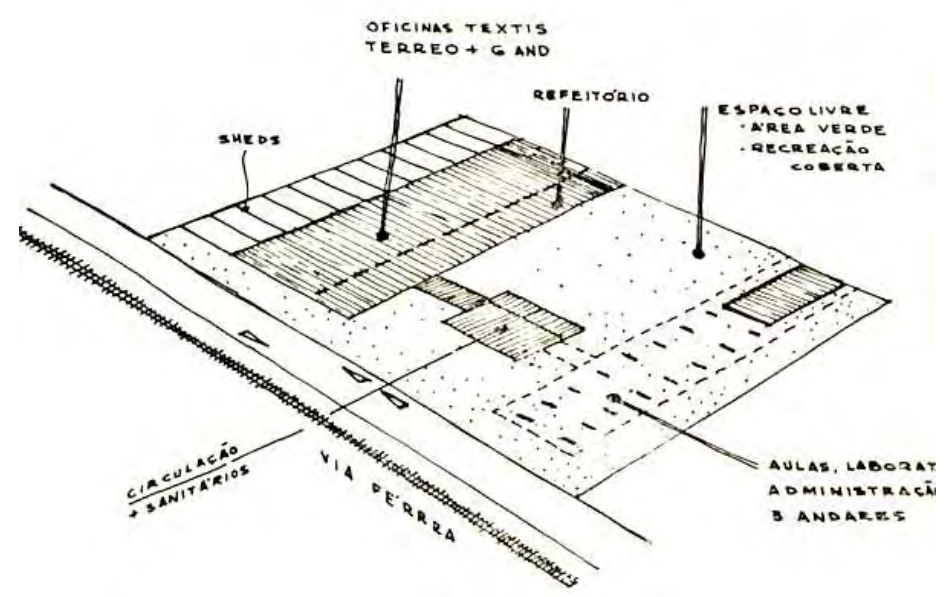


Figura 3: Pavimento térreo, Escola Têxtil Central do SENAI, Brás, 1952

Fonte: Acrópole n 241

(1958:11)

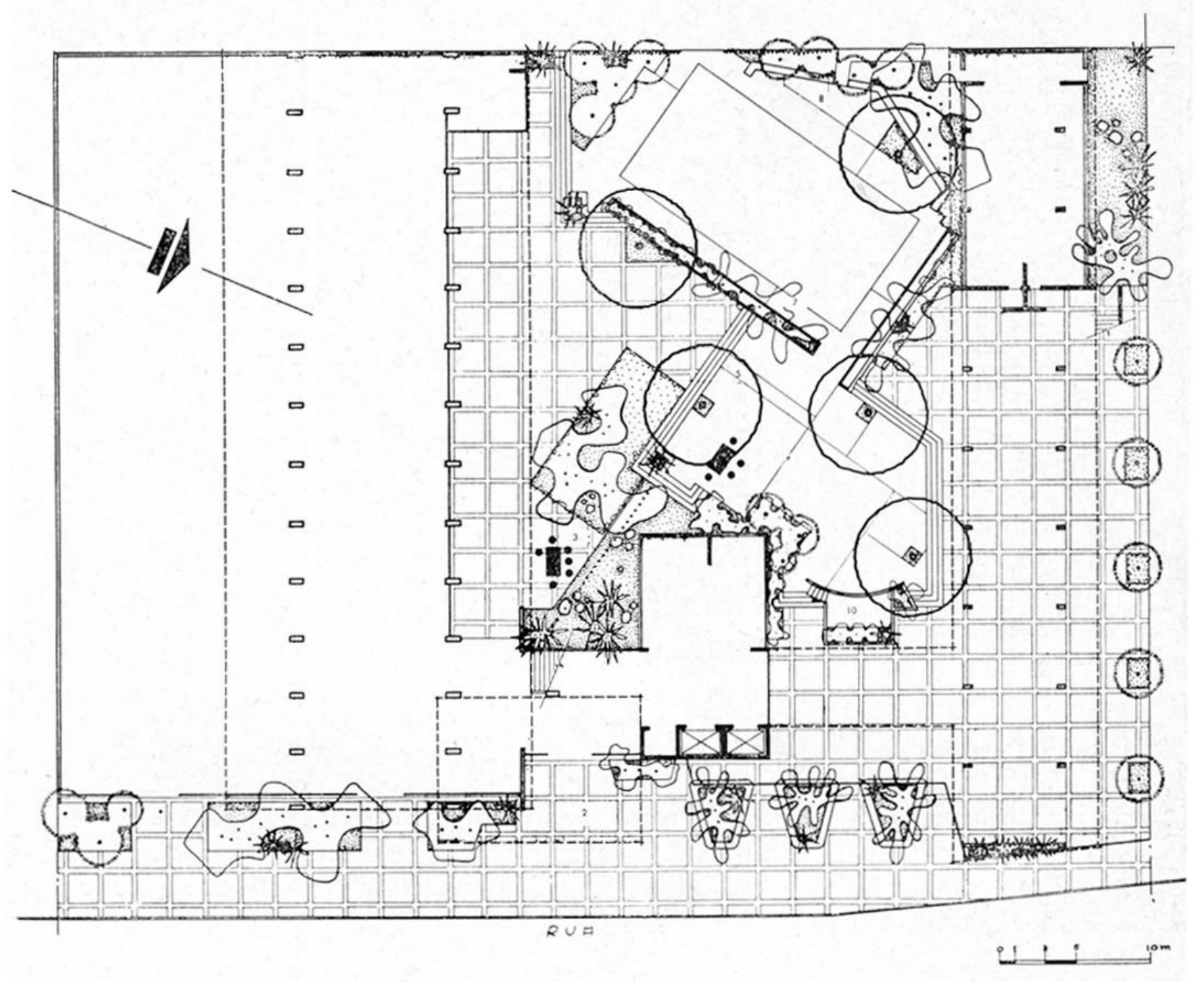


Figura 4: Segundo, terceiro e quarto pavimentos, Escola Têxtil Central do SENAI, Brás, 1952. Fonte: Acrópole n ${ }^{\circ} 241$ (1958:12)

Figura 5: Pavimento tipo, Escola Têxtil Central do SENAl, Brás, 1952.

Fonte: Acrópole n 241

(1958:12)
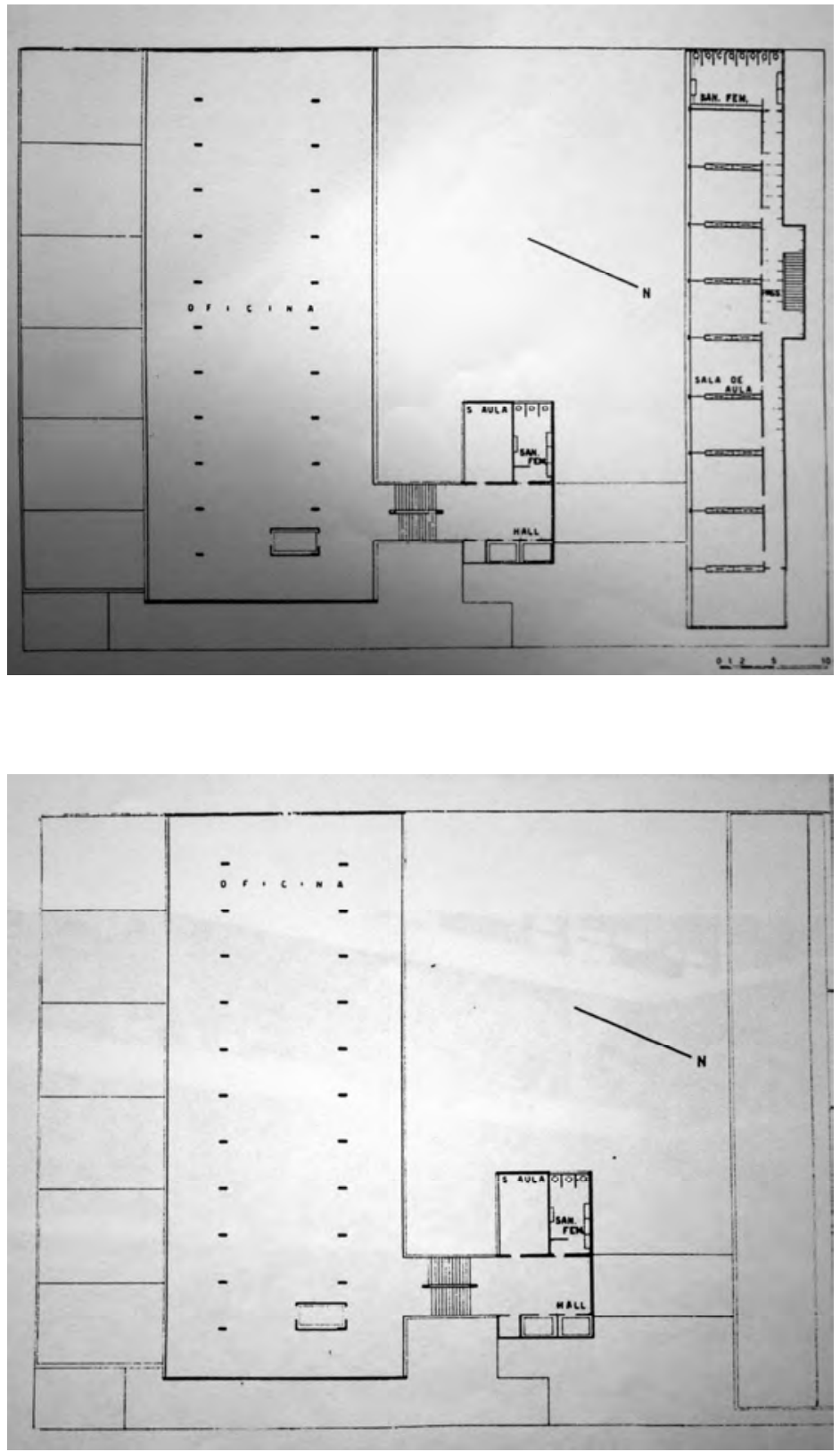

Figura 6: Oitavo e último pavimento, auditório, Escola Têxtil Central do SENAl, Brás, 1952.

Fonte: Acrópole n 241

(1958:12)

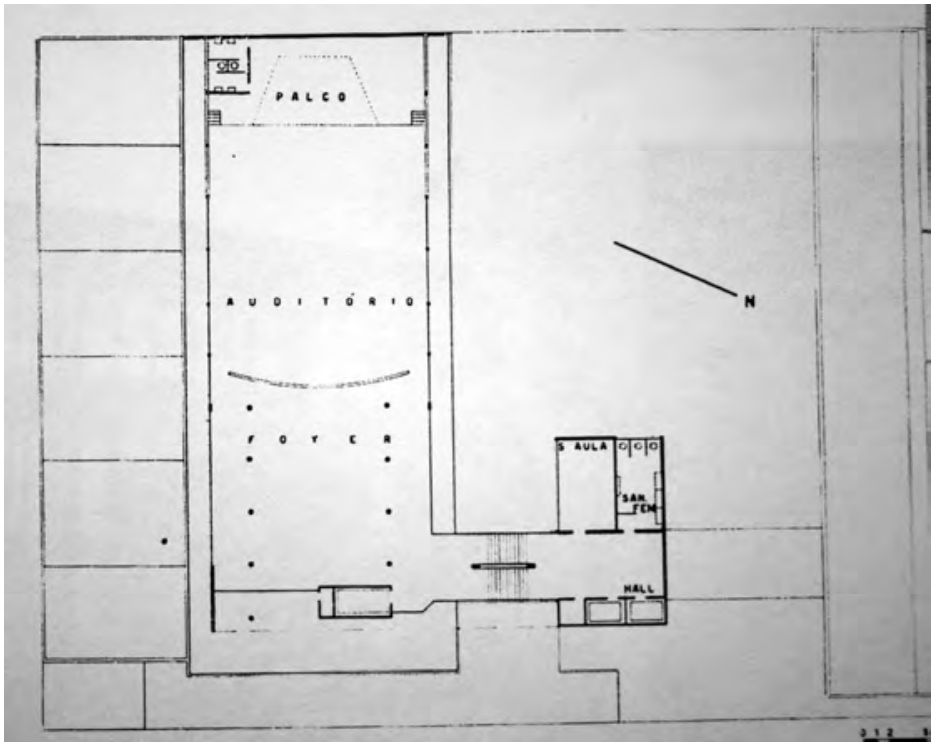




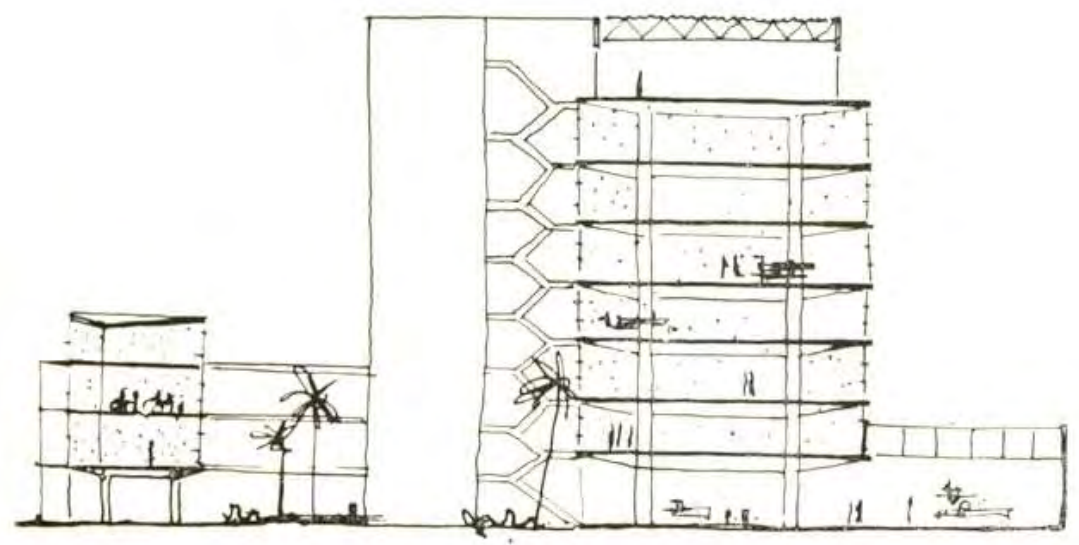

Figura 7: Corte esquemático dos blocos de salas de aula, circulação e oficinas, Escola Têxtil Central do SENAI, Brás, 1952 Fonte: Acrópole n 241

(1958:12)

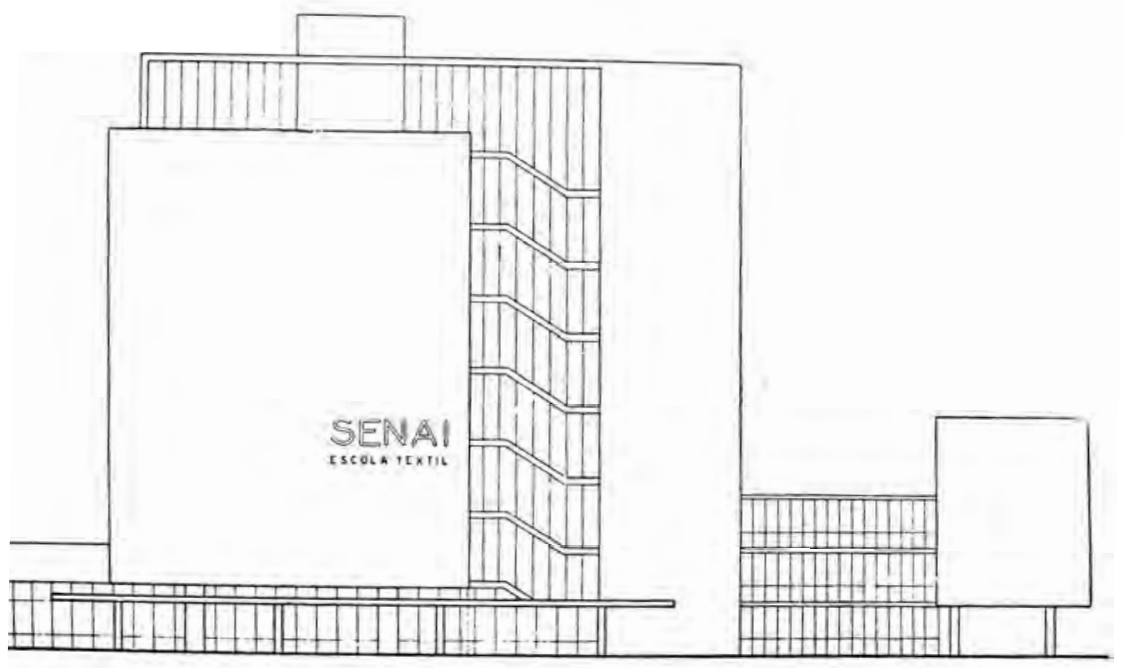

Figura 8: Elevação principal. Escola Têxtil Central do SENAI, Brás, 1952 Fonte: Acrópole n 197 $(1955: 217)$

- primeiro bloco, o das oficinas, era o principal na verticalidade do projeto, composto por oito pavimentos. $\bigcirc$ térreo e mais seis andares, com cerca de $1.000 \mathrm{~m}^{2}$ cada um e com pé-direito de quatro metros, foram destinados às oficinas têxteis, com planta modulada por uma estrutura em pórtico e com iluminação e ventilação bilateral sudeste e noroeste. As oficinas atendiam à flexibilidade e à economia almejadas pela nova pedagogia do SENAI através da planta livre, atendendo a eventuais variações das necessidades das oficinas, e da iluminação natural e ventilação direta. No último pavimento foi localizado o auditório, para atender ao serviço social, como cobertura das oficinas, finalizando o volume e proporcionando como elemento de visibilidade $\bigcirc$ urbano. A sociabilidade foi alcançada através do auditório, um ponto de convívio em comum que também possibilitou a interligação visual da 
Figura 9 - Vista do bloco das oficinas na década de 1950.

Observar a face sudeste envidraçada das oficinas e o volume do auditório no último pavimento.

Fonte: Acrópole n 241

(1958:11) cidade para a escola. No térreo, a face sudeste da oficina se estendeu até $\mathrm{o}$ muro de divisa lateral e recebeu a iluminação por sheds, mantendo a idéia da economia e na face noroeste o refeitório se abriu para a área verde e recreativa da escola, tornando-se um local de atratividade para os alunos.

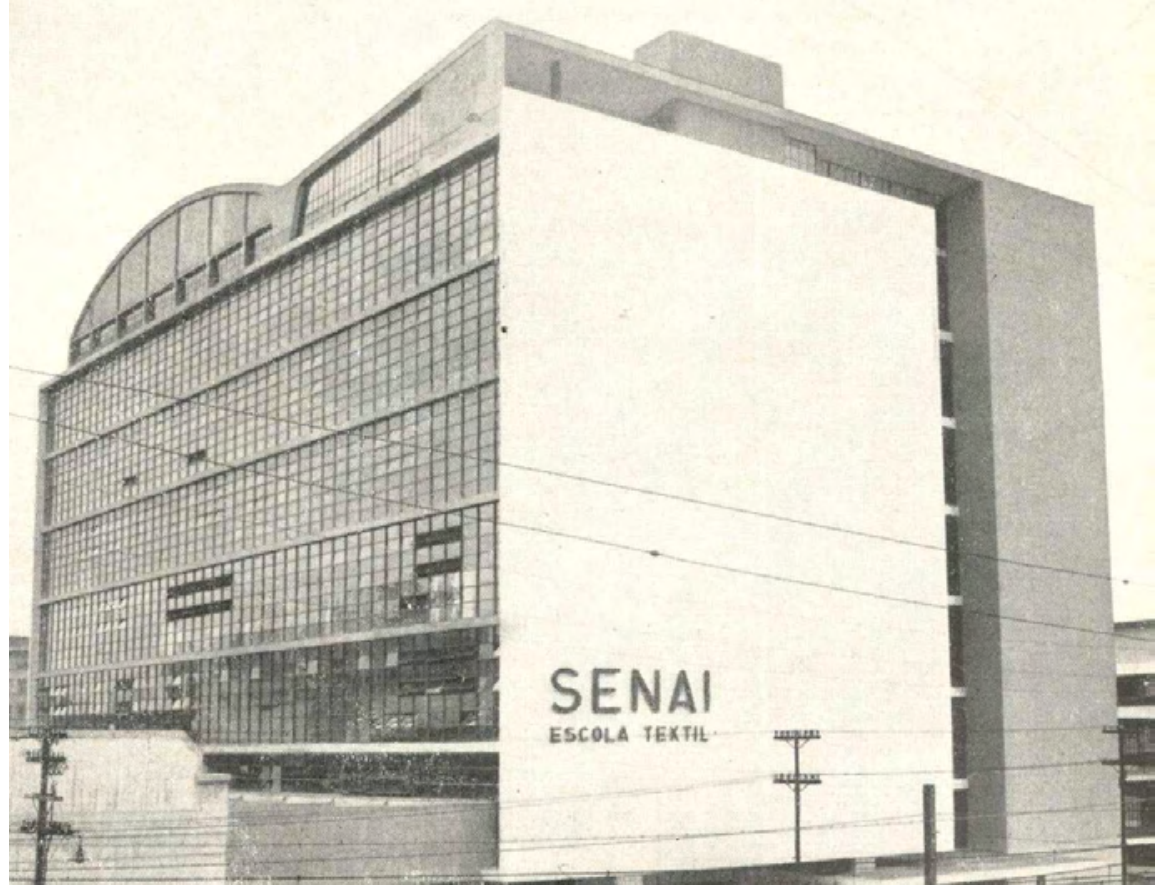

O segundo bloco, o da circulação, foi projetado com nove pavimentos à meia altura do pé-direito das oficinas e continuava com três pavimentos no volume da passarela de circulação. Reunia depósito, elevadores, escada, circulação, salas de aulas anexas às oficinas e os sanitários masculinos e femininos alternadamente por andar. No último pavimento foram projetadas a casa de máquinas e a caixa d'água. Interligado às oficinas, os níveis de piso deste bloco visavam à economia ao projetar tanto os sanitários com uso alternado, intercalados por andar em feminino e masculino e construídos numa mesma prumada, como as das salas de aula, proporcionando a mesma distância de percurso e a visibilidade integral das oficinas, atendendo à nova filosofia do SENAI. Já o terceiro volume, uma passarela coberta com 5.10 metros de largura, com três pavimentos, que unia o segundo com o terceiro bloco, proporcionava a interligação física da prática (primeiro bloco) com a teoria (terceiro bloco) e da escola com o urbano, através de seu vão envidraçado. 


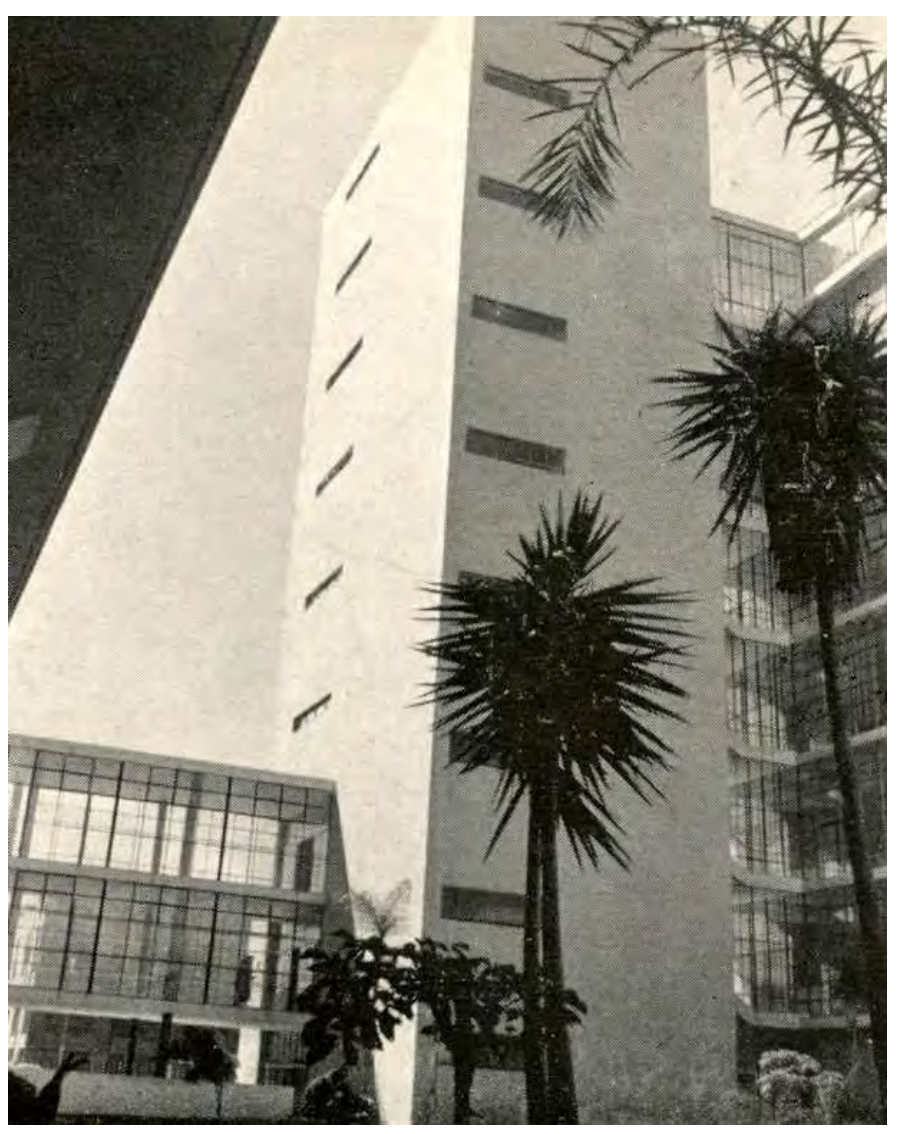

Figura 10 - Vista do segundo bloco, face sudoeste. Observar os volumes da circulação vertical e da passarela coberta, década de Fonte: Acrópole n 241

(1958:11)

O terceiro bloco, o das salas de aula, foi projetado com quatro pavimentos e abrigava no térreo o recreio coberto, sanitários e vestiários e, nos pavimentos superiores, salas de aulas, administração, biblioteca, laboratórios e sanitários. O bloco recebia iluminação e ventilação bilateral sudeste e noroeste, com salas que tinham suas aberturas voltadas para a face sudoeste sendo que na face noroeste havia o corredor de circulação com 2.00 metros de largura. A modulação da estrutura pré-estabeleceu a dimensão interna de cada sala através das divisórias feitas com armários-quadro negro, posicionados no eixo de cada pilar (módulo), atendendo à flexibilidade na necessidade de ampliar o espaço para as atividades didáticas.

A Escola Técnica Têxtil Francisco Matarazzo foi projetada para atender à formação de técnicos para a indústria têxtil e, segundo Habitat 12 (1953:19), foi projetada com capacidade para 800 alunos. Projetada próxima ao centro da cidade de São Paulo, junto à estação do Brás e num entroncamento ferroviário, a escola deveria atender a bairros de grande densidade operária, como Penha e Tatuapé. 
As características particulares da pedagogia do SENAI nortearam a solução arquitetônica desta escola. Assim, por exemplo, a ligação do primeiro com o terceiro bloco, através da passarela coberta, acusa a intenção de interligação, proporcionando fisicamente - contato visual entre a área de trabalho prático e teórico. Outro aspecto de grande importância no projeto foi a sociabilidade obtida pelo uso de pilotis em grande parte do térreo, integrando os blocos com a área livre interna utilizada para as atividades esportivas e sociais. A escola também reflete arquitetonicamente outros pontos básicos da pedagogia do SENAI como: o crescimento das salas de aula através das divisórias móveis, a flexibilidade da planta livre das oficinas, a atratividade da escola através da área recreativa (área verde, recreio coberto, quadra e palco), a sociabilidade através do auditório como salão social circundado pela paisagem urbana, 0 rendimento através dos pavimentos de acesso às oficinas que permitiam a visibilidade a meia altura do pé-direito das atividades práticas, a economia de iluminação, ventilação e menores distâncias a percorrer, através das aberturas e ambientes projetados, além, de outros pontos já citados.

Figura 11 - Fachada principal da Escola Têxtil Central, década de 50.

Fonte: Acrópole nº 241 (1958:10)

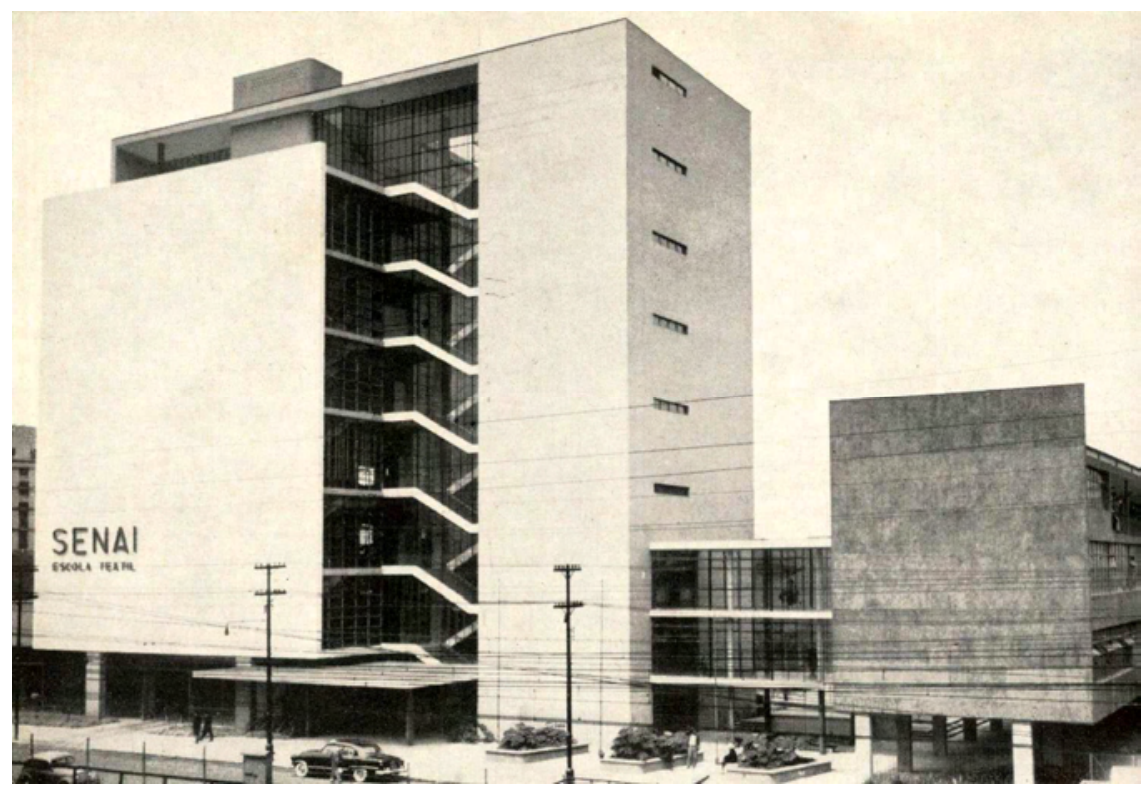

A Escola Têxtil Central constitui-se em uma das maiores referências da arquitetura moderna das escolas do SENAI e reflete as teorias de seus idealizadores, a preocupação com a organização complexa e dinâmica do espaço convergindo suas diretrizes para a educação integral. 


\section{PROJETO 4}

\section{Escola João Martins Coube, Bauru, 1953}

A Escola SENAI João Martins Coube ${ }^{2}$ na cidade de Bauru, interior do Estado, foi projetada em 1953 pelo jovem arquiteto Roberto José Goulart Tibau. Implantada num terreno de 10.407,50 $\mathrm{m}^{2}$ a área de construção do projeto original foi de $3.829,25 \mathrm{~m}^{2}$, sendo $2.132,35 \mathrm{~m}^{2}$ do pavimento térreo, $1.224,78 \mathrm{~m}^{2}$ do pavimento superior e $472,12 \mathrm{~m}^{2}$ do pavimento semi-enterrado (porão). A escola construída ao longo dos 1 16,20 metros da rua Virgílio Malta teve sua fachada principal voltada para a face leste. $O$ edifício marcado pela horizontalidade aproveitou a topografia do terreno resolvendo a distribuição dos espaços em diferentes níveis.

Figura 1: Vista da fachada principal voltada para leste. Marcado pela horizontalidade, o edifício aproveitou a declividade do terreno. Fonte: Arquivo SENAI Bauru

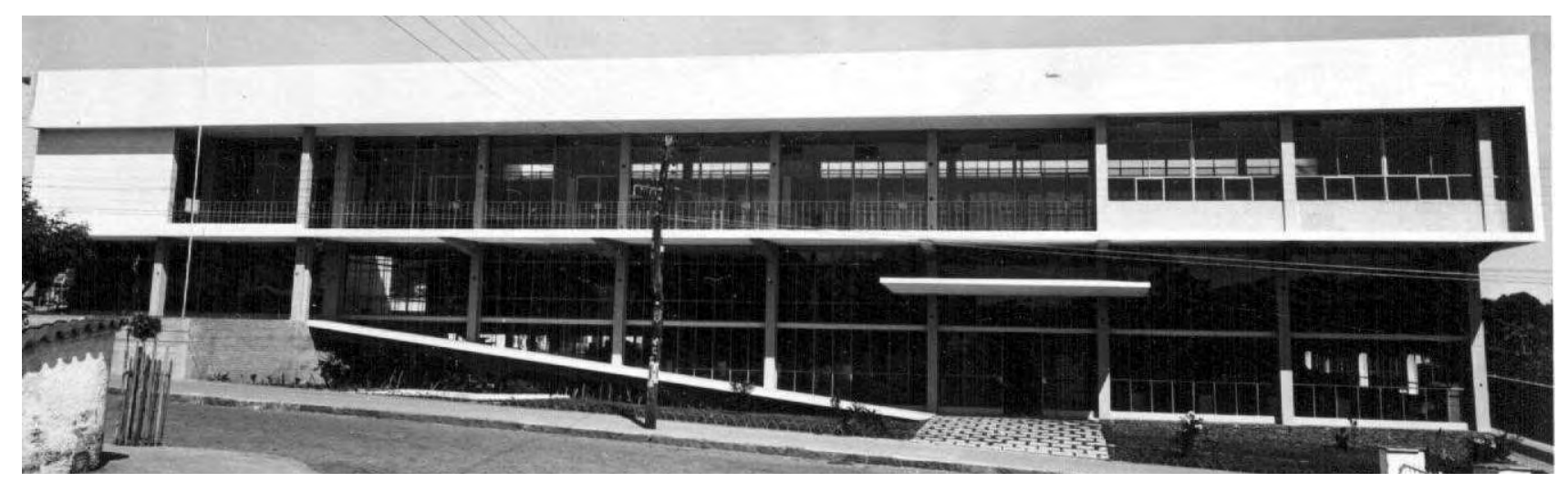

O programa construtivo foi dividido em dois blocos interligados caracterizados pela oficina e escola. $\bigcirc$ projeto, resolvido em três níveis, era composto de: depósito e sanitário da oficina no pavimento semi-enterrado do bloco da oficina; oficina (bloco da oficina), administração e assistência social (bloco da escola) no pavimento térreo em desnível; salas de aulas e dos professores no pavimento superior do bloco da escola. Além dos dois blocos também foi projetada uma passarela coberta que ligava a escola ao Pavilhão Social. Também, no térreo foram projetadas a área de recreio e uma quadra de esportes.

\footnotetext{
2 A Escola SENAI João Martins Coube foi publicada pelas revistas Acrópole $\mathrm{n}^{\circ} 258$ (1960:130-133) e Habitat nº 12 (1953:16).
} 
Os dados relativos ao edifício foram encontrados em diferentes localidades, e periódicos da época, sendo: material fotográfico e projetos de ampliação no arquivo da respectiva sede, cópia do projeto de prefeitura original, bem como do memorial descritivo construtivo e requerimento de aprovação e construção do projeto no arquivo da Prefeitura Municipal de Bauru. Os documentos encontrados, assinados pelo então Diretor Regional do SENAI Roberto Mange e pelo engenheiro responsável L. A. Falcão Baver, revelaram o ano de concepção do projeto, a data de aprovação deferida em 21 de junho de 1954 e a arquitetura idealizada por Tibau. Ainda, para facilitar a leitura arquitetônica do projeto e representá-lo graficamente através de significativos dados do projeto original, foram graficamente redesenhados plantas, cortes e elevações.

Figura 2: Planta de situação do edifício SENAI de Bauru apresentada no projeto original com data de 5 de janeiro de 1953. Observar os elementos já existentes e os projetados por Tibau.

Fonte: Arquivo Prefeitura Municipal de Bauru

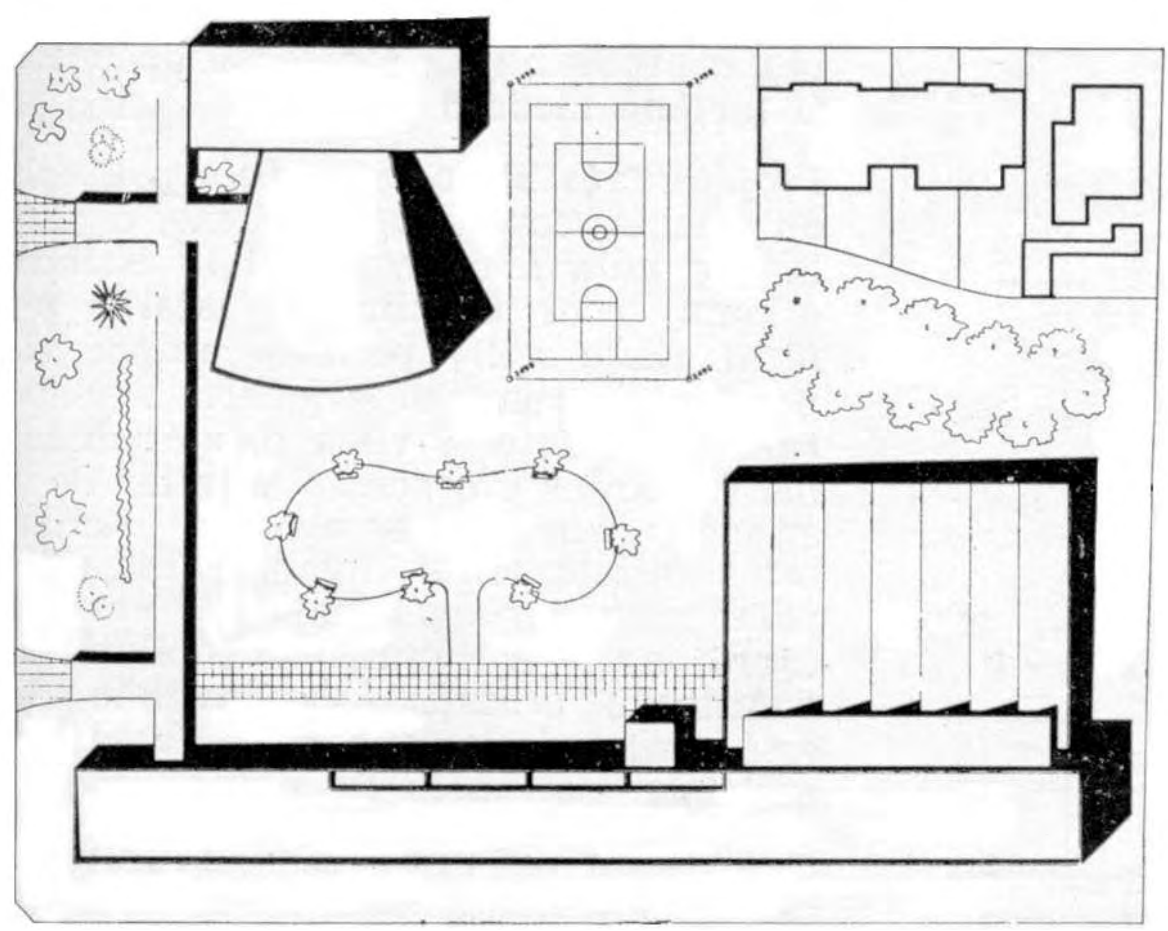




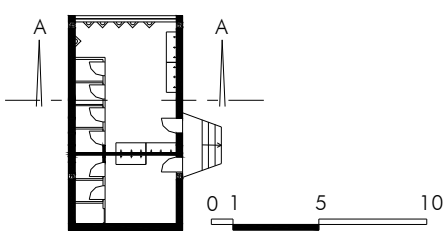

Figura 3: Planta do pavimento semi-enterrado: SENAI. Sanitários sob o hall de entrada da escola. Fonte: Redesenho Ferraz, 2005

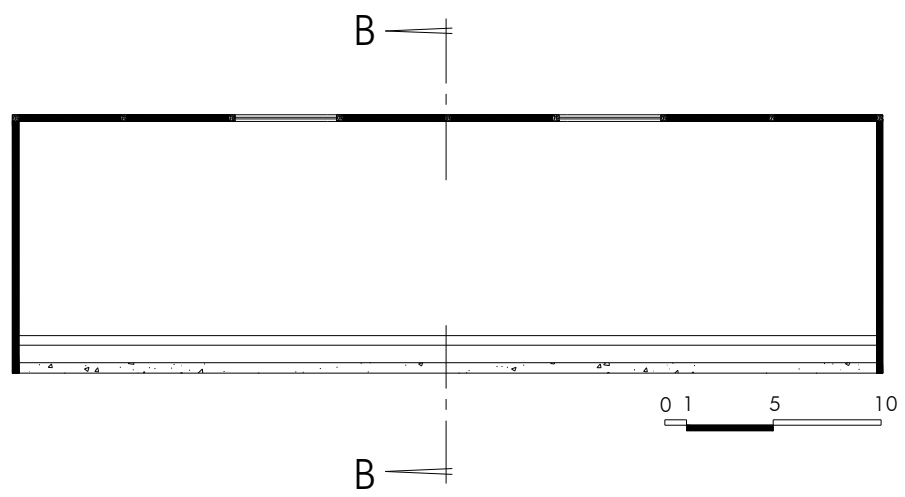

Figura 4: Planta do pavimento semi-enterrado: SENAI. Porão sob os fundos da oficina. Fonte: Redesenho Ferraz, 2005

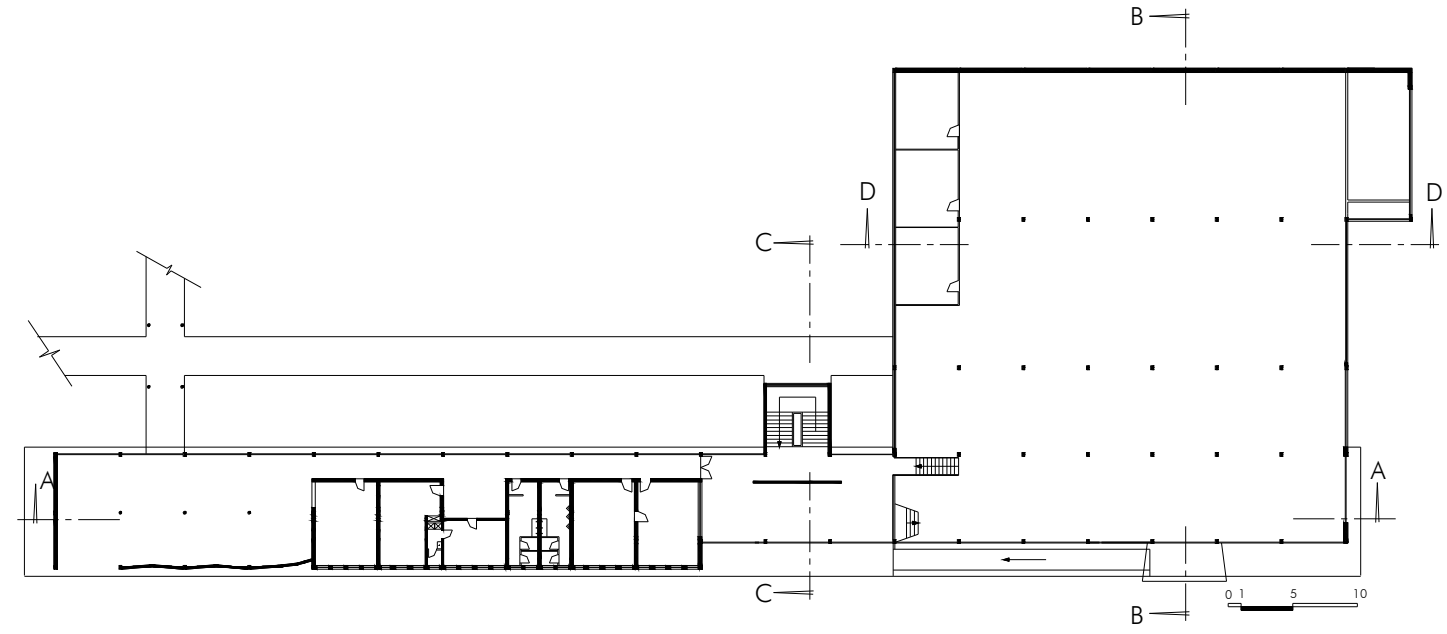

Figura 5: Planta do pavimento térreo: SENAI.

Fonte: Redesenho Ferraz, 2005

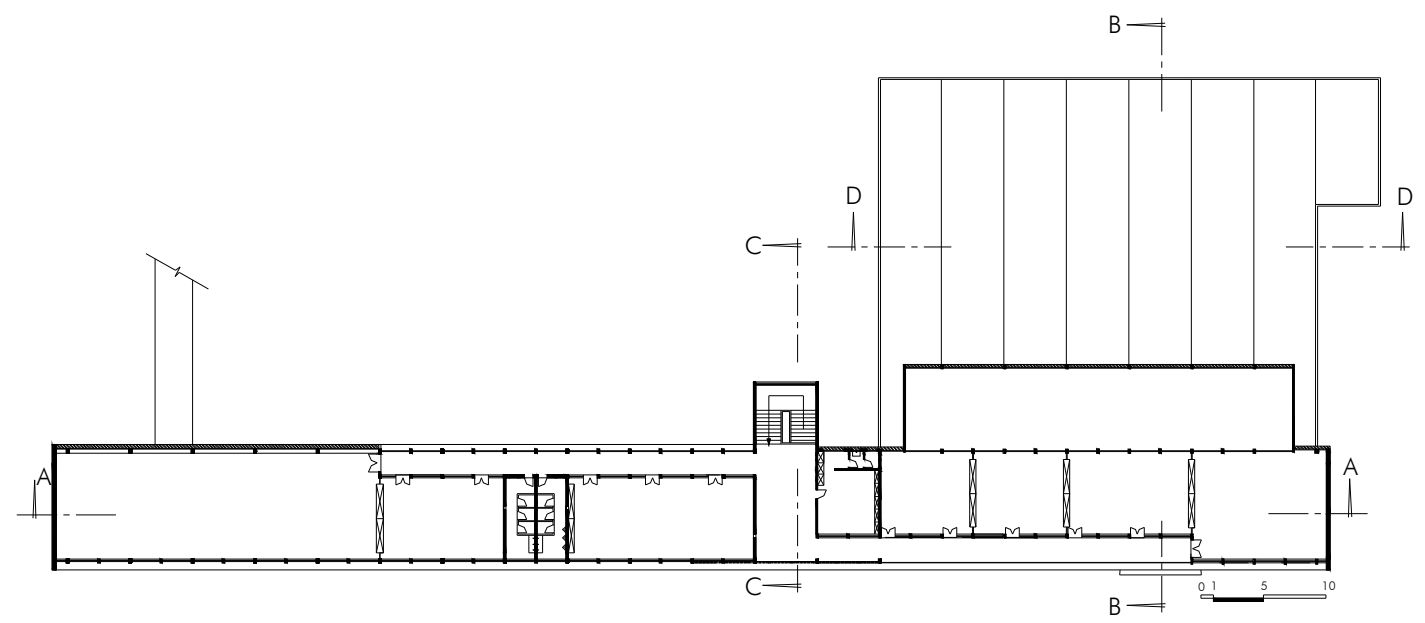

Figura 6: Planta do pavimento superior: SENAI.

Fonte: Redesenho Ferraz, 2005 


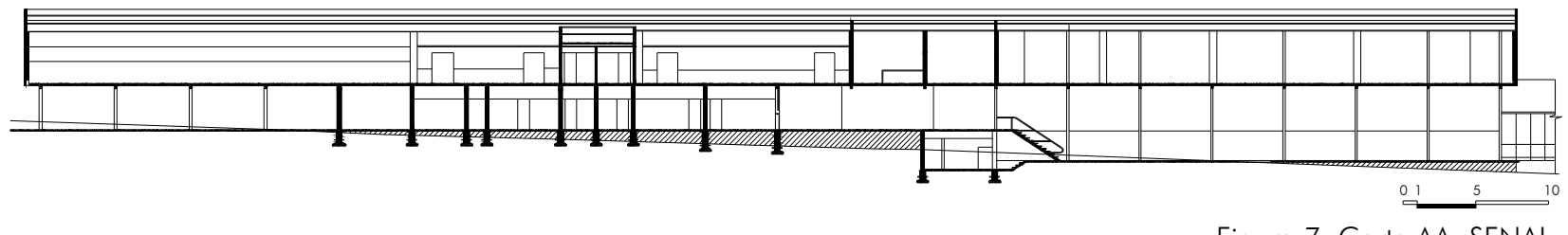

Figura 7: Corte AA: SENAI. Fonte: Redesenho Ferraz, 2005

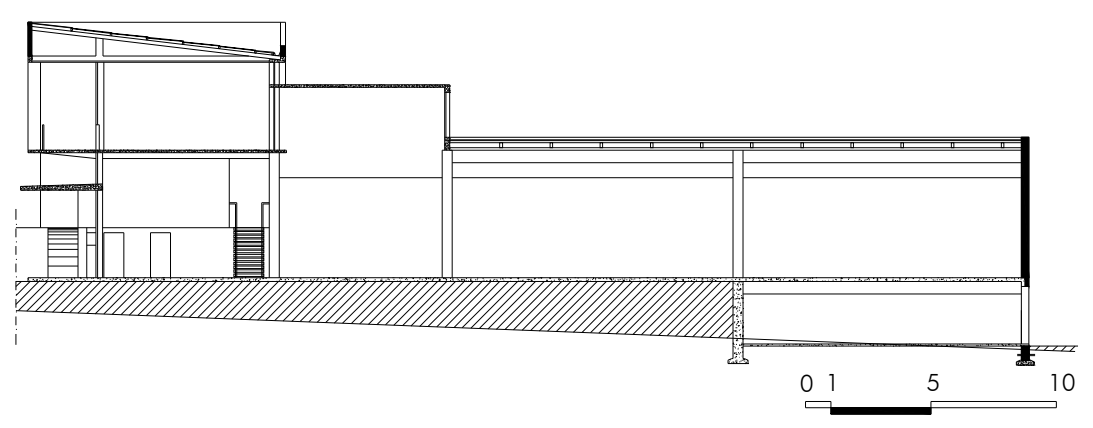

Figura 8: Corte longitudinal BB: SENAI. Fonte: Redesenho Ferraz, 2005

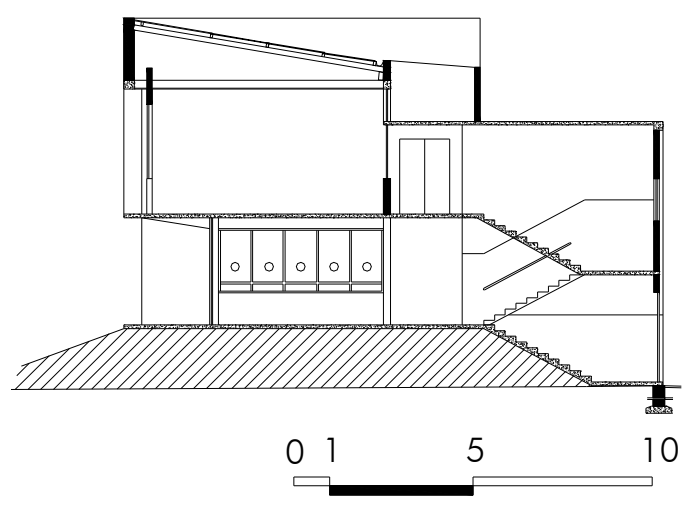

Figura 9: Corte longitudinal CC: SENAI. Fonte: Redesenho Ferraz, 2005

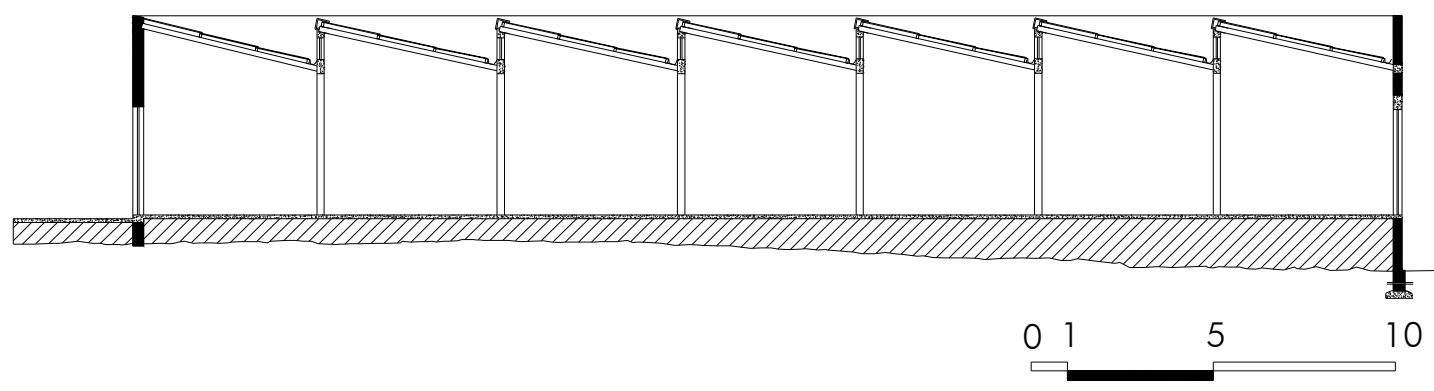

Figura 10: Corte longitudinal DD: SENAI. Fonte: Redesenho Ferraz, 2005 


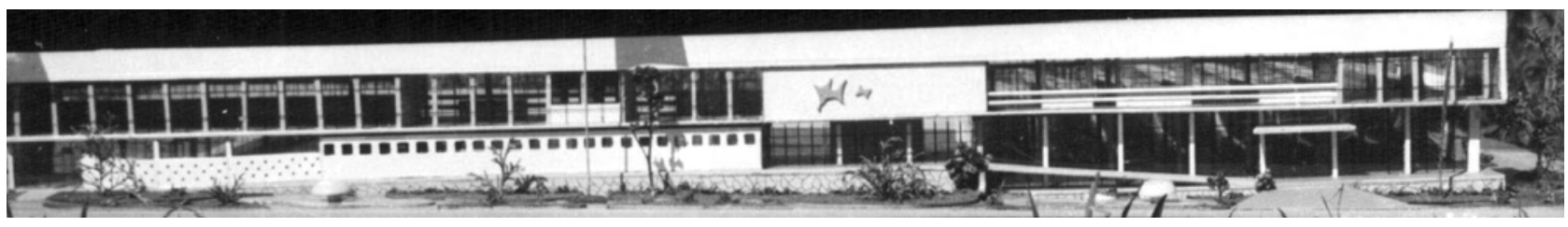

Figura 11: Maquete concebida na década de 50. Vista da elevação principal. Fonte: Arquivo SENAI Bauru

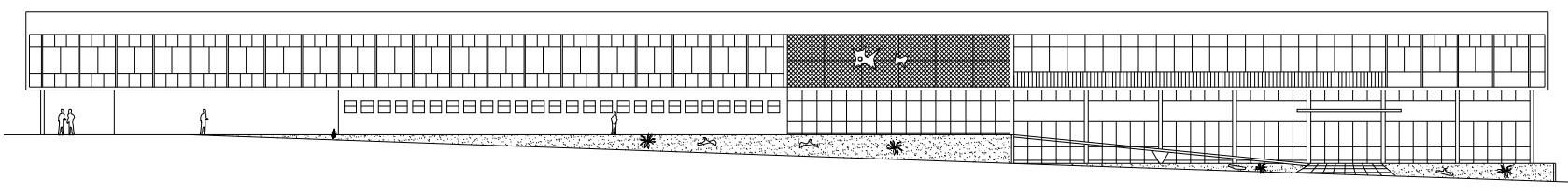

Figura 12: Elevação principal da rua Virgílio Malta: SENAI.

Fonte: Redesenho Ferraz, 2005

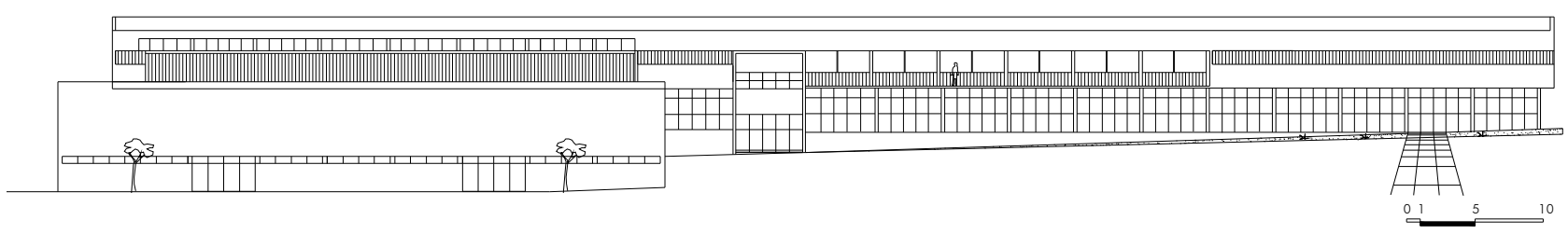

Figura 13: Elevação posterior: SENAI.

Fonte: Redesenho Ferraz, 2005

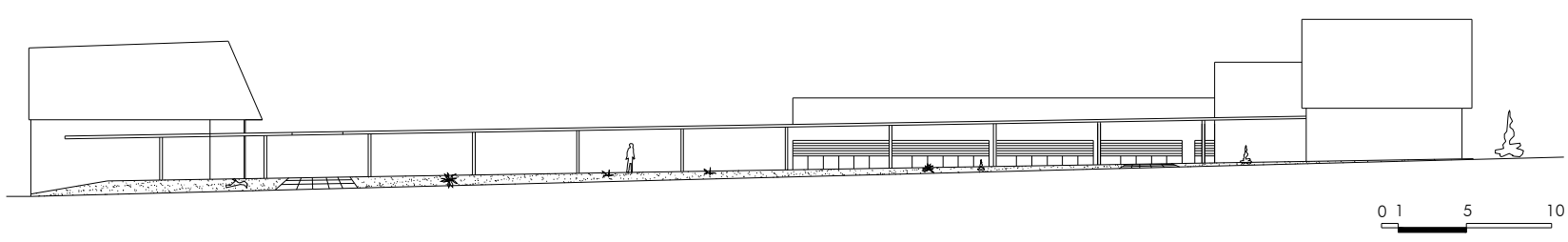

Figura 14: Elevação lateral da rua Manuel Bento Cruz: SENAI.

Fonte: Redesenho Ferraz, 2005

Quando a escola foi projetada, já havia no terreno o pavilhão social e as residências do professores. É importante ressaltar que no projeto original o pavilhão social e auditório (representado em forma de leque na planta de situação) na realidade nunca existiu, somente havia sido construído o pavilhão em forma retangular, porém numa arquitetura tradicional bem diferenciada da perspectiva apresentada em 1953. Existentes até hoje, a residências dos professores e principalmente o pavilhão social são remanescências da arquitetura do SENAI da década de 1940 e, jamais tiveram a plástica idealizada na década de 1950. 
Figura 15: Pavilhão Social construído no final da década de 40. Vista da rua Azarias Leite.

Fonte: Arquivo SENAI Bauru
Figura 16: Vista das residências dos professores e da rua Azarias Leite. Observar ao fundo o Pavilhão Social. Fonte: Arquivo SENAI Bauru
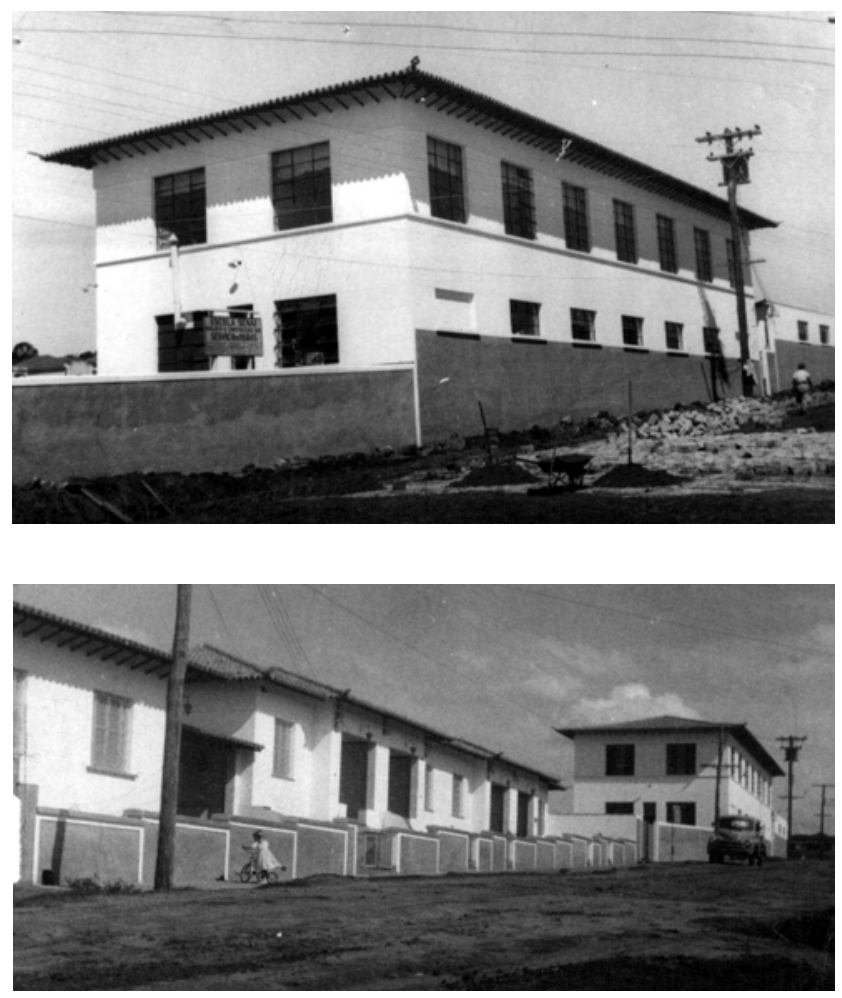

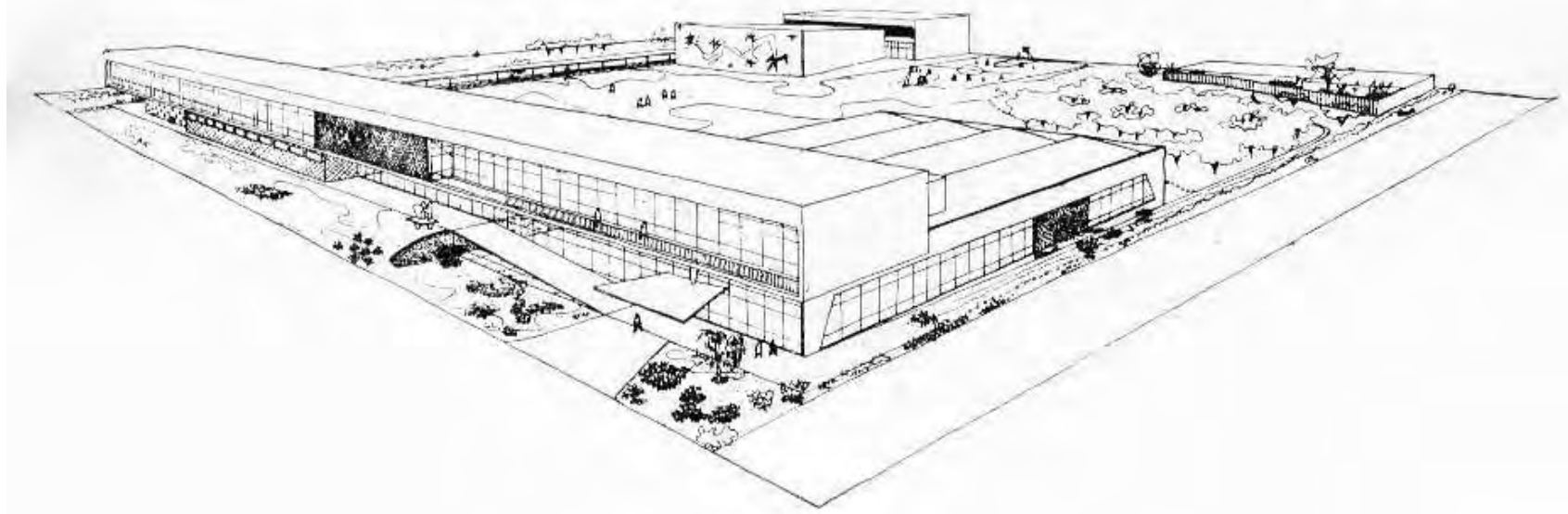

Figura 17: Perspectiva do projeto idealizado por Tibau. Observar em primeiro plano a escola e a oficina. Ao fundo, o auditório que na realidade nunca existiu, assim como as formas modernas propostas para o pavilhão social e as residências dos professores. Fonte: Arquivo SENAI Bauru
O bloco da oficina era composto de dois pavimentos, sendo que no pavimento semi-enterrado abrigava um depósito e no térreo a oficina e algumas salas. Caracterizada como a ala norte do projeto, a oficina foi projetada de forma a aproveitar a topografia do terreno e ao mesmo tempo obter a ligação com as salas de aula. A oficina, com área de $1.330,00 \mathrm{~m} 2$ (inclusas as três salas separadas por divisórias), recebeu diferentes alturas de pé-direito atingindo o máximo de 7,50 metros sob a laje que permite a ligação visual com as salas de aula do pavimento superior. Como local de trabalho, a oficina foi projetada para obter um maior aproveitamento da iluminação natural, 
assim como da ventilação permanente. Além da cortina de vidro voltada para a fachada principal (leste), foram projetadas outras aberturas bilaterais e zenitais para beneficiar a iluminação e a ventilação. A concepção de espaço da oficina conseguiu atingir o objetivo de entrosar a teoria à prática e tornar o espaço de trabalho da escola mais atrativo para os alunos, atratividade. $O$ acesso para a oficina era marcado por uma marquise de entrada, elemento da arquitetura moderna que mostra a influência de Oscar Niemeyer.
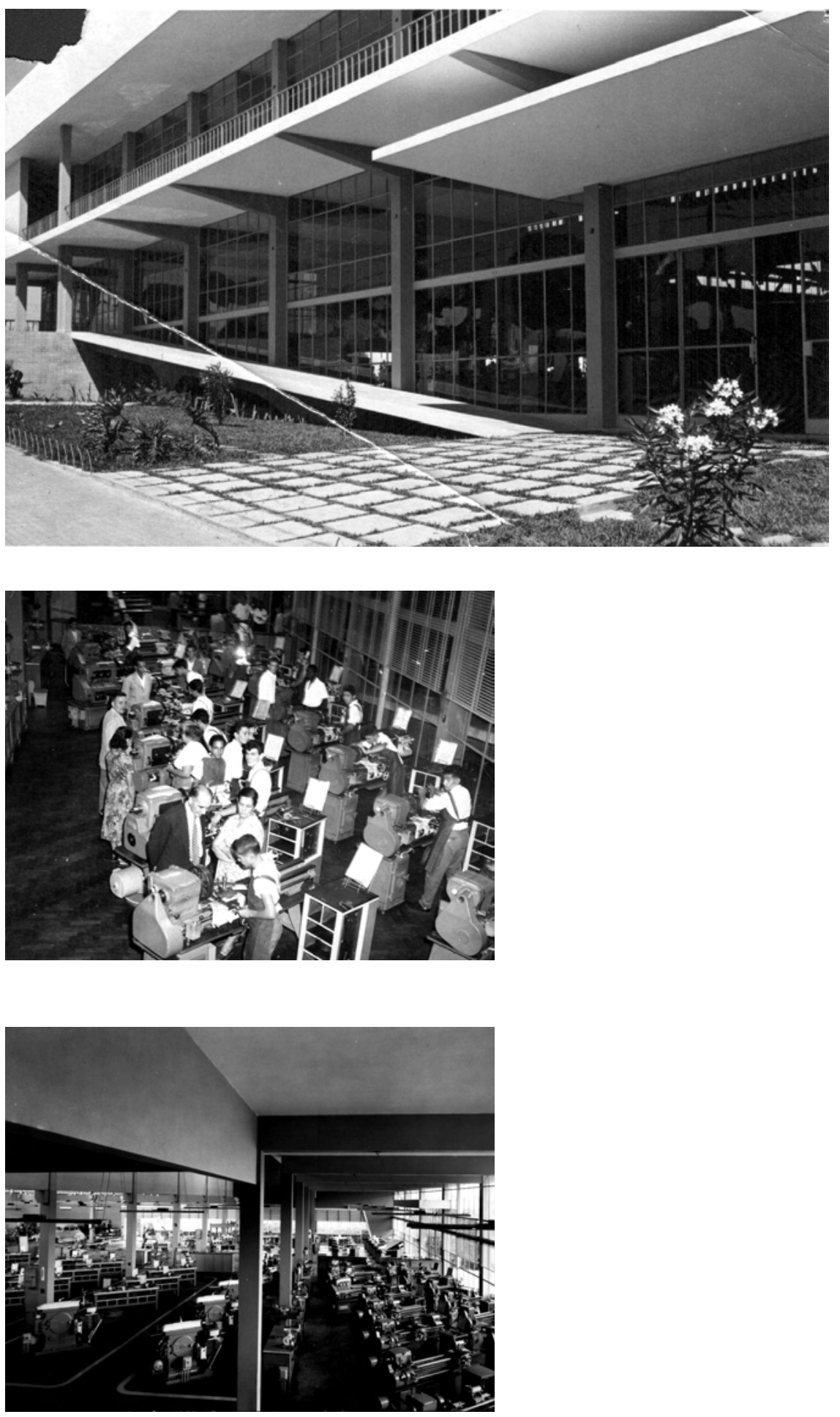

Figura 18: Marquise de entrada da oficina, elemento característico da arquitetura moderna. Fonte: Arquivo SENAI Bauru

Figura 19: Vista interna da oficina. Observar os grandes vãos envidraçados projetados para obter iluminação e ventilação naturais. Fonte: Arquivo SENAI Bauru

Figura 20: Vista interna da oficina. Observar os grandes vãos envidraçados projetados para obter iluminação e ventilação naturais. Fonte: Arquivo R.J.G. Tibau 
bloco da escola era composto de dois pavimentos além de parte do pavimento semi-enterrado que abrigava os sanitários da oficina, sob o hall de entrada da escola. O pavimento térreo da escola, em desnível com o da oficina, foi interligado internamente por uma escada e externamente por uma rampa. A entrada principal para a escola não foi plasticamente tão evidenciada como a da oficina, porém marcou o eixo de circulação interna do edifício: o hall de entrada faz acesso entre oficina (ala norte) e a escola (ala sul). Portanto, o térreo da ala sul, composta pela parte administrativa e social da escola, abrigava a secretaria, diretoria, dentista, médico, copa, refeitório e sanitários. Atendendo a um dos objetivos do SENAI de desempenhar melhor sua função social criando um ambiente favorável ao convívio mútuo entre todos, a sociabilidade, foi projetado o refeitório parcialmente aberto para a rua interligado com o pavilhão social já existente através de uma passagem coberta. No pavimento superior a divisão interna adotada foi através de corredores laterais, assim como no pavimento térreo, porém alternados ora pela fachada oeste e ora pela fachada leste. Ambos os corredores laterais foram projetados abertos para o exterior, possibilitando a relação da paisagem urbana com a paisagem natural, atendendo à atratividade, além de proporcionar sombra nas aberturas das salas de aula. A ala norte abrigava a sala dos professores e quatro salas de aulas, as quais tinham suas janelas voltadas para o pé-direito da oficina, atendendo ao objetivo de unir a teoria com a prática, à interligação. A ala sul era composta de três salas de aula - sapataria, desenho e vocacional - e sanitários. Projetadas com áreas distintas, iluminação e ventilação bilaterais, as salas de aula foram divididas com separações móveis de armários para que estes espaços pudessem se adequar de acordo com a necessidade da escola, proporcionando a flexibilidade no dimensionamento do espaço em função da evolução da indústria e do ensino. 


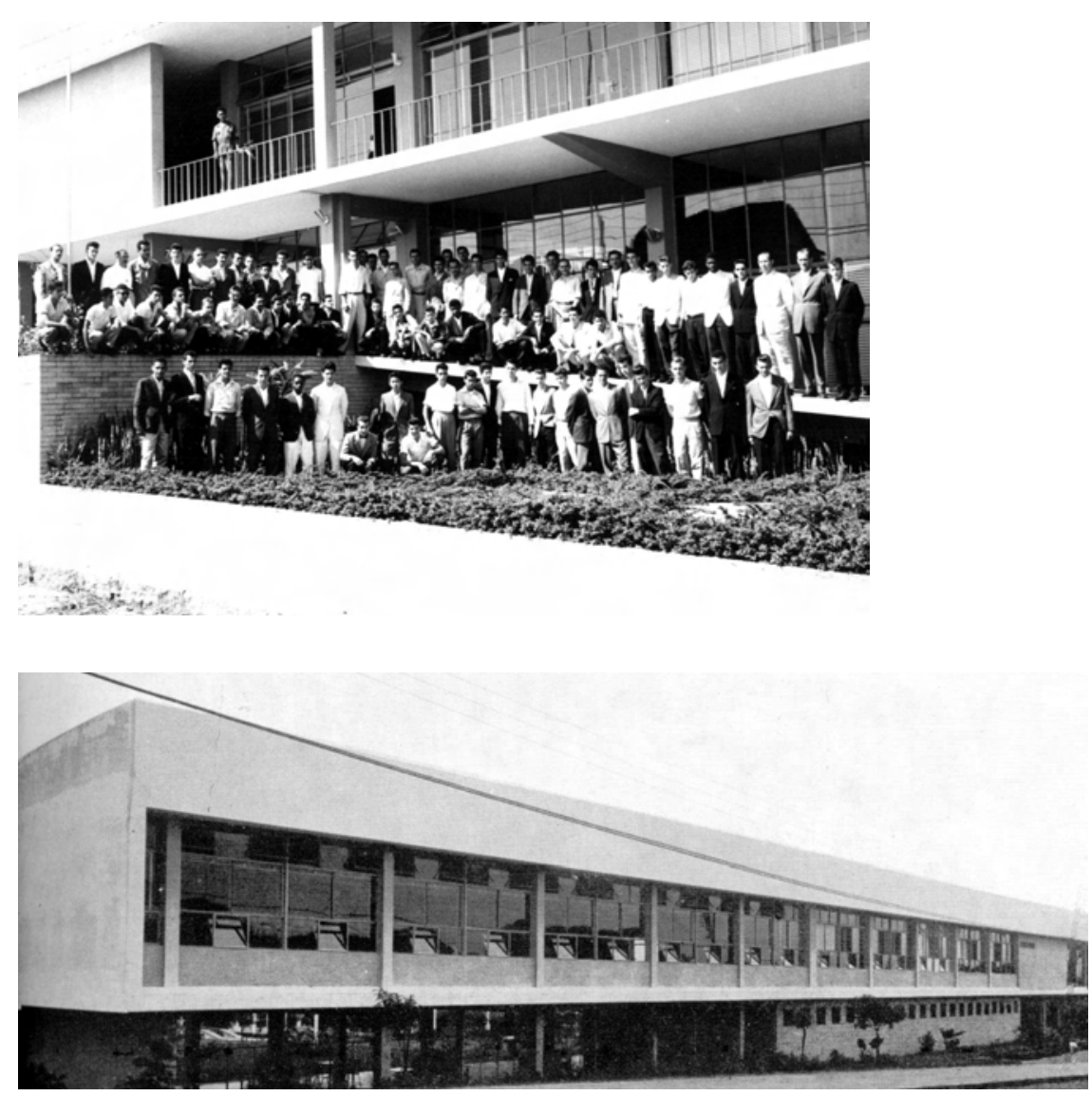

Figura 21: Observar o corredor leste do pavimento superior. Esta circulação além de tornar a escola aberta para a cidade, também proporcionou proteção térmica nas paredes envidraçadas das salas de aula. Foto de 1960.

Fonte: Arquivo SENAI Bauru

Figura 22: Observar o ritmo diferenciado das pequenas janelas do pavimento térreo, ao longo da fachada horizontal.

Fonte: Acrópole $\mathrm{n}^{\circ} 258$ (1960:131)

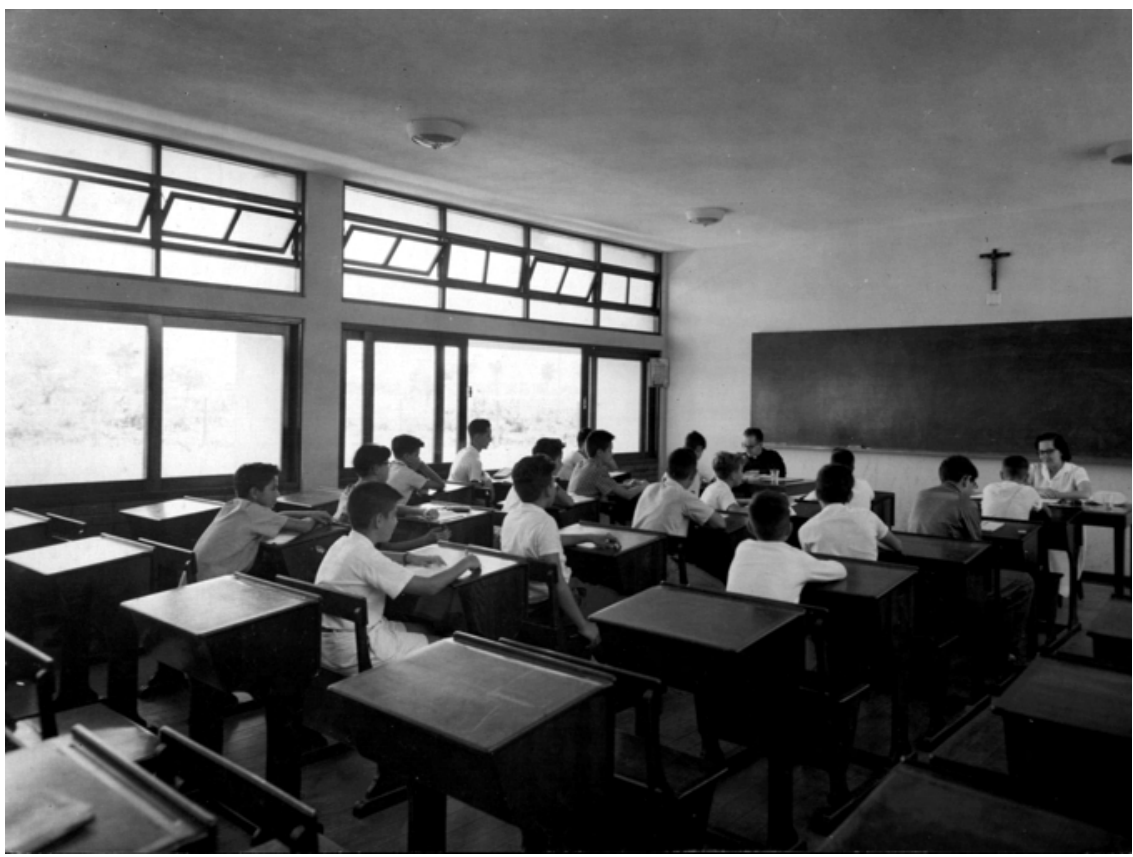

Figura 23: Vista de uma das quatro salas de aula do pavimento superior. As janelas de 2,50 metros de altura foram projetadas para ligar visualmente a aula com a oficina, atendendo um dos objetivos do SENAI de unir teoria e prática. Fonte: Arquivo R. J. G. Tibau

A resolução estrutural da Escola João Martins Coube fez uso do concreto em sua forma retilínea e racionalista, herança dos mestres paulistas. Modulada de pilar a pilar, as amplas janelas proporcionavam aos alunos uma escola aberta para o exterior, concretizando a transparência da escola para a cidade, assim como a preferência projetual em favor do sol da manhã. A fachada 
envidraçada da oficina, protegida termicamente pela laje em balanço do corredor externo lateral do pavimento superior, mostrou como a divisão interna do espaço também se refletiu termicamente na escola, pois o recuo do edifício em relação às circulações laterais beneficiou - conforto térmico em ambos os pavimentos e fachadas. Em particular, o edifício foi projetado para incorporar a arte à arquitetura através dos diferentes planos das fachadas leste e oeste. Seguindo uma das recomendações deixadas por Corbusier, o qual propôs a colaboração dos artistas em parceria com os arquitetos para desempenhar no conjunto arquitetônico a concepção de painéis artísticos, combatendo as noções de artes decorativas e valorizando o regionalismo, Tibau projetou na fachada leste um mural artístico, o qual não chegou a ser construído. A intenção artística foi complementada através dos brises da fachada oeste, "verdadeiros painéis [...] de arte concretista" (ANELLI, 2001:142), atingindo a plástica baseada na concepção do abstrato.

A Escola João Martins Coube de Bauru foi projetada inicialmente para oferecer os cursos de metal, madeira, motores e construção civil, segundo Habitat 12 (1953:17), tendo sido inaugurada em 1957.

A concepção de integrar escola, oficina e lazer, através de edifício flexível, de amplas janelas e aberto para o urbano, estimulou a relação aluno-escola atendendo às necessidades do típico aluno SENAI, ao rendimento, tornando o ensino muito mais eficiente e atrativo.

Figura 24: Em primeiro plano a oficina em desnível e com pédireito duplo em relação ao pavimento térreo da escola. Fonte: Acrópole $n^{\circ} 258$ (1960:130)

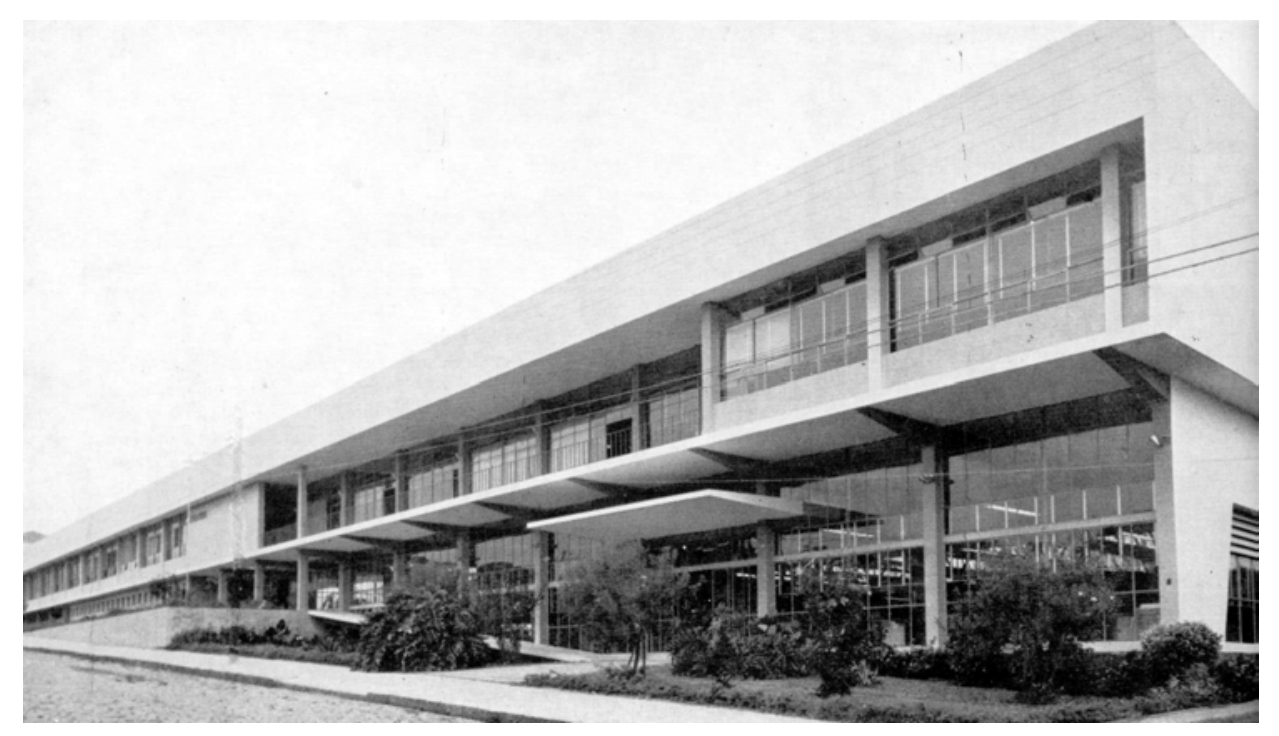




\section{PROJETO 5}

\section{Escola Senai de Piracicaba, 1954}

Projetada por Hélio de Queiroz Duarte e Ernest Robert de Carvalho Mange, a Escola SENAI de Piracicaba ${ }^{3}$, interior de São Paulo. Implantada numa quadra de $7.902,30 \mathrm{~m}^{2}$, a escola foi composta inicialmente por três blocos caracterizados pela oficina, salas de aulas e pavilhão social, com aproximadamente $2.460,00 \mathrm{~m} 2$ de área construída.

projeto foi composto pelos três blocos referidos acima. Seu programa construtivo era: oficina de mecânica, sete salas de aulas, administração e complementos, serviços de assistência social, médica e dentária, recreio coberto com sanitários, auditório, biblioteca, refeitório, vestiários e quadra de esportes.

A planta completa do projeto original não foi encontrada, mas sim diversas pranchas do projeto original, tanto o de prefeitura como o executivo, que revelaram o ano de sua concepção, a implantação geral do projeto, os blocos originais, detalhamentos, cortes e elevações. A planta foi obtida através de um levantamento feito pelo SENAI, o que foi de grande utilidade para o reconhecimento do projeto e seu possível redesenho parcial. Portanto, para facilitar a leitura arquitetônica do projeto e representá-lo graficamente através de significativos dados obtidos no projeto original, foram redesenhados a implantação, as plantas de cada bloco e a elevação principal.

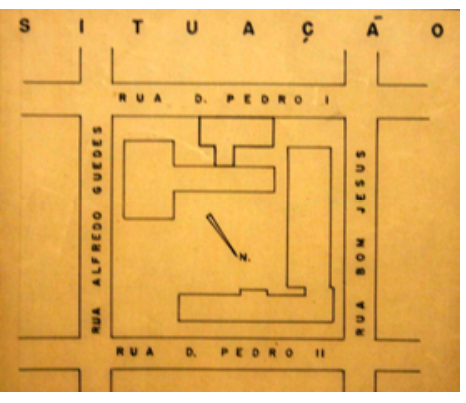

Figura 1: Planta de situação da Escola de Piracicaba, 1954. Fonte: Foto Ferraz, arquivo SENAI

Figura 2: Observar os dados do selo do projeto da Escola de Piracicaba, concebido em fevereiro de 1954, com autoria de Hélio Duarte e Ernest Mange. Fonte: Foto Ferraz, arquivo SENAI

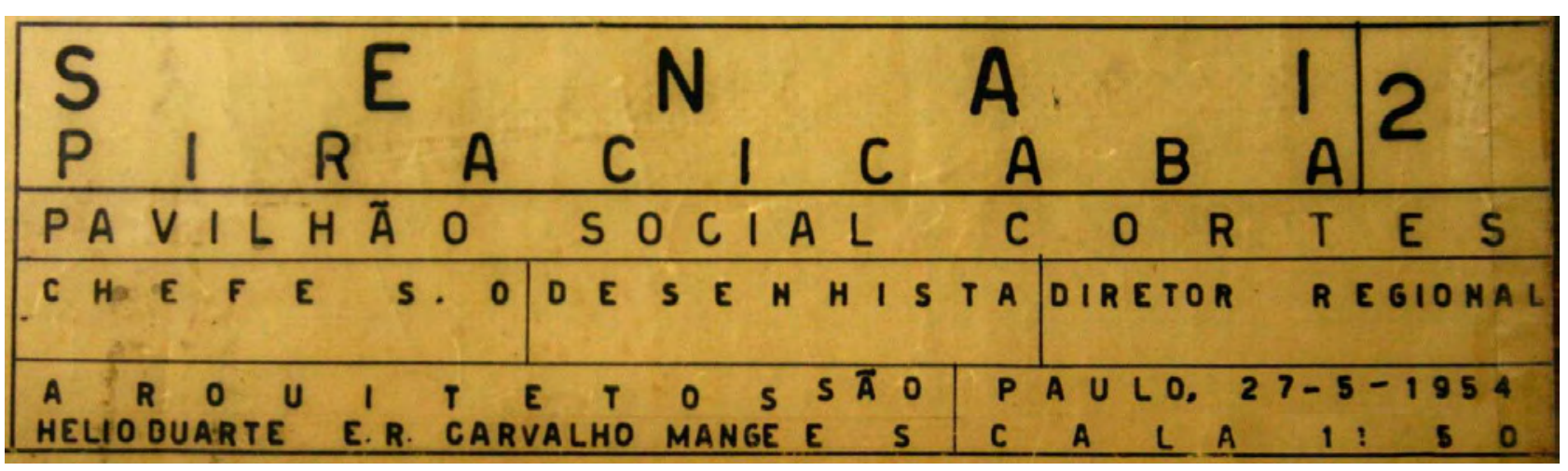

\footnotetext{
${ }^{3}$ A Escola SENAI de Piracicaba foi publicada pela revista Acrópole n 217 (s.d.:12,13 e 14).
} 


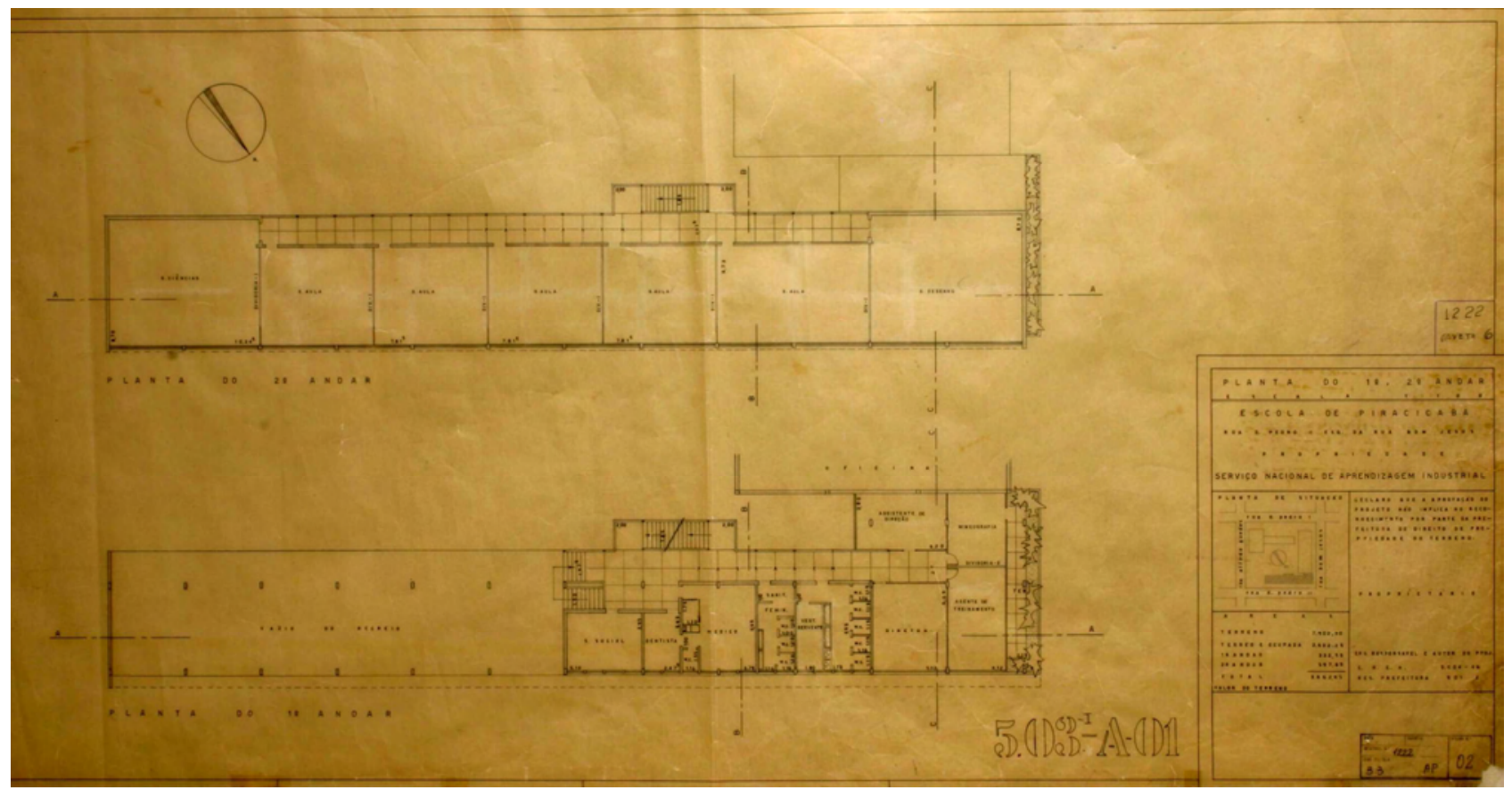

Figura 3: Planta $1^{\circ}$ e $2^{\circ}$ andares $\left(2^{\circ}\right.$ e $3^{\circ}$ pavimentos) do bloco das salas de aula da Escola de Piracicaba, 1954. Única prancha do projeto original das plantas encontrado no arquivo do SENAI.

Fonte: Foto Ferraz, arquivo SENAI

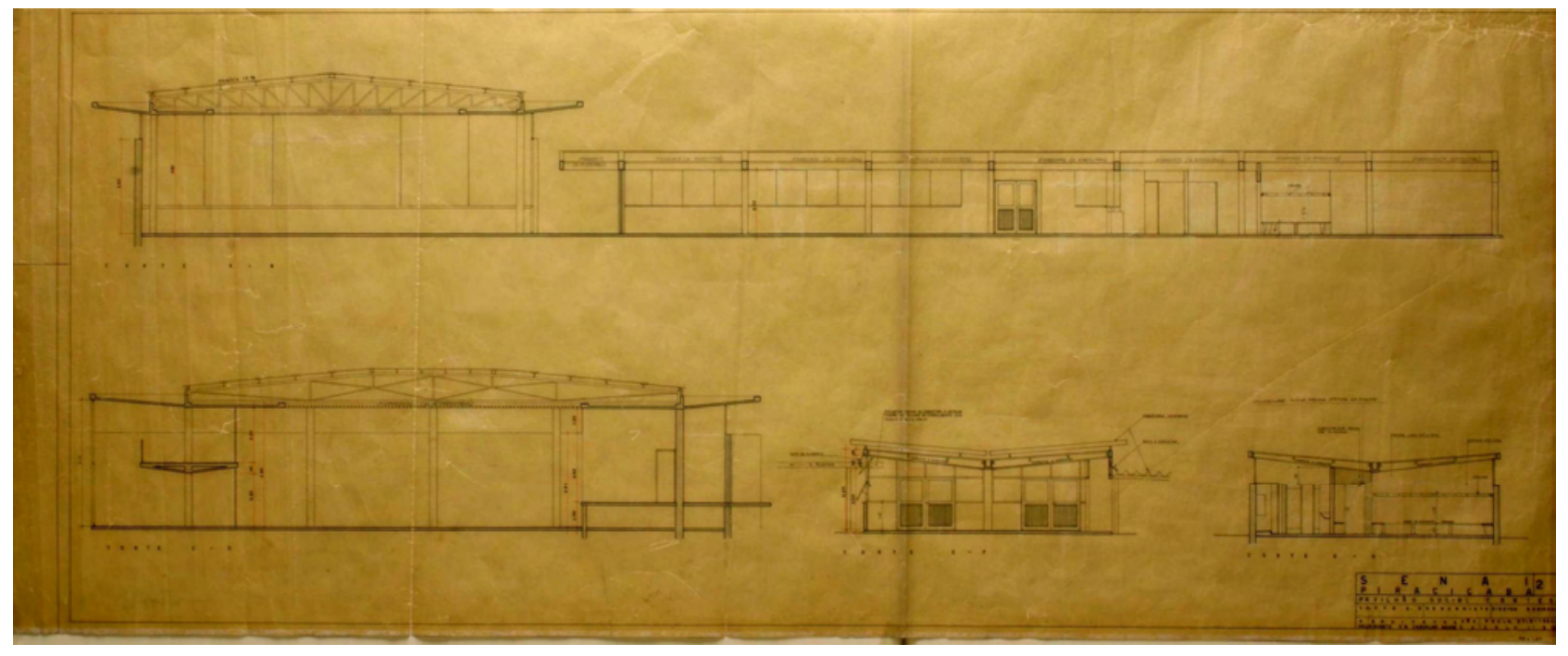

Figura 4: Prancha original dos Cortes do bloco do Pavilhão Social, Escola de Piracicaba, 1954. Fonte: Foto Ferraz, arquivo SENAI 


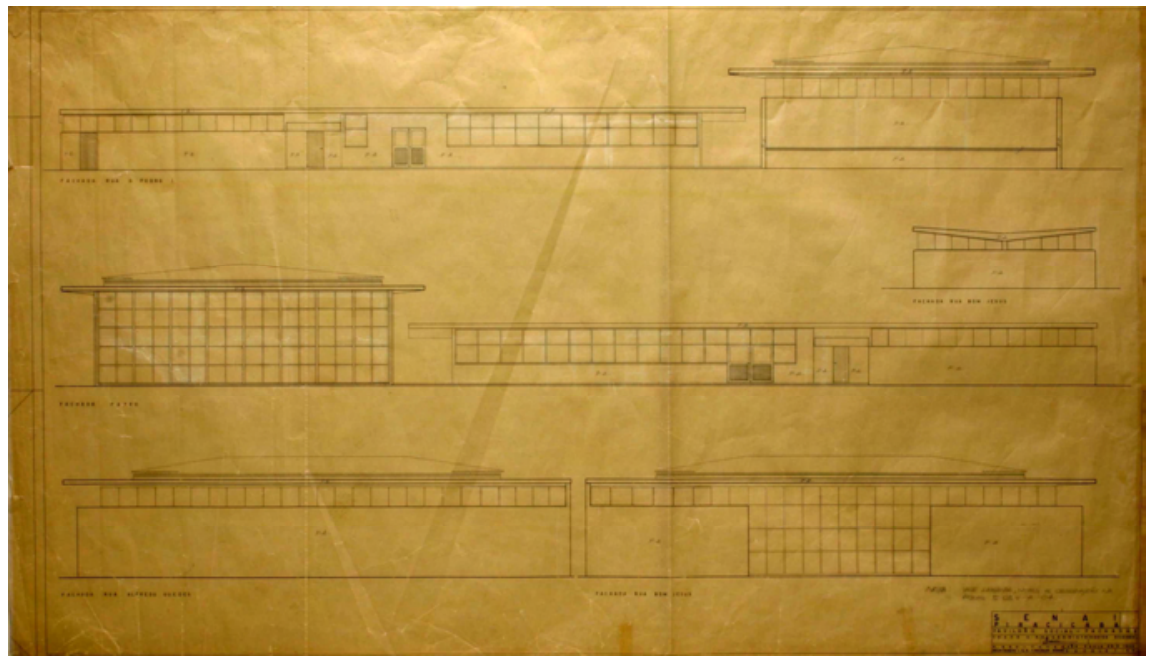

Figura 5: Prancha original das Elevações do bloco do Pavilhão

Social, Escola de Piracicaba, 1954.

Fonte: Foto Ferraz, arquivo SENAI

Figura 6: Redesenho da planta da implantação e pavimento térreo dos blocos da: oficina, salas de aula e pavilhão social.

Fonte: Ferraz, 2005

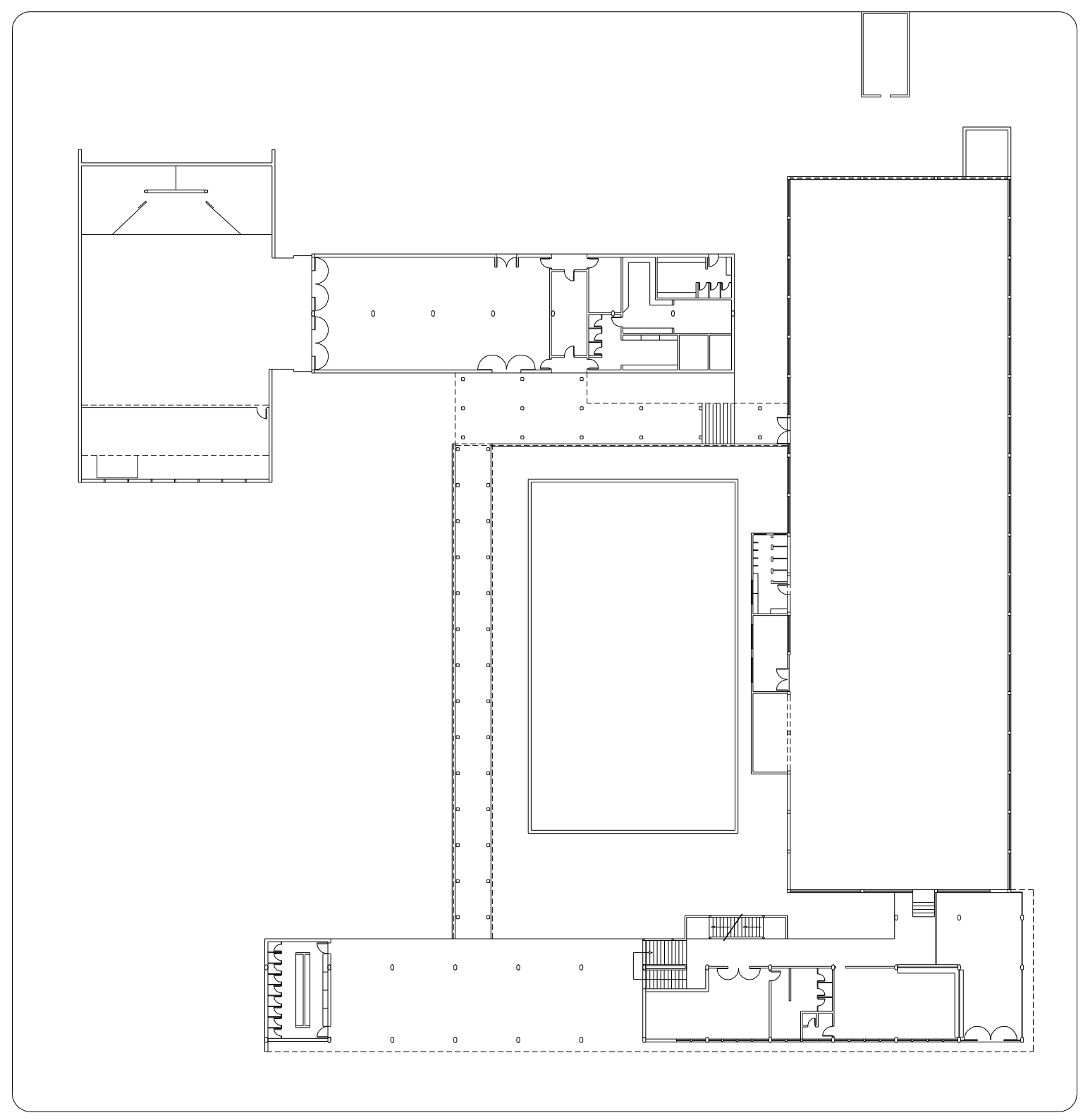




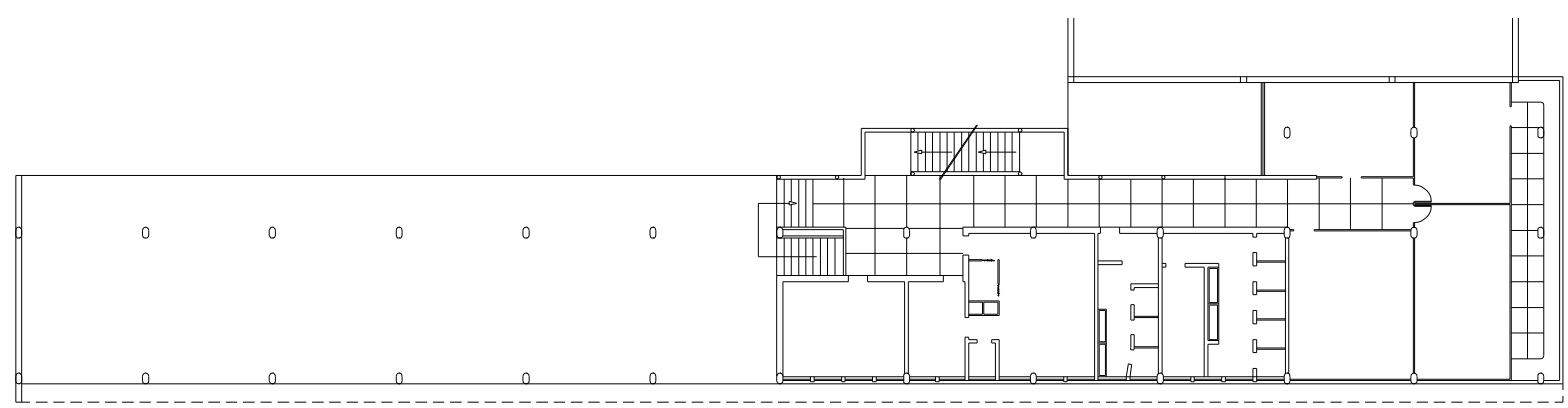

01 10

Figura 7: Redesenho da planta do primeiro andar do bloco das salas de aula. Fonte: Ferraz, 2005

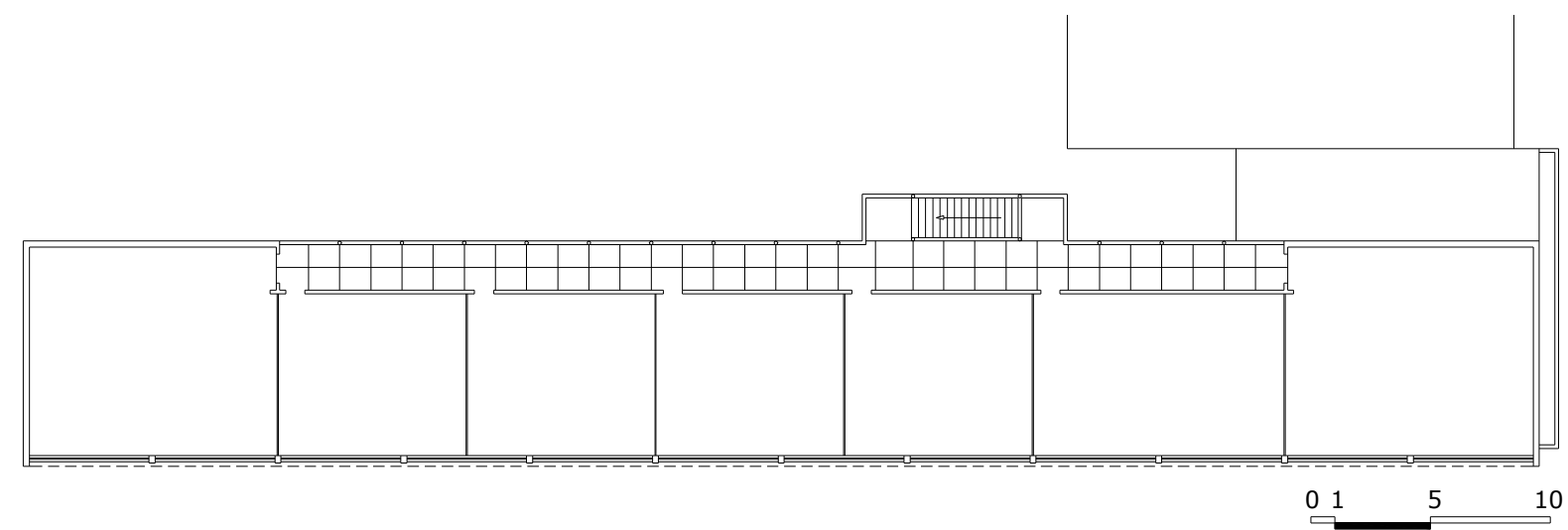

Figura 8: Redesenho da planta do segundo andar do bloco das salas de aula.

Fonte: Ferraz, 2005
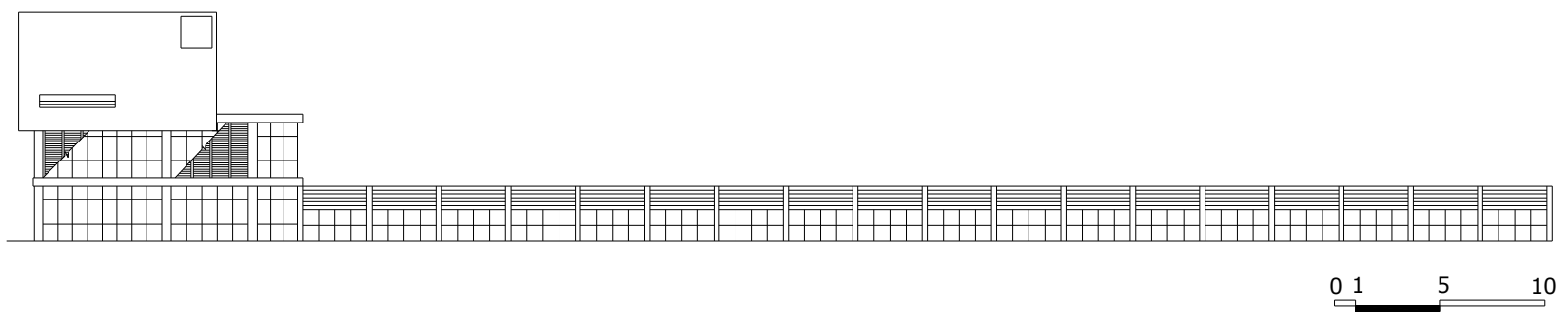

Figura 9: Redesenho da elevação noroeste (rua Bom Jesus).

Fonte: Ferraz, 2005

O bloco que compunha a fachada principal era o bloco da escola. Composto parcialmente por três pavimentos, abrigava no pavimento térreo: hall de entrada, secretaria, sanitários para funcionários e sala de instrutores. O pátio coberto, sustentado por pilotis, foi projetado cerca de dois metros acima do nível do térreo e, com pé-direito de 3,60 metros, interligando-se com o pavilhão social através de uma passarela coberta, atendendo a um dos objetivos do SENAI de desempenhar melhor sua função social criando um 
ambiente favorável ao convívio mútuo entre todos, a sociabilidade e, atendendo à pedagogia da atratividade de ser uma escola para 0 aluno. No primeiro andar (segundo pavimento sobre o térreo) foram projetadas as instalações sociais e administrativas como: assistência de direção, mimeografia, agência de treinamento, diretoria, sanitários e salas de atendimento social, médico e dentário. No último pavimento foram projetadas sete salas de aula, sendo uma de ciência e outra de desenho, separadas por divisórias (flexibilidade), com pédireito de 3 metros, todas com iluminação e ventilação para a face nordeste, permitindo ampla visibilidade para o urbano (sociabilidade). A divisão interna adotada neste bloco foi através de corredor lateral, voltado para a face sudoeste, sendo que no pavimento térreo esta circulação interligava as atividades deste bloco com o bloco da oficina (interligação).
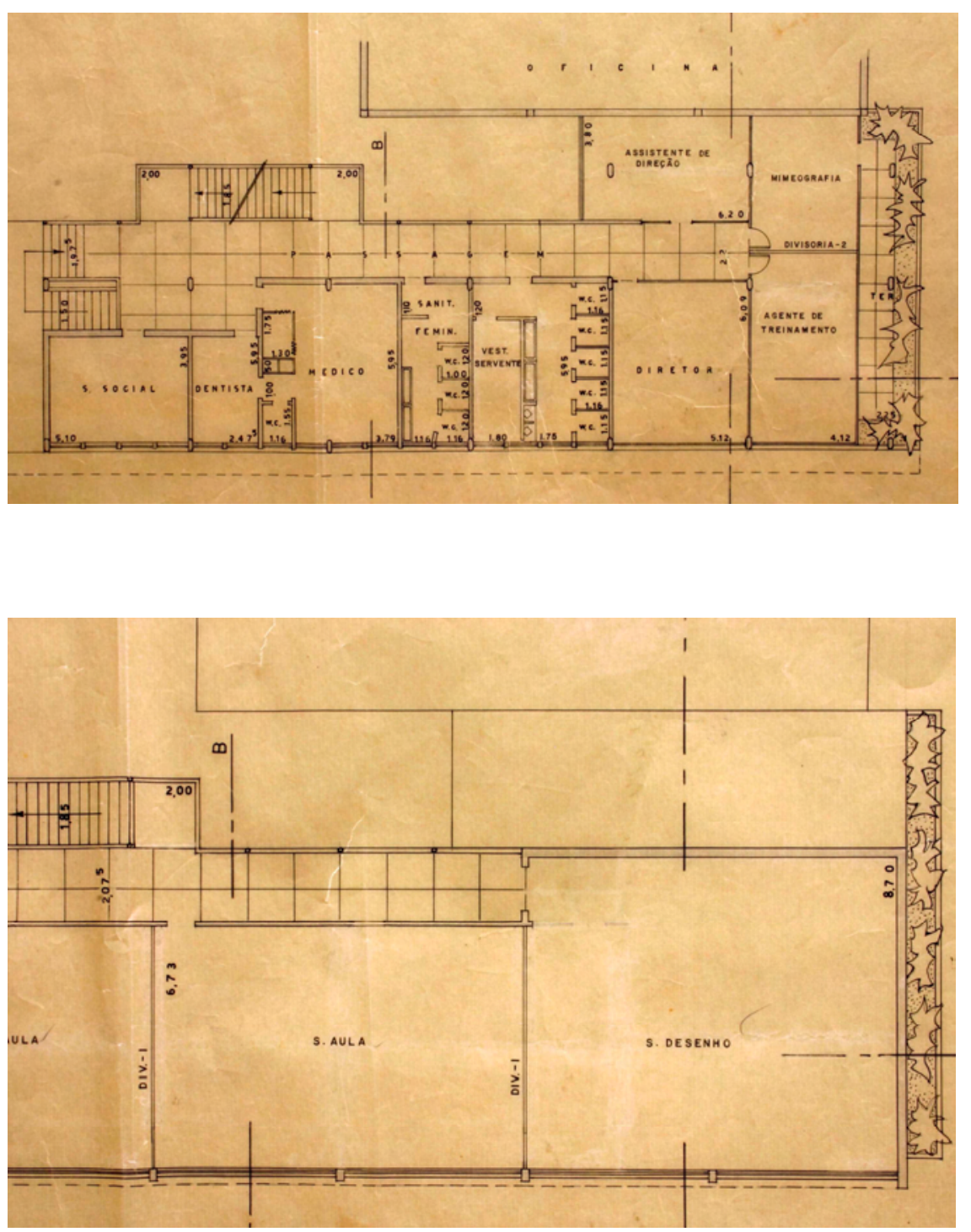

Figura 10: Detalhe da planta do $1^{\circ}$ andar do bloco da escola, Escola de Piracicaba, 1954. Observar circulação lateral e instalações sociais e administrativas. Fonte: Foto Ferraz, arquivo SENAI

Figura 11: Detalhe da planta do $2^{\circ}$ andar do bloco da escola, Escola de Piracicaba, 1954. Salas de aula separadas por divisórias dispostas na modulação do bloco. Fonte: Foto Ferraz, arquivo SENAI 
Figura 12: Corte do bloco da escola na parte que abriga três pavimentos, Escola de Piracicaba, 1954.

Fonte: Foto Ferraz, arquivo SENAI
Figura 13: Elevação do bloco do Pavilhão Social composto por dois volumes, Escola de Piracicaba, 1954. À esquerda volume do auditório e biblioteca e, à direita, volume do refeitório. Fonte: Foto Ferraz, arquivo SENAI

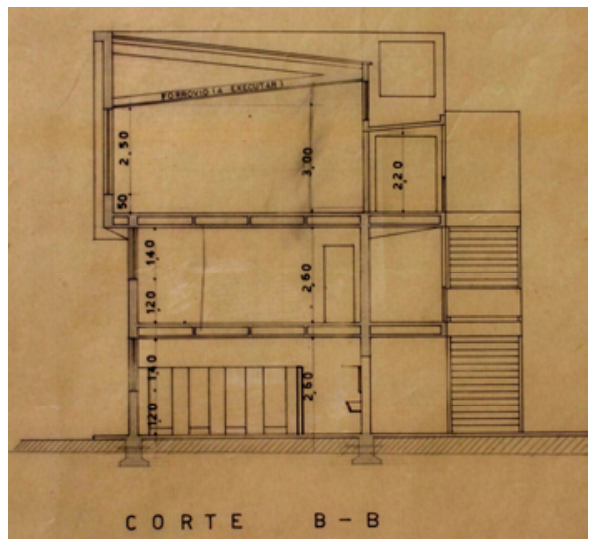

No segundo bloco, perpendicular ao bloco da escola, foi projetada a oficina num edifício horizontal, ao longo da rua Bom Jesus. Modulada no perímetro pela estrutura dos pilares, a oficina possui grande área livre marcada pelo pé-direito de 4 metros, cobertura tipo shed com iluminação zenital, iluminação nas laterais voltadas para as faces nordeste e sudoeste permitindo um melhor aproveitamento da luz, visando à economia proposta pelo SENAI. Ainda, no mesmo bloco foram projetados três anexos: sanitário para os alunos, sala para forja e depósito. A interligação e o rendimento da prática com a teoria foram estabelecidos através de uma ligação somente física, entre blocos, sem oferecer a visão da oficina às salas de aula.

O terceiro bloco, o pavilhão social, foi projetado em forma de " $\mathrm{T}^{\prime}$ e era interligado tanto ao bloco da oficina como ao da escola. Abrigava em um volume o auditório e a biblioteca e, no outro volume, refeitório, cantina, sanitários, vestiários e depósito de merenda. O volume do auditório tinha em sua face nordeste voltada para o pátio, uma fachada toda envidraçada, deixando o acervo da biblioteca em exposição para os alunos, atendendo ao rendimento proposto pelo SENAI.

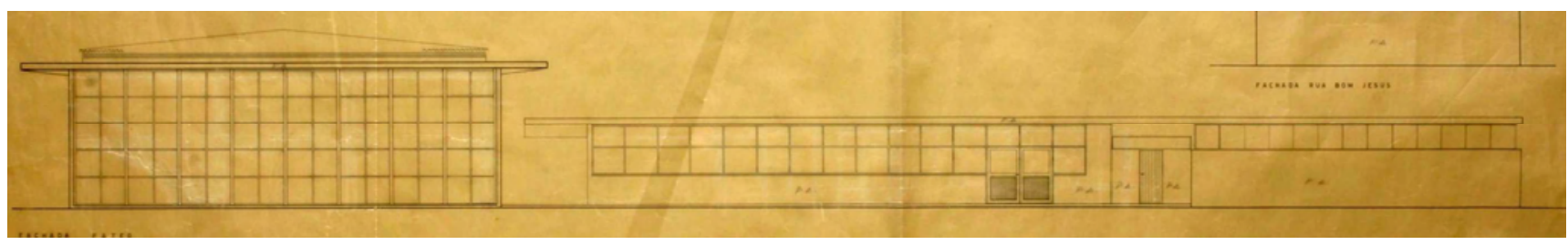



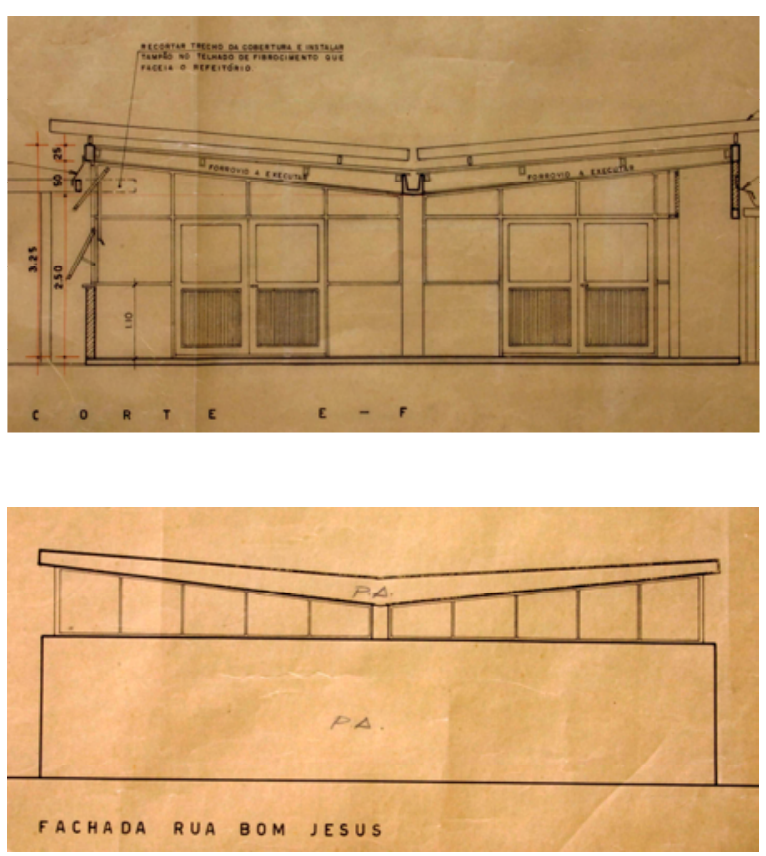

As características particulares da pedagogia do SENAI também condicionaram o projeto desta escola. Assim, as salas de aula, separadas por divisórias, tinham flexibilidade de espaço de acordo com o crescimento da escola. $\bigcirc$ térreo deste mesmo bloco abrigava o pátio coberto do recreio marcado por pilotis, bem como os sanitários, proporcionando a atratividade da escola através do visual da área esportiva (quadra). A sociabilidade foi obtida pelo bloco do pavilhão social como um ponto de convívio em comum para apresentações (auditório), pesquisa (biblioteca) e refeições (refeitório). A perpendicularidade entre os blocos, ligados entre si, acusa a interligação e rendimento, concretizando fisicamente a idéia de unir a teoria com a prática, respeitando algumas dificuldades como a acústica, iluminação e ventilação.

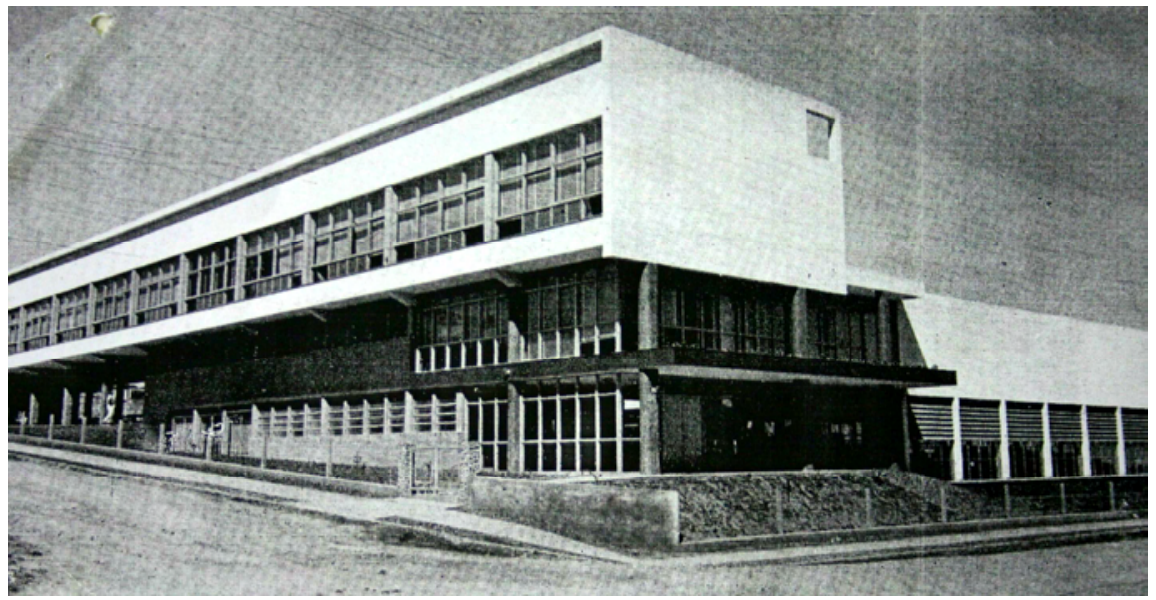

Figura 14: Corte transversal do volume do refeitório, Escola de Piracicaba, 1954. Fonte: Foto Ferraz, arquivo SENAI

Figura 15: Elevação noroeste do volume do refeitório, Escola de Piracicaba, 1954. Fonte: Foto Ferraz, arquivo SENAI
Figura 16: Fachada principal da Escola Senai de Piracicaba, década de 50. Fonte: Acrópole n 217 (s.d.:12) 


\section{PROJETO 6}

\section{Pavilhão Social da Escola Roberto Simonsen, Brás, São Paulo, 1956}

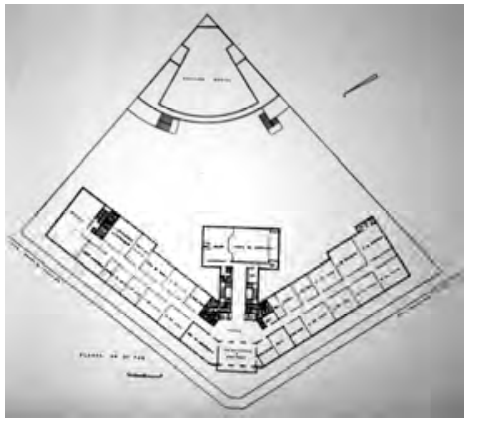

Figura 1: Planta de situação do Pavilhão Social da Escola Roberto Simonsen, Brás, São Paulo, 1956.

Fonte: Bem Estar n ${ }^{\circ}$ 5/6 (1960:7)
Outro exemplo da nova arquitetura do SENAI foi o Pavilhão Social' ${ }^{1}$ construído para atender à Escola Roberto Simonsen, já existente numa arquitetura tradicional. Projetado em 1956 por Hélio de Queiroz Duarte e Ernest Robert de Carvalho Mange, o Pavilhão foi construído para atender à sociabilidade proposta pela nova pedagogia. Localizado no fundo do terreno, com cerca de $1.500,00 \mathrm{~m}^{2}$ de área construída, o Pavilhão não seguiu a grandiosidade do projeto antigo, mas sim uma solução plástica pautada na arquitetura moderna.

O programa construtivo do Pavilhão foi resolvido em dois pavimentos em um único bloco. No térreo foram projetados: recreio coberto, sanitários, cozinha e três salas. $\bigcirc$ primeiro andar abrigava $\circ$ terraço, auditório, sanitários, auditório com palco, camarins e depósito. Em forma de leque, o pavilhão foi projetado com a fachada principal e única voltada para o edifício antigo, sendo os demais perímetros geminados com os lotes vizinhos.

projeto original foi encontrado, tanto pranchas do projeto executivo como de prefeitura, nas escalas 1:50 e 1:100, revelando as dimensões do pavilhão, detalhamentos do projeto, cortes e elevação. O conhecimento do projeto original também foi obtido através da publicação em periódico da época, Bem Estar n 5/6 (1960:7), acrescentando o detalhamento da implantação do projeto no terreno e, a colaboração do arquiteto Lúcio Grinover no projeto arquitetônico e da arquiteta Ayako Nishikawa no projeto de paisagismo. Ainda, para facilitar a leitura arquitetônica do projeto e representá-lo graficamente através de significativos dados obtidos no projeto original, foram graficamente redesenhados plantas, corte e fachada.

1 Pavilhão da Escola Roberto Simonsen, no Brás, foi publicado pela revista Bem Estar n 5/6 (1960:7). 
Figura 2: Observar os dados do selo do projeto em escala 1:100,

Pavilhão Social da Escola

Roberto Simonsen, Brás, São

Paulo, 1956, autoria de Hélio Duarte e Ernest Mange.

Fonte: Foto Ferraz, arquivo SENAI

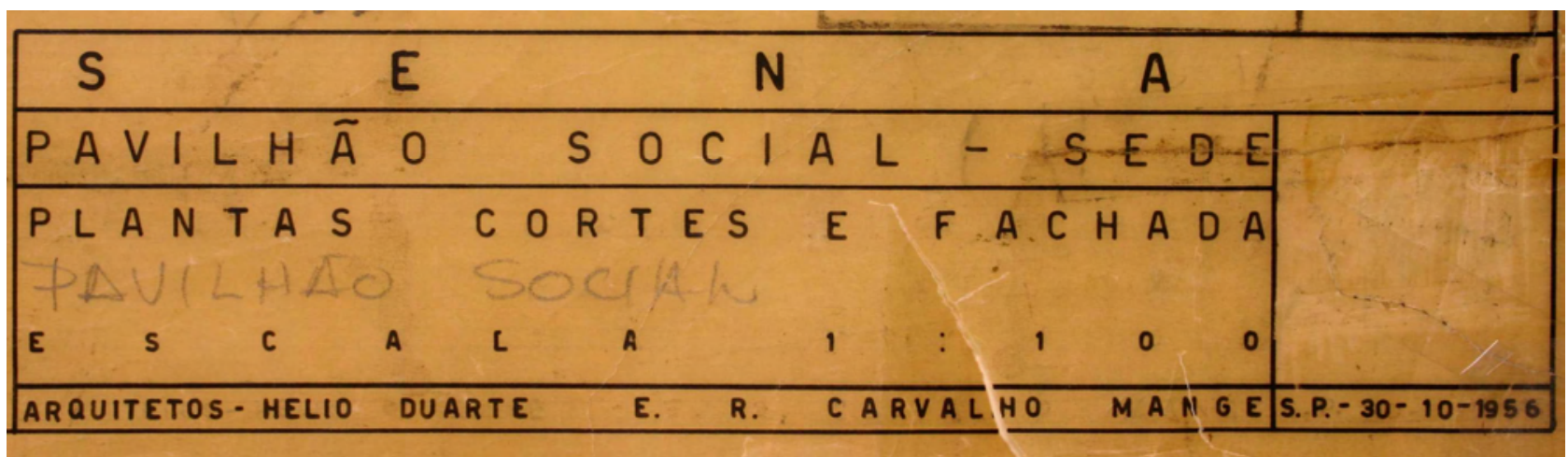

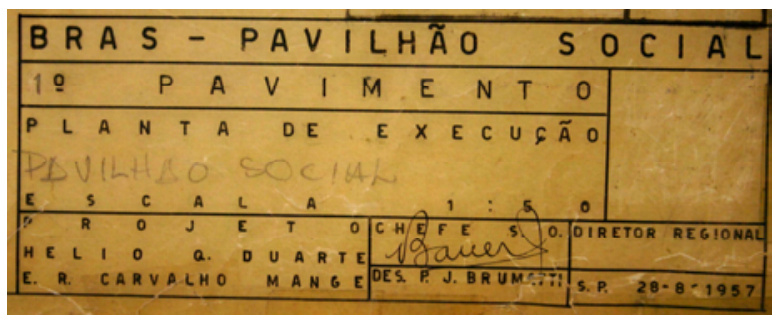

Figura 3: Observar os dados de um dos selos do projeto em escala 1:50, Pavilhão Social da Escola Roberto Simonsen, Brás, São Paulo, 1957, autoria de Hélio Duarte e Ernest Mange. Fonte: Foto Ferraz, arquivo SENAI

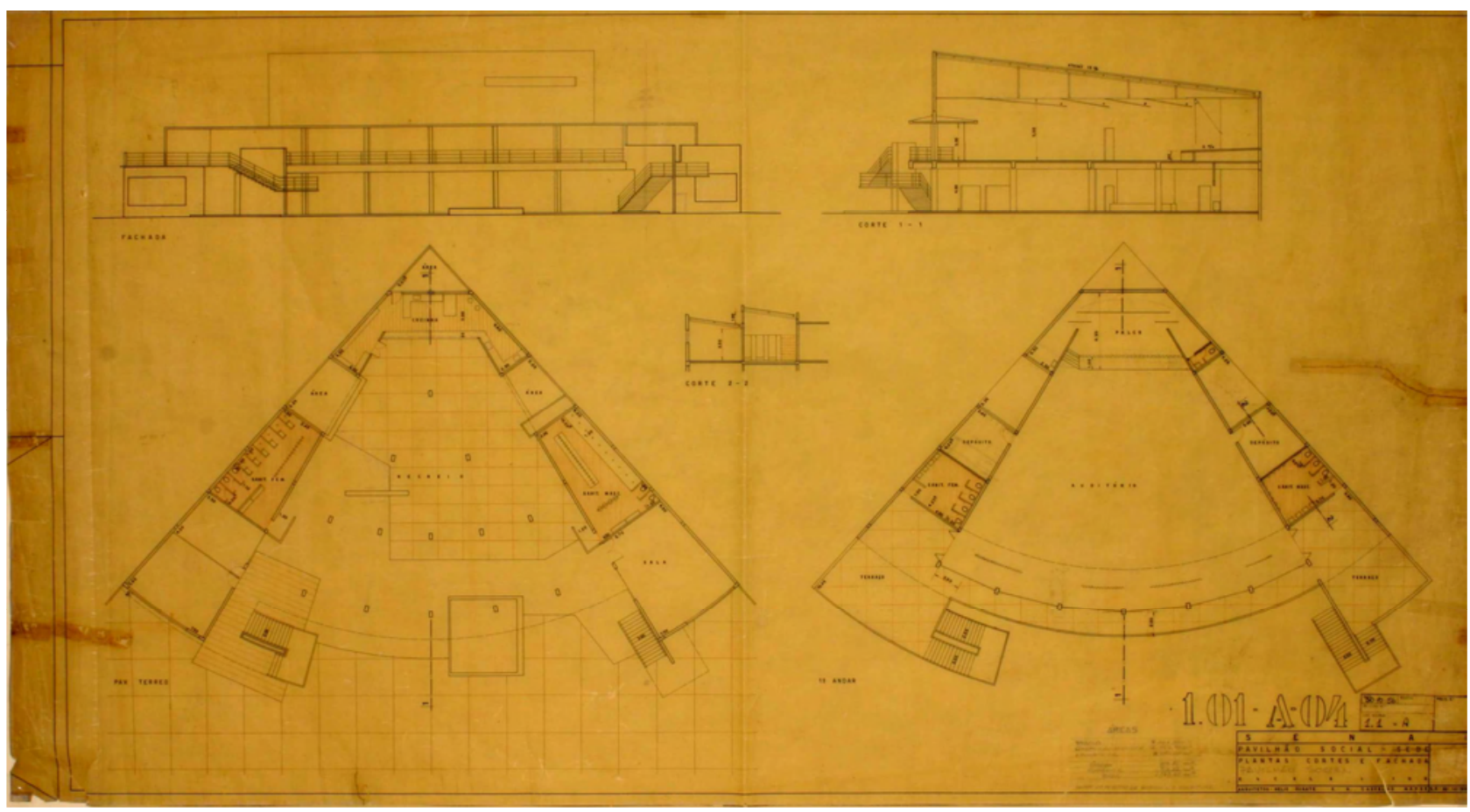

Figura 4: Prancha original em escala 1:100, Pavilhão Social da Escola Roberto Simonsen, Brás, São Paulo, 1956.

Fonte: Foto Ferraz, arquivo 
Figura 5: Planta do pavimento térreo, original na escala 1:100, Pavilhão Social, Escola de Piracicaba, 1956.

Fonte: Foto Ferraz, arquivo SENAI

Figura 6: Planta do $1^{\circ}$ andar, original na escala 1:100,

Pavilhão Social, Escola de Piracicaba, 1956.

Fonte: Foto Ferraz, arquivo SENAI
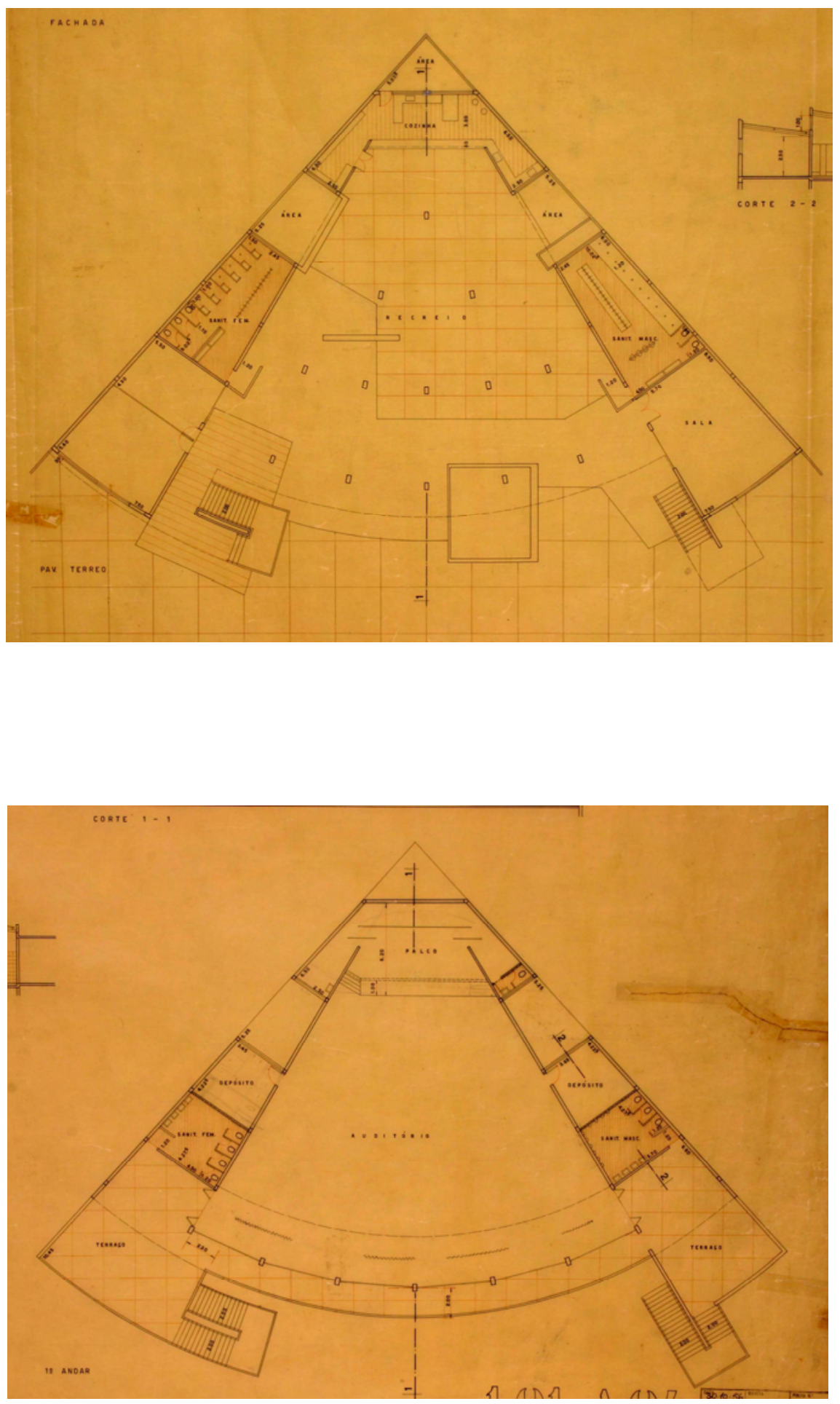


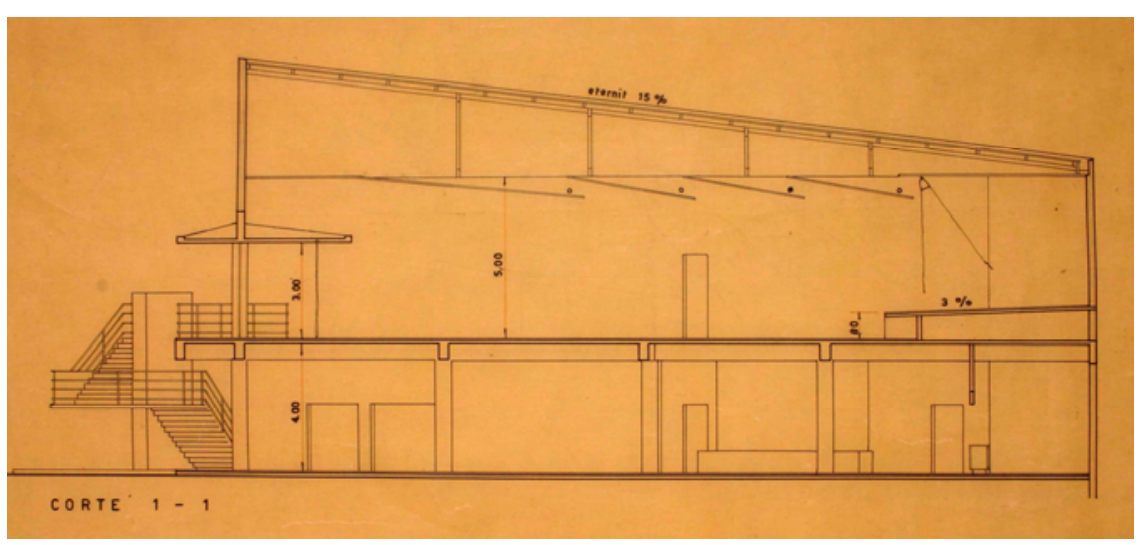

Figura 7: Corte 1, original na escala 1:100, Pavilhão Social,

Escola de Piracicaba, 1956.

Fonte: Foto Ferraz, arquivo SENAI

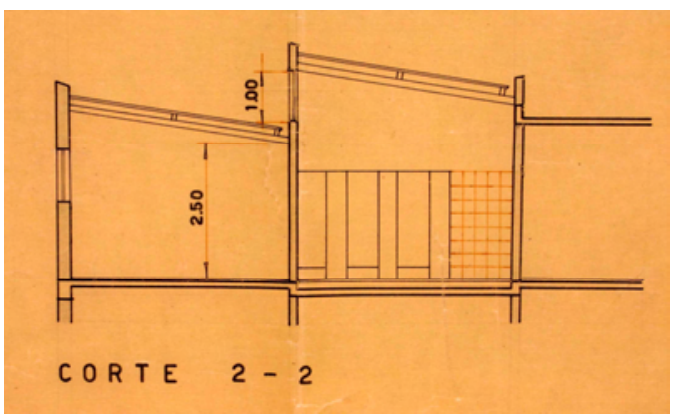

Figura 8: Corte 2, original na escala 1:100, Pavilhão Social,

Escola de Piracicaba, 1956.

Fonte: Foto Ferraz, arquivo SENAI

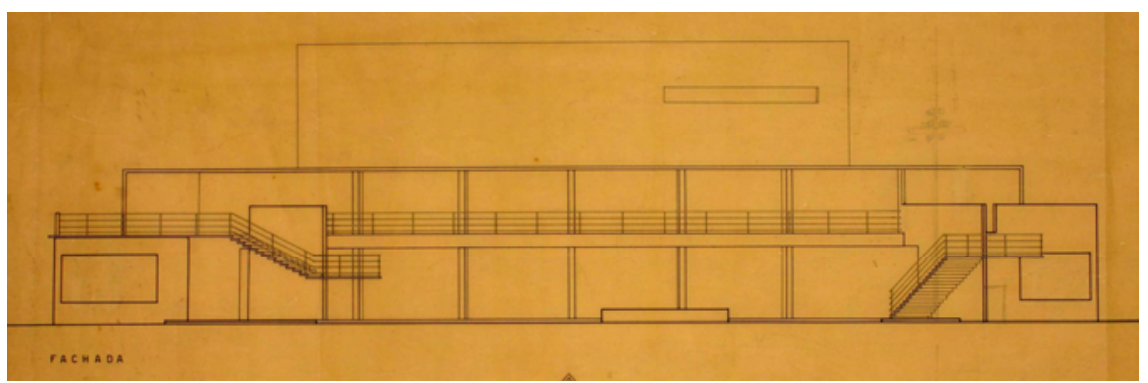

Figura 9: Elevação, original na escala 1:100, Pavilhão Social, Escola de Piracicaba, 1956.

Fonte: Foto Ferraz, arquivo SENAI

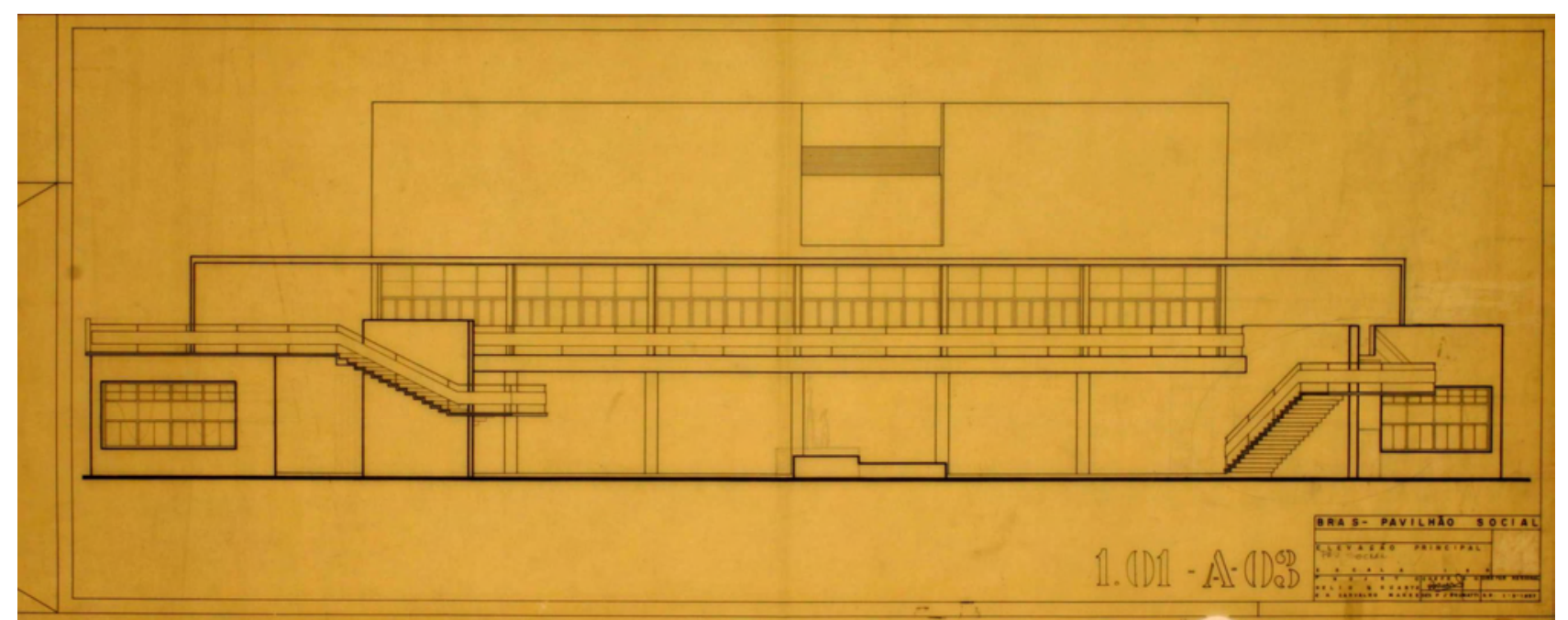

Figura 10: Elevação, original na escala 1:50, Pavilhão Social, Escola de Piracicaba, 1956.

Comparar com a figura anterior, observar diferenças entre o projeto executivo e prefeitura. Fonte: Foto Ferraz, arquivo 


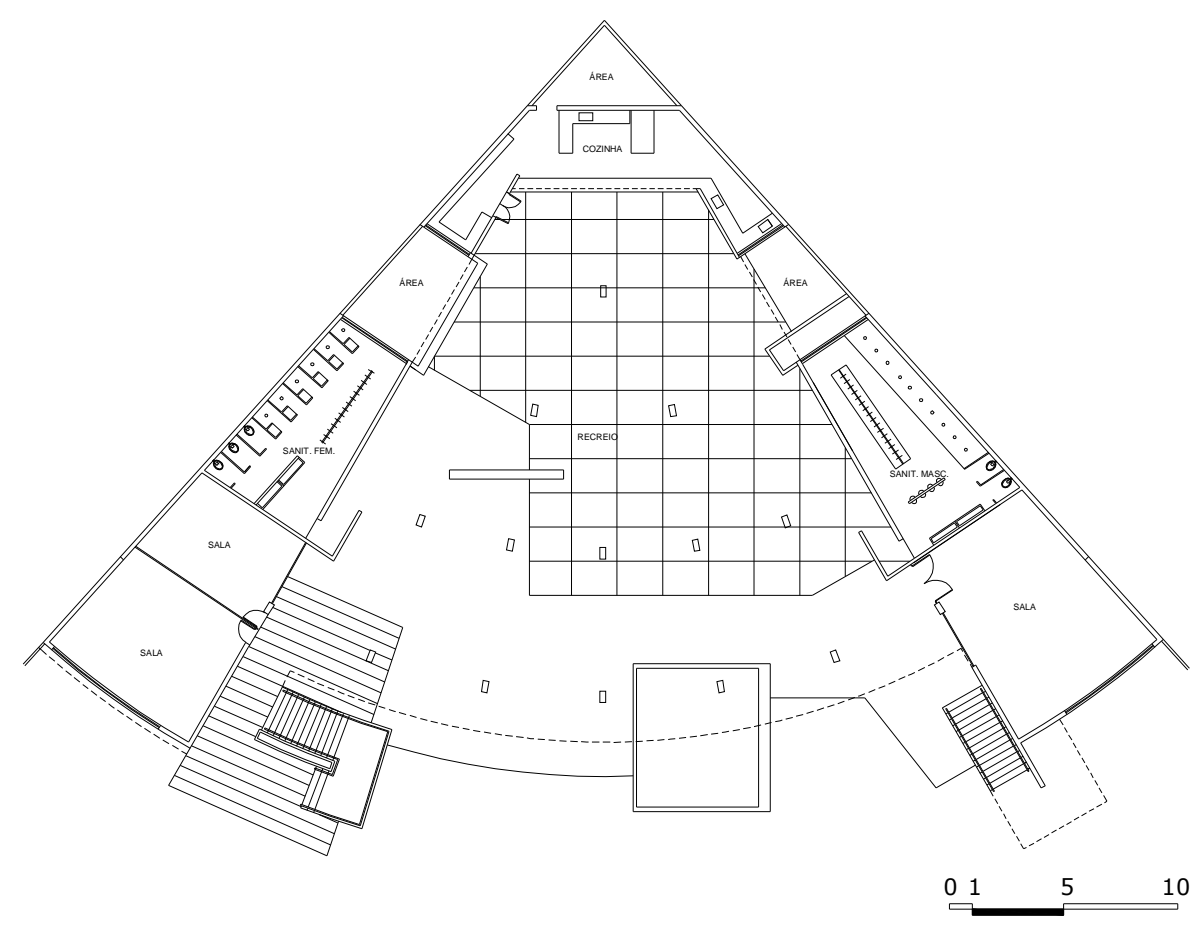

Figura 11: Redesenho da planta do pavimento térreo.

Fonte: Ferraz, 2005

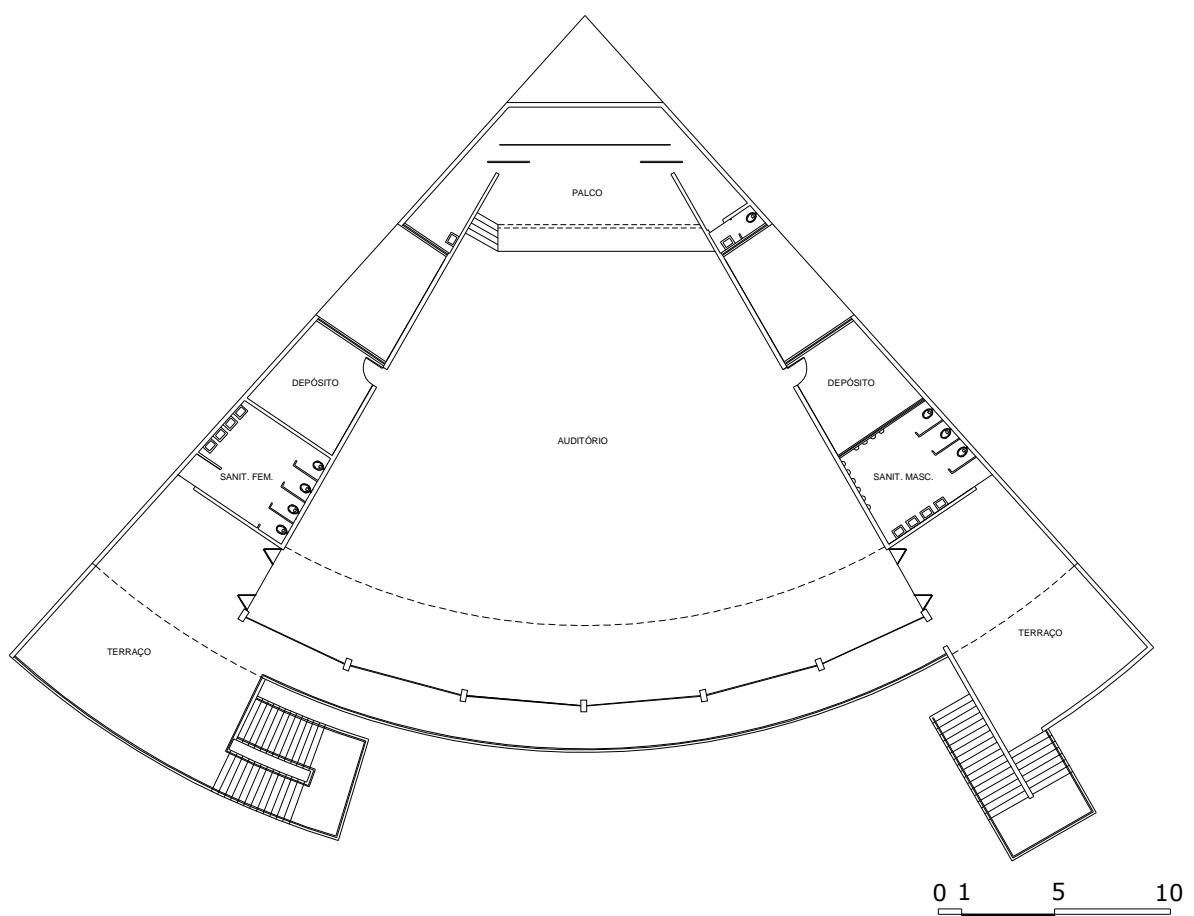

Figura 12: Redesenho da planta do primeiro andar. Fonte: Ferraz, 2005 


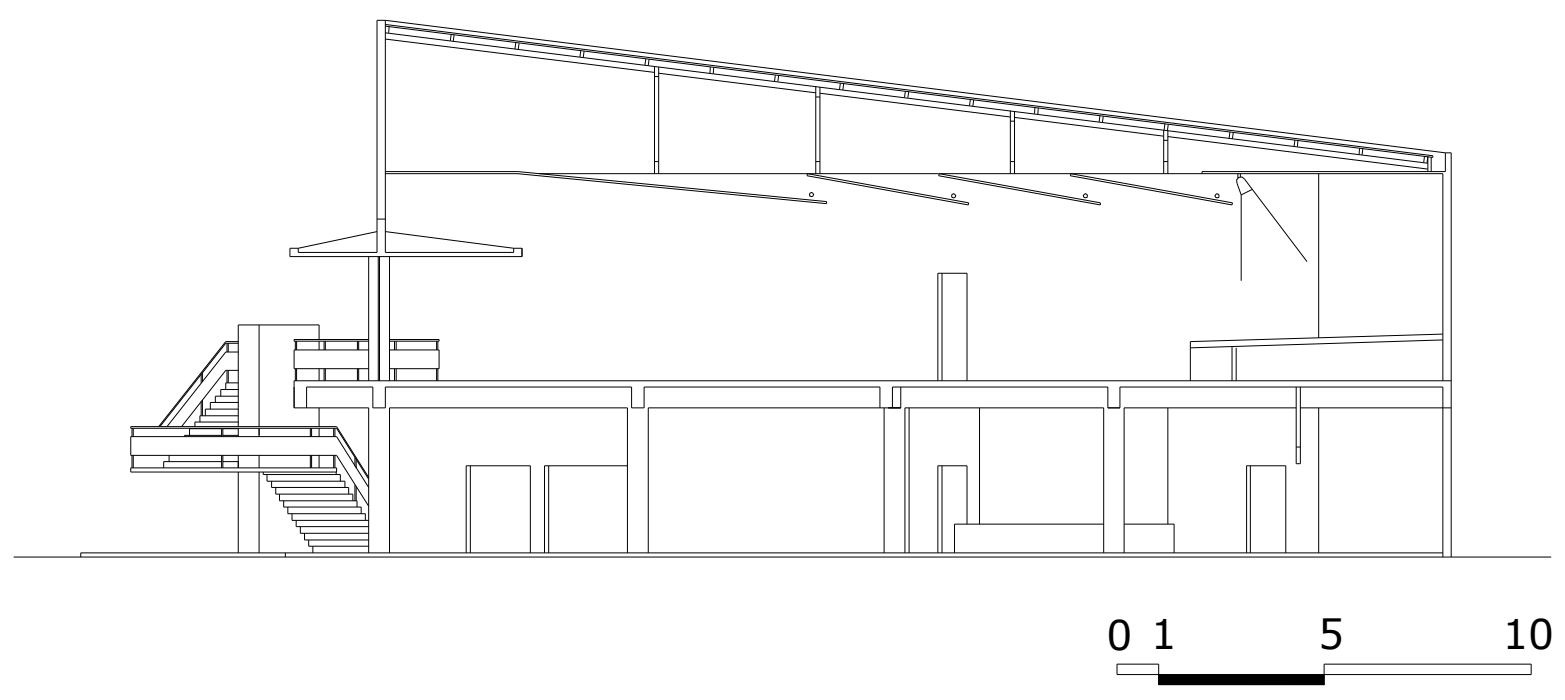

Figura 13: Redesenho do corte 1.

Fonte: Ferraz, 2005

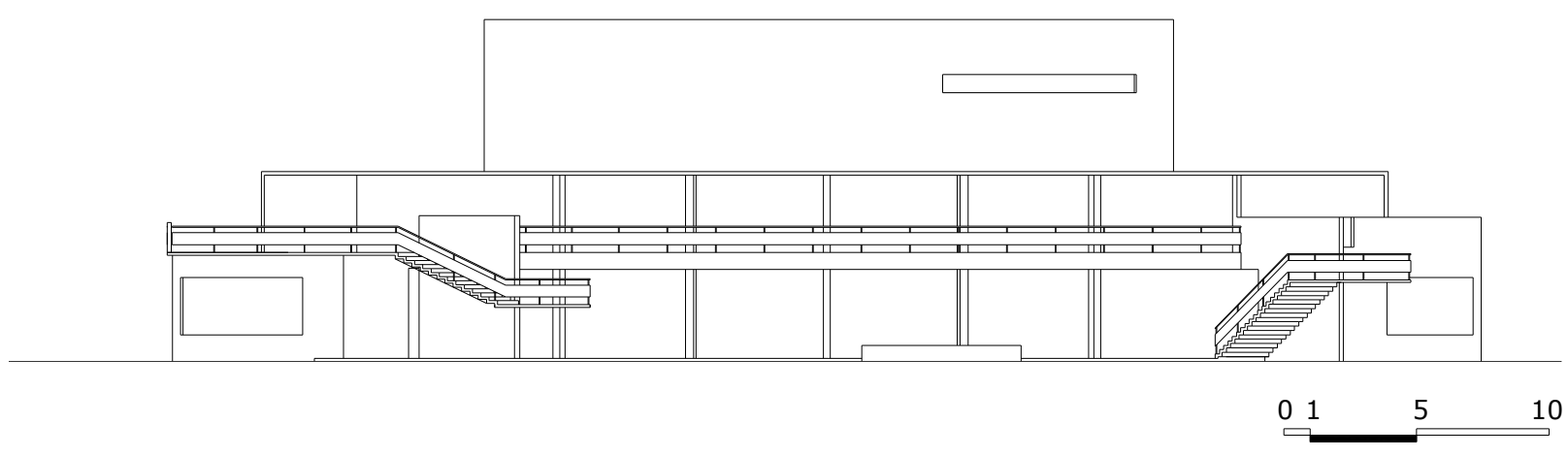

Figura 14: Redesenho da elevação.

Fonte: Ferraz, 2005 
O Pavilhão adotou nos sanitários e depósitos do pavimento superior, iluminação e ventilação zenital através da cobertura tipo shed, conforme mostra o corte 2. Esta solução, além de atender à economia proposta pelo SENAI, foi uma solução para a abertura de vãos em ambientes geminados com o vizinho. Também, as áreas descobertas criadas nas laterais e no fundo do projeto, proporcionaram a abertura de janelas tanto dos depósitos, como dos sanitários e cozinha do pavimento térreo. O recreio coberto foi projetado com pé-direito de 3 metros e o auditório com altura de 5 metros.A Flexibilidade pode ser observada através da planta livre, marcada no térreo pelos pilotis modulados do recreio e, no pavimento superior, pela ausência destes devido à supressão da laje e o uso de forro acústico para o auditório. Ainda, uma das salas projetadas no pavimento térreo foi separada com uma divisória, reforçando a idéia de crescimento. A sociabilidade, principal objetivo a ser alcançado neste projeto, foi alcançada através do recreio que se abre para 0 pátio interno da escola, e do auditório que se abre para um grande terraço, proporcionando espaços de convívio em comum para a escola. Ainda, o projeto resultou na interligação do lazer com a escola, proporcionando atratividade para um edifício que seguia os parâmetros projetuais tradicionais que não atendiam mais aos anseios do SENAI.

Figura 9: Pavilhão Social da Escola Roberto Simonsen, década de 50.

Fonte: Bem Estar n ${ }^{\circ}$ 5/6 (1960:7)

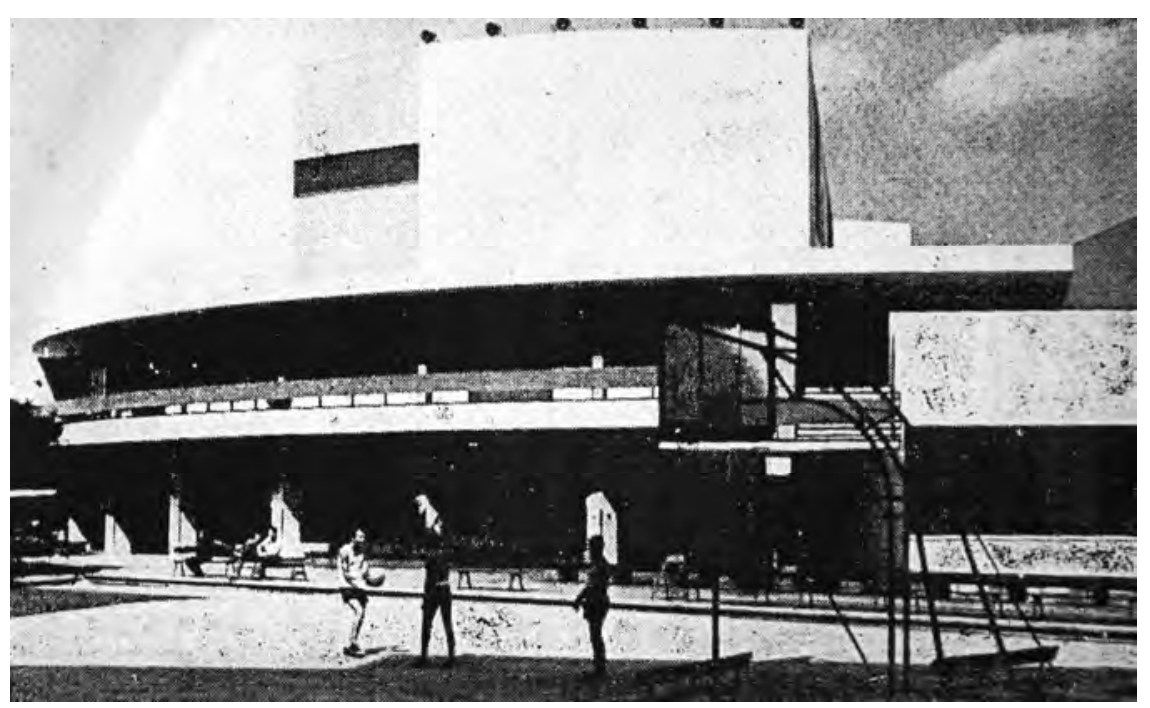




\section{PROJETO 7}

\section{Escola e Internato Antonio Noschese, Santos, 1956}

A Escola e Internato SENAI Antonio Noschese ${ }^{2}$ na cidade de Santos, litoral do Estado, foi um projeto de 1956 pelo arquiteto Roberto José Goulart Tibau. Implantado num terreno de 9.371,25 m² e localizado à Avenida Almirante Saldanha da Gama esquina com a "rua projetada", na Ponta da Praia, o projeto original tinha $6.656,60 \mathrm{~m}^{2}$ de área construída, sendo $4.444,80.5 \mathrm{~m}^{2}$ do pavimento térreo, $1.446,40 \mathrm{~m}^{2}$ do primeiro andar e $765,40 \mathrm{~m}^{2}$ do segundo andar. $\bigcirc$ projeto, implantado ao longo dos 122 metros da avenida, teve sua fachada principal voltada para a face sudeste, composta por diferentes volumes, distribuídos a partir do mesmo nível de piso.

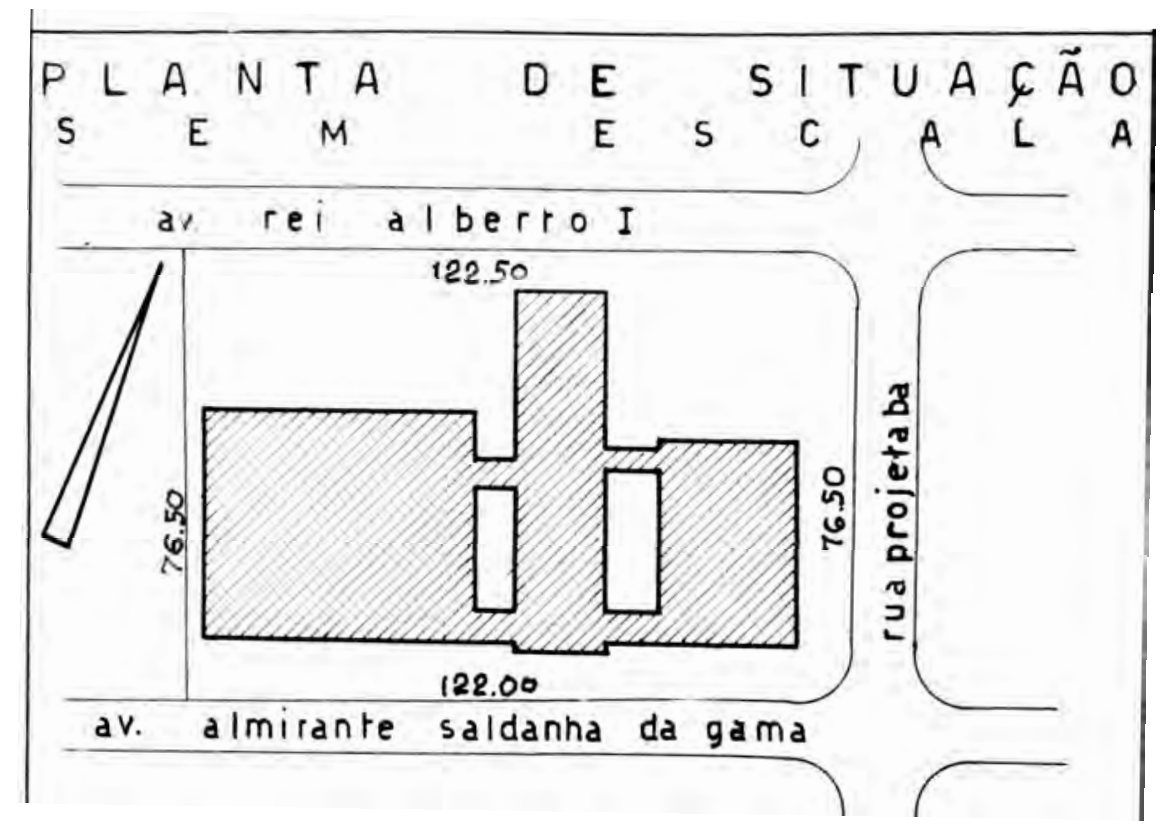

Figura 1: Planta de situação da Escola e Internato Antonio Noschese, Santos, 1956. Fonte: Foto Ferraz, arquivo SENAI

\footnotetext{
${ }^{2}$ A Escola e Internato SENAI Antonio Noschese foi publicada pela revista Bem Estar $\mathrm{n}^{\circ}$ 5/6 (1960:22 e 23).
} 
programa construtivo foi divido em três blocos, sendo o primeiro com oficina e salas de aula, o segundo com escola e internato e, o terceiro com o pavilhão social. Os blocos, interligados por passarelas cobertas, eram compostos de: oficina, depósito, sanitário e salas de aula no primeiro bloco; hall de entrada, diretoria, secretaria, sanitários, recreio coberto, lavanderia, refeitório, copa, cozinha e internato no segundo bloco e, pavilhão social com quadra, arquibancada, sanitários, palco, camarins e depósito no terceiro bloco. Além dos três blocos, os volumes de ligação entre o primeiro e o segundo bloco, funcionam como passarela coberta e abrigam de um lado a sala dos professores, vestiários, cabine primária e, do outro, forja, sala de atendimento médico e dentário. Também, foi projetada uma passarela coberta que liga o segundo com o terceiro bloco do Pavilhão Social.

Parte dos dados relativos ao edifício foram encontrados no arquivo do SENAl, como as pranchas de situação, detalhamentos, cortes e elevações do projeto original, porém pode-se observar que a prancha de situação foi alterada e o papel vegetal "raspado", com reformulações feitas posteriormente. Estes documentos possibilitaram confirmar a data do projeto, suas particularidades e a contribuição da arquiteta Ayako Nishikawa no projeto de paisagismo. $\bigcirc$ conhecimento do projeto original também foi obtido através da publicação em periódico da época, Bem Estar n 5/6 (1960: 22 e 23), acrescentando à planta do projeto, o que foi imprescindível para

Figura 2: Observar os dados do selo do projeto com data de 1956, Escola e Internato Antonio Noschese, Santos. Fonte: Foto Ferraz, arquivo SENAI

\section{a pesquisa.}

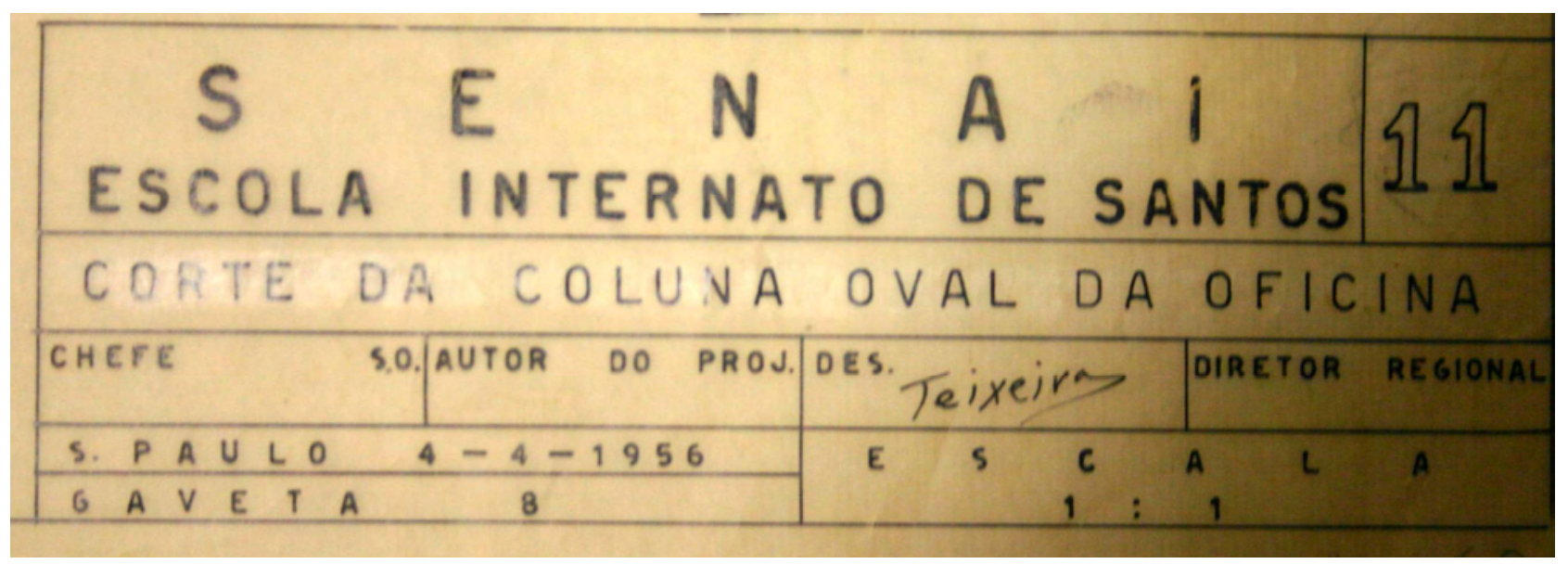




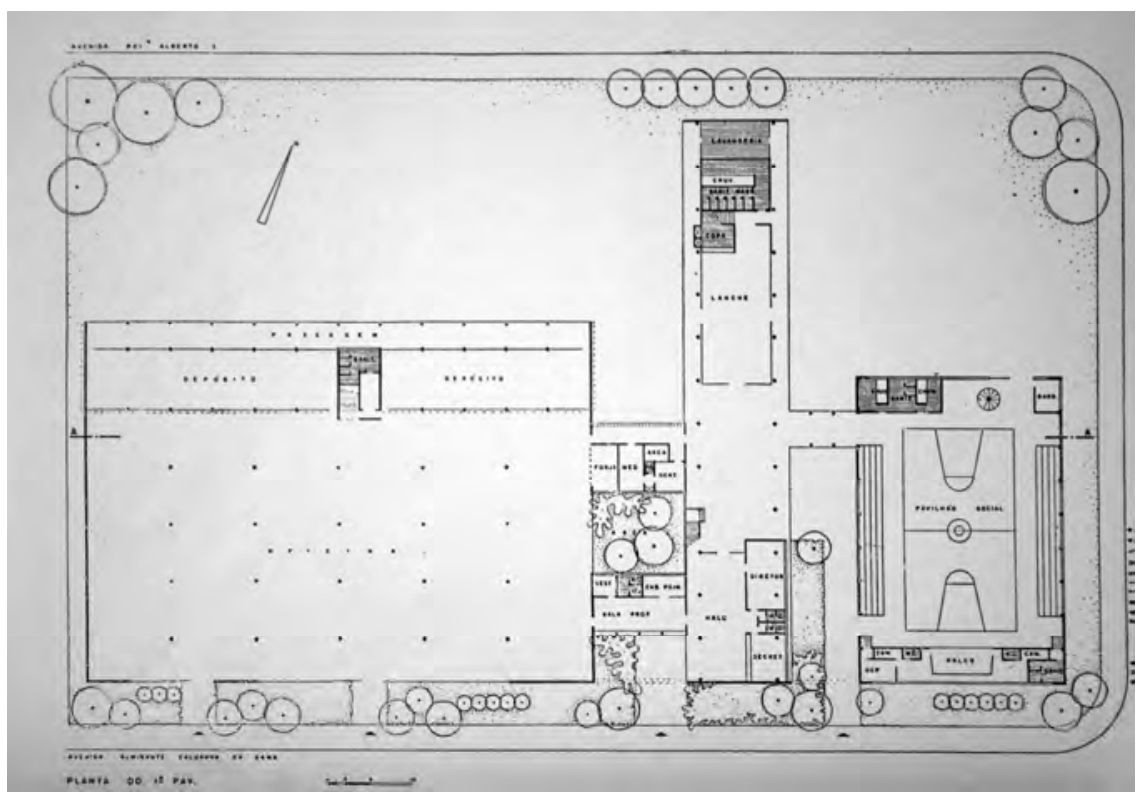

Figura 3: Planta do pavimento térreo, Escola e Internato

Antonio Noschese, Santos,

1956.

Fonte: Bem Estar n ${ }^{\circ}$ 5/6

(1960:22)

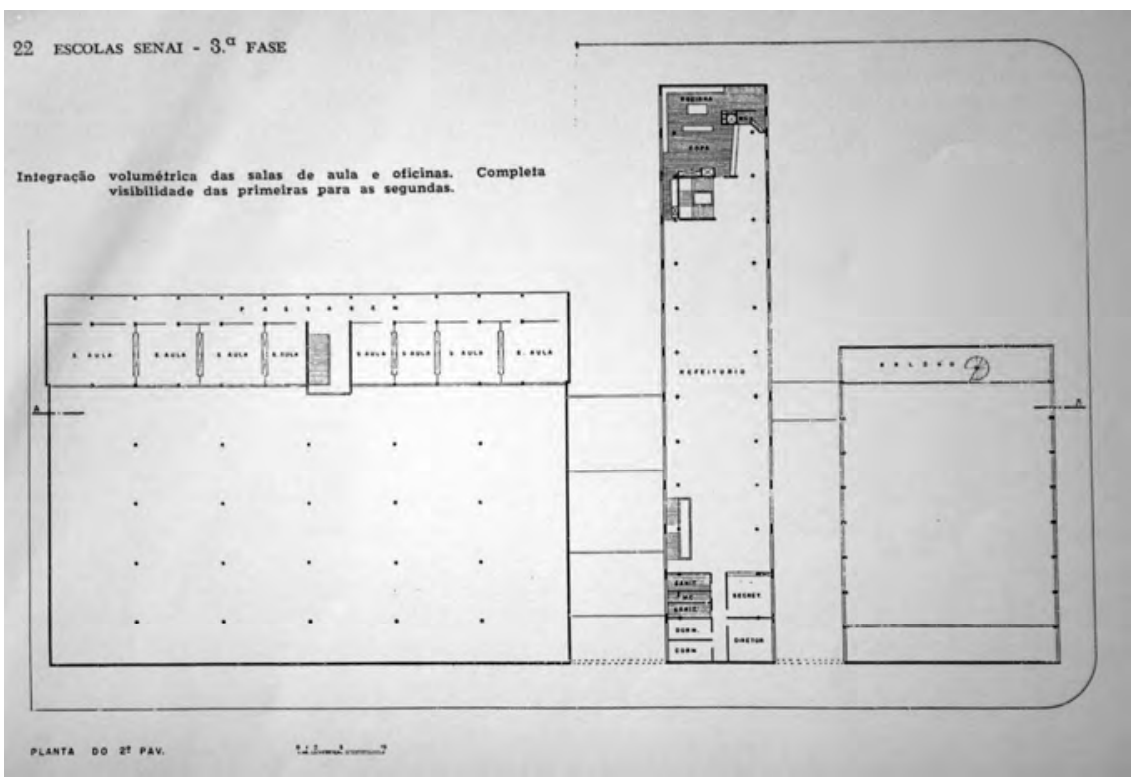

Figura 4: Planta do segundo pavimento, Escola e Internato Antonio Noschese, Santos,

1956.

Fonte: Bem Estar n ${ }^{\circ}$ 5/6

(1960:22)

Figura 5: Planta do terceiro pavimento, Escola e Internato Antonio Noschese, Santos,

1956.

Fonte: Bem Estar n ${ }^{\circ}$ 5/6 (1960:23) 


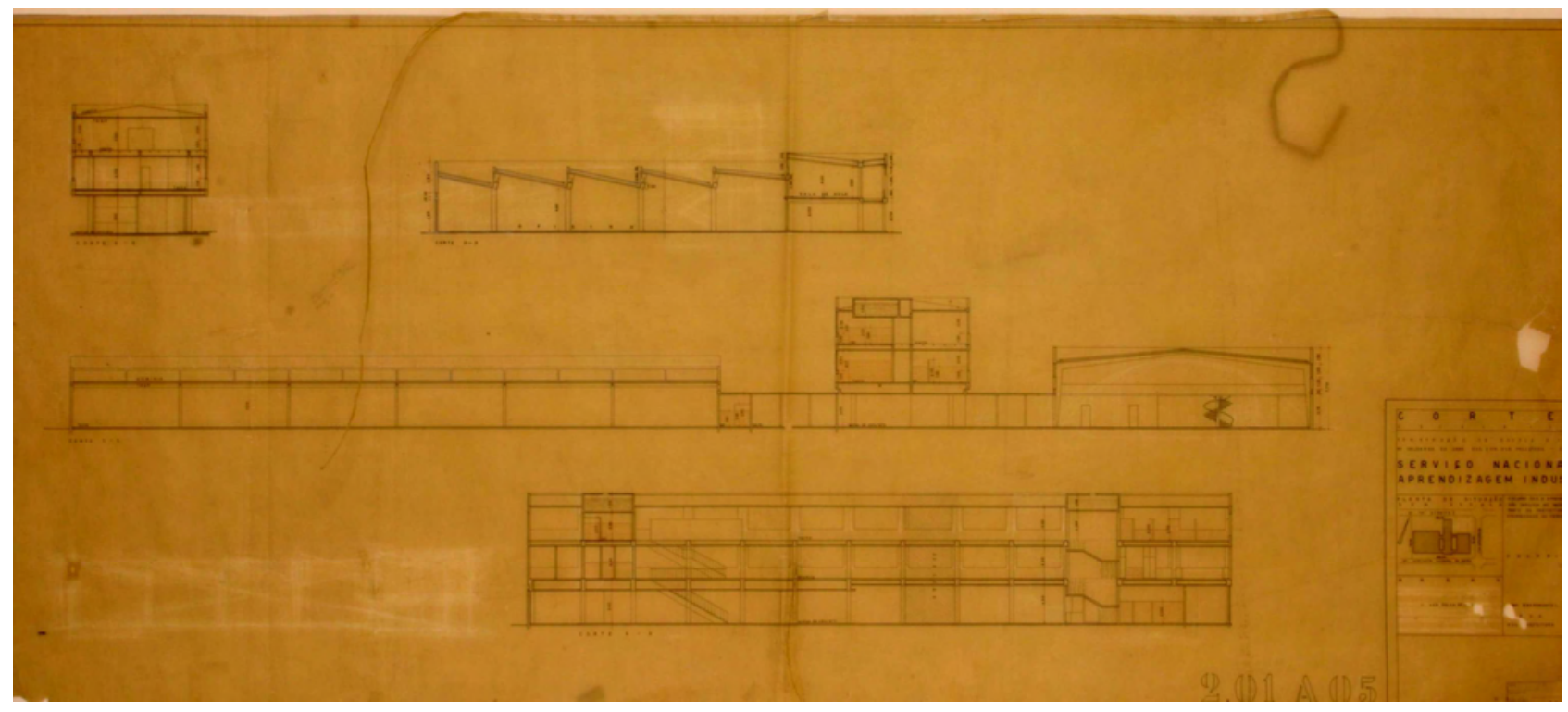

Figura 6: Prancha dos Cortes, original na escala 1:100, Escola e Internato Antonio Noschese, Santos, 1956. Fonte: Foto Ferraz, arquivo SENAI

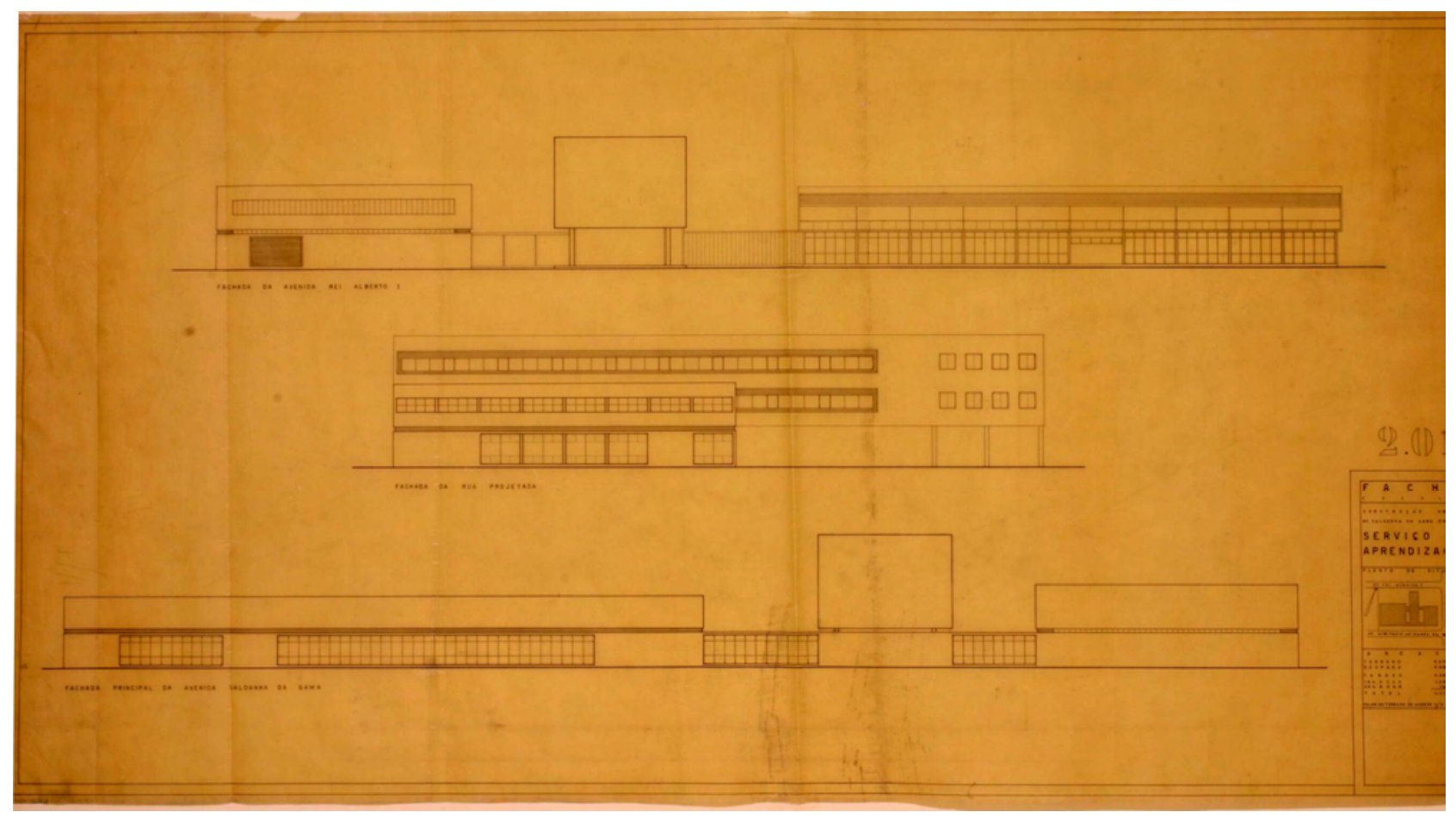

Figura 7: Prancha das Fachadas, original na escala 1:100, Escola e Internato Antonio Noschese, Santos, 1956. Fonte: Foto Ferraz, arquivo SENAI 
primeiro bloco, oficina e salas de aula, era composto de dois pavimentos. No térreo foram projetados: oficina, dois depósitos, sanitário e passagem coberta e, no pavimento superior, oito salas de aula. A oficina foi projetada de forma a obter a ligação visual com as salas de aula. Com pé-direito de 4 metros a oficina era vista das salas de aulas através de janelas voltadas para o pé-direito da oficina, atendendo ao objetivo de unir a teoria com a prática, à interligação. Como local de trabalho, a oficina foi projetada para obter um maior aproveitamento da iluminação natural, assim como da ventilação permanente através da cobertura tipo shed e da cortina de vidro voltada para a fachada principal (sudeste). A concepção da oficina conseguiu atingir o objetivo de entrosar a teoria à prática e tornar 0 espaço de trabalho da escola mais atrativo para os alunos, atratividade. $\bigcirc$ edifício, seguindo uma modulação única, própria do sistema racionalista, permitia a distribuição flexível de seus espaços de acordo com o crescimento da indústria. No pavimento superior, a flexibilidade pode ser observada nas salas de aula divididas com separações móveis de armários para que estes espaços pudessem se adequar às necessidades da escola. Ainda, a circulação adotada neste pavimento foi através de corredor lateral, projetado aberto para o exterior, possibilitando a relação dos alunos com a área de lazer da escola, também atendendo à atratividade.

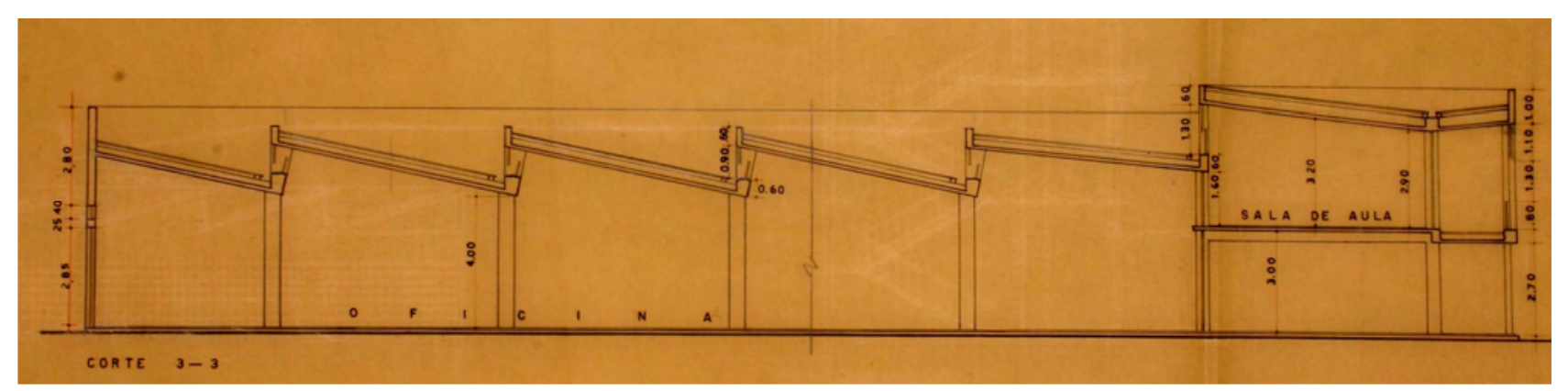

O segundo bloco, escola e internato, era composto de três pavimentos. $\bigcirc$ térreo abrigava o hall de entrada da escola, secretaria, diretoria, recreio coberto, copa, sanitários e lavanderia. $\bigcirc$ primeiro pavimento atendia ao internato e era composto de refeitório, copa, cozinha, sanitários, secretaria e diretoria. $\bigcirc$ último pavimento abrigava os dormitórios, sanitários, sala de enfermagem e rouparia.
Figura 8: Corte 3, original na escala 1:100, bloco da oficina e salas de aula, Escola e Internato Antonio Noschese, Santos, 1956. Fonte: Foto Ferraz, arquivo SENAI 
Atendendo a um dos objetivos do SENAI de desempenhar melhor sua função social, criando um ambiente favorável ao convívio mútuo entre todos, a sociabilidade, foi projetado o recreio coberto, aberto para a área verde da escola que, interligado com o pavilhão social através de uma passagem coberta, tornava o espaço ainda mais atrativo. Este programa de escola e internato se diferencia dos demais até então estudados, pois dois pisos deste edifício foram projetados exclusivamente para atender a um internato, porém a modulação e a planta livre mais uma vez permitiram a disposição flexível tanto nos dormitórios como no refeitório, adequando-se de acordo com o crescimento da escola. Para complementar o programa administrativo e social da escola, este bloco foi interligado com as oficinas através de dois volumes de circulação que abrigavam de um lado a sala dos professores, vestiários, cabine primária e, do outro, foria, sala de atendimento médico e dentário.

Figura 9: Corte 2, original na escala 1:100, bloco da escola e internato, Escola e Internato Antonio Noschese, Santos, 1956.

Fonte: Foto Ferraz, arquivo SENAI

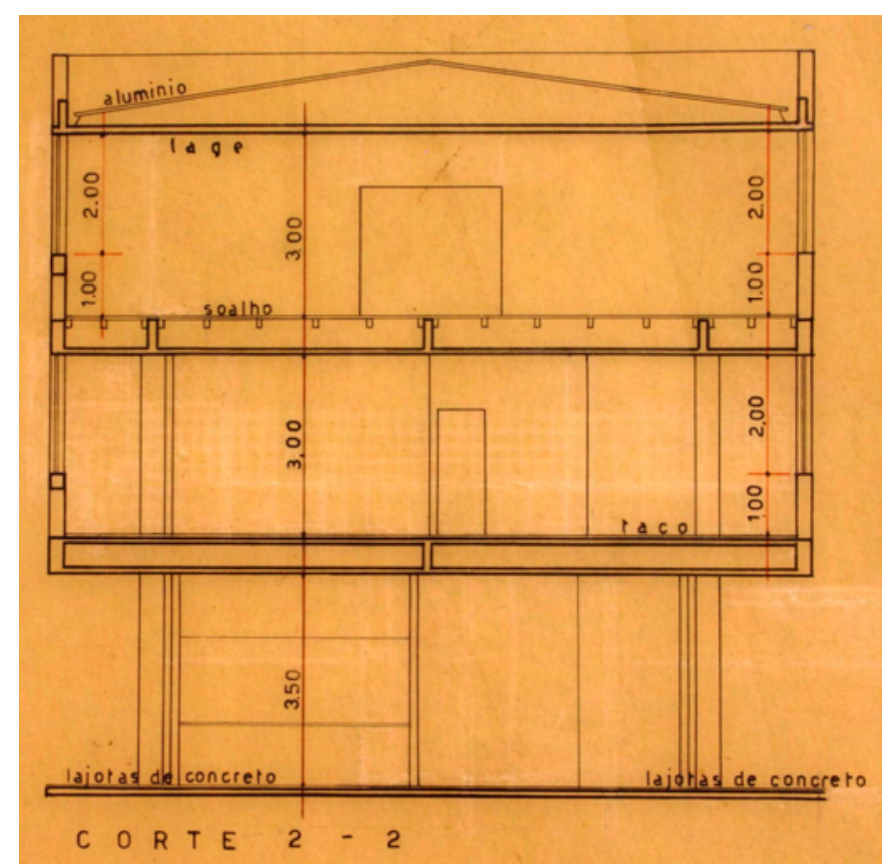

O terceiro bloco, pavilhão social, era composto do pavimento térreo e mezanino. Oferecia o programa construtivo da sociabilidade, através da quadra, arquibancada, sanitários, palco, camarins e depósito. Este bloco foi projetado para ser um espaço que pudesse ser utilizado tanto como quadra de esportes como para auditório (flexibilidade). 


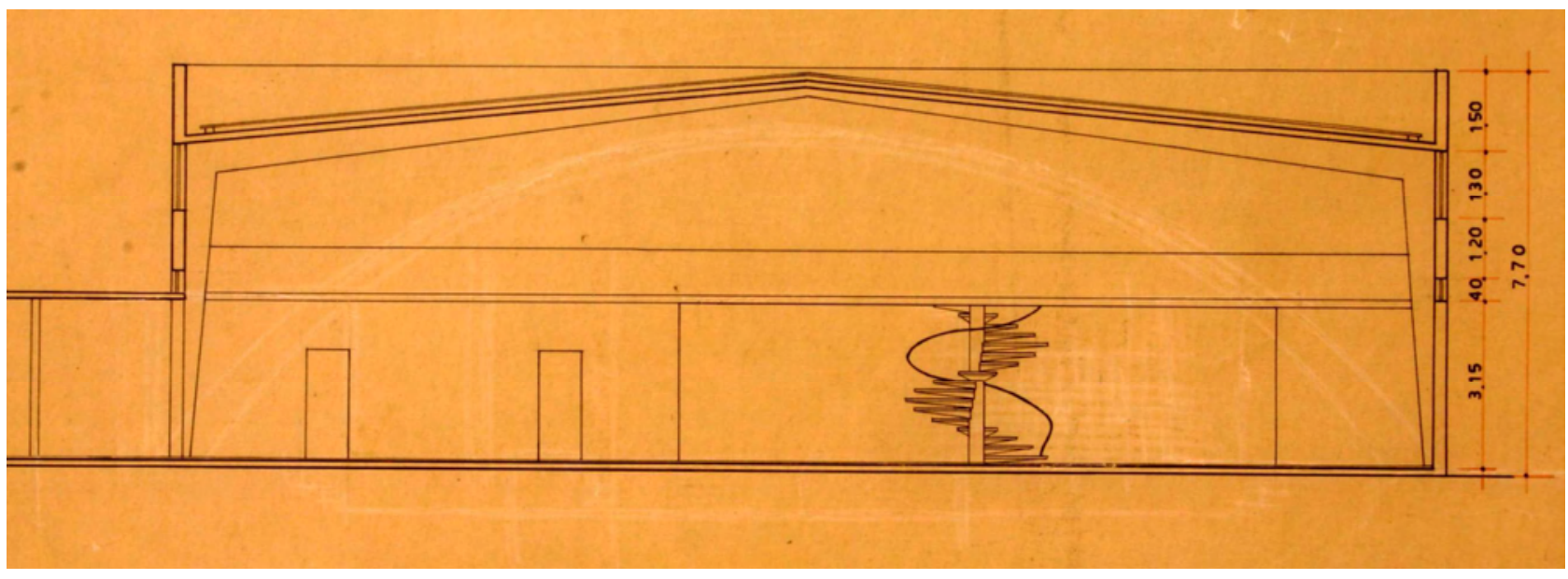

A pedagogia do SENAl também norteou a solução arquitetônica desta escola e internato. Assim, por exemplo: a sociabilidade obtida pelo uso de pilotis no térreo do segundo bloco integrou a escola à área livre interna e, a ligação dos blocos através de passarelas cobertas acusa a intenção de interligação, proporcionando fisicamente o contato visual entre a área de trabalho prático e teórico. $\bigcirc$ projeto também reflete arquitetonicamente outros pontos básicos da pedagogia do SENAI como: o crescimento das salas de aula através das divisórias móveis, a flexibilidade da planta livre das oficinas, a atratividade da escola através da área recreativa (área verde, recreio coberto, quadra e palco), a sociabilidade através do pavilhão social, o rendimento através do acesso visual das salas de aulas às oficinas, a economia de iluminação e ventilação.

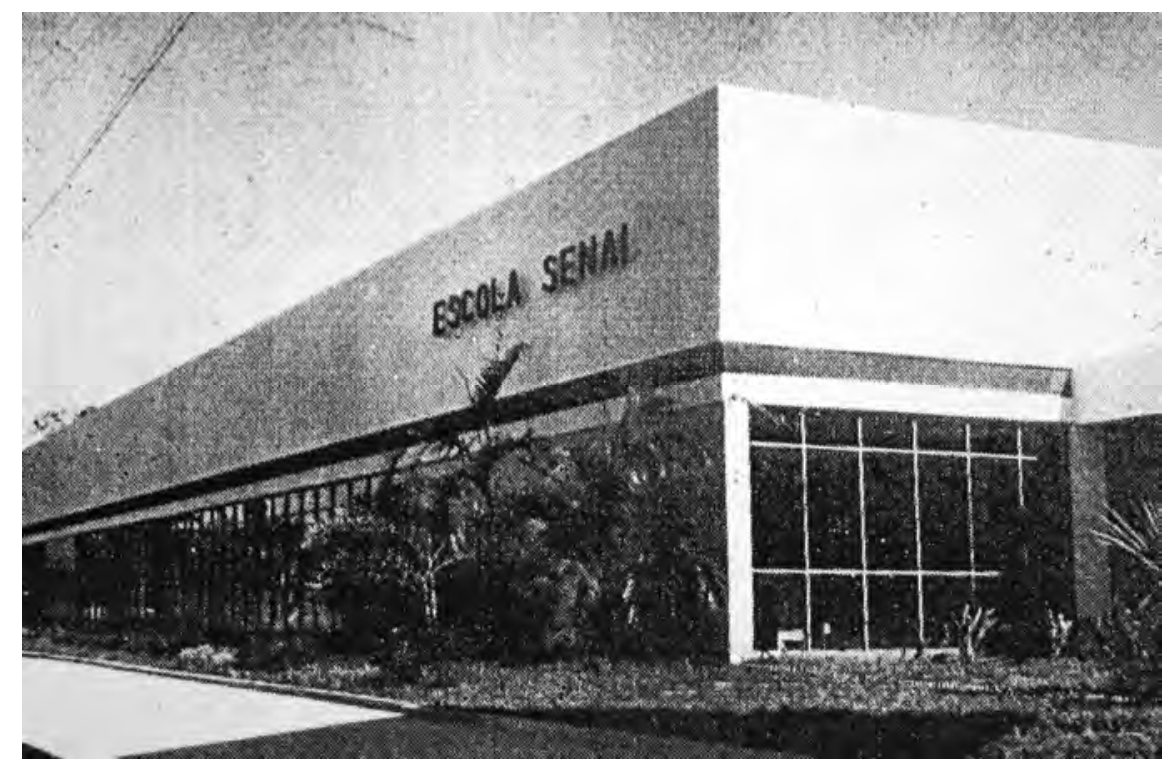

Figura 10: Corte 1 parcial, original na escala 1:100, bloco do pavilhão social, Escola e Internato Antonio Noschese, Santos, 1956.

Fonte: Foto Ferraz, arquivo SENAI
Figura 11: Vista do bloco das oficinas e salas de aula, Escola e Internato Antonio Noschese, década de 50. Fonte: Bem Estar n ${ }^{\circ}$ 5/6 (1960: 23) 


\section{PROJETO 8}

\section{Escola Senai Tatuapé, 1957}

Primeira escola SENAI projetada por Lúcio Grinover, a Escola de Tatuapé também foi construída de acordo com os parâmetros da filosofia educacional do SENAI. Implantada numa quadra de aproximadamente $7.600,00 \mathrm{~m}^{2}$, a escola foi composta inicialmente por três blocos caracterizados pela oficina e salas de aulas, pavilhão social e escola (administração) com aproximadamente $3.400,00 \mathrm{~m} 2$ de área construída.

programa construtivo adotado foi: oficina, seis salas de aulas, depósitos e sanitários no primeiro bloco; secretaria, diretoria, sala dos professores, assistência social, médica e dentária, sanitários e área coberta no segundo bloco; recreio coberto, despensa e cozinha no terceiro bloco. Também, foi projetado um volume, anexo ao primeiro bloco, com os vestiários e sanitários voltados para o recreio coberto. Os três blocos foram interligados entre si por passarelas cobertas e escadas, aproveitando os desníveis do terreno.

A planta completa de execução do projeto original foi encontrada, assim como diversas pranchas do projeto original, tanto 0 ante-projeto como o projeto executivo, que revelaram o ano de sua concepção, o terreno, as plantas dos blocos originais, diversas pranchas de detalhamentos, cortes e elevações. Sucessivas pranchas também revelaram a participação do arquiteto Melanias M. Nagamini nos projetos realizados a partir de 1960, inclusive do projeto executivo do pavilhão social desta escola. $O$ conhecimento do projeto original foi complementado através do material publicado em periódico da época, Bem Estar n 5/6 (1960:15). Ainda, para facilitar a leitura arquitetônica do projeto e representá-lo através de significativos dados obtidos no projeto original, foi graficamente redesenhada a planta e sua implantação no terreno. 


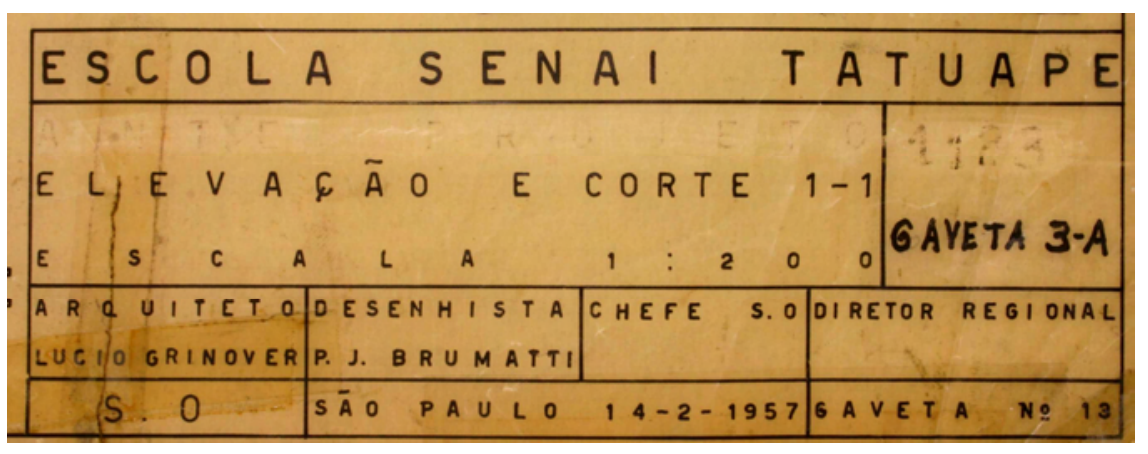

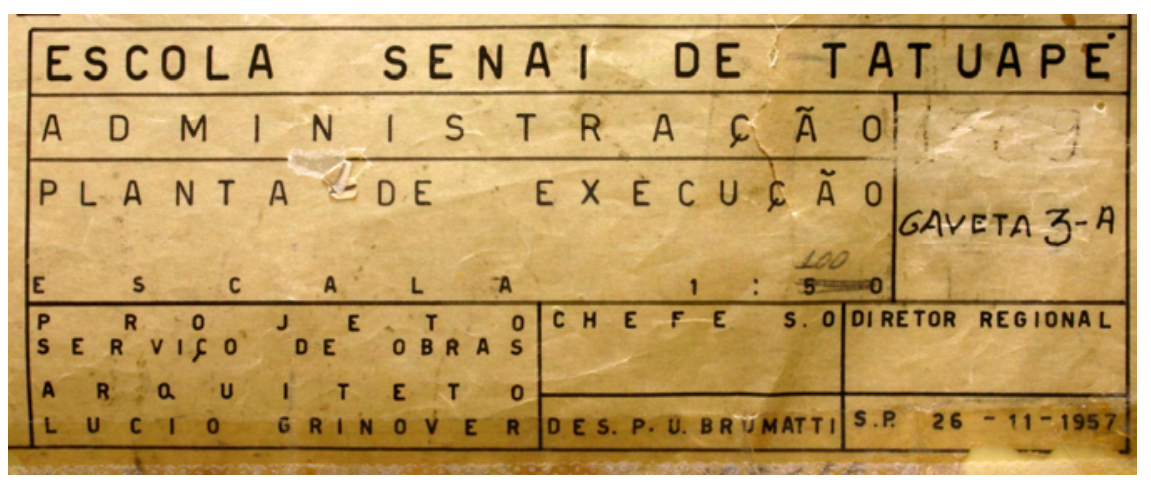

Figura 1: Observar os dados do selo do ante-projeto, original na escala 1:200, da Escola de

Tatuapé, concebido em fevereiro de 1957, com autoria de Lúcio

Grinover.

Fonte: Foto Ferraz, arquivo SENAI

Figura 2: Observar os dados do selo do projeto de execução, original na escala $1: 100$, da Escola de Tatuapé, concebido em novembro de 1957, com autoria de Lúcio Grinover. Fonte: Foto Ferraz, arquivo SENAI

Figura 3: Prancha original das Elevações e Corte, original na escala 1:200, Escola de Tatuapé, 1957.

Fonte: Foto Ferraz, arquivo SENAI

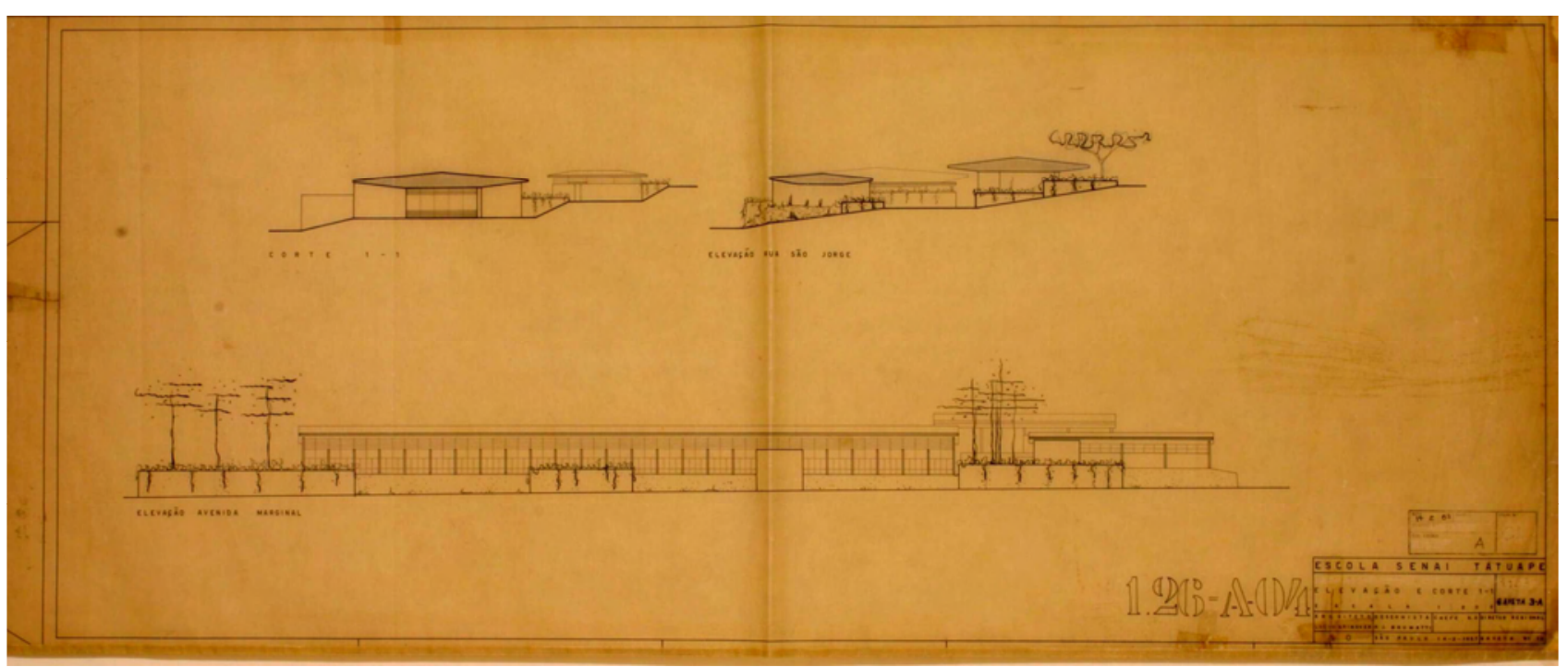


Figura 4: Prancha original do

Corte 1, original na escala

1:200, Escola de Tatuapé,

1957.

Fonte: Foto Ferraz, arquivo

SENAI
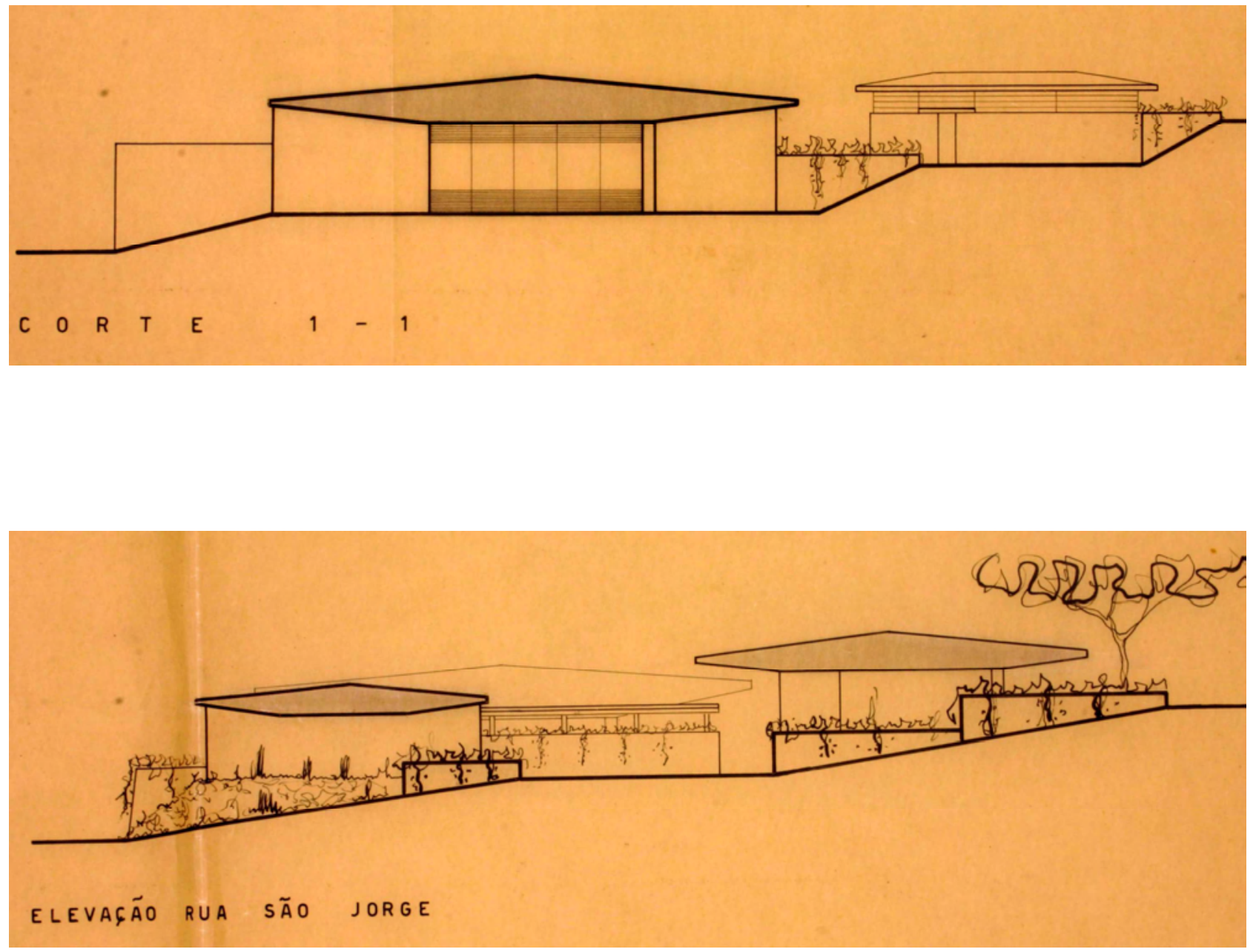

Figura 5: Prancha original da

Elevação da rua São Jorge,

original na escala 1:200, Escola

de Tatuapé, 1957.

Fonte: Foto Ferraz, arquivo

SENAI 
Figura 6: Prancha original das Elevações e Corte, original na escala 1:200, Escola de

Tatuapé, s.d.

Fonte: Foto Ferraz, arquivo SENAI
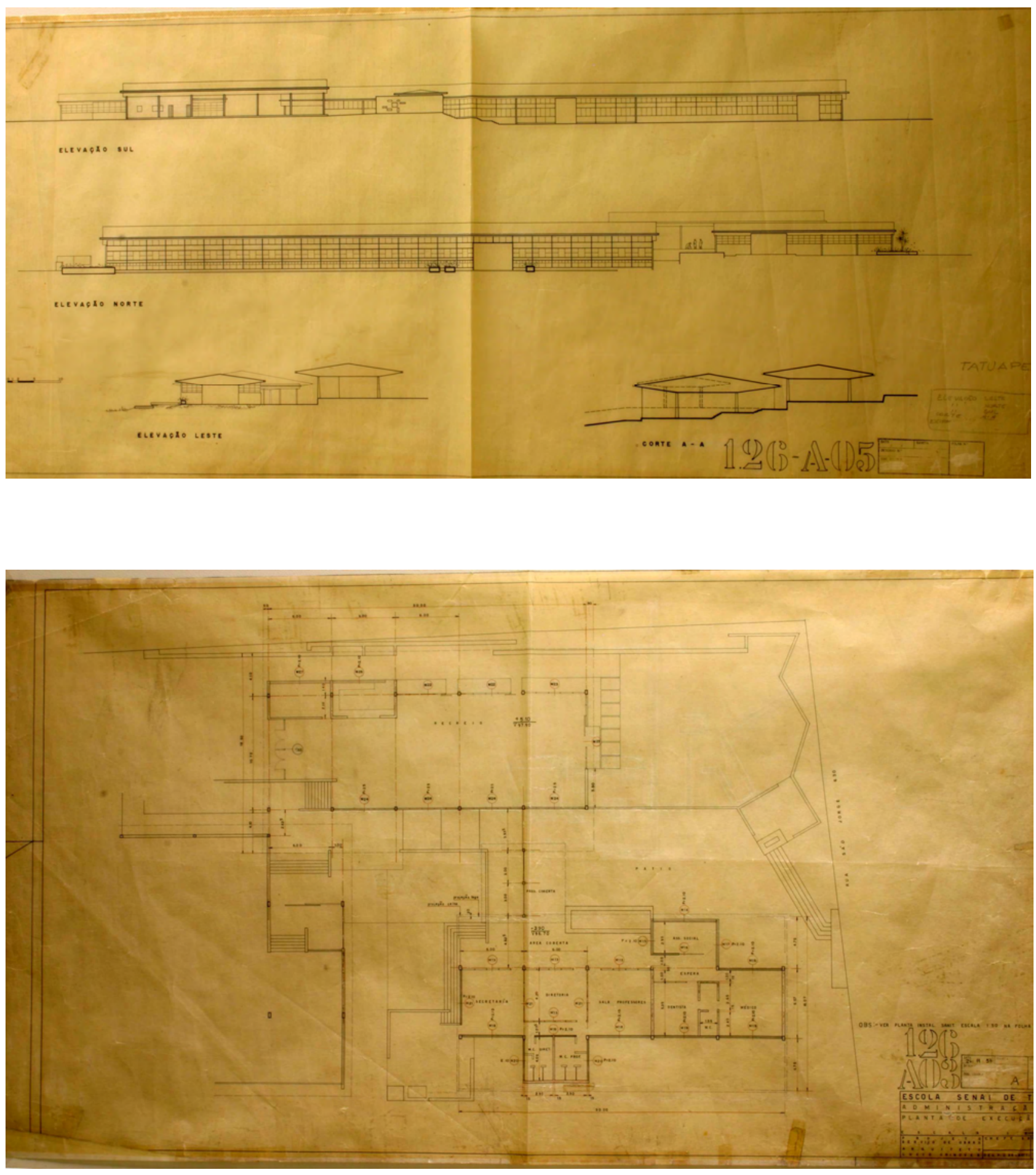

Figura 7: Prancha original do bloco da escola (administração)

e pavilhão social, original na escala 1:100, Escola de Tatuapé, 1957.

Fonte: Foto Ferraz, arquivo 


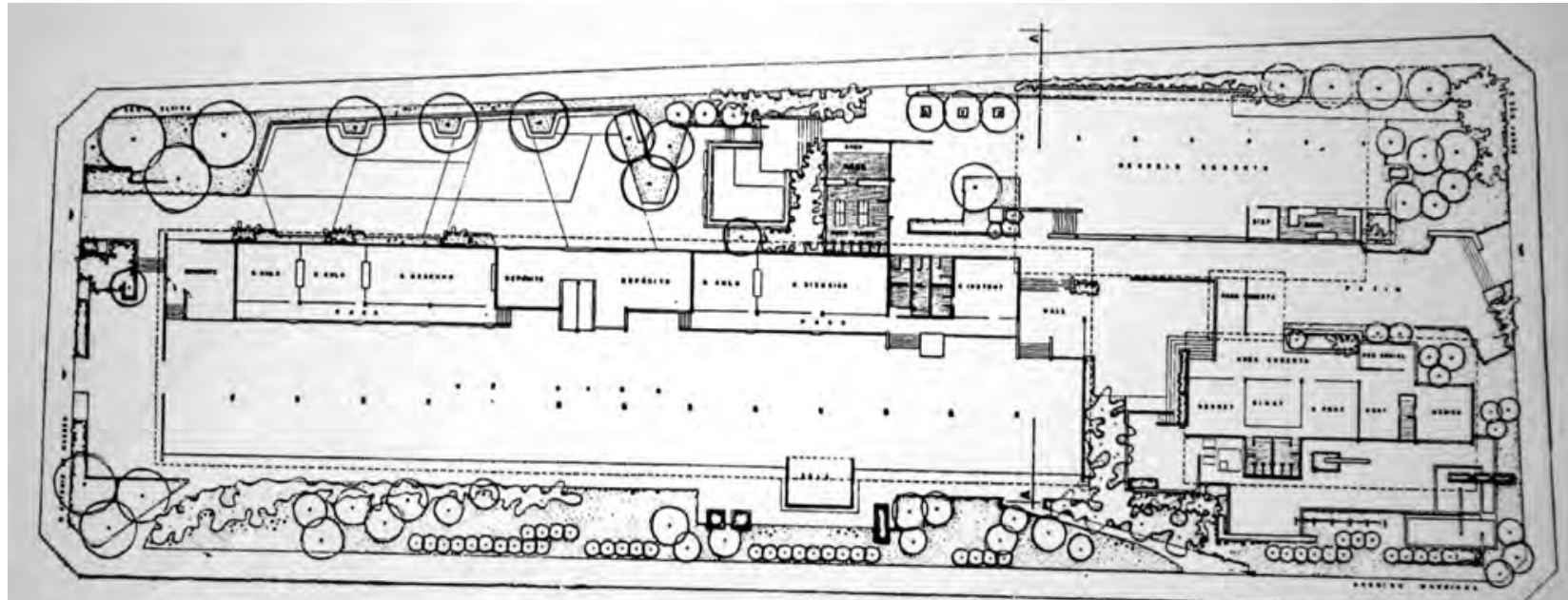

Figura 8: Planta da Escola de

Tatuapé, 1957.

Fonte: Bem Estar n ${ }^{\circ}$ 5/6

(1960:15)

O bloco das oficinas e salas de aula, ao longo da avenida, compunha a fachada principal com seus 98 metros. Composto por um único pavimento, este bloco era dividido em nível, sendo que as salas de aula ficavam em desnível de 1 metro do piso da oficina, possibilitando o rendimento e a interligação da prática com a teoria, estabelecendo a ligação visual entre oficina e salas de aula. Modulado com eixos longitudinais de 7 metros, este bloco foi projetado com planta livre para a oficina e, divisórias móveis para as cinco salas de aula, atendendo à flexibilidade de espaço de acordo com o crescimento da escola. Atendendo à pedagogia da atratividade de ser uma escola para o aluno, as salas de aula receberam iluminação lateral sul através de grandes vãos envidraçados, permitindo ampla visibilidade da área de atividade social interna da escola, e, a oficina recebeu iluminação lateral norte, voltada para o urbano. Composto ainda por uma sala de instrutores, depósitos e sanitários, este bloco foi o implantado no nível mais baixo do terreno e sua ligação com os demais blocos foi obtida através das passarelas cobertas. 


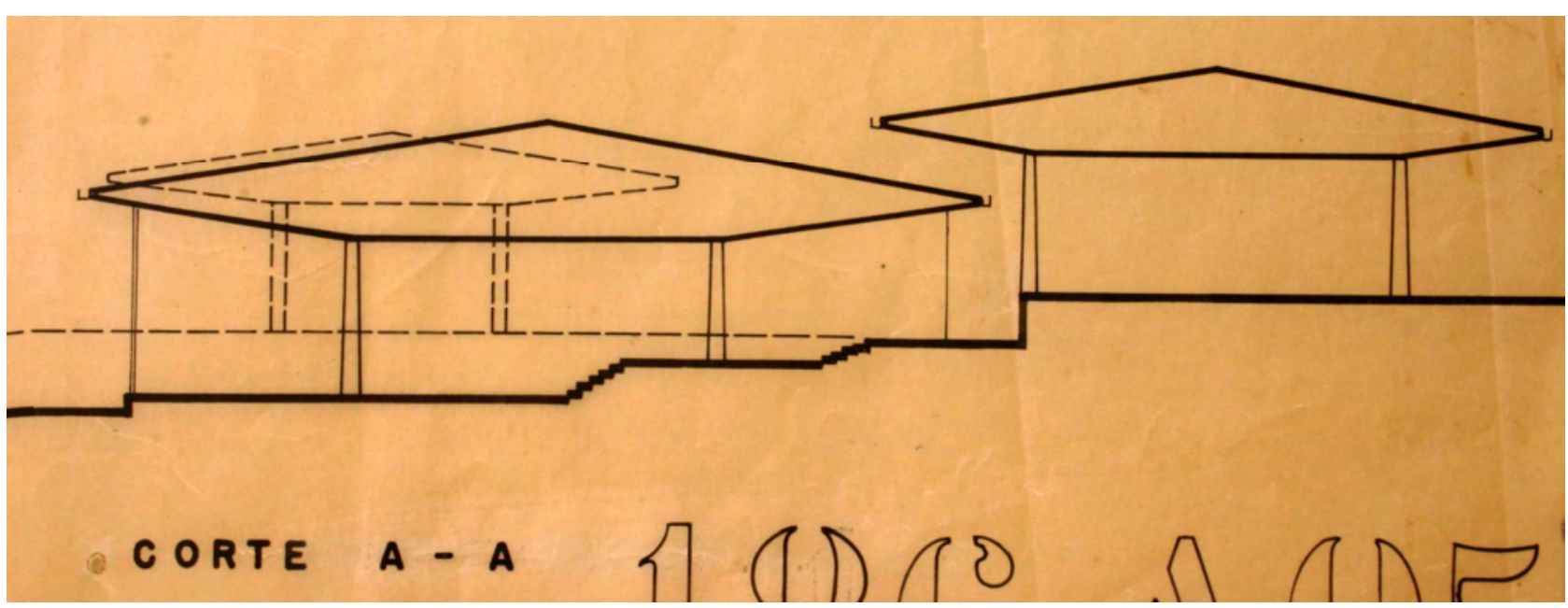

Figura 9: Corte AA, prancha Elevações e Corte, original na escala 1:200, Escola de Tatuapé, s.d.

Observa o primeiro bloco implantando no nível mais baixo.

Fonte: Foto Ferraz, arquivo

segundo bloco da administração da escola, com seus 30 SENAI

metros, complementava a fachada principal ao lado do primeiro bloco. Implantado a 1,90 metros acima do nível da oficina, abrigava os espaços administrativos, salas para atendimento social, médico e dentário, sanitários e área coberta em um único nível. Este conjunto se abria para o pátio de entrada da escola, o qual ficava entre o segundo e terceiro bloco.Interligado diretamente com $\circ$ recreio coberto do terceiro bloco através de uma passarela coberta, o bloco da escola atendia às necessidades administrativas integrando-as à área de recreação, atendendo à sociabilidade.

Figura 10: Elevação leste, prancha Elevações e Corte, original na escala 1:200, Escola de Tatuapé, s.d.

Observar o segundo bloco à esquerda e o terceiro à direita.

Fonte: Foto Ferraz, arquivo SENAI

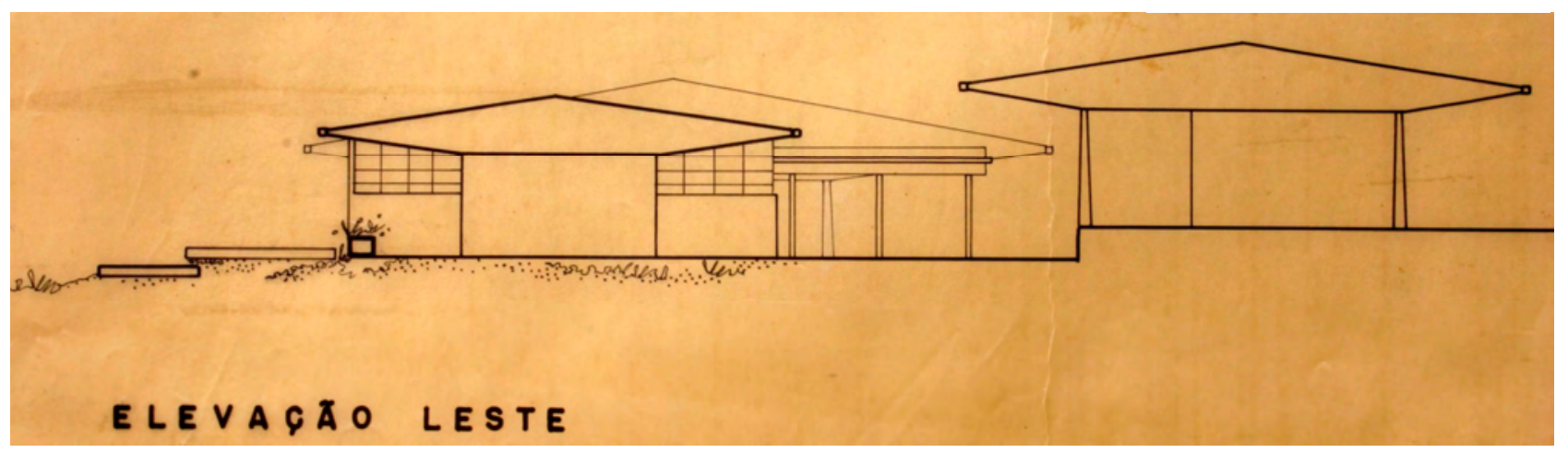


Figura 11: Elevação 1, face sul do volume anexo ao primeiro bloco, original na escala 1:100, Escola de Tatuapé.

Fonte: Foto Ferraz, arquivo
Figura 12: Vista da fachada norte do bloco da oficina e salas de aula, Escola de Tatuapé, década de 50.

Fonte: Bem Estar n 5/6
O terceiro bloco do pavilhão social, modulado com eixos longitudinais de 6 metros, tinha pé-direto de 3,20 metros e abrigava o recreio coberto, despensa e cozinha. Implantado no nível mais alto em relação aos demais blocos, a 3,10 metros acima do piso da oficina, este bloco tinha vários acessos em seus quatro lados. Para complementar o programa de necessidades do pavilhão, também foram projetados os sanitários e vestiários, num volume anexo ao primeiro bloco.

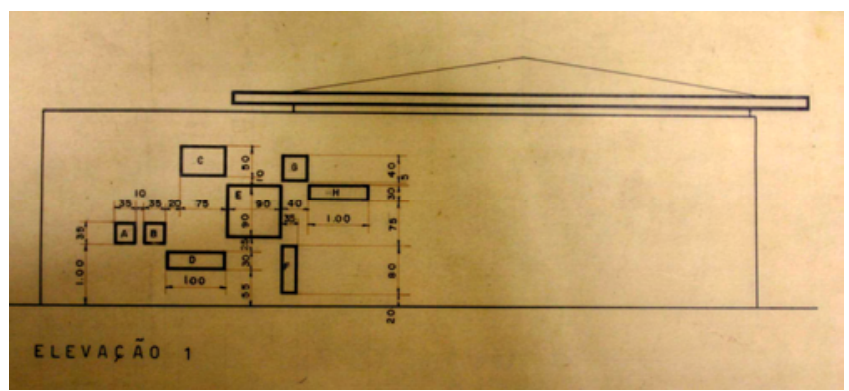

A Escola de Tatuapé foi projetada para atender à construção civil, segundo Bem Estar n 5/6 (1960, p.15) e suas características arquitetônicas também refletem $\bigcirc$ crescimento, flexibilidade, atratividade, interligação, sociabilidade, rendimento e economia propostos na pedagogia do SENAI. Os blocos, ligados entre si, acusam a interligação e rendimento que tornava possível realizar a educação integral. Outro aspecto importante é a composição plástica da cobertura dos três blocos, inovadora nas escola até então apresentadas, intercaladas em cada bloco e desníveis do terreno.

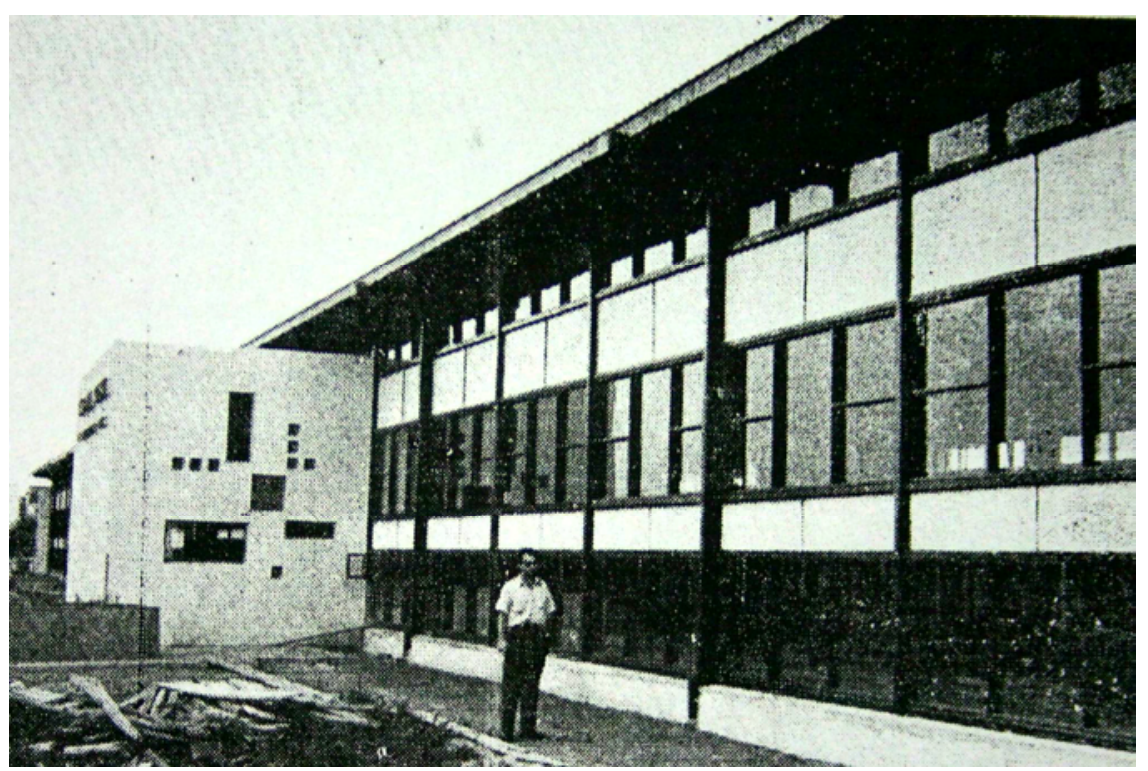




\section{PROJETO 9}

\section{Escola Senai de Cerâmica São Caetano, São Caetano do Sul, 1957}

A Escola de Cerâmica, na cidade de São Caetano do Sul, foi projetada em 1957 pelos arquitetos Hélio de Queiroz Duarte e Roberto José Goulart Tibau. Implantada num terreno de $5.000,00 \mathrm{~m}^{2}$, - projeto original tinha $4.041,00 \mathrm{~m}^{2}$ de área construída, sendo $1.877,00 \mathrm{~m}^{2}$ do pavimento térreo, $495,00 \mathrm{~m}^{2}$ do pavimento intermediário e $1.669,00 \mathrm{~m}^{2}$ do terceiro pavimento. $O$ projeto, implantado ao longo dos 82,25 metros da rua Niterói, teve sua fachada principal voltada para a face norte, composta por um único volume, distribuído a partir de um terreno plano.
Figura 1: Observar os dados do selo da Escola de Cerâmica,

São Caetano do Sul, concebido em novembro de 1957, com autoria de Hélio Duarte e Roberto Tibau. Fonte: Foto Ferraz, arquivo

SENAI
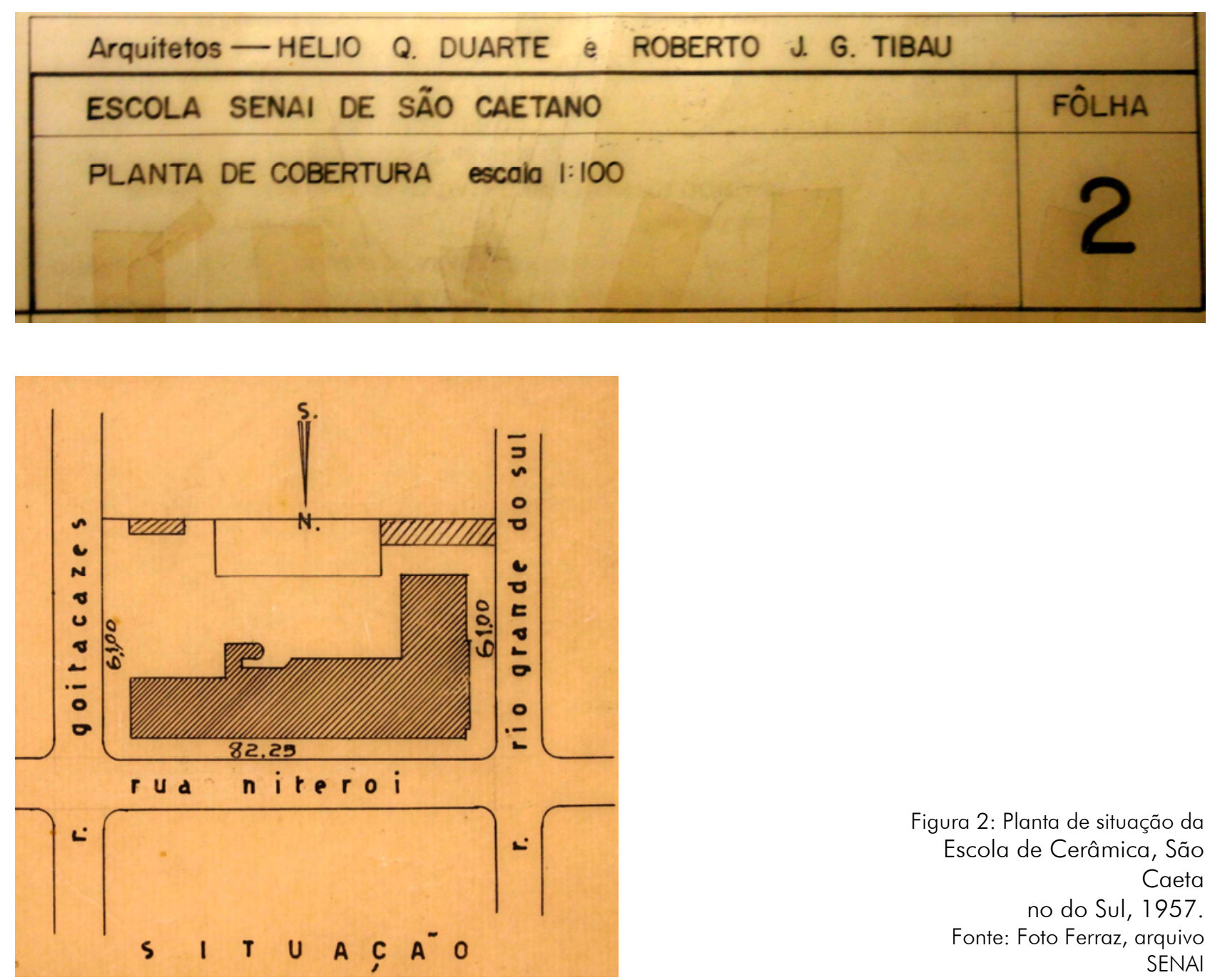

Figura 2: Planta de situação da Escola de Cerâmica, São Caeta no do Sul, 1957. Fonte: Foto Ferraz, arquivo SENAI 
programa construtivo foi dividido em um único bloco, num terreno que já abrigava um pavilhão social de $325,50 \mathrm{~m}^{2}$. Portanto, o partido teve que considerar o aproveitamento da construção existente destinada à recreação e sociabilidade. $\bigcirc$ novo bloco, em forma de "L" teve o pavimento térreo ocupado pela oficina, sanitários, área aberta para fabricação de materiais de construção e salas de apoio. O pavimento intermediário, destinado à área administrativa da escola, funcionava como um mezanino que permitia a ligação visual com a oficina (interligação) e era composto de: diretoria, secretaria, sala de espera, biblioteca, salas de atendimento médico, dentário e de assistência social, sala de seleção, depósito e passarela que conduzia ao elevador, no meio do vazio do pé-direito da oficina. $\bigcirc$ terceiro e último pavimento abrigava as salas de aula, sanitários, laboratórios e sala dos docentes.

- conhecimento do programa construtivo e projeto desta escola foi obtido em parte pelo projeto original parcialmente encontrado e pela publicação no periódico da época Acrópole 314 (1965:40-41). Portanto, as plantas do pavimento térreo e intermediário, não encontradas, foram obtidas no periódico e, no arquivo do SENAI, foram encontradas as pranchas da planta do terceiro pavimento, dos cortes e das elevações do projeto original. Nota-se que a prancha da planta foi posteriormente alterada e reutilizada pelo projetista hidráulico, conforme mostra a figura abaixo:

Figura 3: Planta do pavimento térreo, Escola de Cerâmica, São Caetano do Sul, 1957. Fonte: Acrópole n 314 (1965:41)

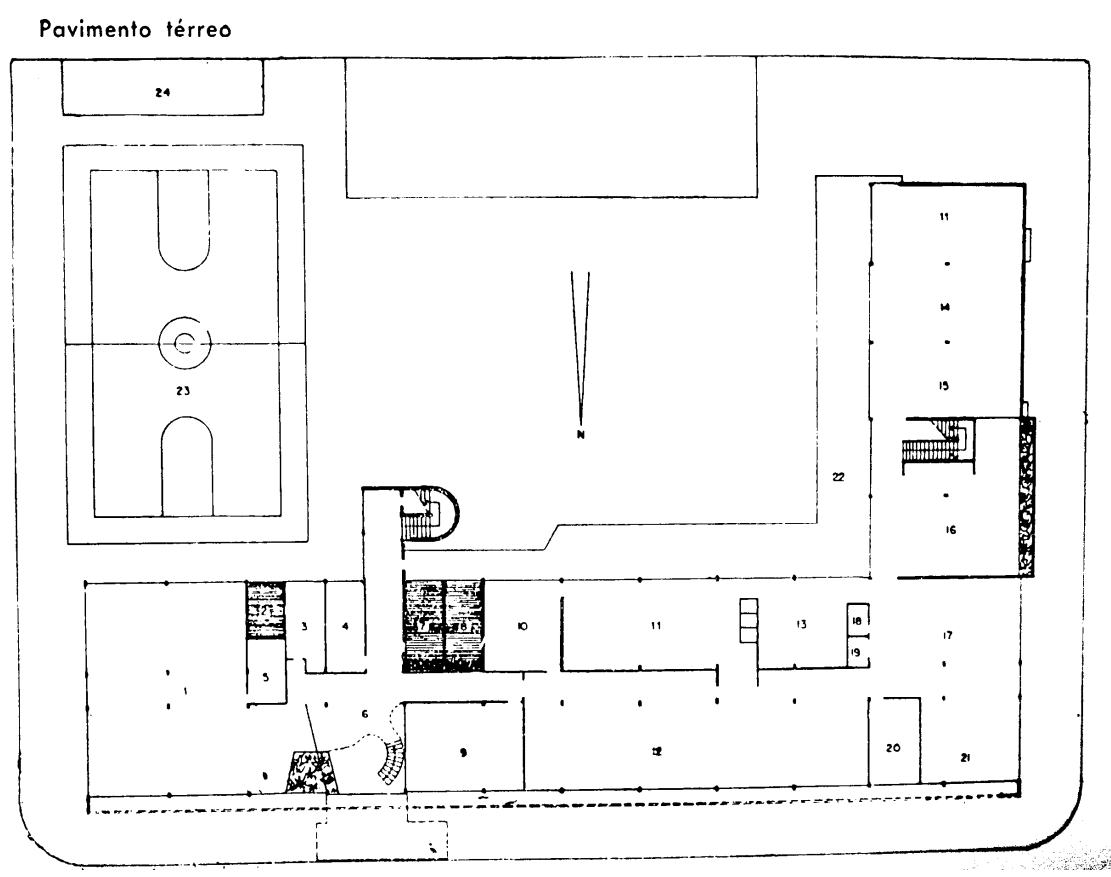




\section{Pavimento intermediário}

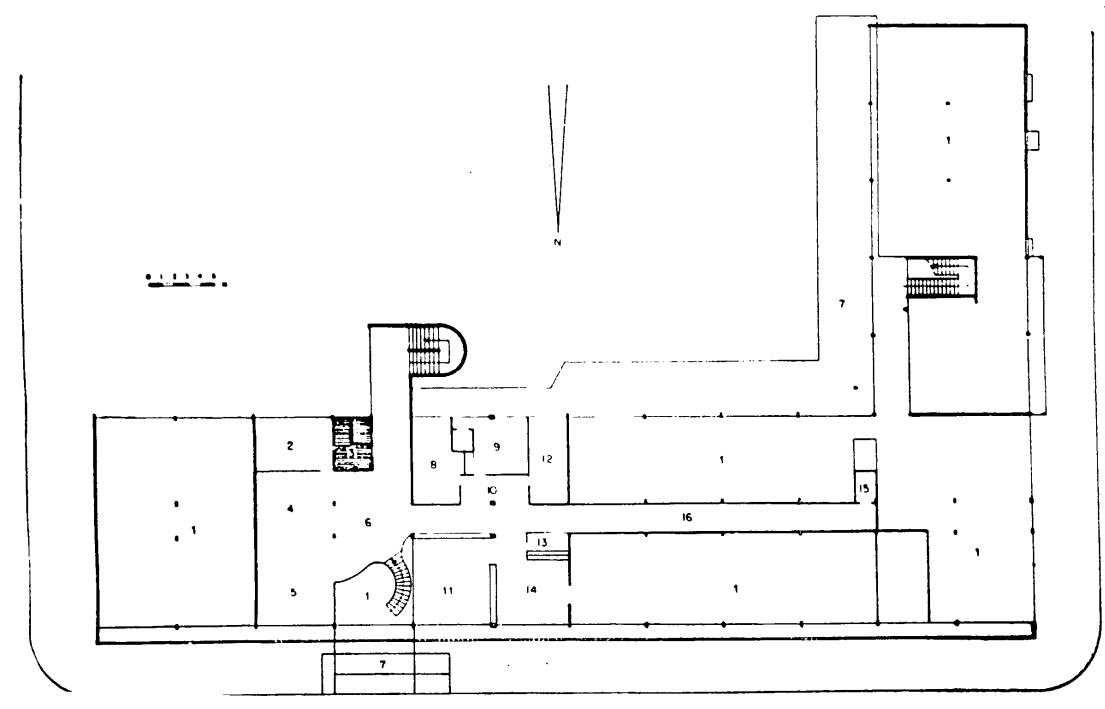

Figura 4: Planta do pavimento intermediário, Escola de Cerâmica, São Caetano do Sul, 1957. Fonte: Acrópole n 314 (1965:41)

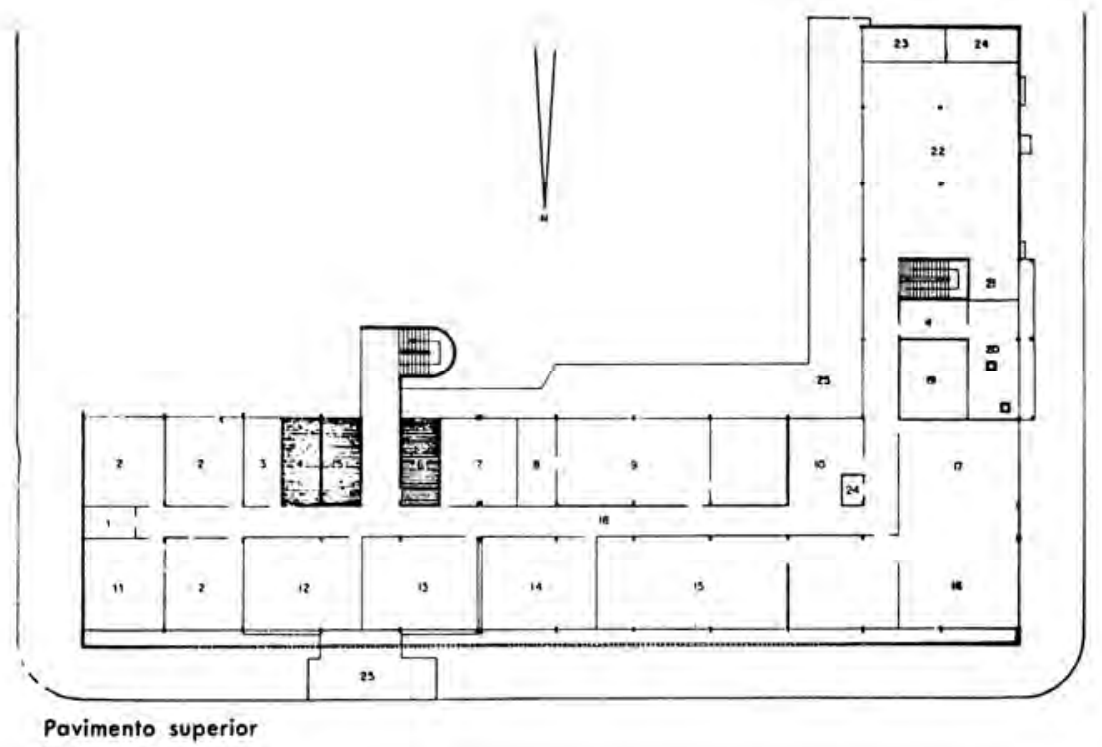

Figura 5: Planta do terceiro pavimento, Escola de Cerâmica, São Caetano do Sul, 1957.

Fonte: Acrópole n 314 (1965:41) 
Figura 6: Prancha da planta do terceiro pavimento, original na escala 1:100, Escola de

Cerâmica, São Caetano do

Sul, 1957. Observar que o

vegetal foi "raspado" e

reutilizado para projeto

hidráulico.

Fonte: Foto Ferraz,

arquivo SENAI

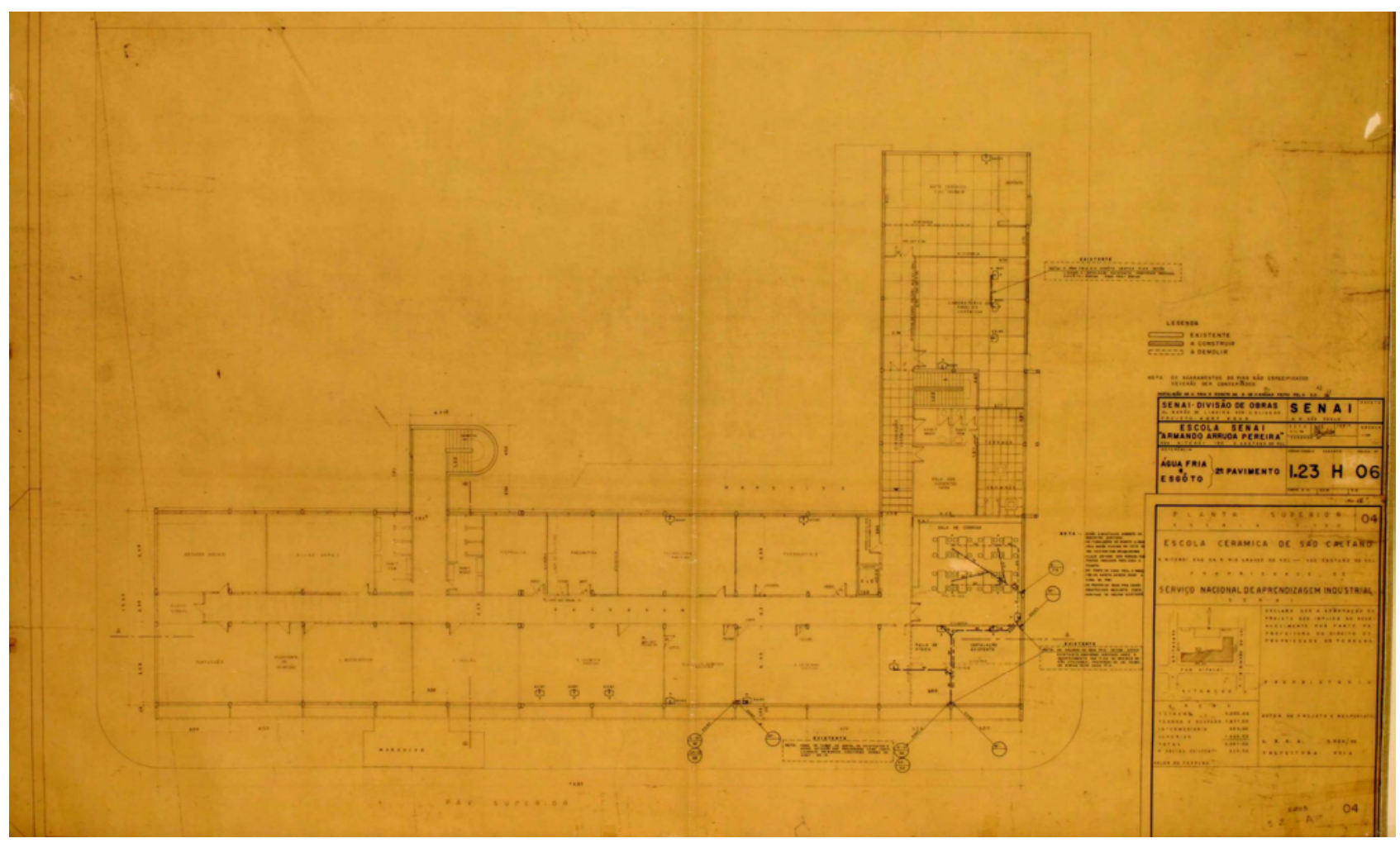

Figura 7: Prancha dos Cortes, original na escala 1:100, Escola de Cerâmica, São Caetano do Sul, 1957.Observar que o vegetal foi "raspado" e reutilizado para reforma. Fonte: Foto Ferraz, arquivo SENAI

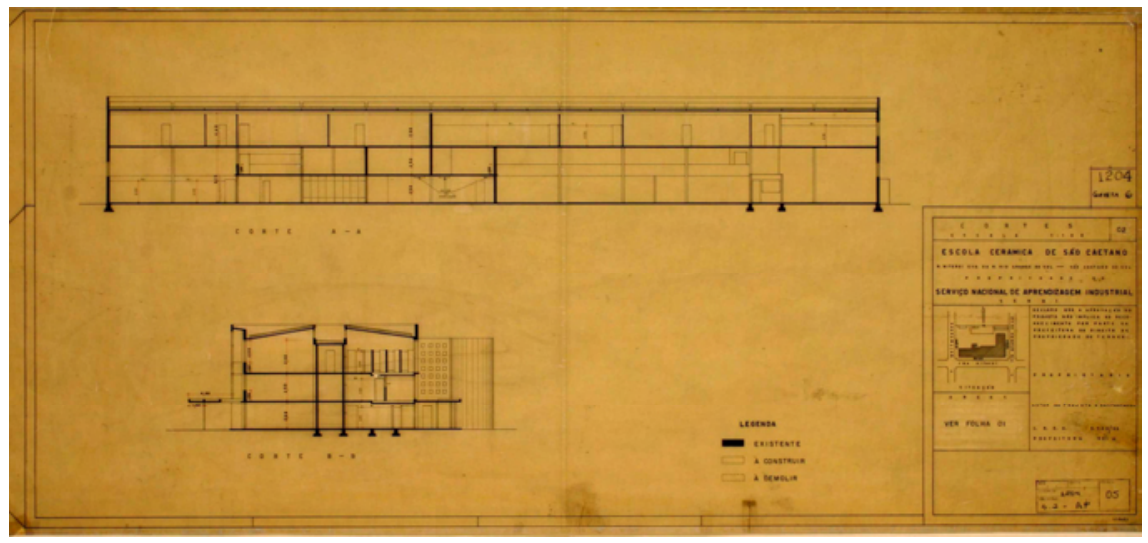

Figura 8: Prancha das Fachadas sul e norte, original na escala 1:100,

Escola de Cerâmica, São

Caetano do Sul, 1957.

Fonte: Foto Ferraz, arquivo SENAI

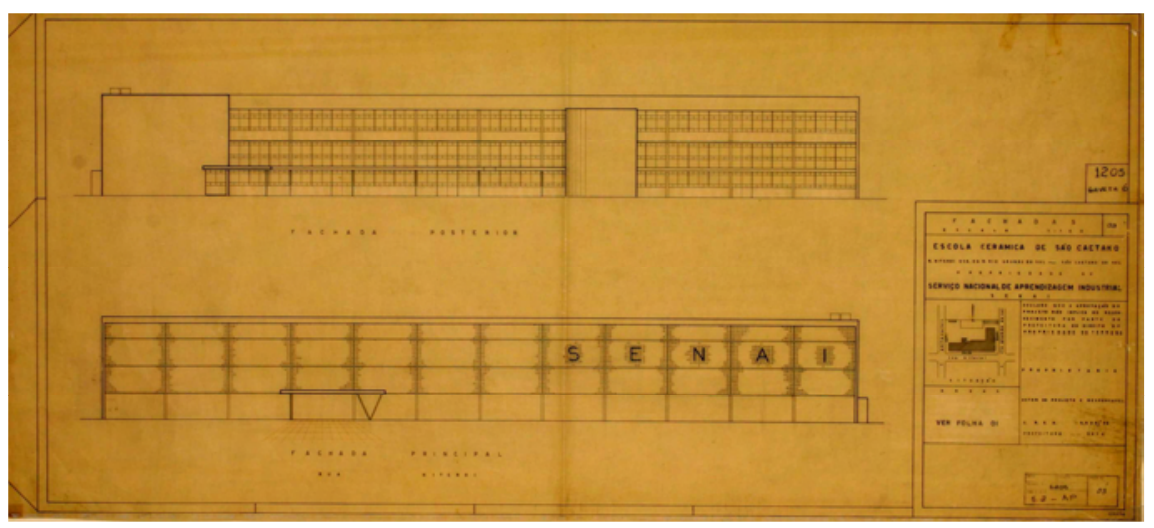




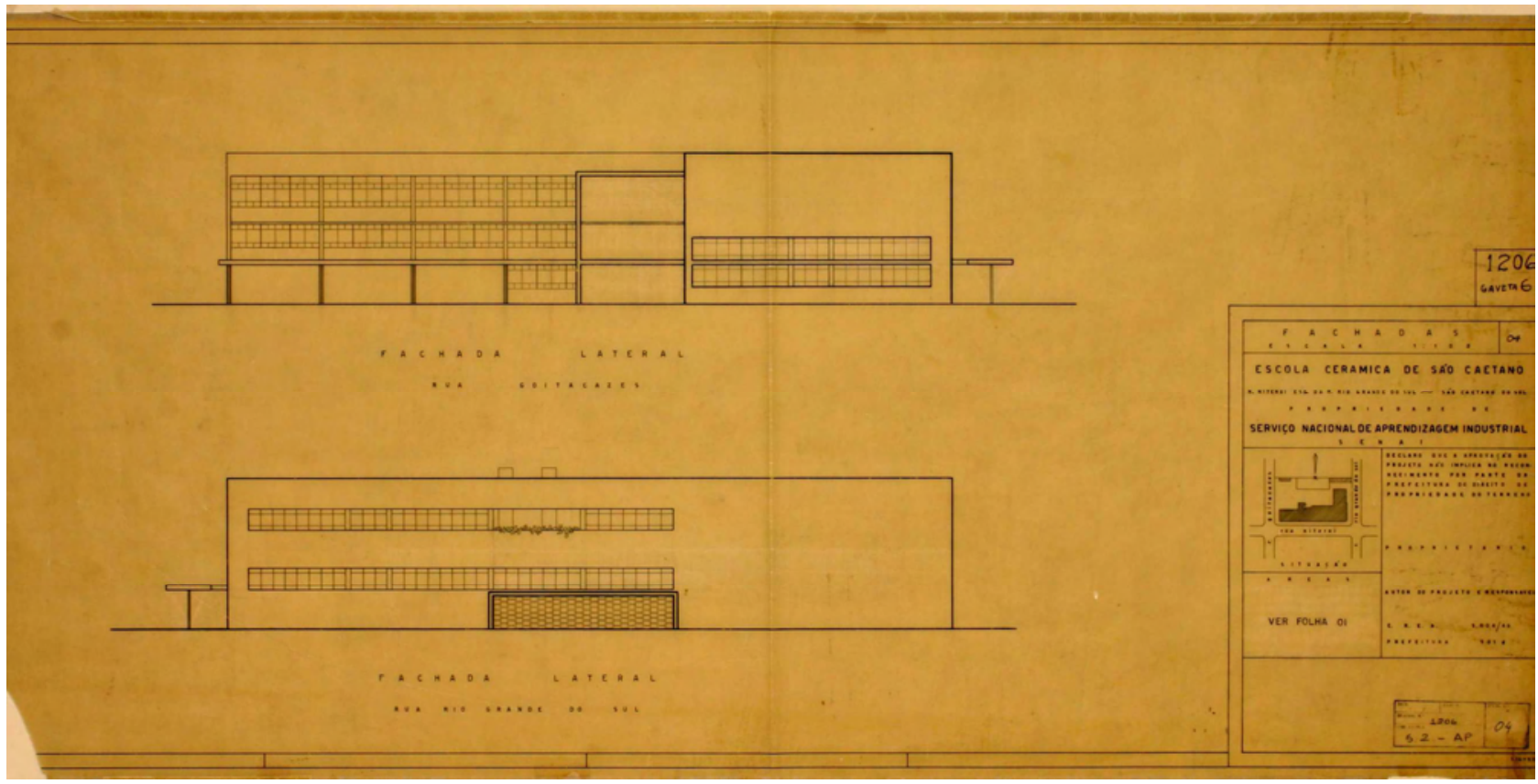

Figura 9: Prancha das Fachadas leste e oeste, original na escala 1:100, Escola de Cerâmica, São Caetano do Sul, 1957. Fonte: Foto Ferraz, arquivo SENAI

bloco marcado pela horizontalidade teve no pavimento térreo a oficina, com fachada norte envidraçada, mas protegida por um sistema de brise solar constituído por um elemento vazado de cerâmica, completamente afastado dos caixilhos (economia). Com pédireito de 5 metros, a oficina foi interligada ao pavimento superior projetado como um grande mezanino administrativo. Assim, o pavimento intermediário com pé-direito de 2,50 metros, sobre parte da oficina e hall de entrada, foi destinado à administração da escola, conforme ilustra o corte B. O terceiro pavimento abrigava diversas salas de aula, sanitários, laboratórios e sala dos docentes, adotando em sua maior ala a modulação longitudinal de 6 metros de eixo entre pilares e a circulação central, com eixo de 2,30 metros, para acesso às salas de aula. Separadas por divisórias, as salas tinham suas aberturas voltadas ora para a face norte e ora para a face sul. $\mathrm{Na}$ outra ala deste mesmo pavimento, perpendicular à maior, foi adotada a circulação lateral voltada para a face leste que, projetada para 0 interior da escola, possibilitou a relação dos alunos com a área de lazer (atratividade). $\bigcirc$ acesso principal da escola era marcado por uma marquise de entrada, elemento característico da arquitetura moderna. 
Figura 10: Corte B, original na escala 1:100,

Escola de Cerâmica, São

Caetano do Sul, 1957.

Fonte: Foto Ferraz,

arquivo SENAI
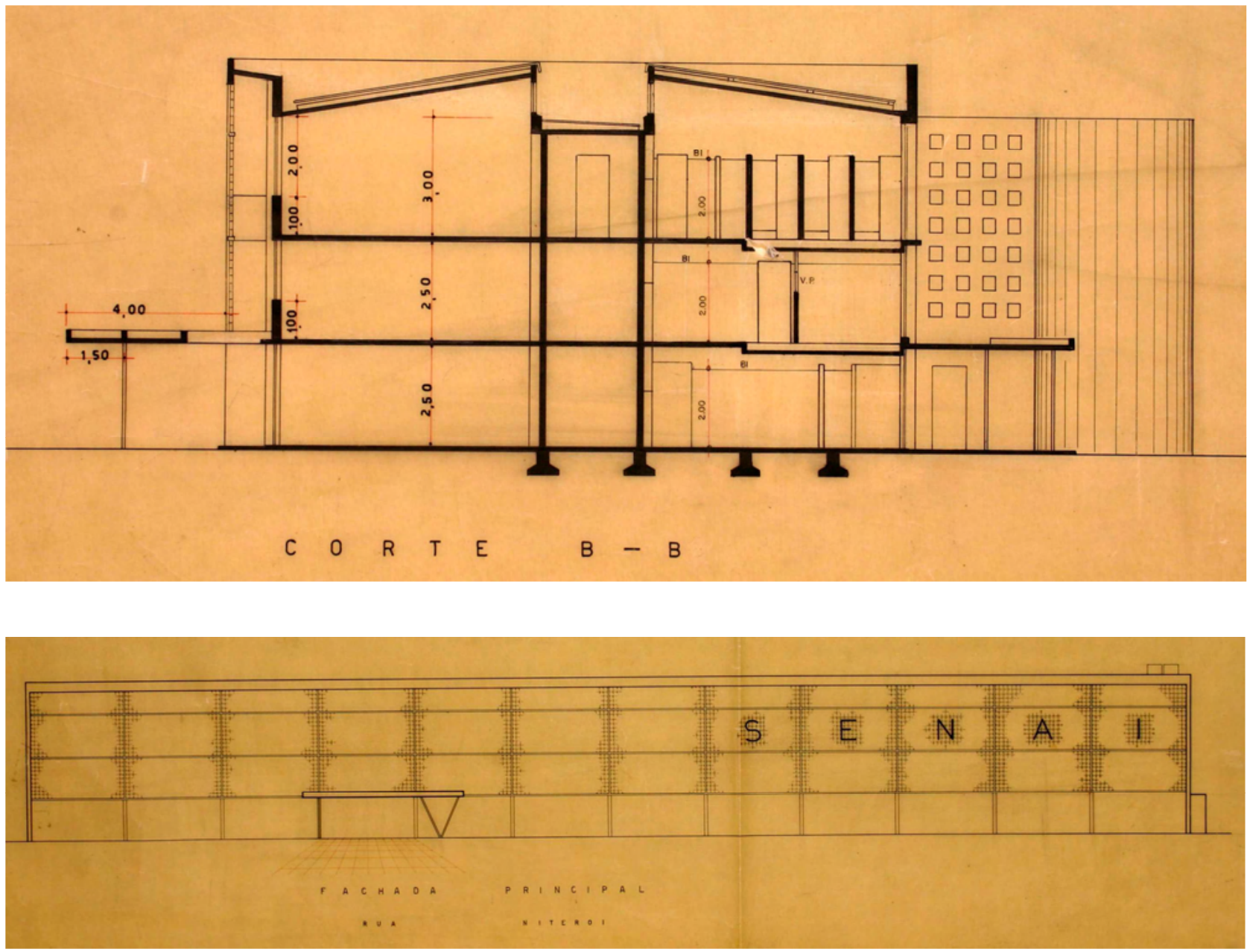

Figura 11: Fachada principal, face norte, original na escala 1:100, Escola de Cerâmica, São Caetano do Sul, 1957. Observar marquise de entrada no acesso principal.
A Escola de São Caetano foi projetada para atender aos cursos de cerâmica industrial, segundo Acrópole n 314 (1965:40) e sua fachada principal revela justamente o objetivo de produção da escola, a cerâmica.

Atendendo a um dos objetivos do SENAI de desempenhar melhor sua função social, a sociabilidade foi alcançada através de parte da oficina aberta sustentada por pilotis, conforme ilustra a fachada leste, e dos grandes vão envidraçados do corredor lateral e das salas de aulas. Mais uma vez, a presença da modulação reforça as idéias de flexibilidade através da planta livre e de crescimento através das divisórias nas salas de aula. Esta escola, confirma uma solução arquitetônica norteada pela pedagogia do SENAI e inova a ligação entre os pavimentos com a presença de elevadores. 
Figura 12: Vista da fachada principal, Escola de Cerâmica, São Caetano do Sul, década de 50.

Fonte: Acrópole no 314 (1965:40)

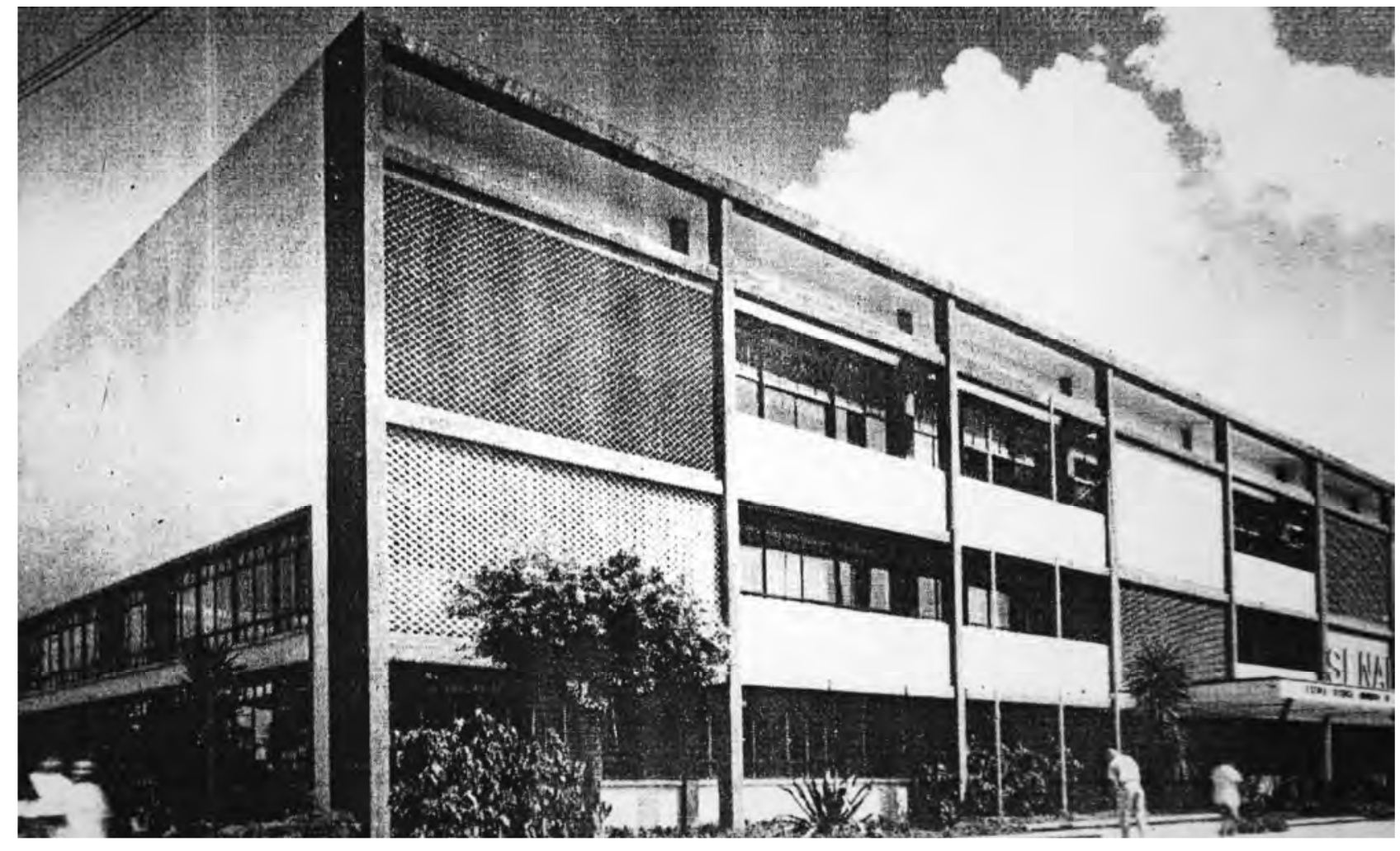




\section{PROJETO 10}

\section{Escola Senai de Jundiaí, 1957}

Projetada em parceria por Roberto José Goulart Tibau e Ayako Nishikawa, a Escola de Jundiaí também foi construída de acordo com os parâmetros da filosofia educacional do SENAI. Localizada à rua Roberto Mange entre as avenidas Francisco Pereira de Castro e Carlos de Sales Bloch, a escola foi implantada num lote de dimensão ainda desconhecida, porém ocupando toda a quadra. $\bigcirc$ projeto original foi composto por dois blocos principais caracterizados pela: administração, oficina e salas de aula, e pavilhão social. Ainda, anexo ao bloco do pavilhão social, foram projetados mais dois blocos de menor porte para bicicletaria, depósito e grêmio estudantil. Além do extenso programa, também foram projetados espaços para área verde e de recreação, tanque de areia, quadras de esportes e arquibancadas.

programa construtivo adotado foi: hall de entrada, secretaria, diretoria, sala dos professores, salas de assistência social, médica e dentária, oficina, seis salas de aulas e sanitários no primeiro bloco; recreio coberto, auditório, palco, camarins, vestiários e sanitários, copa, área de serviço no segundo bloco. Também, nos dois volumes anexos ao segundo bloco, foram projetados: bicicletaria, grêmio e depósito. Os dois blocos foram interligados entre si por escadas, aproveitando os desníveis do terreno.

Grande parte do projeto original ainda não foi encontrado no arquivo do SENAI, porém algumas pranchas já obtidas revelaram o ano de sua concepção, os autores, as fachadas do bloco original da administração, oficina e salas de aula. Sucessivas pranchas revelaram a participação da arquiteta Ayako Nishikawa neste projeto, assim como a ampliação e reformulação do projeto, no ano de 1962, sendo construído um terceiro bloco com salas de aula, perpendicular e anexo ao bloco do pavilhão social. $O$ conhecimento do projeto original foi complementado através do material publicado em periódico da época, Bem Estar n 5/6 (1960:32 e 33). 
Figura 1: Observar os dados do selo do projeto original das elevações do bloco da oficina, original na escala 1:50, Escola de Jundiaí, concebido em julho de 1957, com autoria de Roberto Tibau.

Fonte: Foto Ferraz, arquivo SENAI

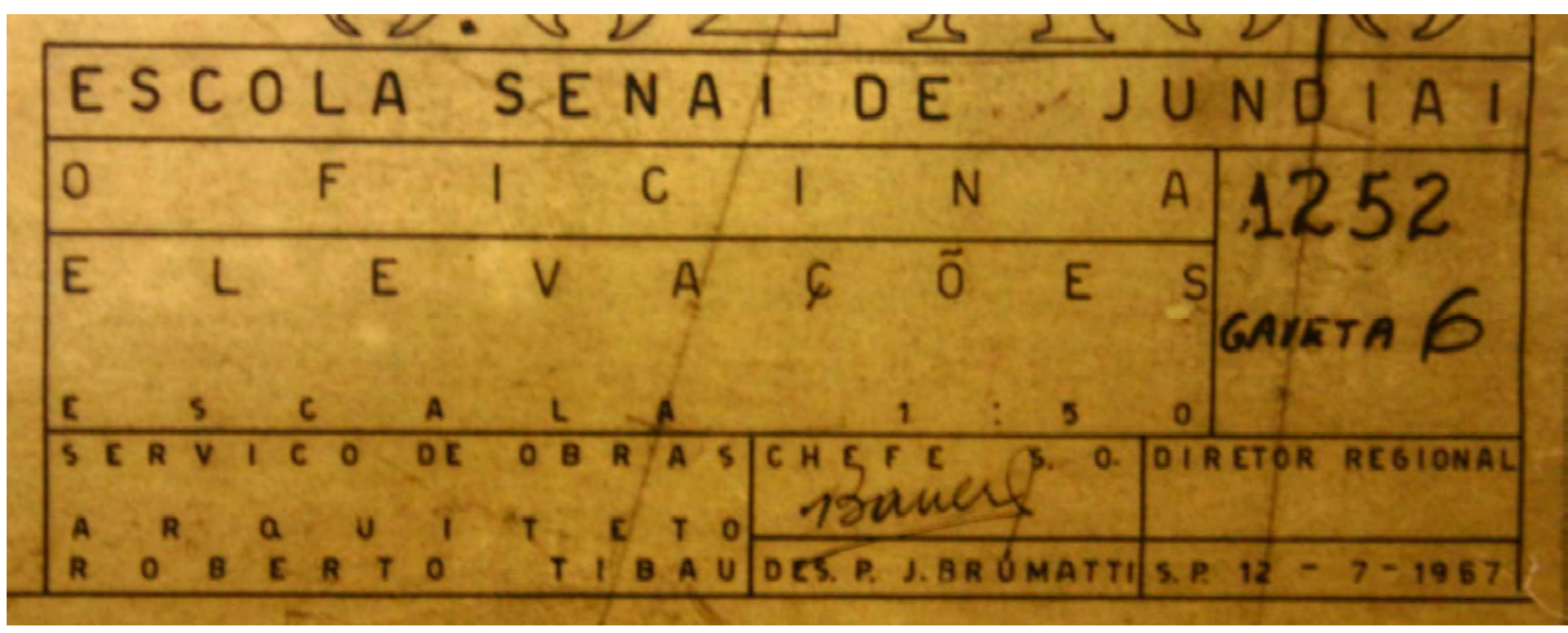

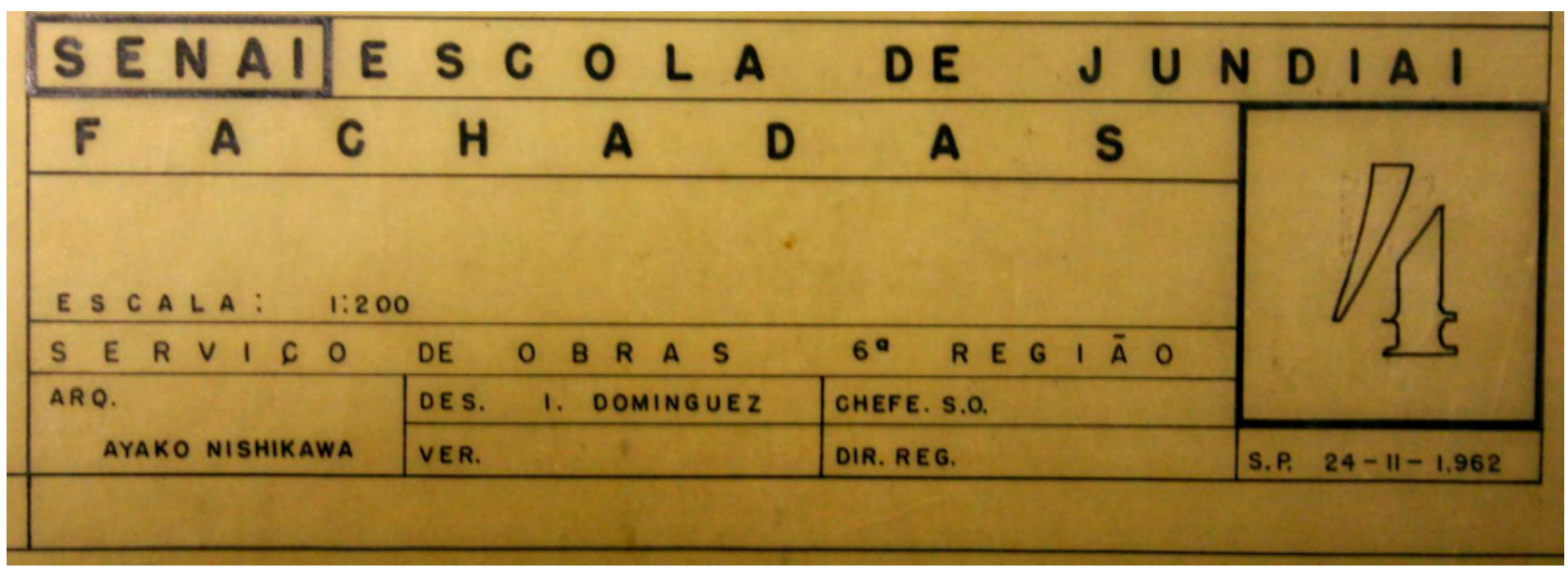

Figura 2: Observar os dados do selo do projeto modificado e ampliado das fachadas da escola, original na escala 1:200, Escola de Jundiaí, concebido em novembro de 1962, com autoria de Ayako Nishikawa. Fonte: Foto Ferraz, arquivo 
Figura 3: Planta do pavimento térreo da Escola de Jundiaí, 1957.

Fonte: Bem Estar n ${ }^{\circ}$ 5/6 (1960:32

Figura 4: Planta do pavimento superior da Escola de Jundiaí, 1957.

Fonte: Bem Estar n ${ }^{\circ}$ 5/6 (1960:33)

Figura 5: Elevação principal (rua Roberto Mange) da Escola de Jundiaí, 1957.

Fonte: Bem Estar n ${ }^{\circ}$ 5/6 (1960:33)
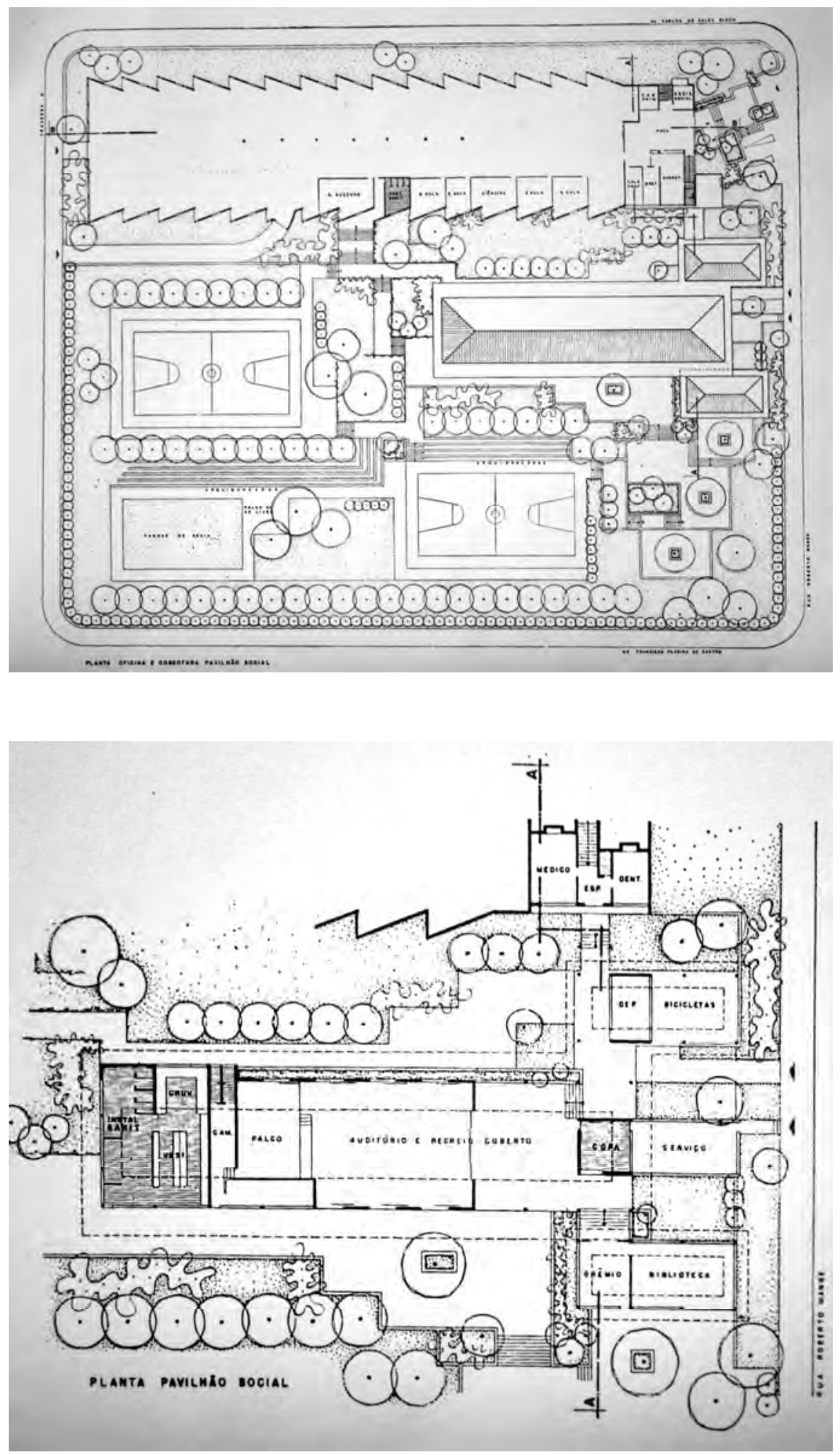

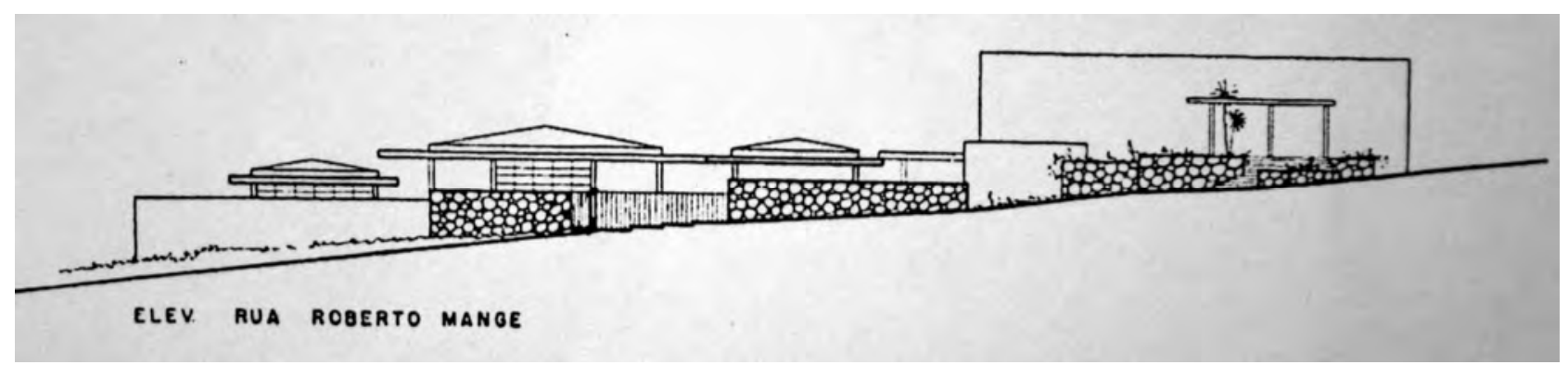




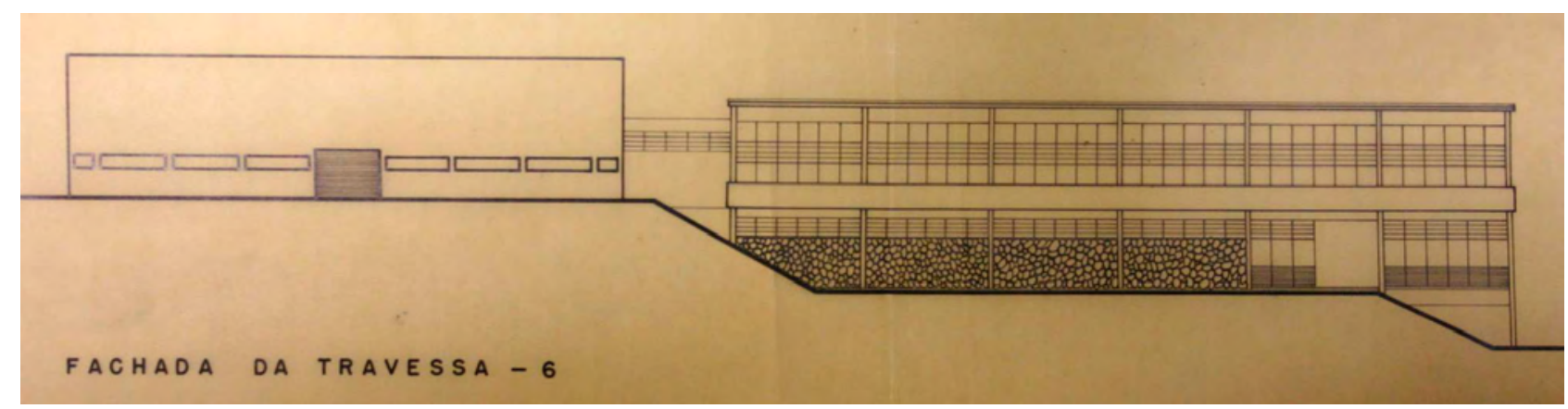

Figura 6: Fachada posterior (travessa 6) retirada da prancha do projeto modificado e ampliado das fachadas da escola, original na escala 1:200,

da Escola de Jundiaí, 1962.

Fonte: Foto Ferraz, arquivo

O primeiro bloco, utilizado pela administração da escola, oficina e salas de aula, foi implantado ao longo da avenida Carlos de Sales Bloch, com acesso pela rua Roberto Mange. Implantado no nível mais alto do terreno, o bloco foi dividido parcialmente em dois pavimentos, sendo térrea a área da oficina e salas de aula e, de dois pavimentos, a área da administração. A administração da escola era composta no pavimento térreo pelo hall de entrada, secretaria, diretoria, sala dos professores, sanitários, salas de assistência social e cabine primária e, no pavimento superior, pelas salas de atendimento médico e dentário. A área destinada à oficina recebeu iluminação e ventilação bilateral (economia), com perímetro escalonado e chanfrado. A estrutura de seu telhado "realizada em alumínio, com cobertura de cimento amianto", segundo Bem Estar n 5/6 (1960:33), proporcionou maior flexiblidade ao espaço, sem a necessidade de pilares de sustentação na área interna. Paralela à área de trabalho prático (oficina) foram projetadas seis salas de aula e as instalações sanitárias, colocadas junto à área das oficinas, marcando a primeira experiência neste sentido (interligação). Atendendo à pedagogia da atratividade de ser uma escola para o aluno, as salas de aula receberam iluminação lateral, permitindo ampla visibilidade da área de atividade social interna da escola. Através de um percurso direcionado por caminhos e escada, o primeiro bloco foi interligado ao segundo como também às quadras de esportes, áreas verdes e de recreação. 


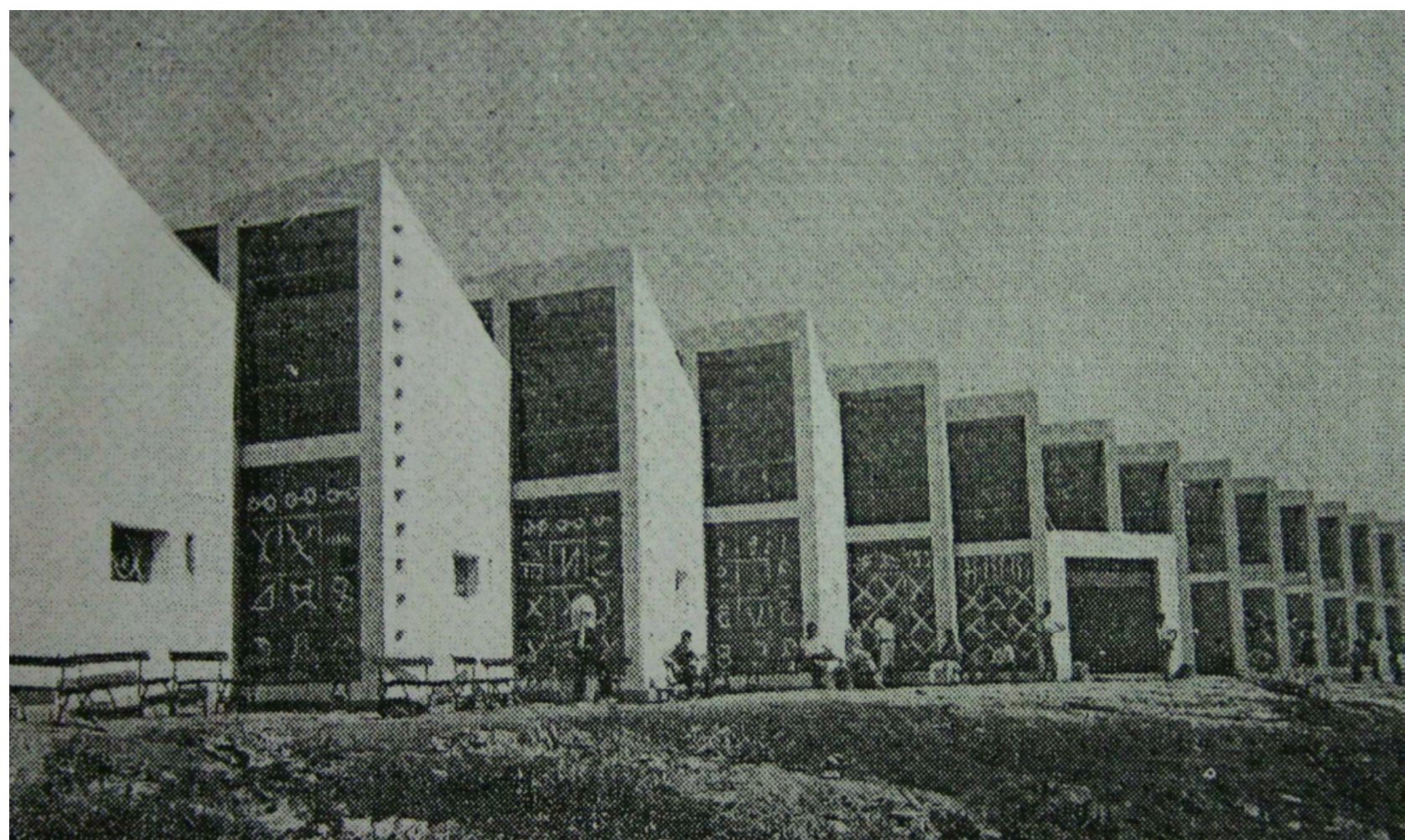

Figura 7: Vista interna do primeiro bloco (oficina, salas de aula e administração), Escola de Jundiaí, década de 50.

Fonte: Bem Estar n ${ }^{\circ}$ 5/6

(1960:33)

O segundo bloco, utilizado como pavilhão social, foi projetado paralelo ao primeiro bloco, e completava a fachada principal juntamente com seus volumes anexos. Projetado em um único pavimento, o pavilhão abrigava: recreio coberto, auditório, palco, camarins, vestiários, sanitários, copa e área de serviço, além dos anexos com bicicletaria, grêmio e depósito. Com acesso independente pela rua, este bloco era circundado por área verde e interligado com a área administrativa do primeiro bloco, atendendo à sociabilidade.

A Escola de Jundiaí também reflete crescimento, flexibilidade, atratividade, interligação, sociabilidade, rendimento e economia propostos na pedagogia do SENAI. Porém, cabe ainda obter mais dados do projeto original para uma análise mais precisa de suas características. Os blocos, ligados entre si, acusam o rendimento que tornava possível realizar a educação integral. Nesta escola, cabe destacar um aspecto importante e inovador, a disposição das salas de aula paralelas e no mesmo piso das oficinas. 


\section{PROJETO 11}

\section{Escola Senai Sorocaba, 1958}

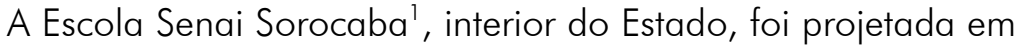
1958 pelo arquiteto Lúcio Grinover. Implantada num terreno irregular de $9.623,00^{2}$, o projeto original contava com 3.645,00 $\mathrm{m}^{2}$ de área construída. $O$ projeto, implantado ao longo dos 121,50 metros da avenida, teve sua fachada principal voltada para a face sul, composta principalmente pelo bloco da oficina.

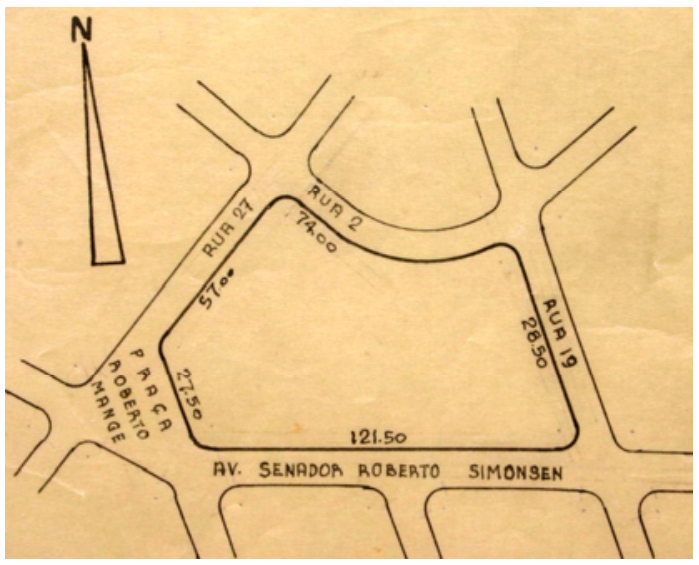

Figura 1: Planta de localização do terreno, Escola Sorocaba, 1958.

Fonte: Foto Ferraz, arquivo SENAI

programa construtivo foi distribuído em um único bloco em "L", sendo dividido em oficina, salas de aula, administração e pavilhão social. Interligados entre si, os principais elementos do programa construtivo foram dispostos num edifício que marcava uma inovação na construção que, segundo Acrópole n 314 (1965:39), "pela primeira vez, estudava-se uma construção em casca de concreto, o parabolóide hiperbólico". ○ programa construtivo completo era composto de oficina, forja, depósito de madeira, sanitários, salas de aula, secretaria, diretoria, biblioteca, sala de reuniões, cabine primária, salas de atendimento médico, dentário e de assistência social, copa, cozinha, despensa, vestiários, recreio coberto, palco, camarins, grêmio estudantil e bicicletaria. Além do extenso programa, também foram projetados espaços para área verde e de recreação, quadra de esportes e, caixa d'água como elemento escultural, que juntos se integravam com o recreio coberto do pavilhão social.

\footnotetext{
1 A Escola Senai de Sorocaba foi publicada pela revista Bem Estar n 5/6 (1960:34 e 35) e Acrópole n 314 (1965:39).
} 
Grande parte dos dados relativos ao edifício foram encontrados no arquivo do SENAI, como as pranchas do ante-projeto original e as pranchas do projeto de prefeitura e executivo, revelando a implantação geral, plantas, inúmera folhas de detalhamentos, corte transversal e diversas elevações. Estes documentos possibilitaram confirmar a data do projeto, suas particularidades e a contribuição do arquiteto Melanias M. Nagamini no projeto executivo do Pavilhão social, no ano de 1960, e da arquiteta Ayako Nishikawa no projeto de paisagismo, iniciado em 1961. O conhecimento do projeto original também foi obtido através das mesmas pranchas do projeto original, publicadas nos periódico da época, Bem Estar n5/6 (1960:34 e 35) e Acrópole n 314 (1965). Ainda, para facilitar a leitura arquitetônica do projeto e representá-lo graficamente através de significativos dados obtidos no projeto original, foi graficamente redesenhada a planta com sua implantação no terreno e a elevação principal sul.

Figura 2: Observar os dados do selo do ante-projeto da Escola Sorocaba, concebido em fevereiro de 1958, com autoria de Lúcio Grinover.

Fonte: Foto Ferraz, arquivo SENAI

Figura 3: Observar os dados do selo do projeto executivo da Escola Sorocaba, concebido em março de 1959, com autoria de Lúcio Grinover.

Fonte: Foto Ferraz, arquivo SENAI

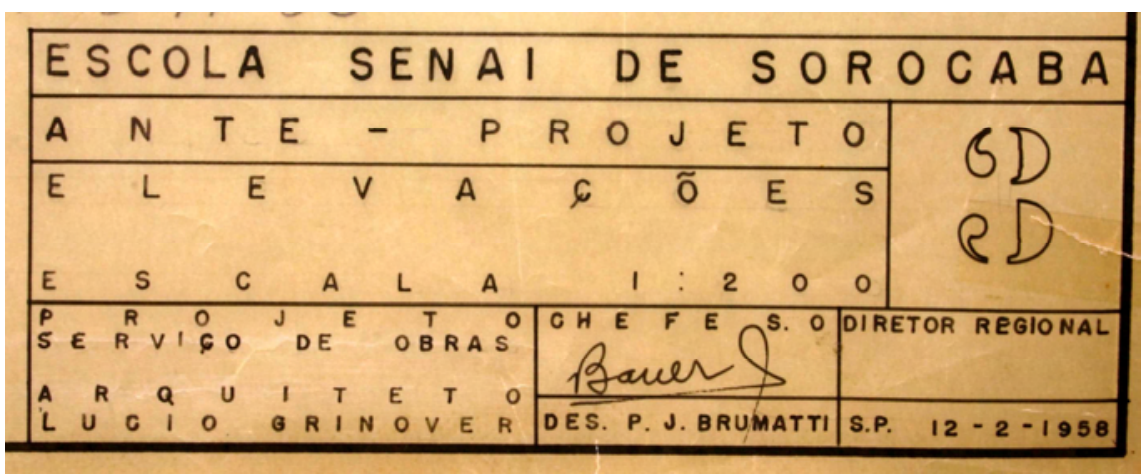

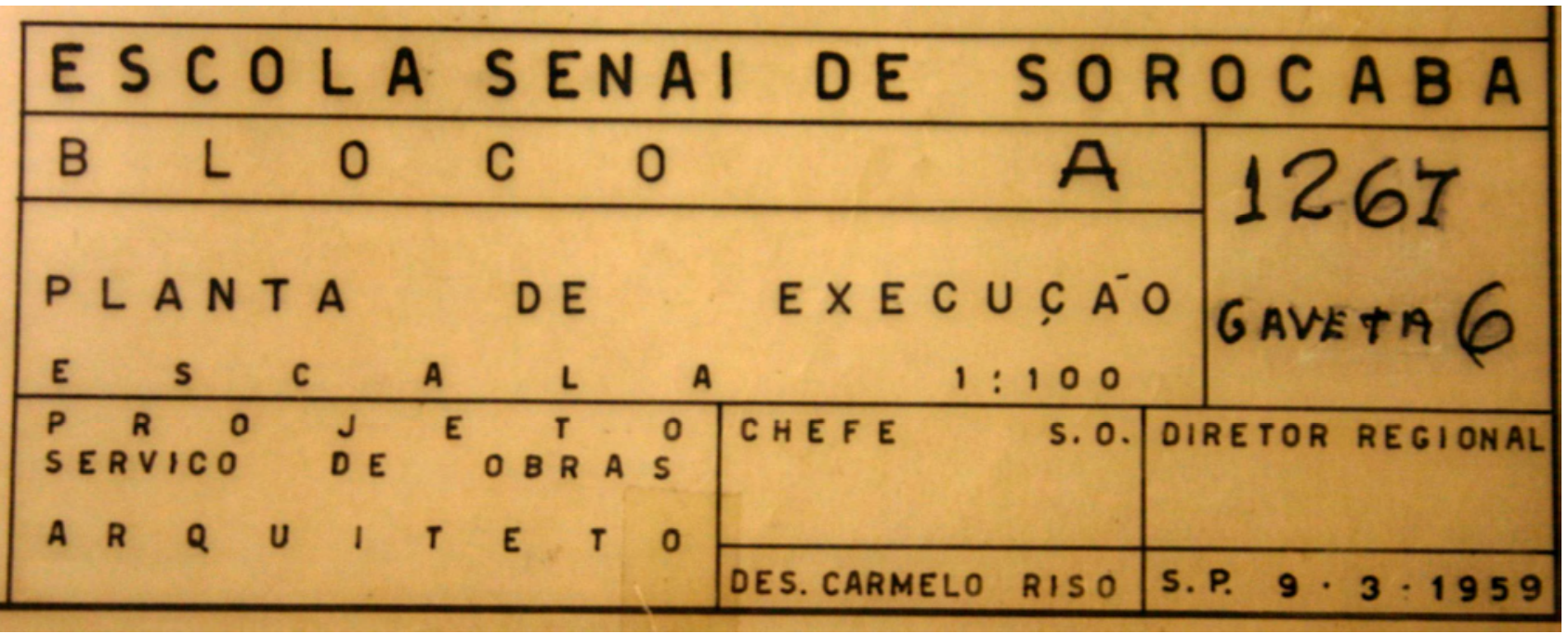


Figura 4: Observar os dados do selo do projeto executivo do Pavilhão Social da Escola Sorocaba, concebido em janeiro de 1962, com autoria de Melanias M. Nagamini. Fonte: Foto Ferraz, arquivo SENAI

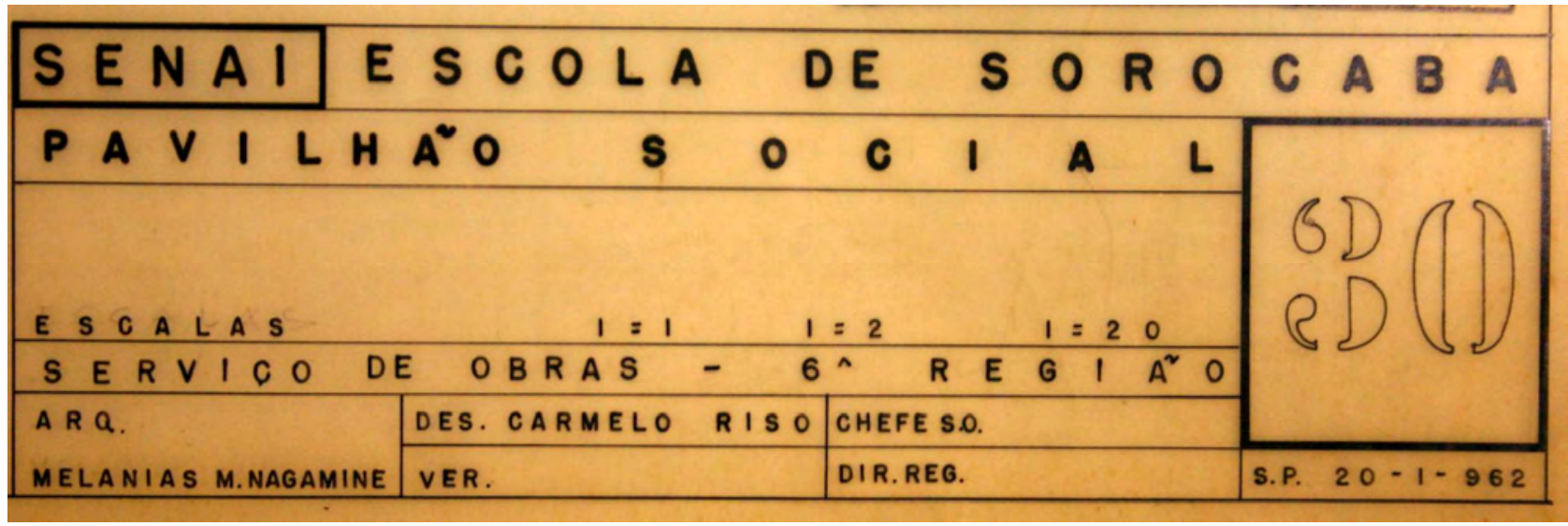

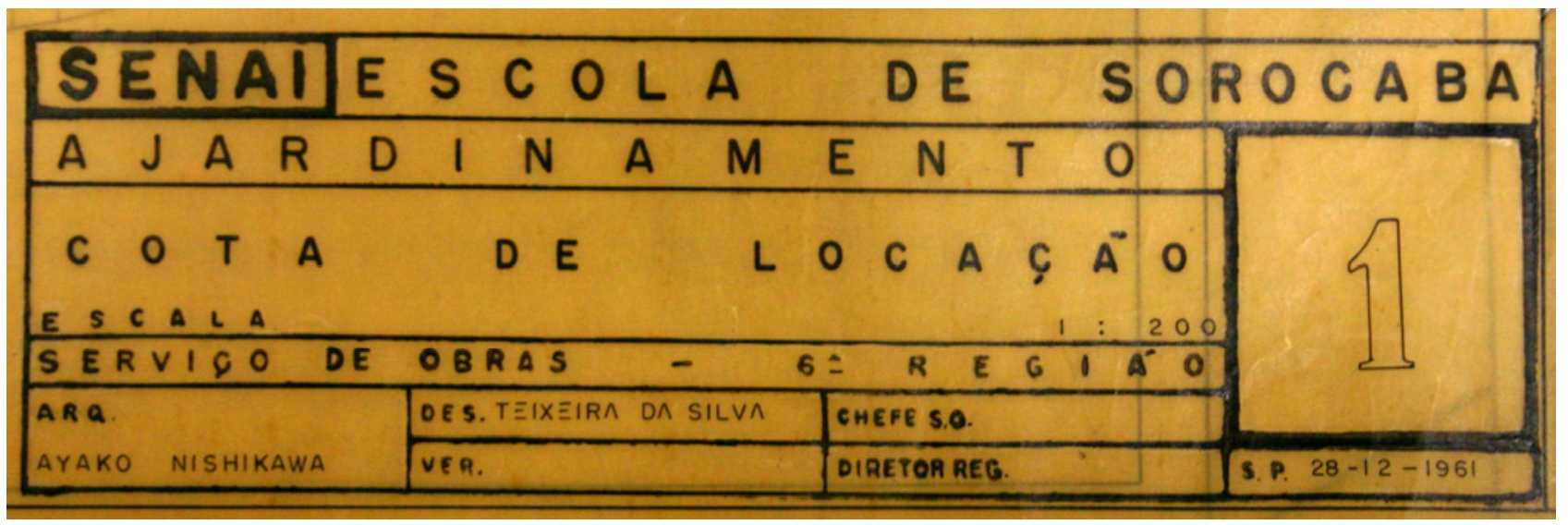

Figura 5: Observar os dados do selo do projeto de paisagismo da Escola Sorocaba, concebido em dezembro de 1961, com autoria de Ayako Nishikawa.

Fonte: Foto Ferraz, arquivo SENAI 
Figura 6: Prancha do anteprojeto das elevações da Escola Sorocaba, 1958

Fonte: Foto Ferraz, arquivo SENAI

Figura 7: Prancha do projeto de prefeitura da planta do pavimento térreo da Escola Sorocaba, 1959

Fonte: Foto Ferraz, arquivo SENAI

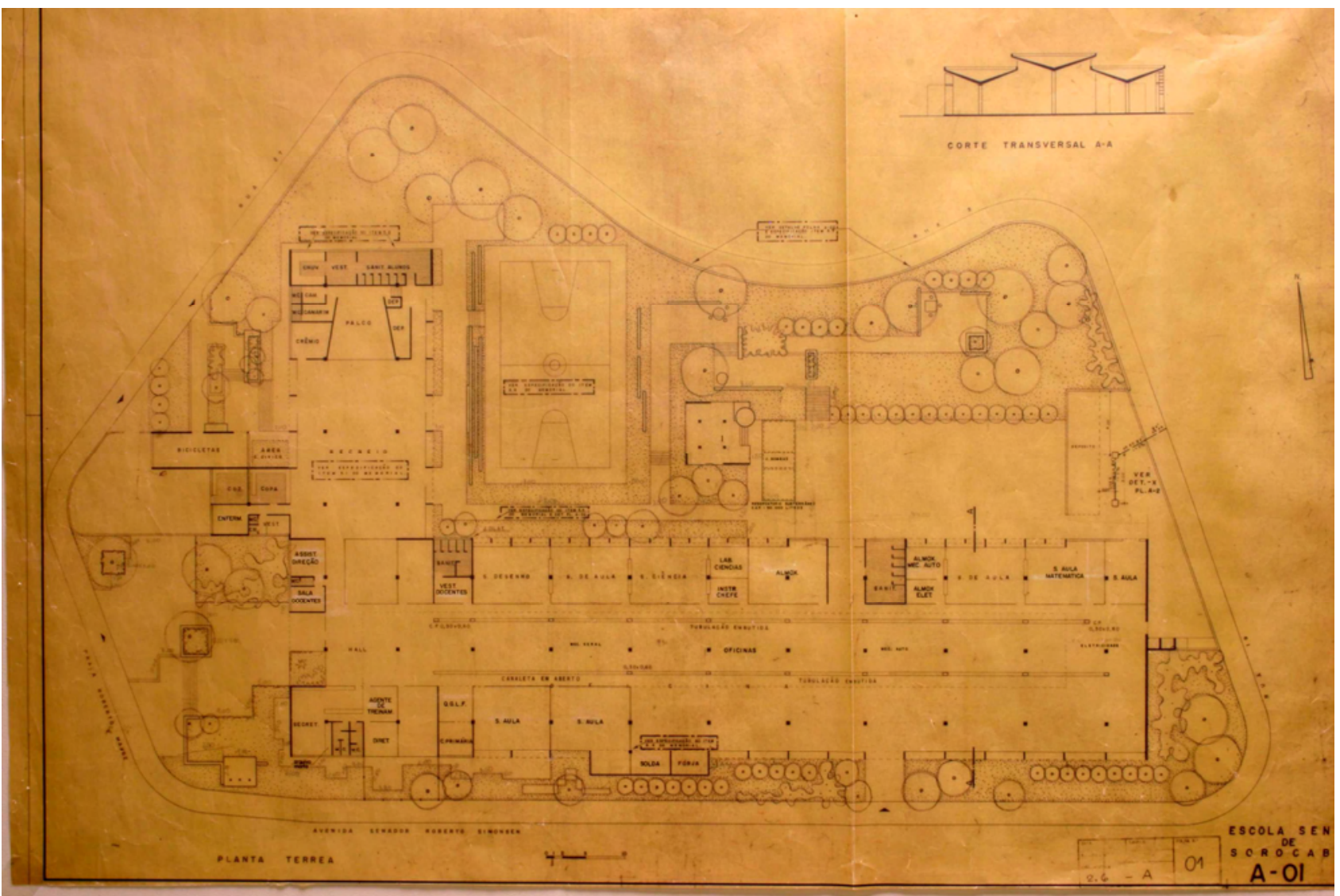




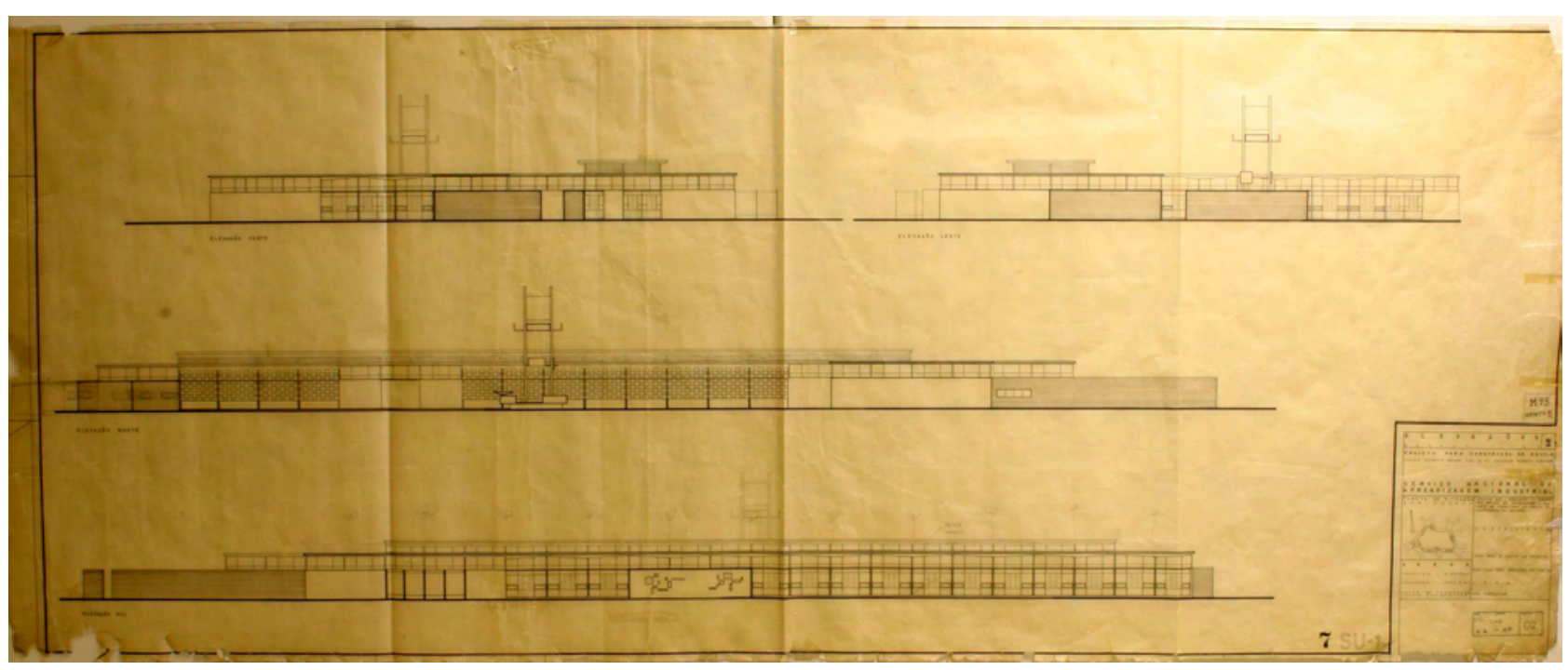

Figura 8: Prancha do projeto de prefeitura das elevações da Escola Sorocaba, 1959. Fonte: Foto Ferraz, arquivo SENAI

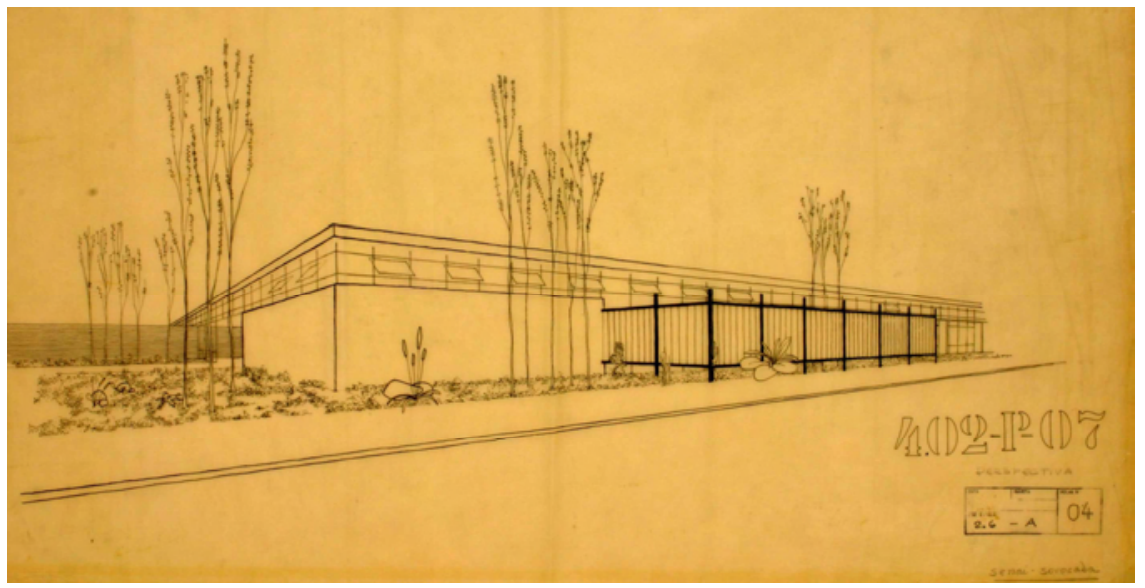

Figura 9: Prancha do projeto de paisagismo, perspectiva da fachada oeste da Escola Sorocaba, 1962. Fonte: Foto Ferraz, arquivo SENAI

Figura 10: Prancha do projeto de paisagismo, perspectiva da fachada norte da Escola Sorocaba, 1962. Fonte: Foto Ferraz, arquivo SENAI

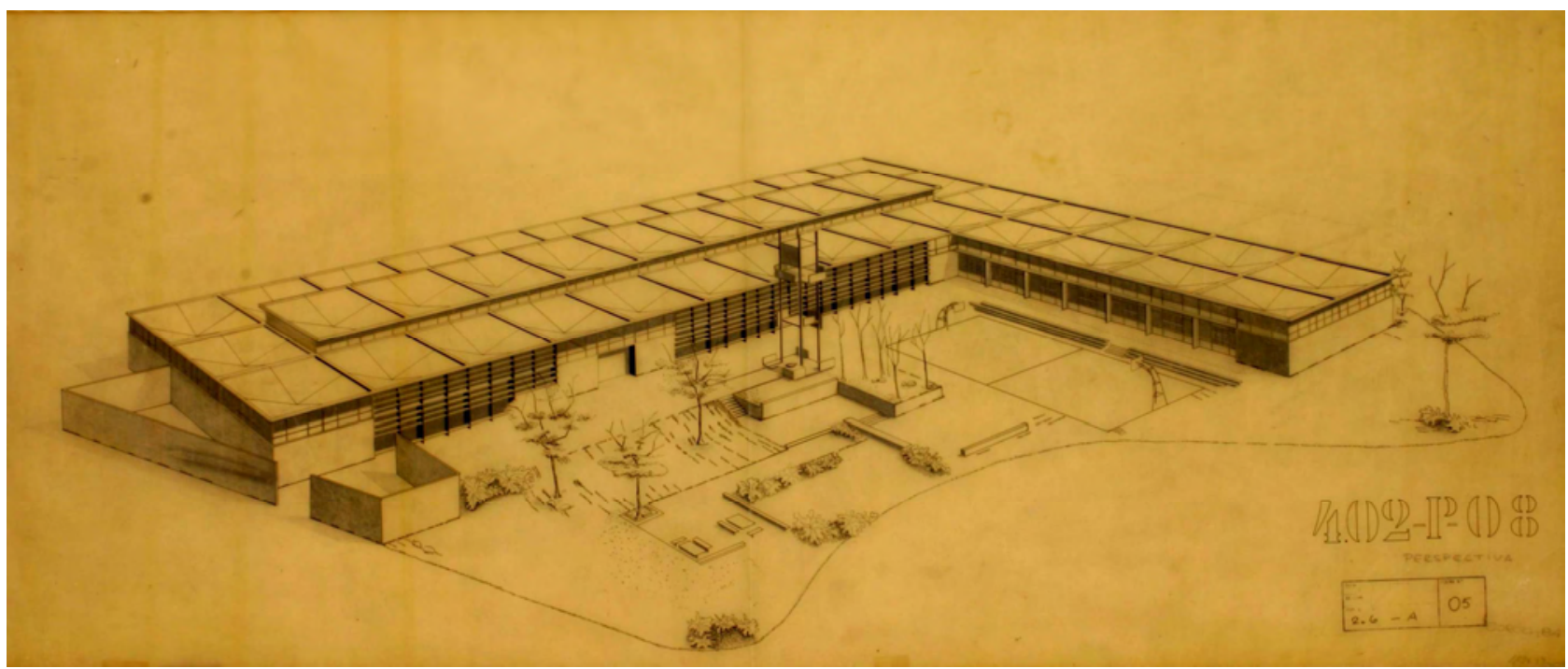




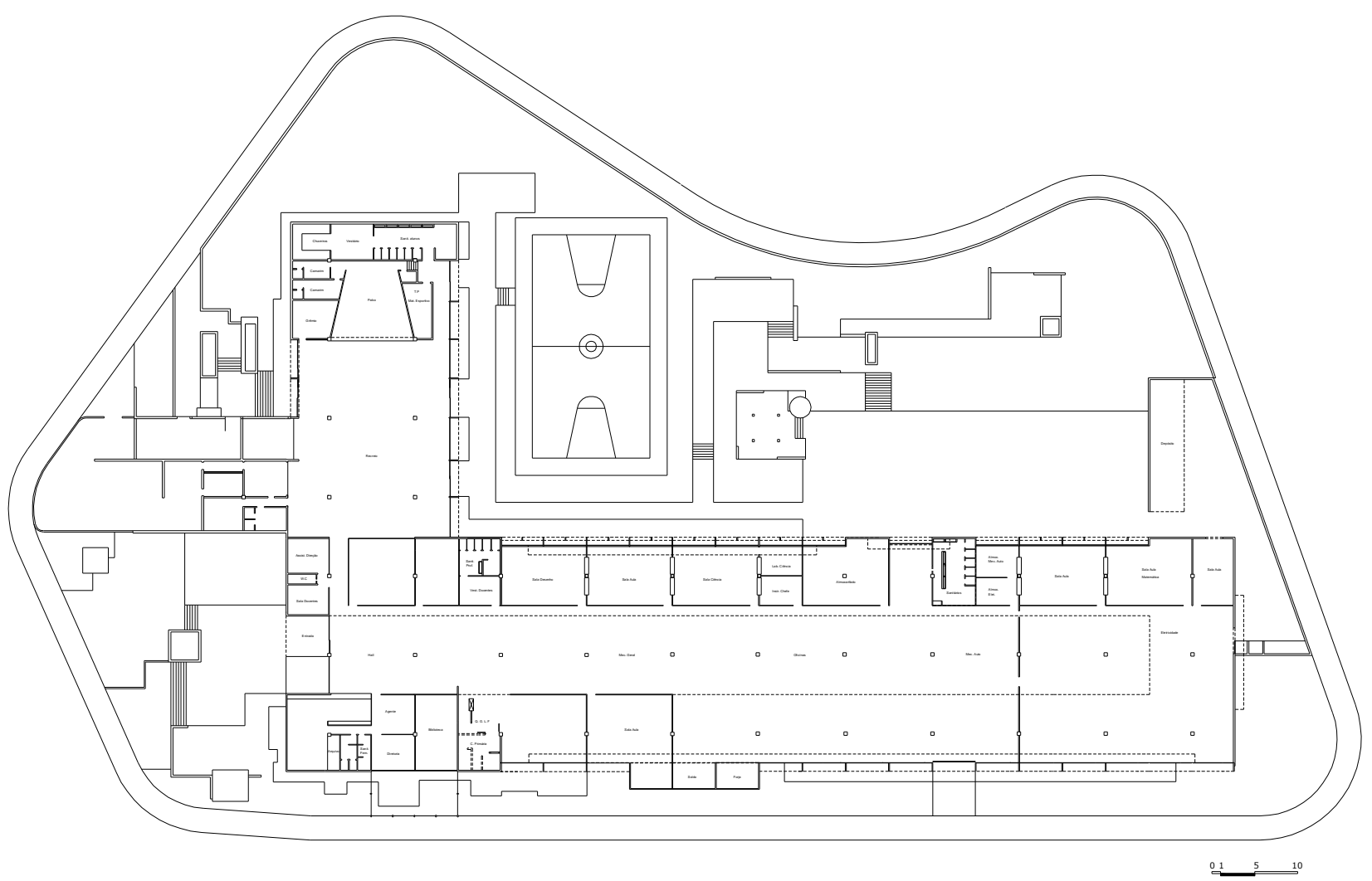

Figura 11: Redesenho da planta original e implantação.

Fonte: Ferraz, 2005

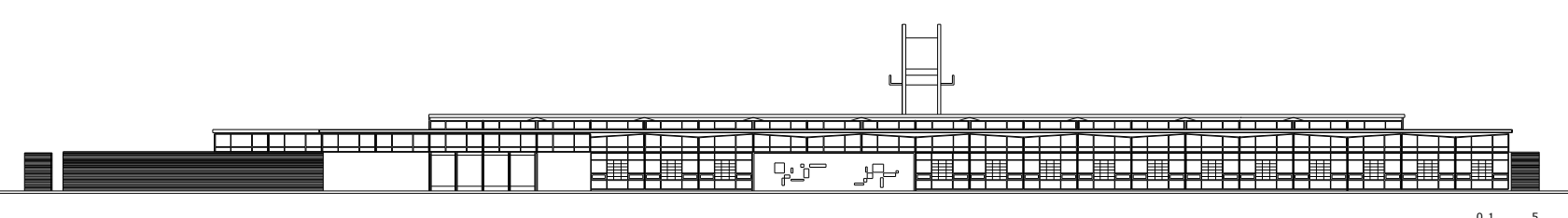

Figura 12: Redesenho da elevação principal sul.

Fonte: Ferraz, 2005

O projeto, resolvido num edifício único dividido em duas alas perpendiculares entre si, foi executado pré-fabricado de concreto armado e coberto por diversos parabolóides hiperbólicos, através de "forma de madeira completamente desmontável, de reaproveitamento total para a concretagem do parabolóide hiperbólico seguinte" (Acrópole n³14, 1965:39). Desta maneira, além dos resultados positivos na execução, o monobloco atendeu às necessidades da escola. 
Integrando em sua maior ala a área da oficina paralela às salas de aula (interligação), a oficina recebeu iluminação e ventilação tanto pela face sul como pela cobertura, possibilitando uma iluminação zenital uniforme na área de trabalho, graças à cobertura elevada no centro desta ala (economia). As salas de aula, com iluminação lateral norte, foram protegidas do sol da tarde com brises solares (ver elevação norte) e separadas com divisórias-móveis, utilizadas para quadro negro e armário (flexiblidade e crescimento). $\mathrm{Na}$ extremidade leste da maior ala foi projetado um depósito de madeira aberto e, na extremidade oeste, a administração da escola, ponto de intersecção entre a ala maior da oficina e salas de aula, com a ala menor do pavilhão social.

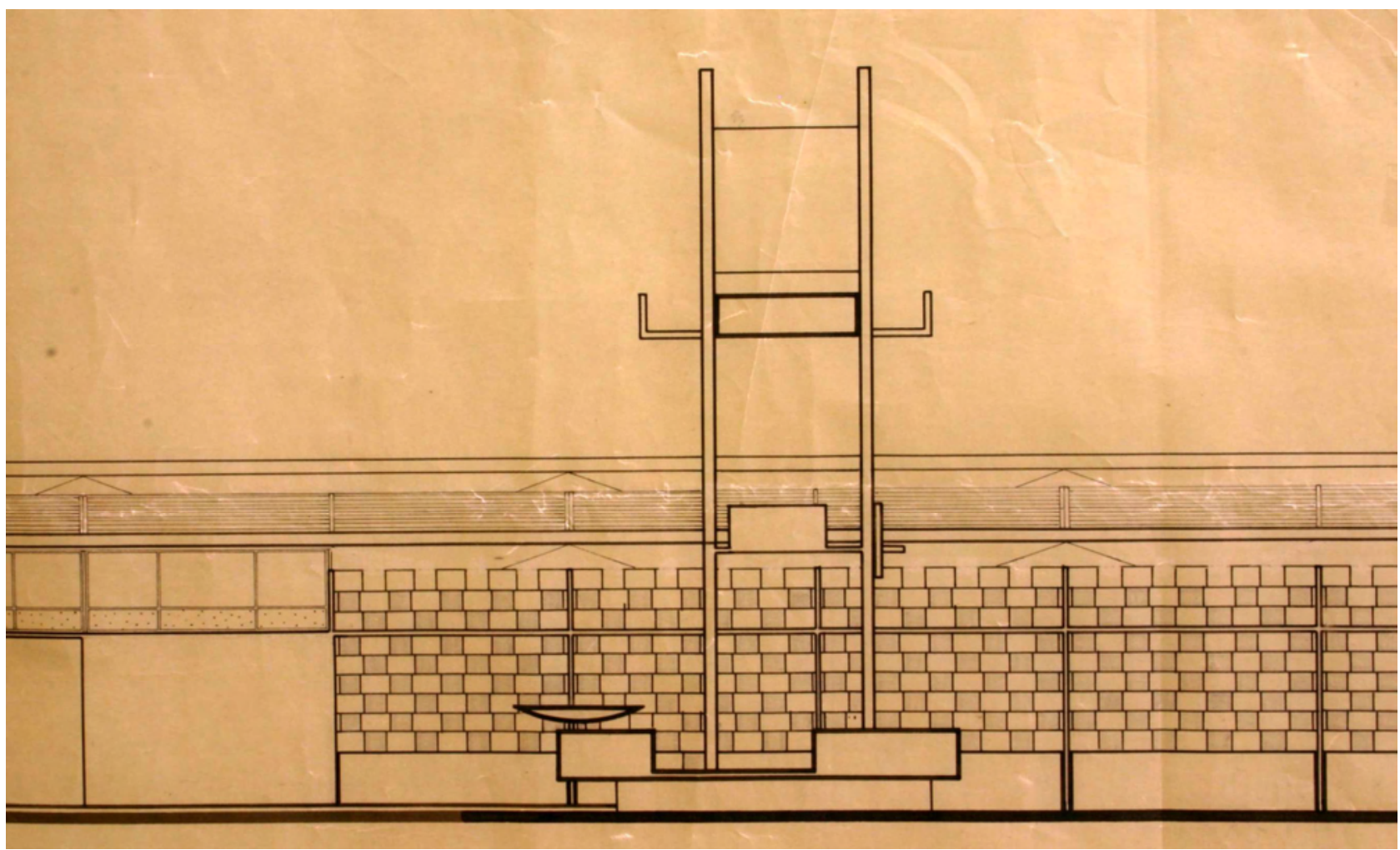

A administração seguia a mesma modulação da oficina e abrigava: hall de entrada, diretoria, secretaria, arquivo, agente de treinamento, sanitários, vestiários, biblioteca, salas dos docentes e assistente de direção, todos integrados com a área de trabalho da oficina e com a área social do recreio coberto (atratividade). Desta forma, a ampla visibilidade de todos os espaços permitia de uma só vez o controle visual das atividades nas salas de aula, oficina recreio e administração (interligação).
Figura 13: Detalhe da elevação norte retirada da prancha do projeto de prefeitura da Escola Sorocaba, 1959. Observar brises e caixa d' água. Fonte: Foto Ferraz, arquivo SENAI 
A menor ala era ocupada pelo Pavilhão Social composto pelo recreio coberto, palco, camarins, grêmio, depósito de materiais esportivos, sanitários e vestiários, além de um volume anexo que abrigava a copa, cozinha, enfermaria, vestiários dos funcionários e bicicletaria. Esta ala era voltada principalmente para a face leste, com portas envidraçadas que se abriam para a área verde e recreativa da escola, assim como para a quadra de esportes (atratividade). 0 pavilhão também seguiu a mesma modulação entre pilares com eixo de 9,20 metros no sentido norte-sul e de 10 metros no sentido lesteoeste.

Figura 14: Perspectiva retirada da prancha de paisagismo da Escola Sorocaba, 1962.

Observar à direita a ala do pavilhão social e à esquerda a ala da oficina e salas de aula. Fonte: Foto Ferraz, arquivo SENAI

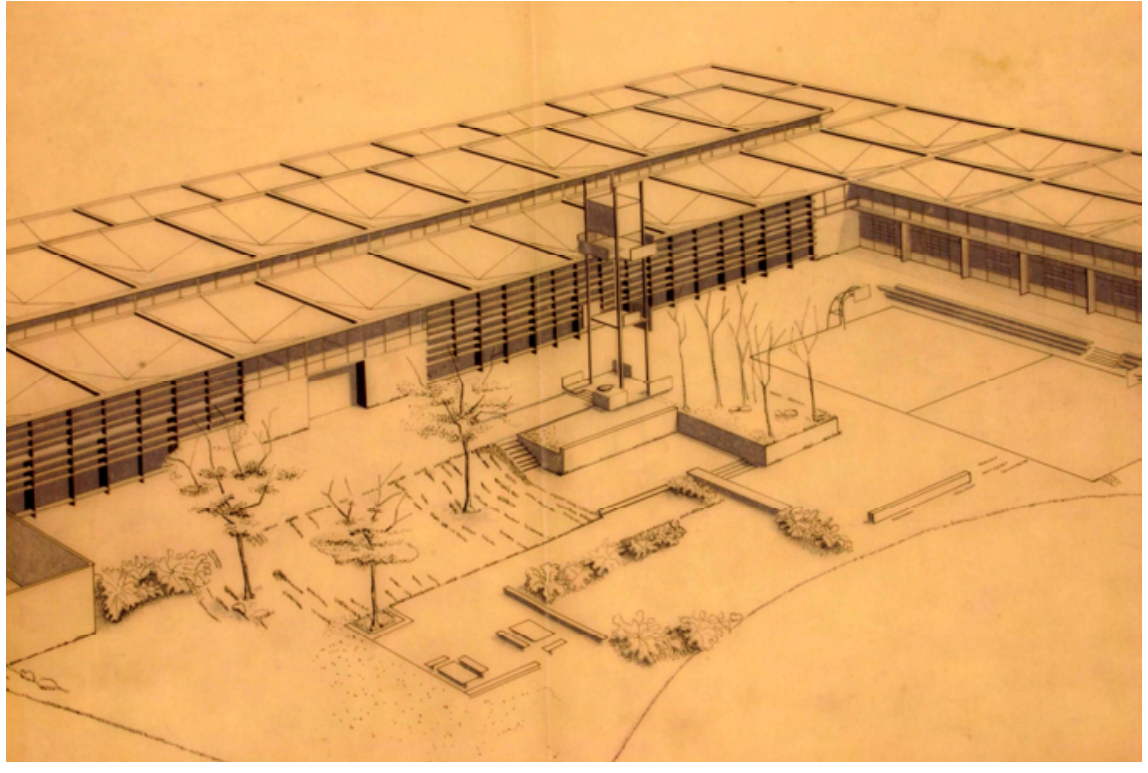

O edifício, seguindo uma modulação única com cobertura em casca de concreto armado, permitiu a flexibilidade de seus espaços de acordo com o crescimento da indústria. As salas de aula divididas com separações móveis de armários para que estes espaços pudessem se adequar de acordo com a necessidade da escola, a ausência do corredor de circulação, o contato com o exterior tanto da escola como do urbano, possibilitou ao aluno, professor e visitante, a integração com o local de trabalho e ensino. Assim, entre outras características, o projeto também reflete arquitetonicamente os pontos básicos da pedagogia do SENAI, porém de forma inovadora do que diz respeito à sua tecnologia de construção. 
Figura 15: Vista da elevação sul da oficina, Escola Sorocaba. Fonte: Acrópole n 314

(1965:39)

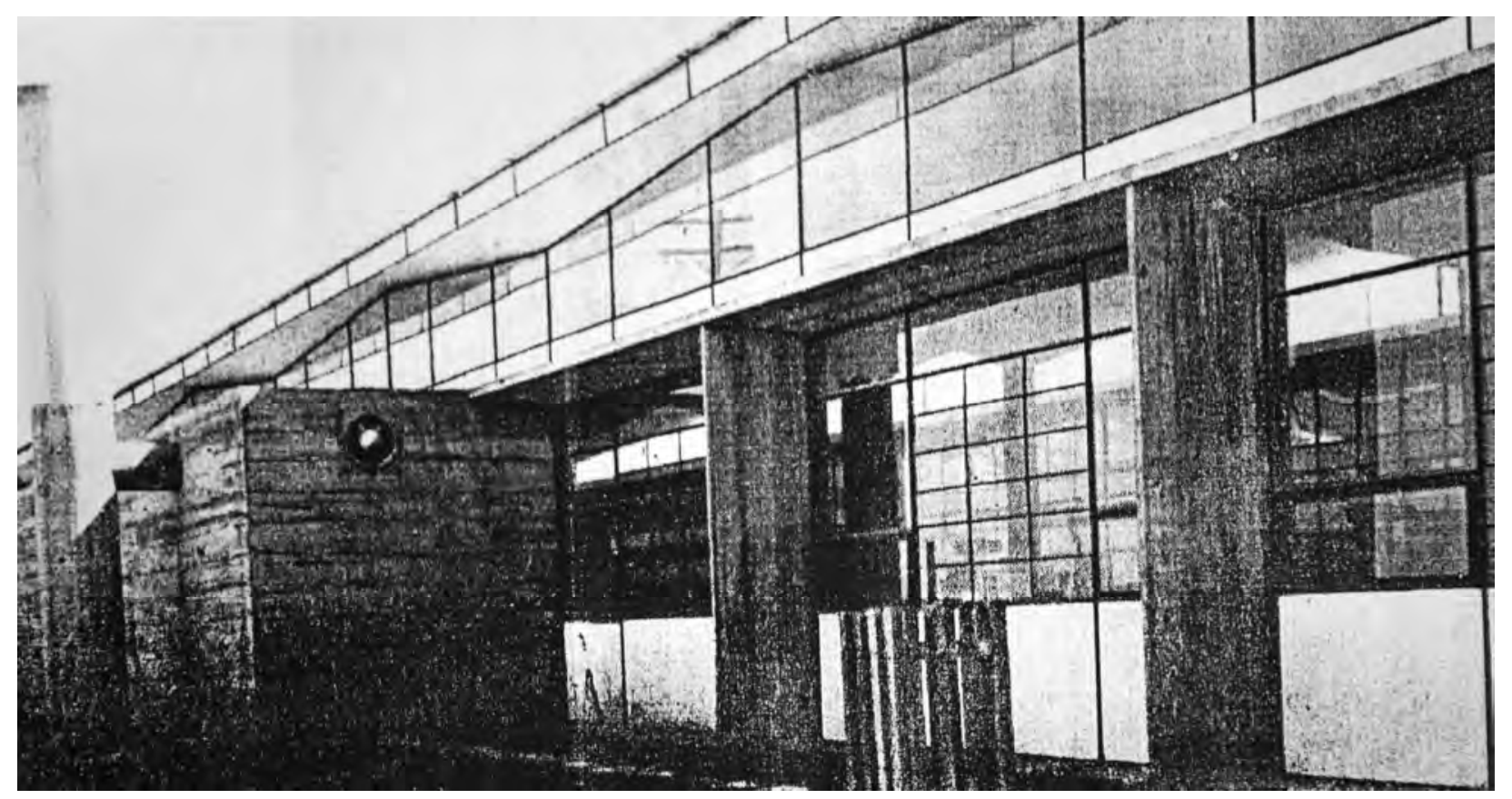




\section{PROJETO 12}

\section{Escola Senai Santa Bárbara d'Oeste, Fundação Romi, 1958}

Projetada por Lúcio Grinover, a Escola Santa Bárbara $\mathrm{d}^{\prime}$ Oeste $^{2}$, no interior de São Paulo, foi uma escola projetada para a Fundação Romi. Ainda não foram obtidos os dados de sua localização e dimensão do lote em que foi implantada, porém sabe-se que a escola foi composta por quatro blocos caracterizados pela oficina, salas de aulas, administração e pavilhão social, com aproximadamente $3.250,00 \mathrm{~m} 2$ de área construída.

A escola teve seu programa construtivo composto de: oficinas, salas de aula, metrologia, biblioteca, sala dos professores, secretaria, diretoria, cabine primária, salas de atendimento médico, dentário e de assistência social, laboratórios, depósito de materiais esportivos, pavilhão social, copa, cozinha, depósito, sanitários, vestiários e quadras de esportes.

projeto original, pesquisado no arquivo do SENAI, foi encontrado parcialmente. Foram encontradas duas pranchas do anteprojeto original (revelando a planta e as elevações), uma prancha com planta e elevação principal modificando parte do projeto original que ainda não havia sido construído, e, por fim, uma prancha do projeto executivo da oficina e administração, assinada, em 1967, por Melanias M. Nagamini. Os dados obtidos revelaram o ano de sua

Figura 1: Observar os dados do selo do ante-projeto da Escola Santa Bárbara d'Oeste, concebido em outubro de 1958, com autoria de Lúcio Grinover. Fonte: Foto Ferraz, arquivo SENAI concepção, a planta original e posteriormente alterada, as elevações e parte do projeto executivo. A planta original também foi publicada no periódico da época Bem Estar n 5/6 (1960:39).

\section{ESCOLA SENAI DE S'A. BARBARA D'OESTE $F \quad U \quad N \quad D \quad A \quad C \quad A \quad O \quad R \quad O \quad M \quad I$ P R O JETO-SERVIGO DE OBRAS DO SENAI

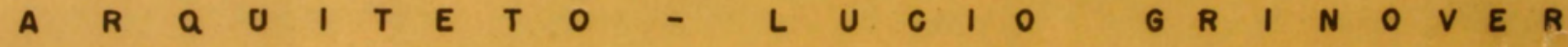 $\bar{E}$ S C A $A$ L A $1: 200-S \bar{A} O$ PAULO $24-10-1958$}




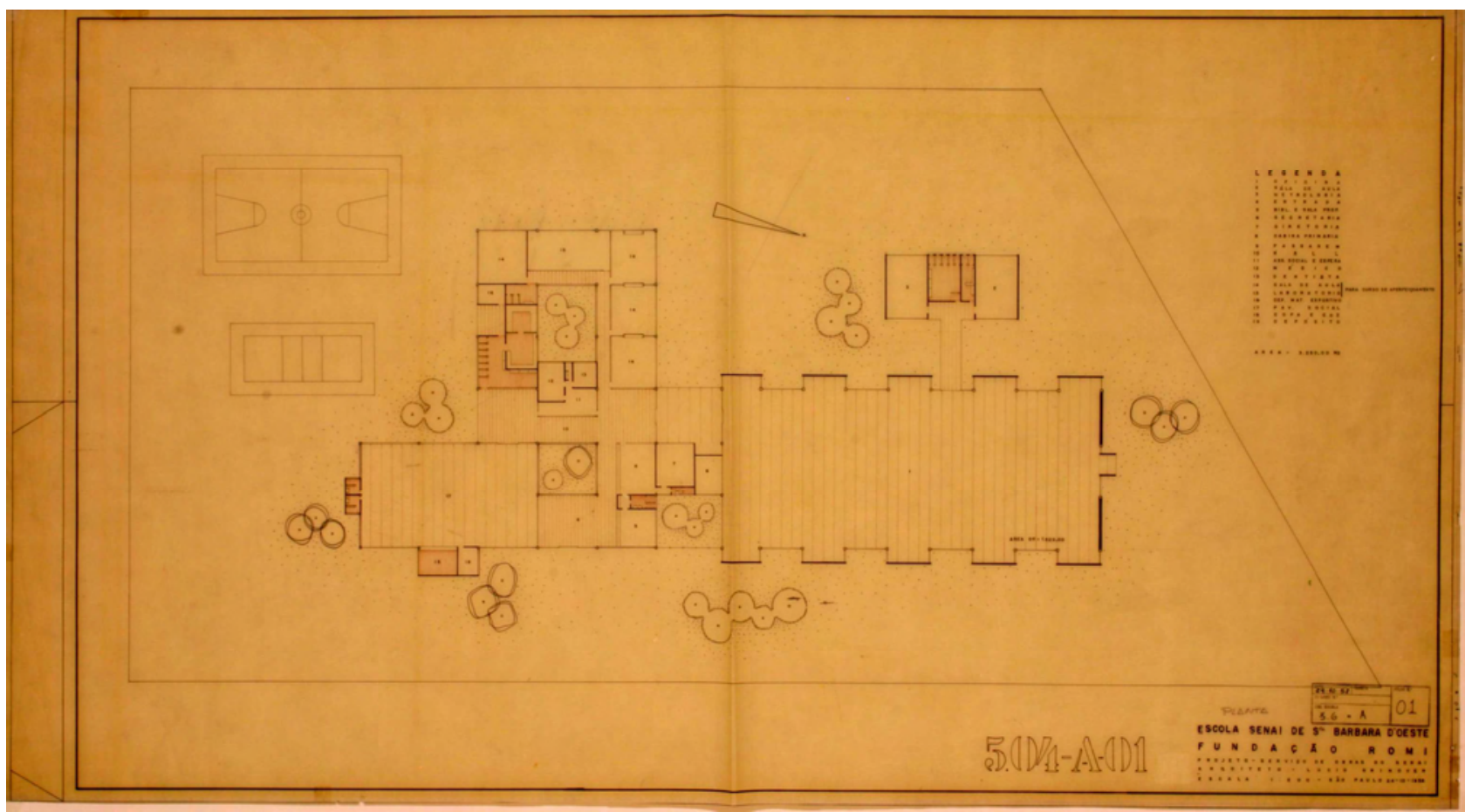

Figura 2: Prancha do ante-projeto da planta, original na escala 1:200, Escola Santa Bárbara d’Oeste, 1958, Lúcio Grinover. Fonte: Foto Ferraz, arquivo SENAI

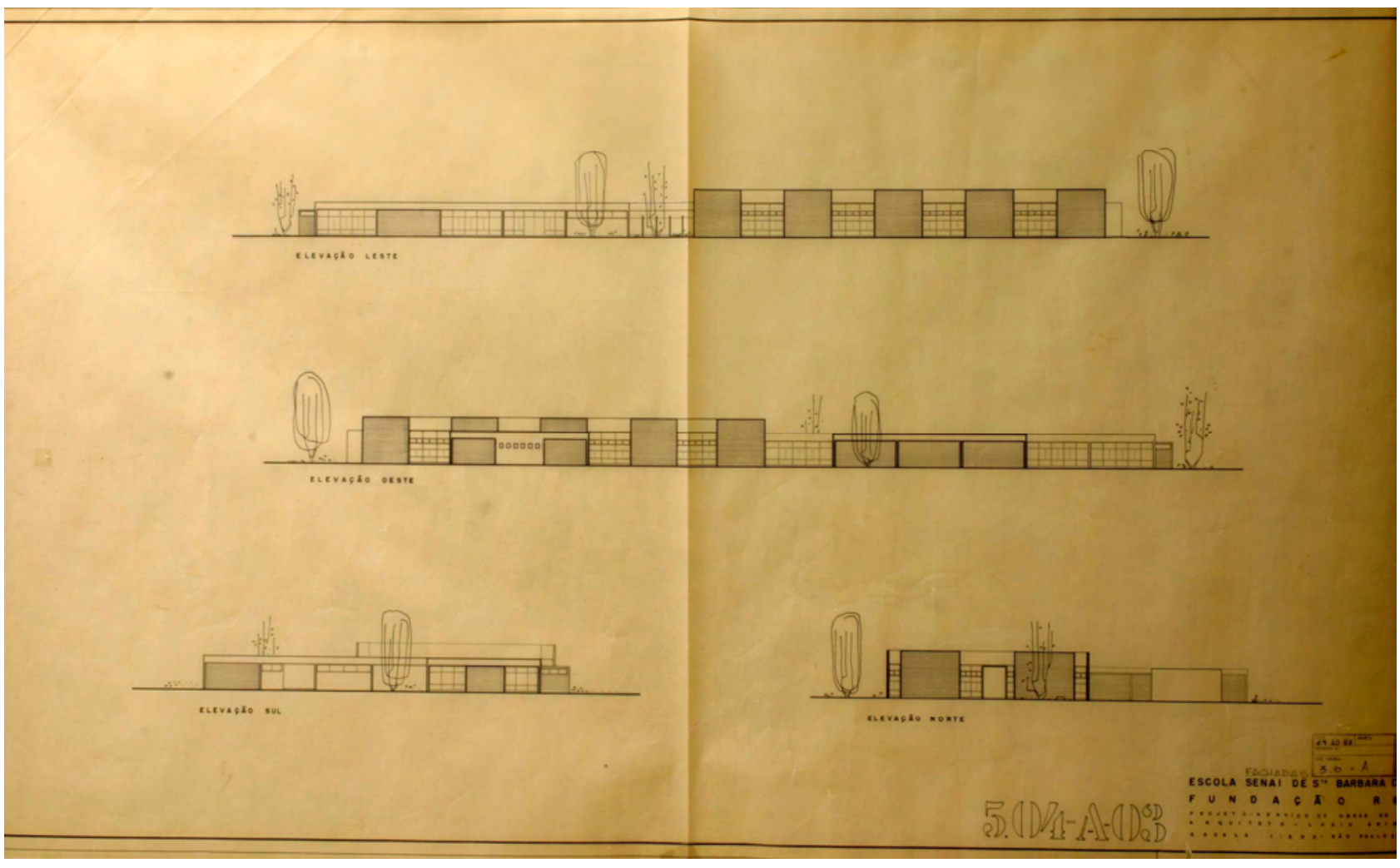

Figura 3: Prancha do ante-projeto das elevações, original na escala 1:200, Escola Santa Bárbara d'Oeste, 1958. Fonte: Foto Ferraz, arquivo SENAI 


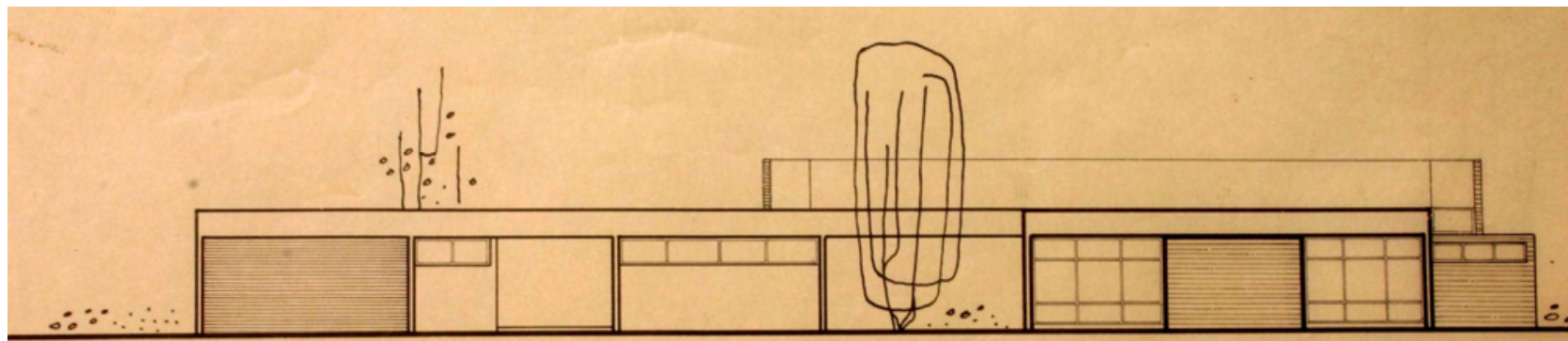

ELEVA ÇÃO SUL

Figura 4: Elevação sul retirada da prancha do ante-projeto, original na escala 1:200, Escola Santa Bárbara d'Oeste, 1958, autoria de Lúcio Grinover.

Fonte: Foto Ferraz, arquivo SENAI

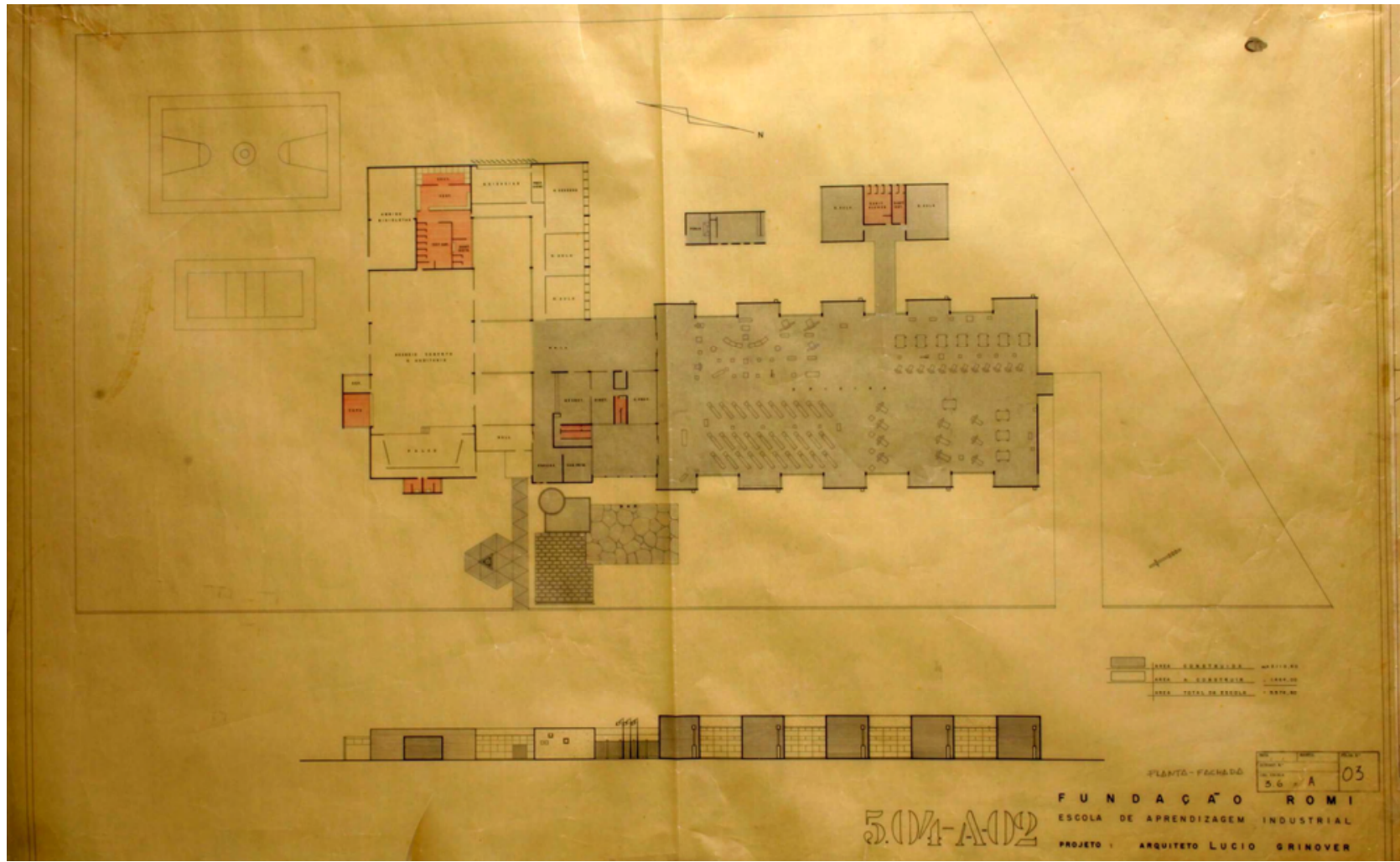

Figura 5: Prancha do projeto reformulado, original na escala 1:200, Escola Santa Bárbara d’Oeste, s.d., autoria de Lúcio Grinover. Observar a alteração feita principalmente no pavilhão social e no hall de entrada

Fonte: Foto Ferraz, arquivo SENAI

A solução adotada no projeto foi a de blocos interligados entre si, com grande movimentação plástica. $\bigcirc$ bloco da oficina era o maior, com cerca de $1.300,00 \mathrm{~m} 2$ de área útil, tinha vão livre longitudinal de 50 metros, sem qualquer pilar de sustentação na área interna. Com iluminação e ventilação bilateral, a oficina recebeu um tratamento diferenciado dos demais projetos até então pesquisados. Suas paredes laterais foram projetadas para as faces leste e oeste com uma movimentação de cheios e vazios, empenas cegas e envidraçadas escalonadas entre si. Anexo a este bloco, em forma de "T" foram projetadas duas salas de aula, sendo uma de metrologia, e 
os sanitários. Disposto na extremidade norte do lote, o bloco das oficinas estava interligado diretamente com o hall de entrada e com a administração da escola.

O segundo bloco da administração foi posicionado no centro de todo o conjunto, sendo responsável por interligar os demais blocos entre si. Composto por hall de entrada, biblioteca, sala dos professores, secretaria, diretoria, cabine primária, salas de atendimento médico, dentário e de assistência social, sua disposição permitia a visibilidade de alunos e professores pelos eixos de circulação entre um bloco e outro, entre a teoria, a prática e o lazer.

O terceiro bloco das salas de aula foi localizado na parte oeste do terreno e estava interligado diretamente com a administração. Neste caso, as salas de aula e os laboratórios foram projetados para cursos posteriores de aperfeiçoamento, adotando as divisórias móveis para a divisão dos ambientes (flexiblidade e crescimento). Ainda, neste mesmo bloco foram projetados o depósito de material esportivo, os vestiários e os sanitários voltados para as quadras de esportes.

quarto bloco do pavilhão social era interligado diretamente com o hall de entrada e com a administração. Seu programa era ser tanto um recreio coberto como um auditório, por isso também abrigava copa, depósito, palco e sanitários.

A Escola Santa Bárbara d'Oeste foi construída pela Construtora Ind. Predial CIPREL Ltda, segundo Bem Estar n5/6 (1960:36) e suas salas de aula foram completamente modificadas, pois "constam somente de espaços dentro da própria oficina sem nenhuma separação das demais atividades".

Esta escola, ainda que sem todos os dados do projeto original, confirma uma arquitetura pautada na filosofia educacional do SENAI e inova o espaço da oficina e sala de aula, atendendo a um dos principais objetivos de entrosamento entre teoria e prática (rendimento). Ainda podemos notar o crescimento através da planta livre, a flexibilidade através das divisórias nas salas de aula, a sociabilidade através do pavilhão social e áreas de recreação, a economia através da iluminação e ventilação naturais, a interligação visual entre as atividades, dentre outros. 


\section{PROJETO 13}

\section{Escola Senai da Mooca, Oficina de calçados, 1959}

A Oficina de calçados da Escola Senai da Mooca ${ }^{3}$ foi projetada em 1959 pelos arquitetos Melanias M. Nagamini e Luiz Carlos Costa. A oficina foi implantada num terreno de aproximadamente $5.150 \mathrm{~m}^{2}$ e contava com aproximadamente 835,80 $\mathrm{m}^{2}$ de área construída, sendo $780,80 \mathrm{~m}^{2}$ do pavimento térreo e $55,00 \mathrm{~m}^{2}$ do sub-solo. $O$ projeto foi incorporado a uma construção já existente (voltada para a rua do Oratório) e ao lado de uma quadra. Denominada posteriormente de "pavilhão social", a oficina adotou grandes vãos envidraçados voltados para a fachada principal, voltada para a cidade, com 25,60 metros de largura e, parede geminada em um dos lados.

Figura 1: Planta de localização do terreno, Escola Senai da Mooca, Oficina de calçados, 1959.

Fonte: Foto Ferraz, arquivo SENAI

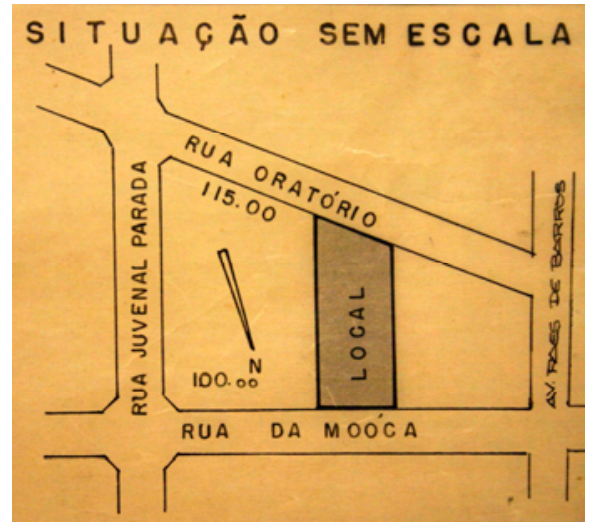

Figura 2: Planta de situação, original na escala 1:500, Escola Senai da Mooca, Oficina de calçados, 1959.

Fonte: Foto Ferraz,

Arquivo SENAI

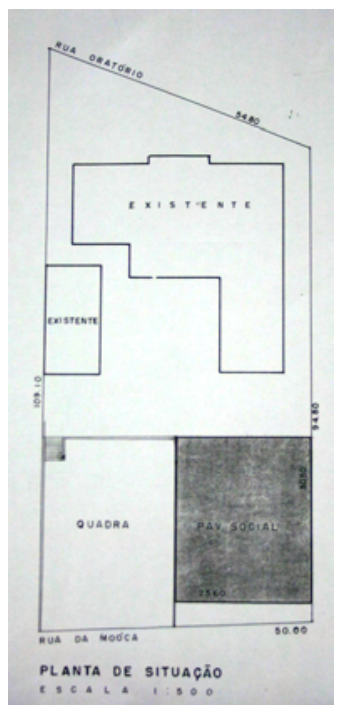

${ }^{3}$ A Escola Senai de Sorocaba foi publicada pela revista Bem Estar n 5/6 (1960:34 e 35) e Acrópole 314 (1965:39) 
O programa construtivo tinha o objetivo de atender à produção de calçados, sendo composto de: espaço amplo para oficina, sanitários e vestiários, sala de chefia e de instrutores, salas depósitos e depósito no sub-solo.

Os dados relativos ao edifício foram encontrados no arquivo do SENAl, como as pranchas do projeto executivo original das plantas, cobertura, cortes, fachadas e diversos detalhamentos. Estes documentos possibilitaram confirmar a data do projeto, a exatidão de suas dimensões, a planta de situação, as dimensões do terreno e a área construída original (informada neste trabalho através do cálculo feito pelas plantas obtidas).
Figura 3: Observar os dados do selo (planta de execução) do projeto da Escola Senai da Mooca, Oficina de calçados, concebido em novembro de 1959, com autoria de Melanias M. Nagamini e Luiz Carlos Costa. Fonte: Foto Ferraz, arquivo SENAI

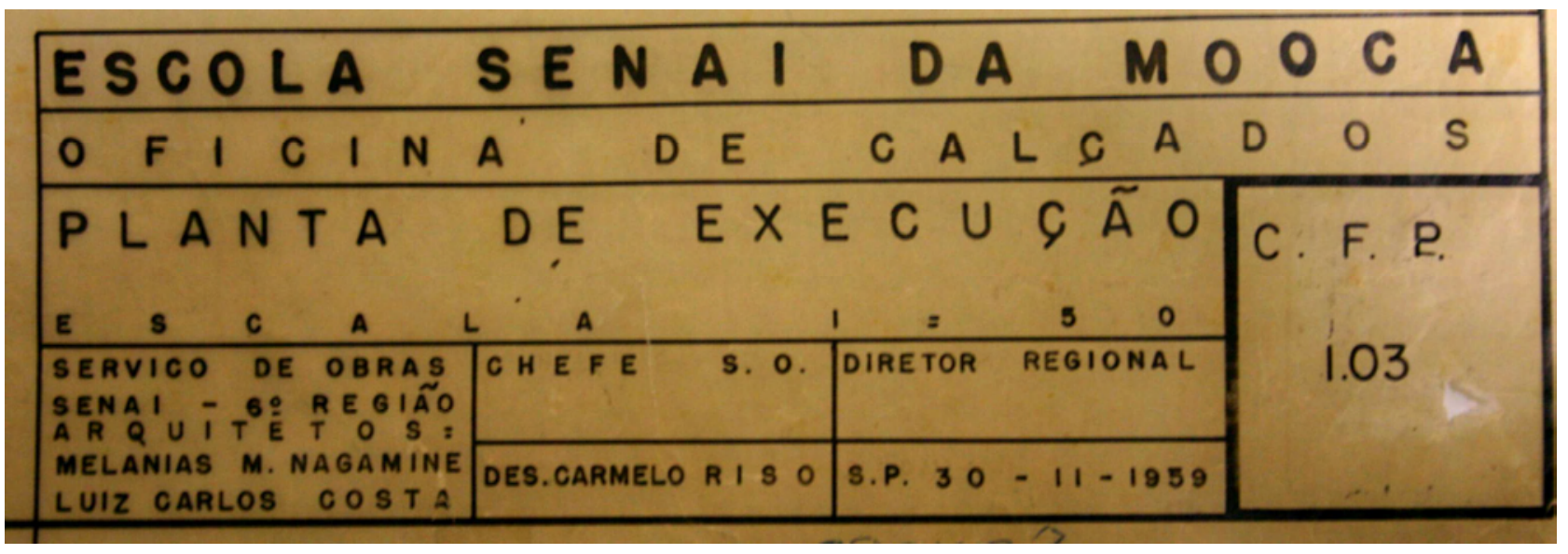

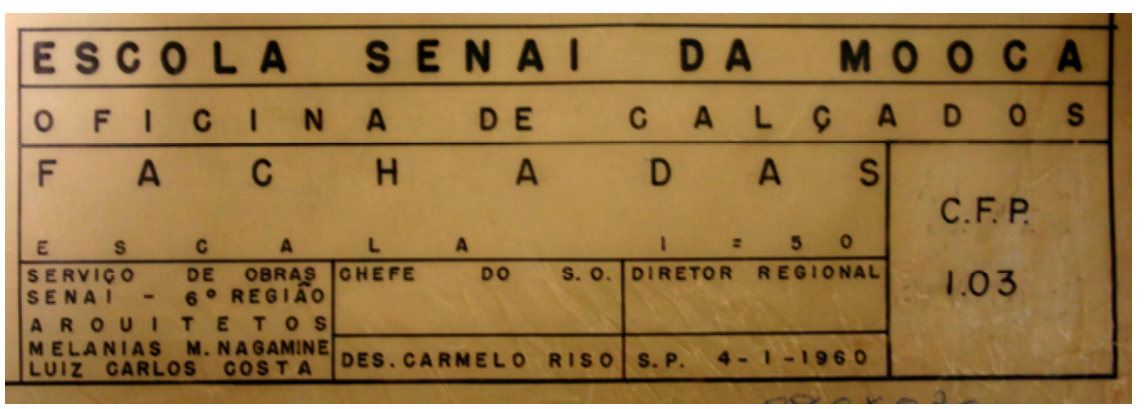

Figura 4: Observar os dados do selo (fachadas) do projeto da Escola Senai da Mooca, Oficina de calçados, concebido em janeiro de 1960, com autoria de Melanias M. Nagamini e Luiz Carlos Costa.

Fonte: Foto Ferraz, arquivo SENAI 
Figura 5: Prancha do projeto executivo das fachadas, original na escala 1:50, Escola Senai da Mooca, Oficina de calçados, 1960

Fonte: Foto Ferraz, arquivo SENAI

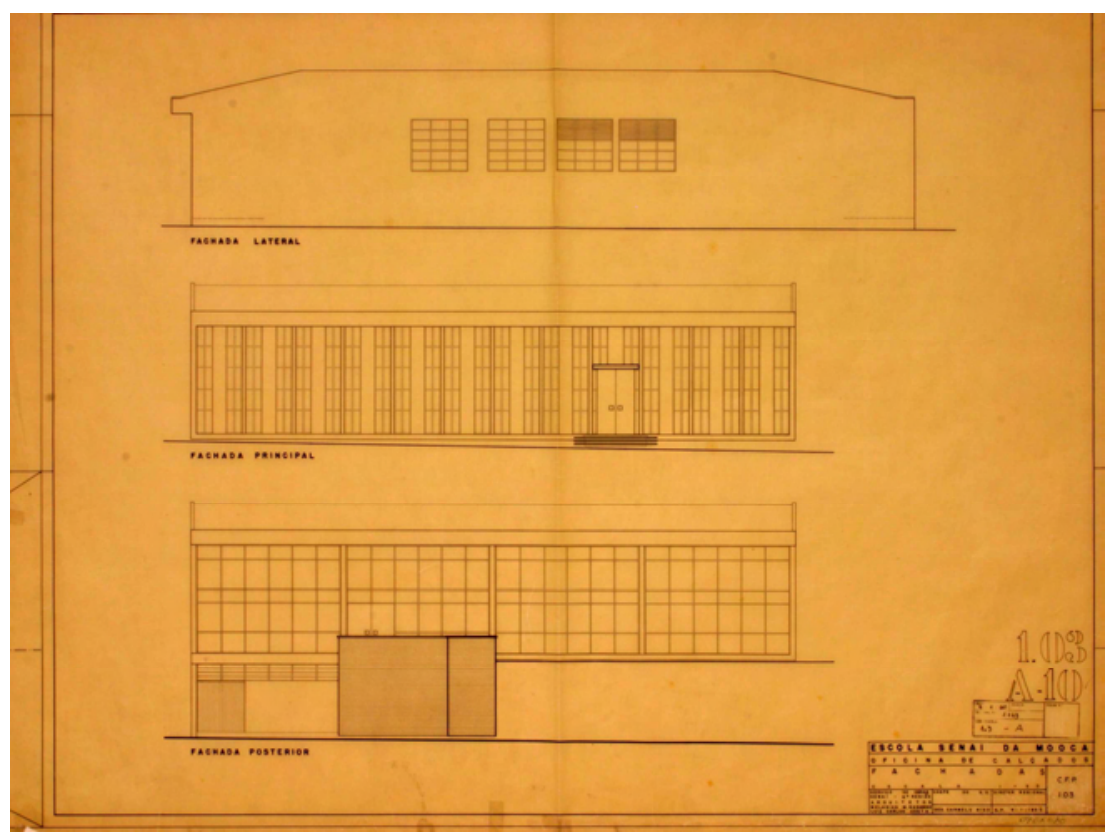

projeto, resolvido num edifício único, foi executado com pilares de concreto modulados em seu perímetro, permitindo vão livre na área da oficina sem a presença de pilares e, cobertura dividida em três tesouras de madeira estruturadas por vigas transversais de concreto. Com pé-direito de 4,50 metros, somente os ambientes anexos à oficina, isto é sanitários, salas e depósitos, receberam forro de eucatex e iluminação lateral sobre o pé-direito de 3,30 metros do rebaixo nas laterais. A oficina recebeu iluminação e ventilação pela fachada principal e posterior. Além do pavimento térreo, foi projetado um depósito no sub-solo, com acesso interno e externo pelos fundos da oficina. A entrada principal foi enfatizada por uma escada e marquise, marcando o acesso principal. Esquadrias em ângulo compunham toda a altura da fachada e interligavam o visual da área de trabalho com o urbano (atratividade).

O projeto, com o programa construtivo restrito ao de uma oficina, não pode ser analisado da mesma maneira que uma escola. Este projeto, ainda que implantado juntamente com uma construção já existente, numa área industrial da cidade de São Paulo, com um programa restrito, reflete alguns aspectos da pedagogia do SENAI como: a estrutura em concreto armado permitindo grandes vãos (flexibilidade e crescimento), as aberturas para iluminação e ventilação naturais (economia) e as oficinas voltadas para a rua permitindo visibilidade ao espectador (atratividade). 
PROJETO 14

\section{Escola Senai Mogi das Cruzes, 1959}

Projetada inicialmente por Lúcio Grinover e Luiz Carlos Costa, com colaboração da arquiteta Ayako Nishikawa, a Escola de Mogi das Cruzes ${ }^{4}$, no interior de São Paulo, foi uma escola localizada num ponto alto da cidade à rua Antonio Cândido Alvarenga entre as ruas Senador Dantas e Otto Unger. A escola foi implantada num lote de aproximadamente $8.400,00 \mathrm{~m}^{2}$ e foi composta por três blocos caracterizados pela oficina e salas de aulas, administração e, pavilhão social.

A escola teve seu programa construtivo composto de: oficinas (mecânica, eletricidade e marcenaria), salas de aula, metrologia, forja, sanitários, sala dos professores e instrutores, secretaria, diretoria, salas de atendimento médico, dentário e de assistência social, depósitos, pavilhão social, copa, cantina, recreio coberto, grêmio, vestiários e quadra e esporte.

O projeto original, pesquisado no arquivo do SENAI, foi encontrado em grande parte. Foram encontradas pranchas do anteprojeto original (revelando planta e elevações), pranchas do projeto executivo das plantas de dois blocos, cortes e elevações, assinadas em diferentes datas a partir de 1959, e pelos três arquitetos citados. dados obtidos revelaram o ano de sua concepção, as plantas originais, corte, elevações, detalhamentos, porém faltaram apenas a planta do pavimento térreo dos blocos do pavilhão social e da administração. A planta original também foi publicada no periódico da época Bem Estar n 5/6 (1960:27).

\footnotetext{
4 A Escola Senai Mogi das Cruzes foi publicada pela revista Bem Estar n 5/6
} (1960:27). 


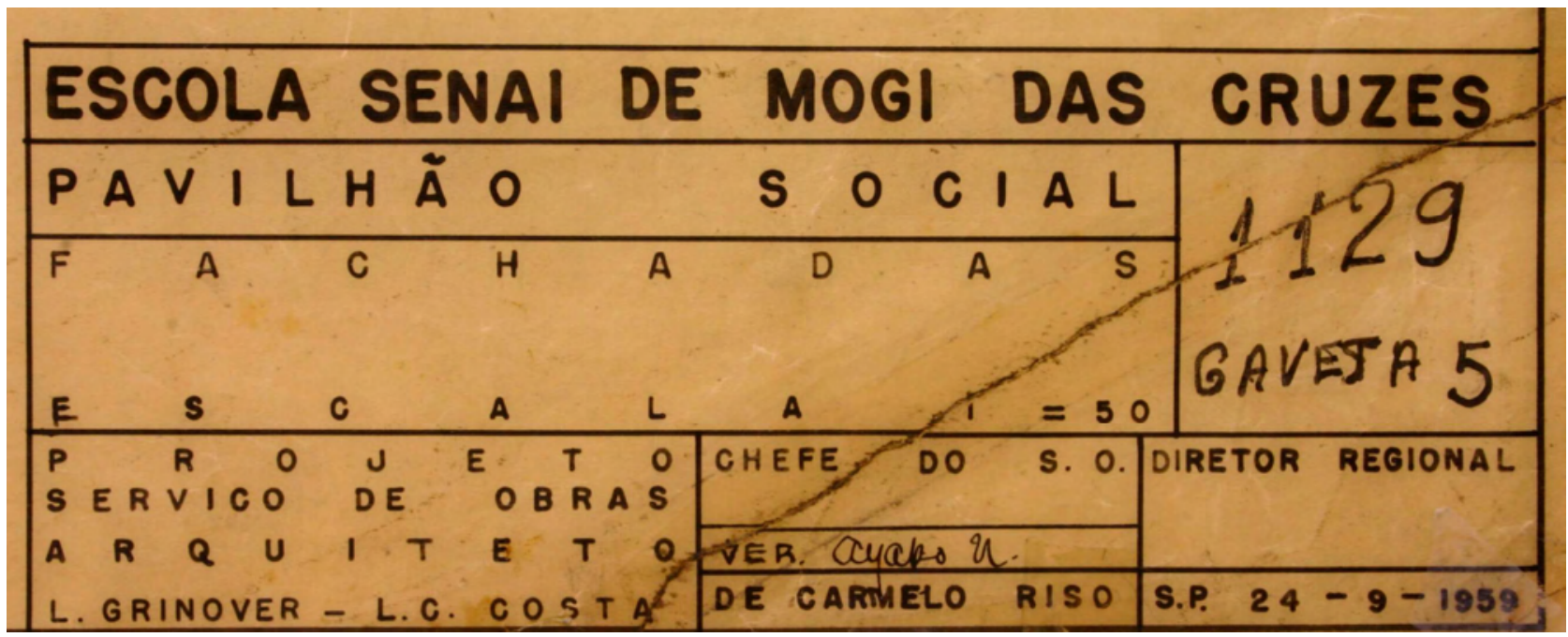

Figura 1: Observar os dados do selo do projeto executivo da Escola de Mogi das Cruzes, concebido em setembro de 1959, com autoria de Lúcio Grinover e Luiz Carlos Costa. Fonte: Foto Ferraz, arquivo SENAI

Figura 2: Observar os dados do selo do projeto executivo de detalhamento da Escola de Mogi das Cruzes,

concebido em maio de 1959, com autoria de Luiz Carlos Costa.

Fonte: Foto Ferraz, arquivo SENAI

Figura 3: Observar os dados do selo do projeto executivo de detalhamento da Escola de Mogi das Cruzes,

concebido em novembro de 1959, com autoria de Ayako Nishikawa.

Fonte: Foto Ferraz, arquivo SENAI
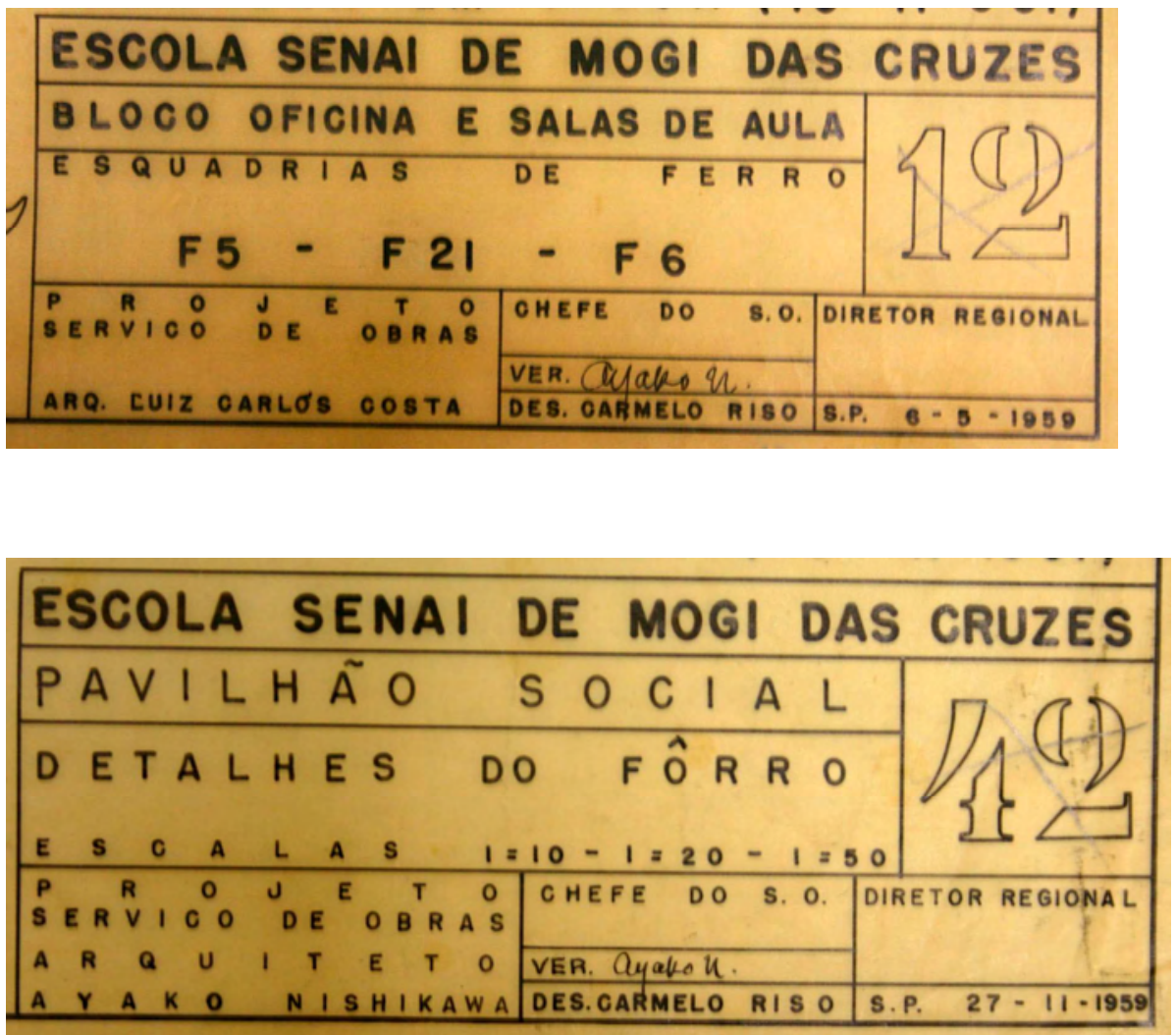


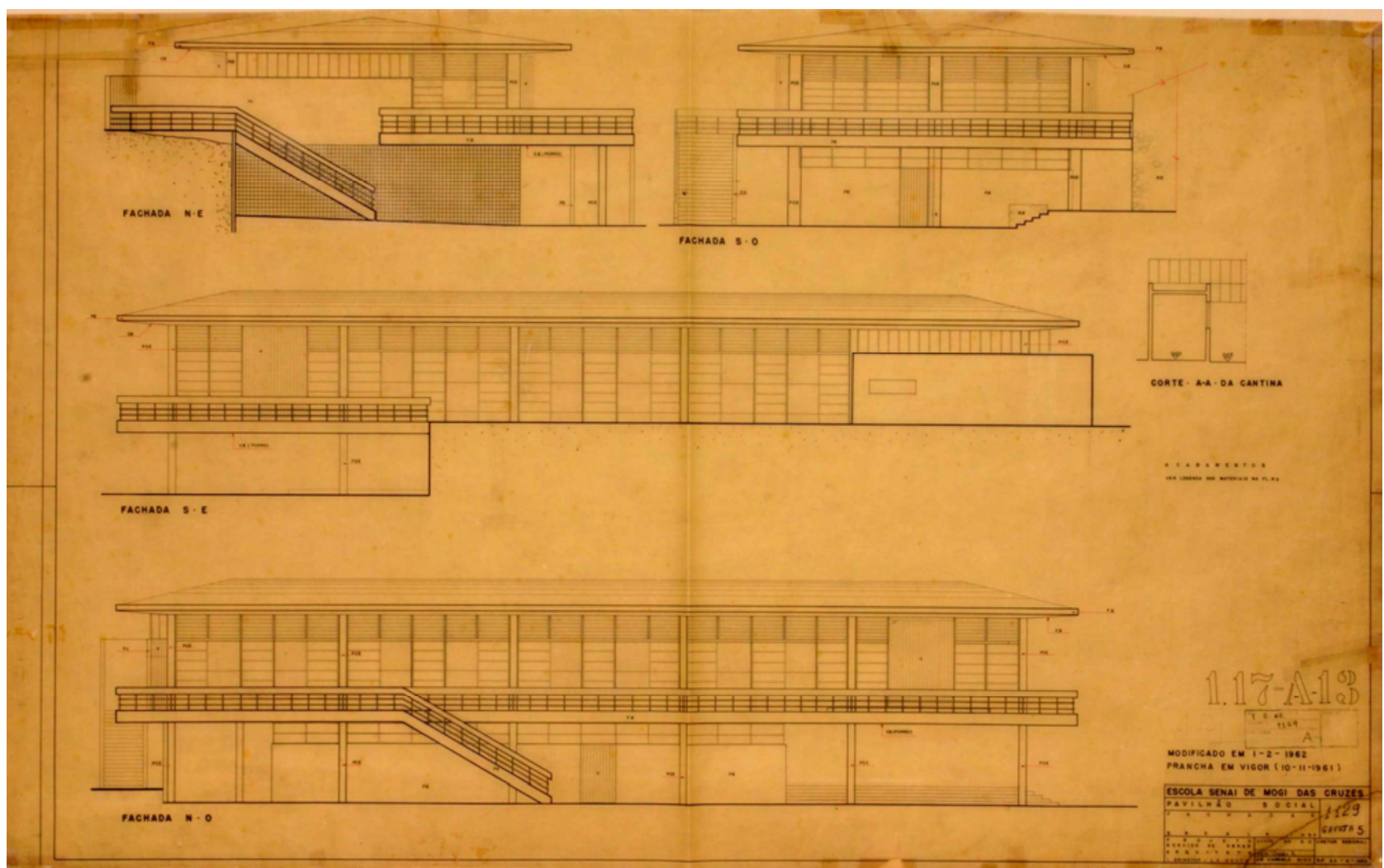

Figura 4: Prancha do projeto executivo das fachadas do Pavilhão Social, original na escala 1:50, Escola de Mogi das Cruzes, 1959 autoria de Lúcio Grinover e Luiz Carlos Costa.

Fonte: Foto Ferraz, arquivo SENAI

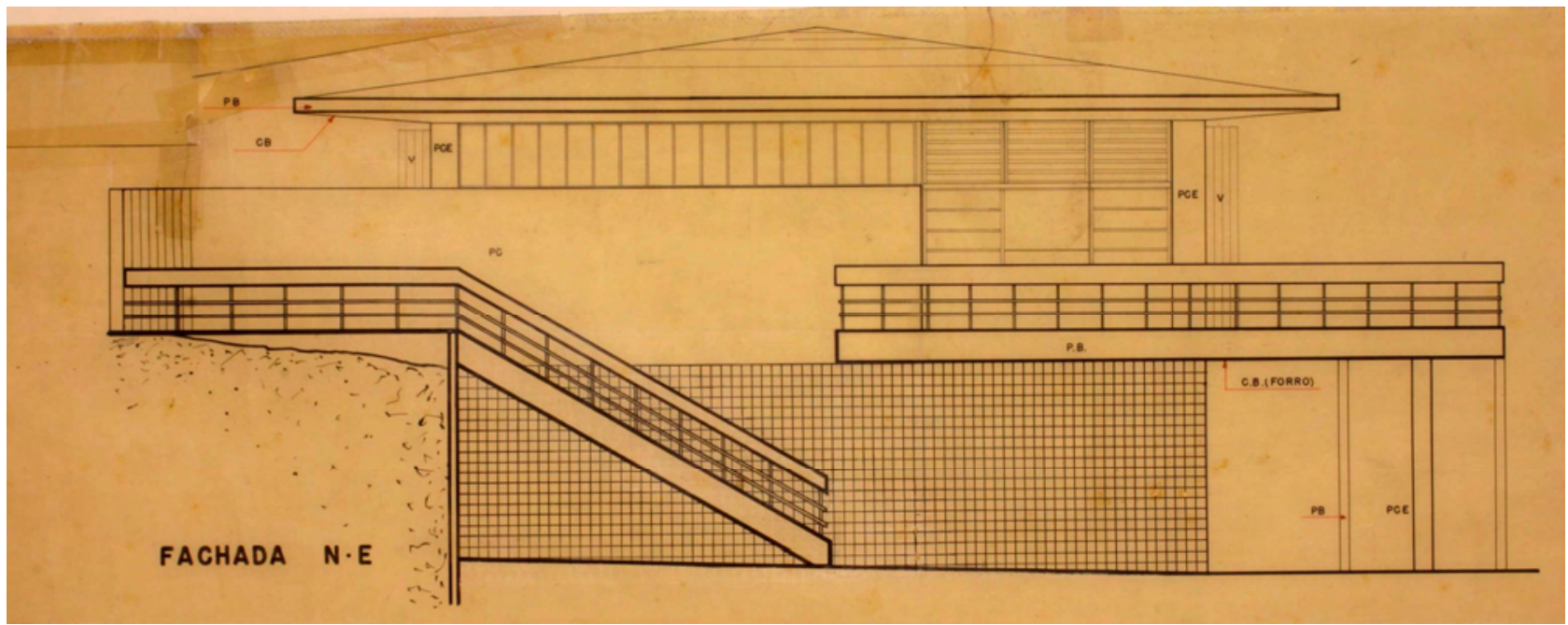

Figura 5: Elevação NE do bloco do Pavilhão Social ,retirada da prancha do projeto executivo, original na escala 1:50, Escola de Mogi das Cruzes, 1959 autoria de Lúcio Grinover e Luiz Carlos Costa.

Fonte: Foto Ferraz, arquivo SENAI 


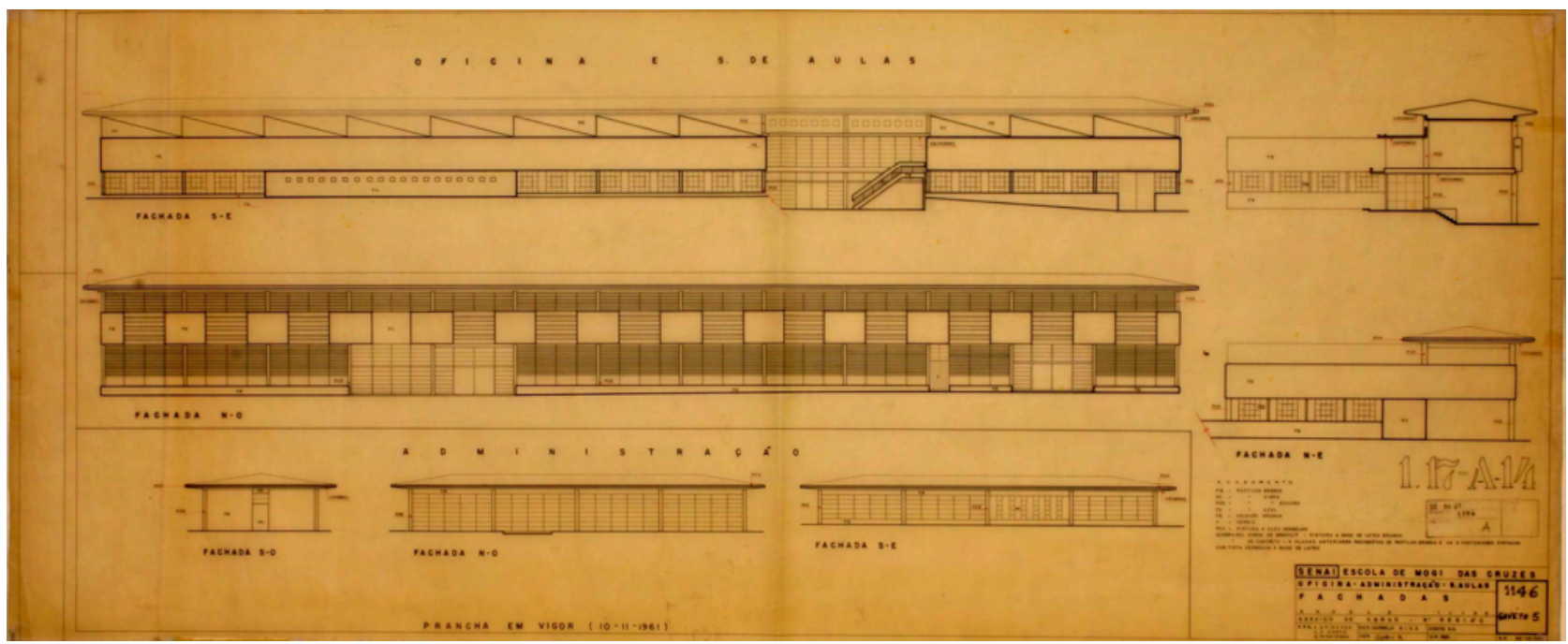

Figura 6: Prancha do projeto executivo das fachadas dos blocos da administração e das oficinas e salas de aula, original na escala 1:100, Escola de Mogi das Cruzes, 1961 autoria de Lúcio Grinover, Luiz C. Costa e A. Nishikawa.

Fonte: Foto Ferraz, arquivo SENAI

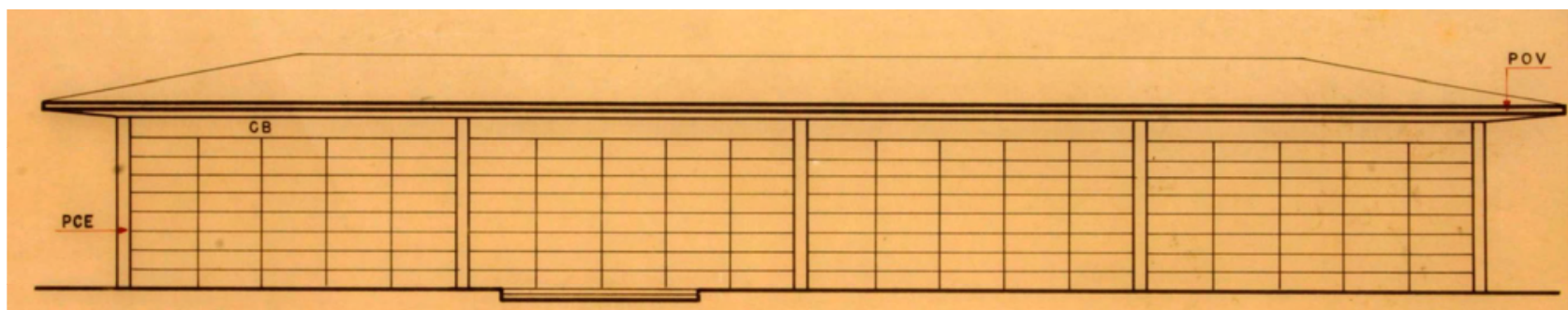

FACHADA N-O

Figura 7: Elevação NO do bloco da administração, retirada da prancha do projeto executivo, original na escala 1:100, Escola de Mogi das Cruzes, 1961 autoria de Lúcio Grinover, Luiz C. Costa e A. Nishikawa.

Fonte: Foto Ferraz, arquivo SENAI

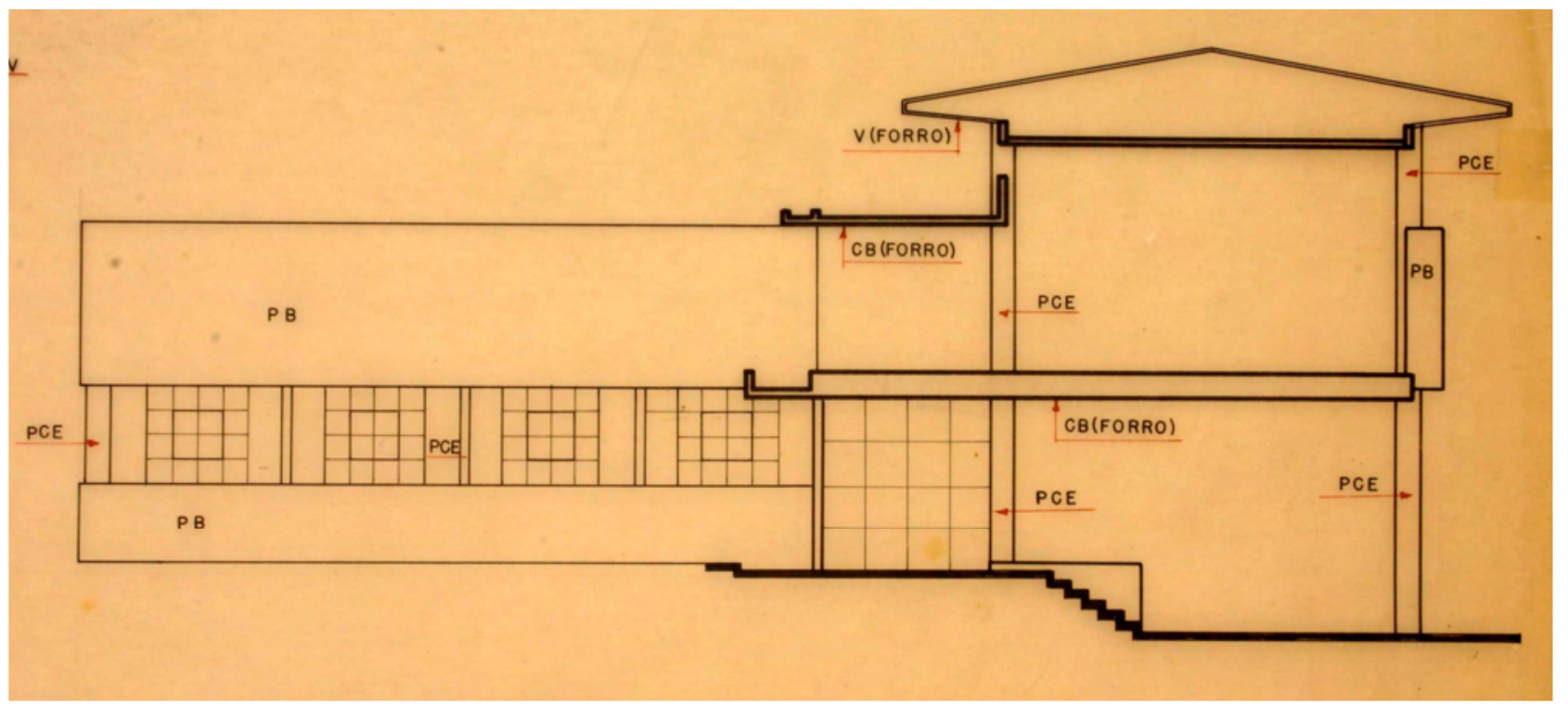

Figura 8: Corte transversal do bloco das oficinas e salas de aula, retirada da prancha do projeto executivo, original na escala 1:100, Escola de Mogi das Cruzes, 1961 autoria de Lúcio Grinover, Luiz C. Costa e A. Nishikawa.

Fonte: Foto Ferraz, arquivo SENAI 
A solução adotada no projeto foi a de blocos interligados entre si, implantados paralelamente uns aos outros. $\bigcirc$ primeiro bloco da administração foi localizado no nível mais alto do terreno e era composto de diretoria, secretaria, sala dos professores, salas de atendimento médico e dentário. Resolvido em um único pavimento, este bloco tinha sua fachada principal envidraçada e voltada para a face noroeste. Através de uma passarela com degraus e coberta, este bloco foi interligado ao segundo bloco localizado no nível mais baixo, com 1,35 metro de desnível.

O segundo bloco, caracterizado por dois pavimentos, era composto no térreo de oficinas de mecânica e de marcenaria, além de forja, depósito, sanitários, metrologia, sala de instrutores e hall de circulação. No pavimento superior foram projetadas sete salas (sendo seis salas de aula e uma biblioteca), a oficina de eletricidade, sala dos professores e sala de ciências. $O$ pavimento térreo foi projetado com desnível de 50 centímetros na lateral noroeste da ala destinada à oficina de mecânica. Sobre este piso, mais baixo que o da oficina, foram projetadas as salas de aula. A oficina de mecânica foi separada das de marcenaria e eletricidade possivelmente para atender os problemas acústicos. A oficina mecânica foi ligada visualmente com as salas de aula através do corredor lateral do segundo pavimento, aberto para o pé-direito duplo da oficina, protegido apenas por um guarda-corpo (interligação). Na ala menor deste bloco, através do pédireito duplo da oficina de marcenaria, a oficina de eletricidade também tinha o acesso visual da marcenaria (rendimento). Modulado longitudinalmente com eixos de 6,70 metros, o bloco adotou nas salas de aula a separação por divisórias (flexibilidade) e aproveitou os desníveis do terreno. 


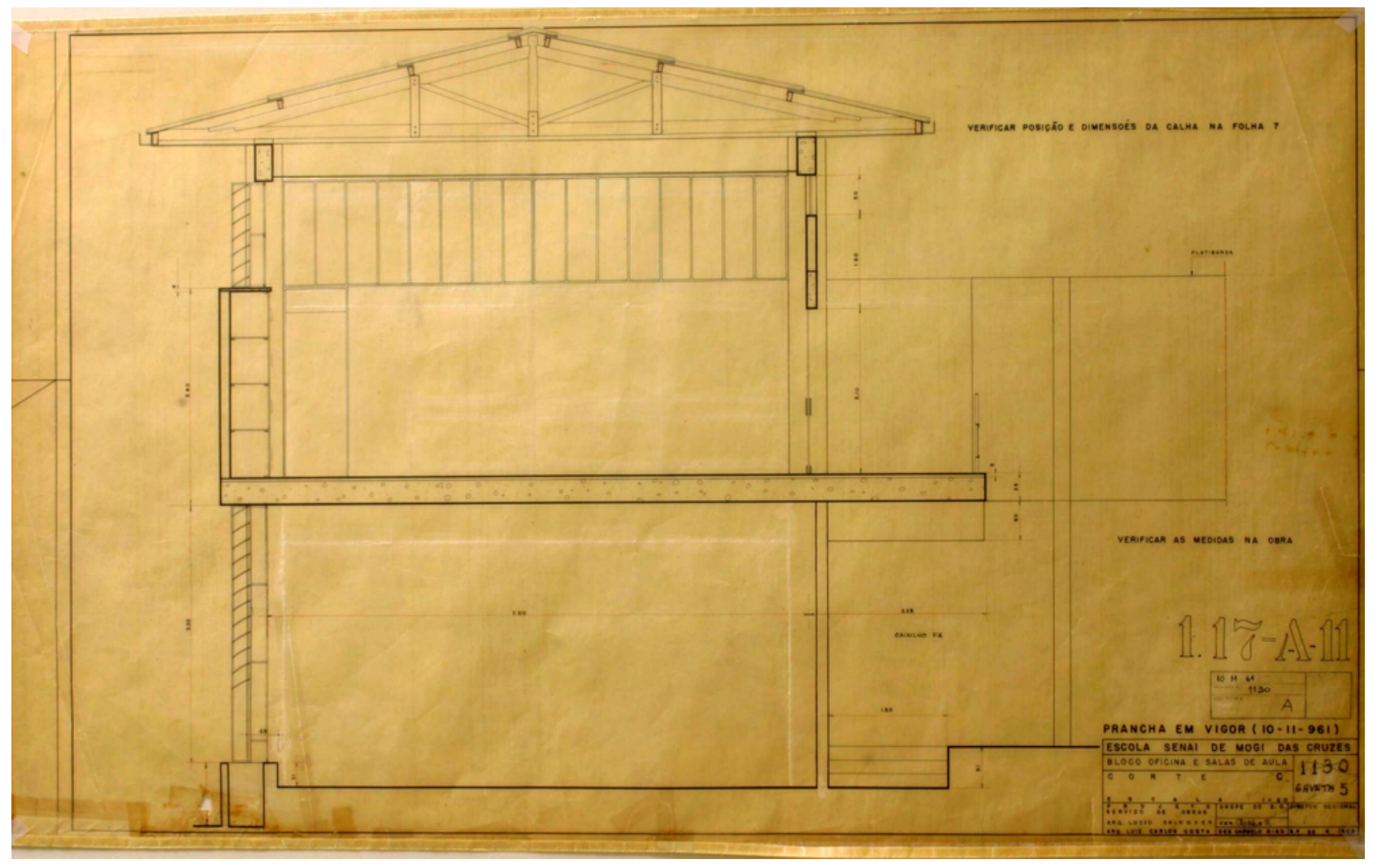

Figura 9: Prancha do Corte C, transversal do bloco das oficinas e salas de aula, original na escala 1:20, Escola de Mogi das Cruzes, abril de 1959 autoria de Lúcio Grinover e Luiz C. Costa. Fonte: Foto Ferraz, arquivo SENAI

O terceiro bloco, o pavilhão social, foi interligado diretamente com o segundo bloco através de uma passarela coberta e uma escada. Composto de dois pavimentos o pavimento térreo possivelmente abrigava os vestiários e o recreio coberto, porém sua planta original ainda não foi encontrada. O pavimento superior, ligado como o pavimento térreo do segundo bloco, era composto do pavilhão social (auditório), palco, camarins, sanitários, grêmio, sala de assistência social, depósito, cantina e copa. Circundado por um terraço, este pavimento foi interligado com as áreas verde e esportiva através de escadas. Com iluminação e ventilação naturais para as faces noroeste, sudoeste e sudeste, o pavilhão permitia ampla visibilidade da escola (sociabilidade e atratividade) e, ao mesmo tempo, atendia à economia proposta pelo SENAI. 


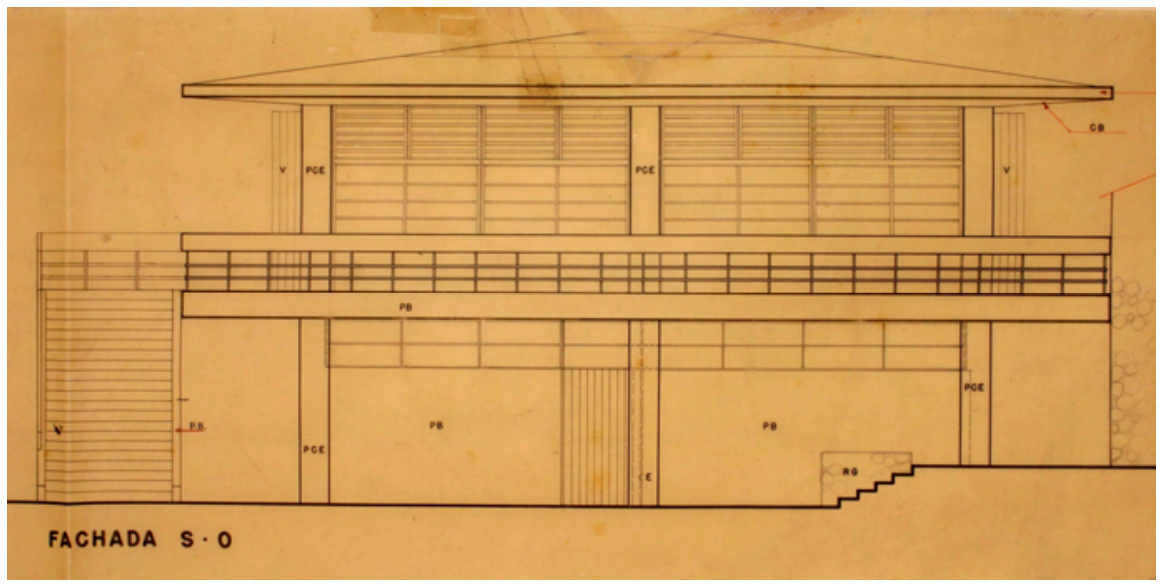

Figura 10: Elevação SO do bloco do Pavilhão Social ,retirada da prancha do projeto executivo, original na escala

$1: 50$,

Escola de Mogi das Cruzes, 1959 autoria de Lúcio Grinover e Luiz Carlos Costa.

Fonte: Foto Ferraz, arquivo SENAI

A Escola Senai Mogi das Cruzes foi construída, segundo Bem Estar n5/6 (1960:27) com "fachada caracterizada pelo jogo de cheios e vazios devido à orientação da mesma".

Esta escola, ainda que sem todos os dados da planta projeto original, revelou inúmeras pranchas de detalhamento do projeto executivo e, confirma uma arquitetura pautada na filosofia educacional do SENAl, inovando na separação das oficinas de acordo com sua especialidade. Podemos observar as características de crescimento (planta livre), flexibilidade (divisórias nas salas de aula), sociabilidade (pavilhão social e áreas de recreação), economia (iluminação e ventilação naturais) e interligação (visual entre as diversas atividades).

Figura 11: Perspectiva da fachada noroeste, Escola de Mogi das Cruzes.

Fonte: Bem Estar n ${ }^{\circ}$ 5/6

(1960:27)

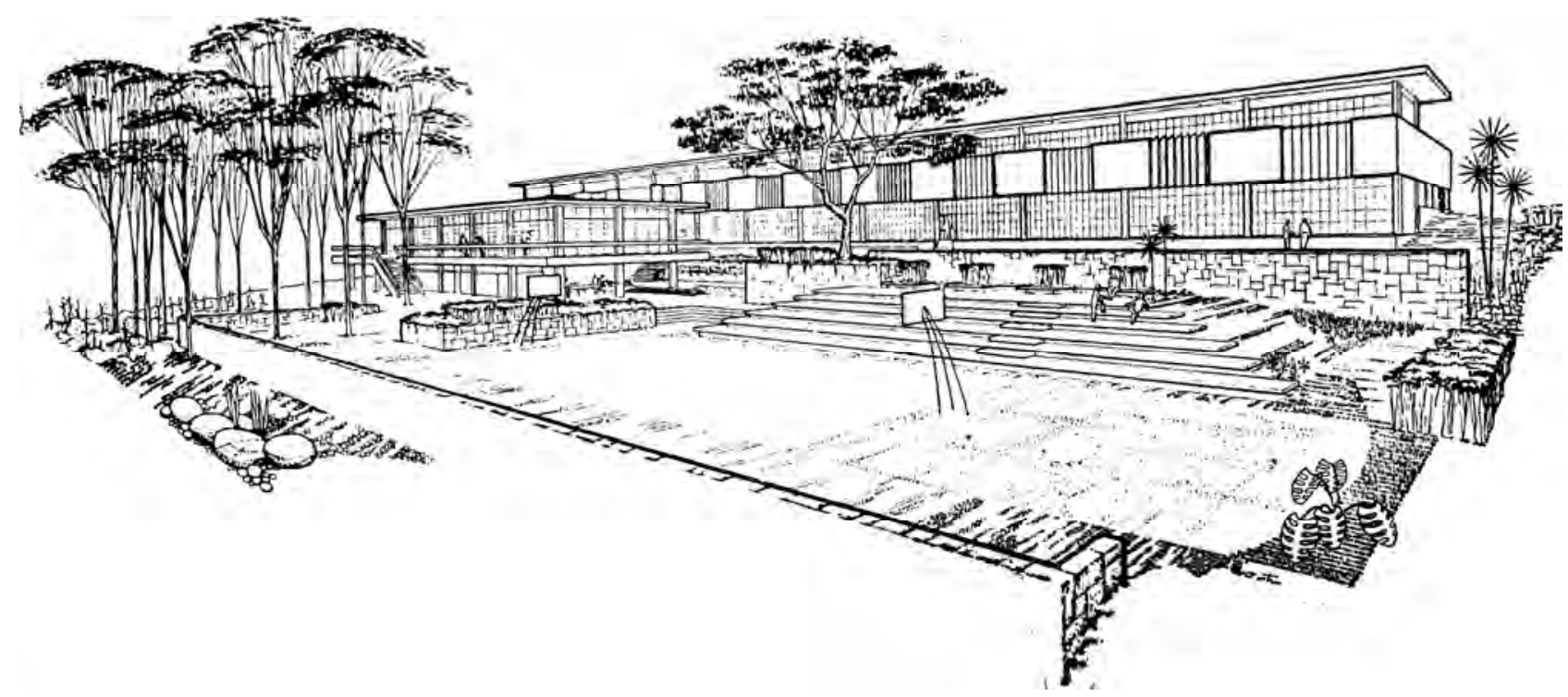




\section{PROJETO 15}

\section{Escola Senai Centro Educacional da Mooca, 1960}

O Centro Educacional da Mooca, São Paulo, foi projetado em 1960 pelo arquiteto Melanias M. Nagamini. Implantado num terreno irregular de aproximadamente $20.315,00 \mathrm{~m}^{2}$ e localizado à rua Bresser 2315, o projeto original contava com cerca de $8.800,00 \mathrm{~m}^{2}$ de área construída. $\bigcirc$ projeto, composto principalmente pelos três blocos da oficina, escola e pavilhão social, denominado de $A, B$ e $C$, também possuía o volume da torre de caixa d'água e da cabine de força.

Figura 1: Planta de situação,

Centro Educacional da Mooca.

Fonte: Foto Ferraz,

arquivo SENAI

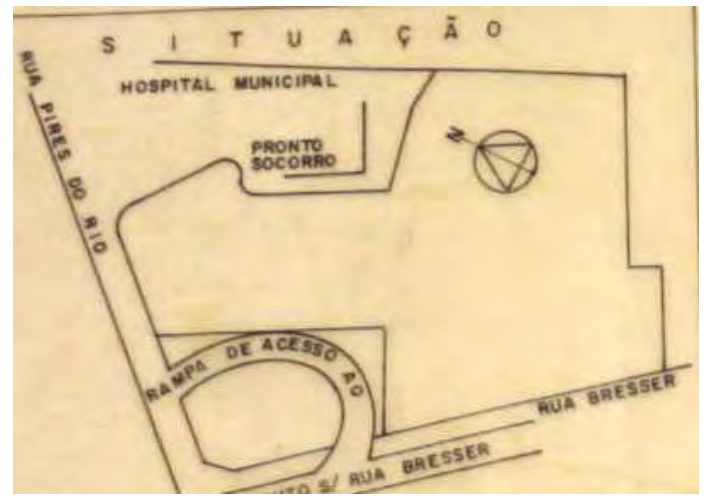

Figura 2: Implantação, Centro Educacional da Mooca.

Observar que esta implantação é de ampliação da escola. $\bigcirc$ bloco $B$ está alterado em relação ao original.

Fonte: Foto Ferraz, arquivo SENAI

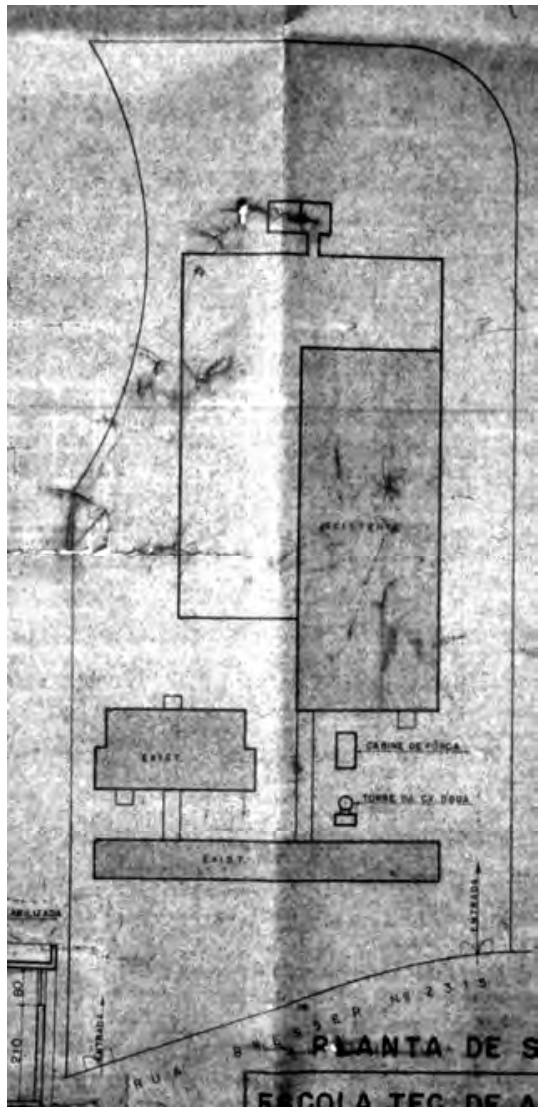


O programa construtivo foi dividido nos blocos $A, B$ e $C$, que interligados entre si eram compostos de oficina, administração, diretoria, secretaria, salas de aula, biblioteca, recreio coberto, auditório, sanitários, vestiários, depósito.

Parte dos dados relativos ao projeto foram encontrados no arquivo do SENAl, como as pranchas do projeto original dos blocos $\mathrm{A}$ e $B$, revelando plantas, corte e fachadas. As demais pranchas encontradas foram de ampliações e reformas do projeto, revelando a implantação geral, detalhamentos, cortes e fachadas do bloco $\mathrm{C}$. Estes documentos possibilitaram confirmar a data do projeto, suas particularidades e a contribuição do arquiteto Melanias M. Nagamini no projeto executivo do bloco $A$ e $B$, no ano de 1960. Porém, ainda não foi encontrada a planta do bloco $C$ da oficina, impossibilitando sua análise precisa.

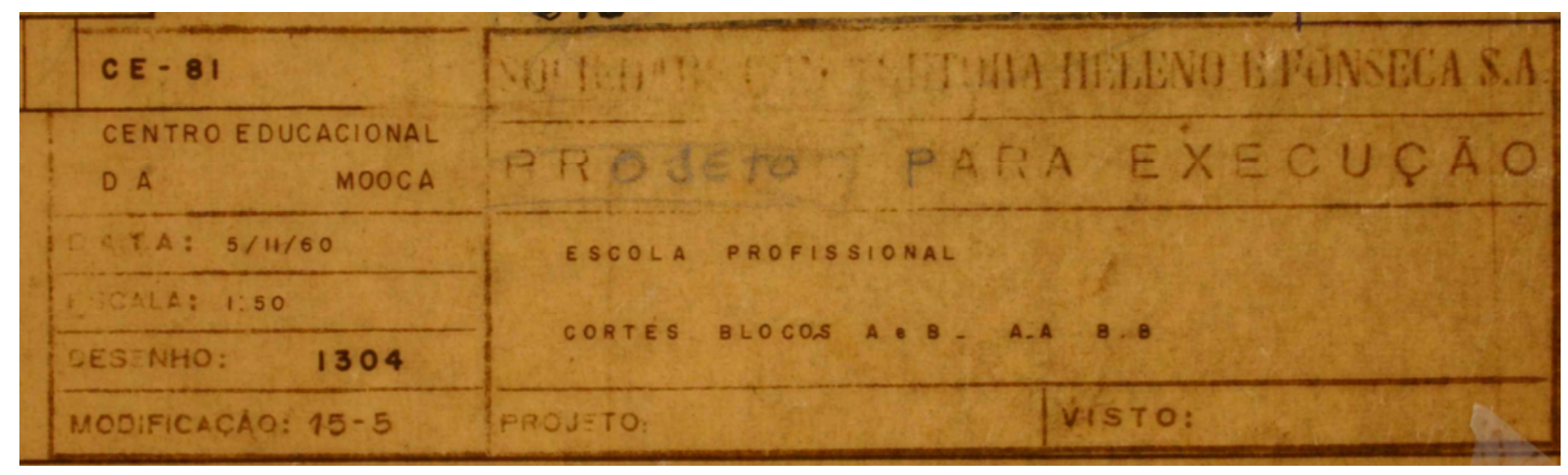

Figura 3: Observar os dados do selo do projeto dos blocos A e B, Centro Educacional da Mooca novembro de 1960. Fonte: Foto Ferraz, arquivo SENAI

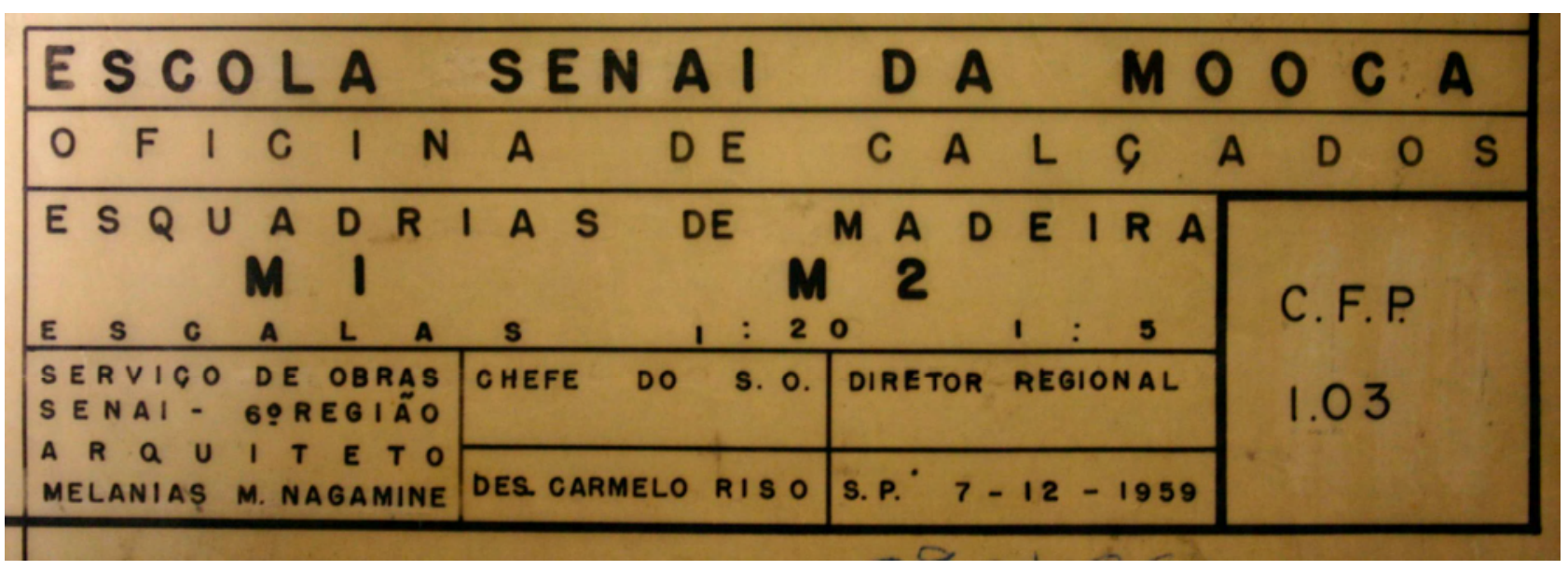

Figura 4: Prancha do projeto executivo dos cortes dos blocos A e B, Centro Educacional da Mooca, 1960. Fonte: Foto Ferraz, arquivo SENAI 


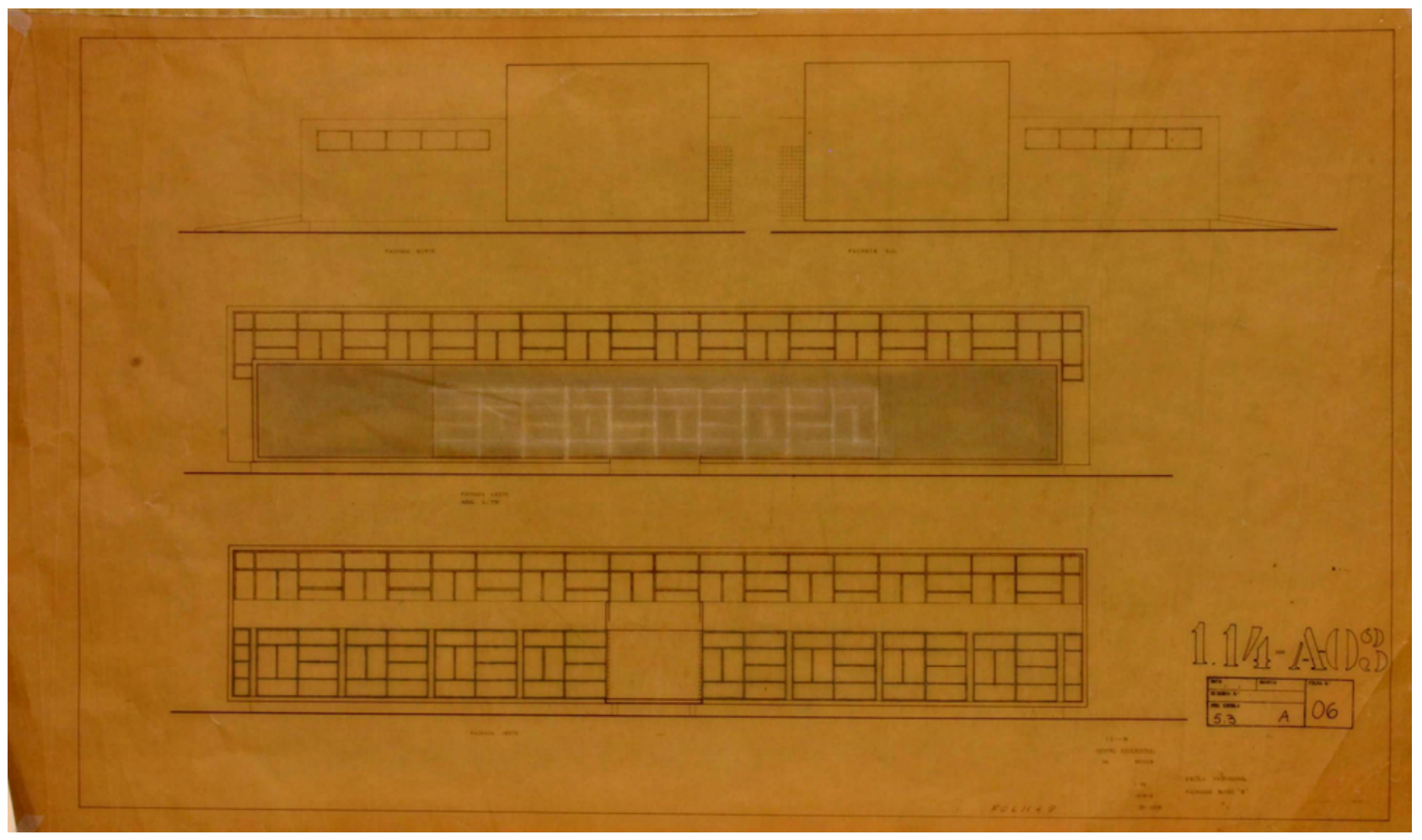

Figura 5: Prancha do projeto executivo das fachadas dos bloco B, Centro Educacional da Mooca, 1960.

Fonte: Foto Ferraz, arquivo SENAI
O bloco A foi projetado paralelo ao bloco B e, ambos, dividiam o programa construtivo da escola. Tanto o bloco A como o B foram projetados com dois pavimentos. Distantes um do outro por aproximadamente 10,50 metros, os blocos foram interligados por uma passarela coberta que permitia o acesso entre os pavimentos superiores. $O$ bloco A foi composto no pavimento térreo por hall de entrada, diretoria, assitente de direção, secretaria, orientador pedagógico, sanitários e quatro salas de aula e, ligado ao pavimento superior através de duas escadas. $O$ pavimento superior abrigava salas de aula, sala dos docentes, depósito e sanitários. Este bloco, um paralelepípedo de $82,20 \mathrm{~m} \times 10,20 \mathrm{~m}$, adotou circulação lateral voltada para a face leste, permitindo a ligação visual com o bloco $B$. 
O bloco B abrigava no térreo o recreio coberto e seus complementos, o pavilhão social. Já o pavimento superior, interligado ao bloco $A$, adotou circulação lateral oeste e abrigava as demais salas de aula, depósito, biblioteca e sanitários. $O$ bloco B, um paralelepípedo de $40,20 \mathrm{~m} \times 9,45 \mathrm{~m}$, finalizava o programa construtivo da escola no pavimento superior e atendia à sociabilidade de ser um pavilhão social no térreo.

O bloco C foi interligado com o A através de uma passarela coberta. Destinado às oficinas, este foi o maior bloco, porém seu projeto original ainda não foi encontrado.

projeto dos blocos $A$ e $B$, através da modulação dos eixos de seus pilares, permitiu a flexibilidade dos espaços de acordo com o crescimento da indústria. A presença de corredores laterais proporcionando o contato com o exterior tanto da escola como do urbano (atratividade), dentre outras características, reflete os pontos básicos da pedagogia do SENAI, porém cabe ressaltar que as oficinas, pela primeira vez, foram implantadas separadamente das salas de aula, não permitindo o acesso visual da prática com a teoria, apenas sua ligação física.

Sabe-se que o Centro Educacional da Mooca foi construído e hoje recebe o nome de "Escola Theobaldo Nigris". Também, pelos documentos analisados, é possível afirmar um anexo construído a esta escola, a "Escola Felício Lanzara". 


\section{PROJETO 16}

\section{Escola Senai de Ribeirão Preto, 1960}

A Escola Senai de Ribeirão Preto, interior de São Paulo, foi projetada por Ernest Robert de Carvalho e Ariaki Kato no ano de 1960. Mesmo sem ter encontrado os dados sobre a localização e área construída do projeto, é possível afirmar que a escola foi composta originalmente por três blocos caracterizados pela oficina e salas de aulas, administração e pavilhão social. Os blocos foram interligados entre si por volumes cobertos com pilares centrais.

A escola teve seu programa construtivo composto de: oficina, salas de aula, sanitários, salas de atendimento médico, dentário e de assistência social, biblioteca, grêmio, salão social, palco, copa, vestiário, quadras de esporte, arquibancadas e áreas verdes.

O projeto original, pesquisado no arquivo do SENAI, foi encontrado parcialmente. Foram encontradas pranchas do projeto original das plantas, cortes, elevações, e detalhamentos dos blocos do pavilhão social e da administração, assim como dos volumes cobertos de ligação entre os blocos. Entretanto, quase nada foi encontrado sobre o bloco da oficina e salas de aula, apenas parte de sua implantação no terreno. Para facilitar a leitura arquitetônica do projeto e representá-lo através de significativos dados obtidos no projeto original, foram graficamente redesenhadas a planta com sua implantação no terreno e as elevações sul e oeste.

Figura 1: Observar os dados do selo do projeto executivo da Escola de Ribeirão Preto, concebido em julho de 1960, com autoria de Ernest Robert de Carvalho e Ariaki Kato.

Fonte: Foto Ferraz, arquivo SENAI

\section{ESCOLA SENAİ DE RIBEIRÃO PRETO $P A V I L H \tilde{A O}$ S OCIAL PLANTA ACABAMENTOS




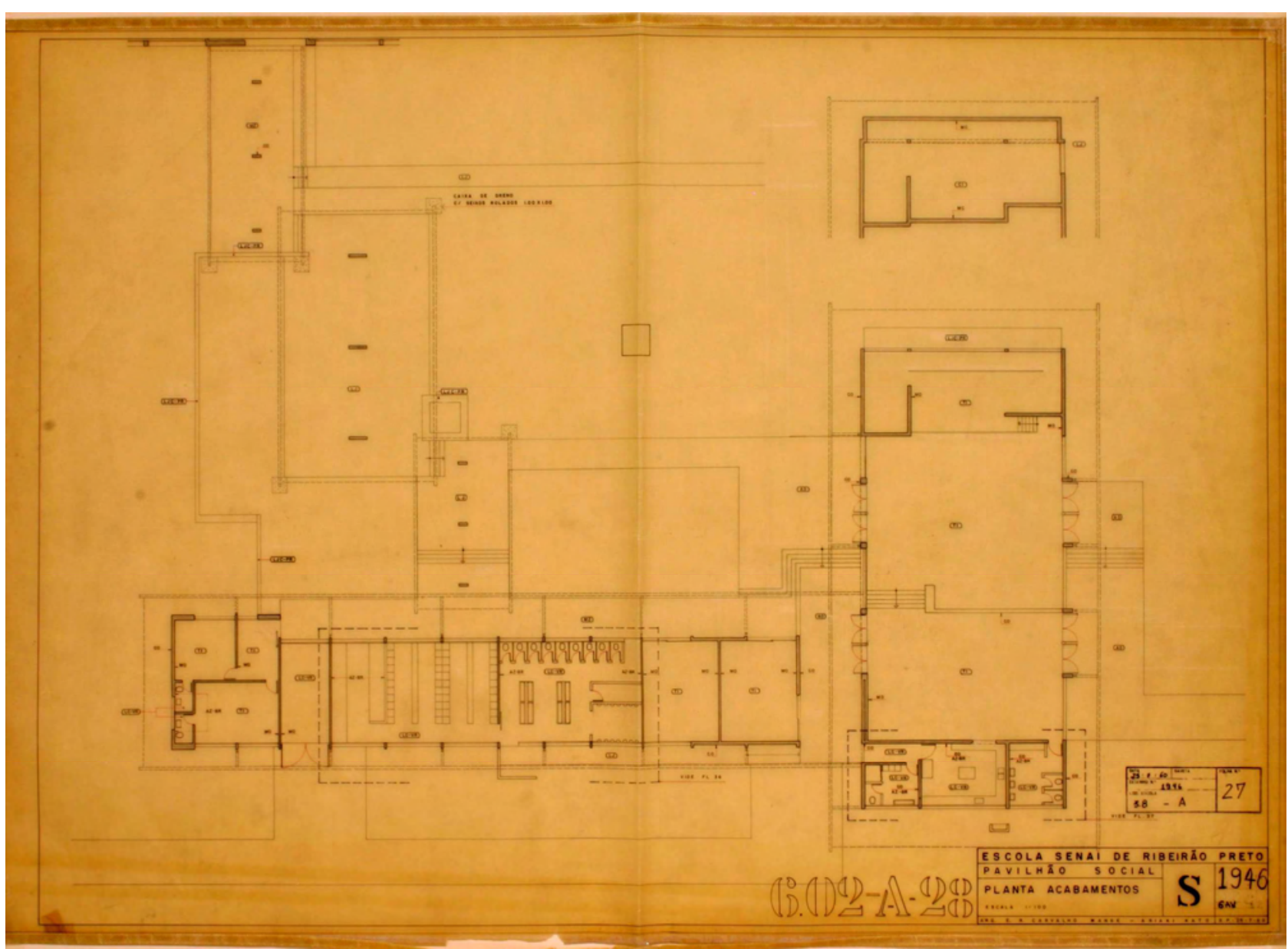

Figura 2: Prancha do projeto executivo da planta dos blocos do pavilhão social e da administração, original na escala 1:100, Escola de Ribeirão Preto, 1960. Fonte: Foto Ferraz, arquivo SENAI

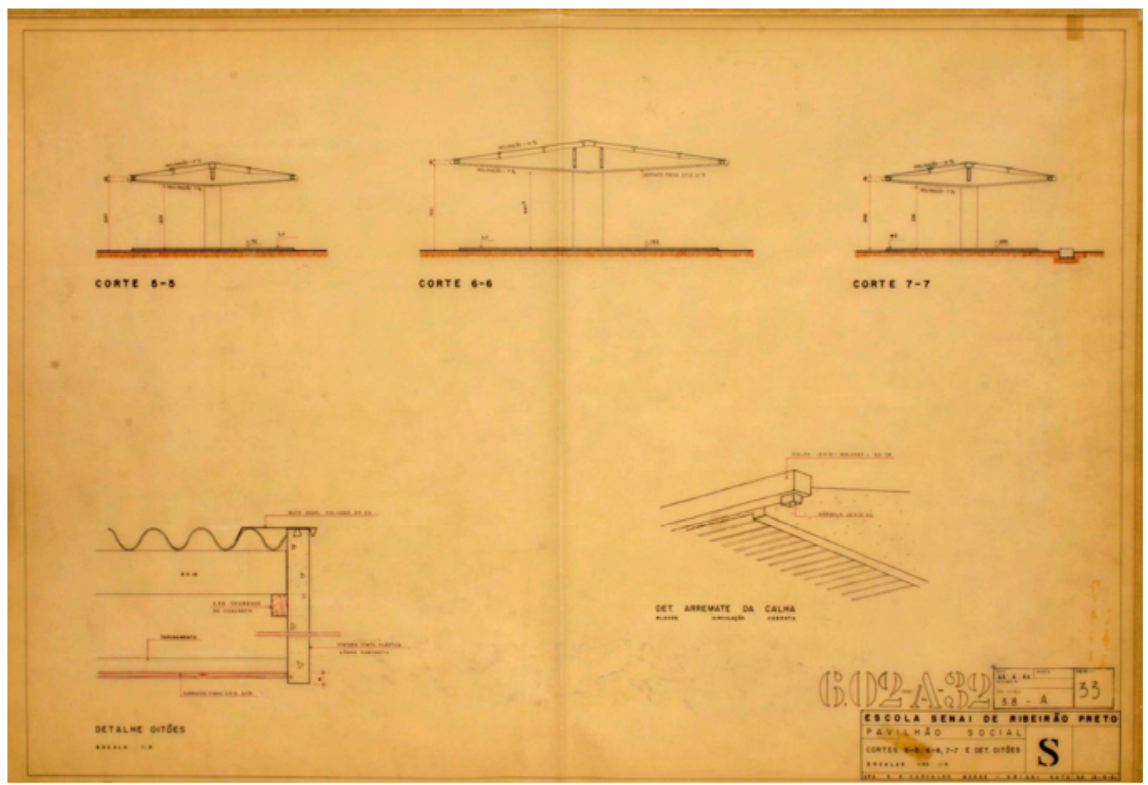

Figura 3: Prancha do projeto executivo dos cortes dos volumes cobertos de ligação entre os blocos, original na escala 1:50, Escola de Ribeirão Preto, 1960. Fonte: Foto Ferraz, arquivo SENAI 


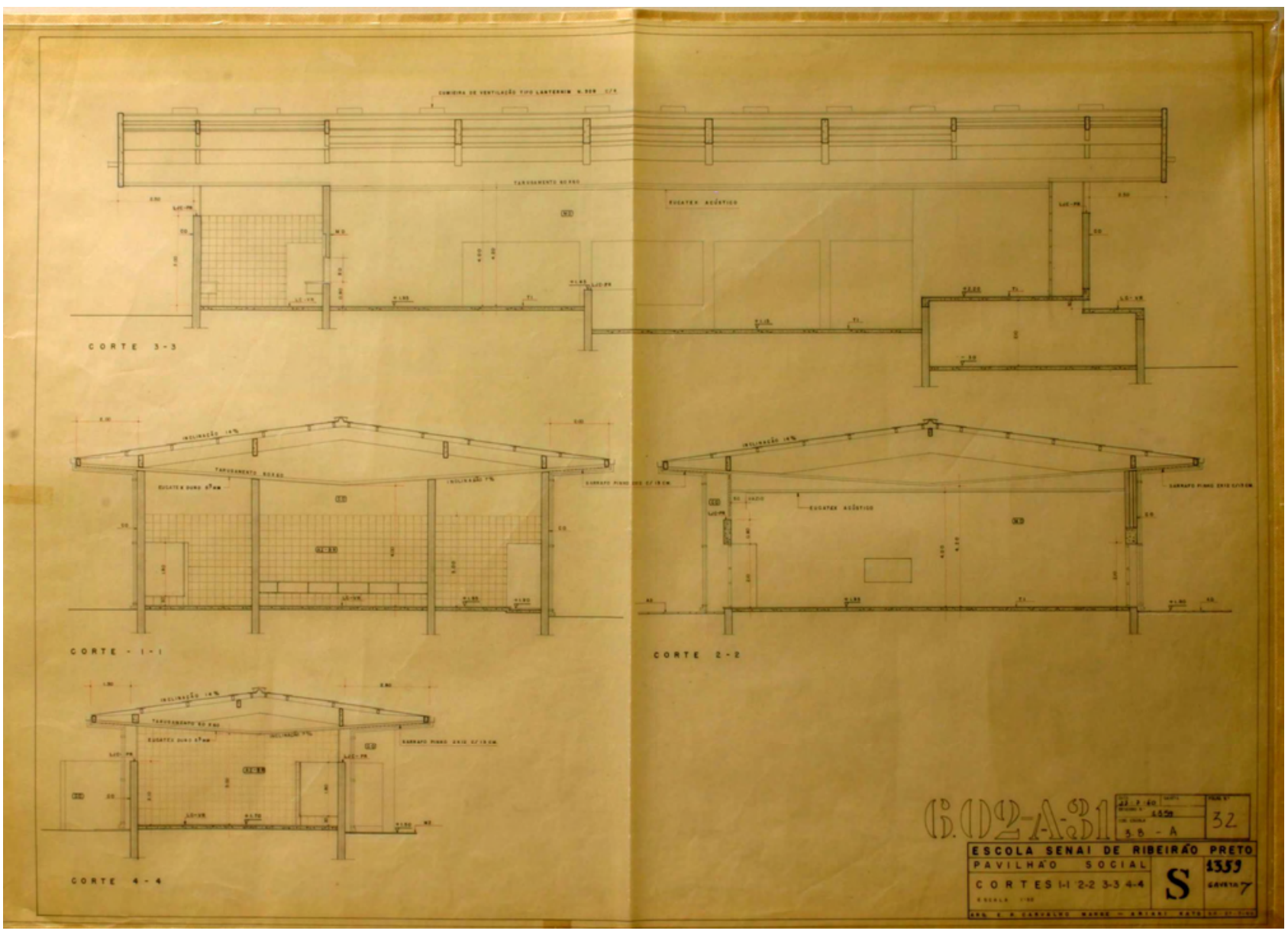

Figura 4: Prancha do projeto executivo dos cortes do bloco do pavilhão social,

original na escala 1:50,

Escola de Ribeirão Preto, 1960.

Fonte: Foto Ferraz,

arquivo SENAI

Figura 5: Prancha do projeto executivo das elevações da escola, original na escala 1:100, Escola de Ribeirão Preto, 1960. Fonte: Foto Ferraz, arquivo SENAI

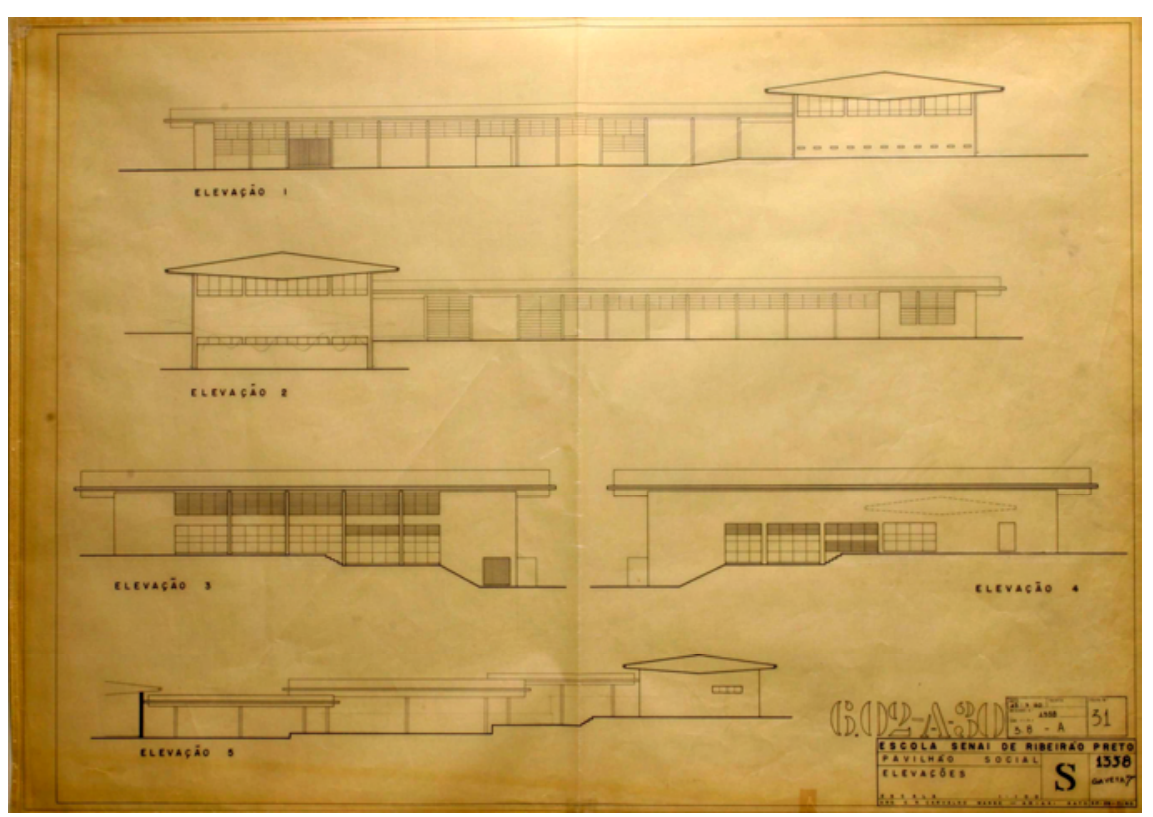




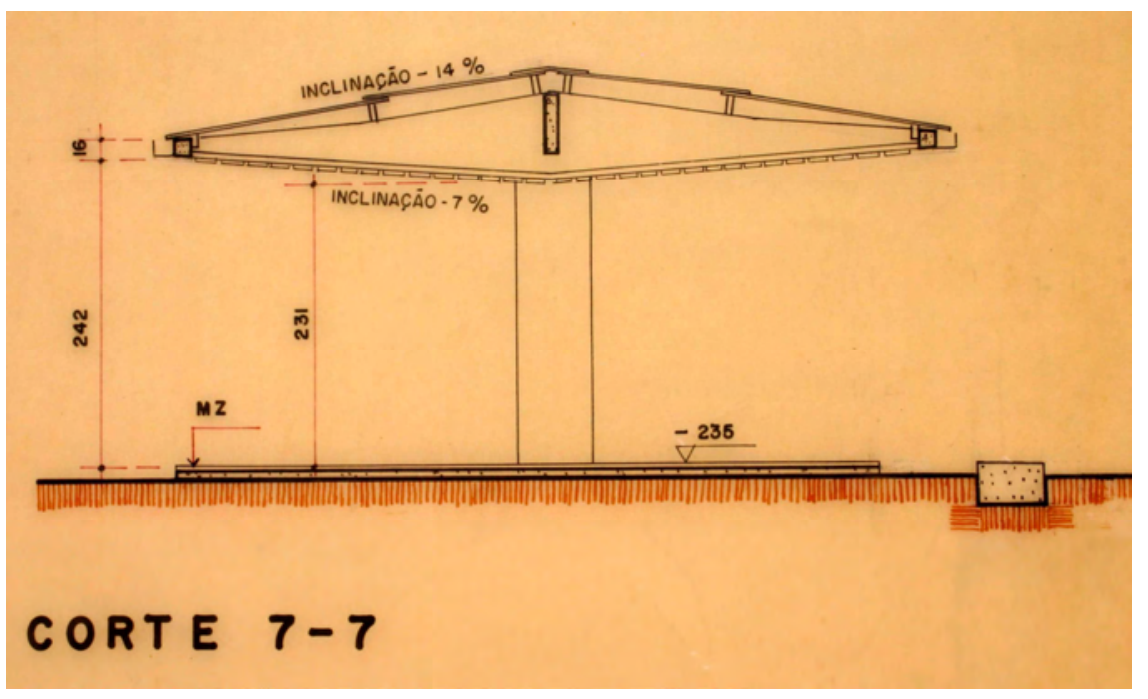

Figura 6: Corte do volume coberto de ligação entre os blocos, retirado da prancha do projeto, original na escala 1:50, Escola de Ribeirão Preto, 1960. Fonte: Foto Ferraz, arquivo SENAI

Figura 7: Elevação oeste do bloco do Pavilhão Social, retirado da prancha do projeto, original na escala 1:100, Escola de Ribeirão Preto, 1960. Fonte: Foto Ferraz, arquivo SENAI

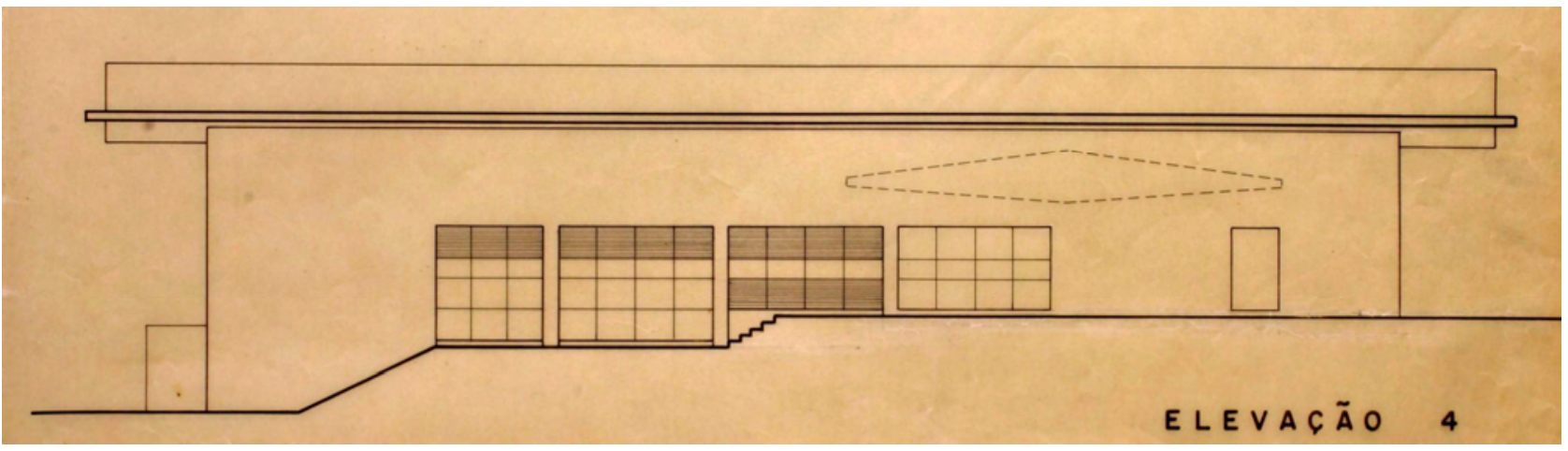




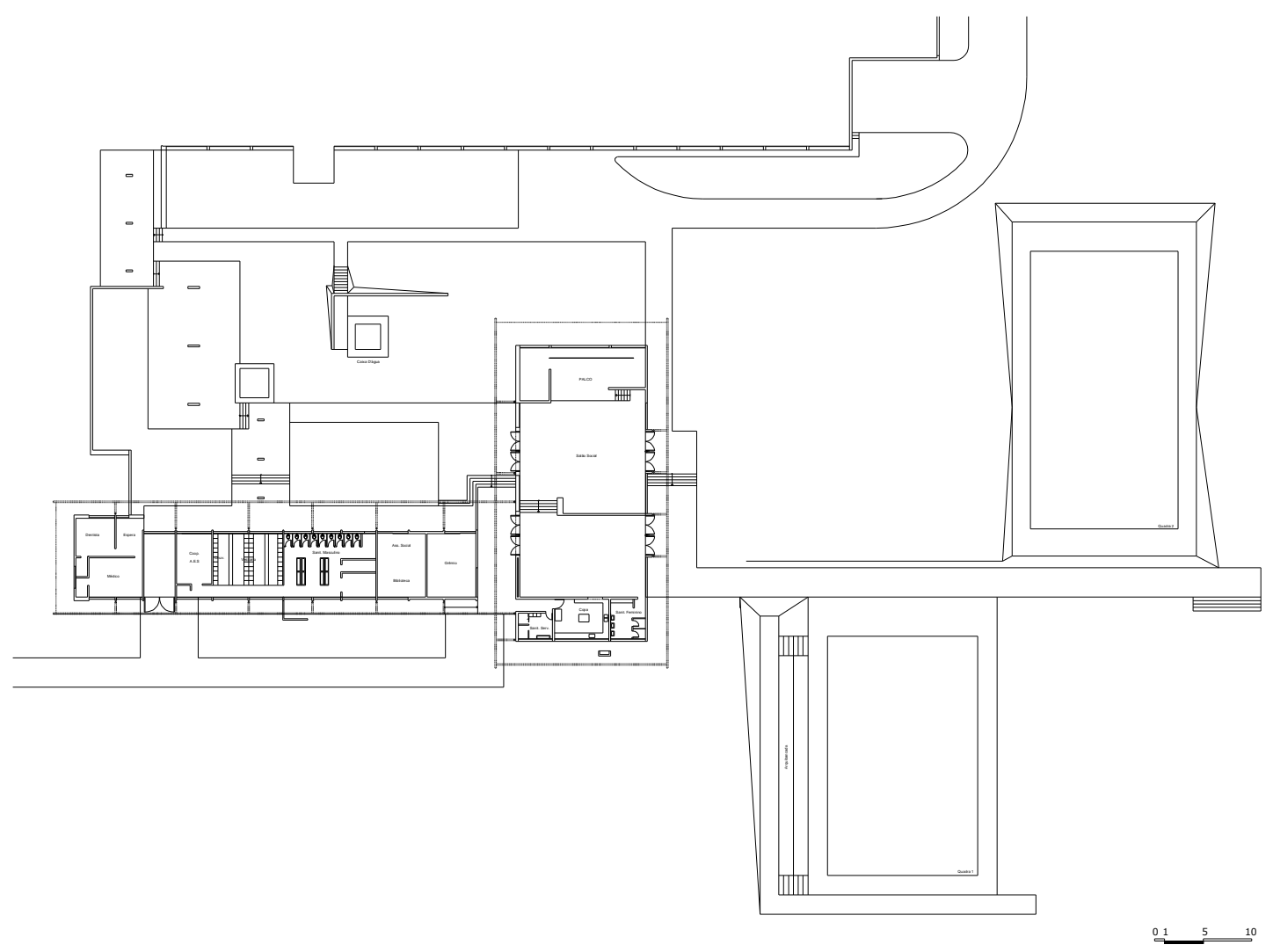

Figura 8: Redesenho da planta do pavimento térreo.

Fonte: Ferraz, 2005

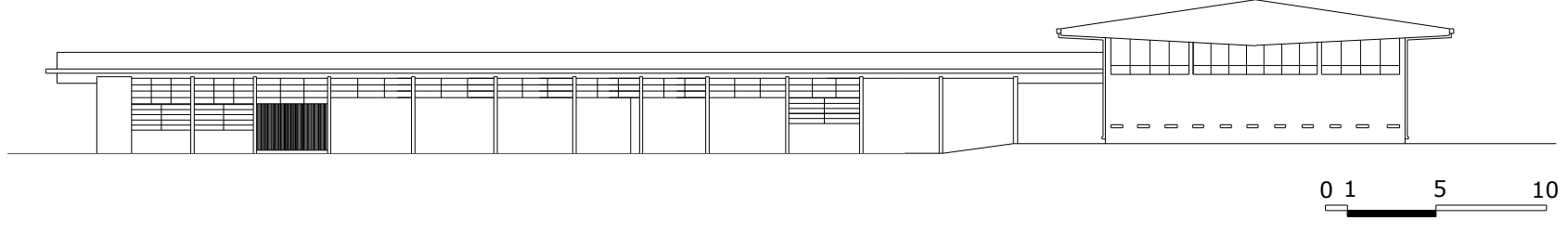

Figura 9: Redesenho da planta da elevação sul da escola.

Fonte: Ferraz, 2005

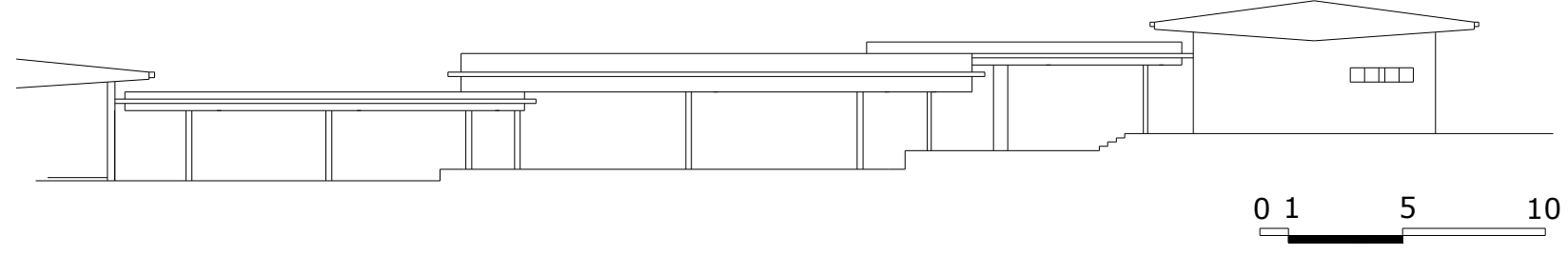

Figura 10: Redesenho da planta da elevação oeste da escola.

Fonte: Ferraz, 2005 
A solução adotada no projeto foi a de blocos interligados entre si, interligados por volumes cobertos. $O$ formato da cobertura é semelhante ao do projeto da Escola de Tatuapé. $O$ primeiro bloco da administração foi localizado no nível mais alto do terreno e era composto de salas de atendimento médico, dentário e de assistência social, biblioteca, grêmio, vestiários e sanitários. Resolvido em um único pavimento, este bloco tinha iluminação e ventilação bilaterais norte e sul, adotando circulação lateral norte, aberta para o interior da escola. O paralelepípedo deste primeiro bloco ocupava 40,50m x $8,85 \mathrm{~m}$ e foi interligado tanto ao bloco das oficinas e salas de aula através dos volumes cobertos e escadas, como ao bloco do pavilhão social, perpendicular aos outros.

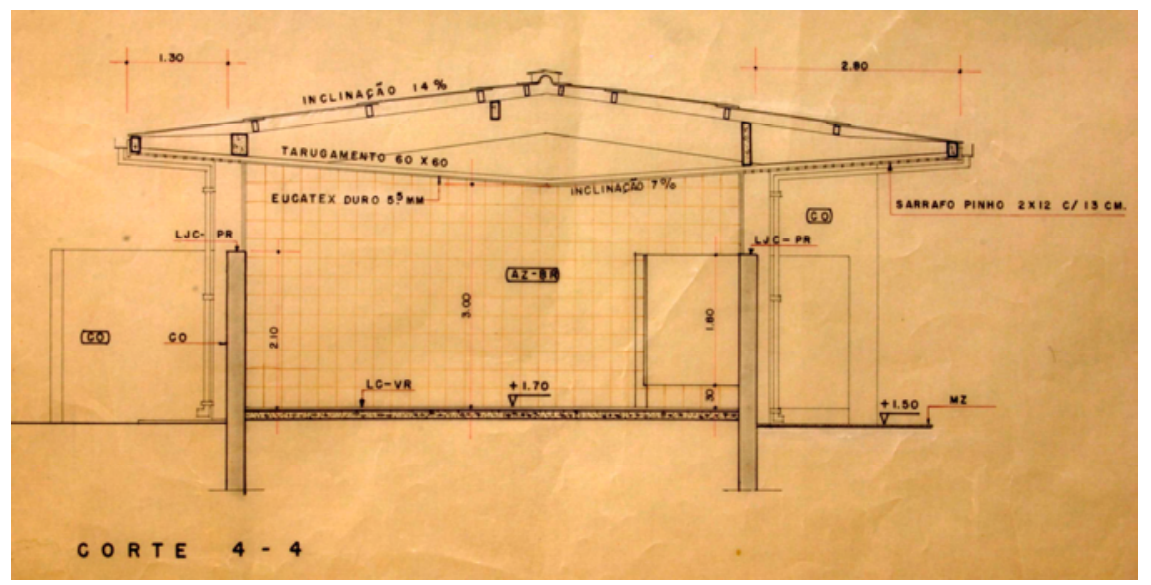

O segundo bloco, caracterizado como pavilhão social, era composto de três diferentes níveis no pavimento térreo e um sub-solo sob o palco. O palco foi projetado a 1.05 metros acima do nível mais baixo e o piso intermediário a $80 \mathrm{~cm}$. O nível mais baixo era utilizado como salão social juntamente com parte do piso intermediário, também projetado para abrigar a copa e os sanitários. Este bloco recebeu iluminação e ventilação bilateral leste e oeste (economia) e foi projetado para atender à sociabilidade da escola.
Figura 11: Corte do bloco da administração, retirado da prancha do projeto executivo, original na escala 1:50, Escola de Ribeirão Preto, 1960. Fonte: Foto Ferraz, arquivo SENAI 


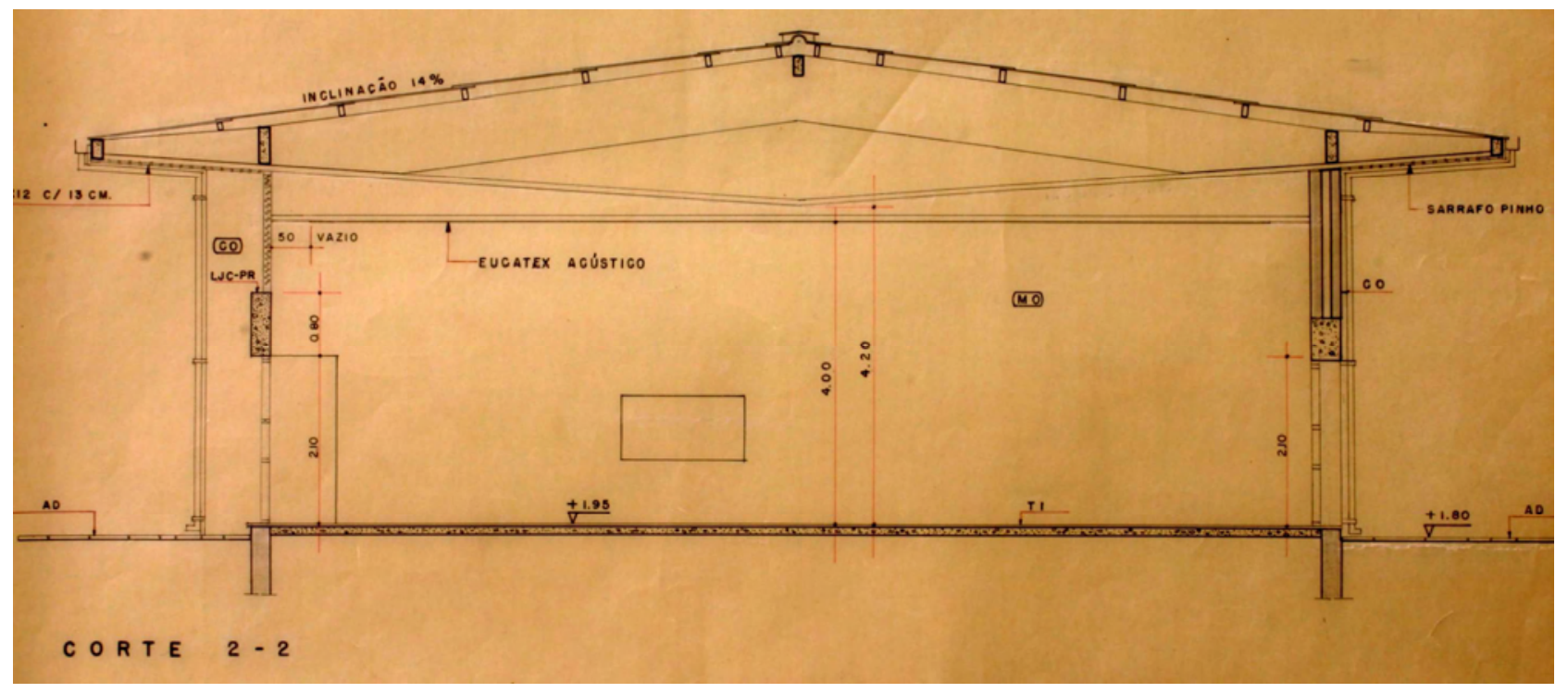

Figura 12: Corte do bloco do pavilhão social, retirado da prancha do projeto executivo, original na escala 1:50, Escola de Ribeirão Preto, 1960.

Fonte: Foto Ferraz, arquivo SENAI

O terceiro bloco, da oficina e salas de aula, foi interligado ao primeiro bloco, porém sua planta não foi encontrada.

A Escola Senai de Ribeirão Preto foi construída e, mesmo sem todos os dados da planta do projeto original, confirma uma arquitetura pautada na filosofia educacional do SENAI, atendendo às características de crescimento (planta livre), sociabilidade (pavilhão social, áreas de recreação e quadras esportivas), economia (iluminação e ventilação naturais) e interligação (visual entre as diversas atividades). 


\section{PROJETO 17}

\section{Escola Senai de São Bernardo, 1961}

Projetada por Lúcio Grinover, a Escola de São Bernardo também exemplifica os parâmetros da filosofia educacional do SENAI. projeto original foi composto por três blocos principais caracterizados pela: oficina, salas de aula e auditório.

O programa construtivo adotado foi: oficina de madeira, oficina geral, sanitários de instrutores e alunos, cabine de força e forja no primeiro bloco; hall de entrada, secretaria, diretoria, sala de espera e salas de assistência social, médica e dentária, depósito, sanitários, grêmio, refeitório, copa, depósito do refeitório, biblioteca integrada à sala dos professores e sete salas de aulas no segundo bloco; salão coberto, palco, sanitário e vestiário no terceiro bloco. Os três blocos foram interligados entre si tanto por uma passarela coberta entre o bloco da oficina e salas de aula, como por uma escadaria coberta entre os blocos das salas de aula e auditório, aproveitando os desníveis do terreno.

Grande parte do projeto original foi encontrado no arquivo do SENAl, como as pranchas do projeto executivo, na escala 1:100, revelando as plantas, cortes e fachadas dos blocos da oficina, salas de aula e auditório, além de diversas pranchas, em diferentes escalas, ricas em desenhos de detalhamento de esquadrias, armários, quadro negro, sanitários, dentre outros. Estes documentos possibilitaram confirmar a data do projeto, suas particularidades e a contribuição do arquiteto Edgardo Tonca no projeto executivo da portaria e cabine de força, em 1962. O projeto original foi obtido no arquivo do SENAI.

Figura 1: Observar os dados do selo do projeto original do detalhamento das esquadrias do bloco da oficina, original nas escalas 1:20 e 1:1, Escola de São Bernardo, concebido em março de 1961, com autoria de Lúcio Grinover. Fonte: Foto Ferraz, arquivo SENAI

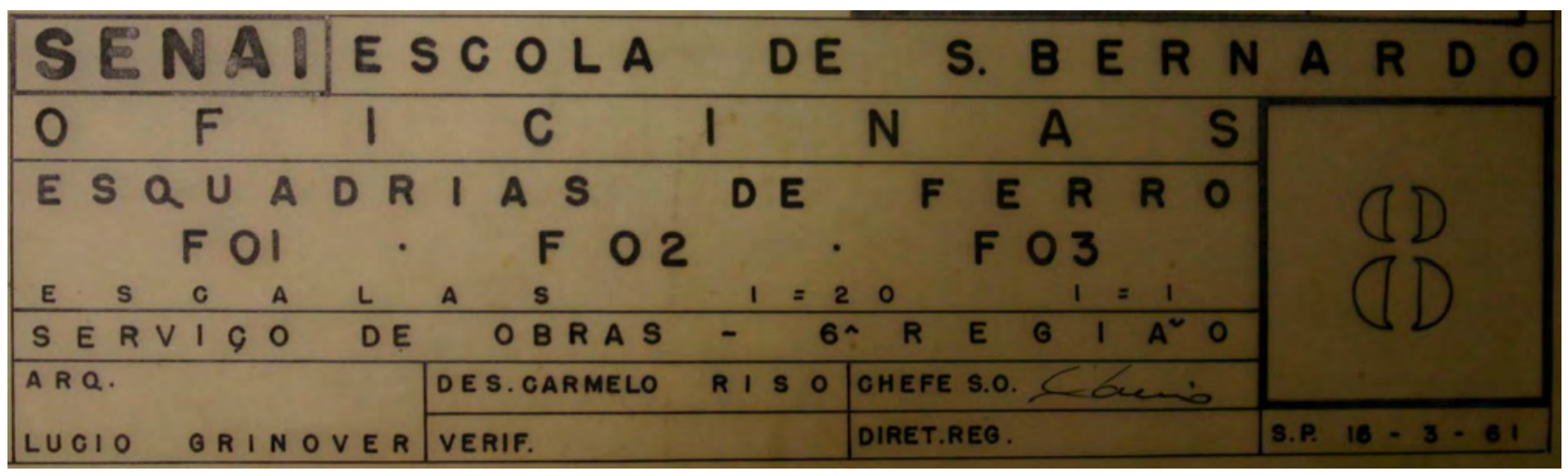




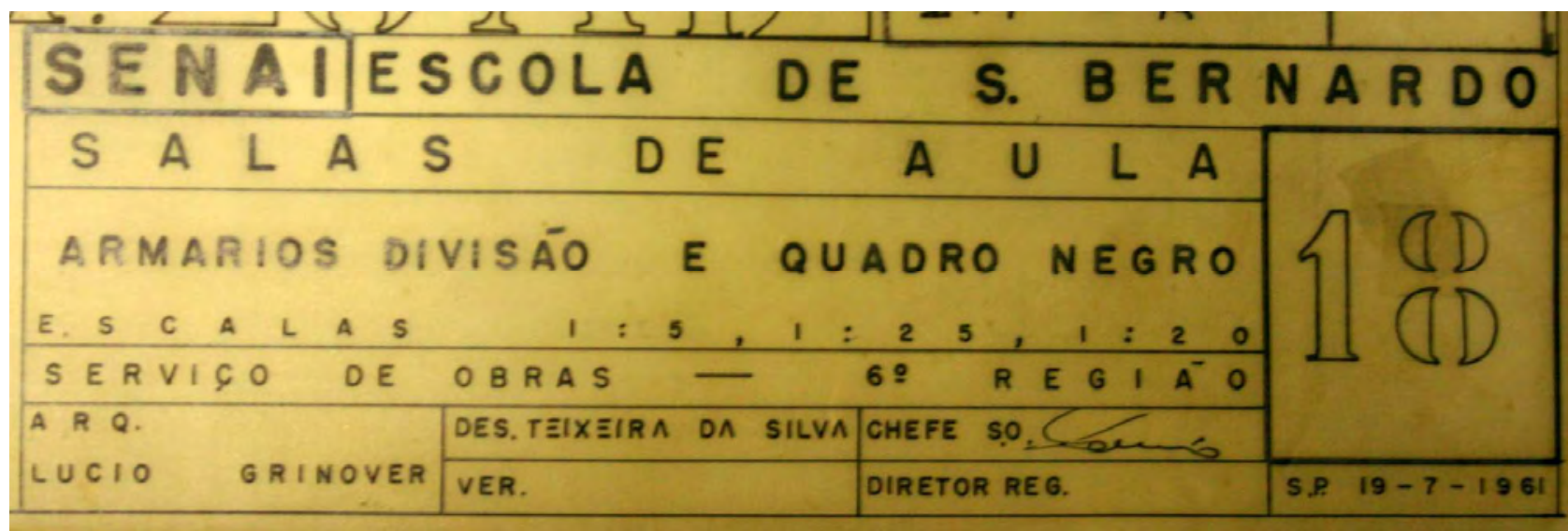

Figura 2: Observar os dados do selo do projeto original do detalhamento dos armários e quadro negro do bloco das salas de aula, original nas escalas 1:5, 1:25 e 1:20, Escola de São Bernardo, concebido em julho de 1961,

com autoria de Lúcio Grinover.

Fonte: Foto Ferraz, arquivo SENAI

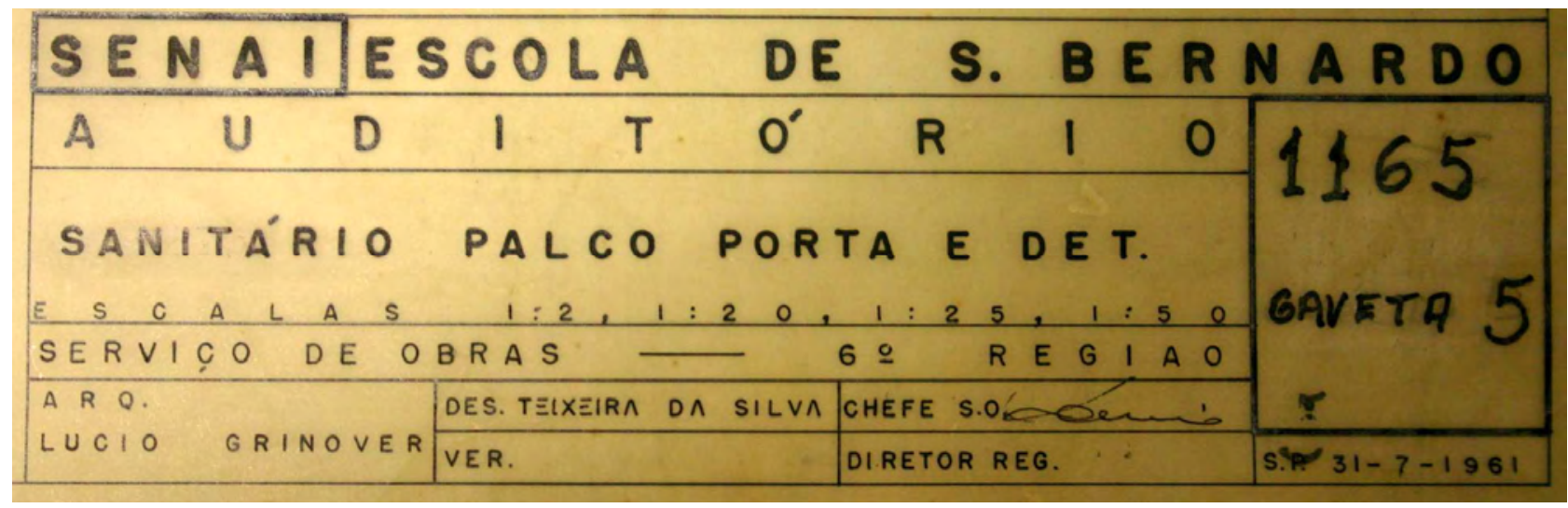

Figura 3: Observar os dados do selo do projeto original do detalhamento do sanitário, palco e porta do bloco do auditório, original nas escalas 1:2, 1:20, 1:25 e 1:50, Escola de São Bernardo, concebido em julho de 1961, com autoria de Lúcio Grinover.

Fonte: Foto Ferraz, arquivo SENAI

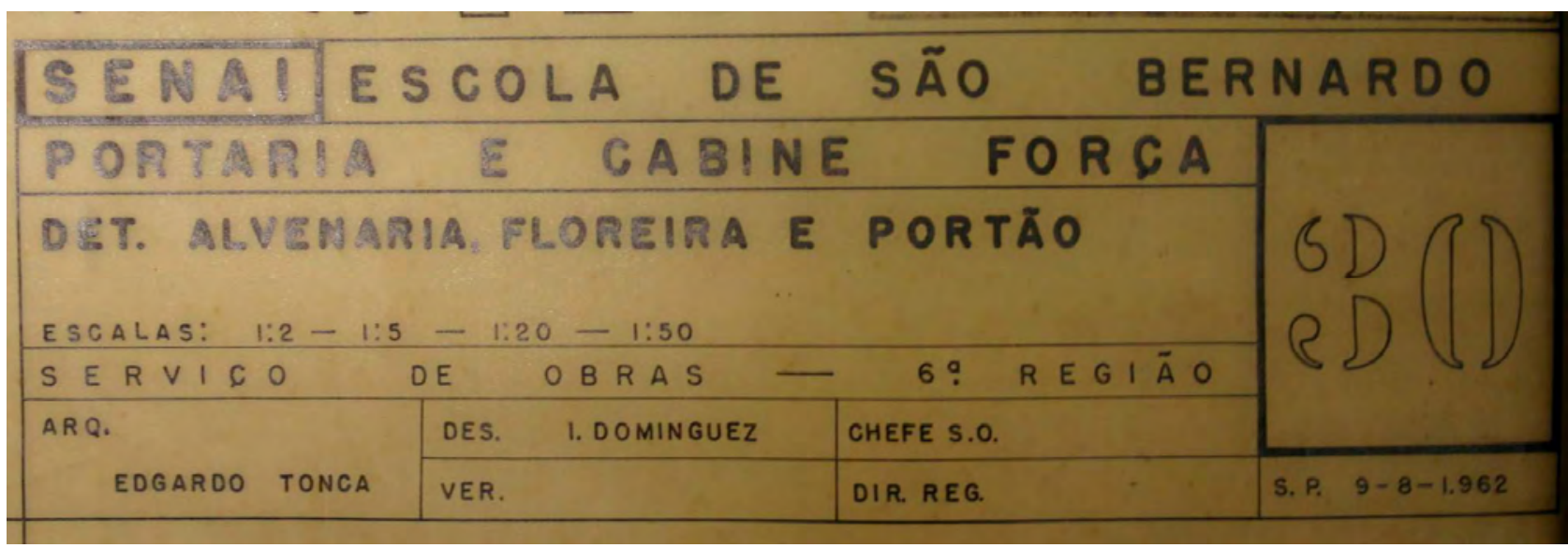

Figura 4: Observar os dados do selo do projeto original do detalhamento da portaria e cabine de força, original nas escalas 1:2, 1:5, 1:20 e 1:50, Escola de São Bernardo, concebido em agosto de 1962, com autoria de Edgardo Tonca.

Fonte: Foto Ferraz, arquivo SENAI 


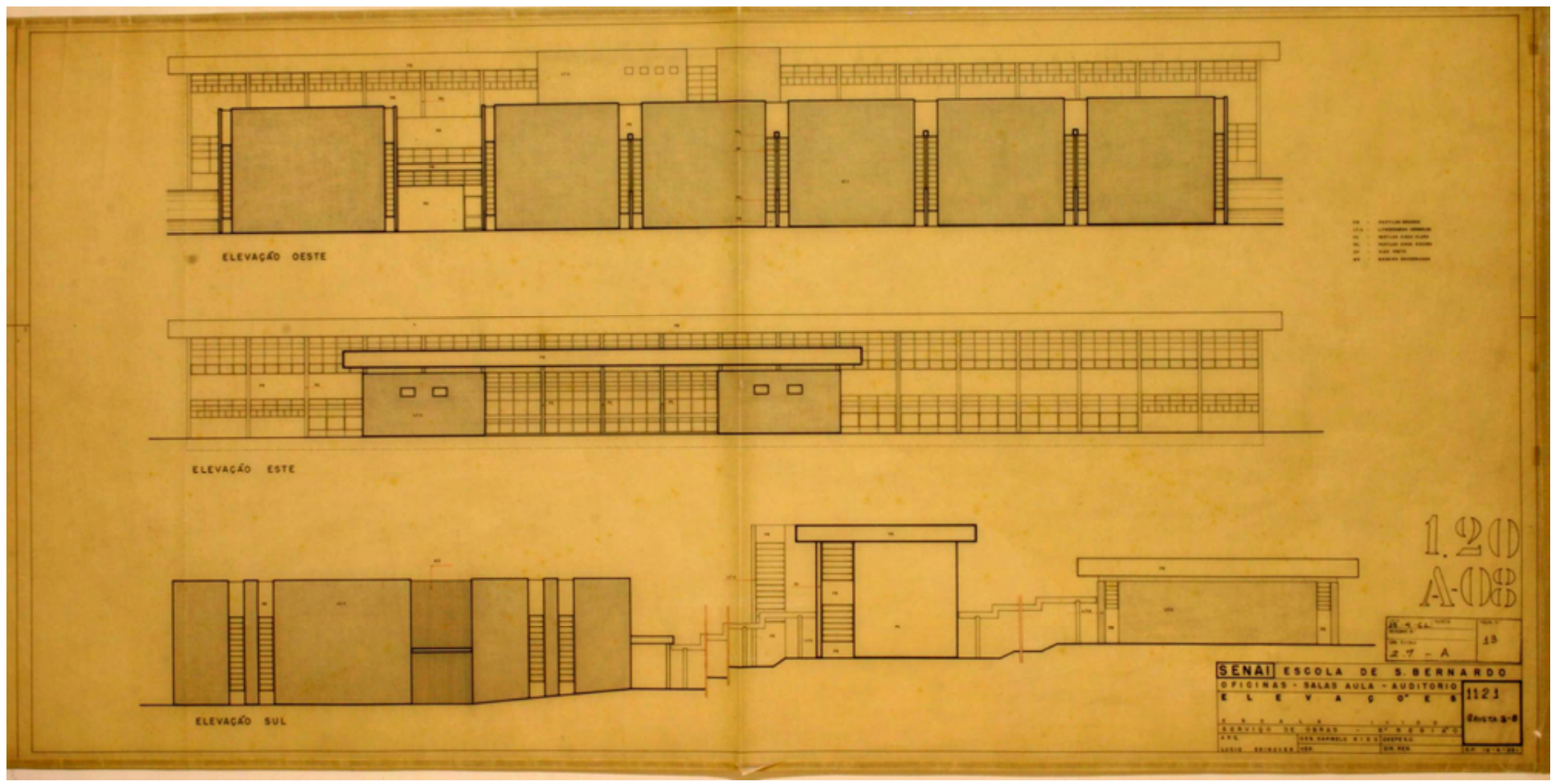

Figura 5: Prancha original das Elevações dos três blocos da oficina, salas de aula e auditório, original na escala 1:100, Escola de São Bernardo, 1961.

Fonte: Foto Ferraz, arquivo SENAI

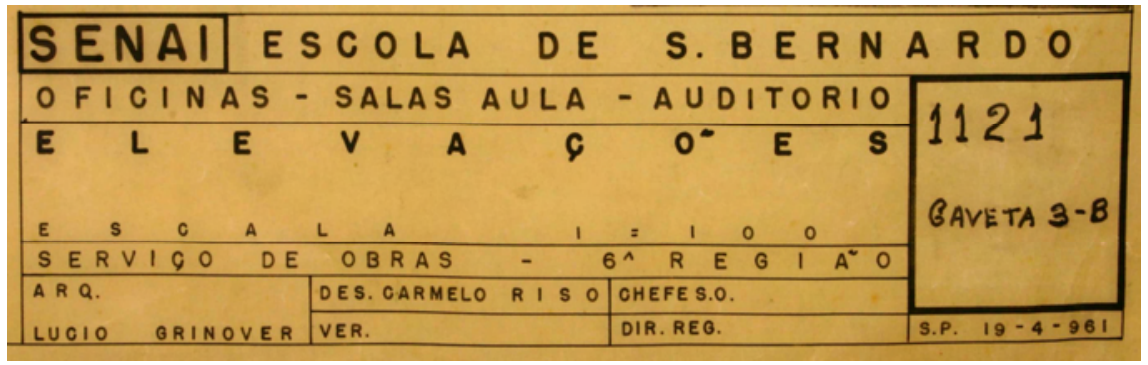

O bloco das oficinas compunha a fachada oeste com seus 68 metros de eixo. Composto por um único pavimento, este bloco foi projetado com pé-direito máximo de 5,50 metros e divido em nível, sendo que a forja e parte da oficina ficavam em desnível de 1 metro do piso da oficina geral, seguindo a topografia do terreno. Solução semelhante a esta, de resolver o piso da oficina em desnível, já havia sido adotada por Lúcio Grinover na Escola de Tatuapé, em 1957. Implantado no nível mais baixo do terreno, o bloco das oficinas era modulado (flexibilidade) com eixos longitudinais de 10 e 6 metros, e com eixos transversais de 10 metros, totalizando um bloco de 68 metros de comprimento $\times 30$ metros de largura de eixo. Tal modulação divide o bloco em duas oficinas com acessos independentes, sendo a oficina de madeira com eixo longitudinal de 6 metros e cerca de $360 \mathrm{~m}^{2}$, localizada na extremidade norte e, a oficina geral com eixo longitudinal de 10 metros e cerca de $1500 \mathrm{~m}^{2}$,
Figura 6: Selo da prancha original das Elevações, Escola de São Bernardo, 1961. Fonte: Foto Ferraz, arquivo SENAI 
Figura 7: Elevação Sul dos três blocos da oficina, salas de aula e auditório, retirada da prancha original das Elevações, original na escala 1:100, Escola de São Bernardo, 1961. Observar o bloco das oficinas no nível mais baixo do terreno e sua ligação com o bloco das salas de aula por uma passarela coberta. Fonte: Foto Ferraz, arquivo SENAI separada da anterior pelos sanitários, cabine de força e vazios. As oficinas receberam iluminação e ventilação por todas as faces, sendo que na face leste foram projetados grandes vãos envidraçados protegidos por uma marquise que permitiam ampla visibilidade da área interna da escola (atratividade e interligação), nas faces norte e sul janelas estreitas e altas de 1 metro $\times 3$ metros compunham as fachadas transversais do bloco e, na face oeste janelas ainda menores de 0,60 metros x 3 metros possibilitavam a iluminação e ventilação constante, sem comprometer as oficinas com o desconforto do sol da tarde. Como local de trabalho, a cobertura tipo shed também foi projetada para obter um maior aproveitamento de luz natural, assim como de ventilação permanente (economia).
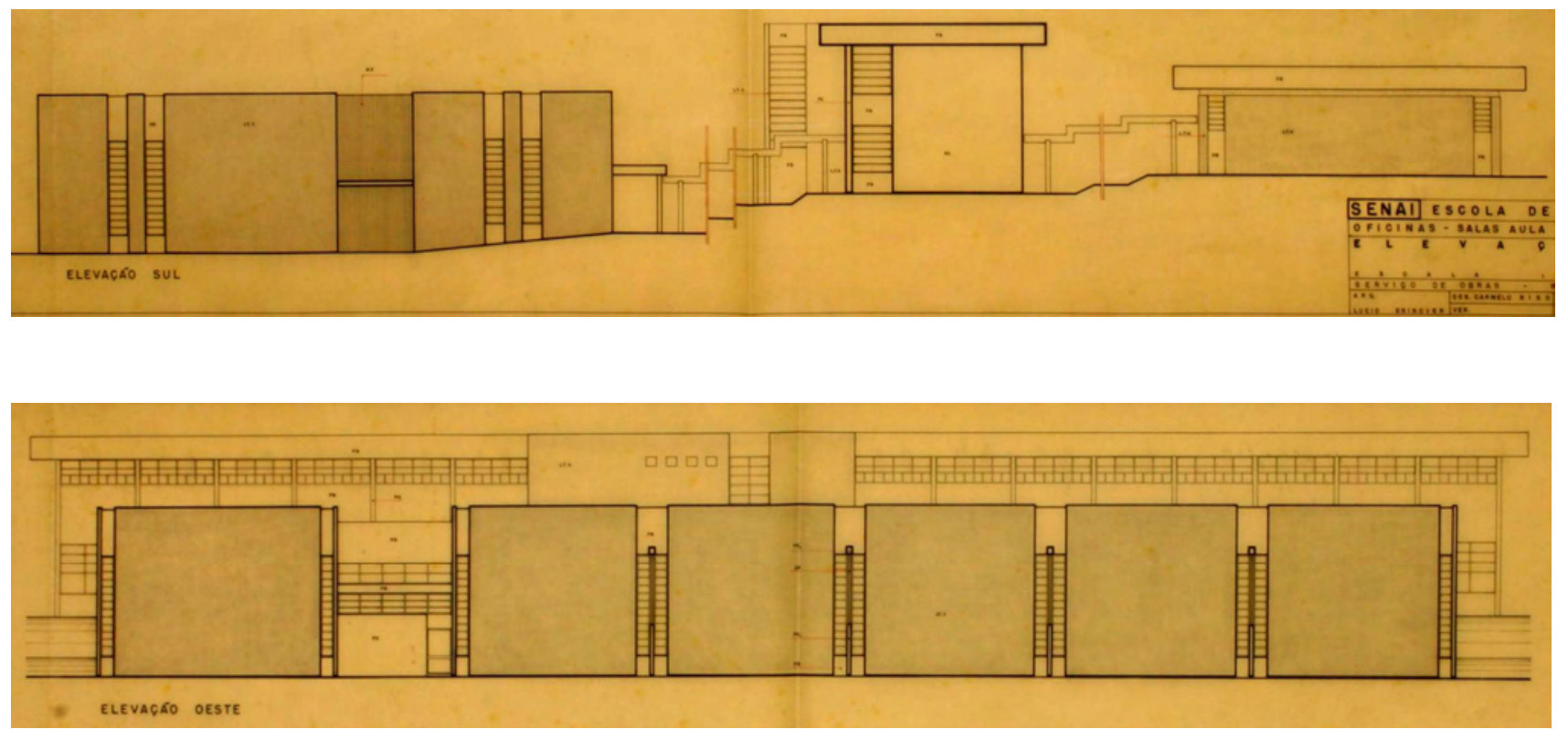

Figura 8: Elevação Oeste do bloco das oficinas e salas de aulc (ao fundo), retirada da prancha original das Elevações, original nı escala 1:100, Escola de São Bernardo, 1961. Observar as aberturas na face oeste do bloco das oficinas e a oficina de madeira localizada na extremidade esquerda da elevação (face norte). Fonte: Foto Ferraz, arquivo SENAI segundo bloco das salas de aulas, paralelo ao bloco das oficinas, foi composto de dois pavimentos em um monobloco de 72,20 metros de comprimento x 8,55 metros de largura de eixo. Implantado a 3 metros acima do nível inferior das oficinas, abrigava no pavimento térreo os espaços administrativos, salas para atendimento social, médico e dentário, sanitários, grêmio, refeitório, copa e depósitos e, no pavimento superior os sanitários, salas de aulas e sala dos professores integrada à biblioteca. Os pavimentos foram interligados por uma escada que, juntamente com o sanitário, grêmio e sala de assistência social, formava um volume central anexo 
ao paralelepípedo. O pavimento térreo, com pé-direito de 4 metros, foi dividido em duas alas, separadas pelo hall de entrada, sendo a área administrativa e de atendimento social na extremidade sul e a área de lazer, o refeitório e respectivo apoio, na extremidade norte. No pavimento superior, com pé-direito de 3,50 metros, a divisão interna adotada foi através de corredores laterais (2 metros de largura), voltados para o oeste, fechados com grandes vãos envidraçados (interligação), seguindo a modulação longitudinal de 4 metros do próprio edifício. As salas de aulas foram projetadas com iluminação lateral leste e divididas com separações móveis de armários tipo quadro negro (crescimento e flexibilidade).

O terceiro bloco, utilizado como auditório, atendendo a idéia de "pavilhão social", compunha a fachada leste do conjunto, a 1 metro acima do nível do bloco das salas de aulas. Paralelo aos blocos das oficinas e salas de aula, este edifício de menor porte foi composto de um único pavimento de 32,00 metros de comprimento x 15,30 metros de largura de eixo, com modulação longitudinal de 4 metros. Com pé-direito de 4,50 metros, o edifício abrigava: palco (em desnível de 0,80 metros do piso geral), salão coberto, sanitário e vestiário, e era interligado com uma arquibancada externa. Com iluminação e ventilação bilaterais leste e oeste, marcadas por oito entradas e saídas, o salão proporcionou a sociabilidade, através do contato com o interior da área livre da escola.
Figura 9: Elevação Leste do bloco do auditório e salas de aula (ao fundo), retirada da prancha original das Elevações, original na escala 1:100, Escola de São Bernardo, 1961.

Observar as aberturas na face leste do bloco do auditório seguindo a mesma modulação do bloco das salas de aula. Fonte: Foto Ferraz, arquivo SENAI

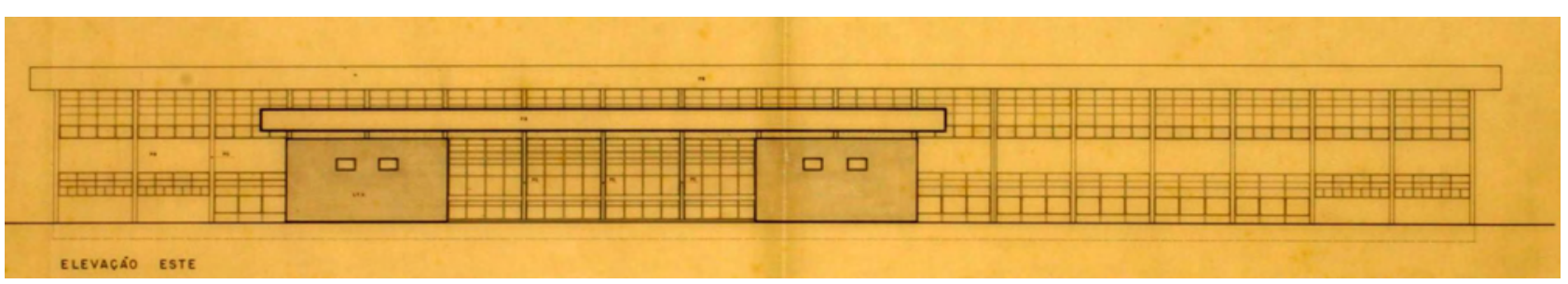

A Escola Senai de São Bernardo foi construída e confirma em sua arquitetura a filosofia do SENAI, atendendo às suas principais características. Porém, assim como no Centro Educacional da Mooca do SENAl, projetado em 1960, as oficinas foram implantadas separadamente das salas de aulas, não permitindo o acesso visual da prática com a teoria. 


\section{PROJETO 18}

\section{Escola Senai de São Carlos, 1961}

Projetada, em 1961, por Ayako Nishikawa em parceria com Ernest Mange, a Escola SENAI de São Carlos foi projetada no mesmo terreno onde já havia sido construído o pavilhão social, exemplo da arquitetura racionalista da década de 1940. O terreno, localizado entre as ruas Marcolino Pelicano, José Benetti, Roberto Simonsen e Cândido Padim, uma quadra com 8.965,00 m², reuniu os elementos do programa construtivo. $\bigcirc$ projeto, caracterizado pela administração, oficinas e salas de aulas, era composto de três blocos com aproximadamente 2.135,50 $\mathrm{m}^{2}$ de área construída.

Figura 1: Planta de situação do terreno da escola Senai de São Carlos, 1961.

Fonte: Foto Ferraz, arquivo SENAI

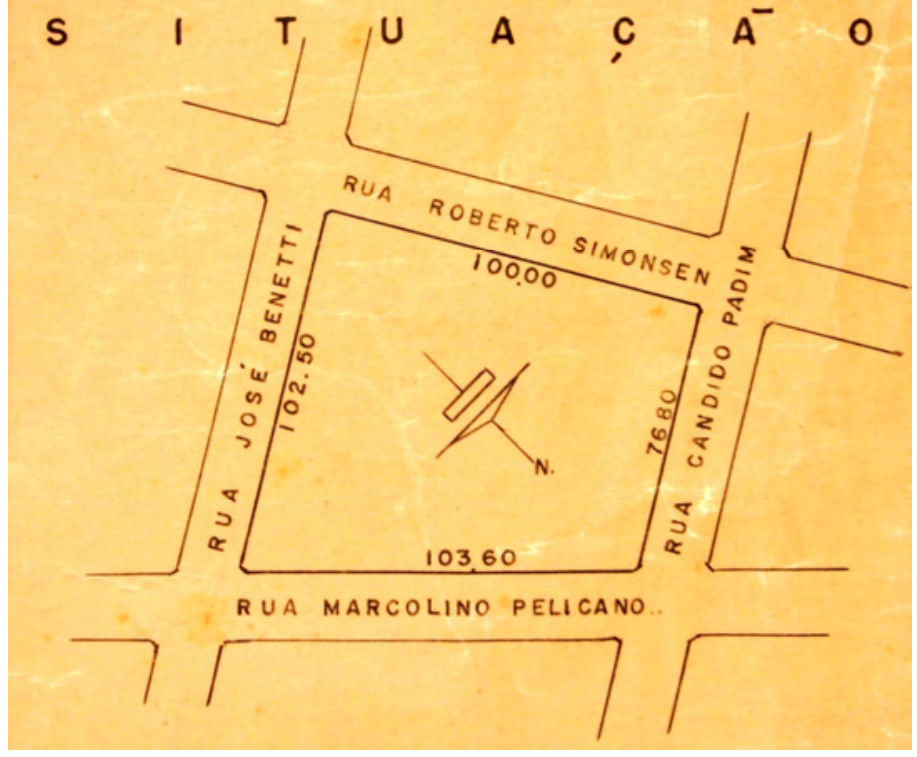

programa construtivo adotado foi resolvido em um único pavimento, marcado apenas por diferentes níveis. $\bigcirc$ primeiro bloco (administração) era composto por hall de entrada, secretaria, diretoria integrada à sala de reuniões, sala de espera, salas de assistência do diretor, cabine primária e sanitários. O segundo bloco (oficinas) abrigava as oficinas de montagem, ajustagem, tornearia e mecânica de autos e, depósito. O terceiro bloco (salas de aula) era composto por cinco salas de aula (sendo uma de desenho e outra de ciências), biblioteca dos professores, sala dos professores, sanitários e vestiário. O terceiro bloco também estava interligado ao pavilhão social existente e ao bloco da administração, através de passarelas cobertas. 
Importantes dados relativos ao projeto original foram encontrados no arquivo do SENAI, como a situação e localização do terreno, a implantação geral dos edifícios, as pranchas de prefeitura com todas as plantas, cortes e fachadas necessários para a compreensão do projeto, além de inúmeras pranchas do projeto executivo com detalhamentos de forro, acabamentos, esquadrias, lavatórios, sanitários, bancos, armários, escadas, quebra sol, ventilação permanente (economia), dentre outros.
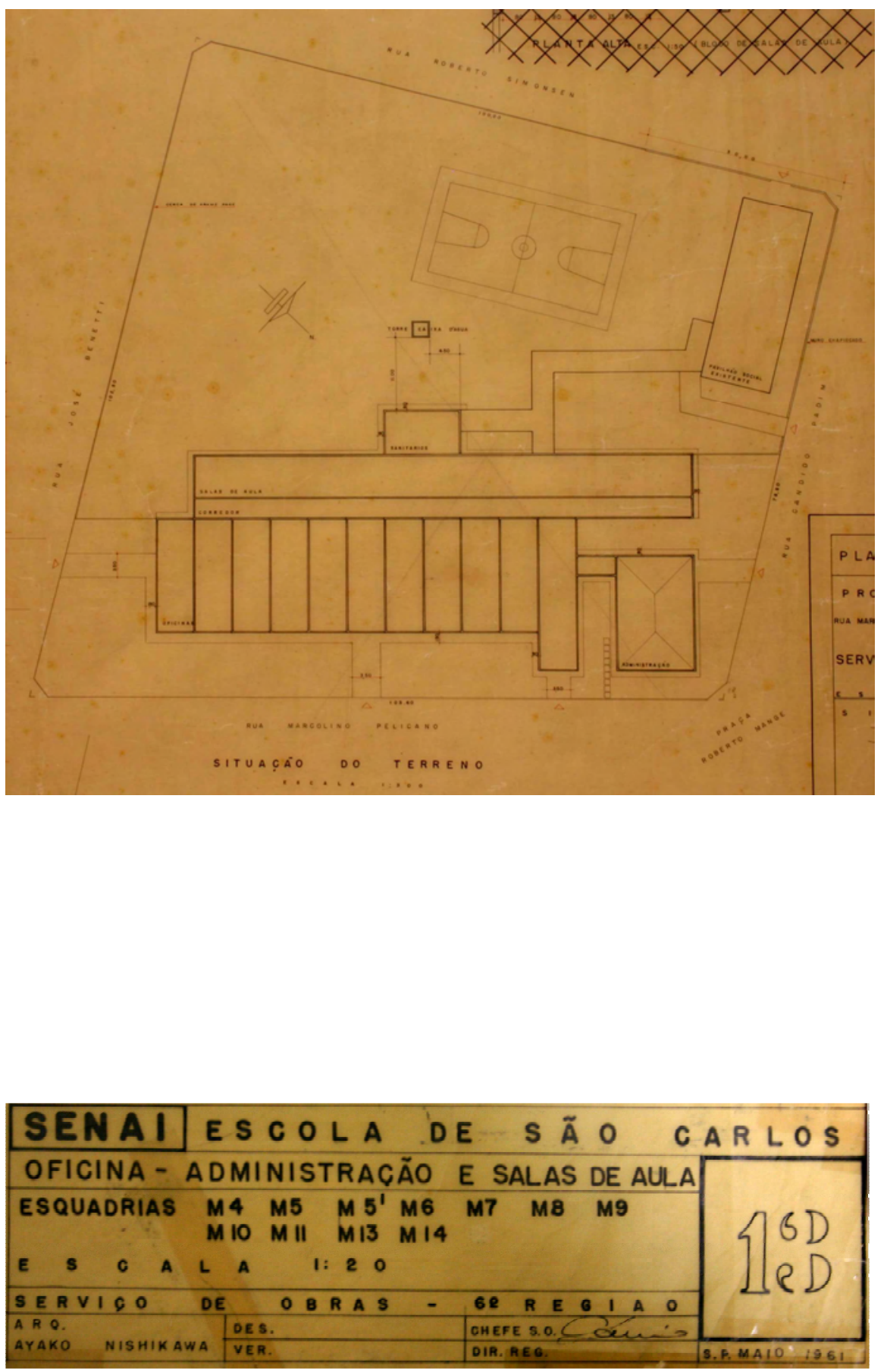

Figura 2: Implantação da escola Senai de São Carlos, 1961.

Observar Pavilhão Social existente. Fonte: Foto Ferraz, arquivo SENAI
Figura 3: Observar os dados do selo do projeto original do detalhamento das esquadrias, original na escala 1:20, Escola de São Carlos, concebido em maio de 1961, com autoria de Ayako Nishikawa.

Fonte: Foto Ferraz, arquivo 


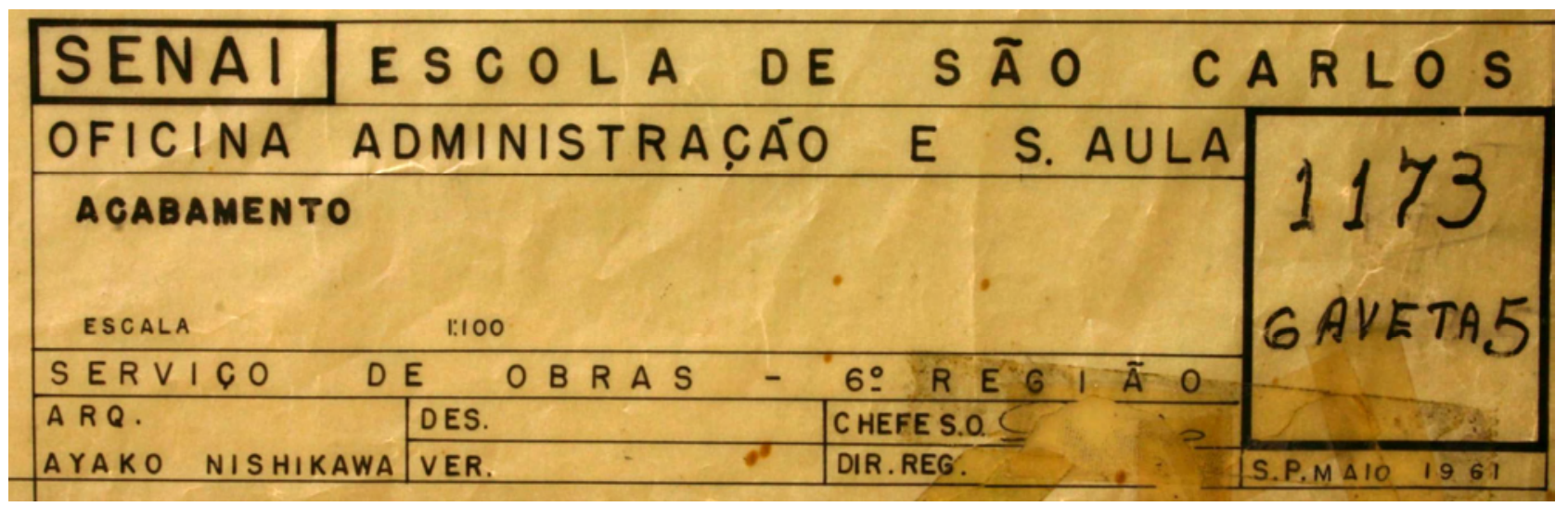

Figura 4: Observar os dados do selo do projeto original do detalhamento de acabamento, original na escala 1:100, Escola de São Carlos, concebido em maio de 1961, com autoria de Ayako Nishikawa.

Fonte: Foto Ferraz, arquivo SENAI

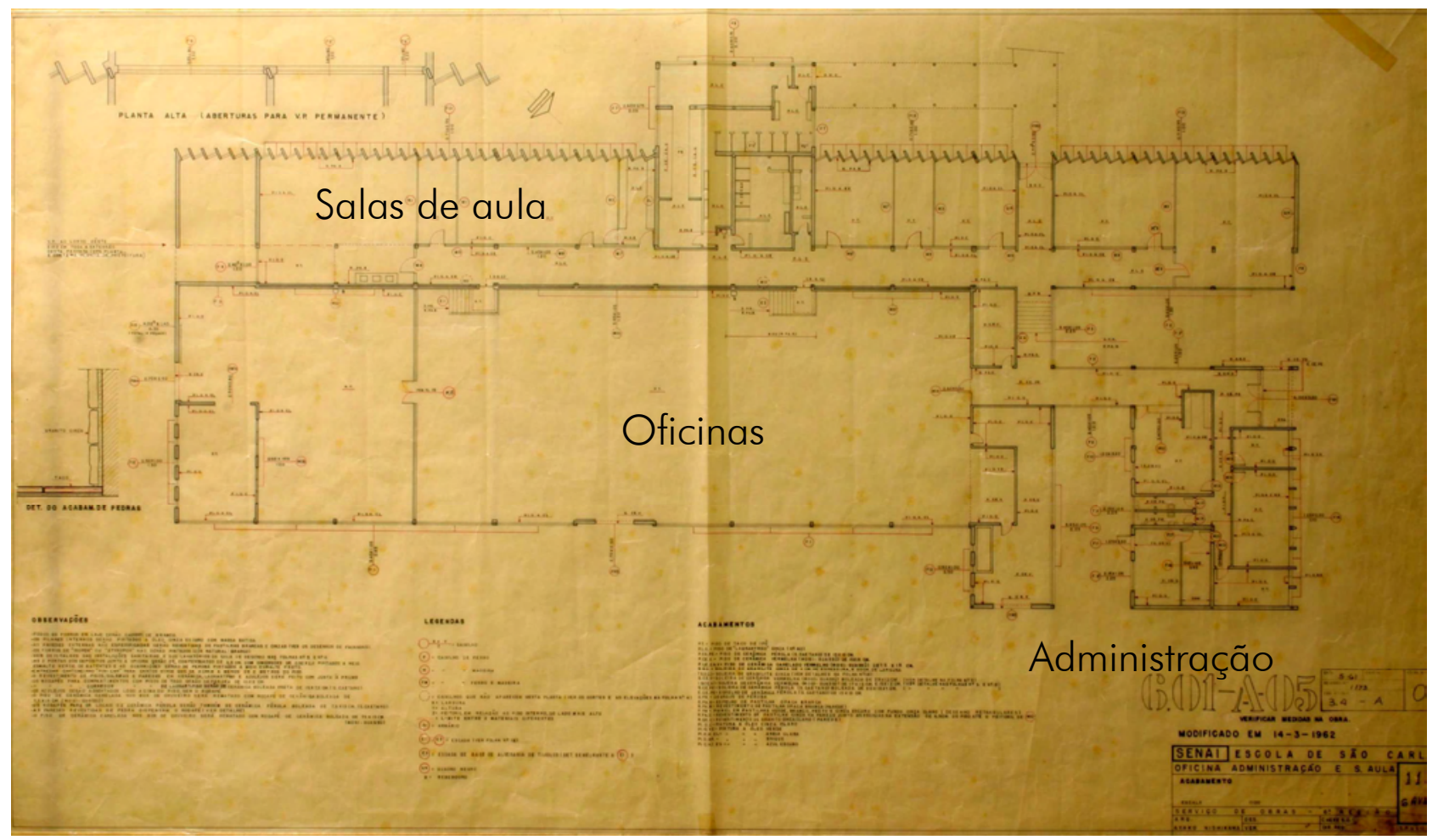

Figura 5: Prancha original do projeto de execução de acabamento dos três blocos da administração, oficinas e salas de aula, original na escala 1:100, Escola de São Carlos, 1961.

Fonte: Foto Ferraz, arquivo SENAI 


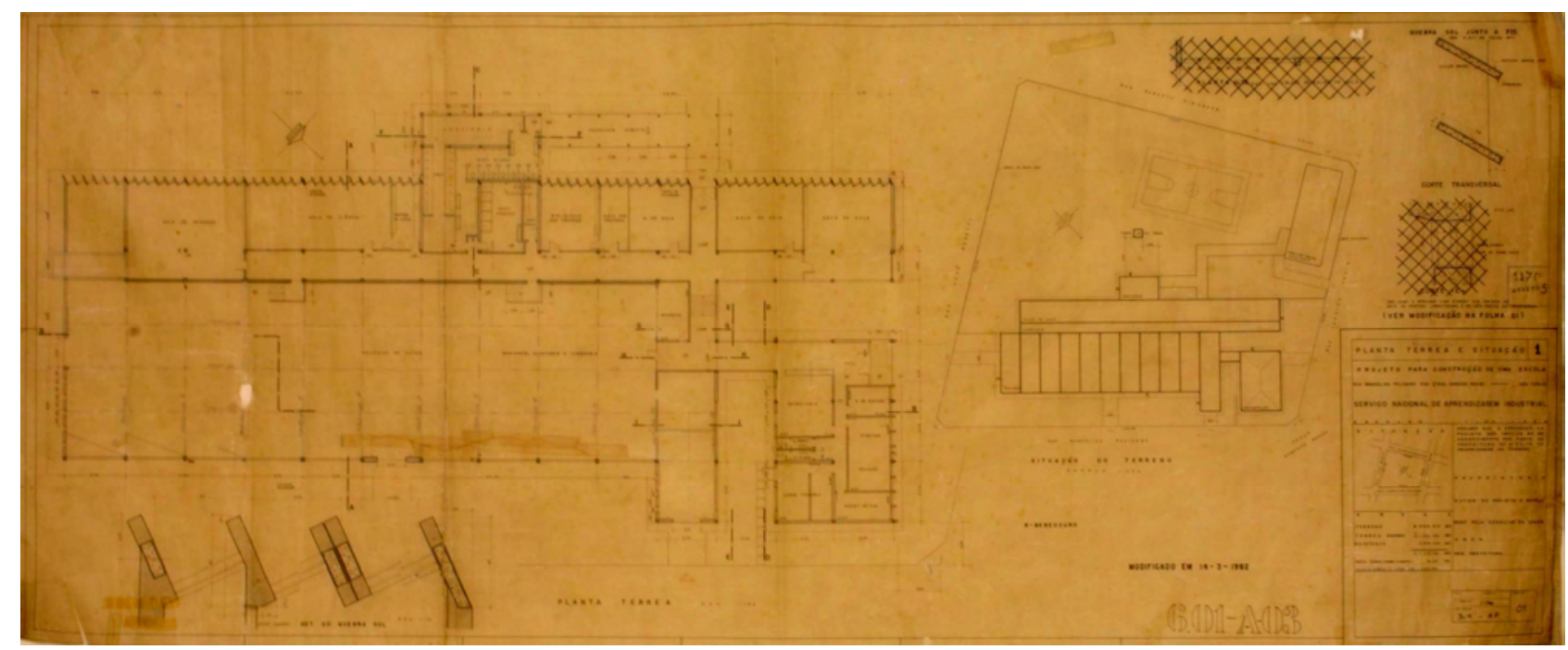

Figura 6: Prancha original do projeto de prefeitura da Planta Térrea e Situação dos três blocos da administração, oficinas e salas de aula, original nas escalas 1:10, 1:100 e 1:300, Escola de São Carlos, 1961.

Fonte: Foto Ferraz, arquivo SENAI

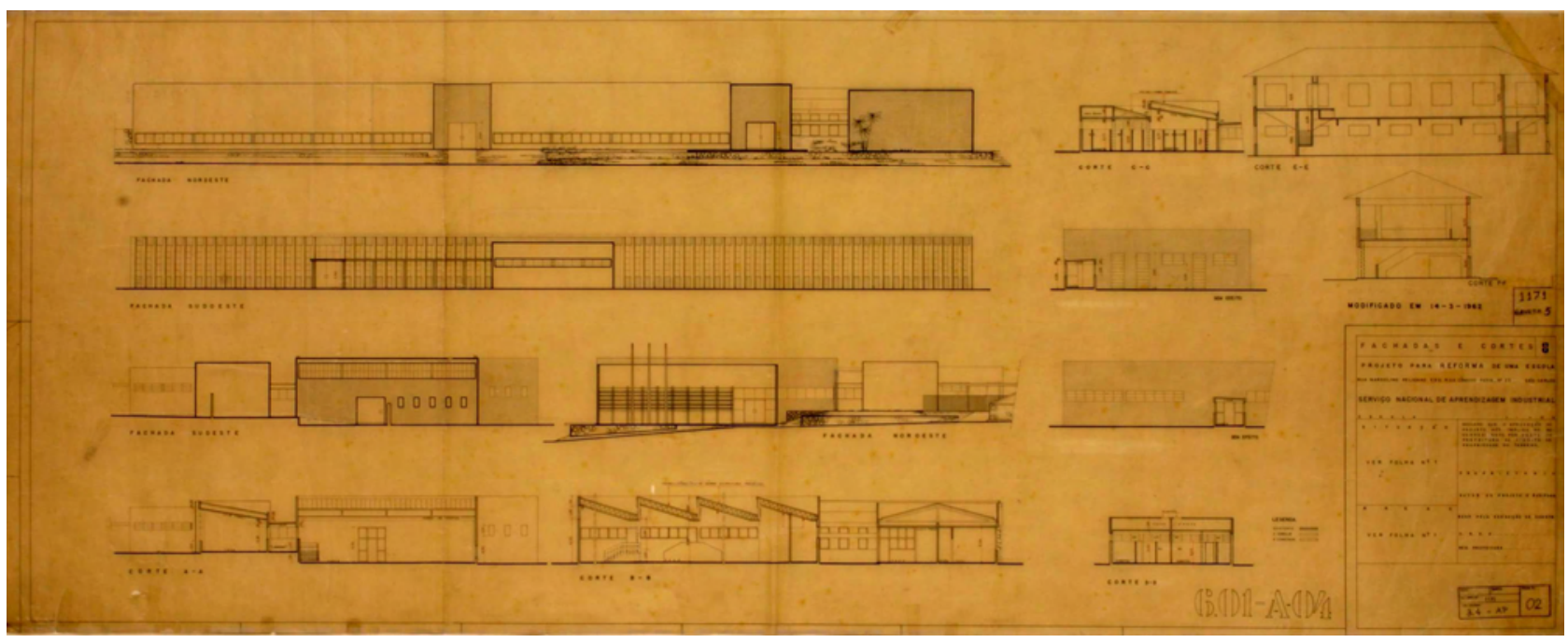

Figura 7: Prancha original do projeto de prefeitura das Fachadas e Cortes dos três blocos e do pavimento social existente, original na escala 1:100, Escola de São Carlos, 1961.

Fonte: Foto Ferraz, arquivo SENAI 
Figura 8: Observar

detalhamento de caixilho de ferro e madeira, Escola de São Carlos, 1961.

Fonte: Foto Ferraz, arquivo SENAI

Figura 9: Observar detalhamento de quebra sol utilizado na face sudoeste das salas de aulas,

Escola de São Carlos, 1961.

Fonte: Foto Ferraz,

arquivo SENAI
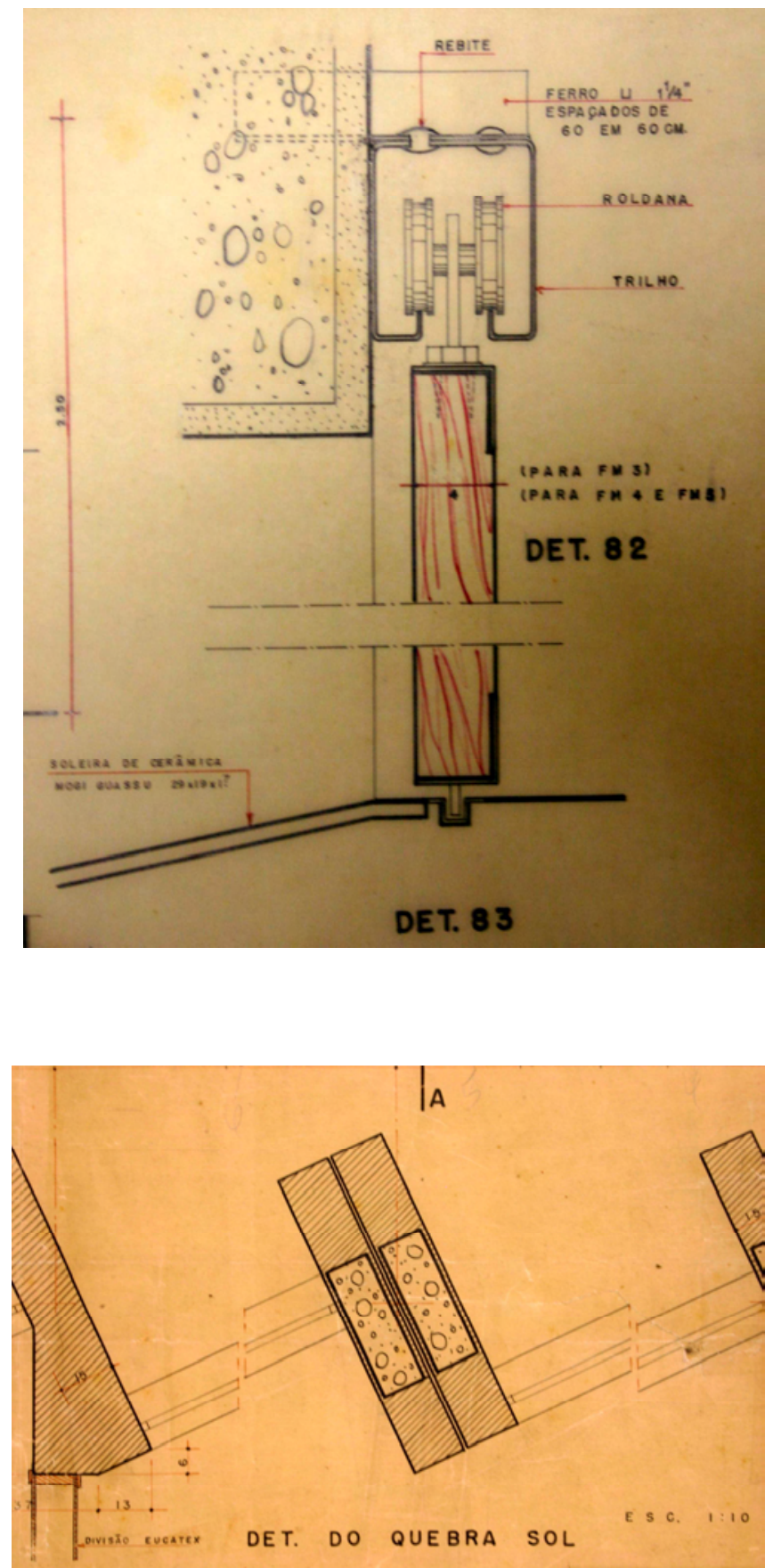

O bloco da administração, localizado na esquina das ruas Marcolino Pelicano e Cândido Padim, em frente à Praça Roberto Mange, abrigava o acesso principal voltado para a rua Cândido Padim, compondo a fachada noroeste com seus 17,10 metros de eixo longitudinal e a fachada nordeste com seus 11,40 metros de eixo transversal. Composto por um único edifício e implantado no mesmo nível do bloco das oficinas, o bloco da administração era modulado (flexibilidade) com eixos longitudinais e transversais de 5,70 metros, 
totalizando um bloco com cerda de $195 \mathrm{~m}^{2}$, interligado diretamente com o bloco das oficinas por uma passarela coberta. Apesar do acesso principal estar neste bloco, o fluxo da entrada da escola estava direcionado às oficinas, enfatizado pelo eixo de circulação da passarela coberta. Os espaços administrativos, com pé-direito de 3,30 metros, receberam iluminação e ventilação nas faces nordeste e noroeste, este protegido por brises solares horizontais.

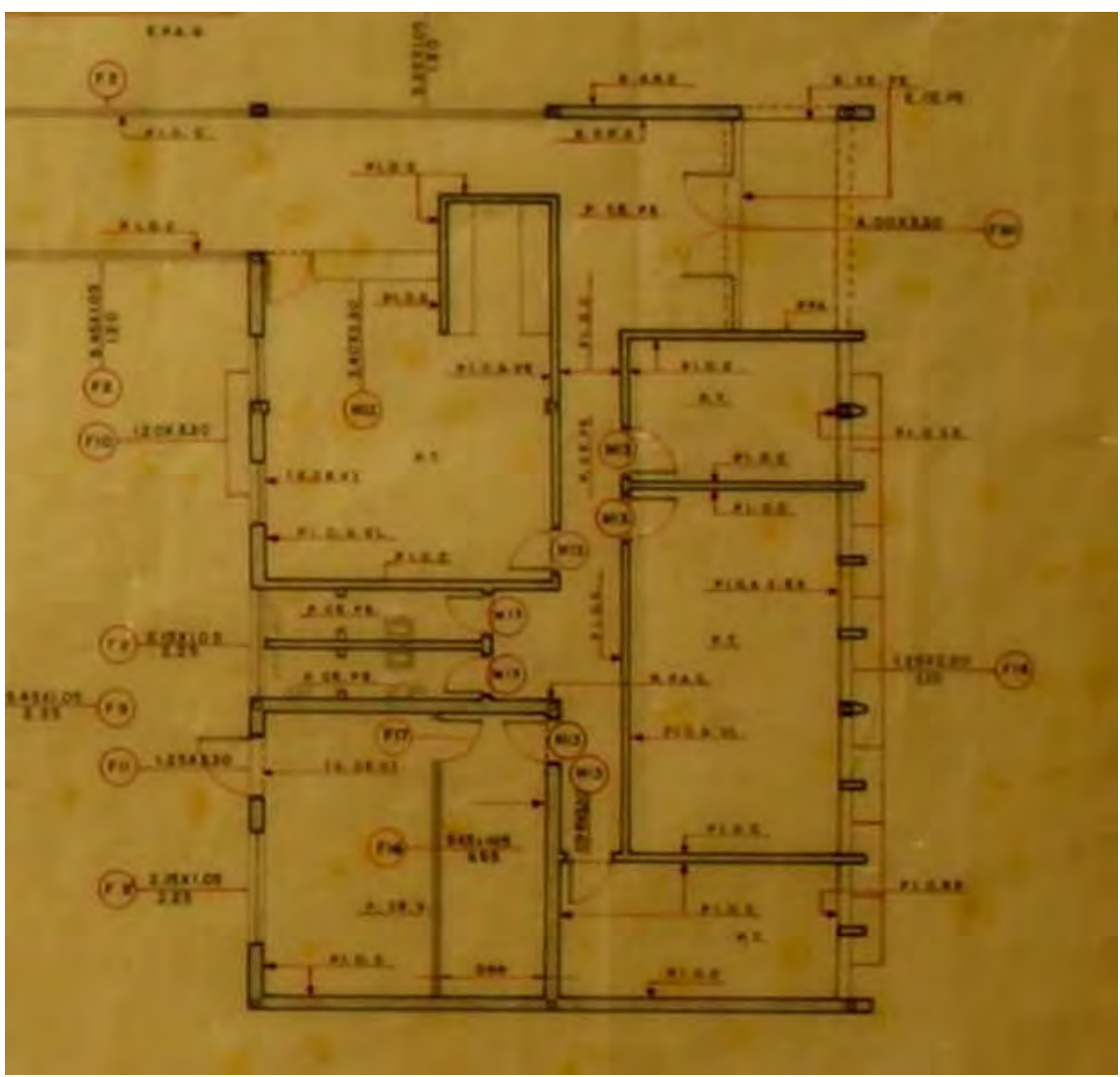

Figura 11: Elevação noroeste, original na escala 1:100, Escola de São Carlos, 1961. Observar o bloco da administração em primeiro plano, brises solares e acesso principal. Fonte: Foto Ferraz, arquivo SENAI

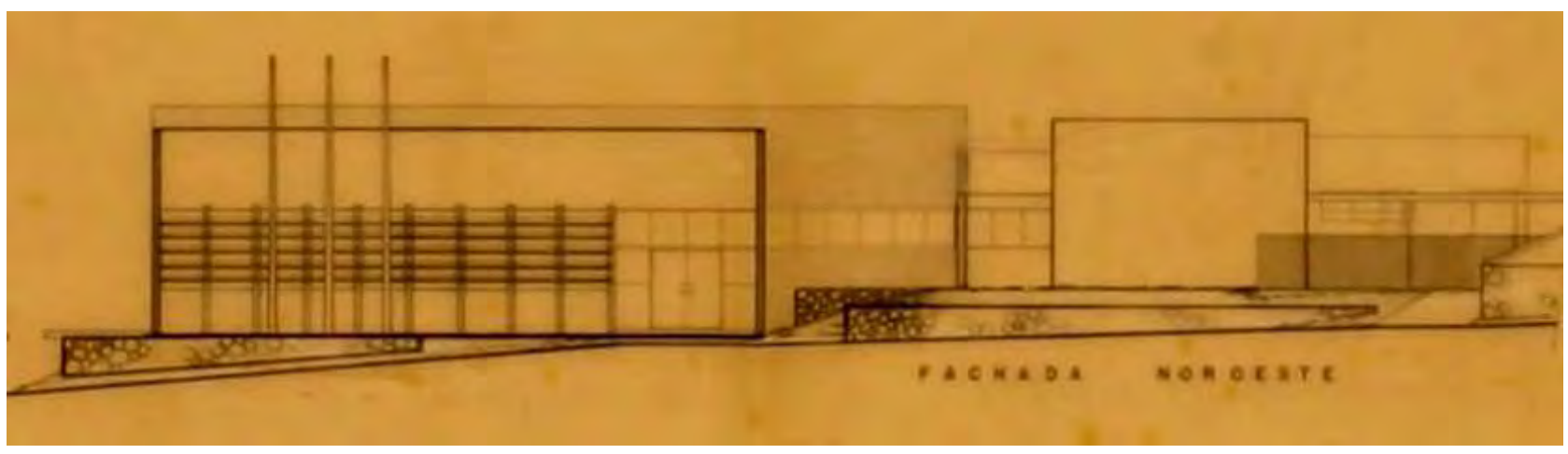


Figura 12: Elevação nordeste, original na escala 1:100, Escola de São Carlos, 1961. Observar a fachada longitudinal do bloco das oficinas, empena cega com pano de vidro horizontal e portas de acesso.

Fonte: Foto Ferraz, arquivo SENAI
O segundo bloco das oficinas, modulado com diferentes eixos, transversal de 8,55 metros e longitudinal de 5,70 metros (idem eixo da administração), compunha a fachada (longitudinal) nordeste com seus 62,70 metros de eixo. Implantada no mesmo nível da administração, a oficina foi projetada com pé-direito de 4,10 metros sob o nível mais baixo da cobertura tipo shed, projetada para obter iluminação, assim como de ventilação permanente (economia). Adotando a planta livre e uma modulação única, própria do sistema racionalista, a oficina permitia a distribuição e uso de seu espaço de acordo com o crescimento da indústria. As oficinas de montagem, ajustagem, tornearia e mecânica de autos, foram implantadas ao longo da fachada principal, podendo ser observadas pelo urbano (atratividade), através do pano de vidro horizontal voltado para o exterior, responsável pela iluminação e ventilação da oficina pela face nordeste. Paralelo ao bloco das oficinas foi projetado o terceiro bloco, totalmente interligado a ele, diferenciado deste apenas por um corredor coberto longitudinal implantado a 1.05 metros acima do nível da oficina. Solução semelhante a esta, de implantar as salas de aula em desnível com o piso das oficinas, já havia sido adotada por Lúcio Grinover na Escola de Tatuapé, em 1957, possibilitando o rendimento e a interligação da prática com a teoria através da ligação visual entre oficina e salas de aula.

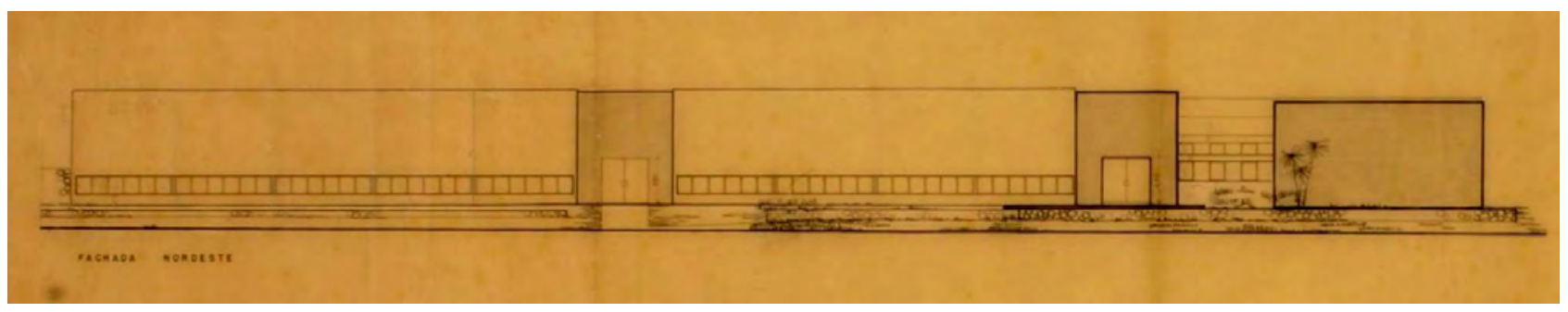

Figura 13: Elevação sudeste, original na escala 1:100,

Escola de São Carlos, 1961. Observar a fachada transversal dos blocos das salas de aula e das oficinas.

Fonte: Foto Ferraz, arquivo SENAI

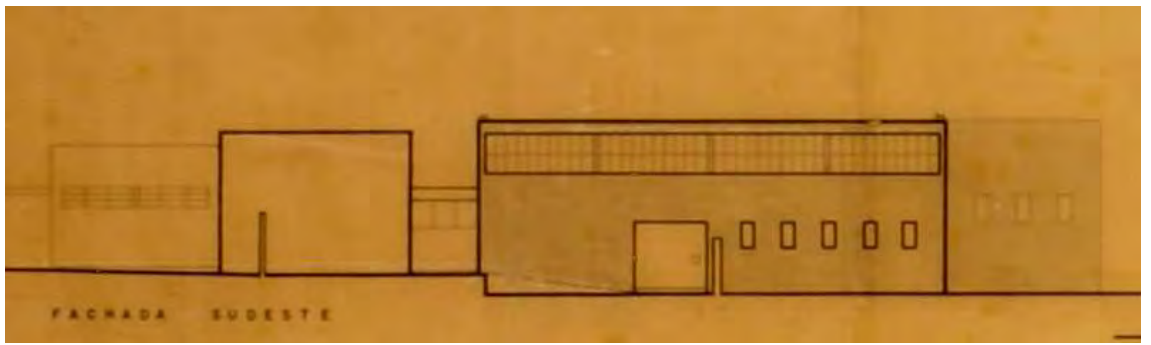




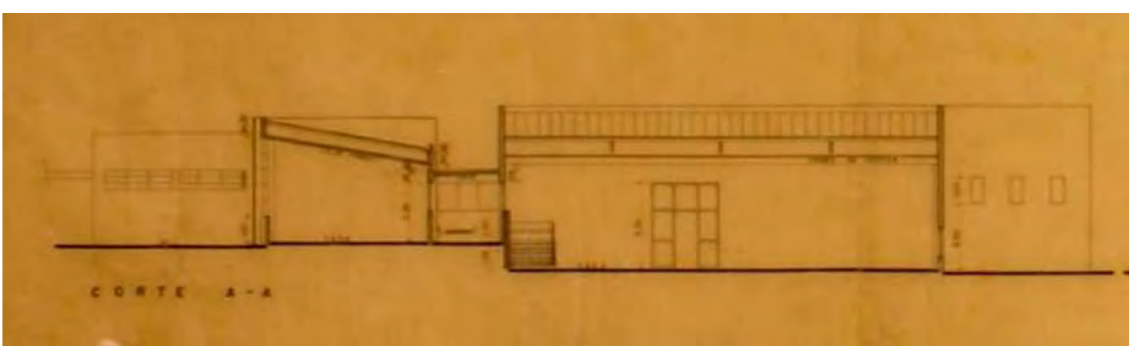

O terceiro bloco das salas de aulas seguiu a mesma modulação da oficina e foi dividido com divisórias móveis (flexibilidade) e somente com paredes na área dos sanitários e vestiário. Com circulação lateral, as salas de aulas obtiveram iluminação e ventilação pela face sudoeste, protegida por brises solares (conforme figura 9 mostrada anteriormente), porém permitindo ampla visibilidade das mesmas pela área de atividade social e de lazer, atendendo à pedagogia da atratividade. Além das cinco salas de aula e salas dos professores com biblioteca, todos voltados internamente para a oficina, este bloco foi conectado ao pavilhão social existente (sociabilidade) através de passarelas cobertas interligadas tanto à circulação das salas de aula, como aos sanitários e vestiários. Solução semelhante a esta, de implantar uma nova escola interligada ao pavilhão social existente, já havia sido adotada por Roberto Tibau na Escola João Martins Coube de Bauru, em 1953, possibilitando a integração da área social da escola ao projeto.
Figura 14: Corte AA, original na escala 1:100, Escola de São Carlos, 1961. Corte transversal dos blocos das salas de aula e das oficinas. Observar o corredor das salas de aula 1.05 metros acima do nível da oficina.

Fonte: Foto Ferraz, arquivo SENAI

Figura 15: Elevação sudoeste, original na escala 1:100, Escola de São Carlos, 1961. Observar a fachada transversal do bloco das salas de aula. Fonte: Foto Ferraz, arquivo SENAI

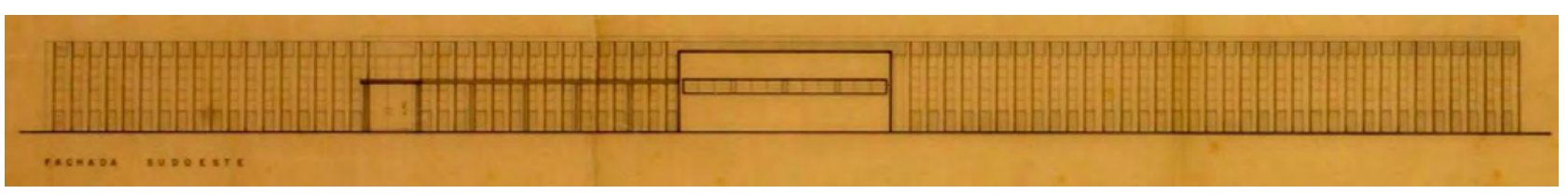

A Escola de São Carlos foi projetada para oferecer os cursos de montagem, ajustagem, tornearia e mecânica de autos, conforme revelaram as plantas do projeto. Sua concepção flexível de integrar oficina, escola e lazer, monitorados pelo bloco da administração, estimulou a relação aluno-escola, atendendo aos objetivos do SENAI. 


\section{PROJETO 19}

\section{Escola Conde José Vicente de Azevedo, Alto do Ipiranga,}

São Paulo, 1964

A Escola Conde José Vicente de Azevedo do Alto do Ipiranga, na cidade de São Paulo, foi idealizada em 1964 por Melanias M. Nagamini e em 1966 realizado seu projeto executivo. Implantada num terreno de aproximadamente $21.424,00 \mathrm{~m}^{2}$ o projeto original completo tinha $13.278,49 \mathrm{~m}^{2}$ de área construída e foi implantado no centro da quadra urbana com fachada apenas para a rua principal e passagem de 5 metros pela rua lateral Gama Lobo. A escola, implantada ao longo dos 100 metros da rua Moreira de Godói, foi projetada em cinco blocos distintos e interligados, com fachada principal voltada para a face norte, composta pela horizontalidade do bloco cinco (administração e salas de aula) e parte do bloco quatro (recreio coberto).

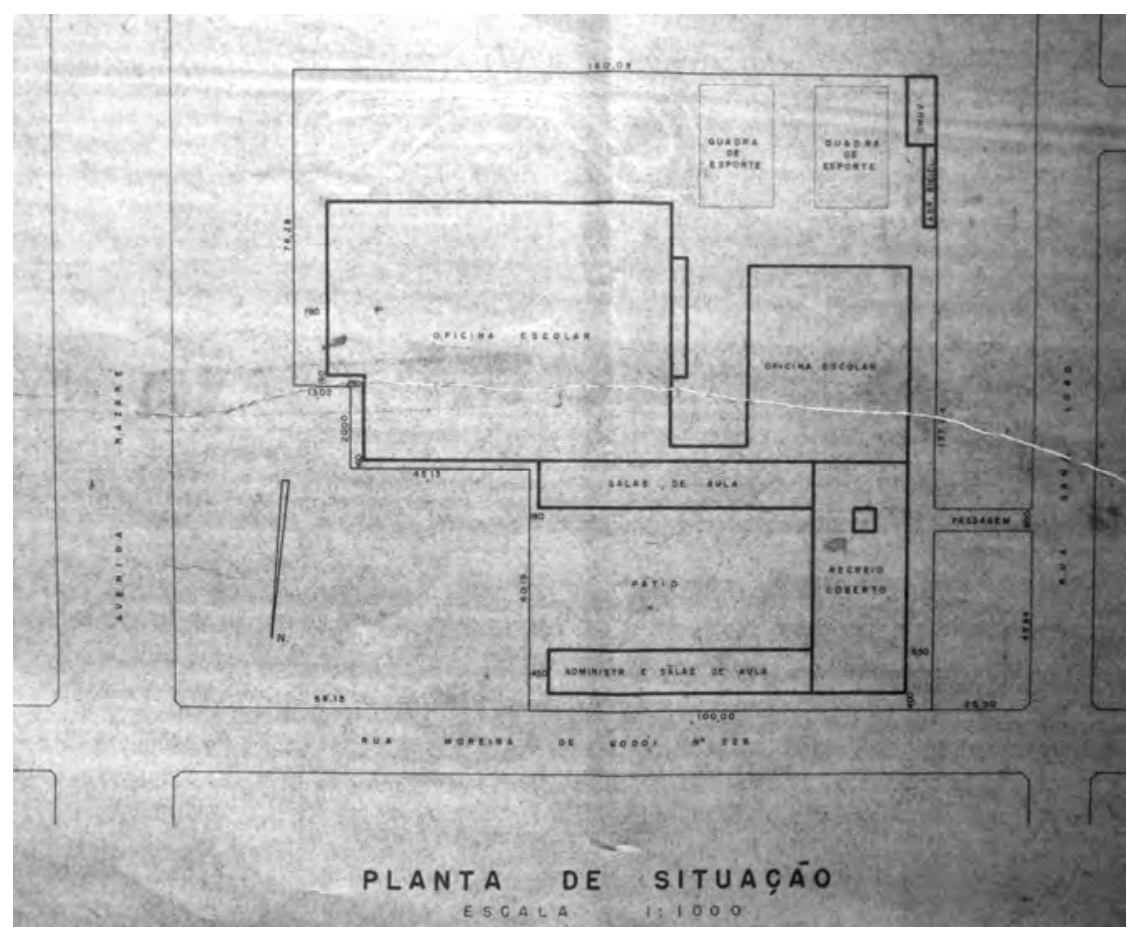

Figura 1: Planta de situação retirada da prancha original do projeto de execução, original na escala 1:1000,

Escola Conde José Vicente de Azevedo do Alto do Ipiranga, 1966.

Fonte: Foto Ferraz, arquivo SENAI 
O programa construtivo adotado foi dividido nos cinco blocos denominados de: bloco 1 (oficina de mecânica e eletricidade), bloco 2 (oficina de madeira), bloco 3 (salas de aula), bloco 4 (recreio coberto) e bloco 5 (administração e salas de aula). O primeiro bloco era composto por oficina escolar de mecânica de veículos, mecânica geral e eletricidade, sanitários, vestiários, depósito, forja, solda, metrologia, sala de instrutores e duas salas de estudos dirigidos. segundo bloco era composto por oficina de madeira, depósito de madeira, sala de acabamento de móveis e duas salas de estudos dirigidos. $\bigcirc$ terceiro bloco era composto por três pavimentos com dezoito salas de aula, sala de material didático, depósito, sanitários, almoxarifado, cabine primária e quadro geral. $\bigcirc$ quarto bloco abrigava o recreio coberto, cantina, copa, sanitários, palco, camarins e sala de assistência social. $\bigcirc$ quinto bloco era composto por dois pavimentos, além do pavimento semi-enterrado, e abrigava hall de entrada, salas de atendimento médico e dentário, secretaria, diretoria integrada, sala de reuniões, auxiliar do diretor, espera, arquivo, grêmio, sanitários e cabina de medição no primeiro pavimento; três salas de aula, sala dos professores, sala dos instrutores, biblioteca, depósito e sanitários no segundo pavimento; estacionamento e casa para vigia (dormitório, cozinha, sala e banheiro) no pavimento semienterrado. Além dos cinco blocos, também foi projetado um bloco independente para as caixas d'águas e bombas, duas quadras de bola ao cesto, arquibancadas e apoio para a área esportiva com abrigo para bicicletas e vestiário independente.

Pranchas do projeto original foram encontradas no arquivo do SENAl, tornando possível o levantamento de dados da escola. As pranchas mais antigas datam de 1964 e revelaram projeto das plantas e fachadas, as demais pranchas do projeto executivo, na escala 1:100, revelaram a planta de situação, plantas, cortes e fachadas dos cinco blocos, além de diversas pranchas, em diferentes escalas, ricas em desenhos de detalhamento. $O$ conhecimento desta escola se ateve aos projetos obtidos no arquivo do SENAI. Para facilitar a leitura arquitetônica do projeto, alguns desenhos do projeto original foram representados graficamente. 


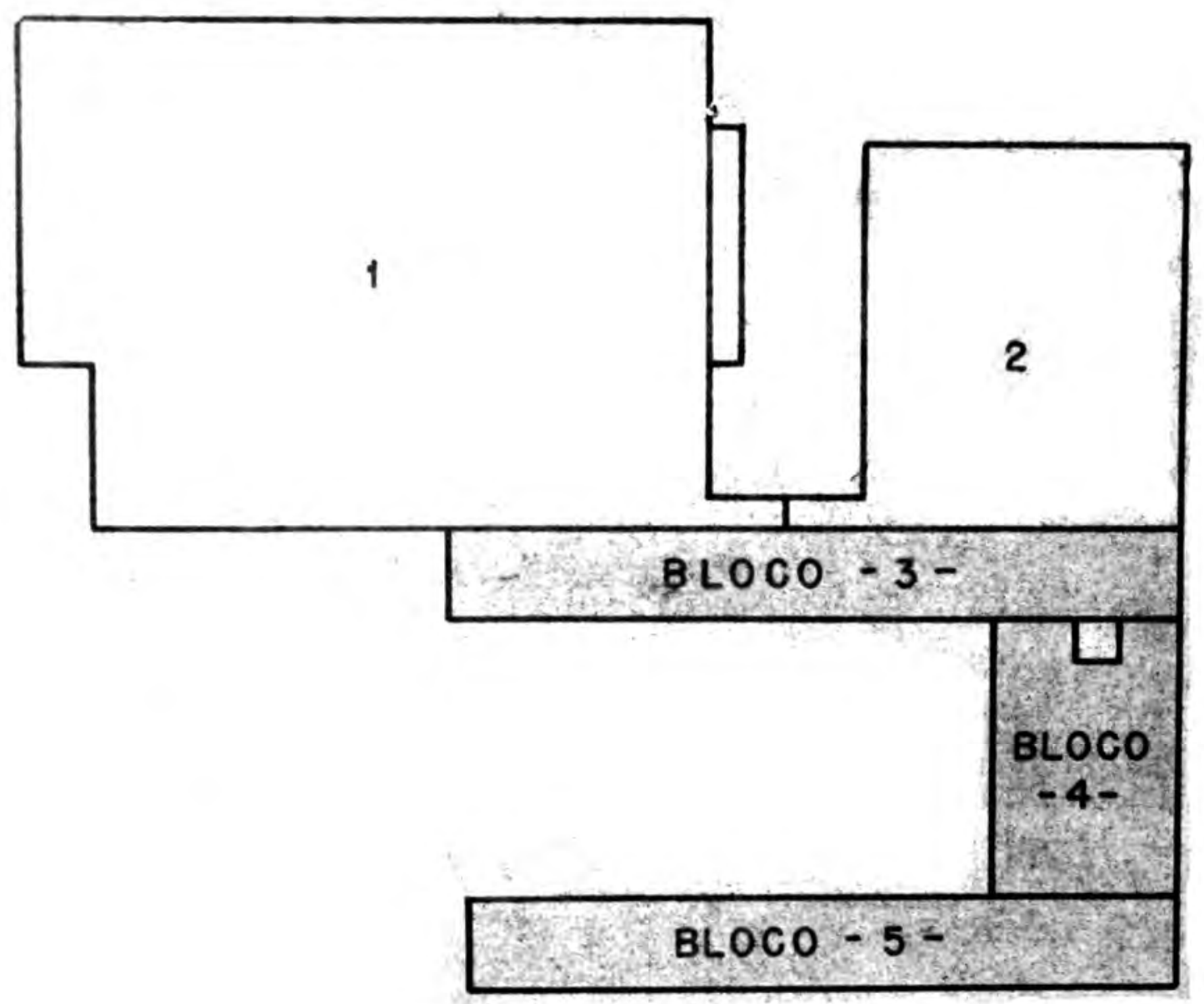

Figura 2: Conjunto dos cinco blocos que formam a Escola Conde José Vicente de Azevedo do Alto do Ipiranga, 1966. Fonte: Foto Ferraz, arquivo SENAI

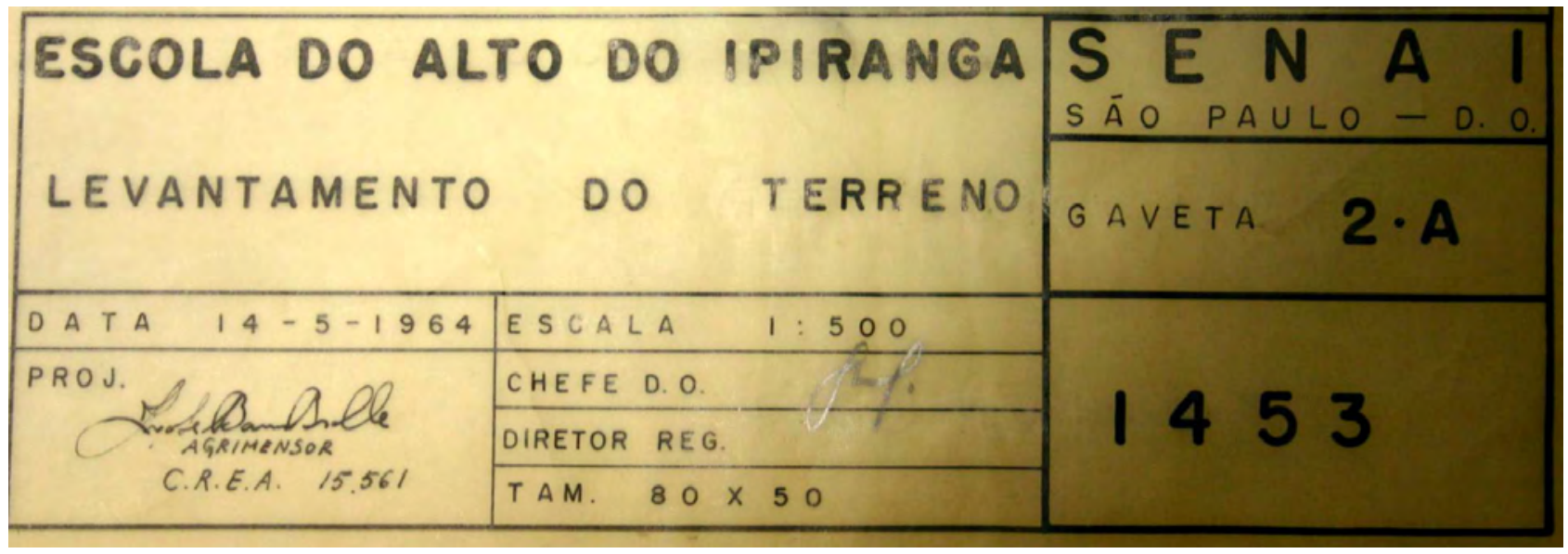

Figura 3: Observar o selo do levantamento do terreno, original na escala 1:500, Escola Conde José Vicente de Azevedo do Alto do Ipiranga, concebido em 1964.

Fonte: Foto Ferraz, arquivo SENAI 


\begin{tabular}{|c|c|c|}
\hline ESCOLA DO AL & TO DO IPIRANGA & $S E N A I$ \\
\hline FACHADAS & LATERAIS & GAVETA 5 \\
\hline $16-11-1964$ & $V E R$. & \\
\hline PROS, $=13$ & CHEFE D.O. & 170 \\
\hline DE5. Teixeirada Silna & DIRETOR REG, & \\
\hline ESCALA T:100 & TAM. $\quad 105 \times 60$ & \\
\hline
\end{tabular}

Figura 4: Observar o selo do projeto das Fachadas Laterais, original na escala 1:100, Escola Conde José Vicente de Azevedo do Alto do Ipiranga, concebido em 1964. Fonte: Foto Ferraz, arquivo SENAI

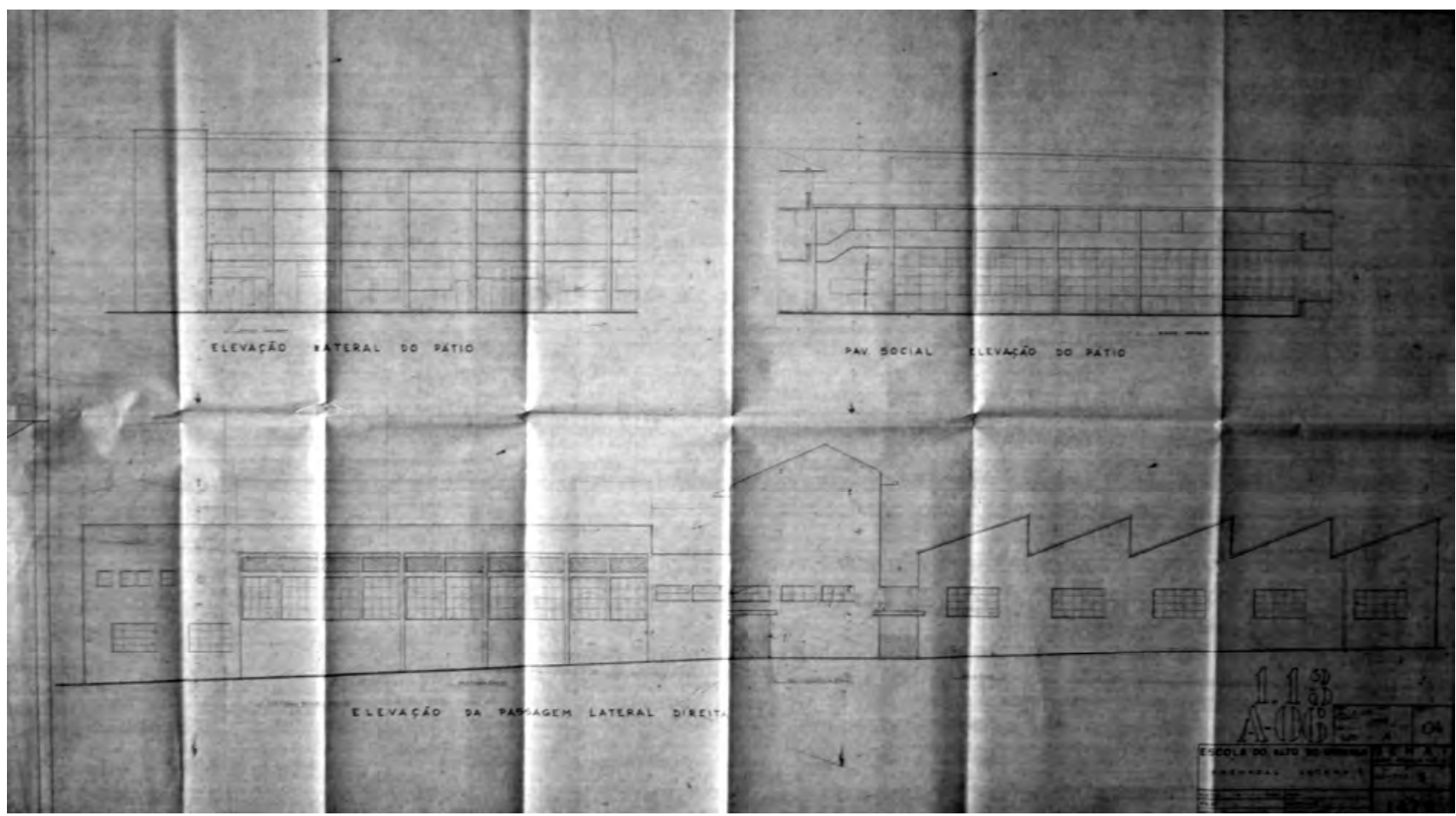

Figura 5: Prancha do ante-projeto das Fachadas Laterais, original na escala 1:100, Escola Conde José Vicente de Azevedo do Alto do lpiranga, concebido em 1964.

Fonte: Foto Ferraz, arquivo SENAI

\begin{tabular}{|c|c|c|}
\hline $\begin{array}{c}\text { ESC. CONDE JOSE } \\
\text { A L T O D O }\end{array}$ & $\begin{array}{l}\text { CENTE DE AZEVEDO } \\
\text { I P I R A N G A }\end{array}$ & 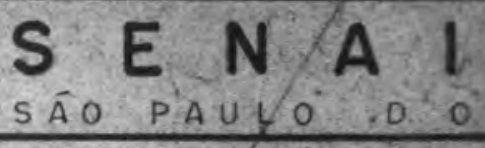 \\
\hline CORTES E & $F A C H A D A$ & 4 \\
\hline DAFA $5-4-1966$ & $\checkmark E R$ deolain & \\
\hline PROJ Eldawian & CHEFE $\quad 0.0$. & \\
\hline DES Pintime & OIRETOR REG. & \\
\hline ESCALA $\quad 1: 100$ & TAM. $\quad 1.47 \times 70$ & \\
\hline
\end{tabular}

Figura 6: Observar o selo do projeto executivo, original na escala 1:100, Escola Conde José Vicente de Azevedo do Alto do Ipiranga, concebido em abril de 1966, com autoria de Melanias M. Nagamini.

Fonte: Foto Ferraz, arquivo SENAI 
primeiro bloco das oficinas escolares de mecânica de veículos, mecânica geral e eletricidade, era o maior edifício da escola, com área total da oficina de $4.704,00 \mathrm{~m}^{2}$. Modulado com eixos longitudinais de 19,60 metros e transversais de 7,50 metros, a planta livre da oficina era fechada da face sul (aberta apenas com porta toldo de 4 metros de largura), ladeada nas faces leste e oeste pelo apoio dos sanitários, vestiários, depósito, forja, solda, metrologia, sala de instrutores e duas salas de estudos dirigidos e, interligada ao bloco 2 e 3 por uma passagem coberta paralela ao bloco 3, responsável pela circulação até outros sanitários e à sala do transformador. Esta passagem, como espaço de circulação entre dois blocos (1 e 3), recebeu clarabóias com ventilação permanente espalhadas em sua cobertura (economia). De acordo com demonstrativo de cálculo encontrado no projeto original, as áreas necessárias na oficina para iluminação e ventilação eram de $940,00 \mathrm{~m}^{2}$ (1/5 da área total) e $626,60 m^{2}$ (2/3 da área total) respectivamente, porém as áreas projetadas foram superiores ao demonstrativo, alcançando $1.254,40 \mathrm{~m}^{2}$ de iluminação e $752,60 \mathrm{~m}^{2}$ de ventilação, atendendo com êxito à economia proposta pelo SENAI. Este índice foi obtido com a solução projetual da cobertura tipo shed utilizada em toda a oficina, com aberturas voltadas para a face sul e, com janelas projetadas para

Figura 7: Observar o selo do a passagem coberta.

projeto executivo do BLOCO 1, original na escala 1:100,

Escola Conde José Vicente de Azevedo do Alto do Ipiranga, concebido em abril de 1966, com autoria de Melanias M.

Nagamini.

Fonte: Foto Ferraz,

arquivo SENAI

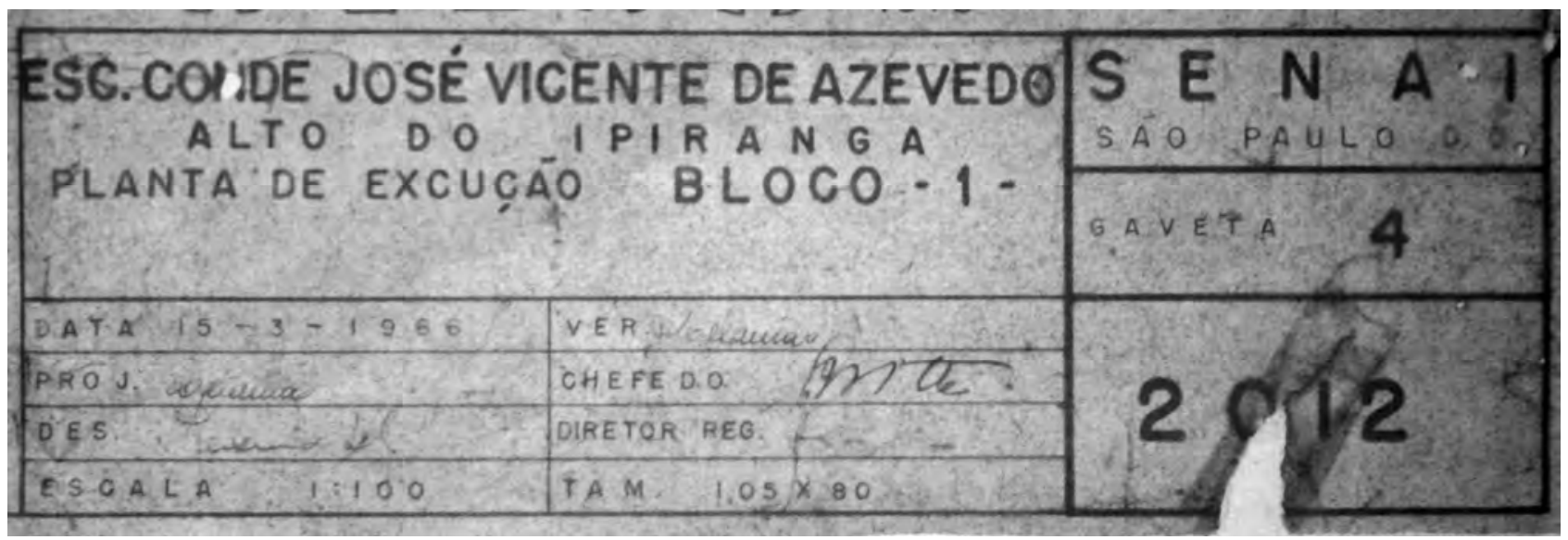




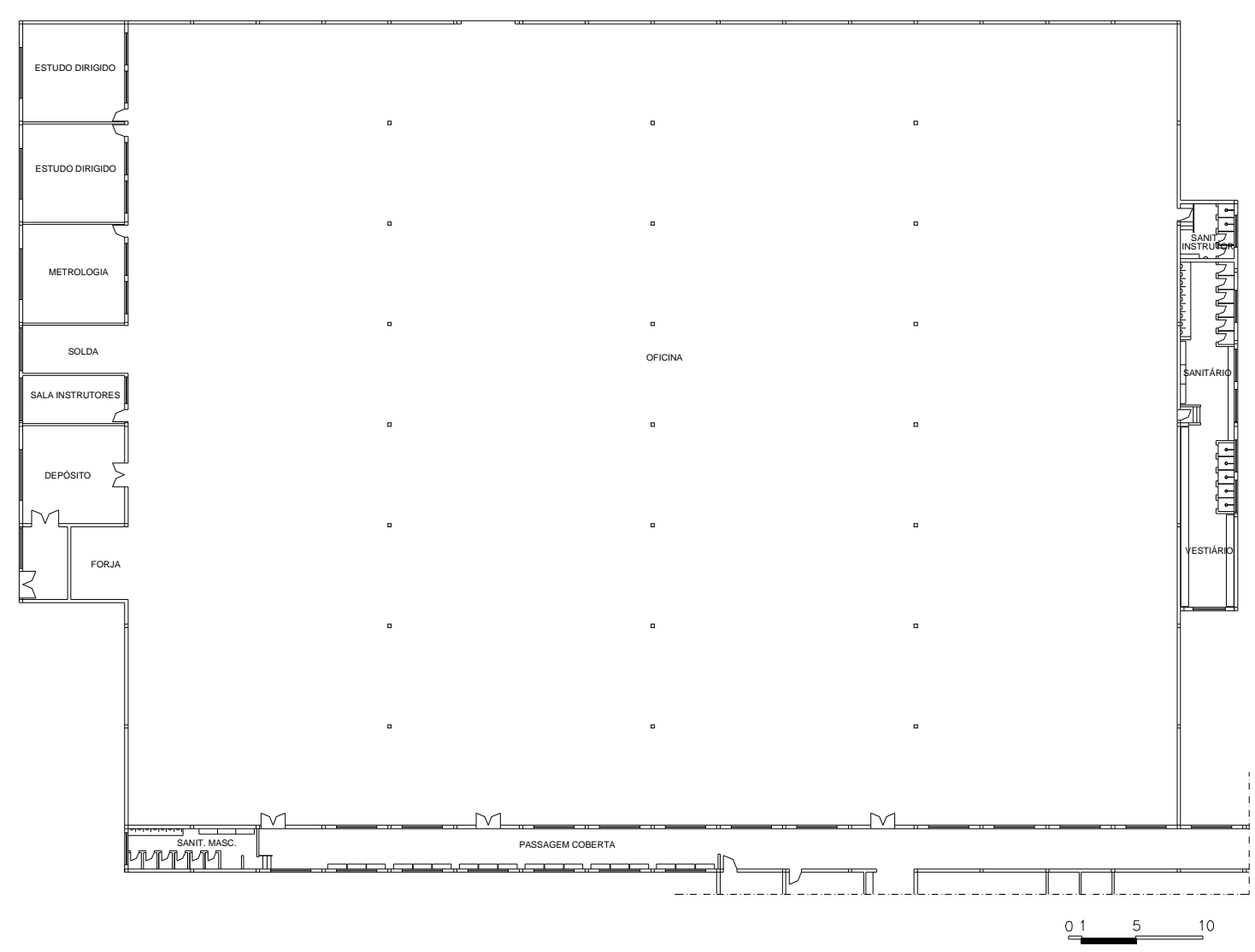

O segundo bloco das oficinas, de menor porte, seguia a mesma modulação do bloco 1, porém com área total da oficina de $1.764,00 \mathrm{~m}^{2}$. Também resolvida em planta livre, a oficina de madeira recebeu vãos envidraçados para as faces norte (corredor), sul (quadras) e leste (pátio que separa o bloco 1 do bloco 2), sendo a lateral oeste ocupada pelo depósito de madeira, sala de acabamento de móveis e duas salas de estudos dirigidos. Interligada ao bloco 1 e 3 pela já referida passagem coberta, esta oficina recebeu pé-direito de 4,75 metros de altura sob o nível inferior da cobertura tipo shed voltada para a face sul. De acordo com demonstrativo de cálculo encontrado no projeto original, as áreas necessárias na oficina para iluminação e ventilação eram de $352,80 \mathrm{~m}^{2}$ (1/5 da área total) e $234,60 \mathrm{~m}^{2}$ (2/3 da área total) respectivamente, porém as áreas projetadas foram superiores ao demonstrativo (economia), alcançando $470,40 \mathrm{~m}^{2}$ de iluminação e $282,240 \mathrm{~m}^{2}$ de ventilação. Diferentemente das demais oficinas, foram projetadas divisórias no espaço da área de trabalho, algumas com altura teto-chão acompanhando a inclinação da cobertura e outras somente com 2,10 metros de altura e montantes prolongados até a estrutura do telhado.
Figura 8: Redesenho da planta original do BLOCO 1. Fonte: Ferraz, 2005 
Figura 9: Observar o selo do projeto executivo do BLOCO 2, original na escala 1:100, Escola Conde José Vicente de Azevedo do Alto do Ipiranga, concebido em abril de 1966 com autoria de Melanias M. Nagamini

Fonte: Foto Ferraz, arquivo SENAI

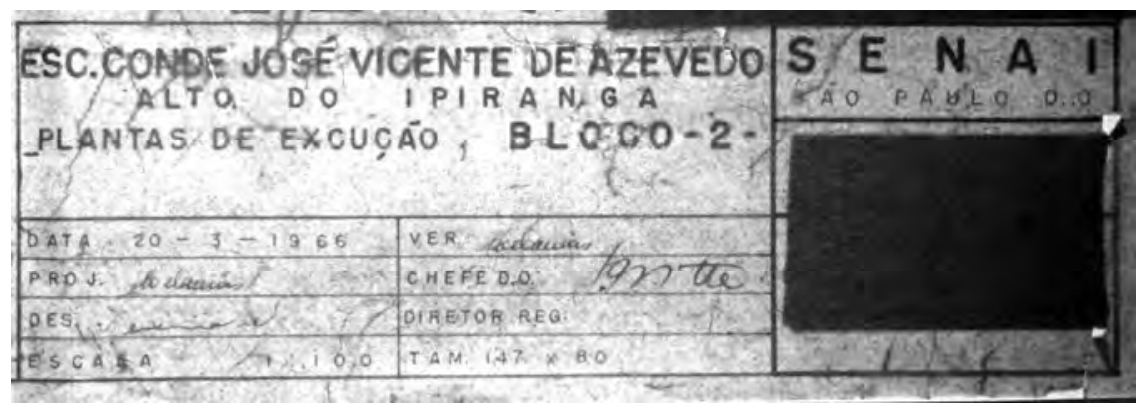

Terceiro bloco das salas de aulas foi projetado com três pavimentos, com pé-direito de 3,50 metros de altura cada, sendo o térreo no mesmo nível de piso das oficinas (bloco 1 e 2). Paralelo e geminado à passagem coberta das oficinas, o bloco 3 abrigava: quatro salas de aula, almoxarifado, cabine primária e quadro geral, sanitário para a escola e sanitários para os alunos e instrutores do bloco 2 no pavimento térreo; seis salas de aula, sala de material didático e sanitários no segundo pavimento; oito salas de aula, depósito e sanitários no terceiro pavimento. A divisão deste bloco adotou circulação lateral norte e salas projetadas na lateral sul, recebendo iluminação e ventilação diretas pela face sul e indiretas pela face norte, protegida pela laje do corredor de circulação aberto. Modulado com eixo longitudinal de 4,90 metros e com dois eixos transversais de 7,75 metros (salas) e 3,00 metros (corredor aberto), foi projetada uma escada na extremidade leste deste bloco para a circulação interna dos diferentes pavimentos. Ainda, este bloco foi interligado diretamente ao bloco 4 pelo corredor de circulação e ao bloco 5 por uma passarela coberta, perpendicular ao bloco 3 e 5, que cruzava o pátio entre os blocos 3, 4 e 5 . Diferentemente da maioria dos projetos anteriores, as salas de aula foram separadas por paredes, ao invés de divisórias, não favorecendo a flexibilidade e o crescimento do espaço.

quarto bloco, perpendicular aos blocos 3 e 5, foi projetado em um único pavimento (no mesmo nível dos blocos 1, 2 e 3). Atendendo à sociabilidade proposta pelo SENAI através do recreio coberto, o bloco 4, com pé-direito de 6 metros, ainda era composto pela cantina, copa, sanitários, palco, camarins e sala de assistência social. Modulado com eixo longitudinal de 6 metros e eixo transversal de 4,90 metros (seguindo o bloco 3), o recreio coberto recebeu 
iluminação e ventilação bilaterais pelas faces leste e oeste, sendo a face leste protegida pela laje do corredor de circulação aberto, paralelo e geminado ao bloco 4. Na extremidade norte do bloco, sob o palco, camarins e sala de assistência social, foi projetado um pavimento semi-enterrado, um pavimento criado na interseção do bloco 4 com o bloco 5, aproveitando a topografia do terreno.

quinto bloco da administração e salas de aula foi projetado com dois pavimentos, com pé-direito de 3,50 metros de altura cada, responsável pela fachada principal da escola. Reunindo a parte administrativa e de assistência médica e dentária no pavimento térreo, o segundo pavimento foi destinado às salas de aulas e apoio aos professores e instrutores. A divisão deste bloco também adotou a circulação lateral (como o bloco 3), com corredor aberto voltado para a face sul, privilegiando a vista do interior da escola. Modulado com eixo longitudinal de 4,40 metros e com dois eixos transversais de 7,75 metros (salas) e 3,00 metros (corredor aberto), foi projetada uma escada no centro deste bloco para a circulação interna entre pavimentos. As salas receberam iluminação e ventilação lateral norte através de grandes vãos envidraçados voltados para $\bigcirc$ urbano (atratividade).
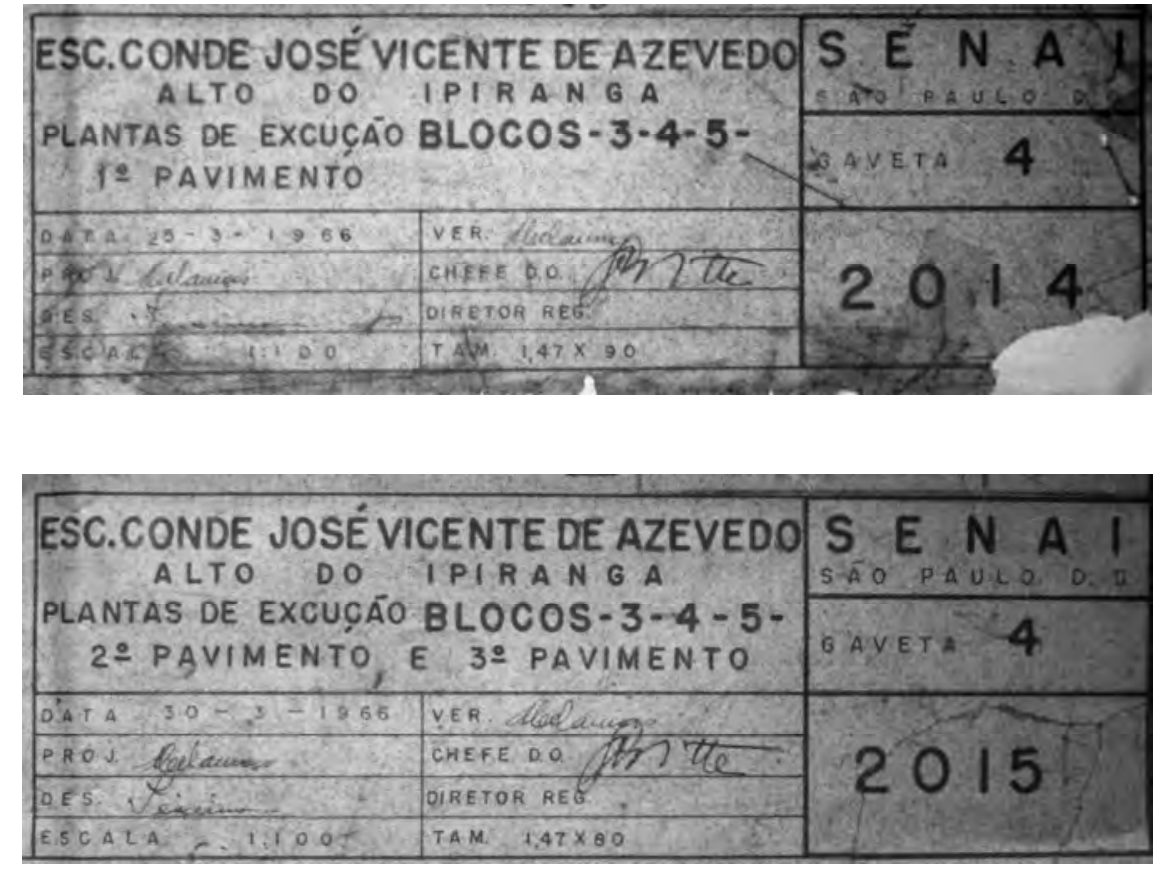

Figura 10 e 11: Observar o selo do projeto executivo dos pavimentos dos BLOCOS 3, 4 e 5, original na escala 1:100, Escola Conde José Vicente de Azevedo do Alto do Ipiranga, concebido em abril de 1966, com autoria de Melanias M. Nagamini Fonte: Foto Ferraz, arquivo SENAI 
Figura 12: Redesenho da elevação norte original.

Fonte: Ferraz, 2005

A Escola Conde José Vicente de Azevedo do Alto do Ipiranga, foi construída e confirma em sua arquitetura a filosofia do SENAI, atendendo às suas principais características. Porém, fazendo parte das escolas projetadas na década de 60, como o Centro Educacional da Mooca do SENAI e a Escola de São Bernardo, as oficinas foram implantadas separadamente das salas de aulas, não permitindo o acesso visual da prática com a teoria, um simbolismo que ao longo da década de 1960 foi pouco praticável. 


\section{Escola Senai de Osasco, 1964}

Projetada em 1964 por Melanias M. Nagamini, a Escola SENAI de Osasco foi projetada num terreno de 18.000,00 $\mathrm{m}^{2}$, localizado na rua Ari Barroso 305 e com fundos para avenida Bussocaba. A Escola reuniu diversos tipos de oficinas e seu programa construtivo foi caracterizado pela administração, salas de aulas, pavilhão social, oficinas de mecânica geral, marcenaria e fundição e, caldeiraria. Os blocos foram implantados de forma paralela um aos outros e, interligados, totalizaram cerca de $7.248,27 \mathrm{~m}^{2}$ de área construída (segundo alvará 2.785 de 16/1 1/1964).

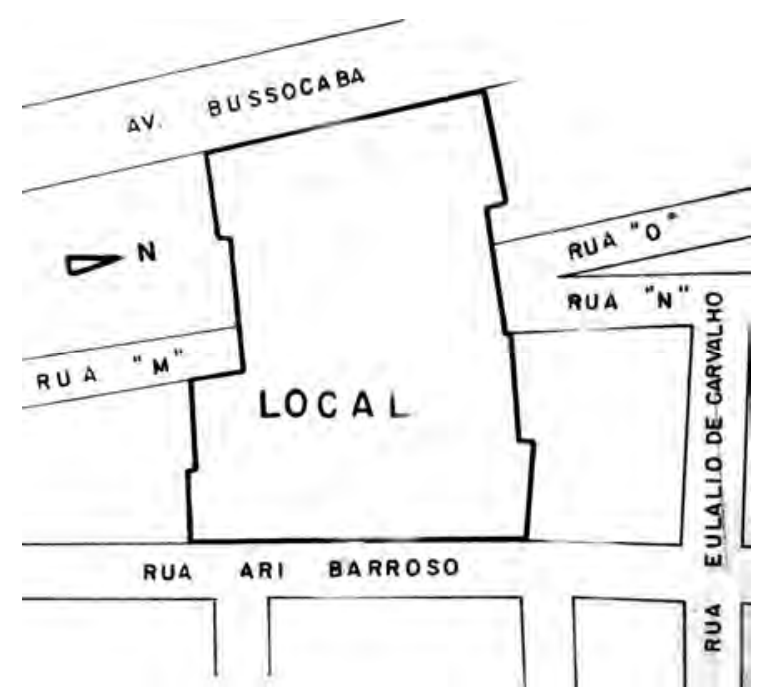

Apenas parte do projeto original foi encontrado no arquivo do SENAI, como duas pranchas denominadas de "cortes" e "fachadas" do projeto, na escala 1:100, revelando o ano de sua concepção, o autor do projeto, os cortes e fachadas dos blocos projetados. Ainda, foi encontrada uma prancha da planta de situação (1967), e sucessivas pranchas do final da década de 70, com projetos de reformas e ampliações da escola. Através do material coletado é possível entender o projeto de forma macro, pois com a ausência das plantas, seu programa construtivo não poderá ser apresentado. conhecimento do projeto original se ateve apenas nos projetos obtidos no arquivo do SENAI, pois nenhuma publicação deste projeto foi encontrada nos periódicos da época.
Figura 1: Planta de situação da Escola de Osasco. Fonte: Foto Ferraz, arquivo SENAI 
Figura 2: Observar os dados do selo do projeto original dos cortes, original na escala 1:100, Escola de Osasco, concebido em outubro de 1964, com autoria de Melanias M. Nagamini. Fonte: Foto Ferraz, arquivo SENAI

\begin{tabular}{|c|c|c|}
\hline \multirow{2}{*}{\multicolumn{2}{|c|}{$\begin{array}{l}\text { ESCOLA DE OSASCO } \\
\text { CORTES A.A, B-B, C.C, D.D, E.E, F-F, G.G }\end{array}$}} & $S_{S A B O} E \underset{P A U L O}{N} A_{D .0} I$ \\
\hline & & \\
\hline DATA $\quad 6-10-1964$ & $V E R$ Melauias & \\
\hline PROJ Belauiar & CHEFE D.O NDThe & \\
\hline DES. Teviaidel & DIRETOR REG. BVQ Quni's & \\
\hline ESCA LA & TAM. $\quad 1.47 \times 1.05$ & \\
\hline
\end{tabular}

Figura 3: Observar os dados do selo do projeto original das fachadas, original na escala 1:100, Escola de Osasco, concebido em dezembro de 1964, com autoria de Melanias M. Nagamini.

Fonte: Foto Ferraz, arquivo SENAI

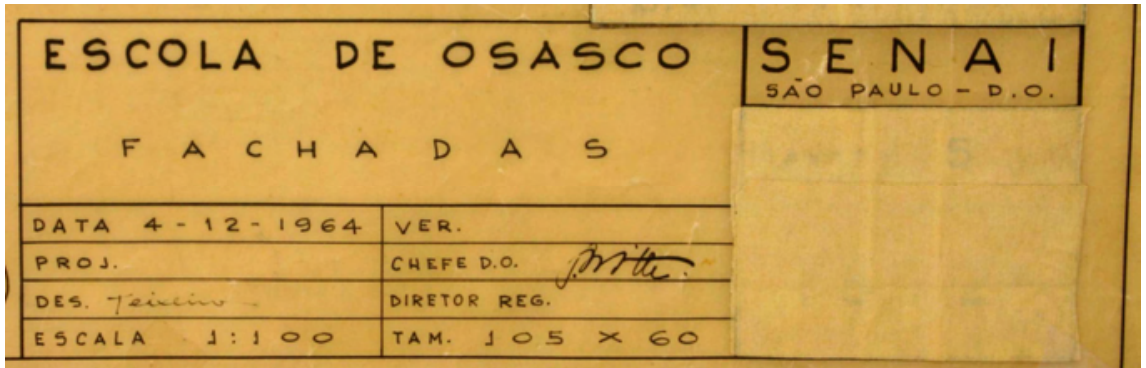

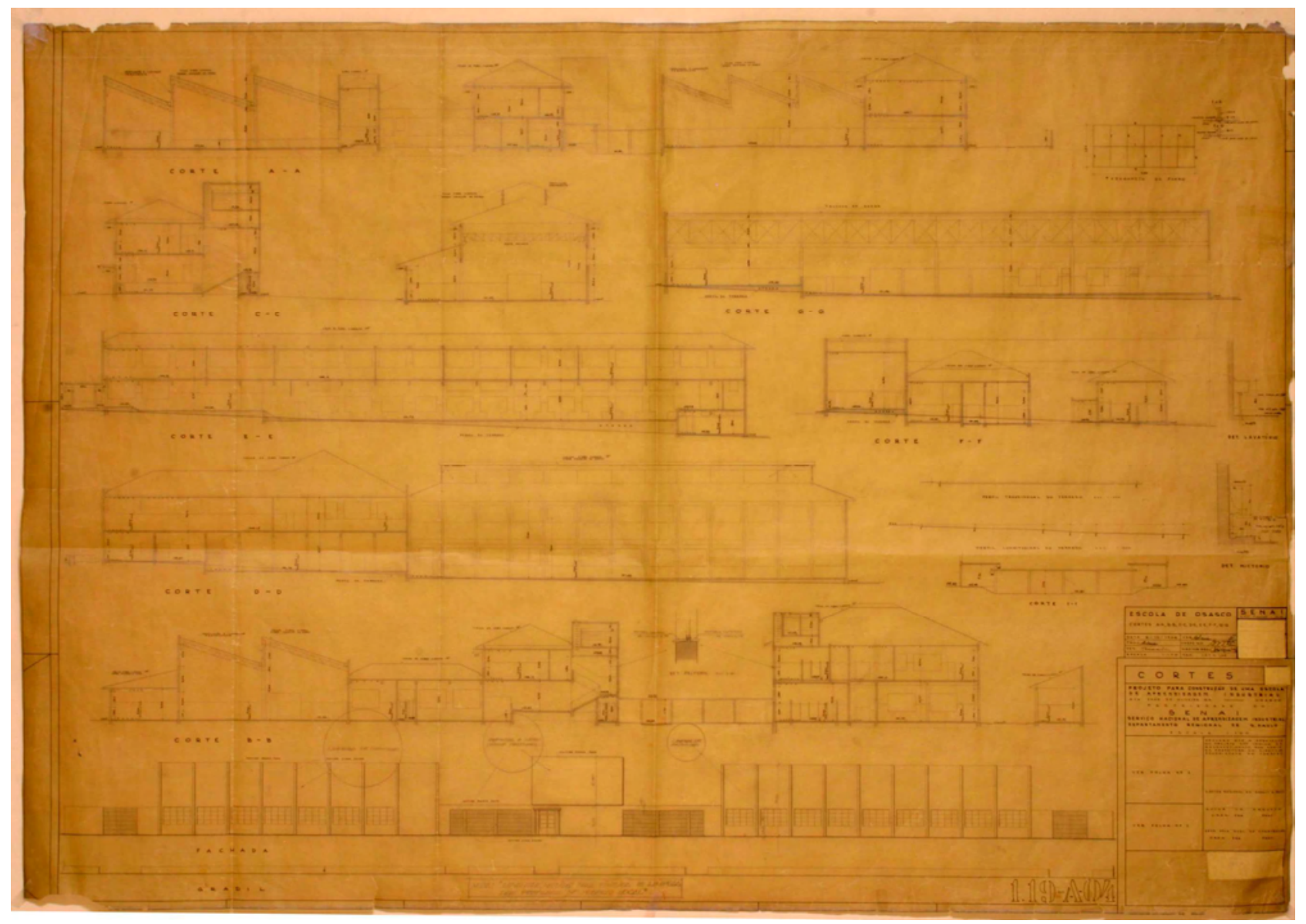

Figura 4: Prancha do projeto original dos Cortes, original na escala 1:100, Escola de Osasco, 1964. Fonte: Foto Ferraz, arquivo SENAI 


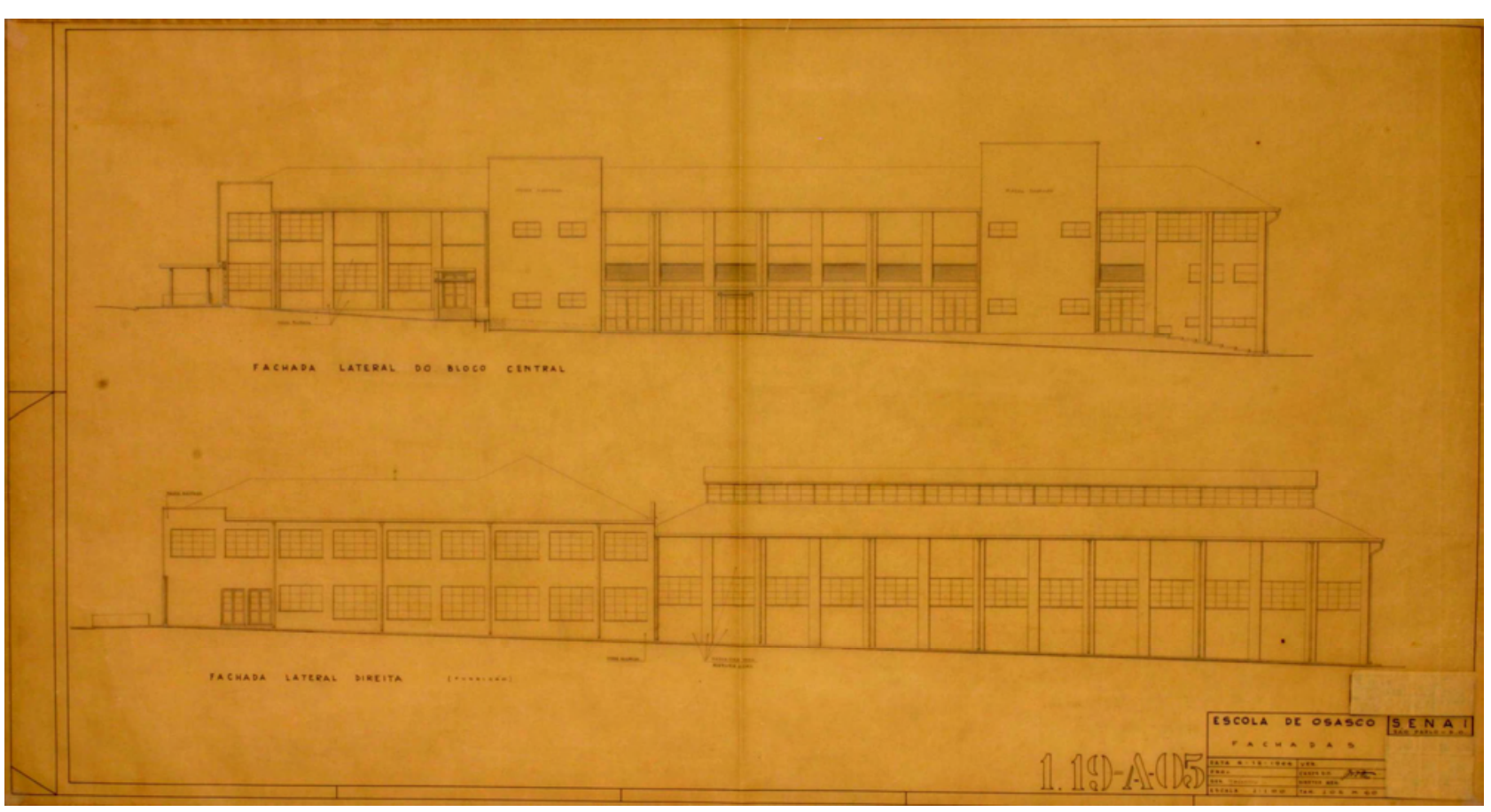

Figura 5: Prancha do projeto original das Fachadas, original na escala 1:100, Escola de Osasco, 1964. Fonte: Foto Ferraz, arquivo SENAI

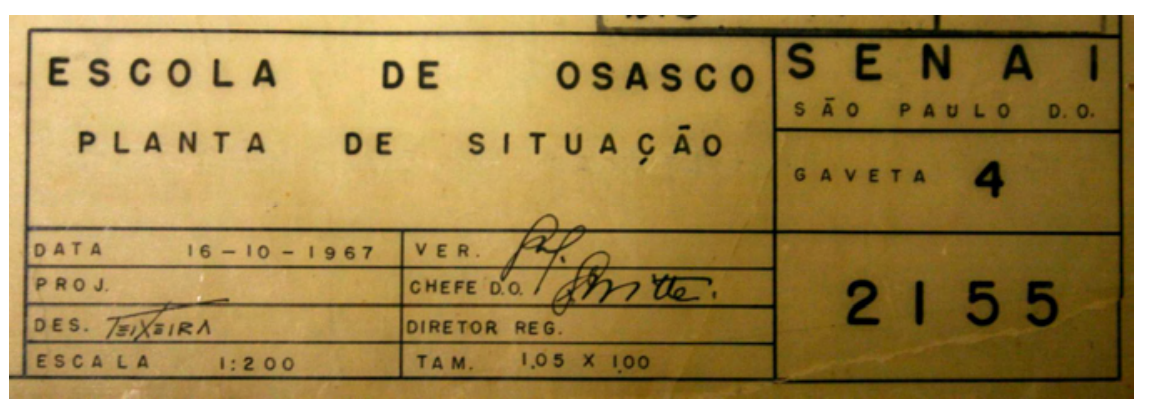

De uma maneira geral, o programa construtivo foi resolvido em quatro blocos, de acordo com a planta de situação, sendo: oficina mecânica no bloco 1; administração, salas de aula e pavilhão social no bloco 2; oficina de marcenaria e fundição no bloco 3; caldeiraria no bloco 4. Os blocos 1, 2 e 3, de maior porte, foram implantados perpendiculares à rua principal e interligados por passarelas cobertas. O bloco 4 foi implantado na extremidade oeste do bloco 1 e também interligado à ele por passarela coberta. Através dos cortes pode-se afirmar que os blocos 1 e 4 tinham apenas um pavimento, enquanto os blocos 2 e 3 foram projetados com dois ou três pavimentos.
Figura 6: Observar os dados do selo do projeto da planta de situação, original na escala 1:200, Escola de Osasco, concebido em outubro de 1967. Fonte: Foto Ferraz, arquivo SENAI 


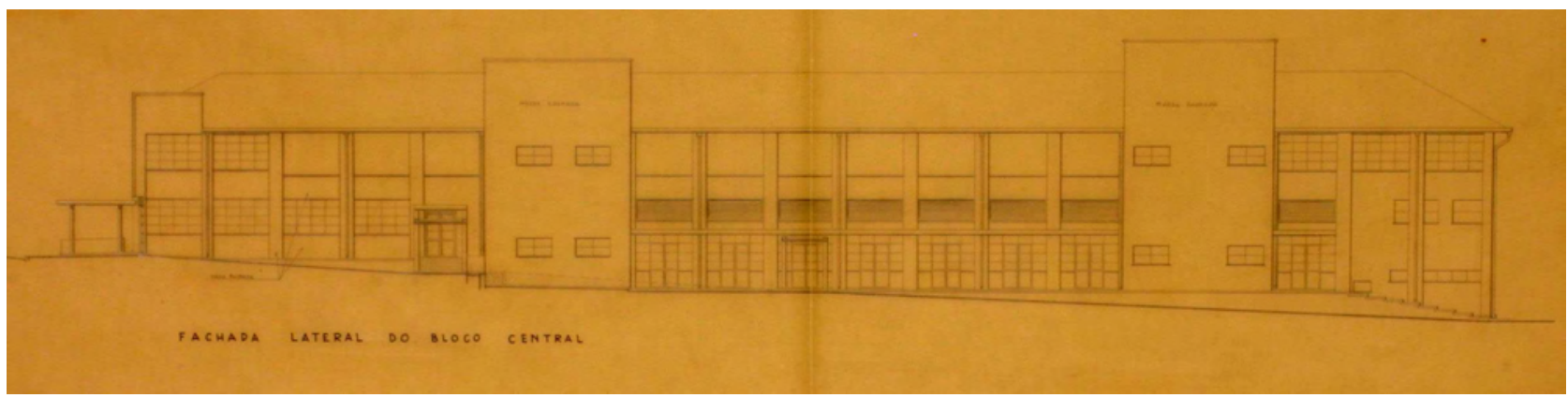

Figura 7: Elevação Norte do bloco 2 (administração, salas de aula e pavilhão social), retirada da prancha original das Fachadas, original na escala 1:100, Escola de Osasco, 1964. Observar o desnível do terreno e o aumento do número de pavimentos.

Fonte: Foto Ferraz, arquivo SENAI

Figura 8: Corte do bloco 2 (administração, salas de aula e pavilhão social), retirada da prancha original dos Cortes, original na escala 1:100, Escola de Osasco, 1964.

Fonte: Foto Ferraz, arquivo SENAI

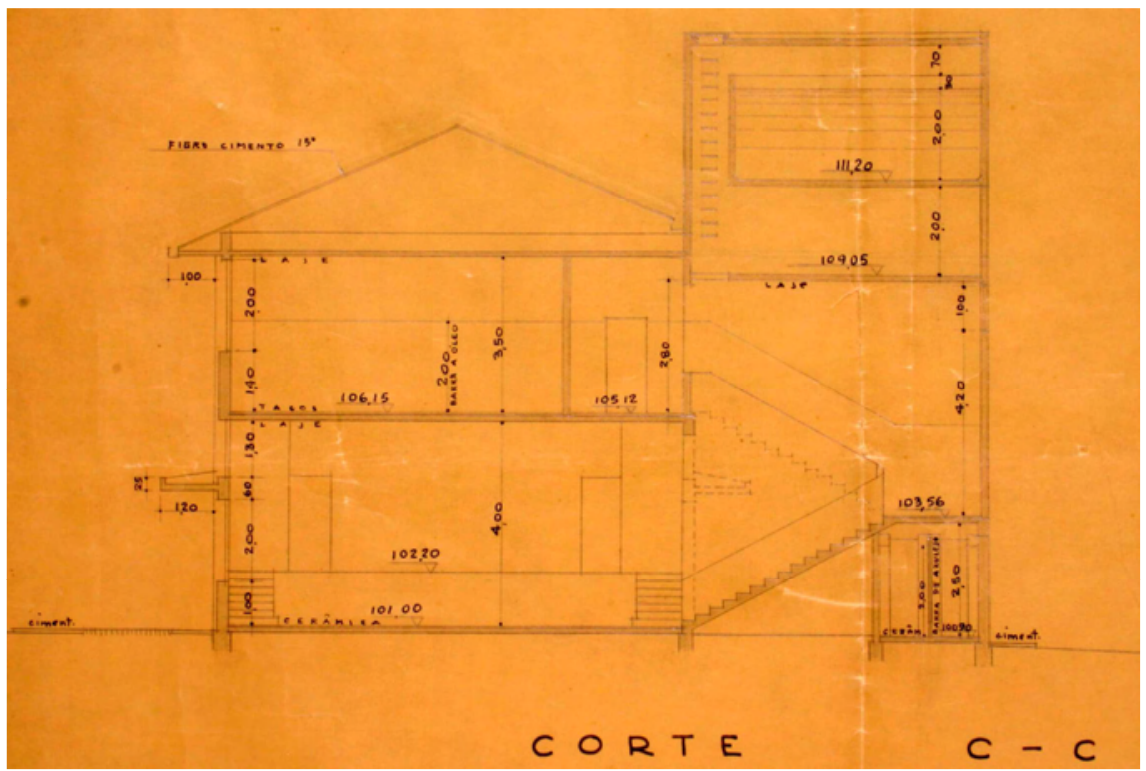

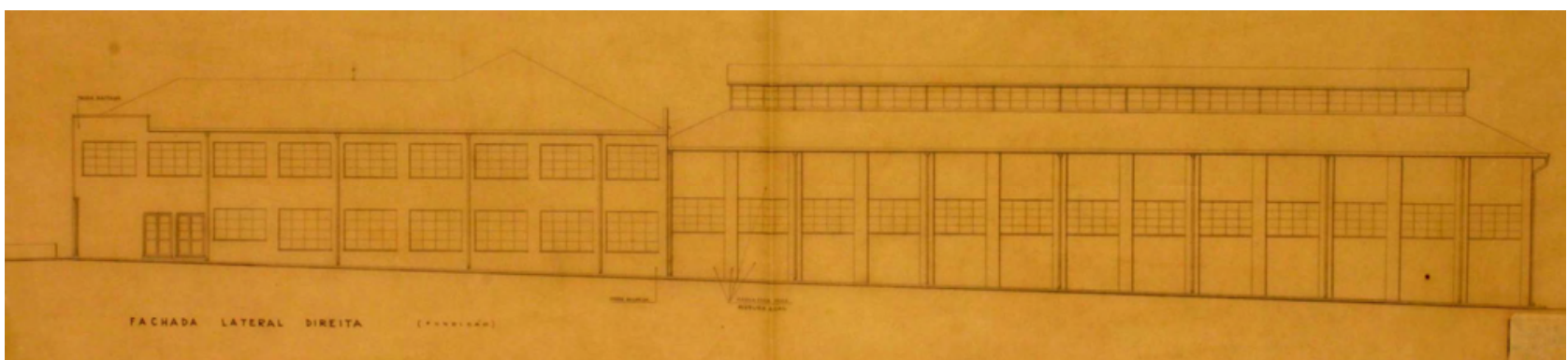

Figura 9: Elevação Norte do bloco 3 (oficina de marcenaria e fundição), retirada da prancha original das Fachadas, original na escala 1:100, Escola de Osasco, 1964.

Fonte: Foto Ferraz, arquivo SENAI 


\section{PROJETO 21}

\section{Escola Senai Hermenegildo Campos de Almeida,}

Guarulhos, 1967

Outra escola projetada com o programa construtivo da nova pedagogia do SENAI foi a de Guarulhos, projetada por Melanias M. Nagamini, em 1967. Localizada na rua Doutor Renato de Andrade Maia número 601 (antiga Avenida Três), entre as ruas Engenheiro Roberto Mange (antiga Rua Quatro), Cavalcante (antiga Rua Seis) e Thomás Biondillo (antiga Rua Três), a escola foi implantada numa quadra de $14.788,00 \mathrm{~m}^{2}$. Com área construída total de $6.425,00 \mathrm{~m}^{2}$, sendo $4.735,00 \mathrm{~m}^{2}$ do pavimento térreo e $1.680,00 \mathrm{~m}^{2}$ do pavimento superior, a escola foi projetada originalmente com três blocos, denominados $A, B$ e $C$, caracterizados pela administração, salas de aula e auditório (bloco $A)$; oficina (bloco $B)$; refeitório e vestiários (bloco C).

A escola teve seu programa construtivo dividido nos três blocos. O bloco A era composto de hall de entrada, secretaria, diretoria, sala de assistente de direção, salas de assistência social, médica e dentária, biblioteca, sala dos professores, sanitários, casa para vigia (dois dormitórios, cozinha, sala e banheiro), auditório, sala de projeção, camarins e dez salas de aulas. $O$ bloco B abrigava a oficina e seus anexos como sanitários, lavatórios, oficina de solda e as salas dos instrutores, coordenação e instrutor chefe. $O$ bloco $C$ era composto do refeitório com cantina, copa, sanitários e vestiários. Além dos três blocos, também foi projetado um bloco de ligação entre o bloco B e C, denominado de "galpão".

O projeto original, pesquisado no arquivo do SENAI, não foi encontrado em sua totalidade. Foi encontrada apenas a prancha do projeto executivo da planta de situação, na escala $1: 200$, revelando a implantação dos blocos, áreas construídas, ano de sua concepção, dimensões e topografia do terreno, endereço da escola e distâncias entre os blocos. Porém, o conhecimento das plantas e cortes dos três blocos foi obtido nas pranchas executivas do projeto de ampliação e reforma desta escola, concebido em 1986, tornando possível a compreensão do projeto através das diferentes simbologias utilizadas nas paredes de acordo com a legenda (parede a demolir, a construir, 
Figura 1: Observar os dados do selo do projeto original da planta de situação, original na escala 1:200, Escola Senai Hermenegildo Campos de Almeida, Guarulhos, concebido em janeiro de 1967, com autoria de Melanias M.

Nagamini.

Fonte: Foto Ferraz,

arquivo SENAI a executar e existente), considerando o projeto original pelas paredes existentes e a demolir. Também, o conhecimento do projeto original se ateve aos projetos obtidos no arquivo do SENAI, pois esta escola não foi encontrada nos periódicos da época.

\begin{tabular}{|c|c|c|}
\hline \multirow{2}{*}{\multicolumn{2}{|c|}{$\begin{array}{r}\text { ESCOLA DE APREND. GOV.DOESTADO } \\
\text { G UAR U L O S } \\
\text { PLANTA DE SITUACQAO }\end{array}$}} & $\begin{array}{lllll}S & E & N & A \\
S A & \end{array}$ \\
\hline & & G A VETA 4 \\
\hline $31-1-1967$ & VER lbelauis. & \\
\hline PROJ. & CHEFE D.O. Wh the & \\
\hline DES Teiveina & DIRETOR REG. & \\
\hline ESCALA $1: 200$ & TAM. $\quad 1.05 \times 68$ & \\
\hline
\end{tabular}

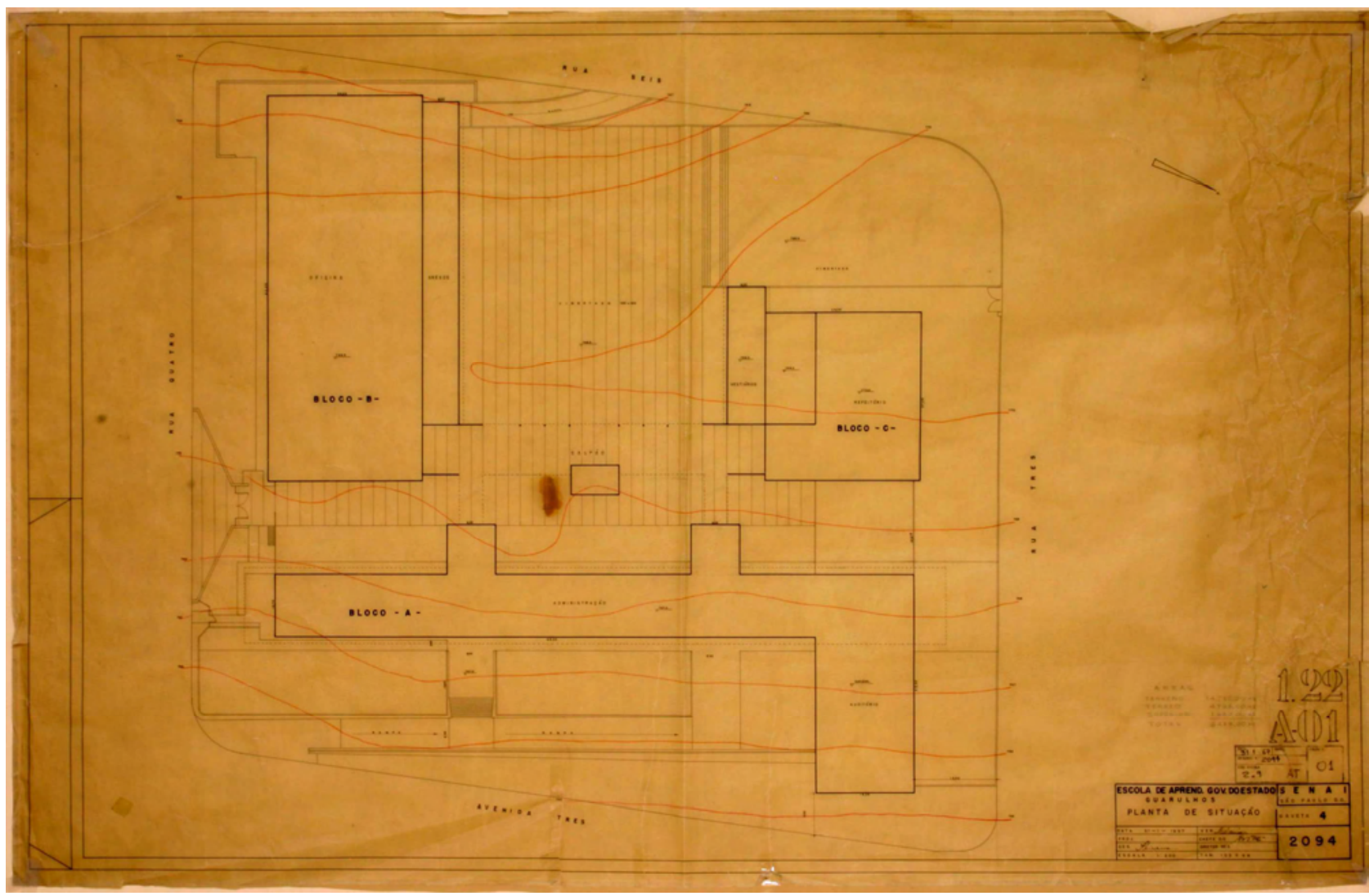

Figura 2: Prancha do projeto original da Planta de Situação, original na escala 1:200, Escola Senai Hermenegildo Campos de Almeida, Guarulhos, 1967.

Fonte: Foto Ferraz, arquivo SENAI 
A solução adotada no projeto foi a de blocos interligados entre si por passagens cobertas, ramificadas de um ponto central, 0 "galpão". O primeiro bloco, bloco A (administração, salas de aula e auditório), foi localizado ao longo da rua Doutor Renato de Andrade Maia, com fachada principal voltada para a face nordeste, num edifício em forma de " $\mathrm{L}$ " composto de dois pavimentos. O pavimento térreo abrigava a administração da escola, a casa do vigia na extremidade sudeste e o auditório na extremidade noroeste, no volume perpendicular à horizontalidade do bloco. A divisão adotada na parte administrativa foi a de corredor central e ambientes bilaterais, corredor este que ligava aos dois halls de acesso das duas escadas que conduziam ao pavimento superior. Já, o auditório, foi projetado com iluminação e ventilação bilaterais nordeste e noroeste, resolvido em um único pavimento. $\bigcirc$ segundo pavimento adotou circulação lateral fechada na face noroeste, voltada para o interior da escola (interligação) e dez salas de aula com iluminação e ventilação lateral nordeste, em favor do sol da manhã e à paisagem urbana (atratividade). As salas foram separadas uma das outras por paredes e por divisórias (crescimento e flexibilidade) e suas aberturas foram protegidas pelos volumes verticais (tipo brises fixos) modulados a cada 2 metros de eixo. Nas caixas de escadas, ambos patamares intermediários das escadas abrigaram pequenos sanitários, favorecendo à economia no sentido de percorrer menores espaços, semelhante à solução adotada na Escola Têxtil do Brás, projetada em 1952. Este bloco foi projetado com recuo do pavimento térreo em relação ao superior, enquanto o pavimento térreo tinha 104,25 metros de comprimento e 10,70 metros de largura, o pavimento superior tinha cerca de 114,25 metros de comprimento e 12,00 metros de largura, solução que beneficiou o conforto térmico ao pavimento térreo, semelhante à Escola Senai de Bauru, em 1953.

O segundo bloco, bloco B (oficina e anexos), foi implantado de forma longitudinal ao longo da rua Engenheiro Roberto Mange, com dimensão de 62,25 metros x 25,25 metros (oficina) anexa ao volume de 52,25 x 6,00 metros (anexos). Seguindo a mesma modulação da estrutura tipo brises verticais fixos das salas de aula do bloco $A$, a área da oficina recebeu iluminação lateral sudeste tanto 
pelos vão envidraçados da modulação de 2 metros de eixo (voltados para a rua, rendimento) como da cobertura tipo shed (economia). pé-direito da oficina recebeu altura mínima de 3,30 metros sob o shed, porém o volume dos anexos foi projetado com pé-direito de 3,18 metros sob laje impermeabilizada. A oficina adotou a planta livre em um único pavimento, sem nenhum desnível (flexibilidade) e ambientes de apoio na lateral noroeste (sanitários, lavatórios, oficina de solda e as salas dos instrutores, coordenação e instrutor chefe), todos separados com paredes e com iluminação e ventilação noroeste, voltadas para a área interna da escola.

O terceiro bloco, bloco C (refeitório e vestiários), foi o bloco projetado no nível mais alto (1,50 metros acima do bloco da oficina) num único pavimento de 3,40 metros de pé-direito resolvido em planta livre. $O$ refeitório recebeu a mesma modulação de 2 metros de eixo nas aberturas laterais nordeste e noroeste, e o apoio da cantina, depósito e copa na extremidade sudoeste. Anexo ao refeitório foram projetados os vestiários, 1,50 metros abaixo do nível do refeitório, com abertura lateral sudeste voltada para o interior da escola.

A pedagogia do SENAl também norteou a solução arquitetônica desta escola, projetada no final da década de 60, porém alguns critérios presentes principalmente nas primeiras escolas foram alterados, como por exemplo, o contato visual entre área de trabalho prático e teórico. Sabe-se que o projeto foi reformado e ampliado na década de 1980 e construído mais um bloco de três pavimentos, denominado bloco " $E$ ". Ainda, a planta do bloco originalmente denominado "galpão" é apresentada neste mesmo projeto com sanitários, vestiários e depósito, porém ainda não é possível afirmar se esta era sua planta original. 


\section{PROJETO 22}

\section{Escola Industrial do Bom Retiro, São Paulo, 1968}

Projetada por Hélio de Queiroz Duarte e Roberto José Goulart Tibau, em 1968, a escola Industrial do Bom Retiro, São Paulo, foi localizada na rua Anhaia esquina com a Avenida C. Elizabet Rubiano. A escola foi composta originalmente por sete blocos (A, B, C, D, E, F e G) caracterizados pelos: recreio coberto e administração (bloco A); administração, sanitários e vestiários (bloco B); salas de aula (bloco C); oficina (bloco D); salas de aula (bloco E); salas de aula, laboratório e depósito (bloco F); casa do zelador (bloco $G$, não construído) e três quadras de esportes.

Figura 1: Implantação da escola, retirada da prancha original da Implantação e Cobertura, original na escala 1:200, Escola Industrial do Bom Retiro, 1968.

Fonte: Foto Ferraz, arquivo SENAI

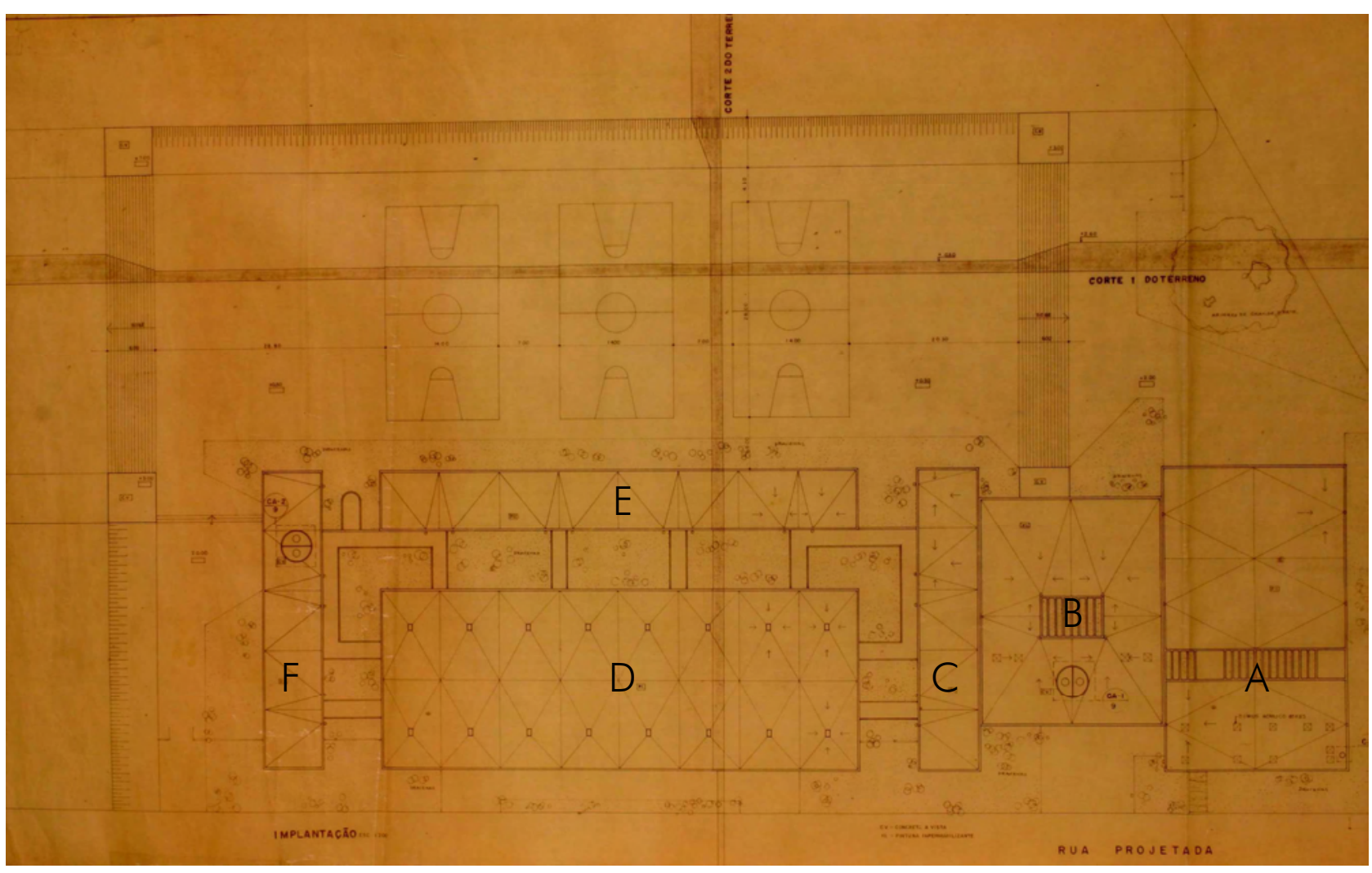


A escola teve seu programa construtivo composto de: secretaria, diretoria, sala de reuniões, sanitários, recreio coberto, despensa e depósito de material didático, no bloco $A$; vestiários e sanitários de alunos masculino e feminino, sanitários de instrutores masculino e feminino, sala dos instrutores, sala dos professores, biblioteca, salas de atendimento médico e dentário, no bloco $B$; três salas de ensino dirigido, três salas de aula para 25 alunos e duas salas de aula para 30 alunos, no bloco $C$; oficina, no bloco D; 16 salas de aula para 25 alunos, no bloco $\mathrm{E}$; dois laboratórios, três salas de aula para 30 alunos, depósito de matéria prima e sanitários, no bloco F; casal do zelador, no bloco G. Os Blocos A, B e C foram projetados com junta de dilatação uns dos outros, porém os blocos $C$, E e $F$ foram interligados ao bloco D por passarelas cobertas. Já, o bloco $G$, não chegou a ser executado conforme o projeto original, porém a cada do zelador foi projetada posteriormente por Roberto Tibau, localizada próxima ao bloco F (figura 2).

Figura 2: Implantação da Casa do Zelador, retirada da prancha original da Situação, Planta e Corte da Casa do Zelador, original na escala 1:500,

Escola Industrial do Bom Retiro, s.d.

Fonte: Foto Ferraz, arquivo SENAI

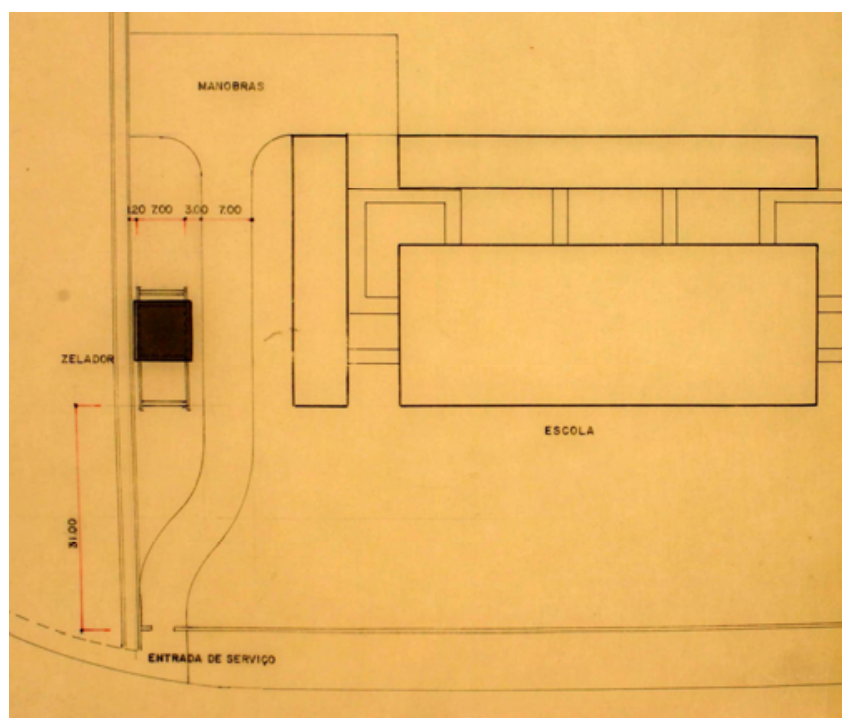

O projeto original, obtido no arquivo do SENAI, revelou as pranchas de implantação e cobertura, das plantas de todos os blocos, dos cortes, das fachadas e de inúmeros detalhamentos. Ainda, foi encontrado o projeto completo da casa do zelador que realmente foi construído, idealizado por Tibau (figuras 9 à 11), ainda sem precisar a data. $O$ conhecimento do projeto original se ateve aos projetos obtidos no arquivo, pois esta escola não foi encontrada nos periódicos da época. 


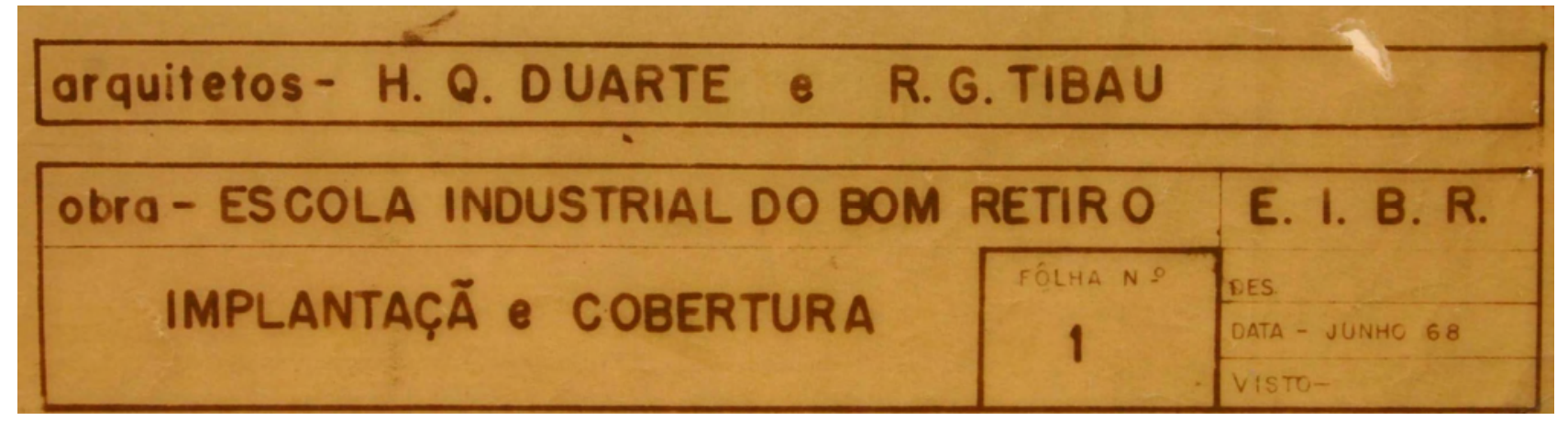

Figura 3: Observar os dados do selo do projeto original da implantação e cobertura, original nas escalas 1:20 e 1:200, Escola Industrial do Bom Retiro, concebido em junho de 1968, com autoria de Hélio Duarte e Roberto Tibau.

Fonte: Foto Ferraz, arquivo SENAI

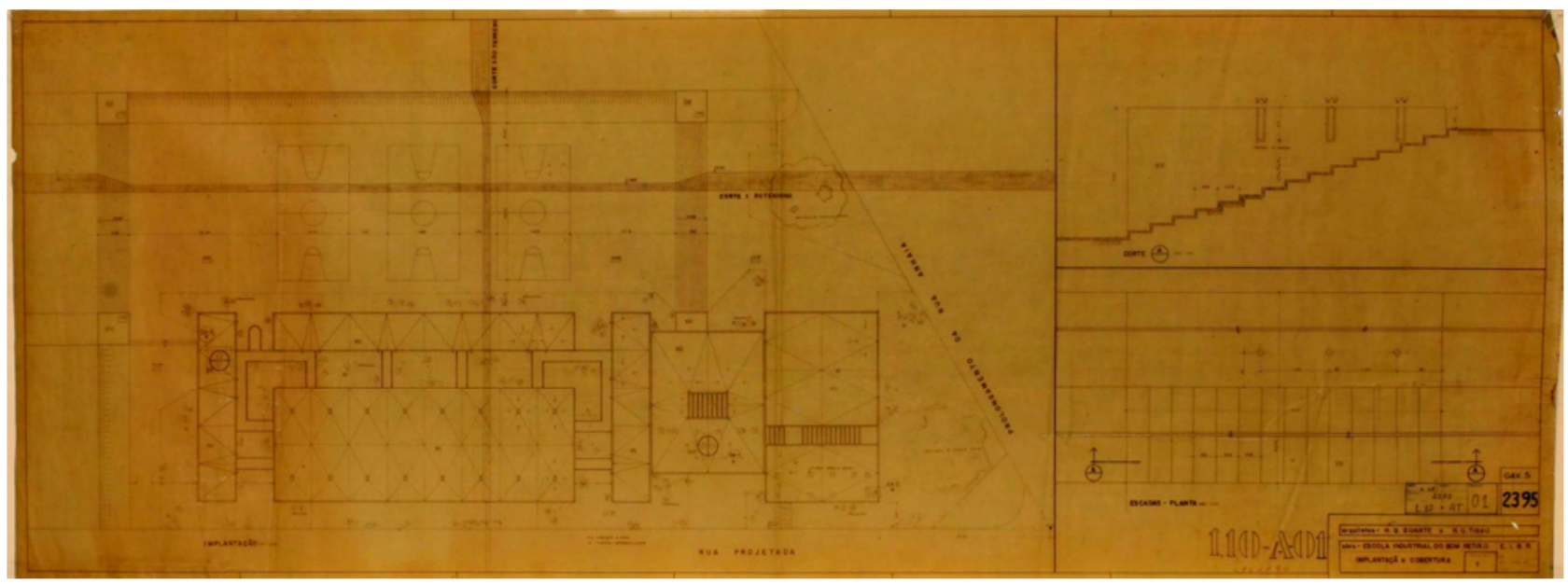

Figura 4: Prancha do projeto original da Implantação e Cobertura, original nas escalas 1:20 e 1:200, Escola Industrial do Bom Retiro, 1968.

Fonte: Foto Ferraz, arquivo SENAI 


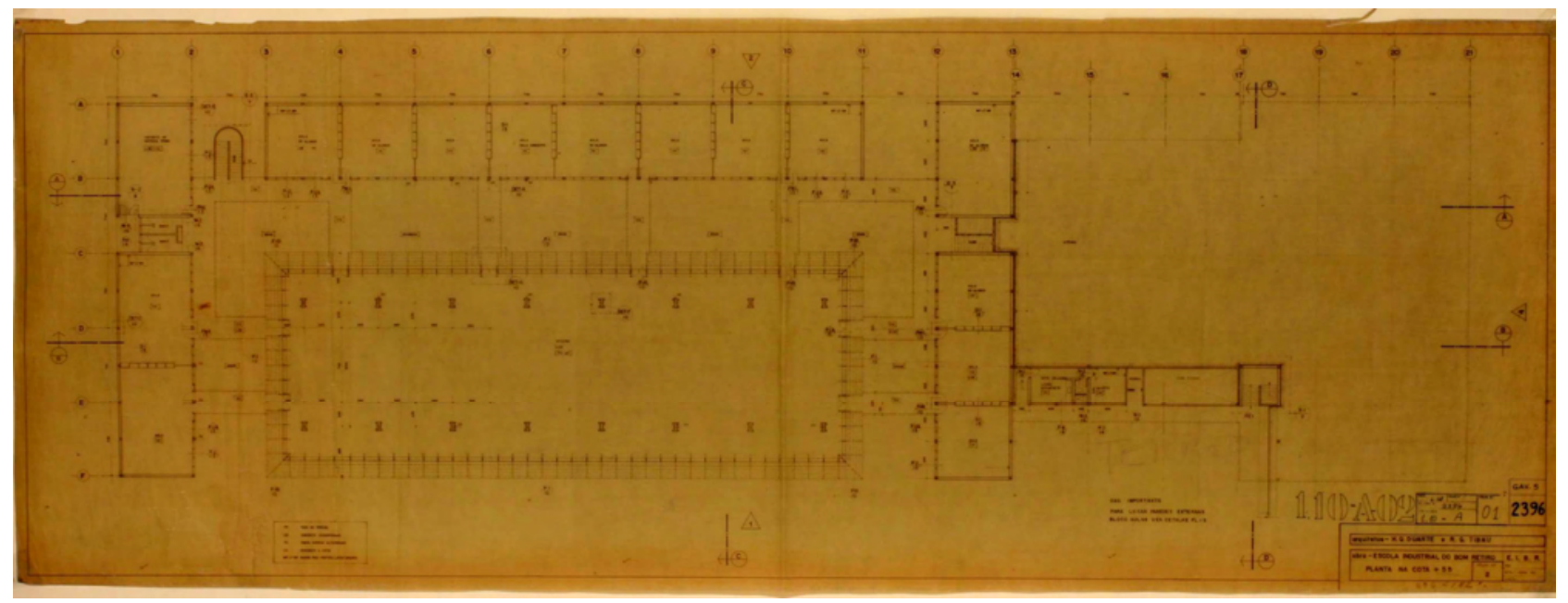

Figura 5: Prancha do projeto original da Planta do Pavimento Térreo (denominada cota +55 ), original na escala 1:100, Escola Industrial do Bom Retiro, 1968.

Fonte: Foto Ferraz, arquivo SENAI

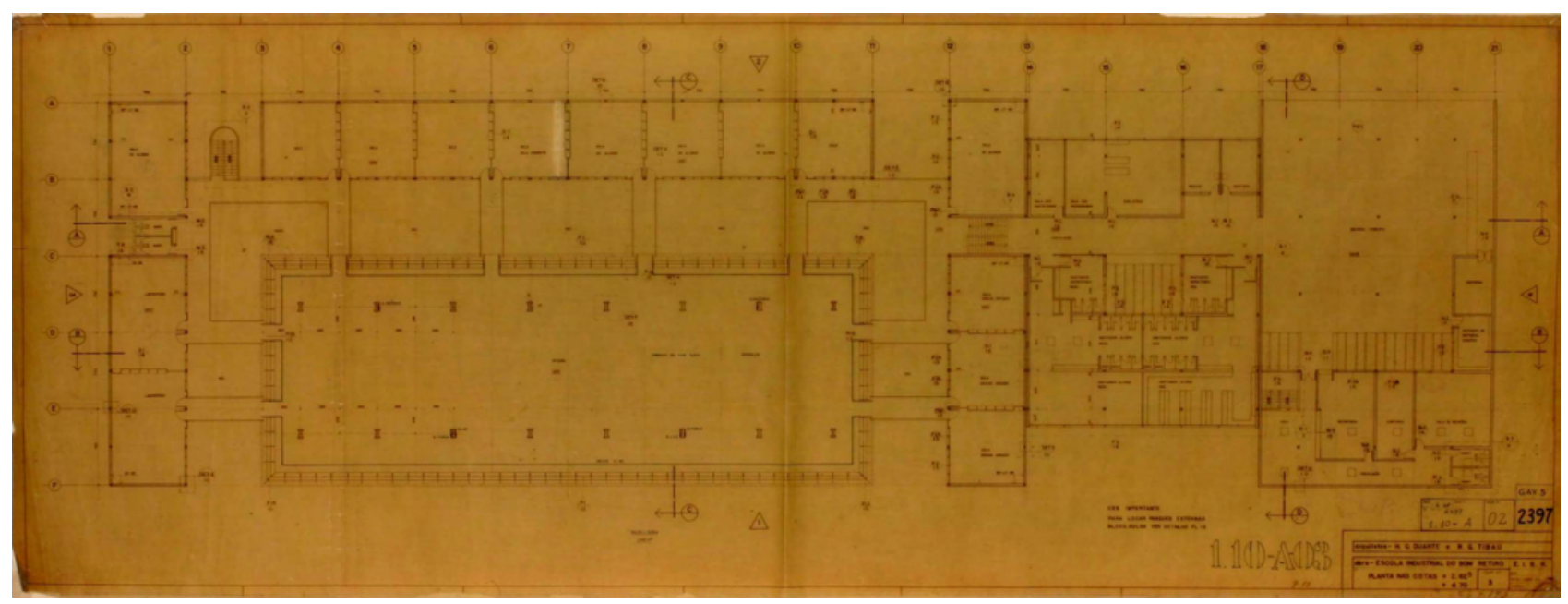

Figura 6: Prancha do projeto original da Planta do Pavimento Intermediário e Superior (denominada cotas +2.625 e +4.70 ), original na escala 1:100, Escola Industrial do Bom Retiro, 1968.

Fonte: Foto Ferraz, arquivo SENAI 


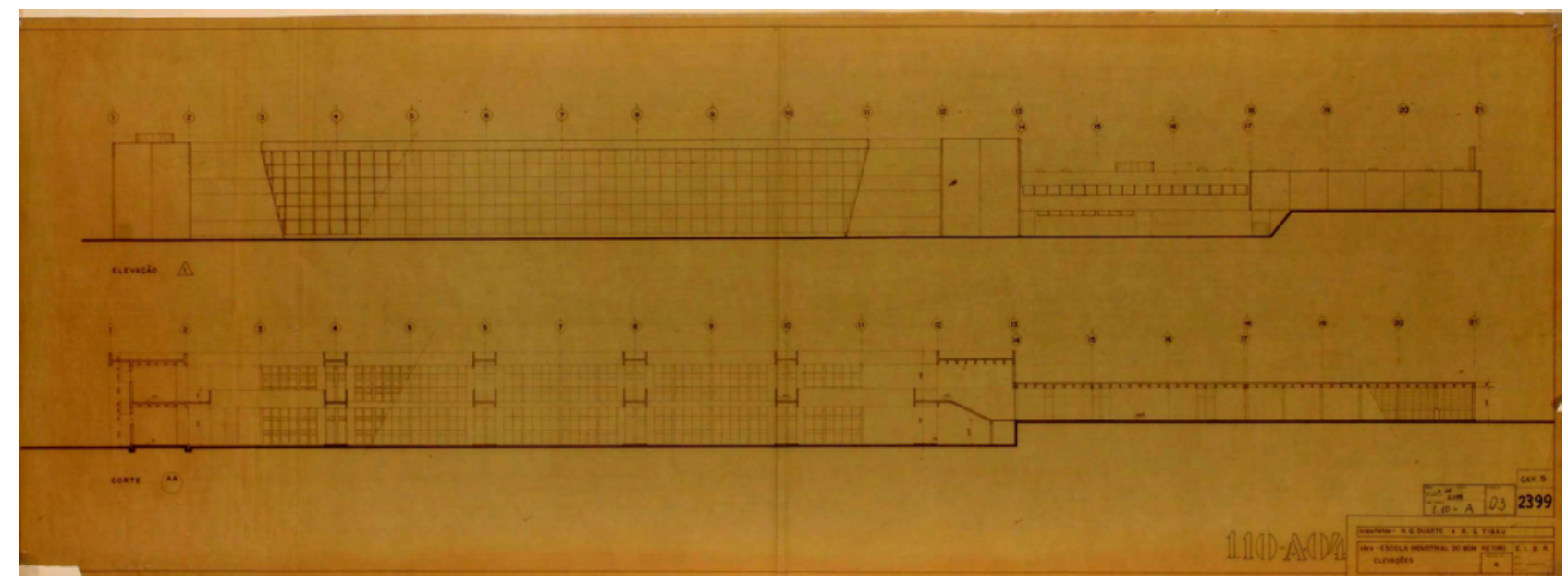

Figura 7: Prancha do projeto original do Corte A e Elevação 1, original na escala 1:100, Escola Industrial do Bom Retiro, 1968. Fonte: Foto Ferraz, arquivo SENAl

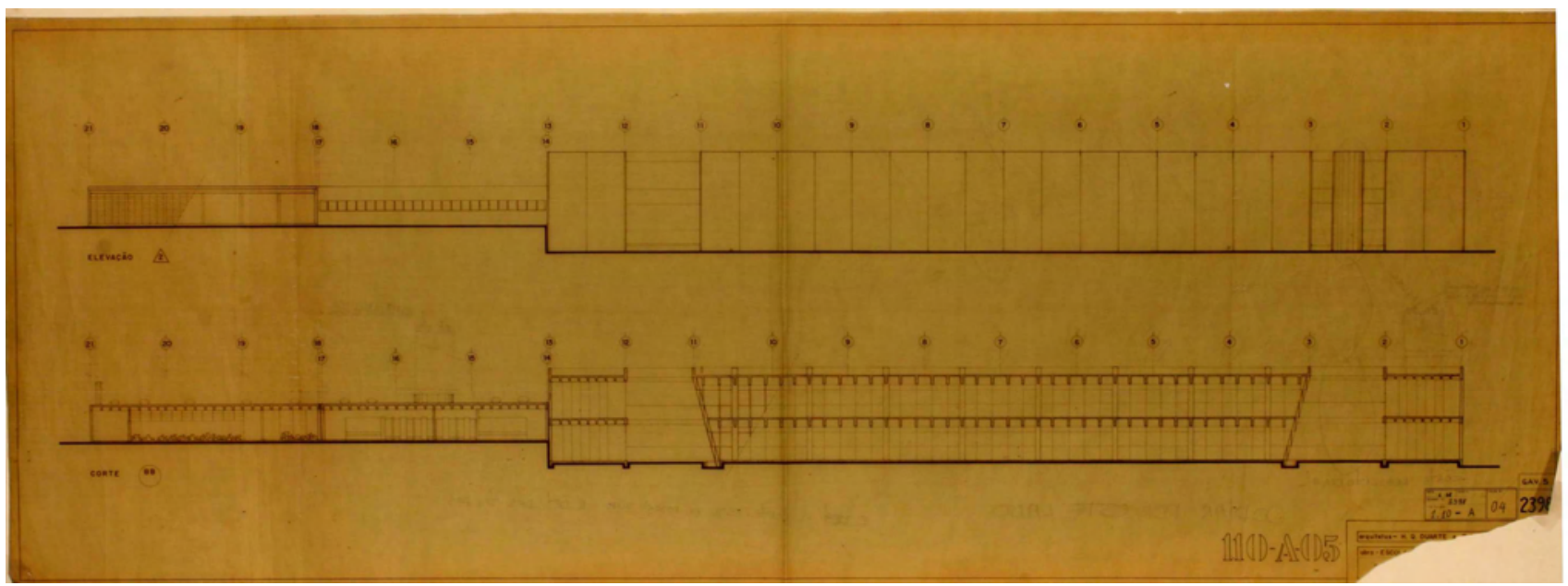

Figura 8: Prancha do projeto original do Corte B e Elevação 2, original na escala 1:100, Escola Industrial do Bom Retiro, 1968. Fonte: Foto Ferraz, arquivo SENAI 


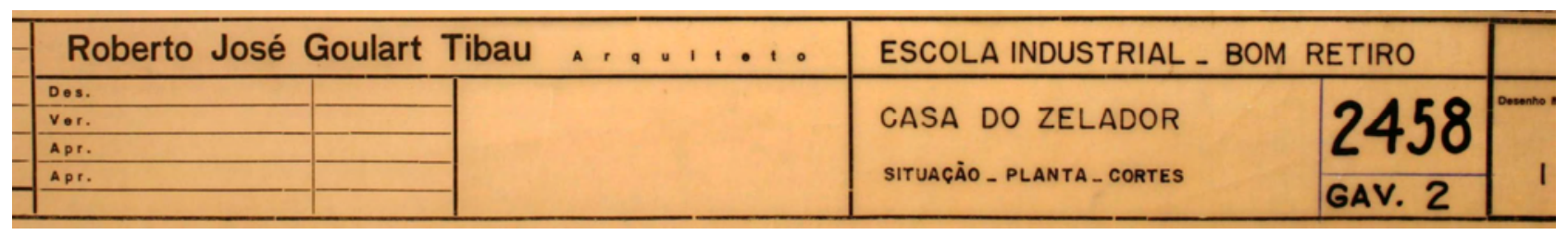

Figura 9: Observar os dados do selo do projeto reformulado da casa do zelador, original nas escalas 1:50 e 1:500, Escola Industrial do Bom Retiro, s.d, com autoria de Roberto Tibau. Fonte: Foto Ferraz, arquivo SENAI

Figura 10: Prancha 1 do projeto da Casa do Zelador, original nas escalas 1:50 e 1:500,

Escola Industrial do Bom Retiro, s.d.

Fonte: Foto Ferraz,

arquivo SENAI

Figura 11: Prancha 2 do projeto da Casa do Zelador, original na escala 1:50, Escola Industrial do Bom Retiro, s.d.

Fonte: Foto Ferraz,

arquivo SENAI
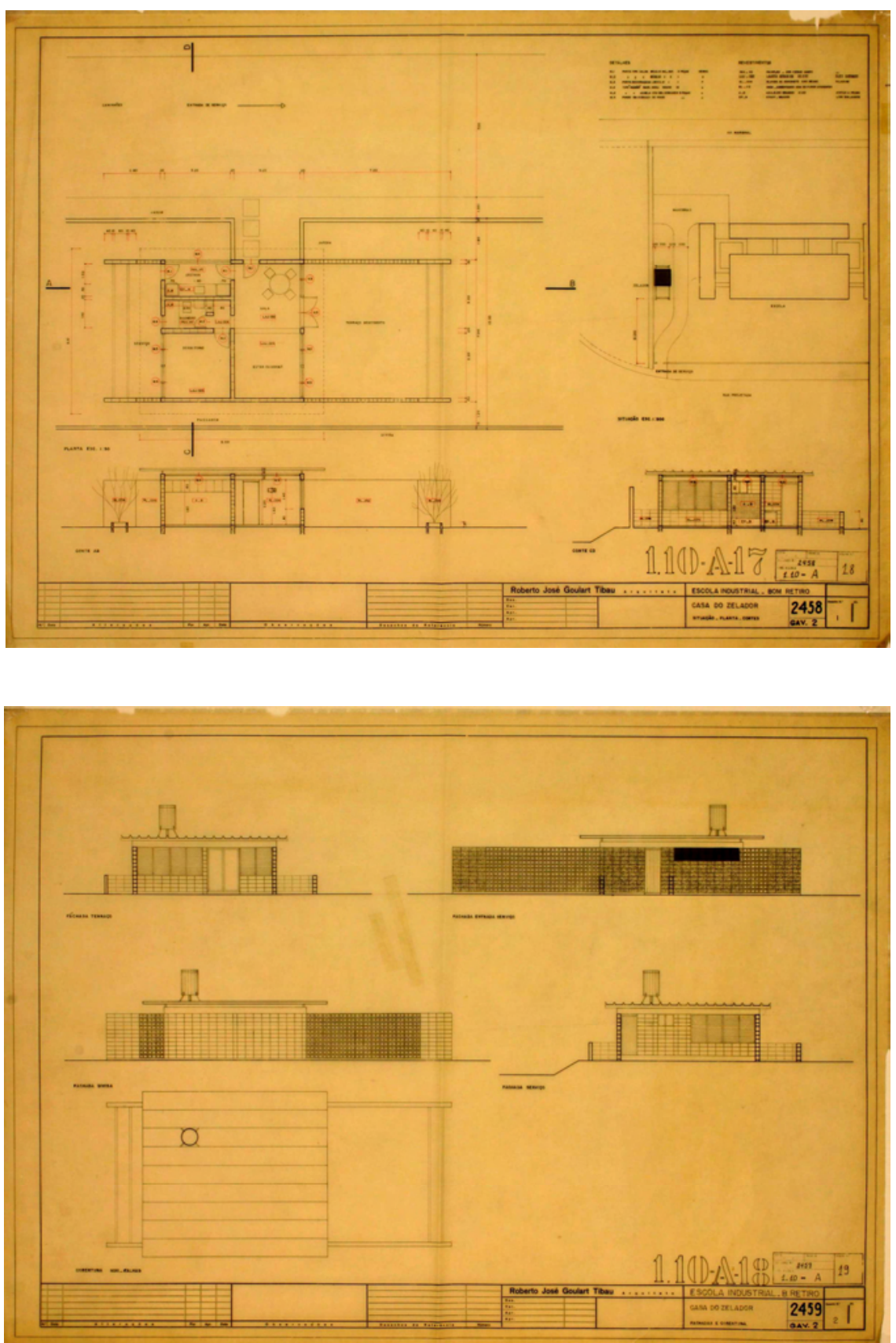
O bloco A foi projetado num único pavimento implantado no nível mais alto do terreno (cota denominada de 2,625), na extremidade nordeste da escola, com pé-direito de 3,15 metros. Modulado com eixos transversal e longitudinal de 7,30 metros, este bloco abriga o recreio coberto em sua grande área livre marcada pela estrutura dos pilares e pela abertura noroeste, única face de iluminação e ventilação diretas, voltada para o lazer da escola. Integrados ao recreio coberto, foram projetados uma despensa e um depósito de material didático. Composto também pela parte administrativa da escola (secretaria, diretoria, sala de reuniões e sanitários), esta ala foi separada do recreio coberto por um grande clarabóia na cobertura, responsável pela iluminação e ventilação das salas, juntamente com os domos acrílicos projetados nestes ambientes.

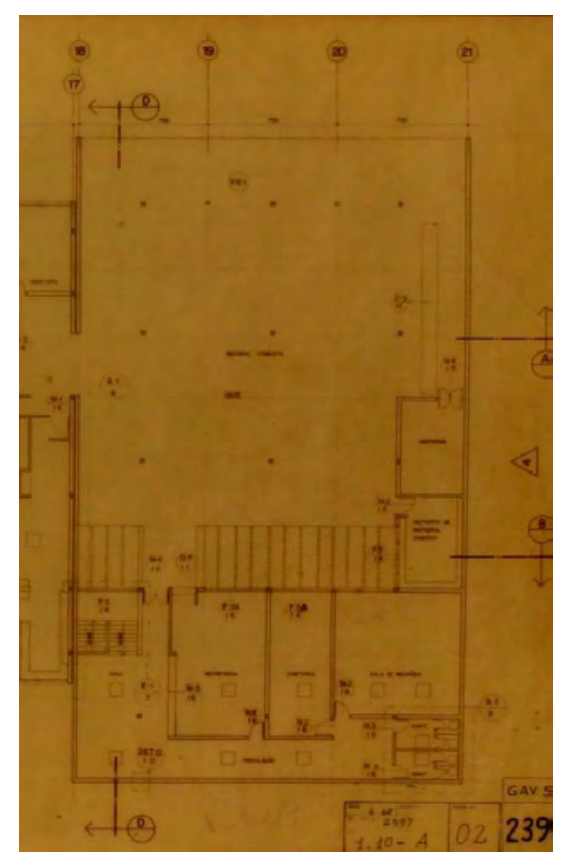

O bloco B foi implantado no mesmo nível do bloco A, seguindo também a mesma altura e modulação, e projetado com junta de dilatação dos blocos A e C, como um bloco de circulação central. Composto de um lado (nordeste) pelos vestiários e sanitários masculino e feminino tanto dos alunos como dos instrutores e, do outro (noroeste), pela sala dos instrutores, sala dos professores, biblioteca e salas de atendimento médico e dentário, este edifício recebeu iluminação e ventilação bilaterais pelas faces noroeste e nordeste, além dos domos de acrílico projetados nos sanitários.
Figura 12: Planta do bloco A, retirada da prancha do projeto original da Planta do Pavimento Intermediário e Superior (denominada cotas +2.625 e

$+4.70)$, original na escala 1:100, Escola Industrial do Bom Retiro, 1968. Fonte: Foto Ferraz, arquivo SENAI 
Figura 13: Planta do bloco B, retirada da prancha do projeto original da Planta do Pavimento Intermediário e Superior

(denominada cotas +2.625 e

$+4.70)$, original na escala

1:100, Escola Industrial do Bom

Retiro, 1968.

Fonte: Foto Ferraz,

arquivo SENAI

Figura 14: Detalhe do Corte do bloco $B$, retirada da prancha do projeto original do Corte $B$ e Elevação 2, original na escala 1:100, Escola Industrial do Bom Retiro, 1968. Observar a junta de dilatação entre o bloco $A$ e $B$ e, os domos de ventilação e iluminação na cobertura.

Fonte: Foto Ferraz,

arquivo SENAI
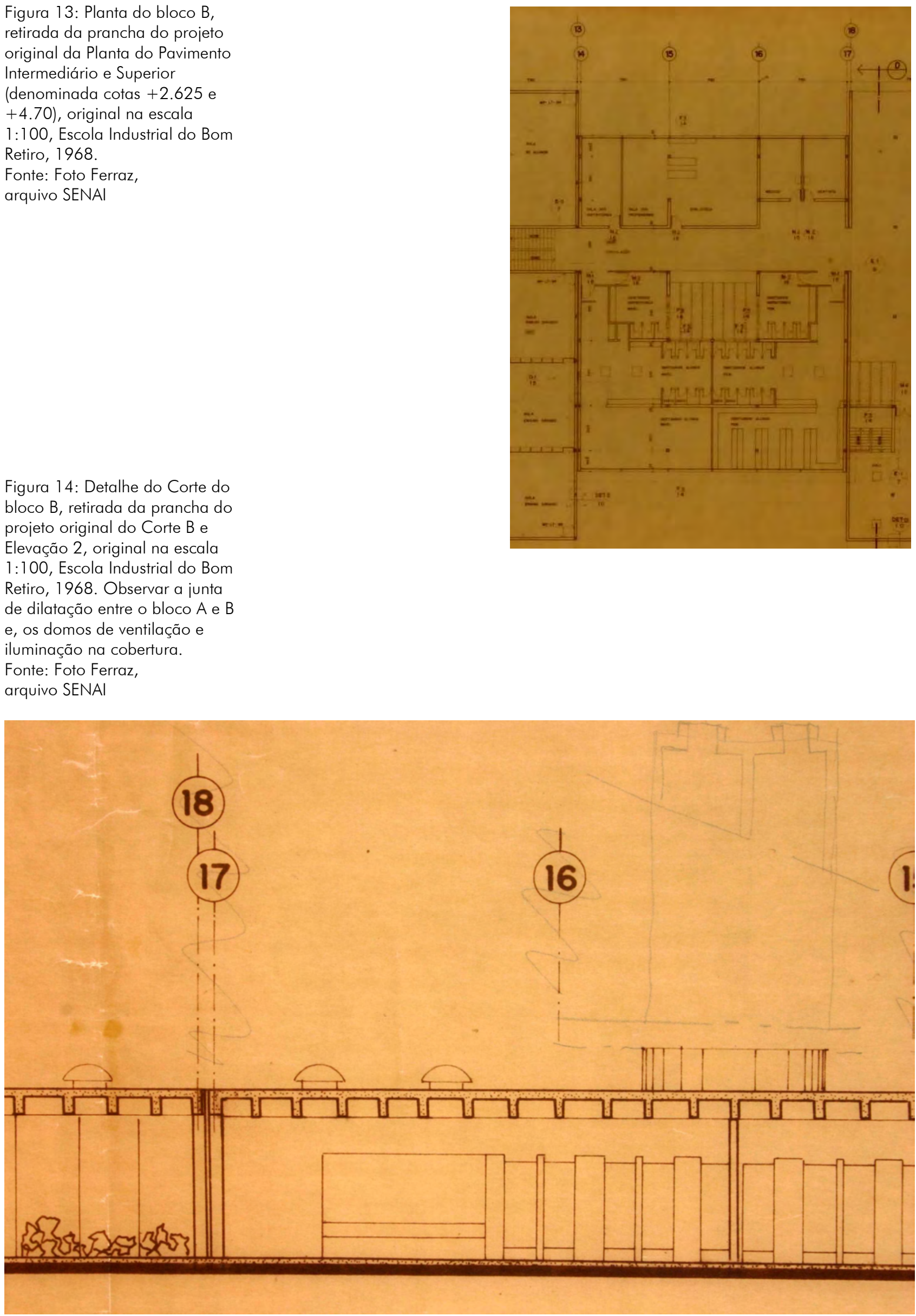


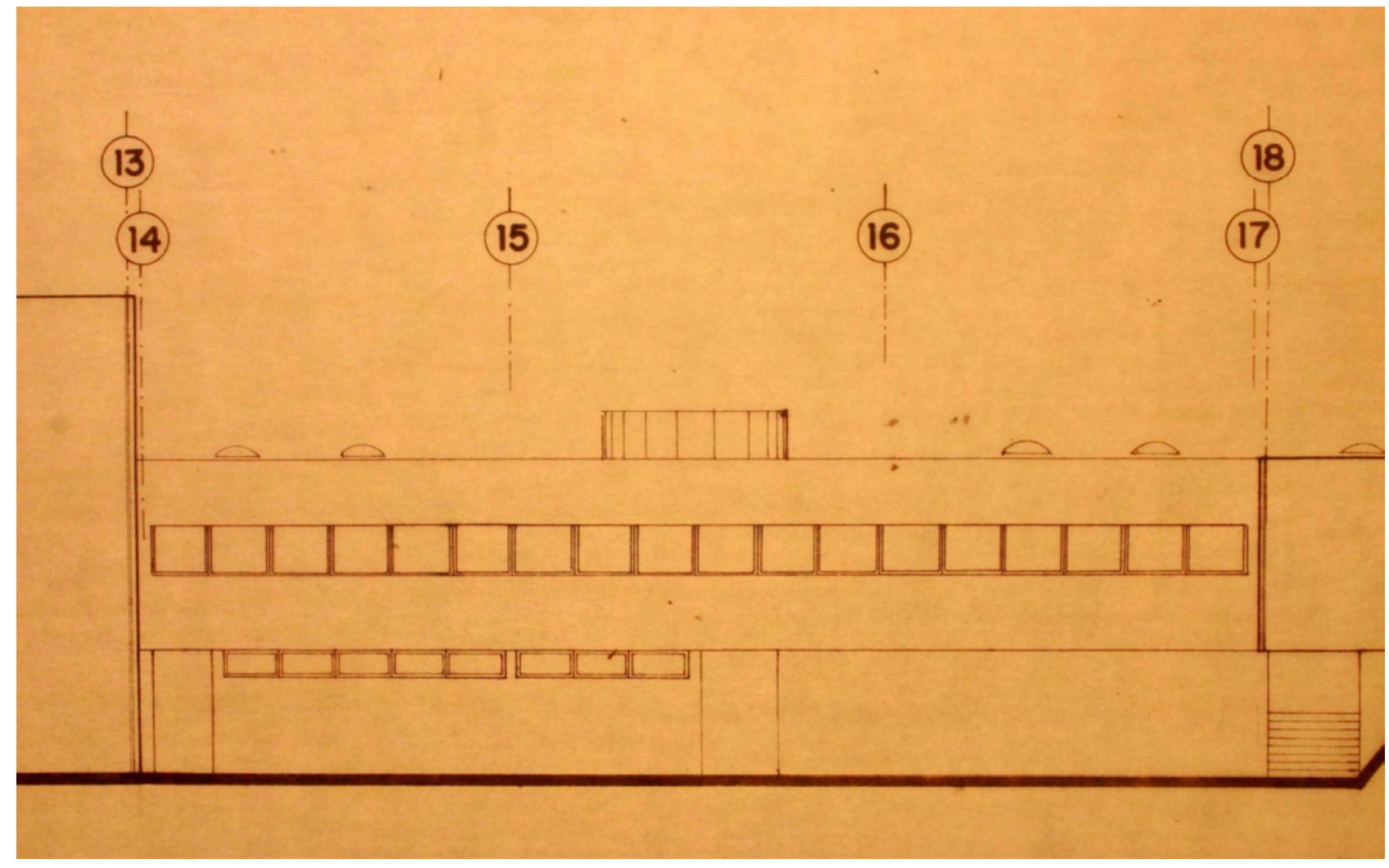

bloco $C$, as salas de aula, foi projetado no nível inferior aos blocos A e B, na cota denominada de 55. Composto de dois pavimentos este bloco foi interligado ao bloco B através de junta de dilatação e ao bloco D através de passarelas. No térreo, foram projetadas três salas de ensino dirigido e uma sala de aula para 30 alunos e, no pavimento superior, três salas de aula para 25 alunos e uma sala para 30 alunos. As salas receberam iluminação lateral sudoeste através de grandes vãos voltados para o edifício da oficina (bloco D), permitindo visibilidade da mesma através das passarelas de ligação entre um bloco e outro. As salas de aula, separadas por divisórias móveis utilizadas como armários e quadro negro, ofereciam flexibilidade ao espaço de acordo com o crescimento da indústria, seguindo a mesma solução adotada na primeira escola projetada SENAI projetada década de 50, a Escola Senai Anchieta, também projetada por Hélio Duarte, mas em parceria com Ernest Mange. Ainda, este bloco abrigava sua caixa de escada localizada no meio do bloco, finalizando e integrando a circulação do bloco anterior.
Figura 15: Detalhe da Elevação do bloco $B$, retirada da prancha do projeto original do Corte $\mathrm{A}$ e Elevação 1, original na escala 1:100, Escola Industrial do Bom Retiro, 1968. Fonte: Foto Ferraz, arquivo SENAI 
Figura 16: Planta do pavimento superior do bloco $C$, retirada da prancha do projeto original da Planta do Pavimento

Intermediário e Superior

(denominada cotas $+2.625 \mathrm{e}$

$+4.70)$, original na escala

1:100, Escola Industrial do Bom Retiro, 1968.

Fonte: Foto Ferraz,

arquivo SENAI

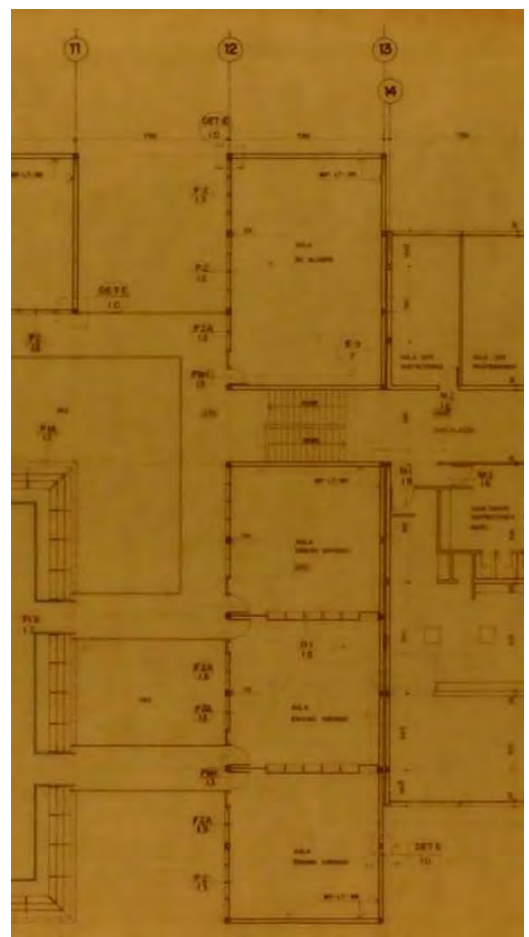

O bloco D, a oficina, projetado na mesma cota do bloco C, apresenta, pela primeira vez, a solução da oficina em dois pavimentos. Modulado com eixo longitudinal de 7,30 metros, o bloco da oficina foi projetado com a maior área dentre os demais blocos da escola. Interligados aos blocos C, E e F por passarelas, o bloco D foi projetado como um centro de ensino prático interligado aos blocos de ensino teórico (interligação e rendimento). Sob as passarelas, uma área ajardinada no nível do pavimento térreo, entre um bloco e outro, proporcionou a integração do paisagismo ao projeto. $O$ bloco da oficina recebeu iluminação e ventilação pelas quatro faces (noroeste, sudoeste, sudeste e nordeste), através de seus panos inclinados, sendo

o pavimento térreo recuado em relação ao superior.

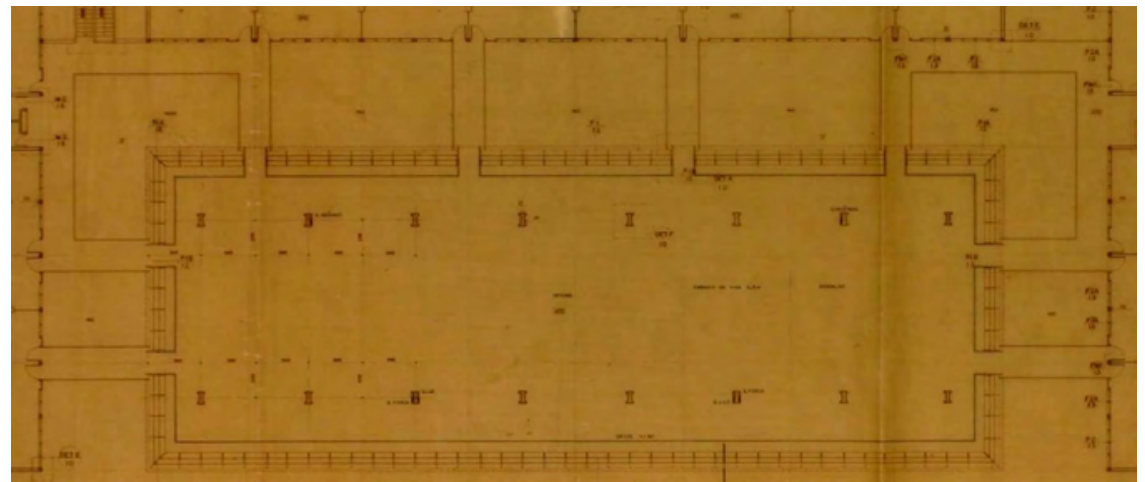

Figura 17: Planta do pavimento superior do bloco $D$, retirada da prancha do projeto original da Planta do Pavimento Intermediário e Superior (denominada cotas $+2.625 \mathrm{e}$ $+4.70)$, original na escala 1:100, Escola Industrial do Bom Retiro, 1968

Fonte: Foto Ferraz, arquivo SENAI 


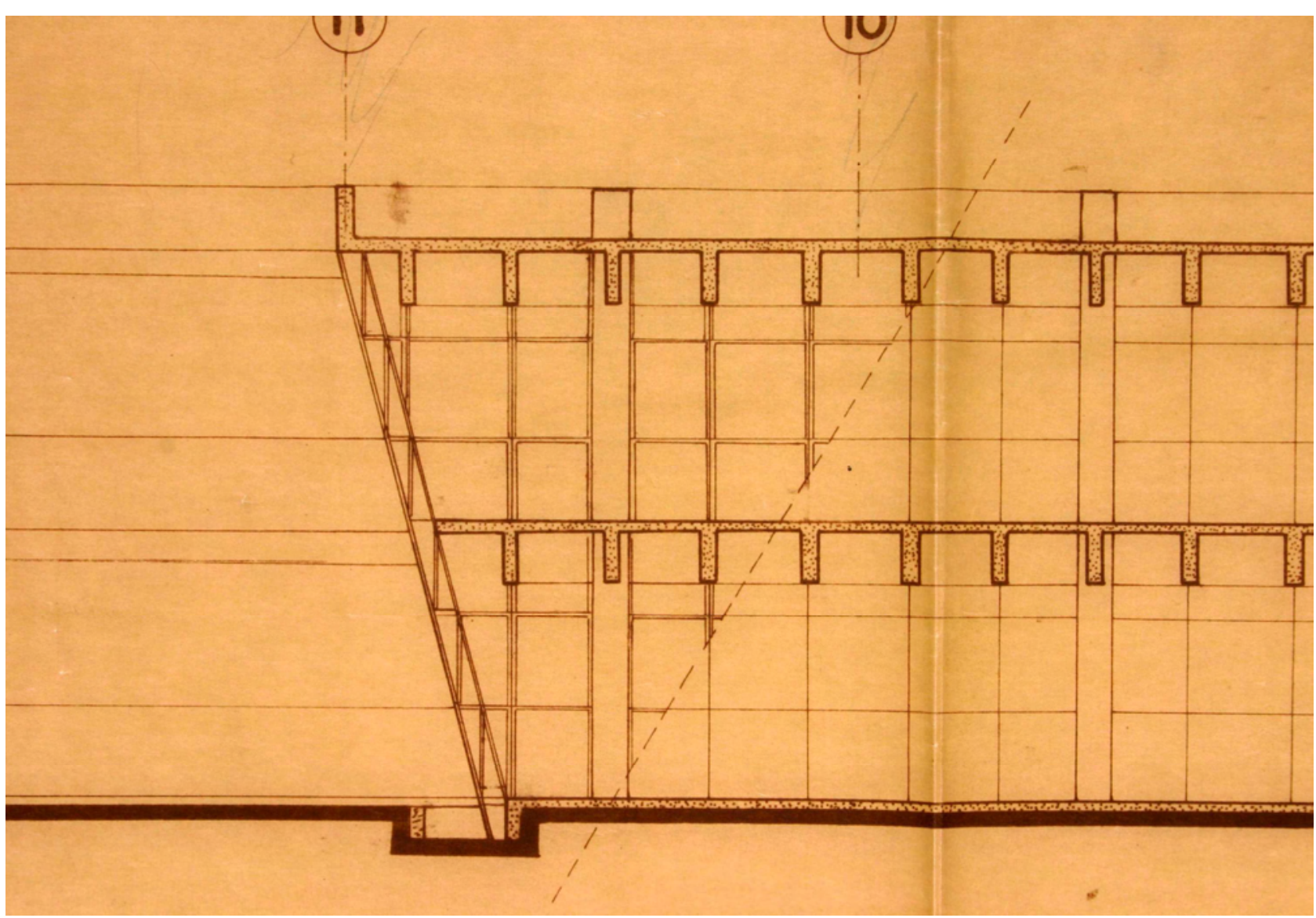

Figura 18: Detalhe da Elevação do bloco D, retirada da prancha do projeto original do Corte B e Elevação 2, original na escala 1:100, Escola Industrial do Bom Retiro, 1968. Observar a solução inédita da oficina em dois pavimentos, a laje nervurada e a face inclinada do bloco $D$.

Fonte: Foto Ferraz, arquivo SENAI

O bloco $E$, paralelo ao bloco $D$, foi projetado exclusivamente para abrigar 16 salas de aula para 25 alunos, seguindo o mesmo nível, pavimentos e modulação do bloco D. Separadas por divisórias móveis utilizadas como armários e quadro negro, assim como no bloco $C$, as salas receberam iluminação e ventilação lateral sudeste. Este bloco não possuía circulação lateral e nem central, portanto o acesso a cada sala de aula foi obtido pelas quatro passarelas que interligavam o bloco $E$ ao $D$, sendo que cada passarela conduzia duas salas ao espaço da oficina, tanto no pavimento térreo como no superior. 
Figura 19: Planta do pavimento superior do bloco $E$, retirada da prancha do projeto original da Planta do Pavimento Intermediário e Superior (denominada cotas +2.625 e $+4.70)$, original na escala $1: 100$, Escola Industrial do Bom Retiro, 1968.

Fonte: Foto Ferraz, arquivo SENAI

Figura 20: Planta do pavimento superior do bloco $F$, retirada da prancha do projeto original da Planta do Pavimento Intermediário e Superior (denominada cotas +2.625 e $+4.70)$, original na escala 1:100, Escola Industrial do Bom Retiro, 1968.

Fonte: Foto Ferraz, arquivo SENAI

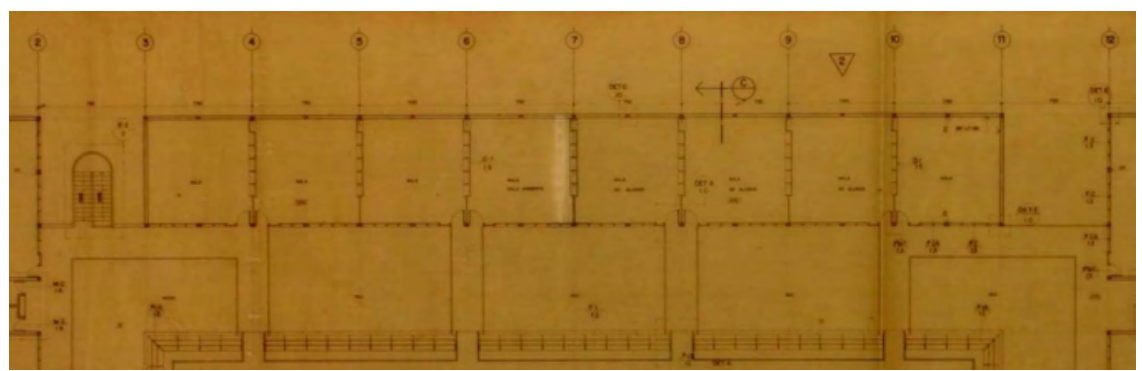

Obloco $F$, perpendicular aos blocos $D$ e $E$, seguiu o mesmo nível, pavimentos e modulação do bloco $\mathrm{D}$ e $\mathrm{E}$. No pavimento térreo, foram projetados depósito, duas salas de aula para 30 alunos e sanitários e, no pavimento superior, dois laboratórios, uma sala de aula para 30 alunos e sanitários. Assim como o bloco $\mathrm{E}$, o bloco $\mathrm{F}$ não possuía circulação própria, apenas as passarelas conduziam o ambientes à oficina. Com iluminação lateral nordeste e pé-direito de 3,65 metros, as salas foram interligadas visualmente ao bloco das oficinas. Entre o bloco $F$ e $E$, foi projetada uma escada que interligava os pavimentos térreo ao superior através da passarela.

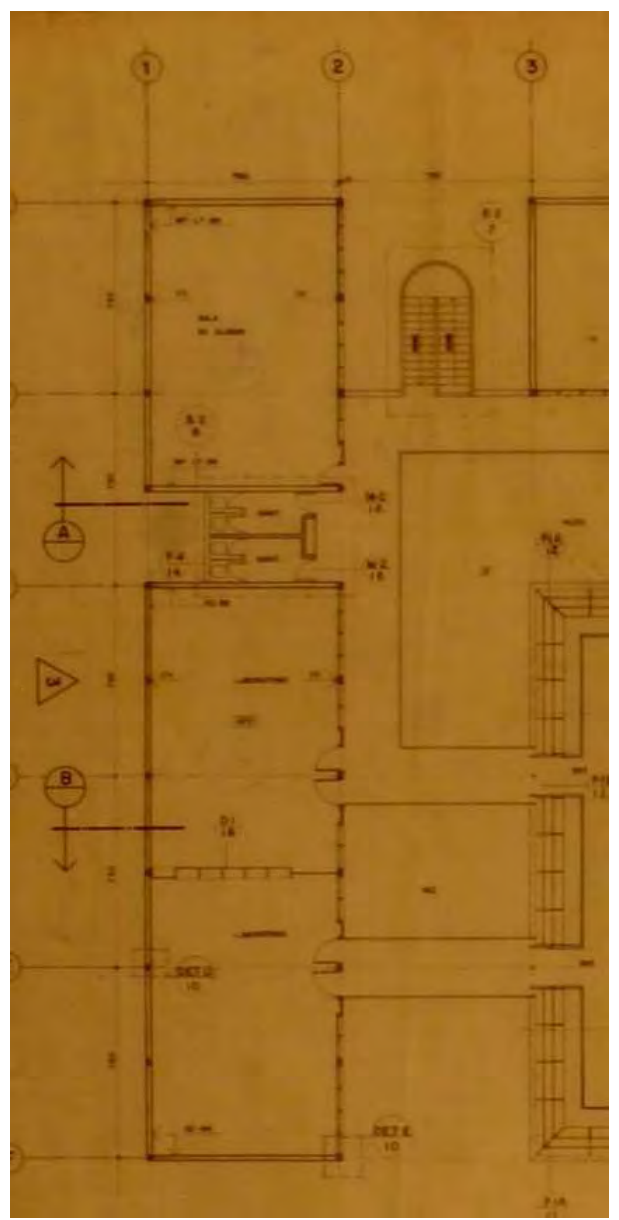


O bloco $G$ não foi construído, porém posteriormente a casa do zelador foi novamente foi projetada e implantada em outro lugar (conforme figura 2). Localizada na face sudoeste do terreno, a casa do zelador foi projetada por Tibau de forma independente dos demais edifícios, com acesso pela entrada de serviço dos caminhões, implantada a 1.35 metros da divisa lateral do lote. $O$ projeto era composto de sala (com possibilidade de ser dividida em sala e dormitório), dormitório, banheiro, cozinha e terraço descoberto.

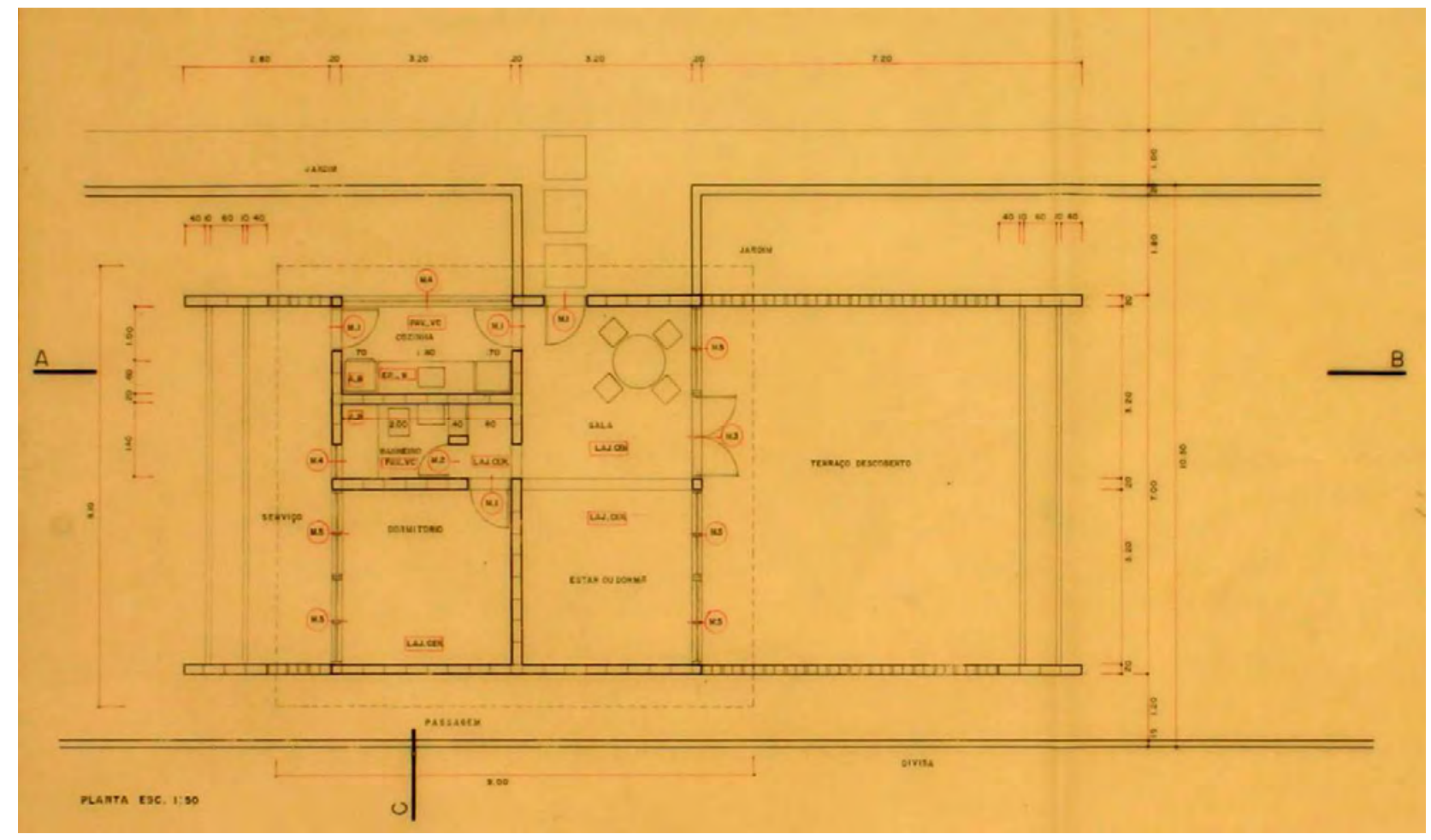

Figura 21: Planta da Casa do Zelador, retirada da prancha 1 do projeto da Casa do Zelador, original na escala 1:50, Escola Industrial do Bom Retiro, s.d. Fonte: Foto Ferraz, arquivo SENAI

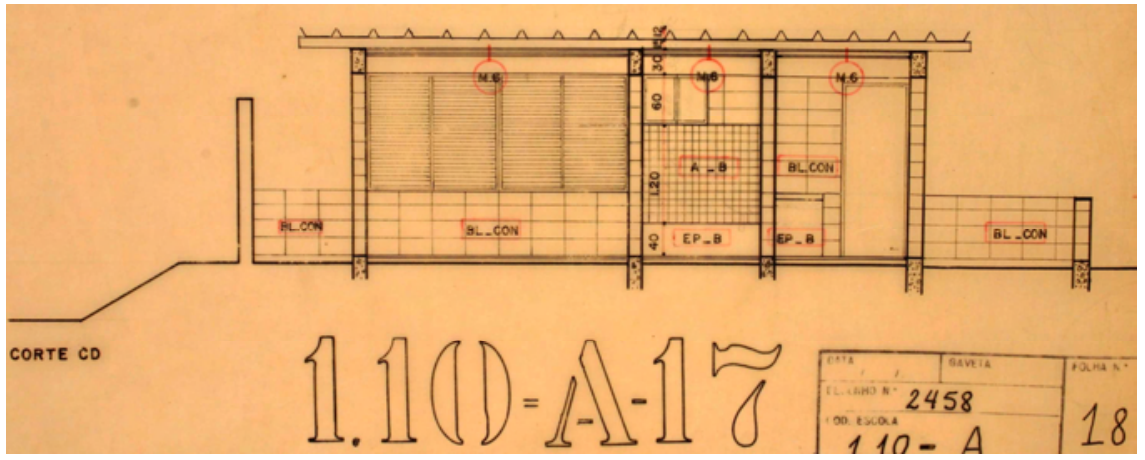

Figura 22: Corte $C D$, retirada da prancha 1 do projeto da

Casa do Zelador, original na escala 1:50, Escola Industrial do Bom Retiro, s.d. Fonte: Foto Ferraz, arquivo SENAI 
Figura 23: Elevação Serviço, retirada da prancha 2 do projeto da Casa do Zelador, original na escala 1:50, Escola Industrial do Bom Retiro, s.d.

Fonte: Foto Ferraz, arquivo SENAI
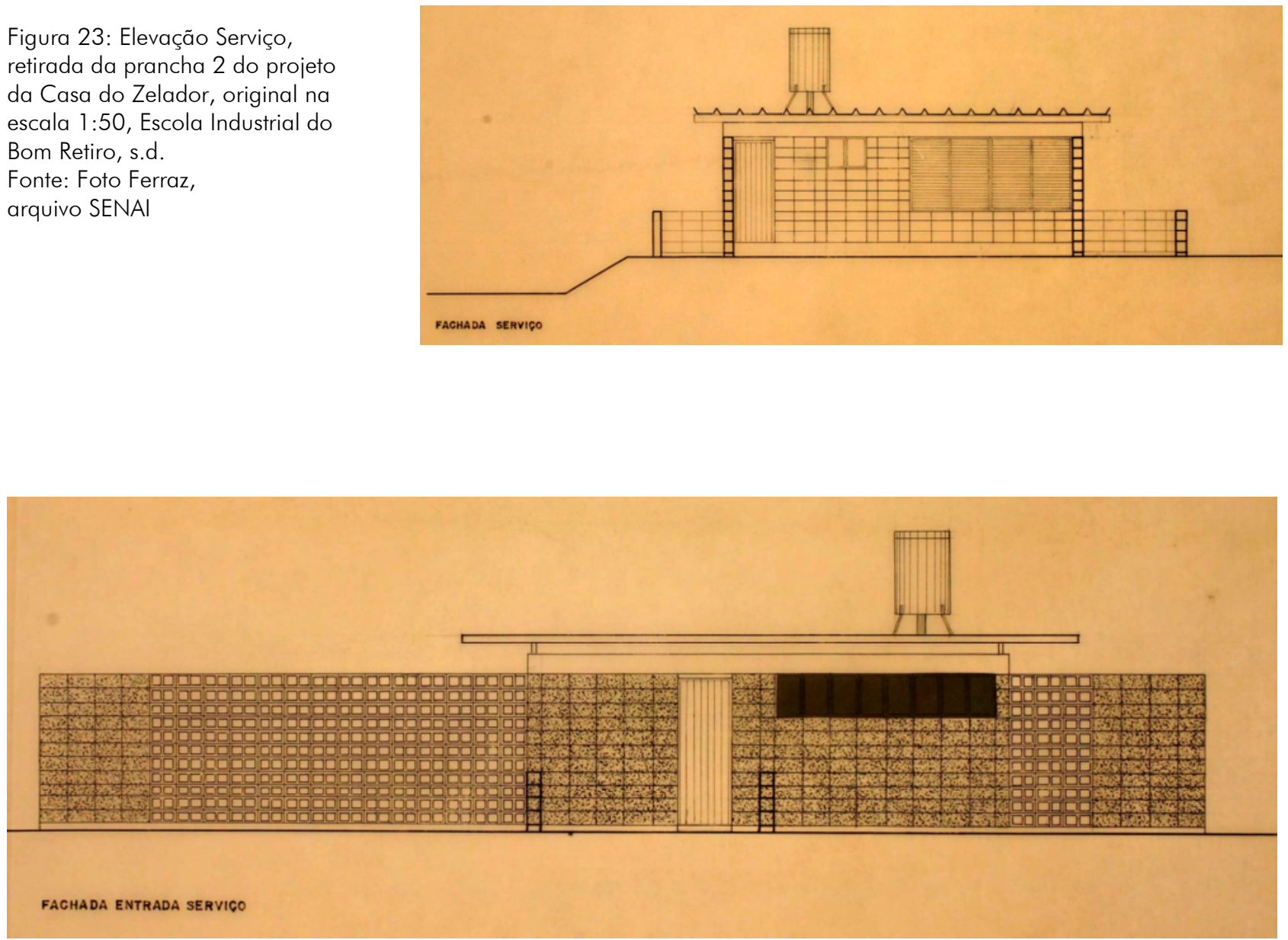

Figura 24: Elevação Entrada Serviço, retirada da prancha 2 do projeto da Casa do Zelador, original na escala 1:50, Escola Industrial do Bom Retiro, s.d.

Fonte: Foto Ferraz, arquivo SENAI

A Escola Industrial do Bom Retiro reflete as características arquitetônicas propostas na pedagogia do SENAI. Os blocos, ligados entre si, acusam o rendimento para realização da educação integral. Um aspecto importante é a solução do bloco da oficina com faces laterais inclinadas e área de trabalho projetada em dois pavimentos, totalmente independente, apenas com acesso entre um piso e outro através das escadas e passarelas externas ao bloco. Apesar de ter sido projetada no final da década de 60, esta escola ainda evidencia a relação entre teoria e prática com as passarelas de ligação entre oficina e salas de aula. Assim como na Escola Anchieta, esta solução evidencia a influência da autoria de Hélio Duarte em ambos os projetos. 


\section{PROJETO 23}

\section{Escola de Limeira, 1968}

A Escola de Limeira foi projetada em 1968 pelo arquiteto Melanias M. Nagamini. Implantada numa quadra de $12.820,00 \mathrm{~m}^{2}$, localizada à Praça Professor Antonio de Queiroz 72, entre as ruas Eduardo Lucato, São Vicente de Paula e Marechal Humberto de Alencar Castelo Branco, o projeto original tinha $5.089,78 \mathrm{~m}^{2}$ de área construída, sendo $3.413,13 \mathrm{~m}^{2}$ do pavimento térreo, $1.425,65 \mathrm{~m}^{2}$ do pavimento superior e $251,00 \mathrm{~m}^{2}$ de áreas cobertas. A escola, projetada ao longo da rua da Praça, teve sua fachada principal voltada para a face leste, composta por diferentes volumes, caracterizados por três blocos: pavilhão social e salas de aula (bloco A), administração (bloco B) e, oficina (bloco C).

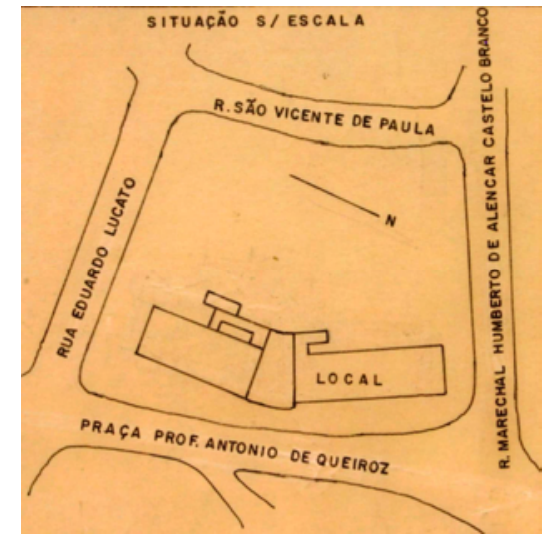

Figura 1: Planta de situação da Escola Senai de Limeira, 1968 Fonte: Foto Ferraz, arquivo

programa construtivo foi dividido nos três blocos, projetados um ao lado do outro, unidos por juntas de dilatação. A escola foi composta originalmente por: pavilhão social, palco, cantina, copa, sala de espera, salas de atendimento médico e dentário, depósitos, sanitários, sala de serventes, oito salas de aula, sala dos professores, sala do auxiliar de direção e biblioteca (bloco A); hall de acesso e exposição, diretoria, sala de espera, secretaria, depósito, sala de instrutor e sanitários (bloco B); oficina, cabine primária, depósitos, sanitários, duas salas de estudo dirigido, salas do instrutor chefe, metrologia, forja e tratamento térmico, solda oxiacetilenica, solda elétrica, corte, gás e duas salas de agência de treinamento (bloco C) e uma quadra de vôlei e basquete com pista de atletismo e arquibancada. 
Os dados completos sobre o projeto executivo original deste projeto foram obtidos no arquivo do SENAI, como as pranchas de situação e locação (figura 2), plantas dos pavimentos térreo e superior, cortes e fachadas, totalizando cerca sete pranchas de desenhos executivo, além de inúmeras pranchas de detalhamento (figuras 3 a 6). Através destas pranchas pode-se afirmar que o projeto foi ampliado em $64,45 \mathrm{~m}^{2}$, ainda no ano de 1968, pois as áreas a construir foram desenhadas sobre a mesma prancha do projeto original.

Figura 2: Observar os dados do selo do projeto, original da escala 1:200, Escola Senai de Limeira, concebido em setembro de 1968, com autoria de Melanias M. Nagamini.

Fonte: Foto Ferraz, arquivo SENAI

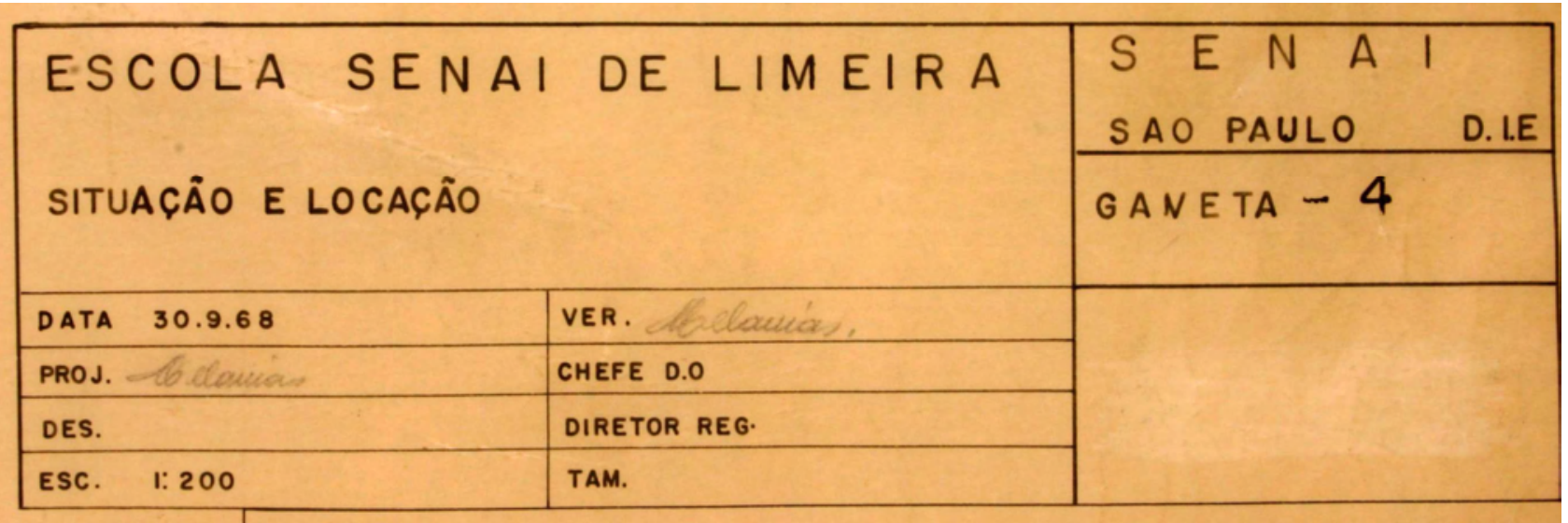




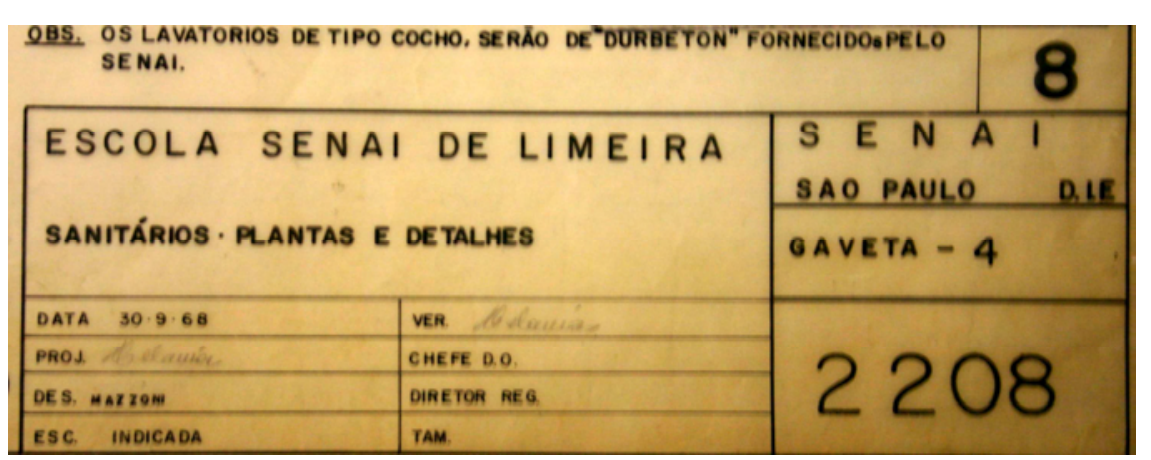

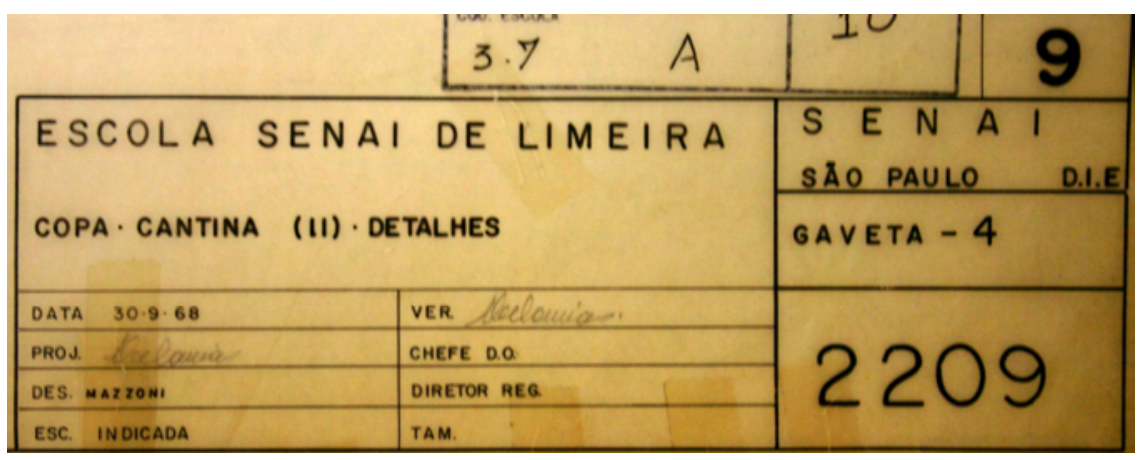

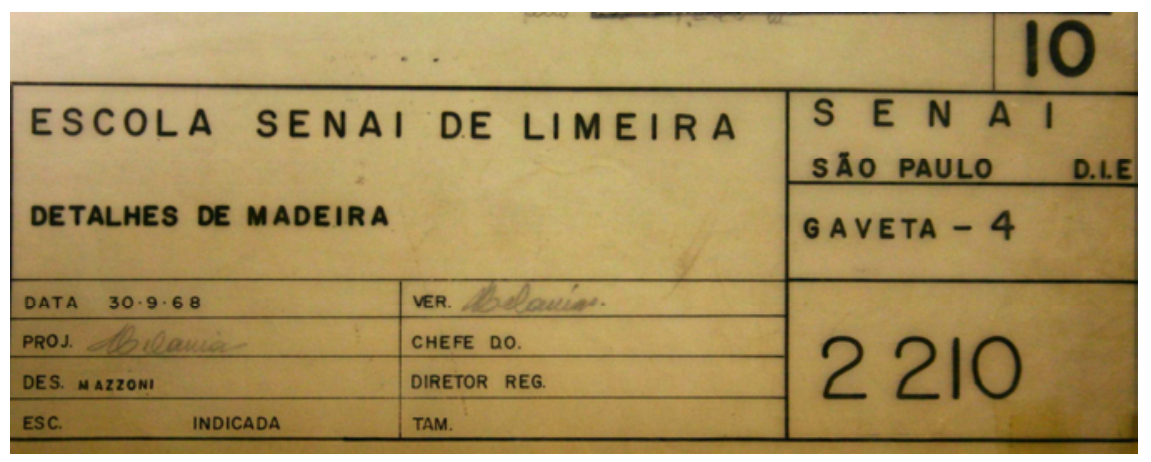

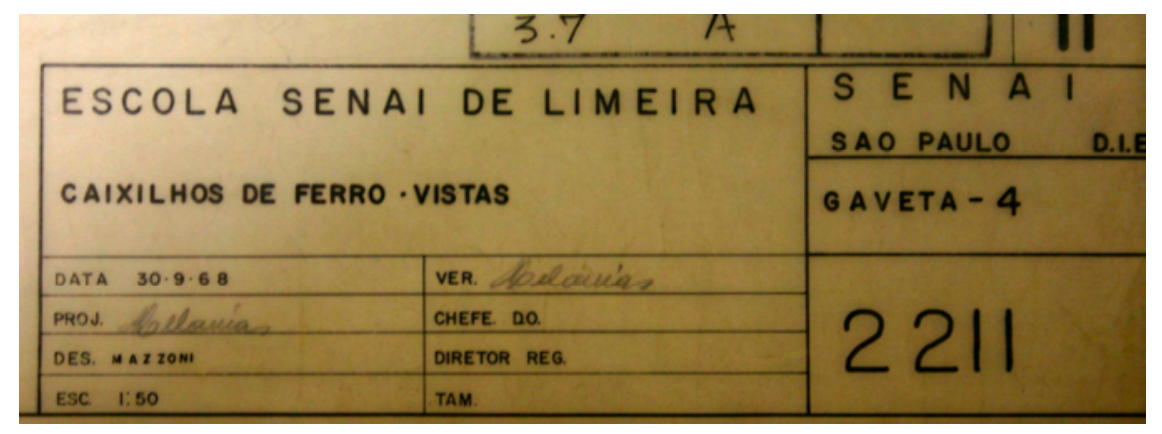

Figura 3: Selo da prancha 8 de detalhamento dos sanitários, Escola Senai de Limeira, concebido em setembro de 1968, com autoria de Melanias M. Nagamini. Fonte: Foto Ferraz, arquivo SENAI

Figura 4: Selo da prancha 9 de detalhamento da copa e cozinha, Escola Senai de Limeira, concebido em setembro de 1968, com autoria de Melanias M. Nagamini. Fonte: Foto Ferraz, arquivo SENAI

Figura 5: Selo da prancha 10 de detalhamento de madeira, Escola Senai de Limeira, concebido em setembro de 1968, com autoria de Melanias M. Nagamini. Fonte: Foto Ferraz, arquivo SENAI

Figura 6: Selo da prancha 11 de detalhamento dos caixilhos de ferro, Escola Senai de Limeira, concebido em setembro de 1968, com autoria de Melanias M. Nagamini. Fonte: Foto Ferraz, arquivo SENAI 


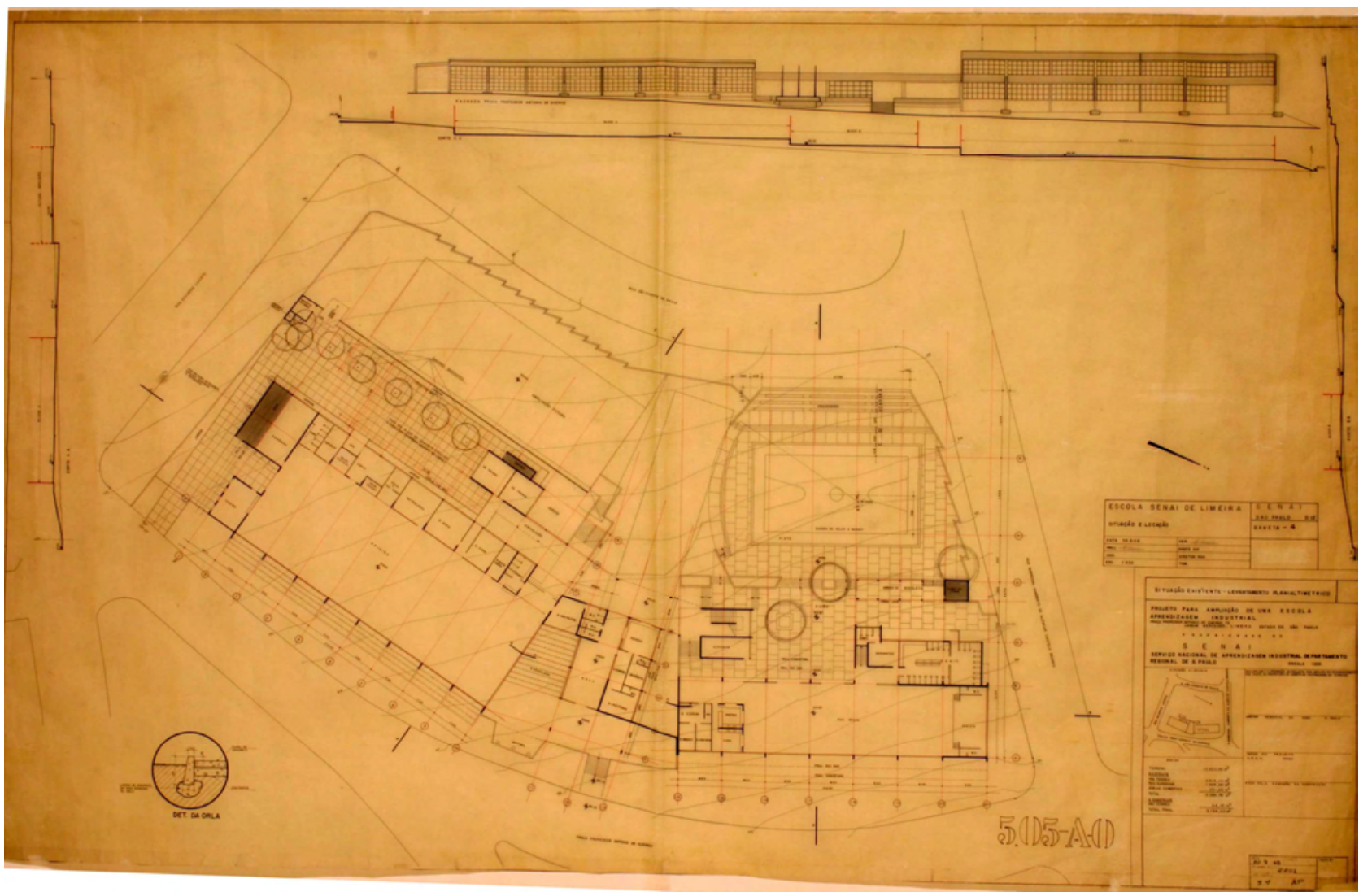

Figura 7: Prancha 1, projeto original, Planta de Situação e Locação, original na escala 1:200, Escola Senai de Limeira, 1968. Fonte: Foto Ferraz, arquivo SENAI

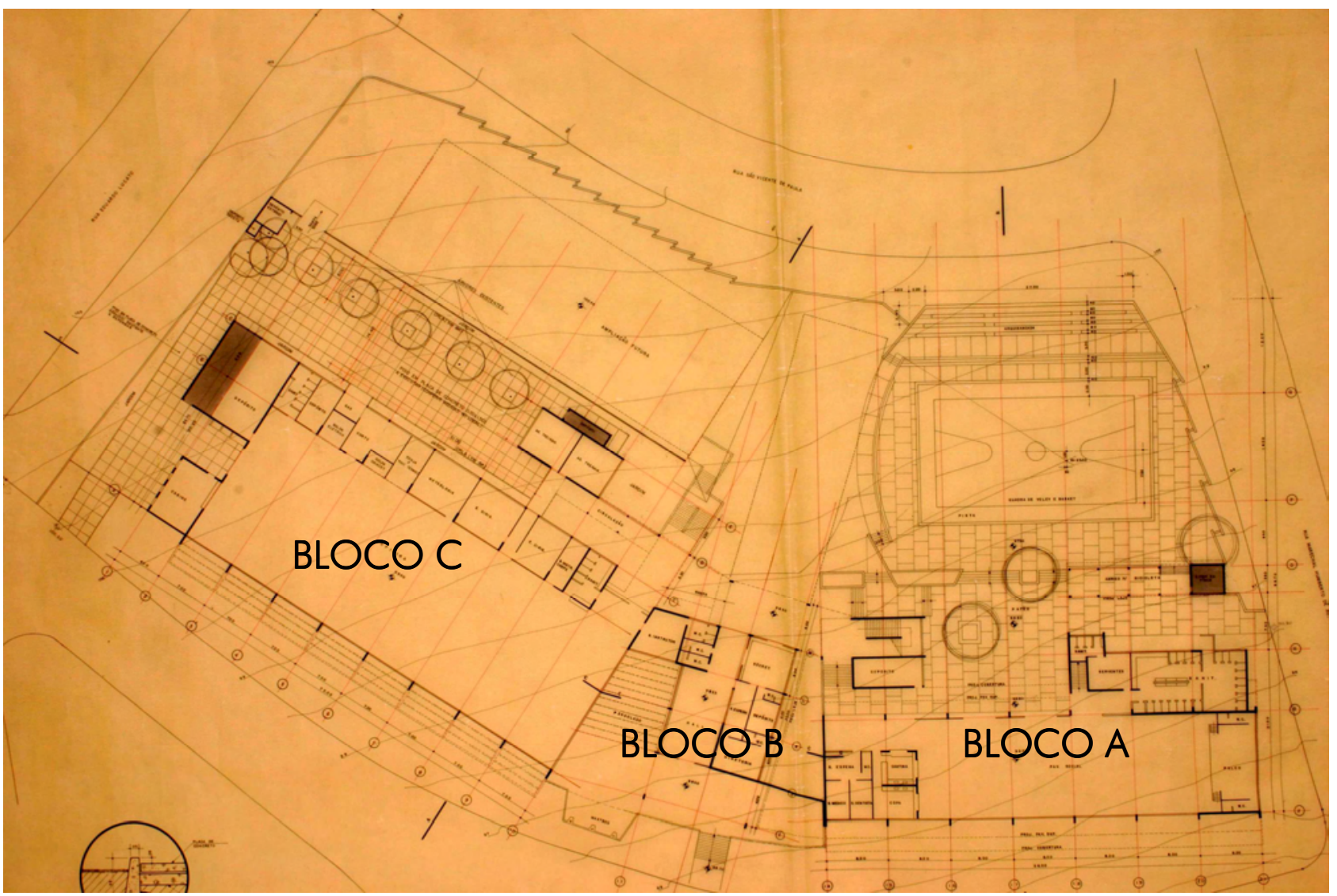

Figura 8: Planta de situação, original na escala 1:200, Escola Senai de Limeira, 1968.

Fonte: Foto Ferraz, arquivo SENAI 


\begin{tabular}{|c|c|c|c|}
\hline \multirow{2}{*}{$\begin{array}{l}\text { ESCOLA } \\
\text { FACHADAS }\end{array}$} & \multirow{2}{*}{\multicolumn{2}{|c|}{ LIMEIRA. }} & $\begin{array}{l}\text { S E N A I } \\
\text { SAO PAULO }\end{array}$ \\
\hline & & & G AVETA - 4 \\
\hline DATA $30.9: 68$ & & ver. Mbelanias & \\
\hline PROJ. Dbelauie & & CHEFE D.O. & \\
\hline DES. MAZZONa & & DIRETOR REG & \\
\hline ESC. $1: 100$ & & TAM. & \\
\hline
\end{tabular}

Figura 9: Selo da prancha 7 de fachadas, Escola Senai de Limeira, concebido em setembro de 1968, com autoria de Melanias M. Nagamini. Fonte: Foto Ferraz, arquivo SENAI

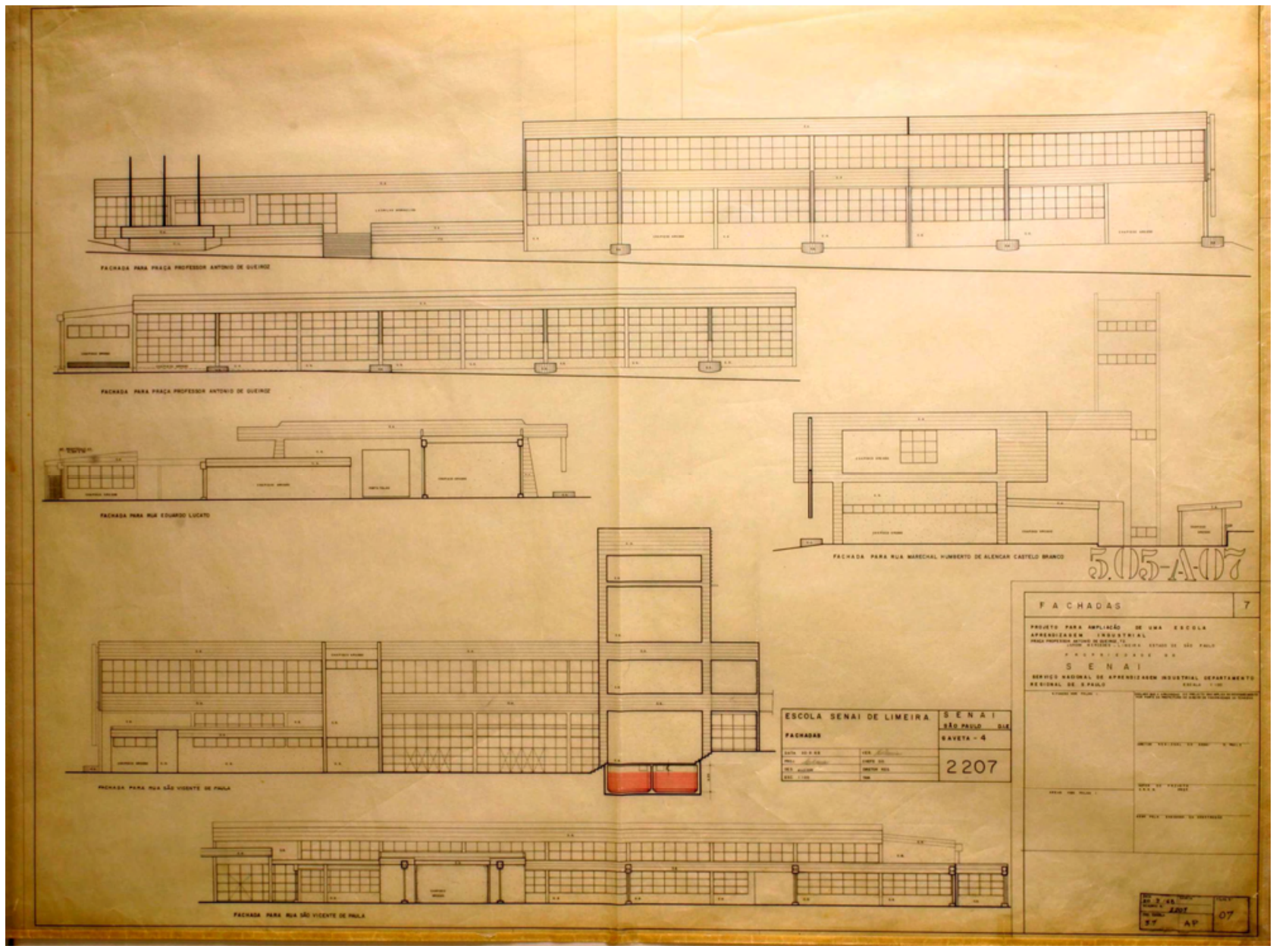

Figura 10: Prancha 7 do projeto original das Fachadas, original na escala 1:100, Escola Senai de Limeira, 1968. Fonte: Foto Ferraz, arquivo SENAI

O primeiro bloco foi projetado em dois pavimentos, no nível mais baixo do terreno (cota 96,90). Modulado com eixos longitudinal de 8,00 metros e transversal de 13 metros, o bloco $A$ recebeu iluminação e ventilação bilaterais pela faces nordeste e sudoeste. $\bigcirc$ pavimento térreo, composto principalmente pela grande área livre do pavilhão social (atratividade e sociabilidade), também abrigava os complementos necessários para atender as atividades dessa área de 
Figura 11: Corte BB (corte transversal do bloco $A)$, retirado da Prancha 6 do projeto original dos Cortes,

original na escala 1:100, Escola Senai de Limeira, 1968.

Fonte: Foto Ferraz, arquivo SENAI

Figura 12: Elevação do bloco A pela rua Marechal Humberto de Alencar Castelo Branco, retirada da Prancha 7 do projeto original das Fachadas, original na escala 1:100, Escola Senai de Limeira, 1968.

Fonte: Foto Ferraz, arquivo SENAI recreação coberta, como palco, copa, cantina, sala de espera, salas de atendimento médico e dentário, depósito, sanitários e sala de serventes. $\bigcirc$ pavimento superior foi destinado principalmente às salas de aula (oito), e seus complementos: sala dos professores, sala do auxiliar de direção, biblioteca, sanitários e depósito. Com circulação central, o pavimento superior dividiu as salas de aula nas laterais longitudinais do bloco, seis projetadas para a face nordeste e duas para a sudoeste, todas separadas por paredes, com iluminação e ventilação direta pelas laterais, mantendo ventilação cruzada pelas aberturas voltadas para a circulação (observar corte BB, figura 11). $O$ pavimento térreo foi recuado em relação ao superior, tornando o pavilhão social termicamente mais confortável.
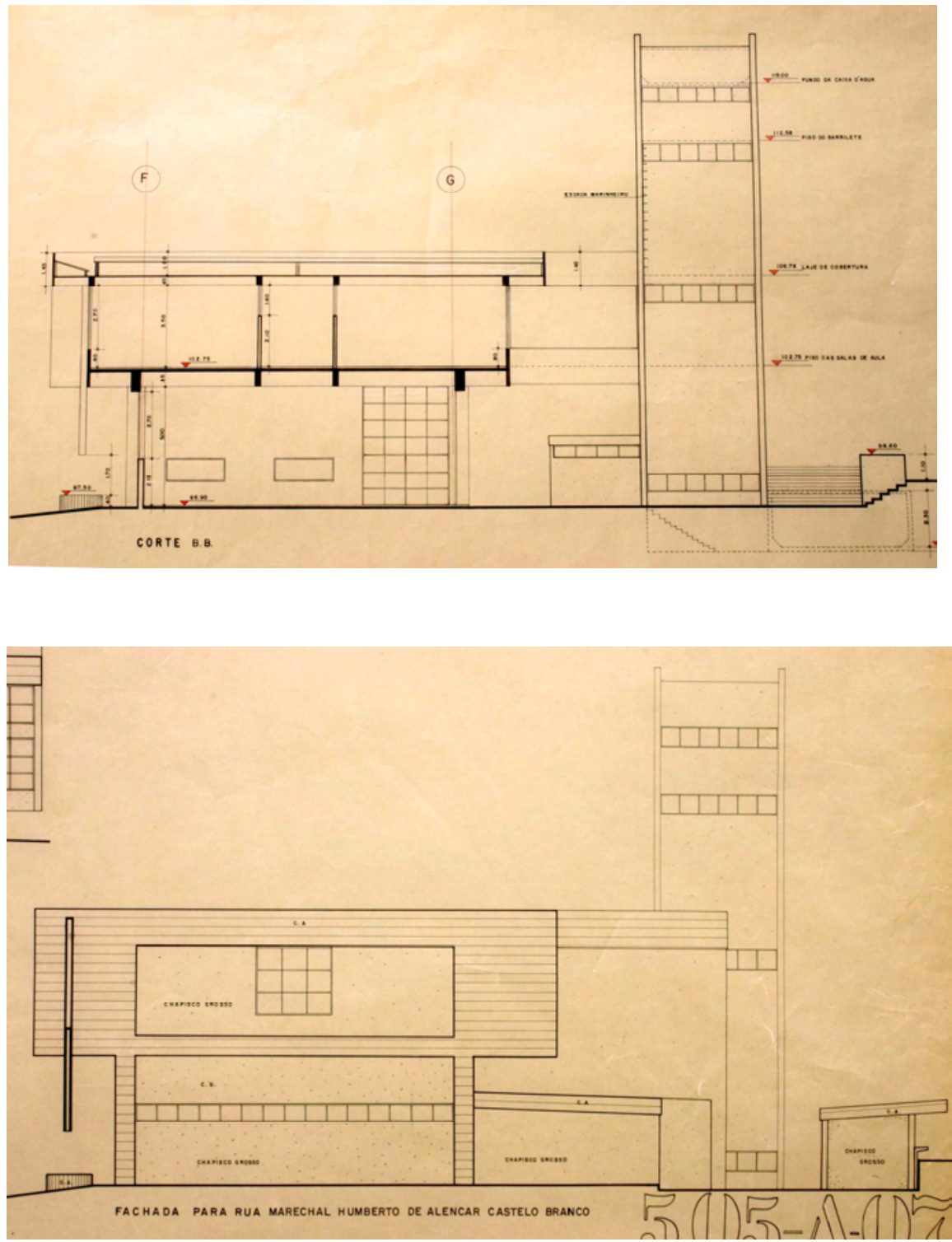
bloco B, projetado em nível intermediário (cota 98,50), foi composto de um único pavimento. Como eixo de ligação entre os blocos A e C, a planta do bloco B foi levemente rotacionada, acompanhando a curva do terreno. Como acesso principal à escola, este bloco era composto de hall de acesso (também projetado como área de exposição), diretoria, sala de espera, secretaria, depósito, sanitários e sala de instrutor (com acesso pela oficina, no bloco C). Com pé-direito de 4,20 metros sob a laje, este bloco além de atender à administração, funcionava com um importante eixo de circulação para as demais partes da escola, tanto à área interna da escola, às atividades esportivas e de lazer, à oficina, como ao pavilhão social e as salas de aula.
Figura 13: Corte CC (corte transversal do bloco $B$ ), retirado da Prancha 6 do projeto original dos Cortes, original na escala 1:100, Escola Senai de Limeira, 1968.

Fonte: Foto Ferraz, arquivo SENAI

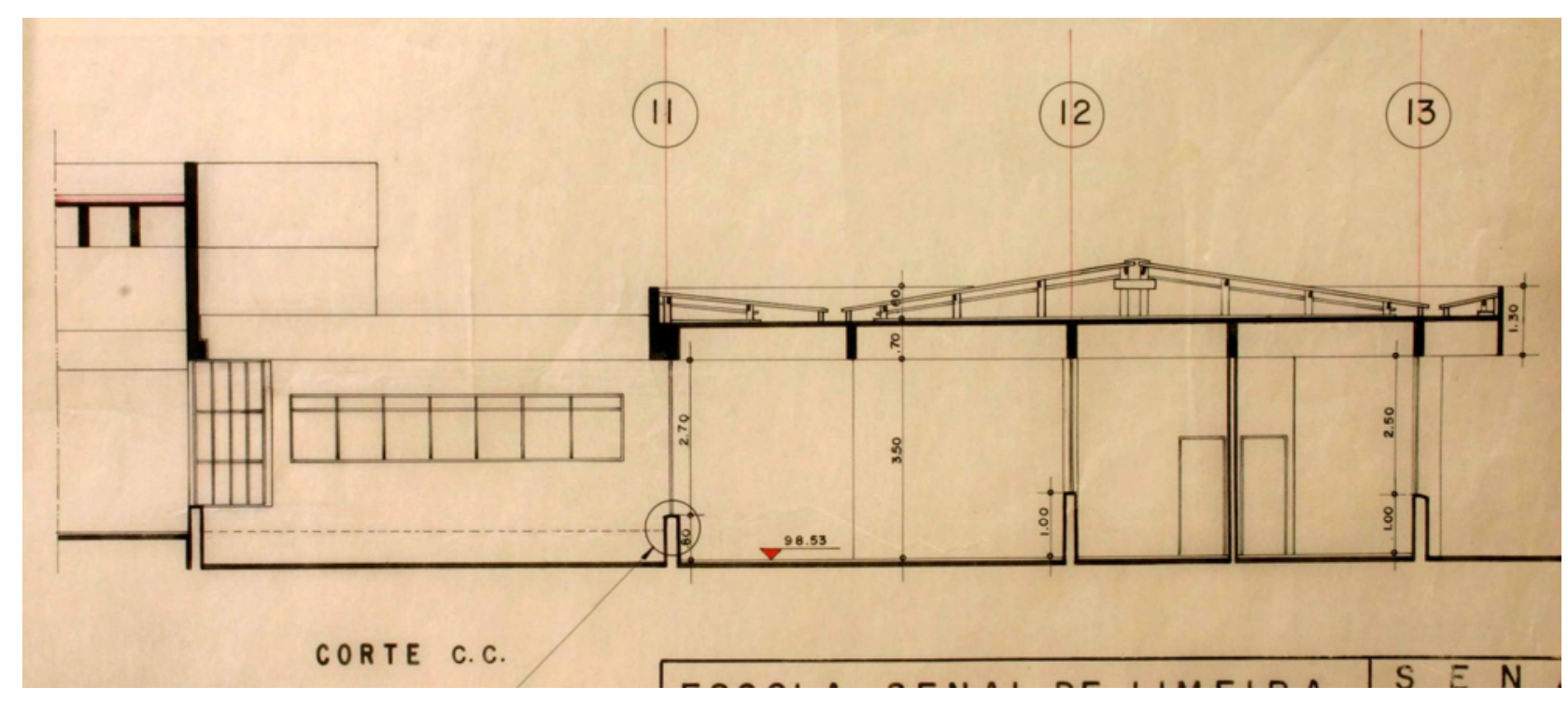


O bloco C, projetado no nível mais alto (cota 99,00), foi resolvido em um único pavimento. Modulado com eixo longitudinal de 7,00 metros, este bloco foi levemente rotacionado em relação aos demais, seguindo a curva do terreno. $O$ programa construtivo foi caracterizado pela oficina e seus complementos como cabine primária, depósitos, sanitários, duas salas de estudo dirigido, salas do instrutor chefe, metrologia, forja e tratamento térmico, solda oxiacetilenica, solda elétrica, corte, tanque de lavar peças, gás e duas salas de agência de treinamento. Porém, estas duas últimas salas foram projetadas separadamente, interligadas ao grande bloco da oficina por passarelas cobertas (figura 14). A área de trabalho da oficina recebeu iluminação e ventilação pelas faces leste e norte (economia), sendo a face leste protegida por um largo beiral de 4 metros. Com pé-direito de 5 metros sob a viga, a planta livre da oficina ficou sem qualquer tipo de pilar devido à solução projetual técnica da laje nervurada.

Figura 14: Elevação do bloco C pela rua Eduardo Lucato, retirada da Prancha 7 do projeto original das Fachadas,

riginal na escala 1:100,

Escola Senai de Limeira, 1968.

Fonte: Foto Ferraz,

arquivo SENAI

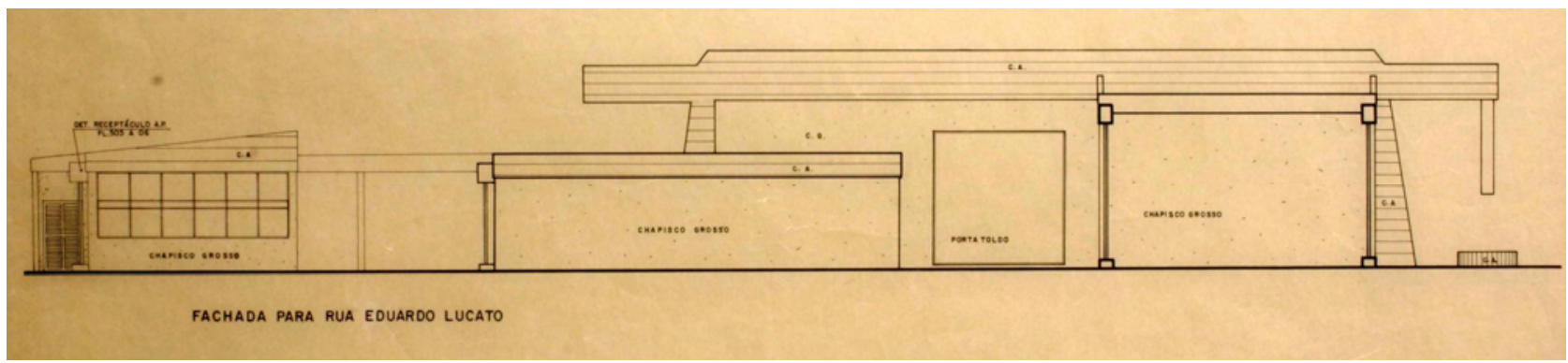

A princípio, este é mais um projeto baseado na filosofia educacional do SENAI, mesmo com algumas soluções diferentes das primeiras escolas projetadas na década de 50, como a divisão das salas de aulas com paredes e a separação visual das salas de aula (teoria) com a oficina (prática). 


\subsubsection{SENAC e SESC 1955-1968: modernas escolas para o ensino do comércio}

Como parte desta geração de profissionais que já vinha atuando anos antes no Convênio Escolar, é importante ressaltar a figura de Oswaldo Corrêa Gonçalves (1917-2005), responsável pelos primeiros exemplares de dois "S" modernos SESC-SENAC, conforme afirmou o arquiteto em entrevista' concedida à pesquisadora no ano de 2002:

\footnotetext{
Ele [o Convênio Escolar], causou muito boa impressão porque os projetos começaram a ser modernos, da arquitetura moderna, coisa que a prefeitura não fazia. Foi o Convênio Escolar o primeiro passo para ampliar a arquitetura moderna nas escolas municipais.
}

FERRAZ (2003:293-297, entrevista completa)

Outra herança deixada pelo Convênio Escolar foi a concepção da arquitetura moderna tributária às idéias de Anísio Teixeira e da Escola Nova, com o objetivo de tornar a escola ativa e interessante através dos diversos processos pedagógicos. Oswaldo Gonçalves $^{2}$, utilizando e aprimorando a experiência obtida durante o Convênio Escolar, realizou no SESC e no SENAC a tarefa de projetar escolas que fossem um incentivo permanente no plano da educação dentro de princípios que pautaram a nova arquitetura escolar de cada Serviço.

Vale lembrar que a provável indicação de Gonçalves, contratado pela Federação do Comércio para projetar as novas escolas SESC-SENAC, tenha sido influenciada pelo contato direto com o presidente desta Federação, o amigo e engenheiro Luís Roberto de Carvalho Vidigal.

\footnotetext{
1 Em 25 de outubro de 2002 Oswaldo Corrêa Gonçalves foi entrevistado pela pesquisadora. Esta entrevista foi publicada na dissertação Marcas do Moderno na Arquitetura de Bauru (FERRAZ, 2003:293-297).

2 Assim como Hélio Duarte, Ernest Mange e Roberto Tibau fizeram no "S" moderno SENAI.
} 
Foi pela Federação do Comércio [quem contratou Gonçalves para fazer os projetos], que a Federação do Comércio é que tem o SESC-SENAC, então eu fui contratado, mas quem mandava e exigia era a Federação que naquele tempo tinha como Presidente o Luís Roberto de Carvalho Vidigal, engenheiro amigo meu, e ele é que passava os trabalhos para eu fazer e eu me lembro que era o SESC-SENAC juntos.

FERRAZ (2003:293-297, entrevista completa)

Com o objetivo de complementar as novas características pedagógicas, os edifícios modernos do SESC-SENAC destacaram a conjugação de arquitetura e artes plásticas, expressa através do suporte de painéis artísticos, conforme uma das recomendações deixadas por Le Corbusier no que diz respeito à valorização dos aspectos regionais, explicitados por Yves Bruand, em Arquitetura Contemporânea no Brasil, além da influência do Movimento Muralista Mexicano que, como atesta Dawn Ades, em Arte na América Latina:

\footnotetext{
"os muralistas mexicanos produziram a mais importante arte revolucionária, de sentido popular, ocorrida neste século, e a influência deles em toda a América Latina [...] tem sido contínua e de longo alcance".
}

ADES (1997:151)

Neste sentido, esta pesquisa procura demonstrar tal arquitetura, cujas construções principalmente no interior do Estado, além de ampliarem a área de divulgação dos princípios da nova arquitetura, visavam atender às necessidades pedagógicas do SESC e do SENAC, aqui reconhecidos através de 10 exemplares apresentados em ordem cronológica. Estes dados podem ser observados pela relação das escolas modernas do SESC e do SENAC (1955-1968) apresentada por tabelas e gráficos baseados na leitura projetual de cada escola investigada.

Os projetos a seguir foram pesquisados nos periódicos da época e em dois arquivos: Faculdade de Arquitetura Urbanismo de Santos (FAUS) $)^{3}$ e Memória Institucional do SENAC ${ }^{4}$.

\footnotetext{
${ }^{3}$ A Faculdade de Arquitetura e Urbanismo de Santos foi criada por Oswaldo Corrêa Gonçalves em 1970 e, após sua morte, em 28 de agosto de 2005, todo o seu acervo (projetos e fotos) foi doado à Faculdade, porém este material ainda não está aberto
} 


\begin{tabular}{|c|c|c|c|c|c|}
\hline \multicolumn{6}{|c|}{ RELAÇÃO DAS ESCOLAS MODERNAS SESC-SENAC: 1955-1968 } \\
\hline ORDEM & $\begin{array}{c}\text { ANO } \\
\text { DE } \\
\text { PROJETO }\end{array}$ & ESCOLA E CIDADE & AUTORES & $\begin{array}{c}\text { ÁREA APROX. } \\
\text { DO TERRENO } \\
\mathrm{m}^{2}\end{array}$ & $\begin{array}{c}\text { ÁREA APROX. } \\
\text { CONSTRUÍDA } \\
\mathrm{m}^{2}\end{array}$ \\
\hline 1 & 1955 & Escola Sesc-Senac, Ribeirão Preto & Oswaldo Corrêa Gonçalves & $4.651,22$ & $1.816,20$ \\
\hline 2 & 1955 & Escola Sesc-Senac, Marília & $\begin{array}{l}\text { Oswaldo Corrêa Gonçalves } \\
\text { Rubens C. Viana e Ricardo Siervers }\end{array}$ & $2.920,00$ & $1.646,00$ \\
\hline 3 & 1956 & Escola Sesc-Senac, Bauru & Oswaldo Corrêa Gonçalves & $3.048,00$ & $1.468,00$ \\
\hline 4 & 1956 & $\begin{array}{l}\text { Escola Senac, Araraquara } \\
\text { (não construída) }\end{array}$ & $\begin{array}{l}\text { Oswaldo Corrêa Gonçalves } \\
\text { Eduardo Corona }\end{array}$ & $1.269,00$ & $1.617,40$ \\
\hline 5 & 1956 & Escola Sesc-Senac, Santos & Oswaldo Corrêa Gonçalves & $3.281,63$ & $2.543,30$ \\
\hline 6 & 1957 & Edifício Sede, São Paulo & Oswaldo Corrêa Gonçalves & * & $*$ \\
\hline 7 & 1958 & Escola Senac, São José do Rio Preto & $\begin{array}{l}\text { Oswaldo Corrêa Gonçalves } \\
\text { Osmar Tosi e Adolfo Rubio Morales }\end{array}$ & $2.603,35$ & $1.610,77$ \\
\hline 8 & 1963 & Edifício Avenida Tiradentes, São Paulo & $\begin{array}{l}\text { Jorge Wilheim e } \\
\text { Miguel Juliano e Silva }\end{array}$ & $*$ & $*$ \\
\hline 9 & 1964 & Escola Senac, Botucatu & Rubens Carneiro Viana & $4.526,90$ & $1.068,00$ \\
\hline 10 & 1964 & Escola Senac, Santo André & $\begin{array}{l}\text { Jorge Wilheim e } \\
\text { Miguel Juliano e Silva }\end{array}$ & $4.204,00$ & $1.584,40$ \\
\hline
\end{tabular}

Tabela 1: Relação das escolas modernas do

SESC-SENAC:1955-1968. Os dados assinalados $(*$ ) não foram encontrados no projeto original.

Fonte: Autora

para a consulta de pesquisadores. Através da autorização do professor da FAUS Gino Caldato, uma exceção foi concedida e todo o acervo de Gonçalves pôde ser consultado pela pesquisadora para a realização deste trabalho. Portanto, são apresentados alguns projetos originais encontrados e uma grande quantidade de fotos ainda inéditas na historiografia.

${ }^{4}$ O Edifício que abriga o setor chamado Memória Institucional do SENAC está localizado em São Paulo, rua Boracéa 33, Barra Funda, sob a organização de Lígia Palhares Silva. Os projetos das décadas de 40,50 e 60 foram consultados neste acervo, rico em material iconográfico sobre o SENAC e também sobre o SESCSENAC (no período em que funcionavam em prédios conjugados). 
Tabela 2: Relação das escolas modernas do

SESC-SENAC:1955-1968.

Observar o número de blocos e o tipo de escola.

Fonte: Autora

\begin{tabular}{|c|c|l|c|l|}
\hline \multicolumn{2}{|c|}{ RELAÇÃO DAS ESCOLAS MODERNAS SESC-SENAC: 1955-1968 } \\
\hline ORDEM & $\begin{array}{c}\text { ANO } \\
\text { DE } \\
\text { PROJETO }\end{array}$ & \multicolumn{1}{|c|}{ ESCOLA E CIDADE } & $\begin{array}{c}\text { No } \\
\text { DE } \\
\text { BLOCOS }\end{array}$ & \multicolumn{1}{|c|}{ TIPO } \\
\hline 1 & 1955 & Escola Sesc-Senac, Ribeirão Preto & 3 & SESC-SENAC \\
\hline 2 & 1955 & Escola Sesc-Senac, Marília & 2 & SESC-SENAC \\
\hline 3 & 1956 & Escola Sesc-Senac, Bauru & 1 & SESC-SENAC \\
\hline 4 & 1956 & $\begin{array}{l}\text { Escola Senac, Araraquara } \\
\text { (não construída) }\end{array}$ & 1 & SENAC \\
\hline 5 & 1956 & Escola Sesc-Senac, Santos & 2 & SESC-SENAC \\
\hline 6 & 1957 & Edifício Sede, São Paulo & 1 & EDIFÍCIO SEDE \\
\hline 7 & 1958 & Escola Senac, São José do Rio Preto & 1 & SENAC \\
\hline 8 & 1963 & Edifício Avenida Tiradentes, São Paulo & 1 & SENAC \\
\hline 10 & 1964 & Escola Senac, Santo André & 5 & SENAC \\
\hline 9 & 1964 & Escola Senac, Botucatu & 2 & SENAC \\
\hline
\end{tabular}

Gráfico 1: Observar as escolas SESC-SENAC:1955-1968 em relação à dimensão lotes.

Fonte: Autora

Gráfico 2: Observar as escolas SESC-SENAC:1955-1968 em relação à área construída. Fonte: Autora
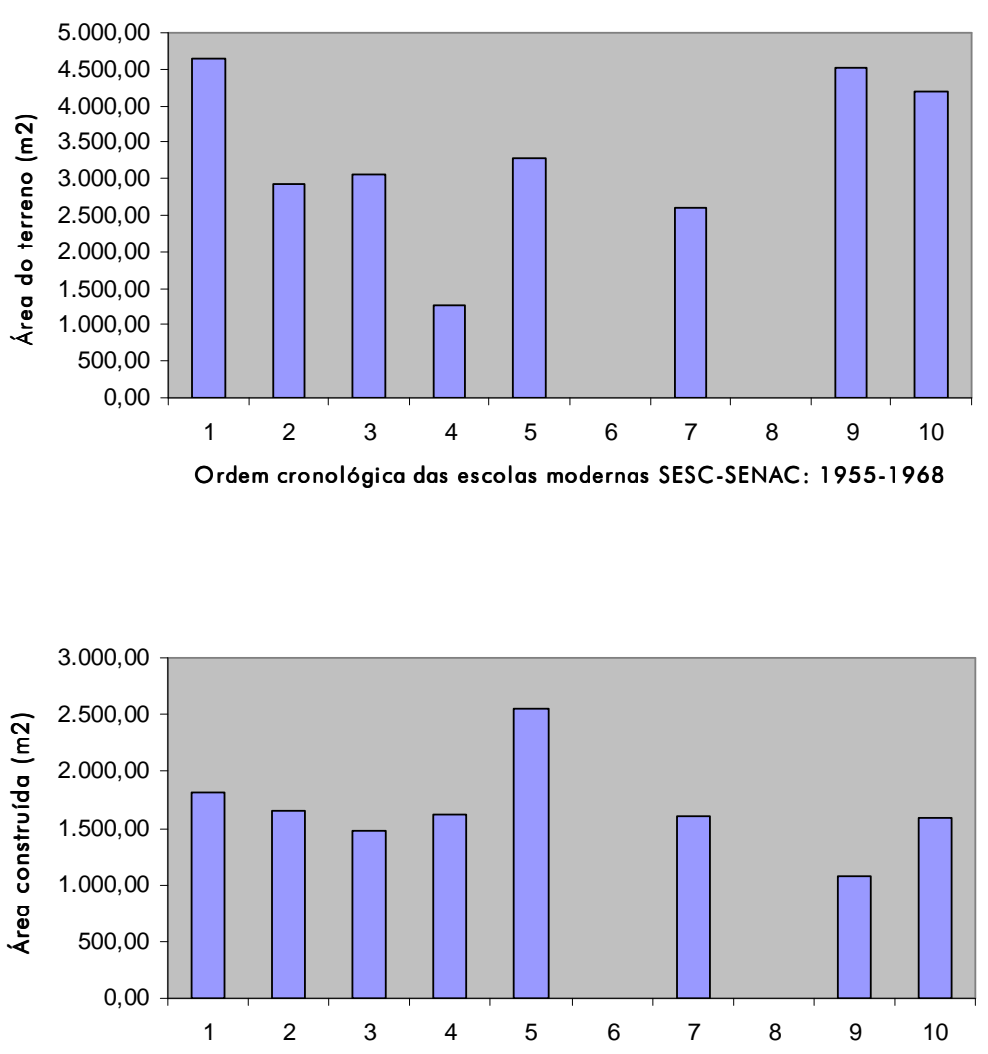

Ordem cronológica das escolas modernas SESC-SENAC: 1955-1968 


\section{PROJETO 1}

\section{Escola Sesc-Senac de Ribeirão Preto, 1955}

Projetada por Oswaldo Corrêa Gonçalves, a Escola SescSenac de Ribeirão Preto' foi a primeira escola a ser projetada e construída de acordo com a moderna pedagogia moderna de seus Serviços. Implantada num terreno e $4.651,22 \mathrm{~m}^{2}$, a escola foi composta originalmente por três blocos, porém apenas dois blocos destinados à escola $\left(1403,06 \mathrm{~m}^{2}\right)$ e à piscina $\left(413,14 \mathrm{~m}^{2}\right)$ foram construídos, totalizando aproximadamente $1816,20 \mathrm{~m}^{2}$ de área construída.

A escola originalmente teve seu programa construtivo dividido em três blocos: o primeiro (não construído) composto de ginásio de esportes, palco e vestiários; o segundo (construído) com piscina, trampolim, terraço e vestiários e, por fim, o terceiro bloco (construído) projetado em dois pavimentos, sendo o SESC no pavimento térreo e o SENAC no pavimento superior. Portanto, o terceiro bloco da escola foi resolvido no térreo com ambientes para atender ao SESC - espera e entrada, salas de atendimento dentário e médico, raio $\mathrm{x}$, registro geral, enfermaria, obstetrícia, pediatria, sala visitadora, sala de corte e costura, copa-cozinha, auditório, sanitários e pátio coberto -, e no pavimento superior para atender ao SENAC - espera e entrada, sala dos professores, biblioteca, museu, sanitários, almoxarifado, sala de datilografia, loja modelo, oito salas de aula, secretaria, arquivo e diretoria.

O projeto original foi encontrado na FAUS, tanto pranchas do ante-projeto como do projeto de prefeitura na escala 1:100, assim como algumas pranchas do projeto executivo. Essenciais para a compreensão do projeto, duas pranchas do ante-projeto revelaram a idéia inicial da concepção em três blocos, iá as quatro pranchas do projeto de prefeitura apresentaram apenas os dois blocos que realmente foram construídos juntamente com algumas modificações destes em relação ao ante-projeto. Ainda, na FAUS, foram obtidas fotos do edifício e da maquete, além do acesso à prancha da perspectiva do projeto. $\bigcirc$ conhecimento do projeto original também 
foi obtido através da publicação em periódicos da época, Acrópole $\mathrm{n}^{\circ}$ 220 (1957:1 19-123) e $A B n^{\circ} 7$ (1972:86-87).

Figuras 1 e 2: Observar os dados dos selos do ante-projeto original da Escola Sesc-Senac de Ribeirão Preto, concebido em 1955, com autoria de Oswaldo Corrêa Gonçalves. Fonte: Foto Ferraz, arquivo FAUS.

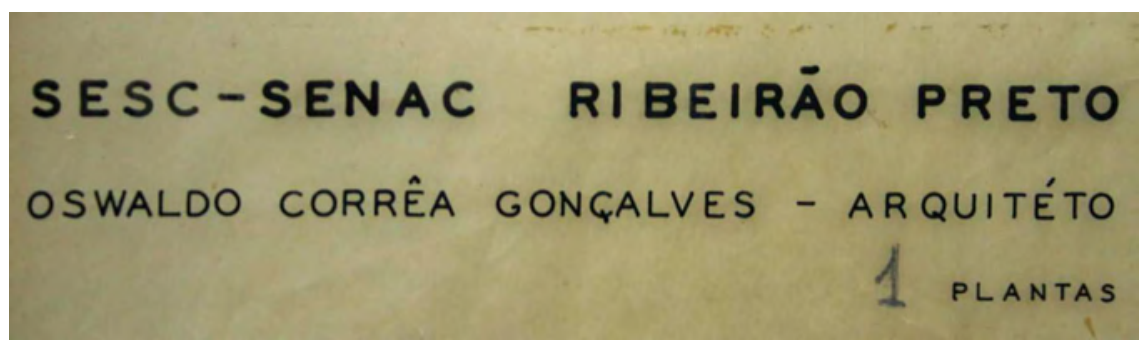

\section{SESC-SENAC RIBEIRÄO PRETO} OSWALDO CORRÊA GONGALVES - ARQUITÉTO Córtes e fachadas 2
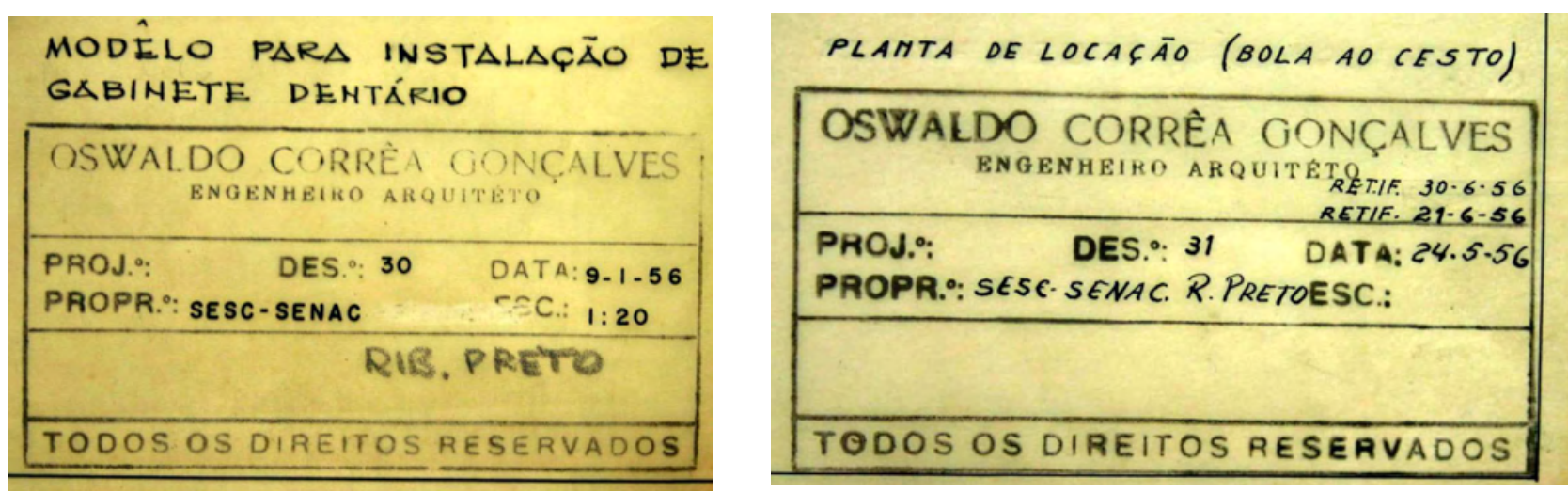

Figura 3 e 4: Observar os dados dos selos do projeto executivo da Escola Sesc-Senac de Ribeirão Preto, concebido em janeiro e maio de 1956, com autoria de Oswaldo Corrêa Gonçalves. Fonte: Foto Ferraz, arquivo FAUS. 


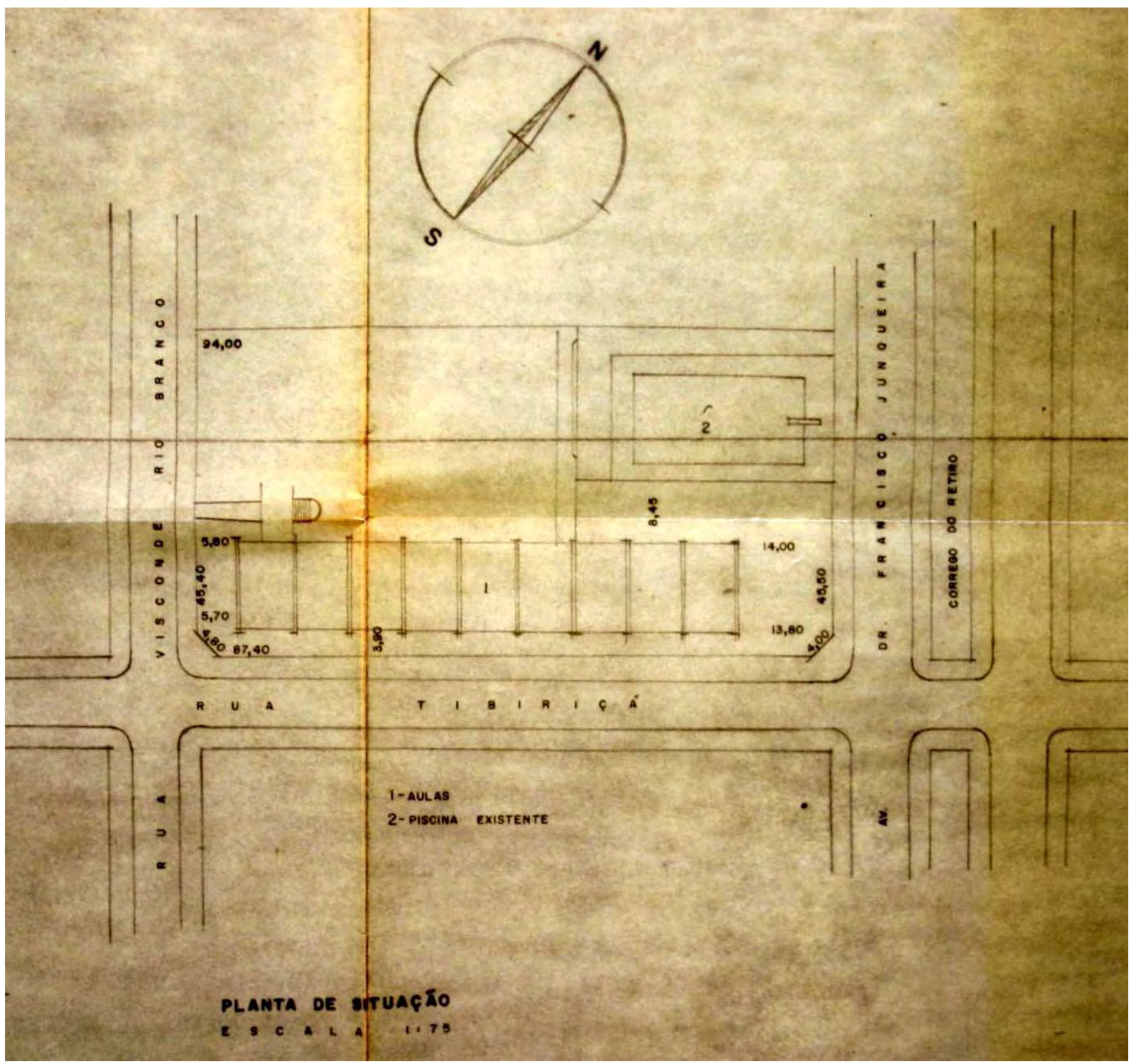

Figura 5: Planta de situação da Escola Sesc-Senac de Ribeirão Preto, retirada da prancha do projeto de prefeitura.

Fonte: Foto Ferraz, arquivo FAUS 


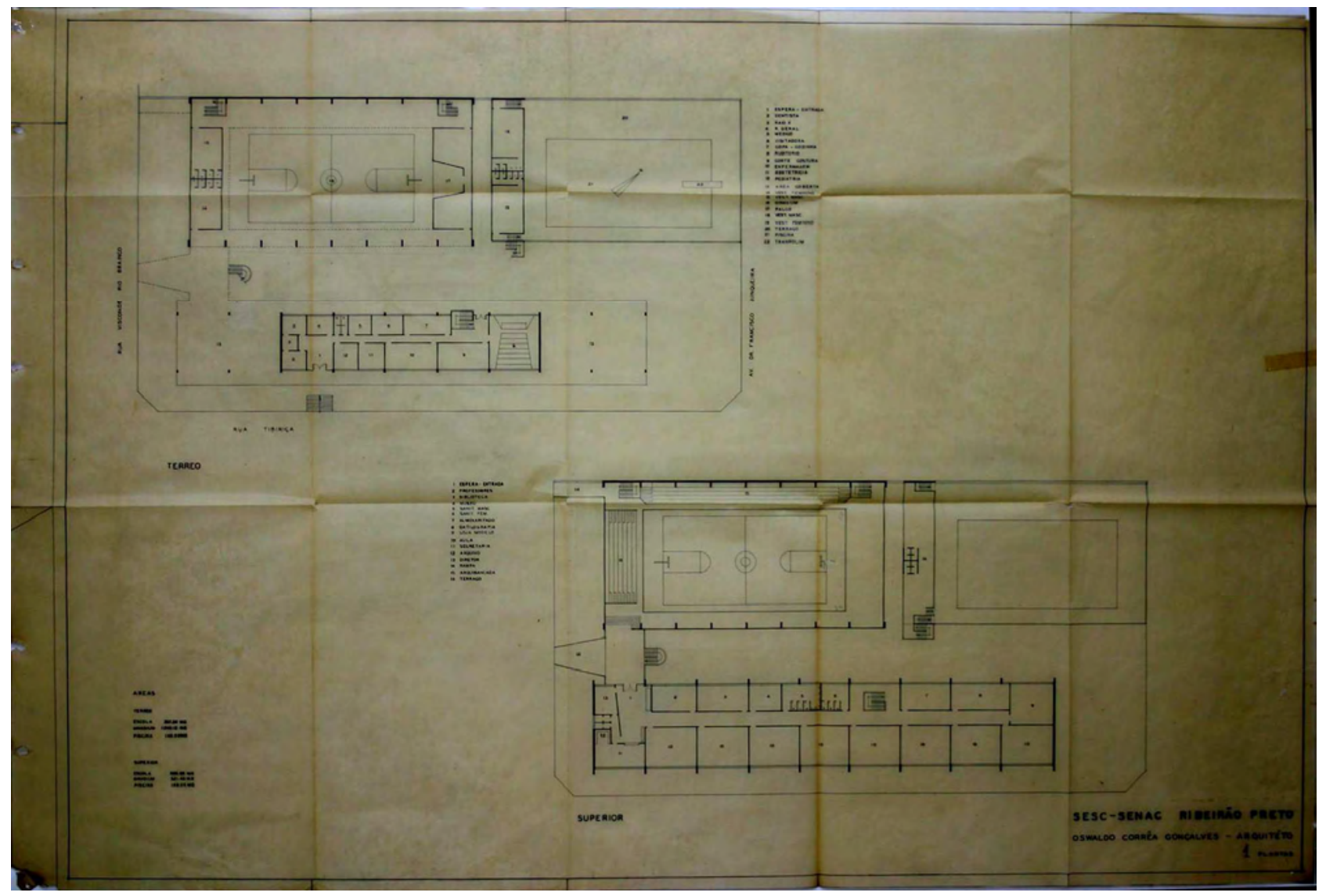

Figura 6: Prancha 1, ante-projeto das plantas da Escola Sesc-Senac de Ribeirão Preto, 1955, Oswaldo Corrêa Gonçalves. Fonte: Foto Ferraz, arquivo FAUS

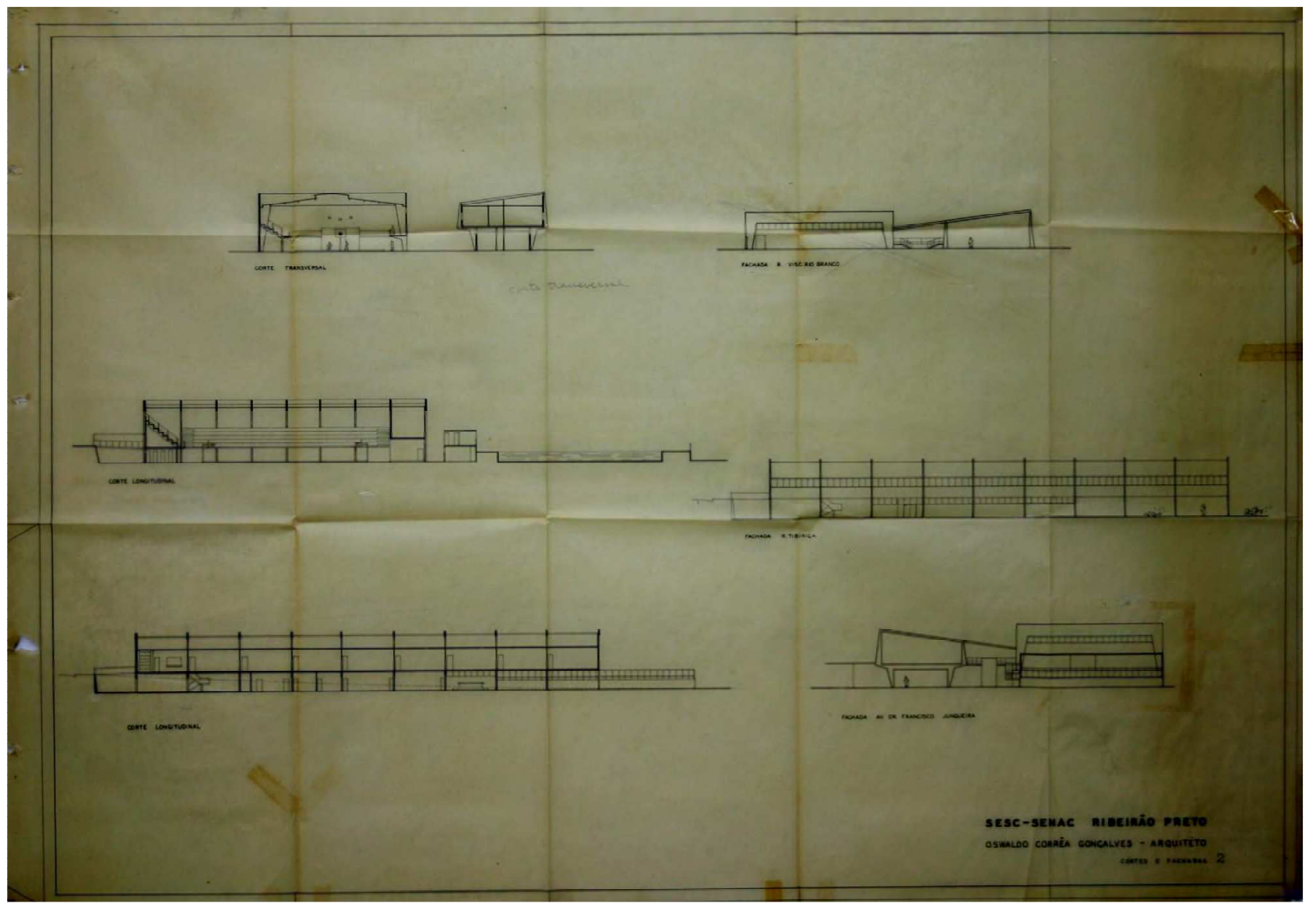

Figura 7: Prancha 2, ante-projeto dos cortes e elevações, Escola Sesc-Senac de Ribeirão Preto, 1955, Oswaldo C. Gonçalves. Fonte: Foto Ferraz, arquivo FAUS 


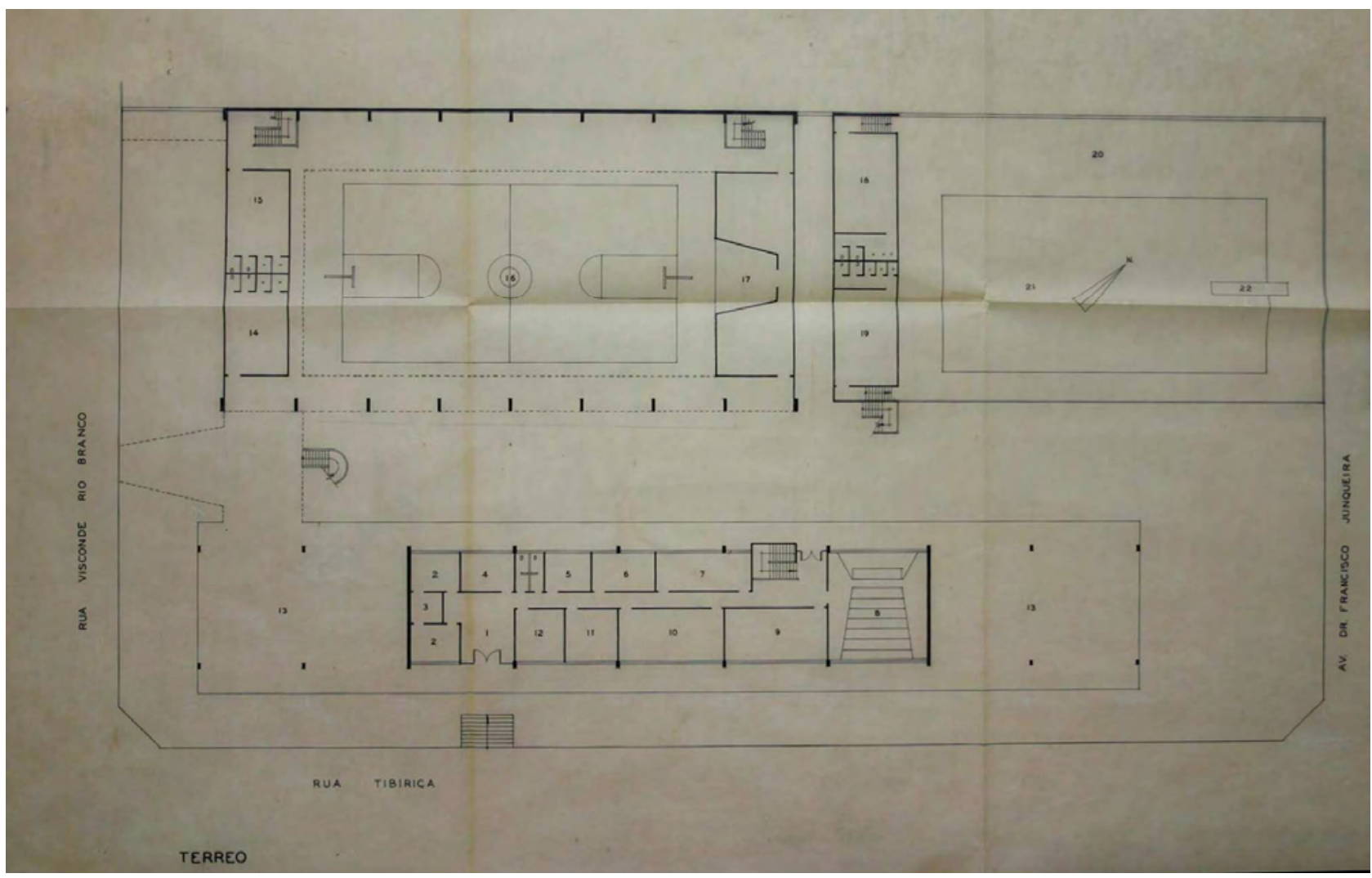

Figura 8: Planta do pavimento térreo (SESC) retirada da prancha 1 do ante-projeto, original na escala 1:100, Escola SescSenac de Ribeirão Preto, 1955, autoria de Oswaldo Corrêa Gonçalves.

Fonte: Foto Ferraz, arquivo FAUS

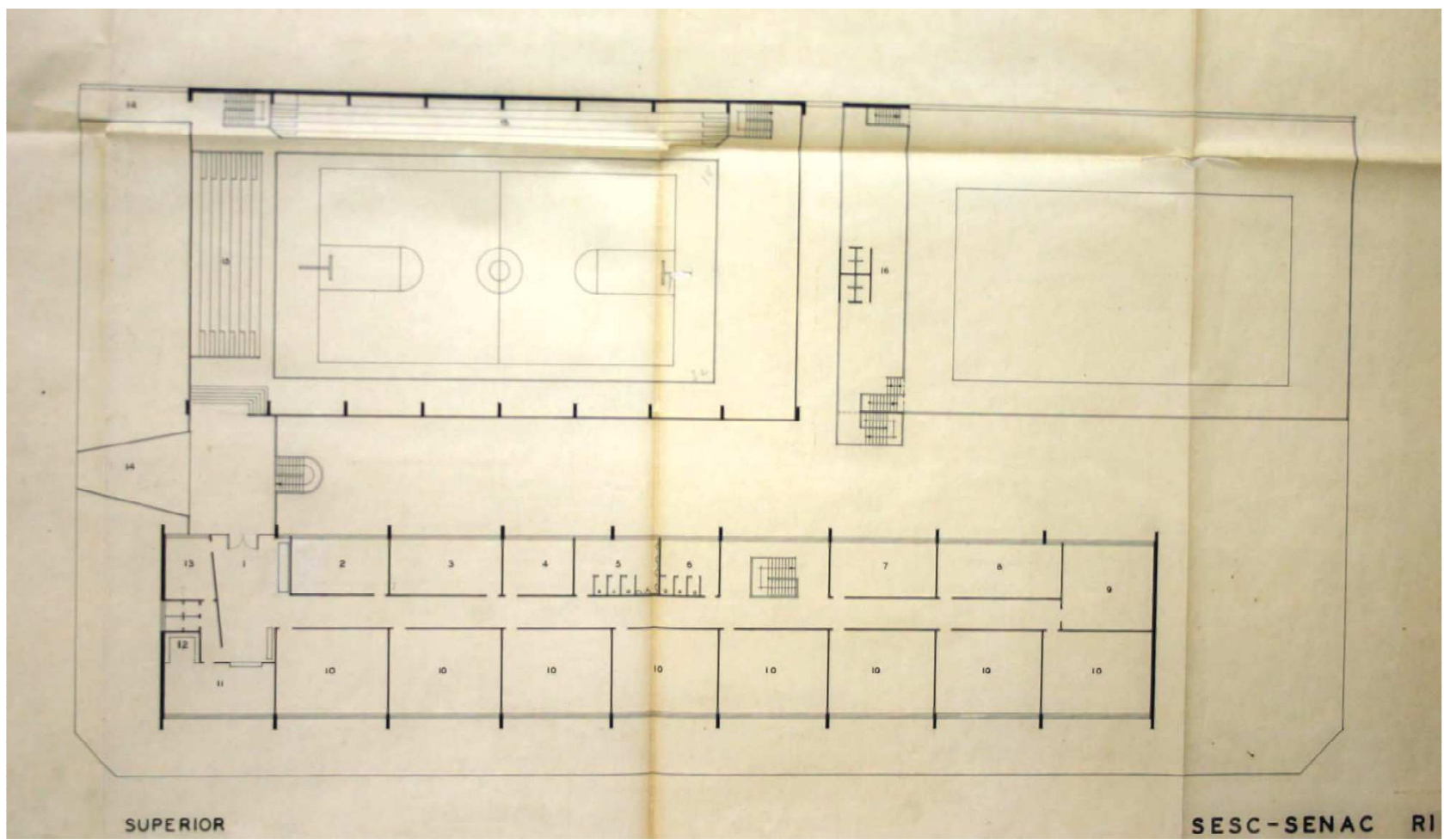

Figura 9: Planta do pavimento superior (SENAC) retirada da prancha 1 do ante-projeto, original na escala 1:100, Escola SescSenac de Ribeirão Preto, 1955, autoria de Oswaldo Corrêa Gonçalves.

Fonte: Foto Ferraz, arquivo FAUS 


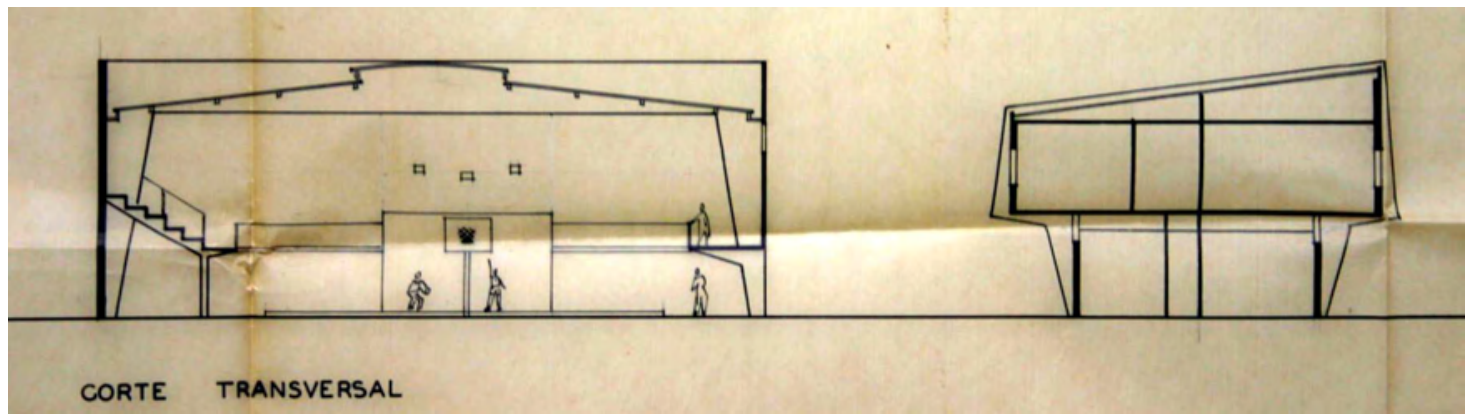

Figura 10: Corte transversal retirado da prancha 2 do ante-projeto, original na escala 1:100, Escola Sesc-Senac de Ribeirão Preto, 1955, autoria de Oswaldo Corrêa Gonçalves.

Fonte: Foto Ferraz, arquivo FAUS

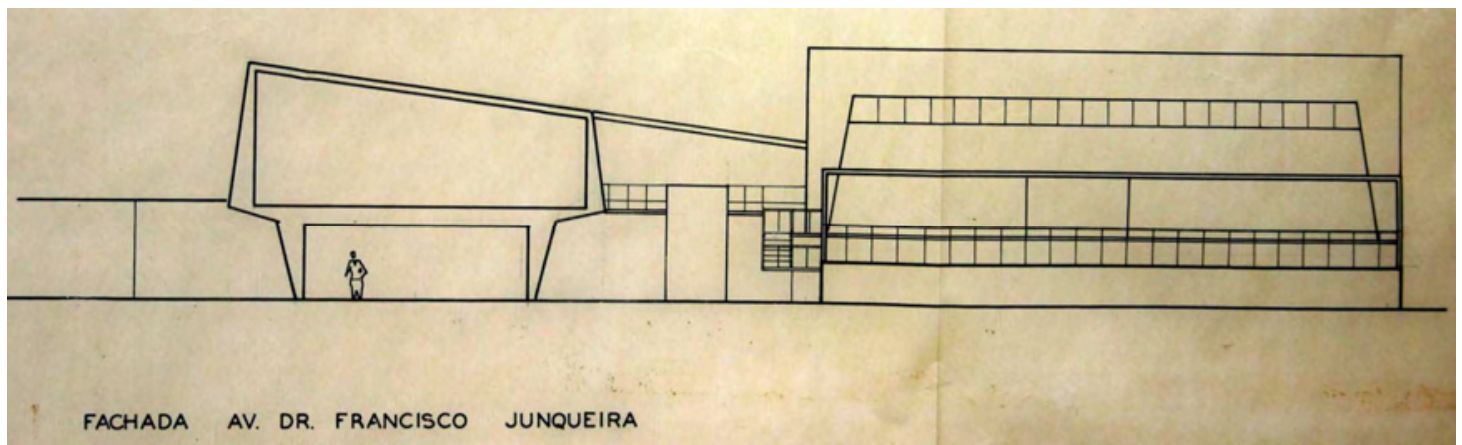

Figura 11: Elevação sudoeste retirada da prancha 2 do ante-projeto, original na escala 1:100, Escola Sesc-Senac de Ribeirão Preto, 1955, autoria de Oswaldo Corrêa Gonçalves.

Fonte: Foto Ferraz, arquivo FAUS

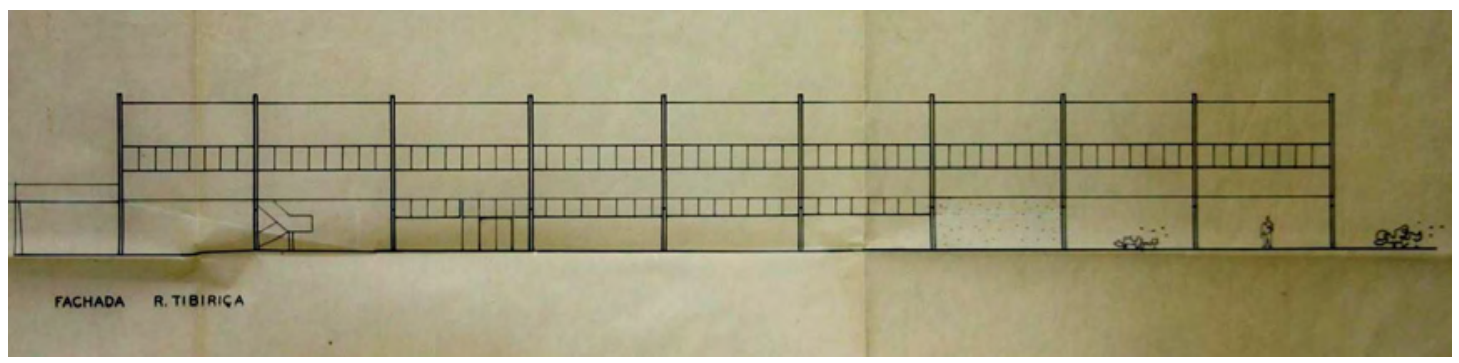

Figura 12: Elevação sudeste retirada da prancha 2 do ante-projeto, original na escala 1:100,

Escola Sesc-Senac de Ribeirão Preto, 1955, autoria de Oswaldo Corrêa Gonçalves.

Fonte: Foto Ferraz, arquivo FAUS

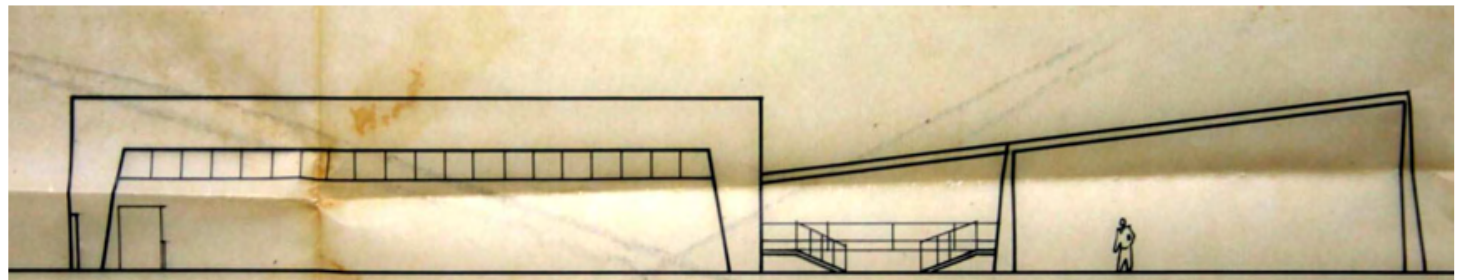

FACHADA R. VISC.RIO BRANCO

Figura 13: Elevação nordeste retirada da prancha 2 do ante-projeto, original na escala 1:100, Escola Sesc-Senac de Ribeirão Preto, 1955, autoria de Oswaldo Corrêa Gonçalves.

Fonte: Foto Ferraz, arquivo FAUS 
Ainda, como documentação complementar às pranchas do ante-projeto composto por três blocos, fotos da maquete revelam a concepção inicial de forma espacial.
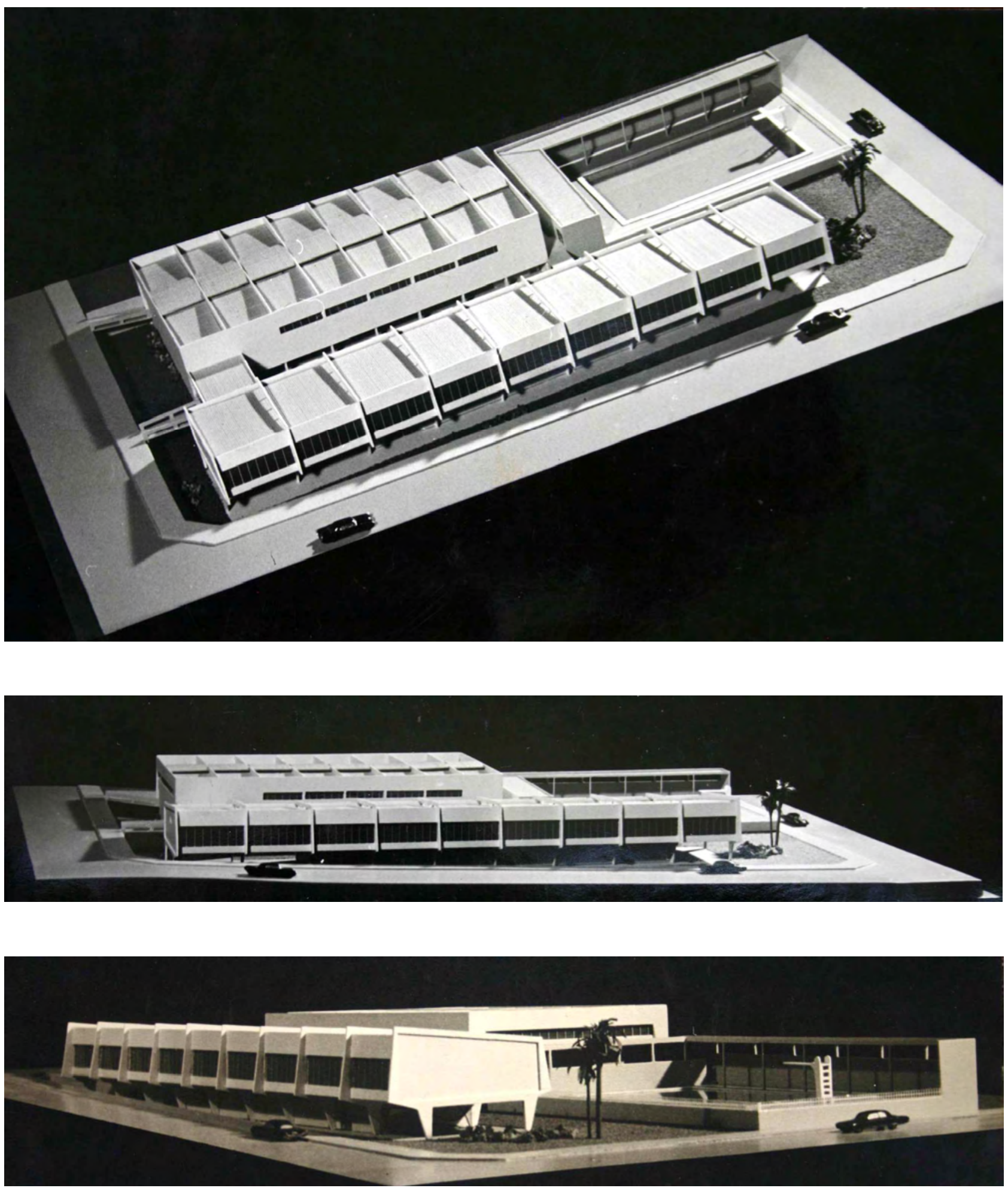

Figuras 14, 15 e 16: Maquete concebida na década de 50 de acordo com o ante-projeto, Escola Sesc-Senac de Ribeirão Preto, autoria de Oswaldo Corrêa Gonçalves. Observar os três blocos que faziam parte da concepção inicial da escola. Fonte: Foto Ferraz, arquivo FAUS 


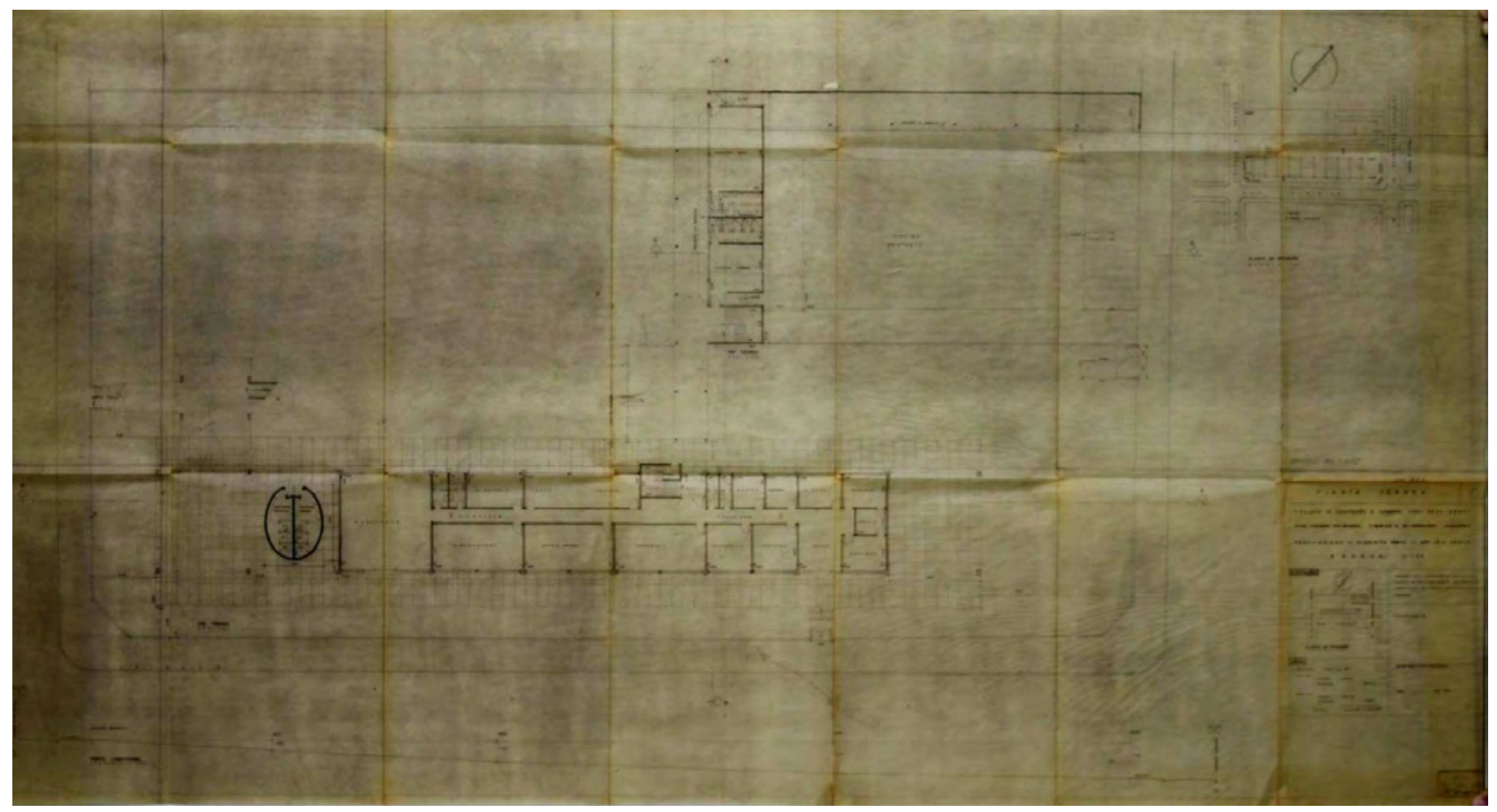

Figura 17: Prancha 1/4 do projeto de prefeitura da Escola Sesc-Senac de Ribeirão Preto, autoria de Oswaldo Corrêa Gonçalves, corrigido em 09/03/1961.

Fonte: Foto Ferraz, arquivo FAUS

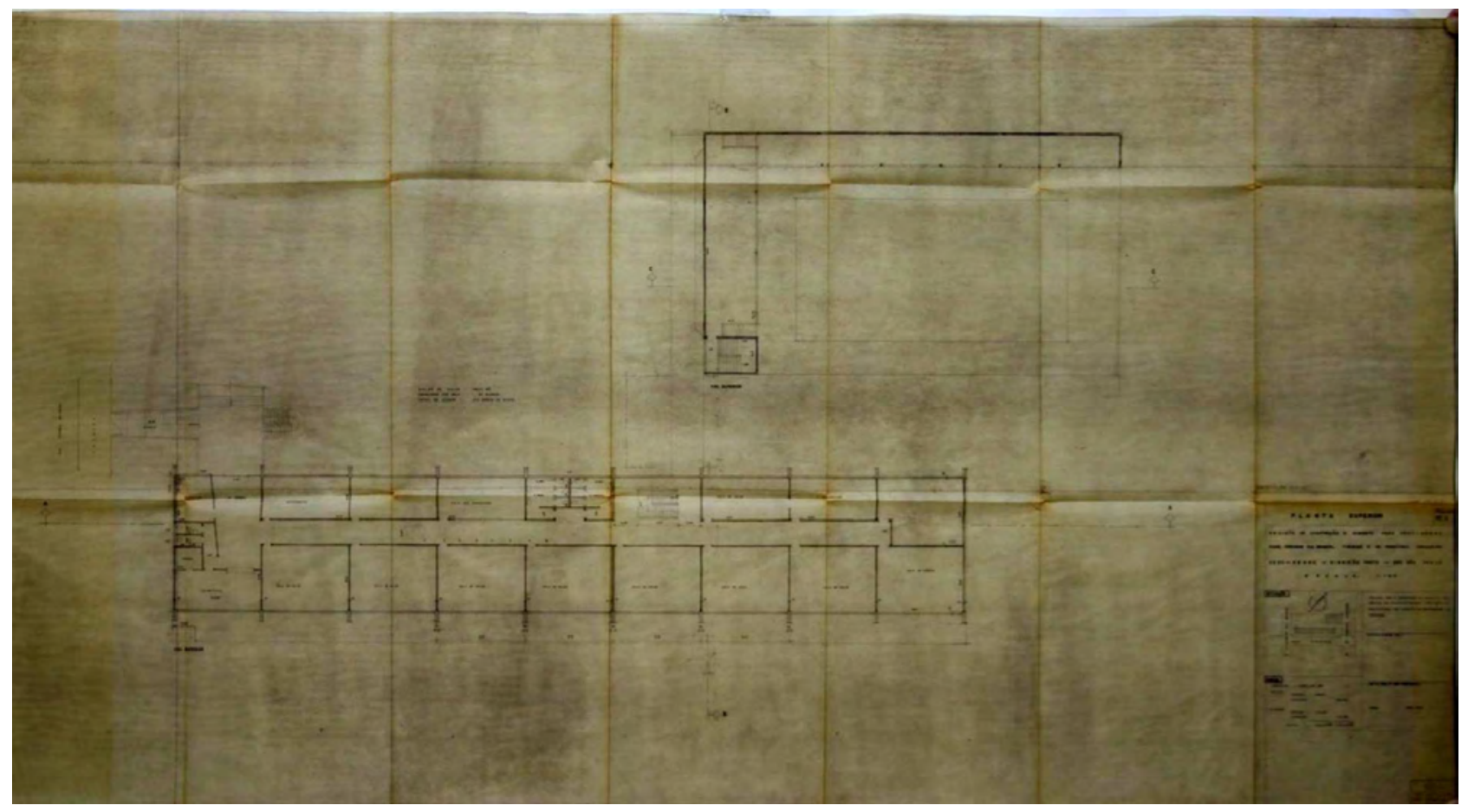

Figura 18: Prancha 2/4 do projeto de prefeitura da Escola Sesc-Senac de Ribeirão Preto, autoria de Oswaldo Corrêa Gonçalves, corrigido em 09/03/1961.

Fonte: Foto Ferraz, arquivo FAUS 


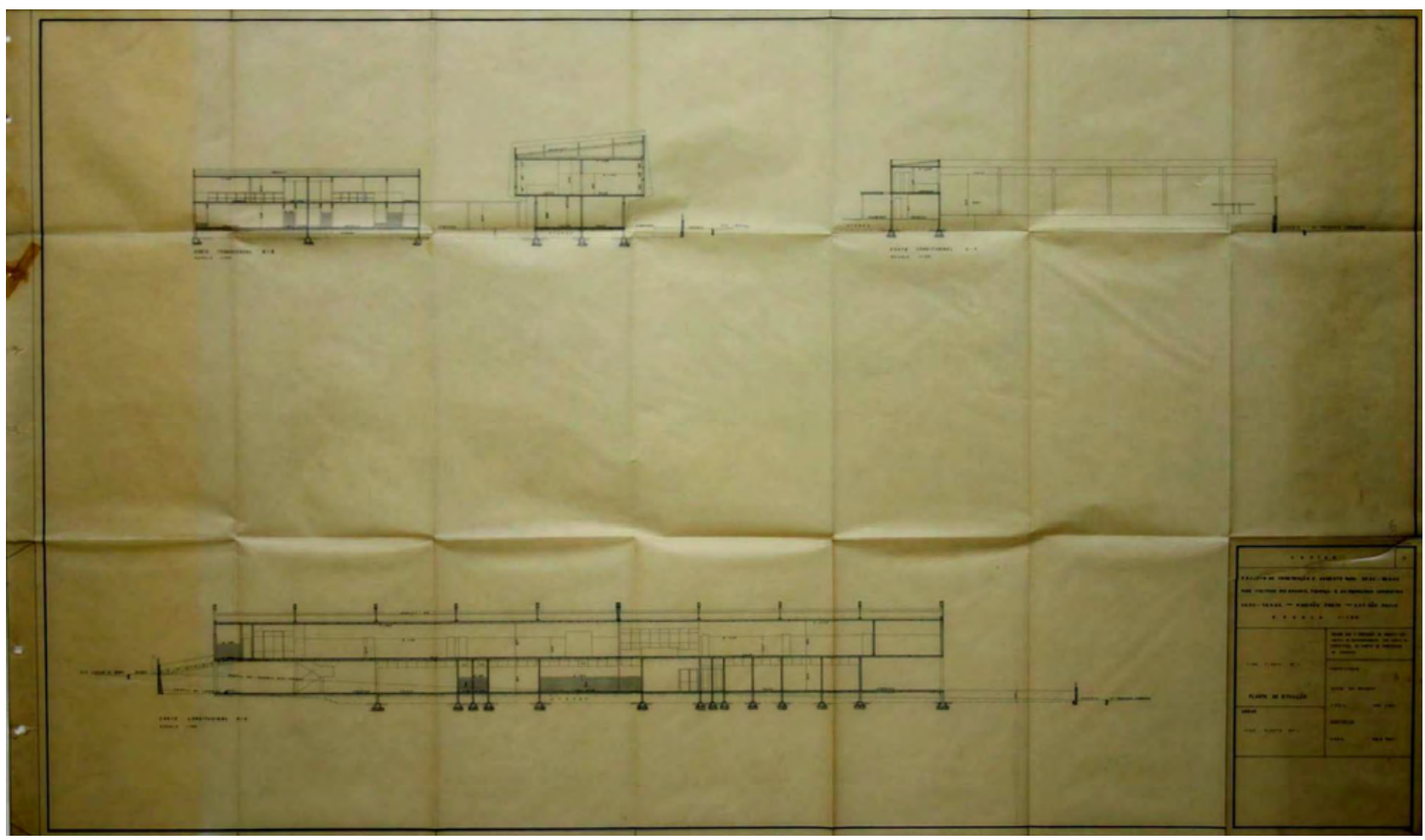

Figura 19: Prancha 3/4 do projeto de prefeitura, Escola Sesc-Senac de Ribeirão Preto, autoria de Oswaldo Corrêa Gonçalves. Fonte: Foto Ferraz, arquivo FAUS

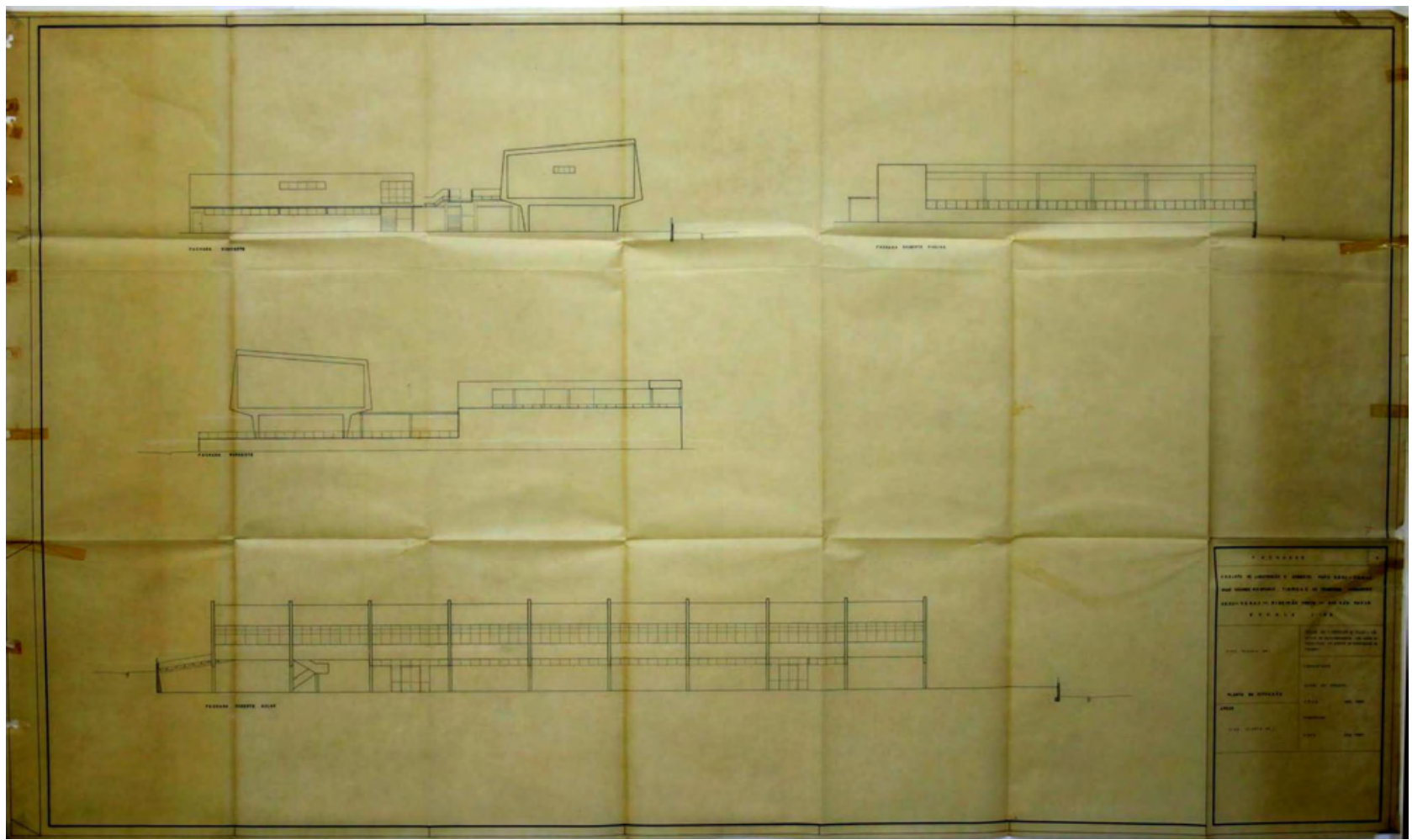

Figura 20: Prancha 4/4 do projeto de prefeitura, Escola Sesc-Senac de Ribeirão Preto, autoria de Oswaldo Corrêa Gonçalves. Fonte: Foto Ferraz, arquivo FAUS 


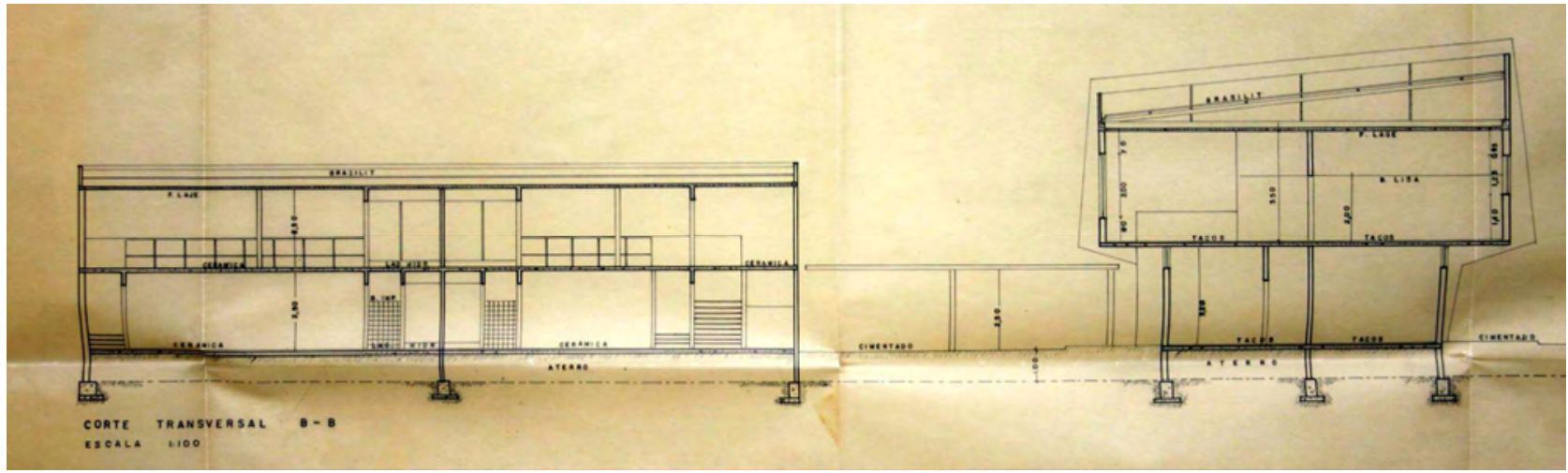

Figura 21: Corte transversal retirado da prancha 3/4 do projeto de prefeitura, original na escala 1:100, Escola Sesc-Senac de Ribeirão Preto. Observar os dois blocos construídos: vestiários da piscina e escola.

Fonte: Foto Ferraz, arquivo FAUS

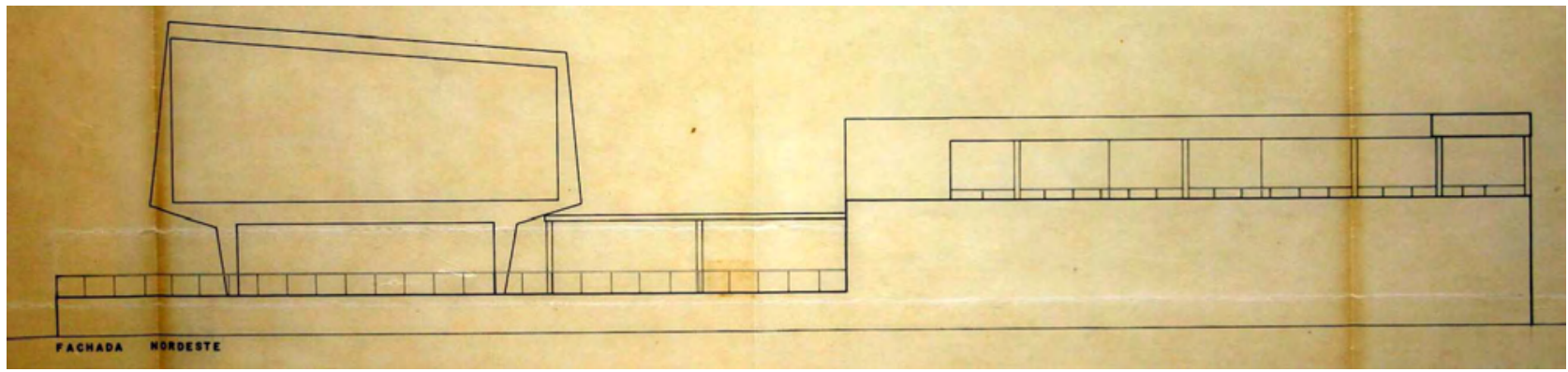

Figura 22: Elevação nordeste retirada da prancha 4/4 do projeto de prefeitura, original na escala 1:100, Escola Sesc-Senac de Ribeirão Preto. Observar os dois blocos construídos: escola e vestiários da piscina.

Fonte: Foto Ferraz, arquivo FAUS

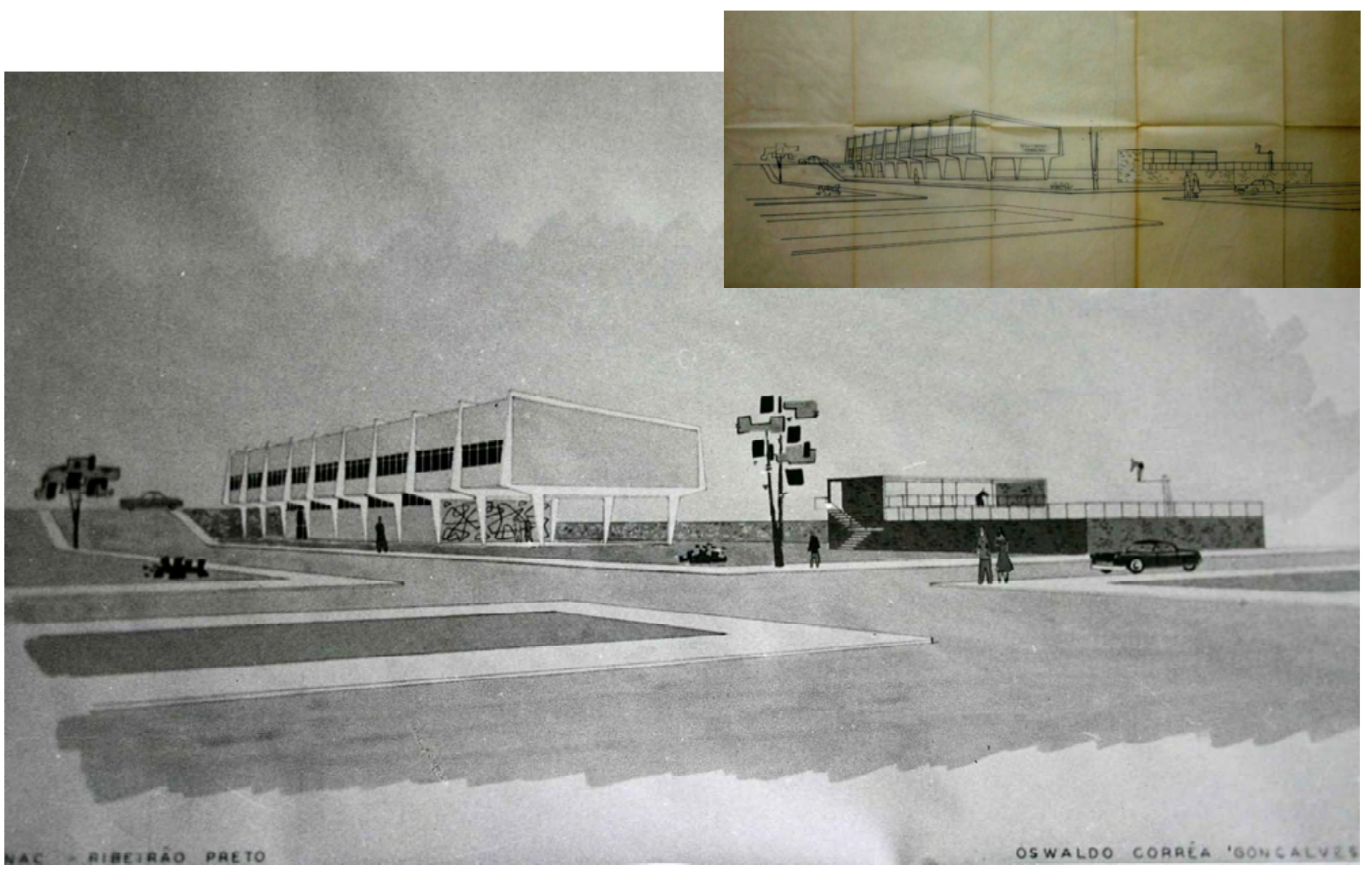

Figuras 23 e 24: Perspectiva do projeto construído (conforme projeto de prefeitura), Escola Sesc-Senac de Ribeirão Preto. Observar os dois blocos construídos: escola e vestiários da piscina.

Fonte: Foto Ferraz, arquivo FAUS 
projeto final, dividido em dois blocos paralelos entre si, foi executado de acordo com suas funções: escola e lazer.

A solução estrutural do bloco da escola foi uma forma geométrica simples, racional e funcional, tanto nas plantas como nas fachadas. A estrutura independente possibilitou liberdade à divisão em planta, permitindo o aproveitamento dos espaços de várias maneiras e possibilitando adequar a dimensão dos ambientes de acordo com as necessidades de cada Serviço. $O$ monobloco como um todo foi resolvido numa estrutura em concreto composta por vários pórticos, que são ao mesmo tempo vigas, pilares, limite da cobertura e fechamento nas extremidades laterais do bloco. Marcado pelos pórticos, oito módulos repetem-se formando a plasticidade ritmada da fachada. O edifício, marcado pela horizontalidade de um bloco compacto, sugere uma certa leveza através do desenho da estrutura independente com a base dos pilares estreita sustentando os pórticos, as grandes aberturas das janelas, a reduzida ocupação do solo pelo pavimento térreo e a laje em balanço do pavimento superior.

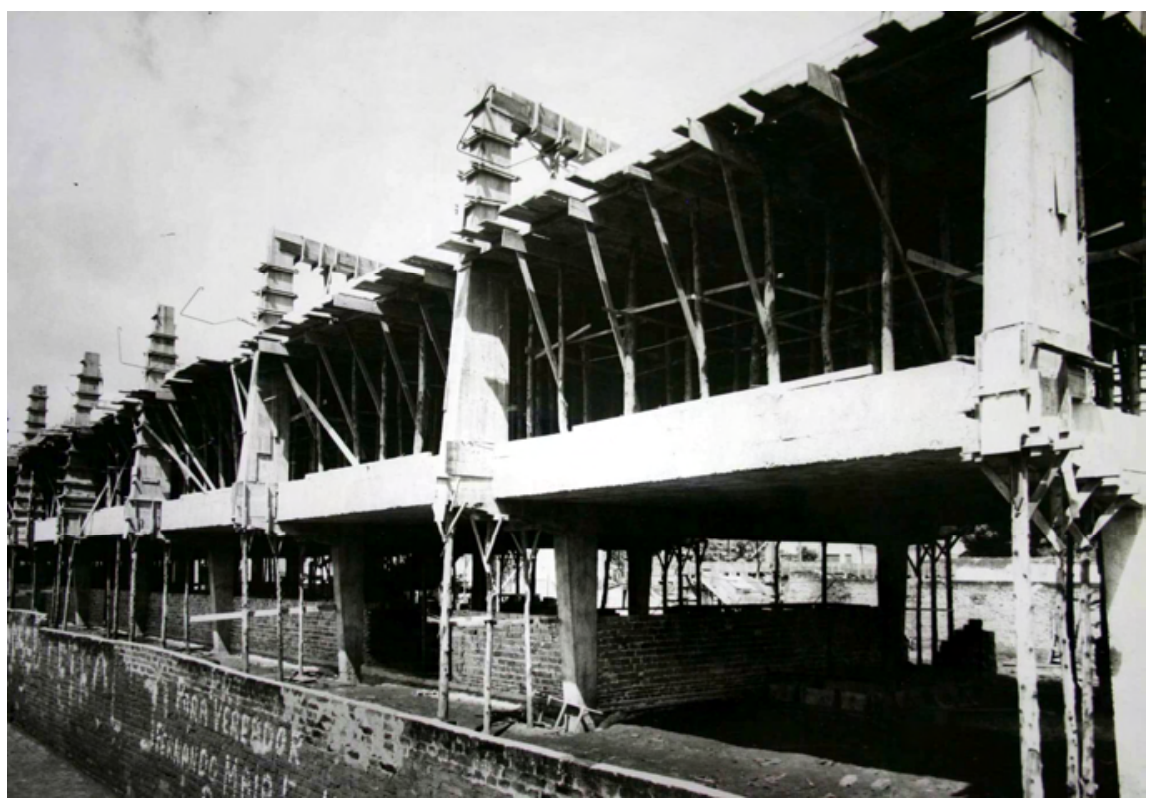

Figura 25: Vista da fachada sudeste do bloco da escola em construção, Escola Sesc-Senac de Ribeirão Preto, dezembro de 1955. Observar os pórticos estruturais. Fonte: Arquivo FAUS 
Figura 26: Vista do recreio coberto do bloco da escola, Escola Sesc-Senac de Ribeirão Preto. Observar a base estreita dos pilares, a reduzida ocupação do solo pelo pavimento térreo e a laje em balanço.

Fonte: Foto Moscardi, arquivo FAUS

Figura 27: Vista da fachada sudoeste da lateral do bloco da escola, Escola Sesc-Senac de Ribeirão Preto. Observar a rampa de acesso ao SENAC pela rua Visconde Rio Branco.

Fonte: Foto Moscardi, arquivo FAUS

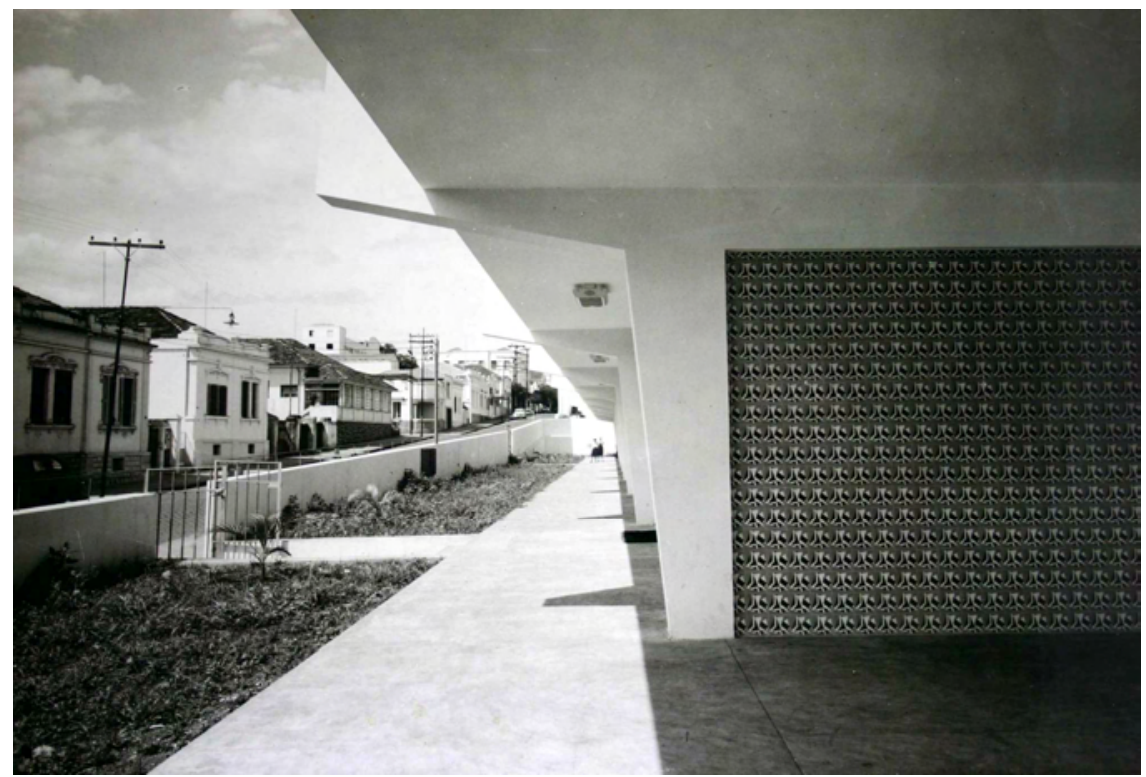

O bloco da escola foi dividido em pavimentos de usos diferentes e com acessos independentes, possibilitando uma separação funcional entre SESC e SENAC. Estes Serviços, apesar de compreenderem diferentes programas, ao mesmo tempo faziam uso comum de alguns espaços no térreo, como recreio coberto, piscina, vestiários e terraço. A escola, com fachada principal voltada para sudeste ao longo da rua Tibiriçá, tinha dois acessos independentes, um para o SESC pela mesma rua e outro para o SENAC pela rua Visconde Rio Branco.

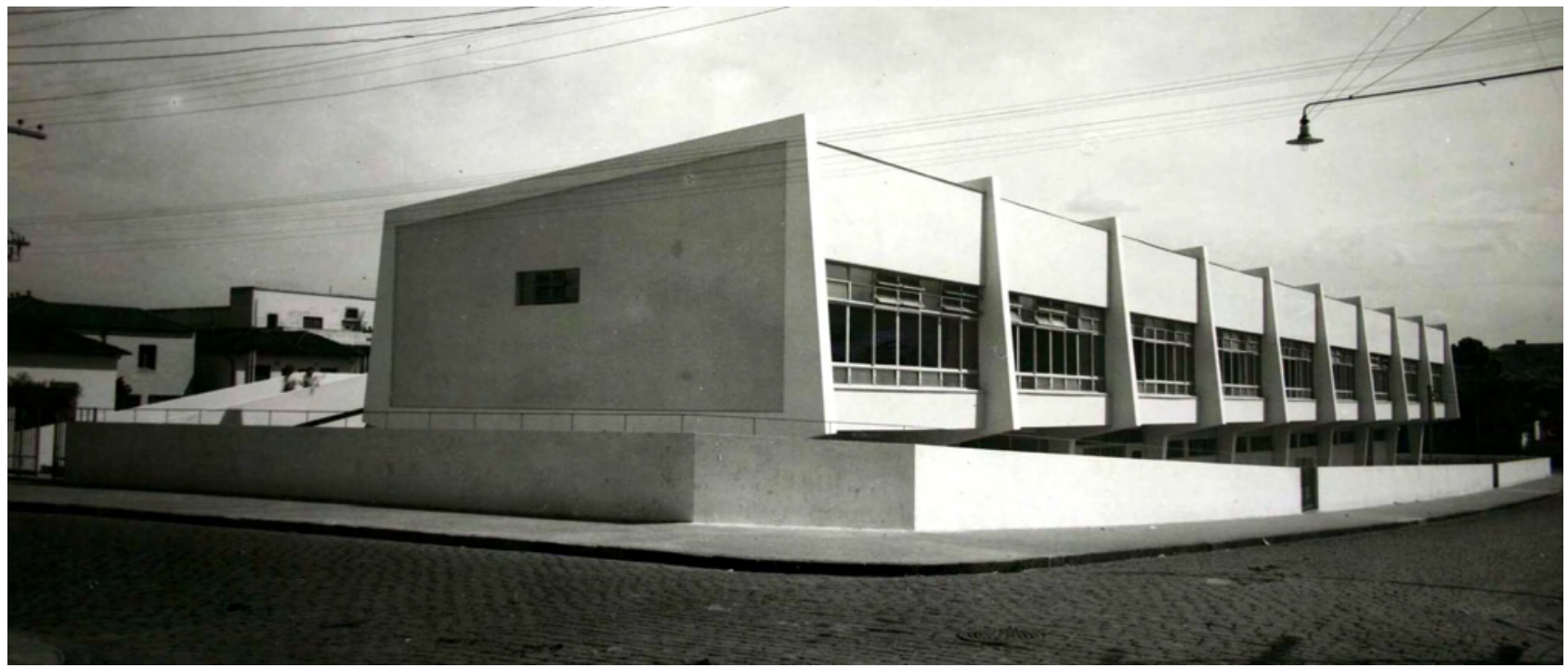




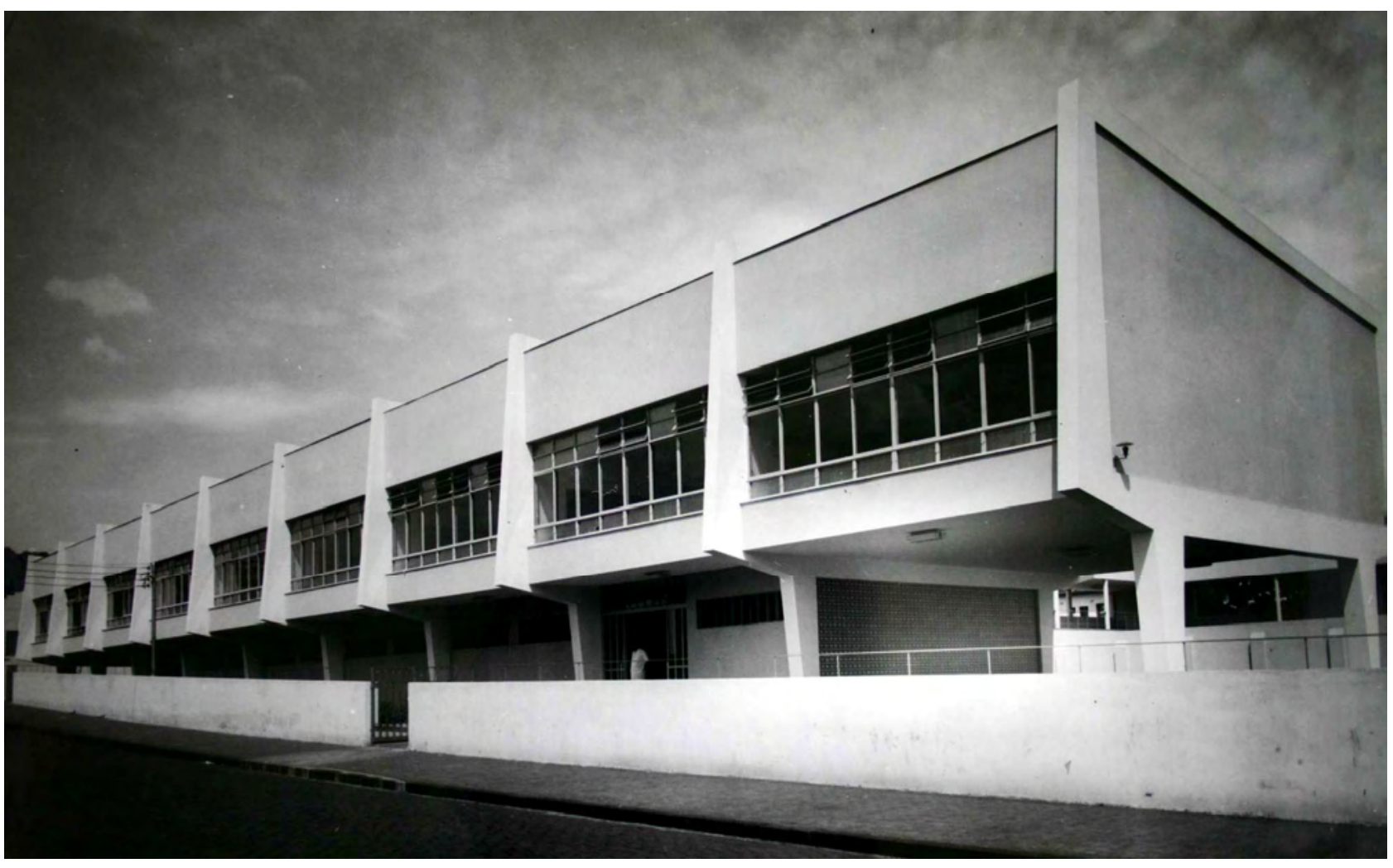

A divisão interna de ambos os pavimentos da escola adotou a divisão de salas em dois lados com circulação central, possibilitando a divisão funcional dos ambientes pelas faces sudeste e sudoeste. Assim, no pavimento superior, as salas de aula e a secretaria receberam iluminação lateral sudeste e as demais salas iluminação lateral sudoeste.

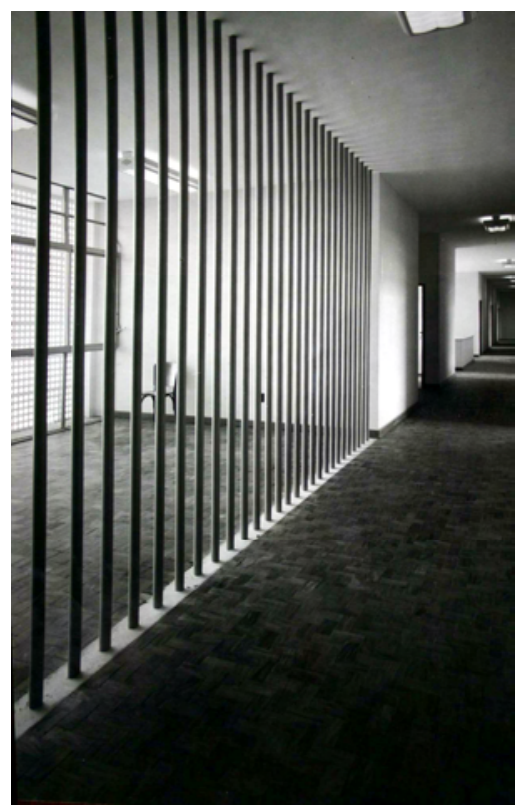

Figura 28: Vista da fachada sudeste do bloco da escola, Escola Sesc-Senac de Ribeirão Preto. Observar o acesso do SESC pela rua Tibiriçá. Fonte: Foto Moscardi, arquivo FAUS

Figura 29: Corredor de circulação central do pavimento

superior. Observar os tubos verticais que permitiam ampla visão do salão de exposição de trabalhos. Fonte: Foto Moscardi, arquivo FAUS 
Figura 30: Iluminação lateral sudoeste. Sala de reuniões dos professores, protegida do sol poente intenso de Ribeirão Preto pelos elementos vazados. Fonte: Foto Moscardi, arquivo FAUS

Figura 31: lluminação lateral sudeste da sala de aula. Janelas sempre à esquerda dos alunos favorecendo a iluminação natural sudeste.

Fonte: Foto Moscardi, arquivo FAUS
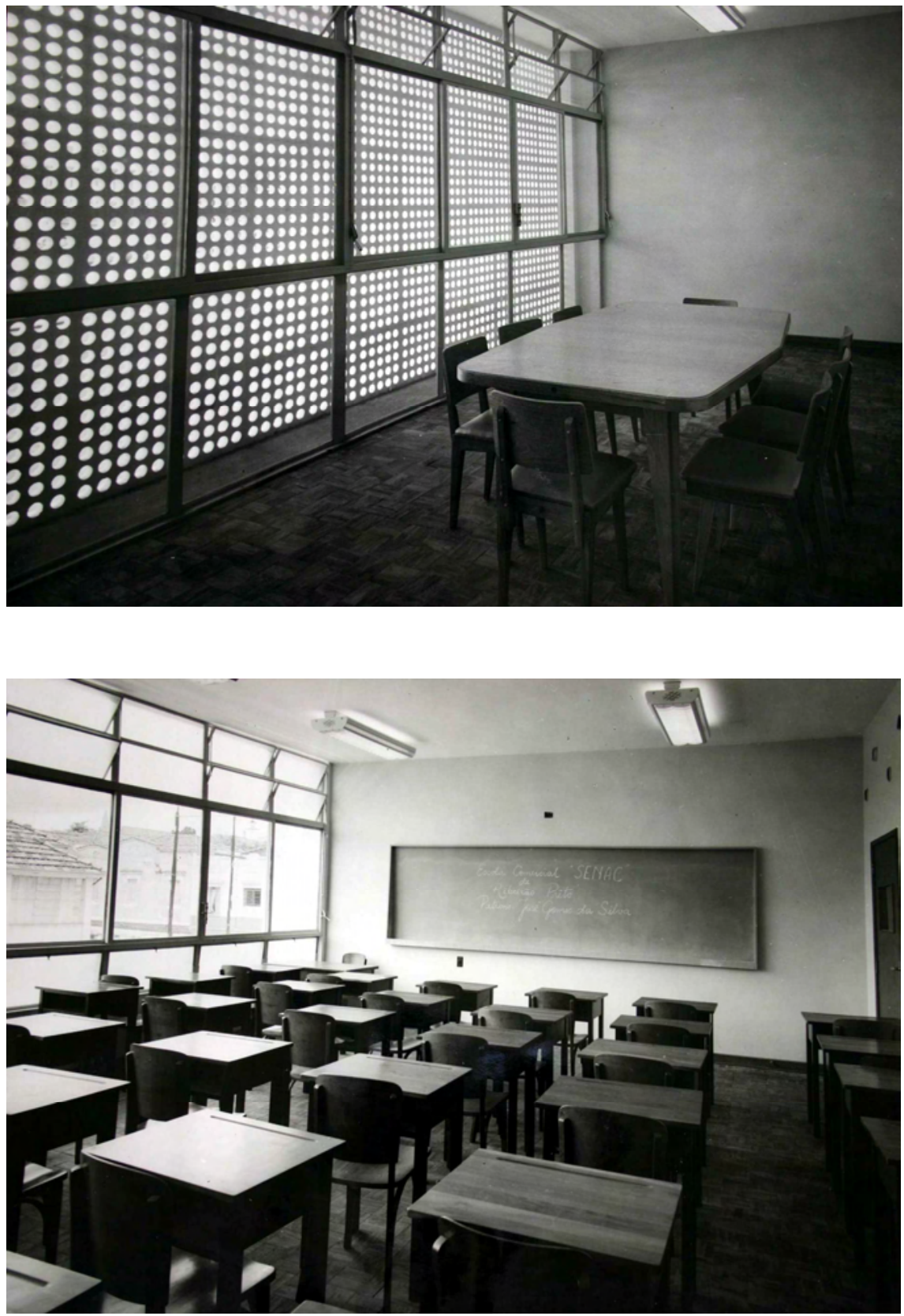

Em relação ao conforto térmico, tendo em vista o clima quente de Ribeirão Preto, foi projetado um sistema de ventilação cruzada permanente nas salas de trabalho. Como exemplo, no pavimento superior, as paredes confrontantes da circulação têm, na parte superior, furos circulares que permitiam a ventilação cruzada entre a circulação e as salas (ver figura 33 apresentada anteriormente). Outro fator projetual importante foi o recuo do pavimento térreo em relação ao pavimento superior, protegendo termicamente as fachadas sudeste e sudoeste do SESC através da laje em balanço que sombreava as janelas do térreo, todas com peitoril de 2,40 metros. 


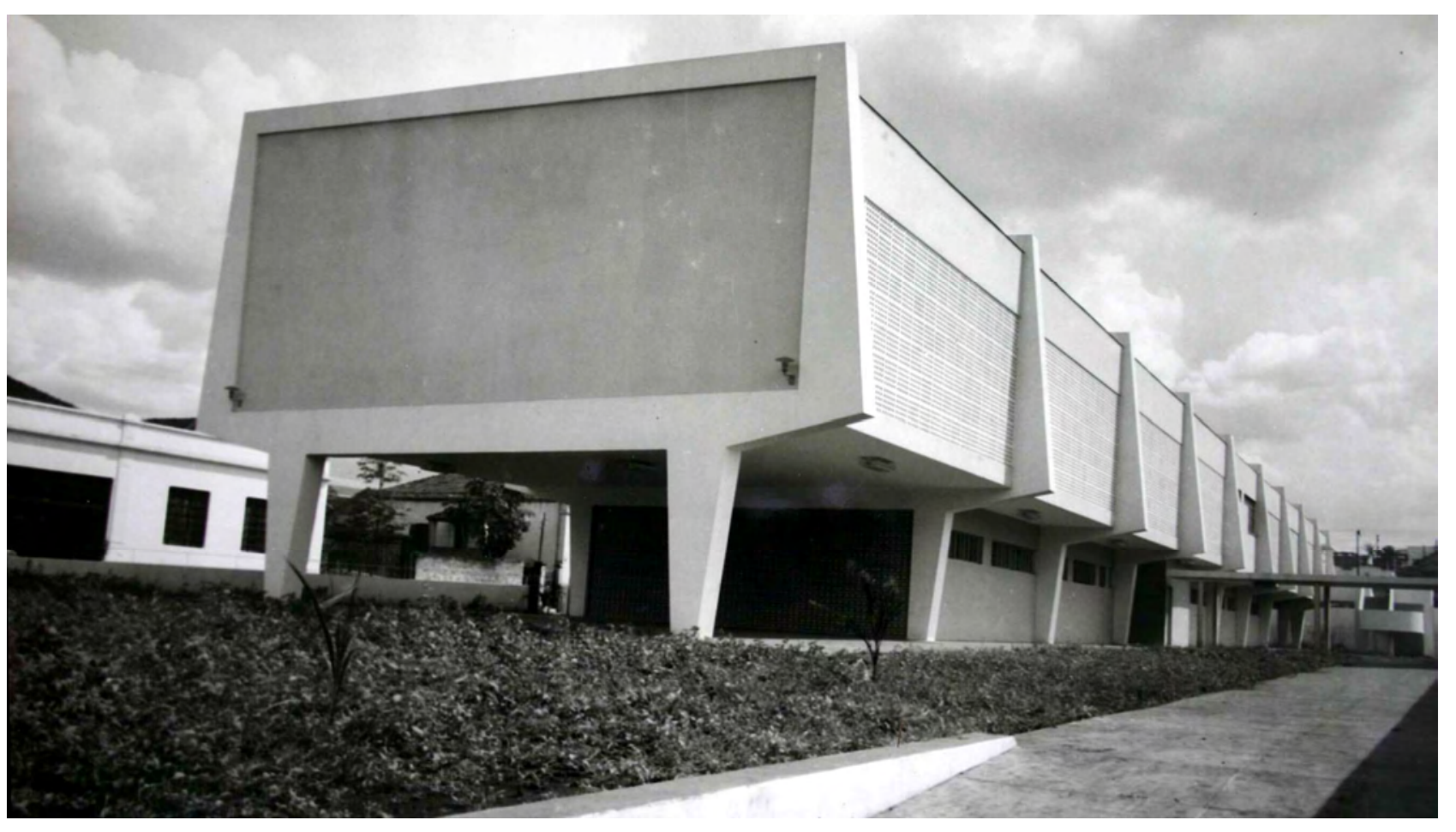

Com o objetivo de ser uma escola que integrava o ensino à assistência social, a concepção projetual foi de amplas janelas e pátio coberto para o lazer circundado apenas por muretas baixas. Outra característica marcante é a presença de murais artísticos aplicando as artes plásticas à arquitetura. Para esta escola foram executados dois painéis: um painel por Irênio Maia, localizado no hall de entrada do SENAC, ocupando toda a parede lateral direita da porta de entrada, e outro painel de ladrilhos hidráulicos de Bi Crisóstomo de Oliveira, localizado no pátio coberto, possibilitando cultura ao espaço de lazer.

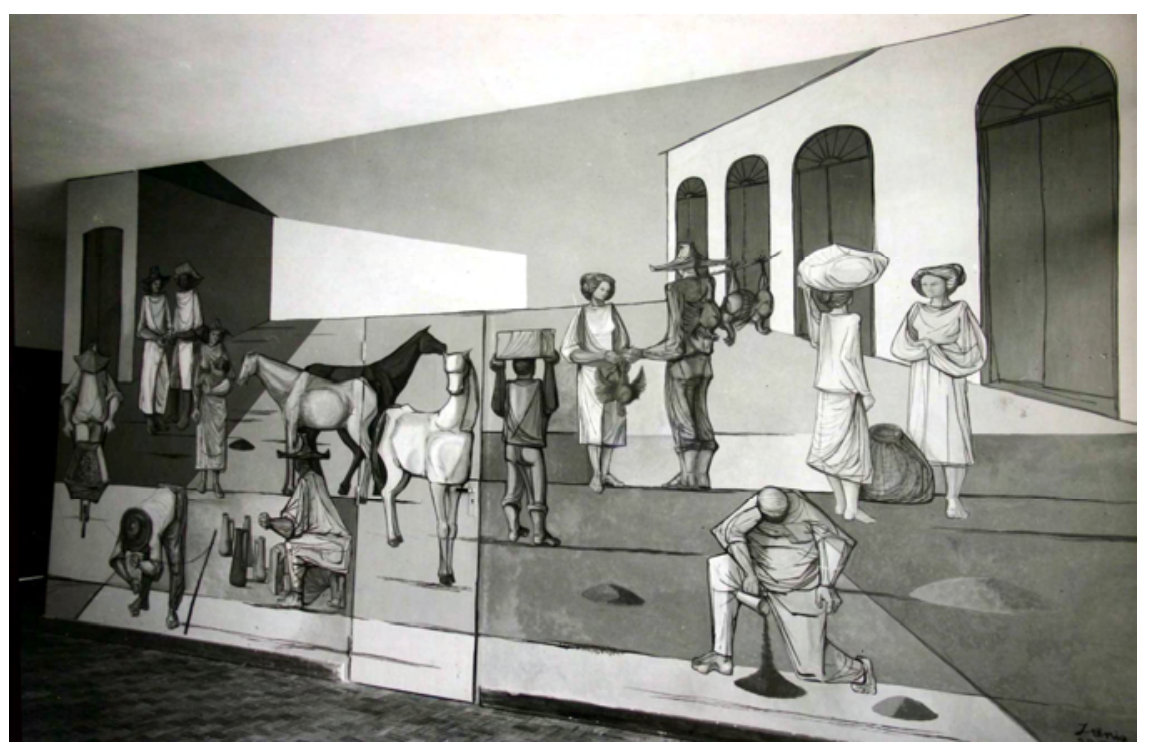

Figura 32: Observar o recuo do pavimento térreo em relação ao superior protegendo termicamente as janelas do térreo.

Fonte: Foto Moscardi, arquivo FAUS

Figura 33: Painel artístico de Irênio Maia executado no hall de entrada do SENAC.

Fonte: Foto Moscardi, arquivo FAUS 
Figura 34: Painel artístico de ladrilhos hidráulicos, $\mathrm{Bi}$ Crisóstomo de Oliveira, executado no pátio coberto. Fonte: Foto Moscardi, arquivo FAUS

Figura 35: Segundo bloco: piscina, vestiário e terraço. Fonte: Foto Moscardi, arquivo FAUS

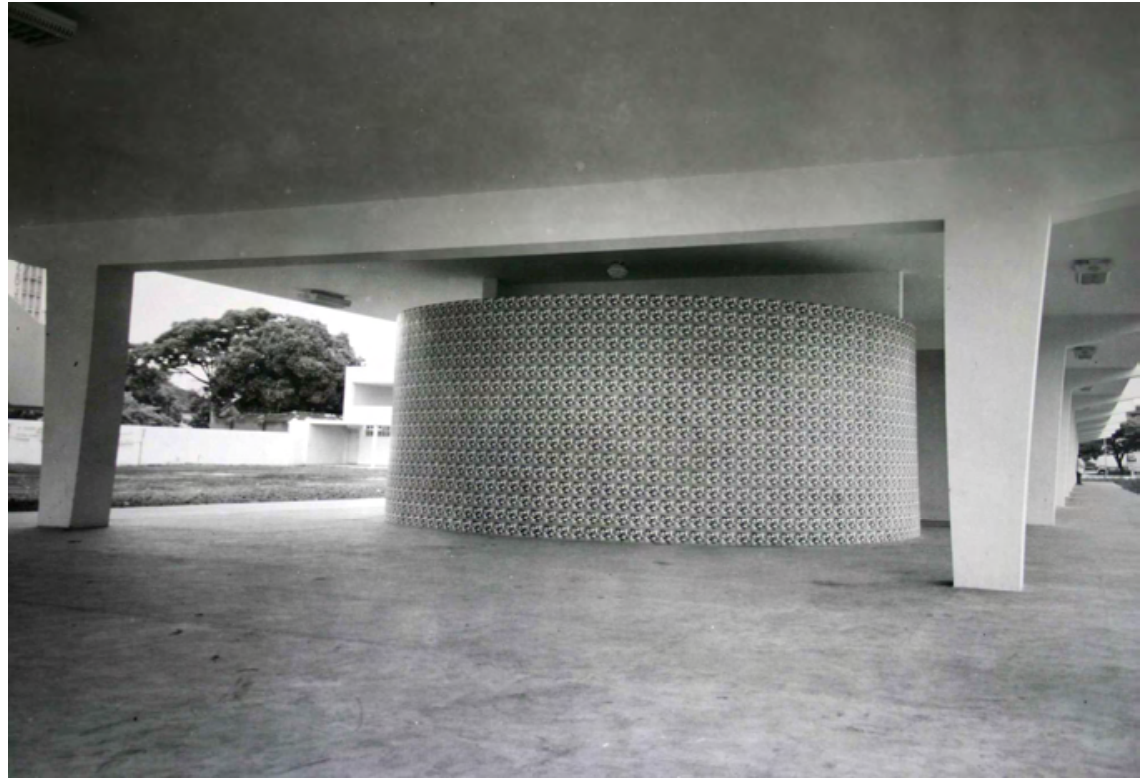

Com a nova pedagogia de estimular a relação aluno-escola, o segundo bloco caracterizado pelo lazer, colaborou na idéia de que o ensino fosse mais um prazer do que um dever. Composto pela piscina, vestiários e terraço, este bloco conjugado à escola oferecia o espaço de lazer de uso comum pelo SESC e SENAC, juntamente com o pátio coberto do próprio bloco da escola.

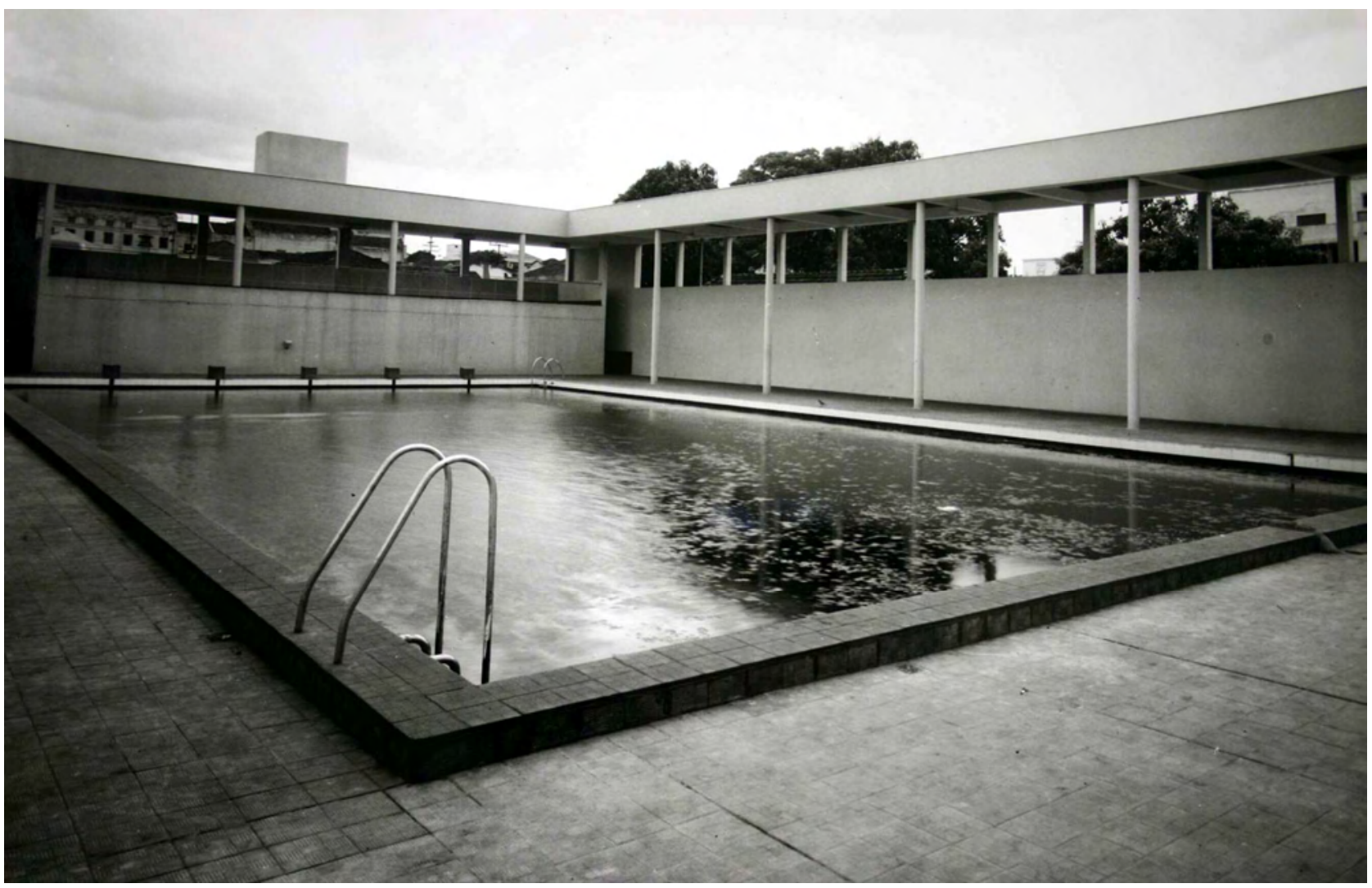




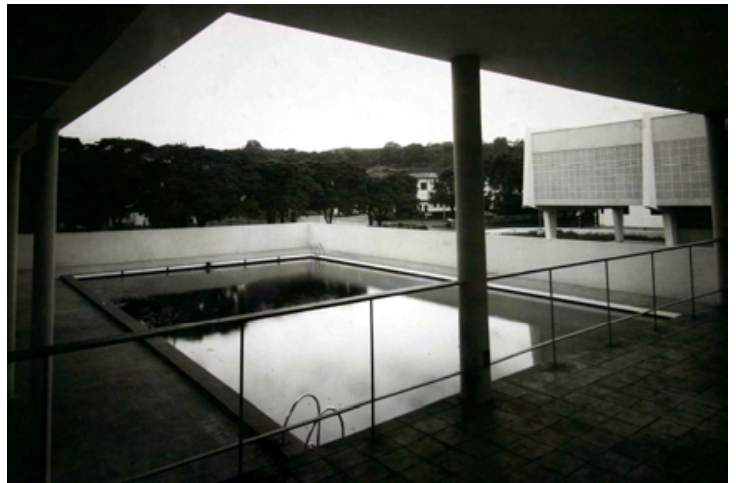

A Escola de Ribeirão Preto, seguindo ensinamentos da arquitetura moderna, aplicou os conceitos de monobloco, janelas envidraçadas, fachada livre, estrutura independente, painel artístico todos eles utilizados para refletir questões de caráter educacional e social. Este projeto, o primeiro edifício próprio SESC-SENAC projetado no interior do Estado de São Paulo, inaugurado em 08/09/1956, foi idealizado em um único edifício escola, abrigando a especificidade de cada serviço em diferentes pavimentos.

Posteriormente, o SENAC vendeu sua parte para o SESC e esta escola passou a ser utilizada somente pelo SESC. O estado atual do SESC de Ribeirão Preto revela várias reformulações em relação ao projeto original. Já, o SENAC, transferiu suas instalações para a escola "José Gomes da Silva", projetada em 1969 por Jorge Wilheim, Miguel Juliano e Silva e Hitoshi Koiama.

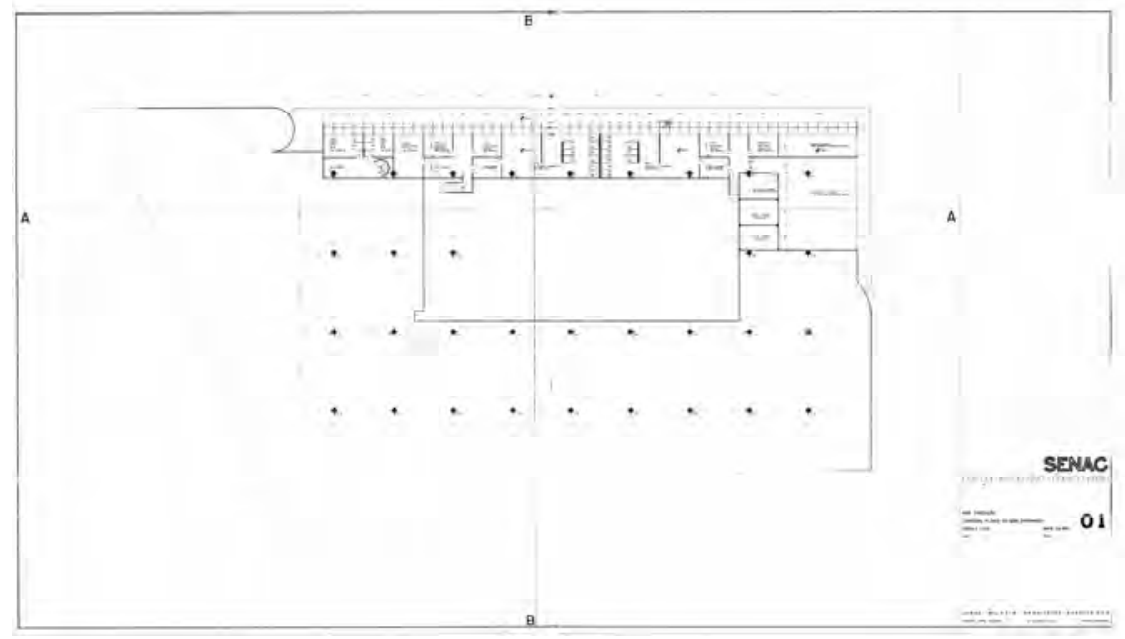

Figura 36: Vista da piscina e escola pelo terraço do segundo bloco. Observar a relação com os poucos vizinhos em nítida oposição formal. Fonte: Foto Moscardi, arquivo FAUS
Figura 37: Prancha do projeto da Escola SENAC "José Gomes da Silva", 1969, autoria de Jorge Wilheim, Miguel Juliano e Silva e Hitoshi Koiama. Fonte: Foto Moscardi, arquivo FAUS 


\section{PROJETO 2}

\section{Escola Sesc-Senac de Marília, 1955}

A Escola SESC-SENAC de Marília' foi projetada em 1955 pelos arquitetos Oswaldo Corrêa Gonçalves, Rubens Carneiro Vianna e Ricardo Siervers. Implantada num terreno de $2.920,00 \mathrm{~m}^{2}$, o projeto original contava com $1.646,00 \mathrm{~m}^{2}$ de área construída. $\bigcirc$ projeto, implantado ao longo dos 48 metros da avenida e ao longo dos 60 metros da rua, teve sua fachada principal voltada para a rua Paraíba, face sudeste, composta pelos blocos do SENAC, auditório e SESC.

programa construtivo foi dividido em dois blocos, um para cada serviço, interligados pelo auditório, circulação e recreio cobertos, de uso comum. O bloco do SENAC, composto de dois pavimentos, abrigava: almoxarifado, sanitários, grêmio estudantil, dependências do guarda, laboratório, sete salas de aula, recreio coberto, loja modelo, sala de datilografia, sala dos professores, diretoria, secretaria, arquivo, biblioteca e hall de entrada. $\bigcirc$ bloco térreo do SESC era composto de: espera, centro juvenil, centro infantil, copa-cozinha, sanitários, enfermaria, obstetrícia, pediatria, sala do médico, duas salas de dentista, raio $x$, corte e costura, almoxarifado, visitadora, diretoria e registro geral. Ainda este bloco abrigava pátio coberto para jogos, com bebedouro e sanitários.

Dados relativos à escola foram obtidos no arquivo da Prefeitura Municipal de Marília e do SENAC-SP, como as cópias de todas as pranchas aprovadas do projeto de prefeitura. $\bigcirc$ conhecimento do projeto original também foi obtido através da publicação em periódicos da época, Arquitetura e Decoração $n^{\circ} 13$ (1955), Acrópole no 244 (1959:131-136) e $A B n^{\circ} 7$ (1972: 79-81). Ainda, o material iconográfico foi obtido na FAUS, revelando fotos da maquete, das pranchas com perspectiva do projeto e do próprio edifício construído.

\footnotetext{
A Escola SESC-SENAC de Marília foi publicada pelas revistas Arquitetura e Decoração $n^{\circ} 13$ (1955), Acrópole $n^{\circ} 244$ (1959, p.131-136) e $A B n^{\circ} 7$ (1972, p.79-81).
} 


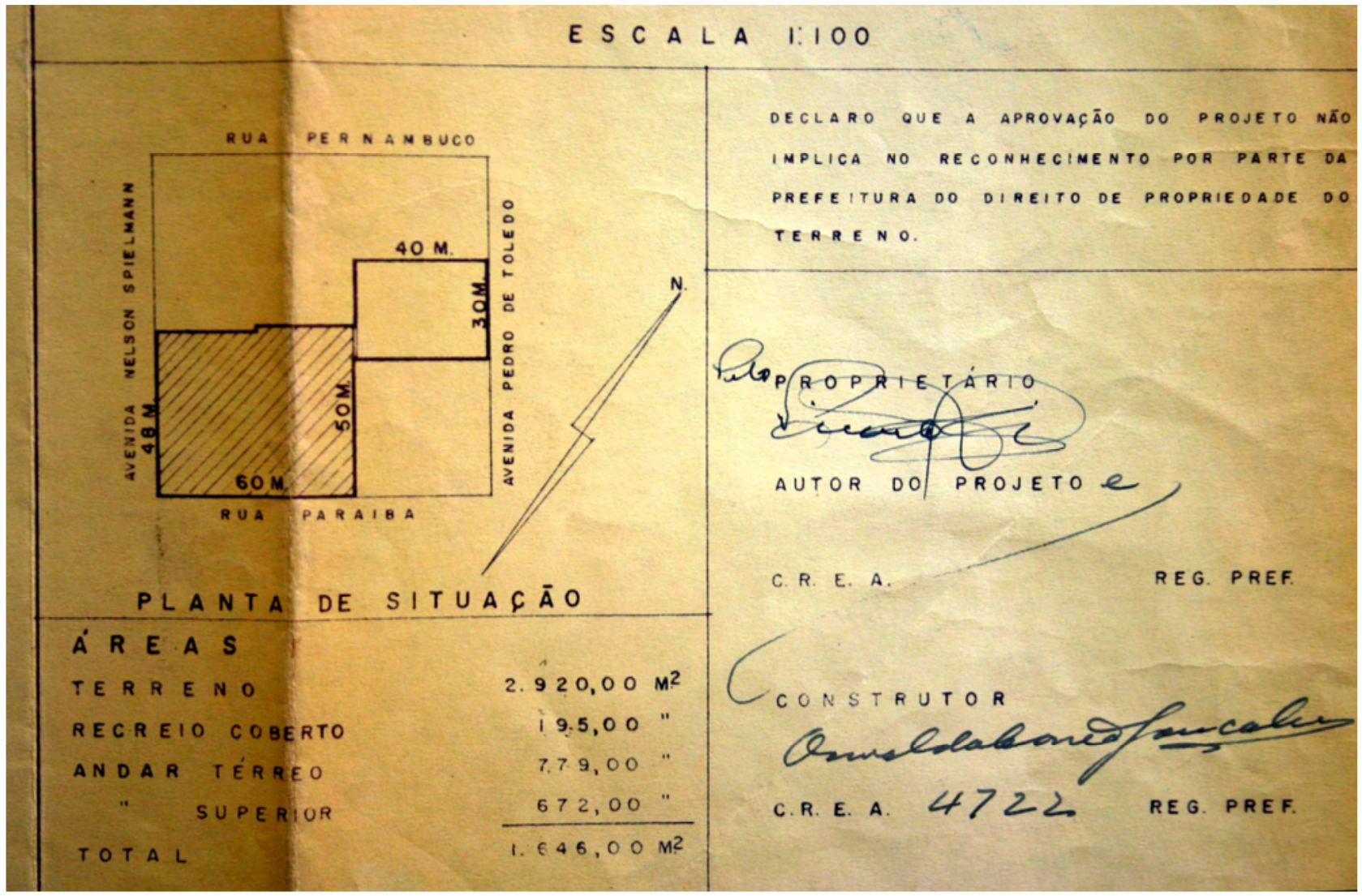

Figuras 1: Observar os dados do selo do projeto de prefeitura da Escola Sesc-Senac de Marília, concebido em 1955, com autoria de Oswaldo Corrêa Gonçalves.

Fonte: Foto Ferraz, arquivo SENAC

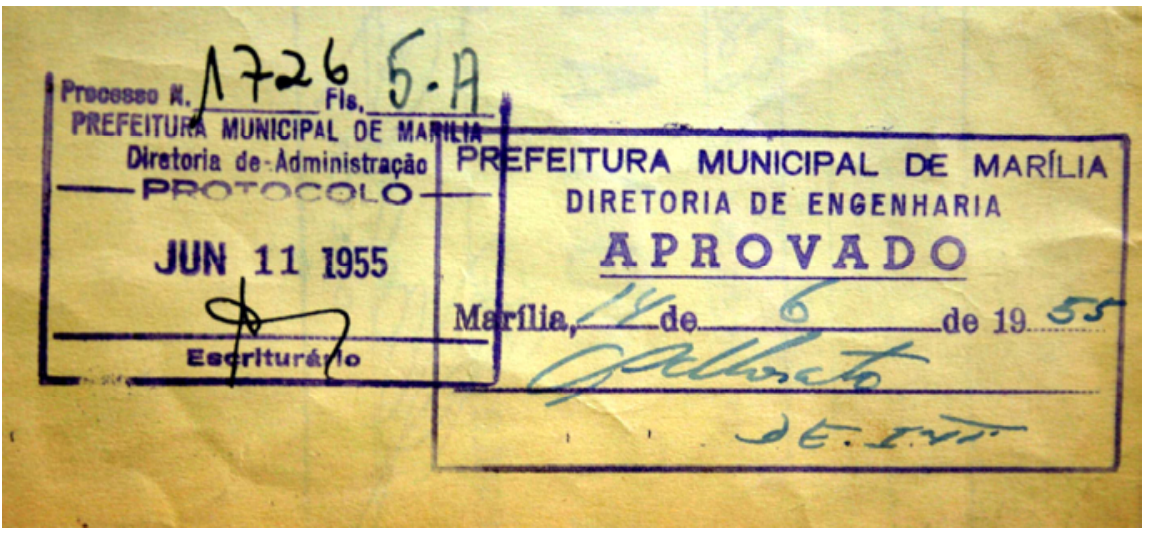

Figuras 2: Data de aprovação do projeto de prefeitura da Escola Sesc-Senac de Marília, junho em 1955. Fonte: Foto Ferraz, arquivo SENAC 


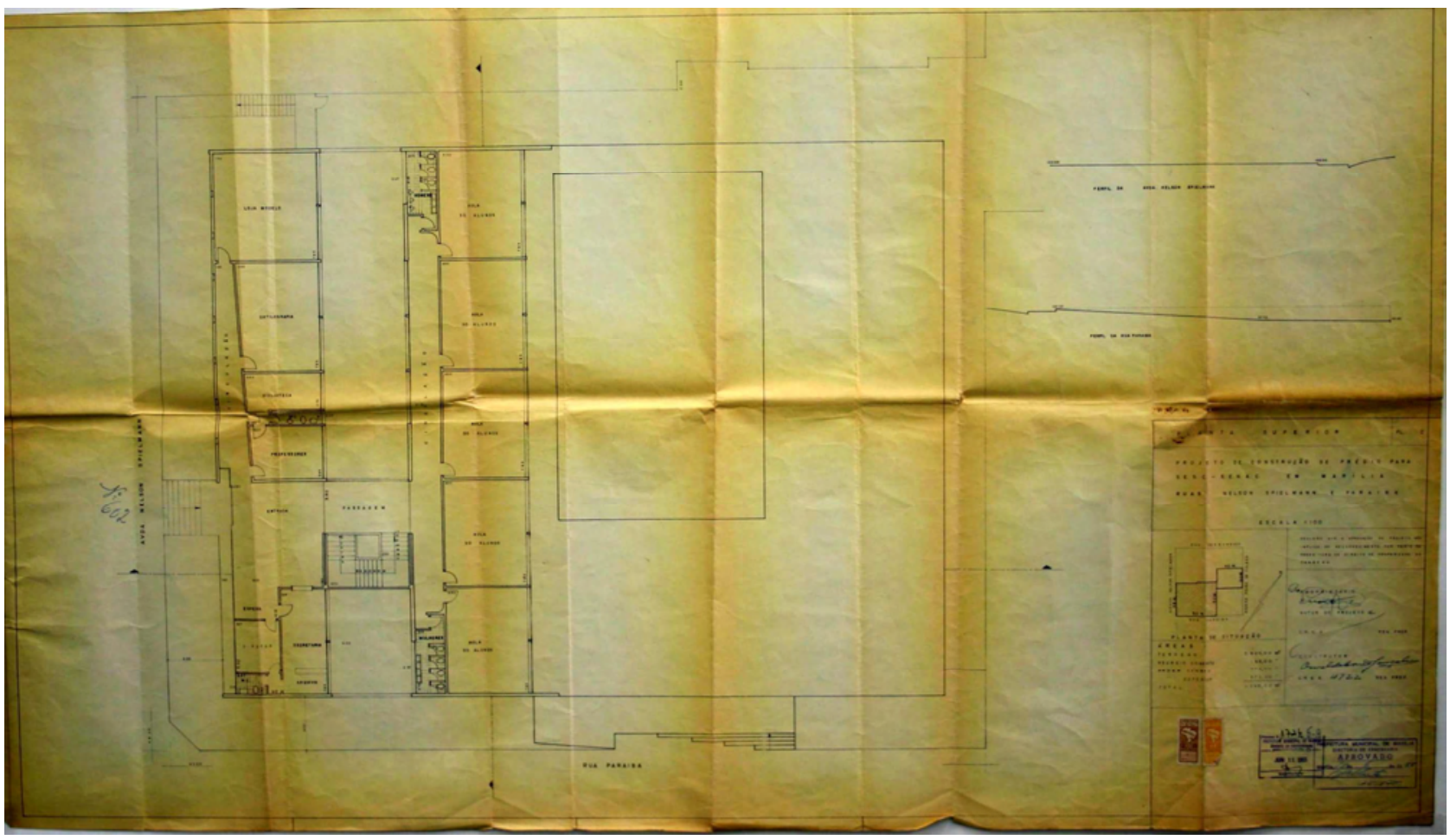

Figura 3: Prancha 1/3 projeto de prefeitura da Escola Sesc-Senac de Marília, 1955, autoria de Oswaldo Corrêa Gonçalves. Fonte: Foto Ferraz, arquivo SENAC

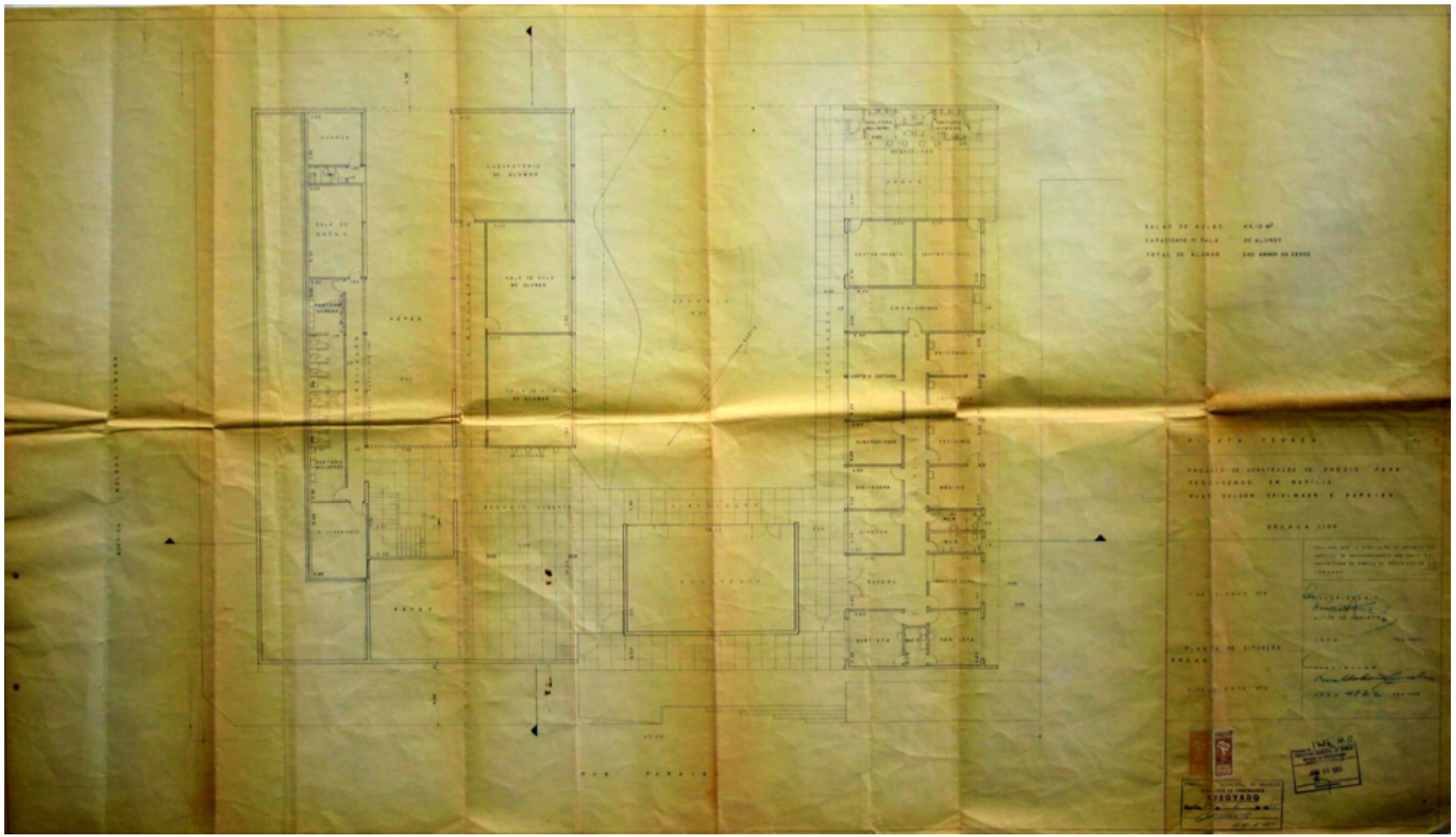

Figura 4: Prancha 2/3 projeto de prefeitura da Escola Sesc-Senac de Marília, 1955, autoria de Oswaldo Corrêa Gonçalves. Fonte: Foto Ferraz, arquivo SENAC 


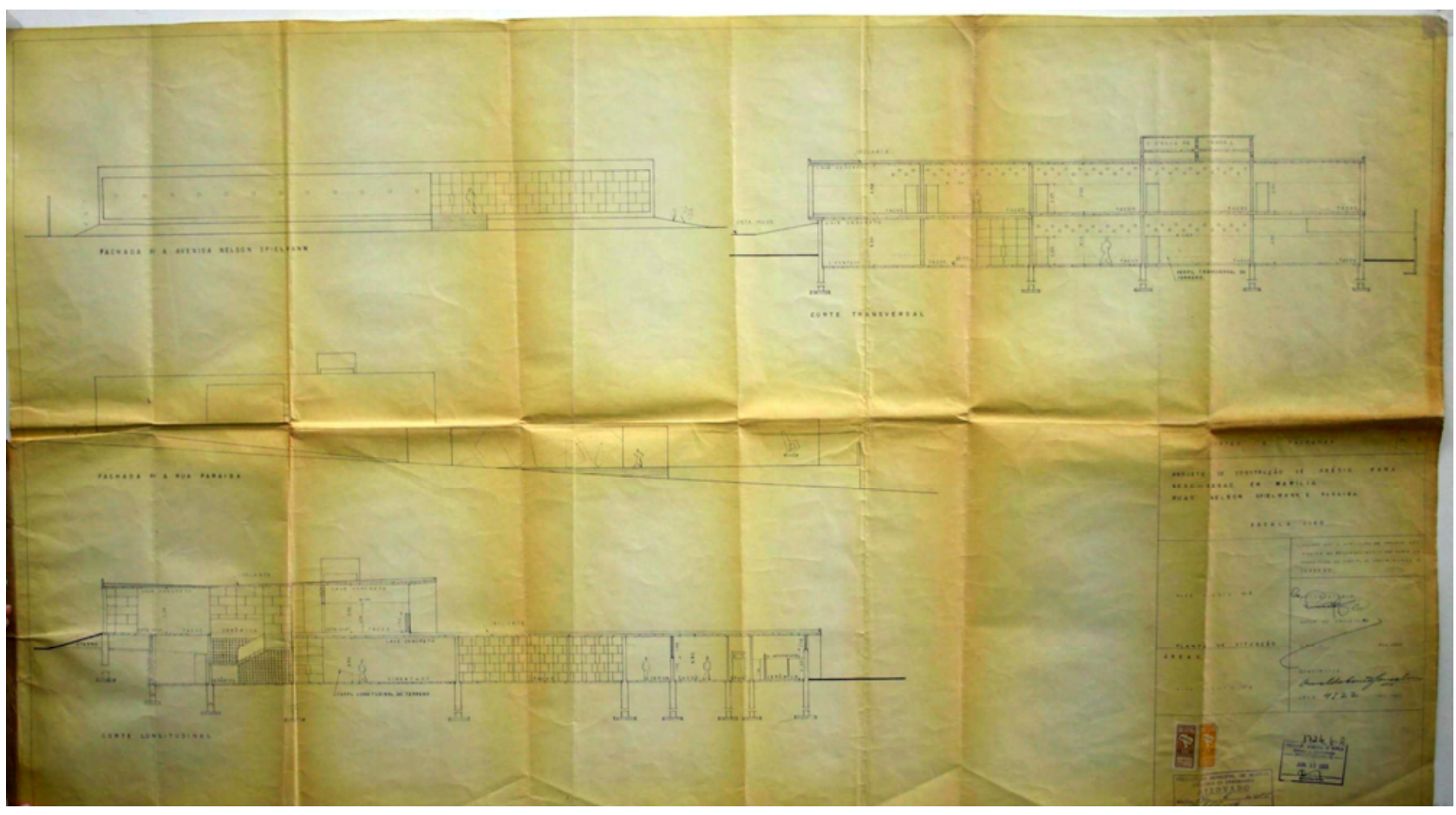

Figura 5: Prancha 3/3 projeto de prefeitura da Escola Sesc-Senac de Marília, 1955, autoria de Oswaldo Corrêa Gonçalves. Fonte: Foto Ferraz, arquivo SENAC

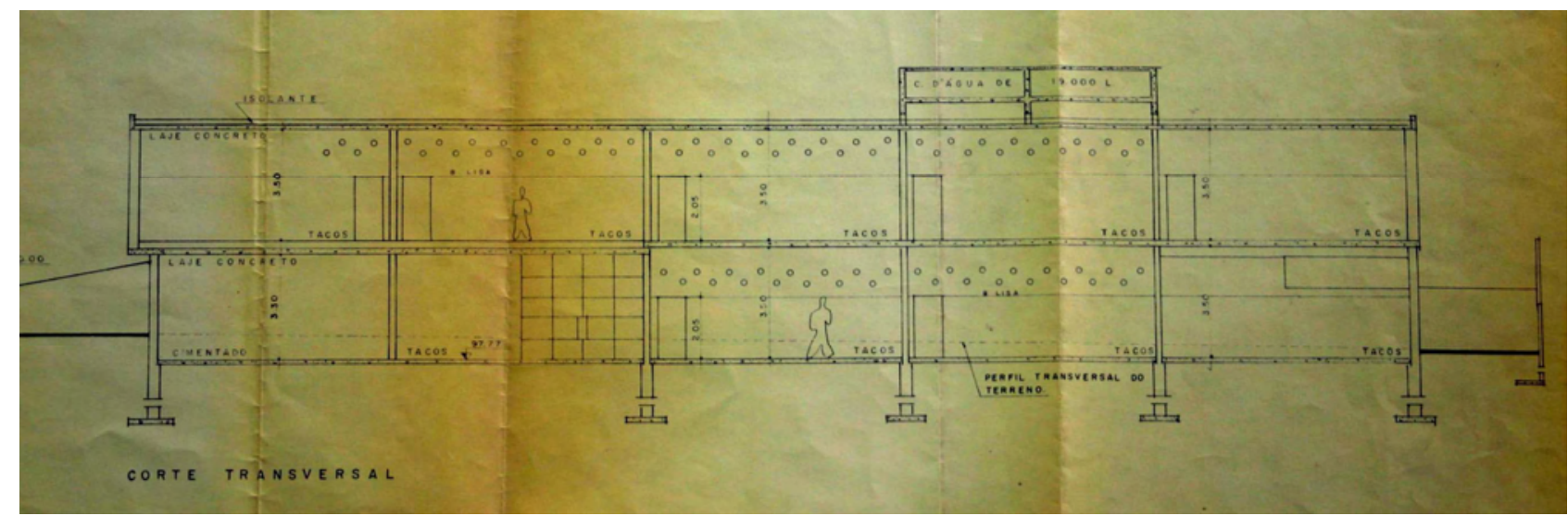

Figura 6: Corte transversal retirado da prancha 3/3 do projeto de prefeitura original na escala 1:100, Escola Sesc-Senac de Marília, 1955, autoria de Oswaldo Corrêa Gonçalves.

Fonte: Foto Ferraz, arquivo SENAC

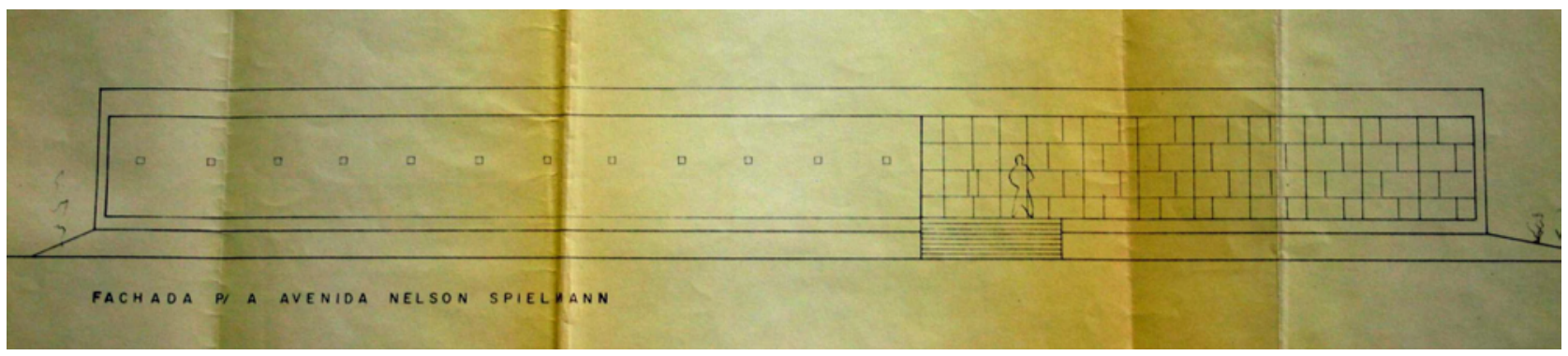

Figura 7: Elevação sudoeste retirada da prancha 3/3 do projeto de prefeitura original na escala 1:100, Escola Sesc-Senac de Marília, 1955, autoria de Oswaldo Corrêa Gonçalves.

Fonte: Foto Ferraz, arquivo SENAC 
Figura 8: Planta do pavimento térreo, Escola Sesc-Senac de Marília, 1955.

Fonte: Arquitetura e Decoração $\mathrm{n}^{\circ} 13$ (1955)

Figura 9: Planta do pavimento superior, Escola Sesc-Senac de Marília, 1955.

Fonte: Arquitetura e Decoração $n^{\circ} 13$ (1955)
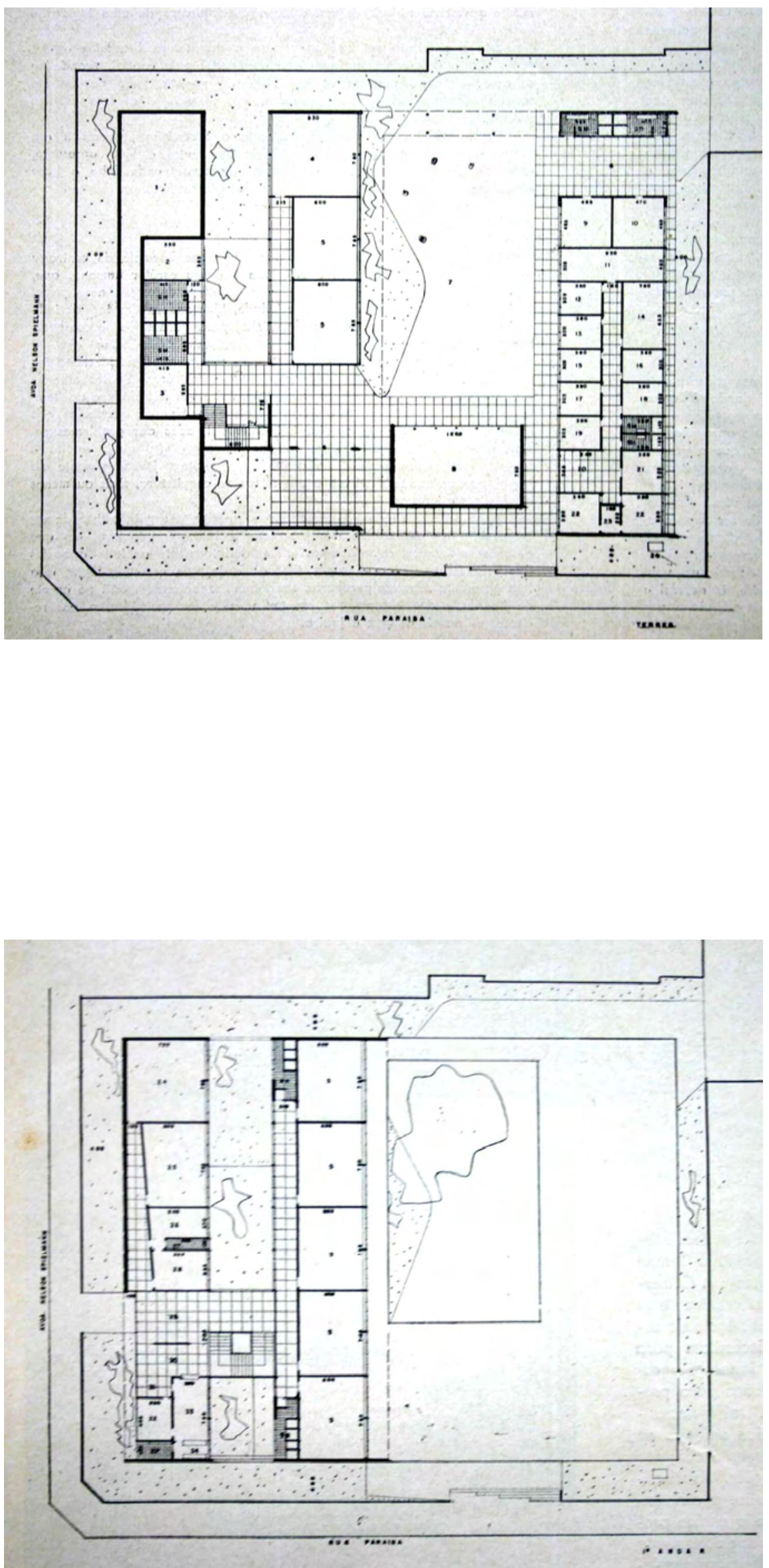


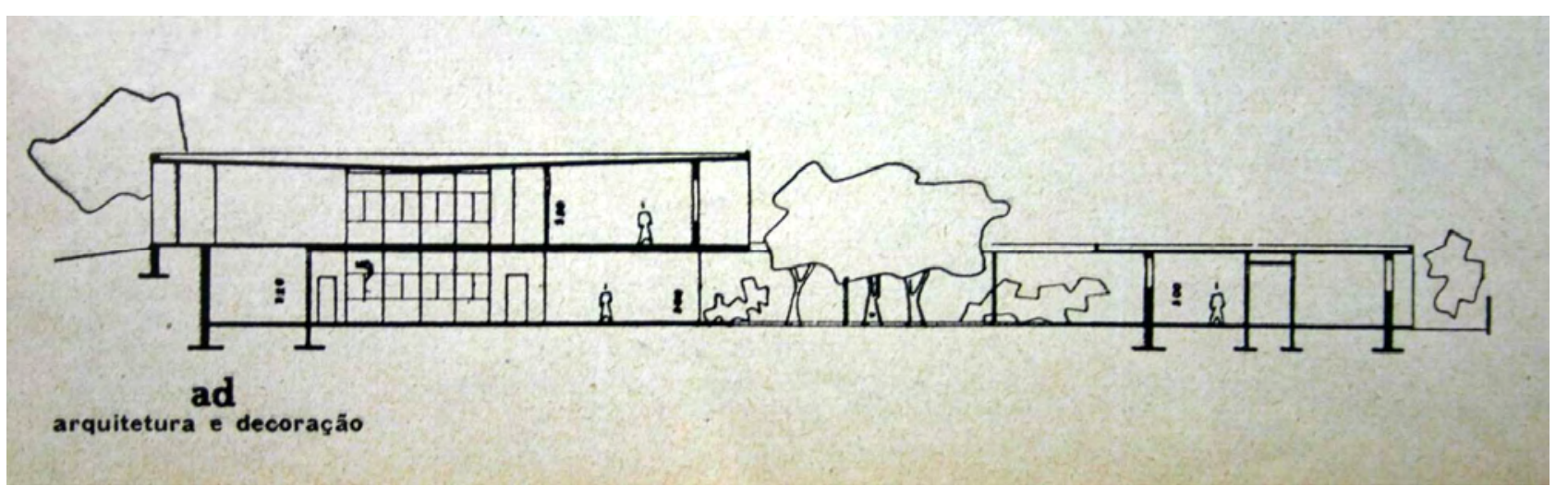

Figura 10: Corte longitudinal, Escola Sesc-Senac de Marília, 1955.

Fonte: Arquitetura e Decoração nº 13 (1955)

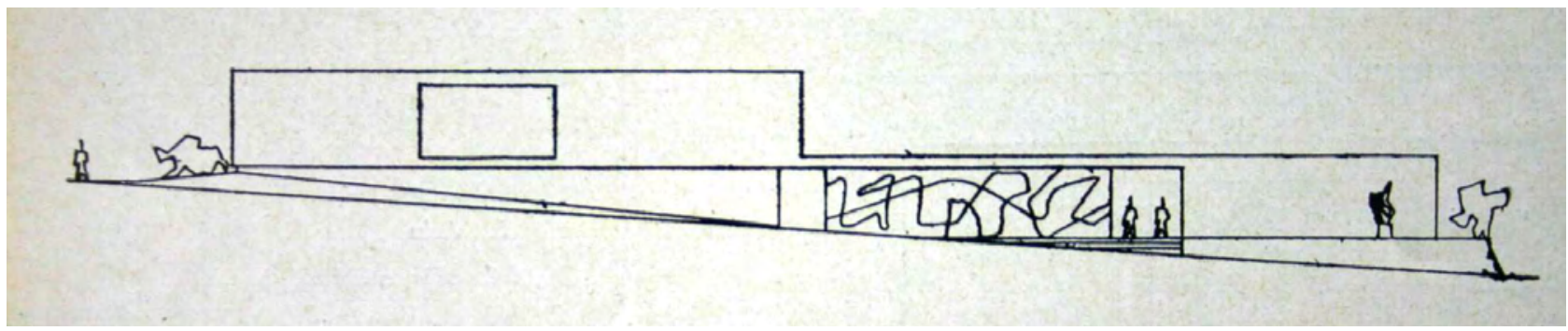

Figura 11: Elevação pela rua Paraíba, Escola Sesc-Senac de Marília,1955.

Fonte: Arquitetura e Decoração n 13 (1955)

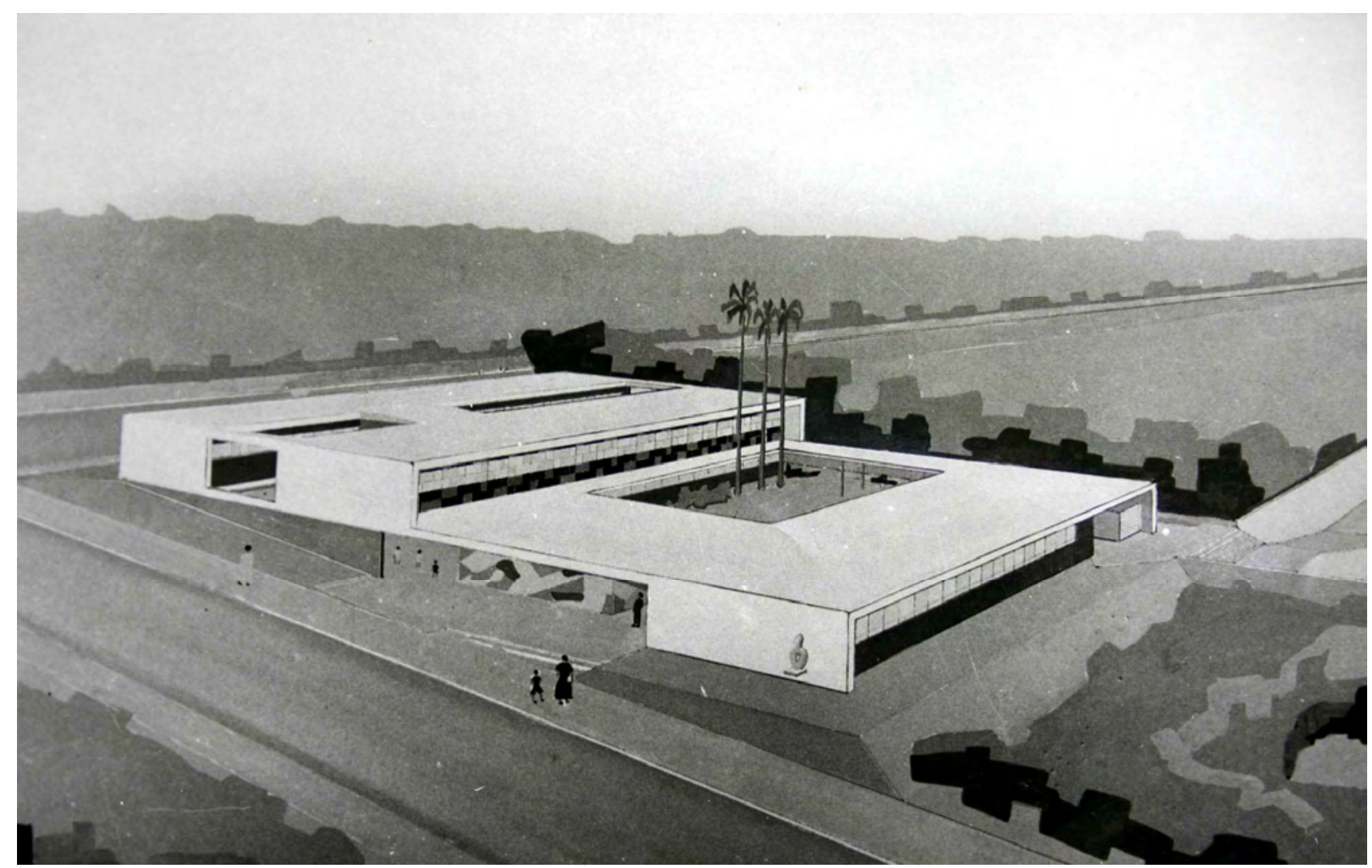

Figura 12: Perspectiva do projeto, década de 50, Escola Sesc-Senac de Marília.

Fonte: Foto Ferraz, arquivo FAUS 


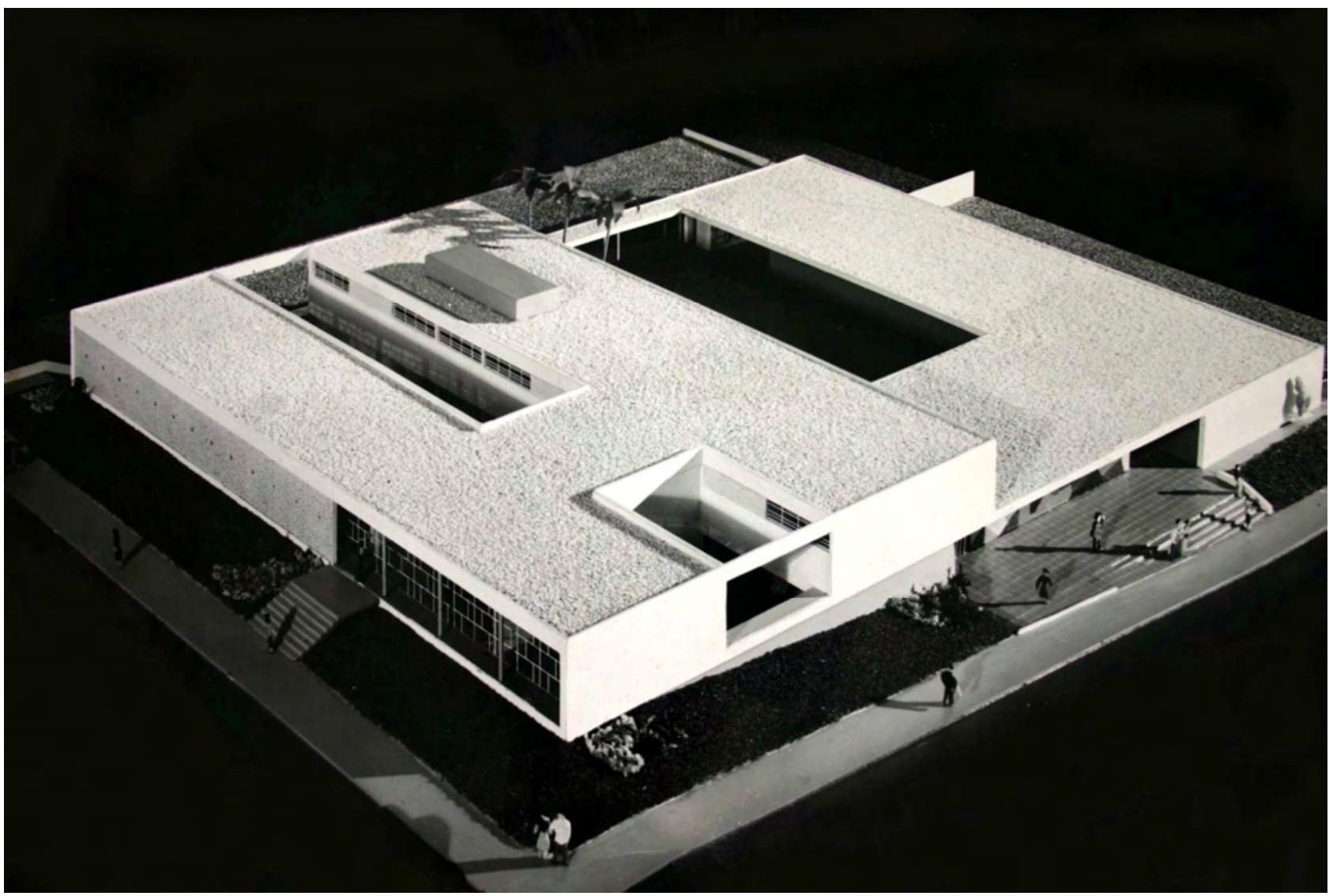

Figura 13: Maquete concebida na década de 50, Escola Sesc-Senac de Marília. Fonte: Foto Ferraz, arquivo FAUS

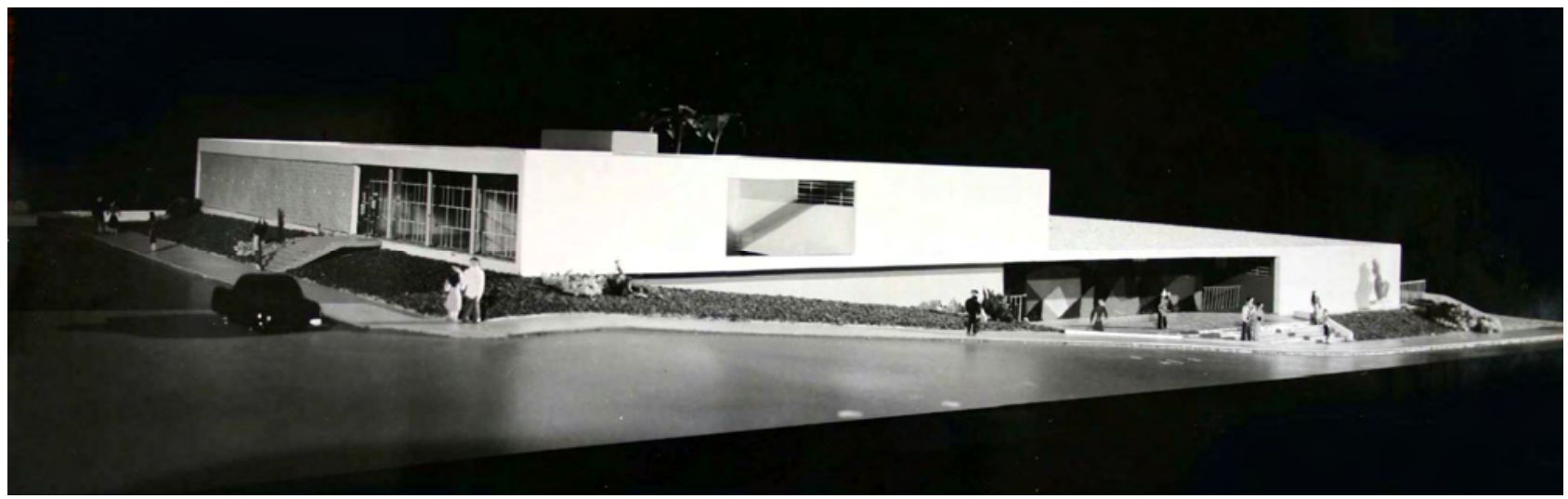

Figura 14: Maquete concebida na década de 50, Escola Sesc-Senac de Marília. Fonte: Foto Ferraz, arquivo FAUS 

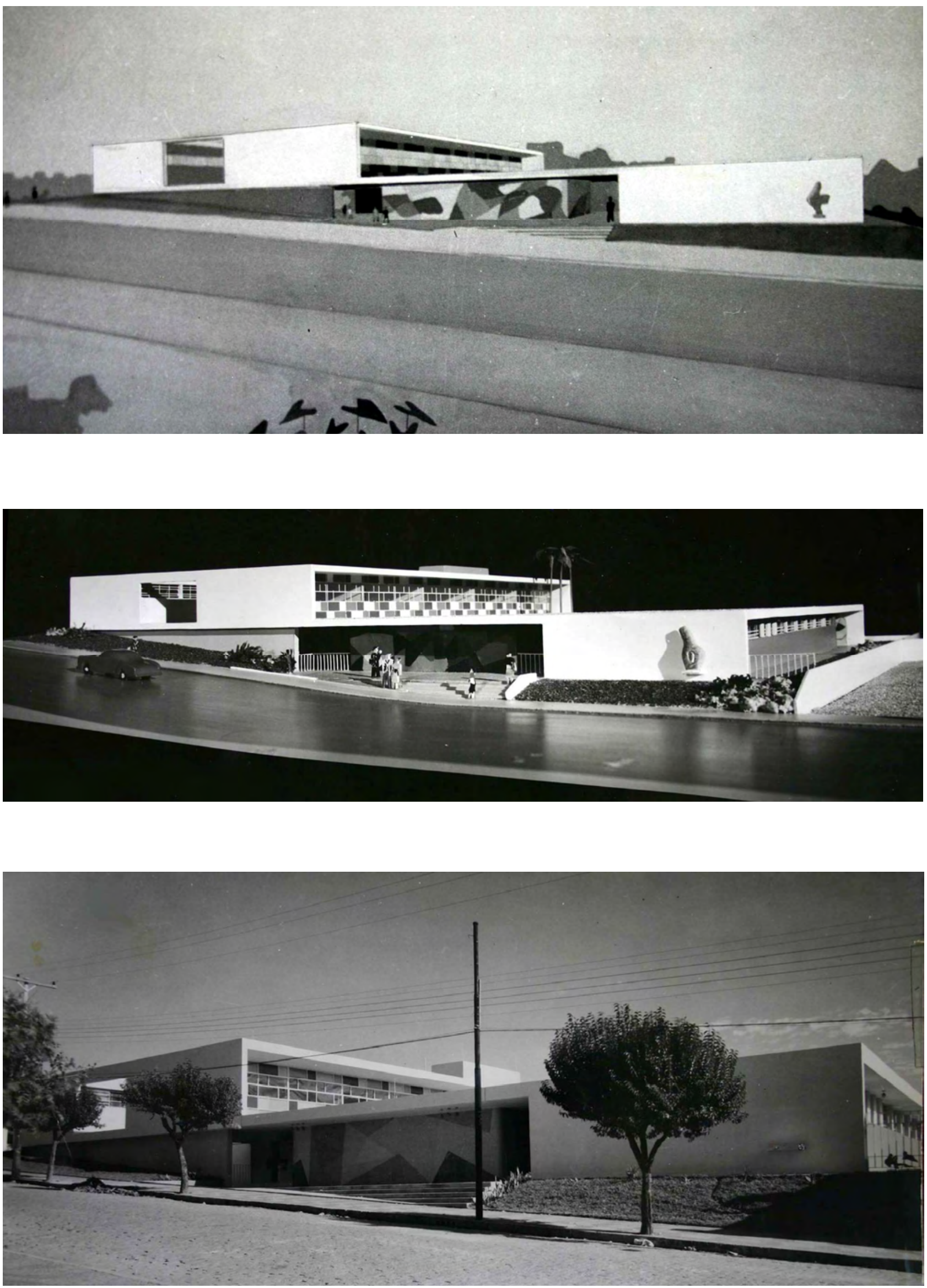

Figuras 15, 16 e 17: Perspectiva, maquete e foto da Escola Sesc-Senac de Marília. Observar as semelhanças e as diferenças entre as etapas de projeto e o edifício construído.

Fonte: Foto Moscardi, arquivo FAUS 
O primeiro bloco, o SENAC, era composto de dois pavimentos. Implantado no nível mais alto do terreno, este edifício teve seu acesso principal pela avenida, através do pavimento superior. O bloco foi dividido em duas alas, sudoeste e nordeste, separadas por um pátio aberto e interligadas por uma passagem coberta e escada. No pavimento superior foram projetados hall de entrada, diretoria, secretaria, arquivo, sala dos professores, sanitários, biblioteca, datilografia e loja modelo (ao longo da face sudoeste) e cinco salas de aula e sanitários (ao longo da face nordeste). Já o pavimento térreo, aproveitando a topografia no terreno, tinha acesso direto pela rua Paraíba e abrigava: almoxarifado, sanitários, grêmio estudantil e dependências do guarda (ao longo da face sudoeste), recreio coberto, duas salas de aula e laboratório (ao longo da face nordeste).

Figura 18: Escola Sesc-Senac de Marília, década de 50 .

Observar o edifício do SENAC projetado em dois pavimentos no nível mais alto do terreno.

Fonte: Foto Moscardi, arquivo FAUS

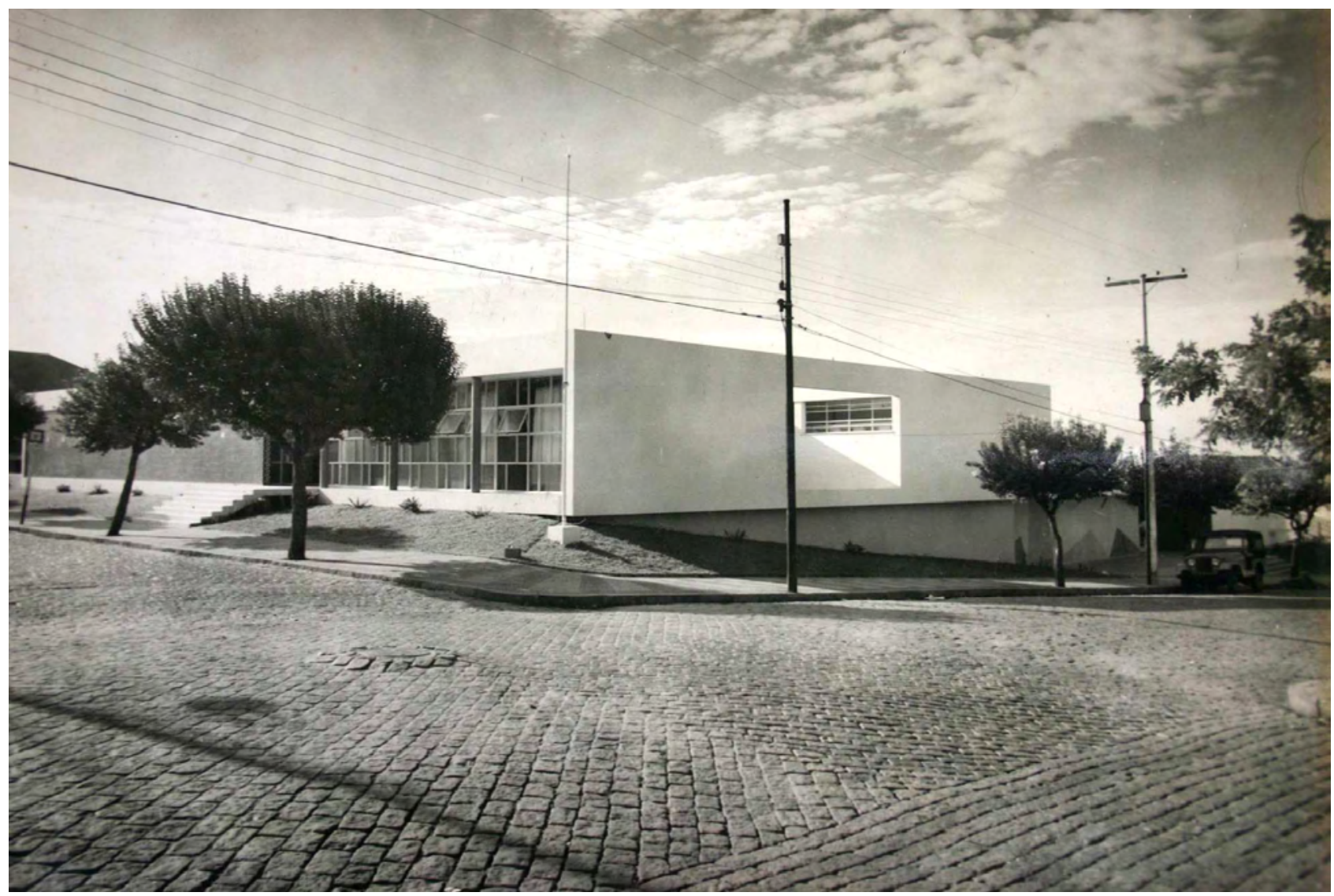




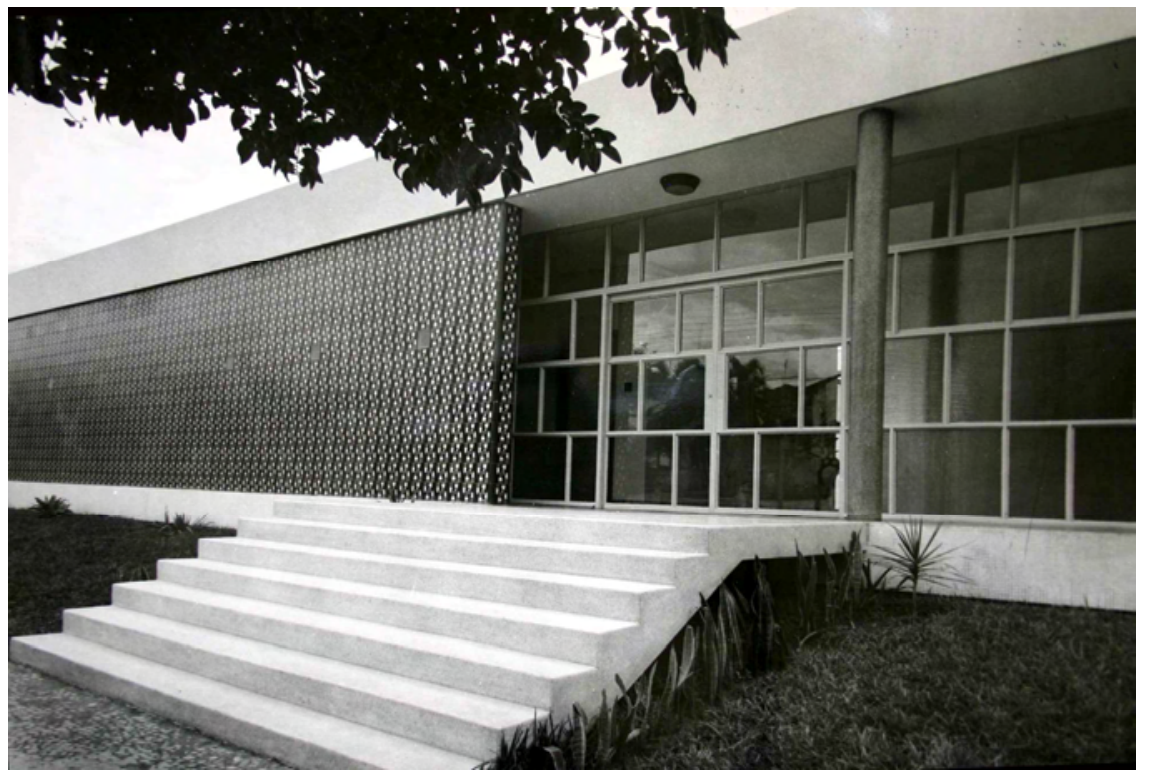

Figura 19: Escola Sesc-Senac de Marília, década de 50. Entrada do SENAC, pelo segundo pavimento, avenida Nelson Spielmann. Fonte: Foto Moscardi, arquivo FAUS

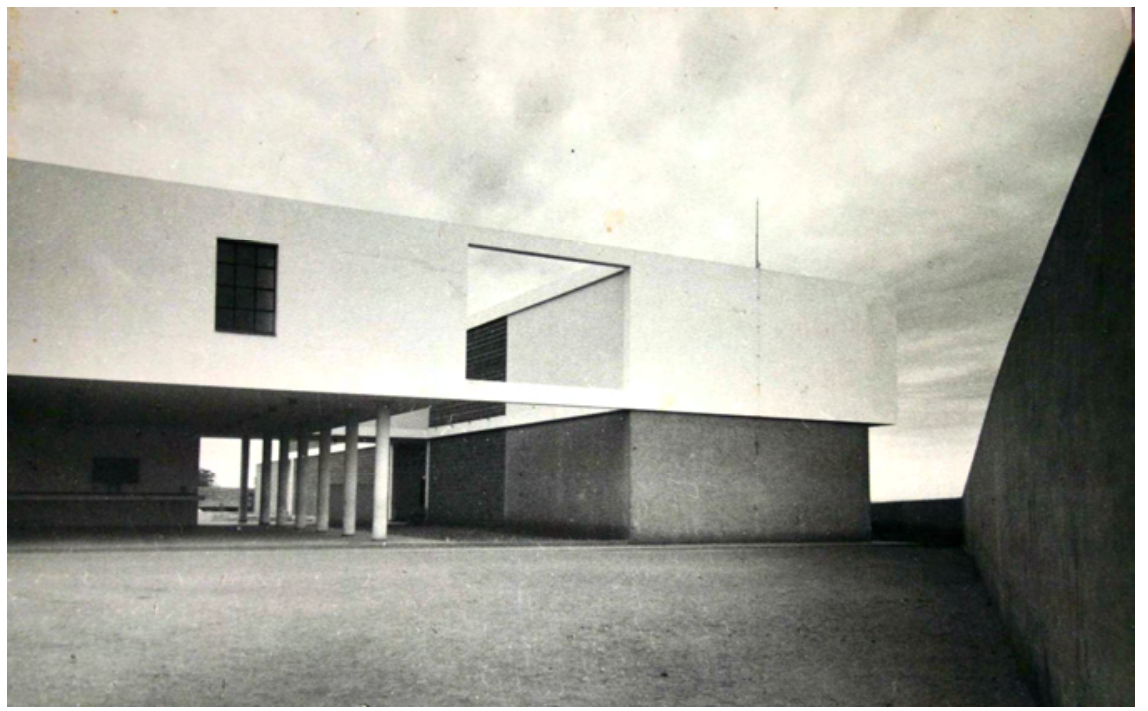

Figura 20: Observar bloco do SENAC projetado em duas alas paralelas, separadas pelo pátio descoberto e interligadas por passarela e escada.

Fonte: Foto Moscardi, arquivo FAUS

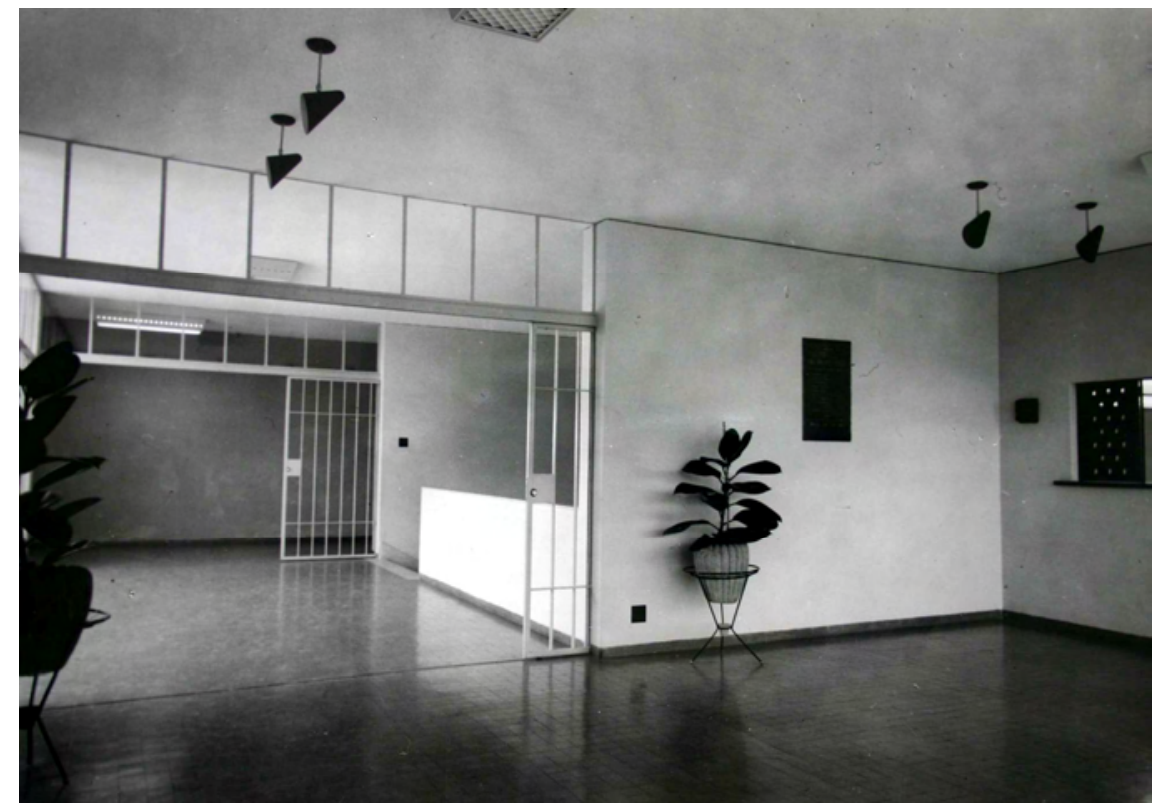

Figura 21: Passarela interna, pavimento superior, interligação entre as duas alas paralelas do bloco do SENAC.

Fonte: Foto Moscardi, arquivo FAUS 
Marcado pela horizontalidade, a circulação interna do edifício do SENAC foi resolvida através de circulações laterais que possibilitavam o acesso entre os ambientes. Vários fechamentos foram idealizados para estas circulações, de acordo com a insolação e os ambientes que elas interligavam (administração, serviço ou salas de aula), sendo projetados elementos vazados e tijolos de vidro. As sete salas de aula e o laboratório, todos projetados com iluminação lateral nordeste, receberam circulação lateral voltada para o pátio interno deste bloco e foram projetadas para 30 alunos, com cerca de 47,10m2 de área útil, cada um.

Figura 22: Circulação lateral de serviço, face nordeste, fechada por elemento vazado de concreto, bloco SENAC.

Fonte: Foto Moscardi, arquivo FAUS
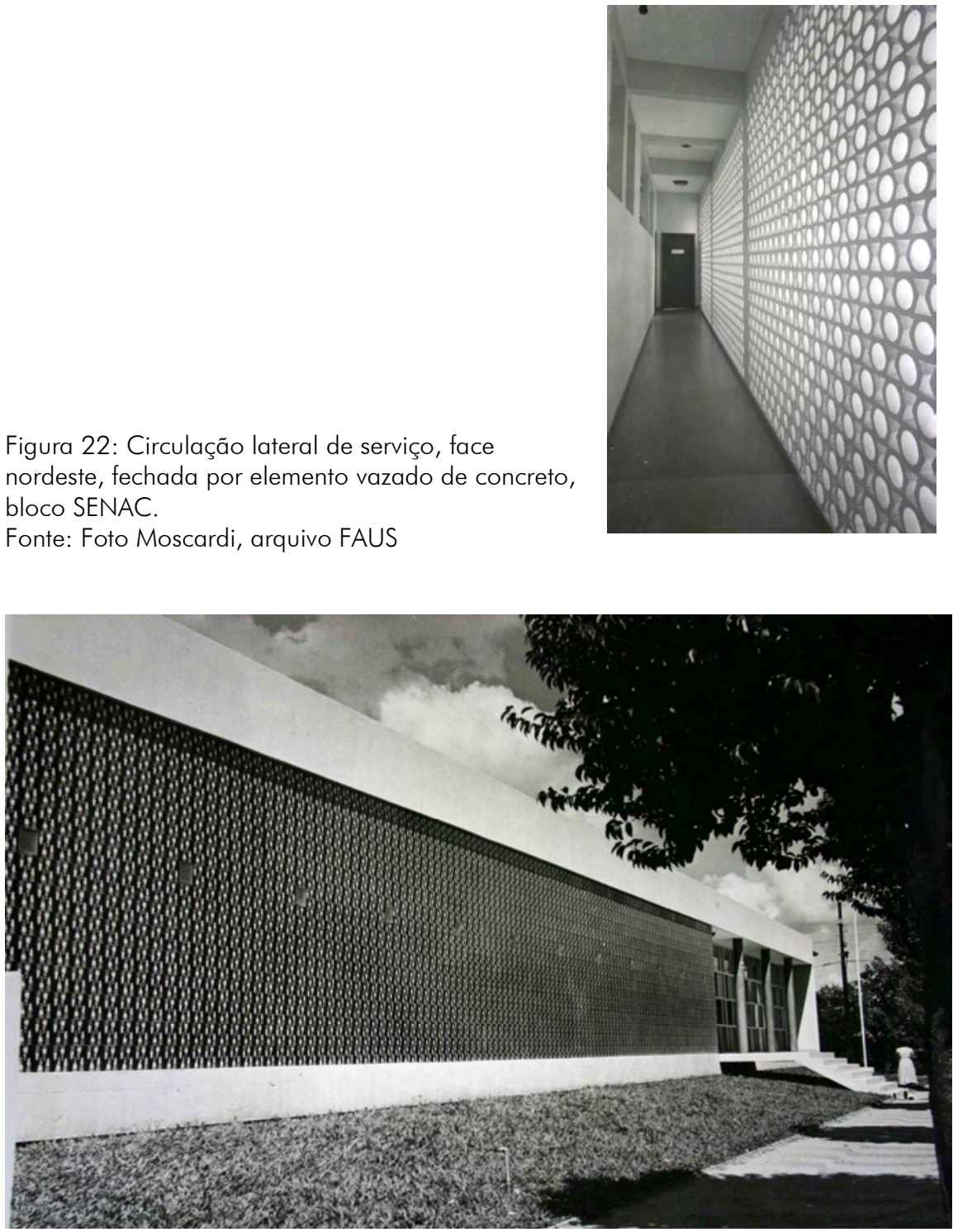

Figura 23: Circulação lateral administrativa, face sudoeste, fechada e iluminada apenas por tijolos de vidro, bloco SENAC.

Fonte: Foto Moscardi, arquivo FAUS 
Outras características podem ser observadas, como em relação ao conforto térmico. A escola como um todo adotou em sua construção "lajes de cobertura que não receberam nenhuma impermeabilização, estando simplesmente recobertas por uma camada de $10 \mathrm{~cm}$ de pedregulho de rio que, sendo ótimo isolante térmico, estabelece uma temperatura baixa e constante para 0 concreto", segundo Acrópole n 244 (1959,p.133). Esta solução colaborou na diminuição das oscilações de temperatura nos ambientes que, juntamente com a ventilação cruzada projetada nas paredes entre salas e circulação, e as lajes em balanço, favoreceram o conforto térmico da escola.
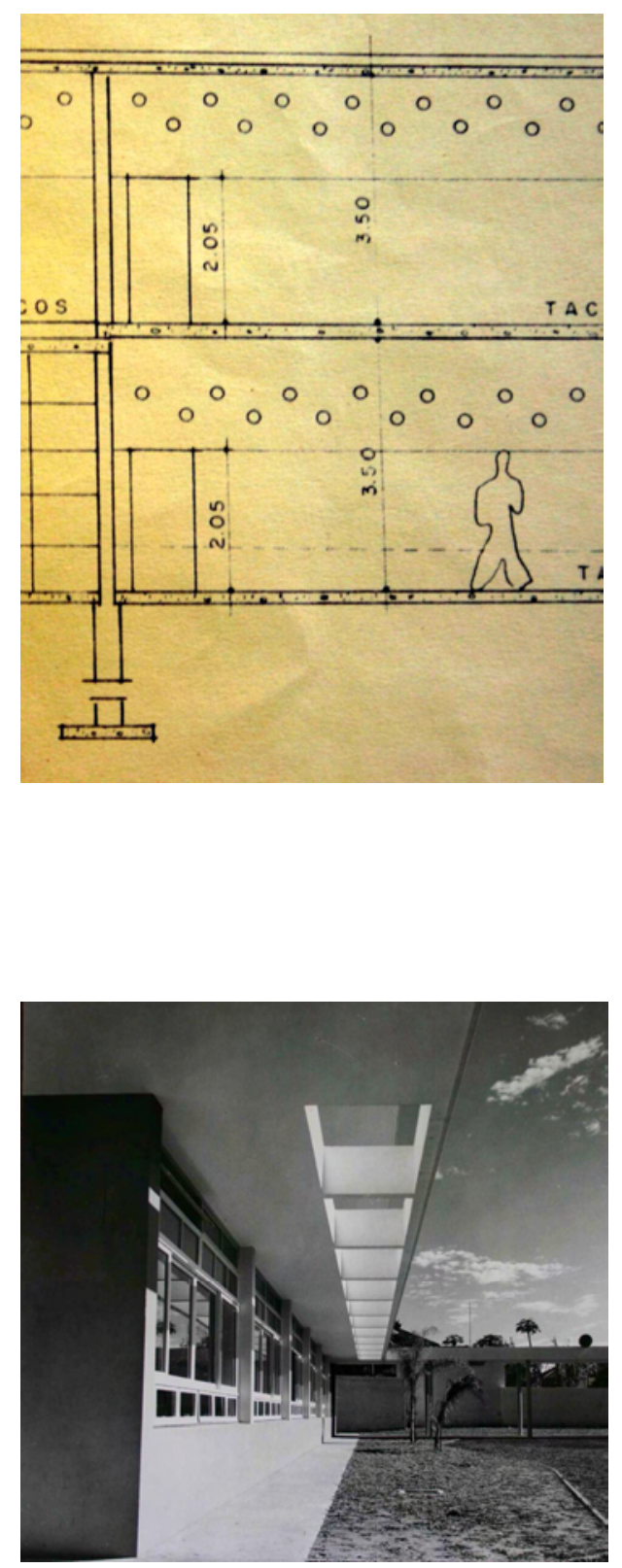

Figura 24: Detalhe do corte transversal do bloco SENAC, retirado da prancha $3 / 3$ do projeto de prefeitura. Observar furos circulares nas paredes para garantir a ventilação cruzada. Fonte: Foto Ferraz, arquivo SENAC.

Figura 25: Laje vazada e em balanço, bloco SENAC, face nordeste.

Observar o sombreamento proporcionado nas janelas das salas de aula e laboratório. Fonte: Foto Moscardi, arquivo FAUS 
O segundo bloco, o SESC, era composto de um único pavimento implantado no nível baixo do terreno, com acesso principal pela rua Paraíba. O bloco adotou circulação central dividindo as salas ao longo das faces sudoeste e nordeste, com iluminação e ventilação laterais para as mesmas. Na extremidade noroeste, foi projetado um pátio coberto para jogos, com bebedouro e sanitários, todos interligados com uma passarela coberta que ligava perpendicularmente os blocos do SESC e SENAC. Também, logo na entrada principal, este bloco foi interligado ao SENAC pelo auditório (com capacidade para 300 pessoas), recreio e circulação cobertos, enfatizando a concepção de serem dois blocos interligados pelos ambientes de uso comum de ambos os serviços.

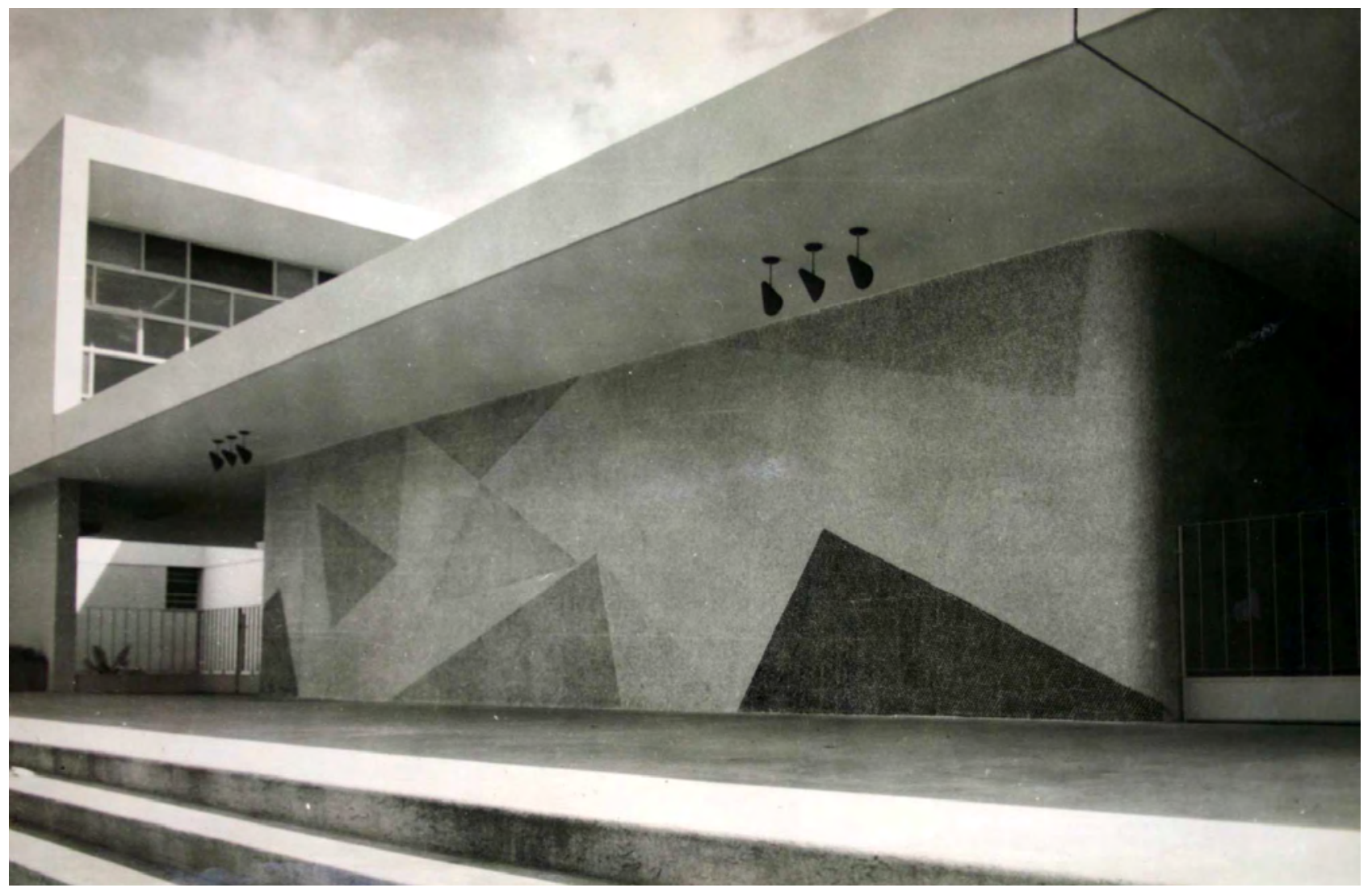

Figura 26: Entrada principal do SESC na extremidade direita da foto. Observar painel artístico no volume do auditório. Fonte: Foto Ferraz, arquivo SENAC. 

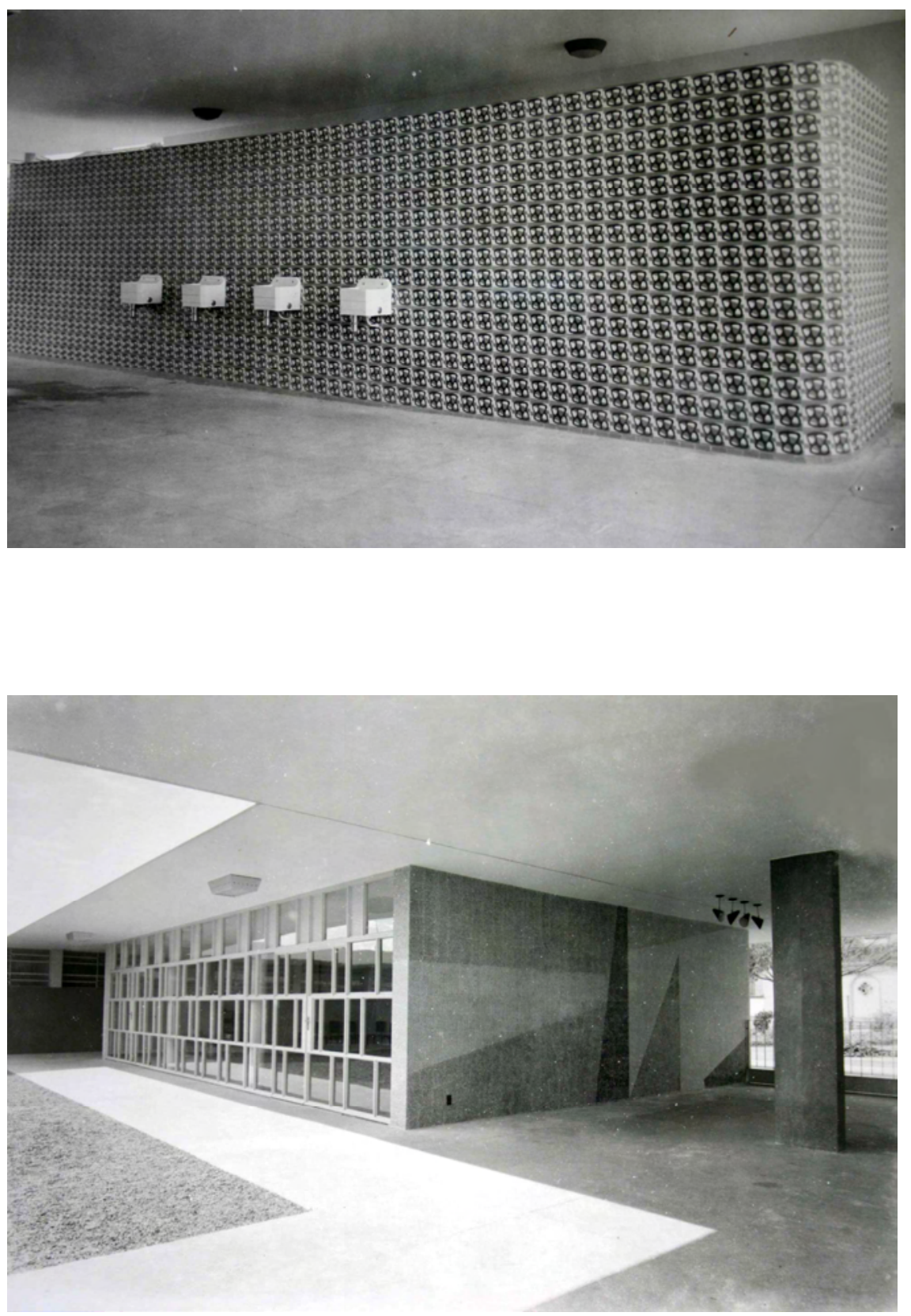

Figura 27: Pátio para jogos com bebedouro. Sanitários foram construídos atrás da parede artística, bloco SESC. Fonte: Foto Moscardi, arquivo FAUS
Figura 28: Vista do auditório, circulação e recreio cobertos, espaços de uso comum do SESC e do SENAC. Fonte: Foto Moscardi, arquivo FAUS

Reforçando a integração das artes plásticas à arquitetura, destacam-se nesta escola dois tipos de painéis, ambos de autoria de Marcelo Grassman: o de pastilhas de vidro revestindo o volume do auditório e o de ladrilho hidráulico tanto na fachada do bloco do SENAC como no bebedouro do SESC. 


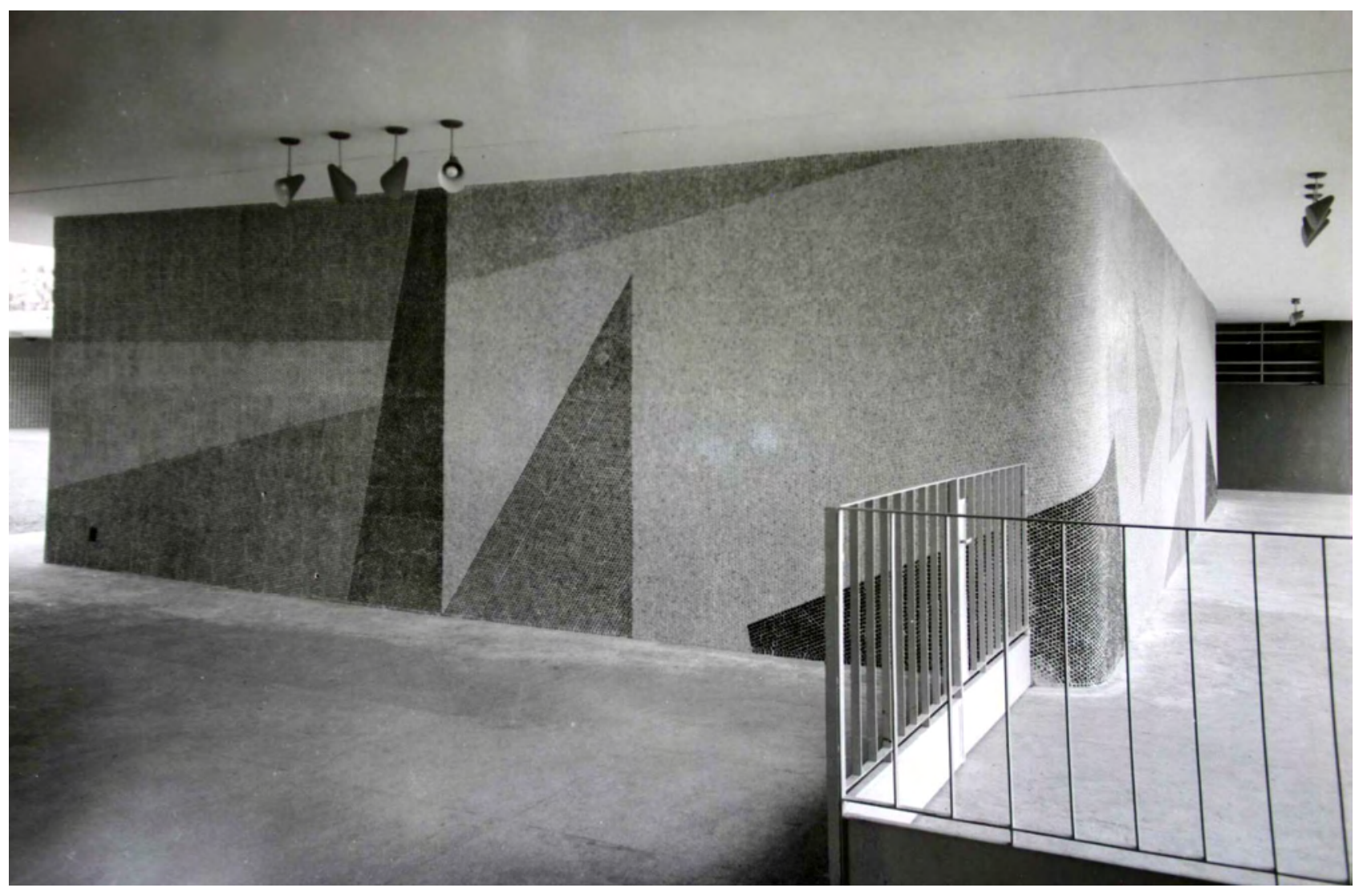

Figura 29: Volume do auditório revestido por pastilhas de vidro em painel artístico idealizado por Marcelo Grassman.

Fonte: Foto Moscardi, arquivo FAUS

A Escola de Marília, condicionada à declividade do terreno, reuniu em seu projeto a construção de dois edifícios com funções diferentes, exigindo acessos independentes, em blocos distintos e interligados pelas dependências de uso comum ao SESC e ao SENAC. Seguindo a idéia de blocos paralelos com pátios internos, estrutura racional e modulada, fachadas livres e retilíneas, a Escola obteve maior leveza através de corte retangular na parede do SENAC, lajes em balanço, paredes recuadas e painéis artísticos. Inaugurada em 12 de abril de 1958, esta escola foi a primeira a ser idealizada com dois blocos interligados.

Posteriormente, em 1971, o SENAC adquiriu a parte do SESC e esta escola passou a ser utilizada somente pelo SENAC. $O$ estado atual do SENAC de Ribeirão Preto revela muitas reformas em relação ao projeto original, descaracterizando muitos dos princípios idealizados. 


\section{PROJETO 3}

\section{Escola Sesc-Senac de Bauru, 1956}

O edifício SESC-SENAC de Bauru' está localizado no centro da cidade num terreno de $3.048,13 \mathrm{~m}^{2}$ com frente para três grandes vias: rua Saint Martin, rua Primeiro de Agosto e a avenida Nações Unidas. Quando o projeto foi concebido, os acessos eram pelas ruas Saint Martin e Primeiro de Agosto, e no local da atual avenida havia somente o Córrego das Flores, hoje canalizado e tamponado por esta avenida. Sua implantação foi alinhada aos passeios, tendo recuo de 4 metros em relação à rua Saint Martin e recuo de 3 metros em relação à rua Primeiro de Agosto. A área total de construção do projeto original foi de 1.468,06 $\mathrm{m}^{2}$, sendo $585,06 \mathrm{~m}^{2}$ (SESC) e 31,50 $\mathrm{m}^{2}$ (sanitários) no pavimento térreo e $851,50 \mathrm{~m}^{2}$ (SENAC) no pavimento superior, portanto a taxa de ocupação do edifício no terreno foi de $42 \%$.

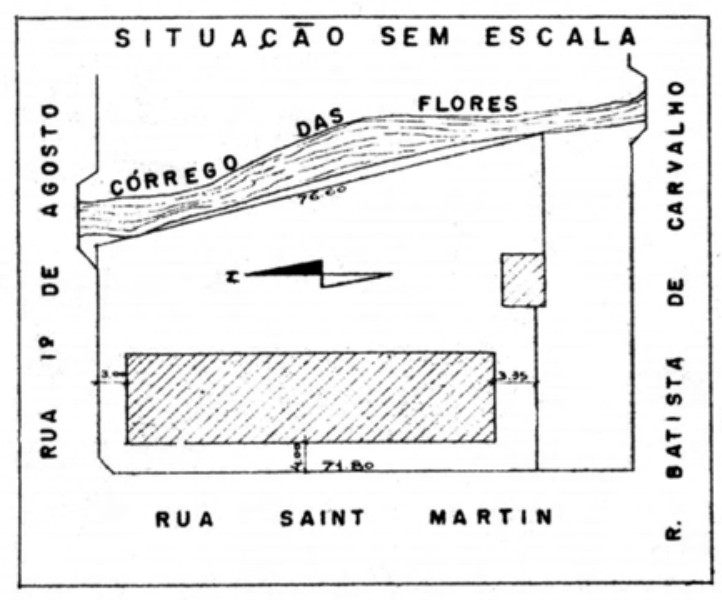

Figura 1: Planta de situação da Escola Sesc-Senac de Bauru, 1956, autoria de Oswaldo Corrêa Gonçalves. Observar que quando o projeto foi concebido não existia a atual avenida Nações Unidas e sim o Córrego das Flores. Fonte: Arquivo Prefeitura Municipal de Bauru

Oedifício, dividido em dois pavimentos de usos diferentes e com acessos independentes, possibilitou uma separação funcional entre o SESC e o SENAC. O pavimento térreo teve seu acesso principal pela rua Saint Martin - fachada oeste - e seus ambientes foram projetados para atender o programa do SESC: recepção, sala de assistência social, salas de atendimento médico e dentário, enfermaria, sala de raio $X$ com câmara escura, sala de corte e costura, diretoria, copa-cozinha, sanitários, além dos vestiários 
femininos e masculinos, projetados independentemente do corpo do edifício principal. Já o segundo pavimento tinha acesso pela rua Primeiro de Agosto - fachada norte - e compreendia o programa para atender o SENAC: sete salas de aula, diretoria, secretaria, sala de professores, biblioteca, laboratório, sala de datilografia, loja modelo, almoxarifado e sanitários.

Os dados relativos ao edifício em estudo foram encontrados em diferentes localidades: material fotográfico, na FAUS, e em periódico da época: Acrópole n 253 (1959); projeto de ampliação, no arquivo de sua respectiva sede em Bauru; projeto original de prefeitura, na FAUS; processo $n^{\circ} 4511 / 56$ de aprovação do projeto e de licença para sua construção, no arquivo da Prefeitura Municipal de Bauru. A partir do número do processo foi possível o acesso à cópia do projeto de prefeitura original, bem como do memorial descritivo construtivo, do requerimento de aprovação e construção do projeto, e do "habite-se" do edifício. Os documentos encontrados no processo $n^{\circ} 451$ 1/56 confirmam que os Departamentos Regionais no Estado de São Paulo do Serviço Social do Comércio e do Serviço Nacional de Aprendizagem Comercial solicitaram a aprovação do projeto e licença para construir em terreno de sua propriedade o edifício-escola SESCSENAC, cujo responsável pelo projeto foi o arquiteto Oswaldo Corrêa Gonçalves e pela construção o engenheiro civil Luiz Edmundo Coube $^{2}$. A aprovação municipal deste projeto aconteceu em 12 dias, sendo que o protocolo de entrada do processo foi em 4 de abril de 1956 (o projeto já estava aprovado pelo Departamento de Saúde do Estado) e sua aprovação foi deferida em 16 de abril de 1956. O "habite-se" - vistoria de conclusão - do edifício foi solicitado em 20 de maio de 1958 pelo diretor do SESC-SENAC Benedito Moreira Pinto e deferido em 4 de junho de 1958.

Ainda, para facilitar a leitura arquitetônica do projeto e representá-lo graficamente através de significativos dados obtidos no projeto de prefeitura original, foram graficamente redesenhados plantas, corte e fachada.

2 Luiz Edmundo Carrijo Coube além de engenheiro, foi prefeito de Bauru de 31/01/1973 a 31/01/1977. Como parte da história da cidade, seu nome foi homenageado no urbano da cidade através da Avenida Engenheiro Luiz Edmundo Carrijo Coube, atual endereço do Campus de Bauru da Universidade Estadual Paulista (UNESP). 


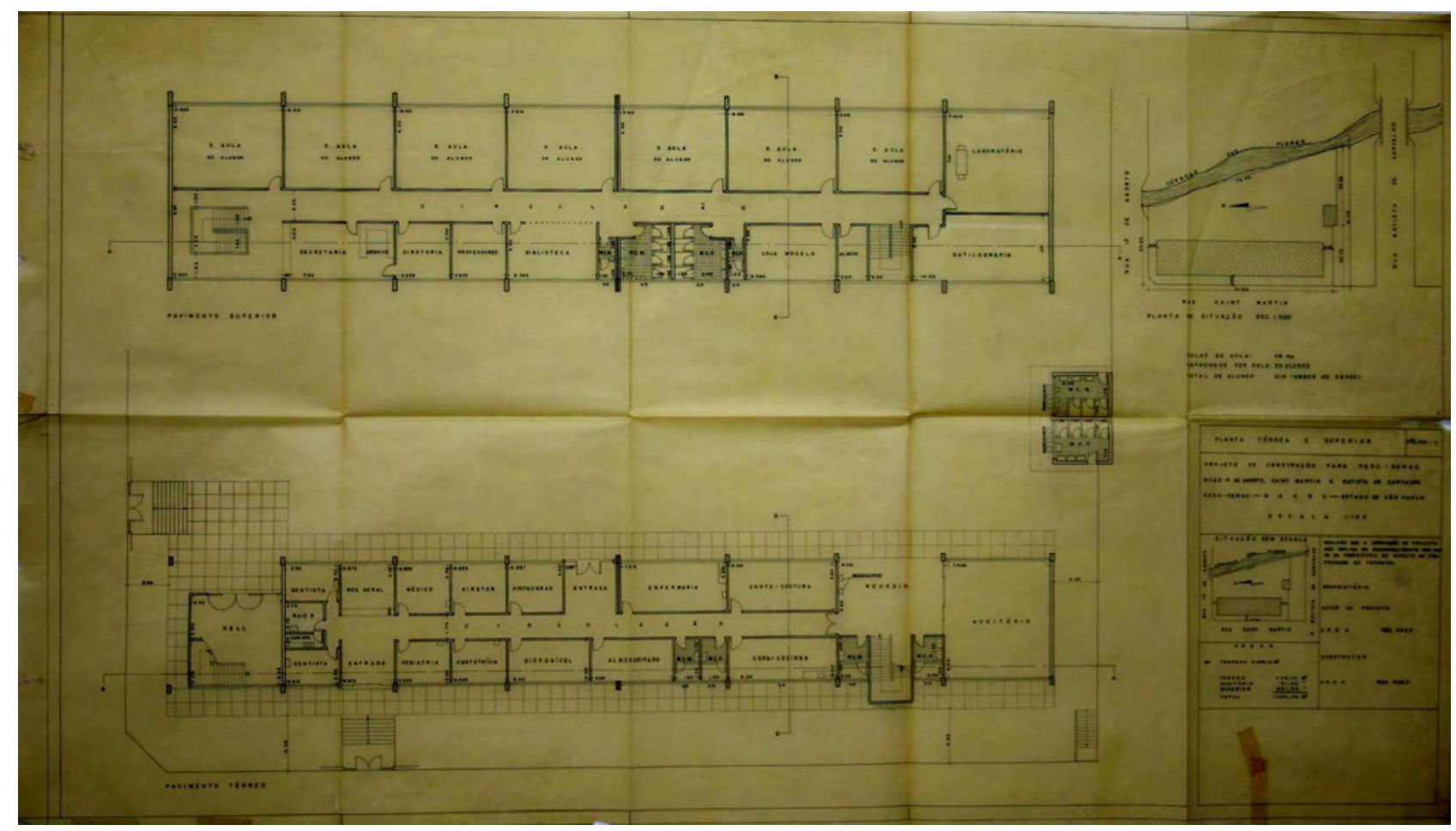

Figura 2: Prancha 1/2 projeto de prefeitura da Escola Sesc-Senac de Bauru, 1956, autoria de Oswaldo Corrêa Gonçalves. Fonte: Foto Ferraz, arquivo FAUS

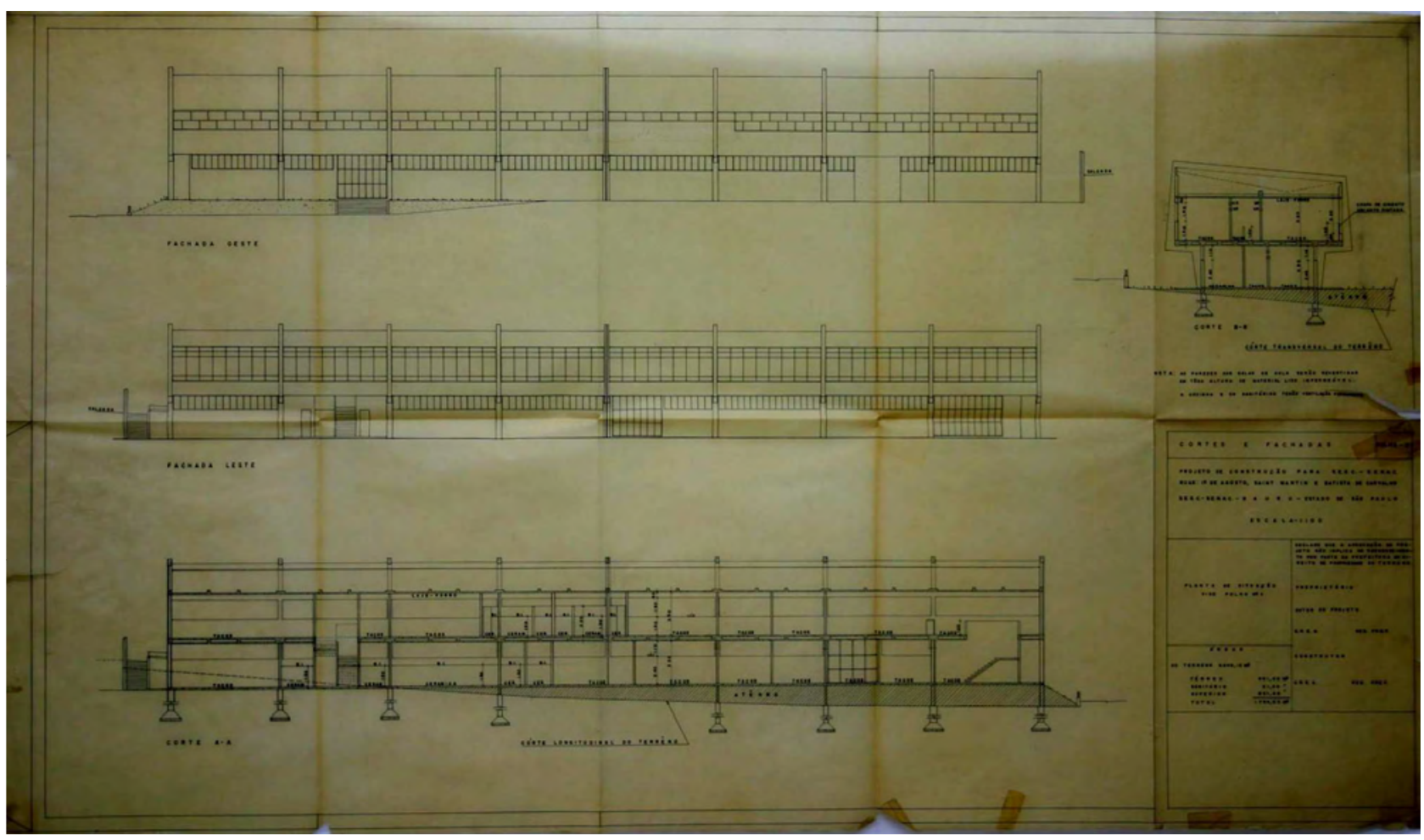

Figura 3: Prancha 2/2 projeto de prefeitura da Escola Sesc-Senac de Bauru, 1956,autoria de Oswaldo Corrêa Gonçalves. Fonte: Foto Ferraz, arquivo FAUS 
Figura 4: Corte transversal retirado da prancha $2 / 2$ projeto de prefeitura da Escola SescSenac de Bauru, 1956, autoria de Oswaldo Corrêa Gonçalves. Fonte: Foto Ferraz, arquivo FAUS

Figura 5: Selo do projeto executivo do detalhamento do muro e mastro de bandeira, Escola Sesc-Senac de Bauru, 1958 autoria de Oswaldo Corrêa Gonçalves.

Fonte: Foto Ferraz, arquivo FAUS

Figuras 6 e 7: Requerimento de aprovação e memorial descritivo da Escola Sesc-Senac de Bauru, 1956, autoria de Oswaldo Corrêa Gonçalves.

Fonte: Arquivo Prefeitura Municipal de Bauru
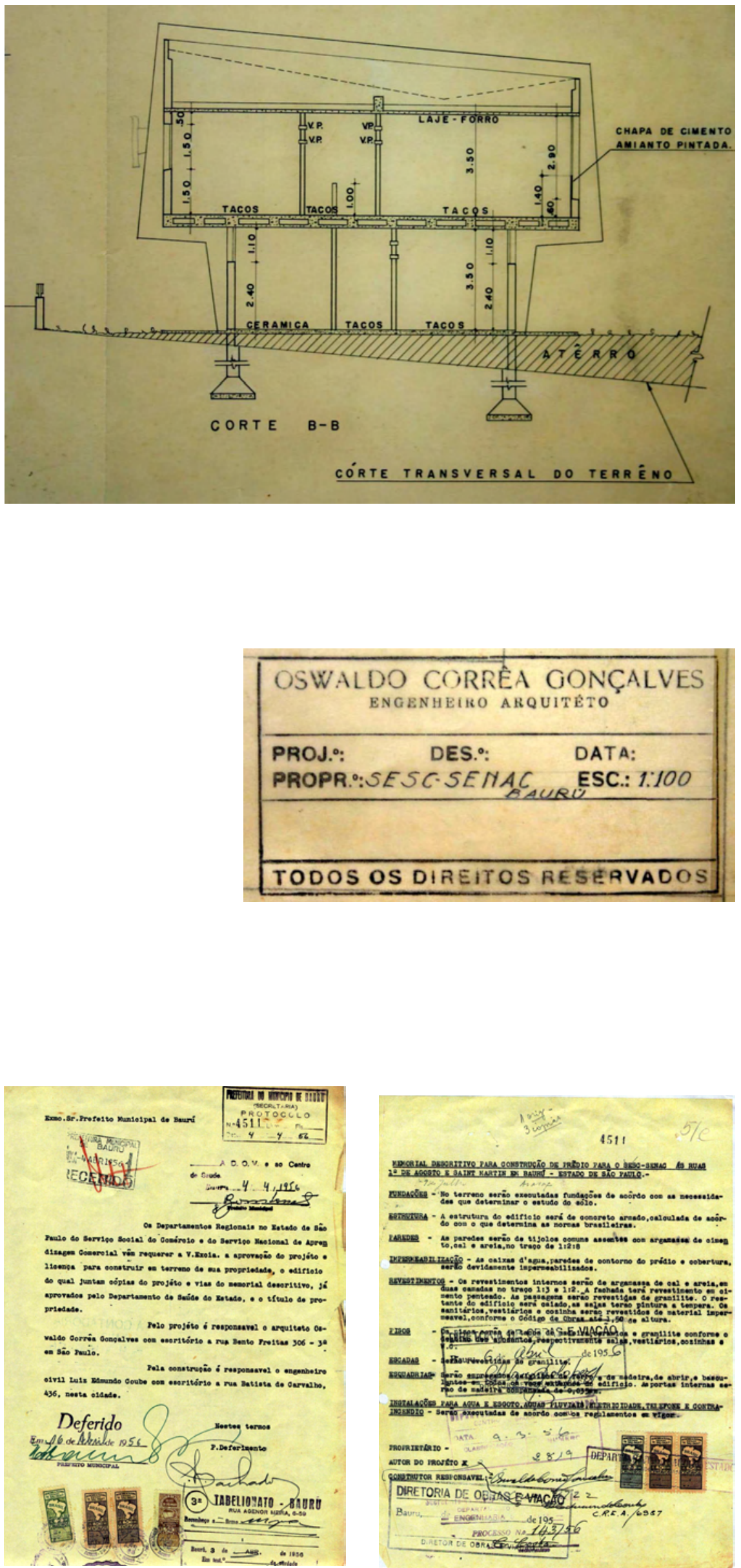


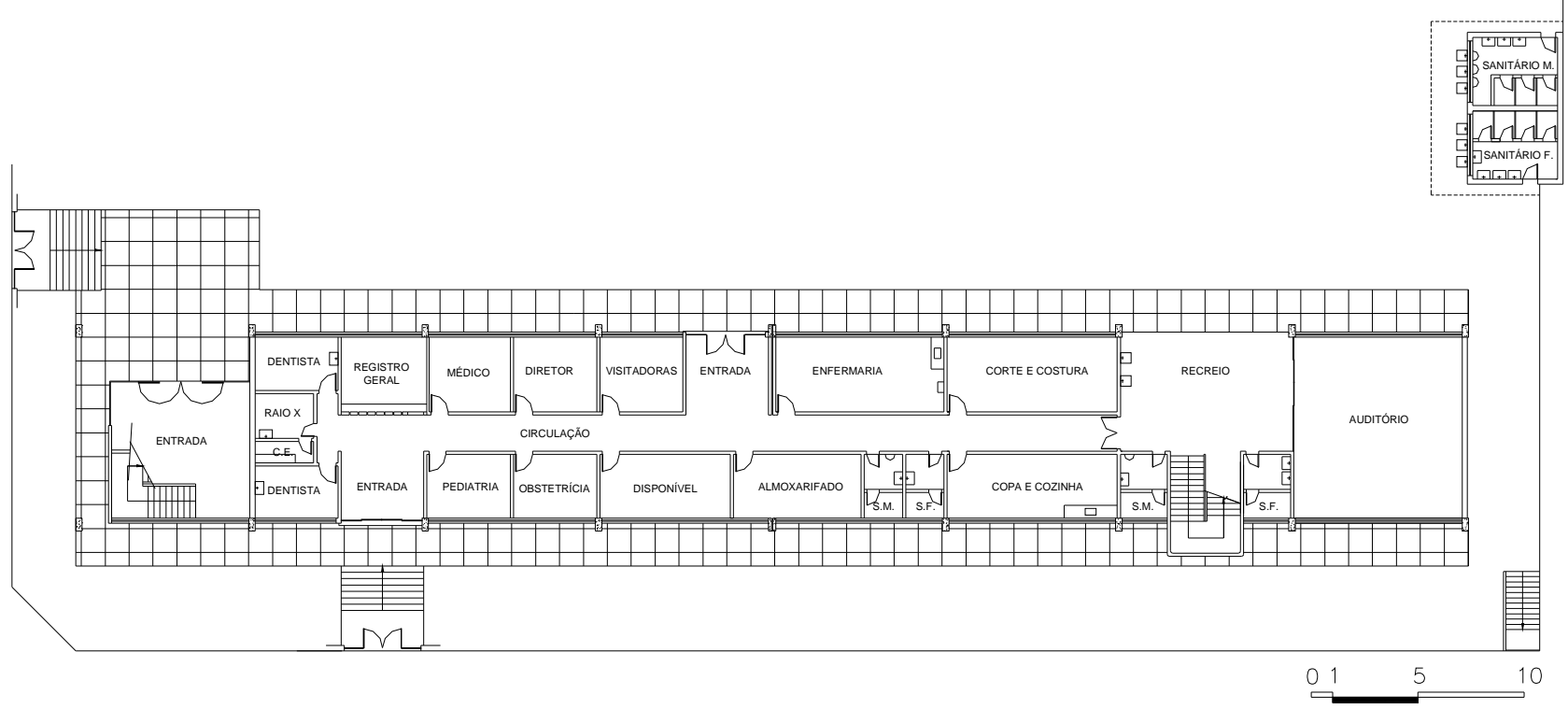

Figura 8: Redesenho da planta do pavimento térreo, SESC.

Fonte: Ferraz, 2006

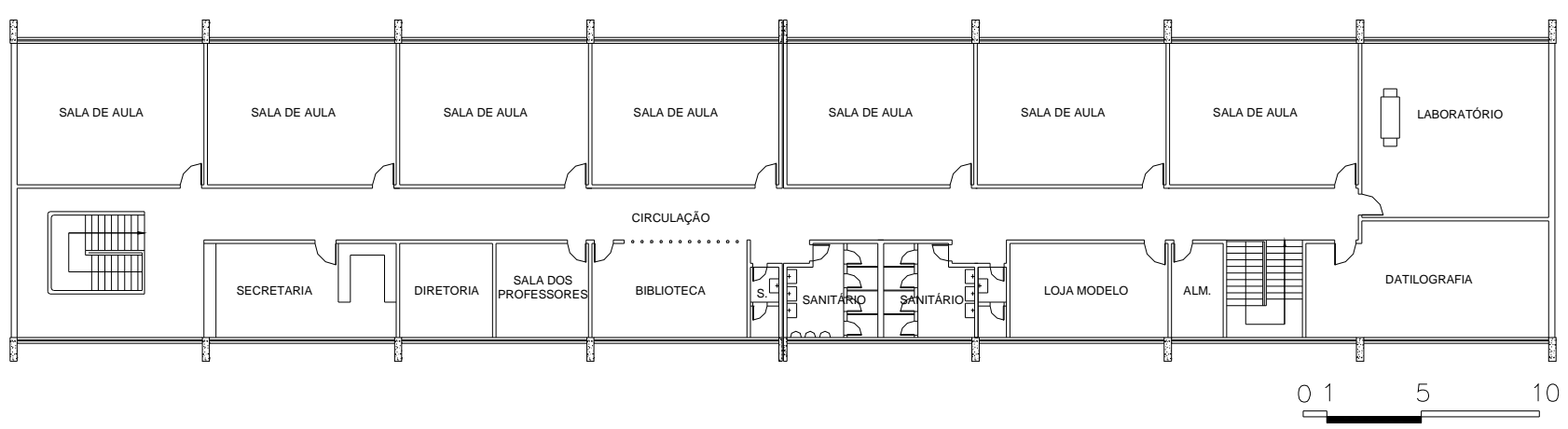

Figura 9: Redesenho da planta do pavimento superior, SENAC.

Fonte: Ferraz, 2006 

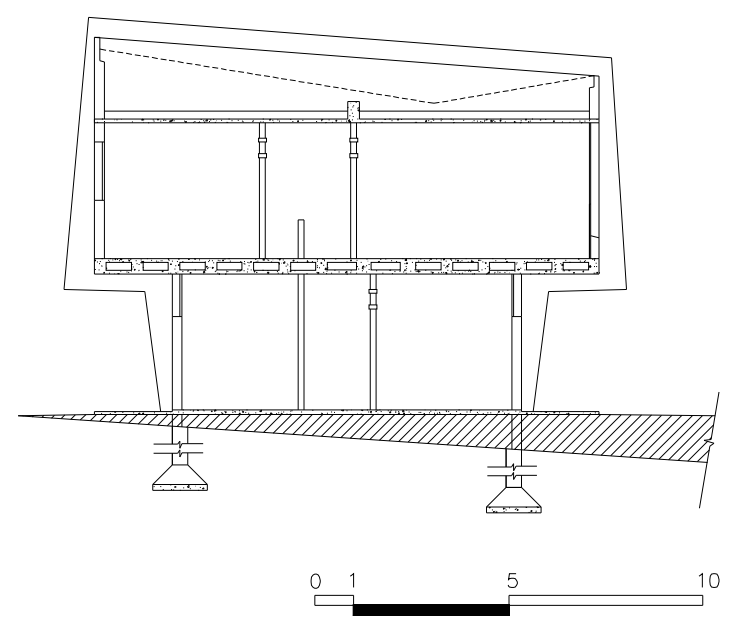

Figura 10: Redesenho do corte transversal, Escola SESC- SENAC DE Bauru. Fonte: Ferraz, 2006

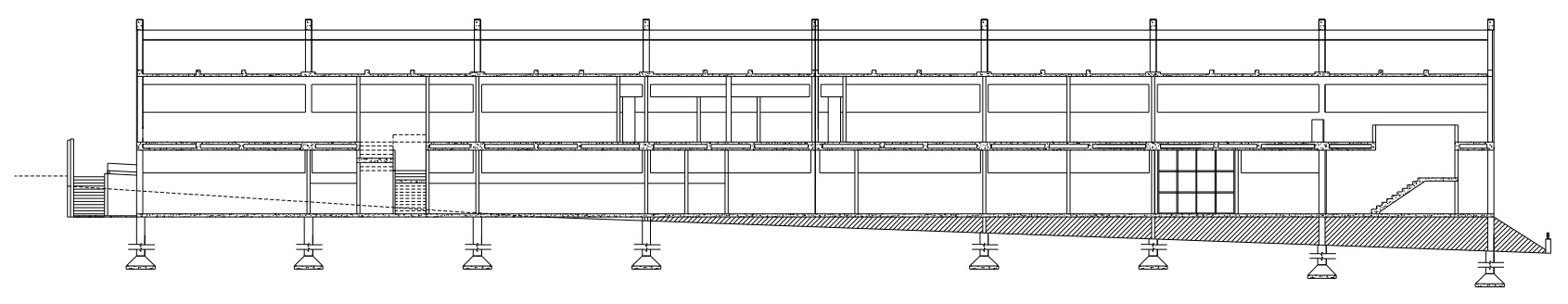

Figura 11: Redesenho do corte longitudinal, Escola SESC- SENAC DE Bauru. Fonte: Ferraz, 2006

Figura 12: Redesenho da elevação oeste, Escola SESC- SENAC DE Bauru.

Fonte: Ferraz, 2006

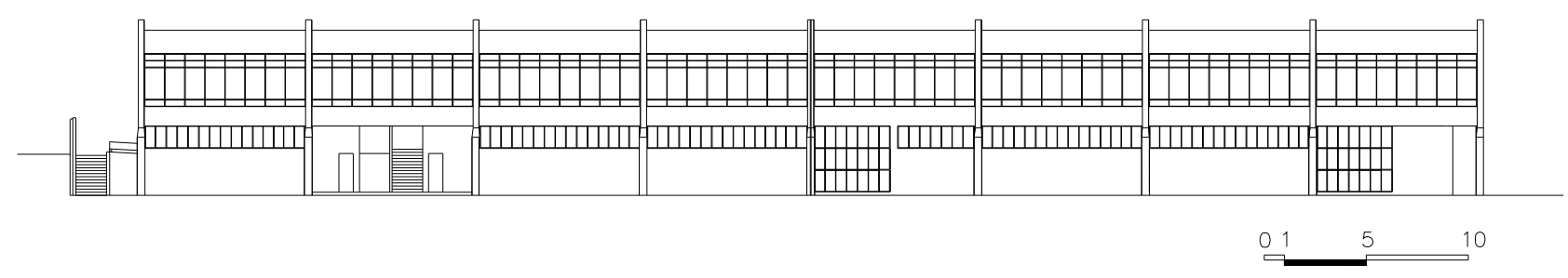

Figura 13: Redesenho da elevação leste, Escola SESC- SENAC DE Bauru.

Fonte: Ferraz, 2006 
- projeto concebido para esta cidade, assim como o de Ribeirão Preto, foi de um único edifício, um grande monobloco ${ }^{3}$ marcado pela horizontalidade, ocupado pelo SESC no pavimento térreo e pelo SENAC no pavimento superior. A divisão interna de ambos os pavimentos adotou a divisão de salas em dois lados com circulação central, possibilitando desta maneira uma maior concentração da área construída do edifício e uma menor ocupação do terreno.

Figura 14: Escola Sesc-Senac de Bauru, década de 50.

Vista da fachada leste voltada para a avenida Nações Unidas.

Fonte: Foto Moscardi, arquivo FAUS

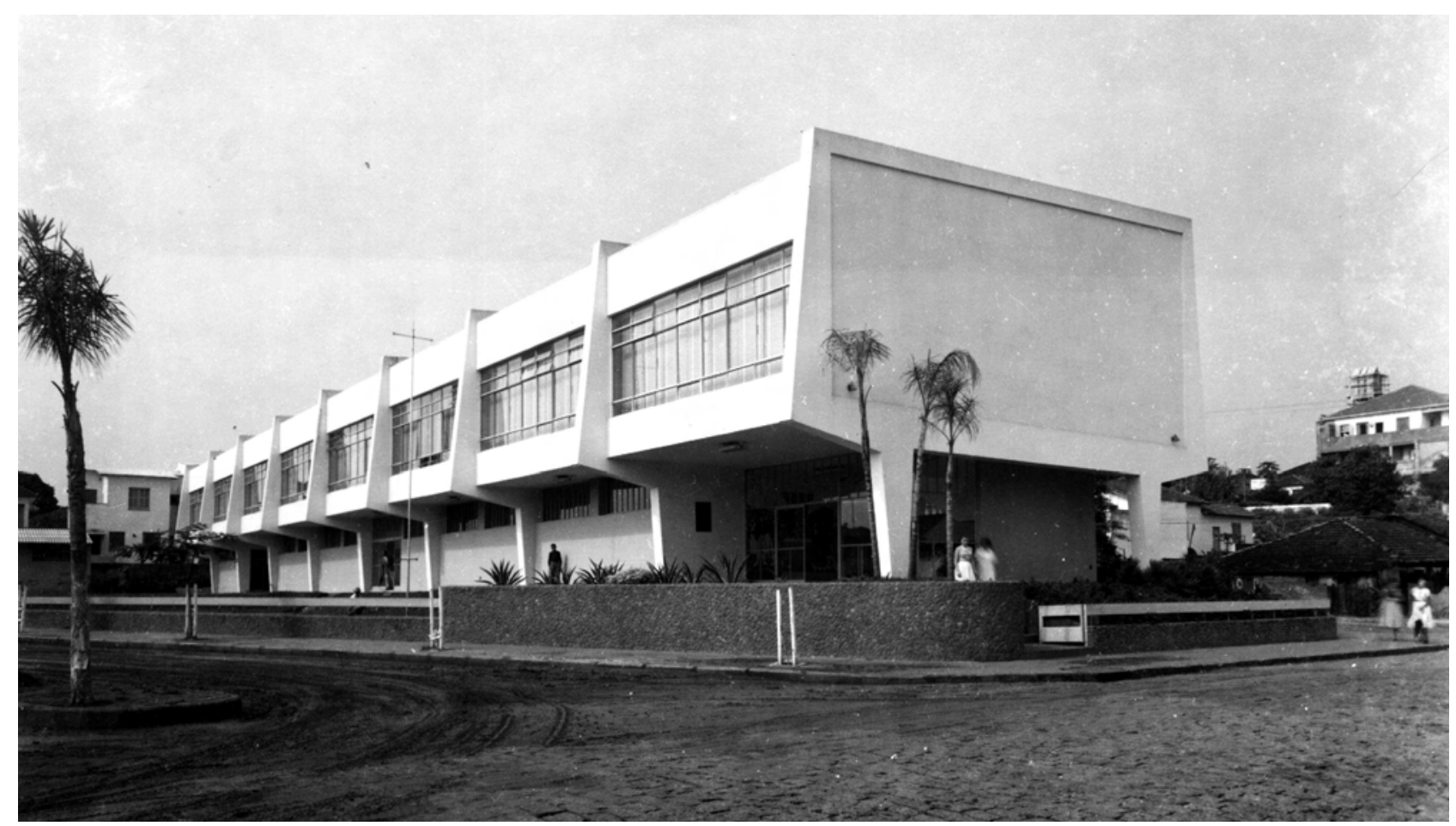

3 Corbusier acreditava que o monobloco era "solução mais apropriada que a disposição clássica de várias alas em torno de um pátio. [...]. ○ monobloco possibilitava aumentar ainda mais essa área e correspondia a uma solução perfeitamente racional, não só sob esse ponto de vista, mas também no que diz respeito à melhor orientação, significativamente facilitada pela redução do edifício a duas fachadas principais" (BRUAND, 1981: 84) 
Figura 15: Escola Sesc-Senac de Bauru, década de 50.

Observar circulação central do SENAC com vista para a biblioteca. Fonte: Foto Moscardi, arquivo FAUS

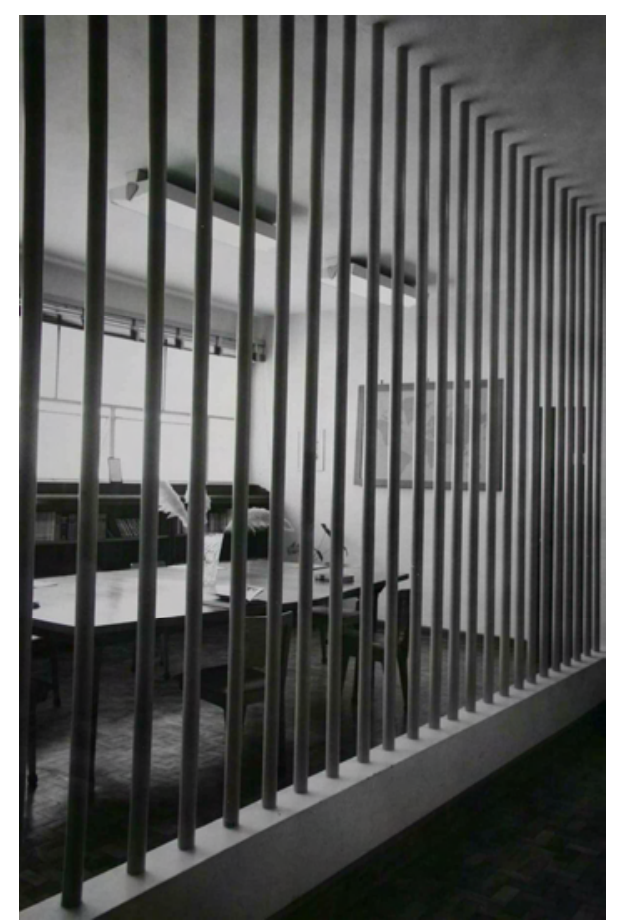

Para cuidar do conforto térmico, tendo em vista o clima quente de Bauru, foi utilizado o "dispositivo adequado para manter ventilação cruzada permanente nas salas de trabalho. Assim, temos nos dois lados do corredor no térreo, arrematados as paredes junto ao forro com placas duplas de elementos vazados. No pavimento superior, as paredes confrontantes da circulação, têm no alto duas fileiras de tubos de fibro-cimento, que permitem a ventilação cruzada através das salas e da circulação em toda a extensão, de uma fachada à outra" [sic] (Acrópole $\mathrm{n}^{\circ}$ 253: 7). O pavimento térreo adotou recuos em relação ao pavimento superior, protegendo termicamente as fachadas leste e oeste do SESC através da laje em balanço. Todas as janelas do térreo eram basculantes e foram protegidas pela laje em balanço pois tinham peitoril de 2,40 metros e altura e 1,10 metros. 


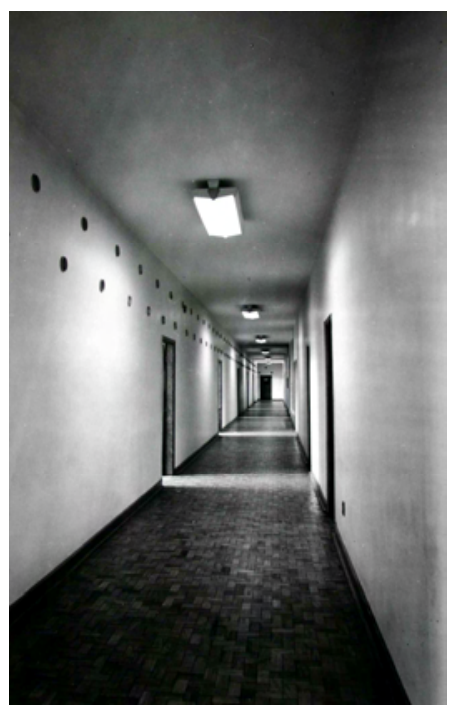

Figura 16: Observar os furos circulares na parede, ventilação permanente entre circulação e salas, Escola Sesc-Senac de Bauru, década de 50. Fonte: Foto Moscardi, arquivo FAUS

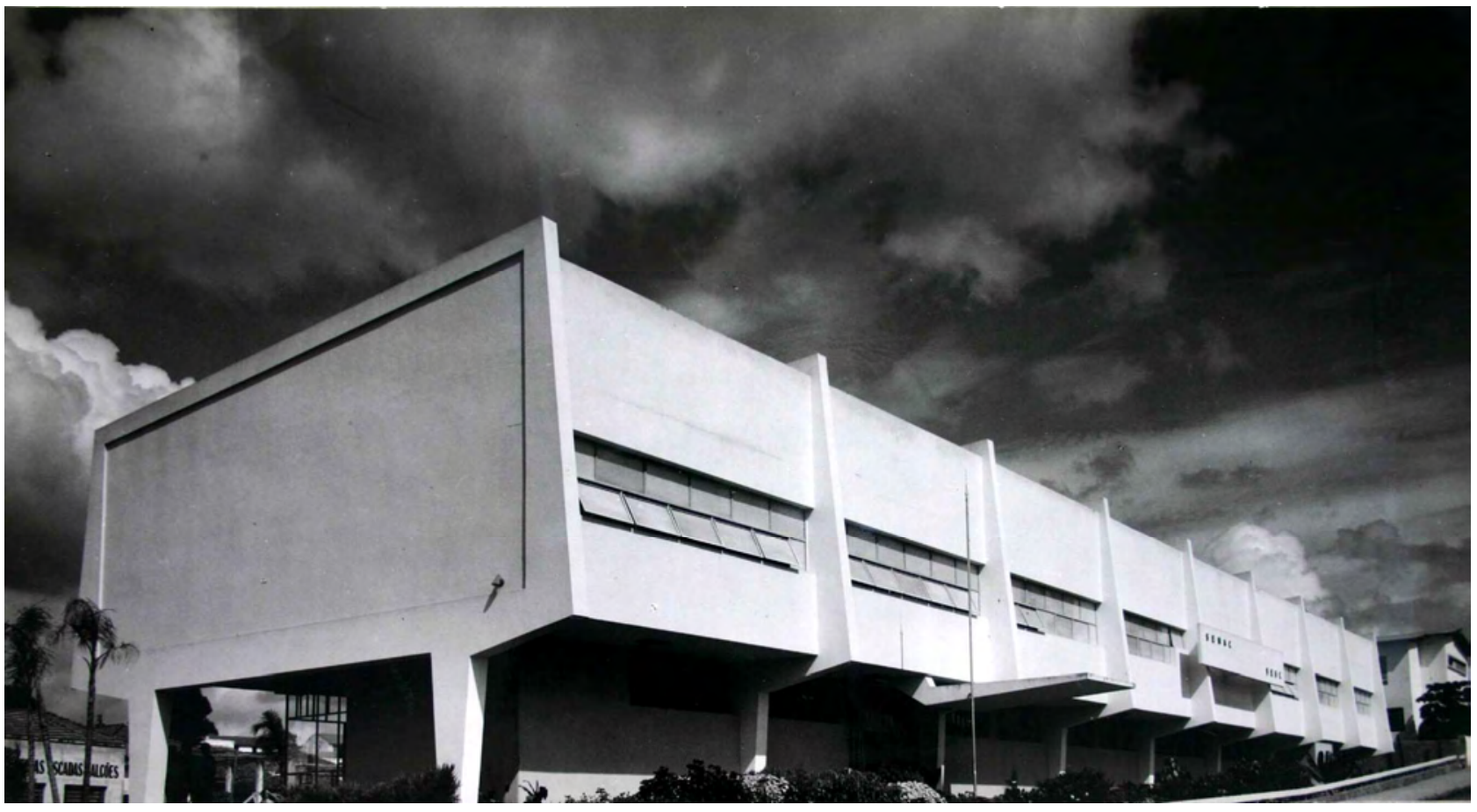

Figura 17: Favorecendo o conforto térmico, a laje em balanço do pavimento superior protege as janelas do térreo,

Em relação às salas de aula do segundo pavimento, as sete salas de aula localizadas na face leste foram projetadas para atender 30 alunos por sala (portanto com capacidade total de 210 alunos) e tanto da fachada oeste (como mostra a foto) como leste. Fonte: Foto Moscardi, arquivo FAUS tinham o formato retangular de $8 \mathrm{~m} \times 6 \mathrm{~m}$ com pé direito de 3,50 metros. A porta de entrada destas salas localizava-se na parte da frente, ao lado do professor, com isso as janelas ficavam sempre à esquerda dos alunos, favorecendo a iluminação natural da face leste. Estas amplas janelas de vãos contínuos marcavam a fachada leste como um grande rasgo horizontal através de suas "cortinas" de vidro 
Figura 18: Salas de aula do SENAC, janelas à esquerda dos alunos, favorecendo a

iluminação natural da face leste. Fonte: Foto Moscardi, arquivo FAUS de 8 metros de largura por 2,60 metros de altura, e proporcionavam aos alunos uma escola aberta para a cidade. Já as janelas do pavimento superior, voltadas para a face oeste, tiveram a altura reduzida para 1,50 metros e adotaram o modelo de abertura maxi-ar elaborado para obter iluminação natural e ao mesmo tempo evitar o sol poente.

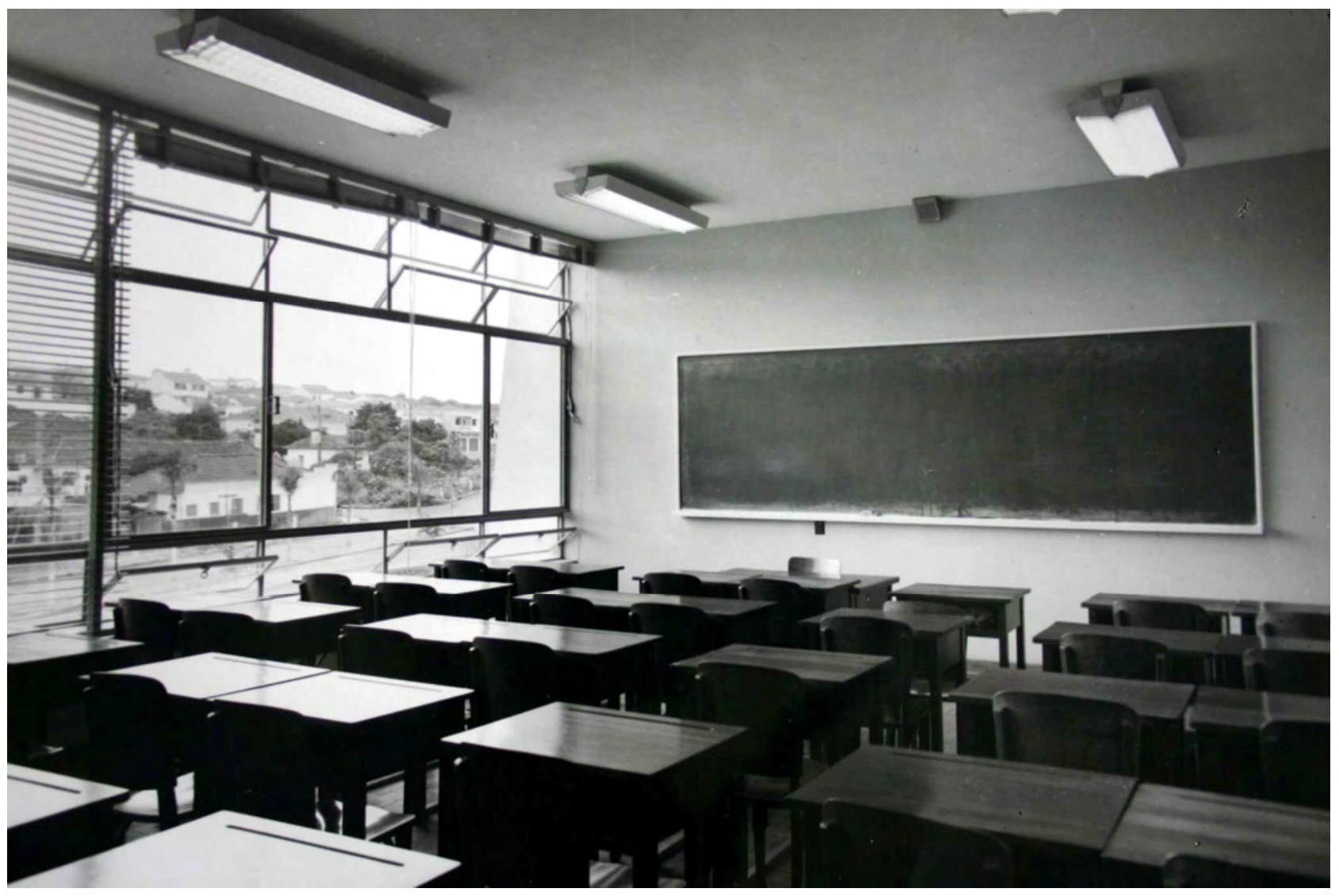

Figura 19: Observar janelas voltadas para a face oeste. Fonte: Foto Moscardi, arquivo FAUS

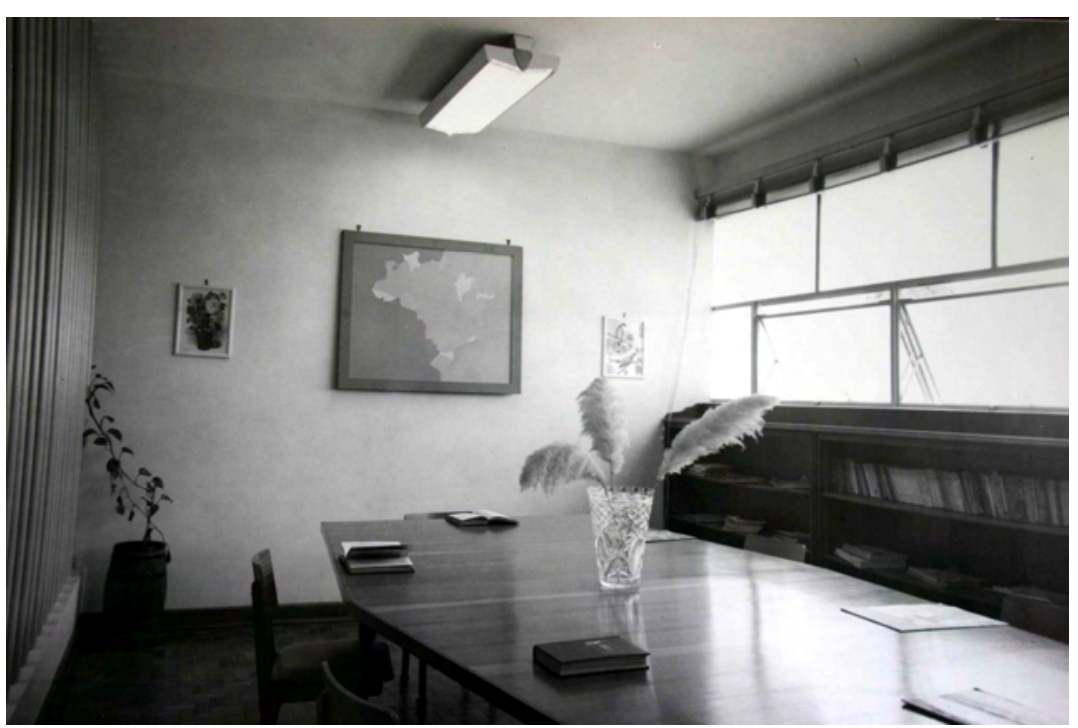


A resolução estrutural deste edifício é de forma geométrica simples, racional e funcional, tanto nas plantas como nas fachadas. A estrutura independente proporcionou liberdade à divisão em planta, permitindo o aproveitamento dos espaços de várias maneiras e possibilitando adequar a dimensão dos ambientes de acordo com a evolução de cada Serviço. Formando um todo, a estrutura é composta por vários pórticos, também seguindo a mesma idéia da Escola de Ribeirão Preto. Marcados pelos pórticos, os módulos repetem-se formando vãos de oito metros, atingindo a plasticidade ritmada da fachada.

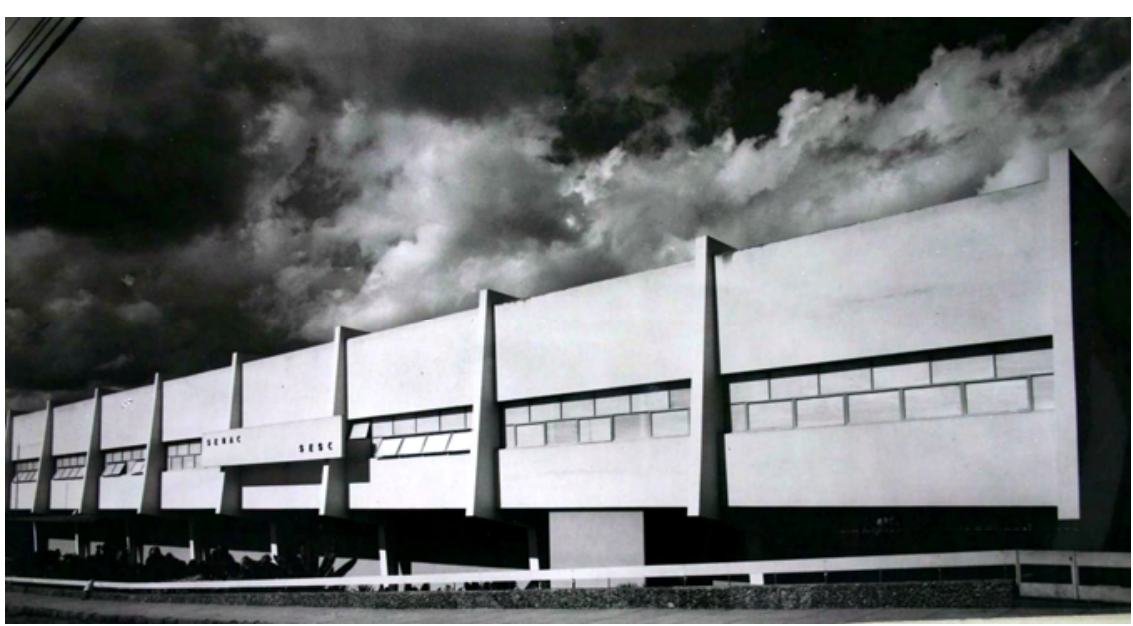

Mantendo uma característica marcante nos projetos de Gonçalves, a presença das artes plásticas aplicadas à arquitetura, no prédio de Bauru foi executado um painel artístico por Irênio Maia, localizado no hall de entrada do SENAC, ocupando toda a parede lateral esquerda da porta de entrada. $\bigcirc$ painel intitulado Abertura dos Portos tinha aproximadamente $22 \mathrm{~m}^{2}$ e representava Visconde de Cairu assinando o documento de abertura dos portos para promover o comércio internacional.
Figura 20: Fachada oeste, monobloco marcado pelo ritmo dos pórticos. Fonte: Foto Moscardi, arquivo FAUS 
Figura 21: Entrada principal do SENAC. Observar painel artístico no hall de entrada.

Fonte: Foto Moscardi, arquivo FAUS

Figura 22: Painel artístico Abertura dos Portos de Irênio Maia. Este painel foi eliminado na execução do projeto de reforma de 1978.

Fonte: Foto Moscardi, arquivo FAUS
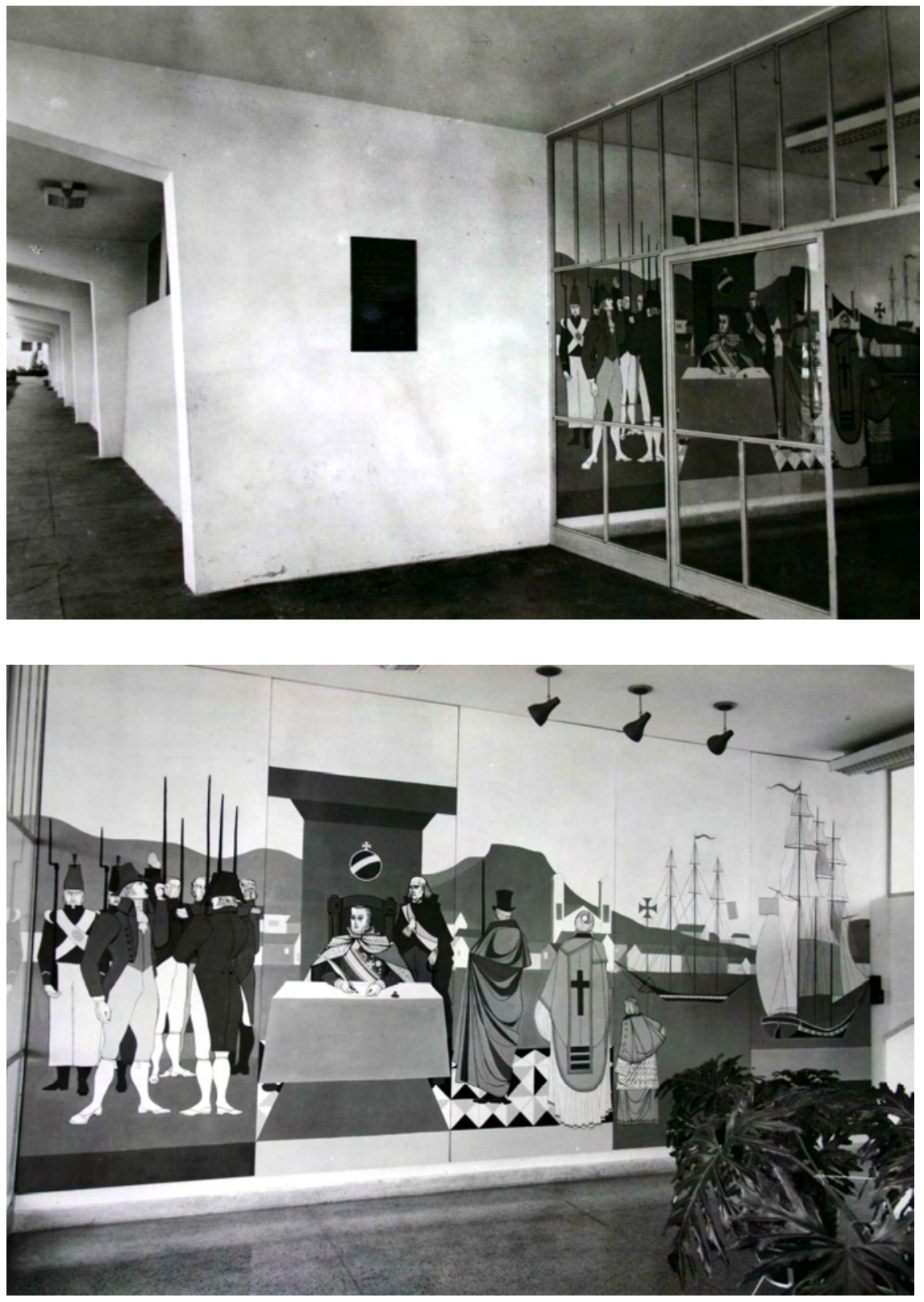

A Escola de Bauru, inaugurada no dia 9 de agosto de 1958, refletiu questões colocadas pela arquitetura moderna, principalmente baseada nos princípios corbusianos. Seu projeto foi concebido no início da construção dos edifícios SESC-SENAC, o que coincidiu com o fim das atividades do Convênio Escolar, portanto também pode ser visto como uma continuação da aplicação das idéias elaboradas anteriormente no Convênio, porém disseminado no interior do Estado através de um rico programa que integrava o ensino à assistência social. $\bigcirc$ estímulo da relação aluno-escola foi alcançado através da concepção projetual de amplas janelas e pátio aberto circundado apenas por muretas com gradis baixos, colaborando para que 0 aprendizado se tornasse cada vez mais prazeiroso. 


\section{IARIO DE S. PAULO - Sabado, 9-8- 1958}

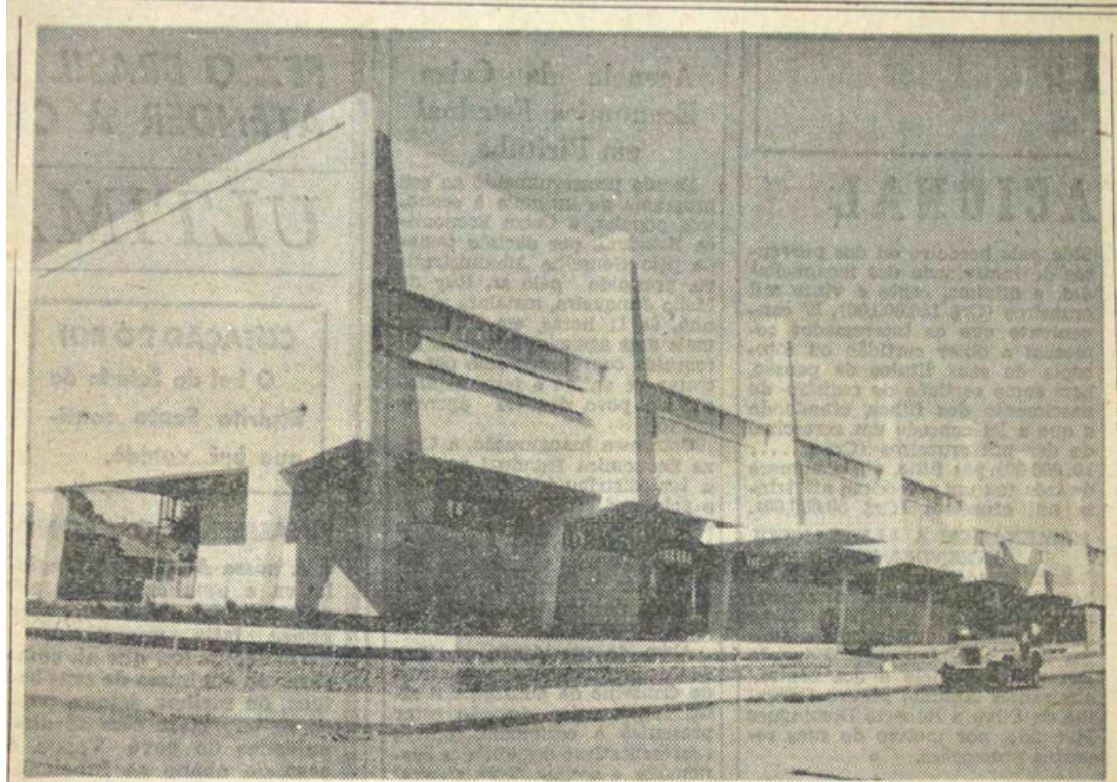

INAUGURACÃO HOJE DO EDIFICIO SESCa solenidade de inauguraçäo do novo Edificio SESC-SENAC, dotado de amplas e modernas instalaçoes destinadas a abrigar os serviços de carater social, educacional e assistencial mantidos por da cidade. Com a nove secle, serüo ampliciass as atividades do "Centro Social Nelson Fernandes", do SESC e das escolas do SENAC, methor apa. rethadas agora para atender a juventude comerciaria e suas familias. Uma caravana composto a cerimonia, que obedecerá as seguinte programa:

10 horas, chegada da caravana de São Paulo; 10,15 '12 horas, cerimonia de cido pelas entides de classe de Bauru, no Automovel Club; 16 horas, recepçăo na Camara Municipal; 17,15 horas, retorno da caravana. Dufante a solenidade de inaulaciacaro do edificio, Conselhos Regionais do SESC e do SENAC, devendo a entrega da chave ser feita pelo $\mathrm{sr}$. Benedito Moreira Pinto e a fita simbólica cortad pelo prefeito municipal de Bauru. No cliché, vepelo prefeito me do novo "Edificio SESC-SENAC".

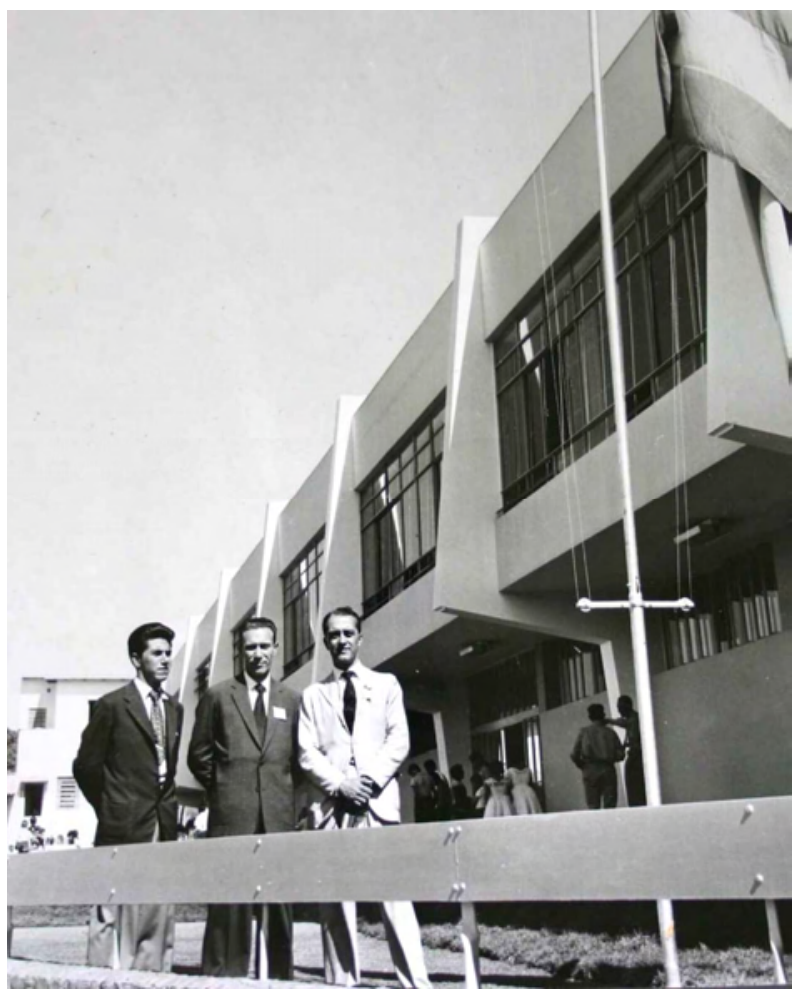

Figura 24: Inauguração da Escola Sesc-Senac de Bauru,

09/08/1058.

Fonte: Arquivo FAUS 
Posteriormente, em 1978, o edifício SESC-SENAC foi reformado e ampliado para funcionar somente como SENAC ${ }^{4}$. O projeto de reforma feito pelo PLURIC -Escritório Pluricurricular de Projetos- teve como autor o próprio Oswaldo Corrêa Gonçalves, o qual manteve a linguagem de sua própria arquitetura, sem descaracterizar os princípios do projeto original. $\bigcirc$ arquiteto projetou um bloco térreo com 339,10 $\mathrm{m}^{2}$ de área construída, perpendicular ao existente. Neste projeto de ampliação foram construídos: refeitório, cozinha, despensa, sala de equipamento de ar condicionado e três sanitários masculinos e femininos. $O$ novo bloco foi interligado ao pavimento térreo existente. Além da ampliação, o arquiteto criou um estacionamento interno e reformulou a divisão dos ambientes do projeto original para atender às necessidades do SENAC, sendo que somente o segundo pavimento manteve a circulação central entre salas. Em ambos os pavimentos as paredes internas foram demolidas e com isso o sistema de ventilação permanente nas salas foi eliminado, danificando parte do conforto térmico do edifício. O pavimento térreo foi ampliado em toda a extensão da fachada leste, eliminando o recuo em relação ao pavimento superior, alteração esta que além de prejudicar termicamente o edifício, modificou o volume estrutural, pois os pilares dos pórticos ficaram enrustidos no interior do edifício. $\bigcirc$ projeto de reforma concebeu uma única escada de acesso para o segundo pavimento, localizada na face oeste do bloco original, e determinou a demolição das duas escadas do projeto original. O hall que anteriormente dava acesso para o SENAC foi fechado e transformado em uma biblioteca. $\bigcirc$ espaço projetado para a biblioteca infelizmente resultou na demolição da parede que continha o painel artístico de Irênio Maia. $\bigcirc$ projeto de reforma permaneceu com dois acessos de entrada, porém modificados do projeto original, sendo um pela rua Saint Martin - modificando o local da porta de entrada - e o outro pela avenida Nações Unidas (antigo Córrego das Flores) - o qual permitia o acesso independente tanto de

\footnotetext{
${ }^{4}$ A separação das duas entidades ocupando prédios independentes não ocorreu apenas em Bauru, mas também de modo geral nos edifícios SESC-SENAC a partir da década de 60, como conseqüência de um novo paradigma: "a construção de centros culturais e desportivos para o SESC" (SESC, 1997, p.229).
} 
pessoas como de veículos - tendo sido projetado um estacionamento interno para oito veículos.

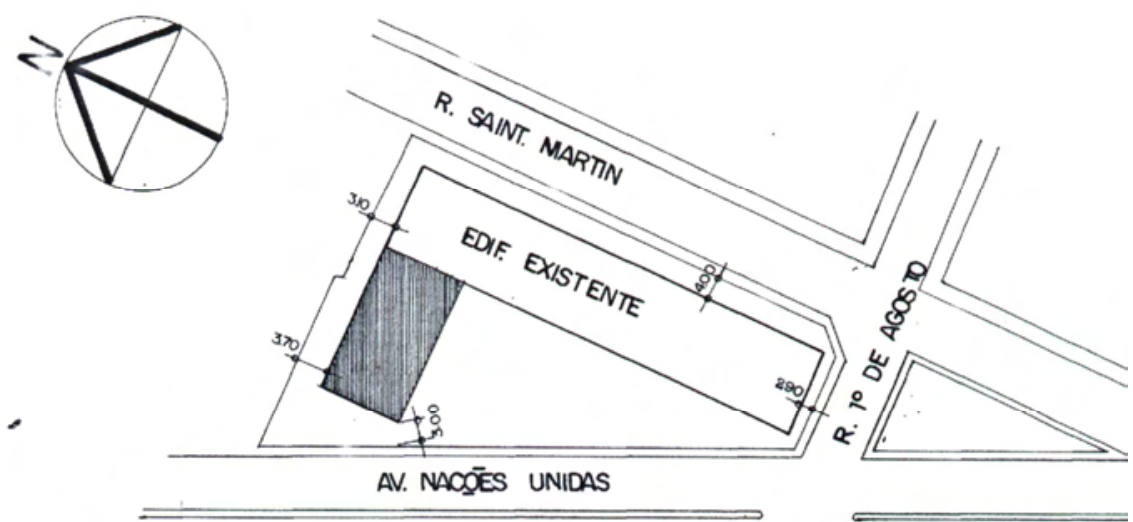

Figura 25: Planta de situação apresentada no projeto de reforma e ampliação de 1978 para o edifício funcionar somente como SENAC. Observar

que no local do Córrego das Flores já havia sido construída a atual avenida Nações Unidas.

Fonte: Arquivo do SENAC-SP

SITUAGĀO/ESCALA 1/1000

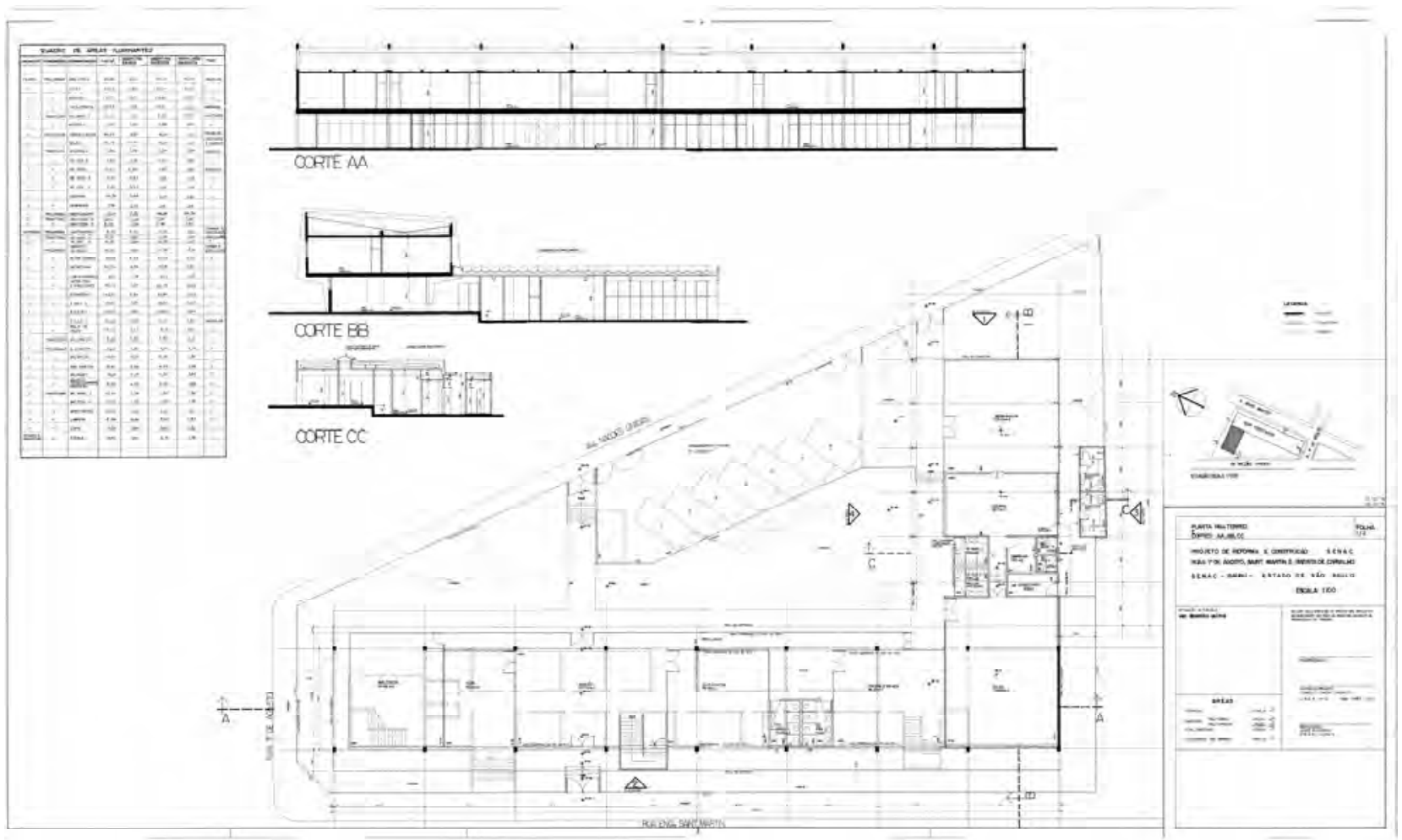

Figura 26: Prancha do projeto de reforma e ampliação da Escola SENAC de Bauru, autoria do Escritório Pluricurricular de Projetos.

Fonte: Arquivo do SENAC-SP 


\section{PROJETO 4}

\section{Escola Senac de Araraquara, 1956}

Outro exemplo da nova arquitetura ao ensino comercial foi a Escola SENAC de Araraquara', projetada pelos arquitetos Oswaldo Corrêa Gonçalves e Eduardo Corona. Este projeto, diferentemente dos demais apresentados neste trabalho, não foi construído. Projetado num terreno anteriormente ocupado por um prédio demolido, o edifício foi baseado na orientação nordeste e sudoeste, tendo suas fachadas ao longo das faces noroeste e sudeste. $O$ terreno escolhido, localizado à rua Nove de Julho 160, tinha 1269,00m², sendo 24 metros de frente e profundidade diferentes, culminando no fundo com o limite físico de um córrego. A escola foi projetada com 1.617,40 m² de área construída, divida em três pavimentos: térreo $\left(644,60 \mathrm{~m}^{2}\right)$, primeiro pavimento $\left(486,40 \mathrm{~m}^{2}\right)$ e segundo pavimento $\left(486,400 \mathrm{~m}^{2}\right)$.

Figura 1: Planta de situação, Escola Senac de Araraquara, 1956, Oswaldo Corrêa Gonçalves e Eduardo Corona Fonte: Fonte: Foto Ferraz, arquivo FAUS
Figura 2: Quadro e área da Escola Senac de Araraquara, 1956, Oswaldo Corrêa Gonçalves e Eduardo Corona Fonte: Fonte: Foto Ferraz, arquivo FAUS
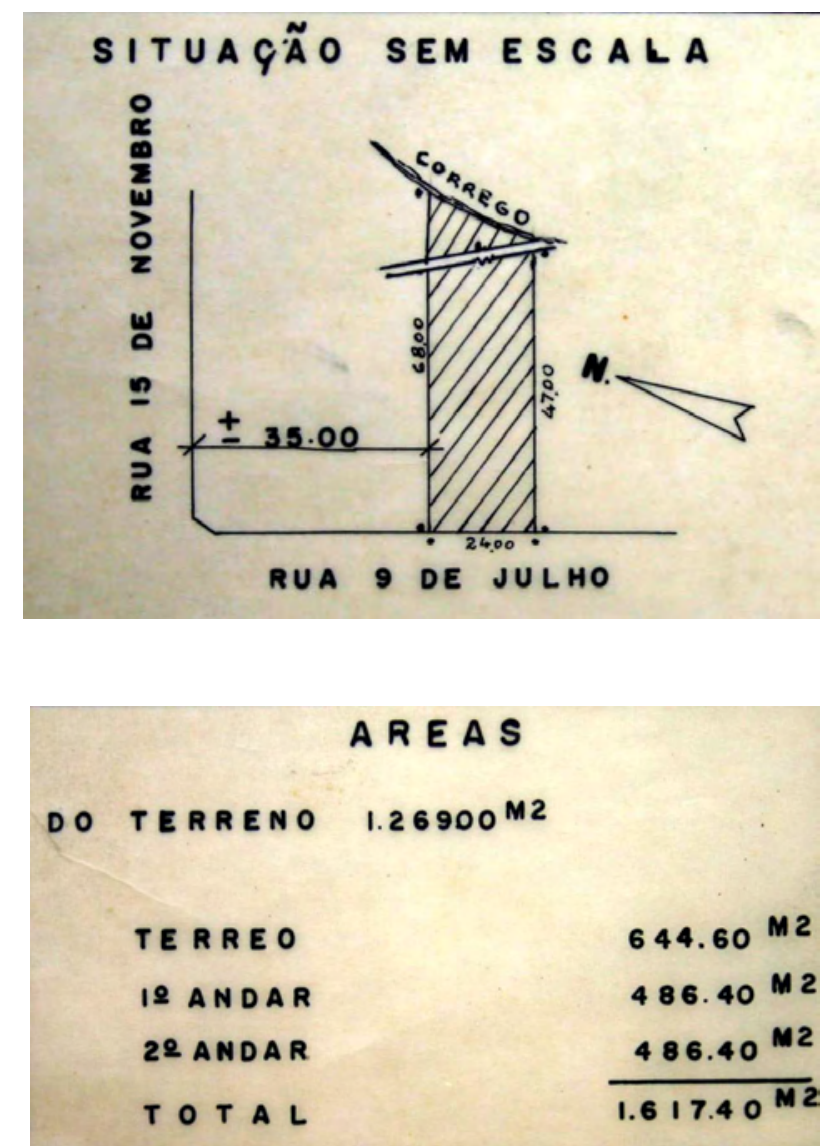


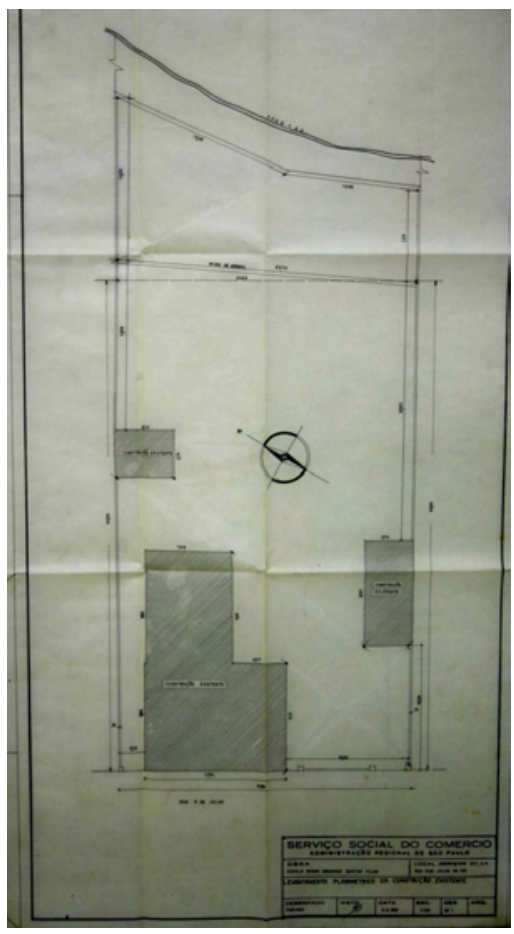

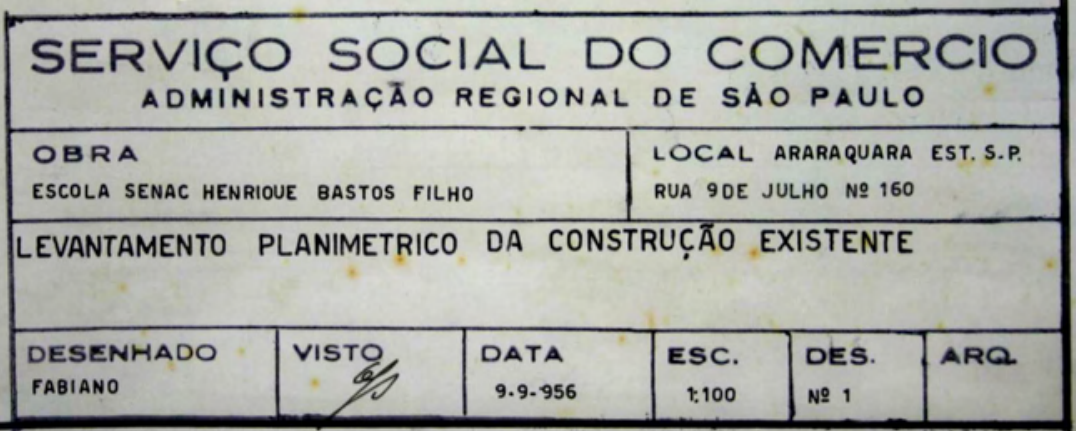

Figuras 3 e 4: Prancha e respectivo selo do levantamento planimétrico do terreno e da construção existente, 1956, revelando a situação do local escolhido para a Escola Senac de Araraquara.

Fonte: Fonte: Foto Ferraz, arquivo FAUS

programa construtivo foi dividido em três pavimentos de acordo com o requerido pelo SENAC. O pavimento térreo era composto de recreio coberto, sanitários, salas de reunião, diretoria e secretaria, depósitos e sala de datilografia. No segundo pavimento foram projetados quatro salas de aula, sala dos professores e sanitários masculino e feminino. $O$ terceiro pavimento, seguindo a mesma divisão do segundo, totalizou oito salas de aula em toda a Escola.

projeto original foi encontrado no arquivo da FAUS, juntamente com fotos da maquete confeccionada na década de 50 e estudo preliminar. Ainda, neste arquivo, também foi descoberto um ante-projeto para a Escola SENAC de Araraquara, de autoria de Gonçalves, datado de 19 de novembro de 1955, porém possivelmente projetado para outro terreno, conforme diferenças projetuais desenhadas como orientação solar e largura da fachada principal. Ainda, o conhecimento do projeto original foi obtido por meio do periódico Habitat nº 43 (1957: 27-29). 
Figura 5: Ante-projeto para a Escola Senac de Araraquara, 19/11/1955, possivelmente projetado para outro terreno, conforme diferenças projetuais (orientação solar e largura da fachada principal), autoria de Oswaldo Corrêa Gonçalves. Fonte: Foto Ferraz, arquivo FAUS

Figura 6: Prancha do anteprojeto da Escola Senac de Araraquara correspondente ao projeto de prefeitura.

Fonte: Foto Ferraz, arquivo FAUS
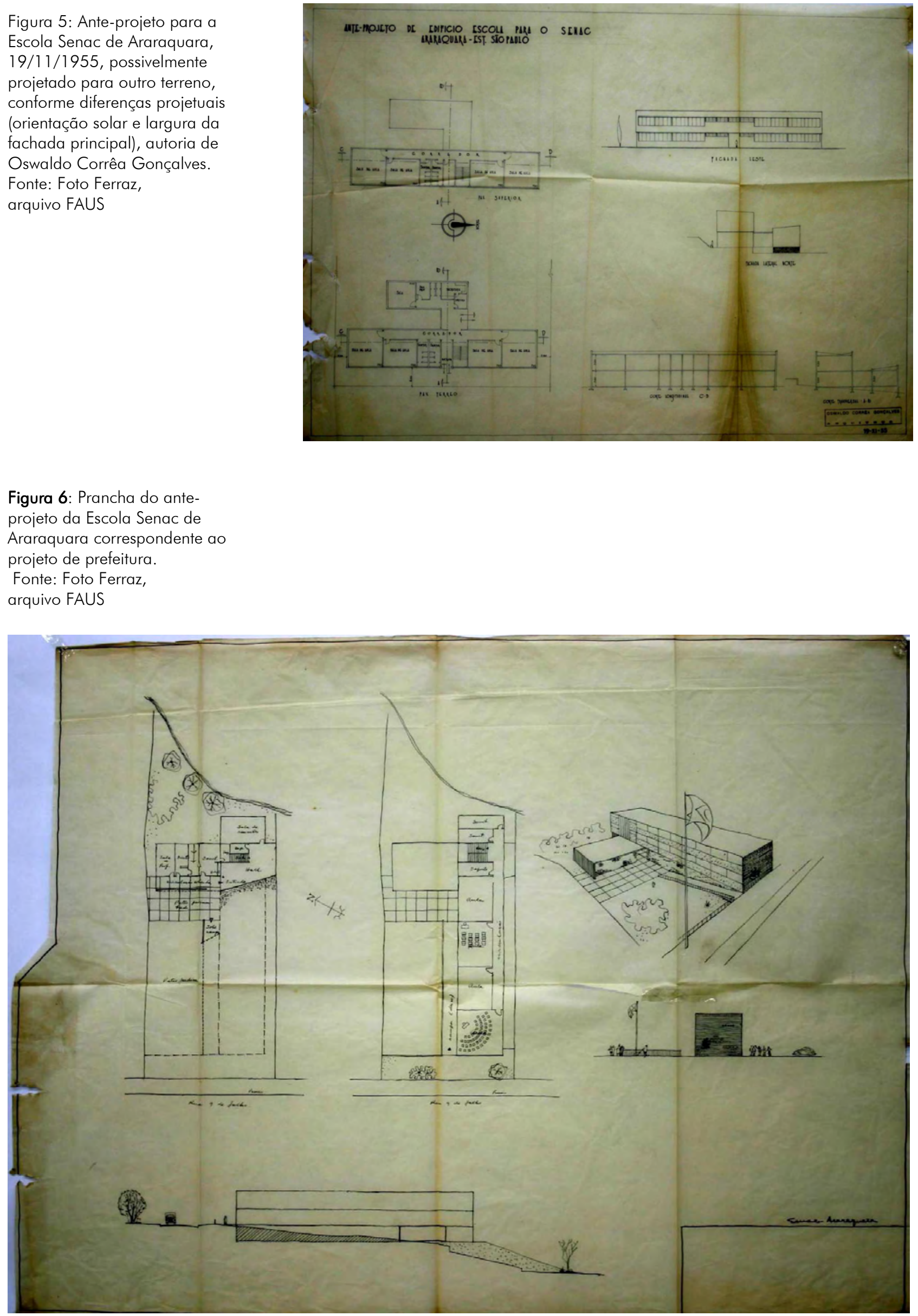

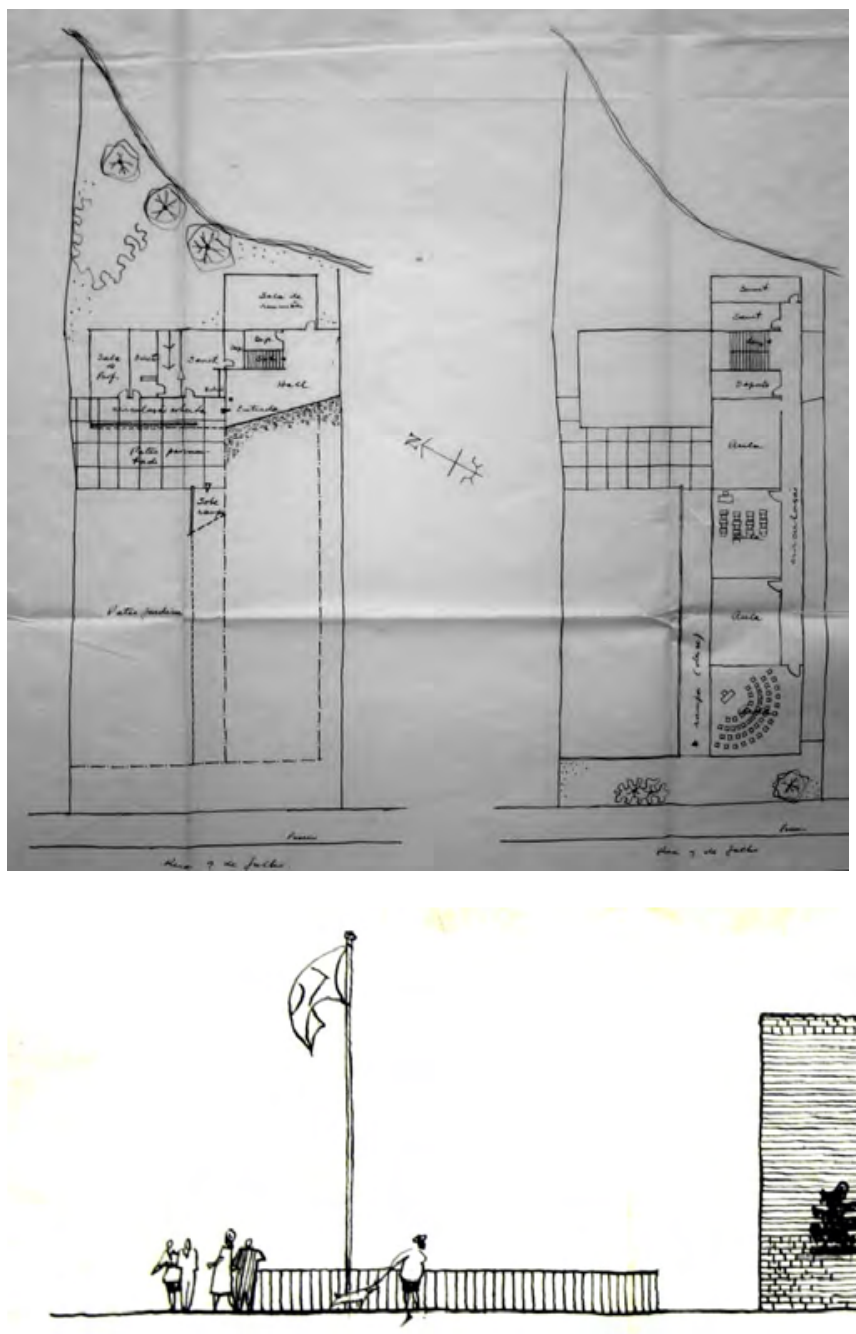

Figura 7: Plantas retiradas da prancha do ante-projeto da Escola Senac de Araraquara. Fonte: Foto Ferraz, arquivo FAUS

Figuras 8 e 9: Elevação principal e perspectiva retiradas da prancha do ante-projeto da Escola Senac de Araraquara. Fonte: Foto Ferraz, arquivo FAUS

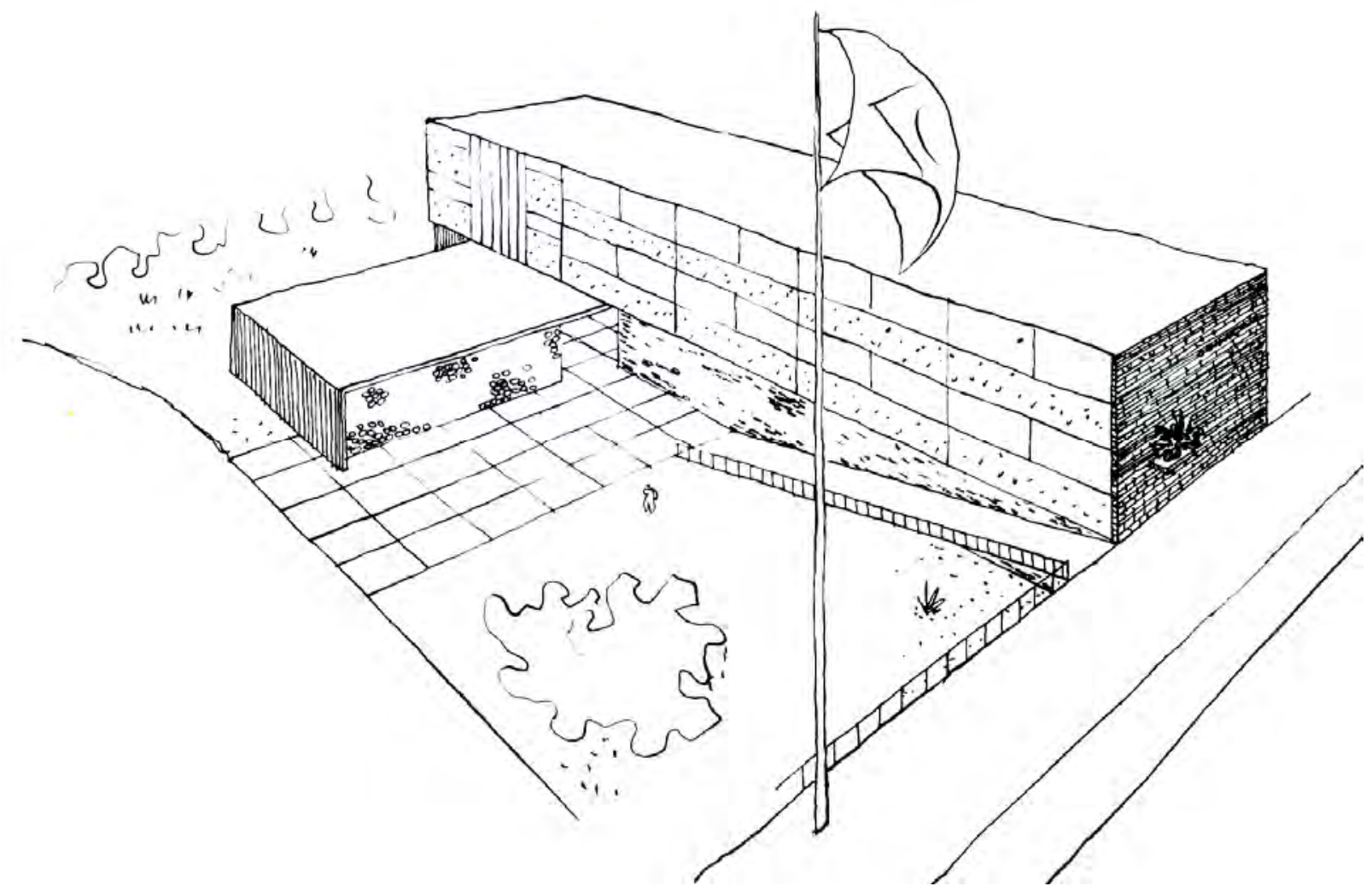




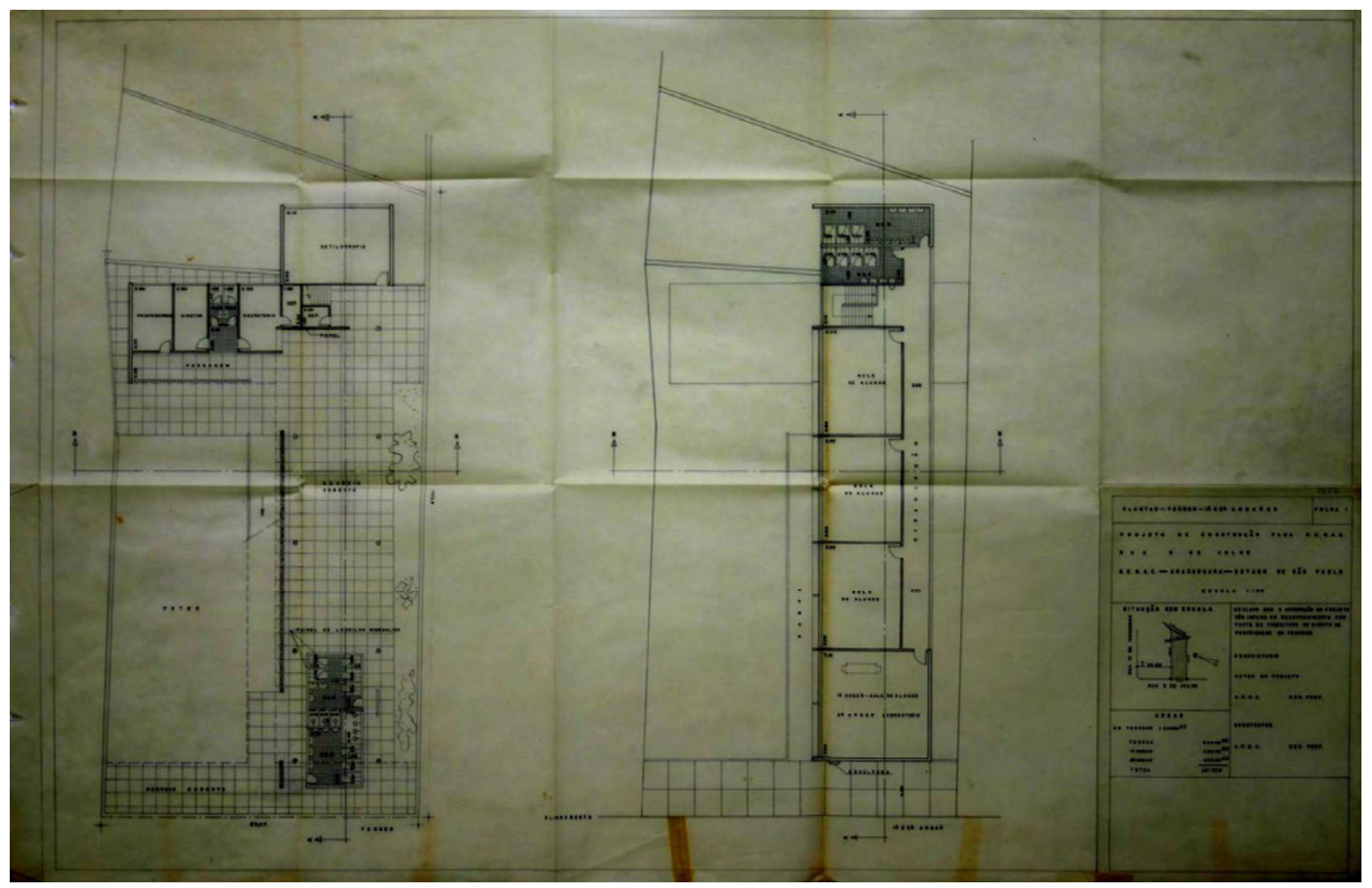

Figura 10: Prancha 1/2, projeto de prefeitura, Escola Senac de Araraquara, 1956, Oswaldo C. Gonçalves e Eduardo Corona. Fonte: Foto Ferraz, arquivo FAUS

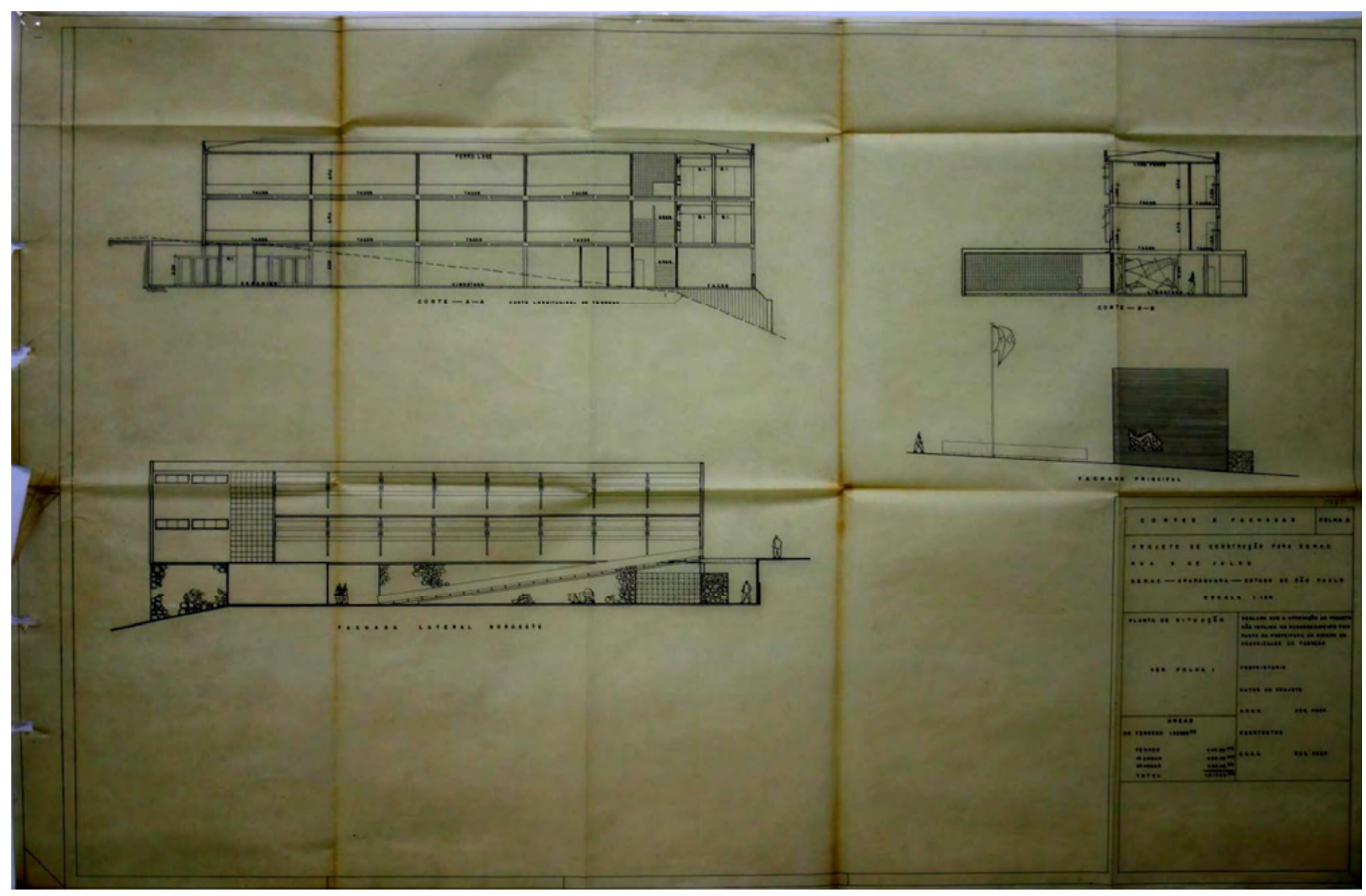

Figura 11: Prancha 2/2, projeto de prefeitura, Escola Senac de Araraquara, 1956, Oswaldo C. Gonçalves e Eduardo Corona. Fonte: Foto Ferraz, arquivo FAUS 


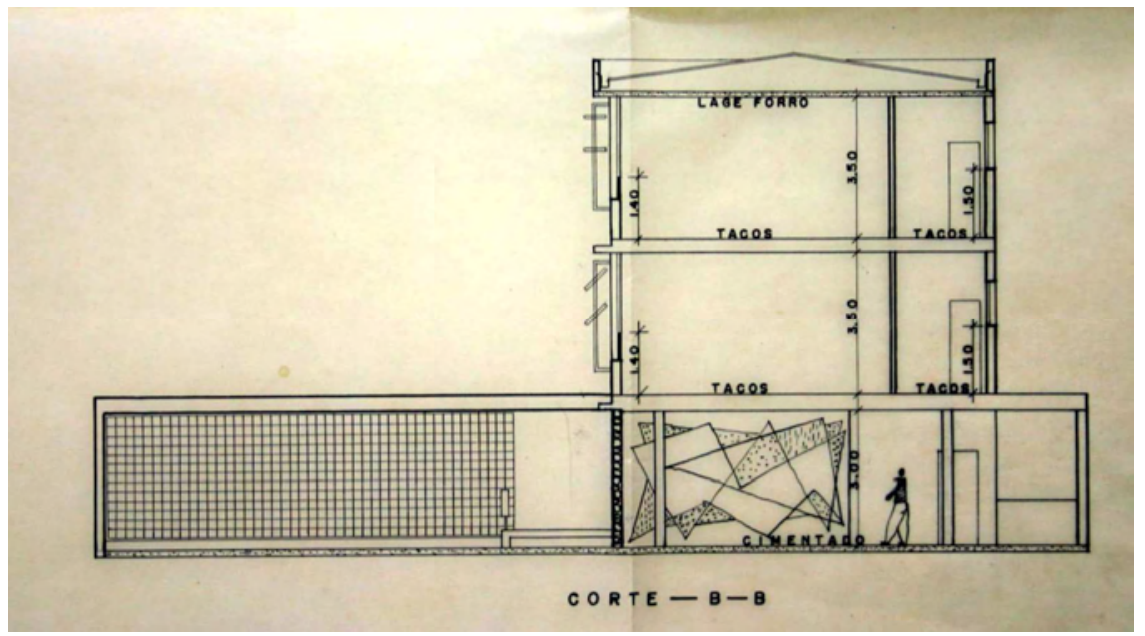

Figuras 12, 13 e 14 : Cortes e elevações retiradas da prancha 2/2 do projeto de prefeitura da Escola Senac de Araraquara,

1956, autoria de Oswaldo Corrêa Gonçalves e Eduardo Corona. Fonte: Foto Ferraz, arquivo FAUS
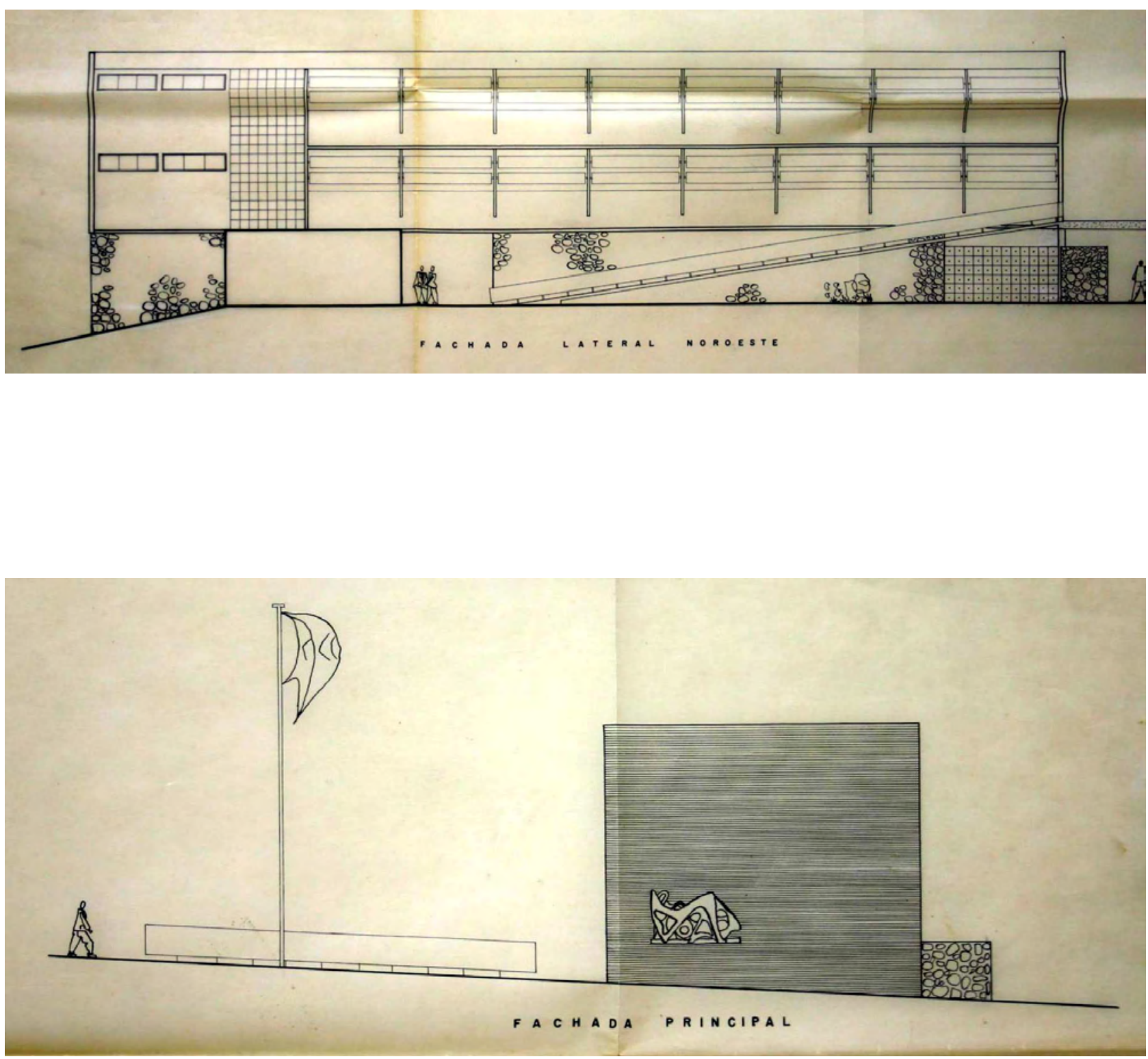

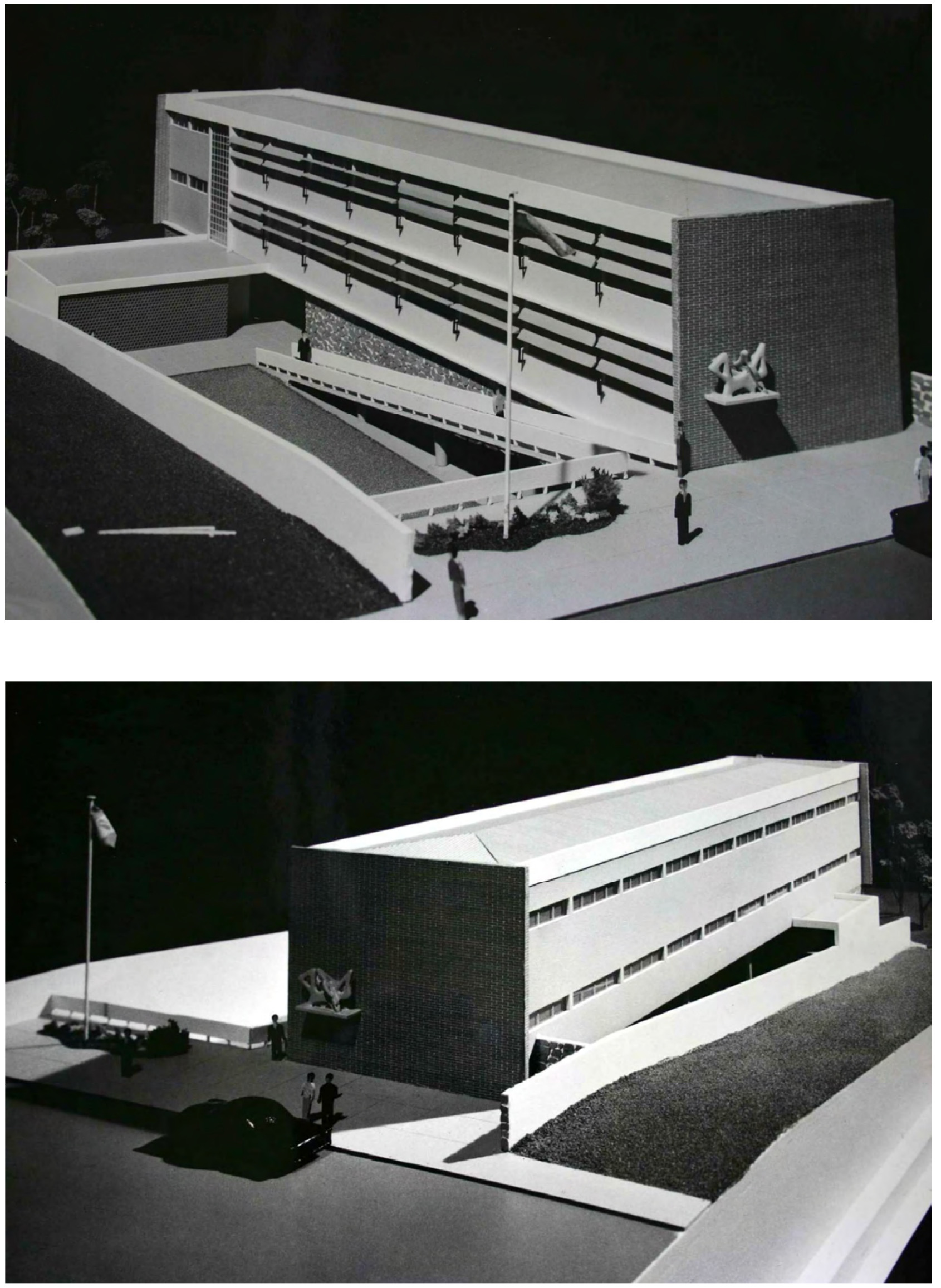

Figuras 15 e 16 : Maquete da década de 50 da Escola Senac de Araraquara (não construída). Vista da fachada lateral noroeste e da fachada principal sudoeste.

Fonte: Foto Ferraz, arquivo FAUS 
O projeto foi idealizado em um monobloco composto por três pavimentos, sendo que no térreo seu volume se estendia de forma perpendicular para atender ao setor administrativo da escola. Aproveitando o declive do terreno, a concepção do projeto adotou programa construtivo distribuído nos três pavimentos, todos interligados por uma escada. $\bigcirc$ acesso ao edifício era pelo pavimento térreo, abaixo do nível da rua, por meio de uma extensa rampa.

\footnotetext{
"A importância que adquire a arquitetura escolar, na formação do gosto e das tendências dos alunos, é altamente educativa. [...] Hoje, a tendência para a nova edificação da escola, corrige amplamente o que tivemos no passado. [...]. O exemplo que hoje trazemos [...], de mais uma escola SENAC, cuja construção vai em breve ser iniciada, em Araraquara, é devido aos arquitetos Corrêa Gonçalves e Corona. Eis um edifício bem projetado, correspondendo a um programa restrito, mas onde os autores procuraram, da melhor maneira, servir à arquitetura e ao ensino".
}

(Habitat n 43, 1957: 27)

O térreo, caracterizado pelo lazer e administração da escola, era ocupado pelo recreio coberto, sanitários, salas administrativas e apenas uma sala de aula para datilografia. Ainda, para complementar a função educacional, o recreio coberto foi aberto para o jardim de recreação que acompanharia a rampa de entrada até o setor administrativo. Neste pavimento, os arquitetos mantiveram a idéia de unir arte à arquitetura e projetaram um espaço para mural junto à secretaria e, revestindo o volume dos sanitários com ladrilhos hidráulicos (Habitat $n^{\circ} 43,1957:$ 29). Ainda, dentro deste aspecto artístico, exteriormente foi previsto um espaço para escultura, na fachada principal (assim como na escola de Marília apresentada anteriormente).

Já os pavimentos superiores, projetados como andar-tipo das salas de aula, receberam divisão interna com circulação lateral sudeste, possibilitando desta maneira iluminação lateral noroeste nas salas de aula. Como parte integrante do programa SENAC, as salas de aula receberam em suas aberturas brises solares horizontais, projetados ao longo da lateral sudeste do monobloco, com o intuito 
de garantir o conforto térmico. Os sanitários, sala dos professores e caixa de escada foram projetados na extremidade final tanto do segundo como do terceiro pavimentos.

A resolução estrutural deste edifício, mesmo não tendo sido construído, revelou uma forma geométrica simples, retilínea e modulada pela estrutura, tornando o projeto flexível ao crescimento da escola e atrativo para os alunos, viabilizando a educação.

Sabe-se que o projeto de 1956 para a escola SENAC de Araraquara não foi construído. Em 1971 outro projeto foi encomendado para a Escola SENAC de Araraquara e este, construído, foi inaugurado em 13 de abril 1972, implantado à rua dos Libaneses e rua João Gurgel, num terreno distante 41,50 metros da rua Espanha, e projetado por Neves e Paoliello SC LTDA com $2.673,09 \mathrm{~m}^{2}$ de área construída.

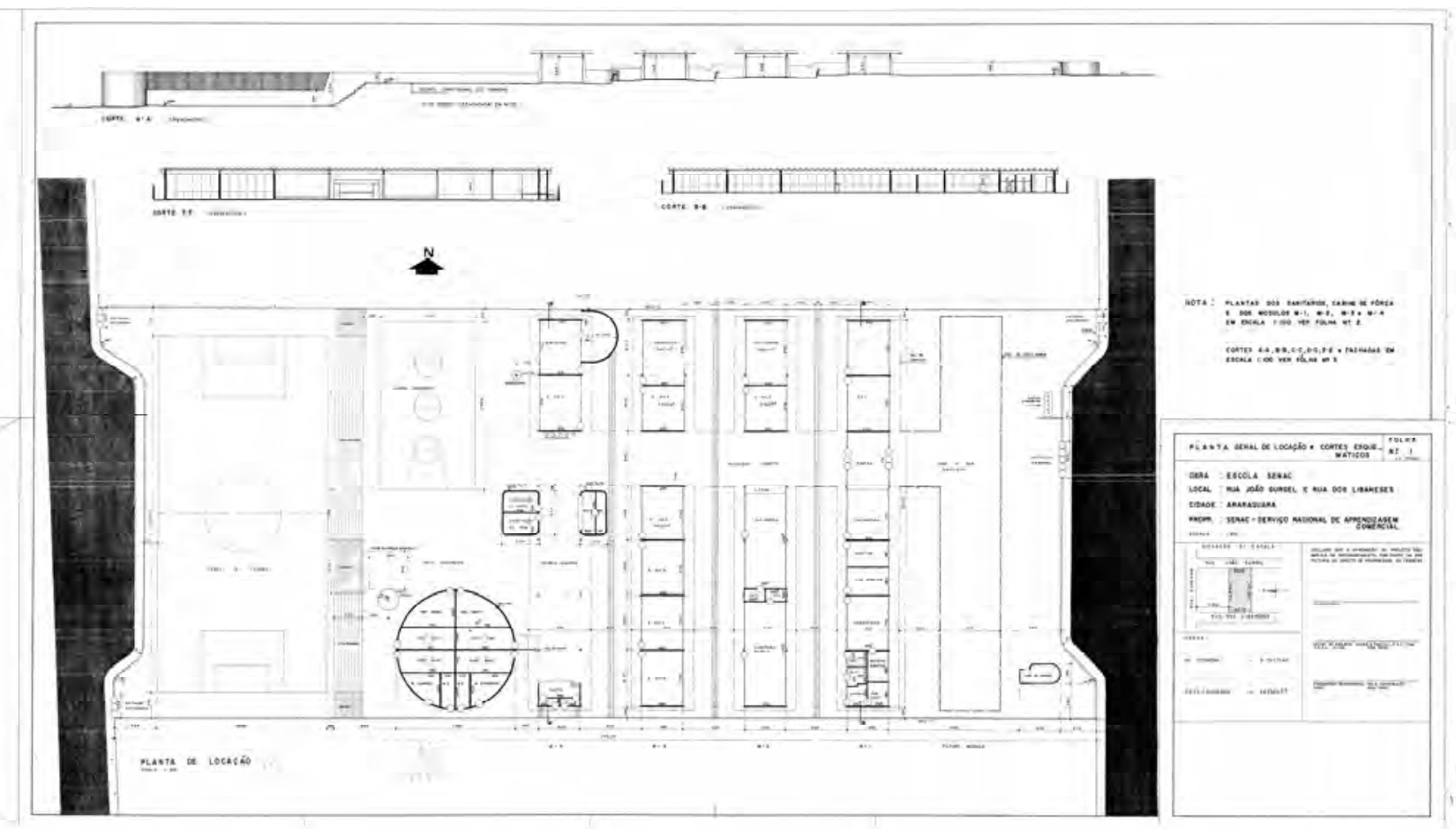

Figura 17 : Prancha 1 do projeto de prefeitura da Escola Senac de Araraquara, autoria de Neves e Paoliello SC LTDA, inaugurada em 13 de abril 1972.

Fonte: Arquivo SENAC-SP 


\section{PROJETO 5}

\section{Escola Sesc-Senac de Santos, 1956}

A Escola SESC-SENAC de Santos' foi projetada em 1956 pelo arquiteto Oswaldo Corrêa Gonçalves. Implantada num terreno de $3.281,63 \mathrm{~m}^{2}$ e localizada na Avenida Conselheiro Nébias 309, o projeto original contava com dois blocos, sendo o SENAC com $1.701,54 \mathrm{~m}^{2}$ de área construída e o SESC com $841,84 \mathrm{~m}^{2}$. O projeto, em dois blocos paralelos e perpendiculares à avenida, foi idealizado numa única fachada para ambos os edifícios, ressaltando a interdependência de cada Serviço.

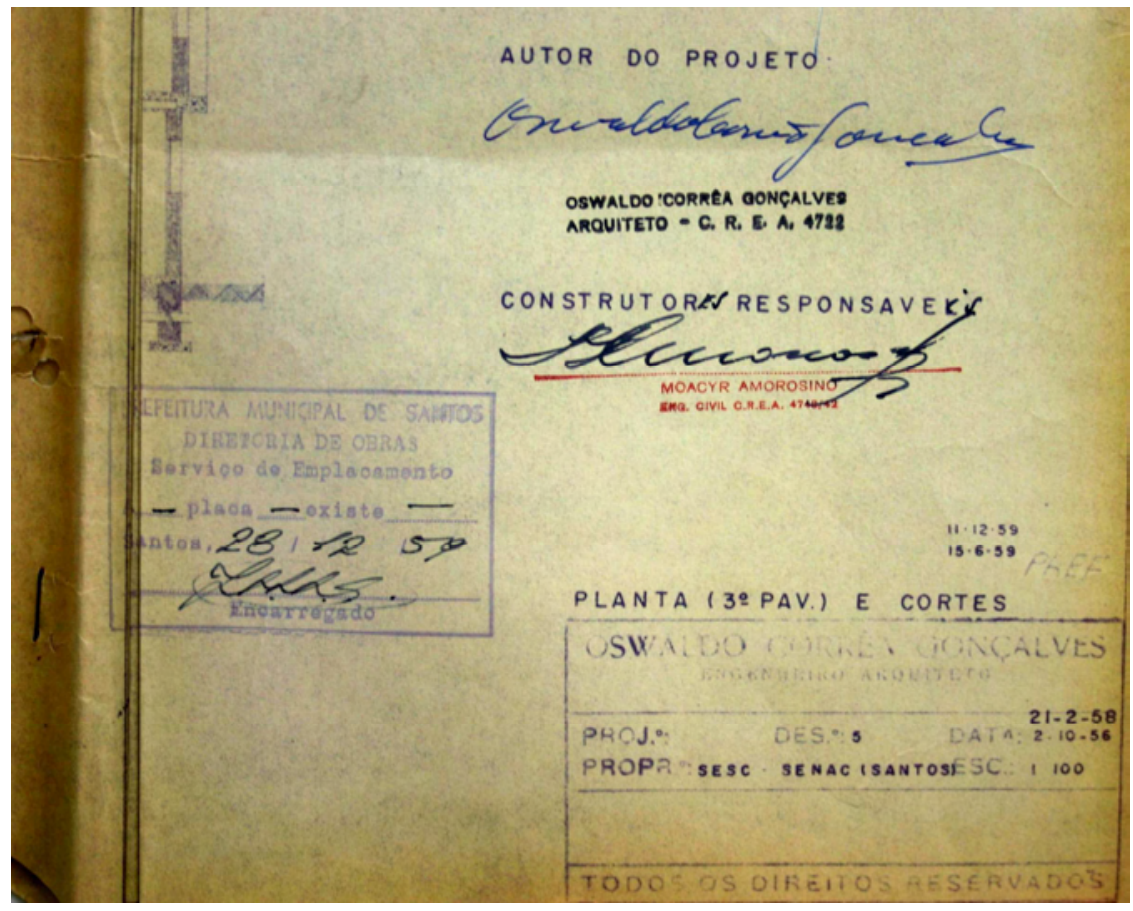

Figuras 1: Observar os dados do selo do projeto de prefeitura da Escola Sesc-Senac de Santos, aprovado em 28 de dezembro de 1959, concebido em 1956 e alterado em 1958 e 1959.

Autoria de Oswaldo Corrêa Gonçalves. Fonte: Foto Ferraz, arquivo SENAC

${ }^{1}$ A Escola SESC-SENAC de Santos foi publicada pela revista Habitat nº 59 (1960:1016). 
programa construtivo, dividido em dois blocos, abrigava dependências de uso comum como pátio ajardinado e recreios cobertos. O bloco do SESC, composto de dois pavimentos, abrigava no térreo hall de entrada, secretaria, diretoria, arquivo, registro geral, quatro salas de atendimento dentário, obstetrícia, pediatria, sala do médico, três salas visitadoras e sanitários. No pavimento superior, os sanitários, biblioteca, corte-costura, copa-cozinha, almoxarifados e salas de culinária, arte, bordado, flores, canto juvenil, canto infantil, acordeom, gaita e piano. O bloco do SENAC, composto de três pavimentos, abrigava no térreo hall de entrada, diretoria, secretaria, arquivo, sala dos professores, sanitários e recreio coberto. No segundo pavimento, cinco salas de aula, loja modelo, biblioteca, datilografia, sala de material didático e sanitários superiores. No terceiro pavimento, sete salas de aula, sala de orientação individual, sala do médico e sanitários.

Parte dos dados relativos à escola foram obtidos no arquivo do SENAC-SP, como as cópias do projeto de prefeitura aprovado. De grande importância foi o material encontrado no arquivo da FAUS, como as pranchas do ante-projeto de 1956, perspectivas e estudo preliminar do ante-projeto de ampliação de 1959, assim como fotos da maquete e do edifício construído. Também, o conhecimento do projeto original foi obtido através da publicação em periódico da época, Habitat nº 59 (1960:10-16).

Figura 2: Selo retirado da prancha do ante-projeto da Escola

Sesc-Senac de Santos, 1956, autoria de Oswaldo Corrêa Gonçalves.

Fonte: Foto Ferraz, arquivo FAUS

\section{OSWALDO CORREA GONÇALVES BNOENHEIHO ARQUITETO} $26-8-56$ PROJ.: DES.": 1 OATA:21-8.56 PROPR: :SESC-SENAC - SANTOSESC:i I:200 


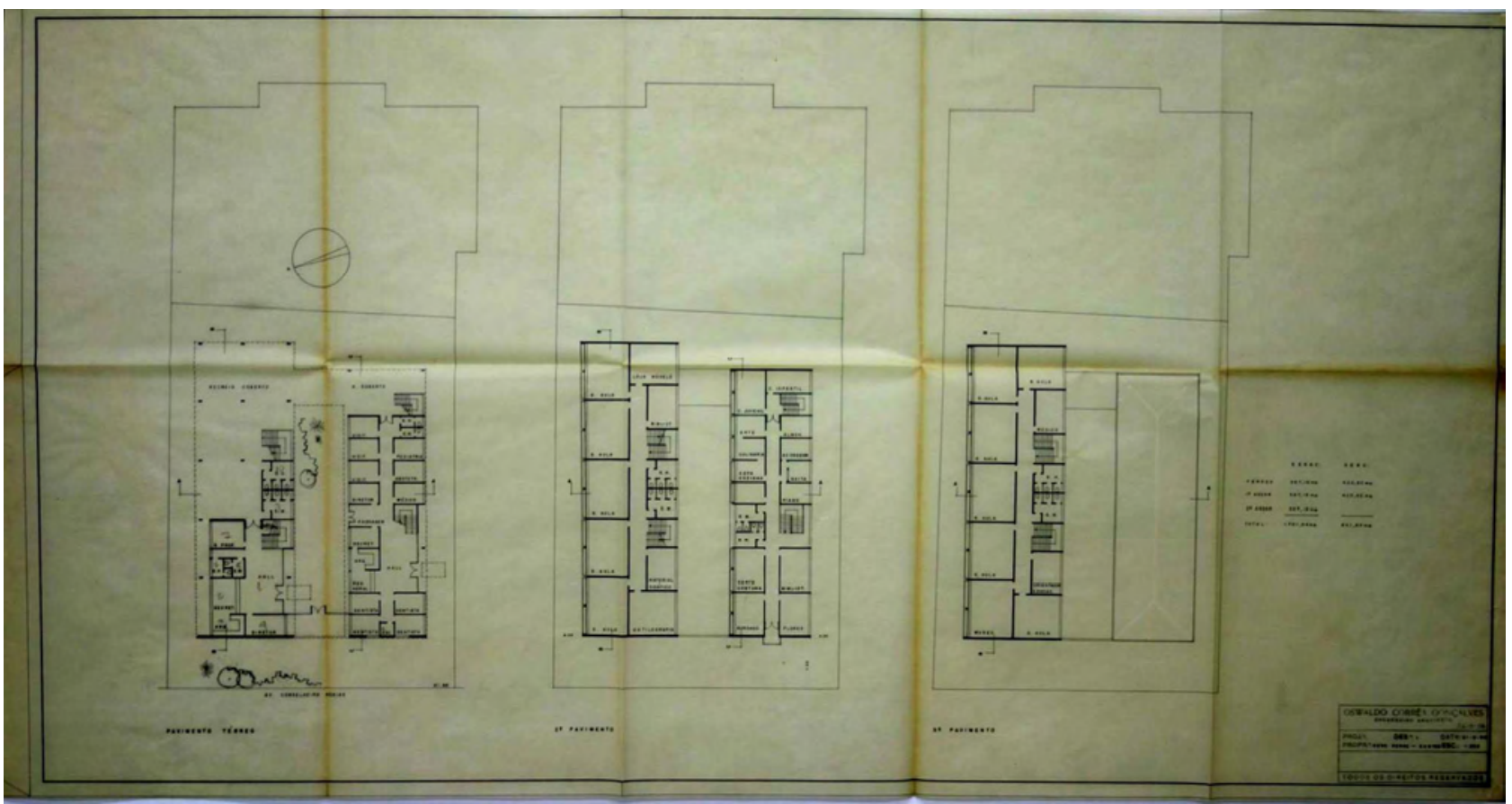

Figura 3: Prancha do ante-projeto da Escola Sesc-Senac de Santos, 1956, autoria de Oswaldo Corrêa Gonçalves. Fonte: Foto Ferraz, arquivo FAUS

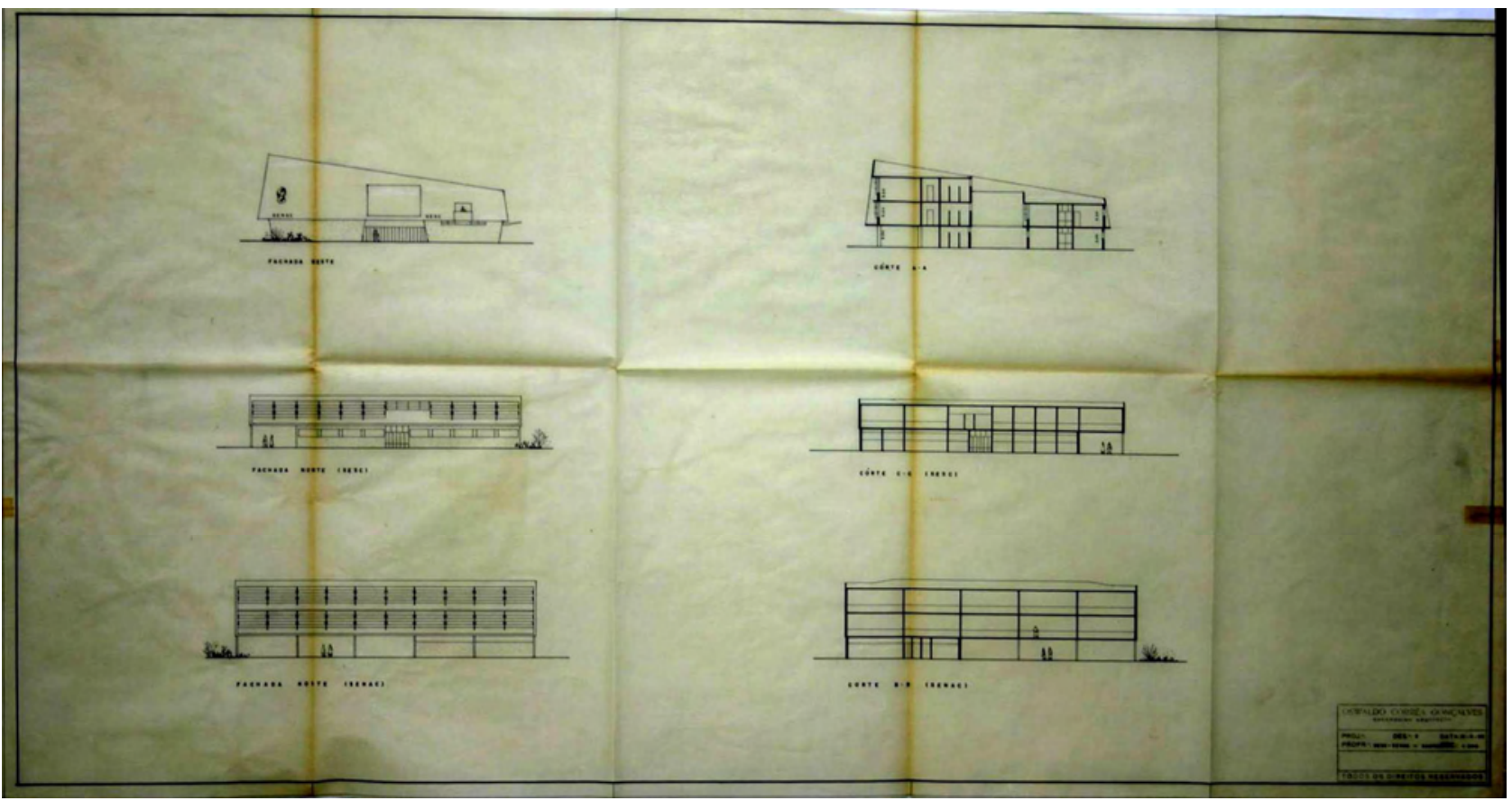

Figura 4: Prancha do ante-projeto da Escola Sesc-Senac de Santos, 1956, autoria de Oswaldo Corrêa Gonçalves. Fonte: Foto Ferraz, arquivo FAUS 

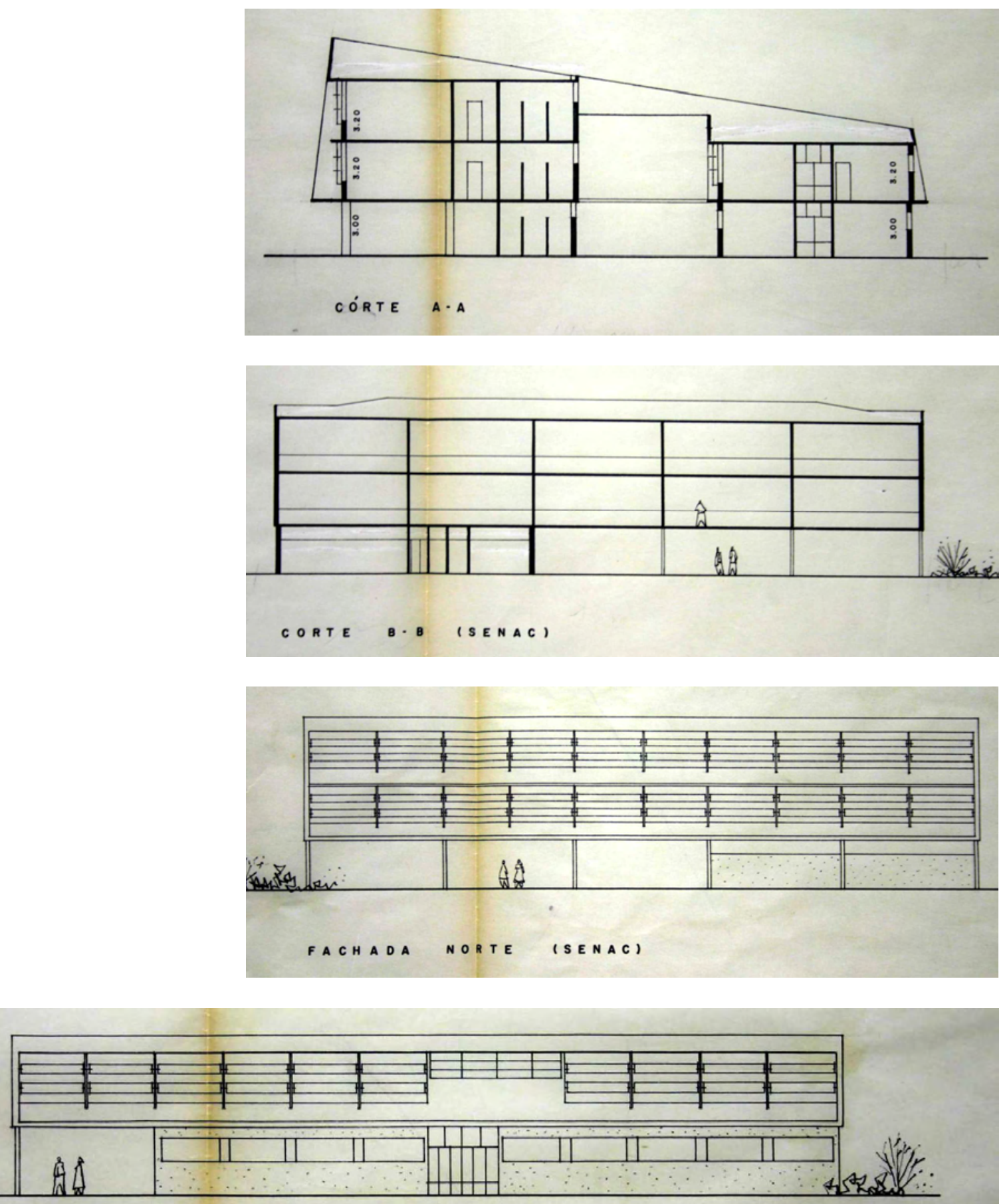

FACHADA NORTE (SESC)

Figuras 5 à 9: Cortes e

Fachadas retirados da prancha do ante-projeto da Escola SescSenac de Santos, 1956, autoria de Oswaldo Corrêa Gonçalves. Fonte: Foto Ferraz, arquivo FAUS

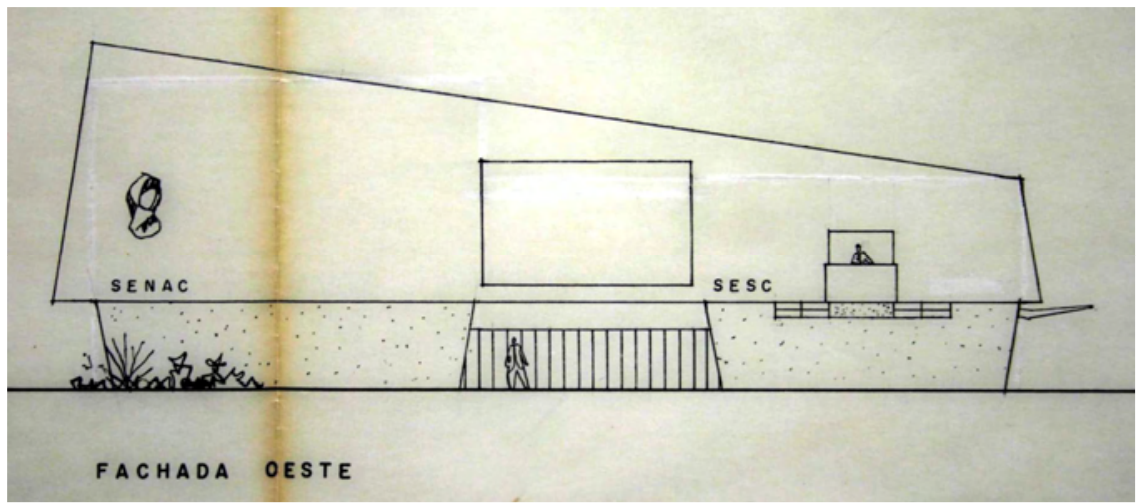



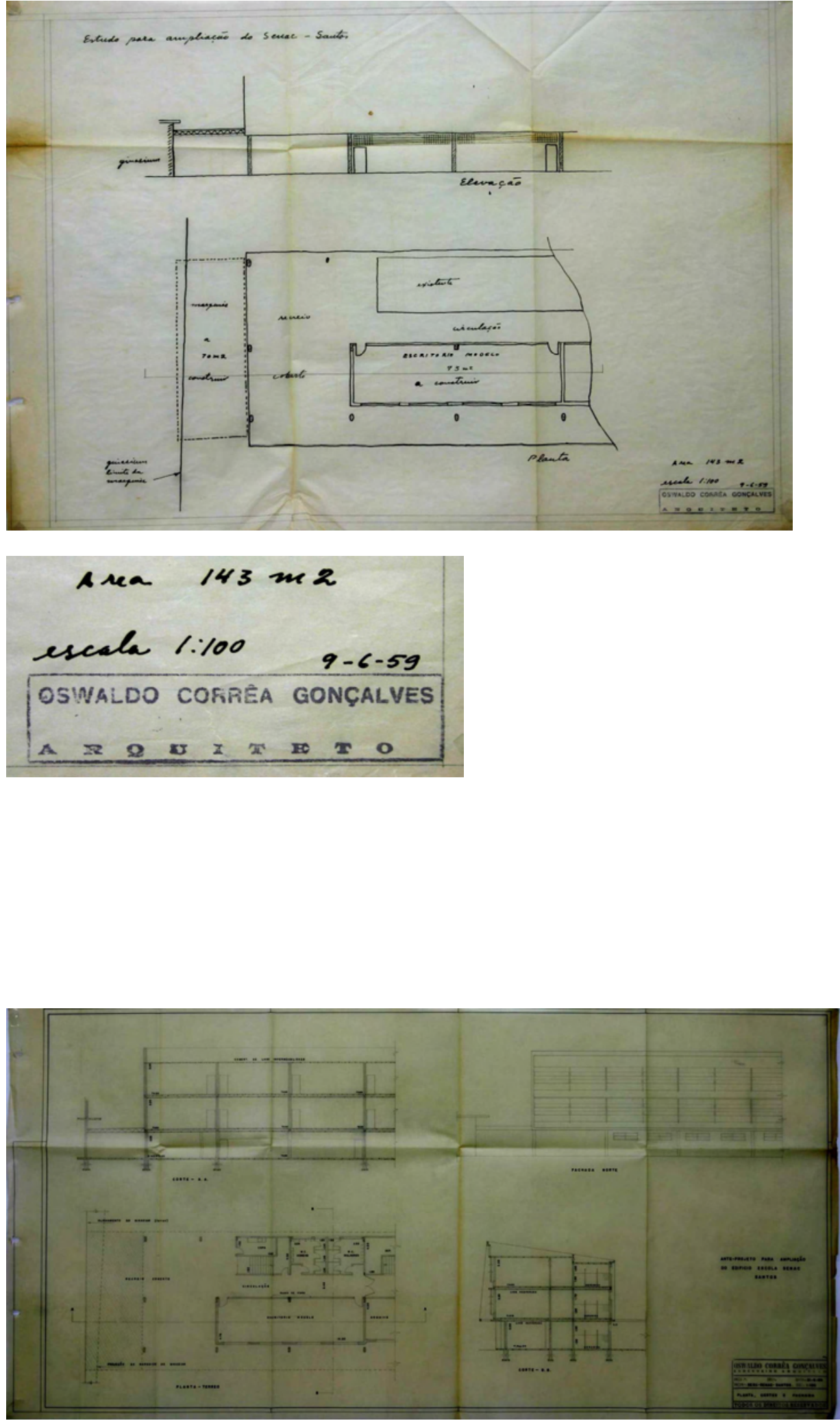

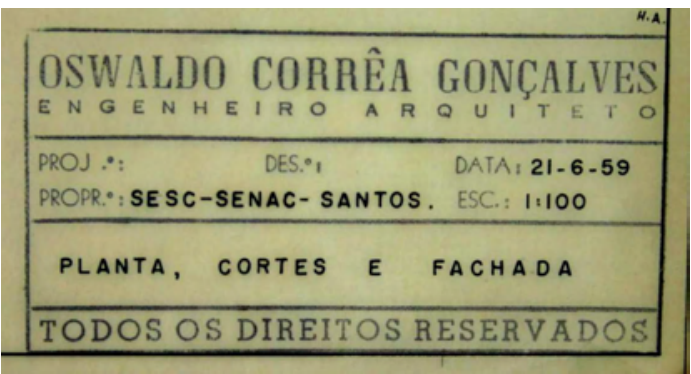

Figura 10: Prancha do estudo para ampliação do Senac de Santos, 09/06/1959,Oswaldo Corrêa Gonçalves.

Fonte: Foto Ferraz, arquivo FAUS

Figura 11: Selo da prancha do estudo para ampliação do Senac de Santos, 09/06/1959,

Oswaldo Corrêa Gonçalves. Fonte: Foto Ferraz, arquivo FAUS

Figura 12: Prancha do anteprojeto para ampliação do Senac de Santos, 21/06/1959,

Oswaldo Corrêa Gonçalves. Fonte: Foto Ferraz, arquivo FAUS

Figura 13: Selo da prancha do ante-projeto para ampliação do Senac de Santos, 21/06/1959,

Oswaldo Corrêa Gonçalves. Fonte: Foto Ferraz, arquivo FAUS 
Figura 14: Perspectiva do projeto, Escola Sesc-Senac de Santos, 22/08/1956, Oswaldo Corrêa Gonçalves.

Fonte: Foto Ferraz, arquivo FAUS
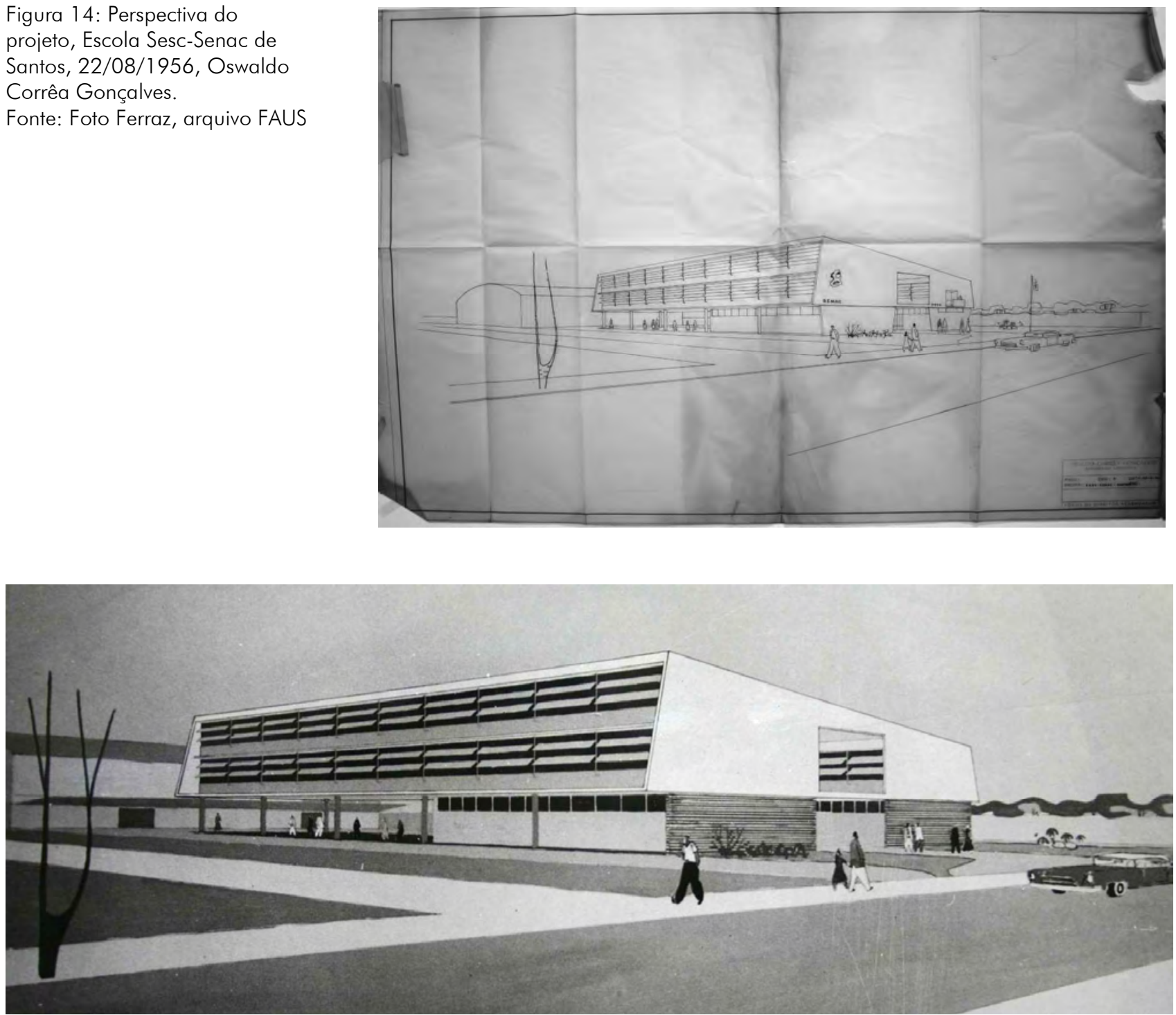

Figura 15: Perspectiva final do projeto, Escola Sesc-Senac de Santos, 22/08/1956, Oswaldo Corrêa Gonçalves. Fonte: Foto Ferraz, arquivo FAUS

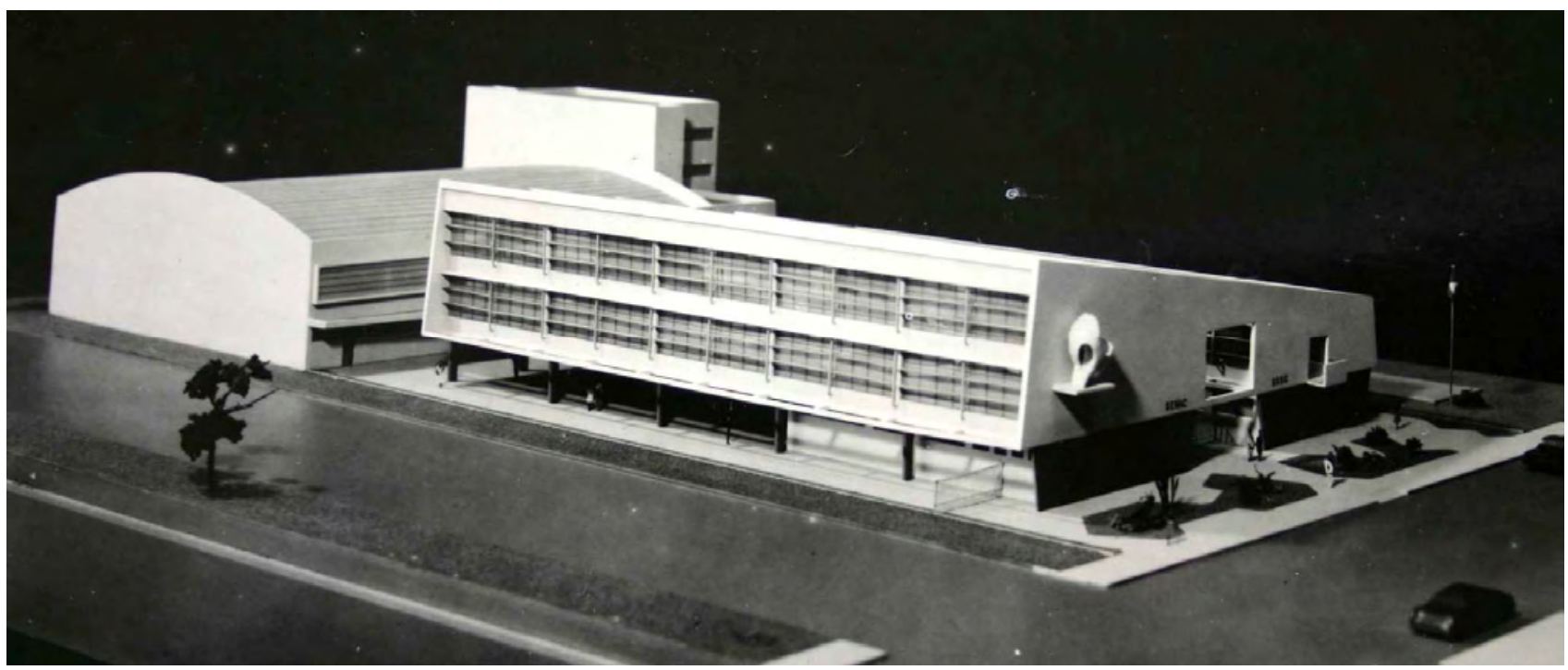

Figura 16: Maquete concebida na década de 50, Escola Sesc-Senac de Santos.

Fonte: Foto Ferraz, arquivo FAUS 


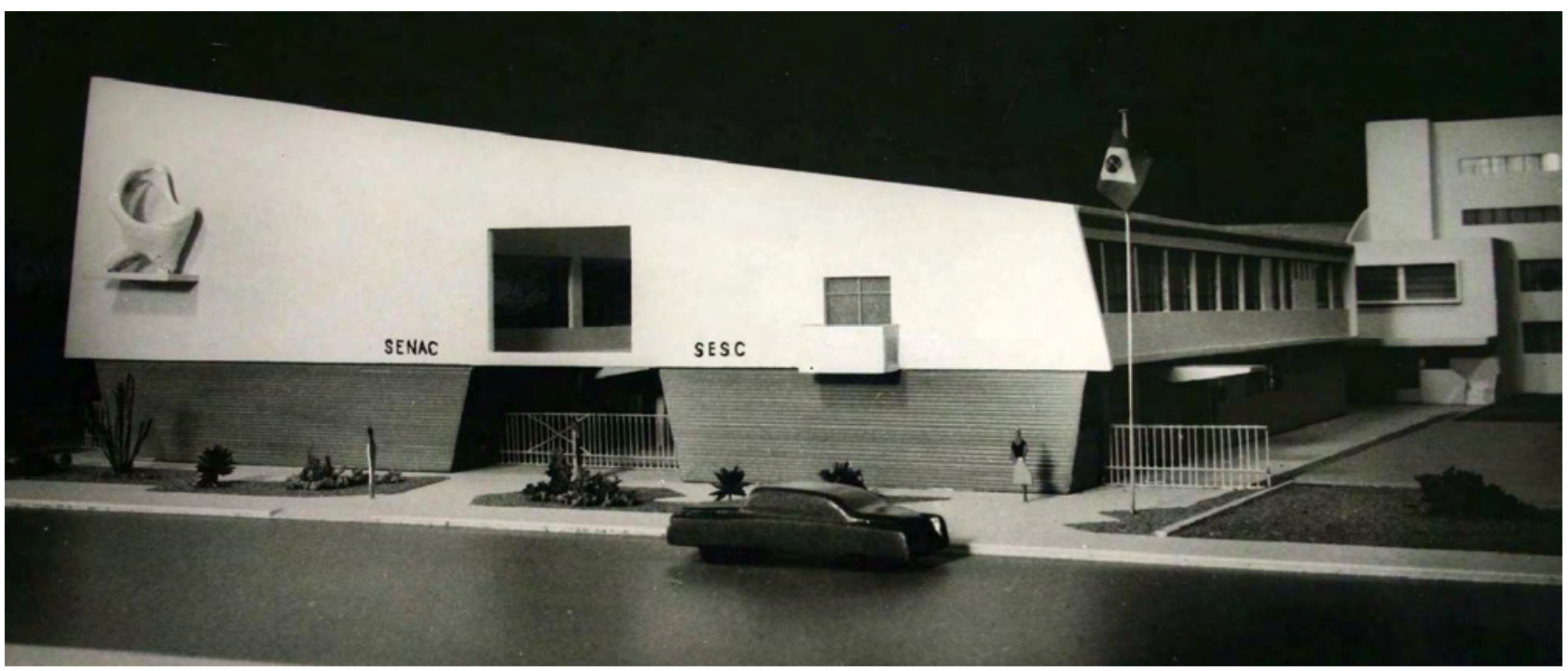

Figuras 17 e 18: Maquete concebida na década de 50, Escola Sesc-Senac de Santos. Fonte: Foto Ferraz, arquivo FAUS

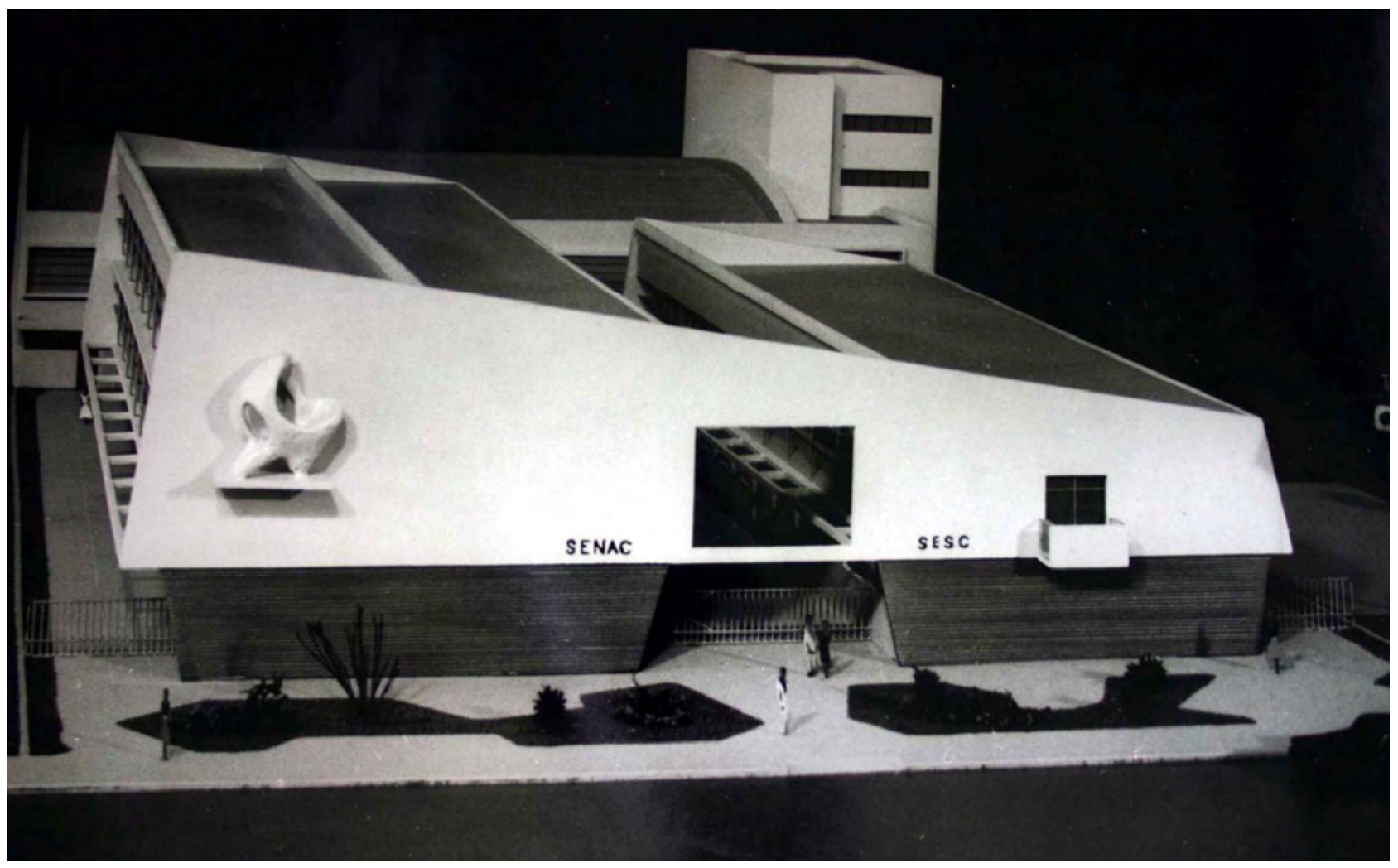


primeiro bloco do SENAC, à direita, teve dois acessos, o principal pelo corredor lateral, marcado por marquise de concreto, e o secundário, pelo corredor de circulação entre os blocos. $\bigcirc$ bloco foi caracterizado no pavimento térreo pelas acomodações administrativas e instalações recreativas e, no pavimento superior, pelas salas de ensino de arte, música e costura. Com circulação interna central, as salas receberam iluminação e ventilação lateral, sendo a face norte protegida por brises solares, evitando o sol poente da cidade de Santos.

Figura 19: Bloco SESC, primeiro edifício a ser construído na Escola Sesc-Senac de Santos. Fonte: Foto Ferraz, arquivo FAUS
Figura 20: Marquise de concreto no acesso principal do bloco do Sesc.

Fonte: Foto Ferraz, arquivo FAUS
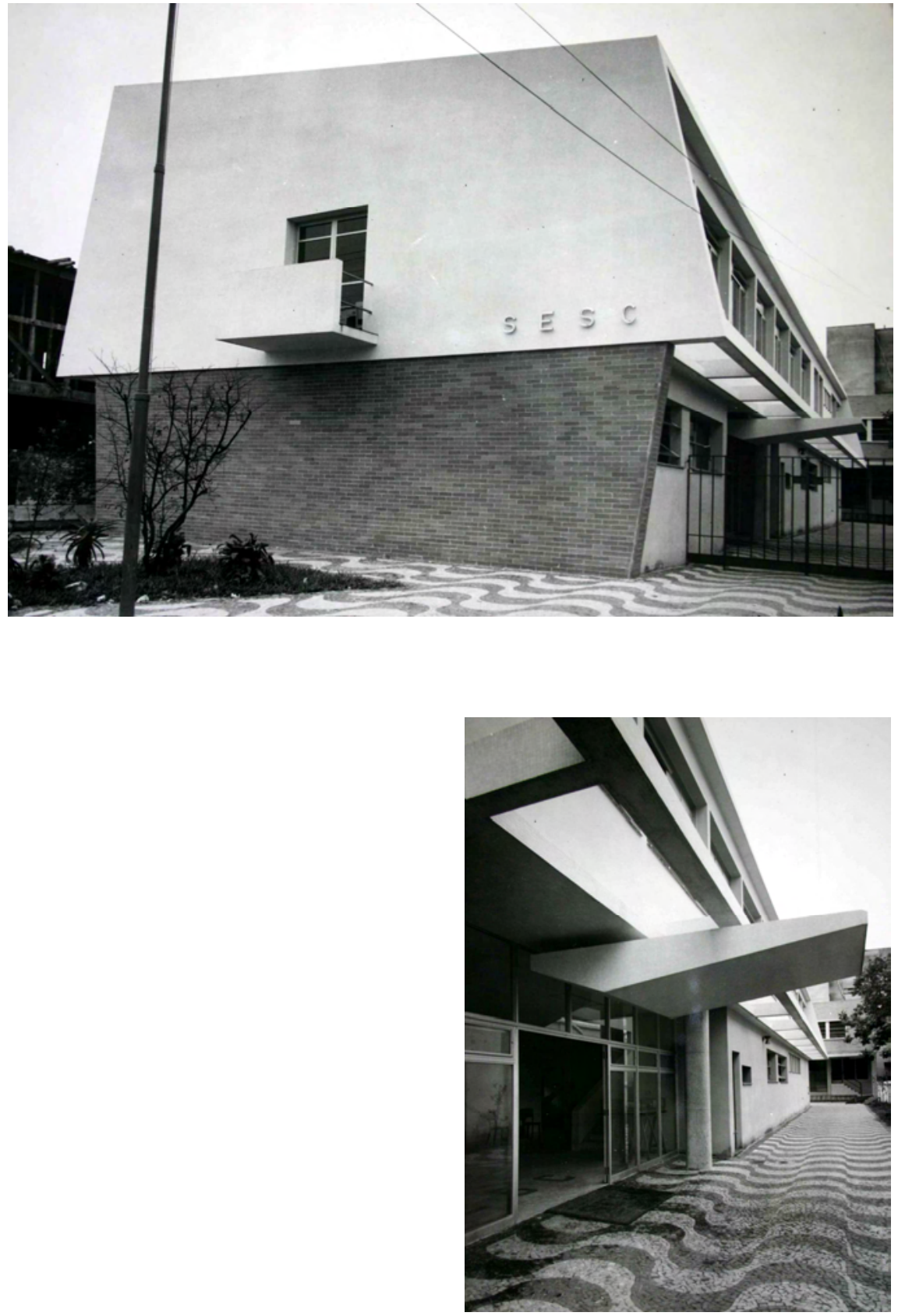
O segundo bloco do SENAC, construído posteriormente ao do SESC, teve seu acesso principal também marcado por marquise de concreto, porém no corredor de circulação entre os blocos. Assim como no bloco do SENAC, o térreo foi composto por salas administrativas e pelo recreio coberto, enquanto dos dois pavimentos superiores abrigavam as salas de aula. Com circulação interna central, as salas de aula foram divididas ao longo das faces norte e sul, todas com iluminação lateral. As dez salas de aula voltadas para o norte receberam brises solares, assim como o bloco do SESC.
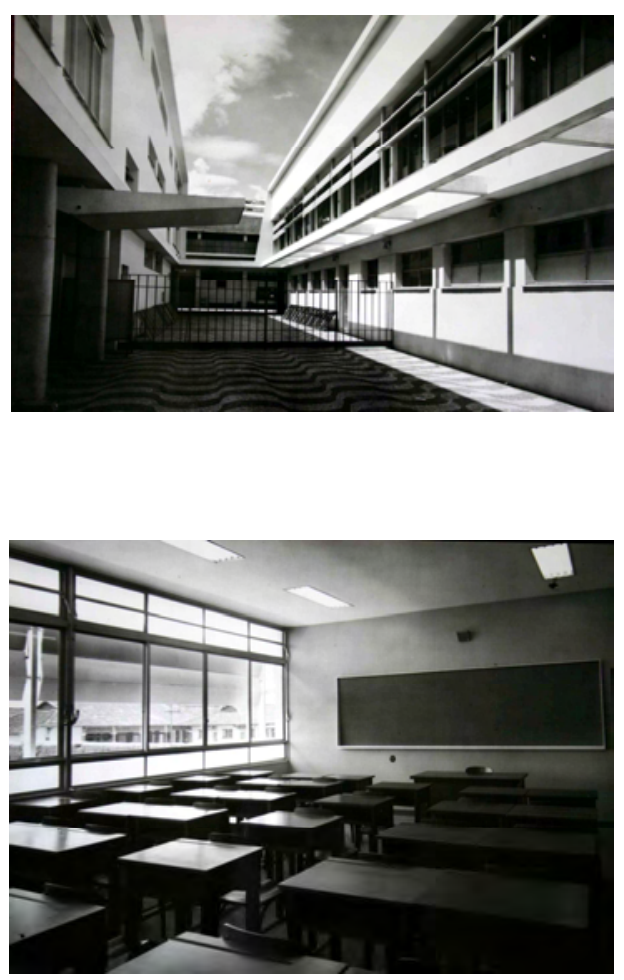

Outra característica pode ser observada em relação ao conforto térmico em ambos os blocos. $\bigcirc$ pavimento térreo é protegido pelas lajes em balanço dos pavimentos superiores, proporcionando sombras nas janelas altas projetadas nas paredes do térreo. A escola como um todo adotou em sua construção a cobertura em laje de forro, plana, com vigas invertidas que, após a cura do concreto, receberam uma camada de pedregulho de rio. Com isso, as lajes então impermeabilizadas, evitam dilatações na cobertura e favorecem o controle de temperatura, essencial na cidade de Santos, com variações meteorológicas instáveis.
Figura 21: Circulação externa entre o bloco do SENAC e do SESC. Observar marquise de concreto no acesso principal do bloco do Senac. Fonte: Foto Ferraz, arquivo FAUS

Figura 22: Salas de aula do SENAC. Janela lateral protegida pelos brises metálicos na face norte. Fonte: Foto Ferraz, arquivo FAUS 
Figura 23: Fachada norte do bloco do SENAC. Observar a sombra nas janelas do térreo, causada pela laje do pavimento superior.

Fonte: Foto Ferraz, arquivo FAUS
Figura 24: Fachada principal da Escola Sesc-Senac de Santos, 1959. Observar com a empena da fachada unificou os dois blocos.

Fonte: Foto Moscardi, arquivo FAUS

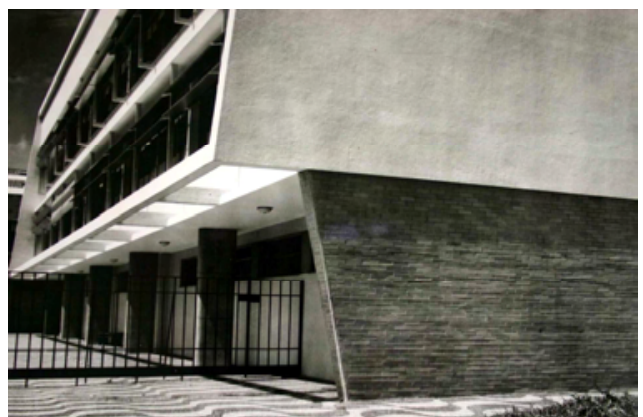

Reforçando a integração das artes plásticas à arquitetura, destaca-se nesta escola a escultura projetada na empena cega da fachada, conforme revelado na maquete.

A Escola Sesc-Senac de Santos, assim como a de Marília, reuniu a solução arquitetônica de dois blocos, com funções diferentes, exigindo acessos independentes e interligados pelas dependências de uso comum. Ao mesmo tempo em que a escola mantém uma circulação central marcando a separação dos blocos, a fachada unifica os mesmos por uma empena inclinada, numa solução arquitetônica de unir educativamente no urbano, ambos os Serviços. Inaugurada em 26 de janeiro de 1960, esta escola funcionou como SESC-SENAC até 1987, quando o SENAC adquiriu a parte do SESC e esta escola passou a ser utilizada somente pelo SENAC.

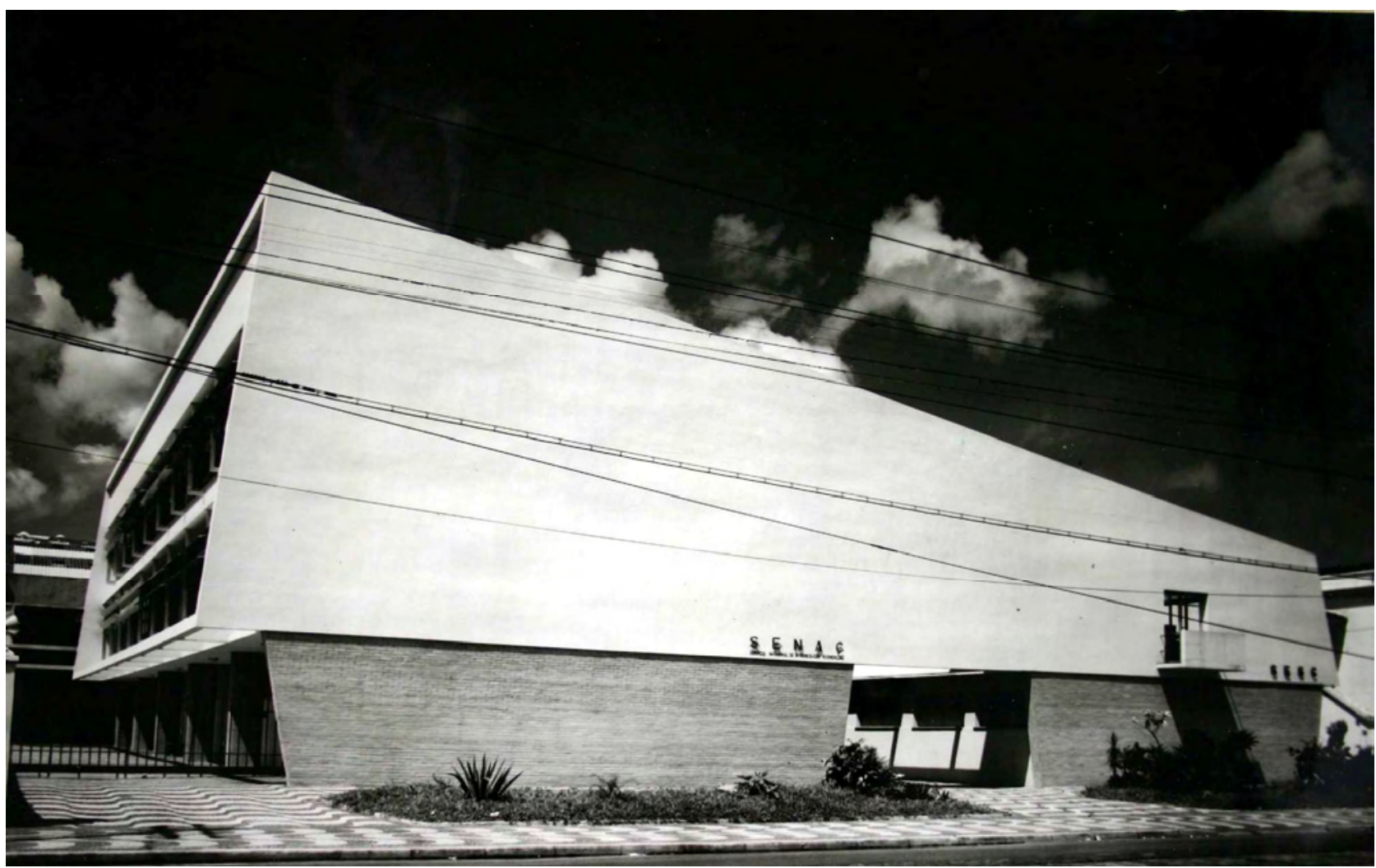




\section{PROJETO 6}

\section{Edifício Sede, São Paulo, 1957}

O Edifício Sede, já mencionado no início deste capítulo, foi projetado num terreno onde anteriormente havia um edifício'. Localizado na rua Doutor Vila Nova 228, São Paulo, o edifício adquirido foi demolido em 1954 devido a problemas estruturais e, segundo relatórios da Memória Institucional do SENAC-SP, em 1957 o Conselho Regional do SENAC de São Paulo aprovou a construção de um novo edifício.

O programa construtivo do novo edifício foi composto com o objetivo de atender às sedes da Administração Regional do SENAC-SP e do SESC-SP. O novo prédio, então chamado Edifício Sede, foi elaborado em 1957. Quanto à autoria deste projeto, sabe-se que Oswaldo Corrêa Gonçalves e o Escritório Técnico Ramos de Azevedo, Engenharia Arquitetura e Construções, Severo e Villares AS estão envolvidos em sua concepção, conforme consta em documentos e fotos encontrados. Possivelmente Gonçalves seja o autor do projeto e Severo e Villares tenham executado a obra, uma questão ainda passível de investigação.

programa construtivo previa a construção de 18 andares, em dois blocos que, juntos, formariam um ângulo obtuso, ainda que separados por um pátio descoberto ajardinado. Com o objetivo de estudar as escolas SESC-SENAC, cabe lembrar que este edifício não foi projetado para ser uma escola, sua função era abrigar as administrações do SESC e do SENAC, portanto sua importante arquitetura deve ser registrada, mas suas características serão brevemente apresentadas por não se tratar especificamente de um edifício-escola.

projeto original executivo foi encontrado no arquivo do SENAC-SP, revelando 12 pranchas e seus respectivos selos com 0 nome de Escritório Técnico Ramos de Azevedo, Engenharia Arquitetura

\footnotetext{
' O editício demolido tinha sido construído em 1946, com 6 pavimentos, para funcionamento do Liceu Nacional Rio Branco. O Edifício foi comprado pelo SENAC para receber a Administração Regional e a Escola SENAC "João Nunes Júnior". Inicialmente foi aprovada a reforma do prédio, porém devido aos problemas estruturais, o mesmo foi demolido em 1954 para em seu lugar ser construído o atual Edifício Sede do SENAC-SP.
} 
e Construções, Severo e Villares AS. Ainda neste arquivo, foi encontrado $\bigcirc$ ante-projeto de paisagismo da arquiteta Ayako Nishikawa, datado de janeiro de 1964. Essenciais para a compreensão do projeto, também foram encontradas fotos da maquete, do edifício construído e das pranchas com perspectivas do projeto, em caixa-arquivo de Oswaldo Corrêa Gonçalves doada à FAUS. O conhecimento da autoria do projeto também foi obtido através da publicação em periódico da época, $A U$ nº 59 (1995:86), revelando a parceria de Gonçalves com Adolfo Rubio Morales e Osmar Tosi.

Figura 1: Selo do projeto executivo do Edifício Sede de São Paulo, concebido 1957. Fonte: Arquivo SENAC-SP

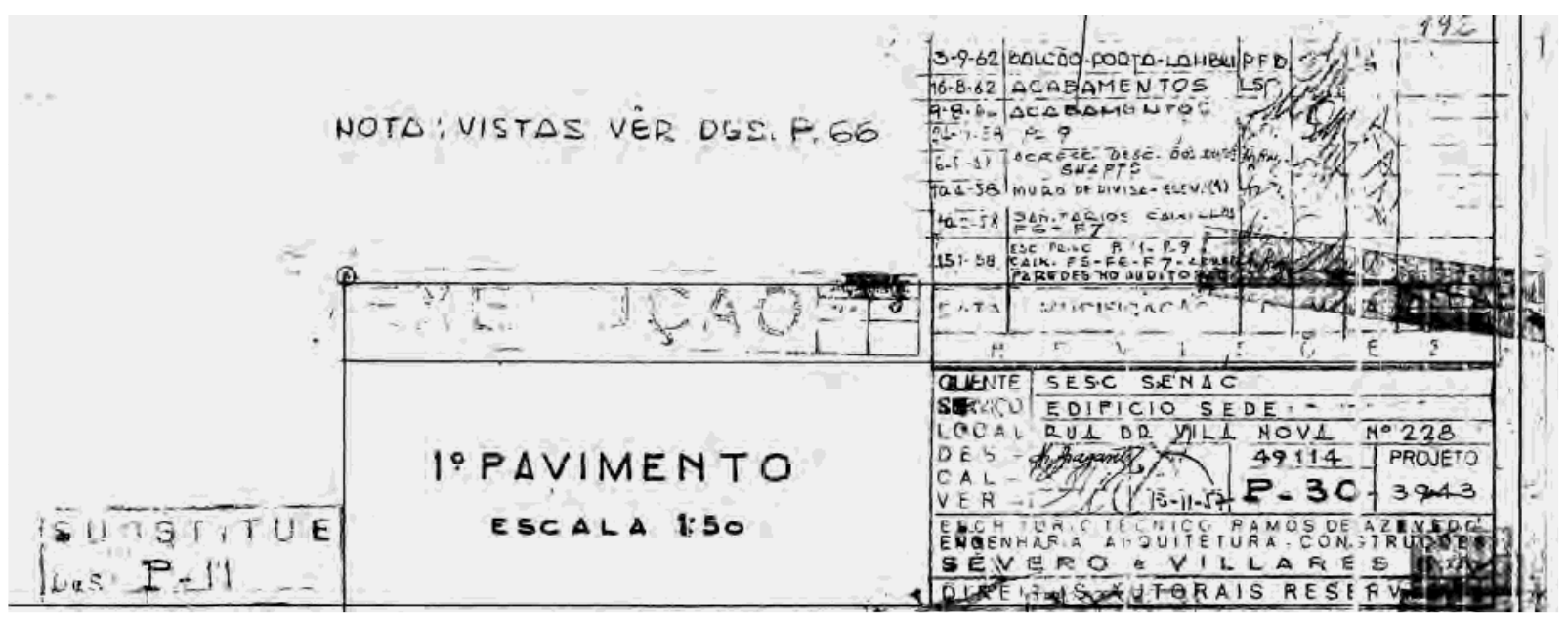




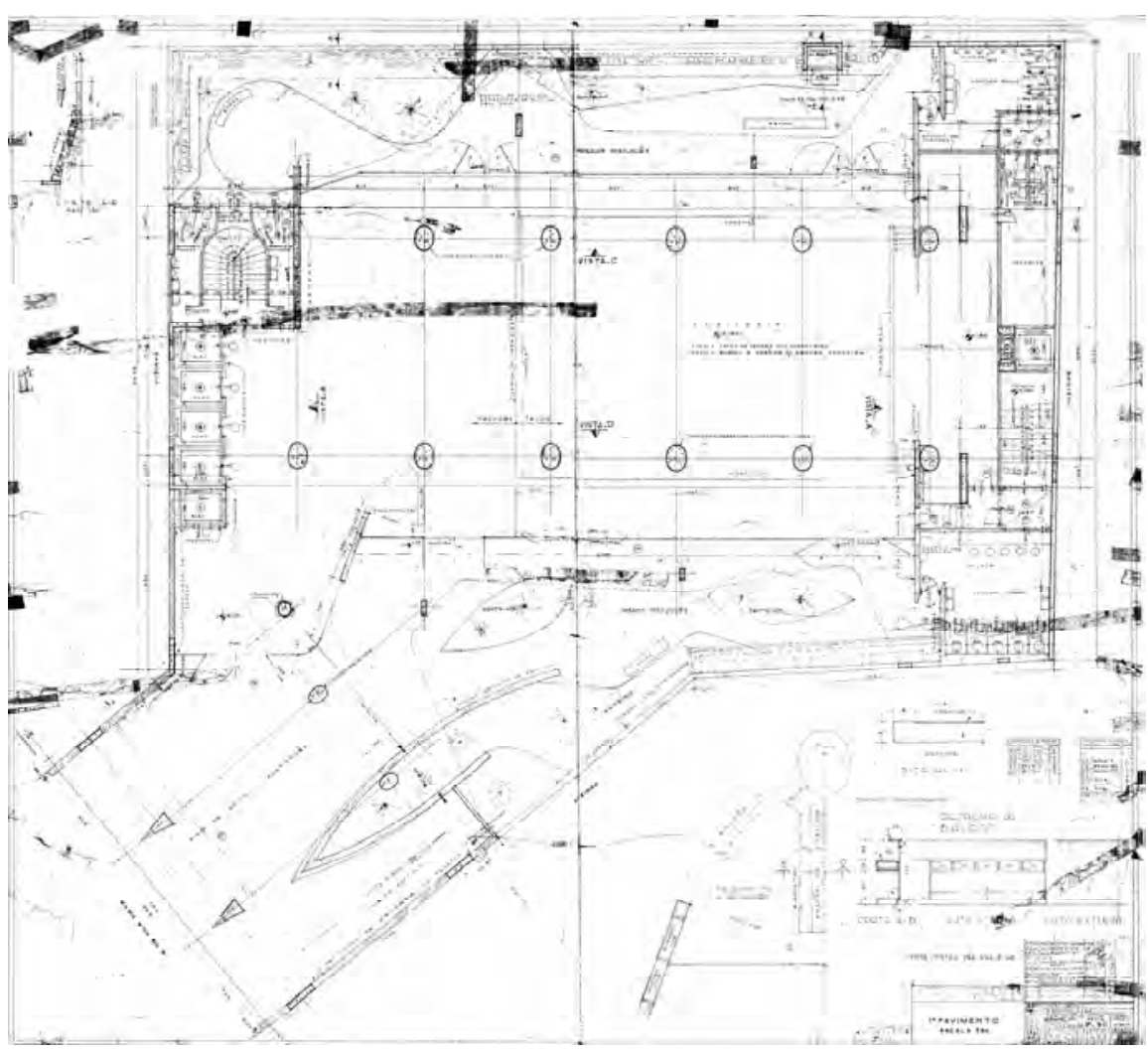

Figura 2: Projeto executivo do Edifício Sede de São Paulo, planta do $1^{\circ}$ pavimento, concebido 1957. Fonte: Arquivo SENAC-SP

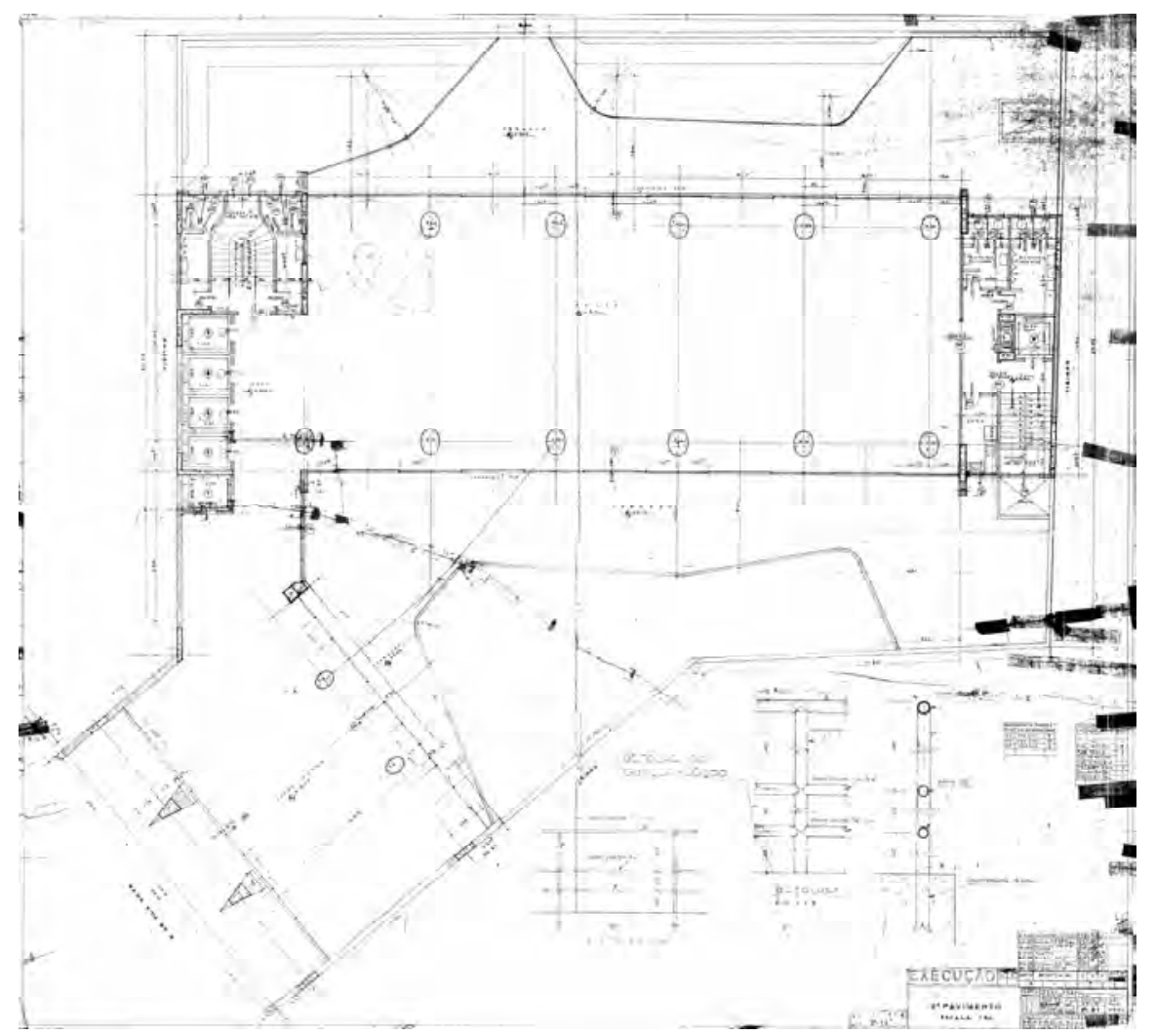

Figura 3: Projeto executivo do Edifício Sede de São Paulo, planta do 2 pavimento, concebido 1957. Fonte: Arquivo SENAC-SP 
Figura 4: Projeto executivo do Edifício Sede de São Paulo, fachada principal, concebido 1957.

Fonte: Arquivo SENAC-SP

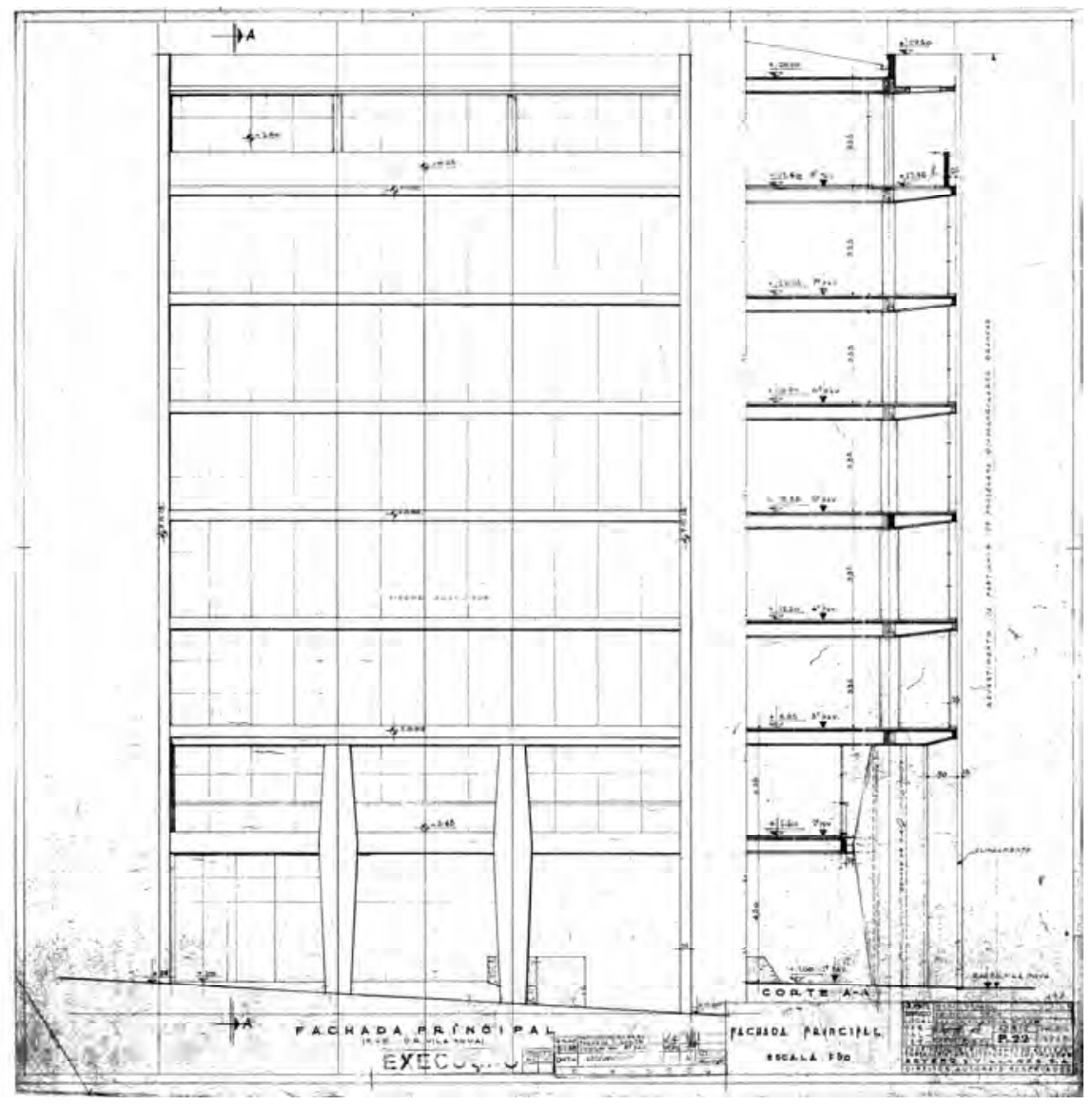

Figura 5: Projeto executivo do Edifício Sede de São Paulo, fachadas AA e BB, concebido 1957.

Fonte: Arquivo SENAC-SP

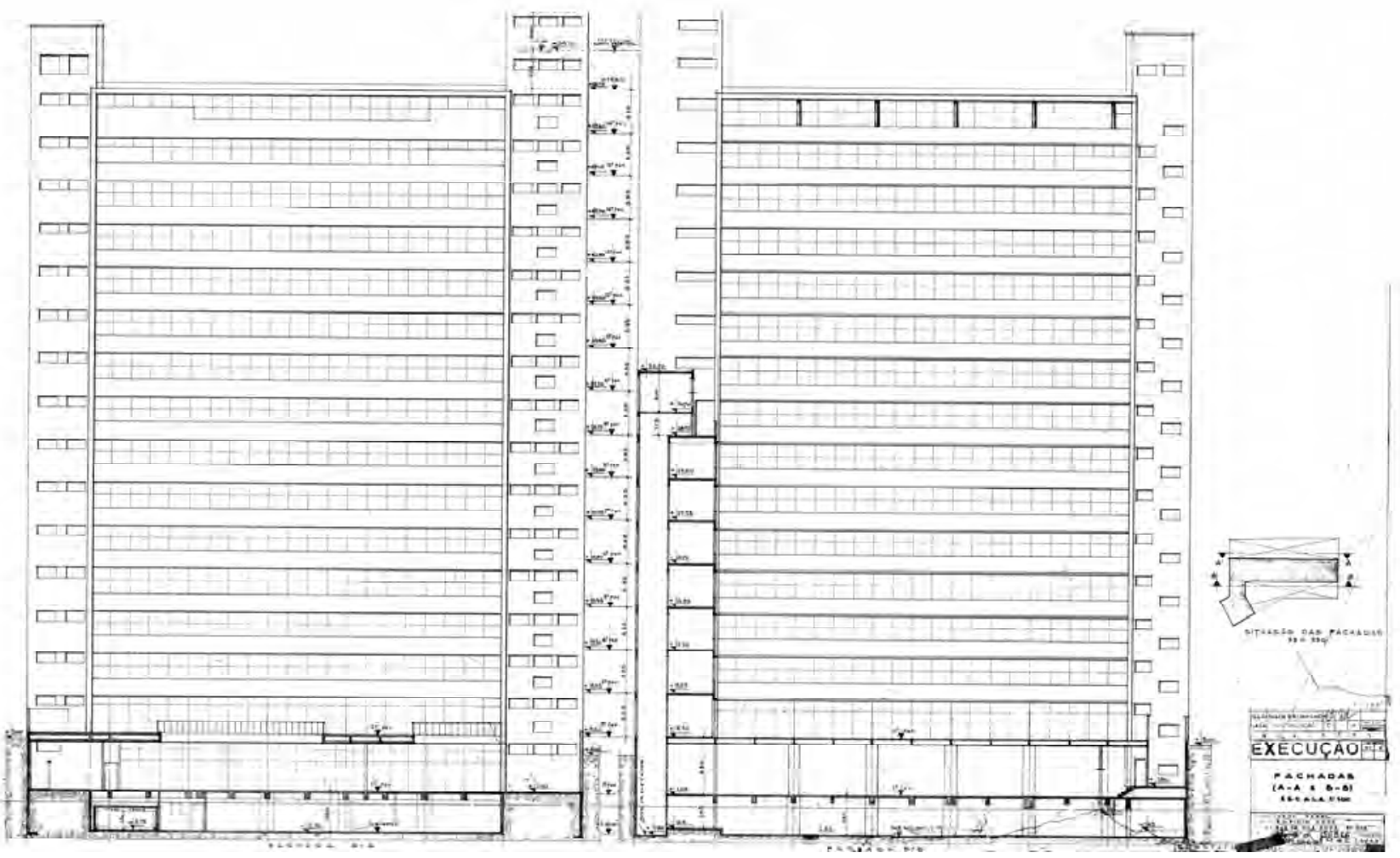




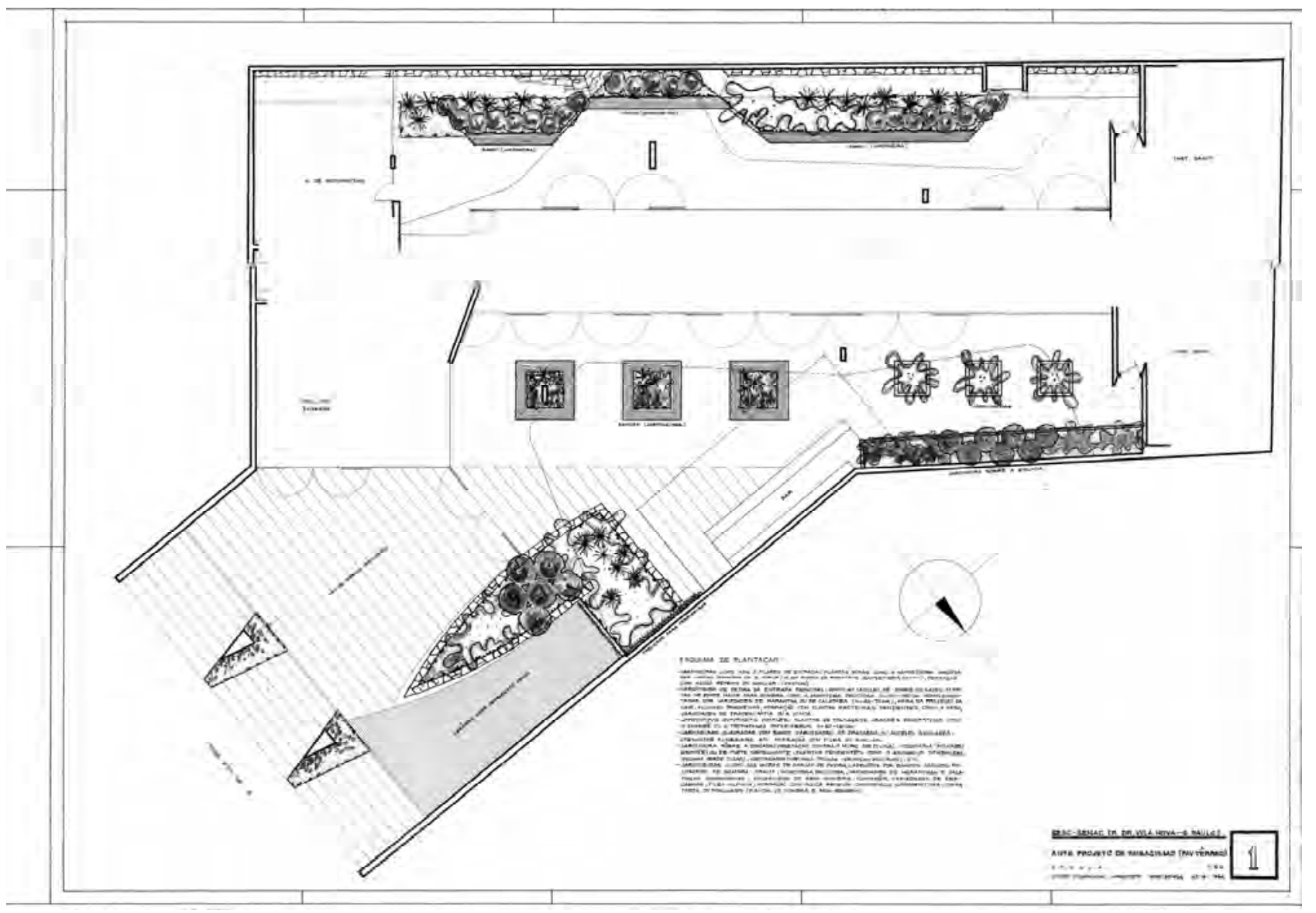

Figura 6: Ante-projeto de paisagismo para o Edifício Sede de São Paulo, arquiteta Ayako Nishikawa, janeiro de 1964. Fonte: Arquivo SENAC-SP

Figuras 7 e 8: Perspectiva do Edifício Sede de São Paulo. Fonte: Foto Ferraz, arquivo FAUS
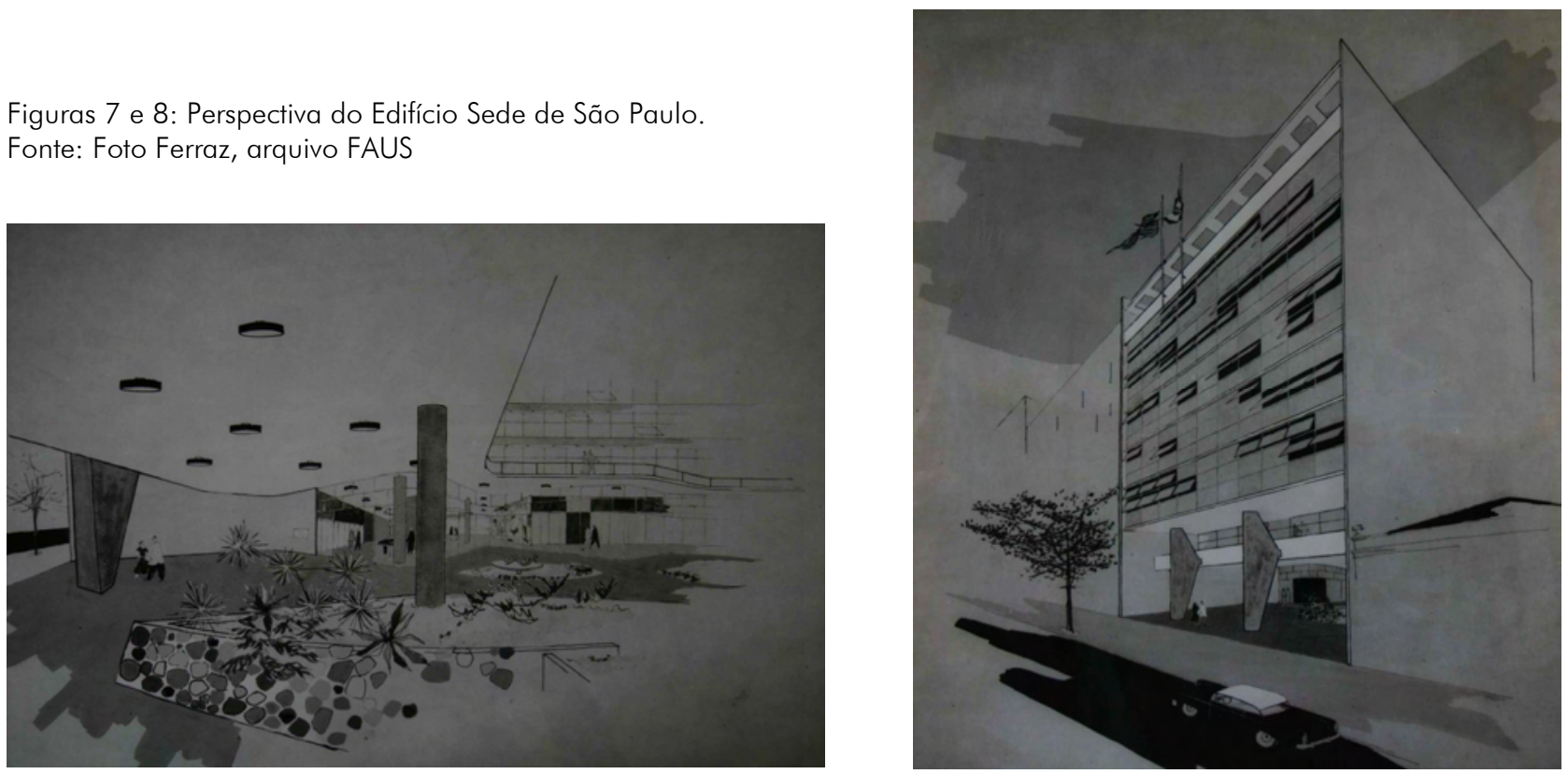
Ainda, como documentação complementar às pranchas do projeto, fotos da maquete revelam a concepção do Edifício Sede.

Figuras 9 e 10: Maquete concebida na década de 50 de acordo com o projeto executivo. Observar os dois blocos interligados e o projeto original com 18 andares (bloco mais alto).

Fonte: Arquivo FAUS
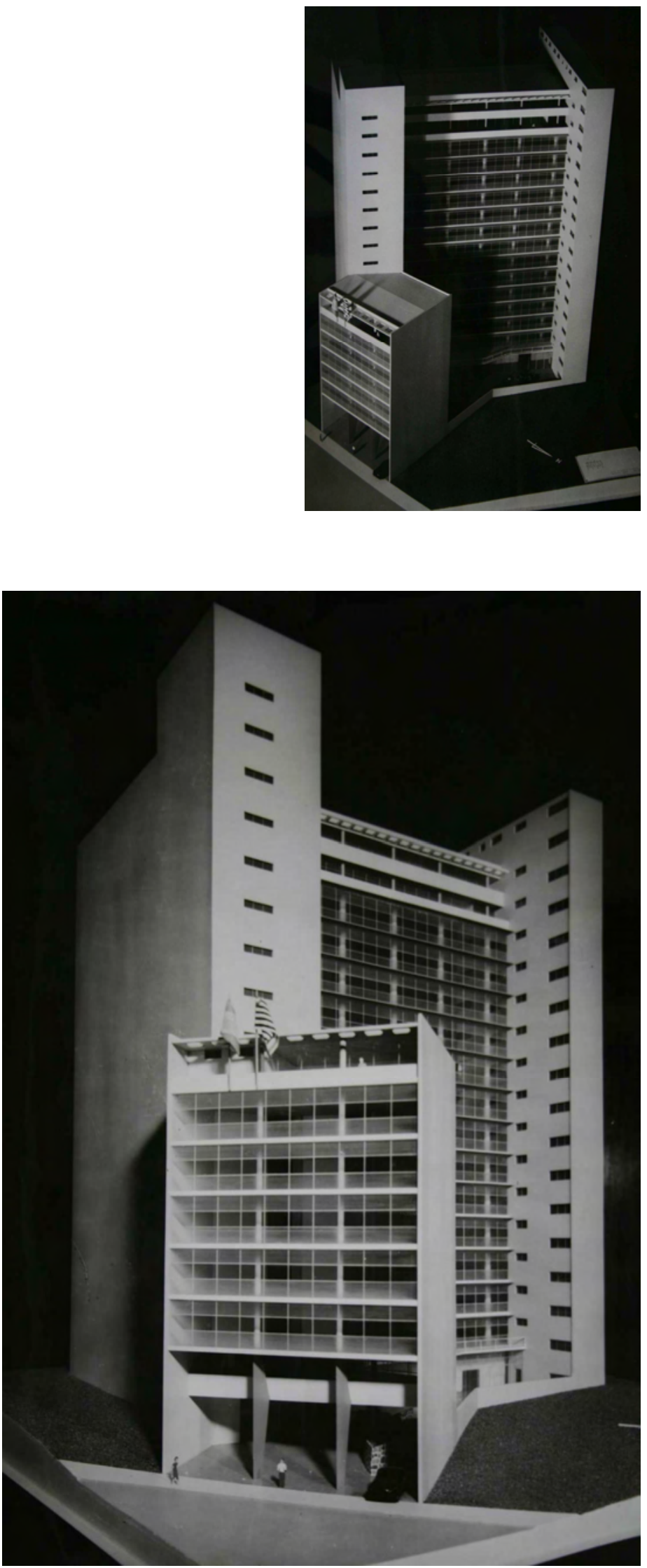
Em 1962, o projeto em construção foi alterado, conforme resolução 51/62 aprovada em 16 de maio do mesmo ano. Esta resolução alterava o projeto inicial do edifício, limitando a construção de um dos blocos para 10 andares, e não 18 andares como haviam sido projetados.

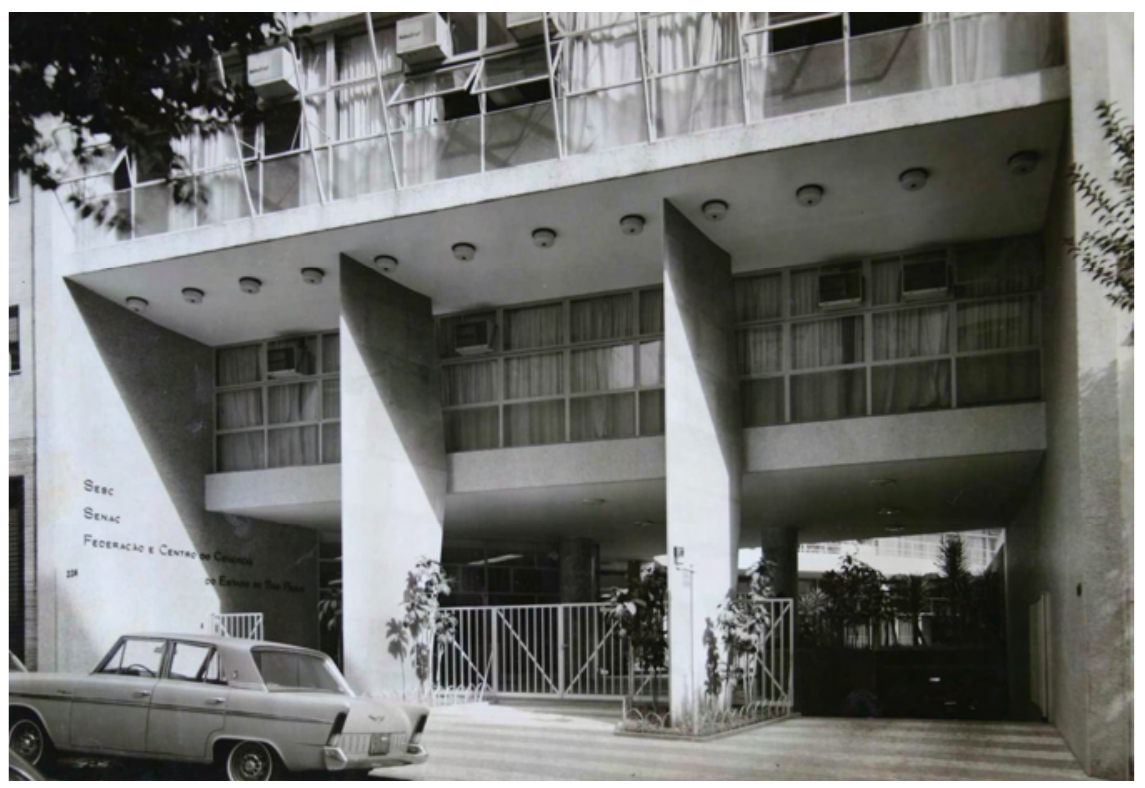

Figura 11: Vista da fachada principal do Edifício Sede. Fonte: Arquivo FAUS

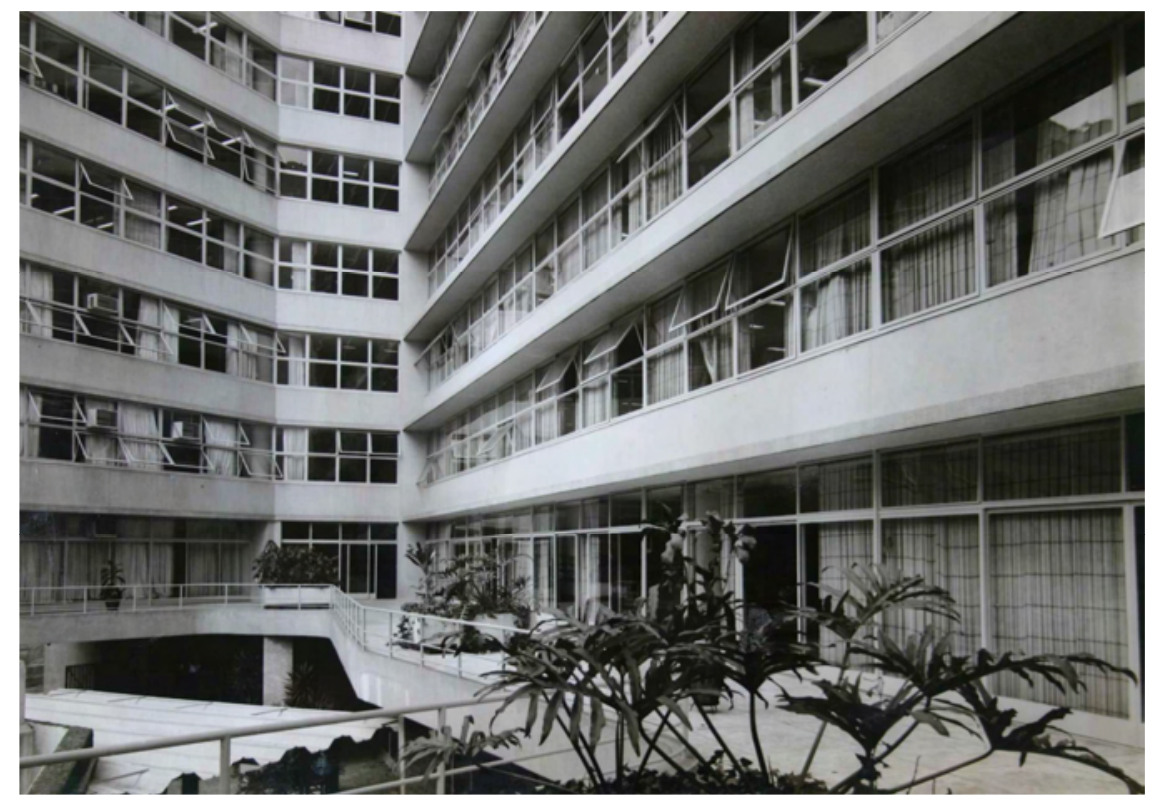

Figura 12: Vista do pátio interno do Edifício Sede. Fonte: Arquivo FAUS 
Edifício Sede, também conhecido como Edifício Visconde de Cayru, atualmente abriga somente o SENAC-SP, pois na década de 70 a Federação do Comércio e o SESC-SP mudaram-se para edifício adquirido na Avenida Paulista.

No Edifício Sede, grandes pilares marcaram a entrada principal de um projeto em altura, monumental, articulado internamente por um pátio interno à altura da escala humana.

Figuras 13: Fachada principal do Edifício Sede, rua Doutor Vila Nova 228, década de 1960, respectivamente.

Fonte: Arquivo FAUS e arquivo pesquisadora

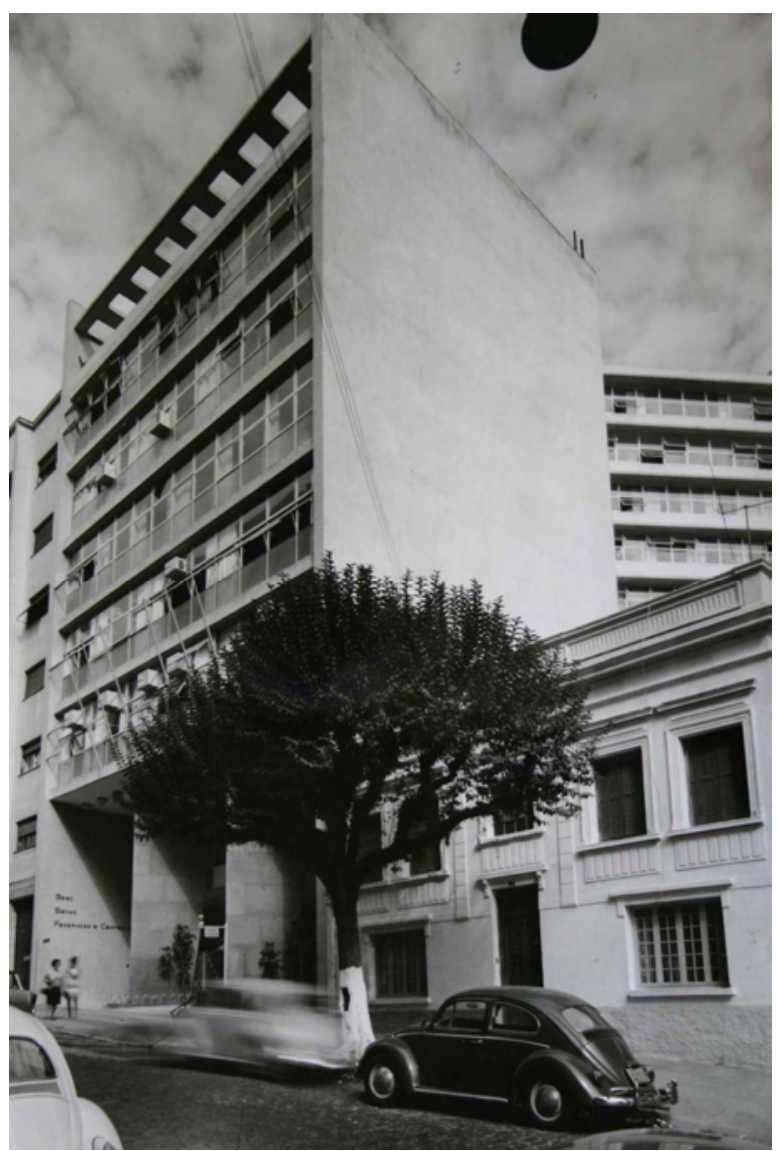




\section{PROJETO 7}

\section{Escola Senac de São José do Rio Preto, 1958}

A Escola SENAC de São José do Rio Preto' foi projetada, em 1958 pelo arquiteto Oswaldo Corrêa Gonçalves e implantada num terreno de $2.603,35 \mathrm{~m}^{2}$ numa quadra localizada entre as ruas Cândido Carneiro, Jorge Tibiriçá, Minas Gerais e avenida do Estradão. $O$ projeto original contava com $1.610,77 \mathrm{~m}^{2}$ de área construída, além do recreio coberto com $389,38 \mathrm{~m}^{2}$. O projeto, implantado ao longo da rua Jorge Tibiriçá, teve sua fachada principal voltada para a face nordeste.

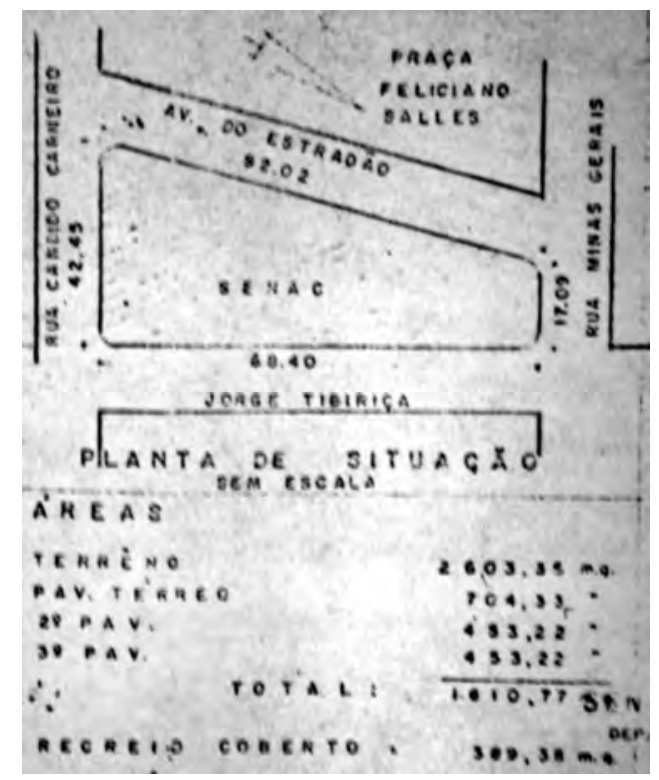

Figura 1: Observar a planta de situação e o quadro de áreas do selo do projeto de prefeitura da Escola Senac de São José do Rio Preto, aprovado em 1958, com autoria de Oswaldo Corrêa Gonçalves. Fonte: Foto Ferraz, arquivo FAUS

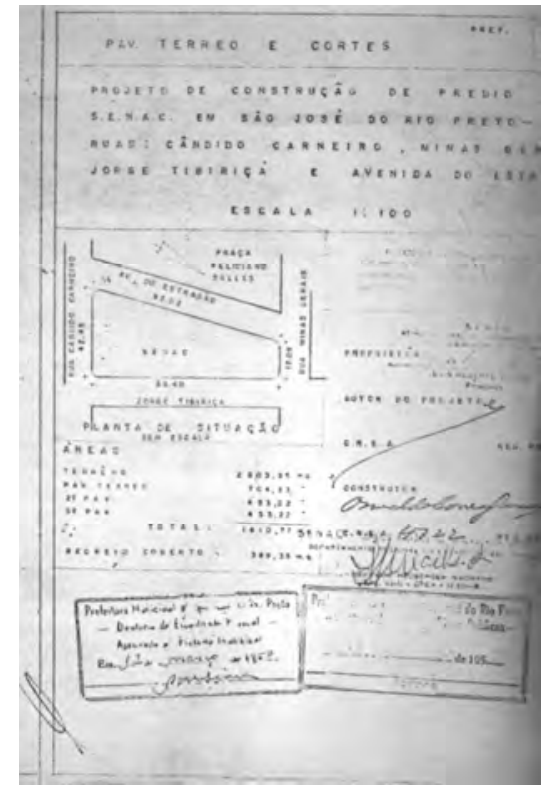

Figura 2: Observar o selo do projeto de prefeitura da Escola Senac de São José do Rio Preto, aprovado em 1958, assinado por Oswaldo Corrêa Gonçalves. Fonte: Foto Ferraz, arquivo FAUS

${ }^{1}$ A Escola SENAC de São José do Rio Preto foi publicada pela $A B n^{\circ} 7$ (1972: 8891). 
programa construtivo foi dividido em um único bloco, em três pavimentos, com administração e recreio coberto no térreo e salas de aula nos dois superiores. $O$ térreo era composto de hall e entrada, secretaria, arquivo, diretoria, sala dos professores, biblioteca, grêmio, sanitários, circulação e recreio coberto, além do jardim, recreio descoberto e quadra de bola ao cesto e arquibancada. Os dois pavimentos superiores abrigavam, cada um deles, seis salas de aula e sanitários feminino e masculino, totalizando doze salas de aula.

Dados relativos à escola foram obtidos no arquivo da FAUS, como as cópias de todas as pranchas aprovadas do projeto de prefeitura e material iconográfico, revelando fotos da maquete e do próprio edifício construído. De grande importância, foi encontrado o projeto original executivo no arquivo do SENAC-SP, na escala 1:50, composto por oito pranchas. $\bigcirc$ conhecimento do projeto original também foi obtido através da publicação em periódico da época, $A B$ n० 7 (1972: 88-91).

Figura 3: Selo retirado da prancha do projeto executivo, Escola Senac de São José do Rio Preto, 23/04/1958, autoria de Oswaldo Corrêa Gonçalves.

Fonte: $A B n^{\circ} 7$ (1972:90-91)
Figura 4: Prancha do projeto executivo, planta do pavimento térreo da Escola Senac de São José do Rio Preto, 23/04/1958, autoria de Oswaldo Corrêa Gonçalves.

Fonte: Arquivo SENAC-SP
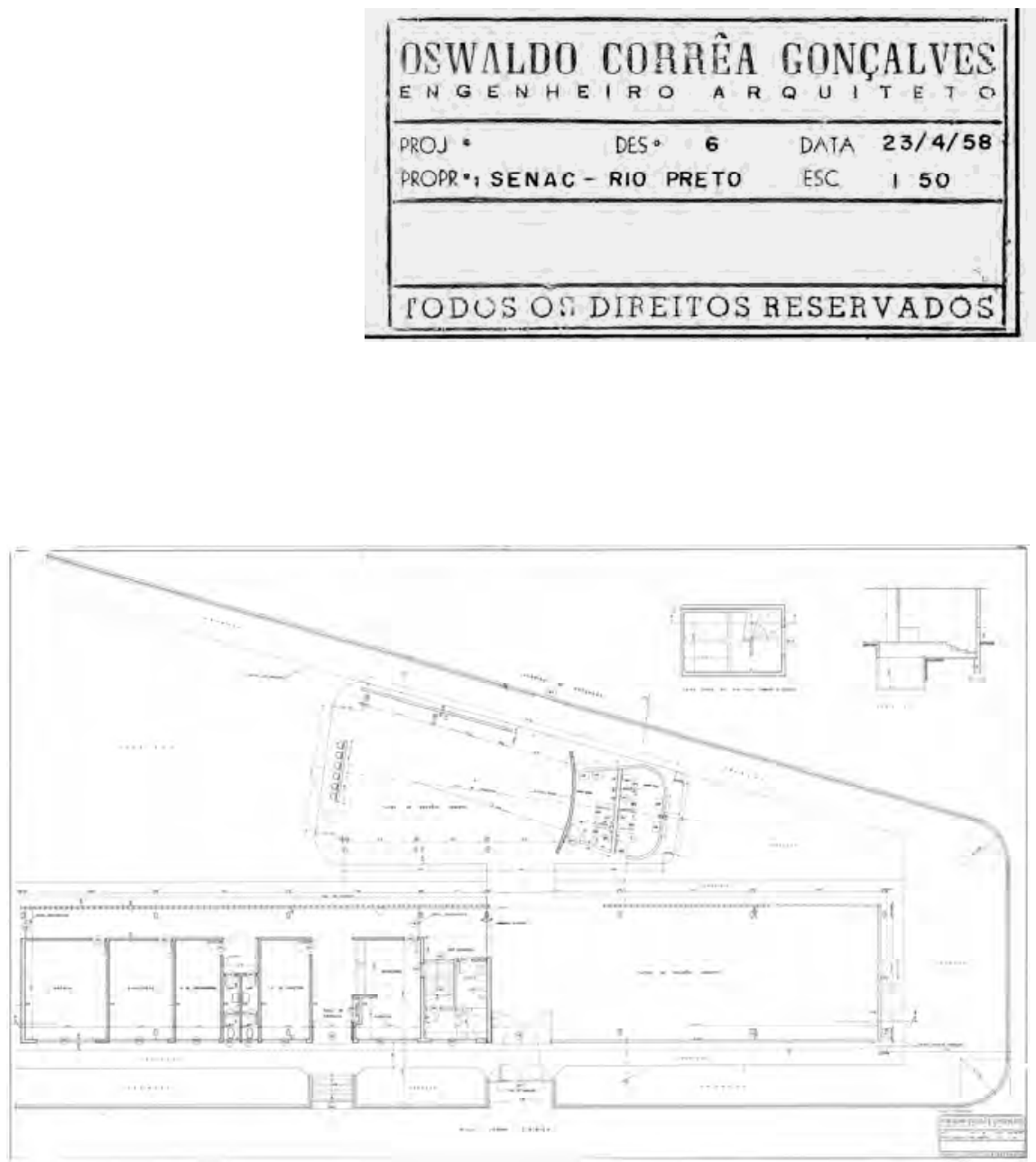


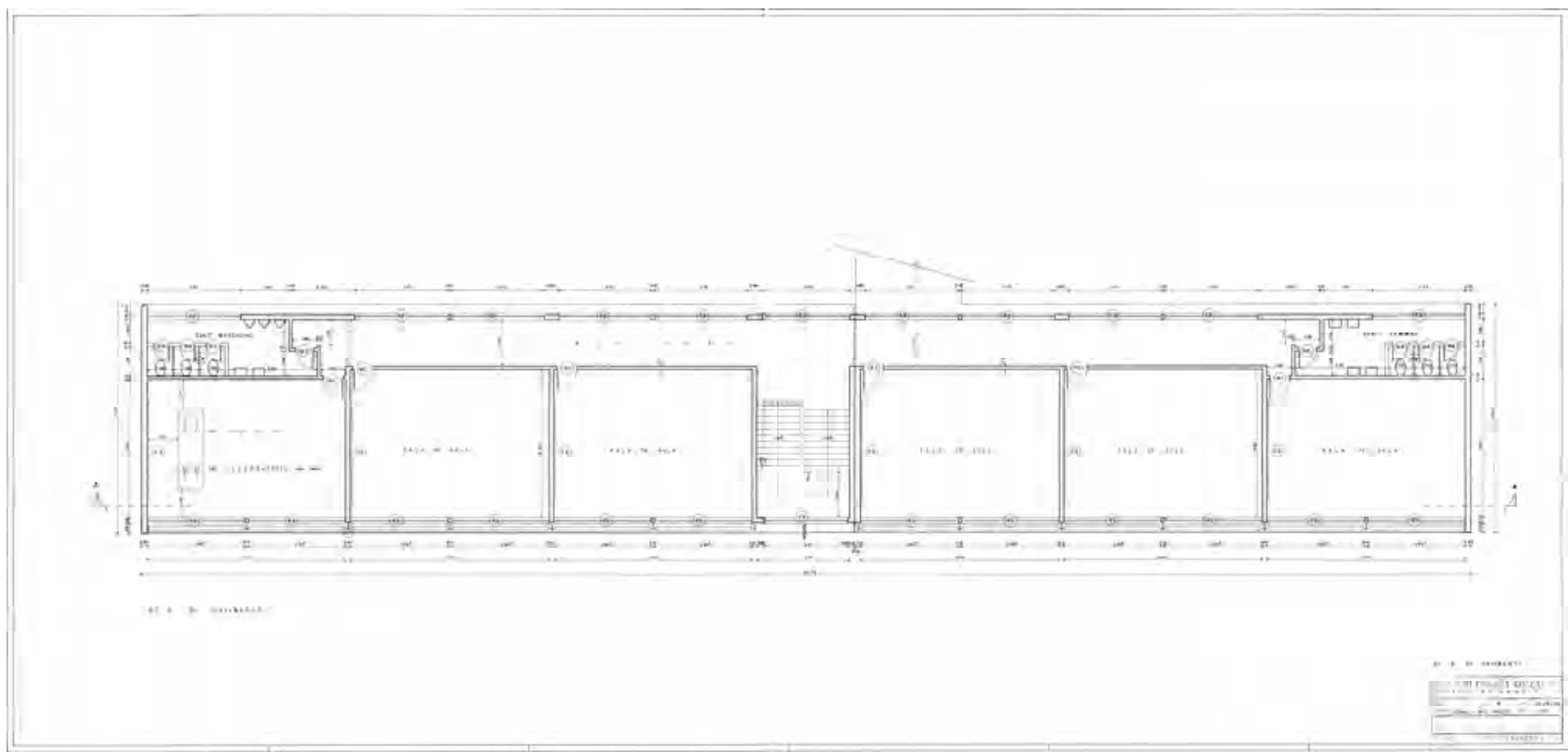

Figura 5: Prancha do projeto executivo, planta dos pavimentos superiores da Escola Senac de São José do Rio Preto, autoria de Oswaldo Corrêa Gonçalves.

Fonte: Arquivo SENAC-SP

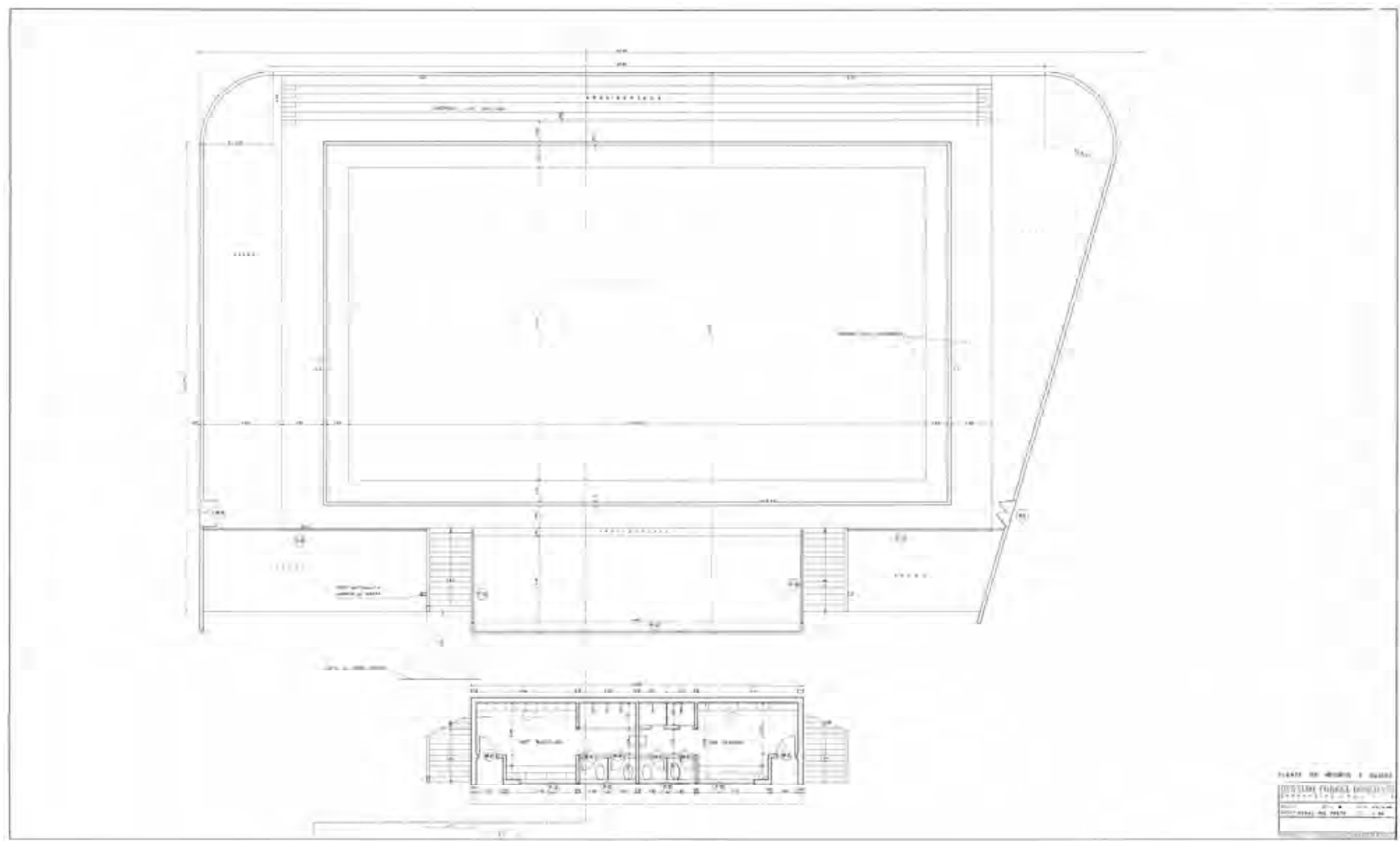

Figura 6: Prancha do projeto executivo, planta da quadra e sanitários da Escola Senac de São José do Rio Preto, autoria de Oswaldo Corrêa Gonçalves. Fonte: Arquivo SENAC-SP 


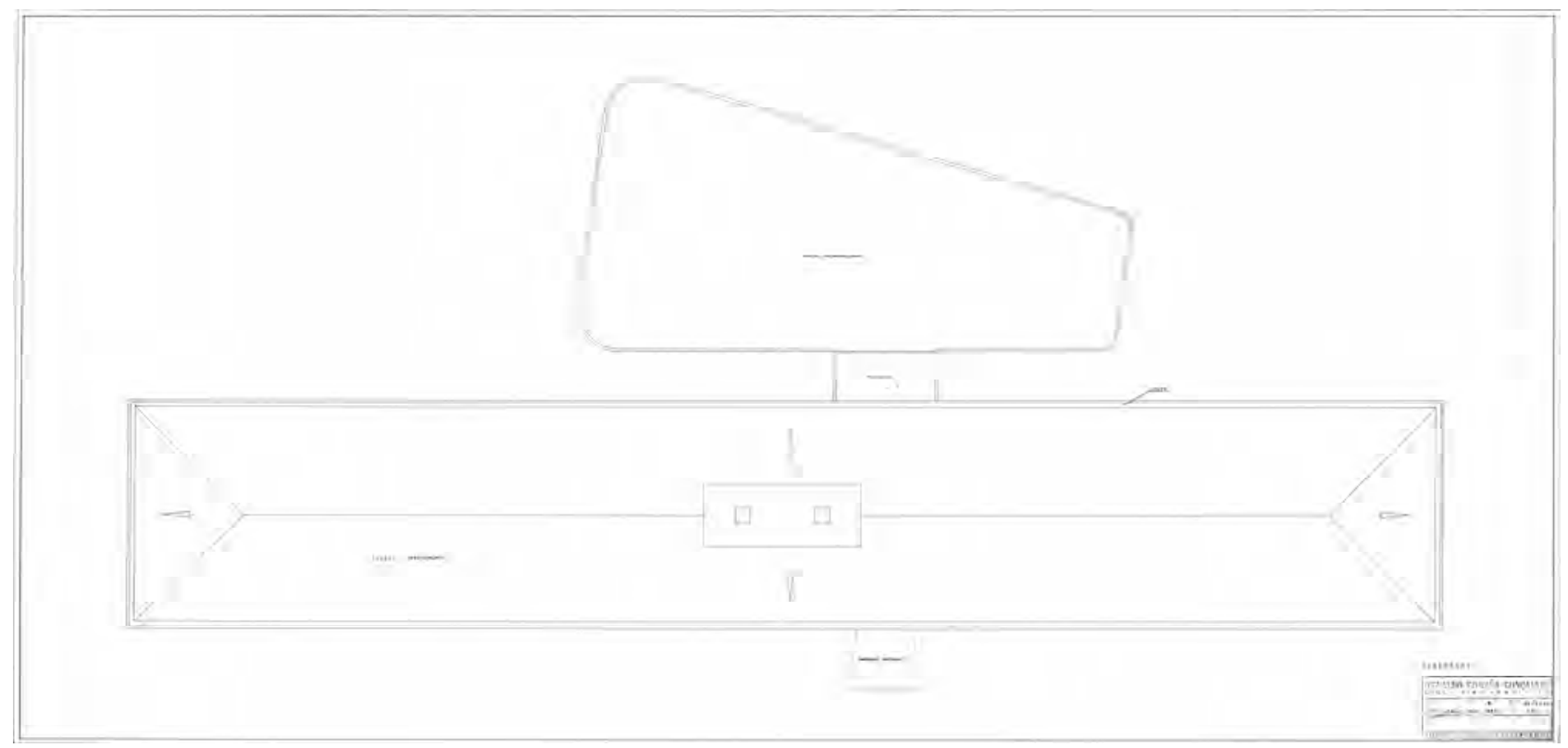

Figura 7: Prancha do projeto executivo, planta de cobertura da Escola Senac de São José do Rio Preto, autoria de Oswaldo Corrêa Gonçalves.

Fonte: Arquivo SENAC-SP

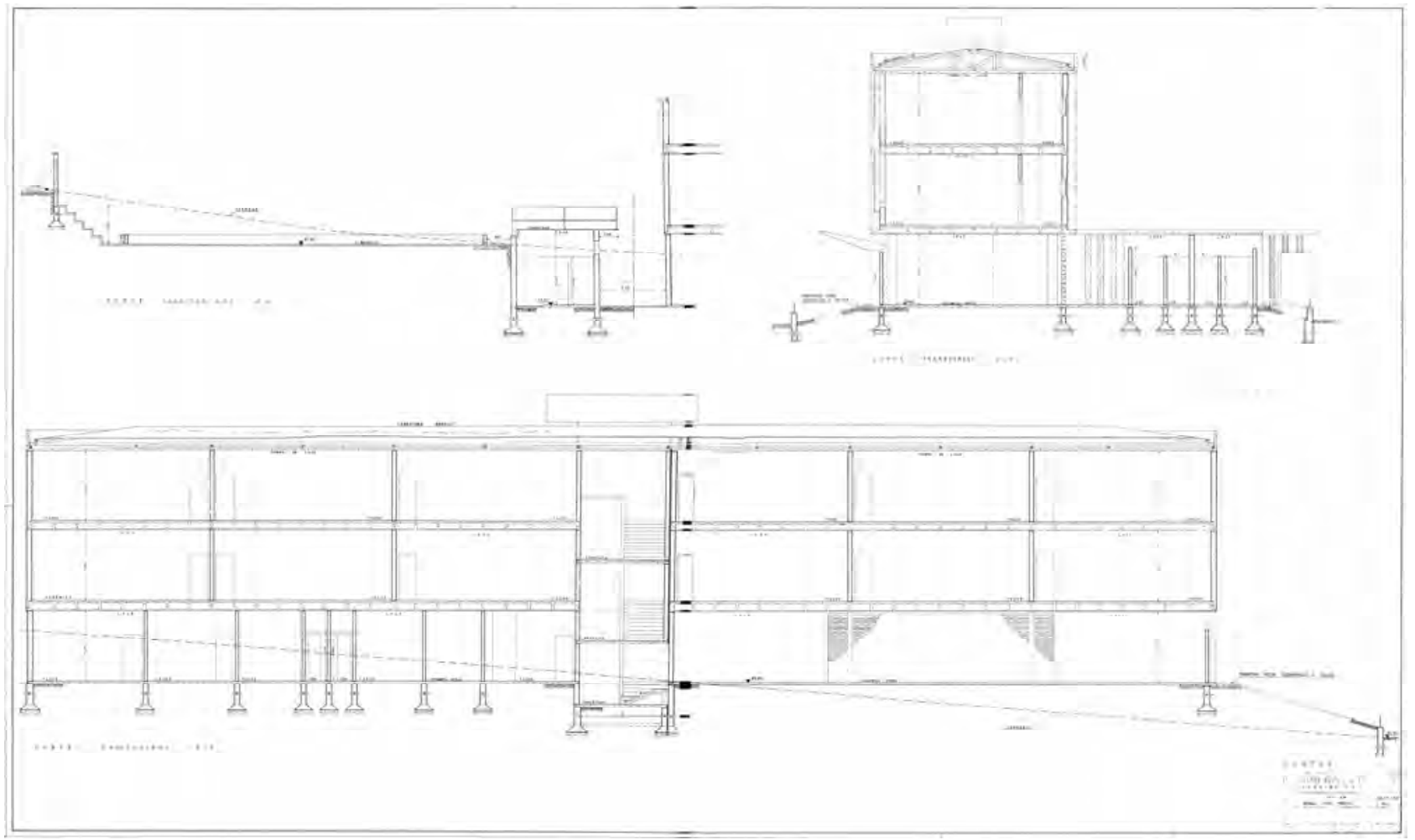

Figura 8: Prancha do projeto executivo, cortes da Escola Senac de São José do Rio Preto, autoria de Oswaldo Corrêa Gonçalves.

Fonte: Arquivo SENAC-SP 


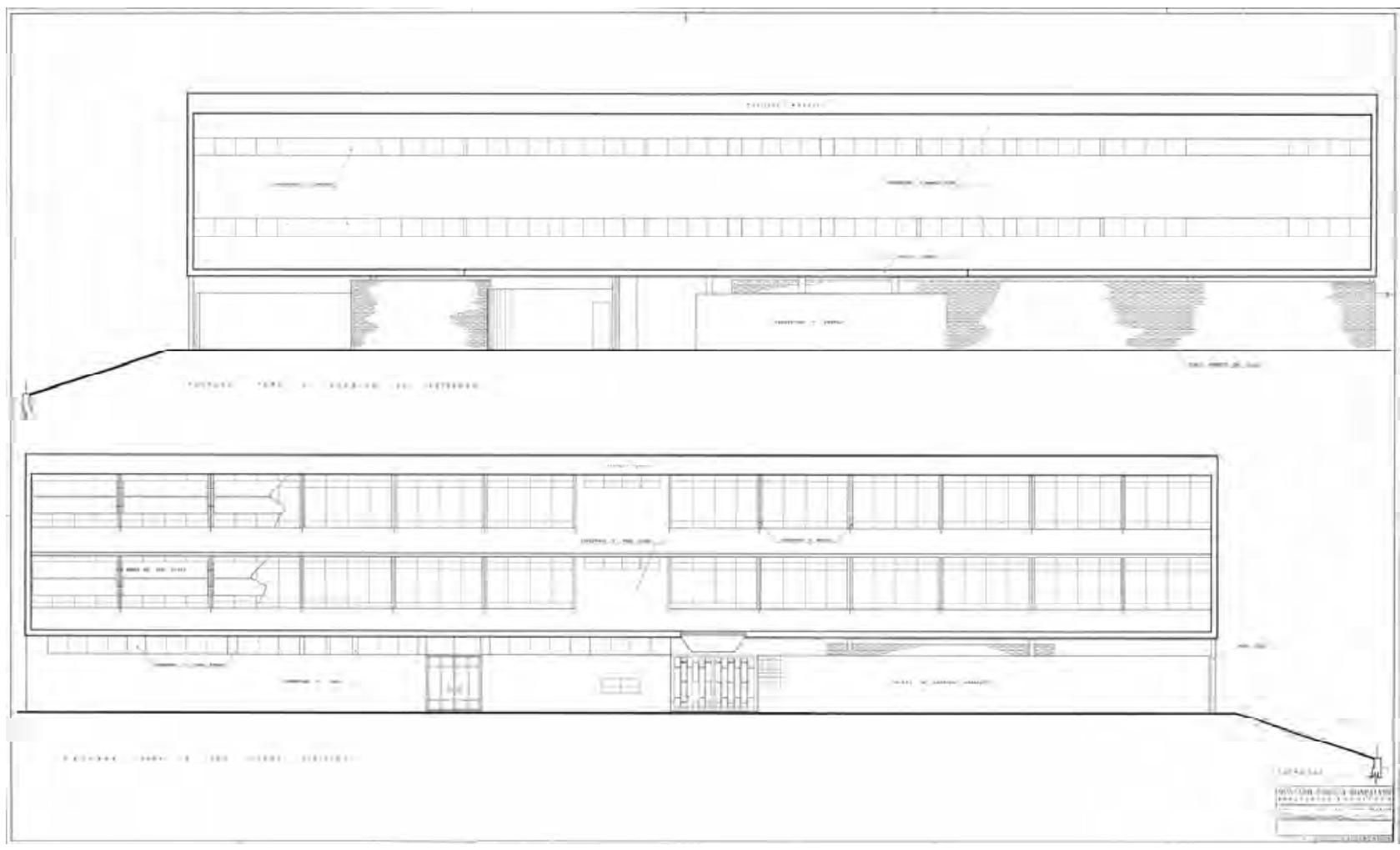

Figura 9: Prancha do projeto executivo, fachadas da Escola Senac de São José do Rio Preto, autoria de Oswaldo Corrêa Gonçalves.

Fonte: Arquivo SENAC-SP

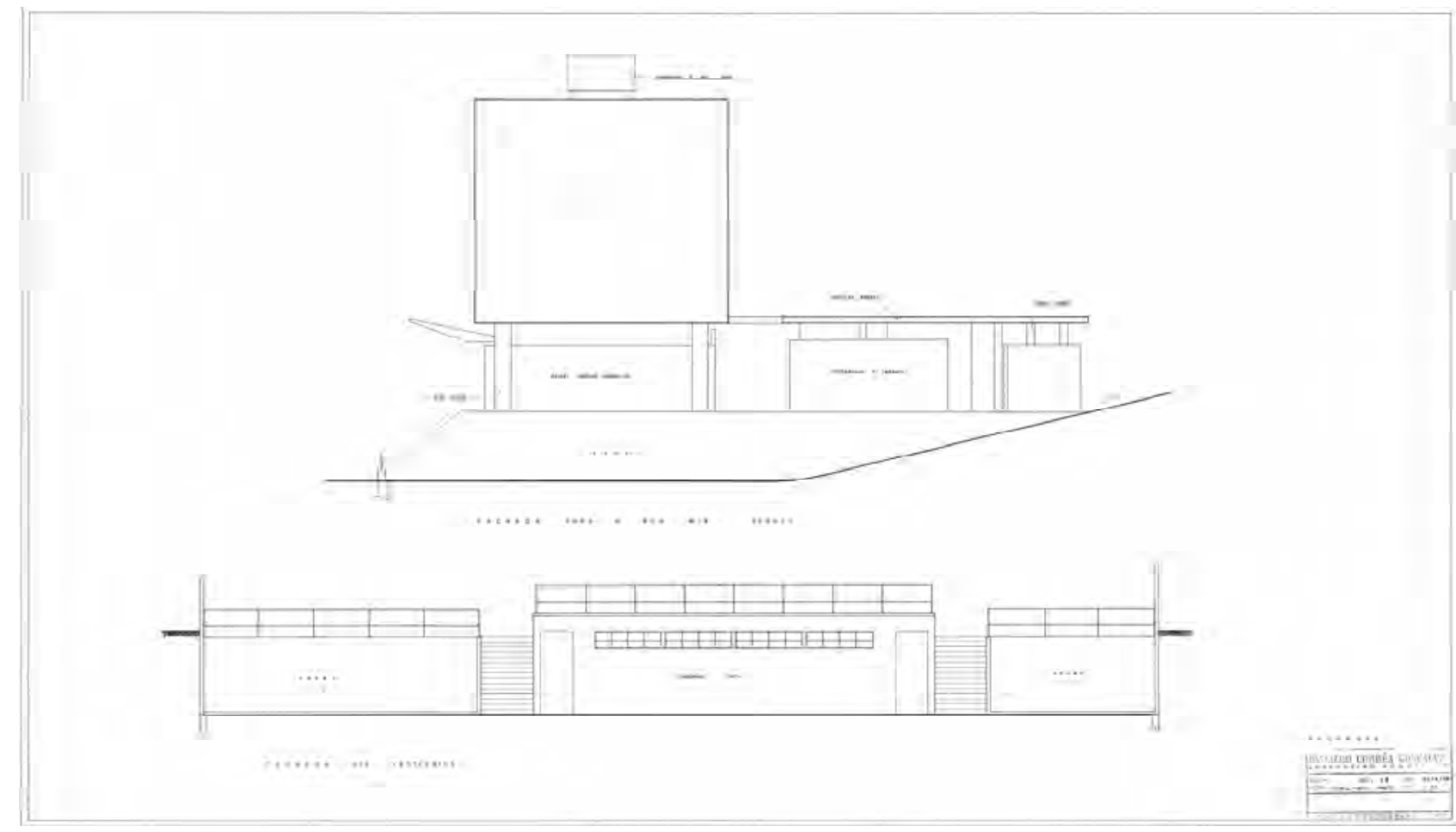

Figura 10: Prancha do projeto executivo, fachadas da Escola Senac de São José do Rio Preto, autoria de Oswaldo Corrêa Gonçalves.

Fonte: Arquivo SENAC-SP 

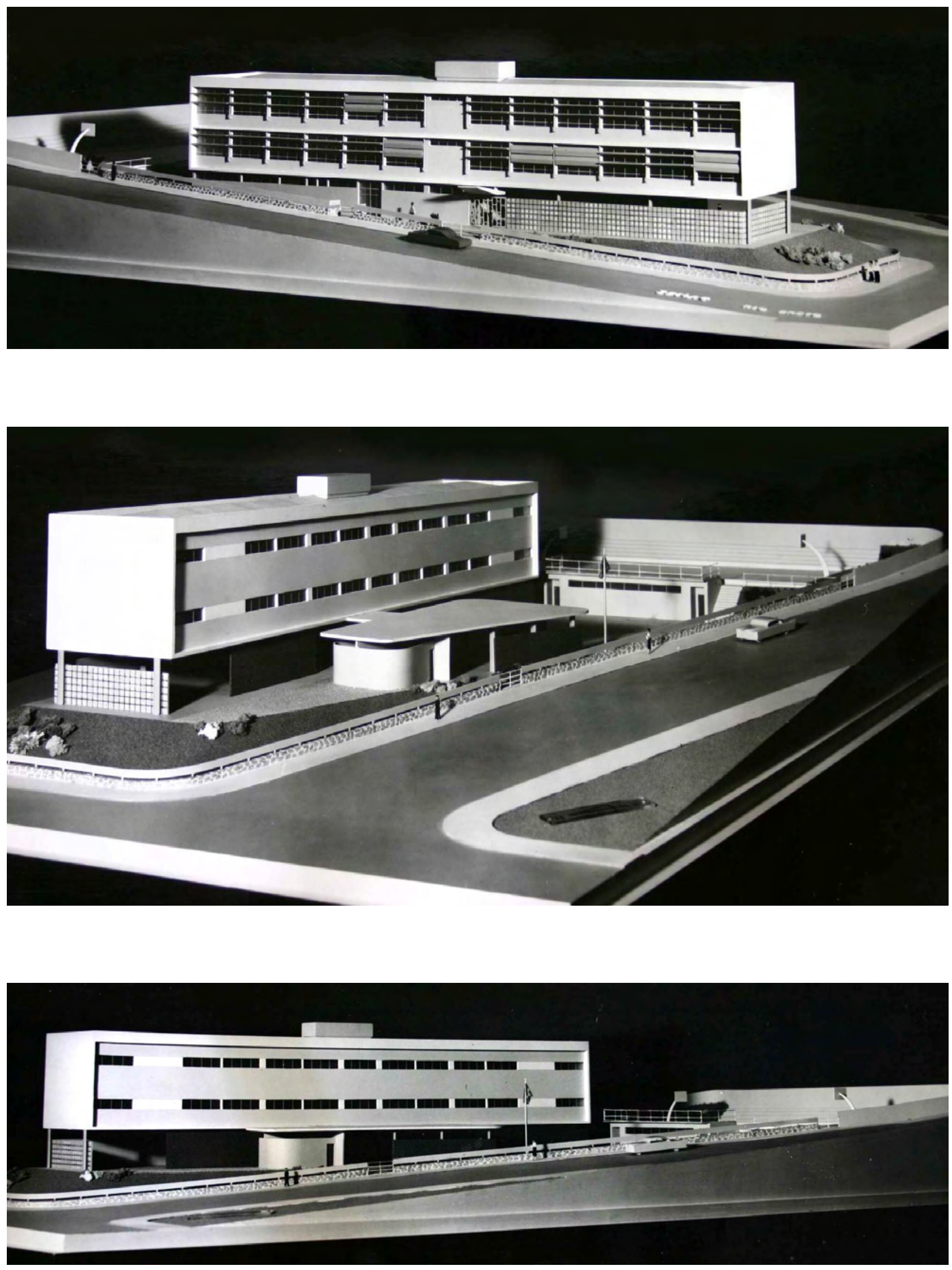

Figuras 11, 12 e 13: Maquete concebida na década de 50, Escola Senac de São José do Rio Preto. Fonte: Foto Ferraz, arquivo FAUS 


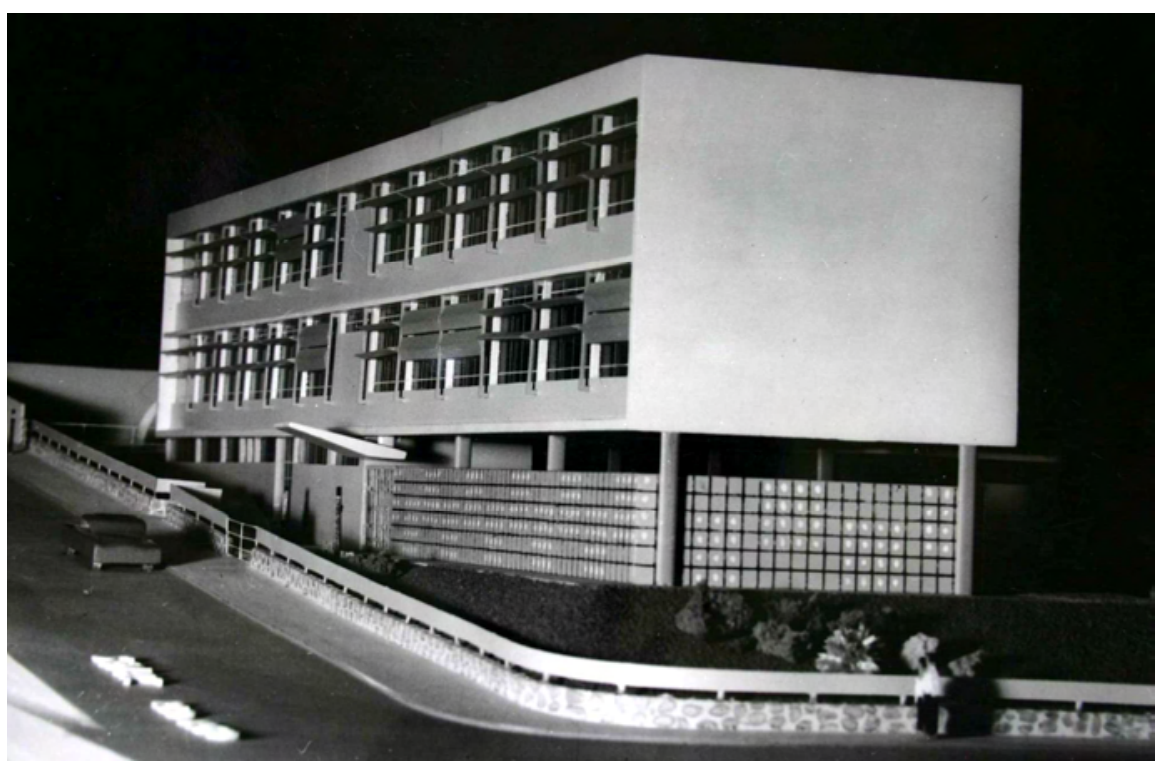

O monobloco do SENAC, implantado ao longo do desnível do terreno, teve seu acesso principal pelo pavimento térreo, na rua Jorge Tibiriçá. Nos três pavimentos projetados foi adotada circulação lateral pela face sudoeste, voltada para o recreio descoberto, sendo que a circulação no térreo foi limitada por tijolos assentados alternadamente e, nos pavimentos superiores por paredes com janelas altas.

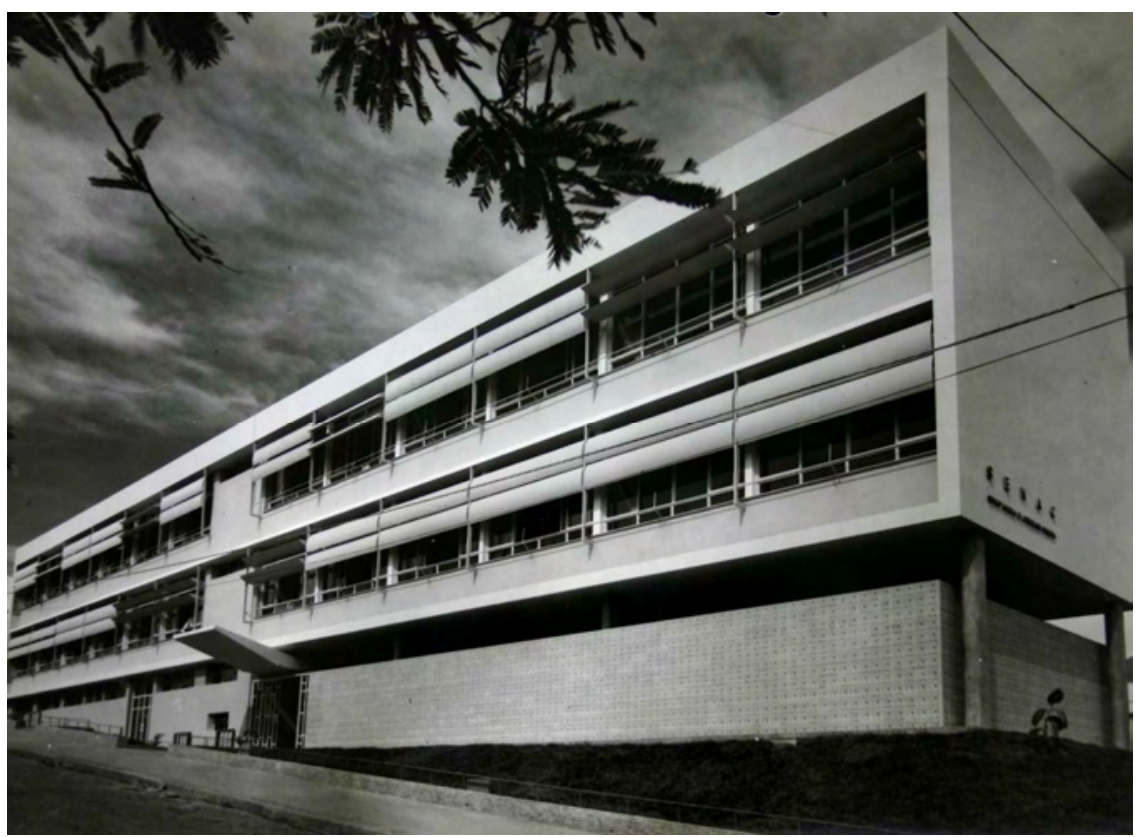

Figura 14: Maquete concebida na década de 50, Escola Senac de São José do Rio Preto. Fonte: Foto Ferraz, arquivo FAUS

Figura 15: Escola Senac de São José do Rio Preto, década de 60. Observar marquise de acesso à entrada principal.

Fonte: Foto Moscardi, arquivo FAUS 
Figura 16: Fachada principal da Escola Senac de São José do Rio Preto, face nordeste. Fonte: Foto Moscardi, arquivo FAUS

Figura 17: Circulação lateral do pavimento térreo limitada por tijolos assentados

alternadamente.

Fonte: Foto Moscardi, arquivo FAUS
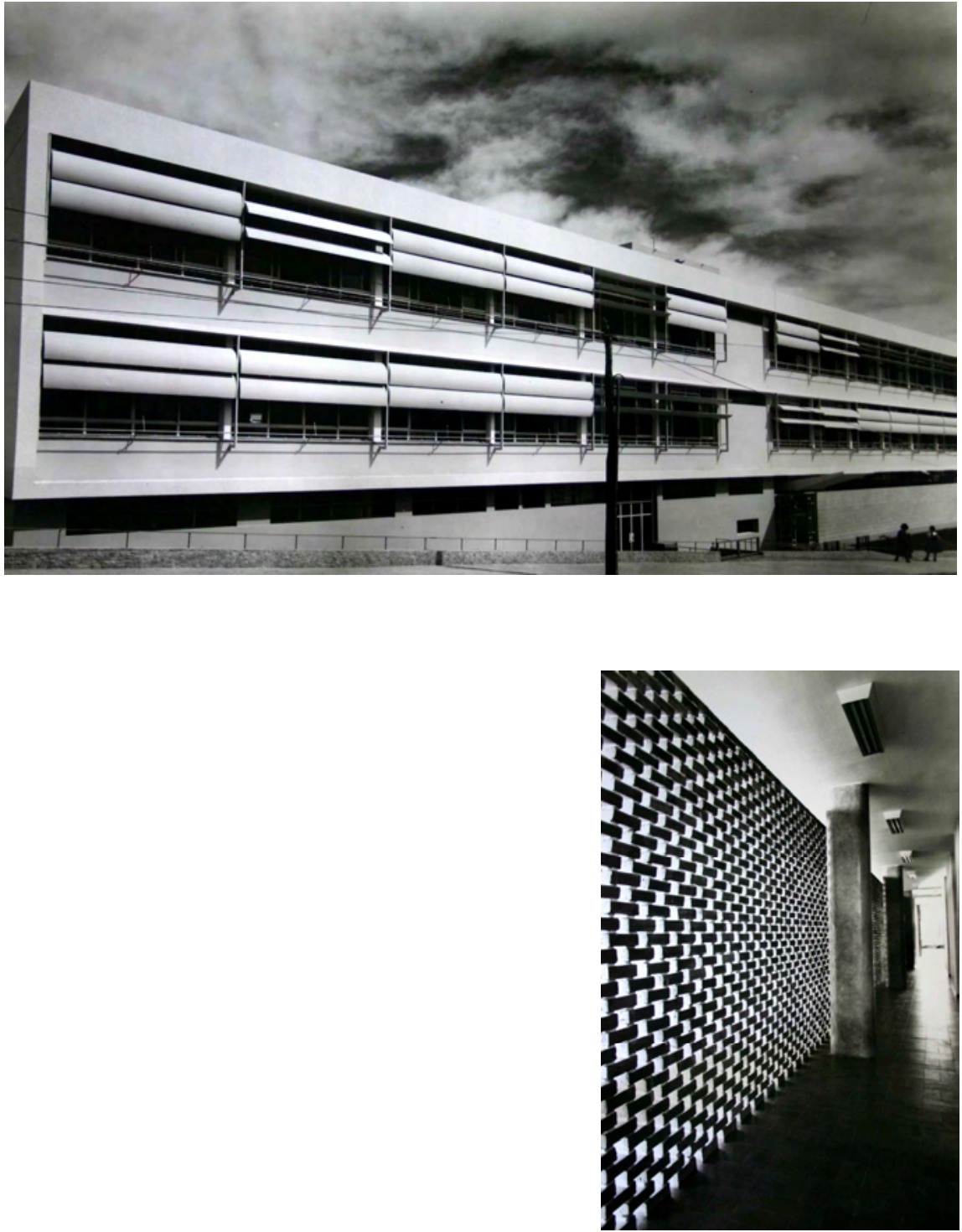

Devido à circulação interna lateral sudoeste, todas as aberturas das salas projetadas foram voltadas para a lateral nordeste, com exceção dos sanitários. Assim, as doze salas de aula, implantadas nos dois pavimentos superiores receberam iluminação e ventilação nordeste, protegidas pelo uso de brises solares horizontais, metálicos e móveis. Além de garantir o conforto térmico nos ambientes de estudo, a presença da ventilação permanente foi prevista nas paredes entre salas e circulação. 


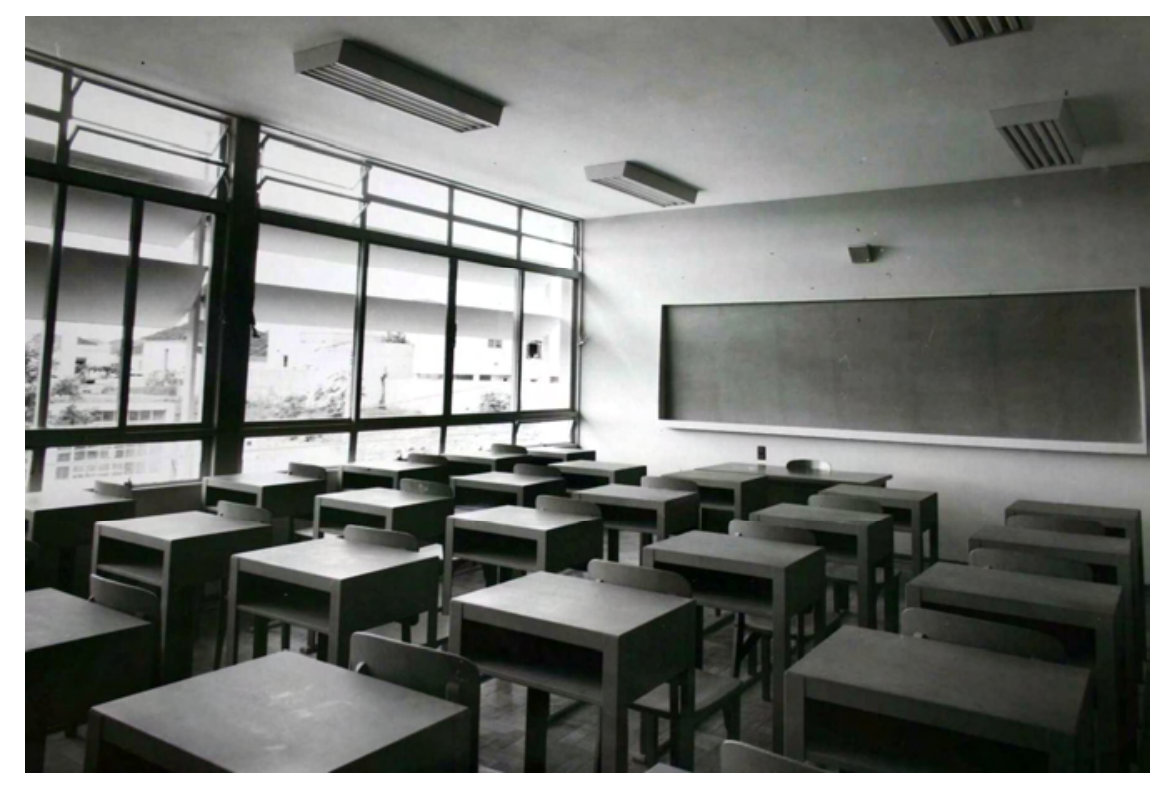

Figura 18: Salas de aula com aberturas voltadas para face sudoeste, Escola Senac de São José do Rio Preto.

Fonte: Foto Moscardi, arquivo FAUS

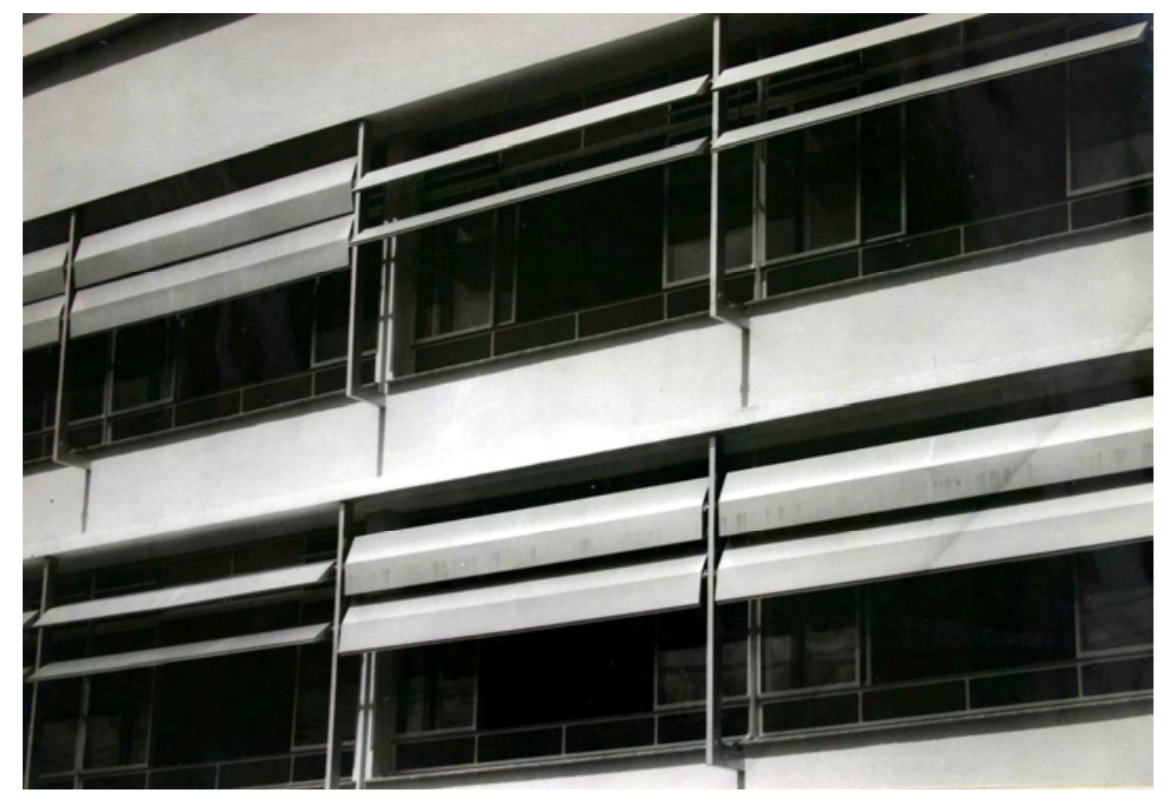

Figura 19: Brises solares, horizontais e móveis, nas aberturas das salas de aula.

Fonte: Foto Moscardi, arquivo FAUS

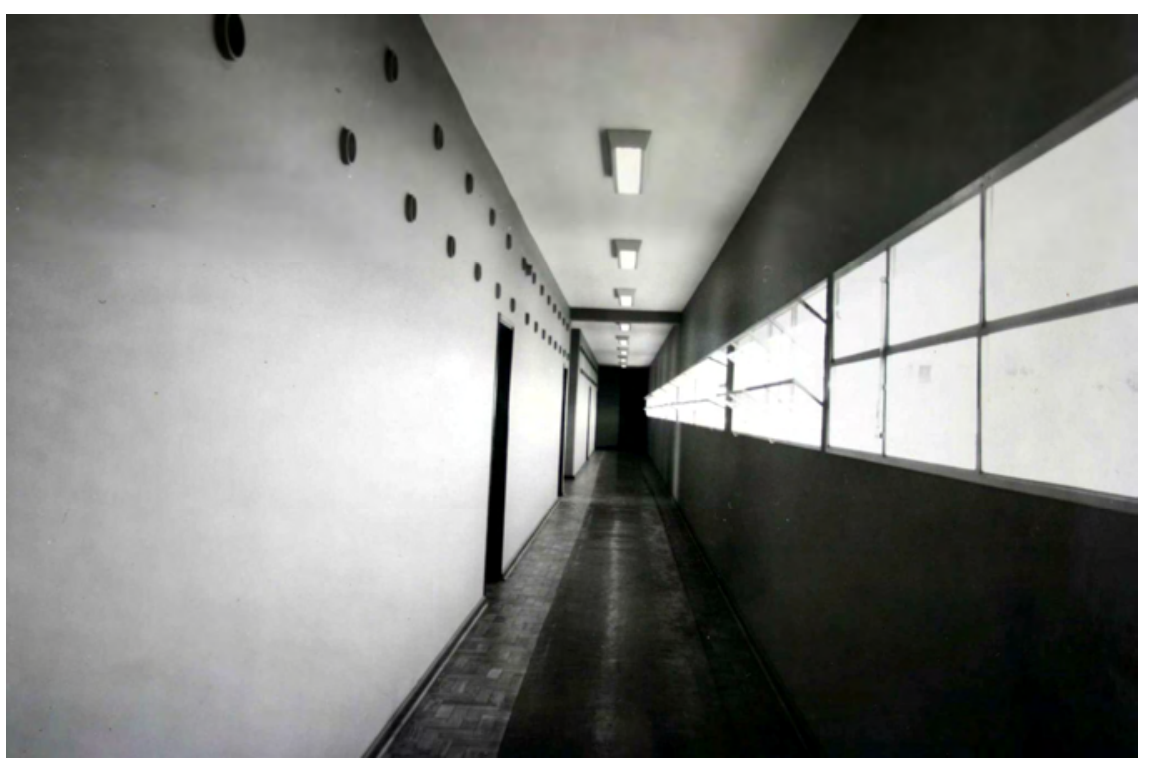

Figura 20: Ventilação permanente na parede entre circulação e salas.

Fonte: Foto Moscardi, arquivo FAUS 
O recreio coberto no pavimento térreo, caracterizado pela planta livre, foi parcialmente fechado por uma parede divisória revestida externamente de ladrilhos hidráulicos, reafirmando o uso de murais artísticos na arquitetura, sob a autoria de Oswaldo de Andrade Filho. A presença da pintura também pode ser observada no mural artístico de Irênio Maia.

Figura 21: Recreio coberto no pavimento térreo, observar dois painéis artísticos: pintura à esquerda da foto e ladrilho hidráulico atrás dos pilares. Fonte: Foto Moscardi, arquivo FAUS

Figura 22: Painel de ladrilho hidráulico na fachada principal como fechamento do recreio coberto, autoria de Oswaldo de Andrade Filho.

Fonte: Foto Moscardi, arquivo FAUS
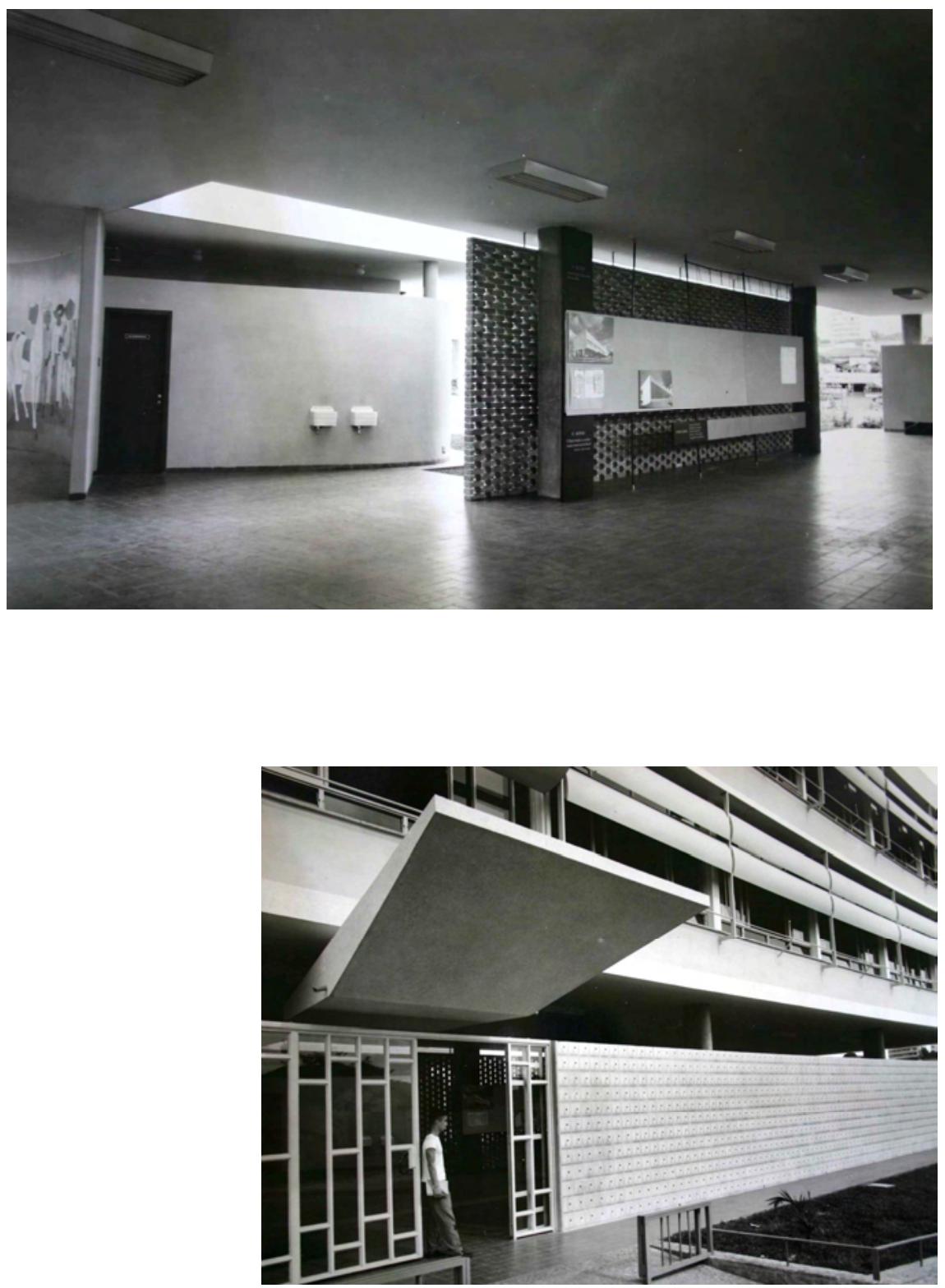


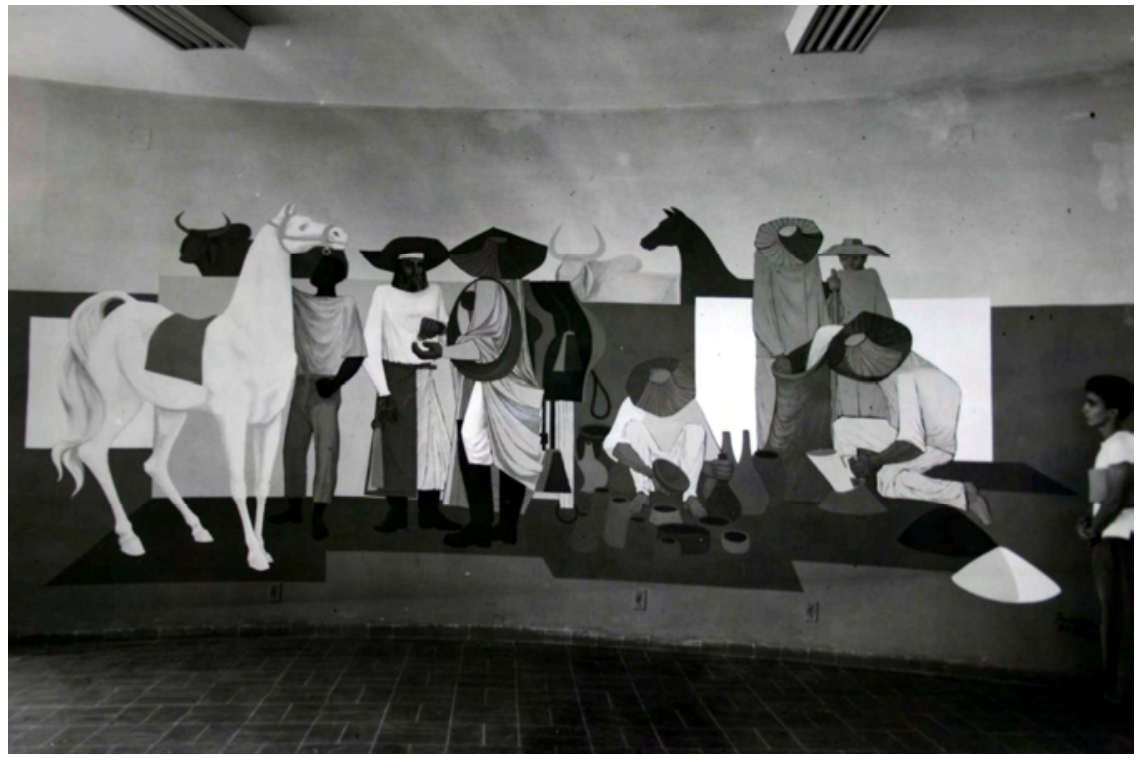

Paralelo às atividades administrativas e pedagógicas, o recreio coberto do monobloco se estendeu a outro recreio coberto, criando um edifício anexo, baixo e sinuoso na fachada sudoeste. Proporcionando uma arquitetura leve ao conjunto, a laje do recreio coberto também abrigava os sanitários masculino e feminino, marcados pelo volume que arrematou com plasticidade a fachada sudoeste. Para complementar o lazer aos alunos, uma quadra de bola ao cesto foi projetada ao longo da rua Cândido Carneiro para atender às atividades esportivas do SENAC.

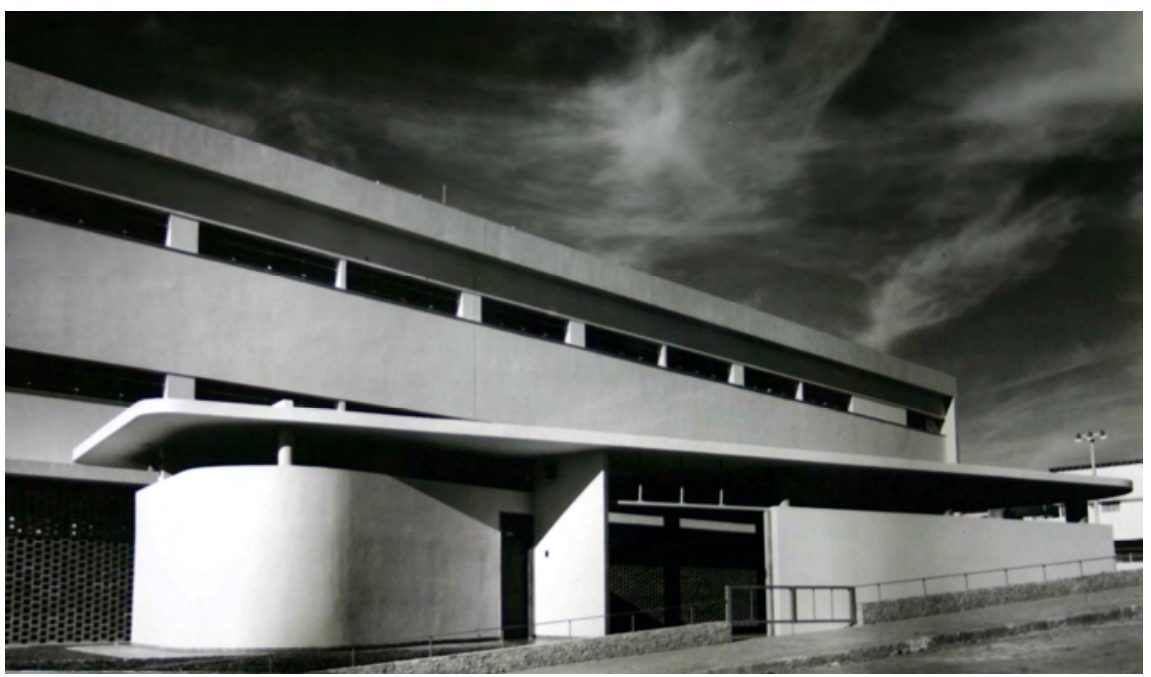

Figura 23: Pintura de Irênio Maia Fonte: Foto Moscardi, arquivo FAUS
Figura 24: Fachada da Escola Senac de São José do Rio Preto, face sudoeste. Observar a laje sinuosa do recreio coberto e sanitários.

Fonte: Foto Moscardi, arquivo FAUS 
Figura 25: Quadra de bola ao cesto projetada da extremidade sudeste do bloco da escola. Fonte: Foto Moscardi, arquivo FAUS
Figuras 26 e 27: Fotos do dia da inauguração da Escola Senac de São José do Rio Preto, 01 de maio de 1960

Fonte: Foto Moscardi, arquivo FAUS

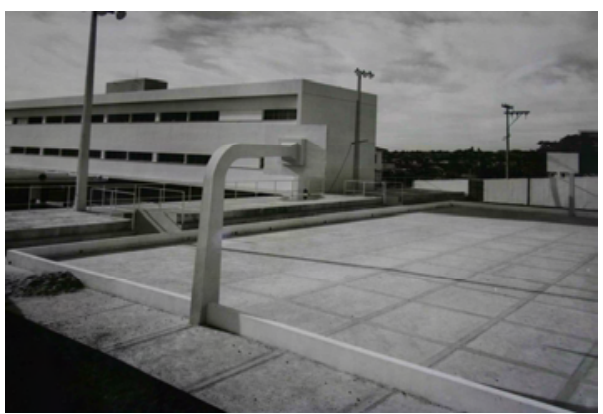

A Escola de SENAC de São José do Rio Preto, também tirando partido da declividade do terreno, assim como o projeto de Marília e a de Araraquara, reuniu em seu projeto a construção de um monobloco e suas dependências de lazer. Seguindo uma estrutura racional e modulada, a Escola predomina a paisagem com sua horizontalidade clara e limpa. Inaugurada em 01 de maio de 1960, sabe-se que esta escola respondeu às preocupações da nova pedagogia SESC-SENAC.
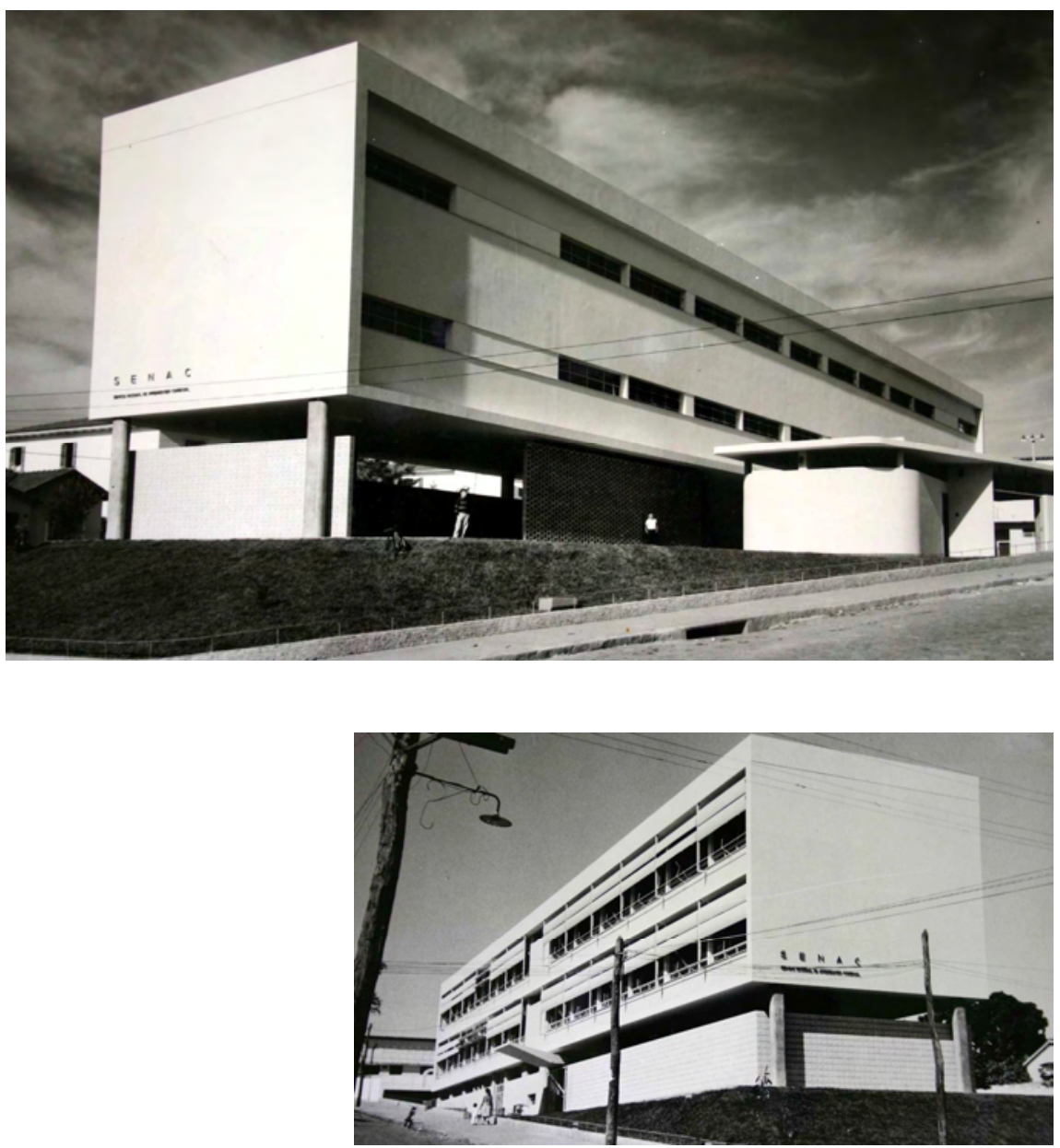


\section{PROJETO 8}

\section{Edifício Avenida Tiradentes,}

\section{Escola Senac João Nunes Júnior, São Paulo, 1963}

O edifício, localizado na Avenida Tiradentes 822, foi construído para abrigar a Escola SENAC João Nunes Júnior, num terreno onde anteriormente havia um edifício em que funcionava a Escola Técnica de Comércio Tiradentes.

O SENAC, com o objetivo de ampliar sua rede de unidades escolares e de melhorar as condições físicas de seus prédios, adquiriu na capital paulista um novo imóvel que, a princípio, funcionaria a Escola SENAC João Nunes Júnior'. O imóvel foi adquirido em 19 de junho de $1961^{2}$ e seu memorial descritivo de reforma foi elaborado pelo engenheiro Frederico de Assis Pacheco Borba, segundo informações obtidas na Memória Institucional do SENAC. Diante do relatório apresentado por Borba, o Conselho Regional em entendimento com os técnicos do Departamento Regional decidiram a demolição do prédio e determinaram a elaboração de um estudo para a construção do novo edifício. $\bigcirc$ primeiro projeto ${ }^{3}$ arquitetônico, em 1963, ficou a cargo do arquiteto Renato Mesquita e do engenheiro José Carlos Campos. Posteriormente, em 1964, foram contratados o desenhista José Martins, para a elaboração de um novo desenho do projeto de arquitetura do edifício, e o engenheiro Henrique Heuberger Machado para realizar os cálculos estruturais. Ainda, em 1966 houve outra alteração no projeto arquitetônico, incluindo mais dois pavimentos ao edifício em construção, sob a responsabilidade do desenhista José Martins. Somente em setembro de 1966 o Conselho Regional deliberou sobre a necessidade de um profissional específico para executar $\mathrm{o}$ projeto de interiores e

1 A Escola SENAC João Nunes Júnior funcionava desde 1947 em instalações provisórias, em prédio alugado. A escolha do novo local para o funcionamento desta escola deu-se pela localização favorável, próxima à Estação da Luz e à Estação Júlio Prestes, que serviam respectivamente às estradas de ferro Santos-Jundiaí e Sorocabana e atendiam diversos bairros e regiões, fazendo ligação do centro com os bairros.

2 Segundo escritura lavrada no livro 894, folha 70, verso no $4^{\circ}$ Tabelião da Capital, registrada em 01 de julho de 1961 sob número 39.277, folha 163 do livro 3-BG da $5^{a}$ Circunscrição de registro de Imóveis da Comarca de São Paulo.

3 Segundo informações obtidas na Memória Institucional do SENAC, o primeiro projeto teve a necessidade de ser alterado por não estar condizente com as novas orientações do ensino e com a metodologia dos novos cursos que seriam implementados neste edifício. 
acabamento desta obra, com o objetivo de dar continuidade à obra dentro das necessidades da Escola SENAC. Sendo assim, foi contratado o arquiteto Jorge Wilheim que propôs o projeto de remanejamento e adequação dos espaços e equipamentos, os detalhes construtivos e decorativos do edifício, assim como a revisão do projeto existente, resultando na elaboração de novas plantas. Portanto, quanto à autoria deste projeto, sabe-se que a proposta final do edifício foi de Jorge Wilheim com colaboração de Miguel Juliano e Silva, porém o projeto arquitetônico original de 1964 é de autoria do desenhista José Martins.

Figura 1: Selo do projeto executivo da Escola Senac João Nunes Júnior,

São Paulo, concebido em 1964, autoria do desenhista José Martins.
Fonte: Arquivo SENAC-SP

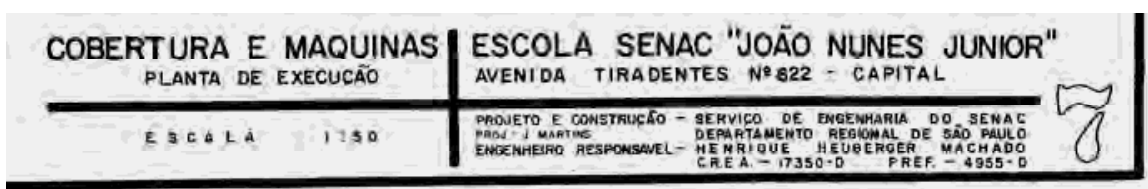

EDIFICIO JOẢO NUNES JUNIOR

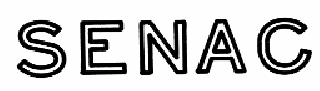

ARQUTETO JORGE WILHEIM* COLABORADOR MIGUEL JULIANO E SILVA

Figura 2: Selo do projeto executivo reformulado da Escola Senac João Nunes Júnior, São Paulo, concebido em 1967, autoria de Jorge Wilheim e colaboração de Miguel Juliano e Silva.

Fonte: Arquivo SENAC-SP

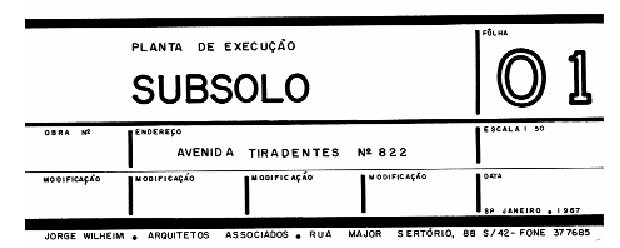

O programa construtivo do novo edifício, proposto por Wilheim e Silva, foi de $6.586 \mathrm{~m}^{2}$ de área construída, composto de sete pavimentos, além do sub-solo, com o objetivo de atender à Escola Senac. Interligados por uma escada e dois elevadores, os pavimentos foram projetados com diferentes divisões e funções. $O$ sub-solo era composto de garagem, cabine primária, almoxarifado, sala de manutenção, depósito, caixa d'água, casa de bombas, ar condicionado e depósito de lixo. O pavimento térreo abrigava a entrada principal, saguão, vitrine e anfiteatro da loja, supermercado pedagógico, portaria, sanitários masculino e feminino, recreio 
coberto, cantina, depósito e auditório para 192 pessoas. $\bigcirc$ primeiro andar era composto de saguão, circulação, sanitários, seis salas de aula, dois almoxarifados, escritório modelo, quatro salas de datilografia e biblioteca. $\bigcirc$ segundo andar abrigava o saguão, circulação, sanitários, salas de aula, curso de manequim, serviço de recrutamento, setor técnico, sala dos professores, setor de colocação e acompanhamento, dentista, sanitários, copa, sala de projeção, secretaria, tesouraria, contadoria, assistência ao diretor, diretoria, setor administrativo, secretaria do diretor e sala do diretor. $\bigcirc$ terceiro andar era composto de saguão, circulação, sanitários, seis salas de aula, depósito, atendente hospitalar, ótica, duas salas de curso ótico prático, sala do curso de vitrinismo, cartazismo e laboratório de línguas. $\bigcirc$ quarto andar abrigava o saguão, circulação, sanitários, quatro salas de aula, sala de médico, duas salas para provação e classificação de café, sala de estética e maquilagem, sala avulsa, sala de manicure, instituto de beleza e dois depósitos. $\bigcirc$ quinto andar era composto de saguão, chapelaria, restaurante, bar, preparo, expedição, copa limpa, copa suja, ante-câmara, duas câmaras frias, sanitários, refeitório, almoxarifado e sala de aula. $O$ sexto andar abrigava o saguão, circulação, sala de aula, refeitório, lavanderia, setor administrativo, ante-sala, sala técnico, diretoria, vestiário e sanitário masculino, sala e sanitário instrutor, almoxarifado, setor operação, sanitários e área reservada.

projeto original executivo, na escala 1:50, foi encontrado no arquivo do SENAC-SP, revelando 14 pranchas e seus respectivos selos, 6 delas do desenhista José Martins e do engenheiro Henrique Heuberger Machado, 8 delas de autoria do arquiteto Jorge Wilheim com colaboração do arquiteto Miguel Juliano e Silva.

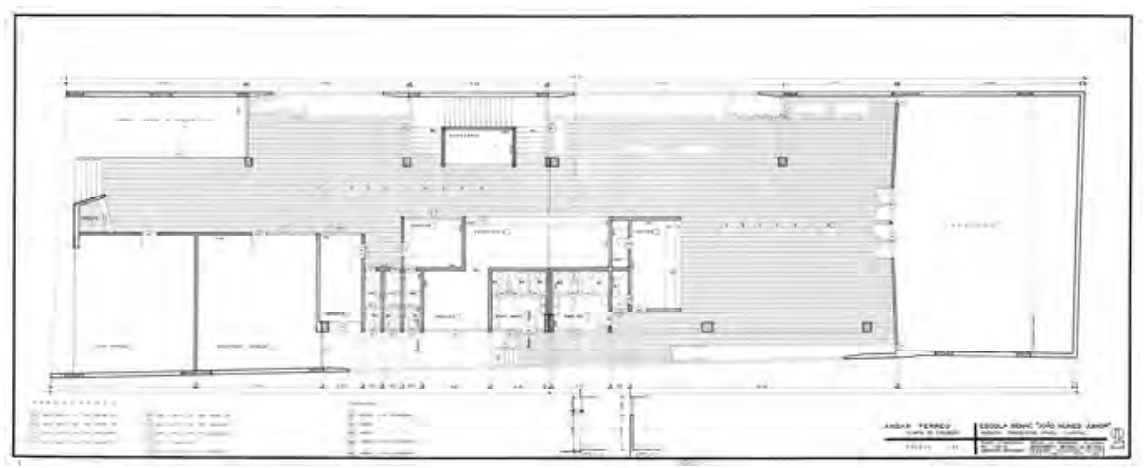

Figura 3: Prancha 2 do projeto executivo da Escola Senac João Nunes Júnior, São Paulo, concebido em 1964, autoria do desenhista José Martins. Fonte: Arquivo SENAC-SP 


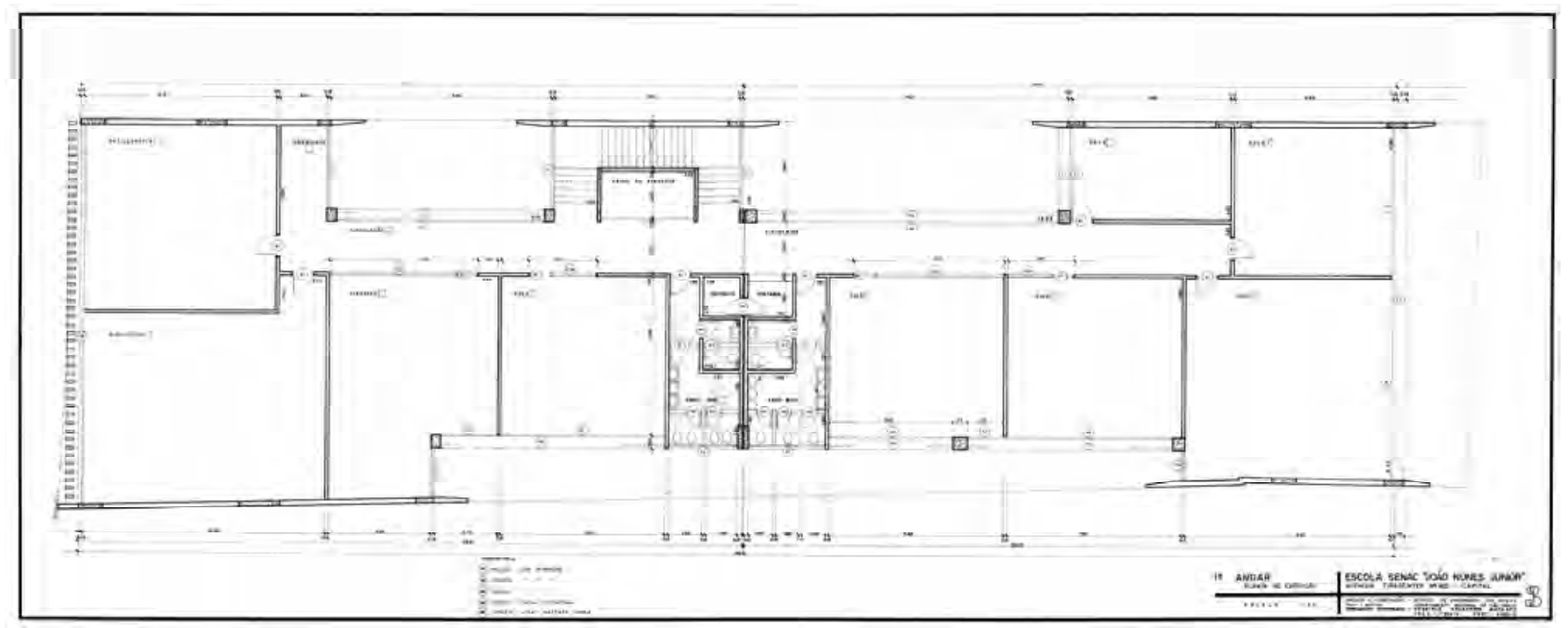

Figura 4: Prancha 3 do projeto executivo da Escola Senac João Nunes Júnior, São Paulo, concebido em 1964, autoria do desenhista José Martins.

Fonte: Arquivo SENAC-SP

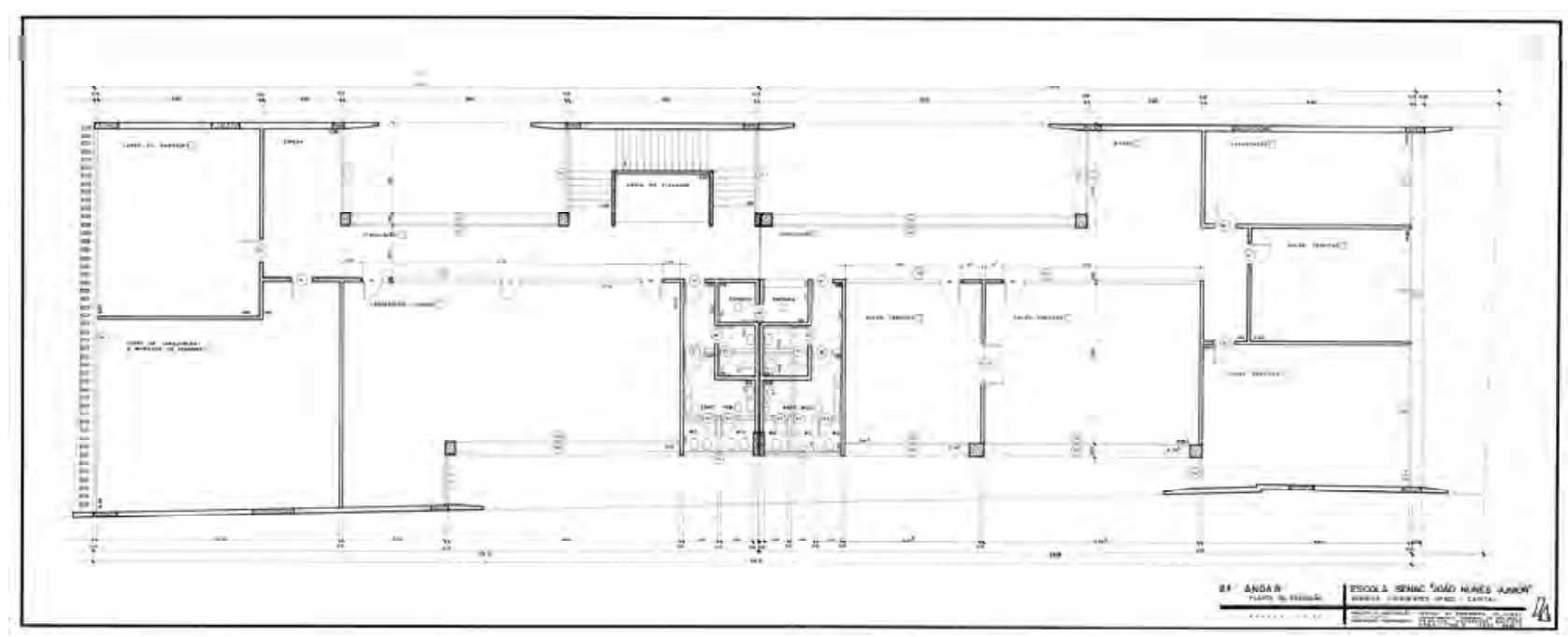

Figura 5: Prancha 4 do projeto executivo da Escola Senac João Nunes Júnior, São Paulo, concebido em 1964, autoria do desenhista José Martins.

Fonte: Arquivo SENAC-SP

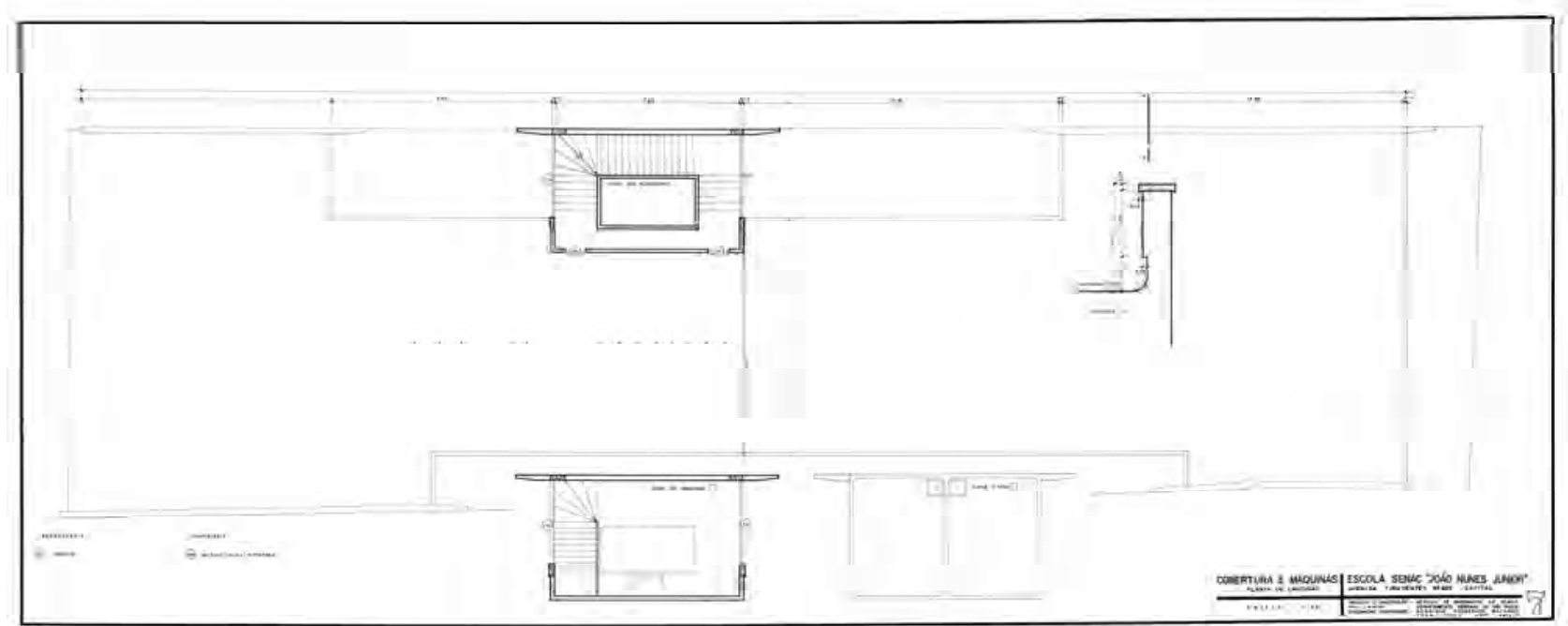

Figura 6: Prancha 7 do projeto executivo da Escola Senac João Nunes Júnior, São Paulo, concebido em 1964, autoria do desenhista José Martins.

Fonte: Arquivo SENAC-SP 


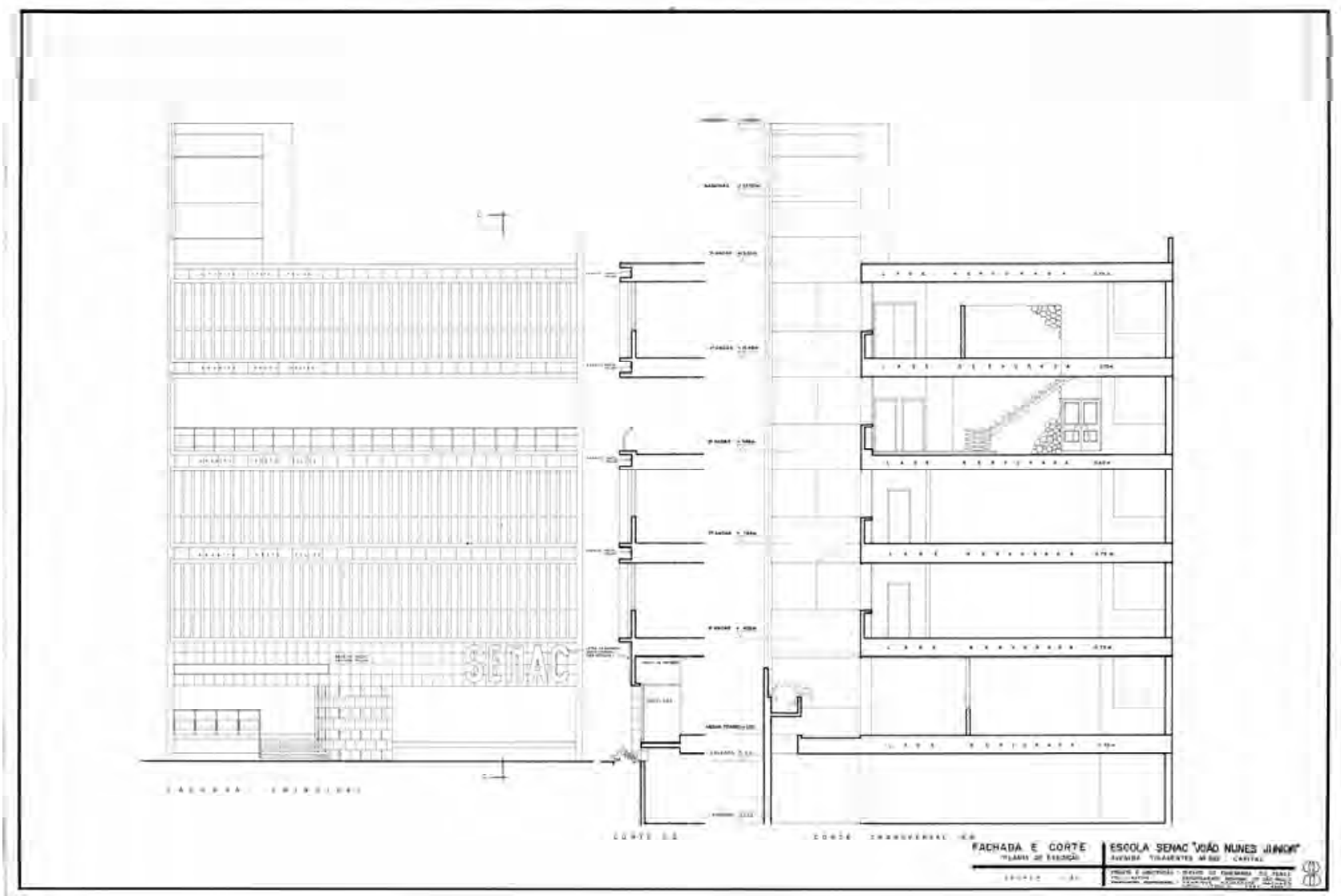

Figura 7: Prancha 8 do projeto executivo da Escola Senac João Nunes Júnior, São Paulo,concebido em 1964, autoria do desenhista José Martins.

Fonte: Arquivo SENAC-SP

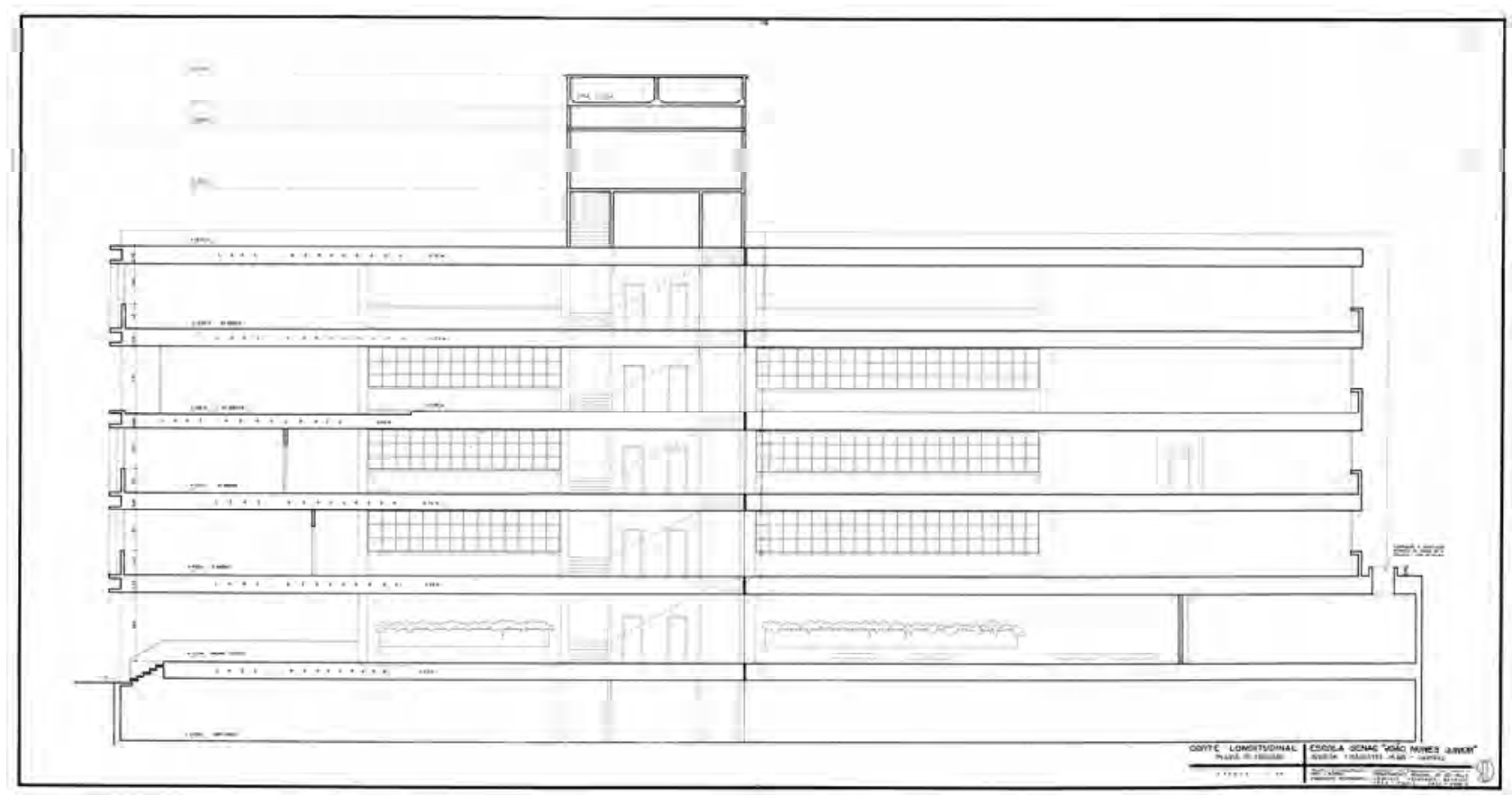

Figura 8: Prancha 9 do projeto executivo da Escola Senac João Nunes Júnior, São Paulo,concebido em 1964, autoria do desenhista José Martins.

Fonte: Arquivo SENAC-SP 

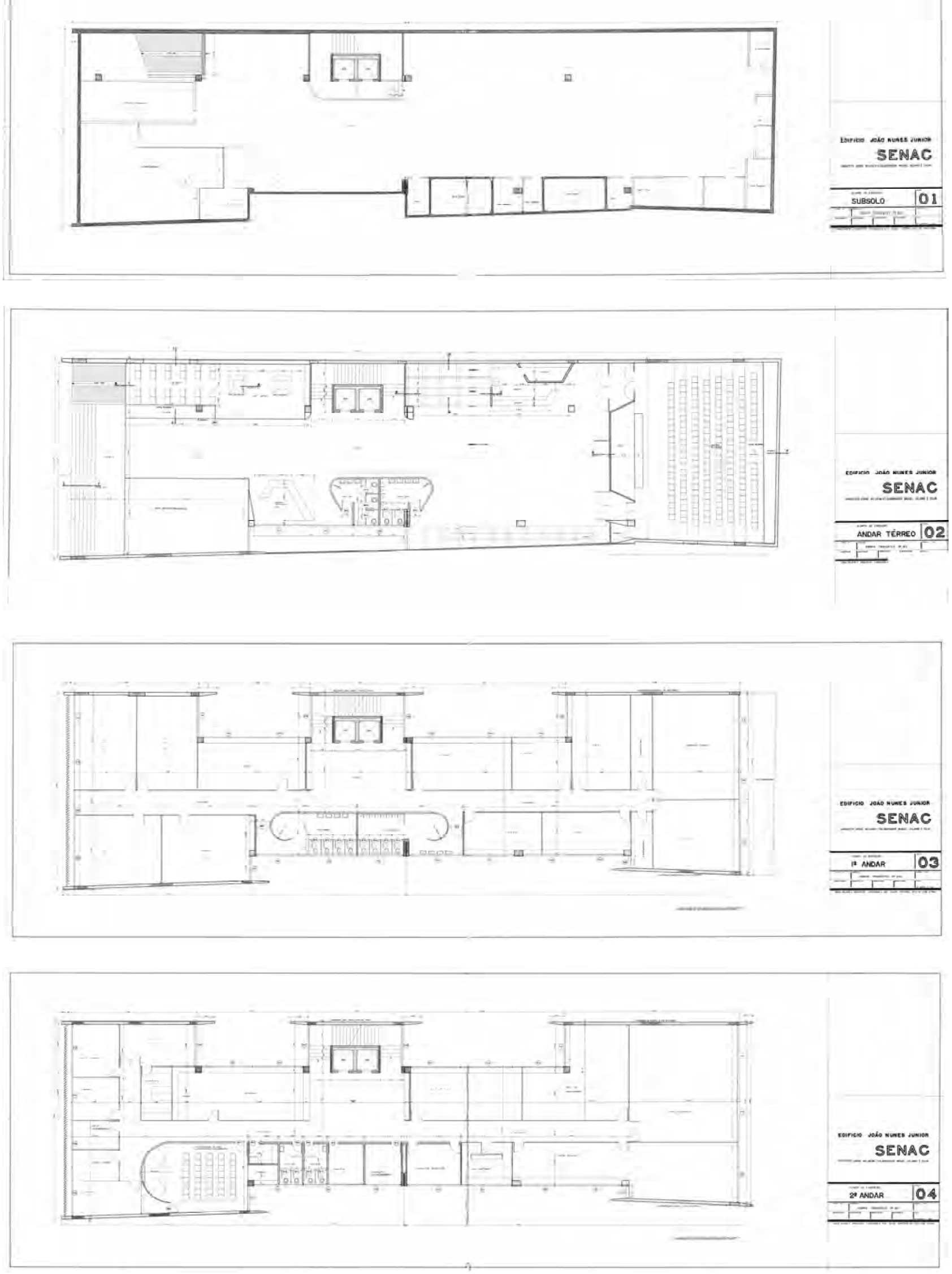

Figuras 9 a 12: Prancha 1, 2, 3 e 4 do projeto executivo da Escola Senac João Nunes Júnior, São Paulo, concebido em 1967, autoria de Jorge Wilheim e colaboração de Miguel Juliano e Silva.

Fonte: Arquivo SENAC-SP 

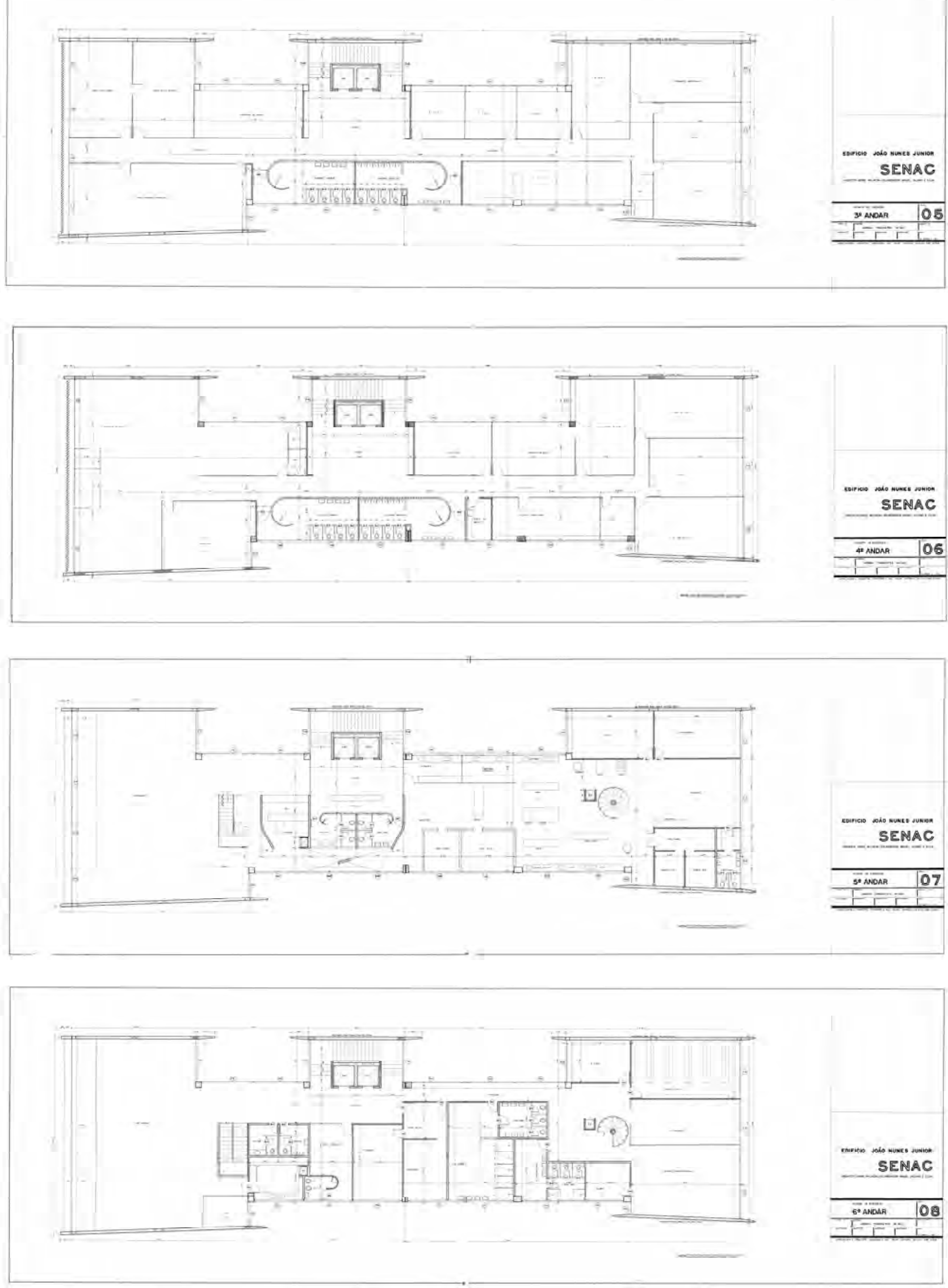

Figuras 13 a 16: Prancha 5,6,7 e 8 do projeto executivo da Escola Senac João Nunes Júnior, São Paulo, concebido em 1967 , autoria de Jorge Wilheim e colaboração de Miguel Juliano e Silva.

Fonte: Arquivo SENAC-SP 
projeto final, com sub-solo e sete pavimentos, foi executado conforme a distribuição interna e acabamentos do projeto de Wilheim. O Edifício recebeu brises verticais voltados para a Avenida, ao longo da fachada de 16,85 metros. O sub-solo, com entrada independente através de rampa de acesso, foi interligado ao demais pavimentos tanto pela escada como pelos dois elevadores projetados. As salas de aula, mesmo projetadas em diversos pavimentos, foram locadas no fundo do edifício, todas com iluminação e ventilação natural bilateral. Com um programa extenso de atividades, o edifício foi construído para formação de diversos cursos como: vitrinismo, manequim, artes fotográficas, farmácia, línguas, ótica, administração, classificação de vegetais, classificação e degustação de café, estética masculina e feminina, enfermagem, turismo, hotelaria, garçon e cozinheiro, conforme ambientes verificados no programa construtivo.

Figura 17: Curso de cabeleireiro feminino, Escola Senac João Nunes Júnior, São Paulo. Fonte: Arquivo SENAC-SP

Figura 18: Curso de degustação de café, Escola Senac João Nunes Júnior, São Paulo. Fonte: Arquivo SENAC-SP
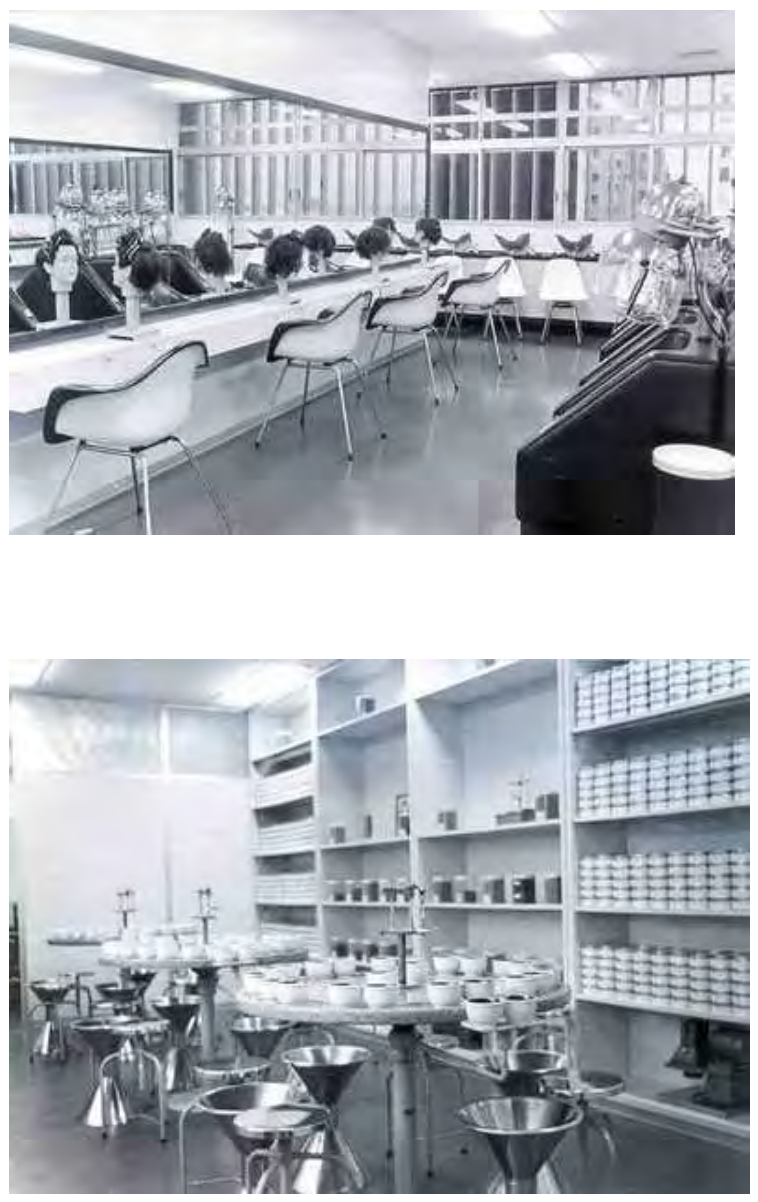

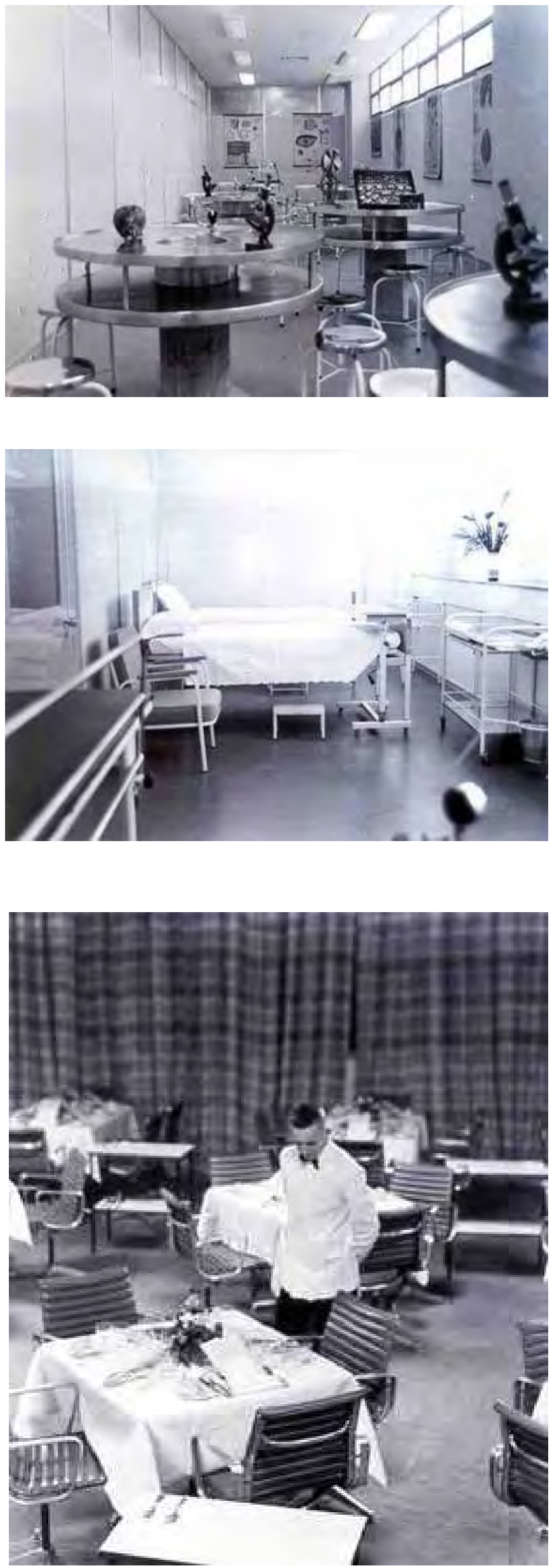

Figura 19: Sala de ótica, Escola Senac João Nunes Júnior, São Paulo. Fonte: Arquivo SENAC-SP

Figura 20: Curso de enfermagem, Escola Senac João Nunes Júnior, São Paulo. Fonte: Arquivo SENAC-SP
Figura 21: Restaurante-Escola, Escola Senac João Nunes Júnior, São Paulo. Fonte: Arquivo SENAC-SP 
Figura 22: Sala de aula, Escola Senac João Nunes Júnior, São Paulo.

Fonte: Arquivo SENAC-SP

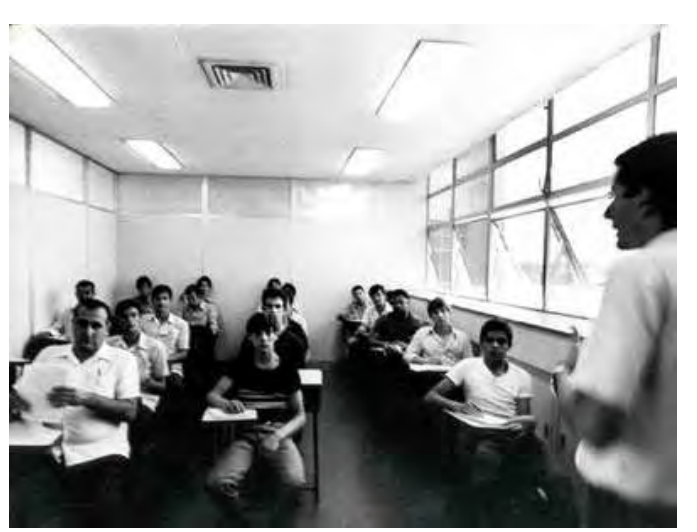

Edifício Senac João Nunes Júnior foi inaugurado no dia 18 de outubro de 1968 e, em 1969, passou a abrigar outras escolas ${ }^{4}$ como: Escola SENAC de Vendas Daniel Machado de Campos, Escola SENAC de Administração Comercial Amin Antônio Calil e Escola SENAC de Artes Comerciais Luiz Gonzaga de Toledo. Outros cursos foram agrupados e, em 1971, originaram escolas específicas, como a Escola de Higiene e Beleza denominada Escola SENAC Edvardo Di Pietro, em 1972, dentre outras. Ainda, em 1973, como conseqüência do termo Escola SENAC para Centro de Formação Profissional, as escolas deste edifício mantiveram seus nomes particulares, sendo o conjunto denominado de Centro de Formação Profissional do Edifício João Nunes Júnior. Em 1978, o edifício assume outra titulação, sendo denominado de Centro de Desenvolvimento Profissional do Edifício João Nunes Júnior e, em 1983 passa a operar como Centro de Desenvolvimento Profissional Ângelo Raphael Lentini ${ }^{5}$. O Edifício passou por várias reformas até chegar ao seu nome atual, Centro de Educação em Saúde 6 , como: na década de 1980 passou por um processo de reforma para abrigar a unidade especializada da saúde ${ }^{7}$; na década de 1990 foi instalado o Núcleo de Comunicação e Informação, construída escada de incêndio e instalado o Laboratório de Radiologia; no início de 2001, outro processo de reforma para adequar o edifício aos novos programas da área de saúde.

\footnotetext{
4 Estas escolas passaram a funcionar neste edifício conforme foi aprovada a Resolução 62/69.

${ }^{5}$ Segundo designação aprovada pela Resolução 44/83.

${ }^{6} \mathrm{O}$ Edifício recebeu a denominação de Centro de Educação em Saúde em 1992.

${ }^{7}$ A unidade especializada SENAC Saúde foi inaugurada em 06 de outubro de 1986.
} 


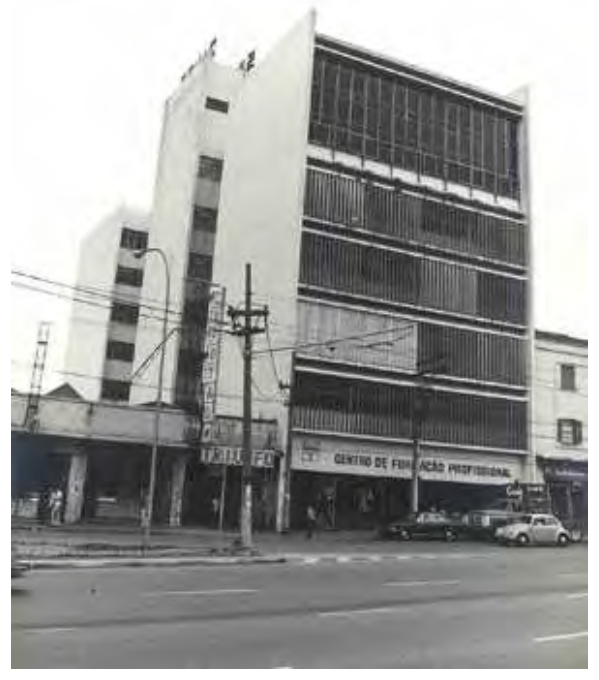

O Centro de Educação em Saúde, antiga Escola Senac João

Nunes Júnior, atualmente está equipado para favorecer a qualidade educacional na área da saúde. Inserido num bairro histórico da cidade de São Paulo, o programa construtivo deste edifício revelou no início uma escola vertical, com extenso programa, mas confinada a um terreno sem áreas para prática de esporte e lazer aberto.
Figura 23: Fachada do Edifício com o nome de Centro de Formação Profissional, São Paulo, 1976 Fonte: Arquivo SENAC-SP

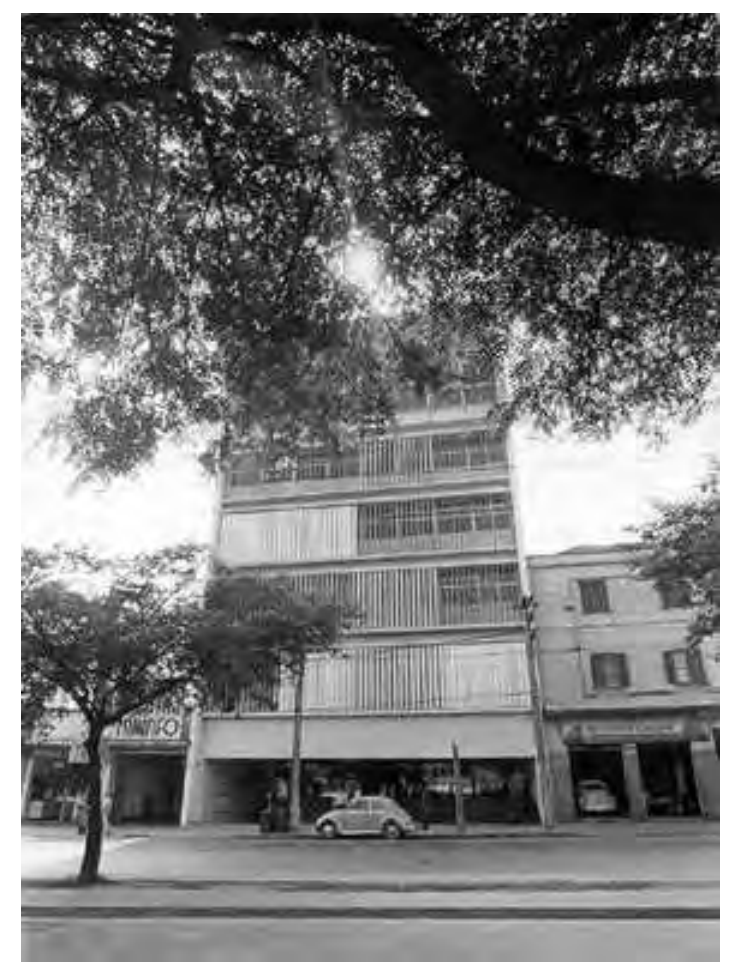

Figuras 24: Fachada principal do Edifício da Avenida Tiradentes 822,1969 Fonte: Arquivo SENAC e arquivo pesquisadora 


\section{PROJETO 9}

\section{Escola Senac de Botucatu, 1964}

A Escola SENAC de Botucatu foi projetada, em 1964, pelo arquiteto Rubens Carneiro Vianna. Implantada num terreno de $4.526,90 \mathrm{~m}^{2}$ e localizada na rua Rafael Sampaio 85, o projeto original contava com cinco blocos, quatro deles paralelos entre si e um perpendicular aos outros quatro, além do bloco dos vestiários e sanitários esportivos.

Figura 1: Planta de situação da Escola Senac de Botucatu, retirada da prancha do "projeto modificativo"

Fonte: Foto Ferraz, arquivo SENAC

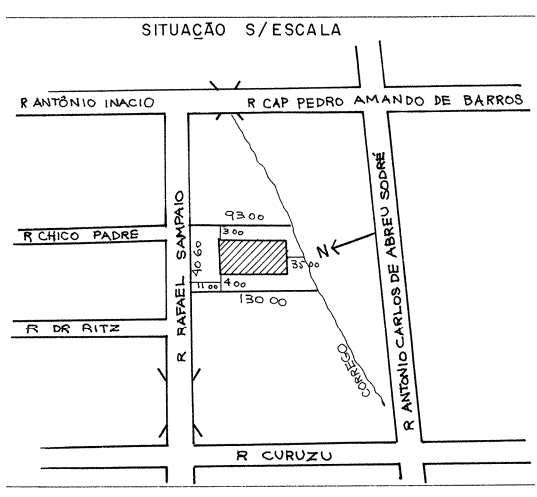

O programa construtivo foi composto de secretaria, diretoria, vice-diretoria, duas salas de orientador, material didático, sala dos professores, biblioteca, grêmio, arquivo morto, sanitários dos alunos, sanitários dos funcionários, cantina, seis salas de aula, escritório modelo, sala de datilografia, laboratório, loja modelo, depósito geral, recreio coberto, recreio descoberto, vestiários e sanitários esportivos, depósito de material esportivo e quadra de jogos.

Os dados relativos à escola foram obtidos no arquivo do SENAC-SP, como quatro pranchas do projeto executivo de 1964, revelando plantas, elevações e a autoria de Rubens Carneiro Vianna e, prancha única do projeto completo de ampliação e reforma, denominado de "projeto modificativo", de autoria de Eliseu Valter Fazaro.

Figura 2: Observar os dados do selo do projeto executivo da Escola Senac de Botucatu, concebido em 21 de janeiro de 1964, autoria de Rubens Carneiro Vianna.

Fonte: Foto Ferraz, arquivo SENAC

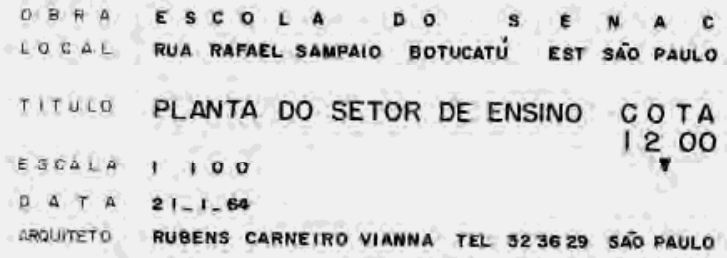




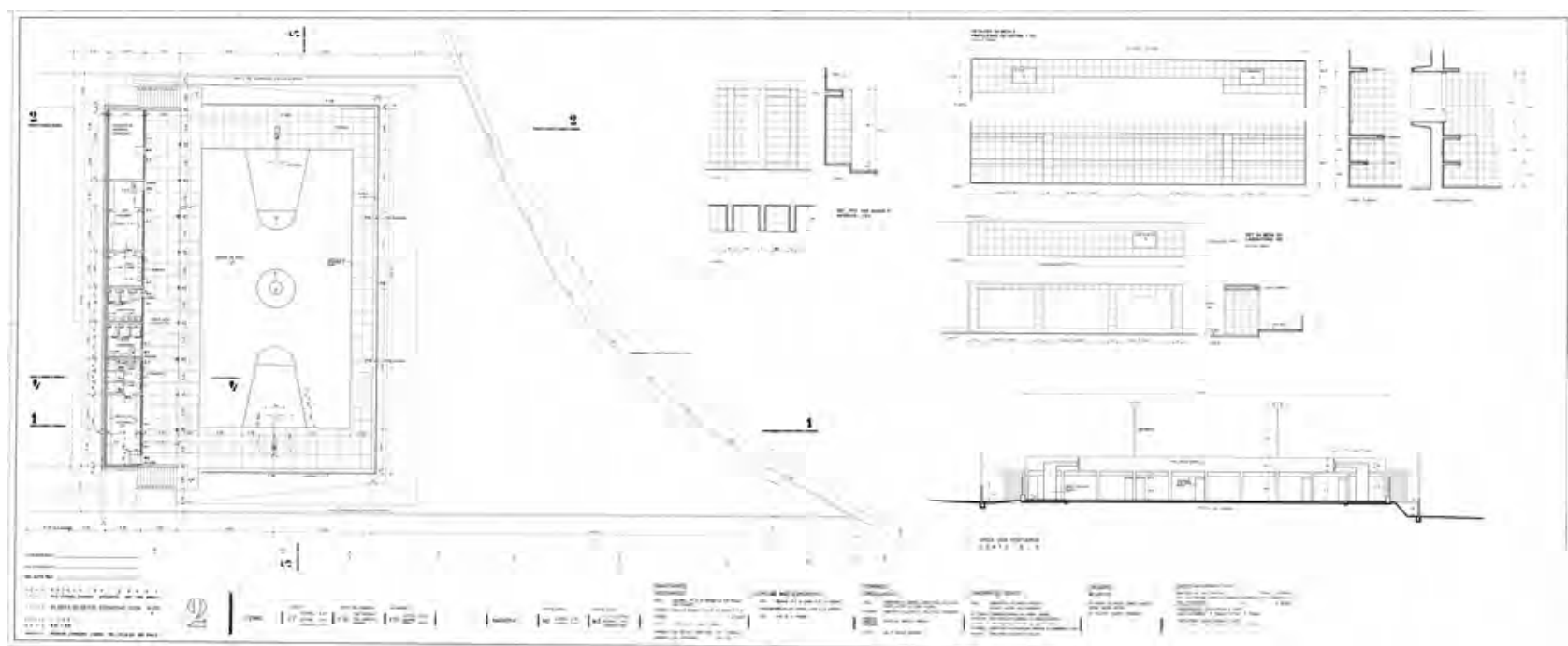

Figura 3: Prancha 2 do projeto executivo da Escola Senac de Botucatu, Planta do setor esportivo, 20/01/1964, Rubens Carneiro Vianna.

Fonte: Arquivo SENAC-SP

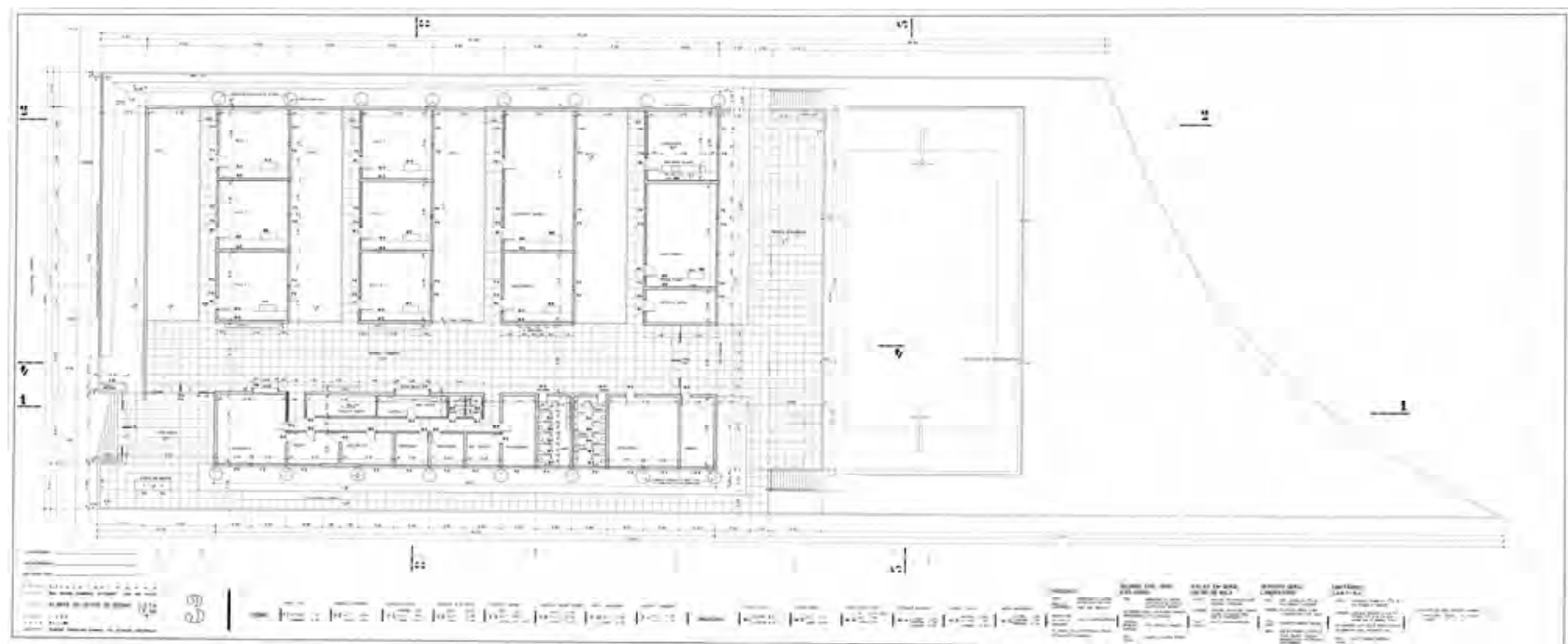

Figura 4: Prancha 3 do projeto executivo da Escola Senac de Botucatu, Planta do setor de ensino, 21/01/1964, Rubens Carneiro Vianna.

Fonte: Arquivo SENAC-SP

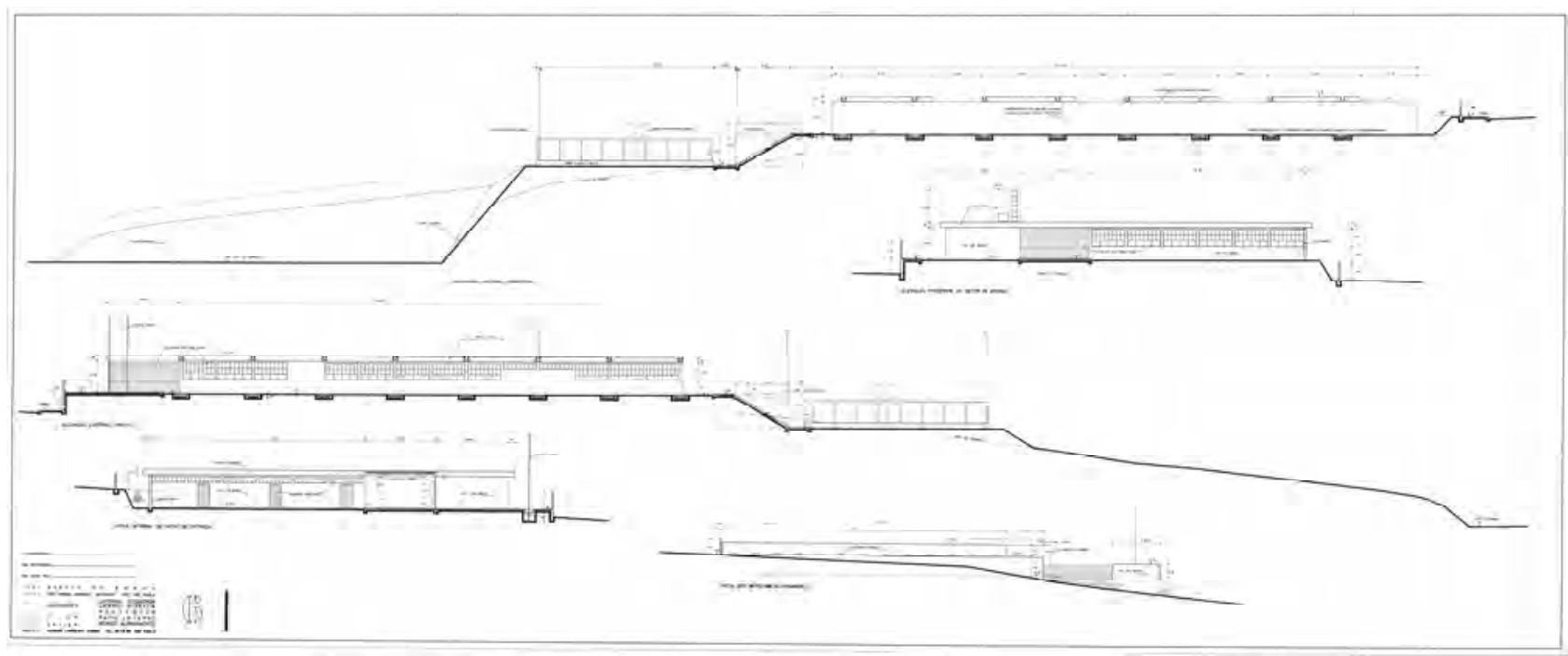

Figura 5: Prancha 6 do projeto executivo da Escola Senac de Botucatu, Elevações, 24/01/1964, Rubens Carneiro Vianna. Fonte: Arquivo SENAC-SP 
projeto foi dividido em dois setores: de ensino e esportivo. O Setor de ensino era composto pelos cinco blocos térreos, todos eles modulados com eixos de 3,30 metros $\times 6,60$ metros. $O$ primeiro bloco, perpendicular aos outros quatro, era composto pela parte administrativa, marcando a fachada e o acesso principal da escola. Este bloco, implantado de forma longitudinal no terreno, abrigava a secretaria, diretoria, vice-diretoria, duas salas de orientador, material didático, sala dos professores, biblioteca, grêmio, arquivo morto, sanitários dos alunos, sanitários dos funcionários e cantina. Todos os ambientes de uso dos alunos foram projetados com acessos independentes, como a biblioteca, os sanitários, o grêmio e a cantina, ambientes estes, voltados para o recreio coberto que era responsável por interligar este bloco aos quatro demais. Já as salas administrativas tiveram seus acessos pontuados na circulação central interna e, suas janelas restritas ao corredor lateral nordeste do bloco.

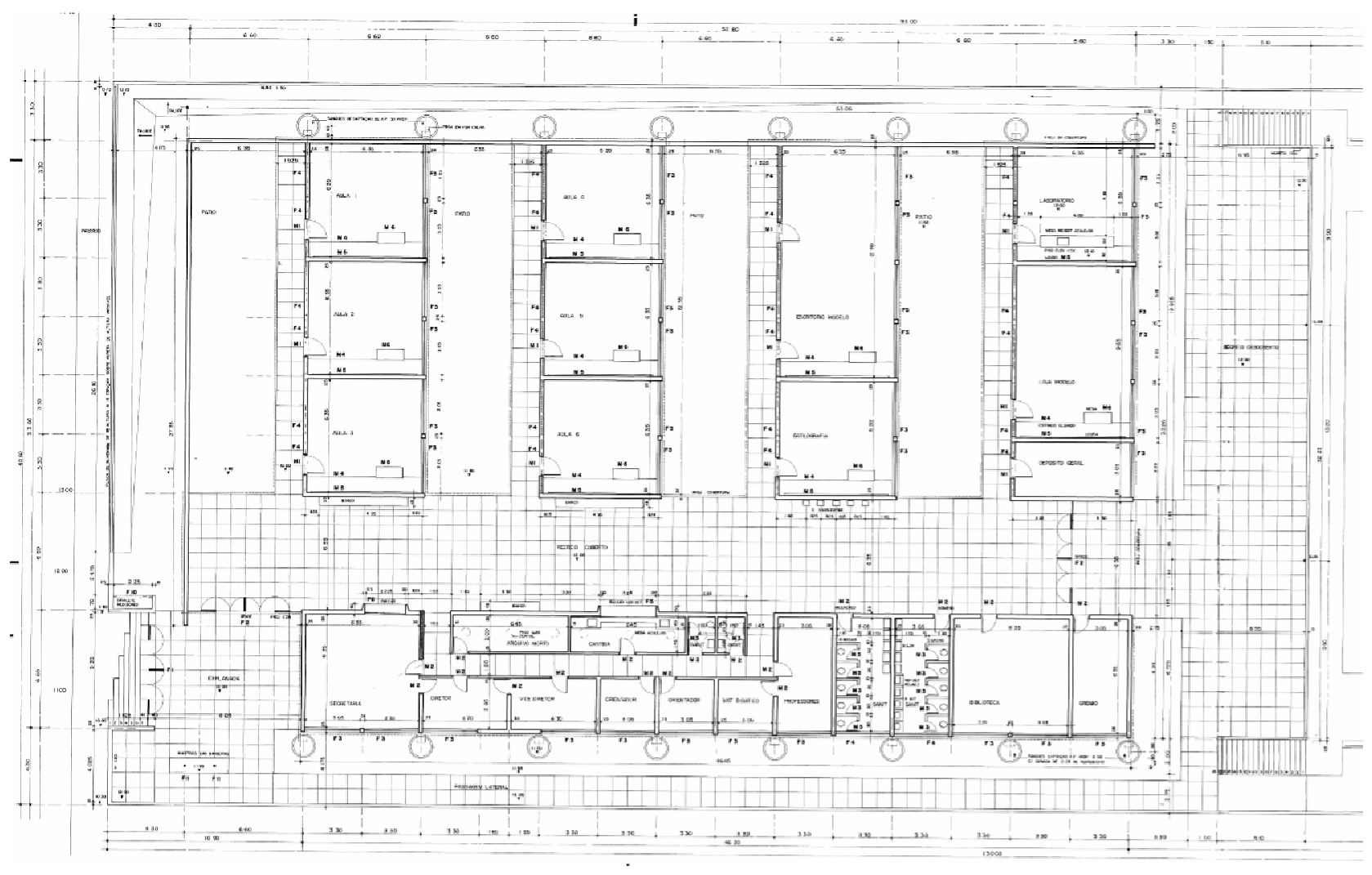

Figura 6: Planta do setor de ensino retirada da prancha 3 do projeto executivo da Escola Senac de Botucatu. Observar o bloco longitudinal da administração e os quatros blocos paralelos da escola.

Fonte: Arquivo SENAC-SP 


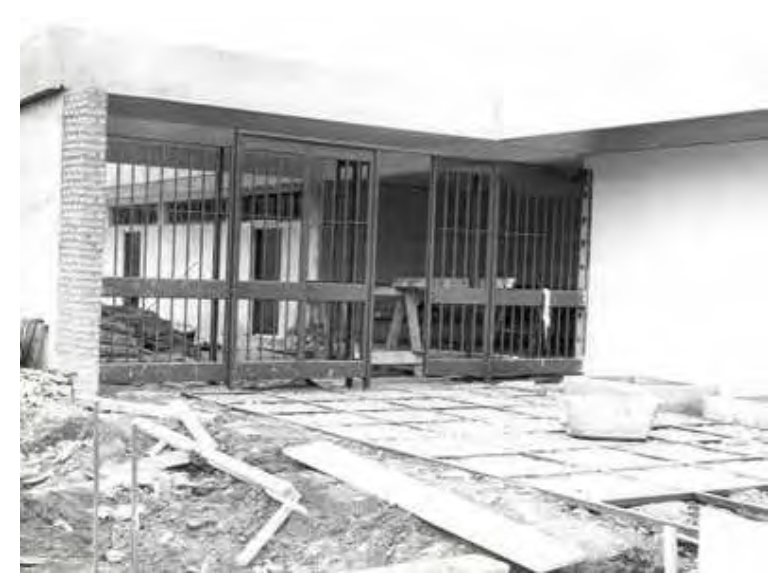

Figura 7: Portão de acesso da Escola Senac de Botucatu. Escadaria de acesso e esplanada em construção. Fonte: Arquivo SENAC-SP
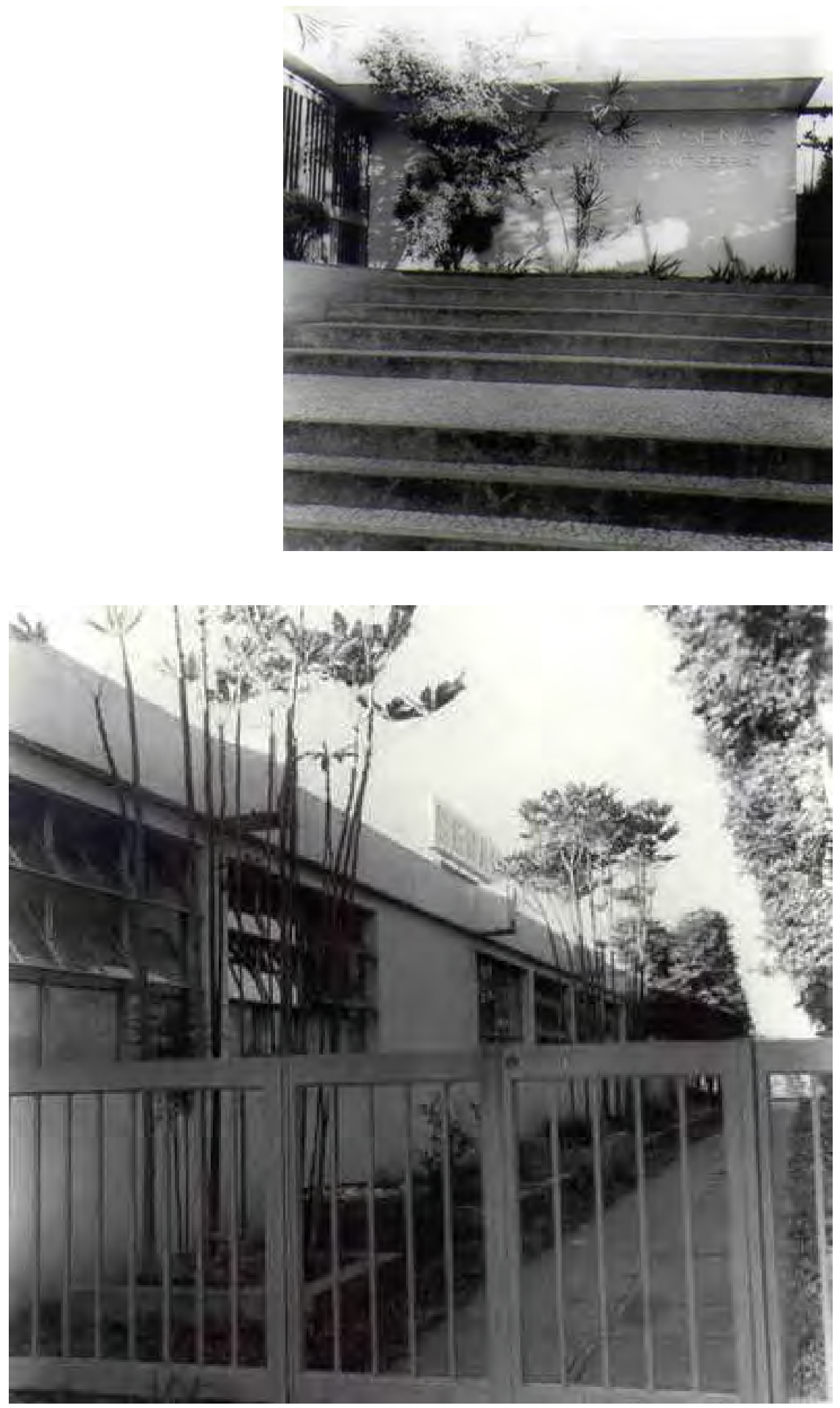

Figura 9: Corredor lateral do bloco da administração, Escola Senac de Botucatu.

Observar as janelas dos ambientes administrativos, voltadas para a face noroeste. Fonte: Arquivo SENAC-SP 
Os segundo, terceiro, quarto e quinto blocos foram projetados com as mesmas dimensões e distâncias uns dos outros, mantendo a modulação de 6,60 metros entre bloco e pátio, entre cheio e vazio. No segundo bloco, assim como no terceiro, foram projetadas três salas de aula em cada bloco, totalizando as seis salas de aula da escola. Já o quarto bloco foi dividido em dois ambientes caracterizados pelo escritório modelo e pela sala de datilografia. $\bigcirc$ quinto bloco, dividido em três salas, abrigava a laboratório, a loja modelo e o depósito geral. Todos este blocos, paralelas entre si, foram separados por pátios ajardinados, proporcionando a integração das áreas verdes ao projeto, diretamente ligadas aos ambientes de ensino.

As salas de aula, com iluminação e ventilação bilateral, tiveram janelas maiores com peitoril baixo projetadas para a face sudeste e janelas menores com peitoril alto para a face nordeste. Tal solução projetual garantiu a ventilação cruzada sem prejudicar o conforto térmico das salas, pois permitiu ampla visibilidade da área ajardinada favorecendo o sol da manhã e, ao mesmo tempo, proteção do sol da tarde nas aberturas sombreadas pelo beiral.

Figura 9: Vista sudeste do pátio ajardinado, projetado entre um dos quatro blocos

perpendiculares entre si. Escola Senac de Botucatu, 1972. Fonte: Arquivo SENAC-SP

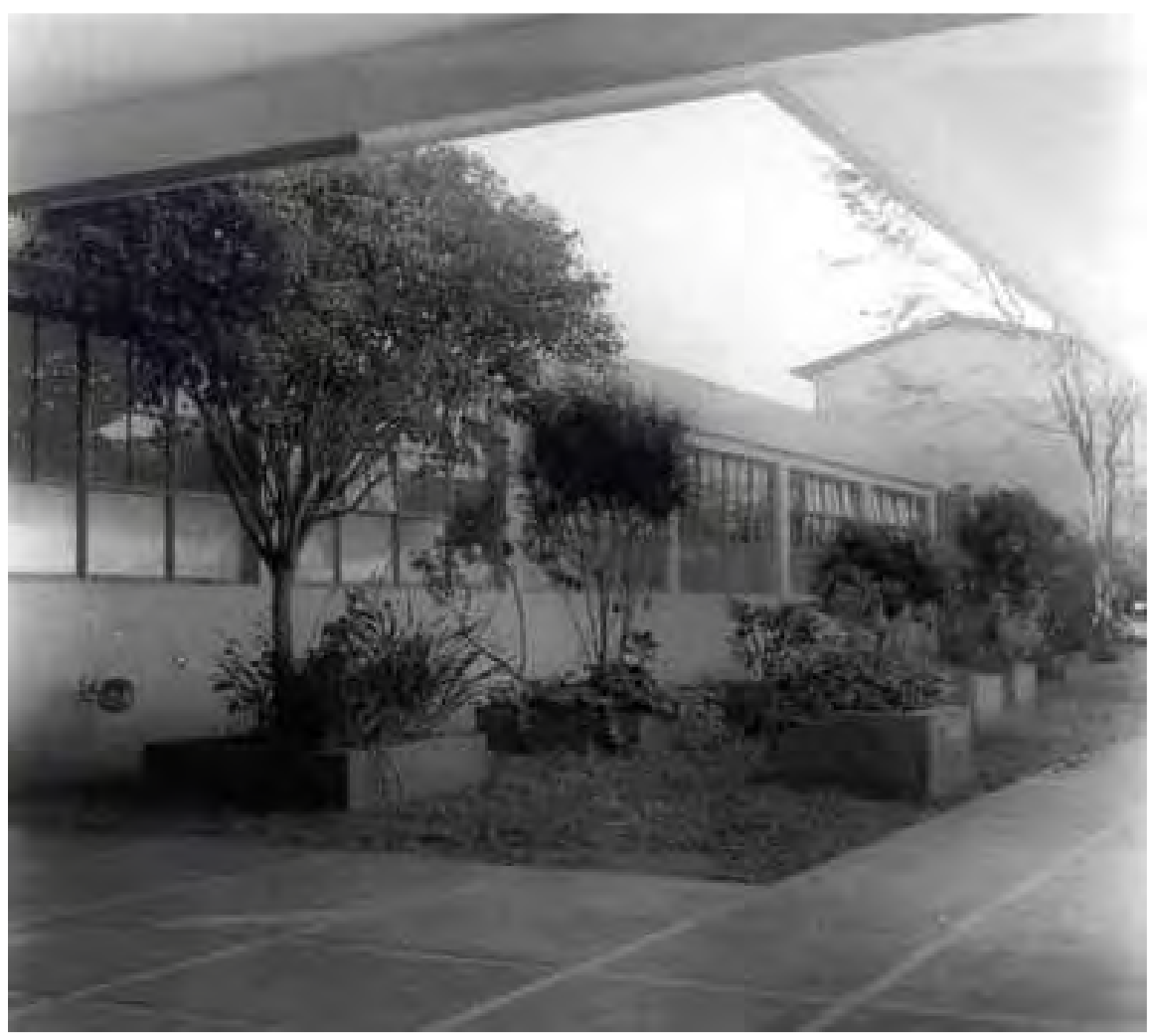




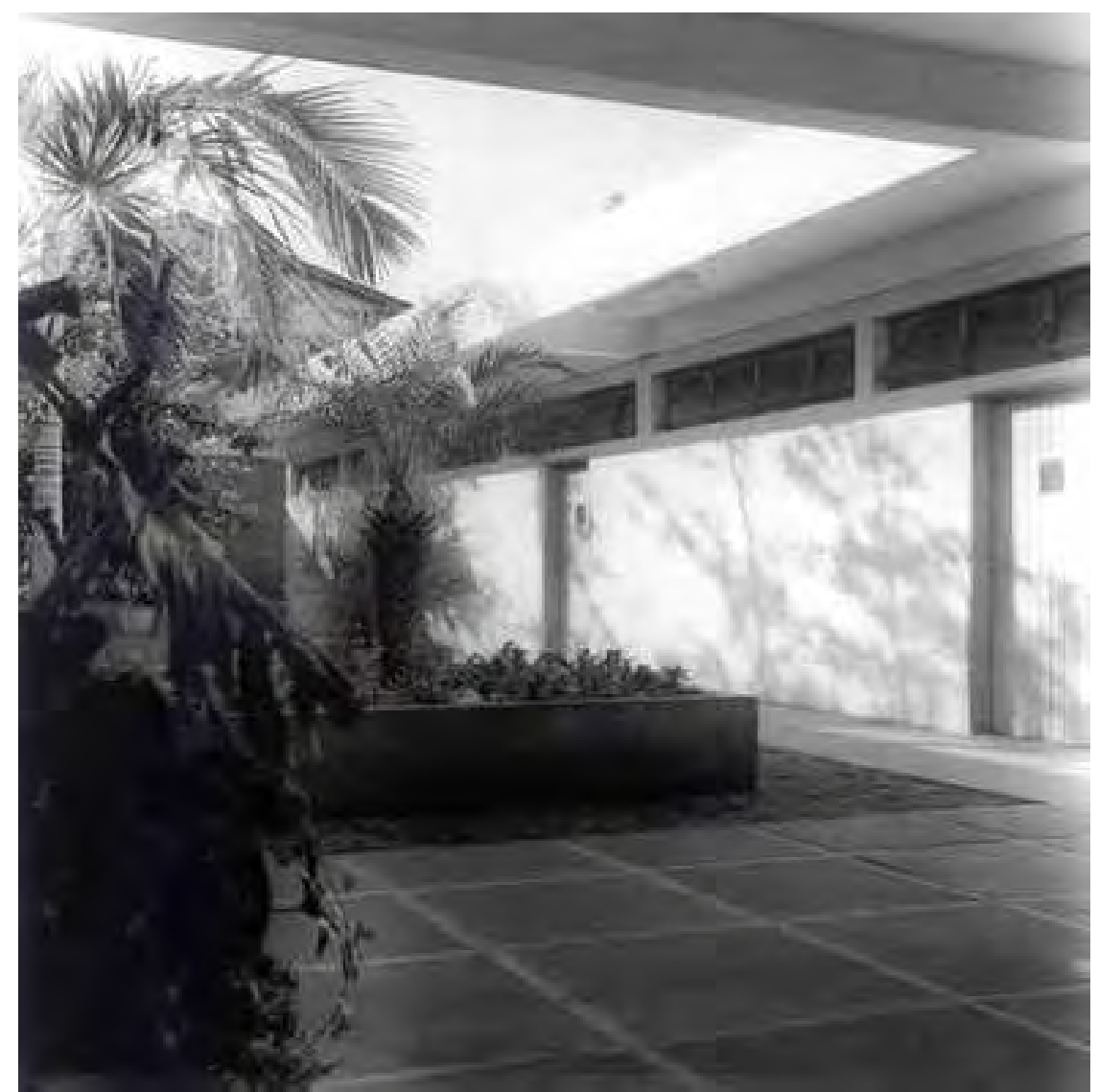

Os cinco blocos do Setor de ensino, unidos pelo recreio coberto e delimitados pelo comprimento do primeiro bloco, foram interligados ao setor esportivo pelo recreio descoberto, paralelo e ao lado do quinto bloco. Acompanhado a topografia do terreno, o setor esportivo foi projetado três metros abaixo do nível do setor de ensino e, por meio de uma escada, a quadra de jogos e suas dependências foram integradas à escola. Sob o recreio descoberto foram projetados os vestiários e sanitários esportivos, assim como o depósito de material esportivo. Atendendo à pedagogia de ser uma escola atrativa aos alunos, a área esportiva juntamente com os recreios coberto e descoberto possibilitaram a integração do ensino com a sociabilidade, através do convívio e do lazer em comum.
Figura 10: Vista nordeste do pátio ajardinado, projetado entre um dos quatro blocos perpendiculares entre si. Escola Senac de Botucatu, 1972.

Fonte: Arquivo SENAC-SP 


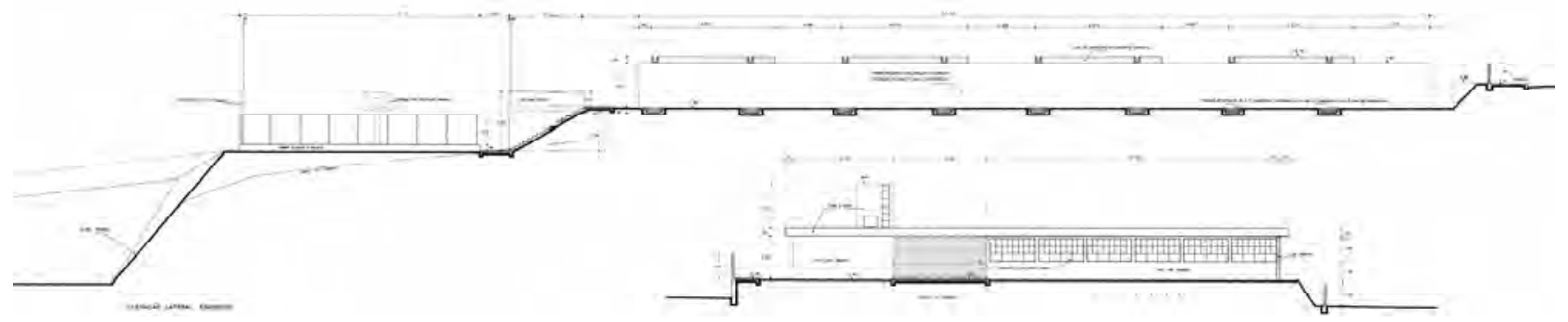

Figura 11: Elevação retirada da prancha 6 do projeto executivo da Escola Senac de Botucatu, observar a topografia do terreno e o Setor esportivo implantado três metros abaixo do nível Setor de ensino.

Fonte: Arquivo SENAC-SP

Figura 12: Construção da quadra de jogos e do bloco dos vestiários e sanitários, Escola Senac de Botucatu, 1965 Fonte: Arquivo SENAC-SP
Figura 13: Fachada principal da Escola Senac de Botucatu em 1986,vdenominada a partir de 1973 de Centro de Formação Profissional Antonio Mont'Serrat. Fonte: Arquivo SENAC-SP

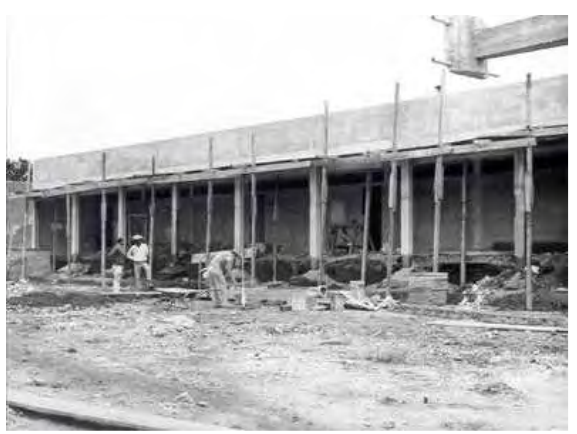

A Escola Senac de Botucatu, Inaugurada no dia 12 de novembro de 1966 e atualmente denominada de Centro de Formação Profissional Antonio Mont'Serrat, reuniu características da nova pedagogia implantada na década de 1950, respondendo algumas intenções pedagógicas como: a interligação física do ensino com os espaços ajardinados e de sociabilidade; a organização racional dos espaços distribuídos em blocos modulados; a integração entre escola, áreas verdes e esportivas, o conforto térmico da ventilação e iluminação natural nas salas de aula, dentre outros.

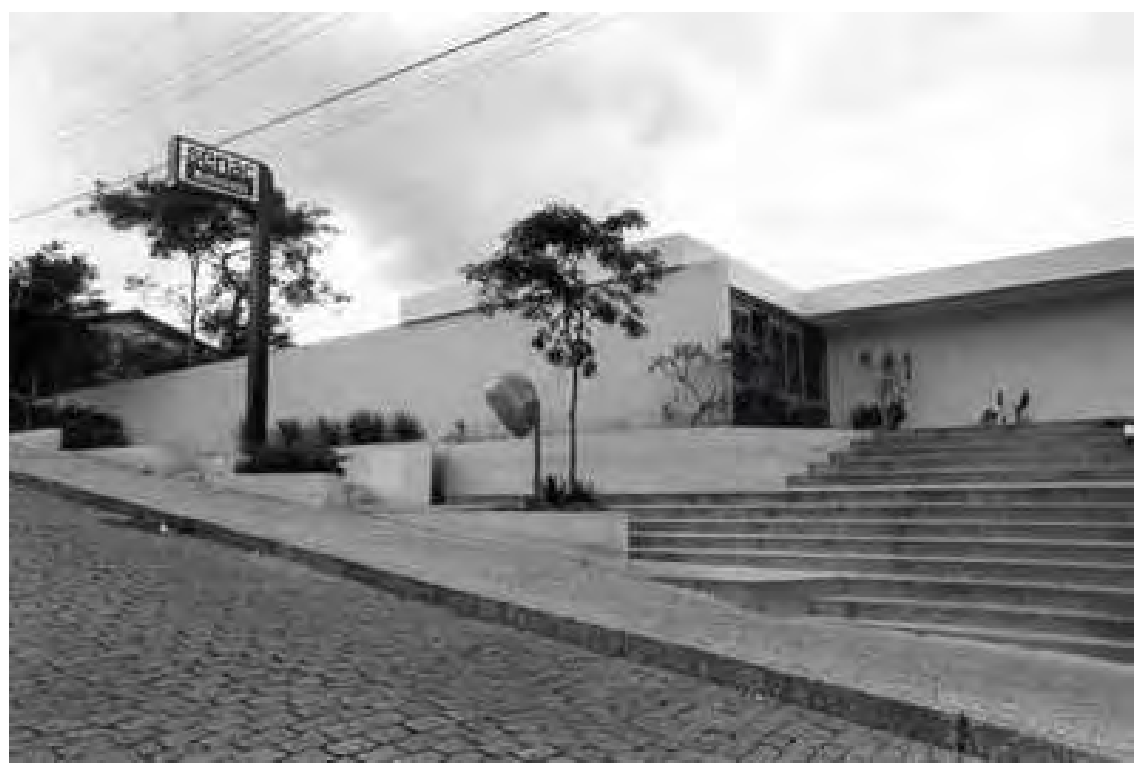


PROJETO 10

\section{Escola Senac de Santo André, 1964}

A Escola Senac de Santo André foi projetada em 1964 pelo arquiteto Jorge Wilheim. Implantada num terreno de 4.204,00 $\mathrm{m}^{2} \mathrm{e}$ localizada à Avenida Projetada, atual Avenida Ramiro Colleoni 110, a área de construção do projeto original foi de 1.585,40 $\mathrm{m}^{2}$, sendo $781,40 \mathrm{~m}^{2}$ do pavimento térreo e $804,00 \mathrm{~m}^{2}$ do pavimento superior, segundo dados do projeto de prefeitura'. A escola construída ao longo do comprimento do terreno, teve sua fachada principal voltada para a face nordeste. $O$ projeto, marcado pela intersecção de dois blocos formando um desenho cruciforme em planta, resolveu a distribuição dos espaços em dois níveis.

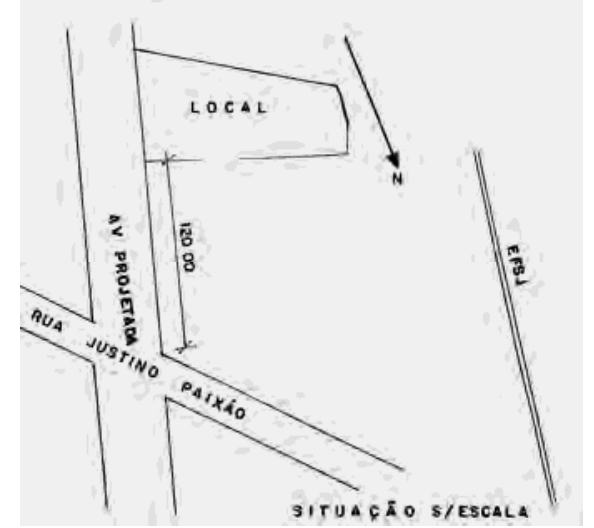

programa construtivo foi dividido em dois blocos, interligados por uma escada, sendo o pavimento térreo composto de: entrada coberta, vestíbulo, secretaria, diretoria, vice-diretoria, duas salas de orientador, sala dos professores, grêmio, copa depósito, sanitários dos alunos, sanitários dos funcionários, loja modelo, escritório modelo, biblioteca, recreio coberto, cantina, sanitário, despensa, depósito de material esportivo e vestiários feminino e masculino. O pavimento superior abrigava seis salas de aula, laboratório, dois depósitos e sala de datilografia, todos projetados sobre o recreio coberto e o vestíbulo. Também, no térreo foram projetadas a área verde e uma quadra de esportes com arquibancada.

\footnotetext{
${ }^{1}$ A área construída que consta no projeto de prefeitura original possivelmente não considerou o recreio coberto como área construída, pois através do projeto executivo, pode-se verificar que o valor total da área construída da escola é maior do que o apresentado.
}

Figura 1: Planta de situação da Escola Senac de Santo André. Fonte: Foto Ferraz, arquivo SENAC 
Os dados relativos à escola foram obtidos no arquivo do SENAC-SP, assim como quatro pranchas do projeto pré-executivo de janeiro de 1964, duas perspectivas do ante-projeto e quatro pranchas do projeto executivo de março de 1964, revelando planta, cortes e elevações finais, e a autoria de Jorge Wilheim. Ainda, foram encontradas duas pranchas do projeto de prefeitura original, revelando a data de aprovação do projeto em 29 de maio de 1964 e o engenheiro civil José Carlos Campos como responsável técnico.

Figura 2: Observar os dados do selo do projeto de pré-execução da Escola Senac de Santo André, concebido em 6 de janeiro de 1964, autoria de Jorge Wilheim. Fonte: Foto Ferraz, arquivo SENAC

Figura 3: Observar os dados do selo do projeto executivo da Escola Senac de Santo André, concebido em 18 de março de 1964, autoria de Jorge Wilheim. Fonte: Foto Ferraz,

arquivo SENAC

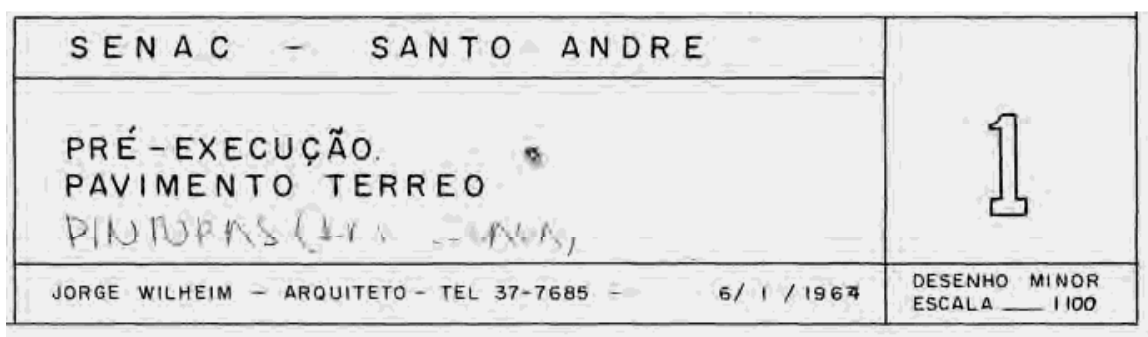




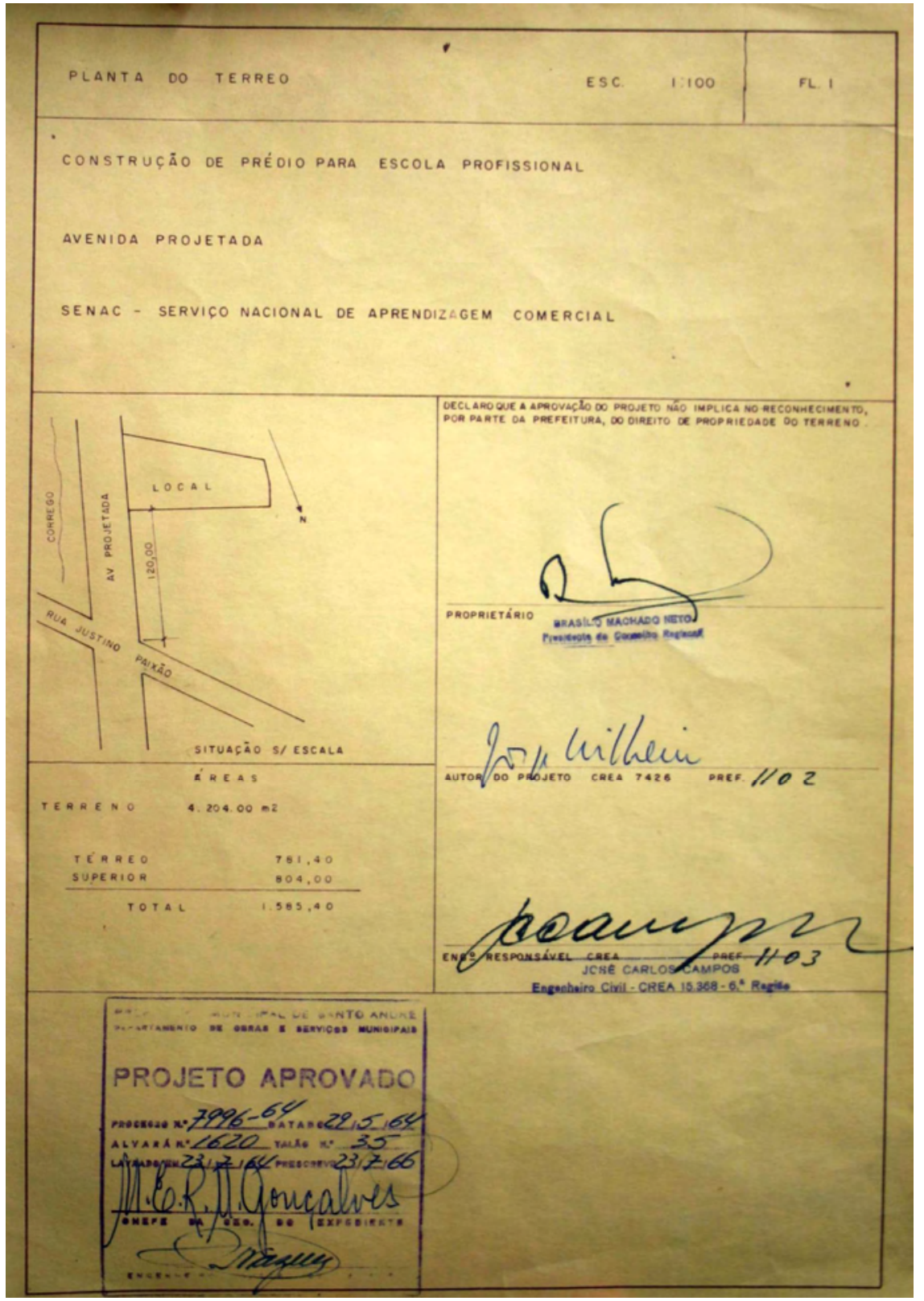

Figura 4: Selo do projeto de prefeitura da Escola Senac de Santo André, aprovado em 29 de maio de 1964, autoria de Jorge Wilheim. Fonte: Foto Ferraz, arquivo SENAC 

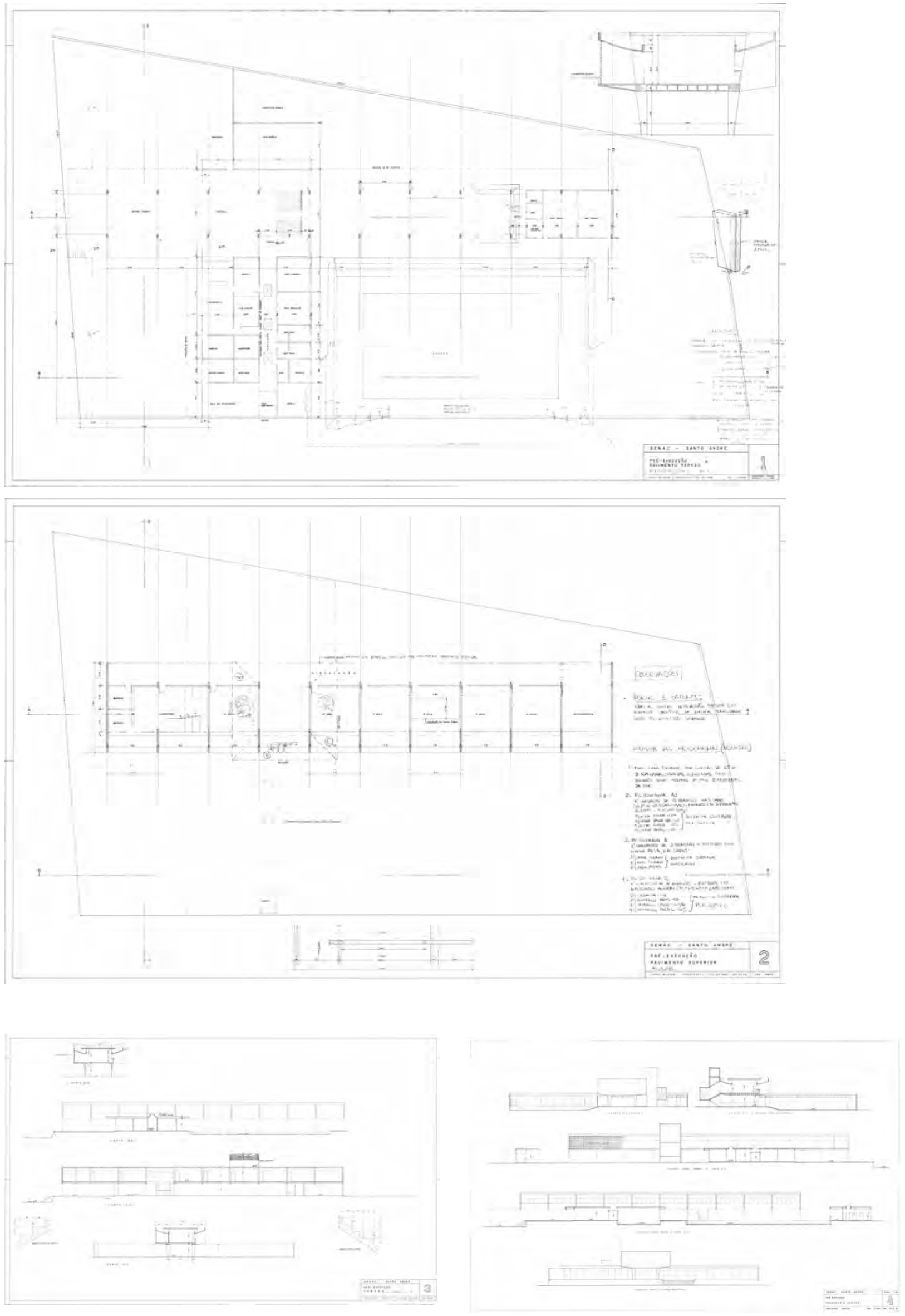

Figuras 5 a 8: Prancha 1, 2, 3 e 4 do projeto de pré-execução, Escola Senac de Santo André, janeiro de 1964, Jorge Wilheim. Fonte: Arquivo SENAC-SP 

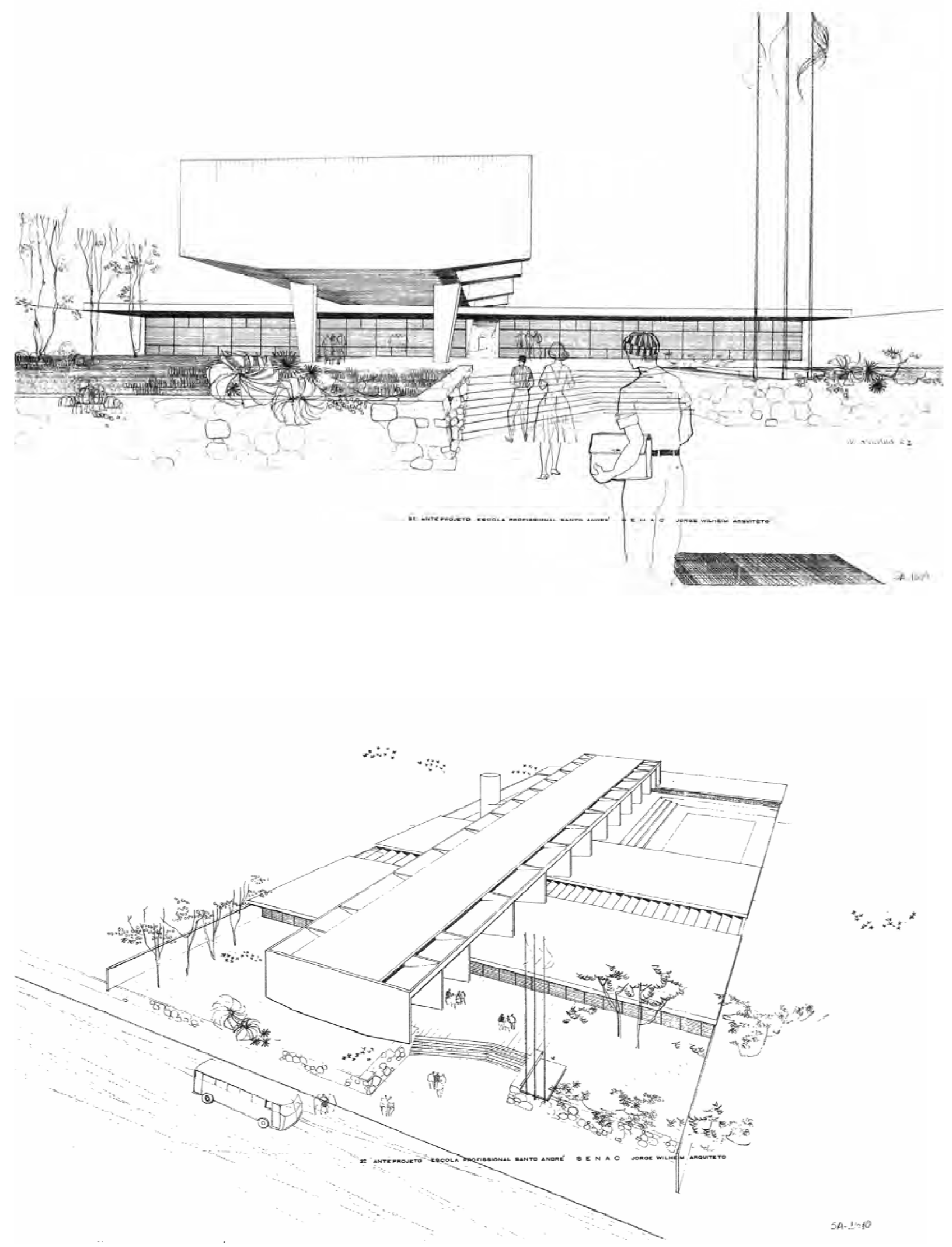

Figuras 9 e 10: Perspectivas do ante-projeto da Escola Senac de Santo André, Jorge Wilheim. Observar o bloco longitudinal, das salas de aula, com dois pavimentos. Fonte: Arquivo SENAC-SP 


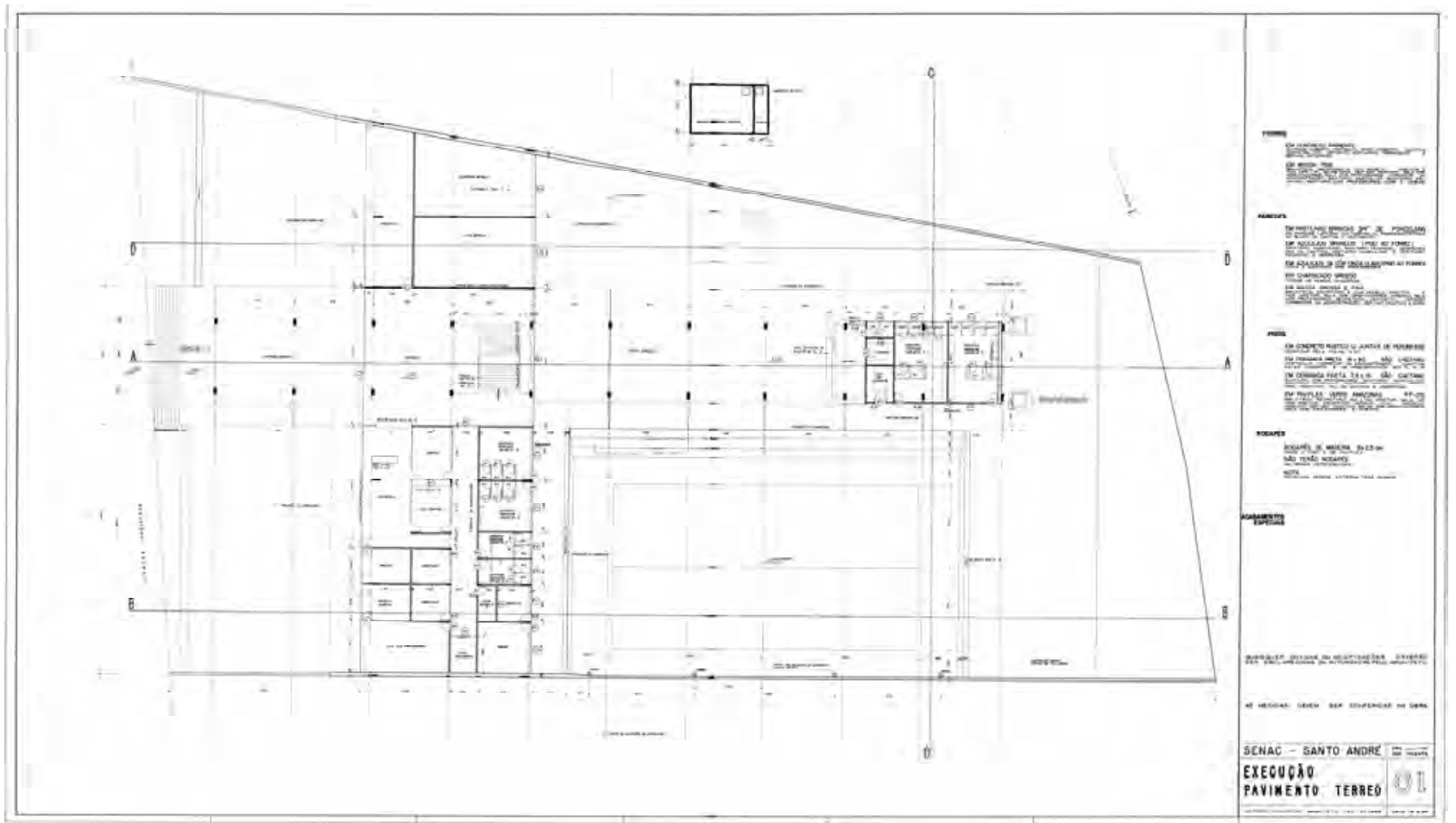

Figura 11: Prancha 1 do projeto executivo da Escola Senac de Santo André, planta do pavimento térreo, março de 1964, Jorge Wilheim.

Fonte: Arquivo SENAC-SP

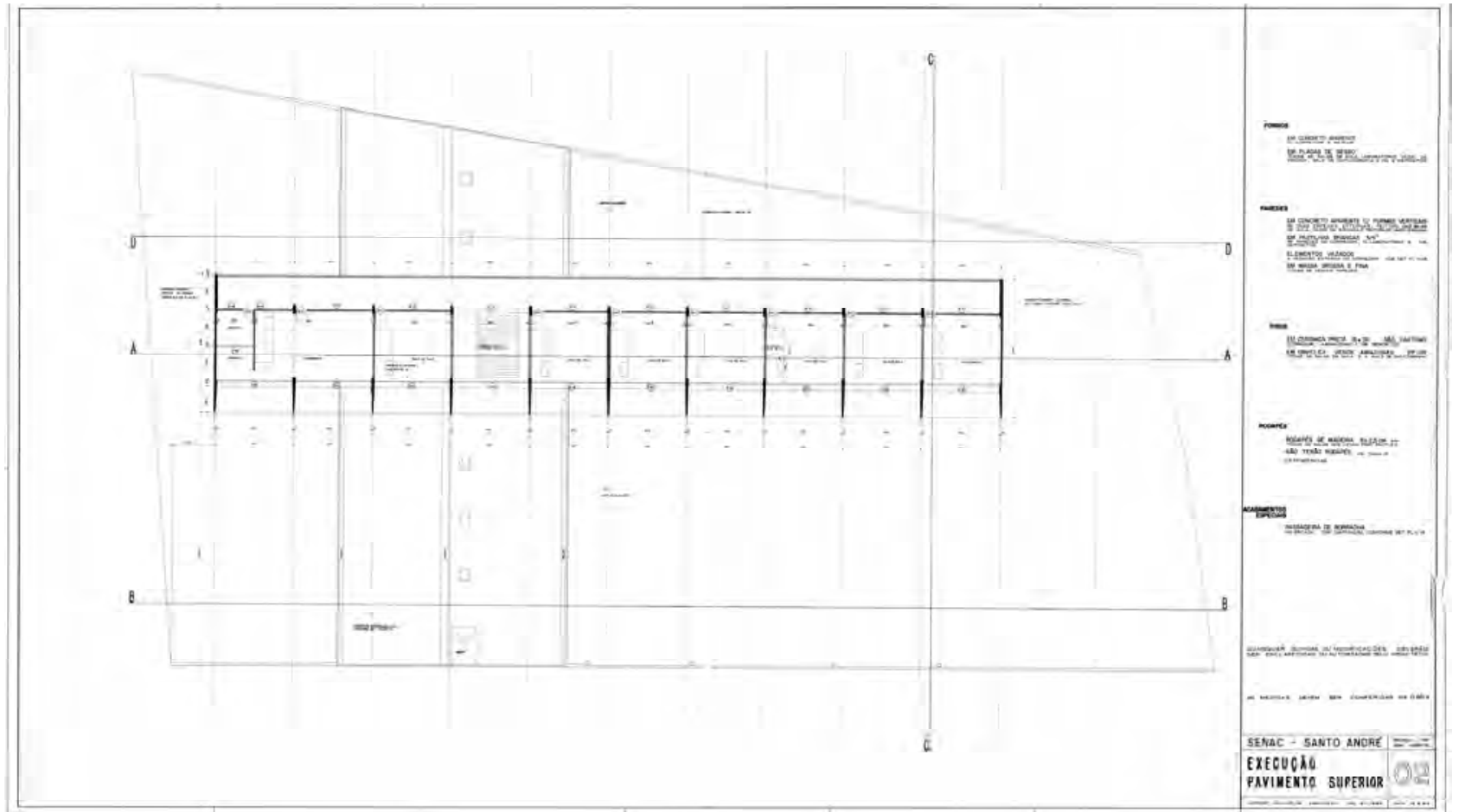

Figura 12: Prancha 2 do projeto executivo da Escola Senac de Santo André, planta do pavimento superior, março de 1964 , Jorge Wilheim.

Fonte: Arquivo SENAC-SP 


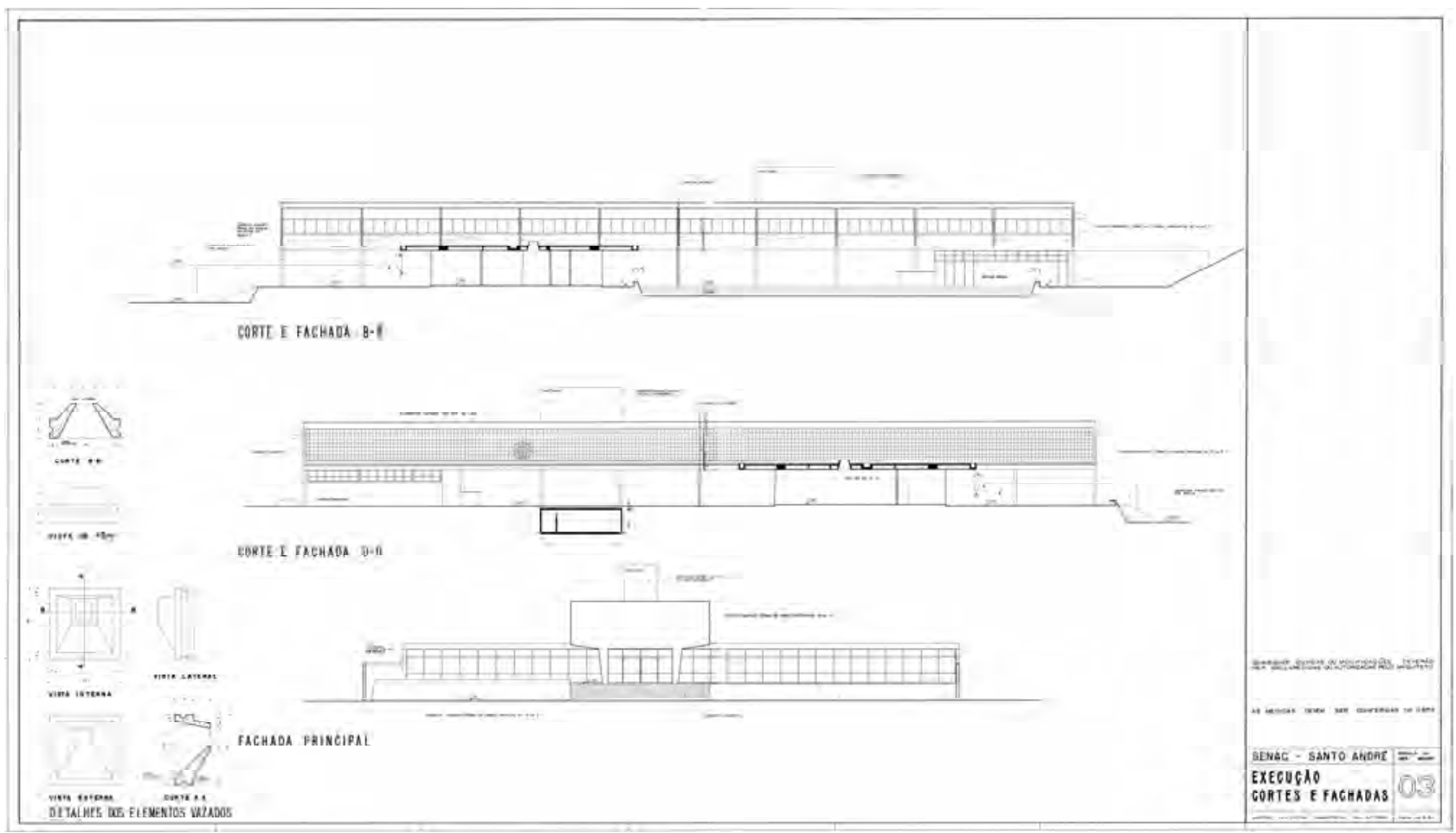

Figura 13: Prancha 3 do projeto executivo da Escola Senac de Santo André, cortes e fachadas, março de 1964, Jorge Wilheim.

Fonte: Arquivo SENAC-SP

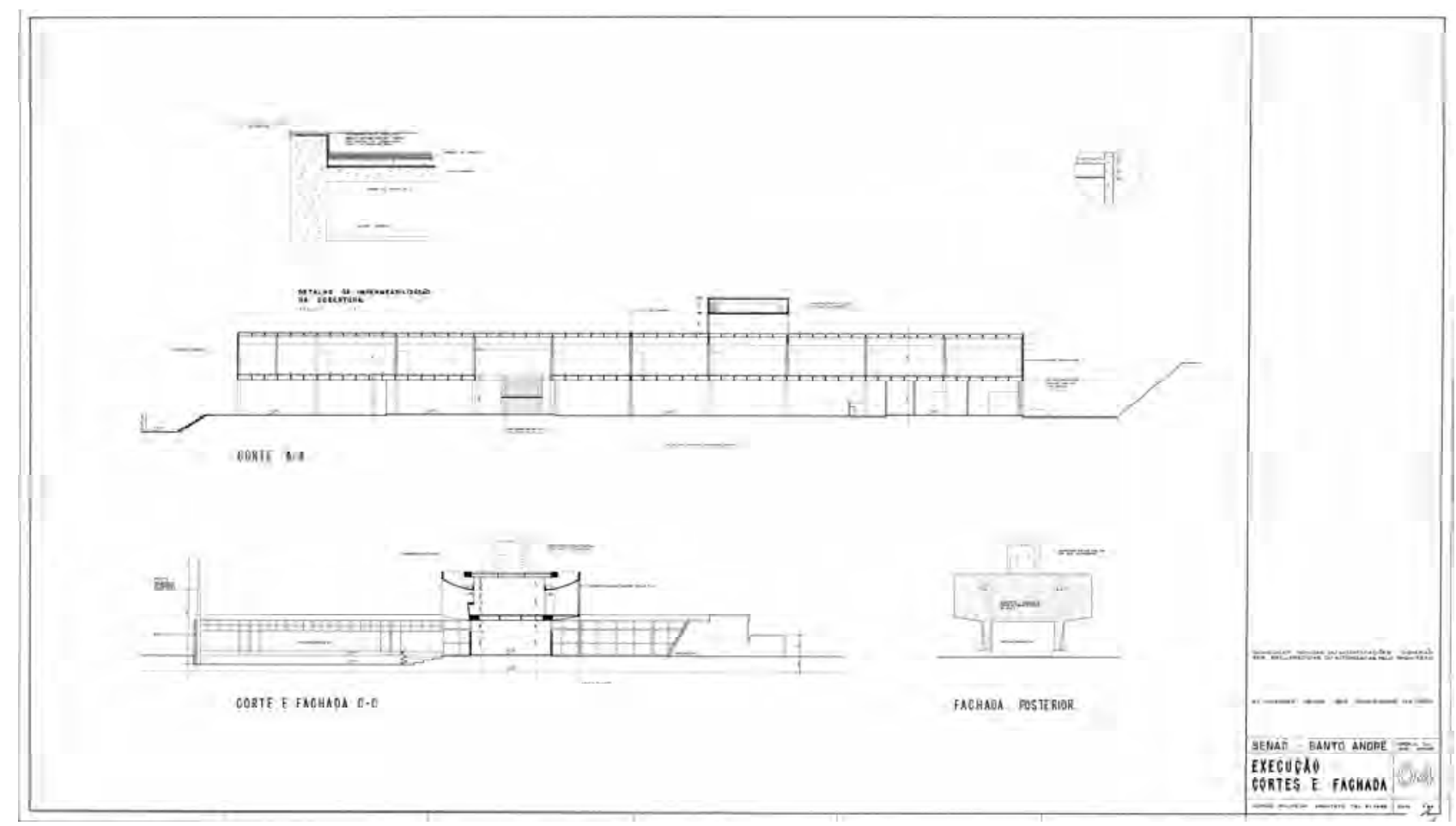

Figura 14: Prancha 4 do projeto executivo da Escola Senac de Santo André, cortes e fachadas, março de 1964, Jorge Wilheim.

Fonte: Arquivo SENAC-SP 
O projeto, resolvido em dois blocos perpendiculares, é caracterizado pela intersecção de um bloco com o outro, marcada pela escada. Enquanto o térreo foi composto pela administração, recreação e espaços modelos do SENAC, o pavimento superior foi destinado ao ensino, abrigando as salas de aula, datilografia e laboratório. $\bigcirc$ monobloco das salas de aula, modulado com eixo transversal de 11,80 metros e eixos longitudinais de 6,70 metros, abrigava no térreo, sob as salas de aula, a entrada, o recreio e o vestíbulo, todos cobertos e estruturados somente pelos pilotis de concreto. Para atender à recreação e ao lazer, foi projetada na extremidade térrea deste bloco a cantina e as dependências da quadra de esportes, como os vestiários e o depósito de material esportivo. No pavimento superior, com circulação lateral sudoeste protegida por elementos vazados de concreto, as salas de aula receberam iluminação e ventilação lateral, voltada para a face nordeste, protegida pelo beiral e fechamentos laterais de concreto. Com a concepção de integrar escola e lazer, as amplas janelas das salas de aula foram voltadas para a quadra de esportes, estimulando a relação do aluno com a escola e tornando o ensino mais atrativo.

Figura 15: Vista do recreio descoberto e do encontro dos dois blocos perpendiculares da Escola Senac de Santo André. Fonte: Arquivo SENAC-SP

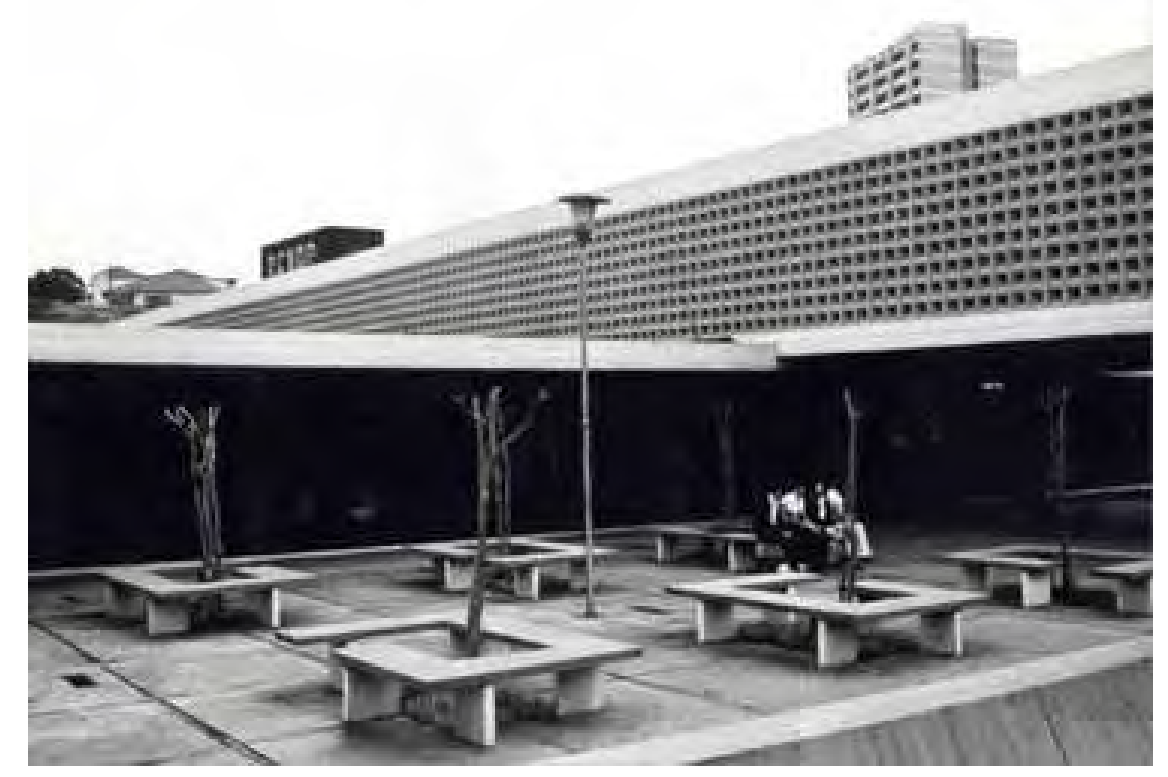




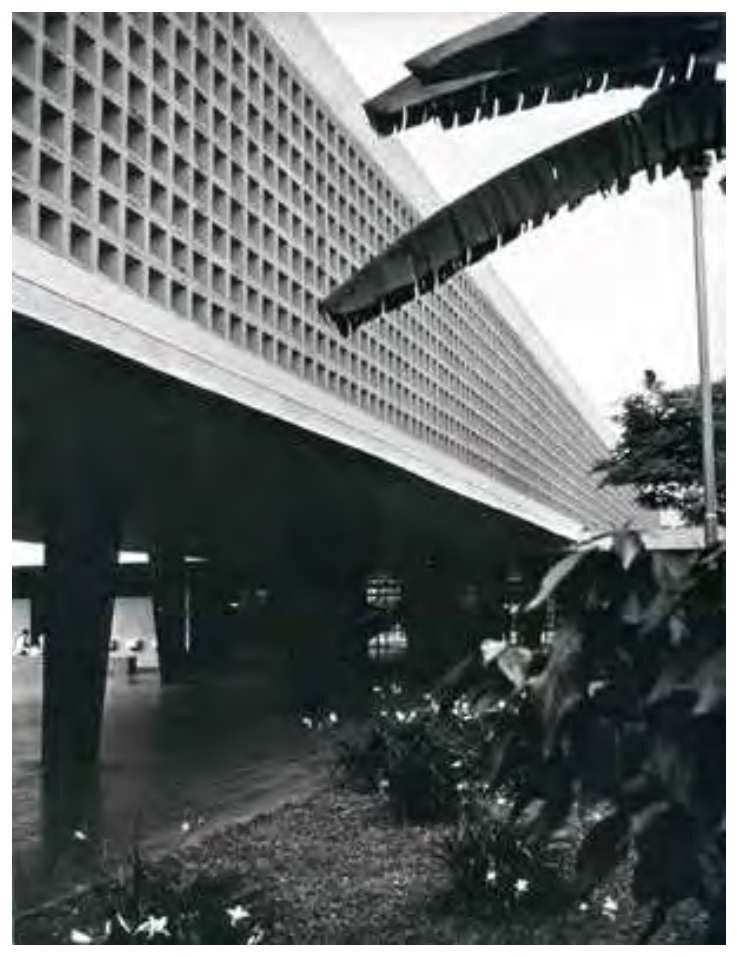

Figura 16: Observar o monobloco das salas de aula.

Recreio coberto no térreo e corredor fechado por elementos

vazados de concreto no pavimento superior. Escola

Senac de Santo André. Fonte: Arquivo SENAC-SP

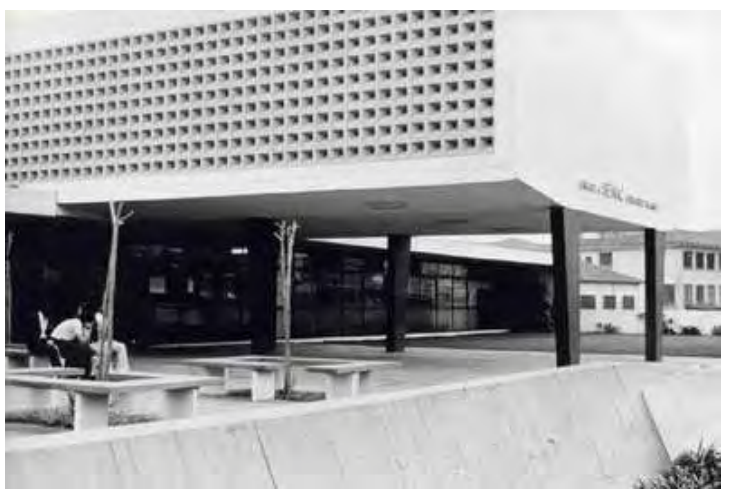

Figura 17: Vista da entrada coberta da escola sob as salas de aula e laboratório. Escola Senac de Santo André. Fonte: Arquivo SENAC-SP

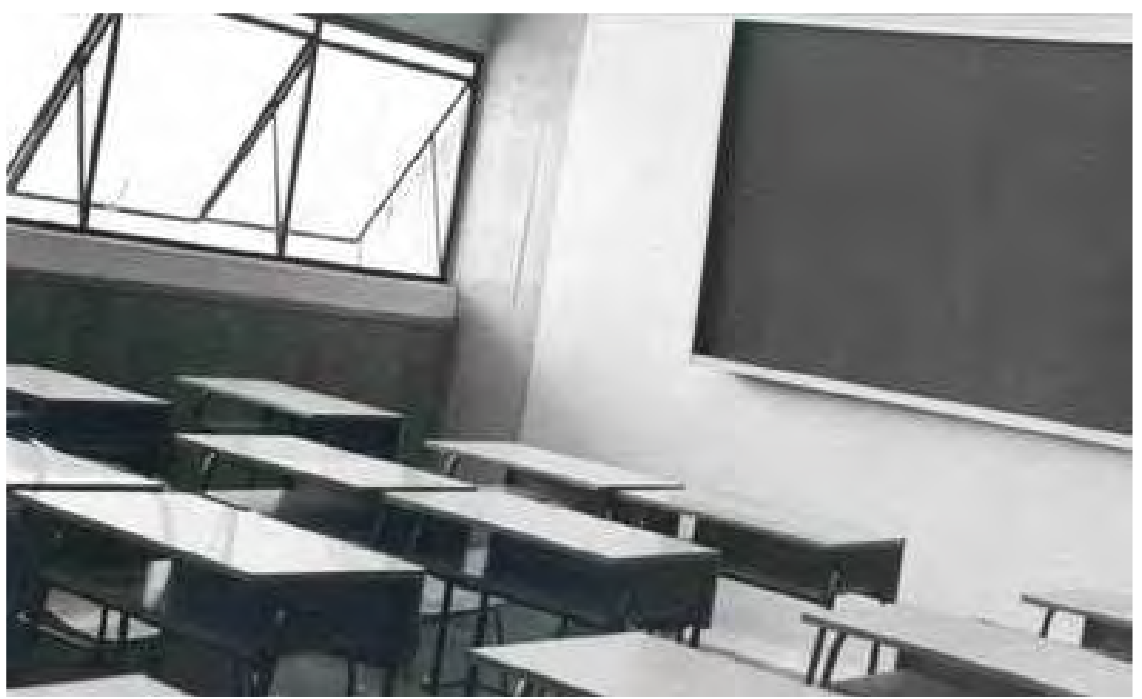

Figura 18: Sala de aula com iluminação lateral nordeste. Escola Senac de Santo André. Fonte: Arquivo SENAC-SP 
Figura 19: Observar as janelas das salas de aula, face nordeste, protegidas pelo beiral e fechamentos laterais de concreto. Escola Senac de Santo André.

Fonte: Arquivo SENAC-SP

Figura 20: Observar as janelas das salas de aula voltadas para a quadra de esportes e a ligação do recreio coberto com a cantina e dependências da quadra. Escola Senac de Santo André. Fonte: Arquivo SENAC-SP
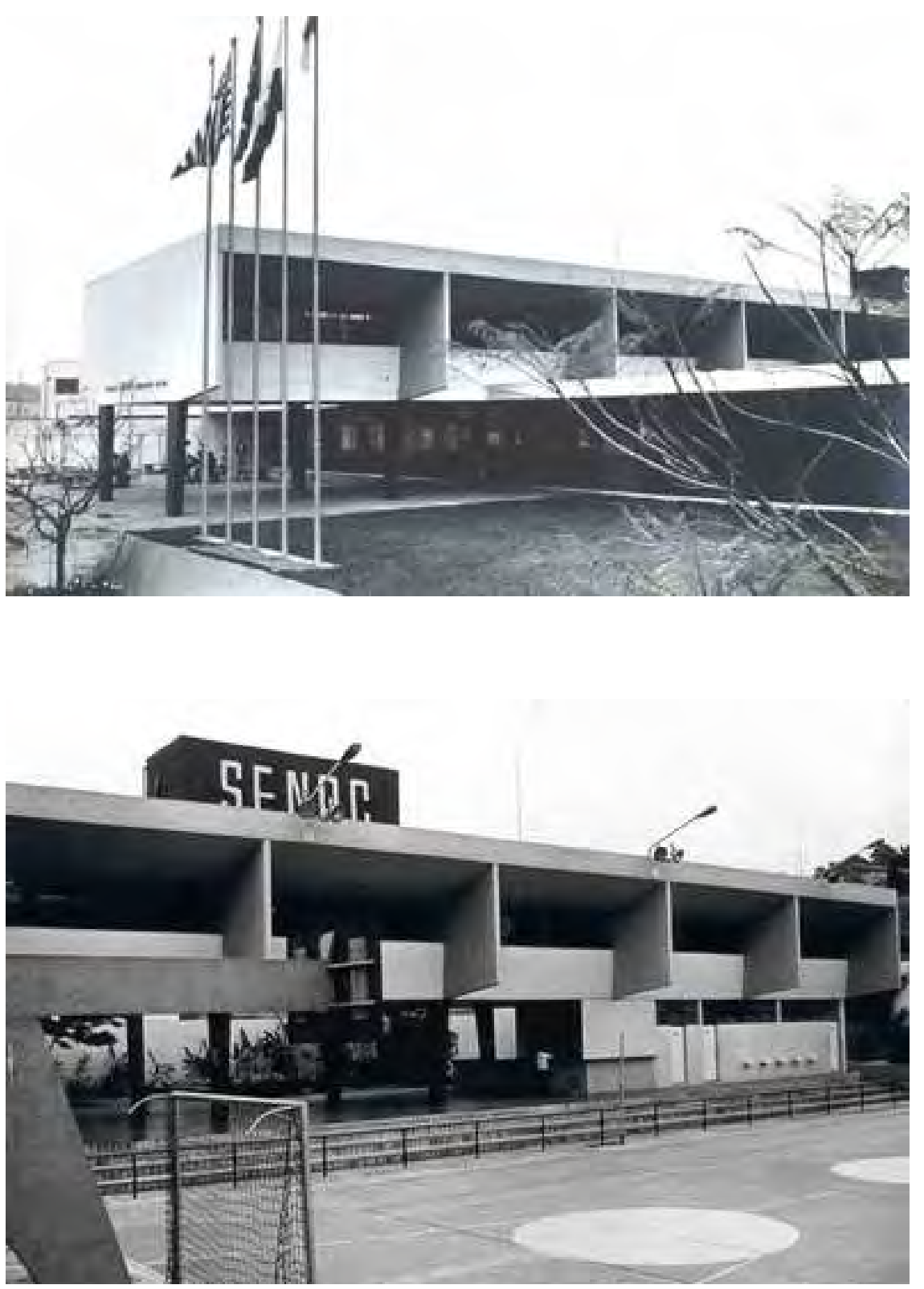

A resolução estrutural da Escola fez uso do concreto aparente e racionalista, na linha dos mestres paulistas. $\bigcirc$ bloco da administração, projetado na ala direita ao longo da fachada, adotou circulação central, separando as salas administrativas dos espaços de uso dos alunos como sanitários, depósito e grêmio. Já a ala esquerda, com biblioteca, loja e escritório-modelo, tinham seus acessos independentes voltados para o recreio coberto e descoberto. A fachada nordeste do bloco térreo foi fechada por caixilho de ferro e vidro, protegida pelo amplo beiral de concreto. 

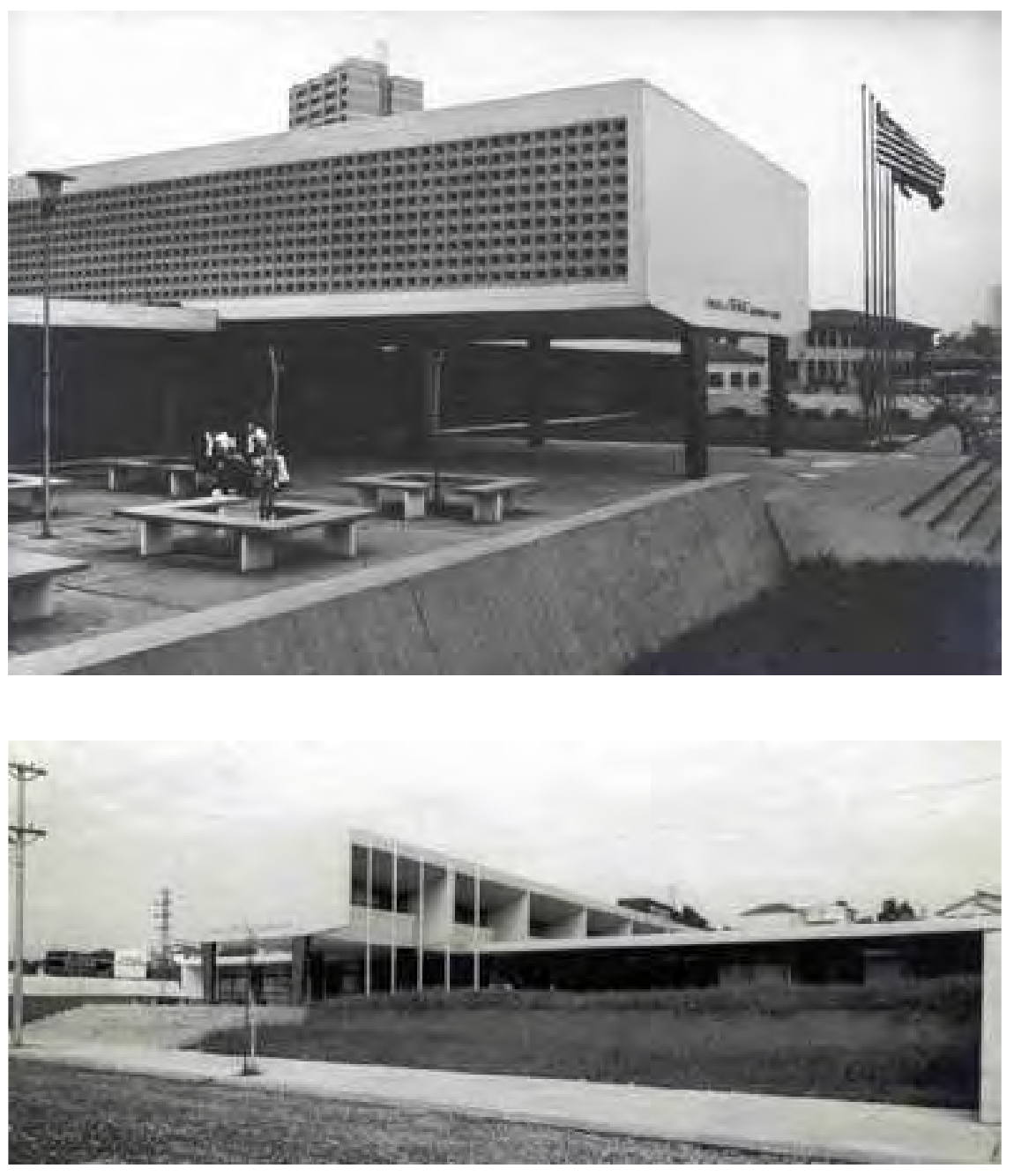

Atendendo e concretizando fisicamente a idéia de unir o ensino à recreação, a intersecção entre os blocos possibilitou a criação de espaços de convívio em comum como a área esportiva e os recreios coberto e descoberto.
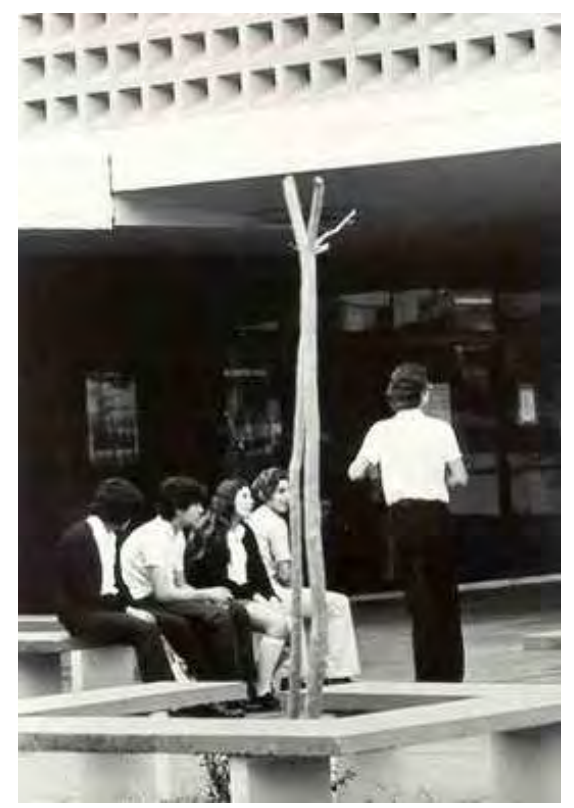

Figura 21: Bloco das salas de aula avançando sobre o bloco térreo e o recreio.

Observar fachada envidraçada voltada para face nordeste. Fonte: Arquivo SENAC-SP

Figura 22: Fachada principal da Escola Senac de Santo André, face nordeste. Fonte: Arquivo SENAC-SP
Figura 23: Recreio descoberto da Escola Senac de Santo André. Fonte: Arquivo SENAC-SP 
Inaugurada no dia 10 de janeiro de 1966, a Escola Senac de Santo André atualmente é chamada de Centro de Formação Profissional Eduardo Saigh e oferece à comunidade da região do $A B C$ uma programação de cursos técnicos, de qualificação e especialização nas áreas de Administração, Comunicação e Artes, Design de Interiores, Educação, Hotelaria, Idiomas, Informática, Marketing e Vendas, Moda, Saúde e Turismo. Também promove oficinas, palestras, seminários e workshops, para atualização e aprimoramento profissional.

Figura 24: Fachada principal da Escola Senac de Santo André, década de 60.

Fonte: Arquivo SENAC-SP

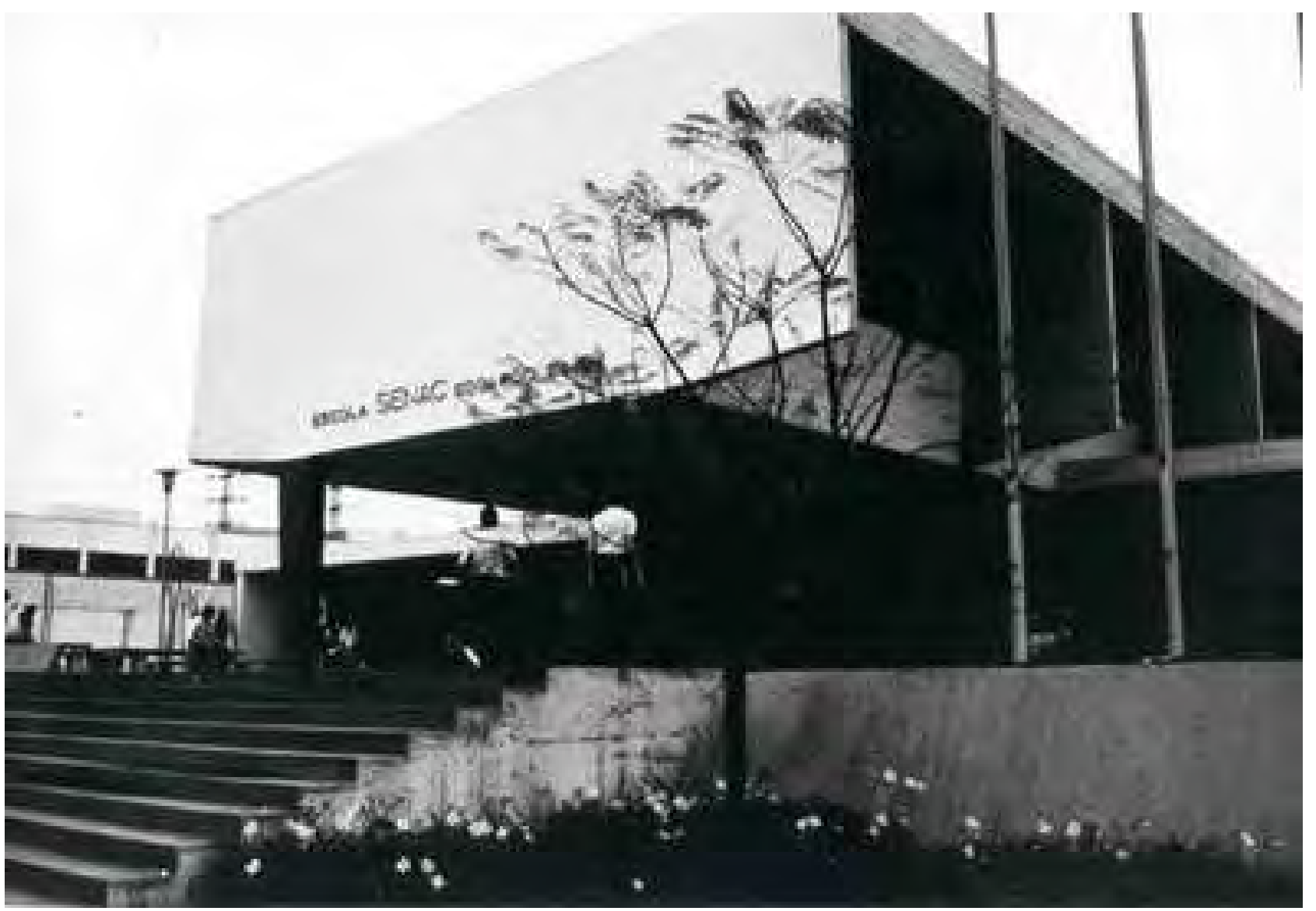




\section{PROJETO 9}

\section{Escola Senac de Botucatu, 1964}

A Escola SENAC de Botucatu foi projetada, em 1964, pelo arquiteto Rubens Carneiro Vianna. Implantada num terreno de $4.526,90 \mathrm{~m}^{2}$ e localizada na rua Rafael Sampaio 85, o projeto original contava com cinco blocos, quatro deles paralelos entre si e um perpendicular aos outros quatro, além do bloco dos vestiários e sanitários esportivos.

Figura 1: Planta de situação da Escola Senac de Botucatu, retirada da prancha do "projeto modificativo"

Fonte: Foto Ferraz, arquivo SENAC

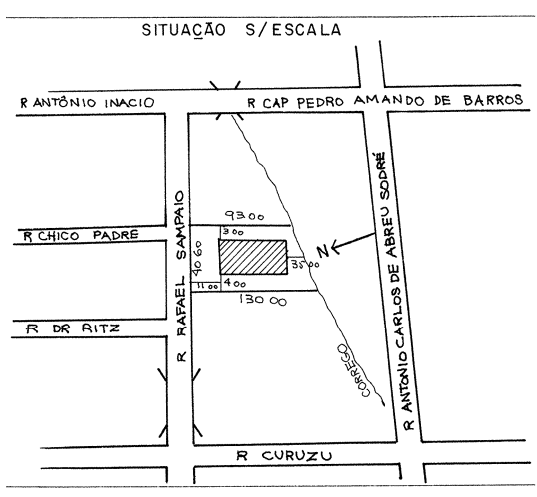

O programa construtivo foi composto de secretaria, diretoria, vice-diretoria, duas salas de orientador, material didático, sala dos professores, biblioteca, grêmio, arquivo morto, sanitários dos alunos, sanitários dos funcionários, cantina, seis salas de aula, escritório modelo, sala de datilografia, laboratório, loja modelo, depósito geral, recreio coberto, recreio descoberto, vestiários e sanitários esportivos, depósito de material esportivo e quadra de jogos.

Os dados relativos à escola foram obtidos no arquivo do SENAC-SP, como quatro pranchas do projeto executivo de 1964, revelando plantas, elevações e a autoria de Rubens Carneiro Vianna e, prancha única do projeto completo de ampliação e reforma, denominado de "projeto modificativo", de autoria de Eliseu Valter Fazaro.

Figura 2: Observar os dados do selo do projeto executivo da Escola Senac de Botucatu, concebido em 21 de janeiro de 1964, autoria de Rubens Carneiro Vianna.

Fonte: Foto Ferraz, arquivo SENAC

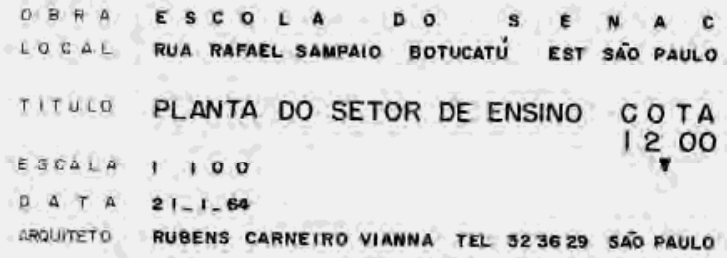




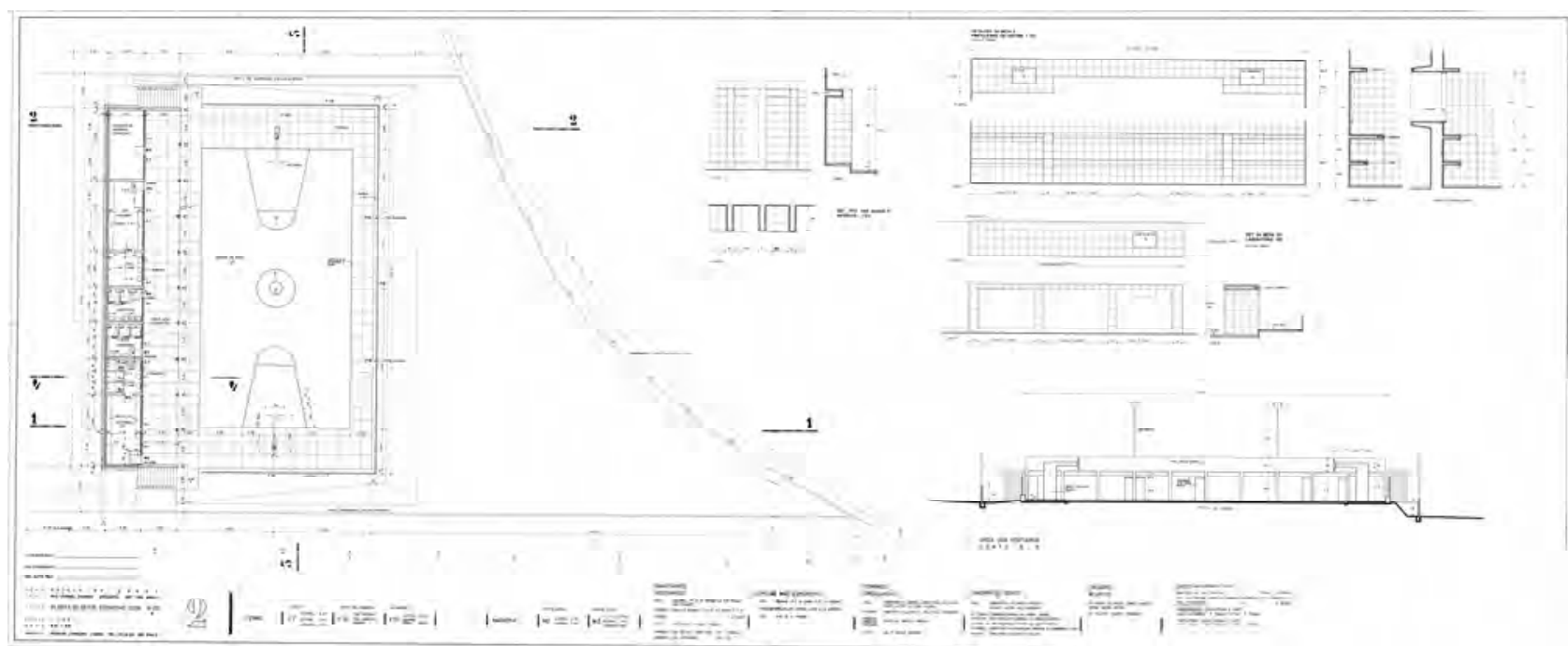

Figura 3: Prancha 2 do projeto executivo da Escola Senac de Botucatu, Planta do setor esportivo, 20/01/1964, Rubens Carneiro Vianna.

Fonte: Arquivo SENAC-SP

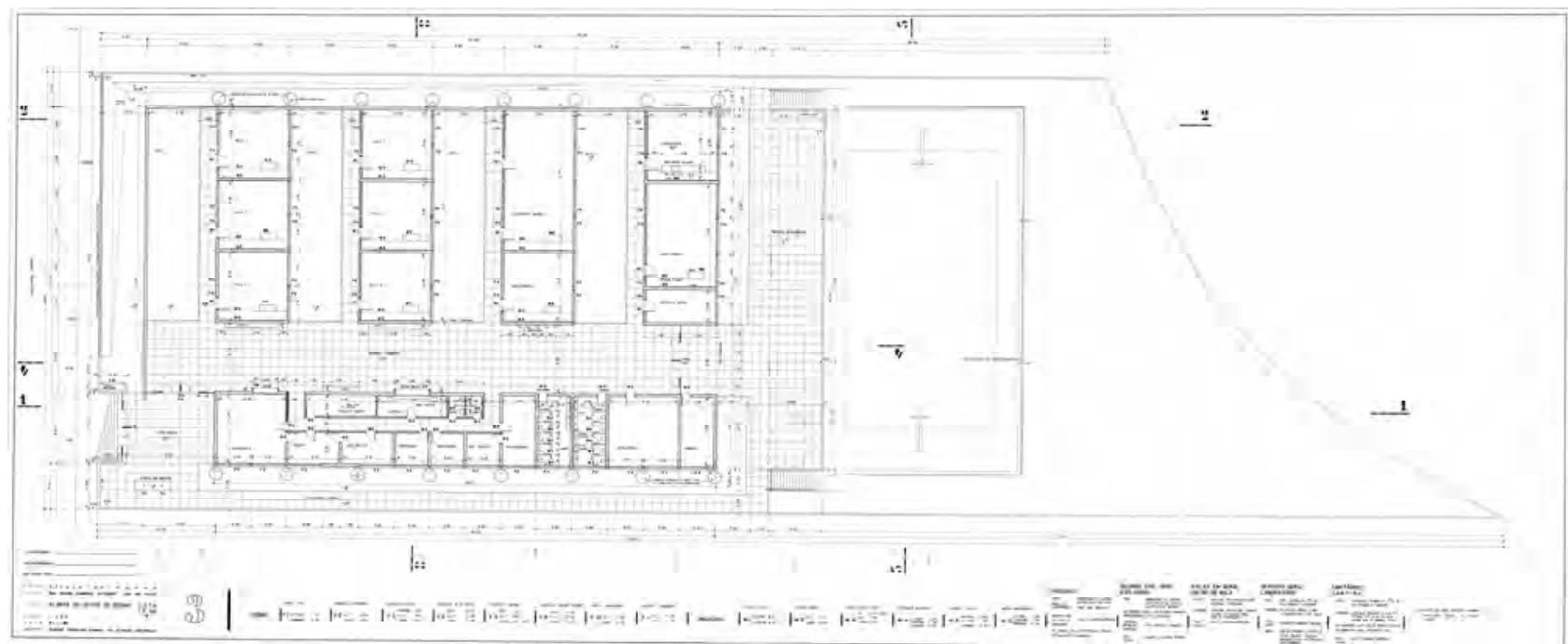

Figura 4: Prancha 3 do projeto executivo da Escola Senac de Botucatu, Planta do setor de ensino, 21/01/1964, Rubens Carneiro Vianna.

Fonte: Arquivo SENAC-SP

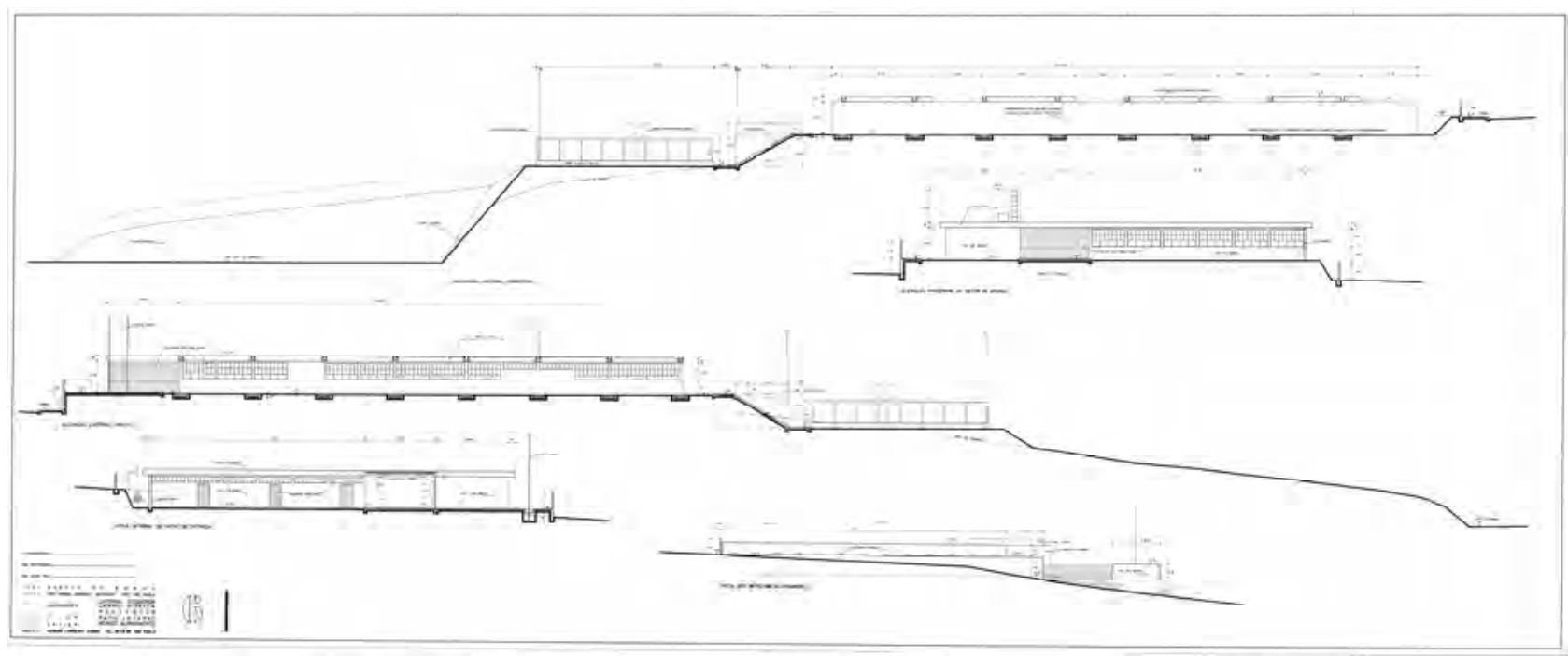

Figura 5: Prancha 6 do projeto executivo da Escola Senac de Botucatu, Elevações, 24/01/1964, Rubens Carneiro Vianna. Fonte: Arquivo SENAC-SP 
projeto foi dividido em dois setores: de ensino e esportivo. O Setor de ensino era composto pelos cinco blocos térreos, todos eles modulados com eixos de 3,30 metros $\times 6,60$ metros. $O$ primeiro bloco, perpendicular aos outros quatro, era composto pela parte administrativa, marcando a fachada e o acesso principal da escola. Este bloco, implantado de forma longitudinal no terreno, abrigava a secretaria, diretoria, vice-diretoria, duas salas de orientador, material didático, sala dos professores, biblioteca, grêmio, arquivo morto, sanitários dos alunos, sanitários dos funcionários e cantina. Todos os ambientes de uso dos alunos foram projetados com acessos independentes, como a biblioteca, os sanitários, o grêmio e a cantina, ambientes estes, voltados para o recreio coberto que era responsável por interligar este bloco aos quatro demais. Já as salas administrativas tiveram seus acessos pontuados na circulação central interna e, suas janelas restritas ao corredor lateral nordeste do bloco.

Figura 6: Planta do setor de ensino retirada da prancha 3 do projeto executivo da Escola Senac de Botucatu. Observar o bloco longitudinal da administração e os quatros blocos paralelos da escola.

Fonte: Arquivo SENAC-SP 


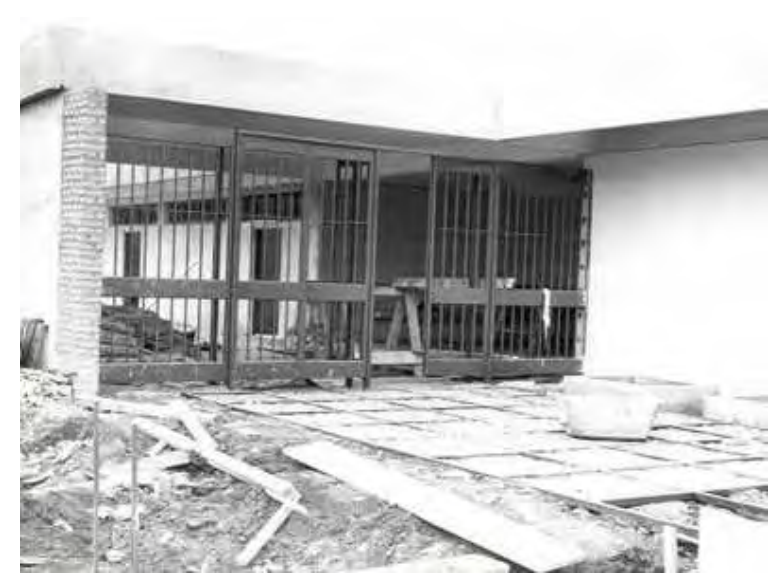

Figura 7: Portão de acesso da Escola Senac de Botucatu. Escadaria de acesso e esplanada em construção. Fonte: Arquivo SENAC-SP
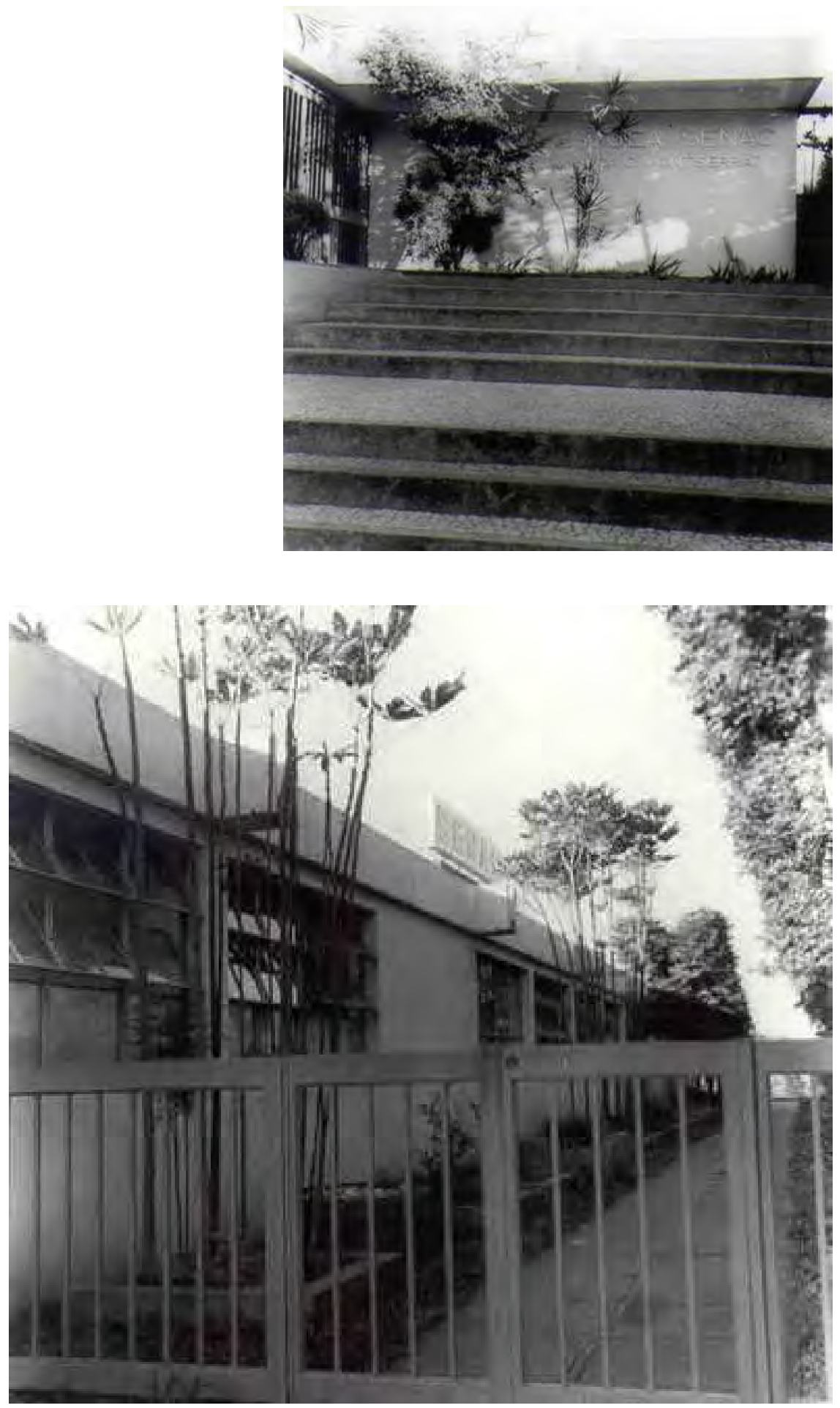

Figura 9: Corredor lateral do bloco da administração, Escola Senac de Botucatu.

Observar as janelas dos ambientes administrativos, voltadas para a face noroeste. Fonte: Arquivo SENAC-SP 
Os segundo, terceiro, quarto e quinto blocos foram projetados com as mesmas dimensões e distâncias uns dos outros, mantendo a modulação de 6,60 metros entre bloco e pátio, entre cheio e vazio. No segundo bloco, assim como no terceiro, foram projetadas três salas de aula em cada bloco, totalizando as seis salas de aula da escola. Já o quarto bloco foi dividido em dois ambientes caracterizados pelo escritório modelo e pela sala de datilografia. $\bigcirc$ quinto bloco, dividido em três salas, abrigava a laboratório, a loja modelo e o depósito geral. Todos este blocos, paralelas entre si, foram separados por pátios ajardinados, proporcionando a integração das áreas verdes ao projeto, diretamente ligadas aos ambientes de ensino.

As salas de aula, com iluminação e ventilação bilateral, tiveram janelas maiores com peitoril baixo projetadas para a face sudeste e janelas menores com peitoril alto para a face nordeste. Tal solução projetual garantiu a ventilação cruzada sem prejudicar o conforto térmico das salas, pois permitiu ampla visibilidade da área ajardinada favorecendo o sol da manhã e, ao mesmo tempo, proteção do sol da tarde nas aberturas sombreadas pelo beiral.

Figura 9: Vista sudeste do pátio ajardinado, projetado entre um dos quatro blocos

perpendiculares entre si. Escola Senac de Botucatu, 1972. Fonte: Arquivo SENAC-SP

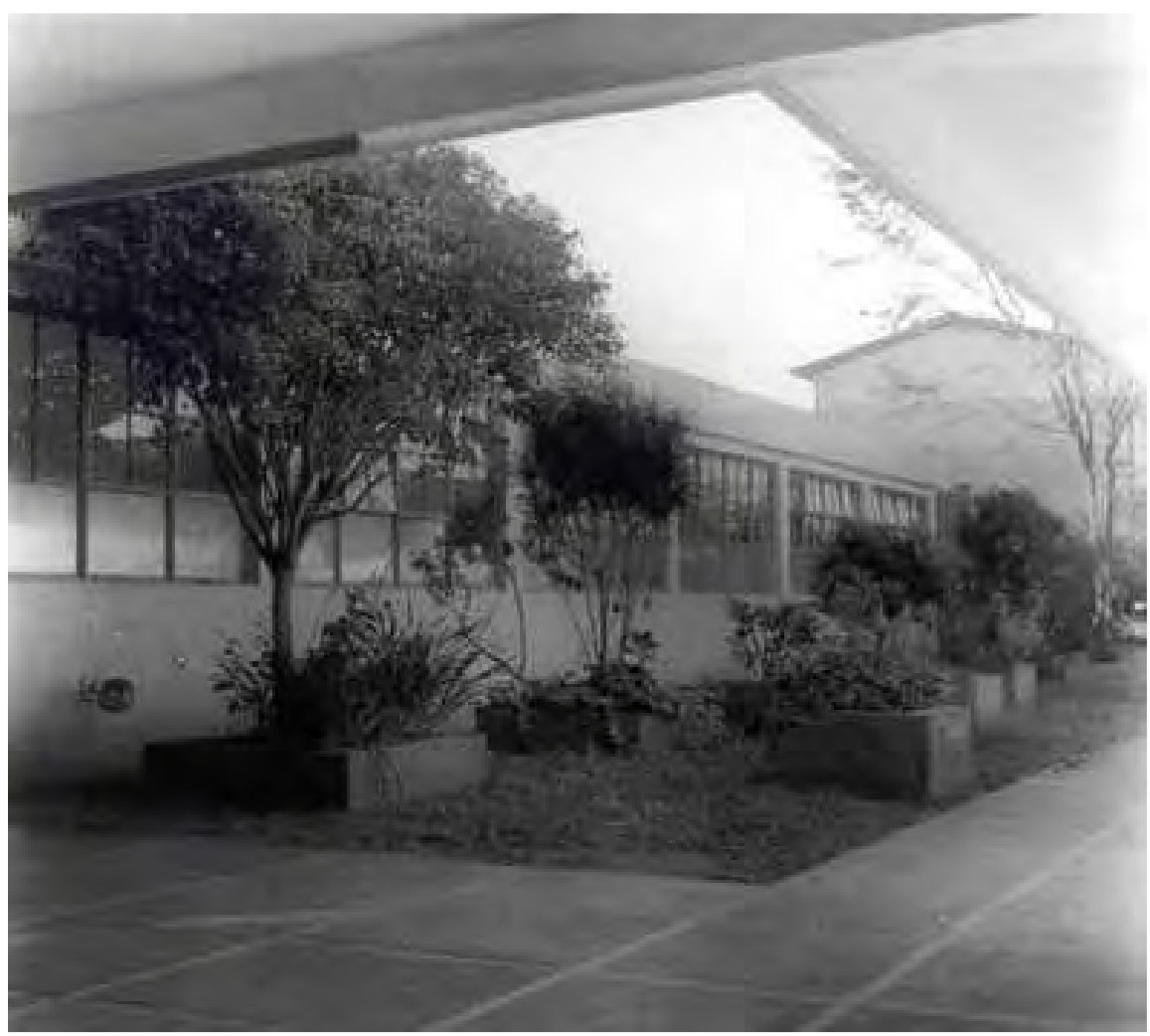




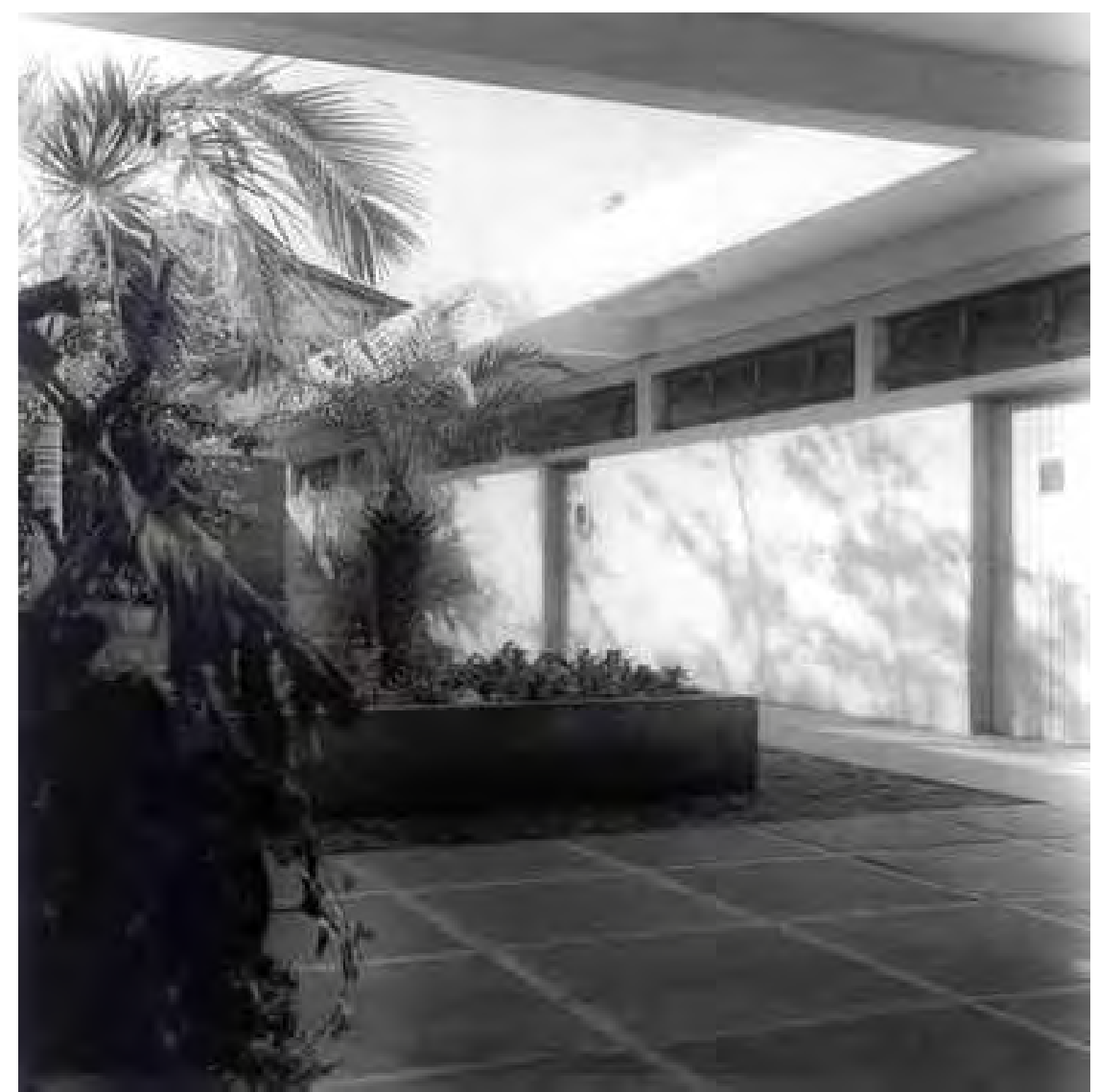

Os cinco blocos do Setor de ensino, unidos pelo recreio coberto e delimitados pelo comprimento do primeiro bloco, foram interligados ao setor esportivo pelo recreio descoberto, paralelo e ao lado do quinto bloco. Acompanhado a topografia do terreno, o setor esportivo foi projetado três metros abaixo do nível do setor de ensino e, por meio de uma escada, a quadra de jogos e suas dependências foram integradas à escola. Sob o recreio descoberto foram projetados os vestiários e sanitários esportivos, assim como o depósito de material esportivo. Atendendo à pedagogia de ser uma escola atrativa aos alunos, a área esportiva juntamente com os recreios coberto e descoberto possibilitaram a integração do ensino com a sociabilidade, através do convívio e do lazer em comum.
Figura 10: Vista nordeste do pátio ajardinado, projetado entre um dos quatro blocos perpendiculares entre si. Escola Senac de Botucatu, 1972.

Fonte: Arquivo SENAC-SP 


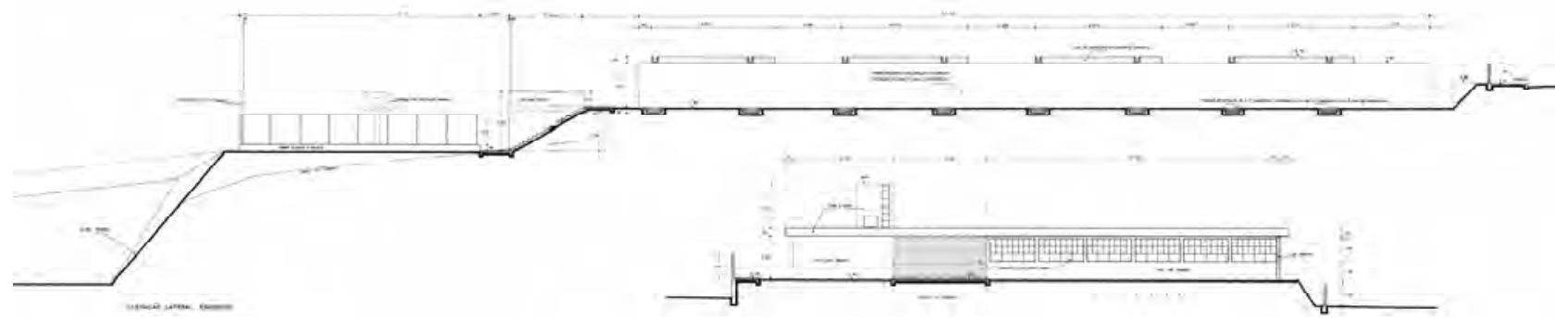

Figura 11: Elevação retirada da prancha 6 do projeto executivo da Escola Senac de Botucatu, observar a topografia do terreno e o Setor esportivo implantado três metros abaixo do nível Setor de ensino.

Fonte: Arquivo SENAC-SP

Figura 12: Construção da quadra de jogos e do bloco dos vestiários e sanitários, Escola Senac de Botucatu, 1965 Fonte: Arquivo SENAC-SP
Figura 13: Fachada principal da Escola Senac de Botucatu em 1986,vdenominada a partir de 1973 de Centro de Formação Profissional Antonio Mont'Serrat. Fonte: Arquivo SENAC-SP

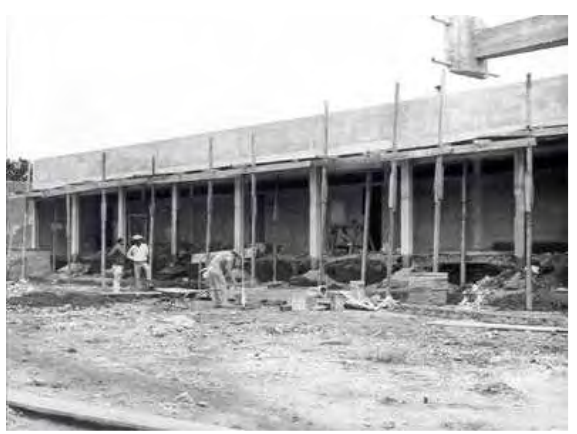

A Escola Senac de Botucatu, Inaugurada no dia 12 de novembro de 1966 e atualmente denominada de Centro de Formação Profissional Antonio Mont'Serrat, reuniu características da nova pedagogia implantada na década de 1950, respondendo algumas intenções pedagógicas como: a interligação física do ensino com os espaços ajardinados e de sociabilidade; a organização racional dos espaços distribuídos em blocos modulados; a integração entre escola, áreas verdes e esportivas, o conforto térmico da ventilação e iluminação natural nas salas de aula, dentre outros.

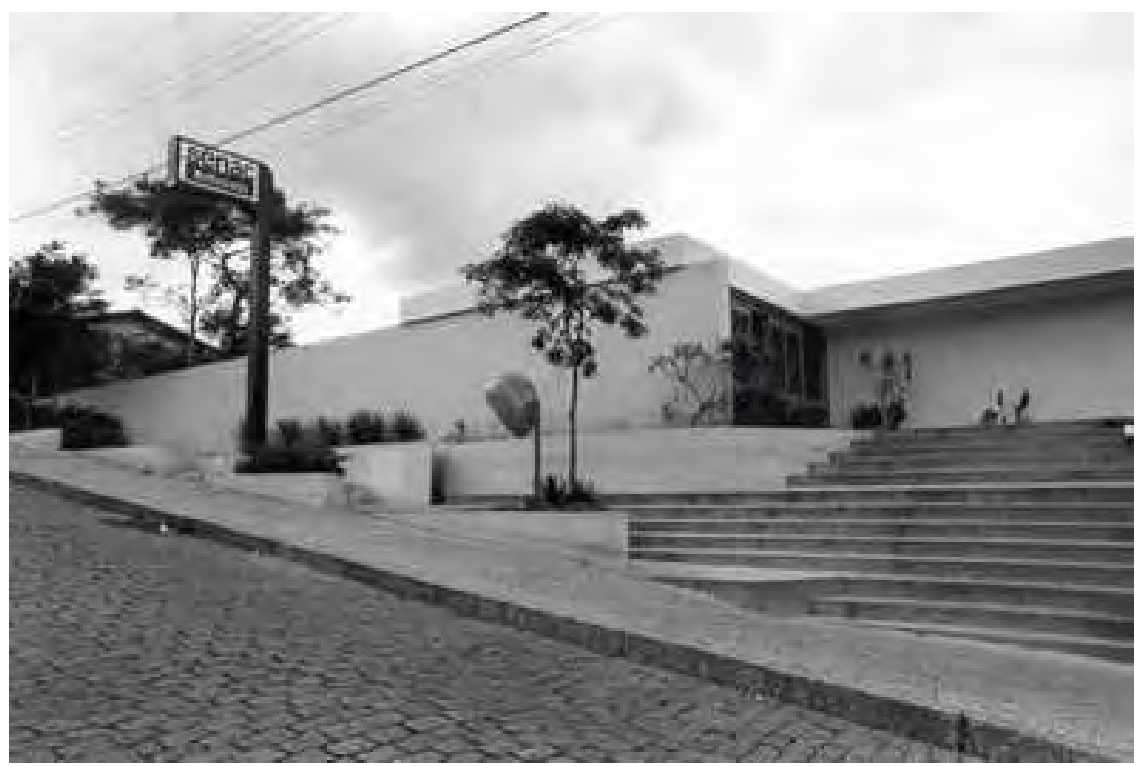




\section{Princípios técnicos, educativos e arquitetônicos da "Escola Nova" dos "S"}

Ao explorar a maneira como os " $\mathrm{S}$ " expressaram na arquitetura de suas escolas as estratégias dos agentes sociais envolvidos em sua construção, é preciso pesquisar o papel destes agentes na construção dos princípios técnicos, educativos e arquitetônicos presentes na sua concepção.

A aceleração do crescimento de São Paulo, com a urbanização e industrialização, característicos dos meados da década de 1940, não por acaso, ocorre no mesmo período em que os "S" foram criados. Dentro deste contexto, as primeiras escolas dos "S", na formulação de seu modelo de ensino no segundo pós-guerra, já tem por base a difusão do paradigma técnico-econômico tayloristafordista'. Na década seguinte, a de 1950, com a consolidação e ampliação de seu trabalho, as modernas escolas "S" buscam formar trabalhadores para uma sociedade que já não falava só em organização racional do trabalho e desenvolvimento tecnológico, mas também em democracia e em reforma social,

De fato, após o levantamento de dados e a leitura projetual de cada escola "S", é fundamental compreender como esta arquitetura moderna brasileira dialogou com o paradigma técnico-econômico, as propostas pedagógicas e a ensejo de seus idealizadores no modo de fazer o edifício-escola. Afinal, os "S" não ficaram limitados apenas à sua função no campo da arquitetura escolar mas passaram a ser em si mesmos "Escolas Novas".

\footnotetext{
1 A noção de paradigma técnico-econômico mapeia todo um campo de debates na história social do trabalho e da tecnologia. Neste caso, a noção de paradigma adotada tem por base Carlota Perez (1985 apud GITAHY, L. 2000:2) que o define como: "um conjunto de princípios do senso comum para a tomada de decisões técnicas e de inversão que se impõe durante um certo período de tempo como o mais eficiente e racional". Do ponto de vista metodológico, também julgamos interessante entender o processo de difusão de um determinado "paradigma tecnológico" como um "movimento social" de engenheiros, industriais, técnicos, gerentes, etc, como fazem diversos autores (GITAHY, L. 2000; NOBLE, 1981; MERKLER, 1980; PIORE e SABEL, 1984).
} 
Neste sentido, este capítulo parte da hipótese de que o conteúdo do ensino industrial e comercial ministrado pelos "S" está ligado aos requisitos da formação profissional característicos do paradigma técnico-econômico taylorista-fordista levando em conta os avanços da psicologia aplicada. Qual seria o trabalhador urbanoindustrial desejável no estado de São Paulo? Quais seriam os "requisitos" do mercado de trabalho da época? Que indústria e que comércio eram aqueles? Qual o perfil deste jovem que se inscrevia para os cursos do SENAI, SESC e SENAC? Pensando nestes requisitos é importante notar que este paradigma técnico-econômico nasce nos Estados Unidos, no final do século XIX, no momento da reestruturação produtiva conhecida como Segunda Revolução Industrial. Mas, ao período estudado, especialmente após a Segunda Guerra Mundial, difunde-se pelo mundo todo, em primeiro lugar, pela própria Europa. Em São Paulo, pioneiros do industrialismo como Roberto Simonsen e Roberto Mange, debatiam a racionalização e administração científica no IDORT, desde os anos da Primeira Guerra. No plano das idéias, o Brasil estava em contato com a modernidade. No entanto, é só nos anos aqui estudados, desde a década de 1940, que estes pressupostos chegam ao terreno das práticas de gestão do trabalho. Assim, O SENAI, SESC e SENAC têm um papel fundamental na formação do trabalhador brasileiro dentro das referidas premissas.

Já o sistema pedagógico empregado teve outras bases, tendo sido adotados métodos pedagógicos modernizadores do ensino industrial e comercial, promovidos por Anísio Teixeira e seus companheiros do movimento pela Escola Nova, baseados nas idéias de John Dewey. Sendo assim, na segunda parte deste capítulo, despontam inúmeras questões merecedoras de investigação: As características pedagógicas implantadas pelos "S" foram baseadas naquela pedagogia de referência norte-americana? Quais seriam as repercussões destes métodos no ensino industrial e comercial brasileiro? E ainda mais claramente, como os aspectos educacionais poderiam estar relacionados aos sete princípios da filosofia arquitetônica das modernas escolas "S"? De fato, tais indagações exploradas de forma cautelosa no decorrer deste capítulo. Porém, é certo que a arquitetura destas escolas foi norteada por uma nova 
pedagogia, como evidenciam os capítulos 1 e 2, que trazia em seu bojo tanto o americanismo ${ }^{2}$, quanto a modernização do ensino brasileiro.

Por fim, considerando as análises da historiografia da arquitetura moderna brasileira, que aponta o papel das obras em tela para a construção de uma ideologia de progresso e de nacionalidade, cabe indagar o sentido da moderna arquitetura paulista das escolas "S", dentro do período em estudo. Em termos do edifício-escola, de que maneira os arquitetos e engenheiros buscavam responder aos conceitos pedagógicos implícitos no modo de fazer uma nova escola? Qual o alcance do trabalho destes idealizadores e de suas escolas? Vale aqui enfatizar o papel deste grupo de profissionais no contexto de sua geração tanto na construção das escolas dos "S" como na arquitetura moderna brasileira enquanto resposta própria, nacional aos problemas de seu tempo.

2 O termo "americanismo" foi utilizado pela primeira vez por Antônio Gramsci, em 1934, no seu famoso texto Americanismo e Fordismo (GRAMSCI, 2001 :239-322). Como enfatiza Harvey (2006:121-122) o líder comunista italiano observa em seus Cadernos de Cárcere que estes dois termos - americanismo e fordismo - "equivalem 'ao maior esforço coletivo em criar, com velocidade sem precedentes, e com uma consciência de propósitos sem igual na história, um novo tipo de trabalhador e um novo tipo de homem'. Os novos métodos de trabalho 'são inseparáveis de um modo específico de viver e de pensar e sentir a vida'. Questões de sexualidade, de família, de formas de coerção moral, de consumismo e de ação do Estado estavam vinculadas, ao ver de Gramsci, ao esforço de forjar um tipo particular de trabalhador' adequado ao novo tipo de trabalho e de processo produtivo". 


\title{
3.1 Paradigma técnico-econômico \\ na formação do trabalhador: \\ taylorismo, fordismo e psicologia aplicada
}

\begin{abstract}
"The essential idea is to treat the diffusion process of the new paradigm as a social movement: of engineers, entrepreneurs, managers etc., as an inflexion point in the so-called 'rationalization movement'. In the case of the diffusion of Taylorism, not only the managers, but also the trade unions, in the case of the so-called welfare societies, participate in the movement. From there, new questions appear now, in which socioeconomic context, and through which means and social groups, are these ideas and practices disseminated".
\end{abstract}

(GITAHY, L., 2000: 2)

Dentro do "paradigma técnico-econômico" que se difundia rapidamente em todo o mundo no segundo pós-guerra, três elementos combinados e entrelaçados formaram a base da organização de trabalho: taylorismo, fordismo e psicologia aplicada.

Enfaticamente o SENAI, conforme afirma WEINSTEIN (2000), adotou estes três elementos dentro do enfoque racional para a capacitação profissional, mas muitas vezes teve que revisar suas práticas para atender a novos processos e estratégias de trabalho. Para atingir ao objetivo da racionalização - produzir as melhores mercadorias no menor tempo e com o menor esforço - era necessário melhorar as relações humanas no local de trabalho. A importância da arquitetura crescia neste sentido. Na visão da autora (WEINSTEIN, 2000: 25), o termo "racionalização" abrange uma variedade de estratégias para a reorganização do trabalho, recusando métodos empíricos pautados na prática e na tradição, em favor de princípios 
"científicos"3. Assim, os industriais aplicaram as estratégias do taylorismo ${ }^{4}$.

Os elementos-chaves do sistema de Taylor eram a simplificação das tarefas e a individualização da força de trabalho. Muitos dos elementos associados ao mesmo tiveram impacto na organização industrial nos Estados Unidos, na Europa (especialmente depois da Primeira Guerra) e posteriormente na América Latina. Segundo BRAVERMAN (1977: 103-109), há três princípios ligados ao taylorismo, especificamente sobre o termo "Gerência Científica do Trabalho". Para o autor, trata-se de retirar do trabalhador qualquer decisão no curso do trabalho: dissociar o processo de trabalho das especialidades dos trabalhadores (dissolver a noção de ofício), separar o trabalho manual do intelectual (separação entre concepção e execução) e, por fim, utilizar o monopólio do conhecimento como forma de controle dos processos e modos de execução.

Na visão de PURSELL (1981:163), o sistema Taylor, então denominado "gestão científica" ou "administração científica do trabalho", tinha o objetivo de aumentar a produtividade (norteamericana) e eliminar os conflitos entre trabalhadores e empregadores. Também, com relação ao trabalho dentro da oficina, o autor coloca que o sistema taylorista incluía uma reorganização da fábrica, um estudo cronometrado das tarefas individuais e a recompensa de um salário maior para encorajar os trabalhadores a obter uma alta produtividade. $\bigcirc$ processo de trabalho era concebido em um escritório de planejamento central responsável pela delimitação de cada tarefa e fornecimento de matéria-prima e dos instrumentos adequados. Desta forma, iá não era papel do trabalhador, por exemplo, encontrar o seu próprio material ou limpar e guardar suas próprias ferramentas.

\footnotetext{
${ }^{3}$ BRAVERMAN (1977:82-83) afirma que: "A gerência científica, como é chamada, significa um empenho no sentido de aplicar os métodos da ciência aos problemas complexos e crescentes do controle do trabalho nas empresas capitalistas em rápida expansão. Faltam-lhe as características de uma verdadeira ciência porque suas pressuposições refletem 'nada mais que a perspectiva do capitalismo com respeito às condições de produção'. [...]. Investigar não o trabalho em geral, mas a adaptação do trabalho às necessidades do capital".

${ }^{4}$ Algumas publicações circulavam no Brasil na primeira metade do século XX sobre os métodos de trabalho industrial, tais como o livro, publicado em 1911, Princípios da Administração Científica, do engenheiro-mecânico norte-americano Frederick Winslow Taylor.
} 
"By standardizing working conditions and by timing each task in the factory, Taylor believed he had turned management into a science. He argued that there was 'one best way' to do every kind of work and that it was best determined by management".

(PURSELL, 1981: 167)

No contexto brasileiro, as principais estratégias tayloristas tais como a simplificação e a divisão de tarefas, assim como a concentração das decisões técnicas nas mãos da gerência e a associação entre salários e produtividade, contribuíram na concepção de ensino dos "S". Por outro lado, é certo que a visão mecânica do taylorismo das características físicas e psicológicas do homem, não foram implantados na concepção dos "S" modernos. No Brasil, vale lembrar que os conceitos básicos do taylorismo - eficiência, cooperação e racionalidade - já vinham sendo promovidos pelo IDORT, do qual Roberto Mange havia sido um dos fundadores. A idéia de produzir mais e melhor em um tempo mais curto era o objetivo básico da postulada racionalização do trabalho, almejado principalmente pelo SENAI, voltado à industrialização do país.

\footnotetext{
"A difusão das técnicas tayloristas ocorre no país natal de Taylor no $1^{\circ}$ quartel deste século (XX). Neste momento, tanto dirigentes industriais quando operários qualificados procuram reorganizar as relações de trabalho dentro da fábrica: se os primeiros desejavam quebrar a crescente autonomia dos segundos, obtida em função do ascenso do movimento sindical americano, estes almejavam ampliar sua esfera de interferência na definição das condições de trabalho".
}

(RAGO \& MOREIRA, 2003: 39)

Dentro deste paradigma, a idéia de cooperação adotada fundamentava-se na promoção de boas relações no ambiente de trabalho, entre patrões e empregados. Eficiência, cooperação e racionalidade eram promovidas visando evitar acidentes de trabalho, o desperdício do próprio tempo, bem como da energia, do trabalho, dos equipamentos, enfim, dos recursos humanos e físicos. 
"Não há dúvidas de que, privilegiando a produtividade e a rentabilidade, os tayloristas e fordistas estavam exprimindo uma preferência com óbvias conotações políticas, mas sempre tendo o cuidado de disfarçá-la com a linguagem da ciência e de sua contribuição para o bem-estar social".

(WEINSTEIN, 2000: 75)

Já o fordismo associa-se a figura de Henry Ford (1863-1947), para o qual os trabalhadores deveriam ter valores morais e sociais adequados e internalizar o senso de disciplina para ter um bom desempenho no trabalho industrial. $\bigcirc$ fordismo implicava num maior envolvimento do industrial no desenvolvimento de serviços sociais, instrução e atividades de recreação para trabalhadores.

"Uma condição essencial para conseguir unir o melhor rendimento à maior humanidade na produção, é dispor de acomodações amplas, limpas e devidamente ventiladas. Nossas máquinas são colocadas muito perto uma das outras. [...]. Oficina não é jardim de recreio. Esta aproximação das máquinas requer, naturalmente, um máximo de salvaguarda e arejamento".

(FORD, s.d.: 93)

Segundo HARVEY (1989:121-122), o fordismo tem como data inicial simbólica o ano de 1914 "quando Henry Ford introduziu seu dia de oito horas e cinco dólares como recompensa para os trabalhadores da linha automática de montagem de carros que ele estabelecera no ano anterior em Dearbon, Michigan". Porém, o autor esclarece que o modo de implantação do fordismo foi muito mais complexo do que isso. Segundo o autor:

"Era tal a crença de Ford no poder corporativo de regulamentação da economia como um todo que sua empresa aumentou os salários no começo da Grande Depressão na expectativa de que isso aumentasse a demanda efetiva, recuperasse o mercado e restaurasse a confiança da comunidade de negócios. Mas as leis coercitivas da competição se mostraram demasiado fortes mesmo para o poderoso Ford, forçando-o a demitir trabalhadores e cortar salários. Foi necessário o 
New Deal de Roosevelt para salvar o capitalismo fazendo através da intervenção do Estado, o que Ford tentara fazer sozinho".

HARVEY (1989:121-122)

O fordismo foi muito influente na indústria automobilística no mundo todo. Vale lembrar que a própria Ford Motor Company está instalada no Brasil desde 1919, inicialmente realizando importação de veículos automotivos. Neste sentido, cabe lembrar dois princípios plicados por Ford, presentes no seu livro My life and Work (1922:80), em relação ao ambiente de trabalho: a redução dos pensamentos por parte do trabalhador e a redução de seus movimentos ao mínimo necessário para o cumprimento das tarefas. Tais princípios, em seu tempo, fazem referência à economia, no sentido do tempo e do espaço:

"The principles of assembly are these:

(1) Place the tools and the men in the sequence of the operation so that each component part shall travel the least possible distance while in the process of finishing.

(2) Use work slides or some other form of carrier so that when a workman completes his operation, he drops the part always in the same place - which place must always be the most convenient place to his hand - and if possible have gravity carry the part to the next workman for his operation".

(FORD, 1922:80)

Nos "S" a idéia de percorrer menores distâncias, tanto quando fosse possível, fazia parte da concepção das instalações das escolas e das próprias oficinas, no caso do SENAI. Dentre muitos aspectos, o que distingue o fordismo do taylorismo, ao ver de HARVEY (1989), é justamente a visão de Ford de uma nova sociedade:

"[...] seu reconhecimento explícito de que produção de massa significava consumo de massa, um novo sistema de reprodução da força de trabalho, uma nova política de controle e gerência do trabalho, uma nova estética e uma nova psicologia, em suma, um novo tipo de sociedade democrática, racionalizada, modernista e populista". 
Neste sentido, cabe destacar o conceito fundamental de Ford, a idéia de produção em massa para o consumo em massa. Ao mesmo tempo em que exigia alto nível de produtividade de seus trabalhadores, o salário oferecido era alto o suficiente para os trabalhadores serem além de produtores também consumidores (FORD, s.d.: 300).

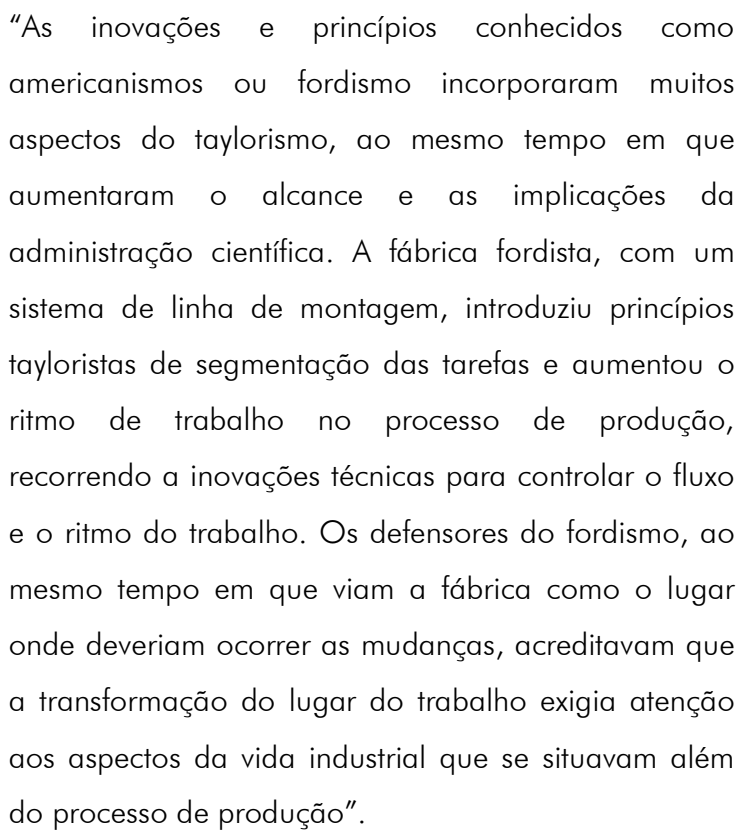

Assim, a intenção de promover o bem estar pela maior produtividade e eficiência visava, dentro do fordismo, a reorganização da sociedade e não apenas da fábrica. Assim como no sistema Ford de produção, as necessidades de serviços médicos e educacionais, as horas de lazer, os espaços de recreação, foram tendências de reforma social nitidamente presentes nas escolas "S". Vale lembrar que para disseminar o fordismo na Europa foi preciso uma revolução das relações de classe (HARVEY, 1989:124) que começou nos anos 1930, mas só deu frutos nos anos de 1950, da mesma maneira em que podemos observar que a disseminação do fordismo no Brasil, embora ocorra mais cedo no plano das idéias, só é implantada parcialmente das práticas sociais, principalmente no pós Segunda Guerra Mundial, justamente na "era de ouro" dos "S".

A questão da experiência é sem dúvida a grande "ênfase" de Henry Ford, no que diz respeito à educação. Neste compasso, os "S" 
pensavam a formação do trabalhador voltada à prática, buscando ensinar por meio da experimentação associada à teoria.

\begin{abstract}
"Ford agreed that the nation's strength rested upon our democratic institutions and technological know-how. He thought technology had been slighted in schools because few institutions taught courses in the history of technology. Most books revealed the outside of machines rather than the inside. Writers leaned toward verbalization rather than visualization. Therefore he encouraged the use of motion pictures in class rooms. The present increased interest in technology suggests that Ford was in many ways ahead of his times".
\end{abstract}

(WIK, 1972:211)

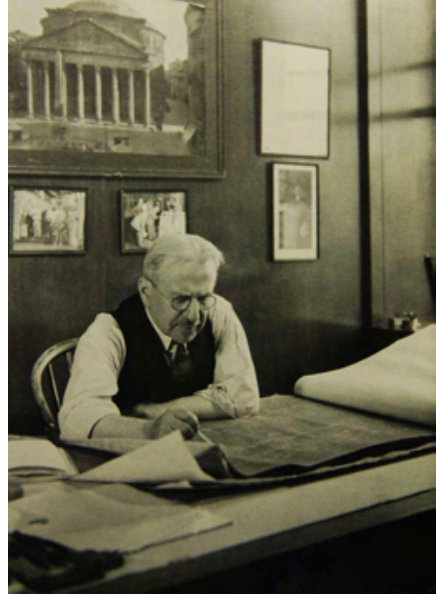

Figura 1: Albert h Kahn em seu escritório em Detroit, 1935. Fonte: KAHN (2001:11)
Outro aspecto que merece ser mencionado aqui é a ligação de Ford com a arquitetura industrial, como referência significativa para a moderna arquitetura escolar voltada à formação para o trabalhador. Segundo BUCCI (1993), autor do livro Albert Kahn: architect of Ford, a contribuição do mesmo ${ }^{5}$ (1869- 1942) para a arquitetura industrial norte - americana é caracterizada pela simplicidade de expressão nos seus projetos de espaços flexíveis para fabricação e produção. Trabalhando em Detroit, Kahn começou uma longa e próspera colaboração com Henry Ford, baseada numa visão de modernismo e indústria. Assim, denominado pelo autor como "o arquiteto de Ford", Kahn já pensava num edifício correspondente aos avanços da máquina e da própria arquitetura ${ }^{6}$.

\footnotetext{
${ }^{5}$ Albert Kahn nasceu em 21 de março de 1869, em Rhaunen, uma pequena cidade perto de Mainz, na Alemanha. Ele viveu sua infância em Echternach até o ano de 1880 quando se mudou com sua família para os Estados Unidos, Detroit. Em 1884 iniciou sua carreira trabalhando na firma de arquitetura Mason e Rice, em Detroit, até o ano de 1895, quando fundou sua própria firma. Em 1908, Kahn foi contratado por Henry Ford para projetar a nova fábrica em Highland Park, em Detroit para introduzir - recém-criado Modelo T. A partir daí muitos projetos foram concebidos, principalmente no desenvolvimento de fábricas norte-americanas. A imensa trajetória e a arquitetura desenvolvida por Kahn podem ser exploradas no livro The Legacy of Albert Kahn, 1970, publicado pelo Instituto de Artes de Detroit.

${ }^{6}$ Kahn rapidamente estabeleceu - se como um arquiteto capaz de responder às novas exigências da produção maciça, utilizando o sistema patenteado de concreto reforçado desenvolvido por seu irmão, o engenheiro Julius Kahn. Guiado por princípios funcionalistas e um senso de organização fabril, Kahn antecipou as operações de linha de montagem e desenvolveu novas características tipológicas para a fábrica moderna. $O$ arquiteto é autor de importantes projetos como: Ford Motor Company River Rouge Plant, Dearborn, Michigan; Burroughs Adding Machine Company, Detroit, Michigan; Tractor Plant, Stalingrad, Russia; General Motors Building, Feira Mundial de Chicago; e Kellogg Company, Battle Creek, Michigan (BUCCl, 1993).
} 
"These exchanges, from which Kahn gained ideas for specific and autonomous elaborations and design management, offered a basis for a 'Fordization' of the firm itself and for its projects as well".

(BUCCl, 1993:125)
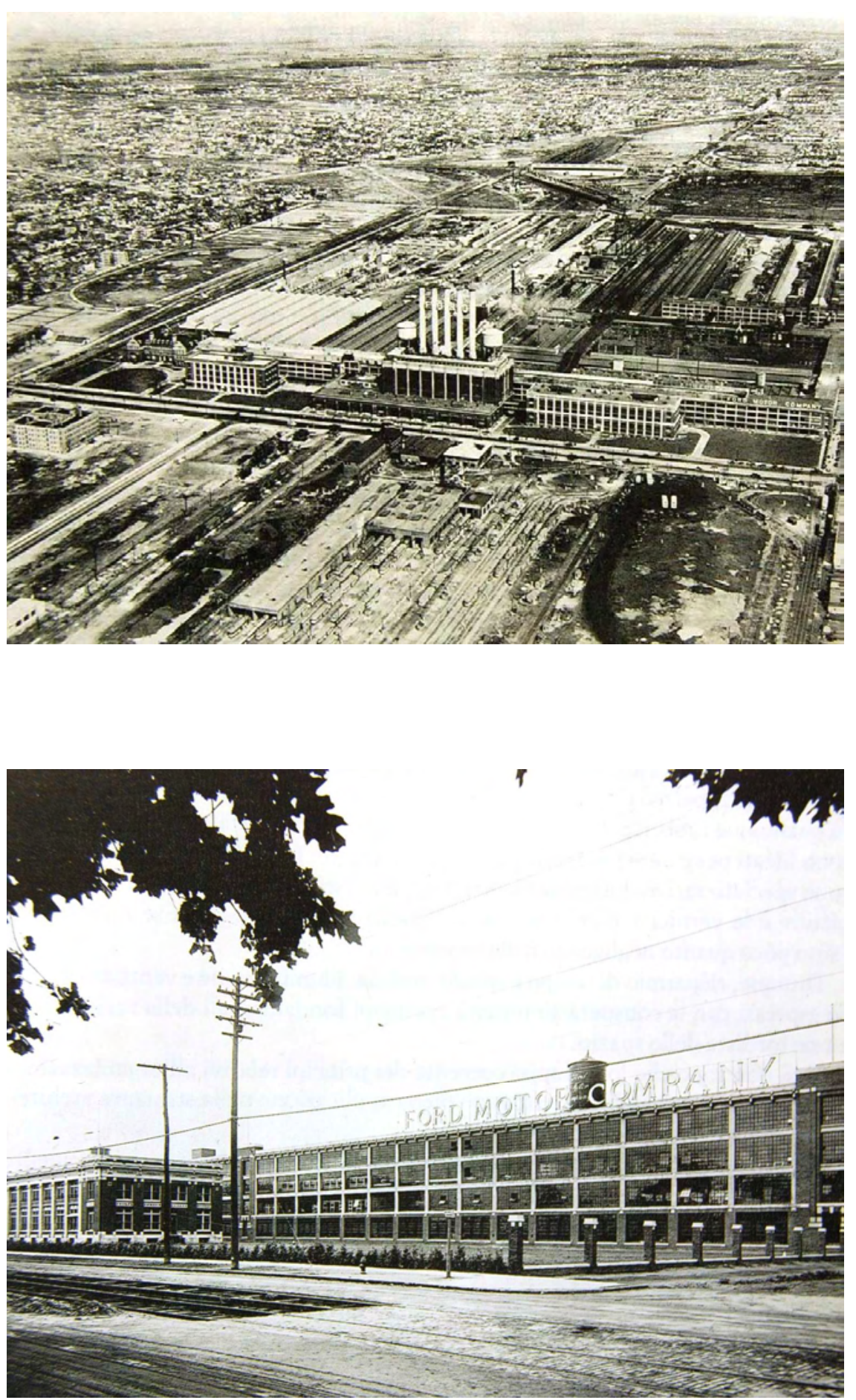

Figura 2: Vista aérea da Ford Motor Company Highland Park, Michigan, 1915.

Fonte: $\mathrm{BUCCI}$ (1993:18)
Figura 3: Albert Kahn e Ernest Wilby. Edifício original da Ford Motor Company Highland Park, Michigan, 1909. Fonte: BUCCI (1993:19) 
Figura 4: Vista aérea da General Motors Building, Feira Mundial de Chicago, 1933

Fonte: BUCCI (1993:74)

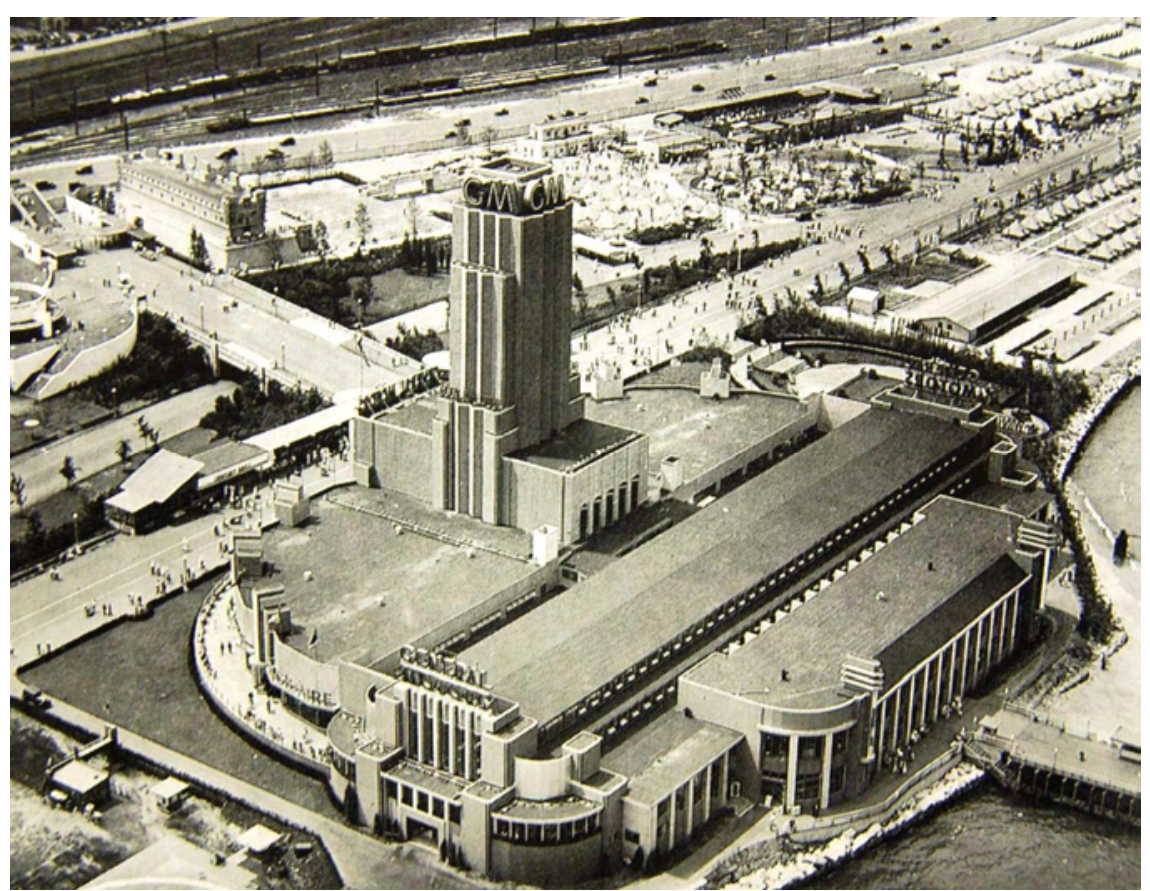


Neste sentido BUCCI (1993:35) afirma a importância dos projetos industriais de Kahn para a arquitetura moderna, enfatizando a adoção da estrutura em concreto armado e a flexibilidade do espaço interno visando a organização no processo de produção.

\footnotetext{
"Yet, the resolution of the internal-external relationship corresponded to the manifestation of the construction principle, and set an early precedent for the Modern Movement to follow".
}

(BUCCl, 1993: 35)

A contribuição de Albert Kahn ${ }^{7}$ é relevante a esta pesquisa por evidenciar primeiro, que a arquitetura industrial favorecida por Ford contribuiu à arquitetura moderna e, segundo, que esta arquitetura estava relacionada às origens do modernismo europeu. No que diz respeito à primeira contatação, vale ressaltar que líderes da arquitetura moderna tais como Le Corbusier e Walter Gropius citaram Kahn como influente na arquitetura por suas soluções para as mudanças industriais do seu tempo, derivadas em grande parte por seu contato com Henry Ford. Le Corbusier afirma sua posição de respeito à arquitetura industrial de Kahn em Vers une architecture (1928:26), ao publicar a foto da Ford Motor Company em Highland Parque. Familiarizado com o conceito taylorista e suas experiências concretas, Corbusier faz elogios ao fordismo e à arquitetura das fábricas da FORD, atenta às características físicas e psicológicas do homem, em Quand les cathédrales étaient blanches: voyage au pays des timides (1937:247-251). Traduzindo as palavras de Corbusier: "De Ford tudo é colaboração, unidade de pontos de vista, unidade de intenções, perfeita convergência de todos os gestos e pensamentos". Além de elogiar Ford, Corbusier enfatiza a qualidade da arquitetura industrial por ele utilizada e considera fecunda sua doutrina. Por fim, Corbusier afirma a experiência de Ford como uma lição para o mundo moderno.

\footnotetext{
7 A Kahn do Brasil Ltda é uma empresa subsidiária da Albert Kahn Associates, Inc. fundada por Albert Kahn em Detroit, EUA, em 1895. A matriz no Brasil, atuante na área de projetos industriais e hospitalares, iniciou oficialmente suas atividades em 1998, embora sua atuação tenha começado anos antes da data oficial de abertura (www.kahndobrasil.com.br).
} 
"Chez Ford, tout est collaboration, unité de vues, unité de but, convergence parfaite de la totalité des gestes et des pensées".

"A travers Ford, je raisonne: Architecture? Construire des abris. Pour qui ? Pour des hommes. Voilà le programme, Comment Exprimer ce programme dans une réalité accessible? Par les techniques. Faire des plans. Des plans réalisables aujourd'hui avec des matériaux et des machines existantes, et répondant aux besoins essentiels de l'homme. Où mettre en ceuvre concrète les virtualités des plans? Dans les usines, dans les ateliers innombrables soumis à la rigueur du contrôle industriel. Comment insuffler l'esprit à cette initiative révolutionnaire? Par l'architecture, expression de l'esprit du temps. Les temps nouveaux sont venus. Ainsi s'établit sur l'aujourd'hui vivant, une doctrine féconde: programme; technique; usines et ateliers; architecture et urbanisme"

CORBUSIER (1937:247 e 249-259 respectivamente)

A segunda constatação, complementando a primeira, segue apoiada em Reyner Banham ${ }^{8}$ (1986:181), ao afirmar que antes de projetar a renomada Fábrica Fagus, Gropius recebeu dois projetos como referência, uma da Fábrica Berverly e outra da recém projetada Fábrica Ford em Highland Park (figuras 2 e 3), de autoria de Kahn. Este fato ressalta a constatação da arquitetura do fordismo exportada como um modelo para a Europa, desde o início do século XX.

A importância desta troca de experiências entre Ford e Kahn traz à tona o papel do "paradigma técnico-econômico" fordista como uma base para a arquitetura industrial não somente nos EUA como também na Europa. Neste sentido, dentro das triangulações - Europa, Eua, Brasil - a experiência desta arquitetura industrial teve considerável impacto dois primeiros locais e, finalmente, também na América Latina. Quanto aos "S", mais diretamente nas escolas SENAI, cabe aqui entender que esta experiência educativa de base fordista privilegiou as relações da escola com a indústria e direcionou sua arquitetura à oficina-escola, focada na formação do técnico e seu trabalho na oficina.

\footnotetext{
${ }^{8}$ Banham discute a evolução do projeto da Fábrica Fagus no livro A Concrete Atlantis: U.S. industrial building and European modern architecture, 1900-1925 (1986), publicado em Cambridge, Massachusetts.
} 
Por fim, um terceiro elemento da base de organização do trabalho, complementar ao taylorismo e ao fordismo, foi a psicologia aplicada, também denominada por BRAVERMAN (1977: 126) como psicologia industrial. Trazido ao contexto dos "S", este terceiro elemento tinha como objetivo a adaptação psicológica do trabalhador a serviço do comércio e da indústria.

Segundo o livro publicado pelo SENAI (1991:80) De Homens e Máquinas, um dos pioneiros da psicologia aplicada foi o alemão Hugo de Münsterberg ${ }^{9}$, com sua obra Psicologia e Eficiência Industrial (publicada na Alemanha em 1912), referência aos que iriam se dedicar a este ramo de conhecimento. Entretanto o ponto crucial no ato de repensar a educação estava justamente na redefinição de sua finalidade social. E, neste sentido, as mudanças na educação foram diretamente influenciadas pelas idéias do pensador norte-americano John Dewey ${ }^{10}$ :

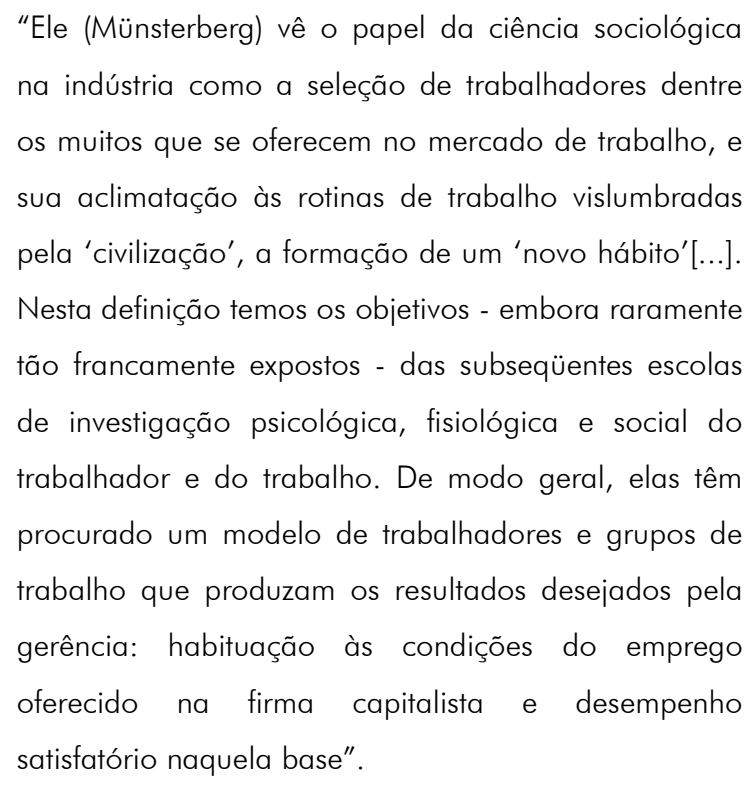

(BRAVERMAN, 1977: 127)

\footnotetext{
9 Segundo BRAVERMAN (1977: 126), a psicologia experimental começou a ser ensinada na Alemanha, no século XVIII, em especial na escola de Psicologia da Universidade de Leipzig. Assim, Hugo Münsterberg foi inicialmente preparado nesta instituição e depois foi para os Estados Unidos onde, em Harvard, observou "o desenvolvimento da gerência moderna em suas formas mais vigorosas e amplas, e se tornou ambição sua consorciar os métodos da escola de Leipzig com a nova prática da gerência científica".

10 Conforme abordado anteriormente, Dewey criou a escola-laboratório na Universidade de Chicago, considerada a primeira escola experimental na história da educação, tendo, no Brasil, como seguidores, os educadores Lourenço Filho e Anísio Teixeira. Também, pautou as idéias dos envolvidos no Convênio Escolar, celebrado entre o Estado e a Prefeitura de São Paulo, em 1948.
} 
A psicologia aplicada visava oferecer instrumentos racionais e "científicos" para determinar as qualificações dos candidatos a emprego. Além disso, no que diz respeito à eficiência, o ambiente de trabalho deveria atender às necessidades psicológicas e fisiológicas do trabalhador, proporcionando as melhores condições no local de trabalho para atingir ao objetivo da racionalização (produzir melhores produtos no menor tempo e com o menor esforço).

A concepção de espaço propício ao trabalho enfatizada pela psicologia aplicada pode ser observada como parte inerente das escolas "S" da década de 1950. Estas buscavam formar uma comunidade para receber e preparar cada jovem e/ou adulto como membro engajado em cooperar e servir, e, ao mesmo tempo, provendo capacitação para a direção própria de cada um, desenvolvendo desta forma, a aptidão de pensar.

Desta maneira, o taylorismo e o fordismo, somados à psicologia aplicada, formavam a base intelectual da discussão internacional sobre a gestão do trabalho que se fortaleceu desde o final da Primeira Guerra Mundial. No Brasil, os industriais e engenheiros de São Paulo estavam sintonizados com o debate internacional a respeito da racionalização. As idéias atravessaram as fronteiras desta sociedade em processo de industrialização e, ao mesmo tempo, a organização racional do trabalho se tornou passível de modificação dentro do contexto nacional específico brasileiro, conforme avançam as décadas de 1950 e 1960. 


\title{
3.2 Educação:
}

\section{elo da modernização no ensino brasileiro}

\author{
"Não é absolutamente uma pequena conquista o fato \\ de se considerar as plantas, hoje em dia, como \\ elemento integrante da arquitetura escolar. A escola- \\ monumento, a escola majestosa e austera, está \\ cedendo seu lugar à escola alegre, horizontal, no meio \\ dos jardins".
}

(TEIXEIRA, 1951: 176 in Habitat)

A arquitetura como parte de um sistema pedagógico, no qual os três "S" modernos foram construídos, consegue em sua própria trajetória projetual reconhecer a interface consistente com a educação. Ao tomar conhecimento dos métodos pedagógicos de modernização no ensino industrial e comercial brasileiro, embasados em John Dewey (1859-1952) ${ }^{11}$ e no seu aluno Anísio Spinola Teixeira (1900-1971), é importante reconhecer como os "S" não ficaram limitados apenas à sua função no campo da arquitetura escolar, mas passaram a ser em si mesmos "Escolas Novas" fundamentadas nestes princípios educacionais.

É neste sentido que se busca capturar o diálogo entre educação e arquitetura no caso em estudo. Estas escolas objetivaram alcançar um incentivo permanente no plano da educação, enunciando alguns princípios que pautaram a nova arquitetura escolar de cada Serviço. Assim, no decorrer desta pesquisa, ao analisar nos arquivos dos Serviços SENAI, SESC e SENAC os projetos arquitetônicos concebidos nas décadas de 1950 e 1960, percebe-se com freqüência como os "aspectos americanos de educação"12

\footnotetext{
11 John Dewey, filósofo e pedagogo norte-americano, nasceu em Burlington, Estado de Vermont. Foi inicialmente professor primário no interior e a partir da reflexão pedagógica desenvolveu seu pensamento. (KOOGAN, 1973, p.1610-1611). Lecionou na Universidade de Minnesota (1888), de Michigan (1889-1894), de Chicago (1894-1904) e finalmente passou a chefiar o Departamento de Filosofia da Columbia University, em Nova lorque (1904-1929), onde Anísio Teixeira o encontrou e foi seu aluno.

12 A expressão entre aspas refere-se ao título de um dos livros de Anísio Teixeira, publicado em 1928. Cabe lembrar que a psicologia aplicada (já apresentada na
} 
divulgados no Brasil por Anísio Teixeira estão presentes na concepção destas escolas. Porém, nota-se que este aspecto ainda não foi investigado sistematicamente no que diz respeito ao sistema "S", o que motivou a iniciativa de explorar, ao menos de forma preliminar, a vasta documentação disponível de Anísio Teixeira, assim como de seu professor John Dewey.

\subsubsection{Os educadores John Dewey (1859-1952) e Anísio Teixeira (1900-1971): um levantamento inicial}

Não se pretende aqui estudar a contribuição pedagógica destes importantes educadores. A bibliografia existente sobre ambos os educadores é vasta. Um levantamento inicial dos livros de autoria de Anísio Teixeira e John Dewey foi realizado na biblioteca da Faculdade de Educação da Universidade de São Paulo, na biblioteca Anísio Teixeira da Universidade Federal da Bahia e nas bibliotecas da Columbia University em Nova York. É nítido como a produção científica deste último educador foi desenvolvida, em sua maioria, nas 
regiões brasileiras em que Anísio Teixeira ${ }^{13}$ atuou, Rio de Janeiro, Brasília e Bahia, além dos Estados Unidos. A intenção desta trilha de pesquisa foi antes registrar e documentar a importância destes dois nomes nas opções pedagógicas dos "S" paulistas, localizando mais um elo ligando a arquitetura à modernização do ensino técnico brasileiro. Este levantamento inicial indica que há excelentes possibilidades de avanço destas questões em pesquisas futuras.

Vale lembrar que, anterior a toda a produção historiográfica sobre o educador Anísio Teixeira, deve-se uma atenção especial à bibliografia sobre John Dewey. Segundo Teixeira (1952:5) "em Dewey, há uma luminosa concepção da escola como parte inerente ao processo social total", assim como uma "renovação pedagógica mundial" de suma importância para compreender a disseminação de suas idéias na vida pedagógica em diversos países, dentre eles 0 Brasil. As idéias de Dewey foram impressas em diversos idiomas, resultando em livros escritos em francês, italiano, alemão, espanhol, búlgaro, grego, turco, russo, sueco, húngaro, japonês, chinês, árabe e português. Teixeira foi o grande tradutor das teorias do mestre, procurando atender à intenção de cada termo da filosofia da educação renovada norte-americana. Assim, entre suas obras, destacam-se no Brasil as traduções para o português supervisionadas por Anísio, além de Vida e Educação (1952), outras como: Como pensamos (1933) e Democracia e educação (1959). Estas obras foram traduzidas dentre as muitas publicações de Dewey ligadas à educação, como: Psychology (1886), My pedagogic creed (1897), School and Society (1900), Psychology and social practice (1901), Child and the curriculum (1902), Educational situation (1902), Interest as related to will (1903), School and the child (1907), Ethical principles underlying education (1909), How we think (1910), Interest and effort in education (1913), Schools of to-morrow (1915), Democracy and Education: an introduction to the philosophy of education (1916) e Human nature and conduct (1922).

As referências bibliográficas do filósofo e educador norteamericano John Dewey, juntamente com as de Anísio Teixeira,

\footnotetext{
${ }^{13}$ Anísio Teixeira foi professor de Filosofia da Educação no Instituto de Educação do Rio de Janeiro, Secretário de Educação do Distrito Federal e Secretário da Educação no Estado da Bahia.
} 
apresentam-se como importante fundamento para um posterior aprofundamento do estudo proposto, principalmente diante da vasta bibliografia encontrada sobre Dewey na biblioteca do Teacher's College na Columbia University, coletamos estas referências visando antes de mais nada o objeto de estudo, a arquitetura das escolas dos "S". Assim, juntamente com as colocações dos autores sobre a relevância do ambiente físico para a educação, é intrigante perceber, dentro da filosofia, como são tratados os conceitos de educação, ambiente e experiência. Segundo DEWEY (1959), a educação é um instrumento necessário à continuidade da vida social que, por sua vez, é uma contínua reorganização, renovação, reconstrução, readaptação do ambiente às necessidades dos seres vivos e viceversa, e, essa readaptação, implica a reorganização da experiência que, para o autor, é educação.

John Dewey nasceu a 20 de outubro de 1859 em Burlington, Vermont. Cursou as escolas primária e secundária de sua cidade. Graduou-se em 1879 como bacharel em artes na Universidade de Vermont, onde se interessou pela filosofia e pelo pensamento social. Dois anos depois ingressou na John Hopkins University, em Baltimore, obtendo o título de doutor em filosofia, no ano de $1884^{14}$, com a tese sobre psicologia de Kant (GEIGER, 1958). Em 1884, passou a trabalhar na Universidade de Michigan como professor até o ano de 1894. No mesmo ano, chamado pela Universidade de Chicago, tornou-se chefe do departamento de psicologia, filosofia e pedagogia, e teve a "ocasião de fundar e dirigir a University Elementary School, primeira iniciativa do gênero, onde pode por em experimentação as suas teorias de educação renovada" (FILHO in DEWEY, 1930:6). Esta Escola Elementar da Universidade foi também conhecida como EscolaLaboratório, trazendo o caráter da escola experimental na história da educação. Juntamente com sua atuação acadêmica em Chicago, Dewey também se aproximou dos sociólogos da Escola de Chicago, e com os problemas sociais e urbanos daquele centro industrial, conforme afirma a citação abaixo:

\footnotetext{
14 Em 1886 Dewey casou-se com Alice Chipman, primeira diretora da Escola Laboratório da Universidade de Chicago. Após a morte de sua primeira esposa, em 1927, Dewey casou-se novamente, em 1945, com Roberta L. Grant. (GOSSI, 2004, p.22).
} 
"Em Chicago, Dewey participou ativamente dos
trabalhos da Hull House, onde teve oportunidade de
conhecer diretamente os problemas sociais e
econômicos causados pela urbanização, pelo rápido
progresso tecnológico e pelo crescente afluxo de
imigrantes: assim teve amplo contato com operários,
sindicatos, políticos de esquerda e radicais de diferentes
orientações".

(MARICONDA, 1980:6)

É no início do século XX que Dewey, ao mesmo tempo em que dirige a instituição em Chicago, escreve intensamente sobre a teoria educacional. Em 1904, foi um ano de mudança profissional. Ao deixar Chicago, torna-se professor de filosofia do Teacher's College da Columbia University, em New York, cargo que ocupou até se aposentar, em 1929. Dewey também difundiu suas idéias por meio de conferências e cursos em diversos países como Tóquio, Pequim, México, Rússia e Turquia (LUZURIAGA, 1944:7). Em 1930, já aposentado, Dewey continuou atuando na redação de inúmeros textos, na atividade teórica e na vida pública a favor de suas idéias progressistas. Dewey faleceu aos 91 anos de idade, em 2 de junho de 1952, em New York (SMITH: 1963).

Na trajetória de Dewey, o fato é que a Universidade de Columbia foi, sem dúvida, o ponto de ligação entre Dewey e Anísio Teixeira, o local onde a filosofia norte-americana foi ensinada ao jovem educador brasileiro, na ocasião orientando de Dewey. As referências norte-americanas trazidas ao Brasil são nítidas, entre as duas viagens realizadas por Anísio Teixeira aos Estados Unidos, entre 1927 e 1929, conforme enfatiza o arquiteto Hélio Duarte:

\footnotetext{
"As viagens aos Estados Unidos proporcionaram ao jovem Anísio Teixeira três fatos igualmente duradouros em sua vida - o conhecimento do grau de adiantamento da educação naquele país; a absorção dos princípios filosóficos de Dewey e finalmente, a 'descoberta' de Monteiro Lobato".
}

(DUARTE, 1973:9-10)

Antes de se ater às diversas impressões que a América do Norte proporcionou, no campo da educação, a Teixeira, é necessário 
rever sua trajetória. Anísio Spinola Teixeira, nascido em Caetité, Estado da Bahia, em 1900, teve nítida sua atuação como: educador, professor, filósofo, teórico, advogado, ativista, renovador, administrador nos quadros do Estado (Diretor Geral da Instrução Pública no Distrito Federal e, na Bahia, criador da Universidade do Distrito Federal e fundador e Diretor do INEP), membro do Conselho Federal de Educação, Reitor da Universidade de Brasília, consultor da Fundação Getúlio Vargas, professor emérito da UFRJ e autor de inúmeras obras sobre educação. Teixeira faleceu em 1971, no Rio de Janeiro, acreditando na escola como instrumento formador do cidadão democrático e tendo desenvolvido esta idéia no Brasil por meio da "escola parque".

Já, quanto à produção bibliográfica de Teixeira, cabe destacar o relatório Aspectos americanos de educação, que contém o primeiro estudo brasileiro sistematizado das idéias de John Dewey em forma de um relatório apresentado ao Governo do Estado da Bahia pelo então Diretor Geral de Instrução, comissionado em estudos da América do Norte (TEIXEIRA, 1928). Este livro, dividido em duas partes, apresenta primeiramente os fundamentos de educação e posteriormente os aspectos americanos de educação. Vale lembrar que este relatório foi publicado após a primeira visita de Anísio aos Estados Unidos, em 1927. Durante a mesma, suas impressões da cultura norte-americana foram anotadas no seu diário de viagem. Portanto, em 1928, de volta ao Brasil, o relatório foi publicado e, no mesmo ano, Anísio volta aos Estados Unidos como aluno do curso de pós-graduação no Teacher's College da Columbia University, em New York, onde se gradua Master of Arts, em Educação. Em meados de 1929, retorna ao Brasil e redige um balanço da Reforma de Instrução na Bahia (1924-1929).

\footnotetext{
"Apresentar, pois, na Bahia, em um breve resumo, tão fiel quanto me foi possível, as idéias com que Dewey fixa o atual sentido de educação, pareceu-me meio talvez favorável, para despertar um interesse concreto pela revisão de nossas próprias concepções".
}

(TEIXEIRA, 1928:7) 
A partir de então, o educador escreveu diversos livros como: Educação progressiva: uma introdução à filosofia da educação (TEIXEIRA, 1933), Educação para a democracia: introdução à administração educacional (TEIXEIRA, 1936), Educação e a crise brasileira (TEIXEIRA, 1956), Educação não é privilégio (1957), Pequena introdução à filosofia da educação: a escola progressiva ou a transformação da escola (TEIXEIRA, 1967), Educação é um direito (TEIXEIRA, 1968), A educação e o mundo moderno (1969), e Educação no Brasil (1969). Ainda cabe destacar os textos A Pedagogia de Dewey: esboço da teoria de educação de John Dewey (TEIXEIRA, 1952), publicado no livro Vida e Educação (1952) - tradução original dos livros The Child And The Curriculum (1902) e Interest and effort in education (1913) de autoria de John Dewey, feita na década de 1950 por Teixeira. Também, cabe destacar Um Presságio de Progresso, publicado primeiramente na revista Habitat, número 4 do ano de 1951 e posteriormente em Depoimento de uma geração: arquitetura moderna brasileira: (XAVIER, 1987:207-209). Segue abaixo um trecho deste "Presságio":

\footnotetext{
"Reconheçamos, entretanto, que nenhum outro elemento é tão fundamental, no complexo da situação educacional, depois do professor, como o prédio e suas instalações. Reconheçamos, também com Pascal, que o homem é feito de tal modo que, embora o sentimento anteceda o gesto, na sua ordem natural, o gesto pode gerar o sentimento. No Brasil, estamos a procurar este efeito. A arquitetura moderna é esse gesto. Possam estes prédios escolares, concebidos em juventude, árdegos e elegantes como potros de raça, impacientes de dinamismo e de amor à vida, comunicar a educação e, pela educação, a existência brasileira, as suas finas e altas qualidades de inteligência, coragem e desprendida confiança no futuro. $\bigcirc$ Brasil precisa, para se realizar, de lirismo que é a capacidade de se esquecer - e de virtude - que é a capacidade de se superar. A sua arquitetura moderna é uma lição magnífica dessas duas atitudes redentoras".
}

(TEIXEIRA, in XAVIER, 1987: 209) 
Este levantamento inicial aponta livros qualitativos e toda uma produção, em diversas áreas de conhecimento, sobre o educador. Além destes trabalhos, também há um grande número de dissertações e teses ${ }^{15}$, compondo uma importante fonte de informação bibliográfica para a compreensão da obra pedagógica deste educador.

Por fim, ainda cabe destacar outras duas referências bibliográficas, a dissertação de mestrado Educação e arquitetura: o ambiente como fator de direção democrática (GOSSI, 2004), pelo fato de apresentar um estudo teórico da relação entre educação e arquitetura no processo de aprendizagem tendo Dewey como referência teórica desta reflexão, e, o livro Escola Classe - Escola Parque: uma experiência educacional, de Hélio de Queiroz Duarte, publicado na FAUUSP, em 1973, com o intuito de divulgar o pensamento no plano educacional de Teixeira e de render-lhe homenagem após seu falecimento em 1971.

\footnotetext{
"Anísio Teixeira foi honrado pela ONU e pela UNESCO, condecorado pelos governos: francês e americano e, lamentavelmente, em nosso país o Autor de Educação não é privilégio não teve, por parte do mundo oficial da educação um reconhecimento à altura dos indiscutíveis méritos de seu espírito. Entretanto, é bom que se afirme, ao homem que
}

15 Destacam-se duas dissertações produzidas na Bahia: Escola Parque: paradigma escolar, 1947-1951 (GERIBELLO, 1989) e, A representação da arte na Escola Parque da Bahia, 1955-1965 (RABELLO, 1992). Também no Rio de Janeiro destacam-se as dissertações: Educação e modernidade: o projeto educacional de Anísio Teixeira (GUIMARÃES, 1982), Sobre o perfil pedagógico de Anísio Teixeira: ensaio avaliatório de sua contribuição à educação do Brasil (JUSTINIANO, 1976), Administração Pedro Ernesto e a Questão Educacional (1931-1936) (NUNES, 2001), Uma escola de professores: formação de docentes na reforma Anísio Teixeira (VIVEIROS DE CASTRO, 1986), Para além do campo educacional: um estudo sobre o Manifesto dos Pioneiros da Educação Nova (XAVIER, 1993), além das teses A construção e definição de políticas de pós-graduação em educação no Brasil: a contribuição de Anísio Teixeira e de Newton Sucupira (LOBO, 1991), Universidade e formação de professores - uma perspectiva integradora: a Universidade de Educação de Anísio Teixeira (MENDONÇA, 1993), Anísio Teixeira: a poesia da ação (NUNES, 1991) e, O Brasil como laboratório: Educação e Ciências Sociais no Projeto do Centro Brasileiro de Pesquisas Educacionais - CBPE/INEP/MEC, 1950-1960 (XAVIER, 1999). Já em Brasília destaca-se a dissertação Passos e descompassos de uma instituição de pesquisa educacional no Brasil: a realidade do INEP (SAAVEDRA, 1988), além de outras realizadas em São Paulo e no Rio Grande do Sul, como: O dependentismo e o desenvolvimento na reflexão de Anísio Teixeira sobre a educação escolar brasileira (BARREIRA, 1989), Descentralização da educação no Brasil: uma abordagem histórica, com enfoque em Anísio Teixeira (TEDESCHI FILHO, 2002), e O público e o privado em educação: o caso Anísio Teixeira e a lgreja Católica no Rio Grande do Sul (ESQUINSANI, 2000). 
desprezara a riqueza para se tornar somente

EDUCADOR e assim poder propor, experimentar e provar um modelo educacional compatível com a realidade brasileira, só haverá um tipo de homenagem capaz de consagrar tão nobre e tão alto feito: a adoção e a disseminação por todos esses brasis do sistema: escolas-classe escola-parque".

(DUARTE, 1973:5)

A contribuição de Teixeira, direcionada à construção democrática, pode se expressar tanto no processo de educação, como na produção da arquitetura moderna brasileira. Com o propósito de expressar a democracia na arquitetura, seus conceitos educacionais rebateram no modo de fazer arquitetura, com a pretensão de que a mesma fosse animadora de uma vida democrática no próprio edifício escola. No caso dos "S", cabe destacar a ligação de Teixeira com Hélio Duarte, o arquiteto que projetou o maior número de escolas SENAI na década de 1950, além de sua experiência anterior na direção dos projetos escolares do Convênio Escolar. Sem dúvida a idéia de "escola parque" como um sistema educacional flexível para atender o Brasil unia educação e arquitetura. Na década de 1950, enquanto Teixeira defendia e aplicava pela primeira vez em Salvador a "escola parque", Duarte era incumbido de projetar as primeiras escolas do SENAI, tendo em conta alguns aspectos educacionais que delinearam a arquitetura moderna das escolas "S"., como pudemos observar no capítulo anterior: crescimento, flexibilidade, atratividade, interligação, sociabilidade, rendimento e economia, todos aplicados ao edifício-escola dos "S", no sentido de criar um ambiente adequado ao processo educativo. 


\subsubsection{Aspectos educacionais aplicados ao}

\section{edifício-escola: os princípios das modernas escolas "S"}

Anísio entendia que era indispensável no papel da educação "uma agência especial - a escola, e um grupo de especialistas - os professores, para tornar possível a educação [...]" (TEIXEIRA, 1928: 14). Assim Anísio assumia a perspectiva de Dewey, para quem, como o primeiro ressaltava, "a educação é fenômeno direto da vida, tão inelutável como a própria vida. A contínua reorganização e reconstrução da experiência pela reflexão [...]" e que "o fim da educação se identifica com seus meios (o processo), do mesmo modo, aliás, que os fins da vida se identificam com o processo de viver" (DEWEY, 1952:10). É por isso que, para Anísio, que defendia enfaticamente a necessidade de dar ao professor, no seu processo de formação profissional, uma sólida base científica, esta não se restringia, de forma alguma, a sua preparação didáticometodológica $^{16}$. E, para Dewey, se a educação como processo de crescimento, desenvolvimento e amadurecimento é um processo de constante "reorganização e reconstrução da experiência", o meio educativo é responsável por estimular, provocar e dirigir este processo educativo. Assim, a escola, como meio educativo, deveria abranger três características:

\footnotetext{
"Primeiro, deve propor um ambiente simplificado, para permitir o acesso da criança. Longe vão os tempos em que a própria vida ainda era tão simples que as crianças nela podiam diretamente participar. [...] A escola deve simplificar esse ambiente complexo para que a criança gradualmente the venha conhecer os segredos e nele participar.

Segundo, deve organizar um meio purificado, isto é, de onde se eliminem certos aspectos reconhecidamente maléficos do ambiente social. A
}

\footnotetext{
16 Para o educador, as "bases científicas" do trabalho docente compreendiam as ciências humanas e sociais aplicadas à educação (biologia, psicologia, sociologia, história, estatística e administração) e a filosofia, que teria um papel central como integradora na prática do professor que, conseqüentemente, teria uma posição privilegiada no seu processo de formação.
} 
escola não visa perpetuar na sociedade os seus defeitos. Em uma sociedade progressiva, ela é órgão específico de uma constante melhoria, pela qual desejamos legar aos nossos filhos a possibilidade de uma vida mais feliz que a nossa.

Terceiro, deve prover um ambiente de integração social, de harmonização de tendências em conflito, de larga tolerância inteligente e hospitaleira. [...] . A escola deve ser a casa da confraternização de todas essas influências, coordenando-as, harmonizando-as, consolidando-as para a formação de inteligências claras, tolerantes e compreensivas". (itálico no texto)

(DEWEY, 1952:16)

Portanto, simplificação, purificação e confraternização, foram pensados por Dewey como fontes de estímulo e de direção para obter uma determinada "resposta" no processo educativo. Assim, seguindo o mestre, Teixeira (1928:15) afirma que "a escola deve oferecer um ambiente social simplificado [...], um ambiente social purificado [...] e por último, um ambiente equilibrado [...]". (itálico no texto). Dentro destes aspectos, pode-se fazer uma analogia com as principais características filosóficas e arquitetônicas que nortearam os projetos das modernas escolas " $\mathrm{S}$ ".

\begin{abstract}
"Que enormes, pois, são as novas responsabilidades da escola: educar em vez de instruir; formar homens livres em vez de homens dóceis; preparar para um futuro incerto e desconhecido em vez de transmitir um passado fixo e claro; ensinar a viver com mais inteligência, com mais tolerância, mais finamente, mais nobremente e com maior felicidade, em vez de simplesmente ensinar dois ou três instrumentos de cultura e alguns manuaizinhos escolares..."
\end{abstract}

(TEIXEIRA, 1967: 41)

\title{
Crescimento
}

Entender o ambiente como dinâmico implica ver um ambiente purificado no sentido de estar propício ao desenvolvimento da vida moderna. Desta maneira, a escola proporcionaria um ambiente de 
diversidade, de mudança permanente e, conseqüentemente de crescimento.

Vale lembrar que na transformação da escola, a "escola nova" ou "escola progressiva", não nega os processos de mudança dentro da "educação progressiva"17, mas sim o que essa perspectiva sugere é procurar lidar satisfatoriamente com estes processos através da reorganização das relações, objetivando a continuidade da vida social e de seu modo democrático.

\begin{abstract}
"A designação 'escola nova', necessária, talvez, em início de campanha, para marcar vivamente as fronteiras dos campos adversos, ganharia, em ser abandonada. Por que não 'escola progressiva', como já vem sendo chamada, nos Estados Unidos?

E 'progressiva', por quê? Porque se destina a ser a escola de uma civilização em mudança permanente e porque, ela mesma, como essa civilização, está trabalhada pelos instrumentos de uma ciência que ininterruptamente se refaz. Com efeito, o que chamamos de 'escola nova' não é mais do que a escola transformada, como se transformam todas as instituições humanas, à medida que thes podemos aplicar conhecimentos mais precisos dos fins e meios a que se destinam". (grifado da autora)
\end{abstract}

(TEIXEIRA, 1967:26-27)

Nesta nova ordem, a "mudança constante" constitui a característica do crescimento, no sentido de estar aberta a oferecer indagações e soluções para um futuro desconhecido, numa permanente revisão que altera o conceito da antiga escola tradicional, pois, segundo TEIXEIRA (1967:30), "temos que construir a nossa

\footnotetext{
17 Vale lembrar que a expressão "educação progressiva" está relacionada ao Progressive Movement norte-americano. Nos EUA, a era progressiva foi um período de reforma iniciado no final do século XIX que se estendeu ao século XX. $O$ Progressive Movement buscava a eficiência para identificar os problemas e os reparar. Os progressistas se opuseram ao desperdício, à corrupção e, as práticas ineficientes e inúteis. Assim, procuravam a mudança na política sob os aspectos da economia, da sociedade e do governo. Na educação progressiva, John Dewey foi um líder representativo da educação americana. Segundo o modelo de aprendizagem de Dewey, as crianças deveriam aprender como se fossem cientistas, num processo de: ter ciência do problema, definir o problema, propor hipóteses para resolvê-lo, avaliar as conseqüências das hipóteses e, por fim, testar a solução mais provável. Todo um processo de aprendizado atendendo ao típico slogan progressivo "aprender fazendo".
} 
escola, não como preparação para um futuro conhecido, mas para um futuro rigorosamente imprevisível".

A idéia de crescimento reforça o próprio conceito de educação como "processo de assegurar a continuidade do lado bom da vida e de enriquecê-lo, alargá-lo e ampliá-lo cada vez mais" (TEIXEIRA, 1967:51).

\section{Flexibilidade}

Como meta arquitetônica, a flexibilidade nas escolas, atendia à natureza dinâmica do ser humano, do ambiente social e da própria evolução da indústria, dentro da premissa de conceber um ambiente equilibrado. Dentro do processo de "reconstrução", a flexibilidade formal do ambiente é fruto de um mundo dinâmico, não estático, como preconizava a concepção educativa de Dewey.

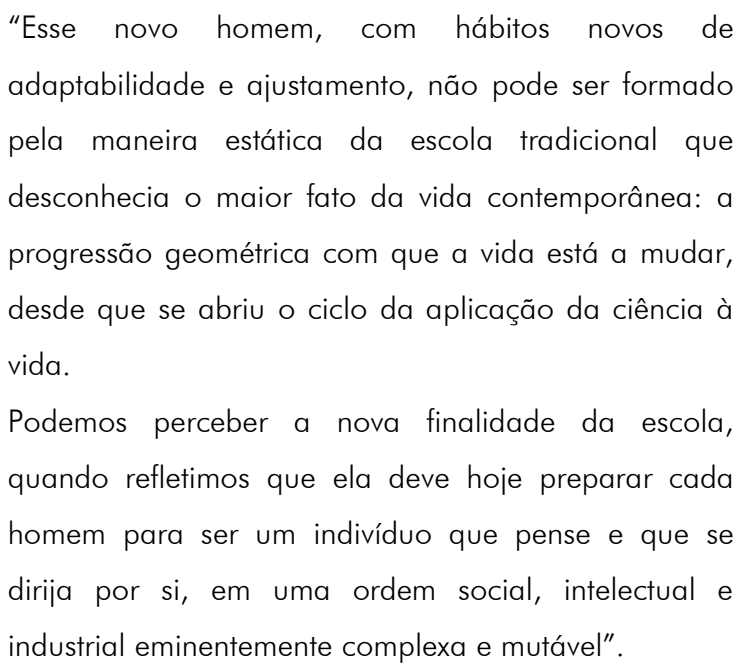

(TEIXEIRA, 1967:36)

\section{Atratividade}

A "escola progressiva" pensava a criança como o centro de seus interesses e, assim, deveria proporcionar o ambiente simplificado, buscando ser uma escola construída para os alunos e pelos alunos. Este era o fundamento da atratividade destas escolas.

Com a tarefa de tornar a escola um instrumento consciente, inteligente e de aperfeiçoamento social (TEIXEIRA, 1967:101), a adoção do sistema "escola-parque" foi decisiva. A idéia de 
socialização das atividades escolares foi desenvolvida no sistema Platoon", composto por "sete pontos cardeais" (TEIXEIRA, 1928:154): fundamentos, uso das horas de lazer, saúde, socialização das atividades escolares, atividades vocacionais, ciências e atividades especiais. Dentre estes, seis pontos tornaram a escola fisicamente mais atrativa ao aluno através de um novo programa construtivo: sala de música e estúdio (uso das horas de lazer), ginásio e recreio (saúde), o auditório (socialização), salas de trabalho manual (atividades vocacionais), sala de ciências (ciências), biblioteca, refeitório e clínica (atividades especiais).

Neste sentido, é nítida a disseminação do sistema Platoon, e conseqüentemente da idéia de escola-parque nas novas escolas ${ }^{19}$ SENAI, SESC e SENAC, projetadas nas décadas de 1950 e 1960, pautadas na "educação integral".

\section{Interligação}

A possibilidade de reflexão ou observação intencional das coisas, segundo Dewey, resulta na aprendizagem. Assim a interligação, pelo menos visual, entre a área de trabalho prático e a área de desenvolvimento teórico faz parte do meio educativo, do ambiente equilibrado.

Para Anísio Teixeira, a íntima relação entre escola e sociedade, baseada na ciência, na democracia e no trabalho, traz como conseqüência a concepção de uma escola ativa. É o fazer, através do método científico, que deve definir uma escola ativa e democrática. Assim a interligação é parte de uma atitude que, disseminada pela sociedade, supera os dualismos entre fins práticos e fins teóricos, através de uma escola única.

\footnotetext{
${ }^{18}$ A Escola Platoon foi um sistema de educação fundado em Detroit e observado por Teixeira durante sua viagem aos EUA. Este sistema buscava uma forma moderna e mais flexível de organização pela construção de edifícios especialmente adaptados aos seus fins, como a Brady School, em Detroit.

19 Com o desafio de responder a esta nova filosofia, as escolas "S" adotaram um novo programa construtivo: salas de aula, oficinas, administração, recreio, auditório, sala de reunião, biblioteca, teatro ao ar livre, sede da associação de ex-alunos, campo de esportes e piscina. E, atendendo a esta nova concepção, a aplicação da arquitetura moderna.
} 
Neste sentido, cabe caracterizar a "experiência" educativa que, segundo Dewey, é intencionalmente instituída para ajudar a lidar com mudanças presentes e outras que possivelmente hão de acontecer. Assim, desenvolver a aptidão de poder aprender com a própria experiência é expandir a inteligência.

\footnotetext{
"A experiência é o resultado, o signo e a recompensa desta interação do organismo e ambiente, que quando se realiza em pleno é uma transformação da interação em participação e comunicação [... $]^{\prime \prime}$.
}

(DEWEY, 1959:47)

ambiente, nesta concepção, como parte da reconstrução do significado da experiência, é tanto um elemento físico como um recurso social que, no edifício escolar, contribui ao estímulo e à eficiência do aprendizado. $E$, a relação entre os ambientes, isto é, a interligação das diferentes atividades, também é tarefa da educação.

\footnotetext{
"Compete aos educadores proporcionar um ambiente em que a experiência como busca de toda espécie de relações com outras coisas possa ser fartamente estimulada e eficazmente mantida em constante atividade. Em certas espécies de ambiente a atividade pode ser de tal modo constrangida que a única significação que the fique seja a de seu direto e tangível resultado isolado [...]. A tarefa da educação [...] é fazer que tais atividades se manifestem de tal modo, e em tais condições, que tornem essas relações o mais perceptíveis possível".
}

(DEWEY, 1959:47)

\section{Sociabilidade}

Ampliar e aprofundar o conteúdo social, somado ao fator psicológico, consistiu um importante aspecto no processo educacional, rebatendo na arquitetura como a construção do ambiente equilibrado. Assim, de forma combinada, o psicológico e o social foram elementos fundamentais na educação de Dewey. 
"Este proceso educativo tiene dos aspectos: uno psicológico y otro social, y ninguno de ellos puede subordinarse al otro o descuidarse sin producir malas consecuencia".

(DEWEY, 1944: 56)

O estímulo social tinha como objetivo educar um indivíduo para a vida, isto é, prepará-lo para um futuro imprevisível. Assim, visava proporcionar o domínio de si mesmo por meio da sociabilidade, uma maneira de educar que desempenhava plenamente as capacidades de cada indivíduo, assim como sua função e sua atuação nas relações sociais.

De fato, a "educação progressiva" confirma a possibilidade de mudanças, porém sugere lidar satisfatoriamente com estas, através da reorganização da significação das relações, objetivando a continuidade da vida social e do seu modo democrático.

"Apenas, - e agora é que se acentua a transformação fundamental por que passa a escola - apenas, urge que não entreguemos ao acidente e ao acaso o que podemos prever e planejar. A escola não pode ficar no seu estagnado destino de perpetuadora da vida social presente. Precisa transformar-se no instrumento consciente, inteligente do aperfeiçoamento social".

(TEIXEIRA, 1967: 93, itálico original)

Dentro da concepção pedagógica de Dewey, a questão da sociabilidade, no caso das escolas do SENAI, SESC e SENAC caracteriza-se pela idéia de convívio comum, vinculada à de educação como um processo social.

"La educación moral ha de centrarse sobre esta concepción de la escuela como un modo de vida social, y la mejor y más profunda preparación moral es precisamente la que se adquiere entrando en las debidas relaciones con los demás, formando una unidad de trabajo y pensamiento".

(DEWEY, 1944: 61) 
Com efeito, a Escola Nova, com o objetivo de ser transformadora de si própria enquanto instituição e da sociedade nos seus aspectos econômicos e sociais, acreditava na atividade social e na sociabilidade como forte corrente de interesse das crianças. Dewey, em Interest and Effort in Education (traduzido por Anísio Spinola Teixeira no livro Vida e Educação, 1952), afirma que desde cedo as crianças identificam seus interesses com os dos outros:

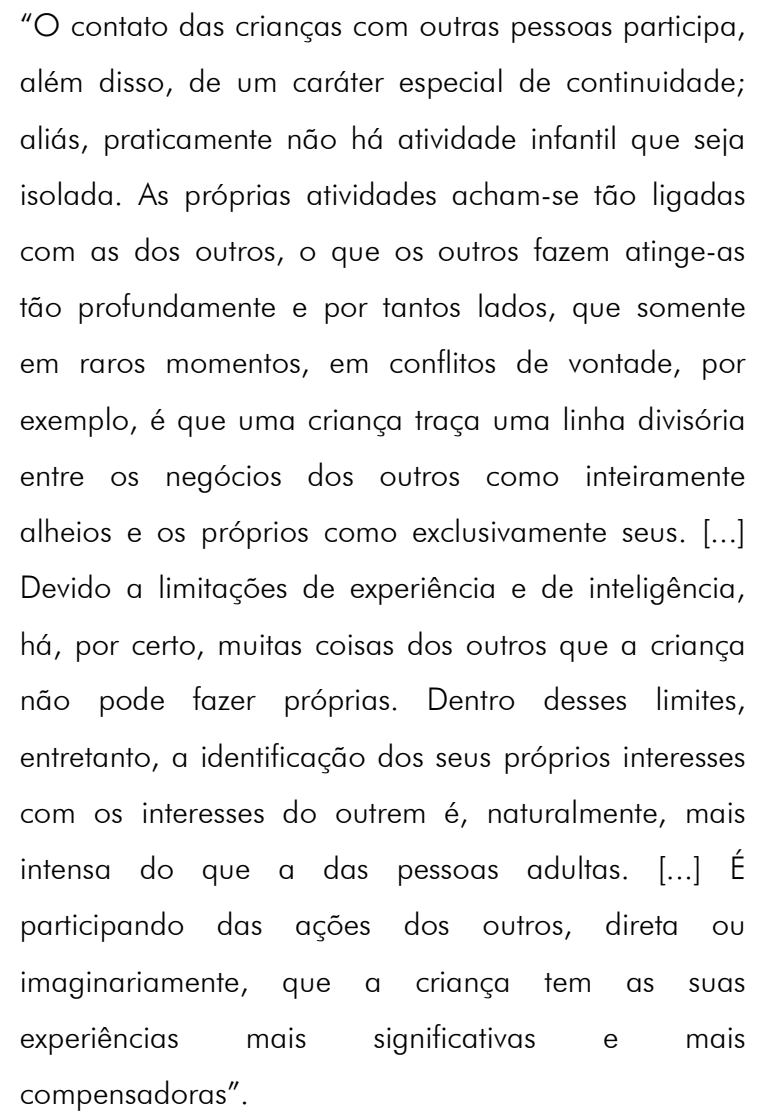

(DEWEY, 1952: 80-81, tradução TEIXEIRA)

Assim, ao compartilhar interesses, a vida social também está vinculada à construção das relações e proporciona novas experiências, resultando num estimulante processo educacional.

"Tudo no indivíduo é, com efeito, social: a sua ação, o seu pensamento ou a sua consciência. $E$ se assim não fosse,,impossível se tornaria a direção do processo educativo".

(TEIXEIRA, 1967:93) 


\section{Rendimento}

Dentro desta visão, a indústria é apontada como a grande diretriz da vida moderna, a integradora do mundo inteiro em um todo

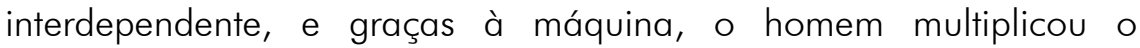
rendimento de seu trabalho (TEIXEIRA, 1967:33). Como uma situação real de experiência, o rendimento faz parte de um ambiente equilibrado, visando realizar a educação integral e um ensino mais eficiente através do entrosamento entre teoria e prática.

\footnotetext{
"Logo, se a escola quer ter uma função integral de educação, deve organizar-se de sorte que a criança encontre aí um ambiente social em que viva plenamente. A escola não pode ser uma simples classe de exercícios intelectuais especializados".
}

(TEIXEIRA, 1967:36)

Assim, como parte da nova filosofia de aprendizagem, a escola transformada seria "um centro onde se vive e não [...] um centro onde se prepara para viver" (TEIXEIRA, 1967:36), uma parte integradora da própria vida do aluno, ligando seus ensinamentos às experiências de fora da escola. Neste sentido, Dewey acreditava que a escola não deveria ter a tarefa de apenas transmitir os conhecimentos armazenados nos livros, mas sim a tarefa de acompanhar o crescimento infantil, desenvolvendo a personalidade de cada criança. Esta maneira de pensar a aprendizagem, alterou o conteúdo e os métodos da escola. As atividades escolares passam a ser desenvolvidas na teoria e na prática, visando o aluno como centro da escola, possibilitando o rendimento pedagógico:

“1) A escola deve ter por centro a criança e não os interesses e a ciência dos adultos;

2) $O$ programa escolar deve ser organizado em atividades, unidades de trabalho, ou projetos, e não em matérias escolares;

3) $\bigcirc$ ensino deve ser feito em torno da intenção de aprender da criança e não da intenção de ensinar do professor; 
4) A criança, na escola, é um ser que age com toda a sua personalidade e não uma inteligência pura, interessada em estudar matemática ou gramática;

5) Os seus interesses e propósitos governam a escolha das atividades, em função do seu desenvolvimento futuro;

6) Essas atividades devem ser reais (semelhança à vida prática) e reconhecidas pelas crianças como próprias".

(TEIXEIRA, 1967: 81-82)

Conforme já referido, entre as diversas experiências que a América do Norte proporcionou à Teixeira, tornou-se relevante 0 conteúdo programático do sistema Platoon ${ }^{20}$, "uma aplicação mais eficiente do edifício e do trabalho do professor [...], oferecendo também um grau superior de eficiência educativa". (TEIXEIRA, 1928: 149). Assim, este sistema "progressivo", procurava:

\footnotetext{
"[...] não só à moderna e crescente existência que a vida e o progresso impunham à escola, mas torná-la, também, mais econômica graças a uma maior eficiência levando-a assim a rendimento mais compatível com a realidade".
}

(DUARTE, 1973:11-12)

\section{Economia}

Dentro dos fundamentos da transformação escolar, a visibilidade integral dos elementos da escola deveria definir os elementos, proporcionar amplitude e alcançar os caminhos e os processos pedagógicos com nitidez.

Nesta perspectiva, o processo educativo vislumbrava edifícios escolares que, além de disponibilizar o trabalho em grupo (reforçando a idéia de sociabilidade descrita anteriormente), fossem compostos de ambientes integrados e econômicos. $\bigcirc$ ambiente escolar, caracterizado por diferentes funções, deveria propiciar espaços adequados às atividades pedagógicas. Por meio de recursos naturais

20 sistema Platoon foi aplicado em uma "escola elementar que funciona simultaneamente em dois grupos, sendo ministrado, em determinado tempo, ensino das matérias fundamentais do curso elementar a um deles, enquanto o outro se ocupa com as matérias especiais" (TEIXEIRA, 1928: 149). No caso do ensino industrial do SENAl, as matérias fundamentais seriam a teoria e as matérias especiais, a prática. 
ou construídos, as escolas deveriam refletir a economia, não no sentido de menor custo, mas sim no sentido de aproveitamento dos recursos naturais, como iluminação e ventilação, e do próprio espaço construído, como encurtamento das distâncias a percorrer de um ponto a outro.

\begin{abstract}
"Nos lugares em que as escolas são providas de laboratórios, oficinas e jardins, e em que se usam livremente dramatizações, brinquedos e jogos, existem oportunidade para se reproduzirem as situações da vida, e para adquirir e aplicar informações e idéias na realização de experiências progressivas. As idéias não ficam segregadas, a formarem uma ilha isolada. Elas animam e enriquecem o curso da vida comum. Os conhecimentos vitalizam-se com o ser postos em ação, com o exercerem a sua função na direção das atividades".
\end{abstract}

(DEWEY, 1936: 178, tradução TEIXEIRA) os espaços tradicionais das salas de aula não satisfaziam o escopo da educação progressiva. Para o desenvolvimento das aptidões, os indivíduos deveriam ter à disposição espaços que realmente promovessem as experiências pedagógicas, de forma integrada e intencionalmente organizada. Idealizada como um ambiente preparado, a escola é colocada por Dewey como uma associação com funções principais e inter-relacionadas. Assim, o edifício escolar deveria ser um "ambiente simplificado", um verdadeiro recurso para o crescimento dos indivíduos.

\footnotetext{
"A primeira função do órgão social que denominamos escola é proporcionar um ambiente simplificado. Selecionando os aspectos mais fundamentais, e que sejam capazes de despertar reações da parte dos jovens, estabelece a escola, em seguida, uma progressão, utilizando-se dos elementos adquiridos em um primeiro lugar como meio de conduzi-los ao sentido e compreensão real das coisas mais complexas.
} 
Em segundo lugar, é tarefa do meio escolar eliminar o mais possível os aspectos desvantajosos do ambiente comum, que exercem influência sobre os hábitos mentais [...].Escolhendo o melhor para usá-lo, exclusivamente, ela se empenha em reforçar o poder deste melhor. À proporção que uma sociedade se torna mais esclarecida, ela compreende que importa não transmitir e conservar todas as suas realizações, e sim unicamente as que importam para uma sociedade futura mais perfeita [...].

Em terceiro lugar, compete ao meio escolar contrabalançar os vários elementos do ambiente social e ter em vista dar a cada indivíduo oportunidade para fugir às limitações do grupo social em que nasceu, entrando em contato vital com um ambiente mais amplo".

(DEWEY, 1936: 21-22, tradução TEIXEIRA)

Como um ambiente especial, o ambiente escolar deveria lidar com a complexidade social e oferecer elementos físicos fundamentais à educação progressiva.

\subsubsection{Do Manifesto à construção de uma Escola Nova e Progressiva}

Ao analisar o Manifesto dos Pioneiros da Educação Nova ${ }^{21}$ como um documento emblemático das representações e valores de certo grupo de educadores brasileiros, certamente informados quanto às concepções norte-americanas, são destacáveis algumas observações.

${ }^{21}$ Este manifesto foi publicado em 1932 e originado dos debates da $4^{a}$. Conferência Nacional de Educação, realizada no Rio de Janeiro, em dezembro de 1931. Vale lembrar que antes, em 1929, no artigo intitulado "Escola Nova", Lourenço Castanho Filho propôs um sistema de ensino, avaliação e orientação para as escolas brasileiras, baseado nos princípios do taylorismo (AZEVEDO, 1937: 175-192). 
O manifesto, como um documento produzido de forma coletiva pelos educadores, visava conduzir o País a um futuro em que o progresso balizado pelo avanço da ciência o elevaria ao estatuto de nação civilizada (XAVIER, 1993). Este documento, publicado em 1932, foi conduzido por um dos mais destacados integrantes do Movimento da Escola Nova, Anísio Teixeira, durante a administração de Pedro Ernesto, na cidade do Rio de Janeiro, entre os anos de 1931 e 1936 (NUNES, 2001). Vale lembrar que Teixeira, em 1928, já deixava claro seus fundamentos de educação absorvidos como "comissionado em estudos na América do Norte", conforme o relatório Aspectos Americanos de Educação (1928), que traz ao Brasil as idéias de Dewey, traduzidas na pedagogia da Escola Nova.

Na época, Getúlio Vargas, tratou o problema da educação, com o objetivo de formar uma elite intelectualmente bem preparada (FAUSTO, 1994: 336). E, a partir de 1930, a educação passou a ser objeto de uma política centralizadora e modernizadora, tendo como marco inicial a criação do Ministério da Educação e Saúde.

\footnotetext{
"As tentativas de reforma do ensino vinham da década de 1920, caracterizando-se nesse período por iniciativas no nível dos Estados, o que correspondia ao figurino da República federativa. Em São Paulo, o propósito de combater $\bigcirc$ analfabetismo e a preocupação de integrar os imigrantes geraram em 1920 a reforma promovida por Sampaio Dória, só parcialmente executada. Iniciativas reformistas surgiram também no Ceará, pela ação de Lourenço Filho, a partir de 1922; na Bahia, com destaque para Anísio Teixeira (1924); em Minas e no Distrito Federal, promovidas respectivamente por Mário Cassassanta e Fernando de Azevedo (1927).
}

(FAUSTO, 1994: 336-337)

No auge das discussões sobre a Escola Nova, Teixeira escreve o livro Educação Progressiva: uma introdução à filosofia da educação, publicado pela primeira vez em 1933. Neste livro, o autor expõe de forma simples os fundamentos da teoria da educação baseada na experiência, que dirigiu o movimento de reconstrução educacional deste momento. É interessante observar que o pensamento do autor 
não tem preocupações de originalidade, filia-se diretamente ao educador John Dewey, reconhecido como sua principal figura. Esta filiação norte- americana é feita até mesmo em relação a designação de termos, esclarecendo que o termo "Escola Nova" utilizado no Brasil nada mais era do que a "Escola Progressiva", termo então utilizado nos EUA. Neste sentido de designar a escola, nova ou progressiva, ainda cabe chamar atenção para o título original deste livro, Educação Progressiva: uma introdução à filosofia da educação (1933). O mesmo livro foi republicado na década de 1960, com outro título: Pequena Introdução à filosofia da educação: a escola progressiva ou a transformação da escola (1967). Nota-se claramente que na década de 1960 a designação "progressiva" já não era o termo mais atual dentro da teoria da educação pela experiência, passando a ser subtítulo e assim conservando sua referência como registro histórico.

\footnotetext{
“De início, um esclarecimento. Escola Nova. Por que essa designação? Há, aí, mais do que a precariedade insustentável do adjetivo, qualquer coisa de combativo e atrevido, que choca alguns companheiros avisados de trabalho, receosos de uma ofensiva contra os valores reais da escola. A designação 'escola nova', necessária, talvez, em início de campanha, para marcar vivamente as fronteiras dos campos adversos, ganharia em ser abandonada. Por que não escola progressiva', como já vem sendo chamada, nos Estados Unidos? E progressiva, por quê? Porque se destina a ser a escola de uma civilização em mudança permanente e porque, ela mesma, como essa civilização, está trabalhada pelos instrumentos de uma ciência que ininterruptamente se refaz. Com efeito, o que chamamos de 'escola nova' não é mais do que a escola transformada, com se transformam todas as instituições humanas, à medida que thes podemos aplicar conhecimentos mais precisos dos fins e meios a que se destinam".
}

(TEIXEIRA, 1967: 25-26) 
No plano da política educacional, a revolução de 1930 proporcionou a Anísio Teixeira a oportunidade de traçar o seu primeiro planejamento escolar em extensão, isto é, a ampliação da rede de prédios destinados ao ensino primário no Rio de Janeiro (DUARTE, 1973: 21). A partir daí foi introduzido no Brasil o emprego do tipo de escola chamada Platoon, sendo o arquiteto Enéas Silva o encarregado de projetar tais escolas. Em 1935, por motivos políticos, Teixeira solicita sua demissão do cargo de Secretário Geral de Educação e Cultura da Prefeitura Municipal do Rio de Janeiro. Levou suas propostas, mais tarde, para Salvador. Neste contexto, suas propostas educacionais visavam atingir prioritariamente as camadas urbanas mais pobres, considerando-se a educação um instrumento básico para a elevação política e social da população e para o progresso da sociedade como um todo. E, na perspectiva da educação progressiva, o ambiente social foi visto como dinâmico e indissociável do ambiente físico.

Assim, dentro dos aspectos da Escola Nova, importantes conceitos pedagógicos são análogos às principais características filosófico-arquitetônicas que nortearam as modernas escolas "S", a partir da década de 1950. Com o objetivo de ir além de construir escolas tradicionais, as já modernas escolas "S" (documentadas no capítulo 2) abrigaram em seu programa construtivo instalações comunitárias como recreios cobertos, ginásios, bibliotecas, grêmios, e quadras, adotando em seus projetos as concepções da arquitetura moderna, de uma Escola Nova e/ou Progressiva, no sentido de origem do termo. Desta forma, apoiando-se em um novo conceito de educação o ambiente proposto pela Escola Nova é perceptível na arquitetura das escolas "S", ativa e interessante, aberta aos diversos processos pedagógicos, identificada como ambiente físico por uma arquitetura moderna que, neste ponto de vista, foi responsável pela identificação social, pela escola.

Vale lembrar que, na década de 1950,22 a "Escola Nova" continuou sob várias formas de aplicação. Em Salvador, continuando

\footnotetext{
22 Teixeira, no ano de 1950, em Salvador, trabalha na inauguração do primeiro núcleo educacional do modelo experimental de Escola Classe-Escola Parque, o Centro Educacional Carneiro Ribeiro. Também, em 1956 foi criado o Centro Brasileiro de Pesquisas Educacionais (CBPE) ${ }^{22}$, sob a liderança de Teixeira, então
} 
sua trajetória iniciada no Rio de Janeiro, Teixeira idealizou do modelo de "escola parque" um projeto complexo marcado pela passagem da "escola de poucos" para a "escola de todos".

"Mas, para o educador o problema não seria, tão
somente, o corrigir-se a deficiência numérica da falta
de matrícula para alguns, mas, possibilitar, em
extensão, aquilo que realmente estavam a necessitar -
uma escola que fosse mais do que uma escola - um
lugar onde a criança além das atividades corriqueiras
de leitura, aritmética e escrita, pudesse ainda - em dia
letivo completo - ser introduzida às ciências físicas e
sociais e mais, complementar-se através das artes
industriais, desenho, música, dança e educação física". (DUARTE, 1973: 26)

Desta maneira, a década de 1950 marcou um momento político e cultural em que se discutiu e buscou democratizar o acesso à educação, a urbanidade e à modernidade no Brasil. Tanto na pedagogia como na arquitetura, foi um período de mudanças, sendo a nova pedagogia utilizada em sintonia com a arquitetura moderna dos "S" na formação para o trabalho. Por fim, cabe registrar na terceira parte deste capítulo, os autores desta arquitetura moderna escolar paulista e brasileira, não somente como aquela que atendeu à pedagogia, mas também como aquela que atuou na própria afirmação e na ideologia modernizadora do país. interessados em consolidar um campo cultural no país. 


\subsection{Arquitetura Moderna: um gesto para a educação}

Os três "S" modernos foram construídos por profissionais de diferentes formações e atributos que, como idealizadores, conseguiram na própria trajetória a reconhecida atuação projetual estabelecida pela interface consistente com a carreira acadêmica, o entrosamento da teoria com a prática. É certo que cada qual, tanto arquitetos como engenheiros, atendeu ao desafio de projetar uma arquitetura escolar moderna que testifica a unidade arquitetônica implantada nas escolas "S" nos anos 1950.

De fato, dentro dos princípios que pautaram a moderna arquitetura escolar dos "S", além de identificar os responsáveis pela autoria dos projetos concebidos nas décadas de 1950 e 1960, é preciso reconhecer a importância desta geração que atuou conjuntamente na construção da arquitetura escolar moderna brasileira.

\subsubsection{Arquitetos e engenheiros dos " $\mathrm{S}$ " paulistas:} idealizadores e realizadores dos conceitos implícitos em um modo de fazer o edifício-escola

É notável como os idealizadores da arquitetura moderna dos "S" tinham como desafio projetar uma escola que integrasse teoria, prática e lazer, tornando o ensino mais eficiente e atrativo. Para isso, a arquitetura concebida teve fundamentos, elementos e características muito próximas, variando naturalmente o tipo de desenho de acordo com cada idealizador. 
Um dos alvos principais ao documentar os projetos arquitetônicos concebidos para O SENAI, SESC e SENAC, era reconhecer a contribuição destes idealizadores. Desta forma, o trabalho de coleta e síntese desta documentação, assim como de análise projetual, permitiu identificar a presença de duas gerações na concepção das escolas "S", durante as décadas de 1950 e 1960. Primeiramente, a julgar pela ordem cronológica das escolas projetadas, observaremos as trajetórias dos arquitetos da denominada "primeira geração $S$ ". Os responsáveis pela autoria dos primeiros projetos concebidos na década de 1950 para o SENAI foram: Hélio de Queiroz Duarte (1906-1989), Ernest Robert de Carvalho Mange (1922-2005) e Roberto José Goulart Tibau (1924-2003). E, para os SESC e SENAC: Oswaldo Corrêa Gonçalves (1917- 2005), Eduardo Corona $^{23}$ (1921-2001), Rubens Carneiro Viana e Ricardo Siervers. Esta geração, além de ser pioneira a projetar as escolas modernas dos "S", é também assim denominada por ter na sua maioria ${ }^{24}$, arquitetos e engenheiros que já vinham atuando anos antes no Convênio Escolar. Assim, vale lembrar que antes da criação dos "S" modernos, o Convênio Escolar, um acordo estabelecido entre o Estado e o município de São Paulo, propiciou as premissas do movimento de renovação da moderna arquitetura escolar paulista.

Percebe-se que anos antes de ser concebida a primeira escola "S" moderna, é notável a liderança de Hélio Duarte na coordenação dos projetos do Convênio, desde sua criação em 1948, assim como a atuação de sua equipe de arquitetos e engenheiros voltados à arquitetura escolar: Ernest Mange, Roberto Tibau, Oswaldo Gonçalves e Eduardo Corona, todos envolvidos com os "S" anos mais tardes. Assim, é relevante nos edifícios-escola dos "S" a experiência obtida no Convênio Escolar, tributário à concepção da arquitetura moderna, às idéias de Anísio Teixeira e da Escola Nova.

De fato, a maioria dos projetos da década de 1950, como fruto da geração de espírito pioneiro, inovaram o padrão arquitetônico das escolas dos "S" no estado de São Paulo, assim

\footnotetext{
${ }^{23}$ Vale lembrar que o projeto para o edifício SESC-SENAC de Araraquara, publicado na Habitat n ${ }^{\circ} 43$ (1957: 27-29), foi realizado por Corona em parceria com Gonçalves, porém não foi construído.

${ }^{24}$ Desta primeira geração dos "S", Hélio Duarte, Ernest Mange, Roberto Tibau, Oswaldo Gonçalves e Eduardo Corona já haviam atuado no Convênio Escolar.
} 
como, por exemplo, os irmãos Roberto foram os introdutores da arquitetura moderna no sistema SENAI do Rio de Janeiro. Assim, é exatamente na produção recente da historiografia da arquitetura moderna brasileira que são encontrados trabalhos que abrem caminhos para a investigação a respeito dos idealizadores desta primeira geração dos "S". Destaca-se a dissertação de mestrado da engenheira Elaine Rodrigues de Oliveira (1999), A contribuição de Oswaldo Corrêa Gonçalves para a Arquitetura Moderna Brasileira, que se atém à trajetória do arquiteto e seus principais projetos, apresentando referências dos edifícios concebidos para o SESCSENAC. Há também a dissertação de mestrado da arquiteta Cláudia Gomes de Araújo (2004), Arquitetura e cidade na obra de Ernest de Carvalho Mange, que descreve a atuação deste engenheiro e sua parceria com Hélio Duarte e associados na concepção de inúmeros projetos, inclusive do SENAI. Outros artigos publicados pela revista Arquitetura e Urbanismo, também trabalham com os arquitetos relacionados a esta pesquisa. São eles: o artigo de Catharine Gati (1995), Oswaldo Corrêa Gonçalves, construindo a profissão; o texto de Edite Galote R. Carranza e Ricardo Carranza (2002), Documento Roberto José Goulart Tibau; o artigo de Hugo Segawa (1998), Hélio Duarte, moderno, peregrino, educador. Além destas dissertações e mestrados, cabe ressaltar a dissertação de mestrado da autora desta tese, FERRAZ (2003), Marcas do Moderno na Arquitetura de Bauru, que estuda a atuação dos arquitetos modernos na cidade de Bauru, investigando a trajetória e aprofundando o conhecimento de Oswaldo Corrêa Gonçalves e Roberto Tibau.

Quanto a esta primeira geração, cabe começar pela figura de Hélio Duarte, líder no panorama da arquitetura escolar paulista. Duarte freqüentou a Escola Nacional de Belas Artes de 1925 a 1930 (SEGAWA, 1998:60). Como arquiteto, trabalhou inicialmente no Rio de Janeiro e, em 1936, transferiu-se para Salvador, onde iniciou sua atuação acadêmica e teve a oportunidade de conhecer o educador baiano Anísio Teixeira e seus conceitos de escolas-classe e escolasparque, posteriormente aplicados no Convênio Escolar. Em 1944, mudou para São Paulo e iniciou uma fase paulista marcada por diversos trabalhos realizados em equipe. Em 1948, passou a se 
dedicar ao programa do Convênio Escolar até 1952, ano em que projetou a Escola Anchieta e a Escola Têxtil Central juntamente com o engenheiro Ernest Mange e Associados (FERRAZ, 2003). Neste período, Duarte já havia retomado seu papel de educador, como professor na FAU-USP, carreira que seguiu até vir a falecer em 1989.

À trajetória de Hélio Duarte, soma-se a parceria com Ernest Mange e a co-autoria em muitos projetos na área da educação ${ }^{25}$, como as próprias escolas do SENAI. Ernest Mange, um dos filhos de Roberto Mange, engenheiro civil, formado no ano de 1945 pela Escola Politécnica da Universidade de São Paulo, também estagiou no escritório Rino Levi. Entre os anos de 1947 e 1948, já formando, Ernest Mange vai trabalhar com Le Corbusier, em Paris, no escritório executivo da Unidade de Habitação de Marselha, como bolsista do governo francês. Foi no ano de 1949 que começou seu contato com - Convênio Escolar devido à concorrência para a construção de uma escola, sendo que posteriormente foi contratado pela Comissão (ARAÚJO, 2004). No início da década de 50, a sociedade entre Mange, Duarte e dois estudantes da FAU-USP, Leo Quanji Nishikawa e Ariaki $\mathrm{Kato}^{26}$, realizou tanto escolas para o SENAI como outros significativos projetos. Ernest Mange também atuou na área acadêmica, como docente da Faculdade de Arquitetura e Urbanismo e da Escola Politécnica da Universidade de São Paulo, e na administração pública ocupando diversos cargos. Ernest Mange faleceu em 2005, gratificado em participar da realização da visão de seu pai, transformando a nova filosofia de ensino do SENAI em obras concretas.

Já Roberto Tibau, arquiteto de formação carioca que ingressou no campo de trabalho em São Paulo, é destacado pelos diversos projetos escolares que concebeu dentro dos princípios da arquitetura moderna, como também pela sua atuação acadêmica no

25 Segundo ARAÚJO (2004), juntamente com Helio Duarte, Ernest Mange realizou projetos voltados à educação: participou da equipe de projetistas da Comissão Convênio Escolar, realizou projetos para escolas SENAI e planejou dois campi universitários, a Escola de Engenharia de São Carlos e a Universidade Federal de Santa Catarina.

${ }^{26}$ Ernest Mange, em sociedade com o arquiteto Ariaki Kato, desenvolveu projetos de infra-estrutura para a construção de Usinas Hidrelétricas, como acampamentos e núcleos habitacionais para operadores (ARAÚJO, 2004). Os "S" também colhem o fruto desta parceria, com o projeto da Escola SENAI de Ribeirão Preto, em 1960, assinado por ambos. 
curso de arquitetura. Segundo FERRAZ (2003), em 1943, Tibau ingressou na ENBA (Escola Nacional de Belas Artes), dois anos antes da reforma da estrutura desta escola, portanto quando se formou, em 1949, já recebeu seu diploma pela Faculdade Nacional de Arquitetura da Universidade do Brasil. Fez parte da nova geração de estudantes que sucederam os grandes mestres, os quais foram essenciais tanto na sua formação acadêmica, como também na sua vida profissional, conforme afirmou 0 arquiteto em entrevista ${ }^{27}$ concedida à pesquisadora no ano de 2002:

[...]. Era uma arquitetura que, eu vou dizer pra você, uma arquitetura pós-acadêmica porque nós tivemos uma formação muito na base de Oscar [Niemeyer], Artigas, estes caras... mestres, e a gente estudava a arquitetura freqüentando os escritórios que naquele tempo eram mais abertos e a gente tinha condições de conversar com os arquitetos e brincar com eles.[...]. Oscar era um cara fantástico, fantástico! O Artigas também. [sic]

FERRAZ (2003:285-290, entrevista completa)

Recém-formado, em 1950 Tibau chegou a São Paulo e iniciou sua carreira profissional. Em 1951, ingressou no Convênio Escolar, mesmo que inicialmente em caráter provisório. Segundo Tibau, foi ele mesmo quem procurou Hélio Duarte na Prefeitura Municipal de São Paulo, por intermédio de seu veterano colega Eduardo Corona. A primeira geração dos "S" começava a se fortalecer no cenário da arquitetura moderna escolar paulista. Sua atuação profissional no Convênio é marcada por projetos que incluíam as questões sociais e culturais do conceito de educação então proposto, isto é, além de construir escolas, projetar outras instalações comunitárias como parques infantis, ginásios, bibliotecas e teatros populares. Desde o início de sua atuação profissional, o arquiteto adotou em seus projetos as concepções da arquitetura moderna, tendo se destacado como o arquiteto que trabalhou por mais tempo com a arquitetura escolar na Prefeitura Municipal. Enquanto atuava na Prefeitura de São

27 Em 24 de outubro de 2002 Roberto José Goulart Tibau foi entrevistado pela pesquisadora. Esta entrevista completa foi publicada na dissertação Marcas do Moderno na Arquitetura de Bauru (FERRAZ, 2003:285-290). 
Paulo, Tibau foi convidado por Roberto Mange para fazer parte do grupo de arquitetos que iriam projetar as novas escolas do SENAI. Foi exatamente neste contexto que $\mathrm{O}$ jovem arquiteto concebeu os projetos das Escolas SENAI de Bauru (1953), Santos (1956) e Jundiaí $(1957)^{28}$, além de participar do detalhamento da Escola Têxtil Central do Brás, São Paulo (1952). Juntamente com os projetos escolares, o arquiteto iniciou sua carreira acadêmica, em 1952, no Instituto de Arte Contemporânea do Museu de Arte de São Paulo, sendo que sua dedicação ao ensino se consolidou como professor na FAU-USP a partir de 1957, ao mesmo tempo em que se manteve constante na prática profissional através de diversos outros projetos escolares. Como professor da FAU, até a vir a se aposentar na década de 1980, Tibau recebeu o título de doutor em 1972 com a tese intitulada Arquitetura e Flexibilidade. Participou do grupo responsável pela reestruturação do currículo em 1976, foi o representante dos Professores Doutores da Congregação em 1977 e ministrou aulas na Pós-Graduação a partir de 1978, ente outras atividades acadêmicas (FERRAZ, 2003). Ainda nos anos 1990, foi professor da Universidade São Judas em São Paulo e continuou a idealizar inúmeros outros projetos. Tibau veio a falecer em agosto de 2003.

Diretamente ligado ao SENAC e ao SESC, foi a atuação de Oswaldo Corrêa Gonçalves ao projetar na década de 1950 sete edifícios para estes "S", a saber em: Ribeirão Preto, Marília, Bauru, Araraquara, Santos, São Paulo e São José do Rio Preto. Gonçalves foi educado entre Santos, sua cidade natal, e São Paulo, "cursou o primário no colégio São Bento, em São Paulo, como interno. $O$ curso secundário iniciou em Santos no Colégio Luso Brasileiro e terminou em São Paulo no Colégio Rio Branco" (OLIVEIRA, 1999:9). Continuando seus estudos em São Paulo, em 1935, entrou no Curso Preliminar $^{29}$ da Politécnica e, em 1937, entrou na Escola Politécnica de São Paulo formando-se em 1941 como engenheiro-arquiteto. Em 1942, Gonçalves começou a trabalhar na Prefeitura Municipal de São Paulo e, em 1943, voltou para a Politécnica e completou o curso de engenheiro civil em 1945 (FERRAZ, 2003). Em 1945, o arquiteto volta

\footnotetext{
${ }^{28} \mathrm{Em}$ parceria com Ayako Nishikawa.

29 Segundo FICHER (1989), este curso era complementar ao ensino secundário e era obrigatório para os alunos de engenharia.
} 
a trabalhar na Prefeitura Municipal de São Paulo e simultaneamente monta seu próprio escritório. Gonçalves mostrou em seus projetos tanto de edifícios, como urbanísticos, sua preferência pela arquitetura carioca e a aplicação dos princípios corbusianos, conforme entrevista $^{30}$ concedida à pesquisadora no ano de 2002:

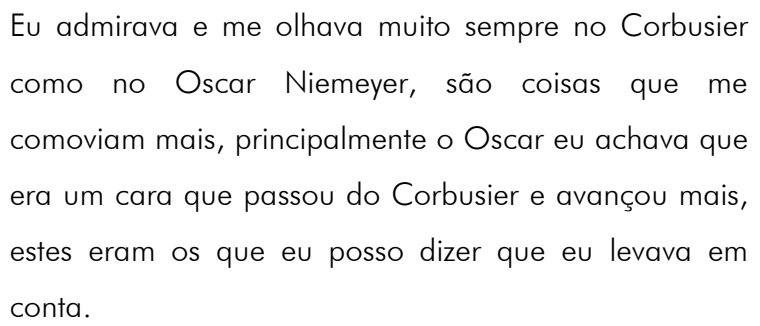

FERRAZ (2003:291-295, entrevista completa)

No final da década de 1940 e início da de 1950, Gonçalves participou da primeira geração do Convênio Escolar projetando várias escolas $^{31}$. Na década de 1950, o arquiteto projetou as escolas do SESC e do SENAC, que segundo GATI (1995:84) representam a "época áurea da sua produção". Gonçalves assumiu a incumbência de projetar as novas escolas SESC e SENAC, facilitada pelo contato direto com o presidente da Federação do Comércio, o amigo e engenheiro Luís Roberto de Carvalho Vidigal. Na década de 1960 Gonçalves se destacou como presidente do IAB, organizador das sessões de arquitetura das Bienais de Artes de São Paulo, elaborador do Plano Diretor Físico de Santos de 1968, projeto urbanístico de Gonçalves e seus sócios, juntamente com Heitor Ferreira de Souza. Já na década de 1970, Gonçalves teve consagrados marcos na sua trajetória profissional: a criação da Faculdade de Arquitetura e Urbanismo de Santos (FAUS), em 1970, a criação e coordenação da I Bienal Internacional de Arquitetura em 1973 e a sociedade com Benno Perelmutter em 1970, consolidada no Escritório Pluricurricular de Projetos (PLURIC) e equipe (FERRAZ, 2003). Deixando aos poucos

30 Em 25 de outubro de 2002 Oswaldo Corrêa Gonçalves foi entrevistado pela pesquisadora. Esta entrevista foi publicada na dissertação Marcas do Moderno na Arquitetura de Bauru (FERRAZ, 2003:293-297).

31 Segundo OLIVEIRA (1999:49) Gonçalves projetou seis escolas para o convênio: G. E. Romeu de Morais (Vila Ipojuca-Lapa), G. E. Canuto do Val (Barra Funda), G. E. Pedro Taques (Guaianazes), G. E. Almirante Visconde de Inhaúma (Bairro Mandaqui), G. E. República do Paraguai (Vila Prudente) e G. E. Carlos Escobar (Tatuapé). 
a atividade projetual que o acompanhou por toda a sua trajetória, desde os anos 1980, Gonçalves passou a dedicar-se às atividades da FAU Santos. Oswaldo Corrêa Gonçalves teve em sua trajetória a luta pela consolidação da profissão, participou do Convênio Escolar, projetou escolas para o SESC e o SENAC, desenvolveu sua visão urbanística, promoveu e participou de diversos congressos e bienais. Contribuiu para o ensino da arquitetura, formou parceria com arquitetos de formações e gerações diferentes. Gonçalves foi, sem dúvida, um colaborador ativo fecundando o trabalho de sua geração, atuante até 2005, ano de sua morte.

Vale lembrar que em parceria com Gonçalves, Rubens Carneiro Viana e Ricardo Siervers foram co-autores da Escola SESCSENAC de Marília (1955), assim como Eduardo Corona da escola de Araraquara (1956, não construída). Desta forma, ressaltando o trabalho em equipe pela arquitetura moderna escolar paulista, é aqui recuperada a obra da primeira geração dos " $\mathrm{S}$ ".

De suma importância, para o trabalho desta primeira geração, apoiada por Roberto Mange, é preciso destacar a atuação do engenheiro Luiz Alfredo Falcão Baver. Responsável pela construção destas escolas, Baver foi uma figura bastante significativa entre os engenheiros de todo o Brasil, principalmente por sua atuação na luta pelo controle de qualidade das construções em concreto. Ao sair graduado da Escola Politécnica, ingressou no SENAI até chegar ao cargo de engenheiro chefe do Serviço de Obras, atividade que exerceu por 13 anos (VASCONCELOS, 1992: 154-155).

Além dos profissionais acima citados, a partir de 1957 outros nomes foram surgindo na autoria das escolas "S". No SENAl, destacam-se Lúcio Grinover, Ayako Nishikawa, Melanias M. Nagamini, Luiz Carlos Costa e Ariaki Kato e, no SESC e no SENAC, Osmar Tosi, Adolfo Rubio Morales, Jorge Wilheim e Miguel Juliano e Silva. Estes idealizadores atuaram principalmente na década de 1960 e são aqui reconhecidos como a segunda geração dos " $S$ ", dando continuidade ao legado dos ideais arquitetônicos e pedagógicos da arquitetura escolar paulista.

Sem dúvida, Hélio Duarte foi o grande nome por trás do trabalho do Convênio Escolar: dirigiu um time de arquitetos composto 
por nomes essenciais à história da arquitetura brasileira, tais como Ernest Mange, Roberto Tibau, Oswaldo Gonçalves e Eduardo Corona. Como referência brasileira, as modernas escolas " $\mathrm{S}$ " paulistas revelam-se uma marca da consistente contribuição desta geração.

Nos "S", embora estas duas gerações e as seguintes tivessem diferentes requisitos ao projetar estas escolas - funções da indústria ou do comércio, limitações de orçamento, área de implantação, dimensões do edifício-escola - cada projeto conseguiu ser único e caracterizado pela plasticidade de cada autor. Assim, ao mesmo tempo em que as modernas escolas "S" tenham empregado os recursos de padronização modular, a solução básica de blocos distintos para suas funções e a articulação dos volumes por eixos de circulação, é valioso observar como cada profissional expressou, à sua maneira, sua intenção na composição, nos espaços iluminados e ventilados, nas áreas livres e nos elementos artísticos, todos integrados à arquitetura moderna. 

Ao estudar o momento histórico de criação dos "S", em sentido mais amplo, é possível reconhecer estes Serviços como parte de uma "campanha" brasileira para envolver as discussões sobre a organização racional do trabalho, o desenvolvimento econômico e técnico e, as noções relacionadas ao bem-estar social do pósSegunda Guerra Mundial. Como reconhece BAER (1966:97), estas instituições destinadas à formação de trabalhadores para a indústria e o comércio são uma herança deixada pelo governo Vargas, apoiada pelo Estado, pela contribuição financeira das folhas de pagamentos dos próprios trabalhadores e empregadores, geridas por estes últimos. Inegavelmente, os resultados da atuação destes Serviços foram e ainda são positivos ao desenvolvimento econômico, ao empresário e ao trabalhador brasileiro, ainda que inicialmente tenham encontrado algumas resistências e críticas feitas aos métodos de ensino e ao funcionamento de suas escolas. Compreendidos no plano geral da estrutura das instituições brasileiras de política econômica e social, os "S" são, sem dúvida, exemplares. Neste sentido, parte do sucesso dos "S" foi a estratégia dos agentes envolvidos em sua criação, reunindo Estado, empresários e trabalhadores, para conseguir "reforma social", ou, numa visão mais crítica, um esforço no plano educativo para "integrar" ou "disciplinar" o operariado brasileiro para assumir seu papel na sociedade urbana e industrial brasileira daqueles anos. Com exemplo disso - uma vez que parte dos formados pelo próprio SENAl atuou na reconstrução do movimento operário durante o período do regime militar pós-1964 -, não é de se surpreender que proeminentes figuras nacionais do novo "sindicalismo", como Luiz Inácio Lula da Silva, são operários formados pelo SENAI.

É certo que a ênfase na formação do operário especializado já fazia parte do discurso em favor da racionalização, desde a década de 1920, defendido pelos engenheiros "Robertos", Simonsen e Mange, principalmente em São Paulo. A "reforma social" desejava mitigar a luta de classes. Porém, acima de tudo, o movimento de engenheiros, empresários e técnicos pela racionalização visava propiciar um desenvolvimento da técnica, de modo que o controle do operário, antes de tudo era uma ferramenta para atacar os problemas 
do desenvolvimento econômico. A "racionalização" era um meio de "organizar" a sociedade brasileira. Outro aspecto do contexto da questão da "reforma social", profundamente relacionado à tese, é o conceito de "educação integral". Esta educação que enfatizava o esforço individual, o aperfeiçoamento técnico, o sentido humano de sociabilidade pelo trabalho e conseqüentemente, o aumento da produtividade, foi identificada na arquitetura moderna das escolas "S". A figura de Roberto Mange foi a grande presença asseguradora deste pressuposto, tanto como o líder do grupo de profissionais e intelectuais envolvidos na "educação integral", como o responsável por esta marca profunda da própria história do SENAI. Sob este foco, respostas foram obtidas dentro do campo de investigação desta tese ao compreender as demandas educacionais da economia e da sociedade brasileira, conjuntamente com as propostas para a educação do trabalhador.

Para bem documentar e analisar as escolas "S" projetadas de 1952 a 1968 em todo o estado de São Paulo foi essencial reconhecer a importância destes serviços no desenvolvimento (ou re-formação, na expressão de WEINSTEIN) da classe operária brasileira, apoiada estrategicamente pelo Estado, como parte de um projeto nacional. Do pós-Segunda Guerra ao golpe militar de 1964, o ensino técnico e os "direitos trabalhistas" passaram a ser um pivô em favor do equilíbrio nas difíceis relações entre patrão e empregado, endossando o esquema corporativista e estimulando a sindicalismo. Assim, numa época em que o Estado já havia criado o "ensino profissionalizante" nas escolas do segundo grau, os " $\mathrm{S}$ " continuaram a acolher uma parcela da população que recebia o ensino profissional ao mesmo tempo em que trabalhava, estimulando os jovens, muitas vezes, filhos dos próprios operários da indústria. Este era o perfil do jovem que se inscrevia para os cursos do SENAI, SESC e SENAC, dado fundamental para entender como eram as escolas naquele momento.

Sem dúvida os "S" eram geridos pela burguesia industrial e comercial muito mais do que pelo próprio Estado. Afinal, o empresariado brasileiro, ainda que dividido em "categorias" de indústria e de comércio, foi o grande empregador do trabalhador brasileiro, quer seja representado pelas grandes indústrias - como da 
siderurgia ou automobilística -, ou pelas pequenas empresas. Indiscutivelmente, os industriais e os empresários comerciais foram os grandes responsáveis pela sobrevivência destes Serviços. Já, o Estado, sem dúvida, foi o que atribuiu poder a estas corporações, um modelo getulista que estimulou a colaboração entre as classes.

Dentro deste âmbito nacional de formação do trabalhador, é interessante perceber como o edifício-escola também teve o objetivo de estimular uma forma de vida democrática, de reforma social, dentro do período histórico conhecido como o da Segunda Revolução Industrial. Assim, ao pesquisar e analisar as escolas dos três " $\mathrm{S}$ ", esta tese se deparou como uma importante produção arquitetônica que se destacou, no estado de São Paulo, para a formação do trabalhador. Sem dúvida, a linguagem arquitetônica das primeiras escolas, construídas na década de 1940, expressa as complexas relações com o campo da gestão do trabalho no período em que foram criados. Já as modernas escolas "S" paulistas, projetadas nas décadas de 1950 e 1960, são exemplares deste casamento da nova pedagogia brasileira com a arquitetura moderna escolar, seguindo a pedagogia da época - a proposta de educar e não apenas de treinar. A questão inicial de como e quando a arquitetura atendeu às características pedagógicas implantadas por estes Serviços foi assim respondida.

Outra questão da tese foi respondida ao identificar que os responsáveis pela autoria das escolas modernas "S" foram arquitetos e engenheiros tributários das idéias de Anísio Teixeira e das experiências do Convênio Escolar, ambas referências fundamentais para a arquitetura escolar paulista. As lideranças de Hélio Duarte nos projetos do SENAl e de Oswaldo Corrêa Gonçalves nos projetos do SESC e SENAC, na década de 1950, juntamente com a presença de Ernest Mange, Roberto Tibau e Eduardo Corona, constatam nos projetos do edifício-escola dos "S" a mesma geração envolvida anteriormente com o Convênio Escolar. Quanto a esta primeira geração dos "S", apoiada por Roberto Mange e pela equipe ligada ao controle do concreto liderada pelo engenheiro Luiz Alfredo Falcão Baver, teve seu líder no panorama da arquitetura escolar paulista, em Hélio Duarte. Este último, documenta sua admiração ao trabalho de 
Anísio Teixeira, ao escrever o livro Escola Classe - Escola Parque: uma experiência eudcacional (DUARTE, 1973).

Ao relacionar os "S" com a formação do trabalhador brasileiro, esta tese reconhece o peso do paradigma técnicoeconômico de origem norte-americana adotado em São Paulo, como aliás em tantos outros países que então aceleram seu processo de industrialização. Líderes empresariais e técnicos como Roberto Simonsen e Roberto Mange, especialmente após a Segunda Guerra Mundial, eram entusiastas do conceito "Learn by doing" que também foi lema dos "S". Além disso, foi possível observar, em paralelo à arquitetura escolar, o valor da moderna arquitetura industrial norteamericana promovida por Albert Kahn, modelo emblemático associado ao fordismo.

No campo da pedagogia, a partir do diálogo de Anísio Teixeira com John Dewey (Brasil com EUA), o movimento de renovação pedagógica acabou incidindo nos métodos de ensino industrial e comercial, ampliando o vínculo dos técnicos e profissionais envolvidos nos "S" modernos com o "americanismo". A modernização pedagógica brasileira e norte-americana, não se limitava a "adaptar" ou "formatar" a educação para o adulto, dando a esta uma direção ideológica. Esta educação abriu espaço à indagação individual no plano do trabalho e da sociabilidade. A intenção pedagógica de então reforçou a observação e o estudo dos fenômenos naturais, políticos, sociais e econômicos. A arquitetura, por sua vez, procurou responder a estas aspirações com seus atributos físicos expressos pela arquitetura moderna escolar, voltada ao ensino técnico e vocacional.

Sem dúvida, ao confirmar uma mudança na história pedagógica norte-americana, com ênfase à educação técnica e vocacional, é essencial notar sua repercussão na arquitetura do edifício-escola, tanto nos EUA como no Brasil. A renovação pedagógica e arquitetônica dos "S" brasileiros é incrivelmente atualizada, pois ocorre no mesmo período e com semelhantes soluções físicas e espaciais, com relações aos Estados Unidos. $\bigcirc$ objetivo pragmático norte-americano, de educar para a "eficiência", típico do "progressivismo", pode ser comparado no Brasil ao 
movimento social dos empresários e engenheiros que obtém o apoio do governo às demandas de escolas técnicas para jovens e adultos. Por fim, na mudança arquitetônica do edifício-escola, a partir de meados do século XX, constatou-se que o diálogo entre Brasil e EUA deu-se na definição dos próprios princípios aplicados na concepção da arquitetura escolar dos "S". Esta confirmação, aponta para a visão global da "triangulação" Brasil, EUA e Europa, não desconsidera que, juntamente com a experiência norte-americana, novos projetos de arquitetura escolar vocacional também estavam sendo desenvolvidos nos países europeus para atender à demanda educacional do pós-guerra, mas sim mostra claramente como o diálogo entre Brasil e EUA envolveu sinuosos caminhos e rebateu nas diretrizes adotadas ao projetar o espaço escolar, no âmbito do pensamento da década de 1950. Neste momento, o fato é que ao rever o edifício-escola norte-americano é possível acompanhar, identificar e até mesmo se surpreender com as semelhanças assim como com as características inéditas de sua arquitetura escolar, se comparadas às escolas "S" paulistas. Exemplo claro deste diálogo são as seis premissas pedagógicas - as próprias diretrizes aplicadas à arquitetura norte-americana da Norma High School (apresentada no capítulo 1), comparadas às sete características norteadoras das escolas modernas "S" paulistas. Utilizando diferentes soluções técnicas e espaciais, a arquitetura de ambas "buscou atender aos conceitos sinteticamente apresentados de crescimento, flexibilidade, atratividade, interligação, sociabilidade, rendimento e economia. Nas respostas às indagações iniciais desta tese, foi instigante desvendar as referências internacionais da concepção das escolas modernas "S". A relação da pedagogia com a arquitetura moderna norte-americana das escolas técnicas e vocacionais foi identificada e a atualização dos arquitetos brasileiros também o foi.

Soluções projetuais arquitetônicas construíram uma escola para a formação do trabalhador que propunha além do ensino técnico, espaços para o desenvolvimento físico e social dos alunos. Tanto na visão de Roberto Mange, quanto nas premissas norteamericanas, a arquitetura deveria sugerir uma escola "aberta". Este modo de ver a escola como um centro social para os jovens

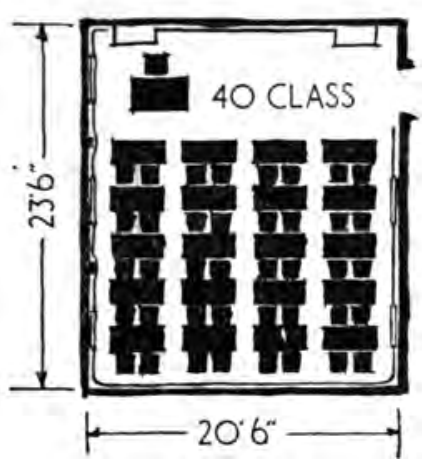

Figuras 1 e 2: Acima, uma proposta para a sala de aula norte- americana. Abaixo, sala de aula da Escola SESC-SENAC de Bauru, década de 1950.

Observar as semelhanças na disposição das mesas "duplas" e a proporção do ambiente. Fonte: The Modern School (1949:64) e Foto Moscardi,

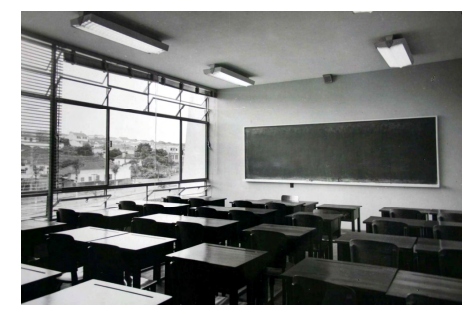




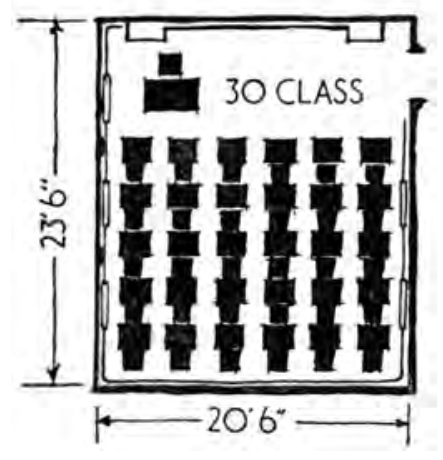

Figuras 3 e 4: Acima, outra proposta para a sala de aula norte- americana. Abaixo, sala de aula da Escola SESC-SENAC de Ribeirão Preto, década de 1950. Observar as semelhanças na disposição das mesas, tanto dos alunos como do professor. Fonte: The Modern School (1949:64) e Foto Moscardi,

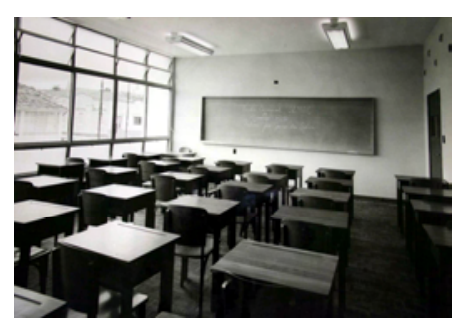

Figuras 5 e 6: A composição geométrica, definida pelos blocos da escola, diversificava a implantação de cada escola, Observar a implantação da High School for Gratiot Township (ao lodo) com a Escola SENAI de Bauru (na página seguinte). As unidades da escola estão claremente definidas em três partes do ensino: social, teórico e prático.

Fonte: The American School and University 1948-1949 (1949:271) e arquivo da Prefeitura Municipal desenvolveu a idéia de atratividade e sociabilidade dentro do espírito de uma educação integral, criou um diferenciado programa construtivo voltado para o aluno, uma escola com recreio, auditório, campo de esportes, piscina, entre outros. Até mesmo no tradicional ambiente destinado ao ensino teórico, a sala de aula, é possível notar semelhanças nos dois países: a dimensão do ambiente, as possibilidades de disposição dos móveis, as "paredes divisórias" das salas de aula estavam claramente associadas com o crescimento e a flexibilidade em ambos os casos. Da mesma maneira, plausíveis soluções arquitetônicas evidenciaram características projetuais semelhantes, tanto na arquitetura escolar dos "S" como no edifícioescola norte-americano, tais como: composição geométrica diversificada gerada pela composição dos blocos (unidades) da escola, em diferentes implantações, permitindo a expansão (crescimento) da escola; passarelas (envidraçadas ou somente cobertas) de ligação entre os blocos, possibilitando o acesso visual ao exterior dentro da premissa de atratividade e rendimento para realizar a educação integral; estrutura modular e racional dos edifícios, possibilitando a flexibilidade do espaço, e assim por diante.

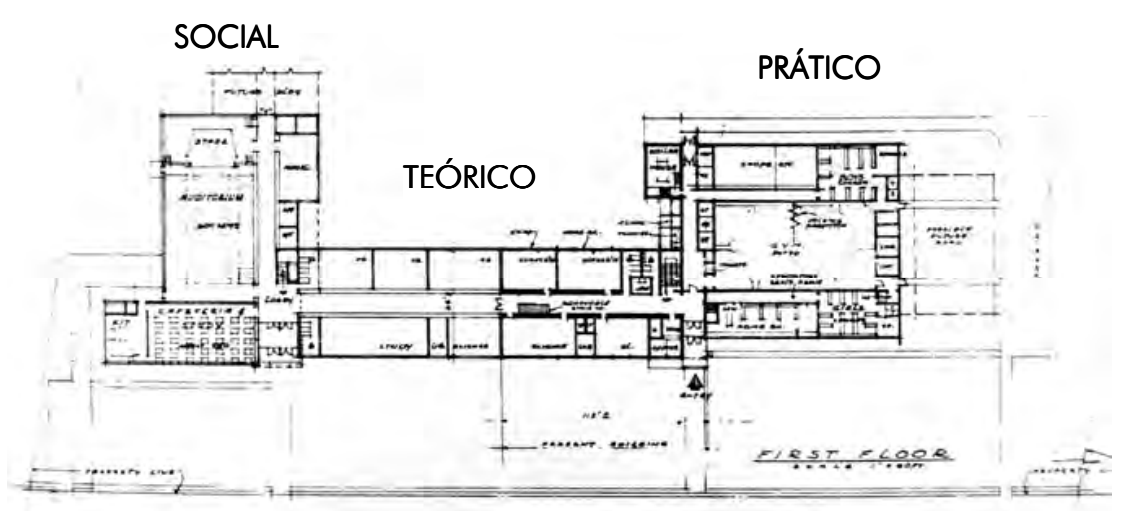



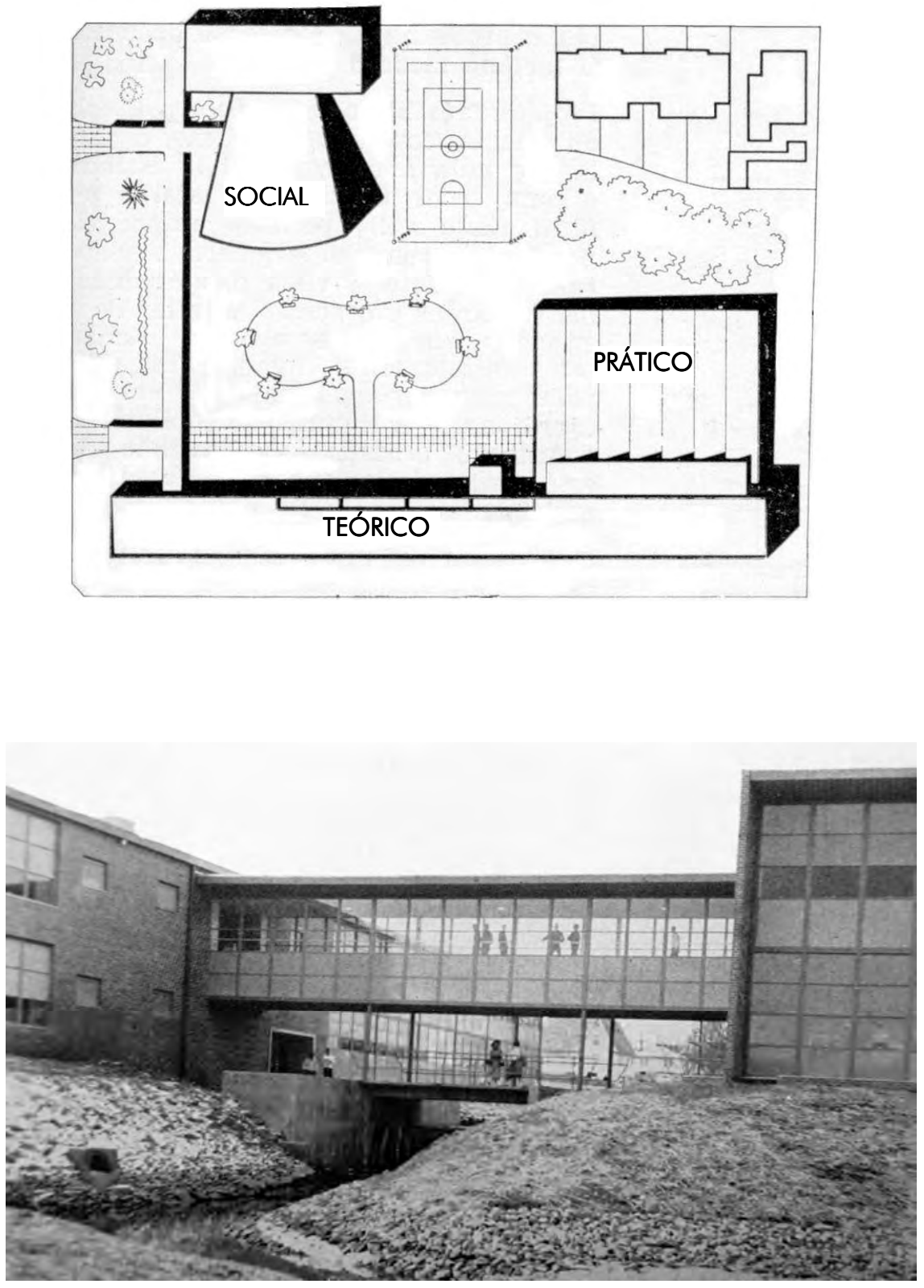

Figuras 7 e 8: A passarela envidraçada de ligação entre blocos foi uma solução utilizada tanto na escola norte-americana como na paulista brasileira. Respectivamente, Salem Washington Township High School, Salem, Indiana (ao lado) e Escola SENAI Têxtil Central do Brás, São Paulo (abaixo), ambas construídas na década de 1950.

Fonte: American Trade Shools Directory 1958-1958 (1959:31)

Acrópole n² 241 (1958:10), respectivamente.

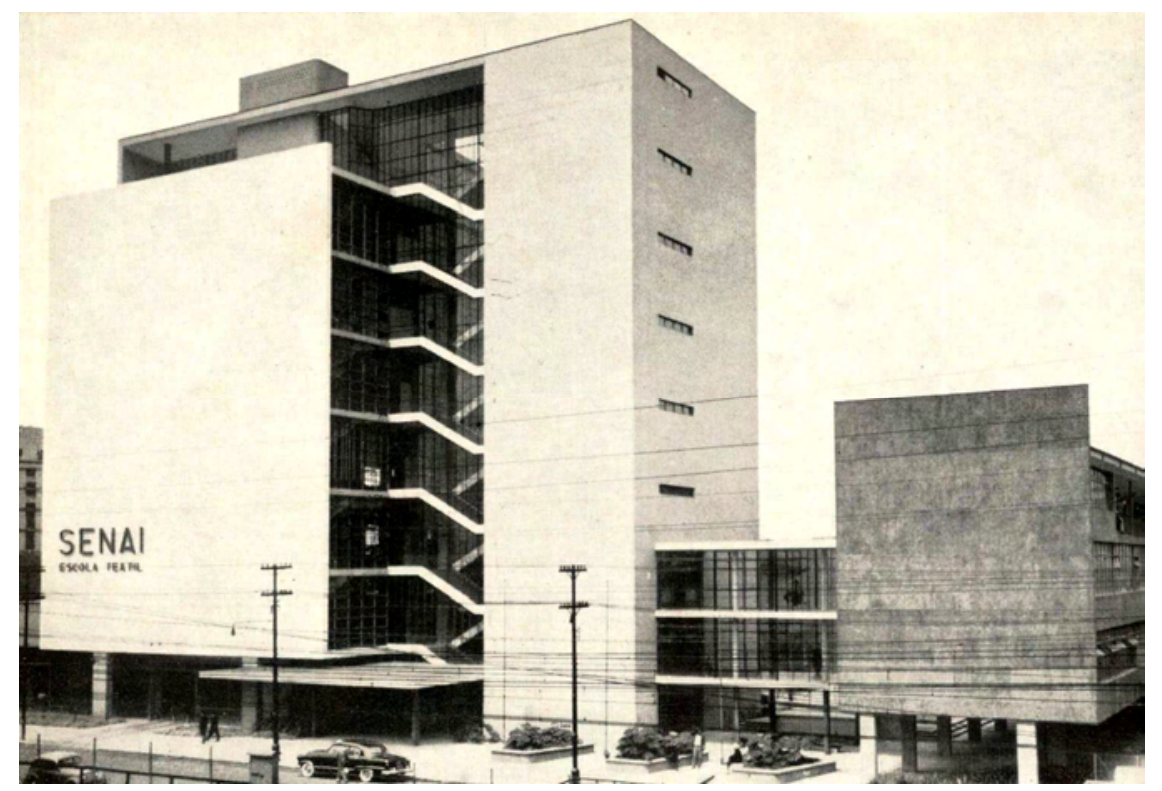


Figuras 9 e 10: A estrutura de concreto, modulada e marcante, apresenta diversas soluções plásticas. Observar, nesta comparação, a semelhança da estrutura da West Charlotte Senior High School, Charlotte, N.C. com a da Escola SENAI de Bauru. Fonte: Architectural Record (1956: $260,261,263)$ e arquivo SENAI Bauru, respectivamente.
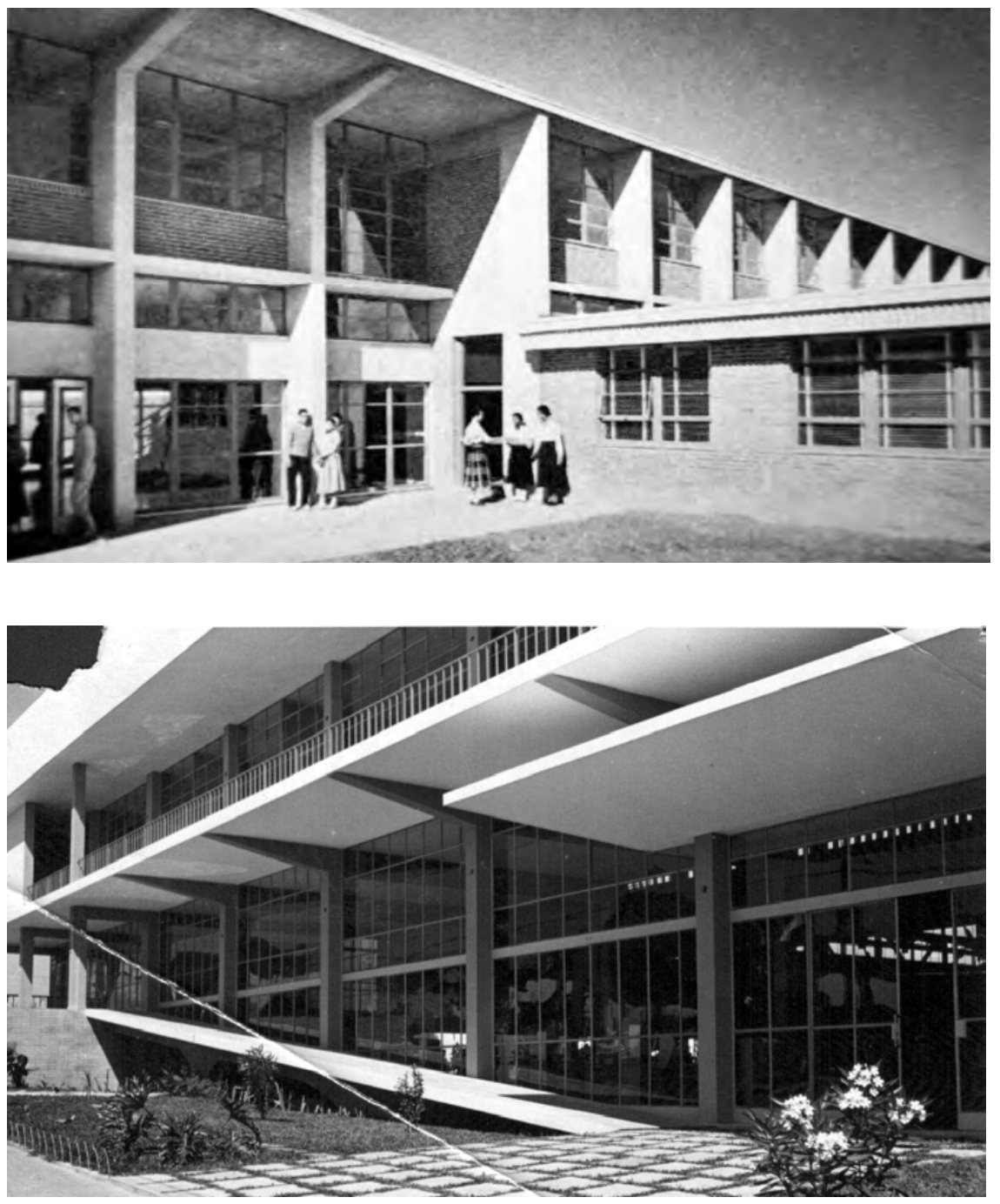

Acima de todas estas semelhanças físicas e espaciais projetadas para atender a pedagogia em voga, vale lembrar que a linguagem utilizada para atender a esta nova concepção foi a da arquitetura moderna. Formas simples, racionais e harmoniosas. Dos grandes vãos de luz natural à aplicação das artes plásticas, elementos foram compostos para despertar no aluno mais do que o ensino técnico industrial e comercial, mas sim à ampliação de horizontes necessária à formação do trabalhador. Sem dúvida a arquitetura moderna das escolas "S" paulistas são referências de âmbito nacional, mas numa visão crítica, é preciso reconhecer que nem todas as suas soluções projetuais foram bem sucedidas e resistiram ao uso. Toma-se como exemplo, a economia no sentido de ambientes com iluminação natural, ventilação direta e com menores distâncias a percorrer de um ponto a outro, que é, sem dúvida, um princípio 
válido e aplicável até mesmo para os dias de hoje. Diferentemente, a interligação visual entre sala de aula e oficina, juntamente com a idéia de rendimento entre teoria e prática, não foi uma solução bem resolvida, no que diz respeito ao conforto acústico, ao ruído nos ambientes de aprendizado.

Uma vez que a arquitetura moderna das escolas dos " $\mathrm{S}$ " marcou o momento de mudança pedagógica destes Serviços, dentro do período fértil da educação nacional, como resposta à "redemocratização" do pós Segunda Guerra Mundial, a volta da "educação para todos", a demanda democrática da República Nova, combinou-se à política corporativista do Estado. É também notável como esta combinação deu suporte físico ao crescimento e consolidação dos "S" no seu esforço de ser uma Escola Nova, como defendia Anísio Teixeira.

fato é que, ao investigar e analisar os 33 projetos da "era de ouro" dos "S", além de enxergar a pedagogia aplicada à arquitetura escolar, foi possível contemplar a riqueza dos desenhos técnicos, feitos à mão, revelada nas inúmeras pranchas dos projetos originais encontrados nos arquivos pesquisados. E, ao manusear estes projetos, uma questão não poderia deixar de surgir. Qual o estado atual de conservação deste marcos da arquitetura brasileira? Sem a pretensão de relatar e avaliar de forma individulizada as mudanças arquitetônicas de cada escola "S" paulista, desde a sua concepção até os dias de hoje, esta tese apresenta, por fim, alguns exemplares "S" em seu estado físico atual. Um alerta para o patrimônio construído que, em alguns casos, já afetou o destino da memória arquitetônica brasileira.
Figuras 11 e 12: Face norte da Escola SENAI Anchieta, Vila Mariana, São Paulo, 1954 e 2003.

Fonte: Arquivo Escola Anchieta e foto Ferraz, respectivamente.
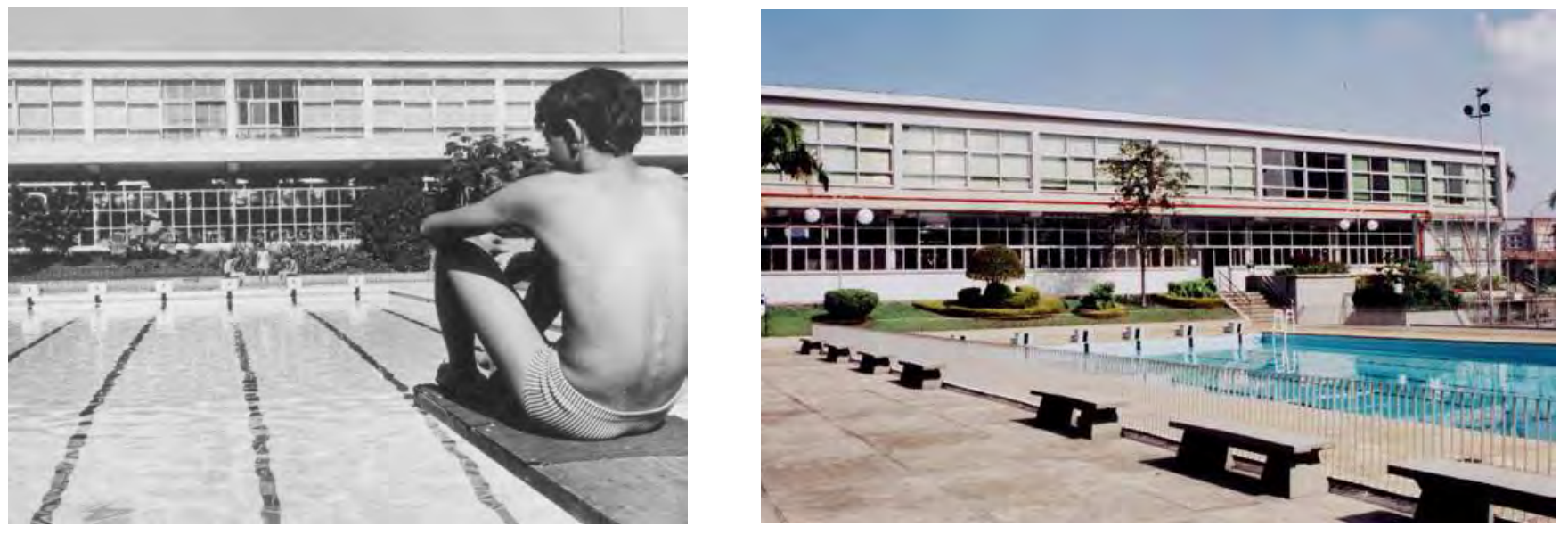

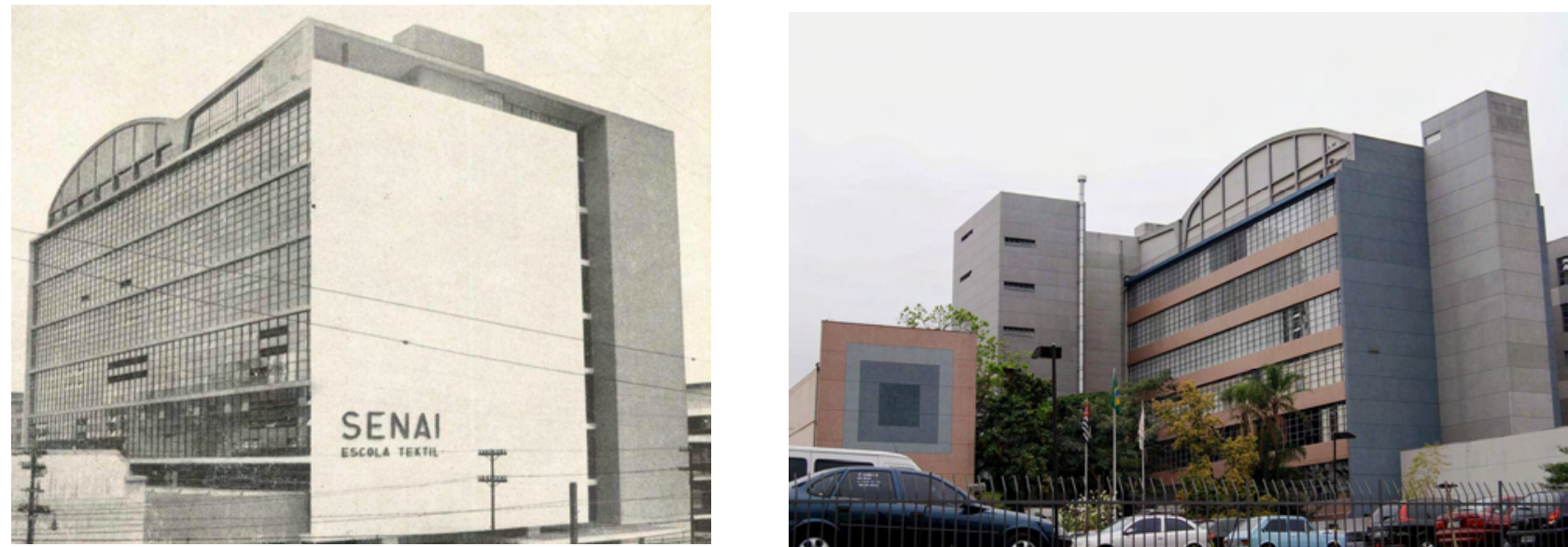

Figuras 13 e 14: Escola SENAI Têxtil Central do Brás, São Paulo. Vistas da faces sudeste, década de 1950 e noroeste, 2007. Fonte: Acrópole n² 241 (1958:11) e foto Ferraz, respectivamente.
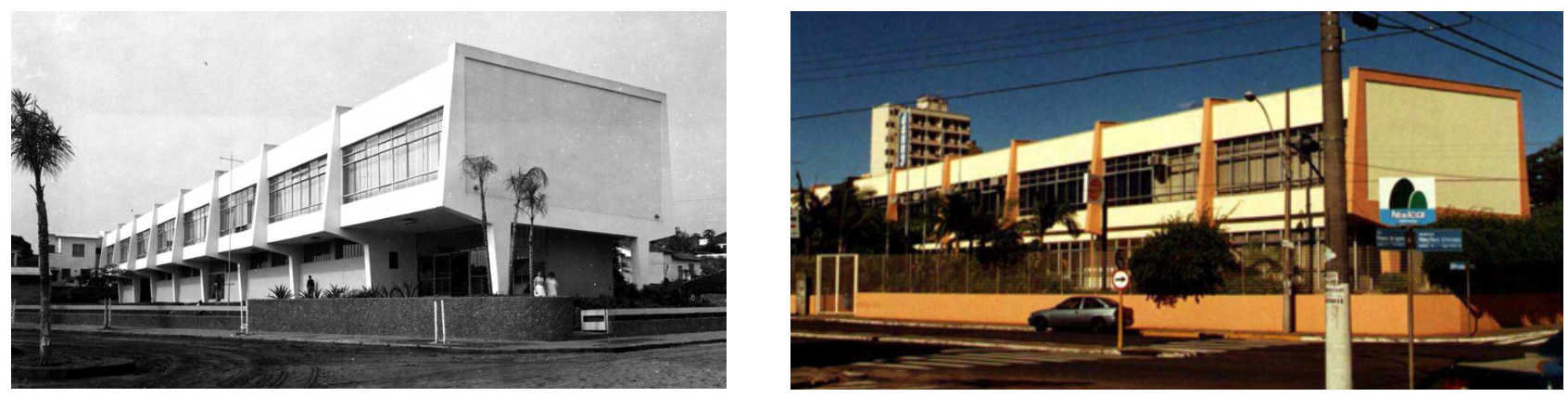

Figuras 15 e 16: O SENAC de Bauru, 2003, antigo SESC-SENAC na década de 1950, revela alterações em relação ao projeto original como gradis em todo o perímetro do terreno com a calçada, elevador externo para deficientes físicos locado na fachada oeste, brises solares em parte das janelas do segundo pavimento voltadas para o oeste, além da reformulações de espaços internos. Mesmo com reformulações concretas e administrativas, o atual edifício SENAC de Bauru ainda é um rico exemplar da arquitetura moderna brasileira.

Fonte:Foto Moscardi, arquivo FAUS, e foto Ferraz, respectivamente.
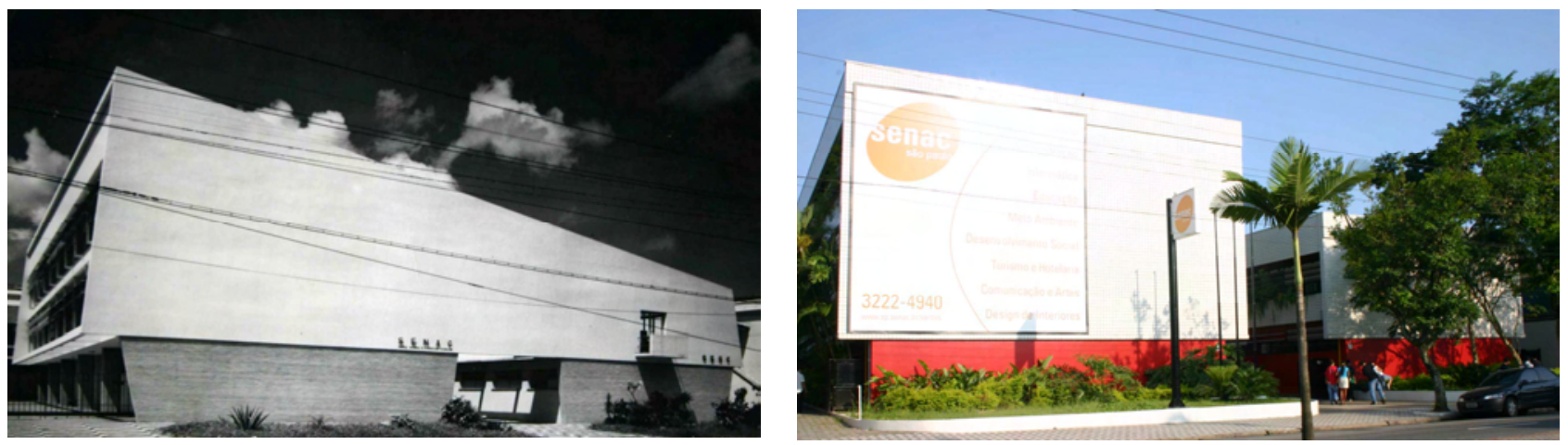

Figuras 17 e 18: Escola SESC-SENAC em Santos, década de 1950, atual SENAC, 2006. Neste caso, o estado atual do SENAC de Santos revelou muitas intervenções ao projeto original, principalmente a projetada pelo arquiteto Sérgio Teperman, descaracterizando de forma penosa o edifício.

Fonte:Foto Moscardi, arquivo FAUS, e foto Ferraz, respectivamente. 
Esta tese acredita ter colaborado na pesquisa da arquitetura moderna escolar paulista destinada à formação do trabalhador e construída como parte do sistema dos três "S", contribuindo para a historiografia da Arquitetura Moderna brasileira, ao articular diversas questões relacionadas ao objeto de estudo. Novos ângulos de abordagem são assumidos e defendidos, com base em um corpo de evidência construído com pesquisa documental. Porém, não se pretende exaurir todo o conteúdo aqui investigado e criteriosamente documentado e analisado. Novas indagações são oferecidas a pesquisas posteriores e a outros pesquisadores. Aos arquitetos, um "tijolinho" na construção da história da arquitetura brasileira. Mas, acima de tudo, uma "ponte" sobre o abismo entre a teoria e a prática, a academia e a vida, tão almejada pela atuação dos "S" para a modernização brasileira. 


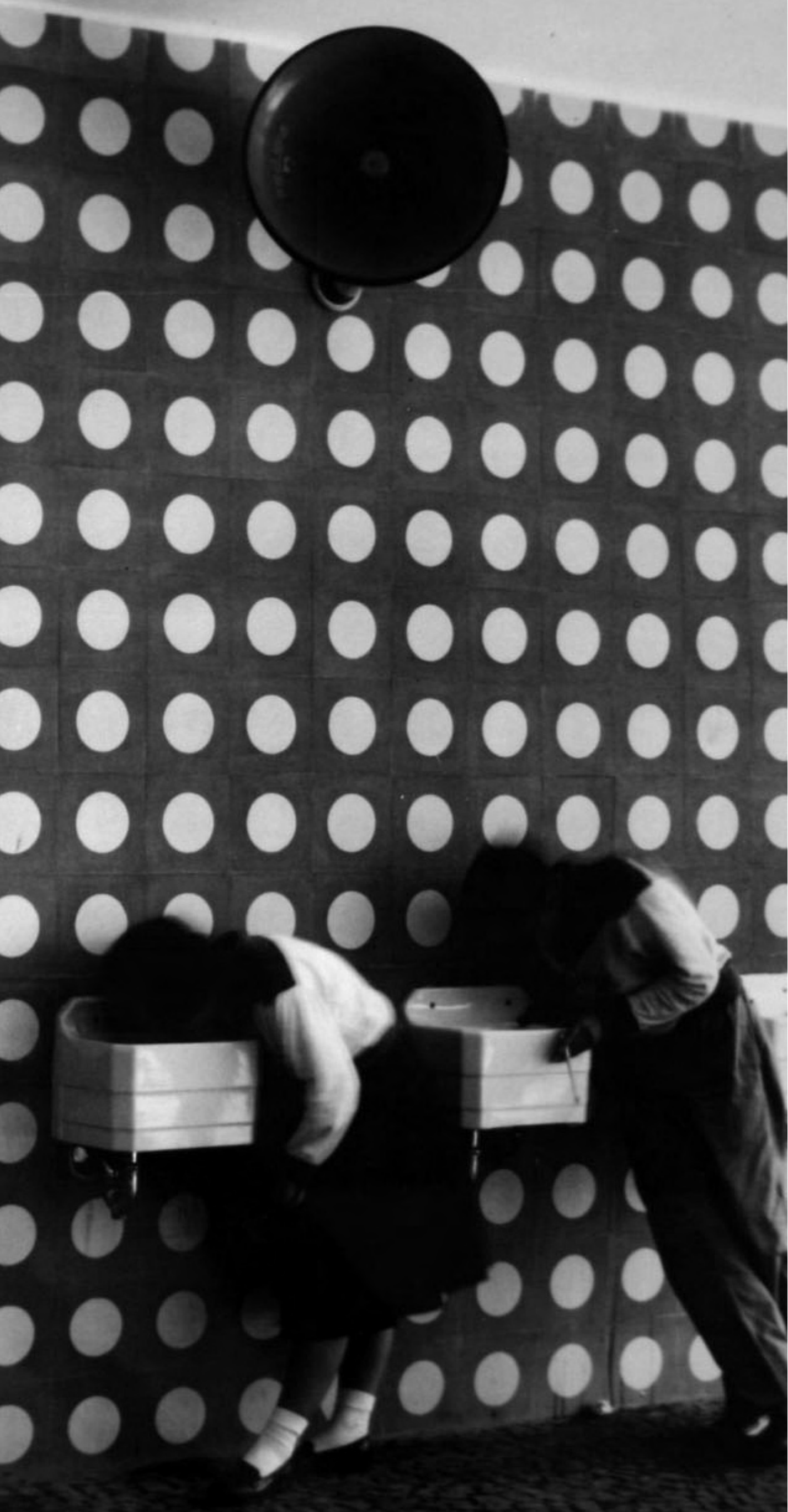


ACRÓPOLE. São Paulo: Gruenwald \& Cia., n. 314, 1965.

ACRÓPOLE. São Paulo: Gruenwald \& Cia., n. 197, 1955.

ALANIS, Enrique X. de Anda. A Arquitetura déco no México: uma proposta de vanguarda em tempos de modernidade. In CZAJKOWSKI, Jorge (org.). Art Déco da América Latina, anais do $1^{\circ}$. Seminário Internacional do Centro de Arquitetura e Urbanismo do Rio de Janeiro. Rio de Janeiro: Secretaria Municipal de Urbanismo, 1966.

ALVES, André Augusto de Almeida. Arquitetura e sociedade em São Paulo 1956-1968: projetos de Brasil moderno. (Dissertação de Mestrado). São Paulo: FAUUSP, Universidade de São Paulo, 2003.

ARANHA, M.L.A. História da Educação. São Paulo, Moderna, 2002.

ARAÚJO, Cláudia Gomes de. Arquitetura e cidade na obra de Ernest de Carvalho Mange. (Dissertação de Mestrado). São Carlos: Escola de Engenharia de São Carlos, Universidade de São Paulo, 2004.

AU. São Paulo, n. 59, abril e maio, 1995.

BAER, Werner. A industrialização e o desenvolvimento econômico do Brasil. Rio de Janeiro: FGV, Depto. de Publicações, 1966.

Brazilian Economy: Growth and Development (5th Edition). Westport, CT, USA: Greenwood Publishing Group, Incorporated, 2001.

BANHAM, Reyner. A concrete Atlantis: U.S. industrial building and European modern architecture, 1900-1925. Cambridge, Mass.: MIT Press, 1986.

BANHARD. Earl Wingert in The American School and University 1931-1932. New York: American School Publishing Corporation, 1932.

BEM ESTAR. São Paulo: Gustavo Neves da Rocha Filho, n. 5/6, 1960.

BENEVIDES, Maria Victória. Governo Kubitschek: Desenvolvimento Econômico e Estabilidade Política 1956-1961. Rio de Janeiro: Paz e Terra, 1979.

BENEVOLO, Leonardo. História da Arquitetura Moderna. São Paulo: Perspectiva, 1976.

BERGQUIST, Charles W. Labor in Latin America: comparative essays on Chile, Argentina, Venezuela, and Colombia. Stanford, Calif.: Stanford University Press, 1986.

BOLONHA, Ítalo. O Senai e a aprendizagem industrial. Revista Senai. São Paulo: n. 97, p. 3-4, 1969.

BRAVERMAN, Harry. Trabalho e Capital Monopolista. A Degradação do trabalho no século XX. Rio de Janeiro: Zahar, 1977.

BRUAND, Yves. Arquitetura Contemporânea no Brasil. São Paulo: Perspectiva, 1981. 
BUCCl, Federico. Albert Kahn: architect of Ford. New York: Princeton Architectural Press, 1993.

CARRANZA, Edite Galote R. \& CARRANZA Ricardo. Documento Roberto José Goulart Tibau. Arquitetura e Urbanismo, São Paulo, n. 103, p.89-95, ago./set., 2002.

CAUDILL, William Wayne. Toward better school design. [S.I.]: F.W. Dodge Corp., 1954.

CHAMBERS, John Whiteclay. The tyranny of change: America in the Progressive Era, 1890-1920. $2^{\text {nd }}$ ed. New Brunswick, N.J.: Rutgers University Press, 2000.

COLE, Bernice. Trade schools - their historical developments and trends specifically illustrated in a study of 5 trade schools in New York City. (Dissertação de Mestrado). New York: Columbia University, 1937.

COPELAND, Harland. In La Escuela y la educación permanente. Tradução de Enrique G. León Lopez, Arigo Coen Anitua. México: Secretaria da Educação Pública, 1976.

CORREIA, Telma de Barros. O IDORT e a taylorização da moradia no Brasil (1932-1950). Anais do VII Seminário de História da Cidade e do Urbanismo. Salvador: UFBA, 2002.

A Construção do Habitat Moderno no Brasil - 1870-1950. São Carlos: Rima, 2004.

COSTA, Eunice R. R. Índice de Arquitetura Brasileira 1950/1970. São Paulo: Universidade de São Paulo/FAU, 1974.

CUNHA, Luiz Antonio. Universidade de temporã: o ensino superior da colônia a era de Vargas. Rio de Janeiro: Civilização Brasileira, 1980.

DEWEY, John. Democracy and education: an introduction to the philosophy of education. New York: The Macmillan company, 1916.

The school and society; being three lecture. Supplemented by a statement of the University elementary school. Chicago: The University of Chicago press; New York, McClure, Phillips \& Co., 1900.

Ensayos de educación. Madrid: Ciudad Lineal, 1926 $\overline{1927 .}$

Filosofia de la educacion: los valores educativos. Madrid: La Lectura,

El Niño y el programa escolar: mi credo pedagógico. Buenos Aires: Losada, 1944

Pedagogia y filosofia. Madrid: Fracisco Beltran, 1930

Art as experience. New York: G. P. Putnan, 1934.

The Schools of tomorrow. New York: E P Dutton, 1934.

Democracia e educação: breve tratado de philosophia de educação. Tradução de Anísio S. Teixeira. São Paulo: Nacional, 1936. 
. Experiencia y educacion. Buenos Aires: Losada, 1939.

. Vida e Educação. Tradução de The child and the curriculum e de Interest and Effort in Education por Anísio Spinola Teixeira. São Paulo: Melhoramentos, 1952.

Democracia e Educação. $3^{a}$ ed. São Paulo: Companhia Editora Nacional, 1959. (tradução de Anísio Spinola Teixeira).

DONOVAN, John Joseph. School Architecture: principles and practices. New York: The Macmillan Company, 1921.

DUARTE, Hélio de Queiroz. Escola Classe - Escola Parque: uma experiência educacional. São Paulo: FAUUSP, 1973.

EDIFÍCIO SESC-SENAC de Ribeirão Preto. Acrópole. São Paulo: n. 220, p. 119-123, fevereiro, 1957.

EDIFÍCIO SESC-SENAC em Santos. Habitat. São Paulo: n. 59, p. 10-16, março e abril, 1960.

ENGELHARDT, N. L. The Evolution of the School Building in The American School and University 1931-1932. New York: American School Publishing Corporation, 1932, p. 55-62.

ESCOLA de Construção Civil do SENAI, Rio de Janeiro. Arquitetura e Engenharia, Belo Horizonte, n. 38, p. 17, 1956.

ESCOLA do SENAI em Niterói. Arquitetura e Engenharia. Belo Horizonte: $n$. 14, p. 38-41, 1950.

ESCOLA Industrial do SENAI. Acrópole. São Paulo: n. 217, p.12-14, 1956.

ESCOLA Senac em Botucatu. Acrópole. São Paulo: n. 299, p.332-333, set., 1963.

ESCOLA Senai de Bauru. Acrópole. São Paulo: n. 258, p.130-133, abr., 1960.

ESCOLA SESC-SENAC em Bauru. Acrópole. São Paulo: n. 253, p. 5-7, novembro, 1959.

ESCOLA Têxtil SENAI em São Paulo. Acrópole. São Paulo: n. 241, p.10-13, 1958.

UMA entrevista com Eric J. Hobsbawm. Estudos Históricos. Rio de Janeiro: vol. 3, n. 6, 1990, p.264-273.

FAUSTO, Bóris. História do Brasil. São Paulo: EDUSP/FDE, 1994.

FERRAZ, Artemis R. F. Marcas do Moderno na Arquitetura de Bauru. (Dissertação de Mestrado). São Carlos: Escola de Engenharia de São Carlos, Universidade de São Paulo, 2003.

As pioneiras escolas modernas do SENAI e seus idealizadores. $\mathrm{V}$ Seminário Nacional DOCOMOMO. São Carlos: Escola de Engenharia de São Carlos, Universidade de São Paulo, novembro de 2003. 
USA, Federal Board for Vocational Education. Vocational education for those engaged in the retail meat business: the program developed in cooperation with the National association of retail meat dealers. Washington: Govt. print. Off, 1930. Boletim 149.

FILHO, Lourenço. In DEWEY, John. Vida e Educação. São Paulo: Melhoramentos, 1930.

FICHER, Sylvia; ACAYABA, Marlene M. Arquitetura Moderna Brasileira. São Paulo: Projeto Editores Ass. Ltda, 1982.

FONSECA, C. S. História do ensino industrial no Brasil. vol. 1. Rio de Janeiro: Escola Técnica Federal do Rio de Janeiro, 1961.

FORD, Henry. My life and work. New York: Arno Press, 1922.

Os Princípios da prosperidade. Tradução de Monteiro Lobato. Rio de Janeiro: Editora Brand Ltda, s.d.

FRAMPTON, Kenneth. História crítica da Arquitetura Moderna. São Paulo: Martins Fontes, 1997.

GATI, Catharine. Documento Oswaldo Corrêa Gonçalves - Construindo a profissão. Arquitetura e Urbanismo. São Paulo: n. 59, p.79-87, abr./mai., 1995.

GEIGER, G.R. John Dewey in Perspective. New York: Oxford University Press, 1958.

GERIBELLO, Wanda. Escola Parque: paradigma escolar (1947-1951). (Dissertação de Mestrado). Salvador: Universidade Federal da Bahia, 1989.

GITAHY, M. L. C. Qualificação e Urbanização em São Paulo: A experiência do Liceu de Artes e Ofícios (1873-1934). In Ribeiro, Maria Alice Rosa (org). Trabalhadores Urbanos e Ensino Profissional. Campinas: UNICAMP, 1986, p.21-88.

GOSSI, Inez dos Santos. Educação e arquitetura: o ambiente como fator de direção democrática. (Dissertação de Mestrado). São Paulo, Faculdade de Educação, Universidade de São Paulo, 2004.

GITAHY, L. A New Paradigm of Industrial Organization. The Diffusion of Technological and Managerial Innovations in the Brazilian Industry. Uppsala: Uppsala University, 2000.

GOODWIN, P. Brazil builds: Arquitecture new and old - 1652-1942. New York: The Museum of Modern, 1943.

GRAMSCl, Antonio. Americanismo e Fordismo. In: Cadernos do Cárcere. Rio de Janeiro: Civilização, 2001 , v.4.

GRINOVER, Lúcio. Problemas de aprendizagem industrial. Acrópole. São Paulo: n. 314, p.37-38, 1965.

GROPIUS, Walter. Bauhaus: nova arquitetura. São Paulo: Perspectivas, 1997. 
HAAR, Sharon in Chicago Public Schools Design Competition. Architecture for education: new school designs from the Chicago competition. Chicago, III.: Business and Professional People for the Public Interest, 2002.

HABITAT. São Paulo: n. 59, março e abril, 1960.

HARVEY, David. A condição pós-moderna: uma pesquisa sobre as origens da mudanca cultural. 15 ed. São Paulo: Loyola, 2006.

HILSDORF, Maria Lúcia Spedo. Pensando a Educação nos tempos Modernos. São Paulo: EDUSP, 1998.

HOBSBAWM, Eric J. Era dos Impérios, 1875-1914. Tradução de Sieni Maria Campos e Yolanda Steidel Toledo. Rio de Janeiro: Paz e Terra, 1988.

HOBSBAWM, Eric J. Era dos extremos: o breve século XX, 1914-1991. Tradução de Marcos Santarrita e revisão de Maria Célia Paoli. São Paulo: Companhia das Letras, 1995.

HOBSBAWM, Eric J. Nações e nacionalismo desde 1870: programa, mito e realidade. Tradução de Maria Célia Paoli e Anna Maria Querino. Rio de Janeiro: Paz e Terra, 1991.

KAHN, Albert. Albert Kahn: inspiration for the modern. Ann Arbor, Michigan: University of Michigan Museum of Art, 2001.

KAHN, Albert. The legacy of Albert Kahn. Detroit: Detroit Institute of Arts, 1970.

KOPP, Anatole. Quando o moderno não era um estilo e sim uma causa. São Paulo: Nobel EDUSP, 1990.

KORNBLUH, Joyce L. A new deal for workers' education: the workers' service program, 1933-1942. Urbana: University of Illinois Press, c1987.

LUZURIAGA, Lorenzo in DEWEY, John. El Niño y el programa escolar: mi credo pedagógico. Buenos Aires: Losada, 1944.

MARICONDA, Pablo Rubén in DEWEY, John. Vida e Obra. In Os Pensadores. São Paulo: Abril Cultural, 1980. Traduções por Murilo Otávio Rodrigues Paes Leme, Anísio Spinola Teixeira, Leonidas Contijo de Carvalho.

MINDLIN, Henrique E. Arquitetura moderna no Brasil. Rio de Janeiro: Aeroplano, 1999.

NOBLE, D. F. American by Design. Science, Technology, and the Rise of Corporate Capitalism. New York: Alfred A. Knopf, 1977.

NOBLE, Stuart Grayson. A history of American education. New York: Holt, Rinehart \& Winston, Inc., 1954.

NOVO Edifício do SENAC em Araraquara, Estado de São Paulo. Habitat. São Paulo: n. 43, p. 27-29, 1957.

NUNES, João Roberto Oliveira. Administração Pedro Ernesto e a Questão Educacional (1931-1936). (Dissertação de Mestrado). Rio de Janeiro: UERJ/IFCH, 2001. 
OLIVEIRA, Elaine Rodrigues. A contribuição de Oswaldo Corrêa Gonçalves para a Arquitetura Moderna Brasileira. (Dissertação de Mestrado). São Carlos: Escola de Engenharia de São Carlos, Universidade de São Paulo, 1999.

PIORE, Michael J.; SABEL, Charles F. The second industrial divide: possibilities for prosperity. New York: Basic Books, 1984.

PURSELL, Carroll W. Technology in America: a history of individuals and ideas. Jr. Cambridge, Mass.: MIT Press, c1981.

RAGO, Luzia Margareth; MOREIRA, Eduardo F. P. O que é taylorismo. São Paulo: Brasiliense, 2003.

RIBEIRO, M. L. História da Educação Brasileira. A Organização Escolar. Campinas: Autores Associados, 2003.

(org). Trabalhadores Urbanos e Ensino Profissional. Campinas: UNICAMP, 1986.

$\mathrm{RICH}$, Lorimer. College Architecture in transition in The American School and University 1931-1932. New York: American School Publishing Corporation, 1932, p. 109-112.

ROMANELLI, O. História da educação no Brasil 1930-73. Petrópolis: Vozes, 1978.

SCHWARTZMAN, Simon; BOMENY, Helena Maria Bousquet; COSTA, Vanda Maria Ribeiro. Tempos de Capanema. Rio de Janeiro: Paz e Terra, 1984.

SCHAEFFER, MLGP. Anísio Teixeira: formação e primeiras realizações. (Dissertação de Mestrado). São Paulo: Faculdade de Educação da Universidade de São Paulo, 1988.

SEGAWA, Hugo. Hélio Duarte - moderno, peregrino, educador. Arquitetura e Urbanismo. São Paulo: n.80, p. 59-65, 1998.

_.. Arquiteturas no Brasil 1900-1990. São Paulo: EDUSP, 1999.

SMITH, J. E. The Spirit of American Philosophy. New York, 1963.

SENAC. Rede de Unidades SENAC-SP: Novos paradigmas arquitetônicos em educação. São Paulo: SENAC, 1994.

SENAI (SP). De homens e máquinas. São Paulo: SENAI, 1991.

O Giz e a graxa: meio século de educação para o trabalho. São Paulo: SENAI, 1992.

História e Percursos: O Departamento Nacional do Senai (1942-2002). Brasília: 2002.

SESC (BR) Conselho Regional de São Paulo. SESC São Paulo 50 anos - uma idéia original. São Paulo: SESC/SP, 1997.

SESC-SENAC. AB Arquitetura Brasileira. São Paulo: n. 7, p. 78-91, 1972.

SESC-SENAC Marília São Paulo. AD Arquitetura e Decoração. São Paulo: n. 13, setembro e outubro, 1955. 
SILVA, Marinete dos Santos. A Educação Brasileira no Estado-Novo (1937. 1945). São Paulo: Livramento, 1980.

SIMÃO, Maria Fernanda de Lima. Entre o pensado e o construído: um estudo sobre o Curso de Formação de Docentes do CEFET-MG. (Dissertação de Mestrado). Belo Horizonte: Pontifícia Universidade Católica de Minas Gerais, Programa de Pós-graduação em Educação, 2004.

SOUZA, Abelardo de. Arquitetura no Brasil: depoimentos. São Paulo: Diadorim/USP, 1978.

STILLMAN, Cecil George; CLEARY, R. Castle. The modern school. London: Architectural Press, 1949.

STUBBLEFIELD, Harold W. Adult education in the American experience: from the colonial period to the present. San Francisco: Jossey-Bass Publishers, 1994.

STUBBLEFIELD, Harold W; KEANE, Patrick. Adult education in the American experience: from the colonial period to the present. San Francisco: JosseyBass Publishers, 1994.

TAYLOR, F. W. Princípios de Administração Científica do Trabalho. São Paulo: Atlas, 1960.

TEIXEIRA, Anísio Spínola. Aspectos americanos da educação: relatório apresentado ao Governo do Estado da Bahia pelo diretor geral de instrução, comissionado em estudo na América do Norte. Typ. de São Francisco, 1928.

Educação progressiva: uma introdução à filosofia da educação. São Paulo: Nacional, 1933. $\overline{1951 .}$

Um presságio de progresso. Habitat. São Paulo: v.4, n. 2, p. 175-177,

A Pedagogia de Dewey: esboço da educação de John Dewey, in Vida e Educação de John Dewey. São Paulo: Melhoramentos, 1952.

A educação e a crise brasileira. São Paulo: Nacional, 1956.

Pequena introdução à filosofia da educação: a escola progressiva ou a transformação da escola. 8. ed. São Paulo: Nacional, 1967.

Educação é um direito. São Paulo: Nacional, 1968.

A educação e o mundo moderno. São Paulo: Nacional, 1969.

Educação não é privilégio. 3. ed. São Paulo: Nacional, 1971.

Educação no Brasil. São Paulo: Nacional, 1971.

Educação para a democracia: introdução a administração educacional. Rio de Janeiro: José Olympio, s.d.

THE State Education Department, Division of School Building and Grounds. Planning Guide for Vocational-Industrial and Vocational-Technical Building Facilities for Comprehensive High Schools, no. 18. Albany: The University of the State of New York, September, 1950. 
TOBIAS, José Antonio. História da Educação Brasileira. São Paulo: Juriscredi Ltda, 1972.

WEINSTEIN, Barbara. For social peace in Brazil: industrialists and the remaking of the working class in São Paulo, 1920-1964. Chapel Hill, N.C.: University of North Carolina Press, 1996.

(Re) Formação da classe trabalhadora no Brasil (1920-1964). São Paulo: Cortez CDAPH-IFAN - Universidade São Francisco, 2000.

WIK, Reynold M. Henry Ford and grass-roots America. Ann Arbor: University of Michigan Press, 1972.

WILLIE, Charles V. \& MILLER, Inabeth. Social goals and educational reform: American schools in the twentieth century. (Series Contributions to the study of education, n²7). New York: Greenwood Press, 1988.

VASCONCElOS, Augusto C. de. O concreto no Brasil. São Paulo: Pini, 1992.

XAVIER, Alberto (Org.). Depoimento de uma geração: arquitetura moderna brasileira. São Paulo: Associação Brasileira de Ensino de Arquitetura/Fundação Vilanova Artigas/Pini, 1987.

XAVIER, Libânia Nacif. O Brasil como laboratório: Educação e Ciências Sociais no Projeto do Centro Brasileiro de Pesquisas Educacionais CBPE/INEP/MEC (1950-1960). (Tese de Doutorado). Rio de Janeiro: PUC/Departamento de Educação, 1999.

Para além do campo educacional: um estudo sobre o Manifesto dos Pioneiros da educação nova. (Dissertação de Mestrado). Rio de Janeiro: Departamento de Educação, PUC, 1993.

YOUNG, Lloyd P. In The American School and University 1931-1932. New York: American School Publishing Corporation, 1932. 